

\section{REVISTA DE DIREITO INTERNACIONAL}

\section{BRAZILIAN JOURNAL OF INTERNATIONAL LAW}

\section{Editores responsáveis por essa edição:}

Editores gerais

Marcelo Dias Varella, Nitish Monebhurrun

Editor especial

Bruno Valim Magalhaes, Christiani Amaral Buani

ISSN 2237-1036 
REVISTA DE DIREITO INTERNACIONAL

BRASILIAN JOURNAL OF INTERNATIONAL LAW

Programa de Mestrado e Doutorado em Direito

Centro Universitário de Brasília

Reitor

Getúlio Américo Moreira Lopes

Presidente do Conselho Editorial do UniCEUB

Elizabeth Regina Lopes Manzur

Diretor do ICPD

João Herculino de Souza Lopes Filho

Coordenador do Programa de Mestrado e Doutorado e Editor

Marcelo Dias Varella

\section{Linha editorial}

A Revista de Direito Internacional (RDI) foi criada como instrumento de veiculação de trabalhos acadêmicos relacionados a temáticas tratadas pelo Direito Internacional Público e Privado. A revista é sucessora da Revista Prismas, que foi dividida em dois periódicos (junto com a Revista Brasileira de Políticas Públicas), em virtude do aumento do impacto e interesse dos autores em submeter artigos. Na busca pelo desenvolvimento e construção de visões críticas a respeito do Direito Internacional, a RDI possui sua linha editorial dividida em dois eixos:

1. Proteção internacional da pessoa humana: abrange questões referentes ao direito internacional ambiental, direito humanitário, internacionalização do direito, além de pesquisas sobre a evolução do direito dos tratados como forma de expansão do direito internacional contemporâneo.

2. Direito Internacional Econômico: abrange questões referentes aos sistemas regionais de integração, direito internacional econômico e financeiro e solução de controvérsias comerciais e financeiras. A RDI busca incentivar a pesquisa e divulgação de trabalhos relacionados às disciplinas voltadas para o estudo do Direito Internacional publicando artigos, resenhas e ensaios inéditos. A revista está aberta às mais diversas abordagens teóricas e metodológicas impulsionando a divulgação, o estudo e a prática do Direito Internacional.

Editor Gerente

Marcelo D. Varella, Centro Universitário de Brasília, Programa de Mestrado e Doutorado em Direito, Brasília/DF, Brasil

Editor Adjunto

Nitish Monebhurrun, Centro Universitário de Brasília, Revista de Direito Internacional, Brasília/DF, Brasil

\section{Comitê editorial}

Alice Rocha da Silva, Centro Universitário de Brasília

Cláudia Lima Marques, Universidade Federal do Rio Grande do Sul

José Augusto Fontoura Costa, Universidade de São Paulo

Julia Motte Baumvol, Université d'Evry Val d'Essonne

Nádia de Araújo, Pontíficia Universidade Católica do Rio de Janeiro

Sandrine Maljean-Dubois, Universidade Aix-Marseille, França

Carolina Olarte Bacares, Universidade Javeriana, Colômbia

\section{Layout capa}

Departamento de Comunicação / ACC UniCEUB

\section{Diagramação}

S2 Books

Disponível em:

www.rdi.uniceub.br

\section{Circulação}

Acesso aberto e gratuito.

Matérias assinadas são de exclusiva responsabilidade dos autores.

Citação parcial permitida com referência à fonte. 
Revista de Direito Internacional / Centro Universitário de Brasília, Programa de Mestrado e Doutorado em Direito, volume 14, número 1 - . Brasília : UniCEUB, 2011 -

Quadrimestral.

ISSN 2237-1036

Disponível também on-line: http://www.rdi.uniceub.br/

Continuação de: Revista Prismas: Direito, Políticas Públicas e Mundialização. Programa de Mestrado em Direito do UniCEUB.

1. Direito Internacional. 2. Políticas Públicas. 3. Mundialização. I. Programa de Mestrado em Direito do UniCEUB. II. Centro Universitário de Brasília.

CDU 34(05)

Ficha catalográfica elaborada pela Biblioteca Reitor João Herculino

\section{Endereço para Permuta}

\section{Biblioteca Reitor João Herculino}

SEPN 707/907 Campus do UniCEUB

Cep 70790-075 Brasília-DF

Fone: 61 3966-1349

E-mail: biblioteca@uniceub.br 


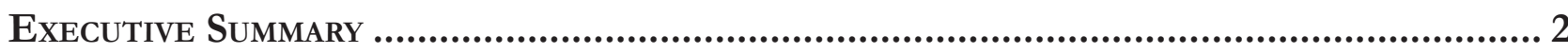

Daniel Balaban

Crônicas Sobre o Direito Alimentar e o Combate À Fome .......................................... 5

South-South Food and Nutrition Security promotion: the Brazilian experience

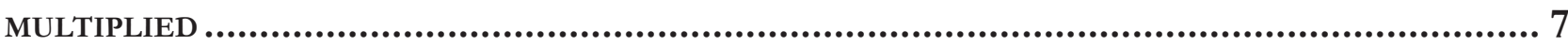

João Almino

Access to Food as a Human Right: Brazil, WFP and South-South Cooperation .......10 Carlos R. S. Milani

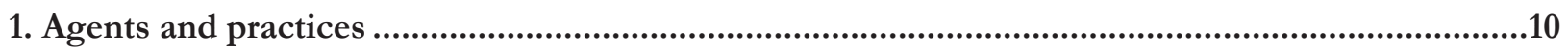

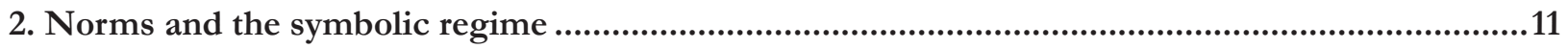

Dossiê temático: Direito Alimentar e Combate À Fome ...............................................13

WFP'S ROLE IN BUILDING SUSTAINABLE BRIDGES BETWEEN THE RIGHT TO ADEQUATE FOOD AND THE FREEDOM FROM HUNGER ...............................................................................15

Christiani Amaral Buani e Bruno Valim Magalhães

Direito humano À alimentaÇão, (IN) SEgURANÇa ALIMENTAR E DESENVOLVIMENTO: OS DESA-

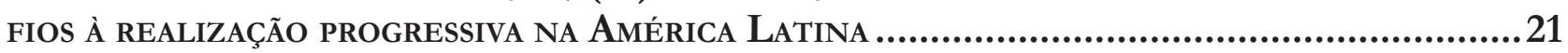

Sinara Camera e Rubia Wegner

1. Introdução ........................................................................................................................... 22

2. Direito humano à alimentação: contexto do surgimento e da afirmação................................... 23

3. A realização progressiva do direito humano à alimentação, regime alimentar internacional e desenvolvimento

4. Direito humano à alimentação, segurança alimentar e nutricional e realização progressiva: as experiências na união europeia e américa latina ...................................................................... 29

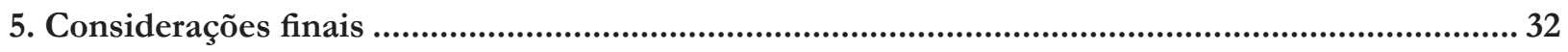

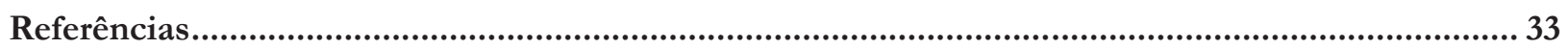


STATE'S INTERNATIONAL RESPONSIBILITY FOR THE HUMAN RIGHT TO FOOD:

Paula F. Strakos e Michelle B.B. Sanches

1. Introduction 37

2. Historical development of the human right to food ............................................................... 38

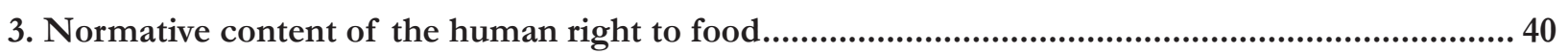

4. State's obligation to the human right to food ....................................................................................41

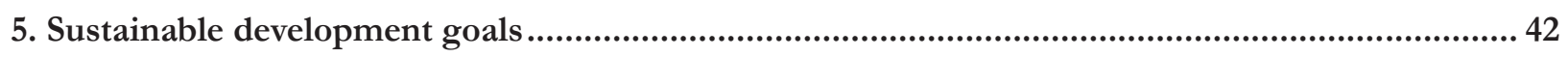

6. The role of agroecology in the implementation of the HRF ...................................................... 42

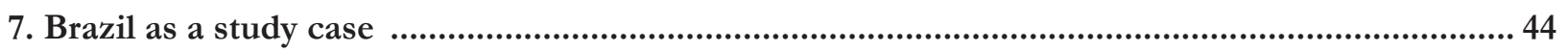

8. Brief overview on the implementation of the hrf in Brazil ....................................................... 44

9. Institutional framework of the brazilian state for the implementation of human right to food .... 45

10. Brief overview on public policy towards the realization of the HRF ........................................ 46

11. Agroecology public policy for the realization of the hrf in Brazil................................................ 47

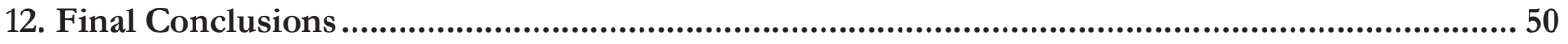

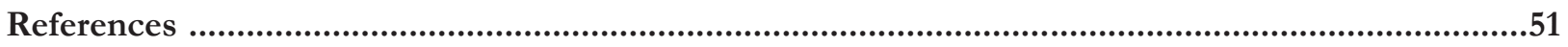

NEgotiating AgRiCULTURE IN THE WORLD TRADE ORgANIZATION: FOOD

SECURITY AS A NON-TRADE CONCERN......................................................................55

Ana Luísa Soares Peres e Letícia de Souza Daibert

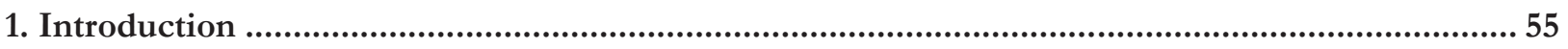

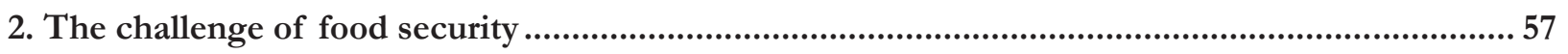

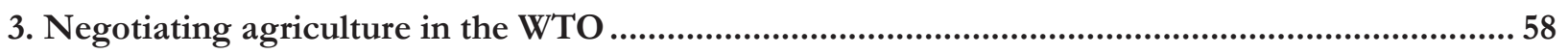

3.1. Historical Background on Agriculture Negotiations: from GATT/1947 to the WTO............................. 58

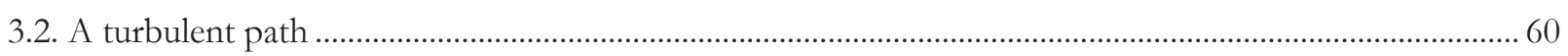

4. The relation between trade in agriculture and food security .....................................................61

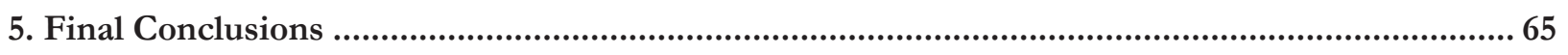

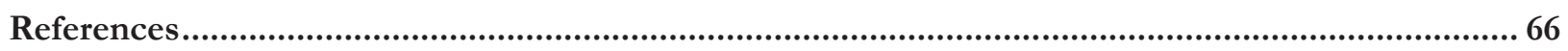

QUANDo HABITAR CORRESPONDE AO DIREITO HUMANO À ALIMENTAÇÃo ..............................69

Fernanda Viegas Reichardt e Maria Elisa de Paula Eduardo Garavello

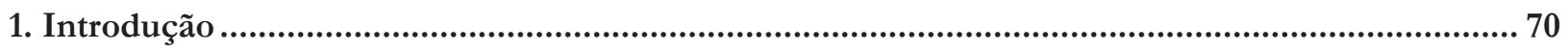

2. O "território" e a "territorialidade" Xavante: do simbólico ao vivido.......................................... 72

3. (In)segurança alimentar e "subalternidade alimentar" ................................................................... 75

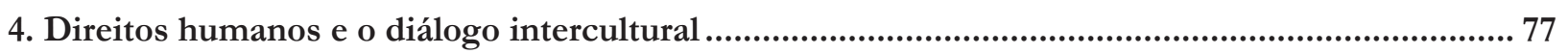

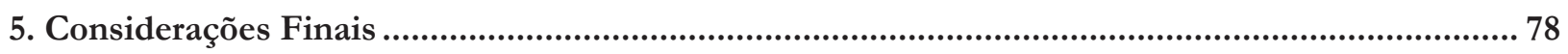

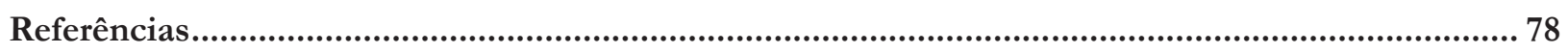


Hiran Catuninho Azevedo

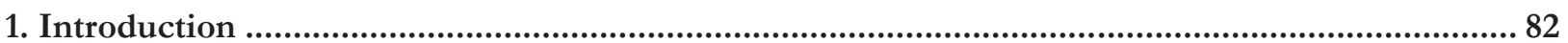

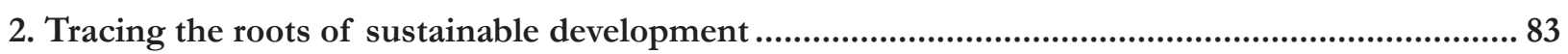

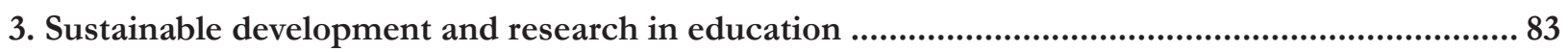

4. How a sustainable education can support the hunger erradication?........................................... 85

5. Questioning sustainable development for social and intergenerational justice ............................ 88

6. Adult education: cultural tensions and sustainability ................................................................. 90

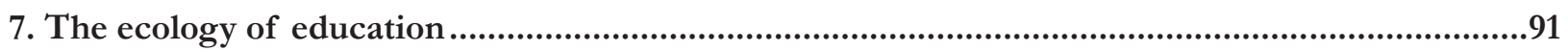

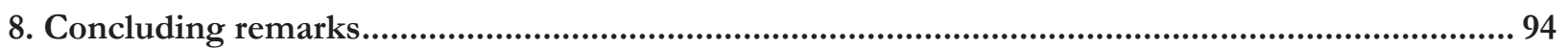

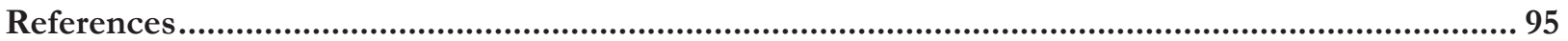

O DIREITO HUMANO E FUNDAMENTAL À ALIMENTAÇÃO ADEQUADA E À CONDIÇÃo

FEMININA NO PROGRAMA Bolsa FAMÍLIA: EMPODERAMENTO Às AVESSAS? ............................99

Rosalice Fidalgo Pinheiro e Laura Garbini Both

1. Introdução

2. Entre universalismo e relativismo: a afirmação do direito humano à alimentação adequada .....101

3. As políticas públicas em favor do direito humano e fundametal à alimentação adequada............104

4. A condição feminina e o programa Bolsa Família ............................................................................107

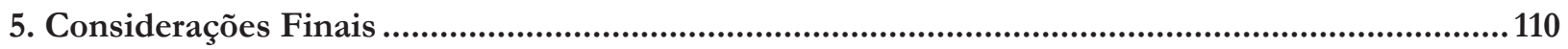

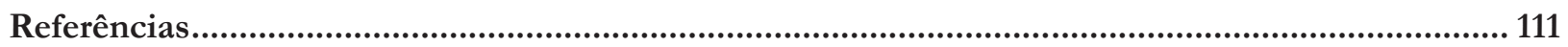

Food SECURITY IN INDIA............................................................................... 114

Ranjana Ferrão

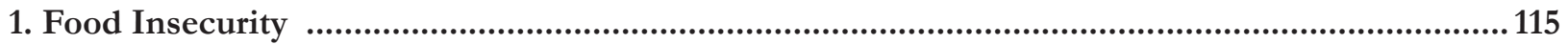

2. The Right to Food under International Law ............................................................................... 115

3. Food Insecurity in India ................................................................................................................116

4. Green Revolution in India ................................................................................................................117

5. Food Security and Governance .......................................................................................................117

6. Public Distribution System ..................................................................................................................117

7. Integrated Child Development Scheme (ICDS) ..........................................................................118

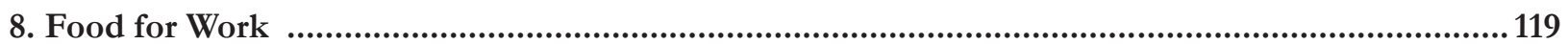

9. Legal Control for Food Security ................................................................................................119

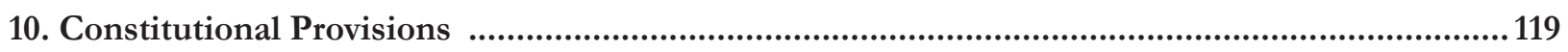

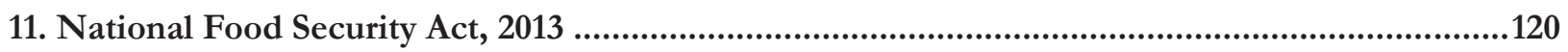

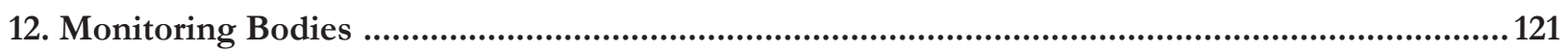




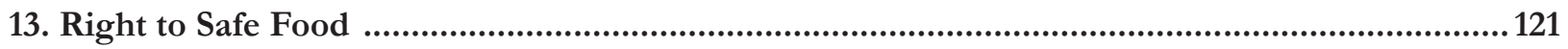

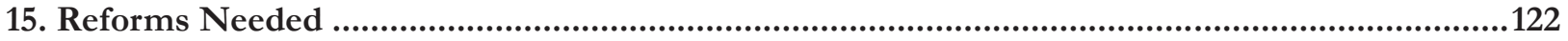

16. Final Conclusions .....................................................................................................................122

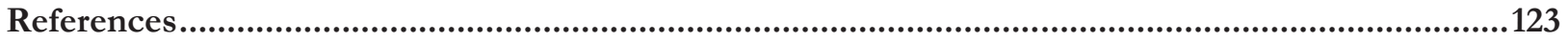

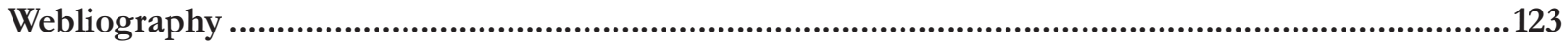

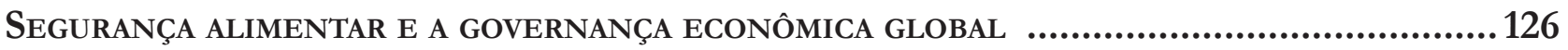

Danielle Mendes Thame Denny, Douglas de Castro, Alexandre Ricardo Machado, José Valverde Machado Filho e Gabrielle Fontes Witt

1. Introdução ..................................................................................................................................127

2. Causas estruturais da insegurança alimentar............................................................................128

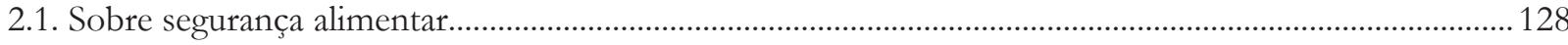

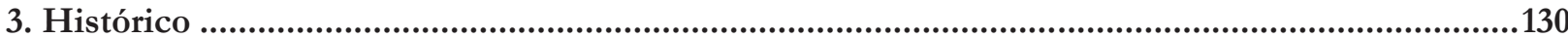

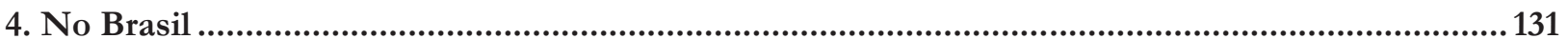

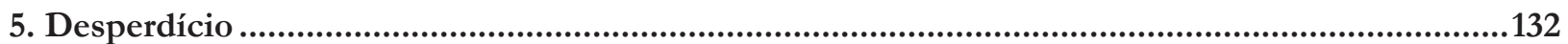

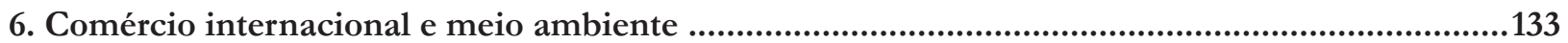

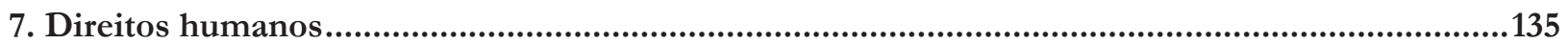

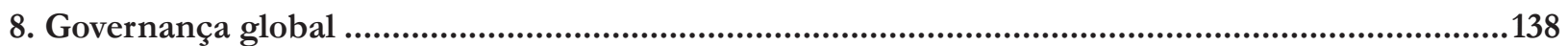

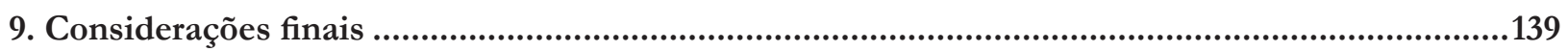

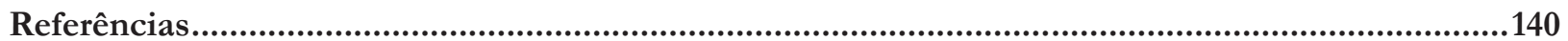

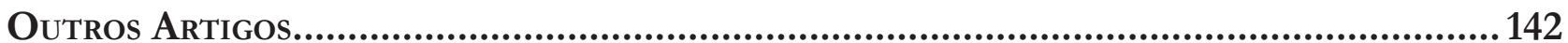

The legal implications of the Draft Universal Declaration of the Rights of

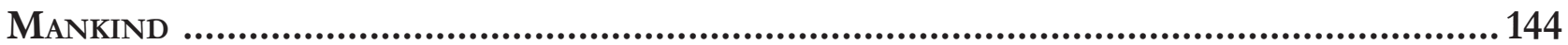

Catherine Le Bris

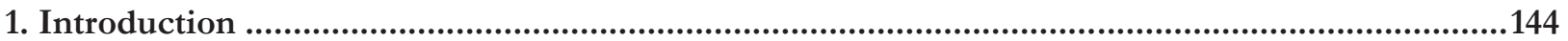

2. Rights of mankind and duties towards mankind: normative implications of the

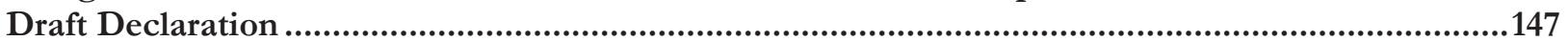

2.1. Rights of mankind and human rights: between autonomy and interdependence ................................... 148

2.2. Duties towards mankind and rights of mankind: between complementarity and added value ............. 152

3. A United Mankind and a Plural Mankind: institutional perspectives for the

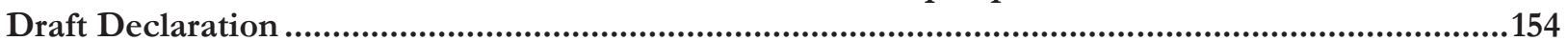

3.1. United Mankind: A Supranational Institution as the Custodian of Rights of Mankind .........................155

3.2. Plural mankind: decentralized exercise of the rights of mankind within the international

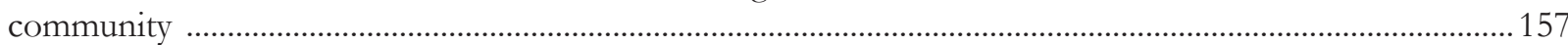

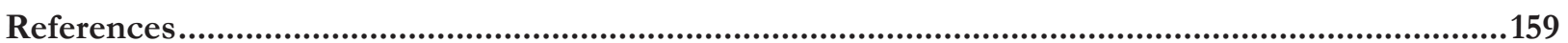

Annex 1 - Draft Universal Declaration of the Rights of Mankind (Paris, 25 September 2015) ........ 161

1.1. The Principles 


\section{Litigating Indigenous Dispossession in the Global Economy:}

Charis Kamphuis

1. Introduction \& Context: Global Resource Conflicts and the Governance Gap ..........................166

2 The Negritos Story: An account of dispossession (the case tells a story about life)...................171

2.1. Dispossession Story: Agrarian Reform, neoliberalism, transnational mining \& corruption.................. 172

2.2. The Turn to Law: An unresponsive state and the emergence of local activism ................................... 177

2.3. Developing a Legal Strategy: Putting dispossession into a rights framework ...................................... 179

3. The Negritos Case: Litigating a dispossession claim (the story of the case itself) ....................183

3.1. The Amparo: A cause of action for dispossession in Peru? ............................................................... 183

3.2. Dispossession as Knowledge and Power: An equitable approach to the limitation period .................. 186

3.3. Dispossession as Actions and Omissions: A doctrinal approach to the limitation period ..................... 191

3.4. San Andres de Negritos Campesino Community v Yanacocha Mine .................................................. 193

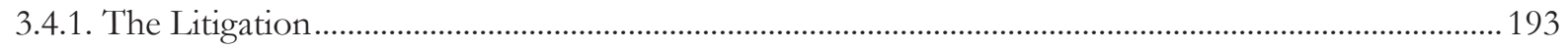

3.4.2. Critical Analysis of the Appeal Court Decision ......................................................................... 195

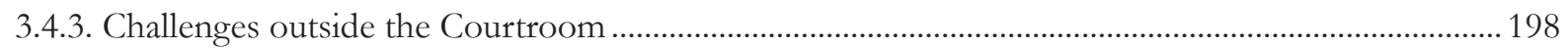

3.5. Negritos Case Next Steps: Precedents \& Remedies .............................................................................. 200

3.5.1. The Indigenous Status of Campesino Communities in International Law ................................... 201

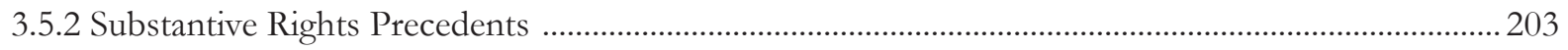

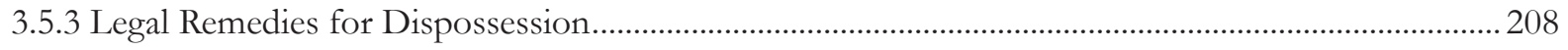

4. Conclusion: Dispossession Research and Law Reform Agenda...............................................210

References......................................................................................................................215

UNE DÉFINITION DU PRÉ-INVESTISSEMENT CONFORME À L'APPROCHE FRANÇAIS MAIS CONTRAIRE À L'APPROCHE AMÉRICAINE AU SEIN DES TRAITÉS BILATÉRAUX

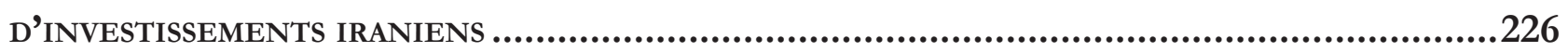

Peyman Dadras

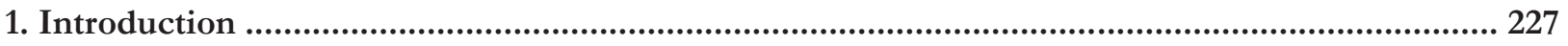

2. L'impact des TBI sur la question de pré-investissement .................................................... 229

3. L'apport de la jurisprudence arbitrale sur cette question ............................................... 232

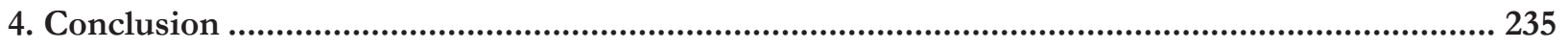

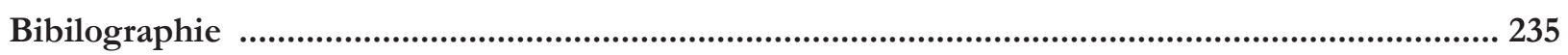


CONFLITOS ENTRE REGULAÇÕES INTERNAS RELATIVAS À INTERNET E O DIREITO DO COMÉRCIO INTERNACIONAL: O PAPEL DA OMC PERANTE O SISTEMA DE COMPUTAÇÃO DA NUVEM ............238

Alice Rocha da Silva e Filipe Rocha Martins Soares

1. Introdução

2. A tensão entre regulações locais e o comércio internacional...................................................241

3. O Direito da OMC aplicável às regulações locais sobre computação na nuvem ........................ 244

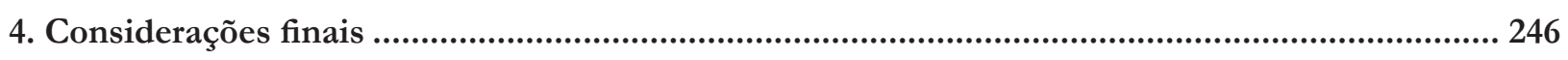

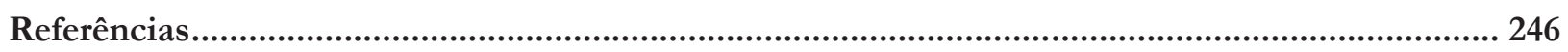

Prélèvement: origem, EVoluÇão E OCASO do PRIVILÉgio NAS SUCESSÕES

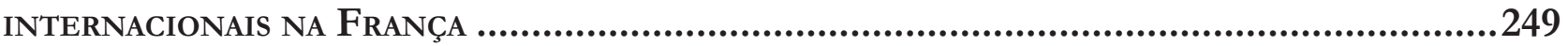

Fernando Pedro Meinero

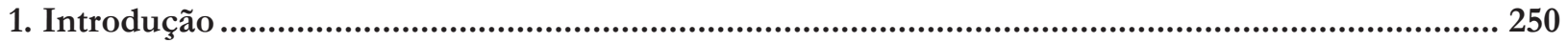

2. Do direito de albinágio ao surgimento prélèvement ..................................................................... 250

2.1 Direito de albinágio como anti-privilégio .........................................................................................................251

2.2 Direito de albinágio como pilar da política externa francesa ............................................................... 252

2.3 Abolição do direito de albinágio e o surgimento do droit de prélèvement..................................................253

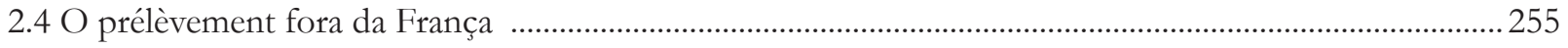

3. Interpretação do Prélèvement na doutrina e na jurisprudência francesa ...................................... 256

4. A declaração de inconstitucionalidade do prélèvement .............................................................. 259

5. Considerações Finais ......................................................................................................................261

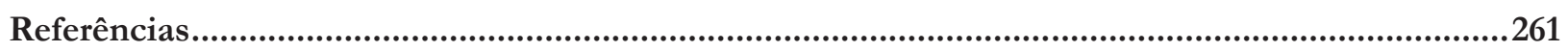

Os CONTRATOS INTERNACIONAIS DE FINANCIAMENTO E O CENTRO FINANCEIRO DE Nova IorQue: CONSIDERAÇÕES SOBRE A AUTONOMIA DA VONTADE .................................265

Fernanda Torres Volpon

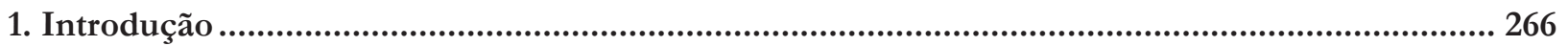

2. Breves Considerações sobre Lei Aplicável e Eleição de Foro na Doutrina Brasileira ................. 267

3. Visão econômica da escolha da lei aplicável e eleição de foro nos contratos internacionais .........271

4. $\mathrm{O}$ caso dos contratos internacionais de financiamento: o centro 'financeiro-judicial' de Nova Iorque ........274

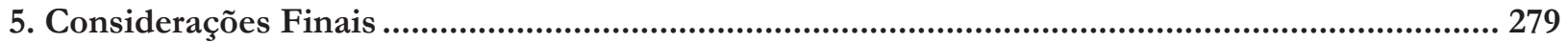

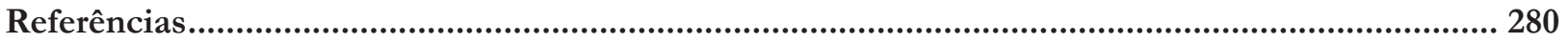

Mercosul e o meio ambiente: ANÁlise da tUtela regional ambiental .......................284 Clarissa Ferreira Macedo D'sep

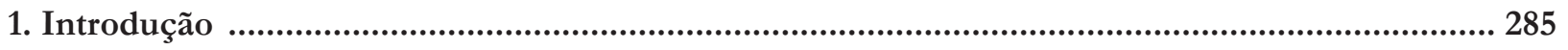

2. O Mercosul e o meio ambiente: uma retrospectiva e a proteção ambiental integrada ................ 285 
2.2. Tutela Ambiental Regional: da proteção ambiental integrada à proteção ambiental autônoma, interação recíproca.

2.3. Desenvolvimento sustentável: conceito integrador de matérias e de sujeitos dotado de pluralidade

de efeitos

3. O acordo-quadro sobre o meio ambiente do Mercosul (AQMAM): da análise da proteção autônoma do meio ambiente regional a uma abordagem prospectiva do direito ambiental regional do Mercosul

3.1. O significado e a abrangência de um Acordo-Quadro Ambiental Regional: efeitos jurídicos

3.2. A proteção regional autônoma do meio ambiente: o alvorecer do direito ambiental regional do Mercosul

3.3. O Acordo-Quadro Ambiental do Mercosul: entre prognósticos e prospectivas.

4. O Acordo-quadro sobre Meio Ambiente do Mercosul (AQMAM) e o Comércio Internacional: uma análise aplicada.

4.1. O desenvolvimento sustentável: um caminho sem volta .....

Referências

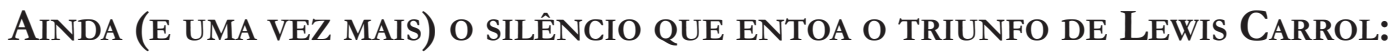
a Regra N ${ }^{\circ} 42$ do Supremo Tribunal Federal

Thiago Aguiar Pádua e Bruno Amaral Machado

1. Introdução .....

2. Fragmentos do pensamento criminológico latino-americano: vetores para uma releitura do controle penal dos crimes contra a humanidade

3. STF e o julgamento dos crimes contra a humanidade: controle penal e o largo termidor. 300

4. Tempo, Direito e Memória ..... 305

4.1. Semânticas do esquecimento 306

4.2. O esquecimento como punição (de quem? por que?) 307

4.3. O esquecimento como limite e como proteção (de que? por que?) 307

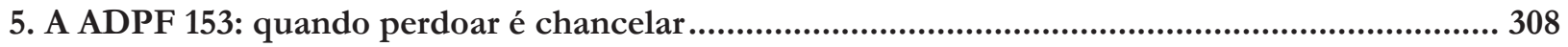

6. A extradição $n^{\circ}$ 1362: quando não extraditar é perpetuar a violação............................................. 308

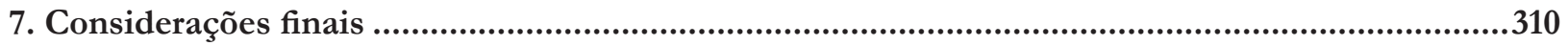

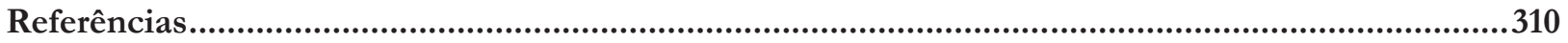

\section{A Natureza Jurídica do Sistema de Solução de Controvérsias da OMC} E DE SuAs Decisões: Solucionando um ImbRóglio ...............................................................316

Camila Capucio

1. Introdução: Contexto e Relevância da Análise Proposta ..............................................................317

2. Breve análise da evolução histórica do Sistema de Solução de Controvérsias da OMC................317

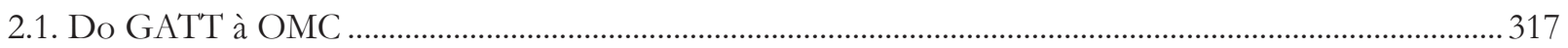


2.2. O "novo" sistema de solução de controvérsias alcançado na Rodada do Uruguai 320

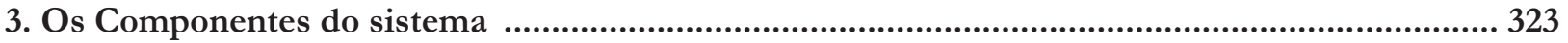

4. Especificidades do Sistema de Solução de Controvérsias da OMC............................................... 326

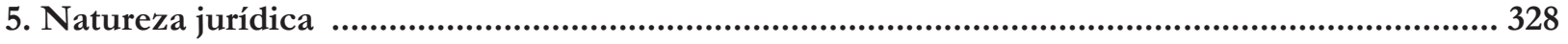

6. Detalhamento conceitual................................................................................................................331

7. Apontamentos Finais: Características daCompreendendo as decisões do Sistema de

Solução de Controvérsias da OMC .................................................................................................. 333

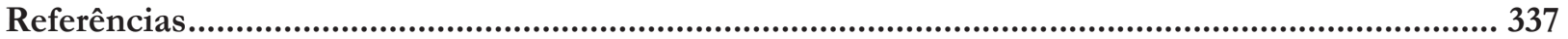

Brics: Desafios do desenvolvimento Econômico e socioAmbiental.............................342

Magno Federici Gomes e Luís Eduardo Gomes Silva

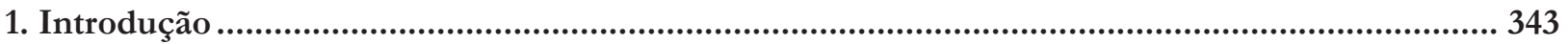

2. Análise primeva do desenvolvimento sustentável e suas implicações ......................................... 344

3. Brics: crises e políticas públicas ...................................................................................................... 346

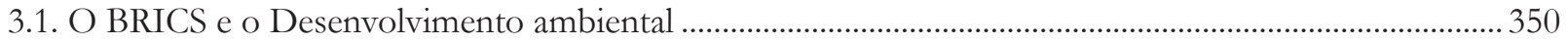

4. O desenvolvimento sustentável e as questões sociais ...................................................................351

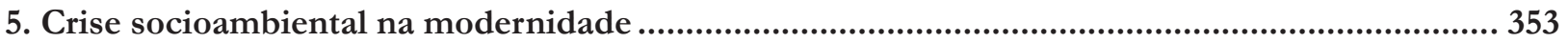

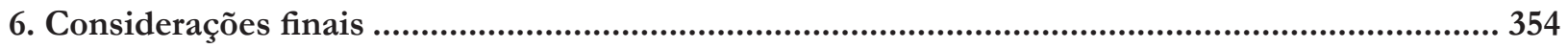

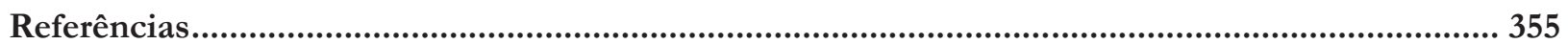

REVER OU ROMPER COM VESTFÁlIA? POR UMA RELEITURA DA EFETIVA CONTRIBUIÇÃo DOS ACORdOS DE PAZ DE 1648 À CONSTRUÇÀO DO MODELO VESTFALIANO DE ESTADOS.............358

Luiz Magno Pinto Bastos Junior

1. Introdução. 359

2. (Re)leituras sobre A NATUREZA E O SIGNIFICADO da Guerra dos Trinta Anos ................. 360

3. Qual o significado dos acordos de paz de Vestfália?

3.1. Reflexão crítica sobre o caráter juridicamente inovador dos acordos de paz para o direito internacional contemporâneo.

3.2. Reflexão crítica sobre a centralidade dos acordos de paz de vestfália para a afirmação

da soberania dos estados 367

4. Sistema (Lógica) de Vestfália e os traços constitutivos do sistema de Estados..............................371

5. Considerações finais ............................................................................................................................ 374

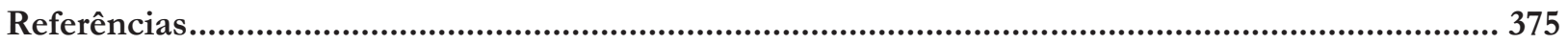

Justiça de TRANSIÇÃo EM SUA GÊNESE: A AlEMANHa Pós-NAZiSMo .................................378 Bruno Galindo

1. Introdução

2. Contextualizando o advento do nazismo 
3. Constitucionalismo weimariano e seu esvaziamento material.................................................... 382

4. Derrota militar e exposição dos crimes nazistas ............................................................................ 387

5. Parâmetros jurídicos e humanitários da primeira experiência de justiça de transição da História

5.1. Julgamentos dos criminosos nazistas: o Tribunal Militar Internacional de Nuremberg e seus desdobramentos judiciais

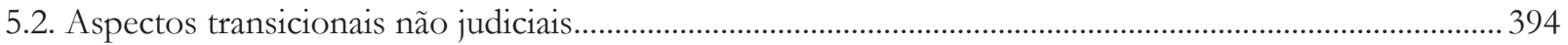

6. A título conclusivo: alcance da justiça de transição na Alemanha pós-nazismo ............................ 398

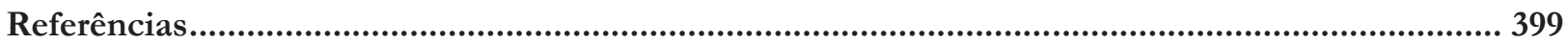

QUANDO JULGar SE TORNA UM ESPETÁCUlO: A INTERAÇÃo ENTRE O SUPREMO

Tribunal Federal e a opinião pública, A Partir de Reflexões da

LITERATURA ESTRANGEIRA

Patrícia Perrone Campos Mello

1. Introdução 404

2. As instâncias majoritárias podem não ser representativas?

3. A instância contramajoritária pode ser representativa? Casos em que a jurisdição constitucional deu vazão à vontade popular

4. Casos em que a jurisdição constitucional se curvou à vontade popular .

5. Razões da convergência entre as cortes constitucionais e a opinião pública: reflexões

a partir da literatura estrangeira

6. O STF e a justiça espetáculo

7. Considerações finais

Referências

TolerânCIA E Refugio: um ENSAIO A PARTIR do ACORdo EU-TurQuia .

Flávia Cristina Piovesan e Ana Carolina Lopes Olsen

1. Introdução

2. Tolerância como fundamento do direito internacional dos refugiados

3. O tratamento dispensado aos refugiados no acordo união européia-turquia

4. Intolerância e discriminação: afluxo de refugiados desafia a sinceridade dos valores europeus ocidentais.

5. Perspectivas para a recuperação ou remodelação da tolerância

6. Considerações finais 441

Referências

Normas Editoriais

Envio dos trabalhos: 446

www.rdi.uniceub.br. 


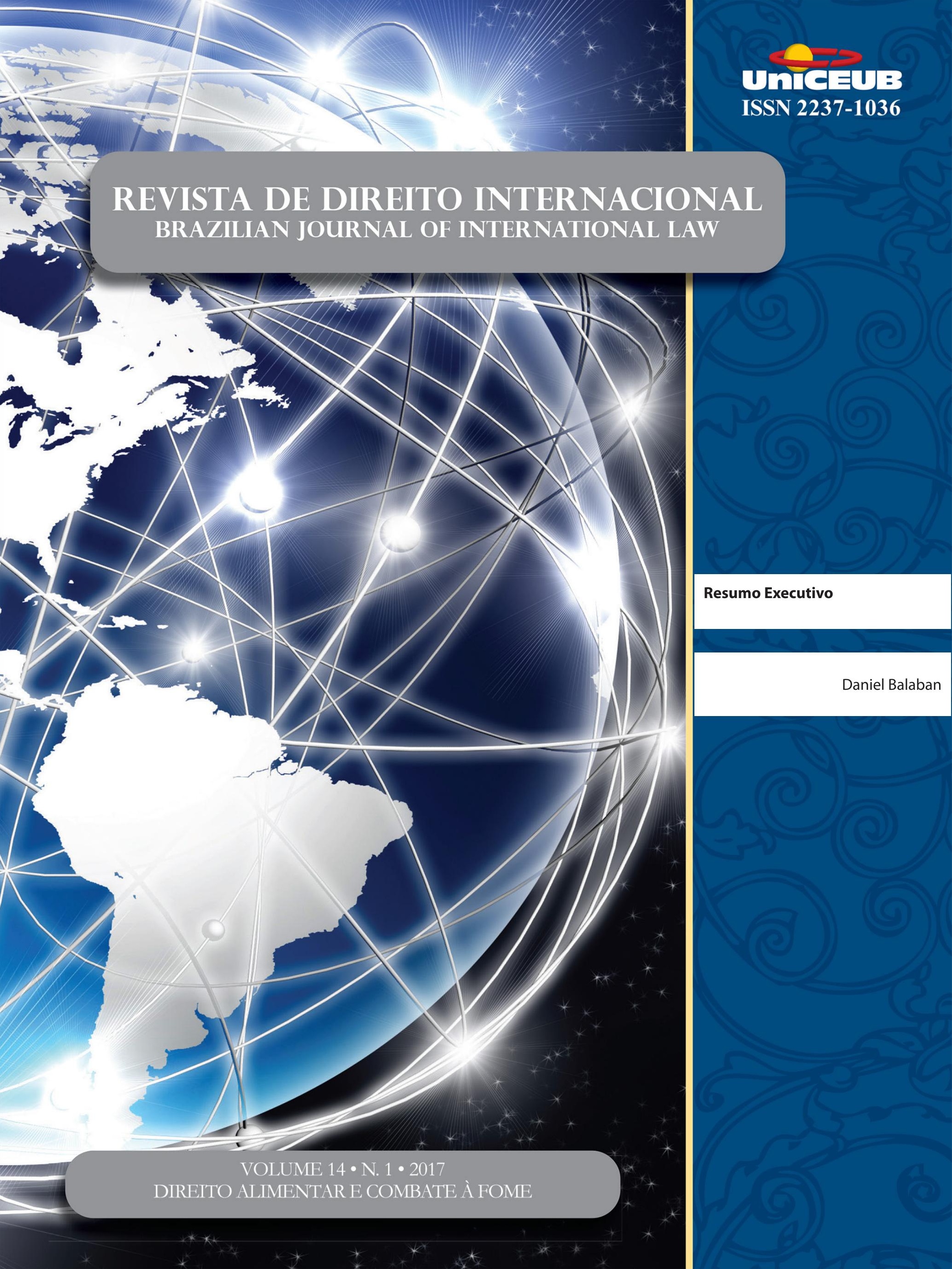




\section{Executive Summary}

Daniel Balaban*

Food and nutrition security, beyond being at the very basis of the human survival, is at the core of the individual and social development. Despite our vital dependency on eating adequately every day and the challenge of eliminating hunger, scientific research can further explore the connections between the political actions aimed at fighting hunger worldwide and systematic knowledge appraising and dissemination. This opportunity is significant, especially for the Brazilian academia, which has the chance to investigate national experiences in fighting hunger, since Brazil became an inspiration for other countries to develop their own policies and programs.

Distinguishing the Brazilian accomplishments in food and nutrition security, since 2011, the United Nations World Food Programme has been working through its Centre of Excellence against Hunger in Brazil to support developing countries to find their own solutions for many of their food and nutrition security challenges. The Sustainable Development Goals (SDGs), established in 2015, were another push in this direction. These United Nations' new Global Goals modernize the debate over food and nutrition security with a human rights approach, and set a roadmap for acting towards the eradication of hunger in all its forms and dimensions. The SDGs also highlight the important role of international cooperation, especially South-South cooperation, in achieving food security for all.

The Centre of Excellence in Brazil, celebrating its fifth anniversary, partnered in 2016 with the University Center of Brasilia to foster bridges between politics and science, publishing together this Dossier on Fighting hunger worldwide. This dossier presents articles and scientific findings on food and nutrition as a basic human right. The first part of the dossier focuses on linking Law, Political Science, and International Relations to public policies; connecting the human rights framework as a social construct to political actions of WFP and national governments, like Brazil. The first reflection comes from Ambassador João Almino, director of the Brazilian Cooperation Agency, talking about South-South food and nutrition security promotion: the Brazilian experience multiplied.

Professor Carlos Milani, from the Institute of Social and Political Studies of the State University of Rio de Janeiro, casts light on the Access to food as a buman right: Brazil, WFP and South-South cooperation. Finalizing this reflexive background for the complete research papers, Christiani Buani and Bruno Valim Magalhães, from the Centre of Excellence against Hunger in Brazil, bring into discussion WFP's role in building sustainable bridges between the right to adequate food and the freedom from hunger.

After this reflexive background, complete research articles follow first connections between politics and science and advance on sharing and systematizing knowledge. Their results come from desk researches, conceptual framework applications, and qualitative methods. Taking into account the debate over the human right to food, the article Human right to food, food (in) security and development: the challenges to the progressive achievement in Latin America, written by Sinara Camera and Rubia Wegner, evaluates the historical human rights construction and its internationalization and diversification, such as

* Daniel is the director of the World Food Programme Centre of Excellence against Hunger and holds a Master of Science in International Relations from the University of Brasilia. 
the human right to food. The discussion is based on an interdisciplinary analysis of the measures adopted by Latin American and European countries. In a second moment, it verses on the right to adequate food and food security in terms of economic development.

Rosalice Fidalgo Pinheiro and Laura Garbini Both present a discussion on the Human and fundamental right to adequate food and the female condition in the Bolsa Familia Program: an upside down empowerment? Beyond fighting hunger, this article tackles gender debates, considering the policies of food and nutritional security as public policies in favor of the family. The female condition was highlighted in the Bolsa Família program because it prioritizes women as the main beneficiaries. The study points out that while some researchers indicate a loss of their autonomy in face of the labor market, others recognize the strengthening of their role in the family. The article concludes that by improving the feminine condition, due to the high percentage of families where the women is the sole person in charge, food security was strengthened for the families served by the program.

Food is the basic element of community self-reliance. It provides jobs, values culture, enables communitarian engagement, and supports public health. The study Food Security and the Global Economic Governance, by Danielle Mendes Thame Denny et al., discusses the causes of food insecurity, and analyzes food wasting in Brazil, contextualizing this issue under an international environmental economic law approach, to finally address the problem under the perspective of global governance. The main conclusion of this paper is that food insecurity is caused by maldistribution rather than by lack of food, and that the tools of global governance to coordinate conflicting interests in pursuit of the common goal of hunger eradication have much to improve.

In a global food system dedicated to free trade that encourages exports, the trend is to grow monoculture crops on a large scale for distant markets. In reflections like Negotiating agriculture in the World Trade Organization: food security as a non-trade concern, Ana Luísa Soares Peres and Letícia de Souza Daibert bring up evidences indicating that if food security is treated as any trade issue, this perspective may partially undermine developing countries' actions towards fighting hunger. International trade is only one element in fighting hunger worldwide, meaning that well-designed trade policies and rules on agricultural trade may contribute to accomplishing food security, as long as they are part of a broader initiative that can reach all the many levels of the issue.

Other articles in this dossier recommend possible solutions for that. Paula F. Strakos and Michelle B. B. Sanches' State's international responsibility for the buman right to food: implementation in Brazil through agroecology finds that that the application of agroecological public policy in Brazil constitutes a relevant opportunity to positively address several obstacles found in previous public policies, such as the contradictions resulting from low intersectoriality. This analysis shows that the normative content of the human right to food can be addressed and implemented through this strategy.

After the findings that the Brazilian experience could and should be used as a building block for further development towards a more effective implementation of the human right to food by integrating social, economic and environmental concerns through agroecology, Hiran Catuninho Azevedo arguments in her study The role of sustainable learning policies on the fight against hunger in adult education that educational processes based on sustainability context bring the opportunity to rethink the lack of collective coordination on food security, especially among states. Understanding how industry and society grow and develop is essential to know how they learn and how we can innovate with them to fight hunger globally and promote inclusive growth.

Still debating on Brazil's advances on food security as a right and as a system, Fernanda Viegas Reichardt and Maria Elisa de Paula Eduardo Garavello presents the challenge of When dwelling corresponds to the buman right to food. They propose, after an extensive research project, a dialogue between three themes, territoriality, food sovereignty and human rights. This study's interest is restricted to the human right to food conceived in cultural terms linked to a territory, more specifically, in the native-Brazilian land of Pimentel Barbosa, a Xavante territory located in the Brazilian western state of Mato Grosso.

Bringing the attention of the Brazilian academia to other food security conditions, Ranjana Ferrao outlines Food security in India, analyzing and discussing a historical perspective of food management in India. This article dwells on the legislative changes made to ensure the right to food, the setting of administrative bodies and the creation of public welfare schemes. After a series of 
empirical and framework applications, it proposes some recommendations.

Finally, celebrating scientific knowledge connected to political action, this dossier hopes to contribute to the literature on the issue, and to aid other researchers in their work. Most of all, we hope to contribute to an education strongly based on discussions among stu- dents, researchers, practitioners and to inform the broader public about new developments and ideas on fighting hunger worldwide. For that, the WFP Centre of Excellence thanks the University Centre of Brasilia Law School faculty for the opportunity of jointly creating and disseminating this knowledge. Enjoy your reading. 


\section{CRÔNICAS SOBRE O DIREITO ALIMENTAR E O COMBATE À FOME}




\section{South-South Food and Nutrition Security promotion: the Brazilian experience multiplied}

João Almino*

Over the past few decades, Brazil has seen the strengthening of its South-South cooperation actions as an important axis of its foreign policy. At the same time, the country has experimented positive outcomes for its social policies, especially those impacting Food and Nutrition Security (FNS); thereby, driving the attention from the international community into Brazil's success story. Within the scope of the Hunger Zero strategy, which currently is United Nations Sustainable Development Goal 2, Brazil laid down a set of interlinked social instruments and frameworks. This policy intertwining, while furnishing Brazil with multisectoral and inclusive policy tools, has changed the country's FNS background, withdrawing the nation from the World Hunger Map and reducing significantly its indexes of extreme poverty.

Therefore, Food and Nutrition Security constantly solidifies itself as one of the main thematic axis of the Brazilian South-South cooperation. In this field, the knowledge and experience exchange from Brazil takes place in two strategic areas: school feeding and smallholder farming. It was precisely with the purpose of supporting countries in the development of sustainable school feeding programs that the Brazilian Cooperation Agency (ABC) signed a partnership with the World Food Programme (WFP) in 2010. This joint action allowed the creation of the Centre of Excellence against Hunger: a knowledge hub for sharing Brazilian experiences and best practices in sustainable school feeding, and a facilitator for the fulfilment of the demands of developing countries.

Both in this partnership, as well as in the South-South cooperation agen$\mathrm{da}$ as a whole, $\mathrm{ABC}$ is responsible for coordinating the Brazilian technical cooperation. Accordingly, it is the responsibility of $\mathrm{ABC}$ to negotiate, develop, execute, monitor and evaluate the initiatives resulting from the requests received from developing countries. Within the scope of the collaboration established with the Centre of Excellence, it is important to spotlight the support and expertise of the National Fund for the Development of Education (FNDE). This implementing institution, since the beginning of the ABC-WFP partnership, in 2010, has been providing technical and financial resources for the strengthening of school feeding programs in partner countries.

Proportionally, the political commitment of the Brazilian Government to eradicate hunger and poverty is able to find a concrete example in the partnership established between the Brazilian Cooperation Agency and the World Food Programme through its Centre of Excellence. With this collaboration, it became possible to share and to promote a comprehensive and integrated set of Brazilian public policies for FNS at an international level, stimulating qualified policy dialogue on this topic. As the Brazilian School Feeding model advocates the creation of an institutional market through the local purchase of foodstuffs from smallholder agriculture, the model guarantees the provision of nutritionally balanced and adequate meals, meeting the daily needs of students. The dissemination and acceptance of this

Brazilian diplomat and Ambassador-Director of the Brazilian Cooperation Agency. PhD in Philosophy, Sorbonne 
Brazilian model has been amplified due to the commitment and facilitation of the Centre of Excellence. Correspondingly, the dedication and professionalism of the Centre and its technicians have stood out in all the activities carried out during these 5 years.

Currently, the cooperation programme initiative prioritizes 23 countries. All the beneficiaries have already made study visits to Brazil and have received direct technical assistance through training activities, advisory, national consultations and participation in seminars. The joint work of ABC, FNDE and the Centre to strengthening global actors in Food and Nutrition Security was evidenced by the position adopted by African Union heads of state, which, at its 26th Summit in January 2016, recognized the value and potential of school feeding programs that promote the purchase of local foodstuffs. This was derived from an African Union study mission to Brazil in late 2015, led by the High Commissioner for Human Resources, Science and Technology. The visit was carried out through the partnership between the Government of Brazil and the Centre, which has motivated the adoption of the school feeding model as a continental strategy for improving educational indicators, for promoting smallholder farming, and for achieving the Sustainable Development Goals (SDGs).

Finally, reiterating its support to the actions taken in favor of FNS, the Brazilian Cooperation Agency celebrates the quinquennial of the Centre of Excellence against Hunger of the WFP under the feeling that united we can transform realities. Although there are still major challenges for overcoming poverty, reducing inequities and promoting social inclusion, $\mathrm{ABC}$ is sure that the collaboration between the Government of Brazil and the Centre of Excellence, powered by South-South cooperation programmes and projects, is an important instrument for overcoming these obstacles. 


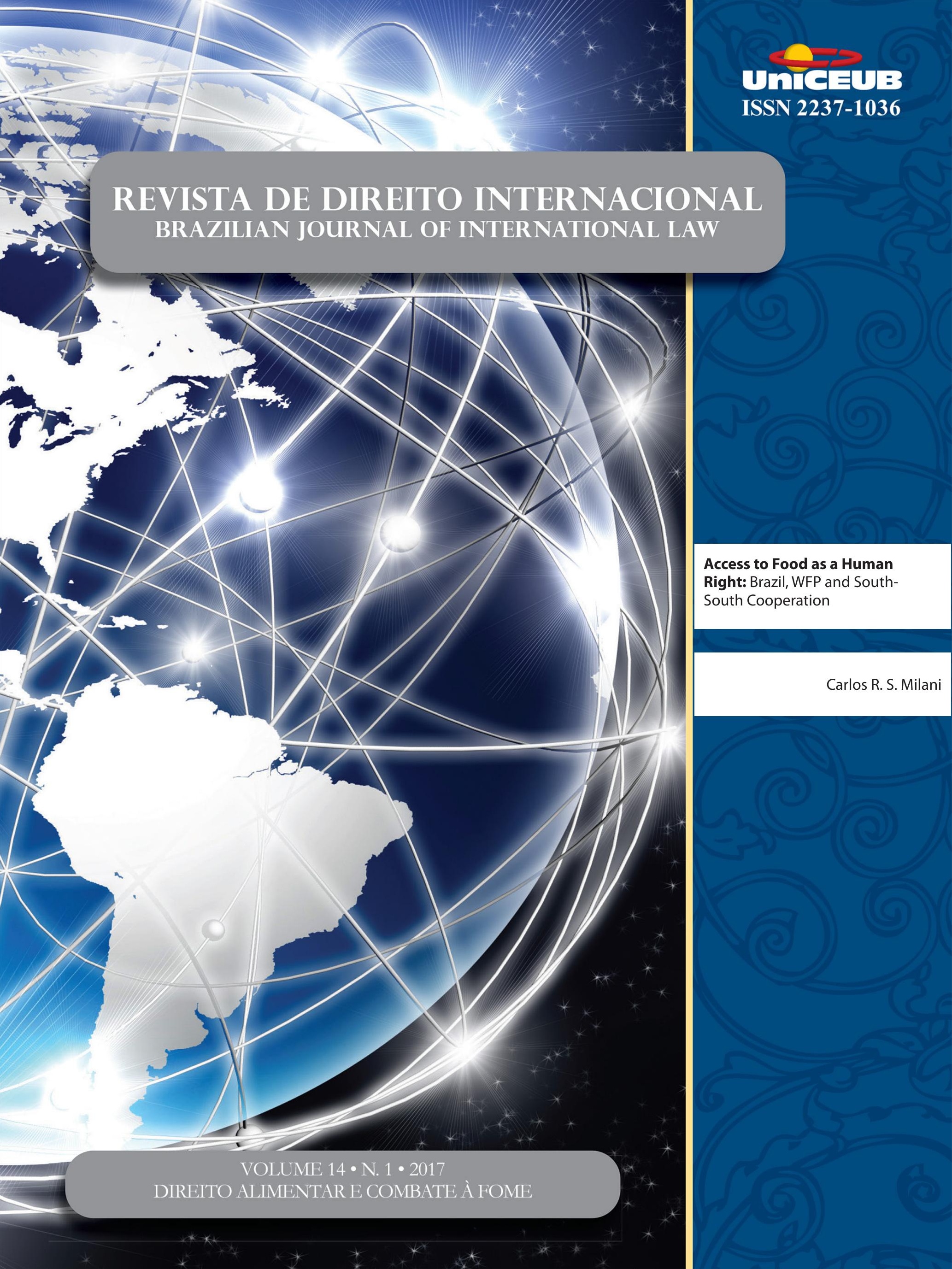




\section{Access to Food as a Human Right: Brazil, WFP and South-South Cooperation}

Carlos R. S. Milani*

Brazil's engagement with international development cooperation (IDC) as a provider is not new; its first experiences date back to the 1960's. However, Brazil's governmental funding and interest in IDC have grown since the 1988 Constitution, which marks the period of national re-democratization of State-society relations. Even if in the nineties Brazil also had some experiences as a provider of IDC, it was during President Lula's administration, after 2003, that both government and civil society organisations have placed a stronger political emphasis and financial resources on South-South cooperation, having mobilised civil servants, several ministries, federal agencies, and subnational entities in the conception and implementation of technical cooperation projects. As part and parcel of this engagement, Brazil's government has also set up a sustainable partnership with the World Food Program with the attempt to disseminate and transfer public policy norms, practices and procedures in the field of the global fight against hunger. Since 2003 Brazil's government has endeavoured to place hunger as one of the worst violations against human rights, thus building a strong coalition with WFP in defending the access to food and nutritional security by poorer populations in Brazil, in Latin America, in Africa and many other developing regions in the world.

Brazil's governmental action in this field is mainly related to policy transfer and policy diffusion in various fields such as local food purchase programs, school nutrition projects, as well as small farming and agriculture development activities. Even if the amounts related to Brazil's cooperation programmes should not be compared to what OECD-DAC countries have been doing in humanitarian aid and agriculture cooperation, Brazil's contribution can be analysed at least from two other perspectives: (i) agents and practices; (ii) norms and the symbolic regime.

\section{Agents and practices}

Delivering technical cooperation through civil servants from ministries and public agencies is one of Brazil's IDC main characteristics. Indeed, particularly since the 1988 Constitution and through the re-democratization years, civil servants and technical consultants have developed expertise in education, health, agriculture, culture, and public management, and have also gained suitable knowledge and first-hand experience on the actual functioning of the domestic politics and the complex interplay among interest groups. Civil servants are the main agents of implementation of Brazilian IDC; they tend to be less expensive than national and international market professionals, and come from several institutions, ministries, and public agencies such as FIOCRUZ (public health) or EMBRAPA (agriculture). Their participation in Brazilian IDC has so far contributed to hindering the increase of an "aid industry" in Brazil. As a result, many civil society organizations end up being excluded from IDC projects and programmes. There 
are exceptions such as Viva Rio, Associação Alfabetização Solidária (ALFASOL), Missão Criança, which are examples of NGOs currently being involved in the Brazilian Cooperation Agency's educational and humanitarian cooperation projects. By the way, it is relevant to highlight that several Brazilian NGOs dealing with rights (human rights, women's rights, right to development, right to a safe environment, etc.) criticize the Brazilian government for what they label as a "participation deficit", a subject that still needs more attention from academic social science research and advocacy policy networks.

\section{NORMS AND THE SYMBOLIC REGIME}

The Brazilian government, particularly between 2003 and 2015, defended that the access to food is a human right. Nonetheless, in the deployment of its IDC projects, the government avoided terminology, criteria and norms related to OECD's DAC and North-South Cooperation. Words such as aid, practices such as political conditionality (human rights, democracy, etc.), relationships such as donor/recipient, among others, were absent from the official diplomatic discourse and the Brazilian IDC narratives. A critical approach toward traditional aid, as well as the country's own capacities to promote its development without much dependency on North-South cooperation, have fostered the emergence of Brazil's IDC based on horizontality, non-conditionality and the demand-driven principle. In official documents produced by $\mathrm{ABC}$ and IPEA, for instance, horizontality implies a lack of hierarchical relationships between Brazil and its partner country, in terms of decision-making and project implementation; non-conditionality means that the Brazilian government respect other sovereign developing nations, and does not impose any political conditionality related to democracy or human rights attached to its IDC programmes; the demand-driven approach is rooted in the idea that developing countries are those who formulate and organize their demands in view of cooperating with Brazil, without any interference coming from Brasilia.

Of course all this diplomatic rhetoric needs to be contrasted with empirical research, which is just emerging within Brazilian and international academic and independent work. Moreover, particularly during Lula da Silva and Dilma Rousseff's mandates, Brazil's foreign policy has been investing in the construction of a sym- bolic regime that is also strongly rooted in South-South solidarity. Brazil is not a member of OECD, and favours debates and proposals on IDC under the umbrella of United Nations ECOSOC's Development Cooperation Forum, which is acknowledged by Brazilian foreign policy as a legitimate and universal multilateral institution or exchange and negotiation.

Besides, Brazil's refusal to apply the norm of political conditionality is another key aspect of Brazilian development cooperation in Haiti (and elsewhere). Brazil's government emphasizes State-to-State cooperation, respect for sovereignty, and a decision making process driven by the demands of the partner country as fundamental norms in its development cooperation programmes. Those who believe that donor countries can promote, and impose, their values (including liberal democracy) through their foreign aid policies generally criticize Brazil's refutation of the political conditionality norm. The same applies to those who think that beneficiary countries can actually change their domestic politics thanks to the donors' application of the conditionality clause.

Referring to Sciences-Po Professor Bertrand Badie's last book, Le Temps des Humilies, one can even say that the use of conditionality is revealing of a "politics of humiliation" that serves to reinforce the hierarchical relationship between the "donor" and the "receptor". The term "political conditionality" appears in various ways in the literature on development cooperation, but gained prominence from the 1980s and 1990s, though its first application it was during the period of structural adjustment programmes in the 1980s. Specialized literature is still today very divided on this issue: it lacks empirical evidence on reasons why or in which cases donor countries apply the political conditionality clause; there is no evidence either on the causal nexus between its application and domestic political improvement in beneficiary countries. In the case of Brazil, the government prefers the emphasis on sovereignty and national ownership to the promotion of human rights and democracy without taking the reality of local contexts into account.

All this being said, one should not forget that Brazil's official IDC programmes also provoke public debate within academic circles and civil society organisations on their private-public contradictions or even on the way Brazil may end up "exporting" its own domestic ten- 
sions in the field of agriculture development. Brazil promotes small scale farming and food security in its IDC activities, but it is also an agribusiness champion. In some cases IDC activities may also reveal conflicts of interests between peasants or small family agriculture, on one side, and large industrial agriculture, on the other. One example of such a conflict may be the Pro-Savana project developed in Mozambique by the Brazilian and the Japanese governments. With an aim to foster open evaluations and continuous monitoring of Brazil's present and future engagement with the World Food Programme and other bilateral and multilateral development agencies, these contradictions should also be at the heart of national and international public debates 


\section{DOSSIÊ TEMÁTICO: DIREITO ALIMENTAR E COMBATE À FOME}




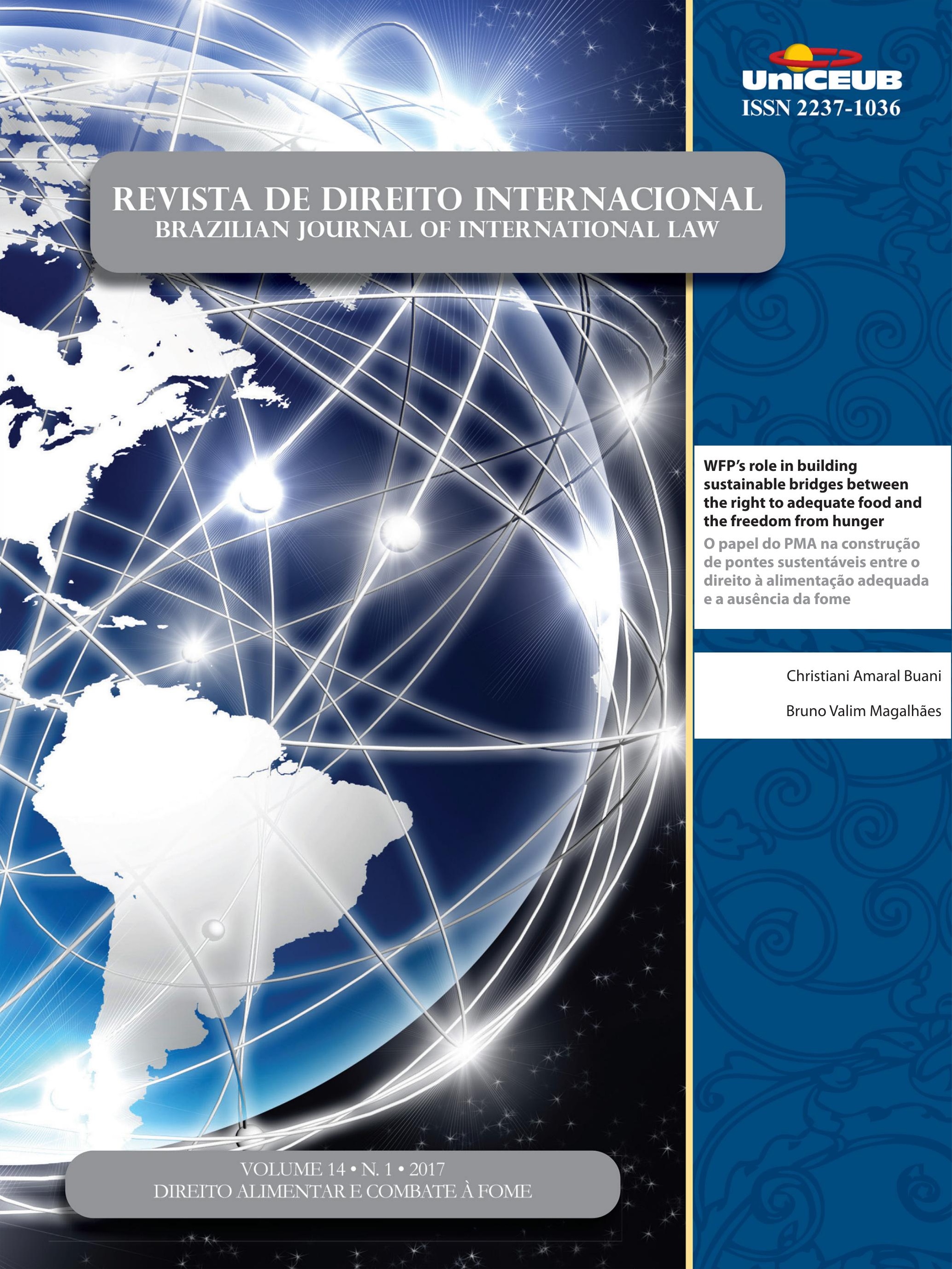




\title{
WFP's role in building sustainable bridges between the right to adequate food and the freedom from hunger*
}

\author{
O papel do PMA na construção de pontes \\ sustentáveis entre o direito à alimentação \\ adequada e a ausência da fome
}

\author{
Christiani Amaral Buani** \\ Bruno Valim Magalhães***
}

\begin{abstract}
This communication applies a human rights approach and a human security framework to the United Nations World Food Programme's dual-logic of food assistance-food aid. This is based on description and analysis of the evolution of UN's legal frameworks on the right to adequate food and the freedom from hunger. Estimations will rely on the analysis of WFP contribution on promoting food and nutritional security as a means for achieving the Zero Hunger sustainable development goal paradigm.
\end{abstract}

Key words: development aid, food assistance, food and nutrition security

\section{Resumo}

Esta comunicação aplica uma abordagem de direitos humanos e um quadro de segurança humana à lógica dual da assistência alimentar-auxílio alimentar do Programa Alimentar Mundial das Nações Unidas. Isso se baseou na descrição e análise da evolução dos quadros jurídicos das Nações Unidas sobre o direito à alimentação adequada e a ausência da fome. As estimativas aqui se basearão na análise da contribuição do PMA para a promoção da segurança alimentar e nutricional como meio de atingir o paradigma do objetivo de desenvolvimento sustentável Fome Zero.

Palavras-chave: auxílio ao desenvolvimento, assistência alimentar, segurança alimentar e nutricional

* Autores convidados

** $\mathrm{PhD}$ in International Law (University Centre of Brasilia) and head of the Programme team at the WFP Centre of Excellence against Hunger. E-mail: chris.buani@gmail.com

*** MSc in International Politics (University of Brasilia) and part of the Programme team at the WFP Centre of Excellence against Hunger. E-mail: bruno.magalhaes@wfp.org
One of the principles of modern Law is that its legality is neither restricted to the modern-states conceptuality nor is people-innate. Rather, it is an earthly social construct process. Accordingly, reflections and contestation are commanding activities to the maintenance of that precept. To rethink and to reinterpret constantly public commitments to international relations is to meditate on what the society is and on what the human consortium needs as lawful instruments for people protection and empowerment. As tools for $21^{\text {st }}$ century's legal design and enforcement, international institutions, such as the World Food Programme (WFP), cannot drift away from this juridical 
debate. Appropriately, this brief essay will stand on this legal background while applying both a human rights approach and a human security framework to WFP's dual-logic of food assistance-food aid. Estimations will rely on the analysis of this institution's human secure contribution on promoting food and nutritional security as intervenient variables; providing means for synthesis of a few outcomes on the global rights-based Zero Hunger sustainable development goal paradigm.

Currently, hunger is taken as a condition in which a person, for a sustained period, is unable to have sufficient access to available food to meet basic nutritional needs and perform essential daily activities. However, linking food availability and accessibility to its nutritional utilization is a relative new legal feature. Up to the 1980s, the food utilization adequacy was not boldly incorporated into the concept. Thereby, whenever focusing on the right to adequate food and freedom from hunger, it is relevant to highlight that related legal backgrounds play pivot-roles, since the end of the World War II, for scaling up social food and nutritional needs till today's Zero Hunger development goal. The first sight of this movement came with US President Franklin D. Roosevelt's call for the Hot Spring Conference, the cornerstone for the future UN Food and Agriculture Organization (FAO), in 1943. During this conference it was designed the concept that food security meant a "secure, adequate, and suitable supply of food for everyone", focusing mostly on the availability of food. Additionally, in a more idealistic sphere, in 1945, Roosevelt included in his Four Freedoms speech, as one of the freedoms: the freedom from want. Which would be included later by the UN as the access to wanted food. Sufficient availability and access to food would provide security and free people from hunger.

Despite no legal binding deriving from Roosevelt's actions in the late 1940s, those concepts of food security and freedom from want formed part of the 1948 Universal Declaration of Human Rights adopted by the United Nations, a global legal apparatus. Recognizing that this freedom is one fundamental part of the right to a human life with dignity and security, the 1948 Declaration cites that as a freedom to live in dignity, "Everyone has the right to a standard of living adequate for the health and well-being of himself and of his family, including food" (Article 25). From this point on, freedom from want got its food variable as an international lawful right. Continuously, in 1966, the Internatio- nal Covenant on Economic, Social and Cultural Rights reiterated the Universal Declaration of Human Rights, reinforcing the freedom from want as "the fundamental right of everyone to be free from hunger" (Article 11). Freedom from hunger would only cover both access and availability of food. No mention to the adequacy as the utilization of the food. Adequacy is linked to the quantitative supply sufficiency to the demand of food.

When it started to be noted that availability alone was not the only pathway for development and for self-sufficiency, the concept of food for development was introduced and institutionalized. The creation of the World Food Programme (WFP) in 1963 is one prominent example for that. Scheduled to go into operation in 1963, as a three-year experimental program, WFP's efforts focused on emergency assistance, relief and rehabilitation, and special operations. Initially its focus was on emergency assistance, or food aid logic, as its logistics helped save many communities by the distribution of food, giving people access to it. As the years passed, WFP followed the legal development this essay brings on. After the survival aid, featuring emergency relief and rehabilitation, the institution started seeking a fair performance of services for its served communities through technical cooperation programs. This new approach composed WFP's development aid feature, or the food assistance logic. Two logics for the same paradigm of freeing people from hunger.

In the 1980s, following the green revolution, which helped to increase food availability, it was recognized that food emergencies and even famines were not caused as much by catastrophic shortfalls in food production as by acute declines in the purchasing power of specific social groups. Therefore, food security was broadened to include both physical and economic access to food supply. In that decade, poverty alleviation and the role of women in development were promoted. Accordingly, as daily economic activities are one essential feature for overcoming poverty and gender inclusion, nutrition starts to come in as it is at the basis for proper personal performance as a health input. This scenario is one of the main reasons why after the entry into force of the of the Covenant, the Establishment of the Committee on Economic, Social and Cultural Rights, in 1985, oversaw the adoption of the General Comment No. 12 The Right to Adequate Food, describing the various UN member-states' obligations derived from the Covenant, regarding the right to food and freedom from hunger. 
Utilization of food is now parallel with food access and availability when treating hunger and can start to be seen, as well, as right to adequate food.

Subsequently, in the 1990s, concrete plans were defined to eradicate or at least reduce hunger and malnutrition drastically. In addition, the human right to adequate food and nutrition was internationally reaffirmed and committed national governments to a more proactive role. In addition to the fact that the academia and donors acknowledged that food aid alone, the provision/availability of food isolated, was a barrier for self-sufficiency and sustainable development. Later, in 2000, building upon a decade of major United Nations events, governments engaged in a new global partnership to reduce extreme poverty and setting out a series of time-bound targets that have become known as the Millennium Development Goals. The first one of these goals was to halve, between 1990 and 2015, the proportion of people who suffer from hunger, including nutrition.

This evolution evidences that modern Law structure has no existence or causal powers apart from social processes and their agents. Accordingly to this background, the right to adequate food became modernly characterized as the obligation to respect, promote, protect and to take appropriate steps to achieve progressively the full realization of all of this freedom from hunger lawful backdrop. Proportionally, the right to properly eating cannot be simply translated as having access to intake supply - the freedom from hunger stricto sensu till the 1980s.

It became immerged in social relations appropriate measures that guarantee the exercise and enjoyment of the right to adequate food, which intertwines intrinsically with development - hence, building sustainable bridges, as this essay proposes on its title. This is so because the right to adequate food now takes into consideration that provisions have adequate utilization and absorption of nutrients in aliment in order to all people at all times be able to live a healthy and active life. Consequently, in the late 1980s, as international regulations started moving beyond protecting people only from geopolitical risks, international legality became more concerned with a human secure life with dignity, or societal risks; what reinforces the considerations from the 1985 General Comment No. 12 onwards.

In a last analysis, this late $20^{\text {th }}$ century human secure focused jurisprudence aims at a child who did not die; a disease that did not spread; an ethnic tension that did not trigger; a dissident who was not silenced; a human spirit that was not crushed. It has been proven that people who are already free from hunger stricto sensu, but suffer from access to adequate food utilization are still at risk, because nutritional inadequacy not only hinders socioeconomic advance but also may cause human casualties, fostering the risks described just above. These factors threaten local, regional and international stability as people's lives might be at stake.

This ultimate ratio has led to new global conversations, and this right to adequate food has been translated as a crucial social debate within the United Nations 2030 Agenda and its 17 main durable objectives for global advances - a rereading of the Millennium Development Goals. Listed as the $2^{\text {nd }}$ Sustainable Development Goal (SDG) to be achieved on this 2030 Agenda, the Zero Hunger paradigm, as stated in the first paragra$\mathrm{ph}$, has consolidated itself into a single target-set able to double sustainable food production systems, mostly smallholder farmers' harvesting and stocking, and also capable to sustain that people keep free from hunger stricto sensu and free from any form of malnutrition. As a means to achieve such targets, the $17^{\text {th }}$ SDG, Partnerships for the Goals, aims at enhancing capacity building, policy and institutional coherence, and promoting multi-stakeholder partnerships. Moreover, it is interesting to visualize the evolution of the legal spectrum again affects those development goals. This essay has shown the construction of the debates from freedom from hunger to right to adequate food. Those led to the Millennium Development Goal of cutting by half hunger, which, finally, unfolded as the Zero Hunger challenge proposed by the SDG 2 .

This is why theorized change-pathways to achieving the SGD 2 agglomerates arguments around people-centered precepts. Reinforcement of this proposition requires a set of actions able to impact on the most emergent and urgent human food and nutritional needs and able to allow transition from quick action reliefs to locally owned capacities - food aid to food assistance. Finally avoiding the recurrence of inhumane conditions in the long run. Therefore, it is already consolidated in WFP's Strategic Plans and Policy Issues since 2009 that institutional effects are essential to achieve that transit to broader development goals. For example, in WFP's 2009-2013 and 2014-2017 Strategic Plans, an action designed to attend an emergency relief call should be scaled-up in a locally owned and efficient food and nutrition 
policies and legal landmarks logic; all integrated to social protection and food and nutrition security strategies. Concomitantly, focusing the planning on transitional outcomes to structuring the demand of local and smallholder agriculture; whose design and implementation are thought to be culturally and nutritionally sensitive.

Nevertheless, despite its importance and new developments, legal studies on food scarcely deepen into this human secure approach to the international law. Alternatively, this is why this communication attempts to find subsidy on WFP. Following a chronological argument evaluation, by the time of its creation, in the 1960s, the great purpose of the WFP was to be a multilateral organization that could use food provisions as an effective resource to promote development. As well as to respond rapidly to emergency needs - already constructing the bridges described above. WFP after the 1990s developed a dual-logic approach beyond food aid. The organization went beyond granting access and availability to food and started to assist peoples develop their own way to reach and produce adequate food, freeing themselves from hunger sustainably. Under these two logics, WFP put into action three spheres: emergency aid; pre-school and school meals; and other economic and social assistance as food for development projects.

Essentially, under this dual-logic paradigm and because of its name, WFP tended to be thought only as a special organization for the distribution of food to the hungry people in-crisis - meeting only freedom from hunger needs. Despite emergency relief and feeding of special vulnerable groups, WFP's recognized obligations' significance lays in its role as an instrument of human secure economic and social development, not only aid. WFP understood it should not only feed people: it could protect and empower them through the right to adequate food development without expanding its legal mission. This is why discussions in the late 2000s have shifted how this agency planned its policy issues and frameworks in its 2009 Policy on Capacity Development. Part of the larger triennial 20092013 and of 2014-2017 Strategic Plans, whose main goals were to consolidate the bridges this essay debates.

Explaining why WFP activities now recurrently include: the concept of national planning for social as well as economic development; the importance of the human factor in development and the urgent need to mobilize human resources; and the need to tackle the problem of under and unemployment that existed throughout developing nations. The type of aid legally granted by WFP is particularly suitable for the large subsistence of smallholding farming sector, the basis for locally consumed food, and this is why new tools for catalyzing this processes were needed.

Therefore, as food assistance started gaining a more essential role in projects involving a relatively high amount of labor, and as WFP understood that its purchase power to food distribution affects and shapes local markets, as it assists its sustainable development. Evidence-based studies have demonstrated that potential harmful effects could be avoided if food aid is granted as part of well-designed assistance development plans in emerging nations. Attaining the right to adequate food entailed development demands not only to meet freedom from hunger needs, but also to end these freedom demands.

This constitutes one of the reasons why WFP's legal framework for hunger and food design follows a collective-shared relations ethos and is able to rethink and to reinterpret constantly its public commitments to people's protection and empowerment. Mirroring the international conjectural developments since its foundation in the 1960s, WFP has, since 2009, migrated from an aid-strategic plan basis to an assistance-strategic plan basis without expanding its mandate or shocking it with UNDP's or FAO's, whose actions follow closely but do not overlap those of WFP.

Consecutively, as this sustainable bridges were built, WFP found evidences in Brazil of a leading example of how to overcome hunger with a people-centered approach able to complement the UN's agency long knowhow on food aid. The Brazilian transition from food aid to food assistance through its Zero Hunger strategy includes programs that bridge freedom from hunger and right to adequate food at the same time they proportionate local capacity building. Brazilian policies like its National School Meal Program, Food Acquisition Program and technical expertise assistance to smallholder farmers became some of the country's flagships.

Brazil's shift from food aid to food assistance, focusing on citizens' capacity development, brought closer Brazilian late 2000s' policies with WFP 2009's dual-logic shift. As a means to catalyze this national successful practice among demanding developing countries, Brazil and WFP combined their expertise on food and nutrition security and right to adequate food, both multiplied 
by South-South cooperation actions designed in one knowledge hub: the WFP Centre of Excellence against Hunger - created in Brasilia in 2010.

The Centre has engaged since 2010 with more than 75 emerging countries and has influenced more than 28 countries with tangible outcomes. Some results can be quickly measured as political and legal outputs for capacity development for sustainable food and nutrition security and right to adequate food, such as working and action plans, and some outcomes as full legal frameworks and policy structures to consolidate the sustainable bridge this essay argues about. These positive outcomes influenced part of a now driving normative policy for WFP's next five years. The development-enabling and life-empowering work that respect, promote and protect the poorest and most marginal people became today's central cause for WPF's strategic plans approach, such as the 2017-2021 Strategic Plan. Reinforcing 1948's and 1985's right to adequate food, and 2009-2013 and 2014-2017 Strategic Plans' designs.

Bringing the conclusions back to the Law's basic precept as an earthly social construct process, WFP strengthens legal frameworks as pivot-players, such as the Centre of Excellence, for scaling up social food needs to development goals as it incorporates into its strategies working collaboratively across institutional boundaries at the humanitarian-development and peace-building nexus. In-line with the 2017-2021 policy on WFP's role in human security and transition.

\section{ReferenCES}

BUANI, Christiani. Da reconstrução de estado ao desenvolvimento: por uma nova legitimidade das Nações Uni- das - o caso do Programa Mundial de Alimentos em Ruanda (Doctoral thesis). Brasilia: UniCEUB, 2014.

BUNDY, Donald et al. Rethinking School Feeding Social Safety Nets, Child Development, and the Education Sector. Directions in Development. Washington: The World Bank, 2014.

DEVEREUX, Stephen. Social Protection for Enhanced Food Security in Sub-Sabaran Africa. UNDP Working Paper 2012-010. New York: UNDP, 2012.

DOLOWITZ, David. MARSH, David. "Learning from Abroad: The Role of Policy Transfer in Contemporary Politics". Governance, v. 13, n. 1, Jan. 2000.

MARTIN, Mary; OWEN, Taylor. Routledge Handbook of Human Security. London: Routledge, 2013.

MOYO, Dambisa. Dead Aid: Why Aid Is Not Working And How There Is A Better Way For Africa. Vancouver: Douglas \& Mcintyre, 2009.

PARIS, Roland. "Human Security: Paradigm Shift or Hot Air?”. International Security, v. 26, n. 2, fall, 2001.

SHAW, John. The UN World Food Programme and the Development of Food Aid. London: Palgrave McMillian, 2001.

TADJBAKHSH, Shahrbanou. In Defense of the Broad View of Human Security. In: UNITED NATIONS. Good Practices in South-South and Triangular Cooperation for Sustainable Development. Nova York: UNSSC, 2016.

WORLD FOOD PROGRAMME. Centre of Excellence against Hunger. 2015. Available on: <http://documents.wfp.org/stellent/groups/public/documents/ reports/wfp275593.pdf?_ga $=1.232771807 .175049668$ 5.1470605167>. Access: 07 Aug. 2016. 


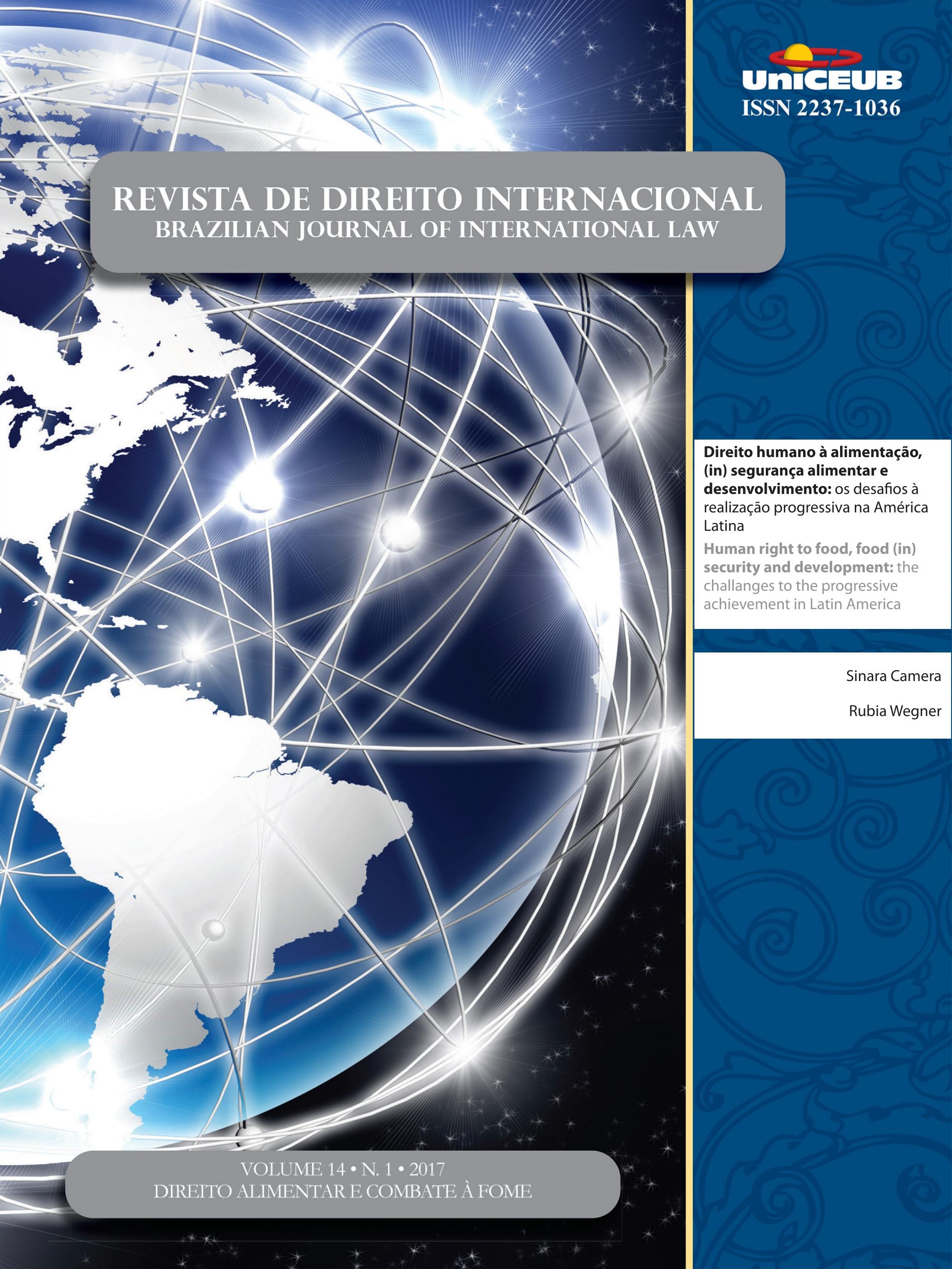




\title{
Direito humano à alimentação, (in) segurança alimentar e desenvolvimento: os desafios à realização progressiva na América Latina*
}

\author{
Human right to food, food (in) security \\ and development: the challanges to the \\ progressive achievement in Latin America
}

Sinara Camera**
Rubia Wegner***

\section{Resumo}

Desde a Conferência da Food and Agriculture Organization (FAO) de 1996, o direito humano à alimentação foi estabelecido como obrigação dos Estados nacionais. À comunidade internacional coube o papel de garantir que, nos países periféricos, fossem criados mecanismos de implementação de controle dessas obrigações. O que está em questão é garantir o acesso ao alimento e, nesse aspecto, além da geração de emprego e renda, estão a distribuição e a comercialização dos alimentos. Esses elos da cadeia ocorrem, especialmente, nos países subdesenvolvidos à revelia do setor privado que, em grande medida, são empresas transnacionais. O presente texto visa analisar, interdisciplinarmente, essas questões, à luz das medidas adotadas pelos países latino-americanos e europeus. A metodologia adotada nessa pesquisa teórica é bibliográfica e descritiva. Assim, serão analisados: a) os processos de internacionalização e diversificação dos direitos humanos forjando a criação de novos direitos a serem protegidos, como o direito humano à alimentação; b) a realização progressiva do direito humano à alimentação e do regime alimentar internacional em termos de desenvolvimento econômico; c) a questão da segurança alimentar e nutricional e a progressiva realização do direito humano à alimentação, a partir das experiências da União Europeia e América Latina. Nesse contexto, verifica-se que o maior desafio à realização progressiva do direito humano à alimentação na América Latina está nos fatores econômicos e estruturais e referentes à evolução do sistema agroalimentar internacional.

Palavras-chave: Direito humano à alimentação. Segurança alimentar e nutricional. Regime alimentar internacional. Desenvolvimento. América Latina.

\section{Abstract \\ ABSTRACT}

\footnotetext{
Estadual de Campinas (UNICAMP/SP/Brasil). Departamento de Ciências Econômicas da Universidade Federal Rural do Rio de Janeiro. E-mail: rubicawegner@gmail.com

** Professora do Curso de Direito das Faculdades Integradas Machado de Assis (FEMA/ Universidade do Vale do Rio dos Sinos (UNISINOS/RS/Brasil), com período de doutoramento sanduíche na Universidade de Sevilla (US/ cana, área de concentração Direito do Mestrado em Integração Latino-Americana (MILA) da Universidade Federal de Santa Maria (UFSM/ RS/Brasil). E-mail: aiacamera@hotmail.com
}

Since the Food and Agriculture Organization (FAO) Conference in 1996, the human right to food was established as an obligation of national states. To the international community fit the role to ensure that, in the 
peripheral countries, implementation of control mechanisms of these obligations were created. The question was to ensure access to food and, in this respect, in addition to generating employment and income, are the distribution and marketing of food. These links in the chain occur especially in developing countries by default private sector that largely are transnational companies. This text aims to analyze interdisciplinar these issues in the light of the measures adopted by Latin American and European countries. Thus, will be analyzed a) the internationalization and diversification of human rights forging the creation of new rights to be protected, such as the human right to food; b) about the progressive achievement of human right to food in the international food regime in terms of economic development; and c) the issue of food and nutricional security and the progressive achievement of human right to food from european union and latin america experiences. In this context, the greatest challenge to the progressive achievement of the human right to food in the Latin Ameri$\mathrm{ca}$ is in the economic and structural factors and related to the evolution of the international agrifood system.

Keywords: Human right to food. Food and nutricional security. International food regime. Development. Latin America.

\section{INTRODUÇÃo}

Desde os arranjos que antecedem a Declaração Universal dos Direitos Humanos, de 1948, há esforços no sentido de promover a realização desses direitos, buscando-se envolver os Estados a não só comprometerem-se na sua garantia, mas também a criarem meios para efetivá-los. Para isso, as leis são essenciais, mas a sua existência não é suficiente; faz-se necessário o desenvolvimento de políticas que viabilizem a sua concretização. Diante dos cenários de aprofundamento e diversificação dos direitos humanos, notadamente após a Década de 1990, nos processos de afirmação internacional e nacionais, surgem novos direitos fundamentais à dignidade humana.

Nesse catálogo está o direito humano à alimentação (DHA), estabelecido na Conferência da Food and Agriculture Organization (FAO) de 1996, como obrigação dos Estados Nacionais pela sua efetivação. Determinou-se, também, que à comunidade internacional caberia o papel primordial de garantir que, nos países periféricos, erigissem-se mecanismos com vistas a torná-lo mais do que um jogo abstracionista. Essas diretrizes buscam permitir acompanhar instrumentos dos Estados e da comunidade internacional, notadamente da FAO, e suas articulações práticas. O que está em questão é garantir o acesso ao direito a alimentos e, nesse aspecto, além de, reconhecidas as condições à segurança alimentar, observada a geração de emprego e renda, estão a distribuição e a comercialização dos alimentos.

Nesse contexto, relações econômicas, comerciais e financeiras, entenda-se — se consubstanciam às dificuldades de realização do DHA. Em 2013, o índice de preços dos alimentos da FAO marcou em média 209,9 pontos, estando 1,6\% abaixo do registrado em 2012 e $9,1 \%$ menor do que o relativo a 2011, quando este índice alcançou níveis inauditos. Cereais - em crescimento próximo a 7,2\% em relação a 2012 —, óleos e açúcar tiveram seus preços reduzidos em função do aumento da sua oferta, enquanto que carne - alimentos proteicos de modo geral — seguiu com preço elevado.

A importância desse artigo se encontra no contexto de aumento dos índices de fome e desnutrição no mundo e a segurança alimentar e nutricional ${ }^{1}$ foi, amplamente, tratada em termos dos limites ao acesso e as condições da comercialização e distribuição de alimentos foram discutidas em fóruns mundiais. No entanto, os avanços para solucionar esse problema foram limitados, mas não podem ser considerados ineficazes de todo. Entre 2010 e 2012, aproximadamente 870 milhões de pessoas não consumiram alimentos a contento das necessidades nutricionais diárias; desse total, pelo menos 852 milhões vivem em países subdesenvolvidos. ${ }^{2}$ Ainda de acordo com dados da Organização das Nações Unidas para Fome e Alimentação (FAO), em 2009, eram mais de um bilhão de pessoas em situação de fome no mundo, das quais 63\% estariam na África.

Dessa forma, o presente artigo visa analisar as ques-

1 Segurança alimentar e nutricional é a realização do direito de todos ao acesso regular e permanente a alimentos de qualidade, em quantidade suficiente, sem comprometer o acesso a outras necessidades essenciais, tendo como base práticas alimentares promotoras de saúde, que respeitem a diversidade cultural e que sejam social, econômica e ambientalmente sustentáveis. MALUF, Renato Sérgio. Segurança Alimentar e Desenvolvimento Econômico na América Latina: o caso do Brasil. Revista de Economia Política, São Paulo, n.15, p.134-140, 1995.

2 Dados de 2013, retirados da Food and Agriculture Organization, disponíveis em: < http://www.fao.org/home/en/>. 
tões da progressiva realização do direito humano à alimentação nos Estados, observando-se as condições para a segurança alimentar e nutricional, a partir da análise dos principais movimentos e mecanismos estatais na América Latina em comparação com medidas da União Europeia. Essa comparação é uma forma de se pensar a relação entre realização do direito humano à alimentação com desenvolvimento econômico. Para tanto, dividiu-se o presente trabalho em três momentos: primeiramente serão analisados. Assim, serão analisados os processos de internacionalização e diversificação dos direitos humanos forjando a criação de novos direitos a serem protegidos, como o direito humano à alimentação. Em um segundo momento, discorrer-se-á sobre a realização progressiva do direito humano à alimentação e do regime alimentar internacional em termos de desenvolvimento econômico. Por fim, será tratada a questão da segurança alimentar e nutricional e a progressiva realização do direito humano à alimentação, a partir das experiências da União Europeia e América Latina.

\section{Direito humano à alimentação: Contexto DO SURGIMENTO E DA AFIRMAÇÃO}

A partir do pós-Segunda Guerra Mundial, inicia-se a expansão dos direitos humanos, impulsionada pela internacionalização desses direitos, sendo colocados como referencial ético para orientar as relações intra e interestais. A ruptura no paradigma de direitos humanos, vigente até aquele momento, abre uma senda para a reflexão acerca da necessidade da reconstrução de cenários: interno, com o esforço adequação (em maior ou menor medida, nos diferentes espaços do Globo) a novos padrões éticos e morais; e externo, com o surgimento do Direito Internacional dos Direitos Humanos (DIDH).

O desenvolvimento do DIDH consiste na construção de um sistema de normas internacionais, que preveem procedimentos e firmam instituições para garantir a implementação dessa nova concepção de direitos humanos, promovendo mundialmente o seu respeito nos e pelos Estados. Ainda, há que se considerar, nesse processo de afirmação de uma ordem internacional para a proteção dos direitos humanos, a própria criação da Organização das Nações Unidas $(\mathrm{ONU})^{3}$ e das suas

3 Destarte, a busca pelos objetivos da ONU é marcada pela crescente normatização internacional dos direitos humanos e leva a so- agências especializadas. ${ }^{4}$ A expansão de organizações internacionais com propósitos de cooperação amplia, significativamente, a agenda internacional para que se possam conjugar novas e emergentes preocupações na proteção dos direitos humanos.

Como documento inaugural, tem-se a Declaração Universal de 1948, que a concepção contemporânea de Direitos Humanos e suas intenções de universalidade e indivisibilidade. A ela se somam os Pactos Internacionais sobre Direitos Civis e Políticos e o sobre Direitos Sociais, Econômicos e Culturais, de 1966. Os três documentos passam a representar o International Bill of Human Rights (a Carta Internacional dos Direitos Humanos), declarada jus cogens pela Corte Internacional de Justiça (CIJ), em 1970. À Carta foram acrescidos uma série de amplos tratados especiais de direitos humanos (proscrição da tortura, extinção das formas de discriminação em relação à mulher etc.). ${ }^{5}$

Ainda, na Conferência Mundial dos Direitos Humanos de Viena, promovida pelas Nações Unidas, em 1993, foi reforçada a validade universal dos direitos humanos, apesar de uma certa resistência dos países asiáticos, que tentavam relativizá-los e de uma outra cosmovisão da interpretação islâmica dos direitos humanos. A Declaração de Direitos Humanos de Viena, em seu \ $5^{\circ}$, afirma: "todos os direitos humanos são universais, interdependentes e interrelacionados. A comunidade internacional deve tratar os direitos humanos globalmente, de forma justa e equitativa, em pé de igualdade e com a mesma ênfase."

ciedade internacional a não mais admitir a soberania como obstáculo à sua atuação para evitar ou cessar violações. Dessa forma, aumentam as pressões da comunidade internacional para que as condutas estatais estejam compassadas com a observância dos direitos fundamentais dos indivíduos que se encontram em seu território. A ONU tem como objetivos: a defesa dos direitos fundamentais do ser humano; garantir a paz mundial, colocando-se contra qualquer tipo de conflito armado; buscar mecanismos que promovam o progresso social das nações; criar condições que mantenham a justiça e o direito internacional. ORGANIZAÇÃO DAS NAÇÕES UNIDAS. Carta das Nações Unidas. 1945. Disponível em: <http:// www.un.org/spanish/Depts/dpi/portugues/charter/index.htm>. Acesso em: 10 out. 2016.

4 As agências especializadas, como a Organização das Nações Unidas para a Alimentação e Agricultura (FAO), a Organização das Nações Unidas para a Educação, Ciência e Cultura (UNESCO), a Organização Mundial da Saúde, entre outras, são criadas mediante acordo firmado por Estados, vinculadas às Nações Unidas, mas possuem autonomia, com independência jurídica e de conteúdo.

5 BIELEFELDT, Heiner. Filosofia dos Direitos Humanos. Trad. Dankwart Bernsmüller. São Leopoldo: UNISINOS, 2000, p.11. 6 ORGANIZAÇÃO DAS NAÇÕES UNIDAS. Declaração e 
A Década das Conferências, como ficou conhecida a de 1990, exsurge a fim de encontrar respostas à complexidade das temáticas assumidas como prioridades, diante da inter-relação entre segurança, economia, direitos humanos e democracia, apresentando a conexão global entre elas. Esse contexto fez com que se disseminasse a concepção de que

[...] se os temas abordados eram globais, o que ocorresse numa área afetaria as outras. A indução lógica poderia levar também a uma interpretação político-jurídica se não kantiana, de imperativos éticos categóricos, pelo menos grociana, de interesses compartilhados: num mundo efetivamente globalizado, o interesse de todos seria o interesse de cada um; as diferenças individuais de enfoques podem e devem ser administradas pelo Direito. Em lugar da abstenção perante as jurisdições nacionais, as conferências propunham esforços abrangentes, de todos os atores influentes.

A Declaração de Viena e o Programa de Ação, considerando as grandes mudanças ocorridas no cenário internacional, incluem, como temas fundamentais: a promoção e o incentivo do respeito aos direitos humanos e às liberdades fundamentais para todos; do respeito ao princípio da igualdade de direitos e da autodeterminação dos povos; da paz; da democracia; da justiça; da igualdade; do Estado de direito; do pluralismo; do desenvolvimento; das melhores condições de viver e de solidariedade. Tudo a fim de dar novos passos no compromisso da comunidade internacional, com vistas a alcançar progressos substanciais nos direitos humanos. ${ }^{8}$ Em relação ao cenário de desenvolvimento de novos direitos a serem protegidos, surge em 1996, na Conferência da FAO, o direito humano à alimentação. Os Estados Nacionais devem garantir a sua efetivação. À comunidade internacional cabe o papel de garantir que, nos países periféricos, erijam-se mecanismos com vistas a torná-lo mais do que um jogo abstracionista. O que está em questão é garantir o acesso ao alimento e, nesse aspecto, a geração de emprego e renda, bem como a distribuição e a comercialização dos alimentos.

Programa de Ação de Viena. 1993. Disponível em: < http:/ /www. pge.sp.gov.br/centrodeestudos/bibliotecavirtual/instrumentos/ viena.htm>. Acesso em: 10 out. 2016.

7 ALVES, José Augusto Lindgren. Relações Internacionais e Temas Sociais. A Década das Conferências. Brasília: IBRI, 2001. 8 ORGANIZAÇÃO DAS NAÇÕES UNIDAS. Declaração e Programa de Ação de Viena. 1993. Disponível em: < http://www. pge.sp.gov.br/centrodeestudos/bibliotecavirtual/instrumentos/ viena.htm>. Acesso em: 10 out. 2016.
O direito humano à alimentação (DHA) vem adquirindo maior importância no embasamento de programas voltados para garantir a segurança alimentar e nutricional (SAN) e de leis de segurança alimentar em diferentes países. A perspectiva desse direito traça elementos específicos para a atuação do Estado no tocante ao acesso aos alimentos pela população, podendo ser definido por:

[...] ter acesso, de maneira regular, permanente e livre, seja diretamente, seja mediante compra em dinheiro, a uma alimentação quantitativa e qualitativamente adequada e suficiente, que corresponda às tradições culturais da população a que pertence o consumidor e que garanta uma vida psíquica e física, individual e coletiva, livre de angústias, satisfatória e digna. ${ }^{9}$

A construção desse conceito foi marcada por um longo caminho de discussões em organismos internacionais, ${ }^{10}$ tendo em vista a complexidade que o tema envolve. Em outras palavras, os embates na sua construção se relacionavam com a definição os responsáveis pelo seu cumprimento, as punições cabíveis, custos e recursos e, ainda, dois aspectos mais abstratos: a sua definição e orientação para ser cumprido pelo mundo subdesenvolvido partia de países ricos, impulsionadores de uma 'ordem alimentar mundial' extremamente desfavorável para as populações pobres dos países subdesenvolvidos. Além disso, trata-se de um direito de todas as pessoas, mas aquelas afetadas pela fome se destacariam das demais em termos de medidas e de programas adotados sob a definição de DHA. Além disso, por falta de condições físicas, psicológicas, as pessoas em situação de fome não teriam capacidade de atuarem como sujeitos do seu direito a uma alimentação adequada. ${ }^{11}$

Não se coloca em dúvida o quão imprescindível é o consumo diário e em quantidades adequadas de nutrientes pela população de um país. Sabe-se, também,

9 FOOD AND AGRICULTURE ORGANIZATION. Diretrizes voluntárias: em apoio à realização progressiva do direito à alimentação adequada no contexto da segurança alimentar nacional. Roma, 2004. Disponível em: <http://www.fao.org/docrep/006/ Y5160s/Y5160s00.htm>. Acesso em: 12 out. 2016, p. 04. Para maiores esclarecimentos e reflexões se indica: BOURRINET, Jacques; FLORY, Maurice. L'ordre alimentaire mondial. Economica: Paris, 1982.

10 Com base nas leituras feitas, acredita-se que o debate, nos organismos multilaterais, sobre essa limitação conceitual tenha se intensificado nos anos 1980.

11 HABIB, Bernard. Droits de l'homme et alimentation. In: BOURRINET, Jacques; FLORY, Maurice L'ordre alimentaire mondial. Economica: Paris, 1982. 
que essa imprescindibilidade por si só não determina que todos tenham acesso a alimentos. Como exemplo, em 2009, havia um bilhão de subnutridos no mundo, dos quais 53 milhões eram latino-americanos. ${ }^{12}$ Alimentar-se é uma necessidade básica do ser humano, que requer uma regulamentação pública com vistas a garanti-la em condições adequadas à população. Os números ligados à situação alimentar no mundo, de modo geral, mostram que os Estados nacionais, especialmente os não desenvolvidos, não alcançaram uma fórmula para solucionarem a inacessibilidade aos alimentos.

Mobilizações internacionais destinadas a transformar, positivamente, o quadro da fome no mundo, no que se destacam os Objetivos para o Desenvolvimento do Milênio do que a assinatura das diretrizes voluntárias é resultante, os números parecem difíceis de serem contornados favoravelmente:

\begin{abstract}
Aunque se han logrado progresos significativos hacia la consecución de la meta establecida en los objetivos de desarrollo del Milenio (ODM) de reducir a la mitad la proporción de personas subnutridas, será necesario acelerar el ritmo a fin de poder alcanzar el objetivo para el año 2015. Lograr el objetivo de la CMA de reducir el número absoluto de personas hambrientas de casi 800 millones a 400 millones resultará más difícil, pues para ello se requerirán progresos mucho más rápidos. ${ }^{13}$
\end{abstract}

Por outro lado, tão ou mais importante do que o estabelecimento do seu conceito é a importância da sua materialização: "[...] food security stands as a fundamental need, basic to all human needs and the organisation of social life. Access to necessary nutrients is fundamental, not only to life per se, but also to stable and enduring social order." "N No sentido colocado por Josué de Castro, em Geopolitica da Fome, tratar da questão do acesso aos alimentos significa a valorização fisiológica do homem. A carência de nutrientes na dieta alimentar constitui fator para reduzir a capacidade da população em se desenvolver como seres humanos plenos. ${ }^{15}$

12 FOOD AND AGRICULTURE ORGANIZATION. El estado mundial de la agricultura y la alimentación. Roma, 2009. Disponível em: <http://www.fao.org/docrep/012/i0680s/i0680s. pdf $>$. Acesso em: 12 out. 2016.

13 FOOD AND AGRICULTURE ORGANIZATION. El estado mundial de la agricultura y la alimentación: comercio agrícola y pobreza ¿puede el comercio obrar en favor de los pobres? Roma, 2005. Disponível em: <ftp://ftp.fao.org/docrep/fao/008/ a0050s/a0050s_full.pdf >. Acesso em: 12 out. 2016.

14 HOPKINS apud MAXWELL, Simon. Food security: a postmodern perspective. Food Policy, v.21, n.2, p.155-170, 1996, p.158. 15 CASTRO, Josué de. Geopolítica da Fome: ensaio sobre os problemas de alimentação e de população. v.1. São Paulo: Brasil-
Nos últimos anos, tem-se percebido um reforço da importância de se alcançar a condição de Segurança Alimentar e Nutricional em que a realização progressiva do Direito Humano à Alimentação estaria concretizada. Representa considerar, normativamente, o alimento como um requerimento para a existência humana e uma exigência das/para as atividades humanas. É essencial; deve ser tomado pela sua totalidade, caso contrário, não seria imprescindível. Para se efetivar, a alimentação precisa ser encarada em toda sua complexidade: condições da produção agroalimentar, nível de desenvolvimento do país, confiança nas instituições.

Entretanto, não existem determinações claras sobre o melhor método para construir o caminho para a realização do DHA, isto é: garantir o acesso ao alimento com base na transferência de renda monetária ou atrelada à compra de alimentos. Afinal, se ao Estado cabe obrigação de garantir alimentação suficiente e adequada, então, uma política de transferência de renda para se enquadrar, conceitualmente, na garantia da segurança alimentar deve ser complementada com dispositivos para tal. ${ }^{16}$

O direito ao desenvolvimento econômico está, reiteradamente, atrelado ao direito alimentar. ${ }^{17}$ Entretanto, a efetivação do direito humano à alimentação, a garantia de que será, progressivamente, realizado nos países não desenvolvidos, envolve toda a comunidade internacional. Além disso, evidencia o hiato existente entre as economias avançadas e periféricas, quanto à inserção econômica internacional.

\section{A ReAlização progressiva do direito HUMANO À ALIMENTAÇÃO, REGIME ALIMENTAR INTERNACIONAL E DESENVOLVIMENTO}

Nas Diretrizes Voluntárias - documento elaborado pela $\mathrm{FAO}$, em $2004^{18}$ - estabelece-se a recomendação

iense, 1968.

16 TAKAGI, M. et al. A política de segurança alimentar e nutricional do Brasil a partir do programa Fome Zero. In: ORTEGA, A.C.; ALMEIDA FILHO, N. Desenvolvimento territorial, segurança alimentar e economia solidária. Campinas-SP: Editora Alínea. 2006, p.159-184.

17 EIDE, Asbjorn. Human rights requirements to social and economic development. Food Policy, v. 21, n. 1, 1996, p. 23-39.

18 Sua mais recente edição foi lançada em 2015, mas o texto segue substancialmente sendo o aprovado em 2004. Pode-se acessar a edição de 2015 em: <http://www.fao.org/3/b-y7937o.pdf>. 
para que todos os atores internacionais assumam responsabilidades pela alimentação. Ressalta, também, o comércio internacional como importante mecanismo para o estabelecimento da Segurança Alimentar e Nutricional por meio da promoção do desenvolvimento econômico que ele deve acarretar. Atenta para o papel da Organização Mundial do Comércio (OMC) na regulamentação de um comércio menos desigual entre países desenvolvidos e não desenvolvidos. ${ }^{19}$ Ademais, no comércio agrícola pesam os subsídios e outras tarifações utilizadas pelos países desenvolvidos.

Além disso, o referido documento ressalta a importância da atuação conjunta da comunidade internacional para a realização progressiva do direito humano à alimentação, colocando-a em termos de cooperação técnica, descrita como segue:

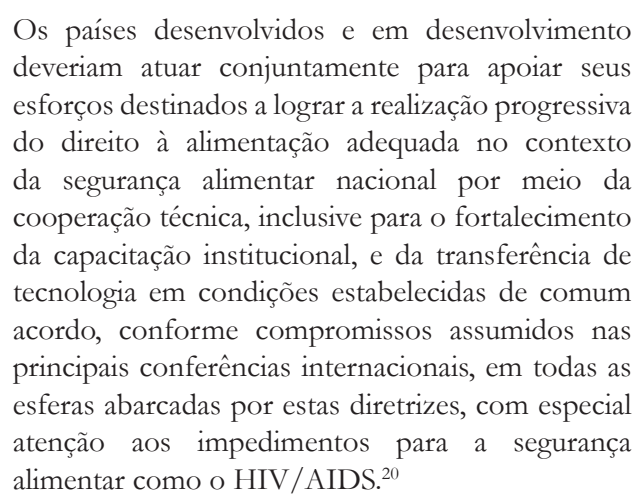

Entretanto, há elementos caracterizadores do sistema alimentar mundial que tendem a interferir na realização progressiva do direito humano à alimentação seriam: concentração de poder e de recursos nas grandes companhias de produção e de distribuição de alimentos, sistemas de ofertas de alimentos que excluem os pequenos agricultores, que produzem em menor escala, comércio internacional excludente até mesmo nas negociações para arrefecimento de barreiras. ${ }^{21}$

Numa perspectiva histórica, a constrição de alimentos detonada pela $2^{a}$ Guerra Mundial nos países desen-

19 FOOD AND AGRICULTURE ORGANIZATION. Diretrizes voluntárias: em apoio à realização progressiva do direito à alimentação adequada no contexto da segurança alimentar nacional. Roma, 2004. Disponível em: <http://www.fao.org/docrep/006/ Y5160s/Y5160s00.htm>. Acesso em: 12 out. 2016.

20 FOOD AND AGRICULTURE ORGANIZATION. Diretrizes voluntárias: em apoio à realização progressiva do direito à alimentação adequada no contexto da segurança alimentar nacional. Roma, 2004. Disponível em: <http://www.fao.org/docrep/006/ Y5160s/Y5160s00.htm>. Acesso em: 12 out. 2016.

21 MAXWELL, Simon; SLATER, Rachel. Food policy: old and new. Food Policy, v.21, n.5-6, 2003, p.531-553. volvidos, sobretudo, deu à autossuficiência de alimentos um caráter praticamente de segurança nacional e de condição básica para existência de segurança alimentar. Nesse cenário nasce a Organização das Nações Unidas para a Alimentação e a Agricultura (FAO), em 16 de outubro de $1945 .^{22}$ A pauta era organizar os alimentos e a agricultura com vistas a orientar a produção e a distribuição dos alimentos e evitar situações de carestia.

Essas discussões, para ordenar a agricultura internacional em termos de política comercial, evidenciaram os protecionismos dos EUA e Europa para com o setor. Destarte esses países perseguirem o livre comércio, esse arranjo internacional para agricultura fez valer os interesses protecionistas dos países avançados. Os EUA, por exemplo, conseguiram manter suas medidas de controle de importação e comércio administrado por meio do GATT (General Agreement on Tariffs and Trade ou Acordo Geral de Tarifas e Comércio), em detrimento da Organização Internacional do Comércio. A impossibilidade desses países se entenderem, EUA e Grã-Bretanha principalmente, solapou a emergência de uma Comissão Internacional de Alimentos (World Food Board) e, por conseguinte, de um planejamento multilateral eficiente na distribuição de alimentos. Assim, a organização dos alimentos se tornou nacionalmente regulado. ${ }^{23}$

O sistema de comércio pró-desenvolvimento é aquele que se fundamenta em países ricos reduzindo suas tarifas e subsídios para os países menos desenvolvidos, ainda que a concorrência imperfeita dos mercados impeça afirmar que o livre comércio poderia beneficiar todos os produtores de commodities agrícolas dos países em desenvolvimento. ${ }^{24}$

As desregulamentações ${ }^{25}$ do sistema financeiro ame-

22 A FAO é a Organização das Nações Unidas para a Agricultura e Alimentação. Maiores informações sobre a Organização podem ser acessadas em: <http://www.fao.org/home/en/>, ou na FAO Brasil: <https://www.fao.org.br/>.

23 FRIEDMANN, Harriet. Uma Economia Mundial de Alimentos Sustentável. In: BELIK, W.; MALUF, R.S. (orgs.) Abastecimento e Segurança Alimentar: os limites da liberalização. Campinas: IE/Unicamp, 2000, p. 1-22.

24 SHAIKH, Anwar. Globalization and the myth of free trade. New School University: New York, 2003.

25 A revolução dos derivativos foi essencial para a estabilização dos mercados de moedas e fomentando a capacidade global de distribuição dos títulos do Tesouro americano, a partir da derrocada do câmbio fixo. Redução dos custos dentro dos EUA, com o aumento das economias de escala adquiriu função anti-inflacionária sob o dólar ancorando o capitalismo mundial. Não se tratava de redução do papel do Estado americano, mas da defesa do fim da regulação. 
ricano e europeu iniciadas entre as décadas de 1970 e 1980, e aprofundadas nas décadas que se seguiram, tornam ainda mais complexa a relação entre países desenvolvidos e em desenvolvimento no sistema alimentar global (Quadro 1). Dessa forma, os EUA se tornam o epicentro da análise dos fatores influentes sobre a realização progressiva do DHA. Em uma perspectiva histórica, o despejo de grãos, em economias subdesenvolvidas, promovido pelos EUA no auge daquele processo na década de 1980, permitiu o reforço deste, além de tornar ainda mais difícil o acesso à alimentação nesses países (Quadro 1). Veja-se o tratamento à agricultura dispensado pelos EUA e sua relação com a posição do mercado internacional entre 1900 e1990:

\begin{tabular}{|c|c|c|}
\hline Período & Contexto & Tratamento à agricultura \\
\hline $\begin{array}{l}\text { Corolário da } \\
\text { Doutrina Mon- } \\
\text { roe de Theodore } \\
\text { Roosevelt, } 1904\end{array}$ & $\begin{array}{l}\text { Construção uma } \\
\text { área de livre } \\
\text { comércio especial- } \\
\text { mente com seus } \\
\text { vizinhos }\end{array}$ & $\begin{array}{l}\text { Logística eficiente e acor- } \\
\text { dos tarifários para comer- } \\
\text { cializar bens agrícolas ao } \\
\text { menor custo. }\end{array}$ \\
\hline Crise de 1929 & $\begin{array}{l}\text { Produção indu- } \\
\text { strial representava } \\
42 \% \text { do total } \\
\text { mundial, embora } \\
\text { houvesse desigual- } \\
\text { dade da economia } \\
\text { doméstica }\end{array}$ & $\begin{array}{l}\text { Estava particularmente } \\
\text { vulnerável a desvalori- } \\
\text { zação de preços. }\end{array}$ \\
\hline $\begin{array}{l}\text { Entre as décadas } \\
\text { de } 1940 \text { e } 1970\end{array}$ & $\begin{array}{l}\text { Comércio exterior } \\
\text { era mecanismo } \\
\text { para compensar } \\
\text { excesso de capaci- } \\
\text { dade e penetrar no } \\
\text { aparato de policy- } \\
\text { making dos países } \\
\text { europeus objeto } \\
\text { do Plano Marshall. }\end{array}$ & $\begin{array}{l}\text { As exportações da agri- } \\
\text { cultura eram muito im- } \\
\text { portantes, porém se man- } \\
\text { tinham em apenas } 5 \% \text { do } \\
\text { PIB de } 1929 \text {. }\end{array}$ \\
\hline $1970-1980$ & $\begin{array}{l}\text { Consolidar sua } \\
\text { posição hegemôni- } \\
\text { ca a partir da sua } \\
\text { 'base imperial } \\
\text { doméstica'. }\end{array}$ & $\begin{array}{l}\text { Vantagens competitivas } \\
\text { na agricultura; expansão } \\
\text { considerável de milho, } \\
\text { produtividade agrícola } \\
\text { superior à de várias } \\
\text { indústrias; commodities } \\
\text { agrícolas com preços } \\
\text { elevados. Expansão entre } \\
\text { essas décadas de mais de } \\
\text { 300\% das exportações } \\
\text { agrícolas globais. }\end{array}$ \\
\hline
\end{tabular}

$\overline{\text { A liberalização das finanças e a volatilidade aceleraram a competição }}$ e a mobilidade de capital ante a persistência da pressão inflacionária, dos salários e aumento dos preços de commodities, nos 1970s. Com a rejeição, em 1976, do keynesianismo são definidas as políticas próglobalização ou a estratégia de acumulação liderada pelas finanças, como pode-se verificar em PANITCH, Leo; GINDIN, Sam. The making of global capitalism: the political economy of American empire. Verso: London, New York. 2012.

\begin{tabular}{|c|c|c|}
\hline Período & Contexto & Tratamento à agricultura \\
\hline $\begin{array}{l}1974 \text { a década de } \\
1980\end{array}$ & $\begin{array}{l}\text { Posição desta } \\
\text { potência em } \\
\text { relação ao desen- } \\
\text { volvimento dos } \\
\text { países do Terceiro } \\
\text { Mundo; encora- } \\
\text { jamento desses } \\
\text { países a comprar } \\
\text { notas do Tesouro } \\
\text { americano, amém } \\
\text { dos petrodólares. } \\
\text { Grandes quantias } \\
\text { de dinheiro saíram } \\
\text { emprestadores } \\
\text { para tomadores } \\
\text { estrangeiros. } \\
\text { Bancos dos EUA } \\
\text { se tornaram a } \\
\text { primeira fonte de } \\
\text { financiamento de } \\
\text { balanços de paga- } \\
\text { mentos e de inve- } \\
\text { stimentos públicos } \\
\text { e privados. }\end{array}$ & $\begin{array}{l}\text { Promoção agressiva das } \\
\text { exportações agrícolas } \\
\text { estadunidenses para sub- } \\
\text { stituir ajuda alimentar aos } \\
\text { países subdesenvolvidos } \\
\text { (Trade Act). Entrada do } \\
\text { modelo agrícola estaduni- } \\
\text { dense nesses países, in- } \\
\text { duzindo a transformação } \\
\text { da agricultura familiar em } \\
\text { orientada para exportação } \\
\text { e agronegócio. O Primei- } \\
\text { ro Mundo exportava mais } \\
\text { bens agrícolas do que o } \\
\text { Terceiro Mundo. }\end{array}$ \\
\hline $1980-1987$ & $\begin{array}{l}\text { Volatilidade finan- } \\
\text { ceira. Quebra da } \\
\text { bolsa. }\end{array}$ & $\begin{array}{l}\text { Adoção de políticas } \\
\text { protecionistas para en- } \\
\text { frentar alto desemprego, } \\
\text { devastação de parque } \\
\text { industrial e agrícola e } \\
\text { apreciação do dólar. } \\
\end{array}$ \\
\hline $1987-1990$ & $\begin{array}{l}\text { Grandes firmas } \\
\text { de tecnologia } \\
\text { avançada; firmas } \\
\text { financeiras eram } \\
\text { principais atores } \\
\text { da Revolução } \\
\text { de TI }\end{array}$ & $\begin{array}{l}\text { Grandes avanços de bio- } \\
\text { tecnologia. }\end{array}$ \\
\hline \multicolumn{3}{|c|}{$\begin{array}{l}\text { Quadro 1. Tratamento à agricultura dado pelos EUA e sua relação } \\
\text { com a posição do mercado internacional. (1900-1990) } \\
\text { Fonte: Elaboração própria com base em PANITCH, Leo; } \\
\text { GINDIN, Sam. The making of global capitalism: the political } \\
\text { economy of American empire. Verso: London, New York. } 2012 .\end{array}$} \\
\hline
\end{tabular}

Em 2008, o aumento dos preços de alimentos afetou populações com menor poder aquisitivo em diferentes países. A quantidade de alimentos consumida por uma família foi reduzida, além de alimentos menos calóricos e menos nutritivos tomarem maior relevância em sua cesta de consumo. ${ }^{26}$ Estimativas da FAO relativas aos efeitos da 'crise alimentar' apontam para aumento de mais de 173 milhões de pessoas em situação de fome e desnutrição. A agricultura, mais especificamente, os grãos (commodity), passa a se enquadrar, cada vez mais, nos mercados futuros.

26 FOOD AND AGRICULTURE ORGANIZATION. El estado mundial de la agricultura y la alimentación. Roma, 2009. Disponível em: <http://www.fao.org/docrep/012/i0680s/i0680s. pdf $>$. Acesso em: 12 out. 2016. 
Como fatos recentes na agricultura e relacionados às relações econômicas - neste caso, financeiras, essencialmente - estão a financeirização da agricultura e a política de mudança da matriz energética impetrada por EUA e União Europeia. Em 2008, fundos de investimento controlavam entre 50 a $60 \%$ do comércio de commodity, ou seja, essas mercadorias passaram a ser tratadas como meros ativos financeiros: o preço do arroz, por exemplo, cresceu 31\% em março de 2008 e o do trigo, $29 \%$ em fevereiro de 2008 , o que teria estimulado investimentos em Wall Street da ordem de US\$ 130 bilhões. ${ }^{27} \mathrm{O}$ investimento externo direto (IED) da agricultura apresentaria, também, crescimento ao longo dos últimos anos. Para África e Ásia, esse investimento tem se mostrado mais atrativo. Além disso, o agronegócio, em termos gerais, foi mais favorável em termos de políticas de atração de investimento externo, em 2012. ${ }^{28}$

A necessidade de os países desenvolvidos buscarem diversidade energética, expressa em estratégias direcionadas a fomentar a seguridade nesse campo, foi sendo revelada por meio de estudos e assinatura de acordos com economias subdesenvolvidas ${ }^{29}$ que, em 2004, a publicação Estratégia para Agricultura, pela United States Agency for Internacional Development (USAID), consolidou no âmbito de instituições como Organização dos Estados Americanos (OEA), Banco Interamericano de Desenvolvimento (BID) e Comissão Econômica para América Latina e o Caribe (CEPAL), a ideia de que era necessária a substituição energética vinculada a uma nova forma de uso do solo e da água. É a multidimensionalidade da Iniciativa Energética Mesoamericana (IEM) que permite a exportação de agrocombustíveis para os EUA.

De fato, em 2000, a produção mundial de agrocombustíveis 315 milhões de barris por dia e, em 2009, essa

27 MCMICHAEL, Philip. A food regime analysis of the 'world food crisis'. Agriculture and Human Values, Springer, 31 July, 2009.

28 UNCTAD. Global value chains: investment and trade for development. World Investment Report 2013. New York e Genebra, 2013.

29 Deve-se destacar a "Alianza para el Uso Sustenible de La Energía" (AUSE), que visava tratar de temas como aumento dos investimentos, da promoção de energias limpas e diversificação de energias renováveis e os interesses dos EUA nessa aliança eram respaldados pelo BID, Cepal, ONU e Banco Mundial. TERÁN, Juan Fernando. La economía de los biocombustibles: una mirada a los proyectos hegemônicos para América Latina. In: Fernandes, Bernardo M. (Org.), Campesinato e agronegócio na América Latina: a questão agrária atual. São Paulo: Expressão Popular, 2008, p. 339-364. produção aumentou para 1,6 bilhão de barris por dia. ${ }^{30}$ Ainda com base na Unctad, seus picos de crescimento se deram no período de 2002 a 2008, com variação anual em torno de 30\%. A demanda mundial por terras, com base em dados do Banco Mundial, cresceu deveras a partir de 2008, tendo sido comercializados mais de 45 milhões de hectares, $75 \%$ na África e no Brasil e na Argentina teriam sido 3,6 milhões. $\mathrm{O}$ aumento da demanda por terras e da transferência daquelas agriculturáveis tem ocorrido nas seguintes commodities: milho, soja, cana-de-açúcar, dendê, arroz, canola, girassol e floresta plantada. ${ }^{31}$

Dessa forma, por mais que se avance no estabelecimento de vontade de tornar o acesso à alimentação igualitário em todo o mundo, há fatores de ordem financeira e econômica que tendem a impedir a sua concretização. O regime alimentar internacional ${ }^{32}$ está assentado na produção agrícola em larga escala, na homogeneização dos hábitos alimentares, nos oligopólios nos diferentes elos da cadeia produtiva dos alimentos — tradin$g s$, produção, distribuição e comercialização. Em função do desempenho do comércio das commodities, as relações capitalistas provocam contextos históricos, geopolíticos, culturais, ecológico e nutricional diferentes para o acesso à alimentação. No entanto, na consolidação do modelo do agronegócio, o contexto de acesso à alimentação que prevalece não é aquele preconizado pelas diretrizes do direito humano à alimentação. ${ }^{33}$

30 UNCTAD. Price formation in financialized commodity markets: the role of information. New York/Genebra: 2011.

31 BANCO MUNDIAL. Rising global interest in farmland: can it yield sustainable and equitable benefits? Washington D.C. 07 de setembro de 2010.

32 A compreensão da organização do capital das relações agrícolas no tempo e no espaço geográfico ao configurar, também, o processo de reprodução e produção da força de trabalho. É um conceito histórico que tem servido para demarcar, em períodos diferentes, a produção e circulação de alimentos em escala mundial conquanto se articulam e se movimentam as potências hegemônicas em cada período de tempo determinado MCMICHAEL, Philip. A food regime analysis of the 'world food crisis'. Agriculture and Human Values, Springer, 31 July, 2009.

33 MCMICHAEL, Philip. A food regime analysis of the 'world food crisis'. Agriculture and Human Values, Springer, 31 July, 2009. 


\section{Direito humano À alimentação, SEGURANÇA ALIMENTAR E NUTRICIONAL E REALIZAÇÃO PROGRESSIVA: AS EXPERIÊNCIAS NA UNIÃO EUROPEIA E AMÉRICA LATINA}

As obrigações que o direito humano à alimentação confere ao Estado consistem em: (a) proteger, ou seja, evitar que pessoas ou organizações infrinjam o direito a se alimentar de outras pessoas o que se recomenda seja evitado por meio da promulgação de leis e estabelecimento de órgãos que investiguem tais casos; (b) respeitar, isto é, os governos não devem privar ou dificultar o acesso pelos seus cidadãos ao alimento; e, por fim, (c) satisfazer - o governo deve facilitar o acesso pelos grupos vulneráveis de alimentos, bem como criar instrumentos para que esses grupos possam seguir se alimentando por si mesmos e prover alimentos nas situações em que a segurança alimentar da população estiver ameaçada por motivos alheios a sua vontade.

Dessa forma, pelo menos no âmbito das instituições governamentais e na vontade dos Estados, Europa e América se valem de normativas específicas para tratar de direito humano à alimentação e ambas se pautam na jurisdição estatal na definição do escopo e da aplicação dessa obrigação. ${ }^{34}$ Seria temerária uma comparação estrita entre União Europeia e América Latina, uma vez que se trata de economias com distintos níveis de desenvolvimento, bem como de formação econômica e histórica. Dessa forma, nesse trabalho, serão ressaltadas as medidas adotadas pelo Bloco europeu e por Estados latino-americanos para a realização do direito humano à alimentação e à segurança alimentar e nutricional (SAN).

Nessa perspectiva, e de forma comparativa, vale refletir sobre os caminhos percorridos pelo direito humano à alimentação na União Europeia, já que não foram desenhados por organismos internacionais, mas resultaram de medidas autônomas a partir da agricultura. Reconhece-se que o comércio agrícola vem sofrendo modificações, indicando que o crescimento das exportações agrícolas tem ocorrido nos países desenvolvidos, especialmente da União Europeia, “[...] cuya participación en las exportaciones agrícolas totales ha pasado de algo más del 20 por ciento a comienzos del decenio de

34 NARULA, Smita. The right to food: holding global actors accountable under international law. Columbia Journal of Transnational Law, v.44, 2006, p.690-800.
1960 a más del 40 por ciento en la actualidad." ${ }^{35}$

Verifica-se, portanto, que a agricultura foi posta como elemento-chave na consecução da integração europeia. Utilizou-se a Política Agrícola Comum (PAC), também, para lidar com diferenças de estrutura produtiva, rendimentos e custos de produção. ${ }^{36}$ Todavia, alguns problemas foram sobressaindo-se, como a redução de trabalhadores empregados nesse setor ao mesmo tempo em que se incrementavam os subsídios, do qual é possível inferir que os maiores beneficiados dessa política protecionista são os grandes produtores rurais.

Por outro lado, a Política Agrícola Comum (PAC) proporcionou vantagens à consolidação da União Europeia, enquanto bloco econômico, quais sejam: unicidade de mercados para os produtos agrícolas, preferência comunitária no comércio internacional; solidariedade financeira, em que o orçamento da União cobre todos os custos, subsídios a exportações. O fortalecimento da PAC pressupunha certo nível mínimo de produção nacional, por razões sociais ou ambientais, ou de autoabastecimento para evitar independência total do exterior. ${ }^{37}$

A partir de negociações na OMC, essa política comum teria de experimentar ${ }^{38} \mathrm{o}$ arrefecimento em seu nível de protecionismo, ao mesmo tempo em que essa possibilidade desperta a contrariedade de fazendeiros beneficiados pelos maciços subsídios governamentais. "Por isso, a PAC tem sido alvo de severas críticas desde a Rodada do Uruguai, até a presente Rodada de Doha da Organização Mundial do Comércio [...]." ${ }^{39}$ Ademais,

35 FOOD AND AGRICULTURE ORGANIZATION. El estado mundial de la agricultura y la alimentación: comercio agrícola y pobreza ¿puede el comercio obrar en favor de los pobres? Roma, 2005. Disponível em: <ftp://ftp.fao.org/docrep/fao/008/ a0050s/a0050s_full.pdf $>$. Acesso em: 12 out. 2016.

36 PERALES, R. B. Condicionamientos Internos y Externos de la PAC: elección, mantenimiento y abandono de la protección via precios. Madri: Ministério de Agricultura Pesca y Alimentacion, 1994.

37 PERALES, R. B. Condicionamientos Internos y Externos de la PAC: elección, mantenimiento y abandono de la protección via precios. Madri: Ministério de Agricultura Pesca y Alimentacion, 1994.

38 Em novembro de 2010, Bruxelas comunicou em linhas gerais a reforma da PAC. Conforme documento da Comissão Europeia, a nova orientação da política agrícola da UE será o fornecimento de alimentos seguros e em quantidade suficiente, bem como gestão sustentável dos recursos naturais. Pode-se conferir em: <http:// www.jornaldenegocios.pt $/$ home.php?template $=$ SHOWNEWS_ V2\&id $=454579>$.

39 SQUEFF, Tatiana de A. F. R. Cardoso. O Desenvolvimento da Política Agrícola Comum da União Europeia. Revista de Direito Internacional, Brasília, v. 13, n. 3, p. 374-389, 2016, p. 385. 
esse protecionismo desfavorece a cooperação internacional, especialmente no que diz respeito ao desenvolvimento do comércio internacional. Está “[...] muito mais inclinado à manutenção do status quo no que diz respeito a mercado internacional (já que dominado largamente pela União Europeia), do que efetivamente a formação de um espaço voltado à troca aberta de mercadorias, pautadas na especialidade produtiva." 40

De outro lado, tal fato, dentre outros aspectos, dá margem para mudanças no âmbito do processo de integração econômica, possibilitando aprofundar o tratamento do setor agroalimentar, em termos de incorporar assuntos relacionados com segurança do alimento. Além disso, dá espaço para o aprofundamento do comércio agrícola 'norte-sul', viabilizando, desse modo, que essa importante atividade produtiva contribua para o desenvolvimento dos países não desenvolvidos.

Portanto, a agricultura apresenta-se como setor estratégico para países desenvolvidos e em via de desenvolvimento. No grupo dos países desenvolvidos, como na União Europeia, percebe-se um intenso corporativismo para com os produtores rurais beneficiados com os incentivos à sua produção, ao mesmo tempo em que onera consumidores e a inserção internacional de Estados em desenvolvimento. ${ }^{41}$

O grupo dos países em desenvolvimento, como na América Latina, a agricultura, além de exercer funções básicas para o crescimento e desenvolvimento econômico das economias dos países, representa importante fonte de ganhos no comércio internacional.

Para perseguir los objetivos de sus políticas
alimentarias y agrícolas, los gobiernos han recurrido
a diversos instrumentos normativos, desde los
impuestos al comercio y los contingentes de
producción hasta el monopolio de las importaciones
y la prohibición de las exportaciones. Aunque sus
objetivos e instrumentos han variado con el tiempo,
en función, entre otras cosas, del nivel de desarrollo
económico y de la importancia de la agricultura en
sus economías y sociedades, los gobiernos de todo
el mundo siguen considerando que la alimentación
y la agricultura son esferas fundamentales para las
cuales es necesario establecer políticas. ${ }^{42}$

40 SQUEFF, Tatiana de A. F. R. Cardoso. O Desenvolvimento da Política Agrícola Comum da União Europeia. Revista de Direito Internacional, Brasília, v. 13, n. 3, p. 374-389, 2016, p. 385.

41 PERALES, R. B. Condicionamientos Internos y Externos de la PAC: elección, mantenimiento y abandono de la protección via precios. Madri: Ministério de Agricultura Pesca y Alimentacion, 1994. 42 FOOD AND AGRICULTURE ORGANIZATION. El estado mundial de la agricultura y la alimentación: comercio ag-
Nesse contexto, verifica-se que a segurança alimentar e nutricional possui elementos constitutivos (acesso, regularidade e qualidade) interrelacionados com o setor agrícola em termos de produção (comercialização, comércio internacional, condições do produtor). Esses elementos em conjunto induzem a afirmar que a população deve se valer de condições para se apropriar dos alimentos inócuos de maneira permanente, em quantidades adequadas para satisfazer suas necessidades nutricionais diárias. Isso só é possível diante da articulação do Estado.

Na América Latina, evidencia-se o reconhecimento de que o Estado deve assumir um compromisso efetivo em realizar o direito humano à alimentação e criar mecanismos para garantir a segurança alimentar e nutricional. Há um aparato legal que vem sendo construído desde 2003 pelos Estados latino-americanos, além dos esforços da FAO para o estabelecimento das Diretrizes Voluntárias para a promoção do Direito Humano à Alimentação em 2004, inserindo o combate à fome como um tema prioritário na agenda internacional. Afirmam-se como instrumentos para garantir o DHA: cooperações internacionais para o desenho de medidas que melhorem métodos de produção, conservação e distribuição de alimentos.

Importante ressaltar as medidas projetadas/implementadas pelos governos da América Latina, que vêm se destacando na discussão e incorporação desse eixo ético-normativo a medidas que visem desmantelar situações de insegurança alimentar e nutricional (ISAN), conforme pode-se verificar no quadro que segue:

\begin{tabular}{|l|l|l|}
\hline Países & Instrumentos & Objetivo \\
\hline Argentina & $\begin{array}{l}\text { Lei de Criação do } \\
\text { Programa Nacional } \\
\text { de Nutrição e } \\
\text { Alimentação (2003) }\end{array}$ & $\begin{array}{l}\text { Coloca o Estado no papel } \\
\text { indiscutível de garantir o } \\
\text { DHA e cidadania. Foco } \\
\text { inicial em crianças até } \\
14 \text { anos, grávidas, idosos } \\
\text { com mais de 70 anos }\end{array}$ \\
\hline Bolívia & Desnutrição Zero & $\begin{array}{l}\text { Erradicar a desnutrição } \\
\text { até 2010. Enfatiza } \\
\text { menores de 10 anos } \\
\text { e sua aplicação inicia } \\
\text { pelos municípios com } \\
\text { maior nível de ISAN }\end{array}$ \\
\hline
\end{tabular}

rícola y pobreza ¿puede el comercio obrar en favor de los pobres? Roma, 2005. Disponível em: <ftp://ftp.fao.org/docrep/fao/008/ a0050s/a0050s_full.pdf>. Acesso em: 12 out. 2016, p. 29. 


\begin{tabular}{|c|c|c|}
\hline Brasil & $\begin{array}{l}\text { Lei Orgânica de } \\
\text { Segurança Alimentar } \\
\text { e Nutricional (2006) }\end{array}$ & $\begin{array}{l}\text { Determina a } \\
\text { criação de um } \\
\text { Sistema Nacional de } \\
\text { Segurança Alimentar e } \\
\text { Nutricional. }\end{array}$ \\
\hline Cuba & $\begin{array}{l}\text { Ratificou a } \\
\text { Declaração } \\
\text { Universal dos } \\
\text { Direitos Humanos } \\
\text { e aprovou } \\
\text { as Diretrizes } \\
\text { Voluntárias }\end{array}$ & $\begin{array}{l}\text { Em 2007, o relator } \\
\text { especial da FAO } \\
\text { destacou o empenho } \\
\text { cubano em fazer } \\
\text { cumprir o DHA. } \\
\text { O país mostraria } \\
\text { criatividade, além } \\
\text { de apoiar medidas } \\
\text { que levem a uma } \\
\text { aceitação conceitual e à à } \\
\text { realização institucional } \\
\text { desse direito. }\end{array}$ \\
\hline Equador & $\begin{array}{l}\text { Lei de Segurança } \\
\text { Alimentar e } \\
\text { Nutricional (2005) }\end{array}$ & \\
\hline Guatemala & $\begin{array}{l}\text { Lei do Sistema } \\
\text { Nacional de } \\
\text { Segurança Alimentar } \\
\text { e Nutricional (2005) }\end{array}$ & $\begin{array}{l}\text { Seu texto é denso } \\
\text { pela forma que trata } \\
\text { a ISAN. Ressalta o } \\
\text { papel do Estado, } \\
\text { amparando-se na } \\
\text { Constituição do país. } \\
\text { Visa mobilizar amplos } \\
\text { setores da sociedade, } \\
\text { estabelece critérios } \\
\text { para transgenia e } \\
\text { comercialização. } \\
\text { Determina } \\
\text { responsabilidades } \\
\text { orçamentárias. }\end{array}$ \\
\hline México & $\begin{array}{l}\text { Lei de planejamento } \\
\text { para a soberania e } \\
\text { SAN }\end{array}$ & $\begin{array}{l}\text { Destaca ciência } \\
\text { e tecnologia na } \\
\text { preservação da } \\
\text { biodiversidade e } \\
\text { respeito à cultura } \\
\text { indígena. Propõe } \\
\text { um programa de } \\
\text { emergência para } \\
\text { erradicar a desnutrição } \\
\text { até } 2015 \text {. Volta-se } \\
\text { para a produção } \\
\text { dos campesinos. } \\
\text { Preocupação com a } \\
\text { dependência alimentar } \\
\text { do país. }\end{array}$ \\
\hline Peru & $\begin{array}{l}\text { Lei do direito a } \\
\text { uma alimentação } \\
\text { adequada (2007) }\end{array}$ & $\begin{array}{l}\text { Reconhece que o } \\
\text { desenvolvimento } \\
\text { econômico requer } \\
\text { compromisso com o } \\
\text { DHA. }\end{array}$ \\
\hline
\end{tabular}

Quadro 2 - A América Latina e a realização progressiva do Direito Humano à Alimentação

Fonte: Elaboração própria.
Embora constitua uma iniciativa importante para tratar de um problema histórico-estrutural, essas leis (Quadro 2) por si só não bastam para resolver problemas de ISAN. De modo geral, essas leis falham por não terem estimado alocação orçamentária de acordo com a magnitude do problema, nem mesmo asseguram progressividade no gasto e a não regressividade nos investimentos em políticas alimentares. A documentação de casos de demandas estratégicas e de desenvolvimento de jurisprudência são, ainda, exíguos, dado o reduzido número de denúncias da violação do direito humano à alimentação.

Criar um aparato legislativo nacional e de prática administrativa imbuído da cultura dos direitos humanos representa viabilizar punições para as violações, bem como para os responsáveis por executá-las e orçamentos para induzir a realização progressiva dos direitos humanos, considerando-se que a sua realização é interdependente ao processo de desenvolvimento econômico desses países. Assim, um determinado aparato judicial/ legislativo construído deve ser respaldado por medidas como promoção do emprego, distribuição de renda, da terra dentre outras que sejam capazes de promover melhores condições de vida à população e inserção desse investimento no sistema econômico. ${ }^{43}$

O tratamento da Segurança Alimentar e Nutricional (SAN) na UE está direcionado ao compromisso em fornecer alimentos seguros, observando-se a sustentabilidade. Há um ideário de que sob o respaldo da reforma da PAC, a questão agrícola deverá ser colocada a serviço dos europeus, apesar de, em menor medida, também enfrentar problemas relacionados com distribuição, comercialização, transgenia etc., como os países latino-americanos.

Ainda, vale destacar o papel da União Europeia na assistência a nações da América Latina, Ásia e África para que elas alcancem a condição de SAN e, portanto, caminhem para a paulatina realização do DHA. Em 2009, o Bloco despendeu dois milhões de euros para apoiar pequenos agricultores de maneira a incrementar a produção agrícola em 50 países. Sua contribuição ocorre por meio da ajuda na compra de adubos e sementes, bem como fomentar programas de microcrédito para agricultores locais e melhorar condições de transporte

43 EIDE, Asbjorn. Human rights requirements to social and economic development. Food Policy, v. 21, n. 1, 1996, p. 23-39. 
na zona rural. ${ }^{44}$ Sua contribuição para esse tema segue uma perspectiva ampla e interrelacionada, associada à promoção do desenvolvimento econômico.

\section{Considerações finais}

A alimentação é fundamental à sobrevivência do ser humano. Porém, sob a lógica das relações mercantis, o acesso a ela é conduzido pelos ditames do sistema de preços de mercado, o que exclui parte da população: aquela que não conta com renda (ou renda suficiente) para adquirir gêneros alimentícios. Portanto, inacessibilidade aos alimentos e exclusão social são elementos que se inter-relacionam e se reforçam em suas mazelas. Verifica-se que, para romper com esse ciclo, é necessária a atuação do Estado, que não poderão ser resumidas a ações emergenciais (normalmente paliativas), mas por meio de medidas no âmbito da mudança estrutural. A comparação entre as ações em países desenvolvidos (União Europeia) e em desenvolvimento (América Latina) mostrou que a realização do direito humano à alimentação depende muito mais de políticas nacionais do que apenas de resoluções e tratativas de agências intergovernamentais como a ONU.

Nesse sentido, a sedimentação do conceito de direito humano à alimentação em foros de organismos internacionais e, mais normativamente, por meio de tratados, representa a busca pela construção de instrumentos, a partir da atuação do Estado, para proteger populações, sobretudo os grupos vulneráveis. Assim, respeitar, proteger e satisfazer necessidades nutricionais diárias são funções de Estado e não de benevolência.

Caso os Estados não disponham de meios para a realização do direito humano à alimentação, deverão acionar a ajuda internacional. Os mecanismos de cooperação internacional são fundamentais no fomento às políticas internas dos Estados menos desenvolvidos, destacando-se as ações da FAO. Salienta-se, também, o importante papel atribuído à sociedade (na qual está incluído o setor privado) que para além do (e com o) Estado, é responsável pela garantia do direito humano à alimentação.

44 UNIÃO EUROPEIA. Comissão Europeia. A Europa consigo: breve perspectiva do que fez a União Européia a longo deste ano. 2010. Disponível em: <file://C:/Users/Sinara/Downloads/ NA3110661PTC_002\%20(2).pdf>. Acesso em: 15 out. 2016.
Como pode-se verificar nas análises do presente ensaio, um sistema normativo, por si só, não garante a proteção dos direitos. O Estado tem a obrigação de garantir a observância e a efetivação dos direitos humanos. No que se refere ao direito humano à alimentação, assegurá-lo, respeitá-lo implica na adoção de medidas mais incisivas do ponto de vista econômico-estrutural. A garantia de que o direito humano à alimentação será, progressivamente, realizado nos países não desenvolvidos envolve toda a comunidade internacional.

Os passos curtos e descompassados dados na direção da realização do DHA na América Latina encontram razão nas dinâmicas econômicas, nos instrumentos jurídicos e nas estratégias e escolhas estatais que vão desde o plantio até a distribuição dos alimentos. Está evidenciado, sobretudo, que o hiato existente entre as economias avançadas e as periféricas, quanto à inserção econômica internacional, reflete-se em problemas sociais relativamente graves nesses países e que, para de fato se resolverem, precisariam de medidas de cunho mais estrutural, capazes de induzir a aumentos de renda, emprego, investimento.

Fatores estruturais — distribuição de renda, reforma agrária, emprego, educação, saneamento básico — que condicionam o acesso econômico aos alimentos em países não desenvolvidos devem ser considerados em políticas públicas desses países para que, em longo prazo, a segurança alimentar e nutricional thes seja realidade. Nesse sentido, o subdesenvolvimento reforça quadros de insegurança alimentar e até mesmo os explica, justifica-se, então, que a segurança alimentar e nutricional venha representando um eixo de desenvolvimento expresso no desenho de políticas públicas nesses países. ${ }^{45}$

Fala-se neste artigo em soberania alimentar, pois buscaria permitir aos países formularem seus modelos de produção, distribuição e comercialização, sem influência da OMC e de empresas transnacionais. Entretanto, fundamental compreender a alimentação como um direito básico e não restringi-la a uma commodity.

Pode-se concluir também que, apesar de nos países não desenvolvidos o acesso a alimentos adequados não ser livre em função de fatores socioeconômicos mais complexos, é possível notar que, na União Europeia, a alimentação está sujeita, também, a problemas relacio-

45 MALUF, Renato Sérgio. Segurança Alimentar e Desenvolvimento Econômico na América Latina: o caso do Brasil. Revista de Economia Política, São Paulo, n.15, p.134-140, 1995. 
nados à distribuição, à comercialização, à inocuidade, à transgenia, à interferência do grande capital. Nesse contexto, verifica-se o maior desafio à realização progressiva do direito humano à alimentação: a evolução do sistema agroalimentar internacional. As dinâmicas que dele partem são capazes de impor padrões, cuja observância pelos países pode desencadear relativos descumprimentos ao direito a uma alimentação adequada e à segurança alimentar.

\section{REFERÊNCIAS}

ALVES, José Augusto Lindgren. Relações Internacionais e Temas Sociais. A Década das Conferências. Brasília: IBRI, 2001.

BANCO MUNDIAL. Rising global interest in farmland: Can it yield sustainable and equitable benefits? Washington D.C. 07 de setembro de 2010.

BIELEFELDT, Heiner. Filosofia dos Direitos $\mathbf{H u}-$ manos. Trad. Dankwart Bernsmüller. São Leopoldo: UNISINOS, 2000.

BOURRINET, Jacques; FLORY, Maurice. L'ordre alimentaire mondial. Economica, Paris, 1982.

CASTRO, Josué de. Geopolítica da Fome: ensaio sobre os problemas de alimentação e de população. São Paulo: Brasiliense, 1968, v.1.

EIDE, Asbjorn. Human rights requirements to social and economic development. Food Policy, v. 21, n. 1, 1996, p. 23-39.

FOOD AND AGRICULTURE ORGANIZATION. E1 estado mundial de la agricultura y la alimentación. Roma, 2009. Disponível em: <http://www.fao. org/docrep/012/i0680s/i0680s.pdf >. Acesso em: 12 out. 2016.

El estado mundial de la agricultura y

la alimentación: comercio agrícola y pobreza ¿puede el comercio obrar en favor de los pobres? Roma, 2005. Disponível em: <ftp://ftp.fao.org/docrep/fao/008/ a0050s/a0050s_full.pdf>. Acesso em: 12 out. 2016.

Diretrizes voluntárias: em apoio à realização progressiva do direito à alimentação adequada no contexto da segurança alimentar nacional. Roma, 2004. Disponível em: <http://www.fao.org/docrep/006/ Y5160s/Y5160s00.htm>. Acesso em: 12 out. 2016.
FRIEDMANN, Harriet. Uma Economia Mundial de Alimentos Sustentável. In: BELIK, W.; MALUF, R.S. (orgs.) Abastecimento e Segurança Alimentar: os limites da liberalização. Campinas: IE/Unicamp, 2000, p. 1-22.

GOMES JÚNIOR, Newton Narciso. Segurança Alimentar e Nutricional como princípio orientador de políticas públicas no marco das necessidades humanas básicas. Universidade de Brasília (UnB): Tese de Doutoramento. 2007.

GORDILlO, G.; JIMÉNEZ, F. El Nuevo Eje de la Seguridad Alimentaria. IAI-IHDP 2004 Global Environmental Change Institute on Globalization and Food Systems. São José, Costa Rica. 2004.

MALUF, Renato Sérgio (Orgs.) Abastecimento e segurança alimentar: os limites da liberalização. Campinas, SP, IE/UNICAMP, 2000.

MALUF, Renato Sérgio. Segurança Alimentar e Desenvolvimento Econômico na América Latina: o caso do Brasil. Revista de Economia Política, São Paulo, n.15, p.134-140, 1995.

MAXWELL, Simon. Food security: a post-modern perspective. Food Policy, v.21, n.2, 1996, p.155-170.

MAXWELL, Simon; SLATER, Rachel. Food policy: old and new. Food Policy, v.21, n.5-6, 2003, p. 531-553.

MCINERNEY-LANKFORD, Siobhán. Human Rights and development: a comment on challenges and opportunities from a legal perspective. Journal of Human Rights Practice, v.1, n.1, mar., 2009, p. 51-82.

MCMICHAEL, Philip. A food regime analysis of the 'world food crisis'. Agriculture and Human Values, Springer, 31 July, 2009.

NARULA, Smita. The right to food: holding global actors accountable under international law. Columbia Journal of Transnational Law, v.44, 2006, p.690-800.

ORGANIZAÇÃO DAS NAÇÕES UNIDAS. Carta das Nações Unidas. 1945. Disponível em: <http:// www.un.org/spanish/Depts/dpi/portugues/charter/ index.htm >. Acesso em: 10 out. 2016.

Declaração e Programa de Ação de Viena. 1993. Disponível em: <http://www.pge.sp.gov. br/centrodeestudos/bibliotecavirtual/instrumentos/ viena.htm >. Acesso em: 10 out. 2016.

PANITCH, Leo; GINDIN, Sam. The making of glo- 
bal capitalism: the political economy of American empire. Verso: London, New York. 2012.

PERALES, R. B. Condicionamientos Internos y Externos de la PAC: elección, mantenimiento y abandono de la protección via precios. Madri: Ministério de Agricultura Pesca y Alimentacion, 1994.

SHAIKH, Anwar. Globalization and the myth of free trade. New School University: New York, 2003.

SQUEFF, Tatiana de A. F. R. Cardoso. O desenvolvimento da política agrícola comum da União Europeia.

Revista de Direito Internacional, Brasília, v. 13, n. 3, p. 374-389, 2016.

TAKAGI, M. et al. A política de segurança alimentar e nutricional do Brasil a partir do programa Fome Zero. In: ORTEGA, A.C.; ALMEIDA FILHO, N. Desenvolvimento territorial, segurança alimentar e economia solidária. Campinas-SP: Editora Alínea. 2006, p.159-184.
TERÁN, Juan Fernando. La economía de los biocombustibles: una mirada a los proyectos hegemônicos para América Latina. In: Fernandes, Bernardo M. (Org.), Campesinato e agronegócio na América Latina: a questão agrária atual. São Paulo: Expressão Popular, 2008, 339-364.

UNCTAD. Price formation in financialized commodity markets: the role of information. New York/ Genebra: 2011.

UNCTAD. Global value chains: investment and trade for development. World Investment Report 2013. New York e Genebra, 2013.

UNIÃO EUROPEIA. Comissão Europeia. A Europa consigo: breve perspectiva do que fez a União Européia a longo deste ano. 2010. Disponível em: <file:///C:/ Users/Sinara/Downloads/NA3110661PTC_002\%20 (2).pdf>. Acesso em: 15 out. 2016. 


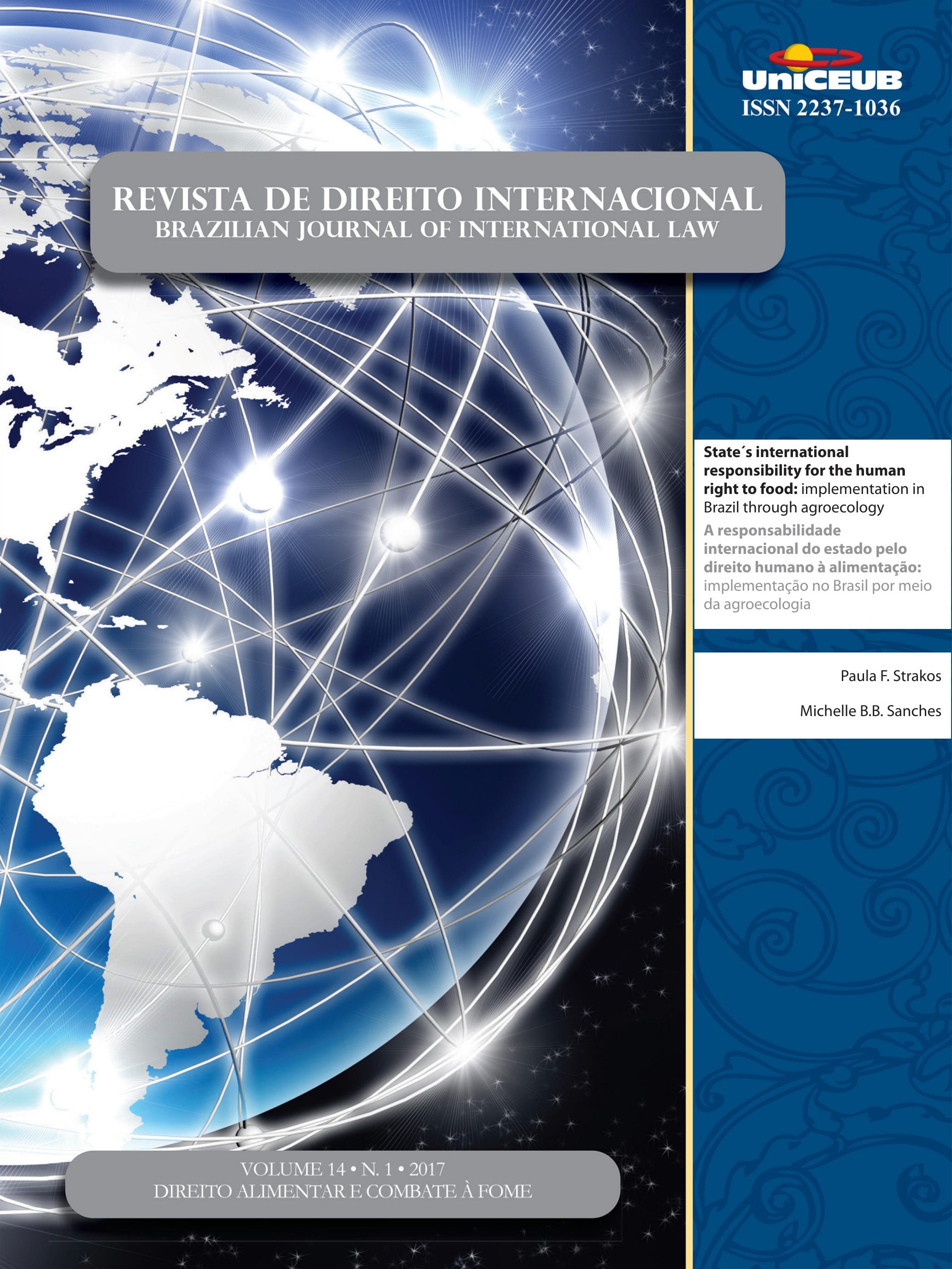




\title{
State's international responsibility for the human right to food: implementation in Brazil through agroecology*
}

\author{
A responsabilidade internacional do \\ estado pelo direito humano à alimentação: \\ implementação no Brasil por meio da \\ agroecologia
}

Paula F. Strakos**

Michelle B.B. Sanches***

\begin{abstract}
This paper analyzes the implementation of the international obligation to the progressive realization of the human right to food (HRF) by the Brazilian State with a special focus on public policy to promote agroecological practices. The aim therein is to evaluate the potential benefits of the use of agroecology as means to implement the HRF as well as identify potential areas for further development. First, a historical and legal examination of the HRF will shed light on its current legal framework, on its detailed normative content and on the State's obligation arising therefrom, with a focus on agroecological practices as means to its implementation. In a second section, we will analyze the implementation of the HRF in the Brazilian legal system, including its applicable institutional framework and the most relevant public policies. We conclude that the application of agroecological public policy in Brazil constitutes a relevant opportunity to positively address several obstacles found in previous public policy such as the contradictions resulting from the lack of integration in a complex net of institutions. The analyses of the Brazilian agroecological framework shows that the normative content of the HRF can be addressed and implemented through this strategy. The Brazilian experience could and should be used as a building block for further development towards a more effective implementation of the HRF by integrating social, economic and environmental concerns through agroecology.
\end{abstract}

Keywords: Human right to food. Food security. Agroecology. State obligation. Sustainability. Brazil. Public policy.

\section{Resumo}

Este artigo analisa a implementação da obrigação internacional da realização progressiva do Direito Humano à Alimentação (DHA) pelo Estado Brasileiro com foco especial nas políticas públicas que promovem práticas agroecológicas. O escopo deste estudo é avaliar os potenciais benefícios do 
uso da agroecologia como uma forma de implementação ao DHA assim como identificar potenciais áreas a serem desenvolvidas. Primeiramente, um exame histórico e normativo do DHA trará luz ao seu contorno jurídico, seu conteúdo normativo e à obrigação Estatal decorrente do DHA, com foco em práticas de agroecologia como forma de sua implementação. $\mathrm{Na}$ segunda seção, analisaremos a implementação do DHA no sistema legal brasileiro, incluindo sua estrutura institucional e as políticas públicas mais relevantes. Concluímos que a aplicação da política pública voltada à agroecologia no Brasil constituí uma relevante oportunidade para endereçar positivamente diversos obstáculos encontrados em políticas públicas anteriores, tal como as contradições resultantes da falta de integração de uma complexa rede institucional. A análise do contorno jurídico para implementação de práticas agroecológicas no Brasil evidencia que relevantes aspectos do conteúdo normativo do DHA podem ser endereçados e aplicados por meio desta estratégia. A experiência brasileira pode e deve ser utilizada como alicerce para progressiva e efetiva implementação do DHA, integrando interesses sociais, econômicos e ambientais através da agroecologia.

Palavras chave: Direito humano à alimentação. Segurança alimentar. Agroecologia. Obrigação estatal. Sustentabilidade. Brasil. Política pública.

\section{INTRODUCTION}

Even though the world produces enough food to provide every human being with an adequate diet, ${ }^{1}$ there are still, in the second decade of the 21 st century, estimated 795 million undernourished people, ${ }^{2}$ corresponding to approximately one over nine people on the earth. The international community has long ago acknowledged the primarily role of food security for life in dignity and recognized the human right to food

1 FOOD AND AGRICULTURE ORGANIZATION OF THE UNITED NATIONS. Anti-Hunger Programme. A twin-track approach to hunger reduction: priorities for national and international actions. Rome: FAO, 2002, p. iii - first page of the executive summary. Available at: <ftp://ftp.fao.org/docrep/fao/006/j0563e/ j0563e00.pdf>. Access on: 06 jan. 2017.

2 FOOD AND AGRICULTURE ORGANIZATION OF THE UNITED NATIONS; IFAD; WFP. The State of Food Insecurity in the World 2015. Meeting the 2015 international hunger targets: taking stock of uneven progress. Rome: FAO, 2015. Available at: <http:// www.fao.org/3/a-i4646e.pdf>. Access on: 06 jan. 2017.
(HRF) as binding international law for signatory states of the International Covenant for Economic, Social and Cultural Rights (ICESCR) and other international agreements, with corresponding state obligation. Nevertheless, the definition of the exact normative content and corresponding state obligation for the HRF is still an ongoing process and has only in the last decades attained sharper outlines. Even more recently the international community renewed its commitment to eradicate hunger until 2030 as key commitment under the Sustainable Development Goals (SDGs).

Hunger and poverty are intrinsically linked so that one cannot be solved without the other. Both issues concentrate mainly in rural areas of developing countries, amounting to $75 \%$ of the people living in hunger being in the rural areas of developing countries. ${ }^{3}$ Thus, enhancing the productivity of family farmers is a key element not only in the fight against hunger and poverty, but also to set the conditions for inclusive economic growth. Moreover, empowering family farmers to produce agroecological food is an alternative that might build resilience urgently needed by the most vulnerable climate change victims and at the same time, achieve social and environmental sustainability, as deeper analyzed below.

On the other side of the social spectrum, the urban and more affluent part of population, mostly in economic developed parts of the globe, is increasingly changing its food demands towards secure food production for human health and the environment as well as, to a smaller extent, socially just and regional food production. Herrings point out that "food politics does not disappear with success in the historical struggle with scarcity, but does acquire new dimensions." ${ }^{4}$ Food politics in the financially developed world has turned into a path for self-expression and its effects can be most prominently seen in the outgrowth of the transnational organic social movement and the major shifts it has generated in the food market, ${ }^{5}$ representing an important

3 FOOD AND AGRICULTURE ORGANIZATION OF THE UNITED NATIONS; IFAD; WFP. Reducing Poverty and Hunger: The critical Role of Financing Food, Agriculture and Rural Development. Rome: FAO, 2002. p. 12. Available at: <ftp://ftp.fao.org/ docrep/fao/003/Y6265E/Y6265E.pdf>. Access on: 06 jan. 2017.

4 HERRING, Ronald J. How is food political? market, state and knowledge. In: __ (Ed.). The Oxford handbook of food, politics and society. New York: Oxford University, 2015. p. 8

5 For more in this regard see: WILLER, Helga; YUSSEFI-MENZLER, Minou; SORENSEN, Neil (Ed.). The world of organic agricul- 
call for social and environmentally safe food production.

The apparent dichotomy between the harsh realities faced by rural population and the affluent urban population can be brought together to benefit the totality of society. Agroecological food production is a promising path on that direction and might play a decisive role for States to implement their international human rights obligations for food. Especially in a country like Brazil, with a major social inequality gap and where the distant realities of rich and poor meet on a common space in everyday life, agroecology might represent a decisive strategy to socially and economically include small holder farmers, while at the same time addressing the urgent need for environmentally sustainable use of land and attend the demand for healthier food production.

Regarding State's behavior towards the realization of the HRF, the former Special Rapporteur ${ }^{6}$ of the HRF identified a deep contradiction in the global efforts to realize human rights in general and the HRF in particular. Such contradiction is referred to as a "schizophrenia in the United Nations System and in State's public policy." ${ }^{\prime \prime}$ On the one side, the international community as well as individual States recognize and take measures to implement the HRF. The latest step in this direction by the international community was the compromise made through the SDG to end hunger by 2030 . On the other hand, the United Nations agencies and States individually approve and implement measures that have a direct negative effect on food production and markets, especially harming small scale farmers and the most vulnerable rural population. Examples are deregulation and agricultural trade liberalization agreements, such as the currently discussed Transatlantic Trade and Investment Partnership (TTIP), or the approval of corporate centralization of big global agricultural input companies, such as the acquisition of Monsanto, the highly controversial and largest seed company in the world, by Bayer AG, a major drug and crop chemical maker.

In order to demand from States, both in court and in the political arena, that public policy respect, protect

ture: statistics and emerging trends. Bonn: IFOAM, 2008.

6 The Special Rapporteur is an independent expert appointed by the Human Rights Council to analyze and report about the implementation of the HRF by member States. See Resolution 2000/10, April, 2000, Human Rights Council.

7 ZIEGLER, Jean et al. The fight for the right to food: lessons learned. Geneva: The Graduate Institute Publications, 2011. p. xii. and fulfill the HRF, it is cardinal to promote a legal debate to crystallize the State's obligation arising from the normative framework of the HRF. This article aims to contribute to the discussion of the State's responsibility for the HRF with a multilevel approach from international law, national law and public policy as means of implementation of international human rights obligations. The first part will focus on the international arena, contextualizing the HRF historically, untangling its normative content and analyzing the role of agroecology as means of its implementation through a conceptual method. In the second part we will analyze the use of agroecology by the Brazilian State, as means of progressive implementation of the HRF in order to identify its compliance and/or non-compliance with its international legal obligation. For such purposes, we will make a brief descriptive exposure of the Brazilian legal and institutional framework for the implementation of HRF and related public policies, focused on agroecological practices, followed by an analytical evaluation of the compliance by the Brazilian State of its human rights obligation. We do not intend to make an exhaustive analysis of the Brazilian institutional framework nor to compare public policy towards the implementation of HRF, but rather analyze the role of agroecology as means of implementation of HRF in Brazil.

\section{Historical deVELOPMENT OF THE HUMAN RIGHT TO FOOD}

The recognition of the HRF can be traced back to the emergence of the human rights regime itself through the Universal Declaration of Human Rights (UDHR) in 1948. The UDHR included the HRF as a component of the right to an adequate standard of living in Article 25, para. 1. Equally, the HRF has been expressly included in the complementary treaty to the UDHR, the International Covenant on Economic, Social and Cultural Rights (ICESC) in Article 11. Nevertheless, the HRF framework did not received significant legal attention in the international arena until the late 1990.

Before this point, the international debate on the subject revolved around the concept and implementation strategies of food security with a focus on food availability and public policy to improve food production. The challenge to feed a fast growing population 
was addressed through technological advancement in high-yielding crop varieties and public investment in infrastructure, including price incentives and irrigation infrastructure to support the use of those crops. This process resulted in the so-called Green Revolution which started in the mid-1960s and reached its high point of productivity between 1980 and 1990 when successive generations of genetically modified crops were developed and inserted into the market ${ }^{8}$. The Green Revolution was a success in terms of an increase in productivity capability pro hectare and was a remarkable achievement in regards to lowering food prices globally and solving the material demand for food. Since then, there is a general consensus that the world produces enough food to feed the global population.? Although the Green Revolution contributed to the solution, it could not solve the problem of hunger and malnutrition in the world. The extremely poor and poor people in the world, approximately 795 million in $2015,{ }^{10}$ continue to be undernourished.

Apart from not solving the problem of hunger, the Green Revolution also had significant side effects from social and environmental perspectives. On the environmental level, the intensive application of industrialized monoculture plus intense uses of water, fertilizers and pesticides, have caused an increasing pressure of ecosystem services and led to high rates of land degradation, land nutrient run-off, water system pollution from farm waste and chemical inputs, water depletion through excessive use, less resilience through reduced genetic diversity and, ultimately, contributed to climate change. ${ }^{11}$ On the social level, the agriculture tech-

8 EVENSON, R. E.; GOLLIN, D. Assessing the impact of the green revolution: 1960 to 2000. Science, v. 300, n. 5620, p. 758-762, May. 2003. p. 759.

9 FOOD AND AGRICULTURE ORGANIZATION OF THE UNITED NATIONS. The State of Food Insecurity in the World. 2002. Foreword. Available at: <http://www.fao.org/docrep/005/y7352e/ y7352e02.htm\#TopOfPage>. Access on: 15 out. 2016; FARMER, B. H. Perspectives on the 'Green Revolution' in South Asia. Modern Asian Studies, v. 20, n. 01, p. 175-199, 1986.

10 FOOD AND AGRICULTURE ORGANIZATION OF THE UNITED NATIONS. The State of Food Insecurity in the World 2105. Rome: FAO, 2015. p. 26. Available at: <http://www.fao.org/3/ai4646e/index.html> Access on: 15 out. 2016.

11 Some 40 percent of agricultural land has been strongly or very strongly degraded in the past 50 years by erosion, salinization, compaction, nutrient depletion, biological degradation, or pollution. MILLENNIUM ECOSYSTEM ASSESSMENT. Ecosystems and buman well-being: a framework for assessment. Washington, DC: World Resources Institute, 2005. p. 64. Available at: <http://www.millenniumassessment.org/documents/document.300.aspx.pdf $>$ Access niques implemented during the Green Revolution did not necessarily benefit the small holder farmers. On the contrary, in some occasions, it contributed to the increasing marginalization and elimination of small-hold local farmers or traditional communities. This is because the new agriculture technology is highly dependent on external inputs such as agrochemicals and the transgenic seeds themselves, which small-hold or traditional farmers might not have been able to either afford or compete with. ${ }^{12}$ Deep irony lies in the fact that the rural population of developing countries accounts for the majority of the world population suffering from food insecurity. ${ }^{13}$

This led the international community to realize that the problem of hunger and malnutrition had a much stronger link to food access, poverty and social inequality, rather than the availability of food itself. The concept of food security developed accordingly and shifted its focus from food availability to include the elements of (1) access to food, and in the following decades, to include the elements of (2) utilization, to address nutritional considerations and qualitative aspects, (3) risk, to address vulnerability, and lastly, and (4) sustainability, to allow food security for present and future generations. ${ }^{14}$

The concept of food security was approved by the international community at the World Food Summit 1996, including all of the elements mentioned above as follows: "Food security exists when all people, at all times, have physical and economic access to sufficient, safe and nutritious food to meet their dietary needs and food preferences for an active and healthy life." ${ }^{15}$ The concept of food security is continuously evolving

on: 20 out. 2016.

12 See: ELVER, Hilal. Interim report of the Special Rapporteur on the right to food, Promotion and protection of human rights: human rights questions, including alternative approaches for improving the effective enjoyment of human rights and fundamental freedoms, UN Doc. A/70/287, 2015. p. 20; WEINGÄRTNER, Lioba; TRENTMANN, Claudia (Ed.). Handbuch Welternährung. Frankfurt: Campus Verlag, 2010. p. 55.

13 FOOD AND AGRICULTURE ORGANIZATION OF THE UNITED NATIONS. The State of Food Insecurity in the World 2105. Rome: FAO, 2015. p. 26. Available at: <http://www.fao.org/3/ai4646e/index.html > Access on: 15 out. 2016.

14 BROWN, Lynn; GENTILINI, Ugo. On the edge: the role of food-based safety nets in helping vulnerable households manage food insecurity. In: GUHA-KHASNOBIS, Basudeb; ARCHARYA, Shabd S.; DAVIS, Benjamin (Ed.). Food insecurity, vulnerability and buman rights failure, (no location). Basingstoke: Palgrave Mcmillan, 2007. p. 82-105. p. 83.

15 Art. 1, World Food Summit Plan of Action. 
as an operational concept in public policy to address the complexities of the subject. ${ }^{16}$ Most recent concerns have addressed the need to create resilience for climate change caused weather variations. Climate change poses a unique threat to food security, including the aspects of availability, accessibility, adequacy and sustainability.

The historical development of the concept of food security shows how the way forward to end hunger and malnutrition requires political and legal engagement rather than complicated technical solutions. The concept of food security carries a significant legal weight but is not binding upon States. The HRF adds the vital element of accountability to food security.

The World Food Summit in 1996 was also a milestone in the acknowledgment of the need to implement a rights-based approach to food security. On that occasion, states reaffirmed the human right to be free from hunger, agreed on the goal to reduce the number of the hungry people in the world in half by 2015, and gave the High Commissioner for Human Rights a specific mandate to further develop the normative content of the HRF and the corresponding state obligation. ${ }^{17}$

After the World Food Summit, the Committee on Economic, Social and Cultural Rights (CESCR) released in 1999 General Comment no. 12 on the right to adequate food (General Comment no. 12) in its capacity as a monitoring institution of the ICESCR implementation. ${ }^{18}$ Although general comments have a soft law character, they are an authoritative interpretation so that any disagreement by the signatory-States must be legally justified.

The interpretation made in General Comment no. 12 was later endorsed by member-States through the Voluntary Guidelines on the Right to Food (VGRF). The VGRF were prepared by States as a response to the poor development of the compromises assumed in the World Food Summit in 1996 and represent a major effort by the international community to set a clear fra-

16 FOOD AND AGRICULTURE ORGANIZATION OF THE UNITED NATIONS. Trade Reforms and Food Security. Rome: FAO, 2003. p. 25-33. Available at: <ftp://ftp.fao.org/docrep/fao/005/ y4671e/y4671e00.pdf > . Access on: 21 out. 2016.

17 World Food Summit Plan of Action, Objective 7.4.

18 RAE, Isabella; THOMAS, Julian; VIDAR, Margret. The right to food as a fundamental human right: FAO's Experience. In: GUHA-KHASNOBIS, Basudeb; ACHARYA, Shabd S.; DAVIS, Benjamin (Ed.). Food insecurity, vulnerability and buman rights failure. New York: United Nations University, 2007. p. 266 f. mework for state obligations to the HRF. ${ }^{19}$ The VGRF was unanimously approved by States in the 127th Session of the FAO Council in November 2004 and carries a soft law nature. Although soft law instruments are not immediately binding upon States, they have significant legal and political weight and build the base for the crystallization of binding law, ${ }^{20}$ including customary law and general principles of international law. ${ }^{21}$ Additionally, soft law inverts the burden of proof so that the noncompliance of requirements established in VGRF, must be duly justified by States, who cannot allege ignorance or refusal to implement the established steps.

\section{NORMATIVE CONTENT OF THE HUMAN RIGHT TO FOOD}

The CESCR established that the right to adequate food is only realized when "every man, woman and child, alone or in community with others, has the physical and economic access at all times to adequate food or means for its procurement." 22 The normative content of the HRF entails the elements of Availability, Accessibility, Adequacy and Sustainability.

Availability refers to the presence of food in a quantity and quality sufficient for human nutritional needs either made available from natural environment or from the food market. The availability criterion in the natural environment is especially relevant for rural and indigenous populations. It is not met when unsustainable uses of land result in land degradation or forest destruction that prevent the local population from extracting its livelihood from nature or when unsustainable uses or water pollution result in shortages that do not satisfy the basic needs of subsistence agriculture or prevents subsistence fishery activities.

Accessibility refers to physical as well as economical access to food. For economic access to be complied with, the individual's or group's capacity to pay for adequate food must not compromise her/his/their capability to provide for other basic needs also protected

19 ZIEGLER, Jean et al. The fight for the right to food: lessons learned. Geneva: The Graduate Institute Publications, 2011. p. 6-7.

20 HOBE, Stephan. Einführung in den Völkerrecht, 9. Auflage, Tübingen und Basel 2008. p. 206.

21 Laskowski, Silke.

22 General Comment no. 12, para. 6. 
by human rights. Physical accessibility refers to barriers that might prevent an individual or group from having actual access to adequate food, such as older or disabled people, or an indigenous group of people that is hindered from accessing parts of its traditional territory that are essential for their nourishment.

The normative element of adequacy refers to the nurturing qualities of the food and requires it to satisfy dietary needs, to be safe for human consumption, "free from adverse substances" and acceptable within a given culture. $^{23}$

The element of sustainability incorporates the notion of long term availability and accessibility for present and future generations. Even with the exacerbated scientific and technological development in the last century, human knowledge about how to use natural resources and environmental services in a sustainable manner is still controversial. This is reflected in Art. 11(2)(a), ICESCR, upon which the signatory-States expressly include their commitment to improve methods of food production making full use of technical and scientific knowledge to effectively use natural resources.

The ways to achieve sustainability in agriculture is a highly political and controversial. Nevertheless, sustainability in the context of the HRF must be holistically understood and encompass environmental, social, health and resilience aspects. Considering that the majority of people suffering from hunger and malnourishment are in rural areas of the developing world, sustainable agriculture is a path to empower the farmer not only to immediately feed herself/himself out of hunger and undernourishment, but also might be a path out of poverty with support of effective public policy. ${ }^{24}$

\section{State's obligation to the human Right to FOOD}

With a clear vision of the normative content of the HRF, it is possible to extract the State's obligation towards the fulfilment of the right. As any other ESCRight, the HRF is subject to a progressive realization by Sta-

23 General Comment no. 12, para. 8.

24 See FOOD AND AGRICULTURE ORGANIZATION OF THE UNITED NATIONS. Small-scale Agriculture for Inclusive Development in the Near East and North Africa. 2015. Available at: <http:/ / www.fao.org/3/a-au207e.pdf>. Access on: 28 out. 2016. te according to Art. 2 ICESCR. This means that States are not obliged to immediately fully realize all aspects of the HRF but that they must undertake steps, to the maximum of their available resources, to progressively realize the HRF. States are also forbidden to approve any regressive policies that would negatively affect progress in access to adequate food. Nevertheless, the HRF contains core obligation that have immediate effect and cannot be implemented step by step. In essence, the core obligation of the HRF is to mitigate and alleviate hunger even in times of natural or other disasters, economic instability, war or otherwise as provided for in Art. 11, para. 2, ICESCR. Another State obligation with immediate effect is the prohibition to discriminate in access to food on the basis of gender, color, religion, origin, political or other opinion, property, birth or other status, as of Art. 2, para. 2 and Art. 3 ICESCR.

General Comment no. 12 applied the established tripartite division of State's obligation for human rights, namely the respect, protect and fulfill framework. Under the obligation to respect, States must restrain from taking any measures that result in preventing the existing access to adequate food. It constitutes a negative obligation that limits the exercise of State power for any measures that could arbitrarily restrict or impel the existing realization of the HRF. This is the case if States evict people from land that provides their primary access to food or when social security nets are withdrawn from people who do not have any other way to maintain access to adequate food. Another relevant example for the breach of the responsibility to protect are State measures that authorize or incentivize the use of toxic substances in food production that are known to cause harm to human health, once it is part of the normative element of adequacy, for the food to be free from adverse substances. ${ }^{25}$

Under the obligation to protect, the State must take measures to ensure that third parties, either companies or individuals, do not deprive individuals of their access to adequate food. This obligation is positive and requires States to actively take measures through regulation and supervision of non-State actors that harm the exercise of the HRF. This includes regulating situations that lead to discrimination in food access or situations to protect the right to information of consumers. Examples of breaches are the pollution of rivers or soil by

25 ZIEGLER, Jean et al. The fight for the right to food: Lessons Learned. Geneva: The Graduate Institute Publications, 2011. p. 19. 
companies or individuals that prevent rural people from extracting their food from rivers or land.

Finally, the State must, under its obligation to fulfill, pro-actively engage in activities to strengthen individual access to and utilization of resources and means to ensure their livelihood, including food security. The primary obligation is to facilitate the realization of the right by the individuals or groups, but this shifts into an obligation to provide the right directly whenever an individual or group is unable, for reasons beyond their control, to enjoy the right to adequate food by the means at their disposal. It is also applicable in circumstances of natural disasters, climate change and financial instability. Additionally, the positive obligation to fulfil the HRF also includes measures to identify and address the special circumstances of vulnerable groups such as the rural population, landless people, children, women, indigenous population, among others. Providing the means to have access to food to people that otherwise would not have been able to do so is not a matter of charity but rather a right to human dignity. ${ }^{26}$ Letting people starve is a grave violation of the HRF as well as to the right to life and human dignity.

Additionally, the VGRF has contributed to the clarification of States' obligation to the HRF by expressly recognizing the need for a holistic approach to development in order to realize the HRF, which includes the protection of other inseparably connected rights such as the rights to safe drinking water and the highest attainable standard of health. Recognizing that all human rights are universal, indivisible, interdependent and interrelated is essential to achieve food security. ${ }^{27}$ Another important element in the realization of the HRF, according to the VGHR, is capacity development of all stakeholders that can influence the realization of the HRF, at both an individual and institutional level.

\section{Sustainable DeVELopment GoALS}

The international community has newly reaffirmed its commitment to end hunger, achieve food security

26 FOOD AND AGRICULTURE ORGANIZATION OF THE UNITED NATIONS. Implementing the Right to Adequate Food: The Outcome of Six Case Studies, IGWG RTFG Information Paper No. 4. Rome: FAO, 2004. p. 13.

27 Reinforcing the Vienna World Conference on Human Rights, Vienna Declaration und Programme of Action, 1993, Art. I.5. and improve nutrition and promote sustainable agriculture by 2030 , under the SDG no. 2. The SDGs carry significant political and legal weight as a soft law instrument and might constitute international customary law according to progressive interpretations ${ }^{28}$. The compromise contained in the SDG no. 2 is incontrovertibly linked with the legally binding State's obligation for the HRF and constitute, all together, a reinforced recognition of a State's legal duty. They contribute to a clearer definition of a State's obligation as it sets a time limit for its realization and sets a foundation for effective demands.

The SDG reinforced the recognition of the intrinsic link of hunger and poverty. Social protection and assistance are essential to achieve those goals and public investment and policy should focus on landless farmers, under the basic premise that people who are out of extreme poverty are also free from hunger. ${ }^{29} \mathrm{~A}$ wide body of evidence and literature review exists to support the fact that social safety nets, when carefully planned, can be an effective way to remove people from poverty. ${ }^{30}$

\section{THE ROLE OF AGROECOLOGY IN THE IMPLEMENTATION OF THE HRF}

The historical development of the human rights-based approach to food security reasserts the premise that more food production does not necessarily, if at all, result in less people suffering from hunger and malnutrition. ${ }^{31}$ States' human rights obligations to realize

28 See ALSTON, Phillip. Ships passing in the night: the current state of the human rights and development debate seen through the lens of the millennium development goals. Human Rights Quarterly, v. 27, p. 755-829, Aug. 2005. p. 771-775.

29 FOOD AND AGRICULTURE ORGANIZATION OF THE UNITED NATIONS. Acbieving Zero Hunger: the critical role of investments in social protection and agriculture. Rome: FAO, 2015. p. 9. Available at: < http://www.fao.org/3/a-i4951e.pdf> Access on: 28 out. 2016.

30 See BROWN, Lynn; GENTILINI, Ugo. On the edge: the role of food-based safety nets in helping vulnerable households manage food insecurity. In: GUHA-KHASNOBIS, Basudeb; ARCHARYA, Shabd S.; DAVIS, Benjamin (Ed.). Food insecurity, vulnerability and buman rights failure, (no location). Basingstoke: Palgrave Mcmillan, 2007. p. $82-105$. p. p. 82

31 ELVER, Hilal. Interim report of the Special Rapporteur on the right to food, Promotion and protection of human rights: human rights questions, including alternative approaches for improving the effective enjoyment of human rights and fundamental freedoms, UN Doc. A/70/287, 2015. p. 23; NELSON, Rebecca; COE, 
the HRF go far beyond simple availability concerns and must holistically include social and economic solutions to provide accessibility and adequacy, as well as environmental solutions to provide sustainability and adequacy. Nevertheless, the world is still facing the apparent paradox that a widely implemented strategy to solve food security challenges, namely large-scale industrial agriculture with technologies developed during the Green Revolution, is at the same time a possible solution and the cause of food insecurity by contributing to climate change, land degradation, water resources depletion and pollution and marginalization of small-farm agriculture. $^{32}$

A growing consensus can be identified in the scientific community, ${ }^{33}$ academia, ${ }^{34}$ international community ${ }^{35}$ civil society $^{36}$ and public policy, ${ }^{37}$ towards the use of agroecological practices by small holder farmers as a strategy that embraces multiple layers of State obligation for the HRF. Agroecology can be defined as the

Richard. Agroecological Intensification of Smallholder Farming. In: HERRING, Ronald J. (Ed.). The Oxford Handbook of Food, Politics and Society. New York: Oxford University Press, 2015. p. 107.

32 Some 40 percent of agricultural land has been strongly or very strongly degraded in the past 50 years by erosion, salinization, compaction, nutrient depletion, biological degradation, or pollution. MILLENNIUM ECOSYSTEM ASSESSMENT. Ecosystems and Human Well-being: A Framework for Assessment. Washington, DC: World Resources Institute, 2005. p. 64. Available at: <http:// www.millenniumassessment.org/documents/document.300.aspx. pdf> Access on: 20 out. 2016; ELVER, Hilal. Interim report of the Special Rapporteur on the right to food, Promotion and protection of human rights: human rights questions, including alternative approaches for improving the effective enjoyment of human rights and fundamental freedoms, UN Doc. A/70/287, 2015. p. 23.

33 WEZEL, A.; SOLDAT V. A quantitative and qualitative historical analyses of the scientific discipline agroecology. International Journal Agricultural Sustainability, v. 7, n. 1, p. 3-18, 2009.

34 SCHUTTER, Olivier de. Agroecology, a Tool for the Realization of the Right to Food. In: LICHTFOUSE, Eric (Ed.). Agroecology and Strategies for Climate Change. New York: Springer, 2012. p. 1-16; ALTIERI, Miguel A. Agroecology: the science of natural resource management 5 for poor farmers in marginal environments, Agriculture, Ecosystems and Environment 1971. Berkeley: Elsevier Science B.V., 2002. p. 1-24. 35 FOOD AND AGRICULTURE ORGANIZATION OF THE UNITED NATIONS. Agroecology for Food Security and Nutrition Proceedings of the FAO International Symposium. 18-19 September 2014, Rome, FAO. Legal developments in the progressive realization of the right to food, 2014, available at: < http://www.fao. org/3/a-i3892e.pdf $>$. Access on: 10 out. 2016.

36 ABREU, L. S. de; LAMINE C., BELLON S. Trajetórias da Agroecologia no Brasil: entre Movimentos Sociais, Redes Científicas e Políticas Públicas. In: CONGRESSO LATINO-AMERICANO DE AGROECOLOGIA, 2.; CONGRESSO BRASILEIRO DE AGROECOLOGIA, 6., 2009, Curitiba. Anais... Curitiba, 2009.

37 As shown in the following chapter in the case of Brazil. "application of the science of ecology to agricultural systems" ${ }^{38}$ with the aim of increasing agricultural production by optimizing the use of the local ecosystem and natural resources. Humans, together with the local and surrounding environment, are considered part of the ecosystem that generates positive socioeconomic and environmental effects. It incorporates local and indigenous farmer knowledge to create a socially and environmentally local-oriented agricultural practice.

Sustainability is addressed through more efficient use of local natural resources so as not to deplete the sources of land and water; and at the same time, create crops resilient to pests and adverse weather occasions caused by climate change. ${ }^{39}$ Studies suggest that locally developed crops are more adaptable and robust, especially because the transgenerational breeding was dictated by corresponding local ecological and social conditions. ${ }^{40}$ On a social level, public policy to increase research and farmers training in agroecology can empower small-scale farmers to produce for their owns subsistence and provide livelihoods to build a path out of poverty by selling the exceeding amount of food produced. Without heavily depending on external inputs, access to the market might be facilitated, especially into the growing market of organic products. ${ }^{41}$ Poor rural communities have an advantage on the implementation of agroecological practices because it is "relatively labor intensive, most effectively practiced on small plots of land and relies on locally produced inputs". ${ }^{42}$

An agroecological approach to public policy em-

38 SCHUTTER, Olivier de. Agroecology, a Tool for the Realization of the Right to Food. In: LICHTFOUSE, Eric (Ed.). Agroecology and Strategies for Climate Change. New York: Springer, 2012. p. 1-16.

39 See WESTRA, John; BOODY George. Challenges and benefits of developing multifunctional agroecosystems. In: BOHLEN, Patrick J.; HOUSE, Gar. (Ed.). Sustainable agroecosystem management. Integrating ecology, economics, and society. Boca Raton: CRC, 2009. p. 213-229.

40 MOKUWA, Alfred et al. Robustness and strategies of adaptation among farmer varieties of African rice (Oryza glaberrima) and Asian rice (Oryza sativa) across West Africa. PloS ONE, v. 8, n. 3, Mar. 2013.

41 For statistics on growing demand for organic products see LERNOUD, Julia; WILLER, Helga; SCHLATTER, Bernard. 'North America: current statistics'. In: (Ed.). The world of organic agriculture: statistics and emerging trends. Bonn: Research Institute of Organic Agriculture, 2014. p. 251.

42 ELVER, Hilal. Interim report of the Special Rapporteur on the right to food, Promotion and protection of human rights: human rights questions, including alternative approaches for improving the effective enjoyment of human rights and fundamental freedoms, UN Doc. A/70/287, 2015. p. 21. 
braces to tripartite State's obligations to progressively realize the HRF, as it respects existing access to food by preserving the environment and natural resources that allow for small-scale farmers and indigenous population to practice subsistence agriculture, often relying on their traditional knowledge. Additionally, it respects existing access to adequate food by promoting agricultural practices that produce food 'free from adverse substances'. The obligation to protect is implemented by protecting the environment from the negative effects of large-scale industrial agriculture, including climate change, that negatively affect the realization of the HRF. Water resources are protected from farming waste pollution as well as chemical fertilizers and pesticides. Lastly, public policy to incentive small-scale agroecological practices carries a great potential to fulfill the HRF as it creates the necessary condition for the most vulnerable to build a resilient and sustainable, market-oriented agricultural system.

States should invest in knowledge building through research and knowledge sharing through training and encourage self-organized, community networks and partnerships. ${ }^{43}$ Agroecology is a fairly new field of science that carries a great potential to be developed by biophysical and social science research. The Special Rapporteur for the HRF has called upon States to "encourage a major shift from current industrial agriculture to transformative activities such as conservation (agroecology) that supports the local food movement, protect smallholder farmers, empower women, respect food democracy, maintain environmental sustainability and facilitate a healthy diet." ${ }^{44}$

\section{Brazil as a STUdY CASE}

Whereas Brazil has a relatively high GDP, approximately 10 million people still live in extreme poverty in the country. ${ }^{45}$ Brazil is the world's fourth largest food

43 SCHUTTER, Olivier de. Agroecology, a Tool for the Realization of the Right to Food. In: LICHTFOUSE, Eric (Ed.). Agroecology and Strategies for Climate Change. New York: Springer, 2012. p. 1-16. p. 5.

44 ELVER, Hilal. Interim report of the Special Rapporteur on the right to food, Promotion and protection of human rights: human rights questions, including alternative approaches for improving the effective enjoyment of human rights and fundamental freedoms, UN Doc. A/70/287, 2015. p. 24.

45 WORLD BANK. Poverty and Equity Data, Country Dashboard: exporter in the world ${ }^{46}$ and one may infer that for such reason it has sufficient capacity to meet its internal demands on food. However, in 2013, 23\% of Brazilian households faced food insecurity, ${ }^{47}$ especially among the rural population of the Northeast region of the country. ${ }^{48}$ The Brazilian situation might be taken as an example of the current global scenario, in which the primary hindrance to the fulfillment of the HRF is not directly related to food production capacity, but rather to food access and utilization.

Moreover, small-hold holders and family farming play a key role for the implementation of the HRF in Brazil to the extent that such groups represent relevant food production sources, and, paradoxically, also are the most vulnerable ones in regard to food insecurity, and climate change effects, such as drought and floods. Thus, agroecology can be a relevant tool to advance the HRF in Brazil, by enhancing direct access to food and by providing a way out of poverty by the commerce of the exceeding amount of food produced.

Furthermore we will briefly overview the implementation of the HRF in Brazil in general and then focus on the effectiveness of the national public policy to foster agroecological practices as a means of progressive realizing Brazil's international obligation for the HRF.

\section{BRIEF OVERVIEW ON THE IMPLEMENTATION OF THE HRF IN BRAZIL}

Brazil has become an international benchmark in the fight against hunger due to the incorporation of the topic in its agenda as a top priority since 2002, implementing national policies and recognizing the intrinsic link between poverty and hunger with the ultimate goal to break the vicious circle of hunger.

Brazil. 2015. Available at: <http://povertydata.worldbank.org/poverty/country/BRA>. Access on: 30 out. 2016.

46 FOOD AND AGRICULTURE ORGANIZATION OF THE UNITED NATIONS. FAOSTAT. 2015. Available at: < http://faostat.fao.org/beta/en/\#compare> Access on: 30 out. 2016. 47 INSTITUTO BRASILEIRO DE GEOGRAFIA E ESTATISTICA. Segurança Alimentar. 2013. Disponível em: <http://www.ibge. gov.br/home/estatistica/populacao/seguranca_alimentar_2013/>. Acesso em: 30 out. 2016.

48 INSTITUO BRASILEIRO DE GEOGRAFIA E ESTATÍSTICA. Pesquisa Nacional por Amostra de Domicílios: 2004-2009. Available at: <http://biblioteca.ibge.gov.br/visualizacao/livros/liv47241. pdf>. Access on: 30 out. 2016. 
In 2003 the Brazilian government implemented the internationally acknowledged Zero Hunger Program through which hunger, extreme poverty and inequality were addressed holistically with measures to increase access to food, generate jobs and increased income, intensify the agrarian reform and incentive family farming and education.

As part of the Zero Hunger Program, the government implemented also in 2003, the Family Allowance Program (Programa Bolsa Familia), through which enrolled families receive cash transfers conditional upon keeping their children in school and attending preventive health care visits. According to the World Bank, ten years after Bolsa Familia, Brazil has more than halved its extreme poverty - from 9.7 to $4.3 \%$ of the population ${ }^{49}$. Alongside with this impressive reduction in social inequality, Bolsa Familia also provided useful data for scaling other social programs, such as the Brazil Without Misery Plan, that targeted extreme poverty eradication through more comprehensive and systematic poverty reduction actions such as productive inclusion, income security and access to public services.

As a result of such actions, 29 million people were lifted out of poverty between 2003 and 2014. Socio-economic inequality dropped $6.6 \%$ points in the Gini coefficient in the same period (from 58.1 to 51.5). The income level of the poorest $40 \%$ of the population rose, on average, $7.1 \%$ in real terms, compared to a $4.4 \%$ income growth for the population as a whole..$^{50}$ Specifically regarding the fight against hunger and undernourishment, the proportion of people suffering undernourishment decreased from $7.5 \%$ in $2008-2010$ to $6.9 \%$ in $2011-2013 .{ }^{51}$

Finally, in 2010, Brazil integrated the HRF in its Federal Constitution, granting irrevocable validity to such right as a non-amendable clause. ${ }^{52}$ This was a milestone for the development of a legal framework that applies a

49 WORLD BANK. Bolsa Familia: Brazil's Quiet Revolution. 2013. Available at: <http://www.worldbank.org/en/news/opinion/2013/11/04/bolsa-familia-Brazil-quiet-revolution> Access on: 30 out. 2016.

50 WORLD BANK. Countries, Brazil, overview. 2015. Available at: $<$ http://www.worldbank.org/en/country/brazil/overview>. Access on: 30 out. 2016.

51 FOOD AND AGRICULTURE ORGANIZATION OF THE UNITED NATIONS. Food and Agriculture Policy Decision Analyses. Available at: <http://www.fao.org/docrep/field/009/i3759e/ i3759e.pdf $>$ Access on: 30 out. 2016.

52 Constitutional Amendment No. 64, enacted on 02/04/2010. right-based approach to food security in Brazil. National law reacted to the constitutional amendment and, in the same year, the National Food and Nutritional Security System (SISAN) was created through presidential decree No. 7.272 with the goal of fully implementing the HRF and set the guidelines for the National Plan for Food and Nutrition Security (PNSAN). PNSAN aimed to achieving food security through inter-sectoral public actions and policies, guided by the legal framework of the HRF.

\section{INSTITUTIONAL FRAMEWORK OF THE BRAZILIAN STATE FOR THE IMPLEMENTATION OF HUMAN RIGHT TO FOOD}

The agricultural sector is seen in Brazil as a key economic area while at the same time as a decisive instrument for social development. For such reason, Ziegler diagnoses about the schizophrenic State behavior regarding the realization of the HRF can also be identified in Brazil. Institutionally, the agriculture sector is oriented both by the Ministry of Agriculture, Livestock and Food Supply (MAPA), mainly focused on the economic aspects of agriculture, such as agribusiness, enhancing food production and economic growth through land management risk, credit and trade; as well as by the Ministry of Social and Agrarian Development (MDS), responsible for social programs and food security. $\mathrm{Pu}-$ blic policies towards food security are under the budget and coordination of the MDS, whereas MAPA collaborates with the work of MDS within food security and nutrition programs, specially with measures to improve supply chains from family agriculture, as will be further detailed. On one hand, this separated structure grants a positive level of autonomy for the implementation of social development programs mainstreaming food security. On the other hand, it fails to incorporate food security and the HRF with the national agricultural strategy, including the alignment with the commercial use of agriculture and international trade. This current structure misses the opportunity to apply a holistic approach to food security, in which economic as well as social and environmental aspects are integrated in national agricultural strategy, and accentuates the schizophrenic tendency, as will be evidenced in more detail below.

It is important to point out that the Brazilian agra- 
rian and food security institutional framework underwent significant changes in 2016 due to recent restructuring within the Federal Government, performed by the Interim President, as a result of political instability. ${ }^{53}$ The Ministry of Agrarian Development (MDA), originally responsible for land reform affairs, was merged with the Ministry of Social Development and Fight against Hunger and is currently referred to as Ministry of Social and Agrarian Development (MDS). Moreover, the Special Secretariat for Family Agriculture as well as the National Institute of Colonization and Agrarian Reform (INCRA) are no longer related or subject to the former MDA, but lie under the Chief Staff of the Federal Government ${ }^{54}$.

Such institutional changes, including budget and staff, must be carefully observed so as not to lead to a negative impact on the continuity of ongoing social programs originally implemented by the merged institutions and that have a decisive participation in the progressive realization of the HRF. Otherwise, this recent restructuring might contribute to existing chronic disarticulation within Brazilian institutions and characterize a breach of the international obligation of non-regression towards the HRF.

Civil society has also played a decisive role in the advancement of the HRF in Brazil ${ }^{55}$ and as a response to their demands, the Brazilian State has, in a pioneering fashion, created the National Food Security Council (CONSEA), a political and social advisory body for the articulation between government and civil society and for the proposing guidelines for actions related to food security. CONSEA was originally created in 1993, interrupted its functions in 1995 and regained its political force in 2003 for the implementation of the Hunger Zero Program.

In the current context, MAPA and MDS are the most relevant structures for policy making both on agriculture and food security, whereas CONSEA and the Special Secretariat for Family Agriculture contribute for the much needed integration between MAPA and MDS, reconciling agriculture as an instrument for economic growth and social development.

53 Federal Law No. 13.341, enacted on 29.09.2016.

54 Decree No. 8.865 enacted on 29.09.2016.

55 For a detailed analyses of the role of civil society in the advancement of public policies towards the realization of the HRF see: KRACHT, U. (Ed.). Food and Human Rights in Development. Oxford: Intersentia, 2007. p.181-212.

\section{BRIEF OVERVIEW ON PUBLIC POLICY TOWARDS} THE REALIZATION OF THE HRF

The main public policies adopted by the Brazilian State that set guidelines for agricultural practices and are intertwined with or might have influence on agroecology practices, are the Multiannual Plan (PPA), which is the action plan of MAPA, and the Family Farming Harvest Plan (FFHP), which defines the strategic measures on family agriculture and food security, formerly elaborated and coordinated by MDA and currently under the authority of the Chief Staff of the Federal Government and being implemented by the Special Secretariat for Family Agriculture.

The PPA has a decisive relevance for the national agricultural sector and food supply as it sets the priority measures to be adopted by the national agriculture head institution, MAPA. Even though, MAPA is also technically responsible for national food security, in practice the measures implemented are mainly aimed at increasing production and improving trade, as evidenced by the analyses of its competencies established by law opposed to the actions detailed in the PPA. Regarding the measures implemented by MAPA towards food security, the 2012-2015 PPA, contains only one food and nutritional security program, that is under the MDS coordination, and one family agriculture program, that is under the coordination of the Special Secretariat for Family Agriculture. Both programs count with the contribution of MAPA exclusively for the purposes of improving the related food supply chain and credit lines. The fact that MAPA, the institution responsible for agriculture in Brazil, has only limited inputs in food security policies contributes for the lack of integration of HRF obligations into national strategy for agriculture and agribusiness.

The FFHP, developed by the former MDA on an annual basis since 2002 details strategic forms of support to the sector. The current plan (2016-2017) establishes (1) specific credit lines with lower interest rates and also related to agroecological production under the $\mathrm{Na}$ tional Program for the Strengthening of Family Agriculture (PRONAF), (2) insurances for crops impaired due to climate change and climate disaster, (3) technical assistance to farmers, (4) incentives for cooperative activities, (5) support for trade under mandatory public acquisition of food from family farmers, especially under 
the Food Acquisition Program (PAA), which enables the acquisition of food production from small holder farmers by public authorities such as schools and hospitals, (6) measures to empower women and young people on agriculture, and (7) land reform.

These measures have the potential to satisfy many of the requirements made by international law for the realization of the HRF and encompasses commitments made the Brazilian State in the SDG as well as in the VGRF and the call made by the Special Rapporteur towards small-scale agriculture incentives and inclusion of woman in social planning, exposed above. Nevertheless, it is important to observe that the FFHP was originally developed and implemented by MDA, which has been merged into MDS, according to the recent institutional reform. Therewith, the FFHP is now under the coordination of a different institution (Chief Staff of the Federal Government) and must be closely observed in order to make sure the institutional reform does not harm the effective continuation of the program. Eventual impairments on the effective continuation of the FFHP, causing a lower access by rural families to food security, might constitute a breach of State's obligation for the progressive realization of the HRF.

Other relevant public policies implemented after the incorporation of the HRF in the Federal Constitution in 2010 are the PNSAN, mentioned above, and the National Policy for Technical Assistance and Rural Extension for Family Agriculture and Agrarian Reform (PNATER) which was implemented alongside with the National Program of Technical Assistance and Rural Extension in Family Agriculture and Agrarian Reform (PRONATER), also known as the Technical Assistance and Rural Extension Program (ATER). ${ }^{56}$ PRONATER and ATER are focused on providing education through free technical service and rural extension for small holder farmers, family farmers settled by the agrarian reform, riverine (ribeirinhos), indigenous people, quilombolas, fisherfolk among other vulnerable groups. The ATER program contributed to empower small holder farmers through direct knowledge exchange and providing access to information. Its structure is now also being used to promote, disseminate and further develop agroecological practices and knowledge.

The object of the public policies mentioned above represent a promising path towards the progressive

56 Federal Law No. 12.188, enacted on 11.01.2010. implementation of the HRF as they incorporate different aspect of the normative content of the HRF. Significant measures can be identified in regard to the State's obligation to fulfill the HRF promoting small-scale farmers incentives. Nevertheless, it is important to point out a certain lack of integration of such public policies among the different governmental institutions which might lead to the overruling of economic interest over efforts to realize the HRF, especially within MAPA structure. Despite efforts to integrate such policies within different Ministries, as above evidenced, such public policies intend mainly to address different concerns from the Brazilian State in regard to its agricultural development, either related to trade/economic growth, positioning Brazil as a competitor in the international food market, or the Brazilian international obligation to realize the HRF by guaranteeing access to food for its population and fighting undernutrition and poverty.

\section{Agroecology public policy for the REALIZATION OF THE HRF IN BRAZIL}

Even though the main Brazilian public policies related to food, agriculture and poverty eradication carried out over the last decade, have indeed decreased social inequality and provided access to food, as previously mentioned, the Brazilian State still faces the challenge of providing food security for $23 \%$ of its population, especially in rural areas of environmentally damaged regions such as the Brazilian Northeast. As seen above, agroecological practices represent an important path to address social and sustainability challenges at the same time.

In this context, the Federal Government enacted in 2012 the National Policy for Agroecology and Organic Production (PNAPO) through Decree No. 7.794 envisaging the integration, coordination and adaptation of public policies and programs to foster actions for a transition to agroecological and organic production, contributing to sustainable development and the population's quality of life through sustainable use of natural resources, supply and consumption of healthy foods ${ }^{57}$.

From an institutional standpoint, PNAPO is under the Special Secretariat for Family Agriculture, currently

57 PNAPO, art. 1. 
under the Chief Staff of the Federal Government. The Secretariat is competent to address subjects related to family farming, small holder farmers and other vulnerable groups.

The main instrument for the implementation of the PNAPO is the National Plan for Agroecology and Organic Production (PLANAPO). Up to now, the government has developed two national plans, the first one refers to the period of 2013 to 2015 (PLANAPO 20132015) and the second one refers to period of 2016 to 2019 (PLANAPO 2016-2019). According to the report on the monitoring of results of the PLANAPO 20132015, this first plan enabled an approximation between public and private actors interested in agroecology and contributed to the incorporation of the subject in further public policies, as a new field of science.

The PLANAPO 2016-2019 incorporates the experience acquired during the inaugural first period and addresses important obstacles in the implementation of the HRF, including the lack of institutional integration and contradictions in public policy for food security, exposed above. It also recognizes the need for a holistic approach so that measures implemented by different public authorities do not have negative effects on gains achieved through the implementation of agroecological practices. Nevertheless, as seen above, public policy alone has limited effectiveness within the not fully integrated institutional framework exposed.

In order to achieve such needed integration, the plan is subject to two different instances, the first one is the Inter-ministerial Chamber, responsible for the drafting, execution and monitoring of the plan, formed by representatives of the MDS; MAPA; General Secretariat of the Presidency; Ministry of Finance; Ministry of Environment; Ministry of Education; Ministry of Health; Ministry of Science, Technology and Innovation; and Ministry of Fisheries and Aquaculture. The second one is the National Commission, composed by an equal number of members from civil society and Government/public authorities, who will collaborate on the drafting of the plan and engage civil society in its execution and monitoring.

As a result of the engagement of these several actors who are experts on different subjects, the PLANAPO 2016-2019 has highly cross-cutting public policy structure encompassing six major topics: (1) production; (2) use and conservation of natural resources; (3) knowled- ge; (4) trade and consumption; (5) land and territory; (6) socio-biodiversity.

The first topic encompasses multiple aspects of production, including financial support such as insurance and credit lines. Based on the existing PRONAF structures, a specific line of credit for agroecological and organic production (PRONAF Produtivo Orientado) was created together with a specific line of credit conditioned to low GHG emissions on agriculture. The crosscutting nature of PLANAPO is evidenced by the tackling of the climate change even under a sector with high economic background like production.

Another relevant aspect addressed under the topic of production is the conclusion of the National Program for Use Reduction of Agrochemicals (PRONARA). The PRONARA was concluded after long civil society mobilization and articulation with the governmental authorities based on the target established by the first PLANAPO 2013-2015. However, it has not yet been implemented. The advancement of the revaluation on the granting of authorizations for uses of agrochemicals in Brazil is also foreseen to take place during the period of the PLANAPO 2016-2019.

Furthermore, both plans set forth measures to ensure the quality of the organic production, particularly through certification and monitoring for quality control; to provide scale and foster agroecology; actions aiming for recognizing increasing the access to educational projects/programs such as ATER by women and granting credit lines and access to trade policies such as PAA. Such public policy have a significant impact on the realization of the HRF because of their potential to increase sustainable agriculture production and empowering minorities through education and access to credit. Moreover, the certification and quality control structures follow the international trend towards organic food certification and might be a building block in the integration of small-hold organic farmers into the growing international market.

On the subject of sustainable use of resources, PLANAPO 2013-2015 mapped the extractive production and socio-biodiversity products by traditional populations and performed the strengthening of educational program such as ATER specifically related to extractive activities. Moreover, the PLANAPO 2013-2015 resulted in an elaboration of technical parameters for the sustainable management of species and non-timber 
forest products, the consolidation of documents containing technical guidelines for adoption good management practices for organic sustainable harvesting and preparation of contract guidance for extractive producers, which will be disclosed and used during the implementation of PLANAPO 2016-2019. In order to use Brazilian natural resources in an effective manner towards the fulfillment of the HRF, the PLANAPO also aims for a nutritional mapping of native species of flora with relevant nutritional value to support initiatives related to food security and nutrition in order to diversify the Brazilian population diet. This action is another good example of the implementation by the Brazilian State of the HRF to the extent it is not focused only on food access, but also on food adequacy. For such purposes, once again, other relevant issues are encompassed within the strategy to effectively fulfill the HRF, such as sustainable agriculture practices though the establishment of good management for organic sustainable harvesting and extractive activities and empowering of traditional populations through education.

Additionally, the PLANAPO 2016-2019 included measures to disseminate technologies and practices for the recovery of degraded areas by developing a system of information accessible to farmers. The plan also details actions toward hydric security with a focus on the semi-arid regions of the country. This holistic approach is essential to address the challenges faced by the rural population of land degraded or dry areas so that they can rebuilt a sustainable ecosystem that allows them to extract their livelihoods from agriculture.

Within the subject of capacity building, the plan establishes actions for scientific research and the use of regional traditional knowledge as a means to increase and improve agroecological production, articulating with other public policies such as ATER.

The PLANAPO also addresses trade and market entry for agroecological products to allow the small-scale farmers not only to provide for their own dietary needs but also to construct a way out of poverty, and as a consequence, out of food insecurity upon the application of agroecological practices.

On the topic of land and territory, the amplification and consolidation of agroecology practices relies upon the access of farmers to land through land reform as well as the granting of public support for effective productive settlement of landless people. The PLANA-
PO 2016-2019 incorporates such assumption and establishes a set of measures to be undertaken aiming the creation of more sustainable land reform settlements.

In quilombola areas, two major challenges shall be addressed by PLANAPO in the following years: (1) review rules governing the procedure for identification and demarcation and (2) the preparation of the First National Strategic Plan for Entitlement targeting the completion of pending administrative procedures for granting of quilombola territories entitlements by INCRA.

Another important aspect tackled by the PLANAPO 2016-2019 is social biodiversity that addresses the relationship between traditional communities such as indigenous people, quilombolas, rubber tappers (seringueiros), riverine, fisherfolk, babassu coconut breakers and their environment. The common feature of traditional communities is the extraction of their livelihoods from the natural environment and are highly dependent on the forest and the natural forest systems and services. Traditional and extractive knowledge systems are built over centuries of coexistence of the traditional communities with their environment. Thus, it is essential to protect biodiversity so that traditional communities can continue to extract their livelihoods from the natural environment as well as to secure sustainable access to their traditional land or land to which their identity is bound. In this sense, the PLANAPO has the potential to effectively implement the State obligation to protect the HRF of all people, including vulnerable communities.

This short analysis of Brazil's implementation of an agroecological approach to achieve food security does not intend to exhaust the subject but instead highlight important aspects of it to allow for verifying its correspondence with the normative content of the HRF and State's international legal obligation for its realization.

From the framework analyzed above, it is possible to identify a holistic rights-based approach to food security in which different layers of State responsibility are involved. The PLANAPO has a great potential for the full realization of the normative content of HRF by the Brazilian State because its addresses food availability, by increasing production and at the same time allowing for a greater variety. Food Accessibility is increased in so far as the incentives and assistance for food production is given to the most vulnerable population and reduces its food insecurity 
once they can consume their own production. Food adequacy in increased in the application of agroecology by Brazilian public policy by means of producing food free from adverse substances. Finally, the sustainability aspect of the normative content of the HRF is complied with by creating a healthy ecosystem through agroecological practices, capable of producing food for current and future generations, without degradation the soil and natural resources. Moreover, it complies with specific international requirements and soft law commitments as it supports the local food movement and small holder farmers, empowers women and vulnerable groups, respects traditional knowledge while fostering economic growth and tackling social inequality, seeks environmental sustainability and facilitates a healthy and nutritionally balanced diet.

Furthermore, the agroecological public policy embraces the tripartite State's obligations to progressively realize the HRF as it respect existing access to food by preserving the environment and environmental services that allow for different groups to extract their livelihoods. An important step taken under the State's obligation to protect the HRF is the reevaluation of the use of agrochemicals through PRONARA. If this plan is effectively implemented, together with other measures to improve access to organic food, the right of every person to have access to food free of adverse substances will be protected from activities from third parties. Accordingly, the ecosystems that allow for the realization of the HRF will also be protected from the excessive use of agrochemicals by third parties. Finally, the obligation to fulfill the HRF is progressively addressed by incorporating the latest scientific evidence on agroecology as means to achieve sustainable agricultural production and by creating the necessary condition for the most vulnerable people to build a resilient and sustainable, market-oriented agricultural system that might provide for their own subsistence and way out of poverty. The exposed aspects of the agroecological public policy framework also allow for identifying the presence of all elements of the normative content of the HRF.

Another positive aspect to be extracted from the analyses above is that the implementation of agroecology practices avail existing programs, such as PRONAF, PAA and ATER, utilizing the already successful structures and mechanism that have served as valuable tools in the fight against hunger in Brazil, enabling and facilitating the incorporation of agroecology within the institutional framework.

\section{Final Conclusions}

The international legal framework of the HRF has developed a clear outline in the last decades establishing well-defined state obligations and increasingly developing mechanism for its eligibility. The concept of food security as means for the implementation of the HRF is subject to constant review. Concerns over the effects of climate change in general and especially on the most vulnerable rural populations have raised the support in multiple sectors of society for the expansion and application of agroecological practices that incorporate social, economic and sustainability aspects of food production.

Brazil has taken significant steps in the progressive implementation of the HRF since 2002 and has reached a decisive milestone in building a human rights-based approach to food security by incorporating the HRF in its Federal Constitution in 2010. Even though there have been significant advancements since then, including the development and incentives for agroecological practices, agricultural public policy still reflects the schizophrenic behavior of States identified by Ziegler. On one hand the Brazilian State recognizes the HRF and takes measures towards its implementation. On the other hand, the State takes measures that negatively affect the realization of the HRF. This dichotomy can be clearly identified in the analyses of the institutional framework, in which there are two different institutions, one responsible for agricultural development (MAPA) an one responsible for food security and social development (MDS). A brief analyses of public policy applied by both institutions show a lack of integration and coordination so that MAPA, the head agricultural institutions does not prioritize the fight against hunger, but only gives limited support to MDS specifically focused on credit lines and food supply chain. MAPA misses the opportunity to incorporate the HRF in its general national agrarian strategy.

Important enough to merit attention are the institutional adjustments recently applied to the complex net of institutions involved in public policy to achieve food security and the HRF. Political instability led to reforms in the institutional framework that if not well monitored might lead to retrogression in the realization of the HRF, which is expressly forbidden by international law and would imply a breach by the Brazilian State of its international legal obligation. 
The agroecological framework applied by the Brazilian State as of 2013 addresses the four elements of the normative content of the HRF, improving its availability, accessibility, adequacy and sustainability, while at the same time applying the first steps towards the recommendation made the Special Rapporteur in the Report to the General Assembly nr. A/70/287 from 5.08.2015 to shift into conservation agriculture. This features Brazil as a leader in agroecological public policy development and represents an outstanding advance towards the progressive realization of the HRF. It addresses many issues previously neglected by the State such as the integration of public institutions and policies. The integrating and crosscutting aspects of the agroecological framework represent an opportunity to smooth the schizophrenic behavior of the State and take steps towards solving the paradox of a leading food export country that is not able to adequately feed $23 \%$ of its population. The push for large-scale export agricultural export might have economical reasoning but does not constitute State obligations toward the progressive realization of the HRF inasmuch as it does not respond for current or future demands for access to food.

Other important contributions of the agroecological framework are the strengthening of measures to protect cultural minorities and therewith implement the State's obligation not to discriminate, established in Art. 2, para. 2 and Art. 3 ICESCR. Additionally, the agroecological framework contributes to build environmental sustainability and resilience for those cultural minorities, while ate the same time benefiting the collectivity by allowing for food production with a significant lower index of agrochemical uses. The framework builds an important legal base that needs to be continuously reviewed to integrate the knowledge and participation of multiple stakeholders.

Nevertheless, agroecology is not a panacea to the social, political and environmental challenges faced to finally end hunger and malnutrition worldwide. The deep roots of social injustice and consequent hunger and poverty cannot be underestimated. The fight against hunger must count on diligent and inexhaustible efforts in terms of political will, public policy, technical and legal research, investment, capacity building and civil society mobilization.

\section{References}

ABREU, L. S. de; LAMINE C., BELLON S. Trajetórias da Agroecologia no Brasil: entre Movimentos Sociais, Redes Científicas e Políticas Públicas. In: CONGRESSO LATINO-AMERICANO DE AGROECOLOGIA, 2.; CONGRESSO BRASILEIRO DE AGROECOLOGIA, 6., 2009, Curitiba. Anais... Curitiba, 2009.

ALSTON, Phillip. Ships Passing in the Night: The Current State of the Human Rights and Development Debate Seen Through the Lens of the Millennium Development Goals. Human Rights Quarterly, v. 27, p. 755-829, Aug. 2005.

BAKKER, Christine. Climate change and right to life, Limits and potentialities of the human rights protection system. In: QUIRICO, Ottavio; BOUMGHAR, Mouloud. Climate change and human rights: an international and comparative law perspective. New York: Routledge, 2016. p. 71-89.

BROWN, Lynn; GENTILINI, Ugo. On the edge: the role of food-based safety nets in helping vulnerable households manage food insecurity. In: GUHA-KHASNOBIS, Basudeb; ARCHARYA, Shabd S.; DAVIS, Benjamin (Ed.). Food insecurity, vulnerability and buman rights failure, (no location). Basingstoke: Palgrave Mcmillan, 2007. p. 82-105.

COHEN, M. J. C.; ABERMAN, N. L.; THOMPSON, B. Impact of Climate Change and Bioenergy on Nutrition. Rome: FAO, 2003.

COURTIS, Christian. The right to food as a justiciable right: challenges and strategies. Max Planck Yearbook of United Nations Law, v. 11, p. 317-337, 2007.

EIDE, Asbjørn. Final Report of the Special Rapporteur on the right to adequate food of the UN Sub-Comission on Prevention of Discrimination and Protection of Minorities, 1987, UN Doc. E/CN.4/Sub.2/1987/23. This study was later updated in 1999, Updated Study on the Right to Food, UN Doc. E/CN.4/Sub.2/1999/12, 28 June 1999.

ELVER, Hilal. Interim report of the Special Rapporteur on the right to food, Promotion and protection of human rights: human rights questions, including alternative approaches for improving the effective enjoyment of human rights and fundamental freedoms, UN Doc. A/70/287, 2015, p. 20. 
EVENSON, R. E.; GOLLIN, D. Assessing the impact of the green revolution: 1960 to 2000. Science, v. 300, n. 5620, p. 758-762, May. 2003.

FARMER, B. H. Perspectives on the 'Green Revolution' in South Asia. Modern Asian Studies, v. 20, n. 01, p. 175-199, 1986.

FOOD AND AGRICULTURE ORGANIZATION OF THE UNITED NATIONS. Agroecology for Food Security and Nutrition Proceedings of the FAO International Symposium. 18-19 September 2014, Rome, FAO. Legal developments in the progressive realization of the right to food, 2014, available at: <http://www. fao.org/3/a-i3892e.pdf>. Access on: 10 out. 2016.

FOOD AND AGRICULTURE ORGANIZATION OF THE UNITED NATIONS. Anti-Hunger Programme. A twin-track approach to hunger reduction: priorities for national and international actions. Rome: FAO, 2002, p. iii - first page of the executive summary. Available at: <ftp://ftp.fao.org/docrep/fao/006/j0563e/ j0563e00.pdf $>$. Access on: 06 jan. 2017.

FOOD AND AGRICULTURE ORGANIZATION OF THE UNITED NATIONS. FAOSTAT. 2015. Available at: <http://faostat.fao.org/beta/en/\#compare> Access on: 30 out. 2016.

FOOD AND AGRICULTURE ORGANIZATION OF THE UNITED NATIONS. Food and Agriculture Policy Decision Analyses. Available at: <http://www.fao. org/docrep/field/009/i3759e/i3759e.pdf > Access on: 30 out. 2016.

FOOD AND AGRICULTURE ORGANIZATION OF THE UNITED NATIONS. Implementing the Right to Adequate Food: The Outcome of Six Case Studies, IGWG RTFG Information Paper No. 4. Rome: FAO, 2004.

FOOD AND AGRICULTURE ORGANIZATION OF THE UNITED NATIONS. Small-scale Agriculture for Inclusive Development in the Near East and North Africa. 2015. Available at: <http://www.fao.org/3/a-au207e. pdf $>$. Access on: 28 out. 2016.

FOOD AND AGRICULTURE ORGANIZATION OF THE UNITED NATIONS. The State of Food Insecurity in the World. 2002. Foreword. Available at: <http://www.fao.org/docrep/005/y7352e/y7352e02. htm\#TopOfPage $>$. Access on: 15 out. 2016.

FOOD AND AGRICULTURE ORGANIZATION
OF THE UNITED NATIONS. The State of Food Insecurity in the World 2105. Rome: FAO, 2015. p. 26. Available at: <http://www.fao.org/3/a-i4646e/index.html> Access on: 15 out. 2016.

FOOD AND AGRICULTURE ORGANIZATION OF THE UNITED NATIONS. Trade Reforms and Food Security. Rome: FAO, 2003. p. 25-33. Available at: <ftp:/ / ftp.fao.org/docrep/fao/005/y4671e/y4671e00.pdf $>$. Access on: 21 out. 2016.

FOOD AND AGRICULTURE ORGANIZATION OF THE UNITED NATIONS; BIOVERSITY INTERNATIONAL. Sustainable Agriculture and Rural Development (SARD) Policy Brief 11, 2007.

FOOD AND AGRICULTURE ORGANIZATION OF THE UNITED NATIONS; IFAD; WFP. The State of Food Insecurity in the World 2015. Meeting the 2015 international hunger targets: taking stock of uneven progress. Rome: FAO, 2015. Available at: <http://www. fao.org/3/a-i4646e.pdf>. Access on: 06 jan. 2017.

FOOD AND AGRICULTURE ORGANIZATION OF THE UNITED NATIONS; IFAD; WFP. Reducing Poverty and Hunger: The critical Role of Financing Food, Agriculture and Rural Development. Rome: FAO, 2002. p. 12. Available at: <ftp:/ /ftp.fao.org/docrep/fao/003/ Y6265E/Y6265E.pdf>. Access on: 06 jan. 2017.

HERRING, Ronald J. How is food political? market, state and knowledge. In: (Ed.). The Oxford bandbook of food, politics and society. New York: Oxford University, 2015. p. 3-40.

INSTITUO BRASILEIRO DE GEOGRAFIA E ESTATÍSTICA. Pesquisa Nacional por Amostra de Domicilios: 2004-2009. Available at: <http://biblioteca. ibge.gov.br/visualizacao/livros/liv47241.pdf $>$. Access on: 30 out. 2016 .

INSTITUO BRASILEIRO DE GEOGRAFIA E ESTATÍSTICA. Segurança alimentar. 2013. Available at: <http://www.ibge.gov.br/home/estatistica/populacao/seguranca_alimentar_2013/>. Access on: 30 DEZ. 2016.

LERNOUD, Julia; WILLER, Helga; SCHLAT'TER, Bernard. 'North America: current statistics'. In: (Ed.). The world of organic agriculture: statistics and emerging trends. Bonn: Research Institute of Organic Agriculture, 2014.

LOCKIE, Stewart; CARPENTER, David. (Ed.). Agri- 
culture, biodiversity and markets. Livelihoods and agroecology in comparative perspective. London: Earthscan, 2010 .

MILLENNIUM ECOSYSTEM ASSESSMENT. Ecosystems and Human Well-being: A Framework for Assessment. Washington, DC: World Resources Institute, 2005. p. 64. Available at: <http://www.millenniumassessment.org/documents/document.300.aspx.pdf> Access on: 20 out. 2016.

MOKUWA, Alfred et al. Robustness and strategies of adaptation among farmer varieties of African rice (Oryza glaberrima) and Asian rice (Oryza sativa) across West Africa. PloS ONE, v. 8, n. 3, Mar. 2013.

PAARLBERG, Robert L. Food Politics: what everyone needs to know. New York: Oxfrod University, 2013.

PERFECTO, Ivette; VANDERMEER, John; WRIGHT, Angus. Nature's Matrix: Linking agriculture, conservation and food sovereignty. London: Earthscan, 2009.

RAE, Isabella; THOMAS, Julian; VIDAR, Margret. The Right to Food as a Fundamental Human Right: FAO's Experience. In: GUHA-KHASNOBIS, Basudeb; ACHARYA, Shabd S.; DAVIS, Benjamin (Ed.). Food insecurity, vulnerability and human rights failure. New York: United Nations University, 2007.

SCHUT'TER, Olivier de. Agroecology, a Tool for the Realization of the Right to Food. In: LICHTFOUSE, Eric (Ed.). Agroecology and Strategies for Climate Change. New York: Springer, 2012. p. 1-16.

SCHUT'TER, Olivier de; VANLOQUEREN, G. The New green revolution: how twenty-first-century science can feed the world. The Solution Journal. 2011. Available at: <https://dlc.dlib.indiana.edu/dlc/ bitstream/handle/10535/7482/The\%20New\%20 Green\%20Revolution_\%20How\%20Twenty-FirstCentury $\% 20$ Science $\% 20$ Can $\% 20$ Feed $\% 20$ the $\% 20$ World.pdf?sequence $=1 \&$ is Allowed $=\mathrm{y}>$. Access on: 28 out.2016.

TOMUSCHAT, Christian. Human rights: between idealism and realism. 3. ed. New York: Oxford University, 2014.
VALENTE, Flavio L. S. The human right to food movement in Brazil. In: EIDE, W. B.; KRACHT, U. (Ed.). Food and human rights in development. Oxford: Intersentia, 2007. p.181-212.

WARNER, Keith Douglass. Agroecology in action: extending alternative agriculture through social networks. Massachusetts: Massachusetts Institute of Technology, 2007.

WEINGÄRTNER, Lioba; TRENTMANN, Claudia (Ed.). Handbuch welternährung. Frankfurt: Campus Verlag, 2010.

WESTRA, John; BOODY George. Challenges and benefits of developing multifunctional agroecosystems. In: BOHLEN, Patrick J.; HOUSE, Gar. (Ed.). Sustainable agroecosystem management. Integrating ecology, economics, and society. Boca Raton: CRC, 2009. p. 213-229.

WILLER, Helga; YUSSEFI-MENZLER, Minou; SORENSEN, Neil (Ed.). The world of organic agriculture: statistics and emerging trends. Bonn: IFOAM, 2008.

WORLD BANK. Bolsa Familia: Brazil's quiet revolution. 2013. Available at: <http://www.worldbank.org/en/ news/opinion/2013/11/04/bolsa-familia-Brazil-quietrevolution>. Access on: 30 out. 2016.

WORLD BANK. Poverty and equity data, country dasbboard: Brazil. 2015. Available at: <http://povertydata. worldbank.org/poverty/country/BRA>. Access on: 30 out. 2016.

WORLD BANK. Rural Development Unit South Asia Region. india revitalizing punjab's agriculture, report no. 37069, september. 2013. Available at: <https:// openknowledge.worldbank.org/bitstream/handle/109 86/14433/370690IN0Revit1white0cover01PUBLIC1. pdf? sequence $=1$ \&is Allowed $=y>$. Access in: 20 out. 2016.

ZIEGLER, Jean et al. The Fight for the right to food: lessons learned. Geneva: The Graduate Institute Publications, 2011. 


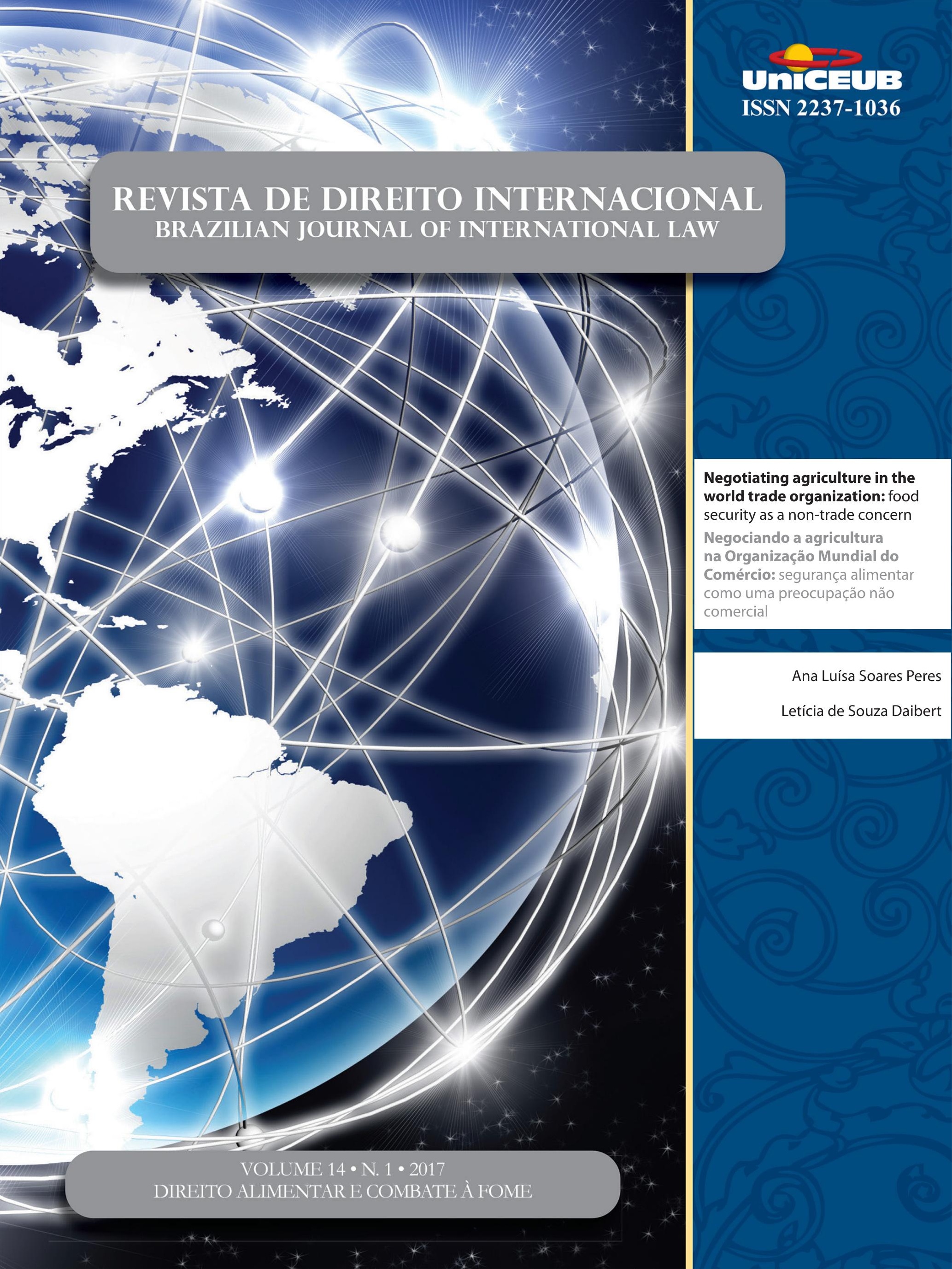




\section{Negotiating agriculture in the world trade organization: food security as a non-trade concern*}

\author{
Negociando a agricultura na Organização \\ Mundial do Comércio: segurança alimentar \\ como uma preocupação não comercial
}

\author{
Ana Luísa Soares Peres** \\ Letícia de Souza Daibert***
}

\section{Abstract}

Food security is an important issue in the current international agenda, for the 2007-2008 economic crisis contributed to the rise in food prices, increasing their volatility. As a complex topic, the efforts to assuring food security cannot be restricted to national initiatives, demanding rather a comprehensive global policy, involving all the interested actors. In this regard, WTO has a shared responsibility in the fight against hunger and in the promotion of the right to food. Trade is one of the many elements related to food security, and it may be a relevant tool in fostering sustainable practices to achieve such goal. Agriculture negotiations in the WTO are aimed at guaranteeing stable and rule-oriented markets, with the liberalization of the agricultural sector and the elimination of distortive practices. Food security is a non-trade concern that must be taken into consideration in the reform talks of the Agreement on Agriculture. The main question on this matter is whether food security should be sought in WTO through the adoption of trade policies, which requires strengthening the discipline on the use of restrictive measures, or through the enhancement of liberalization and cooperation in multiple levels.

Keywords: WTO. Agriculture. Food security. Development. Non-trade concerns. Trade policies.

\section{INTRODUCTION}

Fighting hunger has been a major concern in the international society for many decades now. The efforts towards accomplishing such objective were especially addressed in two global initiatives that require a broader approach on dealing with development and human rights, demanding the implementation of coordinated policies between States, international organizations, civil society, and other entities.

The first one, the Millennium Development Goals (MDG), was an outcome of the United Nations (UN) Millennium Summit, held in New York, in September 2000, when UN Members committed themselves to establish a
** Mestre em Direito Internacional pela UFMG. Bacharel em Direito pela UFMG. Professora. E-mail: analusperes@gmail.com

*** Mestre em Direito Internacional pela UFMG. Especialista em Estudos Diplomáticos pela Faculdade de Direito Milton Campos. Bacharel em Direito pela UFMG. Professora e advogada. E-mail: analusperes@gmail.com 
global partnership to reduce extreme poverty ${ }^{1}$. They set, accordingly, a list of eight goals, and several targets, to be achieved until 2015. The first of the negotiated goals was to eradicate extreme poverty and hunger, with the specific target of halving, between 1990 and 2015, the proportion of people who suffer from hunger. Consequently, "the proportion of undernourished people in the developing region has fallen by almost half since 1990, from 23.3 percent in 1990-1992 to 12.9 percent in 2014-2016"2. Despite the outcomes, there are still about 795 million people worldwide who are estimated to be undernourished, and out of those, more than 90 million children under age five are undernourished and underweight ${ }^{3}$.

Before the agreed deadline expires and given the necessity to widening and deepen the endeavor to accomplish better levels, UN General Assembly adopted, in September 2015, the Resolution 'Transforming our world'. Such document encompasses a sustainable development agenda, which should be implemented by 20304. The 17 Sustainable Development Goals (SDG) officially entered into force on January 1, 2016. The new goals continue to demand coordinated action by all international actors, to promote prosperity whilst protecting the planet. The efforts to end poverty, therefore, must be followed by strategies to promote economic growth and social inclusion, and simultaneously combat climate change and preserve the environment. In this context, the hunger-related goal was separated from the one regarding poverty, indicating that the issue has become a more specific concern and calls for a more well-defined initiative. The second of the SDG seeks, hence, to end hunger, achieve food security and improved nutrition and promote sustainable agriculture.

One may associate fighting hunger with fostering the appropriate conditions for the sustainable practice of agriculture, as this activity, alongside forestry and fisheries, can offer nutritious food for all people and be

1 UNITED NATIONS. General Assembly: Resolution 55/2. United Nations Millennium Declaration, A/RES/55/2, 18 September 2000.

2 UNITED NATIONS. The Millennium Development Goals Report: 2015. United Nations: New York, 2015.

3 UNITED NATIONS. Goal 1: Eradicate Extreme Poverty \& Hunger. Available at: <http://www.un.org/millenniumgoals/poverty.shtml $>$. Accessed on: 24 Oct. 2016.

4 UNITED NATIONS. General Assembly: Resolution 70/1. Transforming our world: the 2030 Agenda for Sustainable Development, A/RES/70/1, 21 October 2015. a resource for decent incomes. It also supports people-centered rural development, since agriculture is the economic sector that employs the most in the world, responsible for the livelihoods of 40 percent of the current global population. Agriculture is, likewise, the main source of income and jobs for poor rural families. Two special categories must be highlighted in this analysis small producers, giving that 80 percent of the total food consumed in a large part of developing countries comes from 500 million small farms worldwide; and women farmers, for, in most part of the developing world, the households are female headed. Providing, accordingly, the necessary resources and investments for small farmers, mainly for women smallholders, is an important measure to enhance food security, as well as to assure the increase in food production, for both local and international markets 5 .

The World Trade Organization (WTO) was created in 1994, and proposes a rule-oriented system to guide trade liberalization and to enhance cooperation and trade flows among the States. The WTO goals, however, surpass the mere trade liberalization and economic progress, to encompass development objectives, such as improving standards of living, promoting sustainable development, and ensuring full employment. W'TO is fully engaged, hence, to the global initiatives aforementioned, as it has a special interest in development issues.

In December 2015, only three months after the adoption of the Resolution 'Transforming our world', the WTO Members agreed, during the Nairobi Ministerial Conference, to abolish agricultural export subsidies, delivering a crucial target of the Zero Hunger SDG, which establishes the responsibility to

correct and prevent trade restrictions and distortions
in world agricultural markets, including through
the parallel elimination of all forms of agricultural
export subsidies and all export measures with
equivalent effect, in accordance with the mandate
of the Doha Development Round ${ }^{6}$.

Trade has, thus, a relevant role to play in achieving the SDGs, as its benefits are important tools to pro-

5 UNITED NATIONS. Goal 2: End hunger, achieve food security and improved nutrition and promote sustainable agriculture. Available at: <http://www.un.org/sustainabledevelopment/hunger/>. Accessed on: 24 Oct. 2016.

6 UNITED NATIONS. Goal 2: End hunger, achieve food security and improved nutrition and promote sustainable agriculture. Available at: <http://www.un.org/sustainabledevelopment/hunger/>. Accessed on: 24 Oct. 2016. 
mote development, in a coordinated and broader policy effort ${ }^{7}$.

This is just the first step towards negotiating agriculture issues in the WTO, as the matter has long been avoided by developed countries, regardless of the complaints of developing Members. The needs of developing countries regarding agriculture are not only economic-related but also comprehend a development feature, as the sector is, in most cases, the foundation for the economic and social structures of these nations.

In the present paper, we will start our analysis by defining food security and relating this concept to the right to food and fighting hunger. This exam aims at presenting the complexity of this phenomenon and the brea$\mathrm{dth}$ of its reach. In the third section, we will assess the negotiations on agriculture in the WTO, providing a historic overview of the long process that culminated in the conclusion of the Agreement on Agriculture (AoA). We will discuss, accordingly, the need to reform such Agreement during the Doha Round, especially in light of the Article 20, and the challenges of such task. The fourth section proposes a critic study on the relation between negotiation in agriculture and the promotion of food security as a non-trade concern. We consider the options available to Members to protect their agricultural markets from food prices volatility, ensuring food availability and access. In this sense, we compare the adoption of trade policies, and their impact on domestic and international markets and the pursuit of greater agricultural liberalization, followed by shared and comprehensive initiatives. We conclude the paper with a reflection on the intricacy of the issue, highlighting the need to seek a broader approach to promoting food security.

\section{The CHALLENGE OF FOOD SECURITY}

The right to food was first recognized in Article 25 of the Universal Declaration of Human Rights from 1948, as part of the right to a decent standard of living. It has since been identified as a broad human right, associated not only with the idea of standards of living but equally with the principle of human dignity. The

7 WORLD TRADE ORGANIZATION. DG Azevêdo: Trade is vital in meeting Sustainable Development Goals. Available at: $<$ https://www.wto.org/english/news_e/news16_e/dgra_21sep16_e. htm>. Access on: Oct. 2016. right to food can be defined as

[...] the right to have regular, permanent and unobstructed access, either directly or by means of financial purchases, to quantitatively and qualitatively adequate and sufficient food corresponding to the cultural traditions of the people to which the consumer belongs, and which ensures a physical and mental, individual and collective, fulfilling and dignified life free from anxiety ${ }^{8}$.

Accordingly, the right to food indicates that access to food markets is as important as the availability of food. Markets play, hence, a central role in the right to food, which demonstrates the connection between economy, trade, development, and human rights. Rules regulating the markets become essential, insofar as they prevent distortions or disloyal conducts, which could lead to or exacerbate food insecurity?.

Food security, in line with the right to food, "exists when all people, at all times, have physical and economic access to sufficient, safe and nutritious food to meet their dietary needs and food preferences for an active and healthy life" ${ }^{\prime 10}$. It is achieved, then, when the combination of four main elements is identified. The first one is food availability, meaning the availability of food in sufficient quantities and on a regular basis. It comprises local stock and production, as well as the ability to bring in food from abroad, either through trade or food aid. The second factor is food access, which entails the capacity to regularly obtain the essential amount of food,

8 UNITED NATIONS. 'Preliminary Report of the Special Rapporteur of the Commission on Human Rights on the Right to Food' (2001) UN Doc. A/56/210, 23 July 2001. para. 22. The definition of the right to food was also discussed in the Committee on Economic, Social and Cultural Rights, which concluded that it should not be limited, and determined that " $[t]$ he right to adequate food is realized when every man, woman and child, alone or in community with others, have physical and economic access at all times to adequate food or means for its procurement. The right to adequate food shall therefore not be interpreted in a narrow or restrictive sense which equates it with a minimum package of calories, proteins and other specific nutrients. The right to adequate food will have to be realized progressively. However, States have a core obligation to take the necessary action to mitigate and alleviate hunger as provided for in paragraph 2 of article 11, even in times of natural or other disasters. UNITED NATIONS. Committee on Economic, Social and Cultural Rights (CESCR), General Comment No. 12: The Right to Adequate Food (Art. 11 of the Covenant), 12 May 1999, available at: <http:// www.refworld.org/docid/4538838c11.html.> Access on: 27 Oct. 2016. para. 6.

9 FEUNTEUN, Tristan. Cartels and the Right to Food: An Analysis of States' Duties and Options. Journal of International Economic Law, v. 18, p. 341-382, 2015. p. 341-343.

10 Rome Declaration on World Food Security and World Food Summit Plan of Action, World Food Summit, November 1996, para. 1. 
through any means, such as purchase, home production, or food aid. The third aspect is food utilization, asserting the nutritional feature that consumed food must have on people's diet. It covers a broad range of actions and conditions, such as cooking, storage and hygiene practices, and water and sanitation infrastructure. The fourth and final characteristic is stability, referring to the achievement of all the three previous components, on a regular basis, as understood in the expression "at all times"11.

As an intricate subject, ensuring food security requires a comprehensive approach, reflecting the increasingly interdependent world. Issues that were previously left to the exclusive competence of municipal law now must be addressed in a wider way, to seek efficient and sustainable answers that may deal with the core of the problem $^{12}$. In this sense, a global action must be pursued, including coordinated policies among all levels, i.e., States, international organizations, civil society, and all international actors that may have an input on the matter. Cooperation is, therefore, fundamental so each nation can guarantee food security to its population, both through domestic resources and capacities, as well as regional and international initiatives. As a global concern, it needs a collective solution and shared responsibilities $^{13}$.

In ensuring food security, States are acting according to their obligations under international human rights law. They must respect the right to food and fulfill it, so their population has appropriate access to the adequate amount of food $^{14}$. The challenge ahead on this aspect is a very difficult one, as food markets must enhance their production by sixty percent to supply the adequate amount of food to a projected world population of 9.7 billion people by $2050^{15}$.

11 DIAZ-BONILLA, Eugenio. Agricultural Trade and Food Security: Some Thoughts about a Continuous Debate. E15Initiative. Geneva: International Centre for Trade and Sustainable Development (ICTSD) and World Economic Forum, 2014. Disponível em: <www. e15initiative.org/>. p. 1.

12 ZHANG, Ruosi. Food Security: Food Trade Regime and Food Aid Regime. Journal of International Economic Law, v. 7, n. 3, p. 565584, 2004. p. 566.

13 ROME Declaration on World Food Security and World Food Summit Plan of Action, World Food Summit, November 1996. para. 1.

14 ZHANG, Ruosi. Food Security: Food Trade Regime and Food Aid Regime. Journal of International Economic Law, v. 7, n. 3, p. 565584, 2004. p. 567.

15 G20. G20 Action Plan on Food Security and Sustainable Food
Hunger is equally a complex concept as it has multiple causes and effects, being aggravated by actions or negligence of several actors, in many spheres. Fighting hunger demands, accordingly, comprehensive policies involving different layers. The right to food as a human right, likewise, encompasses various elements that must be taken into consideration, as well as multilevel initiatives that must be implemented to tackle the issue.

Trade is among the factors that can encourage food security, ensure the right to food, and fight hunger, especially when it comes to trade in agriculture, which will be the central point of the present analysis. In this sense, the World Food Summit has established in its Plan of Action the commitment to guarantee that agricultural trade foster food security and promote a fair and market-oriented system ${ }^{16}$.

\section{Negotiating agriculture in the WTO}

The AoA is the main multilateral regulation on trade in agriculture. The negotiations that resulted in the document were a long and difficult process, as they dealt with a very sensitive subject and the Members had different interests on the topic. Similarly, current negotiations on reforming the AoA have also proved to be problematic, preventing the delivery of the Doha Round.

\subsection{Historical Background on Agriculture Negotiations: from GATT/1947 to the WTO}

Agriculture negotiations have historically been marked by great government involvement and strong interest by the private sector. Although GATT/1947 contracting parties have attempted to bring the subject under multilateral trade discipline, it remained largely at the margin of international rules until the creation of the $\mathrm{WTO}^{17}$.

In view of the aforementioned, developed nations have established complex domestic systems of protection of its agricultural production. They have also raised

Systems, Turkey, 2015, para. 1.

16 ROME Declaration on World Food Security and World Food Summit Plan of Action, World Food Summit, November 1996.

17 STEWART, Terence P. (Ed). The GATT Uruguay Round: A Negotiating History (1986-1992). Commentary. Boston: Kluwer Law and Taxation Publishers, 1993. p. 131 
strong tariff and non-tariff barriers to imports. Reducing or eliminating the level of aid conferred upon the economic sector after it is granted is very difficult, especially if we consider the evolution in the organization and lobby capacity of interest groups ${ }^{18}$.

Agriculture was initially out of the scope of GATT/1947. It was only on the fifth negotiating round that the matter was brought to the table. Indeed, during the Kennedy Round (1962-1967) ${ }^{19}$ the contracting parties adopted several amendments to GATT/1947 general clauses. A very significant modification related to the inclusion of Part IV to the Agreement, which directly regulated problems faced by developing countries ${ }^{20}$. For the first time during the former multilateral trading system, there was a reduction in tariffs applying over certain agricultural products, boosted by negotiations held between the United States of America (USA) and the European Economic Community (EEC) ${ }^{21}$.

Still

[f]rom the outset, agriculture has been viewed
as a 'special case' in the GATT. GATT rules
pertaining to agriculture were originally drafted
to be consistent with the agricultural policies of
the major signatories, rather than vice-versa. In
some cases, the GATT adopted special rules with
respect to agriculture; in other cases, nations gained
special treatment by explicit waivers, reservations
in accession agreements, or informal 'grandfather'
agreements. Still other policies are nominally
addressed by the GATT, but in practice the
provisions have had little or no effect ${ }^{22}$.

With the launch of the Uruguay Round, developing countries advocated for the reduction of protectionist policies in the agricultural sector in force in developed States, which was proven to adversely affect their growth $^{23}$. For that group of nations, agriculture repre-

18 STEWART, Terence P. (Ed). The GATT Uruguay Round: A Negotiating History (1986-1992). Commentary. Boston: Kluwer Law and Taxation Publishers, 1993. p. 131.

19 STIGLITZ, Joseph E.; CHARLTON, Andrew. Fair Trade for All: How can trade promote development? Londres: Oxford University Press, 2005. p. 42.

20 JACKSON, John Howard. Sovereignty, the WTO, and Changing Fundamentals of International Law. Nova York: Cambridge University Press, 2006. p. 98.

21 TREBILCOCK, Michael J.; HOWSE, Robert. The Regulation of International Trade. 2. ed. Nova York: Routledge, 2005. p. 160.

22 STEWART, Terence P. (Ed). The GATT Uruguay Round: A Negotiating History (1986-1992). Commentary. Boston: Kluwer Law and Taxation Publishers, 1993. p. 134.

23 IRWIN, Douglas A.; MAVROIDIS, Peter C.; SYKES, Alan O. The Genesis of GATT. Nova York: Cambridge University Press, 2008. p. 124. sents a large part of the economy. At the time of the WTO negotiations, they already shared the understanding they would benefit from trade liberalization in this sector.

Furthermore, many developing countries, and all least developed countries (LDCs), import food. The potential rise in staple foodstuff was seen as a risk for the maintenance of the subsistence nutrition levels of their population, as they have strain current account budgets ${ }^{24}$.

During negotiations, Jamaica presented a statement expressing its concerns relating to food security. It highlighted the need for extending the special and differential treatment to the agricultural sector, with a view to ensuring food security "[...] through increased self-sufficiency and a stable supply of imported agricultural products at equitable prices ${ }^{25}$ ". Even though Jamaica acknowledged that food security was not the same as self-sufficiency, it affirmed that some minimum level of self-sufficiency was essential to achieve food security. The country emphasized that agriculture and food security were key elements to developing economies, and admitted the importance of food aid programs ${ }^{26}$.

The USA position was diametrically opposed to that of developing nations. It recognized that food security was a common concern of GATT/1947 contracting parties. However, it claimed that food security was the ability to acquire necessary foodstuff and, in this sense, trade-disruptive practices aimed at ensuring self-sufficiency in production would not be acceptable under the new multilateral regime that was being formed ${ }^{27}$.

The Cairns Group ${ }^{28}$ also presented a proposal addressing food security, in which it stated that:

Food self-sufficiency policies are an inappropriate, ineffective and costly means of achieving food

24 STEWART, Terence P. (Ed). The GATT Uruguay Round: A Negotiating History (1986-1992). Commentary. Boston: Kluwer Law and Taxation Publishers, 1993. p. 163

25 FOOD SECURITY. Statement by Jamaica at Eighth Meeting of $\mathrm{Ne}$ gotiating Group on Agriculture. MTN.GNG/NG5/W/65, p. 01

26 FOOD SECURITY. Statement by Jamaica at Eighth Meeting of $\mathrm{Ne-}$ gotiating Group on Agriculture. MTN.GNG/NG5/W/65, p. 01.

27 ELABORATION of United States Agriculture Proposal with Respect to Food Security. MTN.GNG/NG5/W/61. p. 01.

28 Group formed by Argentina, Australia, Brazil, Canada, Chile, Colombia, Costa Rica, Guatemala, Indonesia, Malaysia, New Zealand, Pakistan, Paraguay, Peru, Philippines, South Africa, Thailand, Uruguay and Vietnam. The Cairns Group. Available at: <http:// cairnsgroup.org/Pages/map/index.aspx>. Access on: 31 Oct. 2016. 
security objectives and directly damage the interests of other countries. Secure supplies of food can be achieved through means such as: the maintenance of adequate food and feed grain stockpiles to ensure against shortages; [and] the diversification of sources of supply ${ }^{29}$.

It is thus noticeable that developing countries did not have a uniform negotiating position regarding food security during the Uruguay Round. In fact, agricultural exporting countries were more open to liberalizing agricultural trade. It is worth mentioning that those countries played a key role along the debates.

In this context, the main hindrances to the negotiations on agriculture were the permanence of export subsidies; barriers to market access, such as import quotas; disruptive trade practiced by state trading entities; and health and sanitary regulations ${ }^{30}$. Most of these subjects were object of modest regulation by the AoA.

Indeed, the AoA has initiated the process of reduction of traditional forms of agricultural protection. Under the rules of the Agreement, domestic support to the sector must be quantified and is subject to compulsory minimum reductions. Also, export subsidies must be gradually reduced. Finally, non-tariff barriers existing at the time of the negotiations, such as quotas, must be converted into tariff equivalents ${ }^{31}$.

The Agreement also provides for certain forms of subsidies exempt from reduction commitments, and allows for the imposition of extra duties in situations in which the overall volume of exports exceed a certain level or in which prices fall below the trigger price.

\subsection{A turbulent path}

An important rule included in the AoA is its Article 20, concerning the commitment of the Members in continuing the reform process on the multilateral regulation of agricultural markets. Among the elements that the Members must take into account while doing so, the

29 WORLD TRADE ORGANIZATION. Comprehensive Proposal for the Long-Term Reform of Agricultural Trade. GATT Doc. No. MTN. GNG/NG5/W/128. Available at: <https://www.wto.org/gatt_ docs/English/SULPDF/92090008.pdf. Access on: 31 Oct. 2016.

30 STEWART, Terence P. (Ed). The GATT Uruguay Round: A Negotiating History (1986-1992). Commentary. Boston: Kluwer Law and Taxation Publishers, 1993. p. 134-140.

31 TREBILCOCK, Michael J.; PUE, Kristen. The Puzzle of Agricultural Exceptionalism in International Trade Policy. Journal of International Economic Law, v. 18, p. 233-260, 2015. p. 238. provision mentions the analysis of non-trade concerns:

Article 20: Continuation of the Reform Process

[...] Recognizing that the long-term objective of substantial progressive reductions in support and protection resulting in fundamental reform is an ongoing process, Members agree that negotiations for continuing the process will be initiated one year before the end of the implementation period, taking into account:

(c) $[\ldots]$ non-trade concerns, special and differential treatment to developing country Members, and the objective to establish a fair and market-oriented agricultural trading system, and the other objectives and concerns mentioned in the preamble to this Agreement;

Such norm encompasses the need of discussing matters that relate to trade but are not purely economic, corroborating with the broader goals of the WTO expressed in its preamble, regarding, for example, enhancing living standards and promoting sustainable development. For agriculture negotiations, this means the pursuit of a fair and market-oriented framework, the consideration of developing countries interests and deficiencies, embodied in special and differential treatment rules, and the assessment of an open-ended set of values - the non-trade concerns. Albeit the lack of a definition in the AoA of what a non-trade concern could be, the expression reveals that agriculture policies may have multifunctional purposes, surpassing the mere protectionist objectives. In this sense, governmental support and protection may aim at developing rural areas, alleviating poverty, and combating hunger. With respect to the subject of the present paper, the rise in food prices in global markets and the need to ensure food security may also fall under the non-trade concerns category ${ }^{32}$.

In this regard, the need to reform the AoA becomes even more evident after the economic crisis that hit the world in 2007-2008. Since then, an upsurge in commodities has caused the escalate of the world food prices. Because of this rising, millions of people have been placed in the poverty level, aggravating the food situation, mainly in developing and LDCs countries. Moreover, this framework has contributed not only to the increase in food prices but also to their volatility, insofar this event has a direct impact on food supply,

32 SCHOENBAUM, Thomas J. Fashioning a New Regime for Agricultural Trade: New Issues and the Global Food Crisis. Journal of International Economic Law, v. 14, n. 3, p. 593-611, 2011. p. 601. 
creating a vicious circle. The global food market is now characterized by a growing uncertainty regarding food prices, availability, and accessibility, which are also affected by external factors, such as environment and weather phenomena. Finally, one should highlight that the development process of many countries, especially of those developing nations and LDCs, also constrain the demand for foodstuff ${ }^{33}$.

The scenario becomes even more troublesome by the deliberate action of governments that adopt trade policies to protect domestic agricultural markets. Several W'TO Members have, accordingly, employed measures such as export bans, export quotas or permits, and subsidies to protect domestic supplies from the rise in prices of foodstuff in global markets. In a domino effect, these protectionist practices have spread suspicion all over the world and put trading partners under alarm, promoting insecurity in agricultural markets. Consequently, States have started to seek self-sufficiency, as they could not rely on unstable world markets, which has motivated stockpiling and speculative buying ${ }^{34}$.

Those restrictive practices are part of the beggar-thy-neighbor policies. In periods of economic crises, governments often turn inwards, imposing trade barriers to protect their markets and assets, at the expenses of other countries or of international markets ${ }^{35}$. In the agricultural sector, the beggar-thy-neighbor policies may have even more disastrous outcomes, for the subject is closely related to sensitive non-trade concerns, such as the right to food. In the attempt of isolating the domestic agricultural market and foodstuff prices from the volatility of prices of global markets, protectionist trade measures contribute to enhancing the instability and the prices in the international agricultural market.

The consequences of higher food prices are amplified, and all countries bear the impact, which, however, is a heavier burden on developing countries and LDCs.

33 SCHOENBAUM, Thomas J. Fashioning a New Regime for Agricultural Trade: New Issues and the Global Food Crisis. Journal of International Economic Law, v. 14, n. 3, p. 593-611, 2011. p. 595-597. 34 SCHOENBAUM, Thomas J. Fashioning a New Regime for Agricultural Trade: New Issues and the Global Food Crisis. Journal of International Economic Law, v. 14, n. 3, p. 593-611, 2011. p. 598.

35 For more information about the beggar-thy-neighbor policies following the 2007 economic crisis and the role of the WTO in refraining them, see BALDWIN, Richard E.; EVENETT, Simon J. Beggar-thy-neighbour policies during the crisis era: causes, constraints, and lessons for maintaining open borders. Oxford Review of Economic Policy, v. 28, n. 2, p. 211-234, 2012.
In more developed nations, primary commodities represent only a small share of the cost of processed food products, which are a significant part of the food consumed in those territories, enabling the absorption of the price increase. In poorer States, on the other hand, where that kind of expensive goods are not so consumed, changes in the price of foodstuff are more directly felt, to the extent that food purchases are accountable for a large share of the expenses of a household and shortages are more likely to occur ${ }^{36}$. Similarly, the sensitive aspect of trade in agriculture is confirmed by the heavy short-term impact that food price spikes exert on consumers, especially when dealing with staple goods and the poorer segment of the population ${ }^{37}$.

The challenge in this matter is to identify what is truly a non-trade concern that should allow trade policies, and what is only a disguised protectionist measure. In addition, WTO Members must also reach an agreement as to how non-trade concerns should be included in the reform discussion and which changes they should entail.

All these elements raise issues on how the multilateral trading system could reflect the new reality of agricultural trade and efficiently regulate the markets. It should also be able to advance a continuous liberalization in the sector, whilst providing the appropriate tools to protect legitimate concerns, especially in light of the current prices volatility and the fear of food shortages ${ }^{38}$. This is the point we will address in the next section.

\section{The relation betWeen trade in Agriculture AND FOOD SECURITY}

At first, as the most part of the food consumed in developing countries is from domestic crops, one may think that trade is not directly related to food security. The practice attests, however, that trade can be of an utmost relevance in stabilizing prices and availability of

36 SCHOENBAUM, Thomas J. Fashioning a New Regime for Agricultural Trade: New Issues and the Global Food Crisis. Journal of International Economic Law, v. 14, n. 3, p. 593-611, 2011. p. 598.

37 TREBILCOCK, Michael J.; PUE, Kristen. The Puzzle of Agricultural Exceptionalism in International Trade Policy. Journal of International Economic Law, v. 18, p. 233-260, 2015. p. 245.

38 SCHOENBAUM, Thomas J. Fashioning a New Regime for Agricultural Trade: New Issues and the Global Food Crisis. Journal of International Economic Law, v. 14, n. 3, p. 593-611, 2011. p. 601. 
food in the domestic market, regardless of whether the largest percentage of the food consumed is produced domestically. Additionally, trade in agriculture and foodstuff has been increasing in the last years, a trend that is expected to continue in the coming decades, which impacts the percentage of food imports in the total amount of the food consumed in a given domestic market. The matter becomes even clearer when it comes to volatility, to the extent that volatility seems to have a larger effect in domestic markets than in international ones, commodities that are highly internationally traded have lower volatility than those less traded, and this phenomenon is higher in countries where governments actively interfere in the market and in products that suffer such intervention ${ }^{39}$.

Not coincidently, thus, that a more assertive approach to agriculture is the main demand of developing Members, particularly those that form the G20. The conclusion of the Doha Round depends on substantial progress on this issue, as it has been demonstrated by the debates and outcomes of the last couple of Ministerial Conferences.

In this context, one of the most important issues is to integrate the discussions over food availability and prices in the negotiations. Members must agree on what would be a reasonable solution to cope with the food crisis: to resort to self-sufficiency and protectionism or to maintain and deepen the trading opening orienta$\operatorname{tion}^{40}$. Through the arguments presented in this section, we will show that liberalization is still the best option to answer the problem in a sustainable and long-term way.

Despite the new stress given to the subject, mainly because of the Doha Round and the MDGs, food security is not a new concern in the multilateral trading system. During the Uruguay Round, the Marrakesh Declaration and the establishment of the Net Food-Importing Developing Countries category (NFIDC) represent initiatives aimed at attempting to prevent any possible negative effect of agricultural liberalization in the most vulnerable Members. In most recent efforts,

39 DIAZ-BONILLA, Eugenio. Agricultural Trade and Food Security: Some Thoughts about a Continuous Debate. E15Initiative. Geneva: International Centre for Trade and Sustainable Development (ICTSD) and World Economic Forum, 2014. Disponível em: <www. e15initiative.org/>. p. 1.

40 SCHOENBAUM, Thomas J. Fashioning a New Regime for Agricultural Trade: New Issues and the Global Food Crisis. Journal of International Economic Law, v. 14, n. 3, p. 593-611, 2011. p. 602. during the Doha Round, many developing Members requested the creation of a Food Security Box, which would be a set of lawful and legitimate measures to protect domestic markets. Such proposal later evolved into the Special Safeguard Mechanism (SSM), which, however, would leave the developing countries that opted to implement it in a worse scenario. The losses would not be only in terms of food security, but also of employment, production, and export levels. In this sense, if a developing Member is resolute in adopting a trade policy to ensure food security, the 'least worst' option would be to increase tariffs, provided that the money be invested in research and development strategies for the agricultural sector ${ }^{41}$.

The biggest challenge in this regard is balancing the need for developing countries, and especially for LDCs, to maintain enough policy space to take the appropriate measures to meet their domestic demands, whilst strengthening the multilateral framework on agriculture. Both developing and developed nations resort to trade policies to protect their agricultural markets, and the former group of States also employ those instruments to cope with issues related to poverty and hunger. Trade policies are particularly popular amidst economic crises, as they are relatively easy to implement and represent an immediate response to sensitive subjects that often arouse public outcry and trigger influential lobbies. Nevertheless, the interdependence of the world economy, trade, and market, alongside the increasing role of developing countries in those spaces, makes it impossible to sustain domestic policies that are ever more adverse to the international agricultural markets. Restrictive trade practices become, then, less effective, producing even the contrary results to those initially thought. In the period between 2006-2008, for instance, trade remedies employed to reduce the price of foodstuff in domestic markets were accountable for about half of the increase in world prices of rice. Protectionist measures concerning domestic agricultural markets contribute, therefore, to increase price volatility in the global food market, as they foster beggar-thy-neighbor policies ${ }^{42}$.

41 DIAZ-BONILLA, Eugenio. Agricultural Trade and Food Security: Some Thoughts about a Continuous Debate. E15Initiative. Geneva: International Centre for Trade and Sustainable Development (ICTSD) and World Economic Forum, 2014. Disponível em: <www. e15initiative.org/>.p. 11

42 FOOD SECURITY PORTAL. A New Paradigm for the Doba Development Round: IFPRI Policy Seminar. Feb 26, 2016. Available at: <http://www.foodsecurityportal.org/new-paradigm-doha-devel- 
Enhancing food security requires, accordingly, the reform of the WTO agriculture agreement, to include some specific measures that could properly address the issue on the multilateral trading system. There should be, for example, a more restrictive rule on export controls, to identify the requirements that must be met and the process to be followed upon the implementation of such measures. These have been a common practice among several countries since the 2007 economic crisis, provoking collateral effects on third nations such as food shortage and prices increase. The existing regulation on this matter (Article 12 of the AoA) is very vague and does not impose any real restriction on the employment of the resource, being necessary a more efficient approach. Furthermore, vulnerable Members facing difficulties in satisfying their population right to food should be recognized as "food insecure States". This would enable them to resort to some exceptional well-delimited support or protectionist practices, observed some conditions, aimed at enhancing food security ${ }^{43}$.

As mentioned, food security and the global food crisis are complex phenomena that require coordinated and comprehensive actions to reach a sustainable solution. Trade is only one of the elements impacting food security, and any trade policy or multilateral trading regulation will not be able to answer food security concerns, if not followed by broader inclusive policies. In this sense, efforts must focus on distributive measures, sustainable growth, empowerment of women, and enhancement of health services, to name a few initiatives $^{44}$. Concerning the AoA, reforming the Agreement will not address all the problems, but will represent a progress towards ensuring fair access to food markets and reasonable prices for foodstuff ${ }^{45}$.

Any revision in the AoA must comprise the goals related to food security - availability, access and utilization of food and stability -, which does not necessarily mean that self-sufficiency and trade policies should trump

opment-round $>$. Access on: 29 Oct. 2016.

43 SCHOENBAUM, Thomas J. Fashioning a New Regime for Agricultural Trade: New Issues and the Global Food Crisis. Journal of International Economic Law, v. 14, n. 3, p. 593-611, 2011. p. 607-608. 44 DIAZ-BONILLA, Eugenio. Agricultural Trade and Food Security: Some Thoughts about a Continuous Debate. E15Initiative. Geneva: International Centre for Trade and Sustainable Development (ICTSD) and World Economic Forum, 2014. Disponível em: <www. e15initiative.org/>. p. 2.

45 SCHOENBAUM, Thomas J. Fashioning a New Regime for Agricultural Trade: New Issues and the Global Food Crisis. Journal of International Economic Law, v. 14, n. 3, p. 593-611, 2011. p. 593. trade liberalization nor the achievements implemented through agriculture negotiations in the WTO. On the contrary, trade liberalization in agriculture does not impose any constraint on the government scope of action, being rather a relevant instrument for promoting food security. In this regard, a stable and well-functioning food market is essential in guaranteeing food security, as long as there are adequate assistance and encouraging policies that foment research, exchange of information and practices, infrastructure investments, and extension services, among other capacity building measures. A lasting solution for the problem of hunger and food crisis depends, hence, on multilevel actions, engaging all actors interested on the matter, from States to international organization. In what concerns the WTO, the multilateral regulation on trade in agriculture must be strengthened, trade-distorting and protectionist measures reduced, and mechanisms such as export controls on foodstuffs applied only as last resort ${ }^{46}$.

The needed increase in production of foodstuff demands responsible investments, which benefit from an encouraging environment and well-functioning markets, according to a rule-oriented multilateral trading system. In the same way, transparency in agricultural markets must be enhanced, to facilitate the exchange of information and the availability of data, reducing the likelihood of unexpected price volatility and of disconnected harmful domestic policies ${ }^{47}$.

Nowadays, the center of the food security issue is the impact of high prices and volatility on consumers, shifting the focus from producers, the main object of protection of developed countries. Nevertheless, resorting to trade restrictive policies to ensure adequate food access and availability to consumers may be a counterproductive and very costly practice. They could affect other economic sectors that would have to absorb the artificially increased resources, and the fiscal structure of the government, which could contribute to increasing the volatility of the domestic market. A more efficient and stable way to promote food security would be fostering measures that encourage production, rather than limit trade, and reduce costs, mainly through investments in infrastructure, in research and develop-

46 SCHOENBAUM, Thomas J. Fashioning a New Regime for Agricultural Trade: New Issues and the Global Food Crisis. Journal of International Economic Law, v. 14, n. 3, p. 593-611, 2011. p. 607. 47 G20. G20 Action Plan on Food Security and Sustainable Food Systems, Turkey, 2015. para. 6,7. 
ment and in areas allowed under the AoA. Multilevel efforts comprehending broad initiatives such as support for land ownership by small producers, appropriate management of natural resources, strengthened safety nets, good governance, women empowerment, and macroeconomic stability are essential in achieving this goal. These practices would also contribute to overcoming the impasse between the protection of producers and the protection of consumers. They increase profits for producers, whilst enhancing food supply and reducing prices for consumers ${ }^{48}$.

When addressing food security, the most important element to bear in mind is the impact of the practices and measures on the life of the people who are affected by poverty and hunger, whether they are small producers or impoverished consumers. To be efficient, any policy must represent a combination of broader initiatives to tackle every aspect of the problem, and to consider the heterogeneity of the households. In this regard:

To summarize, when discussing poverty and food
security problems it must be remembered that
trade policies are just an instrument (and in several
cases a blunt one) to address those concerns, with a
variety of potential aggregate and
distributive impacts that need to be considered.
Trade policies can make a positive contribution
to poverty alleviation and food security within a
properly defined globalprogram of macroeconomic,
investment, institutional, and social policies, in
which differentiated approaches and instruments
are targeted to the households and individuals that
suffer from poverty and food insecurity. Usually,
trade policies aimed at a specific food product,
even if labelled "special," "food security staple,"
or any other name suggesting the need for special
consideration, do not necessarily represent the
more effective, efficient, or even equitable, way of
addressing poverty and food security problems of
affected households ${ }^{49}$.

As an example of how distorting trade policies may injure both domestic and global agricultural markets, we can mention the case of Argentina. From 2002-2015, the country's regulation on agriculture was substantially

48 DIAZ-BONILLA, Eugenio. Agricultural Trade and Food Security: Some Thoughts about a Continuous Debate. E15Initiative. Geneva: International Centre for Trade and Sustainable Development (ICTSD) and World Economic Forum, 2014. Disponível em: <www. e15initiative.org/>. p. 248-249.

49 DIAZ-BONILLA, Eugenio. Agricultural Trade and Food Security: Some Thoughts about a Continuous Debate. E15Initiative. Geneva: International Centre for Trade and Sustainable Development (ICTSD) and World Economic Forum, 2014. Disponível em: <www. e15initiative.org/>. p. 4. protectionist, marked by a high level of government interference in the sector. The main goal was to create a gap between the domestic market and the global one. Among the measures implemented were the imposition of "export taxes on most exported grains, quantitative restrictions on grain exports, and maximum prices set for live cattle and retail sales" ${ }^{\circ 0}$. Consequently, domestic crop prices were significantly lower than those prevailing on international markets, since the supply was artificially increased in the internal market. This short-term outcome was accompanied by a heavy increase in the tax burden for Argentinian farmers, as well as the discouragement to invest in new technologies and agricultural practices. On a long-term analysis, these actions could cause the migration of farmers, especially of small producers, to other activities, and the decline of the agricultural productivity, which would result in the increasing of prices $^{51}$.

Following the formation of a new government in December 2015, Argentinian rules concerning the agricultural sector were completely reviewed. In this regard, export taxes for most agricultural products were removed or have been steadily decreasing, and the export permit system was abandoned, making it cheaper and easier to trade agricultural products. Accordingly, a market that was previously stagnated and unsuccessful in exporting its products, have in a few months registered record levels in terms of export values in US dollars. The predictions are also optimistic - in the next ten years, agricultural production in Argentina could grow by up to thirty-one percent, the highest in South Ameri$\mathrm{ca}$, and its share of the international cereal market could increase from three percent to eight percent in a ten-year period ${ }^{52}$.

Besides improving international trade of agricultural products, eliminating restrictive trade policies may also have a positive impact on ensuring food security. Developing countries, as it is the example of Argentina,

50 FOOD SECURITY PORTAL. A New Paradigm for the Doba Development Round: IFPRI Policy Seminar. Feb 26, 2016. Available at: $<$ http://www.foodsecurityportal.org/new-paradigm-doha-development-round $>$. Access on: 29 Oct. 2016.

51 FOOD SECURITY PORTAL. A New Paradigm for the Doha Development Round: IFPRI Policy Seminar. Feb 26, 2016. Available at: $<$ http://www.foodsecurityportal.org/new-paradigm-doha-development-round $>$. Access on: 29 Oct. 2016.

52 FOOD SECURITY PORTAL. A New Paradigm for the Doha Development Round: IFPRI Policy Seminar. Feb 26, 2016. Available at: $<$ http://www.foodsecurityportal.org/new-paradigm-doha-development-round $>$. Access on: 29 Oct. 2016. 
have achieved a fundamental role in the international multilateral trading system. Their policies and decisions have an important influence on international markets and on the pursuing of global food security. This new position, as well as the interdependent arrangement of the current international society, requires a broader system of cooperation and coordinated actions. Independent policies are usually not efficient nor sustainable in the long-term. Furthermore, the Argentinian case also indicates the need of guaranteeing greater transparency in market information-sharing among countries, so trade partners can obtain all the appropriate data to avoid suffering from unexpected changing policy that could affect their own markets ${ }^{53}$.

Therefore, when it comes to trade policies to assure food security, the AoA does not constrain government actions intended to address poverty and hunger, which can have both good and bad outcomes for domestic and global agricultural markets. In the first case, the agreement encourages the adoption of measures to protect the vulnerable share of the population, promoting programs targeting poor producers and/or consumers, and enabling food stocks and domestic food aid initiatives. Developing countries have enough policy space to pursue well-defined programs for food safety and guaranteeing the right to food. On the other hand, the AoA does not preclude the implementation of many disguised protectionist policies either, which contributes to favoring trade distorting practices, worsening the volatility of food prices and aggravating the food crisis ${ }^{54}$.

\section{Final Conclusions}

Food security is a multilayered theme that requires a comprehensive approach, emphasizing the interdependence of the current international society. The seek for a common and sustainable solution must involve the efforts of all interested actors, in a wide range of areas. International trade is only one element in this configu-

53 FOOD SECURITY PORTAL. A New Paradigm for the Doba Development Round: IFPRI Policy Seminar. Feb 26, 2016. Available at: $<$ http://www.foodsecurityportal.org/new-paradigm-doha-development-round>. Access on: 29 Oct. 2016.

54 DIAZ-BONILLA, Eugenio. Agricultural Trade and Food Security: Some Thoughts about a Continuous Debate. E15Initiative. Geneva: International Centre for Trade and Sustainable Development (ICTSD) and World Economic Forum, 2014. Disponível em: <www. e15initiative.org/>. p. 20. ration, meaning that well-designed trade policies and the WTO rules on trade in agriculture may contribute to accomplishing food security, as long as they are part of a broader initiative that can reach all the many levels of the issue.

The reform of the AoA is indispensable in the WTO efforts to promote food security, in line with its development goals and the needs of developing countries and LDCs. WTO Members, when negotiating the new set of rules and commitments, must bear in mind the heterogeneity of the 164 countries that form the membership of the organization. Even among the group of developing countries or the one comprised only of developed nations it is possible to identify different demands and interests. Considering such diversity and the importance of non-trade concerns for the agricultural framework, Members must seek a coordinated position in dealing with the right to food and food security, prioritizing a trade favorable approach over a domestic restrictive and distorting policy.

Instead of policies that artificially impact food availability and prices, countries should focus their efforts on individual and collective measures that promote food security on a long-term basis, through the strengthening of market efficiency in developing States and the enhancement of the international cooperation endeavor. Eliminating export subsidies is an important step towards a more stable global market. This initiative should be followed, for example, by the improvement of market information exchange and the reform of the AoA, to adequate the WTO rules to the current demands of the global agricultural market ${ }^{55}$.

In this regard, the best way to address food security as a non-trade concern in the multilateral trading system is through human and financial resources, as well as strengthening domestic institutions and promoting capacity building. This does not mean that all trade policies should be avoided nor that they do not convey any advantages to those countries that suffer from food insecurity. On the contrary, the AoA must allow the employment of essential and well-defined policies as a temporary resource to protect vulnerable domestic markets from import surges and/or unfair trade

55 FOOD SECURITY PORTAL. A New Paradigm for the Doha Development Round: IFPRI Policy Seminar. Feb 26, 2016. Available at: $<$ http://www.foodsecurityportal.org/new-paradigm-doha-development-round $>$. Access on: 29 Oct. 2016. 
practices $^{56}$. The reform of the AoA in this context is concerning the need to enhance the discipline on these policies, so they cannot serve as protectionist and trade distortive practices, harming the global agricultural market and the food security of other countries, lessening the progress achieved by trade liberalization.

\section{References}

BALDWIN, Richard E.; EVENETT, Simon J. Beggarthy-neighbour policies during the crisis era: causes, constraints, and lessons for maintaining open borders. Oxford Review of Economic Policy, v. 28, n. 2, p. 211-234, 2012.

DIAZ-BONILLA, Eugenio. Agricultural Trade and Food Security: Some Thoughts about a Continuous Debate. E15Initiative. Geneva: International Centre for Trade and Sustainable Development (ICTSD) and World Economic Forum, 2014. Disponível em: <www.e15initiative.org/>.

ELABORATION of United States Agriculture Proposal with Respect to Food Security. MTN.GNG/ NG5/W/61.

FEUNTEUN, Tristan. Cartels and the Right to Food: An Analysis of States' Duties and Options. Journal of International Economic Law, v. 18, p. 341-382, 2015.

FOOD SECURITY PORTAL. A New Paradigm for the Doha Development Round: IFPRI Policy Seminar. Feb 26, 2016. Available at: <http://www.foodsecurityportal. org/new-paradigm-doha-development-round $>$. Last accessed on 29 October 2016.

FOOD Security: Statement by Jamaica at Eighth Meeting of Negotiating Group on Agriculture. MTN. GNG/NG5/W/65.

G20. G20 Action Plan on Food Security and Sustainable Food Systems, Turkey, 2015.

IRWIN, Douglas A.; MAVROIDIS, Peter C.; SYKES, Alan O. The Genesis of GATT. Nova York: Cambridge University Press, 2008.

56 DIAZ-BONILLA, Eugenio. Agricultural Trade and Food Security: Some Thoughts about a Continuous Debate. E15Initiative. Geneva: International Centre for Trade and Sustainable Development (ICTSD) and World Economic Forum, 2014. Disponível em: <www. e15initiative.org/>. p. 20.
JACKSON, John Howard. Sovereignty, the WTO, and Changing Fundamentals of International Law. Nova York: Cambridge University Press, 2006.

ROME Declaration on World Food Security and World Food Summit Plan of Action, World Food Summit, November 1996.

SCHOENBAUM, Thomas J. Fashioning a New Regime for Agricultural Trade: New Issues and the Global Food Crisis. Journal of International Economic Law, v. 14, n. 3, p. 593-611, 2011.

STEWART, Terence P. (Ed). The GATT Uruguay Round: A Negotiating History (1986-1992). Commentary. Boston: Kluwer Law and Taxation Publishers, 1993.

STIGLITZ, Joseph E.; CHARLTON, Andrew. Fair Trade for All: How can trade promote development? Londres: Oxford University Press, 2005.

THE Cairns Group. Available at: < http://cairnsgroup. org/Pages/map/index.aspx $>$. Accessed on: 31 Oct. 2016.

TREBILCOCK, Michael J.; HOWSE, Robert. The Regulation of International Trade. 2. ed. Nova York: Routledge, 2005.

TREBILCOCK, Michael J.; PUE, Kristen. The Puzzle of Agricultural Exceptionalism in International Trade Policy. Journal of International Economic Law, v. 18, p. 233-260, 2015.

UN COMMITTEE ON ECONOMIC. Social and Cultural Rights (CESCR). General Comment No. 12: The Right to Adequate Food (Art. 11 of the Covenant), 12 May 1999, available at: <http://www.refworld.org/ docid/4538838c11.html.> Access on: 27 Oct. 2016.

UNITED NATIONS. General Assembly: Resolution 70/1. Transforming our world: the 2030 Agenda for Sustainable Development, A/RES/70/1, 21 October 2015.

UNITED NATIONS. 'Preliminary Report of the Special Rapporteur of the Commission on Human Rights on the Right to Food' (2001) UN Doc. A/56/210, 23 July 2001.

UNITED NATIONS. General Assembly: Resolution 55/2. United Nations Millennium Declaration, A/ RES/55/2, 18 September 2000.

UNITED NATIONS. Goal 1: Eradicate Extreme Poverty \& Hunger. Available at: < http://www.un.org/ 
millenniumgoals/poverty.shtml>. Accessed on: 24 Oct. 2016.

UNITED NATIONS. Goal 2: End hunger, achieve food security and improved nutrition and promote sustainable agriculture. Available at: <http://www. un.org/sustainabledevelopment/hunger/>. Accessed on: 24 Oct. 2016.

UNITED NATIONS. The Millennium Development Goals Report: 2015. United Nations: New York, 2015.

WORLD TRADE ORGANIZATION. Comprehensive Proposal for the Long-Term Reform of Agricultural Trade. GATT Doc. No. MTN.GNG/NG5/W/128. Avai- lable at: <https://www.wto.org/gatt_docs/English/ SULPDF/92090008.pdf. Access on: 31 Oct. 2016.

WORLD TRADE ORGANIZATION. DG Azevêdo: Trade is vital in meeting Sustainable Development Goals. Available at: <https://www.wto.org/english/ news_e/news16_e/dgra_21sep16_e.htm>. Access on: Oct. 2016.

ZHANG, Ruosi. Food Security: Food Trade Regime and Food Aid Regime. Journal of International Economic Law, v. 7, n. 3, p. 565-584, 2004. 


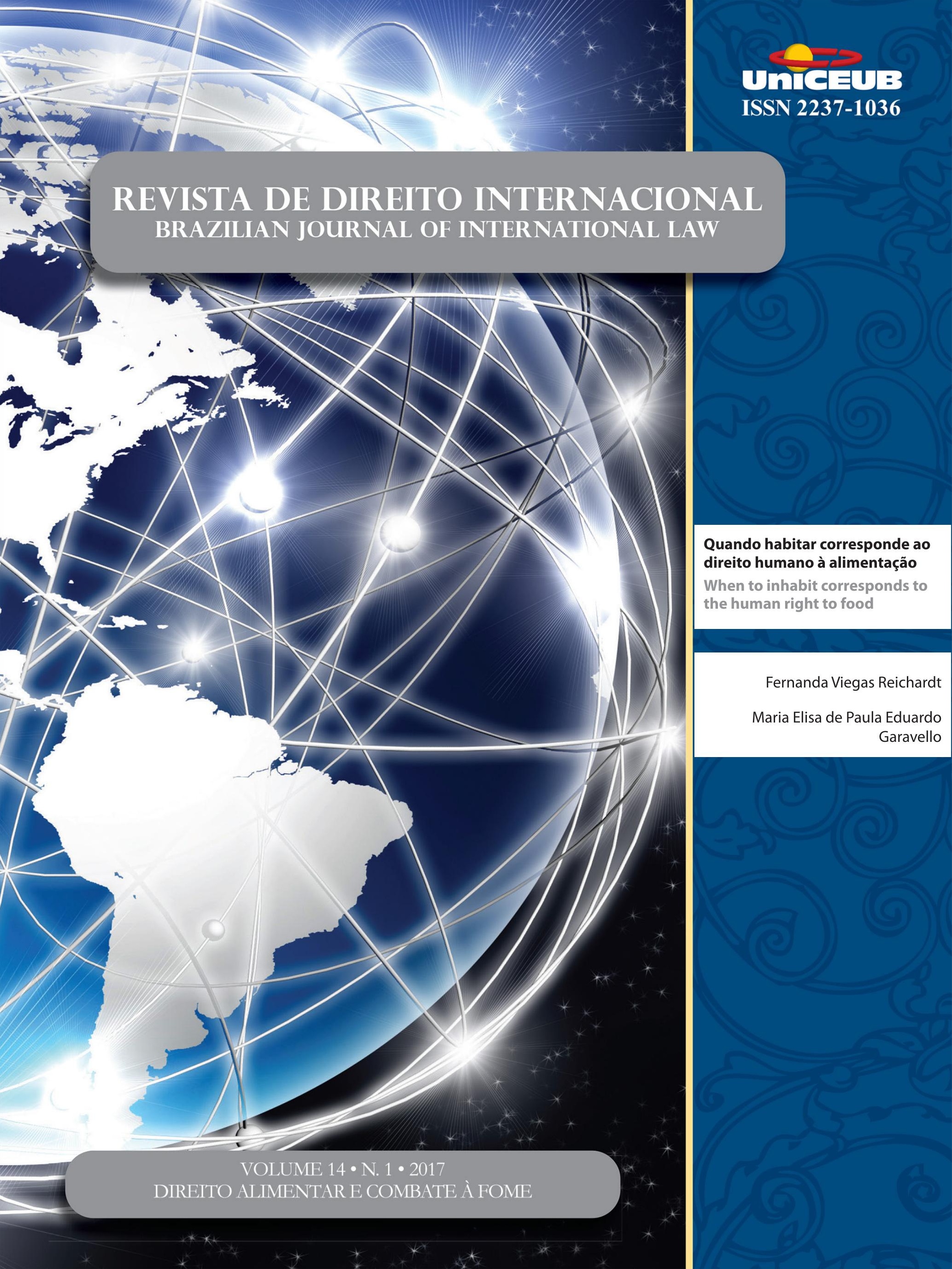




\section{Quando habitar corresponde ao direito humano à alimentação*}

\section{When to inhabit corresponds to the human right to food}

\author{
Fernanda Viegas Reichardt** \\ Maria Elisa de Paula Eduardo Garavello***
}

\section{Resumo}

Neste artigo discutimos o direito humano à alimentação concebido em termos culturais ligados a um "território", mais especificamente, à Terra Indígena [TT] Pimentel Barbosa de ocupação Xavante, localizada no Estado de Mato Grosso, Brasil. Na primeira parte do artigo, procuramos demonstrar que à alimentação do povo Xavante estão vinculados importantes processos culturais, simbólicos e cosmológicos que se comunicam com modos de pertencer a um "território". Já a situação de insegurança alimentar apresentada nesta segunda etapa do artigo, aponta para algo mais do que fragilidade nas condições de sua sobrevivência. Implica, sobretudo, numa condição política negada, já que é retirada dos Xavante seu próprio mundo, ou o "Rô" [ou cerrados, mundo, tudo], que é a condição de sua existência como A'unve [ou povo]. Estamos falando, portanto, de um jogo simbólico muito mais amplo e que leva à destruição dos sentidos sociais desse povo. Assim, insegurança alimentar, desnutrição e altos índices de mortalidade infantil, são sintomas de um problema mais basal, que por sua vez evidencia o uso desigual do amplo "território" brasileiro. Por este motivo, falar do atual contexto de "subalternidade alimentar" do povo Xavante significa também falar da supressão das condições mínimas de sua expressão social em Ró. Na terceira parte, abordamos as possibilidades de os direitos humanos serem colocados ao serviço de uma política emancipatória em relação aos Xavante sobre as possibilidades de uma concepção multicultural dos direitos humanos. Ressalvamos que, ao menos no contexto brasileiro, o diálogo parece uma noção desesperadamente fraca em relação à cultura Xavante. As conclusões finais levam a proposta de que as terras indígenas Xavante voltem a ter sua configuração de território contínuo unindo as terras indígenas através dos cerrados restituindo, ao menos em parte, a territorialidade indígena.

Palavras chave: Cultura Xavante. Cerrado. Soberania alimentar. Conceito de "Ro". "Territorialidade".

\section{Abstract}

In this article we discuss the human right to food considered in cultural terms linked to a "territory", more specifically, to the Xavante Indigenous Land "Pimentel Barbosa", located in the State of Mato Grosso, Brazil. In 
the first part of the article, we try to demonstrate that important cultural, symbolic and cosmological processes are linked to the Xavante conception of food, which is linked with the ways of belonging to a "territory". The food insecurity context of the Xavante people presented in this second stage of the article, points to something more than fragility in the conditions of their survival. It implies, above all, in a denied political condition, since it is withdrawn from the Xavante people their own world. This because the Xavante concept of "Ró" [the tropical savanna ecoregion, their territoriality and their concept of life] is the condition of their existence as "A'uwe" [or Xavante people]. We are arguing that it is a broader symbolic issue that leads to the destruction of the social senses of this people. Thus, food insecurity, malnutrition and high infant mortality rates are symptoms of a more basal problem that shows the unequal use of Brazilian "territory". For this reason, the other side of the coin of the present Xavante people context of "food subalternity" is the suppression of the minimum conditions of its social expression in Ró. In the third part of this article, we discuss the possibilities of human rights being put at the service of an emancipatory policy towards the Xavante and about the possibilities of a multicultural conception of human rights. We emphasize that, at least in the Brazilian context, dialogue seems to be a desperately weak notion of Xavante culture. The final conclusions lead to the proposal that the Xavante indigenous lands should once again have their original configuration, uniting the indigenous lands through the tropical savanna ecoregion, restoring, at least in part, indigenous territoriality.

Keyword: Xavante Culture. Tropical savanna ecoregion. Food sovereignty. Concept of "Ró". "Territoriality".

\section{Agradecimento}

Á Jurandir Siridiwe Xavante, Cacique da Aldeia Etenhiritipá quem revisou o artigo no que se refere à cultura Xavante e o conceito de "Ró" e à Fundação de Amparo à Pesquisa do Estado de São Paulo que financia e viabilisa esta pesquisa.

\section{ACKnOWLedgment}

To Jurandir Siridiwe Xavante, Cacique of the Indigenous village "Aldeia Etenhiritipá" who reviewed the article regarding the Xavante culture and the concept of "Ró" and to the Foundation for Research Support of the State of São Paulo, which finances and makes this research feasible.

\section{INTRODUÇÃo}

Neste artigo propomos como questão central o diálogo entre três temas, "territorialidade"; "soberania alimentar" e "direitos humanos". Nosso interesse restringe-se ao direito humano à alimentação concebido em termos culturais ligados a um "território", mais especificamente, à Terra Indígena [TT] Pimentel Barbosa de ocupação Xavante "território" localizada no Estado de Mato Grosso.

São distintos os contextos em que foram construídas e demarcadas as diferentes Terras Indígenas brasileiras e, portanto, seus impactos foram sentidos de forma diferenciada pelas diferentes populações. De acordo com Gomide ${ }^{1}$, o contato dos Xavante com a sociedade moderna ocidental ocorreu em diferentes momentos, determinando distintas frentes migratórias. Neste artigo referimo-nos aos grupos Xavante que migraram no início do século XVII do Estado de Goiás, e passam a viver no Estado do Mato Grosso, após as travessias dos rios Araguaia, Cristalino e das Mortes. O processo migratório dos Xavante é causado pela descoberta do ouro na então província de Goiás, da chegada dos waradzu [ou 'homem branco"], entre eles mineradores, bandeirantes, colonos e missionários. A vivência nas margens do rio das Mortes permite um certo isolamento até meados dos anos 1940, quando os Xavante são novamente contatados e sua "pacificação" é oficializada pelo Estado brasileiro. No entanto, os Xavante resistem ao contato com os waradzu até meados de 1960 ². Esgotados pelas doenças, pela fome e pelos conflitos, o "contato" entre representantes da sociedade nacional

1 GOMIDE, M. L. Marãnã Bödödi: a territorialidade Xavante nos caminhos do Ró. 2008. 436 f. Tese (Doutorado em Geografia Física) - Universidade de São Paulo, São Paulo, 2008.

2 Vale aqui mencionar a 'equipe de pacificação' do então Serviço de Proteção ao Índios é chefiada por Pimentel Barbosa (1941), nome dado posteriormente à sua Terra Indígena. 
e os indígenas é finalmente "estabelecido". A partir de 1970 e das políticas fiscais do governo federal, destinadas a fomentar a colonização e o desenvolvimento econômico em larga escala da região Centro Oeste brasileira, colonos e fazendeiros chegaram à porção leste da Bacia do Xingu. Imensas extensões de cerrado foram ocupadas pela agropecuária. Devido à intensa ocupação das paisagens mato-grossenses pela pecuária e agricultura, as terras indígenas Xavante são atualmente ilhas de biodiversidade cercadas por extensas áreas degradadas e podem ser consideradas como fragmentos do seu "território" tradicional ${ }^{3}$.

O objeto desse artigo é a relação dos A'uwe Xavan$\mathrm{te}^{4} \mathrm{com}$ os cerrados, principalmente no que se refere à soberania alimentar e aos direitos humanos, que uma vez rompida inviabiliza sua reprodução sociocultural. $\mathrm{O}$ conhecimento profundo sobre os cerrados xavantes é definido e orientado por concepções cosmológicas que norteiam a relação Xavante/Natureza [se é que essa dicotomia existe!] e que são parte constitutiva de sua maneira de ver o mundo e constituir-se no universo. Delimitado o objeto de análise, os seguintes problemas de pesquisa são propostos: (i) qual a relação estabelecida entre "território", cultura, e alimentação pelo povo Xavante?; (ii) em relação aos Xavante, podemos considerar que habitar pode corresponder ao direito humano à alimentação?; (iii) em caso positivo, qual conceito deve ser utilizado, segurança ou soberania alimentar? e; (iv) poderão os direitos humanos serem colocados ao serviço de uma política emancipatória em relação aos Xavante no que se refere ao "território", direito à alimentação e reprodução cultural?

Como possíveis respostas aos problemas formulados sugerimos, como hipóteses, que: (i) para os Xavante, "comunidade humana"; "atividade" e "espaço físico" são termos absolutamente interligados. Os lugares onde vivem; visitam e desenvolvem suas memórias compartilhadas ganham significado simbólico, que inviabiliza uma categorização. Por este motivo, a análise deve-se voltar para os fatores sociais e naturais [ou socioambientais] que se encontram entrelaçados na dicotomia

3 GOMIDE, M. L. Marãnã Bödödi: a territorialidade Xavante nos caminhos do Ró. 2008. 436 f. Tese (Doutorado em Geografia Física) - Universidade de São Paulo, São Paulo, 2008.

$4 \mathrm{O}$ povo indígena brasileiro xavante, autodenominado A'une ["gente"] ou A'wẽ Uptabi ["povo verdadeiro"], pertence linguisticamente à família linguística Jê, a qual, por sua vez, pertence ao tronco linguístico Macro-Jê. Sua língua é chamada akwevén ou aquém [também grafada “acuen"]. humanos e ambiente. (ii) A partir desta concepção, a luta pelo direito humano à alimentação e reprodução cultural, entre outros, é legitimada através da noção Xavante de "território". (iii) No que concerne à segurança/soberania alimentar, adotamos o segundo termo e o interpretamos de forma bastante ampla, como o direito do povo Xavante de decidir sobre seu próprio sistema alimentar e produtivo. Como também, de definir quais alimentos são culturalmente adequados à sua realidade. (iv) Em relação à quarta pergunta, que versa sobre as possibilidades de os direitos humanos serem colocados ao serviço de uma política emancipatória em relação aos Xavante, nossa resposta é um sim muito condicional. $\mathrm{E}$, as condições versam sobre as possibilidades de uma concepção multicultural dos direitos humanos.

Adotamos a bricolagem como metodologia de pesquisa. Oriundo do francês, o termo "bricolage" significa um trabalho manual feito de improviso e que aproveita materiais diferentes. Na apropriação realizada por Lévi-Strauss ${ }^{5}$, o conceito de bricolagem foi definido como um método de expressão através da seleção e síntese de componentes selecionados de uma cultura. Sua existência é explicada a partir de uma epistemologia da complexidade $^{6}$, cujo propósito é manter a confluência da pesquisa moderna e pós-moderna e alimentar os discursos conflitantes entre elas sem delimitar fronteiras conceituais ou o predomínio de uma sobre a outra. A opção pela bricolagem ocorreu por percebermos que ela dialoga com estudos sob a perspectiva do referencial teórico adotado - a complexidade, oferecendo oportunidade de articulação de teorias, metodologias, atuação do pesquisador e participantes no estudo, num esquema multireferencial de construção do conhecimento. A bricolagem tem sido crescentemente utilizada em pesquisas socioambientais por adequar-se à diferentes estudos desenvolvidos na área interdisciplinar, e apresentar-se como método promissor e inovador, no qual os traços subjetivos do pesquisador interagem com os referenciais adotados, de modo interconectado e complementar. Trata-se de uma metodologia que se oeracionaliza em práticas não disjuntivas, antes articuladoras, que possibilita a compreensão abrangente dos objetos de estudo, que articula de modo inseparável a teoria e a prática, que respeita a participação ativa do investigador

5 LEVI-STRAUSS, C. O pensamento selvagem. São Paulo: Nacional, 1976

6 MORIN, E. O problema epistemológico da complexidade. 3. ed. MiraSintra: Publicações Europa-América, 2002. 
no processo de pesquisa, e que considera as nuances e sutilezas presentes na busca pela compreensão de fenômenos complexos. A Bricolagem como metodologia de pesquisa designa uso de várias ferramentas metodológicas para esse Projeto e não exclui a utilização de outras opções metodológicas. O "bricoleur" configura-se dentro de múltiplas modalidades, todas elas podendo ser vistas de modo separado ou, entrecruzado, coexistindo entre si e potencializando ainda mais o trabalho do pesquisador. Assim, este artigo adota: (i) pesquisa bibliográfica e documental; (ii) pesquisa qualitativa através de entrevistas abertas; (iii) a hermenêutica diatópica proposta por Santos (1997) - como caminho para o diálogo intercultural; (iv) a triangulação de métodos como uma estratégia de diálogo entre áreas distintas de conhecimento; entre outras. Esclarecemos que este artigo é resultado de uma pesquisa mais abrangente chamada "Projeto Xingu"”. A subárea de pesquisa "Direito Ambiental \& Sociologia", foca diferentes conflitos socioambientais da região do Alto Xingu e visa argumentar que problemas complexos e interligados [como as questões indígenas, por exemplo,] devem ser abordados e integrados nas políticas nacionais e internacionais, públicas e privadas, especialmente no âmbito jurídico. Os trabalhos de campo do primeiro semestre de 2016 foram realizados na porção leste da cabeceira do rio Xingu, através de entrevistas abertas com diferentes atores sociais, entre eles indígenas Xavante.

O artigo está dividido em três partes. A primeira delas é uma análise das relações entre comunidade humana e espaço físico, ou "territorialidade" Xavante e pretende dar respostas, mesmo que parciais, aos dois problemas inicias apresentados. $\mathrm{Na}$ segunda etapa, apresentamos alguns dados que demonstram o estado de insegurança alimentar que essas populações se encontram. Também argumentamos que, de acordo com a perspectiva Xavante, o conceito de soberania alimentar está intimamente ligado ao conceito de Ró e à sua cosmologia. E, por fim, discorremos sobre as possibilidades de os di-

7 O "Projeto Xingu: Integrando o planejamento do uso da terra e a governança da água na Amazônia: a procura de maior segurança hídrica na fronteira agrícola do Mato Grosso" é um projeto temático financiado pela FAPESP e é parte da primeira chamada do Programa Belmont de pesquisa interdisciplinar internacional. Os participantes do projeto representam não só diferentes disciplinas, mas também universidades e centros de pesquisa nacionais e internacionais. Neste Projeto coordenamos a subárea de pesquisa "Direito Ambiental \& Sociologia", que é, na realidade, uma área de interface entre Direito Ambiental, Ecologia Política, Ciências Sociais, Antropologia e Antropologia do Direito. reitos humanos serem colocados a serviço de uma política emancipatória em relação aos Xavante. Concluímos que, no caso dos Xavante, o direito humano à alimentação deve incorporar a noção de "territorialidade", sob pena de violação desse direito e de outros correlatos.

\section{O “TERRITÓRIO" E A "TERRITORIALIDADE" XAVANTE: DO SIMBÓLICO AO VIVIDO}

A primeira parte deste artigo transita pela antropologia, ecologia humana e geografia e serão comentados aspectos culturais dos Xavante e de sua relação com a "natureza" e com o "território". As noções de "territorialidade" apresentadas pelas diferentes áreas de pesquisa são complexas e não deveriam ser reduzidas em poucas palavras. Contudo, esclarecemos que não pretendemos aqui apresentar um trabalho etnográfico, tão pouco discutir o tema no âmbito da geografia ou mesmo esgotar o assunto. A compreensão de uma sociedade, quando possível, é um processo longo e contínuo, nesse sentido, abordamos aspectos da cultura Xavante sem a pretensão de uma análise exaustiva. Pelo contrário, nós nos restringimos a apresentar alguns aspectos daquela cultura que subsidiarão a discussão sobre soberania alimentar e direitos humanos relacionados aos problemas apresentados na fase introdutória deste artigo.

Esta etapa compreende pesquisa bibliográfica e documental, em especial dados do livro "Na primeira margem do rio: "território" e ecologia do povo Xavante de Wedezé". Outro trabalho que merece destaque entre os demais utilizados nesta etapa, é a tese de doutorado "Marãnã Bödödi - a "territorialidade" Xavante nos caminhos do Ró", desenvolvida na Faculdade de Filosofia, Letras e Ciências Humanas da Universidade de São Paulo, defendida por Maria Lucia Cereda Gomide? . Entre os dados utilizados, destacam-se os obtidos pelo Instituto Socioambiental [ISA]. Pesquisas qualitativas por meio de entrevistas abertas e observação de campo também compõe esse item. Os depoimentos foram validados a partir dos dados obtidos por meio de revisão bibliográfica e documental. A área de estudo compreende a Terra

8 WELCH, J. et al. Na Primeira Margem do Rio: Território e Ecologia do Povo Xavante de Wedezé. Rio de Janeiro: Museu do Índio/ FUNAI, 2013.

9 GOMIDE, M. L. Marãnã Bödödi: a territorialidade Xavante nos caminhos do Ró. 2008. 436 f. Tese (Doutorado em Geografia Física) - Universidade de São Paulo, São Paulo, 2008. 
Indígena [TI] Pimentel Barbosa, em especial a Aldeia Etenhiritipá. Entretanto, várias das considerações aqui trazidas são extensíveis às demais Terras Indígenas que estão localizadas no Estado do Mato Grosso, por serem fragmentos do "território" tradicional de ocupação Xavante. Também por esse motivo, alguns dos dados serão apresentados de forma a abranger a Terras Indígenas Marãiwatsede, Areões [Areões I, Areões II], Marechal Rondon, Parabubure, Chão Preto, Ubawawe, Sangradouro/Volta Grande, São Marcos e Pimentel Barbosa.

Para compreender a noção de "territorialidade" para este grupo indígena, destacamos a importância dos cerrados na cosmologia e a visão de natureza do povo Xavante, através do complexo conceito de Ró, como uma representação Xavante de "território" / "mundo". De acordo com a descrição apresentada pela Associação Warã ${ }^{10}$, o Ró - Mundo A'uwé Xavante, a concepção Xavante sobre o cerrado remete à importância e dependência dos Xavante em relação aos cerrados, como também dos cerrados em relação aos Xavante: [...] O Xavante depende do cerrado e o cerrado depende do Xavante. Os animais dependem do cerrado e o cerrado depende dos animais. Os animais dependem do Xavante e o Xavante depende dos animais. Isso é o Ró. Ró significa tudo para os caçadores Xavante: o cerrado, os animais, os frutos, as flores, as ervas, o rio e tudo mais. Nós queremos preservar o Ró. Através do Ró garantiremos o futuro das novas geraçôs: a comida, os casamentos, os rituais e a força de ser Xavante. Se estiver tudo bem com Ró continuaremos a ser Xavantes. O caçador anda no Ró e aprende a amá-lo. As mulheres aprendem a amá-lo porque o casamento depende do Ró e porque também andam lá para pegar as frutas ${ }^{11}$.

De acordo com Gomide ${ }^{12}$ (2008), os Xavante estabelecem uma ordem quando descrevem o Ró [cerrado, mundo, tudo], como um complexo concêntrico onde no interior está situada a aldeia, o quintal, e logo depois as roças seguidos pelos cerrados [composto por seres animados, como as plantas e animais, e por se-

10 A Associação Warã é uma instituição regularmente constituída pelo povo A'uwé-Xavante da aldeia Idzô'uhu, que significa Abelhinha, localizada na Terra Indígena Sangradouro no Mato Grosso, Brasil. É uma entidade sem fins lucrativos criada em 1997, subordinada a um órgão deliberativo, a assembléia tradicional A'uwe-Xavante, que acontece no Warã, páteo central da aldeia. Tem como missão a preservação do Ró, o mundo Xavante, que representa ao mesmo tempo, cerrado e cultura.

11 TUAN,Yi-Fu. Espaço e lugar: a perspectiva da experiência. São Paulo: Difel, 1977 - 1983

12 GOMIDE, M. L. Marãnã Bödödi: a territorialidade Xavante nos caminhos do Ró. 2008. 436 f. Tese (Doutorado em Geografia Física) - Universidade de São Paulo, São Paulo, 2008. res inanimados, ou "espíritos”]. Essa configuração dos círculos concêntricos é ao mesmo tempo um continuum, no sentido de que cada uma das partes tem limites fluidos. O círculo, por sua vez, representa a figura ideal de igualdade e de intensidade da vida social, e possui uma simbologia especial para as sociedades Jề $\hat{e}^{13}{ }^{14}$.

Esse círculo, ao que os autores se referem, é também apresentado na descrição de Ró pela supracitada Associação Warã: [...] Antigamente o Ró era assim: havia a aldeia, envolta a roça, envolta as frutas, envolta a caça junto com os espiritos, envolta mais caça e mais caça sempre junto com os espiritos. Os espiritos ajudavam a descobrir os segredos que o Ró escondia: onde estava a força do caçador, onde estava a caça, onde tinha cobra e outros segredos. Os caçadores iam pegar a caça mais longe da aldeia, assim os animais fugiam em direção a aldeia. Depois os caçadores iam em outro lugar longe da aldeia. Assim os filhotes iam crescendo sempre e esqueciam a tragédia da caçada. Mais longe que isto só estavam o céu e a outra aldeia onde moram os mortos ${ }^{15}$.

Os espaços de Ró podem ser considerados como a representação do mundo Xavante, lugar onde as interações com o ambiente ocorrem: aldeia, quintal, roça, cerrados e os espíritos. O lugar são centros aos quais os Xavante atribuem valor e onde são satisfeitas necessidades alimentares, culturais, de descanso, reprodução, entre outras ${ }^{16} 17$.

Os quintais da aldeia são compostos principalmente por árvores frutíferas que nasciam do hábito de se "jogar" ao solo as sementes das frutas que são consumidas ${ }^{18}$. Segundo relatos obtidos no trabalho de campo, essa prática contribui na transmissão do conhecimento sobre a coleta. Isto é, o quintal era um espaço que permitia a identificação das frutas comestíveis que seriam, em outros momentos, coletadas no cerrado.

13 Os Xavante pertencem ao grupo linguístico "Akuen" do tronco "Macro-Jê", sua autodenominação é A’uwe que significa "gente".

14 GOMIDE, M. L. Marãnã Bödödi: a territorialidade Xavante nos caminhos do Ró. 2008. 436 f. Tese (Doutorado em Geografia Física) - Universidade de São Paulo, São Paulo, 2008.

15 TUAN,Yi-Fu. Espaço e lugar: a perspectiva da experiência. São Paulo: Difel, 1977 - 1983

16 GOMIDE, M. L. Marãnã Bödödi: a territorialidade Xavante nos caminhos do Ró. 2008. 436 f. Tese (Doutorado em Geografia Física) - Universidade de São Paulo, São Paulo, 2008.

17 WELCH, J. et al. Na Primeira Margem do Rio: Território e Ecologia do Povo Xavante de Wedezé. Rio de Janeiro: Museu do Índio/ FUNAI, 2013.

18 Após a sedentarização em terras demarcadas e a partir da introdução de materiais inorgânicos essa prática passa a ser problemática entre os Xavante, principalmente no que se refere à contaminação de cursos de água. 
Em relação ao cultivo agrícola, acordo com os dados do ISA ${ }^{19}$, o milho ocupa posição de destaque, por se tratar de alimento utilizado em cerimoniais e ter uma simbologia sócio cosmológica para os Xavante. O feijão e a abóbora desempenham um papel apenas secundário na sua economia. Os produtos obtidos na colheita das roças pertencem a cada um dos grupos domésticos que compõe a aldeia. As tarefas de derrubada e queimada da mata cabem aos homens, enquanto o plantio, às mulheres. A dieta básica tradicional xavante consiste em produtos coletados principalmente pelas mulheres: raízes silvestres, castanhas, frutos e outros vegetais. A coleta é suplementada por itens fornecidos pelos homens, como carnes de caça e alguma quantidade de peixe, fontes de proteína que podem ser defumadas para fins de conservação ${ }^{20}$.

Os Xavante obtinham esses alimentos por meio do zomori [ou caminhada longa] em excursões de caça e coleta, que chegavam a durar alguns meses. Daí serem, entre outros motivos categorizados como povo seminômade. $\mathrm{Na}$ estação seca os grupos de viajantes se reuniam em grandes aldeias semipermanentes para a realização de atividades cerimoniais ${ }^{21}$. De acordo com esse padrão de ocupação, o "território" compreendia o espaço necessário para a subsistência xavante e compreendia a extensão territorial que os grupos exploravam no transcurso de um ano.

Após a intensificação da colonização na década de 1960 e a demarcação de suas terras, o padrão tradicional de excursões praticamente desapareceu, em razão da significativa redução das terras disponíveis aos Xavante e do reduzido estoque de caça ali existente ${ }^{22}$. Entretanto, viagens de caça ou pesca mais curtas ainda são realizadas.

As carnes de caça ocupam uma posição central, tanto na dieta, como na vida social. Para os homens, a caça é tanto um afazer econômico importante como

19 INSTITUTO SOCIOAMBIENTAL. Xavante. Disponível em: $<$ https://pib.socioambiental.org/pt/povo/xavante>. Acesso: 30 out. 2016.

20 WELCH, J. et al. Na Primeira Margem do Rio: Território e Ecologia do Povo Xavante de Wedezé. Rio de Janeiro: Museu do Índio/ FUNAI, 2013.

21 GOMIDE, M. L. Marãnã Bödödi: a territorialidade Xavante nos caminhos do Ró. 2008. 436 f. Tese (Doutorado em Geografia Física) - Universidade de São Paulo, São Paulo, 2008.

22 WELCH, J. et al. Na Primeira Margem do Rio: Território e Ecologia do Povo Xavante de Wedezé. Rio de Janeiro: Museu do Índio/ FUNAI, 2013. um marcador de capacidades masculinas, já que é através da caça que expressam as habilidades de resistência física, rapidez, agilidade, vigilância e agressividade, valores cultuados pelo homem Xavante. A caça ainda é componente central de alguns cerimoniais, como o Wai'a [ou ritual de iniciação Xavante], e das celebrações de casamentos ${ }^{23}$.

Contudo, a degradação ambiental, resultado da criação de gado e do monocultivo agrícola no entorno das terras xavante, diminuiu fortemente o estoque de fauna cinegética disponível. As carnes e os pescados, principais fontes proteicas, são escassos na maioria das atuais áreas xavante; nas menores delas, a carência de caça é severa $^{24} 25$.

Como já assinalado, as atuais terras xavante não representam mais do que pequenos fragmentos da extensão total de que eles antes dispunham para sua subsistência. Com isso, na busca por proteína animal, os limites da terra indígena são muitas vezes ultrapassados e graves conflitos sociais em decorrência de invasão de propriedades privadas são frequentes ${ }^{26}$.

Apesar do esforço xavante em manter seu modo de vida tradicional, a intrusão das atividades voltadas para o mercado evidentemente desordenou significativamente o estilo de vida e a economia tradicionais xavante.

Como as terras que os Xavante dispunham já não sustentavam sua economia tradicional, as políticas governamentais implementadas pelo Serviço de Proteção aos Índios e, posteriormente, pela Fundação Nacional do Índio [FUNAI], incentivaram os Xavante a adotar práticas econômicas distintas da tradicional, em particular a agricultura de coivara e a criação de gado. A partir da implantação destas políticas, os Xavante se tornaram crescentemente dependentes dos produtos que cultivavam em roças de coivara, assim como da FUNAI para obtenção de insumos adquiridos em cidades próximas ${ }^{27}$.

23 WELCH, J. et al. Na Primeira Margem do Rio: Território e Ecologia do Povo Xavante de Wedezé. Rio de Janeiro: Museu do Índio/ FUNAI, 2013.

24 GOMIDE, M. L. Marãnã Bödödi: a territorialidade Xavante nos caminhos do Ró. 2008. 436 f. Tese (Doutorado em Geografia Física) - Universidade de São Paulo, São Paulo, 2008.

25 WELCH, J. et al. Na Primeira Margem do Rio: Território e Ecologia do Povo Xavante de Wedezé. Rio de Janeiro: Museu do Índio/ FUNAI, 2013.

26 GOMIDE, M. L. Marãnã Bödödi: a territorialidade Xavante nos caminhos do Ró. 2008. 436 f. Tese (Doutorado em Geografia Física) - Universidade de São Paulo, São Paulo, 2008.

27 INSTITUTO SOCIOAMBIENTAL. Xavante. Disponível em: 
Outra política pública econômica que merece destaque por ter sido extremamente problemática e veio a ser conhecida como "Projeto Xavante". Desenvolvida por toda década de 1980, inseriu a rizicultura mecanizada em grande escala nas terras xavante, sob o argumento da autossuficiência econômica dos Xavante, e do intuito de inseri-los na economia regional. Sua implementação exigia conhecimentos e habilidades tecnológicos, perícia administrativa e investimento financeiro. $\mathrm{O}$ projeto teve sérios efeitos sociais, exacerbando tensões e gerando competição tanto no interior das comunidades xavante como entre elas e a FUNAI. A necessidade de dinheiro levou alguns homens a ocuparem posições como mão-de-obra remunerada a fazendeiros. O Projeto Xavante desequilibrou ainda mais os padrões de subsistência e dieta, criando quase que uma dependência de uma variedade não nutritiva de arroz, alçada à condição de base da dieta, assim como de outros produtos industrializa$\operatorname{dos}^{28}$. Como resultado, muitos conhecimentos sobre a nutrição de alimentos tradicionais se perderam, resultando no contexto de insegurança alimentar apresentado na fase introdutória deste artigo.

De acordo com o exposto, podemos concluir que a demarcação do "território" indígena Xavante em diferentes terras indígenas não contíguas, deu causa a inúmeros conflitos socioambientais e alterou seu modo de vida. Sua reconstituição é, talvez, o maior desafio político do povo Xavante, do qual depende sua própria sobrevivência. Isto porque, por um lado, o "território" indígena compreende as relações de apropriação do espaço que possui em diversas dimensões como política, cultural, simbólica, e cosmológica. Por outro lado a "Terra Indígena" como categoria do direito público, é produzida no processo político-jurídico do Estado, que não incorpora as diferentes dimensões de "território" citadas $^{29} 30$.

A partir do contato entre os povos indígenas com os waradzu [ou sociedade envolvente], estabelece-se um

$<$ https://pib.socioambiental.org/pt/povo/xavante>. Acesso: 30 out. 2016.

28 INSTITUTO SOCIOAMBIENTAL. Xavante. Disponível em: $<$ https://pib.socioambiental.org/pt/povo/xavante>. Acesso: 30 out. 2016.

29 GOMIDE, M. L. Marãnã Bödödi: a territorialidade Xavante nos caminhos do Ró. 2008. 436 f. Tese (Doutorado em Geografia Física) - Universidade de São Paulo, São Paulo, 2008.

30 INSTITUTO SOCIOAMBIENTAL. Xavante. Disponível em: $<$ https://pib.socioambiental.org/pt/povo/xavante>. Acesso: 30 out. 2016. grave conflito no que se refere às distintas lógicas espaciais em confronto ${ }^{31}$. De acordo com depoimentos obtidos no trabalho de campo, confirmado através do trabalho de Gomide ${ }^{32}$, as terras indígenas não correspondem ao território indígena e não são consideradas pelos Xavante como seu "território", mas apenas uma fração dele. Por esta razão, os termos "território" ou "territorialidade" são aqui trazidos entre aspas por compreenderem conceitos modernos ocidentais que guardam distância com conceito de Ró - "cerrados, mundo, nossa terra, tudo".

\section{3. (IN)SEGURANÇA ALIMENTAR E "SUBALTERNIDADE ALIMENTAR"}

Atualmente, em termos populacionais, os Xavante caracterizam-se por ser uma das maiores populações entre os povos indígenas do Brasil. Entretanto, segundo relatório da UNICEF, amplamente divulgado em setembro de 2014, um dos problemas mais graves por eles enfrentado é a elevada taxa de mortalidade infantil, a segunda mais elevada do Brasil, superando os índices de países como Quênia, Gana, Namíbia e Zimbabuéén.

A desnutrição está entre as principais causas de mortalidade infantil. De acordo com o ISA ${ }^{34}$, o sedentarismo, a carência de caça e de outras fontes de proteína, assim como os planos desenvolvimentistas da FUNAI resultaram em dramáticas mudanças na dieta xavante, o que têm levado à desnutrição e a problemas de saúde a ela relacionados, como a anemia. As mudanças na dieta, em especial o gosto recentemente adquirido pelo açúcar e pela farinha de trigo refinada, também se expressam numa alarmante incidência de diabetes. $\mathrm{O}$ consumo de álcool e o alcoolismo, que se relacionam com situações de tensão social, são observados em maior intensidade em comunidades situadas perto de cidades e, se colocam novos problemas de saúde pública para a comunidade (ISA).

31 GOMIDE, M. L. Marãnã Bödödi: a territorialidade Xavante nos caminhos do Ró. 2008. 436 f. Tese (Doutorado em Geografia Física) - Universidade de São Paulo, São Paulo, 2008.

32 GOMIDE, M. L. Marãnã Bödödi: a territorialidade Xavante nos caminhos do Ró. 2008. 436 f. Tese (Doutorado em Geografia Física) - Universidade de São Paulo, São Paulo, 2008.

33 UNICEF. Relatório Unicef. 2014. Disponível em: < http://www. unicef.org/brazil/pt/Pags_040_051_Desnutricao.pdf>.

34 INSTITUTO SOCIOAMBIENTAL. Xavante. Disponível em: $<$ https://pib.socioambiental.org/pt/povo/xavante>. Acesso: 30 out. 2016. 
Ainda segundo dados do ISA ${ }^{35}$, muitas das causas de óbito resultam, em parte, da mudança do padrão de vida seminômade ao sedentarismo e ao confinamento do povo Xavante em um "território" restrito, principalmente no que se refere à contaminação de recursos hídricos [aqui não separamos o conceito de "segurança alimentar" do de "segurança hídrica", por serem intrinsicamente ligados $\left.{ }^{36}\right]$.

No passado seminômade, como o local de instalação das aldeias era frequentemente trocado, o hábito de depositar dejetos perto das casas não apresentava sérios riscos de saúde, como ocorre atualmente. O acúmulo de lixo também se dá pela utilização de materiais inorgânicos, como plásticos e pilhas elétricas que, à diferença dos tradicionais resíduos orgânicos, não se decompõem ${ }^{37} 38$.

Doenças gastrointestinais e infecções respiratórias respondem por uma significativa proporção nas mortes de crianças xavante. Trata-se na sua maioria de doenças tratáveis cujas causas poderiam ser mitigadas através de medidas básicas de saúde pública preventiva. Mais recentemente, a dengue aparece como epidemia na região.

Como um desdobramento dos problemas relacionados à insegurança alimentar [e hídrica] dos Xavante contemporâneos, destacamos a inacessibilidade aos serviços de saúde. Por um lado, o fato da diabetes, do alcoolismo e, mais recentemente, da tuberculose e da dengue serem doenças relativamente novas para os Xavante, dificulta a aplicação de sua medicina tradicional. Por outro, a relação conflituosa que prevalece nos centros urbanos entre indígenas e não-indígenas, que reverbera nos postos de saúde, contribui para a relutância de procurarem assistência na nossa medicina clínica, mesmo em casos graves ${ }^{39}$.

De acordo com pesquisa recente publicada no periódico Diabetology \& Metabolics Syndrome mais de 65\%

35 INSTITUTO SOCIOAMBIENTAL. Xavante. Disponível em: $<$ https://pib.socioambiental.org/pt/povo/xavante>. Acesso: 30 out. 2016.

36 O direito humano à alimentação inclui a água e as diversas formas de acesso à água na sua compreensão e realização.

37 Este problema foi comentado anteriormente ao discutirmos os quintais Xavante e a prática de se "jogar" ao solo as sementes das frutas que haviam sido consumidas.

38 INSTITUTO SOCIOAMBIENTAL. Xavante. Disponível em: $<$ https://pib.socioambiental.org/pt/povo/xavante>. Acesso: 30 out. 2016.

39 INSTITUTO SOCIOAMBIENTAL. Xavante. Disponível em: $<$ https://pib.socioambiental.org/pt/povo/xavante>. Acesso: 30 out. 2016. dos indígenas com mais 20 anos que habitam as Terras Indígenas de São Marcos e Sangradouro/Volta Grande, Mato Grosso, desenvolveram Síndrome Metabólica, condição na qual os fatores de risco para doenças cardiovasculares e diabetes mellitus ocorrem em um mesmo indivíduo. Seus principais componentes são obesidade abdominal, hipertensão arterial sistêmica, dislipidemia e distúrbios do metabolismo da glicose. Entre as mulheres a incidência da Síndrome Metabólica é ainda mais elevada, atingindo $76,2 \%$ das indígenas que participaram do estudo e desenvolveram a doença ${ }^{40}$.

Sedentarismo é uma das possíveis explicações para a grande incidência dessa síndrome entre os Xavante. De acordo com a autora, não é a única explicação. Acredita-se que a principal razão para o elevado número de casos de obesidade, diabetes mellitus e outras doenças seja a mudança dos hábitos alimentares, com aumento do consumo de alimentos industrializados, especialmente de refrigerantes e outros alimentos ricos em açúcares.

Ainda segundo a pesquisadora, dados de 1999 a 2004 mostram que os Xavante apresentam elevados níveis de mortalidade [11,4 óbitos por mil habitantes], especialmente no primeiro ano de vida [96,7 óbitos de crianças menores de 1 ano por mil nascidos vivos], valores bastante superiores às médias da população brasileira, conforme já relatado na fase introdutória ${ }^{41}$.

Na primeira parte do artigo, procuramos demonstrar que à alimentação do povo Xavante estão vinculados importantes processos culturais, simbólicos e cosmológicos que se comunicam com modos de pertencer a um "território" "42 Já a situação de insegurança alimentar apresentada nesta segunda etapa do artigo, aponta para algo mais do que fragilidade nas condições de sua sobrevivência. Implica, sobretudo, numa condição política negada, já que é retirada dos Xavante seu próprio mundo, ou o "Rô", que é a condição de sua existência como A'une [ou povo]. Estamos falando, portanto, de um jogo simbólico muito mais amplo e que leva à destruição dos sentidos sociais desse povo. Assim, insegurança

40 SOARES, F. et al. Prevalence of metabolic syndrome in the Brazilian Xavante indigenous population. Diabetology \& Metabolic Syndrome, 2015.

41 SOARES, F. et al. Prevalence of metabolic syndrome in the Brazilian Xavante indigenous population. Diabetology \& Metabolic Syndrome, 2015.

42 GOMIDE, M. L. Marãnã Bödödi: a territorialidade Xavante nos caminhos do Ró. 2008. 436 f. Tese (Doutorado em Geografia Física) - Universidade de São Paulo, São Paulo, 2008. 
alimentar, desnutrição e altos índices de mortalidade infantil, são sintomas de um problema mais basal, que por sua vez evidencia o uso desigual do amplo "território" brasileiro. Por este motivo, falar do atual contexto de "subalternidade alimentar" do povo Xavante significa também falar da supressão das condições mínimas de sua expressão social em Ró.

Um exemplo interessante remete aos mitos xavante de criação dos animais, em especial com os porcos-queixada. Esse mito nos dá uma dimensão da importância simbólica desse animal na sua cultura, ao nos revelar que a queixada é um "ex"-Xavante transformado e, numa outra metamorfose, é a partir da carne da queixada, ou "ex"-Xavantes, que se recriam os atuais ${ }^{43}$. O mito da queixada narra a seu modo uma história: a das lutas pela sobrevivência, pela autonomia e pelo direito de pertencimento e, nesse sentido, a queixada se metaforiza em maneiras de constituir relações de afeto com Ró.

Finalmente, as expressões "soberania alimentar" e "caridade" [em sentido amplo] não pode ser confundidas. A primeira pressupõe o direito do povo Xavante de decidir sobre seu próprio sistema alimentar e produtivo. A segunda tem implicado num modo sutil de silenciar uma cultura Xavante. Referimo-nos aqui genericamente às políticas desenvolvimentistas, entre elas o já citado Projeto Xavante ${ }^{44}$, que não são um problema apenas na medida em que falham, mas também [e, sobretudo] quando suas metas são alcançadas ${ }^{45}$. Isto é, existem outros modos de viver e de se desenvolver fora da centralidade de um modelo único de desenvolvimento do ocidente moderno. O Xavante apresentam outras alternativas, sendo que as condições de sua reprodução social contêm diferenças e não "estágios de progresso" (Corona \& Almeida, 2014). Naturalmente, não se trata, aqui, de uma argumentação em oposição à "caridade", mas apenas de uma análise crítica de sua face oculta, que interfere na condição cultural dos A'uwe Xavante.

43 GOMIDE, M. L. Marãnã Bödödi: a territorialidade Xavante nos caminhos do Ró. 2008. 436 f. Tese (Doutorado em Geografia Física) - Universidade de São Paulo, São Paulo, 2008.

44 Política que promoveu o cultivo de arroz mecanizada em "terras" xavante.

45 ESCOBAR, Arturo. Encountering development: the making and unmaking of the third world. Princeton: Princeton University Press, 2012.

\section{Direitos humanos e o diálogo INTERCULTURAL}

O direito humano à alimentação adequada está contemplado no artigo 25 da Declaração Universal dos Direitos Humanos de 1948. Sua definição foi ampliada em outros dispositivos do Direito Internacional, como o artigo 11 do Pacto de Direitos Econômicos, Sociais e Culturais e o Comentário Geral no 12 da Organização das Nações Unidas [ONU]. Ora, ao afirmar que a alimentação deve ser adequada entendemos que ela seja adequada aos diferentes contextos culturais, sociais, econômicas de um grupo social e ao contexto climático e ecológico do território no qual esse grupo se insere.

No Brasil, foi aprovada em 2010 a Emenda Constitucional $n^{\circ} 64$, que inclui o direito à alimentação no $\operatorname{artigo} 6^{\circ}$ da Constituição Federal. No entanto, a inclusão desse direito no texto constitucional não significa sua efetividade, que permanece como um desafio a ser enfrentado, principalmente no que se refere ao cerrado e as fronteiras agrícolas amazônicas. Entre estes desafios destacamos o respeito: à diversidade cultural e de formas de organização social; à autonomia na produção [incluindo-se aqui a caça] e consumo de alimentos e; no reconhecimento dos territórios para que os diferentes povos tenham maior soberania, não só alimentar, mas também soberania cultural, simbólica e cosmológica.

Os direitos humanos podem ser emancipatórios? Podem eles ser utilizados por aqueles que não foram pensados como atores de direito? O diálogo intercultural é possível? Quais condições versam sobre as possibilidades de uma concepção multicultural dos direitos humanos?

Para responder a estas questões, mesmo que parcialmente, optamos por sintetizar as ideias contidas no texto "Uma concepção multicultural de direitos humanos" de Boaventura de Sousa Santos. Através deste texto o autor busca superar os entraves entre relativismo e universalismo dos direitos humanos e apresenta as condições para uma concepção multicultural dos direitos humanos.

Santos $^{46}$, parte do reconhecimento de três tensões dialéticas do mundo contemporâneo: (i) o confronto

46 SANTOS, Boaventura de Souza. Uma concepção multicultural de direitos humanos. Lua Nova [online]. n. 39, p. 105124, 1997. Disponível em: <http://dx.doi.org/10.1590/S010264451997000100007>. 
entre regulação e emancipação social; (ii) entre sociedade civil e Estado; (iii) entre o Estado-nação e a globalização. Argumenta que não existe uma única globalização, mas sim diversas formas de globalização. E, contextualiza as questões culturais que permeiam o tema direitos humanos na globalização, sob o prisma social, político e cultural. $\mathrm{O}$ autor propõe cinco condições à afirmação dos direitos humanos como instrumento para o cosmopolitismo [termo por ele utilizado em oposição à hegemonismo].

A primeira delas é a superação do debate entre universalismo e relativismo cultural. Para Santos "[...] Trata-se de debate intrinsecamente falso, cujos conceitos polares são igualmente prejudiciais para uma concepção emancipatória de direitos humanos. Todas as cultuas são relativas, mas o relativismo cultural enquanto atitude filosófica é incorreto. Todas as culturas aspiram preocupações e valores universais, mas o universalismo cultural, enquanto atitude filosófica, é incorreto. Contra o universalismo, há que propor diálogos interculturais sobre preocupações isomórficas. Contra o relativismo, há que desenvolver critérios políticos para distinguir política progressista de política conservadora, capacitação de desarme, emancipação de regulação ${ }^{\text {'47 }}$.

A segunda condição apresentada versa sobre o reconhecimento de que todas as culturas apresentam concepções de dignidade, mas nem todas no contexto dos direitos humanos. A terceira e quarta condições, referem-se, respectivamente, ao entendimento de todas as culturas são incompletas e, portanto, apresentam noções incompletas de dignidade e; essas diferentes percepções de dignidade apresentam algum grau de reciprocidade. Finalmente, apresenta a quinta condição que diz respeito ao reconhecimento da diferença e da igualdade entre os humanos como concepções tão variáveis conforme a cultura ${ }^{48}$.

Entretanto, ao menos no contexto brasileiro, o diálogo parece uma noção desesperadamente fraca em relação à cultura Xavante. O contexto econômico-político e ambiental do leste matogossense é muito desfavorável aos povos indígenas. Suas reivindicações são interpretadas com preconceito e etnocentrismo pelos poderes re-

47 SANTOS, Boaventura de Souza. Uma concepção multicultural de direitos humanos. Lua Nova [online]. n. 39, p. 105124, 1997. Disponível em: <http://dx.doi.org/10.1590/S010264451997000100007>.

48 SANTOS, Boaventura de Souza. Uma concepção multicultural de direitos humanos. Lua Nova [online]. n. 39, p. 105124, 1997. Disponível em: <http://dx.doi.org/10.1590/S010264451997000100007>. gionais, sejam eles formais ou informais. São comuns as campanhas contra a revisão das demarcações de terras indígenas Xavante, pois suas demandas são consideradas como "afronta à soberania nacional". Estes povos são vistos como entraves ao "desenvolvimento" e o "progresso" e os projetos governamentais não levam em consideração a pluralidade étnica e as multiterritorialidades existentes no Brasil.

\section{Considerações Finais}

A soberania alimentar dos povos indígenas está, em grande parte, condicionada à demarcação de territórios indígenas. Trata-se, contudo, de uma demarcação que considere a territorialidade e o modo de vida xavante. No entanto, não é o caso das Terras Indígenas Marãiwatsede, Areões [Areões I, Areões II], Marechal Rondon, Parabubure, Chão Preto, Ubawawe, Sangradouro/Volta Grande, São Marcos e Pimentel Barbosa. A demarcação do território indígena Xavante em diversas terras indígenas ilhadas causa inúmeros conflitos socioambientais, altera seu modo de vida, afeta sua soberania alimentar e, leva à destruição dos sentidos sociais desse povo. Reconstruir o território indígena que é erroneamente e intencionalmente fragmentado e demarcado em ilhas é um grande desafio político para o povo Xavante. O território indígena compreende as relações de apropriação do espaço que possui diversas dimensões como política, cultural, simbólica, e cosmológica de um determinado povo indígena. Por outro lado, Terra indígena é uma categoria produzida no processo político-jurídico do Estado. Assim, a partir do contato entre os povos indígenas e a sociedade envolvente, há um conflito, pois existem distintas lógicas espaciais em confronto. As conclusões finais levam a proposta de que as terras indígenas Xavante voltem a ter sua configuração de território contínuo unindo as terras indígenas através dos cerrados restituindo, ao menos em parte, a territorialidade indígena.

\section{REFERÊNCIAS}

ESCOBAR, Arturo. Encountering development: the making and unmaking of the third world. Princeton: Princeton University Press, 2012 
GOMIDE, M. L. Marãnã Bödödi: a territorialidade Xavante nos caminhos do Ró. 2008. 436 f. Tese (Doutorado em Geografia Física) - Universidade de São Paulo, São Paulo, 2008.

INSTITUTO SOCIOAMBIENTAL. Xavante. Disponível em: <https://pib.socioambiental.org/pt/ povo/xavante>. Acesso: 30 out. 2016.

LEVI-STRAUSS, C. O pensamento selvagem. São Paulo: Nacional, 1976.

MORIN, E. O problema epistemológico da complexidade. 3. ed. Mira-Sintra: Publicações Europa-América, 2002.
SANTOS, Boaventura de Souza. Uma concepção multicultural de direitos humanos. Lua Nova [online]. n. 39, p. 105-124, 1997. Disponível em: <http://dx.doi. org/10.1590/S0102-64451997000100007>.

SOARES, F. et al. Prevalence of metabolic syndrome in the Brazilian Xavante indigenous population. Diabetology \& Metabolic Syndrome, 2015.

TUAN,Yi-Fu. Espaço e lugar: a perspectiva da experiência. São Paulo: Difel, 1977 - 1983.

WELCH, J. et al. Na Primeira Margem do Rio: Território e Ecologia do Povo Xavante de Wedezé. Rio de Janeiro: Museu do Índio/FUNAI, 2013. 


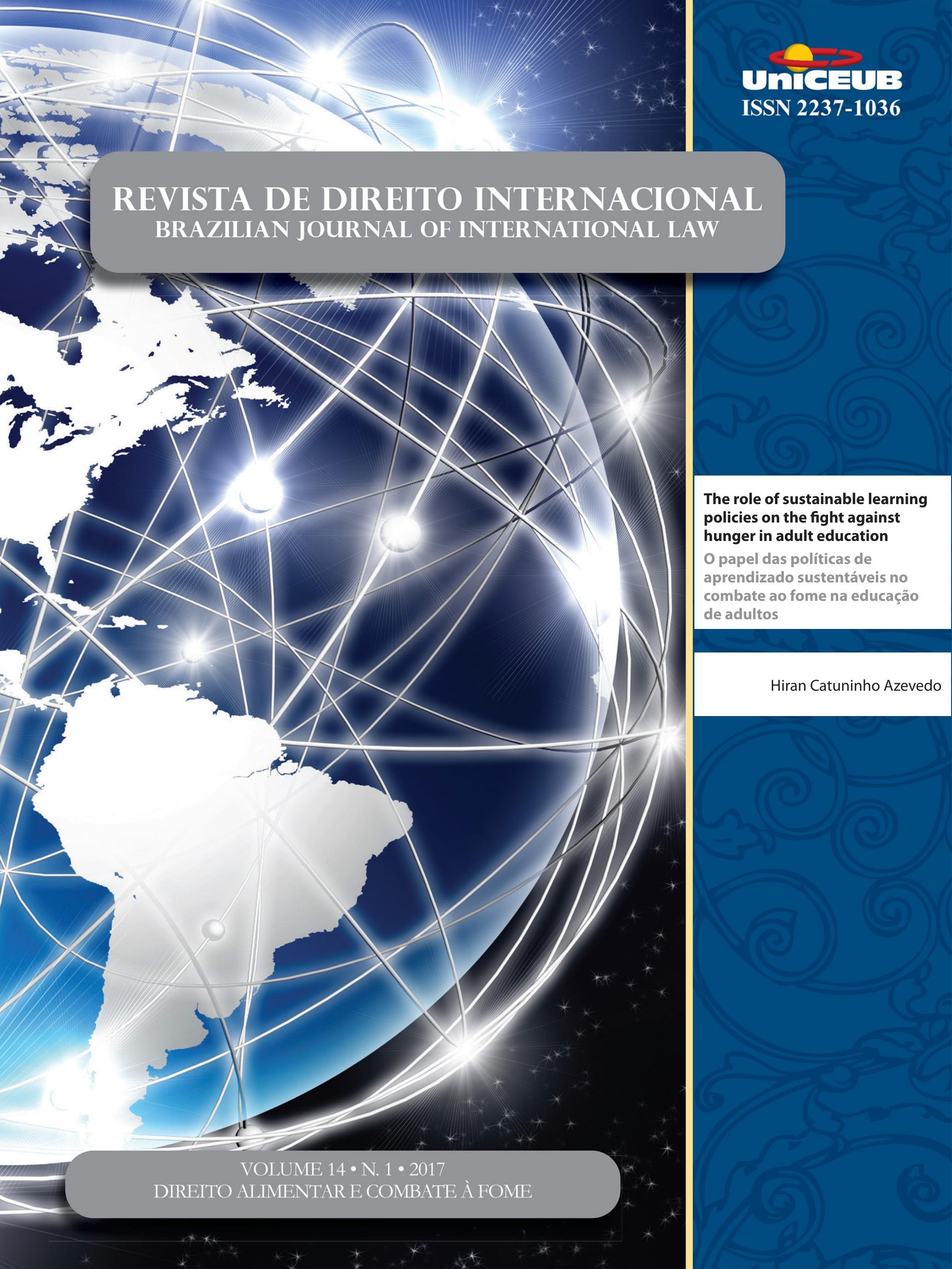




\title{
The role of sustainable learning policies on the fight against hunger in adult education
}

\author{
O papel das políticas de aprendizado \\ sustentáveis no combate ao fome na \\ educação de adultos
}

Hiran Catuninho Azevedo **

\begin{abstract}
We live in an unprecedented world of opulence, but also of extraordinary deprivation and oppression. This paper suggests the role of a sustainable education on the fight against hunger, poverty, and inequalities. If the environmental crisis is not solved, hunger cannot end, especially in underdeveloped countries and regions. Education is, more than ever, an important tool to increase the living standards. Due to sustainable educational processes, we have much more knowledge of how to solve climate problems, reduce poverty and increase food production without destroying Earth resources. Educational processes based on sustainability context also brings the opportunity to rethink the lack of collective coordination, especially among states. We are a civilization that shares the same fate, and together they can build more international cooperation and less competition, and education is a key point to rewrite the human history with no more hunger. Understand how industry and society grow and develop is essential to know how they learn and become productive, and knowledge production, a crucial point in education, already produces countries that are more able than others regarding the development of intensive sectors in state-of-the-art technology, capable of generating more income, better production and reducing their nourishment vulnerability. These effects can be shared with underdeveloped ones. Innovation has been a crucial part of the most developed economies throughout history. The rise of living standards should be attributed to the technological progress, in learning how to do things better. A sustainable educational system is a crucial support to reduce knowledge inequality between developed and underdeveloped countries and help ones with learning difficulties, able to create learning societies free from hunger.
\end{abstract}

Keywords: Education Reduce Inequalities Public Policies Sustainability Hunger Erradication

* Recebido em 31/10/2016 Aprovado em 24/04/2017

** MA in Human Sciences, Department of Human Sciences of The University of Tsukuba, Japan. E-mail: hcatuninho@gmail.com

\section{RÉSUMÉ}

Nous vivons dans un monde sans précédent de l'opulence, mais aussi de la privation et de l'oppression extraordinaire. Ce document suggère le rôle d'une éducation durable sur la lutte contre la faim, la pauvreté et les inégalités. Si la crise de l'environnement ne soit pas résolu, la faim ne peut 
pas finir, en particulier dans les pays et les régions sous-développées. L'éducation est, plus que jamais, un outil important pour augmenter le niveau de vie. En raison de processus éducatifs durables, nous avons beaucoup plus de connaissances sur la façon de résoudre les problèmes climatiques, réduire la pauvreté et accroître la production alimentaire sans détruire les ressources de la Terre. Les processus éducatifs basés sur le contexte de la durabilité apporte également la possibilité de repenser le manque de coordination collective, en particulier parmi les Etats. Nous sommes une civilisation qui partage la même sort, et, ensemble, ils peuvent construire une plus grande coopération internationale et moins de concurrence, et l'éducation est un point clé de réécrire l'histoire humaine sans faim. Comprendre comment l'industrie et de la société grandir et se développer est essentiel de savoir comment ils apprennent et devenir productifs, et la production de connaissances, le point crucial dans l'éducation, produit déjà pays qui sont plus capable en mesure que d'autres concernant le développement des secteurs à forte intensité dans l'état de la dernière technologie, capable de générer plus de revenus, une meilleure production et réduire leur vulnérabilité a la nourriture. Ces effets peuvent être partagés avec les sous-développés. L’innovation a été un élément crucial des économies les plus développées à travers l'histoire. L'hausse du niveau de vie ne devrait pas être attribuée au progrès technologique, pour apprendre à mieux les choses. Le système éducatif durable est un soutien crucial pour réduire l'inégalité des connaissances entre les pays développés et sous-développés et d'aider ceux ayant des difficultés d'apprentissage, capables de créer des sociétés d'apprentissage libre de la faim.

\section{INTRODUCTION}

Sustainable development, or the idea that societies can develop by exploiting natural resources in ways which "meet present needs without compromising the ability of future generations to meet their needs"1, has become a mantra in both policy and practice, at governmental and institutional levels, in business as much as in education. The same applies to the concept of sustainability to address the ability of creating and maintaining the conditions under which sustainable development is possible.

1 WCED, 1987, Sect. 4, Article 27
Etymologically, both the adjective ("sustainable") and the noun ("sustainability") have a long history, as they are derived from the ancient Latin verb sustinere, "to hold up, hold upright, uphold, to bear up, keep up, support, sustain"2. Sustinere is composed from tenere, "to hold, keep ..."3, and sub, "under, below, beneath, ..."4. The verb was already in use in medieval French, and derivations can be found in several Romance languages such as French (soutenir), Italian (sostenere), Portuguese (suster) or Spanish (sostener), and other languages like English (sustain). However, neither the adjective nor the noun made their official appearance in the vocabulary of environmental and social scientists until the $1970 \mathrm{~s}^{5}$, when an informal network of politicians, businessmen and scientists from the Global North (e.g., the United States of America and Europe), still active today under the name "Club of Rome", published The limits to growth: A report for the Club of Rome's project on the predicament of mankind. ${ }^{6}$

Ever since, sustainable development, and the conditions by which it can be upheld, have turned into a core value which has slowly permeated governmental and institutional thinking, in business as well as education; and it is now intrinsically linked with the ways societal problems are thought of and addressed in private and public policy. However, at times when social and economic crises have revealed the fragility of existing policies and institutions, it is imperative to consider how societal sustainability is - and could be - better integrated into adult education and learning policy, and to do so in the multi-level context of the different national, social and cultural environments in which national and transnational levels of governance interact. As a result, the very concept of sustainable development must be put under close scrutiny, drawing on concepts and understandings from different disciplines and identifying strategies and lines of action which could contribute to societal sustainability.

In this theoretical paper, it is considered the topic from the perspective of adult education and learning. Beginning by addressing the conditions under which the concept of sustainable development entered the political debate and consider how it has influenced resear-

\footnotetext{
2 Lewis and Short, 1879 , p. 1822

Lewis and Short, 1879, p. 1853

Lewis and Short, 1879, p. 1772

OED, 2016

Meadows et al. 1972
} 
ch in education. In the main part of our paper, there is an argument for rethinking its ontology. First, it is denounced the reduction of sustainable development to sustainable (economic) growth ${ }^{7}$ and consider the centrality of social justice theory to mitigate inequalities in societal development ${ }^{8}$; then it is showed that this aspect has been a long-standing matter of debate in adult education, and suggest that an awareness of social justice can contribute to understanding sustainability. Finally, it is presented a framework for conceptualising the ecology of education systems ${ }^{9}$ as a key element in creating and maintaining the conditions under which sustainable development is possible. Rethinking societal sustainability in this way can shed new light on the relationships among sustainable development, social justice and the ecology of human development, and, by extension, illuminate the role of adult education and learning policy in fostering societal sustainability.

\section{TRACING THE ROOTS OF SUSTAINABLE DEVELOPMENT}

Contemporary attention to the fact that societies, as dynamic systems, ought to take into account a number of factors to keep developing and growing can be traced back at least to the publication of The limits to growth $^{10}$. This seminal Club of Rome report was the first to present to a worldwide audience a computing model purposely created to account for the relations between diverse factors of development and simulated alternative scenarios for growth, based on available resources. Written by Donatella Meadows, an American environmental scientist, Dennis Meadows, an American scientist who construed the model on which the book stands, and Jørgen Randers, a Norwegian scientist devoted to climate issues, The limits to growth calculated the consequences of rapid world population growth for the finite resources available. In brief, as one of the authors clarifies in hindsight,

Limits to Growth said that the environmental impact of
buman society did increase from 1900 to 1972 because of
growth in population size and growth in the environmental
impact per person. In other words, the ecological footprint of
humanity became heavier because of growth in the number of

7 Seghezzo, 2009

8 Rawls 1971, 1985, 1993, 2001

9 Bronfenbrenner, 1976

10 Meadows et al. 1972 bumans, and because of growth in the amount of resources consumed and pollution generated per person per year. ${ }^{11}$

Thus, The limits to growth drew attention to the fact that natural resources are physically limited and the ecological footprint of humanity would not be able to continue at the same speed and to the same extent as in the past, if the planet and its inhabitants were to survive the (then) present.

Critiques, rejections and positive re-assessments of The limits to growth at a 40-year distance notwithstanding $^{12}$, sustainable development has been intrinsically associated with the exploitation of natural resources, including oil and agricultural land, or the ecological footprint of humanity, and has attracted controversial attention from activists, scientists, politicians and inter-governmental organisations. This is also thanks to the World Commission on Environment and Development (WCED), created in 1983 by the United Nations (and dissolved in 1987), which published another seminal report, Our common future. ${ }^{13}$

It was in Our common future that the concept of "sustainable development" was first used to address a type of growth strategy which was not disconnected from environmental concerns. As a result, the concept rapidly diffused across the world, also under the influence of the United Nations' World Summit on the Environment, held in Rio in $1992^{14}$. Within a few years, this led to the signing of an international treaty on climate change, the Kyoto Protocol of $1997 .^{15}$

\section{Sustainable DEVELOPMENT AND RESEARCH IN EDUCATION}

The growing political attention to sustainable development has not gone unnoticed in education, partly thanks to the United Nations Educational, Scientific and Cultural Organization (UNESCO). In fact, in the same year the Club of Rome published The limits to growth, UNESCO released its report Learning to be: The world of education today and tomorrow ${ }^{16}$. A key "planning

\footnotetext{
11 Randers, 2005, section Limits to Growth 1, paragraph 1

12 Baldi, 2011

13 WCED, 1987

14 UM, 1992, a, b

15 UM, 1998

16 Faure et al., 1972
} 
document" in the history of UNESCO ${ }^{17}$, and a landma$\mathrm{rk}$ in the global history of adult education ${ }^{18}$, the report addressed the danger besetting the environment and, with it, human co-existence as an educational challenge.

\begin{abstract}
Technological development has enabled man to solve many problems, but it has had harmful effects on a number of aspects of contemporary life. All over the world, it contributes to environmental deterioration [...]. It is not only man's environment but - in the near future - bis very fate which may be threatened, and he has already begun to suffer. Rapid changes are winding up tension in people, increasing insecurity, nervous disorders, antisocial behaviour, delinquency and criminality [...] Stimulating awareness of such dangers is a demanding new task for education, but particularly appropriate to it for many reasons and, too often, one that is much underestimated. ${ }^{19}$
\end{abstract}

Three decades later, the United Nations renewed its efforts in highlighting the role education can play in mitigating environmental peril through launching the United Nations Decade of Education for Sustainable Development (DESD) 2005-2014. UNESCO reiterated its commitment to this strategy in the Bonn declaration by stating that

\begin{abstract}
through education and lifelong learning we can achieve lifestyles based on economic and social justice, food security, ecological integrity, sustainable livelihoods, respect for all life forms and strong values that foster social cohesion, democracy and collective action. ${ }^{20}$
\end{abstract}

These policy initiatives emphasised participatory and critical teaching and learning methods designed to motivate and empower learners to change their behaviour - and take action - for sustainable development to be incorporated in policies. Accordingly, for the most part, educationalists have first and foremost focused on how teachers for different subjects work with the concept of sustainability in the classroom ${ }^{21}$, or on how subjects like sustainability or health could be included more fully rather than as merely "residual" issues - in school curricula, so as to promote "healthy and sustainable actions in their students" 2 . Moreover, educationalists have also examined the challenges education for sustainable development poses in terms of justice, environment, human rights and citizenship; and the ways higher education institutions as well as social or environmental professional

17 Singh, 2011

18 Milana, 2016

19 Faure et al., 1972, pp. 99-101

20 UNESCO, 2009, para 5

21 Myers, 2012

22 Simovska and Mannix McNamara 2015, p. vii and education organisations treat and respond to them ${ }^{23}$. Sometimes - if rarely - the above strands of literature extend attention beyond the theory which informs educational praxis at institutional or individual level, to critically examine education policy development in connection with social, economic and environmental crises.

Rather different is the case with those studies which explicitly address the challenges sustainable development poses at the institutional level, including in terms of adopted pedagogies. These studies question the very purpose and nature of educational institutions and how they respond to the policy agenda on sustainability ${ }^{24}$ by teasing out social-environmental relations. What emerges is a range of transformative approaches to re-thinking teaching and learning of and about the relations between environmental degradation and social conflicts ${ }^{25}$ or ideas for re-ordering environmental priorities "to think more carefully about pedagogy and how under global and postcolonial conditions, theory can and should inform the practice of education for a sustainable future"26.

At macro level, growing attention is also being given to the effects of social and economic crises, migration flows or climate change on the sustainable development of contemporary societies and lifestyles. Informed, for the most part, by a "capability approach"27, these studies question predominant paradigms in policy debates on human development. They place an emphasis on the "substantive freedoms" which people value in order to grow old, participate in economic exchange, or engage in political action, rather than on utilitarian aspects or simple access to resources. This way of thinking about human and societal well-being is also found in investigations of lifelong learning policies which contest conventional thinking about the links between education, work and the economy ${ }^{28}$, or in studies on migrants' adaption to new socio-political and cultural environments which question the conditions for full realisation of a good life in the host country ${ }^{29}$. This strand of literature often foresees new policy directions and prompts ideas for "reversing policy-making optics" ${ }^{30}$, for valuing

23 (McFarlane and Ogazon 2011)

24 Blewitt and Cullingford, 2004

25 Misiaszek, 2012

26 Matthews, 2011, p. 236

27 Sen, 1989; Nussbaum and Sen, 1993; Nussbaum 2000

28 Brown, 2013

29 Webb, 2014

30 Livingstone, 2012 
the richness of available knowledge, and for avoiding its waste. Moreover, it calls for policies and programmes which focus on challenging the problems which have led to the current crisis, and encourages economic and ecological change for global sustainable development.

In the same line of thinking, it is proposed a challenge the mainstream conception of sustainable development on which adult education and learning policy draws, including underlying ideas about (economic) growth and prosperity.

\section{How a sustainable education Can SUPPORT THE HUNGER ERRADICATION?}

The sustainable development should not be based only on the fight against poverty. It must also include environmental security and reducing inequality. In 2015, new Sustainable Development Goals were set, because Millennium Development Goals were focused on reducing extreme poverty. In the last 15 years, there was a strong decrease in the number of miserable. Although the number of people in this condition has fallen by half compared to 1990 data, it was not enough to eliminate extreme poverty. On the environmental front, countries made a commitment to stabilize carbon emissions in 1992, and 24 years after, it did not happen yet. Now the danger is growing ${ }^{31}$. The three main threats: climate, biodiversity, and desertification have not been adequately solved yet, then climate change and loss of ecosystems are far worse than they should be ${ }^{32}$. We will not solve the climate issue if we do not solve the problem of increasing poverty in the world, and the reverse is true ${ }^{33}$. Especially in the context of Industry 4.0, a reality we have begun to experience routinely, that means a society with a strong presence of digital technologies, mobility and people connectivity, where the differences between men and machines dissolve and which central value is the information ${ }^{34}$, sustainable educational processes are opportunities to take effective actions against these problems.

This process has occurred in substantive scale and speed, affecting overwhelmingly all dimensions of

31 Sachs, 2015

32 UNEP, 2016

33 UNEP, 2016

34 Castells, 2010 our lives and the way we relate to each other ${ }^{35}$. As an effect, industry 4.0 opens a world of possibilities and risks. Therefore, it is an opportunity to review the relationship between humankind and the technologies we created ${ }^{36}$. We should dominate them, instead of being dominated or use it to oppress our pairs. New technologies should be used to assure everyone opportunities to create wealth and share prosperity, providing decent living conditions for people, whoever and wherever they are. They should ensure the promotion of human dignity to ensure everyone the material conditions for the care of their basic needs and their full potential development, regardless any kind of distinctions, where the hunger erradication, the end of malnourishment and ensure food safety are central points ${ }^{37}$.

If the environmental crisis is not solved, poverty cannot end. Africa, for example, is extremely vulnerable to climate change, since it is already very hot and high temperatures threaten crops. There are also water shortages in many places and high diseases rates. All these environmental crises, if not controlled, will undermine long term development especially in Africa, Asia, and Latin America. If poverty is not confronted, the population of Africa, for example, will continue to grow uncontrollably, even reaching four billion by the end of the century; nowadays are a billion. Populational explosion can exacerbate poverty, undermining biodiversity and the water supply in these continents. For all these reasons, environmental control, including the control of climate change is an integral of ending extreme poverty ${ }^{38}$. Development includes the ability of people to live the life they want to lead without the constraints of poverty, and their subsequent factors, such as hunger, and it occurs not only from a lack of food but from inequalities built into mechanisms for distributing opportunities. In famine, development is menaced, while poorest people still starved because they cannot do anything. They do not control the functioning of nourishment, nor the capability to escape morbidity ${ }^{39}$.

Human action is contributing to global warming. The consequences if greenhouse effect gases are not controlled will be very dangerous ${ }^{40}$. The type of drou-

\footnotetext{
35 Castells, 2010

36 Castells, 2010

37 Sachs, 2015

38 Sachs, 2015

39 Sen, 1981

40 Sachs, 2015
} 
ght that the city of São Paulo faces today will spread around the world. California is under threat, Middle East live with droughts ${ }^{41}$. They will generate social conflicts. The drought in Syria contributed to the outbreak of civil war. Syria faces one of the longest periods of low rainfall in its history, which led to the displacement of more than 1 million people, rising food prices, the social unrest and eventually contributing to war ${ }^{42}$.

Due to industry 4.0, we have much more knowledge of how to solve climate problems - and without education we could not get through this revolution. It is also an opportunity to rethink the lack of collective coordination, especially among States, which many times are hidden behind the economic competitiveness claim. We need to overcome it, as we see events that never happened before. Climate changes and populational increase have created new standards that must be understood. If there is no collective cooperation taking account population dynamics and climate change, crises are inevitable and put at risk Earth existence ${ }^{43}$.

Technology is, more than ever, an important tool to live in a better world ${ }^{44}$. We must consider how educational processes can build revolutions such as industry 4.0, and its power to reduce inequalities and change our lives. Many people, communities, governments and companies are always connected, while in Sub-Saharan Africa and South Asia 1.5 billion do not have access to reliable telecommunications services. It can make our cities, industries, and plantations smarter, cleaner and safer. With the infrastructure provided by industry 4.0, energy systems may be more efficient, with less waste and carbon emissions. It also allows a better preparing to deal with climate change, such as storms, sea level rising and high temperatures, as well as having more spread and reliable transport and feeding systems, with better vehicles and food sharing instead the high concentration of private vehicles and food waste ${ }^{45}$.

The idea that we need a stagnant economy to do not harm the environment is wrong. Humanity likes progress, and poverty reduction depends on it ${ }^{46}$. Industry 4.0 is the perfect opportunity to unlink economic growth from nature destruction. Some say that combi- ning both is not possible, as the use of natural resources has grown in recent decades and we cannot do it without them. It is not wise just to look back, but forward as well. Industry 4.0 creates new technologies, which are cheaper and conserve ecosystems. It is crucial build a strategic and planning cooperation. Especially for poor countries, economic growth is a matter of life or death, and everyone should have access to these technologies 47. Then, sustainable educational processes may engage people, businesses, and governments into this collective convergence.

Industry 4.0 is a hope to develop technologies that allow us to grow consuming fewer fossil fuels, which represents $80 \%$ of our energy use ${ }^{48}$, including real possibilities to make biofuels, wind and solar energy economically advantageous in large scale. The initiatives occurred so far are interesting. There are GPS based electric vehicles automatically piloted that are more energy efficient than the driven by humans. Smart cyber-physical systems make industries more sustainable and competitive, such as biofuels production, with less waste, respecting areas for food, nature and native communities. The improvement of these technologies is the perfect meaning of development - the capabilities of human realization become extensions of our own freedoms. It is an advance on the freedoms we enjoy ${ }^{49}$.

Another challenge in this new scenario is to maintain social achievements and stimulate the increase of productivity with investments in education and innovation, to obtain productivity gains and job creation. New social pacts are important to turn into opportunities this moment of economic disruption ${ }^{50}$. It is necessary to build new alliances to unite people and enable conditions to create a new historical cycle. Industry 4.0, moreover, follows the same trend of its earlier industrial revolution: its hyperconnected nature, at real time. It influences significant changes in production and consumption systems, with extensive use of artificial intelligence. With the end of differentiation between men and machines, there is a new breakdown in the supply chains and business interactions models, which consumers act as producers ${ }^{51}$. In this process, it is expected

\begin{tabular}{ll}
\hline 47 & Sachs, 2015 \\
48 & UNEP, 2016 \\
49 & Sen, 1999 \\
50 & World Economic Forum, 2016 \\
51 & Castells, 2010
\end{tabular}


that more than 7 million jobs will be lost ${ }^{52}$. We have not overcome the adverse effects of the previous industrial revolutions yet, such as high levels of misery, poverty and inequalities, the usual intranational and international conflicts of great destructive capacity and the fast degradation of Earth resources, generated by the relentless wealth accumulation pursuit in a worsening globally scaled competition ${ }^{53}$, problems which a sustainable education is committed to overcome. We are the first generation that can end poverty, but the last one that can save our planet.

All the previous industrial revolutions started in developed countries, arriving late to underdeveloped. The richest countries citizens started to think their economies based on innovation. Innovation has been a crucial part of the most developed economies throughout history ${ }^{54}$. The rise of living standards should not primarily be attributed to the accumulation of capital, but to technological progress, in learning how to do things better ${ }^{55}$. While part of productivity increase reflects the dramatic discoveries impact, much of it has occurred due to small and gradual changes ${ }^{56}$. Thus, it makes sense to focus attention on how societies learn - including how they learn to learn ${ }^{57}$. As its previous industrial revolutions, industry 4.0 brings a new cognitive model to mankind, especially related to wealth creation ${ }^{58} 59$.

Reduce knowledge inequality and help countries with learning difficulties are sustainable development, and for its based education central elements. Understanding how industry and society grow and develop is essential to know how they learn and become productive, and knowledge production, the epicenter of industry 4.0, differs from the consumer goods production. Furthermore, we must consider the subsequent division between developed and undeveloped countries, not just because of the resources or output gap between them, but also of knowledge ${ }^{60}$.

Industry 4.0 already produces a new division of labor, which some countries are more able than others

52 World Economic Forum, 2016

53 Hobsbawm, 1962, 1975, 1987, 1994

54 Stiglitz and Greenwald, 2014

55 Solow, 1956

56 Stiglitz and Greenwald, 2014

57 Arrow, 1962

58 Hobsbawm, 1962, 1975, 1987, 1994

59 Stiglitz and Greenwald, 2014

60 Stiglitz and Greenwald, 2014 regarding the development of intensive sectors in state-of-the-art technology, capable of generating more income, better jobs and reducing their external vulnerability. In national level, those with higher qualifications find higher wages and greater stability opportunities while the others will not find work or will be restricted to more flexible and less paying occupations, such as temporary and part-time jobs. These asymmetries among countries and social groups tend to reproduce indefinitely. Market economies alone typically do not produce and transmit knowledge efficiently, making the richest, richer, and the poorest, poorer, in a circular and cumulative process ${ }^{61}$.

A sustainable education may act as a systemic intervention mechanism, result of essential efforts to allow the poorest and middle-income countries achieve the same level of the developed ones. Thus, it must be the result of more cooperation and less competition among countries, being the union of resources in favor of a civilization that shares the same fate, noble values that converge into a consensus capable of creating synergies and enable an effective and efficient system of international cooperation, given the reluctance of mankind to learn from the historical lessons and the destructive power of our actions. This way, a sustainable education supports substantial progress on many fronts, especially to achieve the necessary reforms to overcome underdevelopment structures.

It can also take an active role in resource allocations to effectively reduce and eliminate those asymmetries, helping "latent economies" to learn the same way of developed ones. With this privilege, the benefits of learning, including the necessary institutional development to the success of these countries can spill over other economic activities ${ }^{62}$. Create learning societies is crucial to increase living standards, and the importance of learning by doing is emphasized ${ }^{636465}$. The only way to learn what is needed for food production growth and food security development is to having an sustainable education, especially in the context of industry 4.0, where the production culture will be crucially based on information. One of the main virtues of an economy is its ability to innovate, and conventional policies focu-

61 Stiglitz and Greenwald, 2014

62 Stiglitz and Greenwald, 2014

63 Arrow, 1962

64 UNESCO, 2015

65 Stiglitz and Greenwald, 2014 
sed on short-term efficiency may be undesirable, if they take a long-term perspective of innovation and learning ${ }^{66}$. This is especially true for developing countries and emerging markets. The sustainable development goals, as its based education, supports the implementation of strong incentives policies to create a fair competition and inclusive production, not only in the area of qualification and professional training of workers for the use of new technologies, but also giving priority to investment in research and development for underprivileged communities, do not allowing them to become mere technology and food consumers, but producers as well. Another supported key point is the development of high technology sectors, able to develop and disseminate innovations that benefit the economy and raise the living standards of humanity, including the improvement of food safety, production and distribution.

\section{Questioning SUSTAINABLE DEVELOPMENT FOR SOCIAL AND INTERGENERATIONAL JUSTICE}

The concept of sustainable development has been primarily associated with environmental concerns. Nonetheless, these concerns have never been entirely independent of economic matters. Underlying the original claim that natural resources are physically limited and that the ecological footprint of humanity could limit growth was a more subtle assumption about "endless economic growth (in economic value) as long as that growth is not associated with growing physical impacts (e.g., in resource use or pollution output)" ${ }^{97}$. Such an ontology - the encouragement of economic growth has strongly conditioned development worldwide, and it remains a source of inspiration for neoliberal reforms of economic and social systems, including education, at both national and international levels.

The same ontology has given rise to the idea of "corporate sustainability", a strategic approach to business that focuses attention on how a company works in its social, cultural and economic environment. The "triple bottom line" was theorised as a model for companies to fully account for the cost of doing business. The first bottom line is a traditional measurement of corporate profit (i.e. the balance between profit and

66 Schumpeter, 1942

67 Randers 2005, Introduction, paragraph 5 loss), the second bottom line measures the degree to which a business has been socially responsible throughout its operations, and finally, the third bottom line also calculates the extent to which the company has acted responsibly towards the environment ${ }^{68}$. This way of thinking about sustainable development in terms of economic growth has led to the model (and slogan) "People, Planet, Profit", where people refers to society at large, planet to the natural environment, and profit to economic and financial prosperity ${ }^{69}$. In principle, triple bottom line thinking represents a major revision of the rationality of business activity. Throughout the history of capitalism, profit has been companies' main priority. Consequences for people and the planet were seldom given serious attention - except when they began to undermine profitability. The triple bottom line principle in business cannot provide sustainability at the societal level, but it can be an important contribution, if it is respected and actually implemented.

However, examples of companies seriously pursuing the triple bottom line approach remain scarce. Moreover, the social and economic crises which have hit individual countries (e.g. Greece) or entire regions (e.g. Europe), over the past decade have clearly shown the limits of such principles. Analysis of governments' responses, five years into the latest global financial crisis, pinpointed a renewed emphasis on individual skills, at least in the Global North, as the panacea "to work through the crisis and reposition the national economy for a post-crisis world" ${ }^{70}$.

Lucas Seghezzo, a critical voice from the Global South, has challenged the oversimplified model of thinking about sustainable development as (potentially) endless economic growth in terms of "People, Planet, Profit", and proposed an alternative model. Seghezzo questions the definition of sustainable development as the use of natural resources in ways that "meet present needs without compromising the ability of future generations to meet their needs" ${ }^{71}$. He argues that this approach is essentially anthropocentric (human-centred) and posits people as undifferentiated members of society, the planet as a mere geographical space, and profit as a short-term measure of the economic value of human actions.

\begin{tabular}{ll}
\hline 68 & Elkington, 1997 \\
69 & Fisk, 2010 \\
70 & Brown, 2013, p. 690 \\
71 & WCED, 1987, Sect. 4, Article 27
\end{tabular}


He further argues that the "People, Planet, Profit" approach emphasises the extrinsic value of natural assets for increasing the stock of "man-made" capital while discharging the intrinsic value of natural resources. Consequently, economic reasons are overestimated at the expense of equity when the links between growth and poverty alleviation or income redistribution are debated, and often "the environmental costs of economic activity are borne by the poor, by future generations, or by other countries" ${ }^{72}$. Moreover, both space and time are often mistreated in sustainability indicators, because "conceptions of time, as notions of space and territory, can differ greatly in different cultures and at different historical moments", and as such hold "an important role in the way we perceive and define nature" 73 . Along this line of argumentation, therefore, Seghezzo has revisited the unidimensional triangle composed by "People, Planet, Profit" and proposed an alternative ontology which integrates the territorial, temporal and personal aspects of development.

To illustrate this framework, I propose a sustainability triangle formed by "Place", "Permanence", and "Persons" [...]. In such a triangle, it is possible to distinguish five dimensions: Place contains the three dimensions of space $(x$, $y$, and z), Permanence is the fourth dimension of time ( $t)$, and the Persons corner adds a fifth, individual and interior, buman dimension (i). Place and Persons, the base of the triangle, represent "real", objective and concrete things that exist in the present time. Permanence, which is located in the upper (or the farthest) corner, is a more "ideal", abstract and subjective projection of events from the other corners into the future. $^{74}$

The general character of Seghezzo's proposed framework shows how difficult it is to develop approaches to sustainability which transcend both the anthropocentric presuppositions and the abstract logic of economics. But the venture in itself is important. And it sheds a new and different light on the links sustainable development holds with social justice, including inter-generational aspects.

The concept of social justice owes considerable debt to the extensive work of American philosopher John Rawls on the theory of justice and a framework for democratic society from the viewpoint of political philosophy ${ }^{75}$. The theoretical backdrop for this political conception of social justice builds on a few assump-

72 Arrow et al. 1995 , p. 92

73 Seghezzo, 2009, p. 546

74 Seghezzo, 2009, p. 547

75 Rawls, 1971, 1985, 1993, 2001 tions. First, that a society is democratic when regulated politically and socially, hence the principle of justice has the scope to specify the "fair" terms of social cooperation, and regulate social and economic inequalities. Second, it also assumes that although in such a politically plural society citizens may adhere to different religious, philosophical, moral etc. doctrines, it is still possible to reach social unity by agreement on basic principles of political justice.

Rawls' theory of justice as fairness builds on hypothetical and ahistorical positions, depicting a society at "point zero", before some institutions gain bargaining advantages as a result of social and historical tendencies which have arisen over time. But it is precisely through recognising the existence of social and historical tendencies which produce unfair social relations that the concept of justice gains relevance - in addressing what would otherwise inevitably result in social inequalities. In fact, Rawls' theory also assumes that at point zero in the development of democratic societies all citizens are equal, as they all have a minimum degree of moral power, or the capacity to understand, apply, and act from the principle of justice as fairness, as well as the capacity to have, revise and pursue the public good. At the same time, all citizens are also free, because they can conceive of themselves and others as having a minimum degree of these moral powers.

\begin{abstract}
Once we view a democratic society as a fair system of social cooperation between citizens regarded as free and equal, what principles are the most appropriate for it? [...] by what principles are differences [...] in life prospects [...] made legitimate and consistent with the idea of free and equal citizens in society seen as a fair system of cooperation? ${ }^{76}$
\end{abstract}

In response to the above queries, two principles of justice as fairness emerge. The first states that "each person has the same indefeasible claim to a fully adequate scheme of equal basic liberties, which scheme is compatible with the same scheme of liberties for all" ${ }^{77}$. Basic liberties are, in fact, essential for developing and exerting the moral power mentioned above. The second principle adds that "social and economic inequalities are to satisfy two conditions: first, they are to be attached to offices and positions open to all under conditions of fair equality of opportunity; and second, they are to be the greatest benefit of the least-advantaged members of society (the

76 Rawls 2001, pp. 39-40

77 Rawls 2001, p. 42 
difference principle)" ${ }^{78}$. Therefore, if the first principle assumes that citizens should have an equal chance to influence policy and gain authority irrespective of their economic and social conditions, the second principle clarifies that certain requirements must be imposed on the basic structure of society to guarantee fair equality of opportunity. In other words, unequal social and economic treatment is "fair" only when it favours greater benefits for the least privileged members of society.

Social and economic crises, migration, climate change and biodiversity underline the urgent need to link social justice concerns to the sustainability of societies and lifestyles - and for education policies which can contribute to this. It is suggested below that a critical engagement with adult education - and in particular with a 20th-century social theorist whose thought emerged in adult education - can contribute significantly to the understanding of sustainable development and inter-generational justice.

\section{Adult education: CUltural tensions and SUSTAINABILITY}

Marcus Singer ${ }^{79}$ has argued that Rawls' principle of fair equality of opportunity, "or at any rate something closely resembling it", together with "an antecedent of the difference principle", play "a prominent role in R. H. Tawney's Equality" ${ }^{80}$. Singer supports his argument with quotes from the book like these ones:

\footnotetext{
Inequality of power is tolerated, when the power is used for a social purpose approved by the community, when it is not more extensive than that purpose requires, when its exercise is not arbitrary, but governed by settled rules, and when the commission can be revoked, if its terms are exceeded. $[. .]^{81}$

No one thinks it inequitable that, when a reasonable provision has been made for all, exceptional responsibilities should be compensated by exceptional rewards, as a recognition of the service performed and an inducement to perform it $[\ldots]$. What is repulsive is not that one man should earn more than others [...]. It is that some classes should be excluded from the heritage of civilization which others enjoy [...] What is important is not that all men should receive the same amount of pecuniary income. It is that the surplus resources of society should be so husbanded and applied that it is a matter of minor significance whether they receive it or not ${ }^{82}$.
}

78 Rawls 2001, p. 43

79 Singer, 2003, pp. 81-82

80 Tawney, 1964 [1931]

81 Tawney, 1964 [1931], p. 17

82 Tawney, 1964 [1931], pp. 17
In the context of the present paper, Tawney's argument is significant not only for its own merits (to which we shall return), but because of who wrote it. R. H. (Richard Henry) Tawney was an English economic and social historian, and a social philosopher; he was also a leading advocate of working-class education, a lifelong member of the Workers' Educational Association (WEA) ${ }^{83}$, one of its very first tutors (and, at the time he wrote Equality, its President). Barry Elsey described him as the "patron saint of adult education" His commitment to the WEA encompassed not only a belief in the importance of education for workers (and their families), but also in the importance of democratic decision-making in education, and of education's role in building and strengthening a democratic society. While Tawney's case matters in relation to fairness, social justice and equality, our focus here is on its implications for societal sustainability. In the quotation above, he wrote not only about, in Rawls' wording, "offices and positions [being] open to all under conditions of fair equality of opportunity" 85 , but of no class being "excluded from the heritage of civilization which others enjoy" ${ }^{86}$. This was a consistent theme in Tawney's thought: he had argued as early as 1914 that working people should not be "excluded from the common heritage of civilization", from which all men and women, irrespective of their occupations are equally capable, as human beings, of deriving spiritual sustenance ${ }^{87}$. This points to the role of common culture in his understanding of social justice, and to his view of education and culture as shared not only by people alive today, but by those in the past and in the future.

\section{Education, as I see it, though it is much else as well, is partly, at least, the process by which we transcend the barriers of our isolated personalities, and become partners in a universe of interests which we share with our fellow-men, living and dead alike. ${ }^{88}$}

As our earlier quote from Learning to be ${ }^{89}$ on the social consequences of rapid technological development suggests, education has often been accorded a key role

83 The Workers' Educational Association (WEA), still offering courses today, was founded in 1903 as "The Organisation for Education of Working Class Men" by Albert Mansbridge. For more information, see WEA, 2013.

84 Elsey, (2001, p. 49)

85 Rawls, 2001, p. 43

86 Tawney, 1964 [1931], p. 112-113

87 Tawney, 1966a [1914], p. 76

88 Tawney, 1966b [1953], pp. 87-88

89 Faure et al. 1972 
in establishing sustainability, including social justice, in human lives and societies. Moreover, adult education has often been deeply connected with radical social and political movements - for democratisation, citizenship etc. Tawney's concept - and its interaction with adult education - provides an example of this, but also of the tensions involved in the struggle for social justice.

It is a truism that, in Europe at least, from the Second World War until the 1970s the links between adult education and social democratic (or socialist) welfare states were close. However, they incorporated a paradox. The political change involved in establishing a welfare state would widen access to cultural goods. Adult education was a beneficiary of this, in part because it was a cultural good, or at least a mechanism by which cultural goods could be shared more widely. "Cultural goods" is of course an ambiguous term; it assumes that elite culture can be parcelled out, distributed - and still retain its value. But it is exactly this ambiguity which made it possible for adult education to become the beneficiary of redistribution through taxation and the state provision of welfare.

Many 20th-century adult educators pursued a simultaneous valuing of "culture" (in the sense of "high culture") and a critique of the existing social, political and economic order. This is especially marked in the work of social movement adult education, one of whose objectives was always to open culture up to the masses but at the same time a critique of the social order was a central motivation and rationale in workers' education throughout the 20th century. The tensions between claiming an elite culture for the people and seeking to change the social order often went unresolved. Tawney, for example, argued that adult education should be "maintained not in order to enable intellect to climb from one position to another, but to enable all to develop the faculties which, because they are faculties of man, are not the attributes of any particular class or profession of men"90. An official report which he (largely) authored mentioned this explicitly. In order to obtain higher education,

it must not be necessary for workpeople to leave the class in which they were born. This is a point to which we attach the greatest importance. [...] [W] e attribute part of the failure of Higher Education among them [the working classes] in the past to the feeling that by means of it their ablest members were being removed to spheres where they would not

90 Tawney, 1966a [1914], p. 77 be available for the service of their fellows. What they desire is not that men should escape from their class, but that they should remain in it and raise its whole level ${ }^{1}$.

This was, of course, both a very radical perspective on social order and a very conservative one. It promised equal access for all to society's cultural goods, while being careful not to destabilise the economic division of labour. For Tawney, politics and education would mean fracturing the links between the division of labour at work and the unequal allocation of rewards. Many of the Oxford academics for whom he wrote the report in 1908 no doubt saw things through a rather different lens: "civilization" would be preserved, but its benefits would be spread to the "great unwashed". Natural social hierarchies would remain undisturbed, but with fuller access to culture and education, the lives and social roles of ordinary people would be more fulfilling.

In the event, welfare states typically encouraged adult education along these lines. But the tension between distribution of well-defined (elite) cultural goods to the working class and the involvement of working-class people in reshaping the character and significance of cultural goods often re-emerged in the institutionalised forms of adult education established by the welfare state.

This tension is one of the challenges confronting ideas about sustainable policy and practice in adult education. It has often contributed to a dual understanding (and organisation) of adult education as either individual consumption of cultural goods or individual "upskilling" through predominantly vocational programmes. The first form does not challenge the class basis of elite culture, while the second form does not challenge the capitalist basis of careers and work organisation. It is, after all, part of the business of adult education both to appreciate and to challenge established knowledge and values. Our argument is that while such tensions are inherent in adult education, it is also democratic practices generated in and through adult education which are best able to address them in developing sustainable policies and practices.

\section{The ECOLOGY OF EDUCATION}

In a wider sense, the concepts of sustainability and sustainable development may also be applied more di-

91 WEA and the University of Oxford, 1909, p. 50 
rectly to educational systems, the processes they frame and how they relate to society. This involves questions of balance between the structure, institutions and workings of educational systems as well as balance in the interaction between these systems with different elements and groups in society.

Sustainability, and by extension sustainable development, in this sense may be informed by the concepts of ecology and ecosystems. This is the study of interactions among organisms and their environment. These interactions are often conceptualised as ecosystems with dynamically interacting parts, including organis$\mathrm{ms}$, the communities they make up, and the inanimate components of their environment. The part of ecology most relevant to education is human ecology, which studies the relationship between humans and their natural, social and constructed environments.

A key contribution to developing an ecological approach to education and learning has been provided by Urie Bronfenbrenner (1979). His background was in developmental and social psychology, but he became increasingly critical of psychological research which tended to focus too much on behaviour in single institutional contexts like the family or the school. His "experimental ecology of education" ${ }^{92}$ was a call for a type of educational research which tries to represent as fully as possible the ecosystems at different levels in which education and learning are embedded. He argued that whether and how people learn in educational settings depends on the relations between the characteristics of the learner and his or her context in each of the principal life environments like home, school or the workplace, but also on the relations and inter-connections which exist among these life environments.

Bronfenbrenner conceptualises the ecological environment "as a nested arrangement of concentric structures, each contained within the next" ${ }^{\prime 93}$. There are four such structures, which Bronfenbrenner calls "systems":

- Micro-systems are the immediate settings containing the learner, for instance the home, the daycare centre, the classroom, the workplace.

- Meso-systems are the interrelations among the major life-settings of a learner at particular points in his or her life.

92 Bronfenbrenner, 1976

93 Bronfenbrenner, 1976, p. 22
- Exo-systems are extensions of the meso-syste$\mathrm{ms}$, embracing the formal and informal social structures' influence or impact on the immediate life-settings. Examples are the world of work, the neighbourhood, mass media, agencies of government.

- Macro-systems are the overarching institutions of culture and society, such as the economic, social, educational, legal, and political structures and systems.

This conceptual framework reflects Bronfenbrenner's background in psychology; it moves from the learners' immediate surroundings outwards to broader contexts and structures of society, and analysis becomes more abstract at the exo- and macro-system levels. As Bronfenbrenner argues, this is partly due to the fact that (in the mid-1970s) too little empirical research on learning and education had in fact tried to capture interactions and influences at these levels; but also reflects the fact that he had based his comprehensive overview of existing knowledge largely on psychological research. Redefinition of the psychological concept of human development was another main aim of his ecological approach; he held that rather than being seen as a process of inner growth, individual development should be defined as "the person's evolving conception of the ecological environment, and his relation to it, as well as the person's growing capacity to discover, sustain, or alter its properties" ${ }^{94}$.

Bronfenbrenner's ecological approach was not only an attempt to overcome limitations in research on human development; it also reflected a critical assessment of developments in society, especially an increased institutionalisation of different life settings, which undermined the interconnections between them. One example is that schooling increasingly takes place in large and standardised institutions, while the links between schools and other micro-systems in children's lives become increasingly tenuous. For Bronfenbrenner this meant that schools became "breeding grounds for alienation" 95 , and he argued that this development threatened basic qualities of society.

No society can long sustain itself unless its members have learned the sensitivities, motivations, and skills involved in assisting and caring for other buman beings. Yet the school, which is the setting carrying primary responsibility for preparing young people for effective participation in adult life, does not, at least

94 Bronfenbrenner, 1976, p.9

95 Bronfenbrenner, 1976, p.231 
in American society, give high priority to providing opportunities in which such learning could take place. This would not be impossible to achieve. For some years I have been advocating the introduction in our schools, from the earliest grades onward, of what I have called a curriculum for caring [...]. The purpose of such a curriculum would be not to learn about caring, but to engage in it: children would be asked to take responsibility for spending time with and caring for others - old people, younger children, the sick, and the lonely ${ }^{96}$.

In this approach, sustainability becomes a question of mutual links and balance between life settings and forces influencing them. This emerges clearly in several of the many hypotheses Bronfenbrenner proposed, for instance hypothesis 38: "The developmental potential of a meso-system is enhanced to the extent that there exist indirect linkages between settings that encourage the growth of mutual trust, positive orientation, goal consensus, and a balance of power responsive to action in [sic] behalf of the developing person" ${ }^{97}$. It should be noted that the approach has a clear normative basis; certain qualities, such as caring attitudes and motivations, are assumed to be positive in a general sense.

Lack of sustainability in the sense indicated by the human ecology approach is common in education and takes many forms ${ }^{98}$. For instance, a public school system may have social justice as one of its official objectives, but at the same time distribute resources mostly on the basis of average student achievement. This can result in schools concentrating resources mainly on high-achieving students and leave the lowest achievers behind. Or a market-based higher education system with institutions at different levels in terms of teaching and research may become dominated by struggles for academic recognition and funding to such a degree that the broader mission of providing quality higher education for a wide segment of the population is undermined. Or the management of an education system may become so bureaucratic that the system is unable to respond to new needs for learning and skills which emerge in labour markets or society. The specific character of such problems depends on the historical trajectories and the dominant policy priorities in given societies, but at a more general level they represent failings in the ecosystems of education and society. They signal lack of sustainability because, if not corrected, they lead to the erosion - and in the end the breakdown - of edu-

96 Bronfenbrenner, 1976, p.53

97 Bronfenbrenner, 1976, p.216

98 Pretorius 2014, Whitty et al. 1998 cational logics.

One example of an ecological approach is a study of the interaction of schools and informal learning organisations in a regional context ${ }^{99}$. Jennifer Lin Russe11 and her colleagues use the concept of ecology as a metaphor to characterise the network of organisations in a locality which provide learning opportunities for youth, and argue that "By employing the language of ecology, we deliberately call attention to two properties: diversity and interdependence" ${ }^{\prime 100}$. In their view, the ecological perspective highlights two crucial properties of the regional education ecosystem: interdependence and diversity. In line with Bronfenbrenner, Russell and her colleagues see interdependence between micro-systems and other entities as a necessary quality, and they argue that this also applies to diversity. "Just as biodiversity is a measure of the health of an ecosystem, diversity in the organizational forms that provide organized educational activity in a region are indicative of a robust learning ecology" ${ }^{\prime 101}$.

For adult education, the balance and the interdependence necessary for sustainable development is often especially delicate. Adult education is generally the least institutionalised sector in educational systems. Establishing specific structures and institutions for adult education run by professional adult educators, and getting these recognised as part of the overall educational system, is necessary to provide stable opportunities for adult learning. But institutionalisation also involves the risk of separating education from the life situations and experiences of adult learners, thus "colonizing the life-world" ${ }^{102}$, which severely limits adult education's potential for developing a broad spectrum of vocational, social and personal capacities. A balance between institutional and non-institutional logics is essential to the sustainability of adult education systems. But balance here does not mean harmonious continuity. As discussed in the previous section, changes, innovations, and even conflicts, are necessary elements in social progress - both in education and elsewhere. But it is important that all actors consider the overall "ecology" of adult education and strive to make this sustainable.

In this paper, it is emphasised social sustainability

99 Russell et al. 2013

100 Russell et al. 2013, p.261

101 Russell et al. 2013, p.262

102 Habermas, 1981 
issues involved in education, especially adult education. But of course institutionalised education also interacts with the natural environment. For instance, schools, like other public buildings, emit greenhouse gases. In a 2008 report on this issue, the Sustainable Development Commission estimated that English schools emitted 8.5 million tonnes of carbon dioxide per year, and greenhouse gases equivalent to 9.4 million tonnes of carbon dioxide per year ${ }^{103}$. The "carbon footprint" of schools is composed of several sources: the use of energy in school buildings; travel and transport to and from schools by cars, trains and other means; supply chains of companies producing goods and services for schools; and schools' waste management ${ }^{104}$. The commission - which was closed in March 2011 by the Conservative coalition government - argued that emissions could be reduced dramatically if steps were taken without further delay.

Thus balance and interdependence, between the different social and educational "systems" where learning occurs and between these systems and their natural environments, are key elements of a sustainable ecology of adult education.

\section{Concluding Remarks}

Undoubtedly, sustainability and sustainable development are widespread conceptions today, and probably no one would contest they are "positive" ones. But their policy implications are not necessarily so, or at least they may become open to larger contestation when attention is focused on the role of adult education and learning policy in fostering societal sustainability, as it was tried to do in this contribution.

First, when are considered the conditions under which the concept of "sustainability", and by extension that of "sustainable development", entered the political debate, it is note that these were born out of a concern of how to secure potentially "endless economic growth" by controlling for the ecological footprint of humanity (i.e. taking into account both the use of natural resources and pollution produced by humankind) ${ }^{105}$. However, these concepts went hand in hand with preoc-

103 SDC, 2008, p. 3

104 SDC, 2008, p. 12

105 Meadows et al., 1972 cupations with the impact of the ecological footprint of humanity on future human co-existence ${ }^{106}$. From this perspective, while anthropocentrism has been strongly present in the interpretation of relations between mankind and the natural environment (i.e. natural resources only hold an extrinsic value for the benefit of humankind), education has been turned into a means for humankind to learn how to maximise (economic) benefit by taking care of the environment and its finite natural resources.

Second, despite the fact that the above views, and the implications they carry, are still en vogue, it is noted in some sectors of society, including education and environmental services, a growing awareness that this ontology of economic growth has silenced a number of other factors which concur with societal sustainability. Among them is the fact that the costs of maximising the benefit of humankind in the use of natural resources produce, rather than reduce, social conflicts, and that the costs of environmental pollution caused by certain societal groups, generations and countries are rarely reduced but rather borne by marginal groups, generations and countries.

It was also discussed the possibility of adopting an alternative ontology, emphasising societal (rather than economic) growth in ways which integrate the territorial, temporal and personal aspects of development ${ }^{107}$. In doing so, we also acknowledged that social and historical tendencies may produce unfair social relations, unless relations among social institutions are regulated to the scope of leveraging social inequalities, also among present and future generations ${ }^{108}$.

From this perspective, if we look at the history of adult education as a social institution, in its relations to social democratic welfare states, we note that it incorporates a paradox or tension between on the one hand making cultural "goods" available to ordinary people from every socioeconomic background, and on the other hand challenging the traditional cultural and social order. This tension, which is still present in welfare state provision for adult education today, must be confronted if adult education policy is to contribute to societal growth in sustainable ways.

Such a policy calls for looking at the ecology of edu-

\begin{tabular}{ll}
\hline 106 & Faure et al. 1972 \\
107 & Seghezzo, 2009 \\
108 & Rawls, 2001
\end{tabular}

108 Rawls, 2001 
cational systems, namely the mutual links education systems hold with multiple life-settings in which learners are embedded, as well as forces which influence these settings, and overarching institutions and structures of culture and society.

Developing frameworks for sustainability in adult education is no easy task, as our attempt in this paper surely shows. Combining frameworks for understanding social and natural environments and combining these with principles of social justice; conceptualising multiple balances without overlooking the potential dynamic change; transgressing anthropocentrism - all this is ambitious. It is emphasised that this perspective is not some kind of "grand theory", but rather a basic framework which could make it possible to navigate the shallows and the depths of the quest for societal sustainability, in research as well as in policy and educational practice.

\section{References}

Arrow, K., Bolin, B., Costanza, R., Dasgupta, P., Folke, C., Holling, C. S., et al. (1995). Economic growth, carrying capacity, and the environment. Ecological Economics, 15(2), 91-95.

Arrow, K. (1962). The economic implications of learning by doing. Oxford: The Review of Economic Studies, Oxford Journals

Baldi, U. (2011). The limits to growth revisited. New York: Springer.

Blewitt, J., \& Cullingford, C. (2004). The sustainability curriculum: The challenge for higher education. London: Earthscan.

Bronfenbrenner, U. (1976). The experimental ecology of education. Paper presented at the American Educational Research Association annual meeting, 19-23 April.

Bronfenbrenner, U. (1979). The ecology of human development: Experiments by nature and design. Cambridge, MA: Harvard University Press.

Brown, T. (2013). Spatial and financial fixes and the global financial crisis: does labour have the knowledge and power to meet the challenge? International Journal of Lifelong Education,32(6), 690-704.

Castells, M. (2010). The Information Age: Economy, Society and Culture. 2nd ed. Oxford: Blackwell.
Elkington, J. (1997). Cannibals with forks: The triple bottom line of 21st century business. Oxford: Capstone Publishing Ltd.

Elsey, B. (2001). R H Tawney, patron saint of adult education. In P. Jarvis (Ed.), Twentieth-century thinkers in adult and continuing education (pp. 49-59). London: Kogan Page.

Faure, E., Herrera, F., Kaddoura, A. R., Lopes, H., Petrovski, A. V., Rahnema, M., et al. (1972). Learning to be: The world of education today and tomorrow. Paris: UNESCO.

Fisk, P. (2010). People, planet, profit: How to embrace sustainability for innovation and business growth. London: Kogan Page Publishers.

Habermas, J. (1981). The theory of communicative action: Reason and the rationalization of society (Vol. 1). Boston: Beacon Press.

Hobsbawm, E. (1975). The Age Of Capital: 1848 - 1875. New York: Vintage Books.

Hobsbawm, E. (1987). The Age Of Empire: 1875 1914. London: Weidenfeld \& Nicolson.

Hobsbawm, E. (1994). The Age Of Extremes: 1914 1991. New York: Pantheon Books.

Hobsbawm, E. (1962). The Age Of Revolution: 1789 1848. New York: World Publishing.

Lewis, C. T., \& Short, C. (1879). A Latin dictionary. Oxford: Clarendon Press.

Livingstone, D. W. (2012). Lifelong learning and lifewide work in precarious times: Reversing policymaking optics. In D. N. Aspin, J. Chapman, K. Evans, \& R. Bagnall (Eds.), Second international handbook of lifelong learning (pp. 269-286). Dordrecht: Springer.

Matthews, J. (2011). Hybrid pedagogies for sustainability education. Review of Education, Pedagogies, and cultural Studies, 33(3), 260-277.

McFarlane, D. A., \& Ogazon, A. G. (2011). The challenges of sustainability education. Journal of Multidisciplinary Research, 3(3), 81-107.

Meadows, D., Meadows, D., \& Jorgen Randers, J. (1972). The limits to growth: A report for the Club of Rome's project on the predicament of mankind. New York: Universe Books.

Milana, M. (2016). Global polity in adult education and UNESCO: Landmarking, brokering, and framing policy. Globalisation, Societies and Education, 14(2), 203-226.

Misiaszek, G. (2012). Transformative environmental 
education within social justice models: Lessons from comparing adult ecopedagogy within North and South America. In D. N. Aspin, J. Chapman, K. Evans, \& R. Bagnall (Eds.), Second international handbook of lifelong learning(pp. 423-440). Dordrecht/Heidelberg/London/ New York: Springer.

Myers, L. (2012). Sustainability education in classrooms. Green. Teacher, 98, 41-44.

Nussbaum, M. C. (2000). Women and buman development: The capabilities approach. Cambridge: Cambridge University Press.

Nussbaum, M. C., \& Sen, A. (Eds.). (1993). The quality of life. Oxford: Clarendon Press.

OED (Oxford English Dictionary) (2016). "sustainable, adj.”. OED Online. Oxford: Oxford University Press. http://www.oed.com/view/Entry/195210?redirected From=sustainable. Accessed 14 April 2016.

Pretorius, S. G. (2014). An education system's perspective on turning around South Africa's dysfunctional schools. Mediterranean Journal of Social Sciences, 5(15), 348-358.

Randers, J. (2005). What was the message of the Limits to growth? What did this little book from 1972 really say about the global future? Zurich: The Club of Rome. http:// www.flow.ph/1/limitstogrowth/What_was_the_message_of_Limits_to_Growth.pdf. Accessed 6 July 2016.

Rawls, J. (1971). A theory of justice. Cambridge, MA: Belknap Press of Harvard University Press.

Rawls, J. (1985). Justice as fairness: Political not metaphysical. Philosophy \& Public Affairs, 14(3), 223-251.

Rawls, J. (1993). Political liberalism. New York: Columbia University Press.

Rawls, J. (2001). Justice as fairness: A restatement. Cambridge, MA: Harvard University Press.

Russell, J. L., Knutson, K., \& Crowley, K. (2013). Informal learning organizations as part of an educational ecology: Lessons from collaboration across the formal-informal divide. Journal of Educational Change, 14, 259-281.

SDC (Sustainable Development Commission). (2008). Carbon emissions from schools: Where they arise and how to reduce them. Report. London, etc.: SDC. http://www.sdcommission.org.uk/data/files/publications/Publish_ Schools_Carbon_Strategy.pdf. Accessed 5 July 2016.

Sachs, J. (2015). The Age Of Sustainable Development.
New York: Columbia University Press.

Schumpeter, J. (1942). Capitalism, Socialism and Democracy. London:Routledge.

Seghezzo, L. (2009). The five dimensions of sustainability. Environmental Politics, 18(4), 539-556.

Sen, A. (1989). Development as capability expansion. Journal of Development Planning, 19, 41-58.

Sen, A. (1999). Development as freedom. New York: Knopf, 1999.

Sen, A. (1981). Poverty and famines. Oxford: Clarendon Press.

Simovska, V., \& Mannix McNamara, P. (Eds.). (2015). Schools for health and sustainability: Theory, research and practice. Dordrecht: Springer.

Singer, M. G. (2003). The ideal of a rational morality: Philosophical compositions. Oxford: Oxford University Press.

Singh, J. P. (2011). United Nations Educational, Scientific, and Cultural Organization (UNESCO): Creating norms for a complex world. London, New York: Routledge.

Solow, R. (1956). A contribution to the theory of economic growth. Oxford: Quarterly Journal of Economics, Oxford Journals.

Stiglitz, J., Greenwald, B. (2014). Creating A Learning Society. New York: Columbia University Press.

Tawney, R. H. (1964 [1931]). Equality. London: George Allen \& Unwin.

Tawney, R. H. (1966a [1914]). An experiment in democratic education. In R. Hinden (ed.), The radical tradition: Twelve essays on politics, education and literature by R.H. Tawney (pp. 74-85). Harmondsworth: Penguin.

Tawney R. H. (1966b [1953]). The Workers' Educational Association and adult education. In R. Hinden (ed.) The radical tradition: Twelve essays on politics, education and literature. R.H. Tawney (pp. 86-97). Harmondsworth: Penguin.

United Nations Educational, Scientific and Cultural Program - UNESCO (2015). Education 2030 Framework for Action. Incheon: United Nations Educational, Scientific and Cultural Program. Available at: http:// unesdoc.unesco.org/images/0024/002432/243278e. pdf Accessed 24 August 2016.

United Nations Environment Program - UNEP (2016). 6th Global Environment Outlook Report. Nairobi: 
United Nations Environment Program. Available at: http://www.unep.org/geo/ Accessed 24 August 2016.

UN (United Nations). (1992a). Rio declaration on environment and development. Annex 1 of the Report of the United Nations Conference on Environment and Development (UNCED, Rio de Janeiro, 3-14 June 1992). A/CONF.151/26 (Vol. I). New York: UN General Assembly. http://www.un.org/documents/ga/conf151/ aconf15126-1annex1.htm. Accessed 6 July 2016.

UN (1992b). Agenda 21. New York: UN. https://sustainabledevelopment.un.org/content/documents/Agenda21.pdf. Accessed 6 July 2016.

UN (1998). Kyoto protocol to the United Nations framework convention on climate change.New York: UN. http://unfccc. int/resource/docs/convkp/kpeng.pdf. Accessed 6 July 2016.

UNESCO (United Nations Educational, Scientific and Cultural Organization). (2009). Bonn declaration. Formulated at the UNESCO World Conference on Education for Sustainable Development held in Bonn, Germany on 31 March to 2 April. Bonn: UNESCO. http:// unesdoc.unesco.org/images/0018/001887/188799e. pdf. Accessed 5 July 2016.

WCED (World Commission on Environment and Development). (1987). Our common future [The Brundtland Report]. New York, NY: Oxford University Press.
WEA (Workers' Educational Association). (2013). A brief history of the Workers' Educational Association. London: WEA. https://issuu.com/weasheffieldwea/docs/ history_booklet?e $=1305752 / 1634711$. Accessed 5 July 2016.

WEA \& University of Oxford (1909). Oxford and working-class education: Being the report of a joint committee of university and working-class representatives on the relation of the university to the higher education of workpeople. 2nd edn. Oxford: Clarendon Press. Digitised facsimile of the first edition (1908) available at https://archive.org/stream/ oxfordworkingcla00workuoft\#page/8/mode/2up. Accessed 5 July 2016.

Webb, S. (2014). Using the experiences of skilled migrants to reflect on continuing education policies for workforce and sustainable development. Encyclopaideia, 18(40), 69-86.

Whitty, G., Power, S., \& Halpin, D. (1998). Devolution and choice in education: The school, the state and the market. Buckingham: Open University Press.

World Economic Forum (2016). The Global Competitiveness Report 2015 - 2016. [online] Geneve: World Economic Forum. Available at: http://www3.weforum.org/docs/Media/TheGlobalRisksReport2016.pdf Accessed 24 August 2016. 


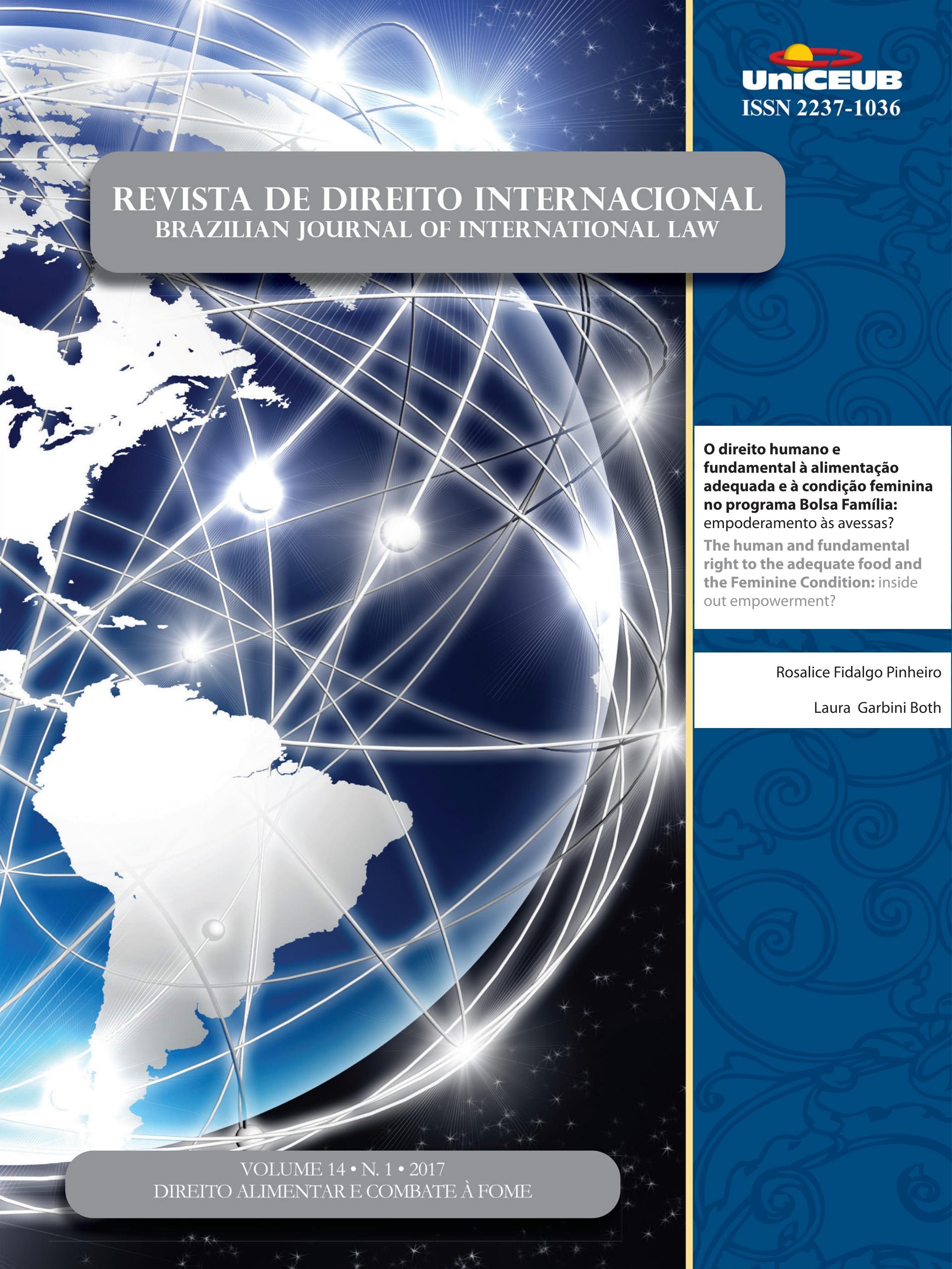




\title{
0 direito humano e fundamental à alimentação adequada e à condição feminina no programa Bolsa Família: empoderamento às avessas?*
}

\author{
The human and fundamental right to the \\ adequate food and the Feminine Condition: \\ inside out empowerment?
}

\author{
Rosalice Fidalgo Pinheiro** \\ Laura Garbini Both***
}

\section{Resumo}

O objetivo deste trabalho é examinar a condição feminina em políticas públicas de efetivação do direito humano e fundamental à alimentação adequada. Considerando-se as políticas públicas de segurança alimentar e nutricional como políticas públicas em favor da família, a condição feminina encontrou destaque no Programa Bolsa Família por estabelecer a mulher como principal beneficiária. Enquanto alguns sinalizam uma perda de sua autonomia em face do mercado de trabalho, outros reconhecem o fortalecimento de seu papel na família. Conclui-se pela melhora da condição feminina, em razão do alto percentual de famílias monoparentais cujas responsáveis são mulheres. Eis o aspecto que guarda originalidade no trabalho: indagar pelo empoderamento às avessas das beneficiárias do Programa. Para realizar esta análise, o trabalho utilizou-se do método dedutivo, e dos procedimentos de pesquisa empírico e bibliográfico. Os marcos teóricos que nortearam a discussão contemplam as obras de Joaquín Herrera Flores, Bila Sorj e Andrea Gama e Nancy Fraser. O plano de trabalho foi divido em três partes: (i) a afirmação do direito humano à alimentação no plano internacional; (ii) sua recepção no plano constitucional e as políticas públicas de segurança alimentar e nutricional; (iii) a condição feminina no Programa Bolsa Família.

Palavras-chave: Direito humano e fundamental à alimentação adequada. Segurança alimentar e nutricional. Políticas públicas. Família. Condição feminina. Programa Bolsa Família. Mestrado em Direitos Fundamentais e Democracia do Centro Universitário Autônomo do Brasil (UniBrasil).E-mail: rosallice@gmail.com

*** Doutora em Educação junto ao Programa de Pós-Graduação em Educação da Pontifícia Universidade Católica do Paraná (PUCPR) e Mestre em Antropologia Social junto ao Programa de Pós-Graduação em Antropologia Social da Universidade Federal do Paraná (UFPR). Professora do Programa de Mestrado em Direitos Fundamentais e Democracia do Centro Universitário Autônomo do Brasil (UniBrasil). E-mail: laura.both@unibrasil.com.br

\section{Abstract}

The study aims to examine the status of women in public policy implementation of the human and fundamental rights to adequate food. Considering the public policy of food security and nutrition and public policies for the family, the status of women found prominence in the Family Allowance Program by establishing the woman as the main beneficiary. While some signal a loss of women's autonomy in the face of the labor market, others 
recognize the strengthening of their role in the family. The results confirmed the improvement of women's status, because of the high percentage of single-parent families whose heads are women. This is the aspect that keeps originality at work: ask the empowerment inside out of the Program beneficiaries. To perform this analysis we used the deductive method and empirical and bibliographic research procedures. The theoretical frameworks that guided the discussion include the works of Joaquín Herrera Flores, Bila Sorj and Andrea Gama and Nancy Fraser. The work plan was divided into three parts: (i) the affirmation of the human right to food at international scope; (Ii) receipt at the constitutional level and the public policies for food and nutrition security; (Iii) the status of women in the Family Allowance Program.

Keywords: Human and fundamental right to adequate food. Food and nutrition security. Public policy. Family. Womanhood; Bolsa Família Program.

\section{INTRODUÇÃo}

A fome e a subnutrição são fenômenos antigos, sendo possível observá-los não apenas em regiões geográficas específicas como a África ou em países devastados pela guerra, mas em países com grandes reservas naturais como o Brasil. Josué de Castro, em sua obra clássica "Geografia da fome", já caracterizava a fome coletiva como um fenômeno social geograficamente universal, a ponto de afirmar que "toda a terra dos homens tem sido também até hoje a terra da fome" ${ }^{1}$. Paradoxalmente, o direito humano e fundamental à alimentação é um direito relativamente novo ${ }^{2}$. Embora já tenha sido afirmado no plano internacional, na Declaração de Direitos Humanos de 1948 e no Pacto Internacional de Direitos Econômicos, Sociais e Culturais de 1966, somente foi recepcionado por um número restrito de Constituições,

1 CASTRO, Josué de. Geografia da fome (O dilema brasileiro: pão ou aço). 10. ed. Rio de Janeiro: Antares, 1984. p. 48.

2 COURTIS, Christian. The Right to Food as a Justiciable Right: Challenges and Strategies. BONGDANDY, A. WOLFRUM, R. (Coord.). Max Planck Yearbook of United Nations Law. Local: Koninklije Brill N., 2007. p. 323; NIVARD, Carole. Le droit à l'alimentation. La Revue des Droits de l'Homme, jun. 2012. Disponível em: <http:// revdh.files.wordpress.com/2012/06/le-droit-c3a0-lalimentation. pdf>. Acesso em: 06 out. 2016. Disponível em: <http://revdh.files. wordpress.com/2012/06/le-droit-c3a0-lalimentation.pdf>. Acesso em: 06 out. 2016. p. 1. ingressando, tardiamente, na Constituição brasileira, por meio da Emenda Constitucional no 64/2010.

Trata-se, ainda, de um fenômeno que decorre de injustiças sociais, exclusões políticas ou econômicas e discriminações ${ }^{3}$. Nesse contexto de exclusão, o direito humano e fundamental à alimentação foi afirmado no plano internacional, em meio ao embate entre universalismo e relativismo, e recepcionado como direito fundamental social na Constituição da República. Para tanto, editou-se a Lei no 11.346/2006, denominada de Lei Orgânica de Segurança Alimentar e Nutricional (LOSAN), que estabeleceu, em seu artigo $1^{\circ}$, o dever do Estado formular e implementar políticas, planos e ações para assegurar aquele direito. É imprescindível que, na formulação dessas políticas públicas, inclua-se a questão de gênero, com vistas a realizar a segurança alimentar e nutricional em favor da família.

Delineia-se, então, o objeto deste trabalho que é contrapor o direito humano e fundamental à alimentação adequada à condição feminina ${ }^{4}$. Considerando-se as políticas públicas de segurança alimentar e nutricional como políticas públicas em favor da família, propõe-se uma difícil equação a ser resolvida: conciliar o combate à pobreza à autonomia das mulheres. O Programa Bolsa Família elege a mulher como principal beneficiária, suscitando controvérsias: enquanto alguns sinalizam uma perda de autonomia da mulher em face do mercado de trabalho, outros reconhecem o fortalecimento de seu papel na família.

Dada a sua amplitude temporal, abrangência social e escala espacial, esse Programa constitui-se como uma política pública que propõe a mitigação de uma situação grave e específica, a fome e a miséria. Entretanto, ele confere visibilidade e alavanca rumo à transformação de outra situação, a condição desigual da mulher na sociedade. Certamente, essa última questão articula-se com a anterior, abrindo e ampliando seus objetivos iniciais, e comprovando o potencial emancipador das políticas

3 Golay, Christophe; ÖZDEN, Melik. Le droit à l'alimentation. Un droit humain fondamental stipulé par l'ONU et reconnu par des traités régionaux et de nombreuses constitutions nationales. Une collection du Programme Droit Humains du Centre Europe - Tiers Monde (CETIM) . Disponível em : < http:/ / www.eoi.at/d/EOI\%20 -\%20Jahresberichte/Monaco/bro1-alim-A4-fr.pdf>. Acesso em: 06 out. 2016. p. 3.

4 Entende-se a condição feminina como o status ou situação da mulher na ordem das relações e representações sociais relativas a determinado contexto social ou cultural. Cada sociedade concretiza em seus termos esta condição. 
públicas que buscam a efetivação dos direitos humanos. É nesses termos que se indaga por um empoderamento ${ }^{5}$ feminino às avessas.

Utilizando-se do método de pesquisa dedutivo, o trabalho parte do tema do direito humano e fundamental à alimentação adequada para desaguar na condição feminina. Para percorrer esse caminho, o trabalho vale-se de dados empíricos do IBGE, relativos ao censo 2010, e do Ministério do Desenvolvimento Social sobre o Programa Bolsa Família que apontam o alto percentual de responsabilidade feminina em famílias monoparentais. Ao seguir o procedimento de pesquisa bibliográfico, elege como marcos teóricos a concepção intercultural de direitos humanos de Joaquín Herrera Flores, as críticas de Bila Sorj e Andréa Gama acerca das políticas públicas brasileiras em favor da família, e as categorias de reconhecimento, redistribuição e representação, problematizadas por Nancy Fraser. Conclui-se pelo fortalecimento do papel da mulher, ao ser eleita como beneficiária principal do Programa Bolsa Família.

O plano de trabalho divide-se em três partes: (i) a primeira delineia a afirmação do direito humano à alimentação adequada no embate entre universalismo e relativismo; (ii) a segunda atem-se à recepção do direito humano e fundamental à alimentação adequada e sua articulação em políticas públicas de segurança alimentar e nutricional voltadas à família; e (iii) a terceira cumpre o desafio de discutir a condição feminina no Programa Bolsa Família.

\section{ENTRE UNIVERSALISMO E RELATIVISMO: A AFIRMAÇÃO DO DIREITO HUMANO À ALIMENTAÇÃO ADEQUADA}

Os direitos humanos são produtos da época moderna, mas estão no seu apogeu ${ }^{6}$. Trata-se de um paradoxo

5 Trata-se da “...autodeterminação de indivíduos e comunidades, objetivando uma participação simbólica e real na busca da democracia e equidade, em que o profissional assume um papel importante na mediação de processos propulsores do empoderamento.” KLEBA, Maria Elisabeth; WENDAUSEN, Agueda. Empoderamento: processo de fortalecimento dos sujeitos nos espaços de participação social e democratização política. Saúde e sociedade, São Paulo, v. 18, n. 4, p. 733-743, 2009. Disponível em: <http://www.scielo.br/pdf/ sausoc/v18n4/16.pdf>. Acesso em: 29 out. 2016. p. 742.

6 VILLEY, Michel. $O$ direito e os direitos bumanos. São Paulo: M. Fontes, 2007. p. 2. do qual Michel Villey vale-se para descrever a trajetória desses direitos, afirmando que irromperam, logo após a Revolução de 1789, na Europa moderna ${ }^{7}$. Se na Declaração dos Direitos do Homem e do Cidadão os direitos humanos representaram, em uma perspectiva contratualista, a luta contra o absolutismo político ${ }^{8}$, no século XX, surgiram, novamente, como recurso, dessa vez, na luta contra o totalitarismo?.

A Primeira Grande Guerra legou coletividades de pessoas destituídas de seus territórios, que deveriam ser eliminadas ou assimiladas, pois provocavam uma tensão entre o Estado e a nação ${ }^{10}$. Os regimes totalitários, por sua vez, promoveram a desnacionalização em massa, ensejando os apátridas e sinalizando uma ruptura dos direitos humanos ${ }^{11}$. Por ocasião da Segunda Grande Guerra, o Estado mostra-se como principal violador desses direitos, resultando em uma reconstrução do referencial ético no plano internacional, por meio da Declaração Universal de 1948. Afirma-se a ideia segundo a qual a proteção desses direitos não pode se reservar ao domínio do Estado, passando-se da jurisdição doméstica à jurisdição internaciona ${ }^{12}$. Eis, segundo Flávia Piovesan, a concepção contemporânea de direitos humanos, caracterizada pela universalidade e indivisibilidade desses direitos ${ }^{13}$. A primeira garante que ser pessoa é requisito suficiente para sua titularidade, e a segunda estabelece que a garantia dos direitos civis e políticos é condição para a observação dos direitos sociais, econômicos e culturais ${ }^{14}$.

7 VILLEY, Michel. O direito e os direitos humanos. São Paulo: M. Fontes, 2007. p. 9-10.

8 VILLEY, Michel. O direito e os direitos humanos. São Paulo: M. Fontes, 2007. p. 4.

9 VILLEY, Michel. O direito e os direitos humanos. São Paulo: M. Fontes, 2007. p. 4.

10 LAFER, Celso. A reconstrução dos direitos humanos. Um diálogo com o pensamento de Hannah Arendt. São Paulo: Companhia das Letras, 2009. p. 142.

11 LAFER, Celso. A reconstrução dos direitos humanos. Um diálogo com o pensamento de Hannah Arendt. São Paulo: Companhia das Letras, 2009. p. 144.

12 PIOVESAN, Flávia. A universalidade e a indivisibilidade dos direitos humanos: desafios e perspectivas. In: BALDI, César Augusto (org.). Direitos humanos na sociedade cosmopolita. Rio de Janeiro: Renovar, 2004. p. 48.

13 PIOVESAN, Flávia. A universalidade e a indivisibilidade dos direitos humanos: desafios e perspectivas. In: BALDI, César Augusto (org.). Direitos humanos na sociedade cosmopolita. Rio de Janeiro: Renovar, 2004. p. 45-71, p. 57.

14 PIOVESAN, Flávia. A universalidade e a indivisibilidade dos direitos humanos: desafios e perspectivas. In: BALDI, César Augusto (org.). Direitos humanos na sociedade cosmopolita. Rio de Janeiro: Renovar, 2004. p. 57. 
Esse processo apoia-se na restrição da soberania estatal e na concepção universal desses direitos. Esboça-se, então, um sistema normativo internacional de proteção aos direitos humanos, representado pela criação da Organização das Nações Unidas em 1945 e pela Declaração Universal dos Direitos do Homem de $1948^{15}$. A Declaração combina os direitos civis e políticos, denominados de primeira geração, com os direitos sociais, econômicos e culturais de segunda geração, rompendo com a tese geracional dos direitos humanos ${ }^{16}$. Também traz consigo uma universalidade de corte axiológico ${ }^{17}$, expressa pelo princípio da dignidade da pessoa humana, que é recepcionada tardiamente pelos ordenamentos jurídicos contemporâneos, como é o caso do artigo $1^{\circ}$, III, da Constituição da República de 1988.

No plano internacional, o artigo XXVI da Declaração Universal de Direitos Humanos de 1948 afirma o direito à alimentação, dentre outros, tem caráter obrigatório. A vantagem dessa afirmação está, justamente, em seu caráter universalista, pois, hoje, a Declaração é aceita por todos os Estados ${ }^{18}$. Rende-se, então, ao direito à alimentação a característica de um direito universal $^{19}$, passível de proteção em um sistema normativo internacional.

No contexto da garantia dos direitos humanos universais, o direito à alimentação adequada foi, expressamente, acolhido pelo Pacto Internacional de Direitos Econômicos, Sociais e Culturais de 1966, em seu artigo 11, como obrigatório para todos os Estados que o aceitaram ou o ratificaram, dentre os quais o Brasil em

15 FACHIN, Melina Girardi. Fundamentos dos direitos humanos: Teoria e práxis na cultura da tolerância. Rio de Janeiro: Renovar, 2009. p. 59-61.

16 Cf. FLORES, Joaquín Herrera. A (re) invenção dos direitos bumanos. Florianópolis: Fundação Boiteux e IDHID, 2009. p. 75-76.

17 FACHIN, Melina Girardi. Fundamentos dos direitos humanos: Teoria e práxis na cultura da tolerância. Rio de Janeiro: Renovar, 2009. p. 69.

18 Golay, Christophe; ÖZDEN, Melik. Le droit à l'alimentation. Un droit humain fondamental stipulé par l'ONU et reconnu par des traités régionaux et de nombreuses constitutions nationales. Une collection du Programme Droit Humains du Centre Europe - Tiers Monde (CETIM) . Disponível em : < http://www.eoi.at/d/EOI\%20 -\%20Jahresberichte/Monaco/bro1-alim-A4-fr.pdf>. Acesso em: 06 out. 2016. p. 10.

19 Golay, Christophe; ÖZDEN, Melik. Le droit à l'alimentation. Un droit humain fondamental stipulé par l'ONU et reconnu par des traités régionaux et de nombreuses constitutions nationales. Une collection du Programme Droit Humains du Centre Europe - Tiers Monde (CETIM) . Disponível em : < http://www.eoi.at/d/EOI\%20 -\%20Jahresberichte/Monaco/bro1-alim-A4-fr.pdf>. Acesso em: 06 out. 2016. p. 8.
1992. Segundo Islândia Costa Bezerra e Kátya Regina Isaguirre, isso "representa um avanço imensurável", sendo possível afirmar que "vislumbra o conhecimento e o reconhecimento, por parte de toda a sociedade, de que o acesso a uma alimentação adequada corresponde, por si só, ao direito de existir e coexistir, vinculado diretamente ao valor da dignidade humana" ${ }^{20}$.

No entanto, o universalismo é passível de críticas, ao se indagar se as normas de direitos humanos têm um sentido tão somente universal ou se são culturalmente relativas ${ }^{21}$. Para os relativistas ${ }^{22}$, cada cultura tem um discurso próprio acerca desses direitos, não havendo lugar para uma moral universal, e sendo imprescindível respeitar as diferenças culturais ${ }^{23}$. Por conseguinte, a internacionalização dos direitos humanos está hoje pulverizada nos sistemas internacional e regional de proteção desses direitos ${ }^{24}$.

O direito humano à alimentação adequada é acolhido, então, no plano regional. O Protocolo de San Salvador de 1988, que completa a Convenção Americana dos Direitos Humanos de 1969, reconhece expressamente em seu artigo 12 o direito à alimentação adequada $a^{25}$, tendo sido ratificado pelo Brasil. Já a Carta Africana dos

20 BEZERRA, Islândia Costa; ISAGUIRRE, Kátya Regina. Direito humano à alimentação adequada (DHAA): a discussão da "geografia da fome" à sua proteção jurídica no Brasil, Revista Pensar, Fortaleza, v. 18, n. 3, p. 675-692, set./dez. 2014. p. 677.

21 PIOVESAN, Flávia. A universalidade e a indivisibilidade dos direitos humanos: desafios e perspectivas. In: BALDI, César Augusto (org.). Direitos humanos na sociedade cosmopolita. Rio de Janeiro: Renovar, 2004. p. 45-71, p. 58.

22 Sobre as formas de relativismo consultar: PIOVESAN, Flávia. A universalidade e a indivisibilidade dos direitos humanos: desafios e perspectivas. In: BALDI, César Augusto (org.). Direitos bumanos na sociedade cosmopolita. Rio de Janeiro: Renovar, 2004. p. 45-71, p. 61.

23 PIOVESAN, Flávia. A universalidade e a indivisibilidade dos direitos humanos: desafios e perspectivas. In: BALDI, César Augusto (org.). Direitos humanos na sociedade cosmopolita. Rio de Janeiro: Renovar, 2004. p. 45-71, p. 60.

24 FACHIN, Melina Girardi. Fundamentos dos direitos humanos: Teoria e práxis na cultura da tolerância. Rio de Janeiro: Renovar, 2009. p. 69.

25 "Toda pessoa tem direito a uma alimentação adequada que lhe assegure a possibilidade de atingir seu pleno desenvolvimento físico e seu pleno desenvolvimento afetivo e intelectual." Tradução livre de: "Toute personne a droit à une alimentation adéquate qui lui assure la possibilité d'atteindre son plein développement physique et son plein épanouissement affectif et intellectuel. » (Apud Golay, Christophe; ÖZDEN, Melik. Le droit à l'alimentation. Un droit humain fondamental stipulé par l'ONU et reconnu par des traités régionaux et de nombreuses constitutions nationales. Une collection du Programme Droit Humains du Centre Europe - Tiers Monde (CETIM). Disponível em: <http://www.eoi. at/d/EOI\%20-\%20Jahresberichte/Monaco/bro1-alim-A4-fr.pdf >. Acesso em: 06 out. 2016. p. 12. 
Direitos Humanos e dos Povos não reconhece, explicitamente, o direito à alimentação, mas prevê um conjunto de direitos, no artigo 16, para seu reconhecimento. Em seu artigo 60, prevê que os Estados africanos devem realizar o direito à alimentação, previsto no plano internacional, aceitando o Pacto Internacional de Direitos Econômicos, Sociais e Culturais. A Carta Africana dos Direitos e bem-estar da Criança, expressamente, assegura, em seu artigo 14, o fornecimento de alimentação adequada e água potável ${ }^{26}$. A Carta Social Europeia de 1961 contempla uma proteção tão somente parcial do direito à alimentação, uma vez que o considera, suficientemente protegido, por meio da previsão do direito ao trabalho, à assistência e à seguridade social ${ }^{27}$.

As diferenças culturais, proclamadas pelos relativistas, mostram-se visíveis quando está em jogo o direito humano à alimentação: indivíduos e grupos mais vulneráveis da sociedade, constantemente discriminados, como as mulheres, crianças, camponeses sem terra, povos indígenas, pescadores, desempregados são os que estão mais sujeitos à fome. Para Christophe Golay e Melik Özden, a solução está em considerar o direito à alimentação como um direito que pertence a todos sem discriminação alguma ${ }^{28}$. Nessa perspectiva, a Convenção sobre Eliminação de todas as Formas de Discriminação das Mulheres estabelece em seus artigos 12 e 14, que o direito à alimentação é reconhecido a todas as mulheres; a Convenção dos Direitos da Criança, nos artigos 24 e 27, garante o direito à alimentação à infância; a Convenção do Estatuto dos Refugiados, nos artigos 20 e 23, garante esse direito aos refugiados; e a Conven-

26 Golay, Christophe; ÖZDEN, Melik. Le droit à l'alimentation. Un droit humain fondamental stipulé par l'ONU et reconnu par des traités régionaux et de nombreuses constitutions nationales. Une collection du Programme Droit Humains du Centre Europe - Tiers Monde (CETIM) . Disponível em : < http://www.eoi.at/d/EOI\%20 -\%20Jahresberichte/Monaco/bro1-alim-A4-fr.pdf>. Acesso em: 06 out. 2016. p. 13.

27 Golay, Christophe; ÖZDEN, Melik. Le droit à l'alimentation. Un droit humain fondamental stipulé par l'ONU et reconnu par des traités régionaux et de nombreuses constitutions nationales. Une collection du Programme Droit Humains du Centre Europe - Tiers Monde (CETIM) . Disponível em : < http://www.eoi.at/d/EOI\%20 -\%20Jahresberichte/Monaco/bro1-alim-A4-fr.pdf>. Acesso em: 06 out. 2016. p. 14.

28 Golay, Christophe; ÖZDEN, Melik. Le droit à l'alimentation. Un droit humain fondamental stipulé par l'ONU et reconnu par des traités régionaux et de nombreuses constitutions nationales. Une collection du Programme Droit Humains du Centre Europe - Tiers Monde (CETIM) . Disponível em : < http://www.eoi.at/d/EOI\%20 -\%20Jahresberichte/Monaco/bro1-alim-A4-fr.pdf>. Acesso em: 06 out. 2016. p. 8. ção dos Povos Indígenas e Tribais, nos artigos 14 a 19, garante a estes povos o direito em questão ${ }^{29}$.

A complexidade dos direitos humanos na sociedade atual não pode ser reduzida à mera contraposição entre universalismo e relativismo. Trata-se de refletir acerca do homem ou da cultura como fundamento desses direitos. Para tanto, o primeiro passo é partir da convicção que os problemas culturais que desafiam os direitos humanos são também problemas políticos e econômi$\cos ^{30}$. Nessa perspectiva, Joaquín Herrera Flores considera o universalismo como uma concepção abstrata de direitos humanos, ancorada em uma racionalidade formal, que ignora a diversidade e diferenças de poder entre identidades sociais diversas. Igualmente, rechaça a concepção relativista como uma visão localista, que ao universalizar seus particularismos, justifica a violação dos direitos humanos ${ }^{31}$. Por isso, propõe a superação dos extremos, por meio de um "universalismo de confluência", segundo o qual o universal não é o ponto de partida, mas o ponto de chegada. Ancorado em uma prática intercultural, o autor afirma que os direitos humanos não são meras declarações textuais ou produtos de uma única cultura, mas processos dinâmicos, que permitem a abertura e consolidação de espaços de luta pela dignidade humana ${ }^{32}$.

Com amparo nos ensinamentos acima, o direito humano à alimentação adequada pode ser compreendido como um produto cultural, "como algo que surge em uma determinada realidade, fruto de um conjunto de relações sociais"33. Essa ideia reflete-se no Comentário Geral no 12 da ONU, delineando os elementos essenciais do direito humano à alimentação adequada: dispo-

29 Golay, Christophe; ÖZDEN, Melik. Le droit à l'alimentation. Un droit humain fondamental stipulé par l'ONU et reconnu par des traités régionaux et de nombreuses constitutions nationales. Une collection du Programme Droit Humains du Centre Europe - Tiers Monde (CETIM) . Disponível em : < http://www.eoi.at/d/EOI\%20 -\%20Jahresberichte/Monaco/bro1-alim-A4-fr.pdf > . Acesso em: 06 out. 2016. p. 11.

30 FACHIN, Melina Girardi. Fundamentos dos direitos humanos: Teoria e práxis na cultura da tolerância. Rio de Janeiro: Renovar, 2009. p. 231-234.

31 FACHIN, Melina Girardi. Fundamentos dos direitos bumanos: Teoria e práxis na cultura da tolerância. Rio de Janeiro: Renovar, 2009. p. $235-242$.

32 FLORES, Joaquín Herrera. A (re) invenção dos direitos humanos. Florianópolis: Fundação Boiteux e IDHID, 2009. p. 68.

33 BEZERRA, Islândia Costa; ISAGUIRRE, Kátya Regina. Direito humano à alimentação adequada (DHAA): a discussão da "geografia da fome" à sua proteção jurídica no Brasil, Revista Pensar, Fortaleza, v. 18, n. 3, p. 675-692, set./dez. 2014. p. 682. 
nibilidade e acesso. Em relação ao primeiro, a alimentação além de ser culturalmente aceitável e passível de satisfazer, em termos quantitativos e qualitativos, as necessidades alimentares do indivíduo, deve ser disponível a cada pessoa, sendo obtida, diretamente, dos recursos naturais ou de um sistema de distribuição adequada. Em relação ao segundo, toda a pessoa deve ter acesso fisicamente e economicamente à alimentação. $\mathrm{O}$ acesso físico se traduz em uma alimentação suficiente e adequada para toda a pessoa, seja ela vulnerável ou não. E o acesso econômico significa que as despesas com uma alimentação suficiente e adequada não podem colocar em risco a fruição de outros direitos humanos ${ }^{34}$.

A perspectiva dos direitos humanos como espaços de luta pela dignidade enseja a discussão sobre o papel dos Estados na concretização desses direitos. Quanto a esse aspecto, Christophe Golay e Melik Özden proclamam que não se trata de uma opção política, mas da obrigação de respeitar, proteger e tornar efetivo o direito humano à alimentação adequada. Em relação ao primeiro, exemplificam os autores que o Estado não pode destituir os povos indígenas e outras minorias de suas terras ou empreender políticas econômicas que resultem no desemprego massivo ou perda do poder aquisitivo da população. Em relação ao segundo, afirmam que o Estado deve impedir que terceiros, como empresas nacionais e transnacionais, deteriorem recursos naturais que possibilitam a alimentação de indivíduos e coletividades. E, finalmente, facilitar e realizar o direito à alimentação, por meio de políticas públicas ou do fornecimento direto àqueles que não têm nenhuma chance de acesso $^{35}$.

Para tanto, o Pacto Internacional dos Direitos Econômicos, Sociais e Culturais impõe aos Estados signatários a obrigação de progressividade na implantação desses direitos e proíbe “...o retrocesso ou a redução

34 Golay, Christophe; ÖZDEN, Melik. Le droit à l'alimentation. Un droit humain fondamental stipulé par l'ONU et reconnu par des traités régionaux et de nombreuses constitutions nationales. Une collection du Programme Droit Humains du Centre Europe - Tiers Monde (CETIM) . Disponível em : < http://www.eoi.at/d/EOI\%20 -\%20Jahresberichte/Monaco/bro1-alim-A4-fr.pdf>. Acesso em: 06 out. 2016. p. 7.

35 Golay, Christophe; ÖZDEN, Melik. Le droit à l'alimentation. Un droit humain fondamental stipulé par l'ONU et reconnu par des traités régionaux et de nombreuses constitutions nationales. Une collection du Programme Droit Humains du Centre Europe - Tiers Monde (CETIM) . Disponível em : < http://www.eoi.at/d/EOI\%20 -\%20Jahresberichte/Monaco/bro1-alim-A4-fr.pdf>. Acesso em: 06 out. 2016. p. 15-16. de políticas públicas voltadas à garantia de tais direitos, cabendo ao Estado o ônus da prova" ${ }^{" 36}$. Cabe, ainda, aos Estados partes assegurar o "núcleo essencial mínimo", que se traduz no "dever de observância do mínimo essencial concernente aos direitos econômicos, sociais e culturais [que] tem como fonte o princípio da dignidade humana [...] demandando absoluta urgência e prioridade" ${ }^{37}$. Indaga-se, então, como o Brasil recepcionou o direito humano à alimentação adequada, cumprindo a obrigação de implantação deste direito, por meio de políticas públicas em favor da segurança alimentar e nutricional.

\section{As POLÍTICAS PÚBLICAS EM FAVOR DO DIREITO HUMANO E FUNDAMETAL À ALIMENTAÇÃO ADEQUADA}

O Brasil coloca-se, dentre os aproximadamente vinte países $^{38}$, que recepcionaram o direito humano à alimentação adequada expressamente em seu direito interno. Não obstante, já fosse possível deduzi-lo de outros direitos fundamentais ${ }^{39}$, ingressou tardiamente no rol de direitos fundamentais sociais do artigo $6^{\circ}$ da Constituição da República, por meio da Emenda Constitucional $n^{\mathrm{o}} 64 / 2010^{40}$.

A recepção do direito à alimentação adequada na Constituição da República evidencia sua passagem de direito humano a direito fundamental. Trata-se de uma distinção tradicionalmente realizada pela doutrina, segundo a qual a denominação "direitos humanos" é reservada ao direito internacional, enquanto a denomi-

36 PIOVESAN, Flávia. Direitos bumanos e o direito constitucional internacional. 12. ed. São Paulo: Saraiva, 2011. p. 235.

37 PIOVESAN, Flávia. Direitos humanos e o direito constitucional internacional. 12. ed. São Paulo: Saraiva, 2011. p. 235-236.

38 NIVARD, Carole. Le droit à l'alimentation. La Revue des Droits de l'Homme, jun. 2012. Disponível em: <http://revdh.files.wordpress.com/2012/06/le-droit-c3a0-lalimentation.pdf $>$. Acesso em: 06 out. 2016. p. 1.

39 Cf. Marcela Müller, ao arrolar os seguintes artigos da Constituição da República: art. $1^{\circ}$, III; art. $3^{\circ}$, III; art. $4^{\circ}$, II; art. $6^{\circ}$; art. $7^{\circ}$, IV; art. 23, VIII e X; art. 208, VII; art.225; art. 227. MÜLLER, Marcela. O direito social fundamental à alimentação adequada e sua proteção no contexto das organizações internacionais. 2014. 143 f. Dissertação (Mestrado em Direito) - Programa de Pós-Graduação em Direito, Universidade de Itaúna, Itaúna, 2014. p. 45.

40 Cf. MÜLLER, Marcela. O direito social fundamental à alimentação adequada e sua proteção no contexto das organizações internacionais. 2014. 143 f. Dissertação (Mestrado em Direito) - Programa de Pós-Graduação em Direito, Universidade de Itaúna, Itaúna, 2014. p. 45-46. 
nação "direitos fundamentais" é característica do direito interno. Entretanto, questiona-se uma possível fragmentação desses direitos operada por esta distinção ${ }^{41}$. Para António-Enrique Perez Luño, referida distinção é inadmissível, pois a diferença reside no grau de concreção positiva:

Los derechos humanos suelen venir entendidos como un conjunto de facultades e instituciones que, en cada momento histórico, concretan las exigencias de la dignidad, la liberdad y la igualdad humanas, las cuales deben ser reconocidas positivamente por los ordenamientos jurídicos a nivel nacional e internacional. En tanto que con la noción de los derechos fundamentales se tiende a ludir a aquellos derechos humanos garantizados por el ordenamiento jurídico positivo, en la mayor parte de los casos en su normativa constitucional, y que suelen gozar de una tutela reforzada ${ }^{42}$.

Com amparo nesse autor, Melina Girard Fachin proclama uma aproximação entre direitos humanos e fundamentais, em face de sua finalidade comum: a proteção efetiva da pessoa humana. É possível afirmar que ambos convergem para a concretização do princípio da dignidade da pessoa humana, sendo preferível denominar o direito à alimentação adequada de direito humano e fundamental ${ }^{43},{ }^{44}$.

O direito humano e fundamental à alimentação adequada está relacionado à fome e à desnutrição. Entretanto, a fome não se reduz apenas aos aspectos biológicos e econômicos. Por outras palavras, não é possível considerá-la tão somente como uma "sensação fisiológica ligada à vontade de comer”, ou dimensioná-la a partir da disponibilidade de alimentos no mercado ou domicílios, tomando por base os gastos familiares ou características do consumo alimentar e, sequer por meio de indicadores de estado nutricional diretos ou indiretos da população ${ }^{45}$. Antes, assevera Flávio Luiz Schieck Va-

41 Cf. FACHIN, Melina Girardi. Todos os nomes e um só sentido: a aproximação dos direitos humanos aos direitos fundamentais tendo em vista sua efetivação prática. Revista Brasileira de Direito Internacional, Curitiba, v. 3, n. 3, jan./jun. 2006. p. 55.

42 LUÑO, António E. Pérez. Los derechos fundamentales. 10. ed. Madrid: Editorial Tecnos, 2011. p. 42. (Temas clave de la Constituicion española).

43 FACHIN, Melina Girardi. Todos os nomes e um só sentido: a aproximação dos direitos humanos aos direitos fundamentais tendo em vista sua efetivação prática. Revista Brasileira de Direito Internacional, Curitiba, v. 3, n. 3, jan./jun. 2006. p. 68.

44 Com base nessa doutrina, que reconhece uma aproximação entre as concepções de direitos humanos e direitos fundamentais, doravante o direito à alimentação adequada será denominado “direito humano e fundamental".

45 VALENTE, Flávio Luiz Schieck. Fome, desnutrição e cidada- lente que a fome tem facetas subjetivas e qualquer

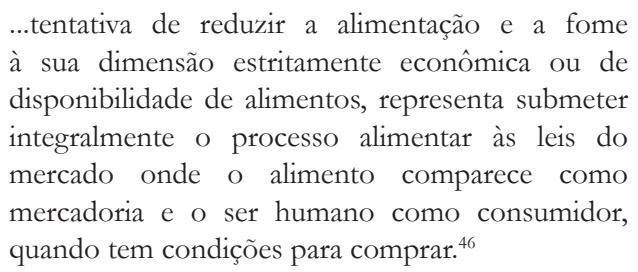

A desnutrição, por sua vez, engloba tanto carências nutricionais como uma ingestão excessiva ou desbalanceada de nutrientes, de tal modo que a obesidade e o consumo inadequado de alimentos mostram-se como problemas de saúde pública. Desse modo, a quantidade e a qualidade do alimento que é oferecido à população, sua produção e comercialização podem se caracterizar como obstáculos à realização do direito humano e fundamental à alimentação adequada. Nos países latino-americanos, isso requer uma alteração da perspectiva da economia agrícola, de mera lógica mercantil à afirmação daquele direito ${ }^{47}$.

Delineia-se um quadro de insegurança alimentar e nutricional que leva à necessidade de elaboração de uma Política Nacional de Segurança Alimentar e Nutricional, editando-se a Lei $n^{\circ} 11.346 / 2006$, denominada de Lei Orgânica de Segurança Alimentar e Nutricional (LOSAN). Sob o princípio da dignidade da pessoa humana $\left(\operatorname{artigo~} 2^{\circ}\right.$ ), essa lei conceitua a segurança alimentar e nutricional como o direito de todos ao acesso regular, permanente, de qualidade, em quantidade suficiente, sem comprometer outros bens essenciais, baseado em práticas alimentares saudáveis, que respeitem a diversidade cultural e sejam ambiental, cultural, econômica e socialmente sustentáveis (artigo $3^{\circ}$ ). Desse modo, o direito humano e fundamental à alimentação adequada articula-se com outros direitos fundamentais sociais, sendo destes, indissociável.

$\mathrm{O}$ artigo $7^{\circ}$ da LOSAN cria o Sistema Nacional de Segurança Alimentar e Nutricional (SISAN), integrado por um conjunto de órgãos dos entes federados e instituições privadas sem fins lucrativos, que tem por objetivo formular e implementar políticas públicas e planos

nia: inclusão social e direitos humanos. Saúde e sociedade, São Paulo, v. 12, n. 1, p. 51-60, jan./jun., 2003. p. 57.

46 VALENTE, Flávio Luiz Schieck. Fome, desnutrição e cidadania: inclusão social e direitos humanos. Saúde e sociedade, São Paulo, v. 12, n. 1, p. 51-60, jan./jun., 2003. p. 57.

47 BEZERRA, Islândia Costa; ISAGUIRRE, Kátya Regina. Direito humano à alimentação adequada (DHAA): a discussão da "geografia da fome" à sua proteção jurídica no Brasil, Revista Pensar, Fortaleza, v. 18, n. 3, p. 675-692, set./dez. 2014. p. 689. 
de segurança alimentar e nutricional, bem como sua promoção, acompanhamento, monitoramento e avaliação (artigo 10). A implementação de políticas públicas para realização do direito humano e fundamental à alimentação adequada, deve respeitar a multiplicidade de características culturais do País, (artigo 4, VI, LOSAN), de tal modo que uma parcela de relativismo cultural tece a segurança alimentar e nutricional.

As políticas públicas em favor do direito humano e fundamental à alimentação adequada inserem-se no sistema de reordenação traçado pela Constituição da República de 1988. Para tanto, passou a considerar os direitos sociais como fundamentais, estabelecendo o compromisso do Estado com o sistema de proteção social, o que acentuou o seu grau de comprometido financeiro e o papel complementar do setor privado para o cumprimento desta tarefa. Estabeleceu a concepção de seguridade social como a forma mais abrangente de proteção e orientou-se pela descentralização e participação social nestas atividades ${ }^{48}$. Entretanto, se por um lado, a Constituição estabeleceu novos princípios, por outro, o Estado engajou-se no projeto neoliberal, que nas últimas décadas resultaram no desmantelamento do sistema de proteção social. Por conseguinte, a "nova política econômica" contrapõe-se à "nova política de proteção social", o que levou o governo brasileiro a optar pela diminuição de financiamento de programas e políticas sociais ${ }^{49}$.

Segundo Flávio Luiz Schieck Valente, o direito humano e fundamental à alimentação adequada deve ser considerado como inseparável do direito à nutrição, dependendo não apenas da disponibilidade de alimentos, mas do respeito às práticas e hábitos alimentares, do estado de saúde das pessoas, da prestação de cuidados especiais aos grupos mais vulneráveis, como crianças, idosos, gestantes, pessoas com deficiência, e de nutrir a si próprio e à sua família com dignidade ${ }^{50}$. Desse modo, é imprescindível que as políticas públicas de segurança alimentar e nutricional atentem para a condição feminina, em razão do papel fundamental desempenhado pela

48 SORJ, Bila.; GAMA, Andréa. Family Policies in Brazil. ROBILA, Mihaela (Coord.). Handbook of family policies across the globe. New York City: Springer, 2014. p. 459-471, p. 459.

49 SORJ, Bila.; GAMA, Andréa. Family Policies in Brazil. ROBILA, Mihaela (Coord.). Handbook of family policies across the globe. New York City: Springer, 2014. p. 459-471, p. 467-468.

50 VALENTE, Flávio Luiz Schieck. Fome, desnutrição e cidadania: inclusão social e direitos humanos. Saúde e sociedade, São Paulo, v. 12, n. 1, p. 51-60, jan./jun., 2003. p. 54. mulher no ciclo da vida e na alimentação da família ${ }^{51}$. Com efeito, as políticas públicas de segurança alimentar e nutricional traduzem-se em políticas públicas em favor da família.

As transformações da família, que se delinearam nas últimas décadas, propõem dois desafios às políticas públicas conduzidas pelo Estado brasileiro nesta seara: (i) dissipar sua fragmentação e (ii) promover a "liberdade de ser na família" 52 .

O primeiro decorre do fenômeno de descodificação do Direito Privado, que legou leis especiais para regular predominante o Direito de Família, como a Lei 8.069/1990 (Estatuto da Criança e do Adolescente) e a Lei 10.741/2003 (Estatuto do Idoso), constituindo microssistemas que tutelam a pessoa sob uma perspectiva interdisciplinar. Por conseguinte, as políticas públicas passaram a ser dirigidas à infância e adolescência, aos idosos, às mulheres, como reflexo dessa pluralidade de estatutos jurídicos. Delineia-se, então, uma política social fragmentada, posto que limitada pela ausência de políticas públicas mais abrangentes. Eis que, por vezes, uma família pobre recebe uma renda mensal, que lhe permite aumentar o consumo, mas mora em local sem qualquer infraestrutura ${ }^{53}$. Em última instância, realiza-se uma política pública em favor do mercado, capaz de aumentar o poder de consumo, mas incapaz de dissipar a desigualdade social entre as famílias ${ }^{54}$.

O segundo decorre da prioridade conferida às mulheres como beneficiárias de programas de transferência de renda, pois elas preferem investir os recursos da família no bem-estar de seus filhos, enquanto os homens tendem a utilizá-los em seu próprio bem-estar.

51 Cf. FRANÇA, Alexandra Beurlen de. O direito bumano à alimentação adequada no Brasil. 2004. 260 f. Dissertação (Mestrado em Direito) - Programa de Pós-Graduação em Direito, Universidade Federal de Pernambuco, Recife, 2004. p. 96.

52 Cf. VILLELA, João Baptista. Liberdade e família. Monografia (TCC) - Faculdade de Direito da UFMG, Belo Horizonte 1980. p. 16.

53 SORJ, Bila.; GAMA, Andréa. Family Policies in Brazil. ROBILA, Mihaela (Coord.). Handbook of family policies across the globe. New York City: Springer, 2014. p. 463.

54 Para Bila Sorj e Andréa Gama, o sistema dualista de políticas públicas no Brasil faz com que estas sejam dirigidas às famílias extremamente pobres, restando às famílias assalariadas e de classe média o estímulo de obtenção de segurança social no mercado, o que reproduz a desigualdade social entre as famílias. SORJ, Bila.; GAMA, Andréa. Family Policies in Brazil. ROBILA, Mihaela (Coord.). Handbook of family policies across the globe. New York City: Springer, 2014. p. 460 
Tais fatos apontam para políticas públicas dirigidas às mães e às crianças, questionando-se sua suficiência para promoção da "liberdade de ser na família" ${ }^{55}$. Trata-se de conciliar o combate à pobreza com a promoção da autonomia das mulheres, substituindo a campanha contra a pobreza de viés maternalista forte, por políticas que melhorem o nível e a qualidade da participação das mães no mercado de trabalho ${ }^{56}$.

Dentre as políticas públicas em favor de famílias em situação de risco, elaboradas pelo Estado brasileiro nos últimos anos, estão os programas de transferência de renda como o Programa Bolsa Família, ao qual se condensa o segundo desafio. Ele tem sido objeto de intensa discussão por priorizar a mulher. Enquanto alguns opinam que ele fomenta o papel da mulher como mãe, privilegiando a família, outros afirmam que ele desencoraja a participação da mulher do mercado de trabalho, enfraquecendo sua autonomia ${ }^{57}$. É a discussão que adiante se enfrenta.

\section{A Condição feminina e o programa Bolsa Família}

Os últimos anos apontam um novo perfil das famílias brasileiras. Em face do princípio da pluralidade familiar, a Constituição da República acolhe as famílias monoparentais, formadas por apenas um dos cônjuges e seus filhos, no artigo 226. Dados do IBGE revelam que $37,3 \%$ das famílias brasileiras têm como responsável a mulher ${ }^{58}$, o que se deve ao alto índice de divórcios e separações e ao crescimento da gravidez na adolescência. E nas famílias monoparentais, $87,4 \%$ das mulheres são apontadas como responsáveis pelo grupo ${ }^{59}$.

55 Cf. VILLELA, João Baptista. Liberdade e família. Monografia (TCC) - Faculdade de Direito da UFMG, Belo Horizonte 1980. p. 16.

56 SORJ, Bila.; GAMA, Andréa. Family Policies in Brazil. ROBILA, Mihaela (Coord.). Handbook of family policies across the globe. New York City: Springer, 2014. p. 469.

57 SORJ, Bila.; GAMA, Andréa. Family Policies in Brazil. ROBILA, Mihaela (Coord.). Handbook of family policies across the globe. New York City: Springer, 2014. p. 467.

58 IBGE. Estatísticas de gênero. Uma análise dos resultados do censo demográfico 2010. Disponível em: <http://biblioteca.ibge. gov.br/visualizacao/livros/liv88941.pdf>. Acesso em: 25 out. 2016, p. 65.

59 IBGE. Estatísticas de gênero. Uma análise dos resultados do censo demográfico 2010. Disponível em: <http://biblioteca.ibge.gov.br/ visualizacao/livros/liv88941.pdf>. Acesso em: 25 out. 2016. p. 65.
Tais fatos representam um desafio à concretização do direito humano e fundamental à alimentação adequada: a desigualdade de gêneros.

No plano internacional, o Pacto Internacional sobre Direitos Econômicos, Sociais e Culturais buscou conter o ciclo de discriminação feminina, caracterizada, dentre outros aspectos, por um fraco poder de negociação doméstico e a distribuição desproporcional de tarefas e responsabilidades familiares. Eis que estabelece em seus artigos $2^{\circ}$ e $3^{\circ}$, a igualdade entre homens e mulheres no que se refere aos direitos econômicos, sociais e culturais. A Convenção sobre Eliminação de todas as Formas de Discriminação, no artigo 12, impõe aos Estados partes a obrigação de prover uma nutrição adequada durante a gravidez e o aleitamento materno. Igualmente, impõe medidas apropriadas para eliminar a discriminação de mulheres em zonas rurais, em seu artigo 14. Com efeito, os Estados devem garantir a realização do direito à alimentação adequada com amparo na igualdade de gêneros e na autonomia feminina ${ }^{60}$. Para tanto, a Diretiva $13.4 \mathrm{da} \mathrm{ONU}^{61}$ recomenda a prioridade às mulheres em programas de segurança alimentar e nutricional, com vistas a reforçar seu papel de tomada de decisões, garantindo que os alimentos sejam empregados em favor das necessidades domésticas ${ }^{62}$.

Nessa perspectiva, o Programa Bolsa Família foi editado no ano de 2003, por meio da Medida Provisória $n^{\circ}$ 132, convertida na Lei $n^{\circ} 10.386 / 2004$. Ele se expandiu pelas regiões mais pobres do país, tendo como objetivos: (i) reduzir a pobreza por meio da transferência de ren-

60 As normas de Direito Privado devem se harmonizar tanto à Constituição, como aos tratados de direitos humanos. Cogita-se, então, de um controle de convencionalidade ou supralegalidade das normas jurídicas internas ao direito humano à alimentação adequada. Cf. CARVALHO, Alexander Perazo Nunes de. Convencionalização do direito civil: a aplicação dos tratados e convenções internacionais no âmbito das relações privadas. Revista de Direito Internacional, Brasília, v. 12, n. 2, p. 342-354, 2015. p. 351. Disponível em: <https://www.publicacoesacademicas.uniceub.br/rdi/article/ view/3756/pdf $>$. Acesso em: 30 jan. 2017.

61 ORGANIZAÇÃO DAS NAÇÕES UNIDAS PARA A ALIMENTAÇÃO E A AGRICULTURA. Diretrizes Voluntárias em apoio à realização progressiva do direito à alimentação adequada no contexto de segurança alimentar nacional. O direito à alimentação. Roma. 2015. p. 28. Disponível em: <http://www.fao.org/3/b-y7937o.pdf>. Acesso em: 30 jan. 2017.

62 SCHUTTER, Oliver de. Droits des femmes et droit à l'alimentation. Rapport sumis par le Rapporteur spécial sur le droit à l'alimentation. Conseil des droits de l'homme. Nations Unies. Assemblée générale, 24 dez. 2012. Disponível em: < http://www.ohchr.org/Documents/ HRBodies/HRCouncil/RegularSession/Session22/A-HRC-22-50_ fr.pdf>. Acesso em: 26 out. 2016. p. 12. 
da familiar e (ii) reforçar o exercício de direitos sociais, como a saúde e a educação, com vistas a romper o ciclo da pobreza. O Programa destina-se às famílias em situação social adversa, com dificuldade de acesso à alimentação adequada, elegendo como critério absoluto a priorização de famílias em situação de vulnerabilidade social: as extremamente pobres com renda mensal inferior a sessenta reais e as moderadamente pobres com renda mensal entre sessenta e cento e vinte reais ${ }^{63}$. Transfere-se às famílias um valor mensal em dinheiro desde que sejam cumpridas certas condições, como manter as crianças em idade escolar na escola e fazer o acompanhamento mensal de saúde e nutrição dessas crianças.

Ao condicionar educação e saúde à segurança alimentar e nutricional, o Bolsa Família expressa e concretiza uma clara visibilidade da condição feminina no contexto familiar no Brasil. Eis que as mulheres são as primeiras beneficiárias do Programa, o que permite lhes atribuir os deveres de manutenção das crianças na escola e de cuidados com a saúde. Nesse aspecto, residem seus resultados positivos como a redução da pobreza, diminuição da disparidade de rendas, maior frequência escolar, cuidados com a vacinação e garantia de que as crianças não serão submetidas ao trabalho ${ }^{64}$.

No entanto, a opção de priorizar as mulheres como beneficiárias do Programa Bolsa Família gera discussões. Vozes proclamam que esta característica reforça a divisão sexual das tarefas no lar e enfraquece a participação das mulheres com o mercado de trabalho. Eis que as beneficiárias teriam menos horas de trabalho e salários menores que outras mulheres que estão no mesmo nível de pobreza, mas não participam do Programa. Após avaliar a relação entre as mulheres beneficiárias do Bolsa Família e o mercado de trabalho, Bila Sorj e Adriana Fontes concluem que:

Tais resultados nos convidam a pensar que se a política de luta contra a pobreza, que é o objetivo do Programa Bolsa Família, mostra uma relativa eficácia, ela não favorece realmente a entrada das mães no mercado de trabalho e não lhes ajuda a encontrar melhores condições de emprego. O $\mathrm{PBF}$, endereçando-se com prioridade às mulheres,

63 SORJ, Bila; FONTES, Adriana. Les politiques publiques au Brésil et l'articulation entre travail et famille. Une comparaison interrégionale. Cabiers du Genre. Paris, v. 1, n. 46, p. 155-176, 2009. Disponível em: <http://www.cairn.info/revue-cahiers-du-genre2009-1-page-155.htm>. Acesso em: 27 out. 2016. p. 164-165.

64 SORJ, Bila.; GAMA, Andréa. Family Policies in Brazil. ROBILA, Mihaela (Coord.). Handbook of family policies across the globe. New York City: Springer, 2014. p. 468. reconhece-lhes, inicialmente, no seu papel familiar e não as incentiva a desenvolver sua autonomia individual $^{65}$.

Trata-se de questionar se tais programas resultariam em uma desigualdade de gênero ${ }^{66}$, pois tenderiam a reforçar a divisão de papéis entre os sexos, por considerar, sobretudo, a proteção dos direitos das mães e das crianças. Eis que semelhante concepção revelar-se-ia restritiva, transpondo para o segundo plano a reivindicação de igualdade entre os sexos, por desconsiderar a mulher como ser humano ${ }^{67}$. Outros identificam o fortalecimento da participação das mulheres no Programa, o que lhes confere maior autoridade no espaço doméstico em razão do aumento do poder de aquisição e recursos para consumo ${ }^{68}$.

Para resolver essa difícil equação, o trabalho analisa as categorias de reconhecimento, redistribuição e representação, problematizadas por Nancy Fraser ${ }^{69}$ e os dados prospectados em pesquisa empírica realizada pelo Ministério do Desenvolvimento Social.

65 Tradução livre de ; "De tels résultats nous invitent à penser que si la politique de lutte conte la pauvreté, qui est l'objectif du Programme Bourse Famille, montre une relative efficacité, elle ne favorise pas réellement l'entrée des mères sur le marché du travail et ne les aide pas à trouver de meilleures conditions d'emploi. Le PBF, en s'adressant en priorité aux femmes, les reconnaît d'abord dans leur rôle familial et ne les incite pas à développer leur autonomie individuelle. » SORJ, Bila; FONTES, Adriana. Les politiques publiques au Brésil et l'articulation entre travail et famille. Une comparaison interrégionale. Cabiers du Genre. Paris, v. 1, n. 46, p. 155-176, 2009. Disponível em: <http://www.cairn.info/revue-cahiers-du-genre2009-1-page-155.htm>. Acesso em: 27 out. 2016. p. 167.

66 SCHUTTER, Oliver de. Droits des femmes et droit à l'alimentation. Rapport sumis par le Rapporteur spécial sur le droit à l'alimentation. Conseil des droits de l'homme. Nations Unies. Assemblée générale, 24 dez. 2012. Disponível em: <http://www.ohchr.org/Documents/ HRBodies/HRCouncil/RegularSession/Session22/A-HRC-22-50_ fr.pdf $>$. Acesso em: 26 out. 2016. p. 12.

67 LE POINT SUR. Le droit à l'alimentation et genre. Roma : FAO L'Organisation des Nations Unies pour l'alimentation et l'agriculture. Unité pour le droit à l'alimentation, 2007. p. 1-2, Disponível em : <http://www.fao.org/3/a-a1610f.pdf>. Acesso em: 06 out. 2016. p. 1.

68 SUÁREZ, Mireya; TEIXEIRA, Marlene (Coord.). O Programa Bolsa Família e o enfrentamento das desigualdades de gênero: o desafio de promover o reordenamento do espaço doméstico e o acesso das mulheres ao espaço público. In: PAES-SOUSA, Rômulo; VAITSMAN, Jeni (Org.). Cadernos de Estudos. Desenvolvimento social em debate. Síntese das pesquisas de avaliação de programas sociais do MDS. 2007. Disponível em; <http://aplicacoes.mds.gov.br/sagirmps/ferramentas/docs/caderno\%20-\%2005.pdf>. Acesso em: 27 out. 2016. p. 22.

69 FRASER, Nancy. Da redistribuição ao reconhecimento? Dilemas da justiça numa era "pós-socialista". Tradução de Júlio Assis Simões. Cadernos de campo, São Paulo, n. 14/15, p. 231-239, 2006. Disponível em: <http://www.revistas.usp.br/cadernosdecampo/ article/view/50109/54229>. Acesso em: 24 out. 2016. p. 236 et seq. 
Os condicionantes estabelecidos pelo Programa Bolsa Família permitem a compreensão da dinâmica da articulação entre os movimentos sociais, o Estado e as políticas públicas. Emergem desta articulação entre o mundo vivido, no qual estão presentes os movimentos sociais ou relações interindividuais, e o sistema, composto pelo Estado e mediado pela esfera pública, demandas por redistribuição, reconhecimento e representação. Nessa seara a segurança alimentar e nutricional está em questão, a partir do olhar da condição feminina na família brasileira. Eis que tais categorias são elementos necessários da constituição da cidadania e dos direitos humanos.

A demanda por redistribuição consiste em dar visibilidade às desigualdades de ordem econômica, expressas na exploração do trabalho, que expropria quem o exerce da possibilidade de acesso ao que produz; na marginalização econômica que impele os trabalhadores a trabalhos que não os satisfazem e/ou que são remunerados de forma inapropriada, não condizente, ou, ainda, na situação extrema que os marginaliza de qualquer possibilidade de trabalho ou de sua inexistência; na privação de um padrão de vida minimamente digno em virtude da precariedade das relações de trabalho.

A dimensão do reconhecimento consiste em dar visibilidade a padrões sociais e culturais de representação, interpretação e comunicação imbuídos de vários tipos de dominação, negação e desrespeito. A dominação cultural que submete sujeitos, em assimetria de poder, a padrões culturais alheios à construção cultural aos quais foram socializados; a negação ou o não reconhecimento de práticas oriundas da construção cultural nativa; e o desrespeito, através da difamação e desqualificação desse padrão cultural não hegemônico.

Finalmente, a representação consiste em abrir espaços de empoderamento, mas não apenas isso. Eis que ele atua em duas frentes: a primeira seria a constituição e/ou ampliação da participação política de grupos minoritários (entendidos aqui como não hegemônicos) em contextos instituídos e consolidados; e a segunda em provocar a constante dinâmica das disputas sobre a justiça para que os limites de contenção nacionais e transnacionais do campo da política e do direito sejam permanentemente avaliados e atualizados.

Com base nas categorias acima referidas, é possível analisar os dados prospectados em pesquisa empírica. De acordo com o CadÚnico (Ministério do Desenvol- vimento Social), no ano de 2016, dos 206.634.867 brasileiros, 22,52\% pessoas são beneficiárias do Programa Bolsa Família. No que tange à distribuição por sexo, entre os beneficiários, $56,62 \%$ são mulheres e esta proporção se repete de forma muito semelhante em todas as regiões ${ }^{70}$. Comparando-se com os dados do Censo 2010, segundo o qual 51\% da população era composta por mulheres, verifica-se, claramente, um perfil mais feminino nas famílias em situação de pobreza ou de extrema pobreza, do que na população em geral.

Essa condição da mulher na sociedade brasileira pode ser explicada pela centralidade da sua condição historicamente construída na unidade doméstica, sempre ligada às atividades de cuidado, zelo e limpeza. No que se refere à unidade doméstica, o padrão cultural histórico da sociedade brasileira reproduz o modelo denominado família nuclear bigeracional ${ }^{71} \mathrm{com}$ funções sociais vinculadas aos laços de afinidades, sendo o casamento um deles, e, ainda, os cuidados da prole e os cuidados com o ambiente doméstico, atribuídos às mulheres.

Os indicadores revelam que as mulheres beneficiárias, em sua maioria titulares do cartão do Bolsa Família, foram adquirindo maior autonomia e poder nas decisões familiares e na compra de bens duráveis, remédios e vestuário, comparativamente às mulheres não beneficiárias. É a sua visibilidade como consumidoras, o que contribui decisivamente para a sobrevivência da família e para o desenvolvimento da economia local. Corrige-se, então, uma injustiça de gênero revelada pela desigualdade econômica, operando a redistribuição.

Esse resultado, também, contribui para que as beneficiárias do Bolsa Família afirmem sua autoridade no espaço doméstico, à medida que são mais respeitadas pelos membros da família por contribuírem com os gastos familiares e a não dependerem do marido ou companheiro. Notam Mireya Suárez e Marlene Libardoni que tal resultado corrobora com as análises que defendem que as mulheres titulares do benefício do Programa Bolsa Família têm ganhos na relação de gênero, à medida que se tornam mais independentes financeiramente dos maridos ou companheiros e com mais autonomia na

70 BRASIL. Ministério do Desenvolvimento Social e Combate À Fome. Relatório de Informaçoes Sociais Bolsa Família e Cadastro Único. Disponível em: <http://aplicacoes.mds.gov.br/sagi-data/METRO/ metro_ds.php?p_id=72>. Acesso em: 31 out. 2016.

71 Tipo ou modelo de família constituído por pai, mãe e filhos. 
alocação de recursos no domicílio ${ }^{72}$. Em um contexto no qual as mulheres não concebem qualquer liberdade para tomar decisões ou alterar posições na hierarquia de gêneros, há o reconhecimento de um padrão cultural de gênero em famílias em situação de pobreza. Mireya Suárez e Marlene Libardoni reconhecem nisto uma mudança e subjetividade individual:

O fortalecimento da identidade feminina é indiscutível porque, como se disse na introdução deste artigo, o Programa Bolsa Família veio fortalecer a condição social de quem, por orientação cultural e subjetividade individual, está posicionada da maneira mais adequada para zelar pelas crianças e de quem assenta seu prestígio no bom desempenho da maternagem ${ }^{73}$.

A participação no Programa também significou uma mudança na percepscão das beneficiárias sobre si próprias como cidadãs, por ocasião da obtenção de documentos como carteira de identidade e certidão de nascimento, ampliando o espaço de existência local, notadamente em áreas rurais. Trata-se de um impacto na representação de cidadania da mulher, “...potencialmente mais marcante que os outros dois [...] porque o conhecimento de ser parte de uma cidadania e a consciência de não a exercer de fato, porque ainda não se tem existência na esfera pública, causa [...] uma reviravolta na subjetividade dessas mulheres" ${ }^{74}$.

Mulheres beneficiárias também têm ampliado sua autonomia na decisão de participar do mercado de trabalho e sobre o uso de métodos contraceptivos, tendências que certamente contribuíram para a expressiva diminuição da fecundidade no Brasil entre 2000 e 2010. Tal fato pode ser verificado, inclusive, entre mulheres de baixa renda, isto é, entre aquelas com renda domiciliar per capita de até $R \$ 70,00$, pois a fecundidade caiu de 5,1 filhos para 3,6 no período.

72 SUÁREZ, Mireya; LIBARDONI, Marlene. O impacto do Programa Bolsa Família: mudanças e continuidades na condição social das mulheres. In: VAITSMAN, J.; PAES-SOUSA, R. (Ed.). Avaliação de politicas e programas do MDS: Resultados. Bolsa Família e assistência social. Brasília: MDS, 2007. p. 143.

73 SUÁREZ, Mireya; LIBARDONI, Marlene. O impacto do Programa Bolsa Família: mudanças e continuidades na condição social das mulheres. In: VAITSMAN, J.; PAES-SOUSA, R. (Ed.). Avaliação de políticas e programas do MDS: Resultados. Bolsa Família e assistência social. Brasília: MDS, 2007. p. 146.

74 SUÁREZ, Mireya; LIBARDONI, Marlene. O impacto do Programa Bolsa Família: mudanças e continuidades na condição social das mulheres. In: VAITSMAN, J.; PAES-SOUSA, R. (Ed.). Avaliação de políticas e programas do MDS: Resultados. Bolsa Família e assistência social. Brasília: MDS, 2007. p. 147.
Esse cenário indica uma vertente de empoderamento de gênero consolidado a partir de uma política pública abrangente, que opera uma agenda universalista, que é a do direito humano e fundamental à alimentação adequada. Mas, moldada por um contexto particular e relativo, no qual os elementos culturais da tradição e do saber local ${ }^{75}$, sobre o papel da mulher na família, configuram como resultante uma nova inserção de status dessas mulheres.

\section{Considerações Finais}

A primeira parte deste trabalho pretendeu retratar a recepção do direito humano à alimentação adequada no contexto de discussão entre universalismo e relativismo. Foi acolhido pela concepção contemporânea de direitos humanos, que expressa indivisibilidade e universalidade na Declaração de 1948 e no Pacto Internacional de Direitos Econômicos, Sociais e Culturais de 1966. O direito humano à alimentação adequada também passa a ser acolhido no plano regional, considerando as diferenças culturais. Esta contraposição, já dissipada pela concepção de direitos humanos como espaços de luta pela dignidade, torna possível conceber aquele direito como um produto cultural que necessita de uma proteção voltada aos grupos mais vulneráveis como as mulheres.

Enfrentando a discussão acerca de uma possível fragmentação entre direitos humanos e direitos fundamentais, a segunda parte deste trabalho optou por considerar o direito humano e fundamental à alimentação adequada com a finalidade de proteção efetiva da pessoa humana. Sua recepção no direito interno, por meio de seu ingresso no rol de direitos sociais do artigo $6^{\circ}$ da Constituição da República de 1988, tem como principal efeito ser objeto de políticas públicas. Quando se volta para a condição feminina estas se revelam como políticas públicas em favor da família. Para tanto, passou-se a examinar o desafio de conciliar o combate à fome com a autonomia da mulher no Programa Bolsa Família.

A terceira parte do trabalho enfrentou as controvér-

75 Segundo Clifford Geertz, o saber local é praticar um "ir e vir hermenêutico entre os dois campos", isto é, a Antropologia e o Direito. Este autor preconiza uma Antropologia interpretativa, situada no relativismo cultural, que permite descobrir princípios gerais em fatos locais GEERTZ, Clifford. O saber local. Novos ensaios em antropologia interpretativa. Traduzido por Vera Mello Joscelyne. Petrópolis: Vozes, 1998. p. 253. 
sias geradas pela prioridade da mulher como beneficiária do Programa Bolsa Família. Recorreu-se às categorias de reconhecimento, redistribuição e representação para avaliar seus impactos. Teve como base em dados empíricos, que apontam um alto percentual de famílias cuja responsável é a mulher e de uma cultura na qual esta não concebe sua liberdade de decisão ou de alterar a hierarquia entre os sexos, conclui-se pelo fortalecimento de sua condição feminina. O Programa Bolsa Família parece responder ao desafio de conciliar o combate à pobreza, à autonomia da mulher, revelando-se como uma vertente de empoderamento de uma agenda universalista, em um contexto relativista.

\section{REFERÊNCIAS}

BEZERRA, Islândia Costa; ISAGUIRRE, Kátya Regina. Direito humano à alimentação adequada (DHAA): a discussão da "geografia da fome" à sua proteção jurídica no Brasil, Revista Pensar, Fortaleza, v. 18, n. 3, p. 675692, set./dez. 2014. p. 677.

BRASIL. Ministério do Desenvolvimento Social e Combate À Fome. Relatório de Informações Sociais Bolsa Família e Cadastro Único. Disponível em: <http://aplicacoes.mds. gov.br/sagi-data/METRO/metro_ds.php?p_id=72>. Acesso em: 31 out. 2016.

CARVALHO, Alexander Perazo Nunes de. Convencionalização do direito civil: a aplicação dos tratados e convenções internacionais no âmbito das relações privadas. Revista de Direito Internacional, Brasília, v. 12, n. 2, p. 342354, 2015. p. 351. Disponível em: < https:/ /www.publicacoesacademicas.uniceub.br/rdi/article/view/3756/ pdf>. Acesso em: 30 jan. 2017.

CASTRO, Josué de. Geografia da fome (O dilema brasileiro: pão ou aço). 10. ed. Rio de Janeiro: Antares, 1984.

COURTIS, Christian. The Right to Food as a Justiciable Right: Challenges and Strategies. BONGDANDY, A. WOLFRUM, R. (Coord.). Max Planck Yearbook of United Nations Law. Local: Koninklije Brill N., 2007. p. 317-337.

FACHIN, Melina Girardi. Fundamentos dos direitos bumanos: Teoria e práxis na cultura da tolerância. Rio de Janeiro: Renovar, 2009.

FACHIN, Melina Girardi. Todos os nomes e um só sentido: a aproximação dos direitos humanos aos direitos fundamentais tendo em vista sua efetivação prática. Revista Brasileira de Direito Internacional, Curitiba, v. 3, n. 3, jan./jun. 2006.

FLORES, Joaquín Herrera. A (re) invenção dos direitos bumanos. Florianópolis: Fundação Boiteux e IDHID, 2009.

FRANÇA, Alexandra Beurlen de. O direito bumano à alimentação adequada no Brasil. 2004. 260 f. Dissertação (Mestrado em Direito) - Programa de Pós-Graduação em Direito, Universidade Federal de Pernambuco, Recife, 2004.

FRASER, Nancy. Da redistribuição ao reconhecimento? Dilemas da justiça numa era "pós-socialista". Tradução de Júlio Assis Simões. Cadernos de campo, São Paulo, n. 14/15, p. 231-239, 2006. Disponível em: $<$ http://www.revistas.usp.br/cadernosdecampo/article/view/50109/54229>. Acesso em: 24 out. 2016.

GEERTZ, Clifford. O saber local. Novos ensaios em antropologia interpretativa. Traduzido por Vera Mello Joscelyne. Petrópolis: Vozes, 1998.

Golay, Christophe; ÖZDEN, Melik. Le droit à l'alimentation. Un droit humain fondamental stipulé par l'ONU et reconnu par des traités régionaux et de nombreuses constitutions nationales. Une collection du Programme Droit Humains du Centre Europe - Tiers Monde (CETIM) . Disponível em : <http://www.eoi.at/d/ EOI\%20-\%20Jahresberichte/Monaco/bro1-alim-A4fr.pdf>. Acesso em: 06 out. 2016.

IBGE. Estatísticas de gênero. Uma análise dos resultados do censo demográfico 2010. Disponível em: < http:/ / biblioteca.ibge.gov.br/visualizacao/livros/liv88941. pdf $>$. Acesso em: 25 out. 2016.

KLEBA, Maria Elisabeth; WENDAUSEN, Agueda. Empoderamento: processo de fortalecimento dos sujeitos nos espaços de participação social e democratização política. Saúde e sociedade, São Paulo, v. 18, n. 4, p. 733743, 2009. Disponível em: < http:/ /www.scielo.br/pdf/ sausoc/v18n4/16.pdf>. Acesso em: 29 out. 2016.

LAFER, Celso. A reconstrução dos direitos humanos. Um diálogo com o pensamento de Hannah Arendt. São Paulo: Companhia das Letras, 2009.

LE POINT SUR. Le droit à l'alimentation et genre. Roma : FAO L'Organisation des Nations Unies pour l'alimentation et l'agriculture. Unité pour le droit à l'alimentation, 2007. p. 1-2, Disponível em : <http://www.fao. org/3/a-a1610f.pdf>. Acesso em: 06 out. 2016. 
LUÑO, António E. Pérez. Los derechos fundamentales. 10. ed. Madrid: Editorial Tecnos, 2011. (Temas clave de la Constituicion española).

MÜLLER, Marcela. O direito social fundamental à alimentação adequada e sua proteção no contexto das organizações internacionais. 2014. 143 f. Dissertação (Mestrado em Direito) - Programa de Pós-Graduação em Direito, Universidade de Itaúna, Itaúna, 2014.

NIVARD, Carole. Le droit à l'alimentation. La Revue des Droits de l'Homme, jun. 2012. Disponível em: < http:// revdh.files.wordpress.com/2012/06/le-droit-c3a0-lalimentation.pdf>. Acesso em: 06 out. 2016.

ORGANIZAÇÃO DAS NAÇÕES UNIDAS PARA A ALIMENTAÇÃO E A AGRICULTURA. Diretrizes Voluntárias em apoio à realização progressiva do direito à alimentação adequada no contexto de segurança alimentar nacional. O direito à alimentação. Roma. 2015. p. 28. Disponível em: <http://www.fao.org/3/b-y7937o.pdf>. Acesso em: 30 jan. 2017.

PEREIRA, Potyara A. P. Discussões conceituais sobre política social como política pública e direito de cidadania. In: BOSCHETTTI, Ivanete et al. (Org.). Política Social no Capitalismo: tendências contemporâneas. São Paulo: Cortez, 2009.

PIOVESAN, Flávia. A universalidade e a indivisibilidade dos direitos humanos: desafios e perspectivas. In: BALDI, César Augusto (org.). Direitos humanos na sociedade cosmopolita. Rio de Janeiro: Renovar, 2004. p. 45-71.

PIOVESAN, Flávia. Direitos humanos e o direito constitucional internacional. 12. ed. São Paulo: Saraiva, 2011.

PRATA, Ana. A tutela constitucional da autonomia privada. Coimbra: Almedina, 1982.

SCHUTTER, Oliver de. Droits des femmes et droit à l'alimentation. Rapport sumis par le Rapporteur spécial sur le droit à l'alimentation. Conseil des droits de l'homme. Nations Unies. Assemblée générale, 24 dez. 2012. Disponível em: <http://www.ohchr.org/Documents/
HRBodies/HRCouncil/RegularSession/Session22/AHRC-22-50_fr.pdf>. Acesso em: 26 out. 2016.

SORJ, Bila.; GAMA, Andréa. Family Policies in Brazil. ROBILA, Mihaela (Coord.). Handbook of family policies across the globe. New York City: Springer, 2014. p. 459471.

SORJ, Bila; FONTES, Adriana. Les politiques publiques au Brésil et l'articulation entre travail et famille. Une comparaison interrégionale. Cabiers $d u$ Genre. Paris, v. 1, n. 46, p. 155-176, 2009. Disponível em: <http:// www.cairn.info/revue-cahiers-du-genre-2009-1-page-155.htm>. Acesso em: 27 out. 2016.

SUÁREZ, Mireya; LIBARDONI, Marlene. O impacto do Programa Bolsa Família: mudanças e continuidades na condição social das mulheres. In: VAITSMAN, J.; PAES-SOUSA, R. (Ed.). Avaliação de políticas e programas do MDS: Resultados. Bolsa Família e assistência social. Brasília: MDS, 2007.

SUÁREZ, Mireya; TEIXEIRA, Marlene (Coord.). O Programa Bolsa Família e o enfrentamento das desigualdades de gênero: o desafio de promover o reordenamento do espaço doméstico e o acesso das mulheres ao espaço público. In: PAES-SOUSA, Rômulo; VAITSMAN, Jeni (Org.). Cadernos de Estudos. Desenvolvimento social em debate. Síntese das pesquisas de avaliação de programas sociais do MDS. 2007. Disponível em; <http:/ / aplicacoes.mds.gov.br/sagirmps/ferramentas/docs/ caderno\%20-\%2005.pdf>. Acesso em: 27 out. 2016.

VALENTE, Flávio Luiz Schieck. Fome, desnutrição e cidadania: inclusão social e direitos humanos. Saúde e sociedade, São Paulo, v. 12, n. 1, p. 51-60, jan./jun., 2003.

VILLELA, João Baptista. Liberdade e família. Monografia (TCC) - Faculdade de Direito da UFMG, Belo Horizonte 1980.

VILLEY, Michel. O direito e os direitos humanos. São Paulo: M. Fontes, 2007. 


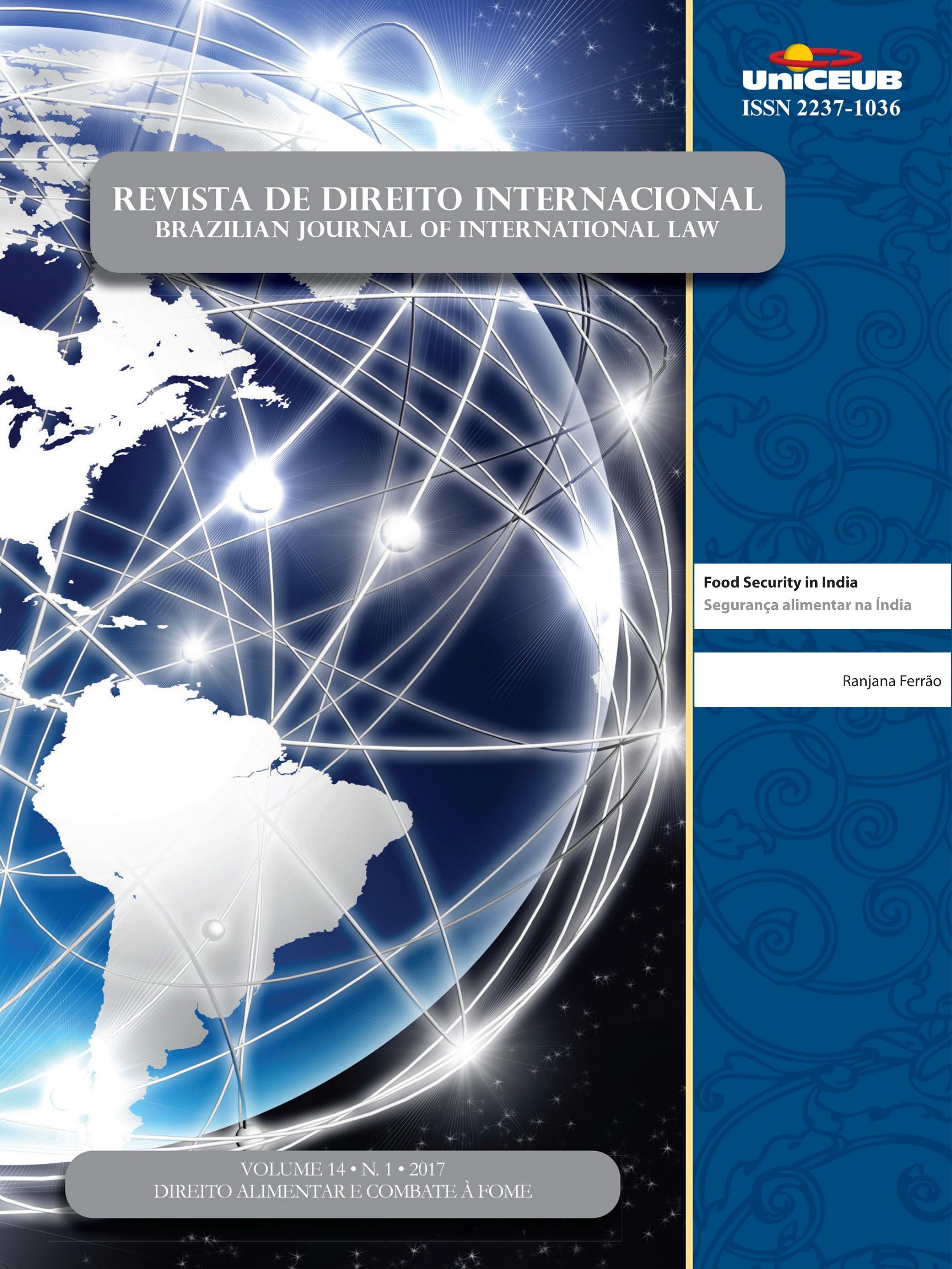




\section{Segurança alimentar na Índia}

Ranjana Ferrão**

\section{Abstract}

The world faces problems of hunger and malnutrition. The world must feed nine billion people by 2050 . This is a huge challenge. The roots of the problem of hunger and malnutrition are not lack of food but lack of access to available food. Most legal system around the globe have codified the right to food. Right to food does not mean right to free food. The State must respect and protect the rights of individuals to feed them. Food Insecurity occurs when people have no access to food or food is not affordable for them to buy it. Food security means eliminating all kinds of hunger present and future. India is country which developed the ideology of 'Grain is God'. It was a land of food security but in the $20^{\text {th }}$ century this food security was transformed into food insecurity. This Article discusses a Historical perspective of food management in India. The Article dwells on the legislative changes made to ensure right to food, the setting of administrative bodies and creation of public welfare schemes. The Article discusses the National Food Security Act, 2013 and outlines the problems in enforcing this legislation. Though India has legislative and administrative bodies yet the problem of food insecurity is not resolved the Article outlines the possible challenges to the government. The Article offers useful suggestions which may guide legislators to solve the problem of food scarcity. The "right to food" is a fundamental human right. Right to food can be interpreted as right to adequate food. This right is of crucial importance for the enjoyment for all other rights i.e right to life and right to health. It applies to everyone. ${ }^{1}$ Hunger and undernourishment directly or indirectly account for over half of the deaths in the world. ${ }^{2}$ Hunger is a violation of human dignity and an obstacle to social, political and economic progress of a country. International law recognizes that everyone has the fundamental right to be free from hunger. ${ }^{3}$ Right to food does not mean right to free food. The State must respect and protect the rights of individuals to feed them. Direct food assistance can be provided by the State in an emergency situation like natural disasters or war. When a country cannot meet this need through its own resources, the State must request international assistance. ${ }^{4}$ India is home to 194.6 million undernou-

* Recebido em $03 / 11 / 2016$ Aprovado em 07/02/2017

** Assistant Professor, V.M. Salgaocar College of Law, Miramar Goa . India B.Sc Chowgule College (University of Goa), LL.B Kare College (University of Goa), LL.M V.M.Salgaocar College of Law (University of Goa), Ph.D V.M.Salgaocar College of Law (University of Goa).E-mail: ranjanaferrao@gmail.com
1 UN Committee on Economic, Social and Cultural Rights (CESCR), General Comment No.12 : The Right to Adequate Food (Article 11 of the Covenant) 12 $2^{\text {th }}$ May 1999. Available at: <http://www.refworld.org/docid/45388389c11.html>. Access on: 17 Oct. 2016

2 The State of Food Insecurity in the World (SOFI) 2002. Available at: <http://www.fao. org/docrep/005/y7352e/y7352e03.htm>. Access on: 5 Oct. 2016

3 The right to food. Available at: <http://www.fao.org/worldfoodsummit/english/ fsheets/food.pdf $>$. Access on: 5 Oct. 2016

4 The Right to Adequate Food, Office of the High commissioner Human Rights. Available at: <www.ohchr.org/Documents/Publications/FactSheet34en.pdf>. Access on: 17 Oct. 2016. 
rished people, the highest in the world..$^{5}$ India is placed at $97^{\text {th }}$ among 118 countries $^{6}$ and its score is 28.5 which are considered a serious level. $51 \%$ of women in the age group of 5 to 59 years are anaemic and $44 \%$ of children under 5 are underweight. Malnourished children have a higher risk of death. India produces enough food to feed its hungry people. However there are no mechanisms to check the loss of food. India lacks storage and transport facilities for food grains. As a result $50 \%$ of the Food is lost before it reaches the poor. India is still struggling to alleviate poverty and unemployment.

\section{FOOd INSECURITY}

The World Food Summit in 1996 defined food security thus: "Food security exists when all people, at all times, have physical, social and economic access to sufficient, safe and nutritious food which meets their dietary needs and food preferences for an active and healthy life." The official definition of food security embraces nutrition; in fact, the accepted definition is of food security and nutrition and not just food security. ${ }^{7}$ The Global food security challenge is the world must feed nine billion people by 2050 .

Food insecurity is created because of problems in food distribution, not food production. ${ }^{8}$ The important question would be: what determines distribution of food between different sections of the community. Food insecurity is measured as a household level concept that refers to uncertain, insufficient, or unacceptable availability, access or utilization of food. It is therefore households that are classified as secure or unsecure. When the household contains one or more food insecure persons the household is considered food insecure. ${ }^{9} \mathrm{Food}$

5 India tops world hunger list with 194 million people. Available at: <http://www.thehindu.com/news/national/india-is-home-to194-million-hungry-people-un/article7255937.ece>. Access on: 29th May, 2015

6 India has made considerable improvements since 1992. In the year 1992 its score was 46.5.

7 Committee on Food Security. Also See NARAYANAN, S. Food Security in India: The Imperative and Its Challenges. Asia and Pacific Studies, v. 2, Issue 1, Jan. 2015.

8 SEM, A. Poverty and Famines An Essay on Entitlement and Deprivation. Oxford: Clarendon Press Oxford, 1981. p. 17

9 Panel to Review U.S Department of Agriculture's Measurement of Food Insecurity and Hunger, Committee on National Statistics, Division of Behavioural and Social Sciences and Education, National Research Council Food Insecurity and Hunger in the United States: insecurity is caused by poverty rather than food scarcity.

\section{The Right to Food Under INTERnational LAW}

The right to food was initially codified in the United Nations Declaration of Human Rights. It refers to the right to food as one aspect of the right to a standard of adequate living to ensure the health and wellbeing of each person. ${ }^{10}$ The right to food is thus explicitly linked to individuals' health and wellbeing.

Article 11 of the International Covenant on Economic, Social and Cultural Rights (ICESCR) ${ }^{11}$ stipulates that the states must recognize and take steps to ensure the realization of the right of adequate standards of living for individuals and families. Adequate standards of living, requires adequate food, clothing and housing. ${ }^{12}$ The focus of the Article is on combating hunger. It invokes an array of means by which food production, conservation and distribution is to be improved. It calls for use of scientific and technical methods, nutritional education, agrarian reforms, and global trade practices, problems of both food-importing and food-exporting countries and equitable distribution of food supplies. ${ }^{13}$

The Convention on the Rights of the Child ${ }^{14}$ (CRC), recognizes "the right of every child to a standard of living adequate for the child's physical, mental, spiritual, moral and social development. ${ }^{15}$ " The CRC requires states to combat child malnutrition" ${ }^{16}$, and to "take appropriate measures" to assist parents in fulfilling their primary responsibility to implement children's right to an adequate standard of living, "particularly with regard to nutrition. ${ }^{17}$ ”

an Assessment of the Measure, The National Academic Press, Washington p. 3

10 See Article 25

11 This treaty was opened for signature in 1966 and came into force in 1976

12 Article 11 para. 1

13 SAUL, B.; KINLEY, D.; MOWBRAY, J. The International Covenant on Economic, Social and Cultural Rights Commentary, Cases Materials. Oxford: Oxford University Press, p. 867

14 Hereinafter referred to as CRC. India acceded to the Convention on 11 December 1992.

15 See Article 21(1). India signed CEDAW on 0 July, 1980. Ratified it on 9th July 1983.

16 See(Article 24(2)(c))

17 See (Article 27(3)) 
The Convention on the Elimination of all Forms of Discrimination Against Women (CEDAW), requires states to ensure that women have "adequate nutrition during pregnancy and lactation ${ }^{18 "}$ " and to "take all appropriate measures to eliminate discrimination against women in rural areas in order to ensure, on a basis of equality of men and women, that they participate in and benefit from rural development and, in particular [...], to enjoy adequate living conditions, particularly in relation to housing, sanitation, electricity and water supply, transport and communications ${ }^{19}$."

\section{FOOD INSECURITY IN INDIA}

India has two recurring problems huge population and uncertain monsoons. One year of drought severely affects food production in the country. There is a large section of food insecure people in India. These are landless people with no land. Traditional artisans, people who provide traditional service, petty self-employed workers, labourers, beggars and destitute. ${ }^{20}$ Women and children specially belonging to economically backward classes and are most vulnerable. People may face chronic hunger when they do not have enough money to buy food. Some people may face seasonal hunger. This happens farmers who have small lands have not benefited from the harvesting season and not made any profit.

In urban areas laborers do not have enough work throughout the year they may face hunger. Some Indian states Odisha, Bihar, Uttar Pradesh, West Bengal, Jharkhand, Chhattisgarh, Madhya Pradesh, and Maharashtra have extreme levels of food insecurity. Districts of Kalahandi and Kashipur districts of Odisha. Palamau district of Jharkhand, Baran district of Rajasthan have permanent food insecurity and famine like conditions.

India's Tryst with Famines - Historical perspective of food management in India

Ancient man saved food grains. Records from Indus Valley civilization show that man developed agricultural practices, produced food grains and saved food grains.

18 See Article 12(2))

19 See (Article 14(2)(h))

20 MEHTA, A. et al. Towards Solutions and New Compacts in a Dynamic Context India Chronic Poverty Report. India: Indian Institute of Public Administration and Chronic Poverty Research center, p. 26
In the period of 321-301 BC kings were advised to provide seeds and make provisions for people during a famine. ${ }^{21}$ The King may either distribute his own collection or income from the rich to the poor.

In the Vedic period of c. 1500 - c. 500 BC the teacher instructed his students to go and grow food grains. Thus grew the ideology of 'Grain is God'. ${ }^{22}$ The Hindus worship Annapurna who is considered the Goddess of nourishment. Anna means food and grains and Purna means full, complete and perfect. ${ }^{23}$ During this time precaution against famines was considered a logical solution to solve food problems. In the period of 342 and 185 B.C the Maurya Empire issued instructions to higher officials to deal with famines and natural calamities. Villages were encouraged to have their own grain reserves and the King had to maintain his own stock of grain to meet emergencies. There were 14 famines between 11 th and 17 th century. There was no shortage of food grain recorded.

The first severe famine, the Bengal famine of 1770 , wiped out nearly one-third of the population of the region. ${ }^{24}$ During this period the frequency of famines increased. The British government did not act against famines. British famine policy in India was influenced by the arguments of Adam Smith. Hence the government remained unaffected and made no changes in the grain market in times of famine. They kept the famine relief as heap as possible with minimum cost to the colonial exchequer. Famines in British India were not caused by the lack of food in a particular geographical area. They were caused by inadequate transportation of food, which in turn was caused due to an absence of a political and social structure.

The Famine Commission was set up in the year 1880. The Famine Commission of 1880 observed that each province in British India, including Burma, had a surplus of food grains, and that the annual surplus amounted to 5.16 million metric tons. The Famine Commission studied the cultivation patterns, practices

21 Kautilya in his chronicle Arthashastra. See BHATIA, B. M. Food Security in South Asia. Oxford: Oxford \& IBH Publishing Co. New Delhi, 1985.

22 HalleguA, M. Z. 100 Desi Stories: Wisdom from Ancient India. Jaico Publishing House, 2015. p. 40.

23 GODDESS Annapuna. Disponível em:h<ttps://journeyingtothegoddess.wordpress.com/tag/grains/

24 NANDA, R. History of Indiaupto 8th century. Availableat: < https:// sol.du.ac.in $/ \mathrm{mod} /$ book $/$ view.php?id=1611\&chapterid=1633>. Access on: 28 Dec. 2016 
and agricultural production practices in India. The result of the Famine Commission was a series of guidelines and regulations on how to respond to famines and food shortages, which were termed as the Famine Code. The Famine Code was passed in the year 1883. The Famine Codes defined three levels of food insecurity, which were near scarcity, scarcity, and famine. Scarcity was defined as three successive years of crop failure, crop yields of one-third or one-half normal and large populations in distress. Famine code was one of the first attempts to predict famine.

In 1947 when India got independence, the Food Grain Corporation was set up. The Food Grain Corporation recommended import of food grains. This could guard against crop failure and also provide for food reserves. The Commission also recommended that the indigenous food grains production should be increased by 10 million tons per annum till self-sufficiency is achieved. The Food Corporation of India ${ }^{25}$ is responsible for the execution of food policies of Central Government. FCI purchases food grains like wheat and rice from the farmers in states where there is surplus production. The food grains are purchased at pre-determined rates. This rate is fixed by the Government. This price is known as Minimum Support Price. Later, the government makes the food grains available to the areas where the production of food grains is insufficient and to the poor section of the society. The system through which FCI makes the food grains available to the poor society is known as Public Distribution System.

Food grains Policy Commission was followed by a number of Commissions which examined the food policy from time-to-time. The Food Corporation of India and the Agriculture Prices Commission were set up in the year 1965. The former was to provide price support to farmers by purchasing quantities that could not fetch minimum support prices in the market, store the grains scientifically, move grains from surplus to deficit areas and make available gains to states to feed poor through the public distribution system. ${ }^{26}$ The Agricultural Prices Commission (now known as the Commission for Agricultural Costs and Prices (CACP), a body on which farmers are also represented, was to advise the Government on price policy for agricultural commodities and

25 Hereinafter referred to FCI

26 BASU, K. India's Foodgrain Policy: An Economic Theory Perspective. Economic \& Political Weekly EPW, v. XiVi, n. 5, Jan. 2011 evolve a balanced and integrated price structure in the perspective of the overall needs of the producers and the consumers.

\section{Green Revolution in India}

Prime Minister Indira Gandhi launched the Green Revolution in India. ${ }^{27}$ The Green Revolution had a series of special agricultural innovative programs which transformed India into surplus production of wheat, rice, cotton and milk. The country was able to become one of the world's biggest agricultural producers and a food exporter. Sadly Green Revolution could not last long. Green Revolution suffered many problems. The owners of large farms were the main adopters of the new technology. Hence Green Revolution benefited the large farmers. The small farmers lagged behind. Since the rich farmers were already better equipped, Green Revolution accentuated the income inequalities between rich and poor. Green Revolution resulted into lower product price and higher input prices which also encouraged landlords to increase rents or force tenants to evict the land. The mechanization pushed down the wages of and employment opportunities for unskilled labor in the rural areas thereby further widening the income disparities. ${ }^{28}$

\section{Food Security and Governance}

The high levels of food insecurity forced the Indian Government to introduce three food intervention programmes during the 1970s. The programmes are Public Distribution System (PDS) for food grains, Integrated Child Development Services (ICDS), Food-for-Work (FFW).

\section{Public Distribution System}

Public Distribution System evolved as a system of management of scarcity and for distribution of food

27 The Green Revolution lasted for a decade from 1967- 1978 28 SEBBY, K. The Green Revolution of the 1960's and Its Impact on Small Farmers in India. Nebraska: University of Nebraska at Lincoln, 2010. Environmental Studies Undergraduate Student Theses, p. 9 
grains at affordable prices. Allocation of food grains under TPDS ${ }^{29}$ is made by the Government of India to Slates/Union Territories for $\mathrm{APL}^{30}$ and $\mathrm{BPL}^{31}$ including Antyodaya Anna Yojana (MY) families. The Central Government has to procure, store, transport food grains from one State to another. The grains are distributed to the poor sections of the society through the Fair Price Shops. The State Governments have to regulate the amount of food grains distributed to fair price shops in different areas. The State Government must identify families below poverty line, issue of ration cards, supervise and monitoring the functioning of Fair price shops.

To streamline the system, Central Government has issued Public Distribution System (Control) Order 2001. The main purpose of the Public Distribution System was to act as a price support programme for the consumer in 1960s. Those were the years of food shortage. The basic items covered were rice, wheat, sugar, edible oil, and kerosene to be sold at subsidized prices.

In spite of the existing targeted public distribution system, Rajasthan was hit by drought in the year 2001 . The Government had failed to implement the Public Distribution scheme, hence people were dying of starvation. The Food Corporation of India (FCI) had godowns which were overflowing with grains. The grains were kept outside the godowns. Due to heavy rains the grains were rotting. To fight hunger people were eating in rotation. Some members eat food on one day while others ate on the other day. The amount of food needed to feed the hungry was 20 million tonnes. The Government had an access of 40 million tonnes. Inspite of this people were dying of starvation, distribution of food was irregular.

Different sections of society filed a PIL in the Supreme Court of India asking to Court to intervene in this situation. The Supreme Court of India in People's Union of Civil Liberties v. Union of India ${ }^{32}$ directed food grains in government godowns to be used to feed people affected by extended drought in the state. The court observed that it is essential to protect the vulnerable groups from starvation. The court directed for imple-

29 Targeted Public Distribution System

30 Above the Poverty Line

31 Below the Poverty Line

32 Public interest litigation Petition (Civil) No. 196/2001 mentation of various schemes. ${ }^{33}$ The court reiterated that right to life guaranteed under the Constitution of India includes right to food. The Court appointed Commissioners to monitor implementation of its orders and make suggestions. It asked for introduction of a range of social protection programmes like providing subsidized food-grain for the needy; feeding schemes for the destitute; school feeding programmes; mother and child nutrition programmes; and programmes guaranteeing employment to all those in rural areas who wanted work.

\section{Integrated Child Development Scheme (ICDS)}

India has the largest food supplementation programme called Integrated Child Development Scheme $(\mathrm{ICDS})^{34}$. This programme was aimed to improve the health and nutrition status of children in the age group of 0-6 years by providing supplementary food. The food is supplied to children through Aanganwadi Centers..$^{35}$ The problem was there were no sufficient number of Aanganwadi Centers to implement the scheme. The Supreme Court of India while hearing the public interest litigation field by People's Union For Civil Liberties vs. Union of India \&Ors ${ }^{36}$ directed to increase the number of AWCS. The Court asked the Government of India to increase the amount to be spent on food for every child. The Court further directed that food must be supplied to children and lactating mothers for 300 days in a year. Mid-Day meal must be provided to all primary schools.

33 The court directed for implementation of various schemes namely (a) Targeted Public Distribution Scheme, (b) Antyodaya Anna Yojana, (c) Mid-Day Meal Scheme, (d) National Old Age Pension scheme, (e) Annapurna Scheme, (f) Integrated Child Development Scheme, (g) National Maternity Benefit Scheme, (h) National Family Benefit Scheme.

34 a. provide necessary conditions for pre-school children to ensure their psychological and social development through early stimulation and education. $\mathrm{b}$. To provide pregnant and lactating women with food supplement. c. To enhance the mother's ability to provide proper child care through health and nutrition education; d. To achieve effective coordination of policy and implementation among the various departments to promote child development.

35 Anganwadi centers are set up one center for the population of 1000 (700 in case of tribal area).

36 Dated 29/04/2004 


\section{FOOD FOR WORK}

Right to be free from hunger implies that the State must not interfere with individuals' livelihoods. Any such legislation found in national law must be corrected. In India in order to enable people to earn their food the state has passed the Mahatma Gandhi National Rural Employment Guarantee Act,2005 $5^{37}$ which aims at enhancing the livelihood security of people in rural areas by guaranteeing hundred days of wage-employment in a financial year to a rural household whose adult members volunteer to do unskilled manual work. It aims to enhance livelihood security in rural areas by providing at least 100 days of wage employment in a financial year to every household whose adult members volunteer to do unskilled manual work. This has provided employment to 1 in 4 in rural household.

\section{Legal Control for Food Security}

India is a party to the International covenant on Economic, Social and Cultural Rights. ${ }^{38}$ India has ratified all international treaties on right to food. The International Covenant on Civil and Political Rights, ${ }^{39}$ The Convention on the Rights of the Child ${ }^{40}$ and the Convention on elimination of all forms of Discrimination against women. ${ }^{41}$ The Government of India has an international commitment to ensure right to food for everyone. Participation, accountability, access to information and access to effective remedies must be ensured at all levels of the implementation of the right to food. The Government of India has an obligation to respect right to food without any discrimination. ${ }^{42}$

Accordingly the Government must respect its citizen's right to food and not take any action that arbitrarily deprives people of their right to food. The Government must protect and enforce appropriate laws

37 Act No. 42 of 2005

38 India is a state party to the Covenant and ratified it on $10^{\text {th }}$ April 1979. India is not a party to the Optional Protocol on the to the International Covenant on Economic, Social and Cultural Rights, 2013.

India has yet to submit a report to the Committee of Economic, Social and Cultural Rights which is over due by 15 years.

39 See Article 6

40 See Article 24 and Article 27

41 See Article 12 and Article 14

42 See General Comment No .12 to prevent third parties, including powerful people and corporations from violating right to food of others. The Government should take positive steps to identify vulnerable groups. Implement appropriate policies and programs to ensure their access to adequate food and water to those who cannot feed themselves for reasons beyond their control. To fulfil the obligation of right to food the government must use all its maximum available resources in every circumstance to ensure the minimum essential level required to be free from hunger. ${ }^{43}$

\section{Constitutional Provisions}

The Constitution of India prohibits discrimination and recognizes human rights. Right to Life is protected as a Fundamental Right under Article 21 of the Constitution of India. The expression 'Life' in this Article has been judicially interpreted to mean a life with human dignity and not mere survival or animal existence. The Supreme Court of India has interpreted the term right to Life as, the right to food, water, decent environment, education, medical care and shelter." ${ }^{44}$ Right to life protected under Article 21 of the Constitution includes Right to water ${ }^{45}$ and the right to live with human dignity and all that goes with it namely bare necessities of life namely adequate nutrition, clothing and shelter over the head. ${ }^{46}$ The right to life includes right to food.

The Directive Principles of State Policy serve to guide interpretation of fundamental rights, including right to life protected by Article 21. Right to Food is inherent to a life with dignity. The State has an obligation to ensure food security to see that the citizens are free from hunger. The state must strive to raise the level of nutrition and the standard of living of its people and improve public health among other primary duties. ${ }^{47}$ The State must direct its policies towards securing adequate means of livelihood for its citizens. ${ }^{48}$ The State must raise the level of nutrition and standard of living and improve public health. ${ }^{49}$ The Right to Food a guaranteed

\footnotetext{
43 SRIVASTAVA, A. Kumar; TIWARY, M. Right to Food. $4^{\text {th }}$ ed. India: HRLN, 2009.

44 Chameli Singh and Others .v. State of Uttar Pradesh (1996)2S.C.C 549

45 Narmada Bachao Andolan v. Union of India A.I.R 2000 S.C3741

46 Francis Corralli Mullin.v. Union Territory of Delhi

47 See Article 47 of Constitution of India

48 See Article 39(a) of Constitution of India

49 See Article 47 of Constitution of India
} 
Fundamental Right is enforceable under Article 32 of the Constitution." 50

\section{National Food Security Act, 2013}

The Government of India has a legislation to ensure that right to food is made available to everyone the $\mathrm{Na}$ tional Food Security Act, 2013. ${ }^{51}$ This legislation follows a life cycle approach. The word food is codified in Indian law. Food has been defined as any substance, whether processed, partially processed or unprocessed, which is intended for human consumption and includes primary food. ${ }^{52}$ Food also includes genetically modified or engineered food or food ${ }^{53}$ containing such ingredients, infant food, packaged drinking water, alcoholic drink, chewing gum, and any substance, including water used into the food during its manufacture, preparation or treatment but does not include any animal feed, live animals unless they are prepared or processed for placing on the market for human consumption, plants, prior to harvesting, drugs and medicinal products, cosmetics, narcotic or psychotropic substances. ${ }^{54}$

The Act defines "food security" as a means to supply entitled quantity of food grains and meal..$^{5}$ The law address all vulnerable groups of people and provides that eligible households are given priority which are place under the Antyodaya Anna Yojana Scheme. ${ }^{56}$ Individuals in the following priority groups are entitled to an AAY card, including: (i) landless agricultural labourers, (ii) marginal farmers, (iii) rural artisans/craftsmen such as potters and tanners, (iv) slum dwellers, (v) persons earning their livelihood on a daily basis in the informal sector such as porters, rickshaw pullers, cobblers, (vi) destitute, (vii) households headed by widows or terminally ill 4 persons, disabled persons, persons aged 60 years or more with no assured means of subsistence, and (viii) all primitive tribal households. Such families identified as beneficiaries under this scheme can receive $35 \mathrm{~kg}$ of rice at the rate of Rs. 3 and Rs. 2 per k.g res-

\footnotetext{
50 See Article 32(1) of Constitution of India

51 Act No. 20 of 2013

52 See Section 2(j) National Food Security Act, 2013

53 India has only one genetically modified crop BT Cotton.

54 See Section 2(zk) National Food Security Act, 2013

55 See Section 2(1) and Section 2(6) National Food Security Act, 2013

56 See Section 2(3) of the National Food Security Act, 2013
}

pectively. Coarse grains are distributed at Rs. 1 per k.g. The State government has to identify people belonging to the Antyodaya Anna Yojana. Once the beneficiary is identified they are issued 'Antyodaya Ration Cards' so that they can obtain grains from the fair price shop. ${ }^{57}$

The National Food Security Act, 2013 provides for payment of food security allowance to persons identified by the State Government in case grains are not supplied. The amount of food security allowance admissible to entitled persons is determined by multiplying the difference between the 1.25 times the minimum support price of the relevant food grain for that marketing season. ${ }^{58}$ The State Government can also wheat flour in lieu of the entitled quantity of food grains. ${ }^{59}$ The Central Government allocates food grains to State Governments at protected prices under the Targeted Public Distribution System. ${ }^{60}$ The distribution percentage is $75 \%$ for rural population and $50 \%$ for urban population. ${ }^{6}$

The law has provisions to provide for nutritional support to pregnant women and lactating mothers. Pregnant and lactating mothers are entitled to meal, free of charge, during pregnancy and six months after the child birth, through the local Anganwadi centers. ${ }^{62}$ Women are to be provided with maternity benefit of Rupees six thousand. ${ }^{6}$ The eldest woman in a household can be considered the head of the household for issue of ration cards which is an identity for distribution of food grains. The law covers food security for people living in remote, hilly and tribal areas. ${ }^{64}$

Nutritional needs of children are their basic rights. Children in the age group of six months to six years,

57 ANTYODAYA Anna Yojana. Available at: < http://www.pradhanmantriyojana.co.in/antyodaya-anna-yojana/>. Access on: 28th Dec. 2016

58 See Section 2(7) and Section 8 of National Food Security Act, 2013. FOOD security allowance in case of non-supply of entitled food grains. Notification issued by Ministry of Consumer Affairs, Food \& Public Distribution. Dated 28-April, 2015. Available at $<$ http:/ / pib.nic.in / newsite/mbErel.aspx?relid=119855>.

59 Section 3(3) National Food Security Act, 2013.

60 See Section3 National Food Security Act, 2013

61 TARGETED public distribution system. Available at: <http:// dfpd.nic.in/public-distribution.htm>. Access on: 20 Oct. 2016.

62 Anganwadi centre provides basic health care in Indian villages. It is a part of the Indian public health-care system. Basic healthcare activities include contraceptive counseling and supply, nutrition education and supplementation, as well as pre-school activities. See https://data.gov.in/dataset-group-name/anganwadi-centers

63 See Section 4, National Food Security Act, 2013

64 See Section 30, National Food Security Act, 2013 
age are to be provided with meal, free of charge, through the local Aanganwadi centers. Children, up to class VIII or within the age group of six to fourteen years, are to be provided free mid day meal except on school holidays. Every school and Aanganwadi center must have facilities for cooking meals, drinking water and sanitation. ${ }^{65}$ The State Government, through the local Aanganwadi, must identify and provide meals, free of charge, to children who suffer from malnutrition. ${ }^{66}$

\section{Monitoring Bodies}

Central Government must allocate required quantity of food grains from central pool to State Governments. ${ }^{67}$ Central Government must bear the costs of transportation of food grains, pay for intra-state expenses, provide assistance to state governments and create modern storage facilities. The Central Government has to make funds available while the State Governments must provide food grains when there is short supply or provide food allowance to the people. Central Government must provide assistance to the States towards cost of intra-State transportation, handling of food grains and Fair price deals.

There are provisions for creating an internal grievance redressal mechanism. Every State Government must put in place an internal grievance redressal mechanism which may include call centres, help lines, designation of nodal officers. The State Government must appoint or designate, for each district, an officer to be the District Grievance Redressal Officer. ${ }^{68}$ State Government shall, by notification, constitute a State Food Commission. ${ }^{69}$ Odisha is the first state in Indi to set up a State Food Commission to monitor the implementation of the National Food Security Act. ${ }^{70}$ Any public servant or authority found guilty, who fails to provide relief is laible to pay a penalty of Rs. $5000 .^{71}$

65 See Section 5, National Food Security Act, 2013

66 See Section 6, National Food Security Act, 2013

67 See Section 22, National Food Security Act, 2013

68 See Section 15, National Food Security Act, 2013

69 See Section 16, National Food Security Act, 2013

70 ODISHA to set up State Food Commission. Available at: http://www.thehindu.com/news/national/other-states/odisha-toset-up-state-food-commission/article8353728.ece>. Access on: 8 Oct. 2016

71 See Section 33

\section{Right to Safe Food}

Right to adequate and safe food needs regulations to make food safe. These regulations must cover food hygiene, quality and labelling standards, labour conditions and land tenure. Regulations must also protect against unfair market practices, such as withholding price information or creating monopolies. States must take action to identify vulnerable groups and design policies that improve their access to food-producing resources or income.

In Centre for Public Interest vs Union Of India \&Ors the Supreme Court of India held that the right to life and human dignity also encompasses the right to have food articles and beverages which are free from harmful residues such as pesticides and insecticides. The Court asked the Food Safety and Standards Authority of India (FSSAI) to conduct periodical inspection and monitor fruit and vegetable markets. The Court held;

\begin{abstract}
Enjoyment of life and its attainment, including right to life and human dignity encompasses within its ambit availability of articles of food, without insecticides or pesticides residues, veterinary drugs residues, antibiotic residues, solvent residues.
\end{abstract}

India passed the National Food Safety and Standards Act, 2006. ${ }^{72}$ This law covers food safety which is defined as the assurance that food is acceptable for human consumption according to its intended use. The Food Safety and Standards Authority of India ${ }^{73}$ has been created for laying down science based standards for articles of food and to regulate their manufacture, storage, distribution, sale and import to ensure availability of safe and wholesome food for human consumption. Ministry of Health \& Family Welfare, Government of India is the Administrative Ministry for the implementation of FSSAI.A consumer can complain to the Food Safety Officer or a Designated Officer of the area or Food Safety Commissioner of the State. The FSSAI has power to recall and remove marketed food from distribution, sale and consumption any food which is unsafe.

\section{Problems in Making Food Security a Reality}

Food Security is a comprehensive term that includes availability of food, accessibility and affordability.

72 Act No.34 of 2006

73 Hereinafter referred to as (FSSAI) 
Country should be able to produce or import food required by it for its citizens. There should be enough stock of food in store in granaries for emergencies. A situation of non-availability of food should not arise. People should not be forced to go in search of food. The food that is available with the government must be easily accessible to its citizens. The Food that is available and accessible with the government must be affordable to the poorest of the citizens.

India has a legislation, the world's best schemes and yet it cannot feed its hungry people. The fundamental problem with the National Food Security Act is the law delegate's power to the State Government and there is often conflict with the Central Government and State Government over the allocation of food grains to states. Hence many states suffer from shortage of food grains. There are huge costs in procuring food grains. State Government are unable to bear costs. States do not have storing facility and transport facility to transfer the food grains.

People are unable to benefit from the Targeted $\mathrm{Pu}-$ blic Distribution system. People do not have employment hence they have no regular income. The Ration shops close by the time the poor laborers reaches home. The laborer has make a tuff decision of forfeiting work and to go and buy food grains. ${ }^{74}$ Food grains are not distributed in the required quantity to the Ration shops. There are times when food grains are not available at the fair price shops. In some areas there is a nexus between private mill owners and corrupt civil supply officials. Hence only the very inferior food grains are supplied to the ration card holders.

The Fair price shop dealers are not appointed on a fair basis. There are errors in the manner of identification of target groups. Fraudulent names are including which denies benefits to the needy sections of society. ${ }^{75}$ Procedure for obtaining food grains is long. No monitoring body and no one supervision process exists to check loopholes within the system. There is no punishment for those found guilty of diversion or wasting

74 BALANI, S. Functioning of the Public Distribution System An Analytical Report. December 2013. Available at: <http://www.prsindia. org/administrator/uploads/general/1388728622 TPDS $\% 20$ Thematic\%20Note.pdf>. Access on: 30th Dec. 2016

75 PUBLIC Distribution System, functioning, limitations, revamping. Available at: <http://www.civilserviceindia.com/subject/ General-Studies/notes/public-distribution-system-functioning-limitations-revamping.html>. Access on: 28th Dec. 2016 public resources.

The law does not act as a permanent poverty alleviation measure. While it does provide some immediate relief, it fails to provide enduring food security to the poor. It would be more appropriate to focus on strategies that reduce poverty and stabilize prices of food grains.

\section{Reforms Needed}

India needs to encourage co-operative Marketing societies which can sell food grains to consumers directly. This will eliminate the middlemen and also eliminate profiteering and black marketing. Bigger societies could have their own storage and warehousing facilities. This will go a long way in reduction of storage losses. The Food Corporation of India should buy food grains from co-operative marketing societies.

Cooperative marketing have made good progress in states like Maharashtra, Andhra Pradesh, Tamil Nadu, Uttar Pradesh and Bihar. The sugarcane marketing societies in Bihar and Uttar Pradesh protect the interests of the members. Cooperative societies in Maharashtra specialize in the sale of tobacco, fruits and vegetables. ${ }^{76}$ Attempts have to be made to use technological solutions to track wastage and rotting of food grains. ${ }^{77}$ In Tamil Nadu, consumers can obtain the stocks position via SMS, and in Chattisgarh, the timing of the arrival of the supplies to the fair price shop. Chhattisgarh has a system for tracking the entire chain from farmer to consumer. Andhra Pradesh has issued smart cards to beneficiaries at fair price shops and Rajasthan issues coupons.

\section{Final Conclusions}

India has to work on making food procurement program and food assistance program more effective. India

76 ASSESSMENT of State Implementation of Business Reforms. September 2015. Available at: <http://dipp.nic.in/English/ Investor/Ease_DoingBusiness/StateAssessmentReport_14Septem ber2015.pdf $>$.

77 PUBLIC Distribution System \& Food Security. Available at: $<$ http://planningcommission.nic.in/plans/mta/mta-9702/mtach8.pdf>. Access on: 28th Dec. 2016 
needs an effective system to identify poor families which will help in making the targeted public distribution system a success. The other area is India needs refor$\mathrm{ms}$ for farmers. Support must be provided to farmers. Farmers need training in agricultural best practices and access to inputs, credit, storage and technology to increase their productivity in a sustainable way. This will raise their own living standards and produce surpluses to help nourish others. Farmers need reliable markets into which they can sell their crops each season and an adequate price to compensate them for their efforts and provide incentive to continue production the following year. Farmers need to be provided with crop insurance and other risk management tools so they can rebound from crop failures or other growing season fluctuations. Farmers must be able to own their land and pledge it. India needs investment to make right to food a reality. This investment is required to build better state of the art facilities to store food grains. The Government of India must encourage private sector investment. Private Companies must use their funds under corporate social responsibility and invest in all areas be it transportation, distribution, storage and energy infrastructure; agricultural research and development; agricultural science, extension, education and the promotion of best practices.

\section{References}

BASU, K. India's Foodgrain Policy: An Economic Theory Perspective. Economic \& Political Weekly EPW, v. XiVi, n. 5, Jan. 2011

Committee on Food Security. Also See NARAYANAN, S. Food Security in India: The Imperative and Its Challenges. Asia and Pacific Studies, v. 2, Issue 1, Jan. 2015.

HALLEGUA, M. Z. 100 Desi Stories: Wisdom from Ancient India,Jaico Publishing House, 2015.

Kautilya in his chronicle Arthashastra. See BHATIA, B. M. Food Security in South Asia. Oxford: Oxford \& IBH Publishing Co. New Delhi, 1985.

MEHTA, A. et al. Towards Solutions and New Compacts in a Dynamic Context India Chronic Poverty Report. India: Indian Institute of Public Administration and Chronic Poverty Research center.

Panel to Review U.S Department of Agriculture's Measurement of Food Insecurity and Hunger, Committee on National Statistics, Division of Behavioural and Social Sciences and Education, National Research Council Food Insecurity and Hunger in the United States: an Assessment of the Measure, The National Academic Press, Washington.

SAUL, B.; KINLEY, D.; MOWBRAY, J. The International Covenant on Economic, Social and Cultural Rights Commentary, Cases Materials. Oxford: Oxford University Press.

SEBBY, K. The Green Revolution of the 1960's and Its Impact on Small Farmers in India. Nebraska: University of Nebraska at Lincoln, 2010. Environmental Studies Undergraduate Student Theses.

SEM, A. Poverty and Famines An Essay on Entitlement and Deprivation. Oxford: Clarendon Press Oxford, 1981.

SRIVASTAVA, A. Kumar; TIWARY, M. Right to Food. $4^{\text {th }}$ ed. India: HRLN, 2009.

\section{Webliography}

Anganwadi centre provides basic health care in Indian villages. It is a part of the Indian public health-care system. Basic health-care activities include contraceptive counseling and supply, nutrition education and supplementation, as well as pre-school activities. See https:/ / data.gov.in/dataset-group-name/anganwadi-centers

ANTYODAYA Anna Yojana. Available at: <http:// www.pradhanmantriyojana.co.in/antyodaya-anna-yoja$\mathrm{na} />$.

ASSESSMENT of State Implementation of Business Reforms. September 2015. Available at: <http://dipp. nic.in/English/Investor/Ease_DoingBusiness/StateAs sessmentReport_14September2015.pdf>.

BALANI, S. Functioning of the Public Distribution System An Analytical Report. December 2013. Available at: <http:/ /www.prsindia.org/administrator/uploads/ general/1388728622 TPDS\%20Thematic\%20Note. pdf $>$.

FOOD security allowance in case of non-supply of entitled food grains. Notification issued by Ministry of Consumer Affairs, Food \& Public Distribution. Dated 28-April, 2015. Available at <http://pib.nic.in/newsite $/$ mbErel.aspx? relid $=119855>$.

GODDESS Annapuna. Disponível em:h<ttps:// 
journeyingtothegoddess.wordpress.com/tag/grains/

India tops world hunger list with 194 million people. Available at: <http://www.thehindu.com/news/national/india-is-home-to-194-million-hungry-people-un/ article7255937.ece>.

NANDA, R. History of India upto 8th century. Available at: <https://sol.du.ac.in/mod/book/view. php?id $=1611 \&$ chapterid $=1633>$.

ODISHA to set up State Food Commission. Available at: http://www.thehindu.com/news/national/otherstates/odisha-to-set-up-state-food-commission/article8353728.ece>.

PUBLIC Distribution System \& Food Security. Available at: <http://planningcommission.nic.in/plans/mta/ mta-9702/mta-ch8.pdf $>$.

PUBLIC Distribution System, functioning, limitations, revamping. Available at: <http://www.civilserviceindia. $\mathrm{com} /$ subject/General-Studies/notes/public-distribu- tion-system-functioning-limitations-revamping.html> .

TARGETED public distribution system. Available at: $<$ http://dfpd.nic.in/public-distribution.htm>.

The Right to Adequate Food, Office of the High commissioner Human Rights. Available at: <www.ohchr. org/Documents/Publications/FactSheet34en.pdf $>$. Access on: 17 Oct. 2016.

The right to food. Available at: < http://www.fao.org/ worldfoodsummit/english/fsheets/food.pdf $>$.

The State of Food Insecurity in the World (SOFI) 2002. Available at: <http://www.fao.org/docrep/005/ y7352e/y7352e03.htm>.

UN Committee on Economic, Social and Cultural Rights (CESCR), General Comment No.12 : The Right to Adequate Food (Article 11 of the Covenant) 12 May 1999. Available at: <http://www.refworld.org/ docid/45388389c11.html $>$. 


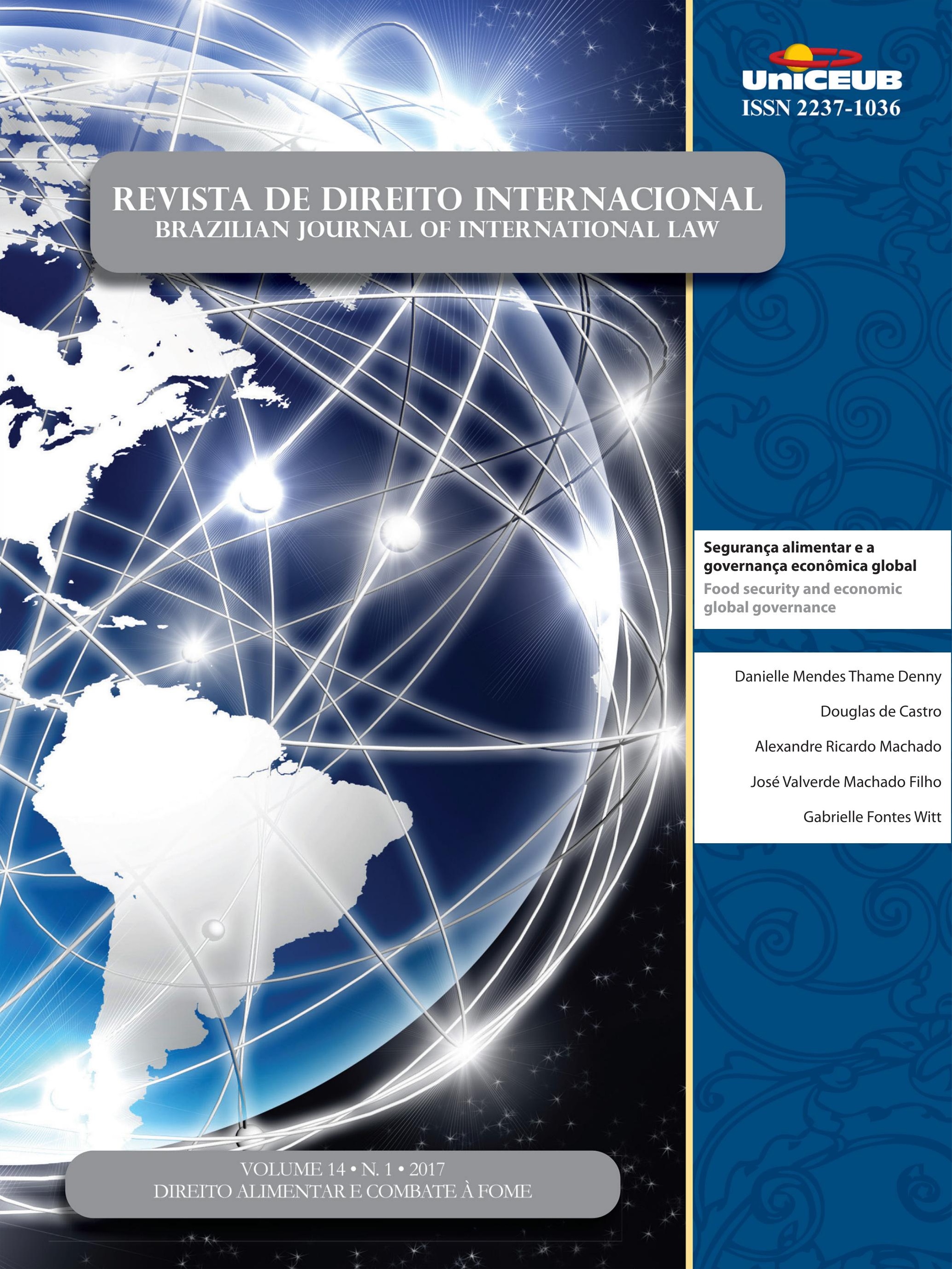




\title{
Segurança alimentar e a governança econômica global*
}

\section{Food security and economic global governance}

\author{
Danielle Mendes Thame Denny** \\ Douglas de Castro*** \\ Alexandre Ricardo Machado**** \\ José Valverde Machado Filho***** \\ Gabrielle Fontes Witt ${ }^{* * * * * *}$
}

* Recebido em 31/10/2016

Aprovado em 01/05/2017

** Pesquisadora Visitante no Whitney and Betty MacMillan Center for International and Area Studies na Universidade Yale, EUA. Doutoranda em Direito Ambiental Internacional na Universidade Católica de Santos, com bolsa da Coordenação de Aperfeiçoamento de Pessoal de Nível Superior. Professora na Fundação Armando Alvares Penteado e na Universidade Paulista. E-mail: danielle.denny@gmail.com

*** Pós-doutorando da Escola de Direito de São Paulo da Fundação Getulio Vargas. Doutor em Ciência Política - Relações Internacionais pela Faculdade de Filosofia, Letras e Ciências Humanas da Universidade de São Paulo. Mestre em Direito pela Faculdade de Direito da Universidade de São Paulo. LL.M. em Direito Internacional pela Brigham Young University. E-mail: douggcastro@gmail.com

**** Doutorando em Direito Ambiental Internacional na Universidade Católica de Santos, com bolsa da Coordenação de Aperfeiçoamento de Pessoal de Nível Superior. Professor na Faculdade de Tecnologia Rubens Lara - Baixada Santista. Diretor da Alexandre Machado Consultoria Estratégica de Negócios. E-mail: alexandre@alexandremachado.com.br

***** Mestre em Direito Ambiental na Universidade Católica de Santos. Secretário executivo do Conselho Estadual de Segurança Alimentar e Nutricional do Estado de São Paulo. E-mail: josevalverdefilho@gmail.com

****** Bacharel em Relações Internacionais pelo Centro Universitário Ritter dos Reis, Porto Alegre, RS. E-mail: gabriellefwitt@gmail.com

\section{Resumo}

O presente artigo tem o objetivo de fazer uma análise da segurança alimentar sob a ótica do Direito Econômico Internacional. Primeiro discorre sobre as causas da insegurança alimentar, em seguida faz um histórico global e brasileiro, contextualizando a questão no Direito Econômico Ambiental Internacional e na defesa dos Direitos Humanos, para, por fim, tratar da problemática sob a perspectiva da governança global. A conclusão principal do trabalho é que a insegurança alimentar vem sendo causada pela má distribuição e não por falta propriamente de alimentos e que as ferramentas de governança global para coordenar interesses antagônicos na busca do objetivo comum da erradicação da fome têm muito a melhorar. A metodologia escolhida foi a análise qualitativa com pesquisa documental, legislativa e bibliográfica.

Palavras chave: Segurança Alimentar, Objetivos do Desenvolvimento Sustentável, Governança Global

\section{Abstract}

This article analyses food security mainly from the Economic International Law perspective. First, it brings the causes of food insecurity, then the global and Brazilian history to contextualize the issue using International Environmental Law, Economic Law as well as Human Rights, to finally address the problem using the lens of global governance. The main argument of this paper is that food insecurity is being caused by misdistribution rather than by lack of food, and that the tools of global governance to coordinate conflicting interests in pursuit of the common goal of hunger eradication have much to be improved. The methodology used was the qualitative analysis with documental, legislative and bibliographic research.

Key words: Food Security, Sustainable Development Goals, Global Governance 


\section{INTRODUÇÃO}

A fome é um problema de ordem mundial e nenhuma nação está imune a esta dificuldade, nem mesmo os países mais desenvolvidos. ${ }^{1}$ Com o avanço tecnológico nos meios de produção, o problema deixa de ser de produtividade insuficiente e passa a se concentrar na má distribuição, na sonegação alimentar e no desperdício. Além disto, outro problema é o fato de que a cadeia alimentar humana está nas mãos de grandes corporações que dominam o destino dos recursos gerados. Uma consequência disso foi o anúncio realizado em junho de 2009, após o aumento dos preços dos alimentos e da crise internacional de 2007-2008, em que o número de pessoas com fome no mundo chegou ao recorde histórico de 1,02 bilhão de pessoas. ${ }^{2}$

A insegurança alimentar tem sido um problema recorrente ao longo da história e, sem dúvida, a fome tem sido manifestada devido a um conjunto de fatores e em certos locais, por quebras de safra, pragas, guerras e conflitos, epidemias ou pelo aumento da população. ${ }^{3}$ A perda de colheitas, pragas e a explosão populacional não foram abordadas de forma eficaz e nos últimos 20 anos têm-se acrescentado outras causas potenciais de insegurança alimentar, na medida em que seu alcance não é agora apenas local, mas potencialmente mundial.

As tentativas de aumentar a segurança alimentar esbaram em dois grandes problemas que estão relacionados: o primeiro deles é o atual modelo do sistema internacional alimentar que está baseado em monoculturas altamente dependentes de agrotóxicos e sementes transgênicas (GMOs), cuja produção está voltada para a exportação; o segundo é que os principais atores neste sistema são as empresas transnacionais (ETNs), cuja finalidade precípua não é a erradicação da fome, mas a geração de lucros. Estas são duas variáveis intervenientes importantes na análise das iniciativas adotadas pelas organizações intergovernamentais e não-governamentais que buscam dar respostas ao problema da fome no mundo.

1 KEARNS, Antony P. The Right to Food Exist via Customary Internacional Law. Suffok Transnational Law Review. Vol.22, n.1, pp. 223-257,1998-1999.

2 COSTA, Claudia V.; BEGNIS, Heron Sergio M. Revista de Economia \& Relações Internacionais. Fome mundial: uma análise de suas causas e da atuação da FAO. Vol. 12(24), pp. 44-60, 2014.

3 PEARSON, Craig. A fresh look at the roots of food insecurity. In: RAYFUSE, Rosemary; WEISFELT, Nicole (Orgs.). The challenge of food seccurity: internacional policy and regulatory frameworks. Cheltennham, UK: Edward Elgar, 2012.
Desse modo, a comodificação dos alimentos que ocorre a partir da adoção do modelo da monocultura está no centro do debate sobre a segurança alimentar, pois coloca o debate entre os dois paradigmas: um centrado no mercado global voltado à exportação, cujo objetivo principal não é a erradicação da fome e que coloca em perigo a biodiversidade; e outro voltado para a produção e distribuição no mercado local, que preserva a biodiversidade e protege o conhecimento tradicional da agricultura familiar. ${ }^{4}$ Reforçando esse argumento com um aporte teórico mais robusto em relação ao segundo paradigma, Shaw sintetiza:

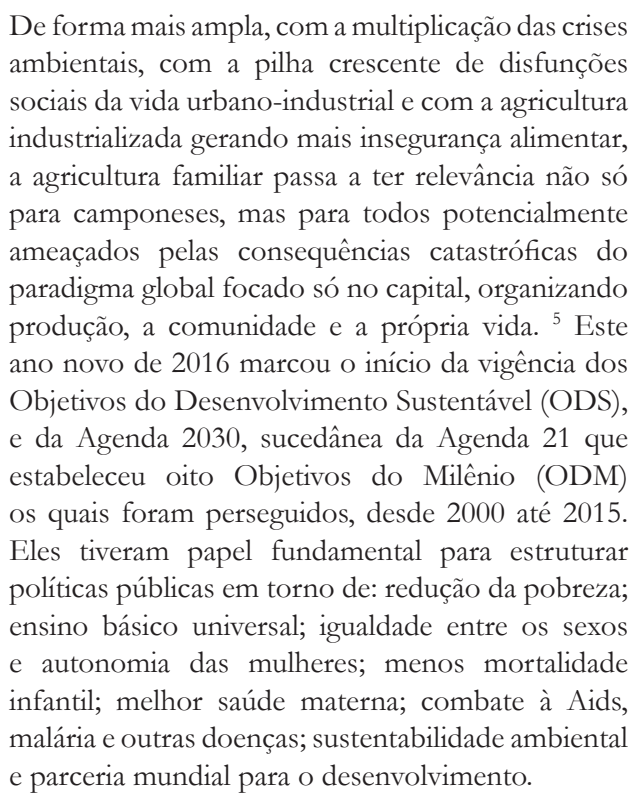

Para atingir esses objetivos, a Organização das Nações Unidas trabalhou, até o ano passado, com um conjunto de 18 metas, monitoradas por 48 indicadores. Essas metas decorriam da Declaração do Milênio, o mais importante compromisso internacional em favor do desenvolvimento e da eliminação da pobreza e da fome no mundo, assinada em setembro de 2000, por representantes de 191 estados membros da ONU, incluindo 147 chefes de Estado. Já a primeira dessas metas era reduzir pela metade os casos de extrema pobreza e desnutrição.

4 SHIVA, V. Monoculturas Da Mente. Perspectivas Da Biodiversidade E Biotecnologia. São Paulo: Gaia, 2003; CARSON, R. Primavera silenciosa. Editora Gaia, 2015.

5 Tradução livre do trecho: "More broadly, as environmental crises multiply, as the social dysfunctions of urban-industrial life pile up, and as industrialized agriculture creates greater food insecurity, the "peasant way" has relevance not only to peasants but to everyone threatened by the catastrophic consequences of global capital's vision for organizing production, community, and life itself." SHAW, D. World Food Security: A History since 1945. 2007 edition ed. Basingstoke England ; New York: Palgrave Macmillan, 2007. 
O relatório da ONU, intitulado The Millennium Development Goals Report ${ }^{6}$ demonstrou que a maioria dos países, inclusive o Brasil, conseguiu alcançar ou se aproximar dessas metas, o que reforça o argumento da eficácia desses instrumentos de soft law, que mesmo não prevendo sanções por descumprimento, têm capacidade de gerar comprometimento e cooperação dos países em busca de resultados. No caso especificamente da primeira meta o resultado foi bastante expressivo, três anos antes do prazo já se havia superado a meta, chegando a dois terços de erradicação de pobreza. No tocante à desnutrição ficou muito próxima, ela atingia $23.3 \%$ da população dos países em desenvolvimento em 1992 e caiu para $12.9 \%$ em 2014 , isso corresponde a $45 \%$ de queda, quase alcançada a meta de redução pela metade, portanto.

Porém, por outro lado, o mesmo relatório deflagrou o quanto ainda há para ser alcançado, mais de 800 milhões de pessoas ainda estão malnutridas, o saneamento básico ainda não chegou para quase um terço da população do mundo e a extrema pobreza tem matado na última década o triplo do que a Segunda Guerra Mundial7. Há um déficit massivo na efetivação de direitos humanos, tanto dos civis e políticos, como dos econômicos, sociais e culturais.

Os principais desafios são enfrentados por países com menor desenvolvimento relativo. E uma das razões é o financiamento, enquanto países industrializados chegam a arrecadar 50 mil dólares por pessoa, países menos desenvolvidos como a Índia nem chegam a duzentos dólares. ${ }^{8}$ Assim a capacidade desses países para financiar medidas para implementar os ODS fica de antemão prejudicada.

Além disso, nos países de menor desenvolvimento relativo a capacidade de aumentar essa arrecadação é limitada. A tributação sobre o consumo tem uma ca-

6 ONU. The Millennium Development Goals Report. 2015. Disponível em: < http://www.un.org/millenniumgoals/2015_MDG_ Report/pdf/MDG\%202015\%20rev\%20(July\%201).pdf > Acesso em 10 de outubro de 2016.

7 "poverty and undernourishment cause some 18 million painful deaths each year, some 450 million during the MDG period, while the entire Second World War caused 'only' around 60 million deaths. This estimate is based on the WHO's classification of deaths by cause, counting as poverty-related all those death causes that are essentially confined to the poor countries. When almost no one dies of diarrhea in the affluent countries and millions die from diarrhea in poor countries, then I assume that diarrhea is a poverty-related cause and diarrhea deaths are poverty-related. I use the WHO's data for 2004 as this year is roughly in the middle of the MDG period." POGGE, Tomas. The Hunger Games. Food ethics (2016) 1: 9. June 2016, Volume 1, Issue 1, pp 9-27

8 POGGE, Thomas e MEHTA, Krishen. Global tax fairness. Nova York: Oxford University Press, 2016, p. 291. racterística de não proporcionalidade, fazendo com que os mais pobres paguem mais tributos e as tributações sobre a renda e patrimônio costumam ser evadidas ou elididas por esquemas ou planejamentos tributários que tendem a reverter recursos para fora desses países.

Assim, o aspecto econômico e financeiro precisa também ser levado em consideração, junto com a análise ambiental e social. Desse modo, o presente artigo visa contribuir com a análise transdisciplinar das causas que promovem a insegurança alimentar e as suas implicações nas dimensões internacional e nacional, bem como seus desdobramentos no Direito Econômico e as contribuições do direito para a solução do problema da fome a partir do marco conceitual da governança. A metodologia escolhida foi a análise qualitativa com pesquisa documental, legislativa e bibliográfica.

\section{Causas estruturais da insegurança ALIMENTAR}

Josué de Castro, em seu livro Geografia da Fome - O dilema brasileiro: pão on aço ${ }^{9}$, aponta que a fome é um fenômeno recorrente de natureza social e natural que recebe pouca atenção da academia e constrange a sociedade. Como se pode ver do gráfico a seguir, esta afirmação feita da década de 1960 é verdadeira e somente passa a fazer parte das discussões acadêmicas a partir das crises alimentares mundiais de 2006 e 2008 que levaram ao aumento de populações expostas à fome.

\subsection{Sobre segurança alimentar}

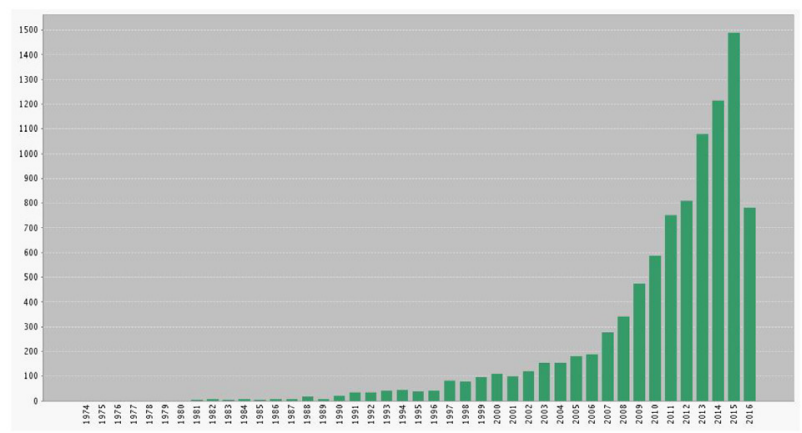

Fonte: Web of Science - artigos publicados sobre segurança alimentar. ${ }^{10}$

9 CASTRO, Josué de. Geografia da fome: o dilema brasileiro: pão ou aço. 10. ed. Rio de Janeiro: Antares, 1983.

10 Esta pesquisa foi feita no dia 04/08/16 no website da Web of 
Tomas Pogge identifica que "é notório o conhecimento atualmente que a humanidade já tem, há algum tempo, todos os meios econômicos, tecnológicos e administrativos para a erradicação completa da pobreza extrema em nosso planeta." ${ }^{11}$ Nesse sentido, a desigual distribuição dos alimentos e o precário acesso aos mesmos pela população é a primeira questão essencial para entender as causas da insegurança alimentar e as consequências da desnutrição, a qual, por sua vez, contribui para a promoção de doenças, tendo por si um grande impacto.

A insegurança alimentar diz respeito à falta de nutrientes e alimentos para a população permanecer "viva", estando diretamente ligada ao acesso diário a alimentos minimamente calóricos que são indispensáveis para que haja energia suficiente para a realização de atividades pelo indivíduo e do próprio funcionamento do organismo. ${ }^{12}$ Em 2000, de acordo com a Organização das Nações para Agricultura e Alimentação - FAO - por exemplo, um adulto, para ser considerado bem nutrido, deveria ingerir $2.500 \mathrm{kcal}$ por dia. Estas 2.500 kcal seriam, então, a linha divisória de identificação dos adultos que se alimentam além, aquém ou de acordo com o necessário ao bom funcionamento do organismo. ${ }^{13}$

A saúde vinda do latim 'salute', significa conservação da vida, vai depender da satisfação das necessidades biológicas básicas, o que lhe assegura as condições mínimas para o seu desenvolvimento, sendo atendidas as necessidades primárias para seu bem-estar. Nota-se que somente alimentar os famintos não alcança totalmente o objetivo para erradicar a fome.

Seja qual for o método de análise e monitoramento da insegurança alimentar, será preciso primeiro definir o que é considerado fome e em seguida quais procedimentos para estimar que a pessoa está enquadrada nesse conceito. O mais usado é o da FAO que define extrema forma de insegurança alimentar quando a energia inge-

Science tendo como parâmetro o termo "food security".

11 Tradução livre para o trecho "It is widely understood now that humanity has been in possession, for some time, of the economic, technological and administrative means for the complete eradication of severe poverty on our planet". POGGE, Tomas. The Hunger Games. Food ethics (2016) 1: 9. June 2016, Volume 1, Issue 1, pp 9-27

12 NUNES, Mérces da Silva. O direito fundamental à alimentação: e o princípio da segurança. Rio de Janeiro: Elseiver, 2008. 13 BEURLEN, Alexandra. Direito humano à alimentação adequada no Brasil. 3.ed. Curitiba: Juruá, 2008. rida pelos alimentos é insuficiente para suprir as necessidades mínimas de uma vida sedentária pelo período maior de um ano. ${ }^{14}$

Esse conceito tem algumas falhas, só considera a ingestão energética, porém seres humanos não conseguem viver apenas de energia precisam de nutrientes como proteínas, vitaminas, minerais e alguns micronutrientes para ser adequadamente nutrido e, em alguns casos, até para sobreviver. Principalmente três deficiências nutricionais relativas à pobreza têm causado milhares de mortes anualmente ${ }^{15}$ : a de vitamina A cuja deficiência aumenta substancialmente o número de mortes anuais de sarampo, diarréia e malária e também causa muita deficiência visual e cegueira; a falta de ferro que gera anemia generalizada em países pobres, provocando mortes em adultos, crianças e gestantes; a deficiência de zinco que, por sua vez, contribui substancialmente para as mortes por diarreia, pneumonia e malária em crianças menores de cinco anos; e a deficiência de iodo, a qual impede o desenvolvimento intelectual e físico.

Além disso, o conceito não leva em conta que centenas de milhões de pessoas em regiões pobres estão infectadas com parasitas que facilmente chegam a absorver mais de um terço dos nutrientes que são consumidos. Muitos, ainda sofrem de patologias que impedem a absorção adequada de nutrientes pelo intestino delgado. Para piorar, o conceito considera o mínimo de ingestão energética necessário para uma vida sedentária, mas nessas regiões esse estilo de vida não é realidade.

Há, portanto, o desafio de fazer com que a população consiga atingir e manter uma alimentação adequada, ou seja, acessar os alimentos em quantidade suficiente e que os mesmos sejam de qualidade. Também, de nada adianta assegurar o acesso ao alimento se o mesmo não for seguro, podendo trazer doenças ou complicações para a saúde. ${ }^{16}$ Existem requisitos mínimos sobre uma alimentação humana correta, no que tange a garantia de alimentos saudáveis, os quais devem ser: (I) seguros, isto é, livre de substâncias prejudiciais à saúde humana; (II)

14 FAO, WFP and IFAD (Food and Agriculture Organization of the United Nations, World Food Programme and International Fund for Agricultural Development). 2012. The state of food insecurity in the world 2012. Rome: FAO, 2012, p.50.

15 POGGE, Tomas. The Hunger Games. Food ethics (2016) 1: 9. June 2016, Volume 1, Issue 1, p. 11.

16 MÜLLER, Marcela. Direito fundamental à alimentação adequada no contexto das organizações internacionais. Curitba: Juruá, 2014, p.32-33. 
saudáveis, ou seja, capaz de gerar saúde ao ser humano, portanto nutritivo; e (III) culturalmente aceito.

Os sintomas da fome e suas causas se manifestam de maneiras diferentes em diferentes níveis da sociedade. É costume ver a fome mostrar-se em nível individual, mas a má distribuição dos alimentos existe em alguns níveis diferentes numa mesma sociedade. Existem cinco diferentes níveis, cuja separação metodológica serve apenas para uma melhor compreensão científica sobre o tema.

O primeiro é em nível internacional, no qual há uma má distribuição dos alimentos entre os países. $\mathrm{O}$ segundo é em nível nacional, sendo mal distribuídos os alimentos dentro de certas regiões ou áreas dentro de um país. O terceiro é em nível de área, em que se nota uma má distribuição de alimentos em bairros ou em determinadas localidades urbanas. A quarta é em nível local de bairro, no qual não são distribuídos de forma igualitária entre as residências e, por último, em nível de domicílios, onde os alimentos não são distribuídos corretamente entre os próprios membros do mesmo lar. ${ }^{17}$

\section{Histórico}

Em nível internacional, a preocupação e o conceito de segurança alimentar começaram a partir da $1^{\mathrm{a}}$ Guerra Mundial mostrando-se que um país poderia dominar o outro controlando seu fornecimento de alimentos, já que nem todos os países tinham uma capacidade suficiente de produzir seus próprios alimentos devido ao caos de guerra na Europa. ${ }^{18}$ Somente na década de 1940, que este conceito se referenciou em âmbito internacional, com a criação da FAO e de organismos internacionais para financiamentos, como o Banco Mundial (BM). ${ }^{19}$ Após a criação da $\mathrm{FAO}$, a primeira menção realizada a partir da questão alimentar se dá na VII Sessão da Conferência da FAO ocorrida em novembro de 1953, em que a assistência alimentar e a utilização de alimentos excedentes era vista como um artefato de segurança alimentar.

17 VALENTE, Luiz Schieck. Direito Humano à Alimentação: desafios e conquistas. São Paulo: Cortez, 2002.

18 NUNES, Mérces da Silva. O direito fundamental à alimentação: e o princípio da segurança. Rio de Janeiro: Elseiver, 2008, p. 58

19 VALENTE, Luiz Schieck. Direito Humano à Alimentação: desafios e conquistas. São Paulo: Cortez, 2002, p. 41
Esta preocupação estendeu-se até a metade dos anos setenta com a crise de escassez de alimentos, pois à capacidade de produção dos países estava diretamente ligada à segurança nacional. Nesta época, segurança alimentar não era considerado um direito do ser humano em ter acesso aos alimentos, mas sim uma política de armazenamento e oferta de alimentos visando à segurança do país, ou seja, a preocupação sempre esteve no alimento e não no ser humano, visto que quanto mais fosse produzido, mais aumentava sua segurança.

Decorrente das Grandes Guerras o alimento passou a ser arma poderosa de uma potência em relação a países mais pobres e incapazes de produzir seus próprios alimentos. Desta forma, os países tentavam atingir sua autossuficiência na produção dos alimentos, buscando eliminar ou reduzir embargos por motivações políticas ou militares. Como resultado, houve um aumento na produção de alimentos no início da década de 1980, mas a eliminação da fome e da desnutrição no mundo não ocorreu. Assim, mostrou-se indispensável cuidar do problema de oferta da capacidade de acesso aos alimentos, visto que esses problemas decorriam por serem muito mais problemas de demanda e distribuição do que propriamente de produção.

A FAO e a Organização Mundial da Saúde (OMS) apresentaram em 1983, um novo conceito de segurança alimentar, inserindo a "oferta adequada de alimentos, a sua estabilidade e a dos mercados de alimentação, bem como o acesso aos alimentos produzidos". Três anos depois, em 1986, o BM anunciou um conceito de segurança alimentar, qual seja, "o acesso por parte de todos, todo o tempo, de quantidade suficientes de alimentos para levar uma vida ativa e saudável"'.20

No contexto de uma economia globalizada, a
produção, a distribuição e o consumo de alimentos
(...) exigem que qualquer análise/ou abordagem
relativa à questão da Segurança Alimentar seja
realizada à luz do princípio da precaução que,
em prol da defesa e da proteção da coletividade,
apresenta-se como instrumento que deve ser
empregado na busca de soluções que permitam
agir com segurança em toda e qualquer situação
que envolva risco potencial que se trate de risco
conhecido ou desconhecido.

20 NUNES, Mérces da Silva. O direito fundamental à alimentação: e o princípio da segurança. Rio de Janeiro: Elseiver, 2008, p. 58-59.

21 NUNES, Mérces da Silva. O direito fundamental à alimentação: e o princípio da segurança. Rio de Janeiro: Elseiver, 2008 p.58. 
Ainda neste mesmo ano, a Cúpula Mundial de Alimentação, implantou a meta de erradicação da fome em todos os países e da redução de pessoas subnutridas até 2015, consolidando também um novo conceito de Segurança Alimentar. A Segurança Alimentar, nos níveis individual, familiar, nacional, regional e global, é alcançada quando todas as pessoas têm, a todo momento, acesso físico e econômico a alimentos inócuos (que não oferecem risco à saúde) e nutritivos para satisfazer suas necessidades dietéticas e preferências alimentares para uma vida ativa e saudável.

E em 1990, a FAO e a OMS acrescentaram ao conceito de segurança alimentar as noções de "alimento seguro ou não-contaminado, de qualidade nutricional e tecnológica, balanceamento da dieta e informação", visto que a segurança dos alimentos está diretamente relacionada ao cuidado, zelo e a atenção no ato de manter saudável a alimentação de outro ser humano.

Como visto anteriormente desde a década de 1980 até os dias atuais, há o problema de desigual distribuição de alimentos produzidos. Segundo Müller ${ }^{22}$, (existem três fatores que sustentam e confirmam a continuação do agravamento deste problema da alimentação da população mundial, sendo eles: (I) os problemas decorrentes do desperdício dos alimentos; (II) as controvérsias permanentes ao comércio internacional devido suas elevações dos preços bem como a quebra do funcionamento da produção nacional de alimentos; (III) e a desigualdade norte-sul sobre o acesso à alimentação, devido à escassez de recursos e de fornecimento dos alimentos para as pessoas.

Percebe-se, portanto que o conceito de Segurança Alimentar e Nutricional (SAN) está em constante estado de formulação, pois trata-se de tema global com uma pauta extensa e capilar, que se interliga as principais transformações ocorridas na sociedade moderna, como por exemplo, em relação a fome que se apresenta sob diversas circunstâncias ocasionadas por guerras, instabilidade política ou mesmo pelos fenômenos naturais, tais como mudanças climáticas que interferem na produção de alimentos. Ou mesmo, pela correlação do tema com a saúde humana e o consumo do alimento adequado e saudável.

22 MÜLLER, Marcela. Direito fundamental à alimentação adequada no contexto das organizações internacionais. Curitba: Juruá, 2014, p.42.

\section{No BRASIL}

Tal transformação conceitual e mesmo de compreensão se verifica também em relação a própria "segurança alimentar", que no Brasil tem estado em debate e modelagem há mais de vinte anos. Nesse sentido, o documento final da I Conferência Nacional de Alimentação e Nutrição, realizada em 1986 estabeleceu o conceito como sendo "a garantia, a todos, de condições de acesso a alimentos básicos de qualidade, em quantidade suficiente, de modo permanente e sem comprometer o acesso a outras necessidades básicas, com base em práticas alimentares que possibilitem a saudável reprodução do organismo humano, contribuindo, assim, para uma existência digna."23

No campo legal brasileiro, o advento da Lei $\mathrm{n}^{\circ}$ 11.346, de 15 de setembro de 2006 cria o Sistema Nacional de Segurança Alimentar e Nutricional - SISAN com vistas a assegurar o direito humano à alimentação adequada. O marco legal

estabelece as definições, princípios, diretrizes, objetivos e composição do Sistema Nacional de Segurança Alimentar e Nutricional - SISAN, por meio do qual o poder público, com a participação da sociedade civil organizada, formulará e implementará políticas, planos, programas e ações com vistas em assegurar o direito humano à alimentação adequada. ${ }^{24}$

A contextualização elaborada, remete a algumas considerações. A primeira delas está relacionada a conceituação de segurança alimentar global diante de uma perspectiva contemporânea que ainda carece de melhor compreensão em face de seu alargado escopo e, que possa ser internalizada e compreendida no Brasil a partir de uma visão sistêmica que observe as variáveis cultural, social, ambiental, econômica, saúde pública etc) e que considere conjunturas regionais e locais.

Outro aspecto está no campo jurídico-legal, que carece ainda de uma ampliação e aperfeiçoamento da estrutura legal, bem como de aprofundamento doutrinário, tendo em vista o principal marco legal ter apenas uma década de vigência. Isso significa dizer, que o "direito à alimentação" previsto na carta magna coloca em perspectiva, especialmente para o Poder Público novos

23 LEÃO, Marília (Org.). O Direito Humano à Alimentação Adequada e o Sistema nacional de Segurança Alimentar e Nutricional. Brasília: ABRANDH, 2013, p. 15.

24 Lei ${ }^{\circ} 11.346 / 2006$, art. $1^{\circ}$. 
deveres até então não percebidos e devidos em políticas públicas.

Por fim, a segurança alimentar e nutricional trata-se de temática nova, porém estratégica para a sociedade contemporânea e, aguarda-se que ganhe mais espaço na agenda do poder público, setor empresarial, academia e sociedade civil com o objetivo macro de garantir às presentes e futuras gerações uma satisfatória qualidade de vida a partir de uma alimentação saudável e adequada.

Estão em trâmite no Congresso Nacional brasileiro três projetos de lei. O primeiro dispõe sobre a redução do desperdício de alimentos, estabelecendo que

$$
\begin{aligned}
& \text { os estabelecimentos dedicados a comercialização } \\
& \text { ou manipulação de alimentos firmarão contratos de } \\
& \text { doação a organizações de natureza social dedicadas } \\
& \text { à coleta e distribuição de alimentos e refeições, } \\
& \text { ou de doação ou venda a empresas dedicadas à } \\
& \text { produção de ração animal e à compostagem. Isenta } \\
& \text { o doador de responsabilidade por dano ocasionado } \\
& \text { pelo consumo do bem, desde que não caracterize } \\
& \text { dolo e negligência. }
\end{aligned}
$$

O segundo estabelece a Política Nacional de Combate ao Desperdício de Alimentos, com o objetivo de "aumentar o aproveitamento dos gêneros alimentícios disponíveis para consumo humano em território nacional", mitigando, assim o desperdício alimentar com o "uso dos alimentos impróprios para o consumo humano em atividades de reciclagem e de alimentação de animais" 26 . O terceiro projeto de lei, por sua vez, estabelece as diretrizes para a "Política Nacional de Erradicação da Fome e de Promoção da Função Social dos Alimentos - PEFSA, fundamentada em uma sociedade fraterna, justa e solidária". ${ }^{27}$

Assim, se no passado a agenda da SAN estava voltada a garantir a capacidade de cada país produzir sua alimentação, bem como a insegurança alimentar decorrida da produção insuficiente de alimentos, sobretudo, entre os países pobres, isso tem sido ampliado. A importância da SAN, na atualidade e seu conceito tem sido objeto de permanente construção e evolução diante das transformações vivenciadas pela sociedade e tem abarcado temas relacionados à saúde humana, especialmente o combate a obesidade e sobrepeso, a saudabilidade e qualidade nutricional dos alimentos, bem como a ampliação das condições de oferta acessível de alimentos.

25 PROJETO DE LEI DO SENADO nº 672, de 2015

26 PROJETO DE LEI DO SENADO n 675, de 2015

27 PL 6867/2013 - CÂMARA DOS DEPUTADOS
Isso por meio do incremento da produção, em especial na agricultura tradicional, familiar, urbana, periurbana, no processamento, na industrialização, na comercialização e no abastecimento, que demandam ações intersetoriais que devem orientar governos e suas políticas públicas.

\section{Desperdício}

De acordo com a FAO, o volume de desperdício de alimentos em todos os países, tem sua diversidade. Em um lado da balança tem-se o desperdício em âmbito internacional, chegando a 1,3 bilhão de toneladas por ano, suficiente para alimentar mais que o dobro das pessoas que hoje sofrem da falta de alimentos; e do outro lado, a questão em que por volta de 870 milhões de pessoas ainda passam fome. ${ }^{28}$

A avaliação ambiental de todos os produtos é baseada em uma abordagem de ciclo de vida que engloba todo o "ciclo alimentar", incluindo a produção agrícola, processamento pós-colheita e armazenamento, distribuição, consumo ou a sua eliminação. Algumas dessas perdas se dão em cada fase da cadeia de fornecimento dos alimentos, principalmente em países em desenvolvimento, como à falta de armazéns adequados, de estradas e de sistemas de refrigeração. Há também problemas de perdas em países desenvolvidos, no qual desperdiçam mais comida nas etapas após o fornecimento aos varejistas, que encomendam, servem e exibem os produtos, e seguindo esta cadeia até os consumidores finais que, muitas vezes, ignoram os restos de alimentos ainda na geladeira, descartando alimentos ainda válidos ou, em razão do tempo, podres.

Esse mesmo estudo realizado pela $\mathrm{FAO}^{29}$, não calculou somente os volumes de alimentos desperdiçados, calculou também os seus impactos ambientais, já que esse desperdício, além de causar enormes problemas sociais e econômicos, traz impactos sobre recursos na-

28 FAO. Organização das Nações Unidas para a Alimentação e a Agricultura. $\mathbf{O}$ desperdício alimentar tem consequências ao nível do clima, da água, da terra e da biodiversidade - novo estudo da FAO. Roma, 2013. Disponível em: <http://www.fao.org/ news/story/pt/item/204029/icode/>. Acesso em: 05 jun. 2016.

29 FAO. Organização das Nações Unidas para a Alimentação e a Agricultura. $\mathbf{O}$ desperdício alimentar tem consequências ao nível do clima, da água, da terra e da biodiversidade - novo estudo da FAO. Roma, 2013. 
turais disponíveis. Assim, quanto maior for a quantidade de alimentos perdidos ou desperdiçado ao longo da cadeia de abastecimento, maior será o custo ambiental. Os impactos ambientais são avaliados em quatro componentes: clima, água, solo e biodiversidade.

Todo este manancial de recursos naturais disponíveis para a produção de alimentos, com o tempo vai contribuindo para sua escassez, pois alimentos produzidos que não iram ser consumidos, além de estarem desfazendo-se do próprio alimento, perdem os recursos naturais que a natureza levou milhares de anos para disponibilizar $^{30}$

\section{Comércio internacional e meio ambiente}

O próximo ponto sobre a desigual distribuição, aborda o comércio internacional quanto às causas da fragilização da economia local. A estabilidade de uma economia local, decorre dos pequenos agricultores, responsáveis pela produção de alimentos primários que virão a ser comercializados e conseguem manter sua vida e sua família na área rural, garantindo também a qualidade sobre os alimentos. O problema surge quando há uma abertura de mercado para multinacionais, pois elas acabam prejudicando o pequeno agricultor, uma vez que os investimentos na produção são estrangeiros e os lucros tendem a não permanecer no local de produção.

O mercado de alimentos global é dominado por pequeno número de empresas que dominam a oferta de mercado, pois há poucos vendedores para muitos compradores. Esse é um dos principais obstáculos do direito social fundamental à alimentação adequada. Isso porque somente as maiores empresas possuem e permanecem com o controle da produção, da comercialização de sementes e, posteriormente, do alimento com o seu devido preço junto ao mercado de commodities. ${ }^{31}$

Dessa maneira, por não serem de seu interesse, estes oligopólios não visam às pequenas produções de alimentos, que são os principais responsáveis pela segurança alimentar, especialmente para as pessoas mais desprovidas, pela sua dificuldade ao acesso ao que é

30 MÜLLER, Marcela. Direito fundamental à alimentação adequada no contexto das organizações internacionais. Curitba: Juruá, 2014, p.43.

31 ZIEGLER, Jean. Destruição em massa: Geopolítica da fome. São Paulo: Cortez, 2013. ofertado pelas grandes indústrias. E, por fim, a desigualdade norte-sul, em que os países do Norte apresentam melhores condições de acesso e qualidade dos alimentos do que comparados aos do Sul. Neste sentido, Moeller constata:

Organizações como empresas multinacionais, ou pelo menos os partidos políticos influenciados por suas doações, parecem estar ganhando cada vez maior controle sobre os governos em todos os níveis, do local ao global, e estão tomando o poder das mãos dos. ${ }^{32}$

A problemática da erradicação da fome está associada à intensificação do processo de internacionalização das empresas transnacionais (ETNs) ligadas ao setor agrícola e apresenta um complicador para se chegar a um consenso mínimo quanto às causas estruturais da fome e as formas de seu combate: seu objetivo primário não é a erradicação da fome, mas o acúmulo de capital, que segundo Foster:

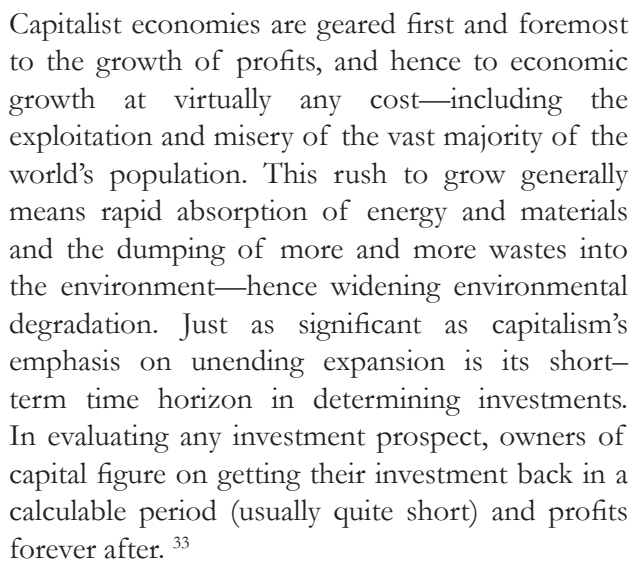

Embora as ETNs não tenham a missão de combater a fome e a prática adotada por elas da monocultura está associada direta ou indiretamente aos maiores desafios ambientais vivenciados neste século, elas apresentam uma concentração de poder na governança do sistema alimentar internacional sem precedentes. Conforme Clapp e Fuchs:

Private, corporate actors have taken on a significant role in the global food system, not only as economic actors responsible for much of the world's food

32 Tradução livre para: "Organizations such as multinational corporations_-or at least the political parties influenced by their donations - seem to be gaining increasing control of the governments at all levels, from local to global, and to be taking power out of the hands of individual citizens" MOELLER, H.-G. Luhmann Explained: From Souls to Systems. Chicago: Open Court, 2006. 33 FOSTER, J. B. Ecology Against Capitalism. Monthly Review. Recuperado agosto 4, 2016, de http://monthlyreview. org/2001/10/01/ecology-against-capitalism/, 2001, outubro 1. 
production, processing, and retailing, but also as political actors in global mechanisms to govern the food system. ${ }^{34}$

Seu crescimento econômico e político está tornado principalmente os países em desenvolvimento grandes exportadores de commodities e grandes compradores de produtos industrializados. O relatório The ECT Century - Erosion, Technology and Corporate Concentrationin the $21^{\text {st }}$ Century apresenta os vários estágios e graus em que as ETNs interferem na cadeia produtiva agrícola:

- The top 10 seed companies control nearly 50 percent of the US $\$ 21 \mathrm{bi}$ llion annual global commercial seed market and nearly all of the genetically engineered seed market.

- The top 10 pesticide companies control 84 percent of the US $\$ 30$ billion annual global pesticide market.

- The top 10 food retailers control 24 percent of the estimated US $\$ 3.5$ trillion global food market.

- The top 10 food and beverage processing companies control 24 percent of the estimated US $\$ 1.25$ trillion global market for packaged foods. ${ }^{35}$

Segundo Clapp e Fuchs, $[\ldots]$ there is a growing critique of the effects that corporate concentration in a globalized food system is having on food security, small-farmer livelihoods, environmental quality, food safety, and consumer sovereignty ${ }^{36}$, o que ocorre em razão de sua visão de curto-prazo no que diz respeito aos investimentos e a forma de sua recuperação, utilizando as monoculturas, pesticidas e GMOs que comprometem seriamente a biodiversidade, aumentam a vulnerabilidade dos países às crises internacionais de commodities e o modus vivendi de milhões de pessoas que vivem no campo.

Para tanto, o exercício de seu poder econômico e político é exercido nas dimensões instrumental e estrutural.

34 CLAPP, J.; COHEN, M. J. Global Food Crisis: Governance Challenges and Opportunities. Waterloo, Ont.: Wilfrid Laurier University Press, 2009.

35 In http://www.etcgroup.org/sites/www.etcgroup.org/files/ publication/281/01/other_etccentury.pdf. Acesso em: 04/08/16.

36 CLAPP, J.; COHEN, M. J. Global Food Crisis: Governance Challenges and Opportunities. Waterloo, Ont.: Wilfrid Laurier University Press, 2009.
$\mathrm{Na}$ dimensão instrumental elas interferem na mais óbvia forma que é o financiamento de campanhas eleitorais, enquanto na estrutural elas influenciam o processo político a partir de um sistema de recompensas e punições dependendo do comportamento dos Estados (p.ex. aumento ou redução de investimentos) e a implementação de um sistema privado de regulação que força os Estados a legitimar tais regimes privados via instituições internacionais (p.ex. ISO 14000). Neste sentido, o agronegócio:

[...] é uma forma de territorialização do capital no campo, que se concretiza no domínio do mercado de insumos, das técnicas e tecnologias da produção, dos sistemas de financiamento, das indústrias de beneficiamento, dos sistemas de transporte e das redes de comercialização. Além disso, esses grupos exercem poder e influência sobre órgãos internacionais como a Organização Mundial do Comércio (OMC), que define regras para o comércio de produtos agrícolas no mundo. ${ }^{37}$

Chegamos assim na encruzilhada em que a necessidade de diminuir a exposição de pessoas aos efeitos negativos da fome pelo aumento da segurança alimentar que é feito pelo sistema alimentar atual controlado pelas ETNs encontra outra dimensão da segurança, a ecológica. Ao relatar a experiência da revolução verde na região de Punjab, Índia, Shiva ${ }^{38}$ coloca:

'Green Revolution' is the name given to this science based transformation of Third World agriculture, and the Indian Punjab was its most celebrated success. Paradoxically, after two decades of the Green Revolution, Punjab is neither a land of prosperity, nor peace. It is a region riddled with discontent and violence. Instead of abundance, Punjab has been left with diseased soils, pestinfested crops, waterlogged deserts and indebted and discontented farmers. Instead of peace, Punjab has inherited conflict and violence. At least 15,000 people have lost their lives in the last six years. 598 people were killed in violent conflict in 20 The Violence of the Green Revolution Punjab during 1986. In 1987 the number was 1544. In 1988, it had escalated to 3,000. And 1989 shows no sign of peace in Punjab. The tragedy of Punjab - of the thousands of innocent victims of violence over the past five years - has commonly been presented as an outcome of ethnic and communal conflict between two religious groups.

Assim, temos um discurso que permeia as instituições internacionais que a segurança alimentar passa

37 SOGLIO, F. D.; KUBO, R. R. Agricultura e Sustentabilidade. PLAGEDER, 2009. In http://www.ufrgs.br/cursopgdr/ downloadsSerie/derad008.pdf. Acesso em: 29/10/16.

38 SHIVA, V. Monoculturas Da Mente. Perspectivas Da Biodiversidade E Biotecnologia. São Paulo: Gaia, 2003, p.19. 
pelo aumento da produção agrícola que a revolução verde proporciona, incluindo o uso de novas tecnologias para superar as limitações impostas pelo meio ambiente, que, no entanto, gera uma maior insegurança tendo em vista o elevado grau de vulnerabilidade introduzida no sistema alimentar, a destruição da biodiversidade, os efeitos adversos no meio ambiente pela introdução de elementos poluidores, o êxodo rural e o aumento da violência no campo, dentre outros. Todos estes fatores contribuem para uma situação de dilema de segurança, em que a tentativa de aumentar a segurança apresenta o efeito oposto, gerando uma espiral de insegurança que torna cada vez mais instável o sistema internacional. Segundo Tang ${ }^{39}$, o dilema de segurança apresenta seis proposições que configuram sua presença:
(1) its ultimate source is fear, which is derived from the "universal sin of humanity";0 (2) it requires uncertainty over others' intentions; (3) it is unintentional in origin; (4) it produces tragic results; (5) it can be exacerbated by psychological factors; and (6) it is the fundamental cause of all human conflicts.

Ampliar a segurança alimentar utilizando o modelo de produção agrícola dominante apresenta falhas graves e gera mais insegurança. O IAASTD no Food Security in a Volatile World apresenta como uma de suas recomendações de natureza urgente para lidar com o tema de segurança alimentar o seguinte:

\begin{abstract}
Promote the diversification of production systems through inclusion of locally important species/ crops to develop a wide range of marketable natural products that can generate income for the rural and urban poor in the tropics and provide ecosystem services, such as soil and water conservation. ${ }^{41}$
\end{abstract}

\section{Direitos humanos}

O direito humano à alimentação foi anunciado enquanto um direito básico do homem na Declaração Universal dos Direitos Humanos (DUDH) de 1948, criando-se uma perspectiva legal e institucional so-

39 TANG, S. The Security Dilemma: A Conceptual Analysis. Security Studies, v. 18, n. 3, p. 587-623. doi: 10.1080/09636410903133050, 2009.

40 Segundo o próprio Tang (2008), Robert Jervis e John Herz apontam ser a fonte primária do dilema de segurança a estrutura anárquica do sistema internacional, o que concordamos.

41 In http://www.unep.org/dewa/agassessment/docs/10505_ FoodSecurity.pdf. Acesso em:05/08/16. bre o tema. ${ }^{42}$ No art. 25 da DUDH consta que "toda pessoa tem direito a um nível de vida suficiente para lhe assegurar a si e à sua família a saúde e o bem-estar, principalmente quanto à alimentação (...)", marcando formalmente o surgimento de uma obrigação as nações perante o ser humano. ${ }^{43}$

Em 1966 a ONU estabeleceu o Pacto Internacional dos Direitos Econômicos, Sociais e Culturais (PIDESC), o qual reconhecem o direito básico sobre uma alimentação adequada. ${ }^{44}$ Segundo Valente ${ }^{45}$, sem este Pacto não poder-se-ia discutir os outros direitos, uma vez que sem uma alimentação adequada, referindo-se a quantidade e qualidade suficientes, não há o direito à vida.

Aliás, o direito à vida é assegurado pelo Pacto Internacional de Direitos Civis e Políticos (PIDCP), em seu artigo $\mathrm{n}^{\circ} 6$, o qual estabelece que " $\mathrm{O}$ direito à vida é inerente à pessoa humana. Este direito deverá ser protegido pela lei. Ninguém poderá ser arbitrariamente privado de sua vida. "Somado a esse o artigo $\mathrm{n}^{\circ} 11$ do PIDESC declara que qualquer pessoa, independentemente de onde estiver em hipótese alguma poderá sentir fome, ou seja, todo ser humano tem o direito de não sentir fome, seguindo o direito de uma alimentação adequada e saudável - ambos ratificados pelo Brasil em 1992.

A FAO, nesse sentido, foi edificada para combater e eliminar a fome mundial, conforme ${ }^{46}$ ressalta:

Os Estados que adotam (aceitam) esta Constituição,
decidimos a promover o bem-estar geral,
intensificando, por sua parte, a ação individual e
coletiva com os fins de: elevar os níveis de nutrição
e de vida (...) e contribuir, assim (...) a libertar a
humanidade da fome; $[. . .]^{47}$

Precisa-se analisar que se necessita deixar de lado questões como fronteira, e questões econômicas para que as pessoas consigam comprar seus alimentos, ter condições de acesso ou possuir meios para produzir.

42 PIOVESAN, Flávia. Direitos humanos e o direito constitucional internacional. $13^{\circ}$ ed, p.6. São Paulo: Saraiva, 2007.

43 MÜLLER, Marcela. Direito fundamental à alimentação adequada no contexto das organizações internacionais. p.56. Curitba: Juruá, 2014.

44 Ibidem p.56.

45 VALENTE, Luiz Schieck. Direito Humano à Alimentação: desafios e conquistas. p.37. São Paulo: Cortez, 2002.

46 NUNES, Mérces da Silva. $\mathbf{O}$ direito fundamental à alimentação: e o princípio da segurança. p.52. Rio de Janeiro: Elseiver, 2008.

47 Ibidem FAO apud NUNES, 2008, p.52. 
Afinal, qualquer pessoa como sujeito de direito, tem o direito de contribuir para melhorar suas condições de existência e não somente esperar alguma atitude do Estado prover uma resposta aos problemas enfrentados pela população, como é a fome e a desnutrição. Percebe-se logo, a função fundamental do direito do livre acesso, tanto físico como econômico, à vida digna, o que inclui o alimento. ${ }^{48}$

Acerca disso, estabeleceu o Pacto Mundial de Segurança Alimentar (PMSA), de 1985, em seu art. $3^{\circ}$ :

\begin{abstract}
A realização da segurança alimentar mundial deve ser um objetivo integrante dos planos econômicos e sociais. As medidas devem ter por finalidade a consecução de três objetivos concretos: produzir um volume apropriado de alimentos, aumentar a estabilidade da oferta alimentar e assegurar o acesso aos alimentos às pessoas que deles necessitam. ${ }^{49}$
\end{abstract}

Ainda no contexto internacional, no ano de 2005, a FAO editou um documento denominado 'Diretrizes Voluntárias para Implementação do Direito Humano à Alimentação Adequada', direcionado ao contexto da segurança alimentar. Nele buscou-se firmar um conjunto de diretrizes, no qual os Estados executam e praticam o direito humano à alimentação em todos os níveis, repassando orientações para que os países possam implementar as políticas públicas que irão proporcionar e prover uma mínima qualidade de atendimento ao direito à alimentação. ${ }^{50}$

Em âmbito brasileiro, "[o] acesso à alimentação é um direito humano em si mesmo, na medida que a alimentação constitui-se no próprio direito à vida. Negar esse direito é, antes de mais nada, negar a primeira condição para a cidadania, que é a própria vida" ${ }^{\prime 51}$, mas somente em 2010 o direito fundamental à alimentação foi incluído à Constituição de 1988, no art. 6 por meio da Emenda Constitucional $n^{\circ}$ 64, passando a ser um direito social fundamental. ${ }^{52}$

48 MÜLLER, Marcela. Direito fundamental à alimentação adequada no contexto das organizações internacionais. p.57. Curitba: Juruá, 2014.

49 NUNES, Mérces da Silva. O direito fundamental à alimentação: e o princípio da segurança. PMSA apud NUNES, 2008, p. 54. Rio de Janeiro: Elseiver, 2008.

50 MÜLLER, Marcela. Direito fundamental à alimentação adequada no contexto das organizações internacionais. p.57-58. Curitba: Juruá, 2014.

51 MRE. MINISTÉRIO DAS RELAÇÕES EXTERIORES. Banco Mundial. [s/d]. Disponível em: <http://www.itamaraty. gov.br/pt-BR/politica-externa/diplomacia-economica-comercial-efinanceira/120-banco-mundial>. Acesso em: 01 jun. 2016.

52 Ibidem p.58.
As primeiras menções sobre o conceito de segurança alimentar no Brasil aparecem somente em 1985 no Ministério da Agricultura (MA) com o começo de uma proposta de Política Nacional de Segurança Alimentar (PNSA). Esta proposta visava responder todas as dificuldades e ausências no que correspondia compreender e alcançar autossuficiência na produção de alimentos e abrangeu a criação de um Conselho Nacional de Segurança Alimentar. ${ }^{53}$

Em 1986, com a I Conferência Nacional de Alimentação e Nutrição, o Brasil adotou um novo conceito de segurança alimentar, consolidando-se em 1994, com a I Conferência Nacional de Segurança Alimentar. ${ }^{54}$ No conceito e concepção brasileira:

\begin{abstract}
Segurança Alimentar e Nutricional consiste em garantir a todos as condições de acesso a alimentos básicos, seguros e de qualidade, em quantidade suficiente, de modo permanente e sem comprometer $\mathrm{o}$ acesso a outras necessidades essenciais, com base em práticas alimentares saudáveis, contribuindo assim para uma existência digna em um contexto de desenvolvimento integral da pessoa humana. ${ }^{55}$
\end{abstract}

O direito fundamental à alimentação encontra-se claro e assegurado na Constituição Federal (CF) de 1988, em diversas prescrições e artigos de lei. Inicialmente, ele está contido no próprio art. $1^{\circ}$ da $\mathrm{CF}$, quando o inciso III traz a dignidade humana como seu fundamento. Afinal a dignidade da pessoa humana só é garantida quando atendida suas condições existenciais mínimas e indispensáveis, como acesso à moradia, alimentação, saúde, educação, entre outras.

Além disso, constitui um dos objetivos da nação a própria erradicação da pobreza e da marginalização, reduzindo as desigualdades como prevê o art. $3^{\circ}$, inciso III da CF. Logo, deve o Estado adotar providências positivas e efetivas voltadas ao combate à pobreza e à marginalização, o que inclui a garantia do alimento.

Conforme o art. 4 o Brasil rege-se as suas relações internacionais pelos princípios como o da prevalência dos direitos humanos previsto no inciso II da CF. Sobre os direitos e garantias fundamentais segue no capítulo II da Constituição o art. $6^{\circ}$ aborda que "São direitos sociais a educação, saúde, o trabalho, a moradia, o lazer,

53 VALENTE, Luiz Schieck. Direito Humano à Alimentação: desafios e conquistas. p.45. São Paulo: Cortez, 2002.

54 Ibidem p.45.

55 NUNES, Mérces da Silva. $\mathbf{O}$ direito fundamental à alimentação: e o princípio da segurança. CNAN apud NUNES, 2008, p. 60. Rio de Janeiro: Elseiver, 2008. 
a segurança (...)". Já o art. $7^{\circ}$ continua a abordar os direitos dos trabalhadores urbanos e rurais, no qual visem à melhoria de sua condição social, para isso, o Estado deve garantir o salário mínimo que seja capaz de atender todas ás necessidades do ser humano e de sua família conforme o inciso IV.

É de competência da União também, previsto no art. $23^{\circ}$ combater os efeitos da pobreza, mas deve buscar-se eliminar todas as suas causas, trabalhando de forma efetiva para que exista uma melhoria na qualidade de vida das pessoas e da população.

O Sistema Nacional de Segurança Alimentar (SISAN), criado em 15 de setembro de 2006, pela Lei $\mathrm{n}^{\circ}$ 11.346 - Lei Orgânica de Segurança Alimentar e Nutricional (LOSAN), com o principal objetivo de garantir o direito à alimentação adequada, ${ }^{56}$

[o] SISAN tem por objetivos formular e implementar políticas e planos de segurança alimentar e nutricional, estimular a integração dos esforços entre governo e sociedade civil, bem como promover o acompanhamento, o monitoramento e a avaliação da segurança alimentar e nutricional no país. ${ }^{57}$

Além disso, conforme o art. $2^{\circ}$ da referida lei:

\begin{abstract}
A alimentação adequada é direito fundamental do ser humano, inerente à dignidade da pessoa humana e indispensável à realização dos direitos consagrados na Constituição Federal, devendo o poder público adotar as políticas e ações que se façam necessárias para promover e garantir a segurança alimentar e nutricional da população. ${ }^{58}$
\end{abstract}

Sob a compreensão dos citados artigos de lei até o momento, nota-se que o direito à alimentação, além de estar na essência da estruturação de direitos básicos ao homem, originário de documentos internacionais, foi sancionado e reconhecido por ser indispensável e são protegidos tanto na Constituição como em normas infraconstitucionais. Para além da realização dos direitos fundamentais ligados à segurança alimentar, que como explicado anteriormente, depende da adoção de políticas públicas que alterem o modelo existente no sentido

56 MÜLLER, Marcela. Direito fundamental à alimentação adequada no contexto das organizações internacionais. p.95. Curitba: Juruá, 2014.

57 SISAN. Sistema Nacional de Segurança Alimentar e Nutricional. Sistema Nacional de Segurança Alimentar e Nutricional. Brasília, 2003. Disponível em: < http://www4.planalto.gov.br/consea/acesso-a-informacao/institucional/conceitos/sistema-nacional-de-seguranca-alimentar-e-nutricional>. Acesso em: 07 jun. 2016. 58 Ibidem de empoderar seus destinatários, se torna necessário também o exame das implicações do atual modelo alimentar em outros direitos fundamentais. ${ }^{59}$

Conforme ficou consignado anteriormente, o modelo do sistema internacional de alimentos está ancorado na participação sem precedentes nas ETNs, que controlam senão toda, boa parte da cadeia produtiva alimentar. Assim, a construção do discurso baseado na falsa premissa de que é necessário o aumento da produção de alimentos para erradicar a fome tem as ETNs como os agentes securitizadores do tema alimentação, cuja audiência encontra boa receptividade por parte dos Estados.

A securitização é um ato de discurso ou linguagem que transforma um fenômeno que é originariamente pertencente a política para a área de segurança (etiquetar o assunto como sendo de segurança). Assim, a securitização da alimentação a partir das narrativas sobre a fome apresentou um objeto que se identificou com uma ameaça existencial potencial nas dimensões internacional e nacional. As narrativas encontram eco em uma audiência que se dispôs securitizar, o que justificou a adoção de medidas emergenciais ou recursos extraordinários para enfrentar a ameaça.

Securitizar é o que Buzan et $\mathrm{al}^{60}$ chamou de política do pânico, em que determinados assuntos de políticas públicas tornam-se confidenciais justificando-se como Raison d'État; direitos e garantias são suprimidas e poderes adicionais são conferidos aos agentes públicos, tudo em nome de um "bem maior". Trata-se de um processo intersubjetivo e prática auto-referida entre ator securitizador, objeto de securitização e audiência.

Além da problemática de supressão de direitos fundamentais em razão da securitização, o modelo atual baseado na monocultura possui um grande potencial de agressão ao meio ambiente (uso crescente de pesticidas, utilização indiscriminada de GMOs e grande consumo de energia para o transporte das commodities do local de produção para os centros de consumo), pois tende a destruir a biodiversidade e por em risco a soberania alimentar local, esclarece Shaw. ${ }^{61}$

59 AMIN, S.; PATEL, R.; SCHUTTER, O. D.; STEDILE, J. P. Food Movements Unite!: Strategies to Transform Our Food System (E. Holt-Gimenez, Org.). Oakland, CA: Food First Books, 2011.

60 BUZAN, B.; WVER, O.; WILDE, J. D. Security: A New Framework for Analysis. Boulder, Colo: Lynne Rienner Pub, 1997. 61 SHAW, D. World Food Security: A History since 1945. 2007 
Com isso, sob a pretensão de aumento da segurança alimentar o que temos é um aumento na insegurança alimentar pois todo sistema se torna ainda mais vulnerável às crises e gera ainda a insegurança ambiental e societal. ${ }^{62}$

\section{Governança global}

O problema da insegurança alimentar tem natureza complexa o que dificulta a eficácia de medidas resolutivas contundentes e sancionatórias. $\mathrm{O}$ avanço nessa área vai, portanto depender da articulação de interesses muitas vezes opostos, inclusive. Diversos canais formais e informais precisam ser construídos para conectar sociedade, iniciativa privada e governos nos âmbitos locais, regionais, federais e global. Canais esses que são fundamentais para a organização da sociedade e tempos de interdependência complexa ${ }^{63}$ entre estados, entre governos e nas relações internacionais de forma mais abrangente.

Conforme a complexidade dos atores e dos temas da política global aumentam, a possibilidade do uso da força, diminui e, com isso, enfraquecem as barreiras divisórias entre local, regional, nacional estrangeiro, assim como entre o publico e o privado. A formação da agenda política, econômica, social e cultural se torna sutil, difusa e muitas vezes altamente especializada e específica para situações ad hoc ou circunstanciais. E os diversos atores surtem efeitos recíprocos, muitas vezes atuando em um tabuleiro objetivando ganhos em outros.

Para tanto, pressupõe um processo continuo de acomodação de interesses conflitantes em busca de ações cooperativas, no âmbito, tanto das instituições formais e dos acordos coercitivos, como em regimes montados para buscar compromissos voluntários e via acordos informais. Assim, as instituições são complementadas por regimes de política internacional, formados a partir de um conjunto de explícitos e implícitos princípios, normas, regras e procedimentos de tomada de decisão

edition ed. Basingstoke England; New York: Palgrave Macmillan, 2007, p. 15.

62 VILLA, R. D. Multidimensional global security. Lua Nova: Revista de Cultura e Política, , n. 46, p. 99-118. doi: 10.1590/ S0102-64451999000100005, 1999.

63 KEOHANE, Robert O.; NYE, Joseph. Power and Interdependence: World Politics in Transition. Nova York: Longman, 2001. capaz de proporcionar a convergência das expectativas dos atores em uma determinada temática.

Os objetivos do desenvolvimento sustentável têm essa finalidade de proporcionar a convergência de esforços em determinadas temáticas. Mas precisam que sejam muito bem feitas as métricas de acompanhamento do cumprimento dessas metas e que haja ferramentas eficientes de revisão para adequar o acordado com os modelos de implementação e de acompanhamento disponíveis num determinado momento.

Um dos problemas do sistema é que estatísticas podem ser manipuladas sem necessariamente deixar de mostrar a realidade. São os próprios países e seus governos locais que fornecem dados sobre o cumprimento ou não das metas. Além disso, a questão da fome propriamente dita tem um interesse político crucial para os Estados e portanto as organizações internacionais multilaterais responsáveis pelo acompanhamento das metas, como a FAO e o Banco Mundial, podem ser vulneráveis à pressão política. Afinal, os Estados membros têm a liberdade de apontar ou substituir a qualquer momento os seus representantes nessas organizações e são os Estados que contribuem com o orçamento das organizações internacionais.

O Portal ODM ${ }^{64}$ no âmbito do Brasil, é um exemplo de ferramenta criada para acompanhar o cumprimento das metas, apresentando dados relacionados a elas em relação a cada um dos 5.564 municípios brasileiros. A iniciativa é resultado de uma parceria entre o Observatório de Indicadores de Sustentabilidade, o programa SESI do Paraná, o Sistema FIEP e o Instituto de Promoção do Desenvolvimento, sob a coordenação do Programa das Nações Unidas para o Desenvolvimento e apoio do Fundo das Nações Unidas para a Infância, o Movimento Nós Podemos Paraná, o Núcleo de Apoio a Políticas Públicas, o Ministério do Planejamento e a Secretaria Geral da Presidência da República.

A finalidade desse portal é permitir que a Administração, empresas e também a sociedade possam acompanhar a prática de seus municípios, envolvendo o atores em âmbito local no processo de implementação de políticas públicas. Todavia, ainda que as informações, estejam previstas para serem atualizadas em tempo real, nem sempre os dados oficiais estão disponíveis, apesar

64 FIEP. Portal ODM. Disponível em < http://www.portalodm. com.br > Acesso em 10 de outubro de 2016. 
da vigente Lei de Acesso a Informação.

A principal função do portal é traduzir a linguagem técnica dos dados contidos em documentos oficiais para o público em geral. As informações podem ser consultadas em relatórios dinâmicos que incluem números, gráficos e comparativos com as metas, pois as informações brasileiras são integradas ao sistema de informação da ONU, chamado DevInfo ${ }^{65}$. Por meio desse programa é possível gerar relatórios específicos, personalizados, cruzando os diferentes indicadores e comparando esses dados entre cidades, estados e regiões.

O DevInfo é um sistema de gerenciamento de dados relativos ao desenvolvimento humano. É uma ferramenta tecnológica para estocar, organizar e apresentar informações de uma maneira uniforme que facilite o compartilhamento. Esse software agrega indicadores previstos nos ODS e também outros definidos pelos usuários. Segue os padrões internacionais de estatística, funciona instalado e também online para facilitar o acesso público e disseminado aos seus registros. Porém se as pessoas responsáveis pela subida dos dados e indicadores não for honesta ou se houver falha quantitativa da verificação do cumprimento ou não da meta, todo o sistema vai ser alimentado com informações erradas e vai ficar comprometida a credibilidade da análise consolidada.

Outra dificuldade do sistema é dar tratamento de objetivo para algo que é Direito Humano. A linguagem de metas convida a uma "abordagem diacrônica e incremental: nós temos uma certa distância para atravessar, e assim partimos na direção do nosso destino e abordá-lo passo-a-passo" "66. Esse tipo de abordagem é imprópria em certos casos em que Direitos Humanos estão em jogo, o autor dá um exemplo marcante, se estivéssemos falando do direito humano de não ser escravizado, faria sentido traçar um plano de 25 anos com o objetivo de reduzir pela metade o número de escravos? ou de tornar a escravidão metade menos cruel?

Reconhecemos em diversos textos de Direitos $\mathrm{Hu}$ manos o direito à vida digna, dessa forma está previsto o direito humano de não ser submetido a instituições

65 DEVINFO. About DevInfo. Disponível em < http://www.devinfo.org/libraries/aspx/AboutDevInfo. aspx?'T=ADI\&PN=diorg/di_about.html $>$ Acesso em 10 de outubro de 2016.

66 POGGE, Tomas. The Hunger Games. Food ethics (2016) 1: 9. June 2016, Volume 1, Issue 1, p. 25 econômicas que façam com que milhares de pessoas previsível e evitavelmente não possam satisfazer suas necessidades básicas, fiquem doentes, tenham pior capacidade cognitiva, menor expectativa de vida e em pior qualidade. Vista sob esse prisma, a arquitetura jurídica orientada por metas e objetivos nesse caso é muito injusta, corresponde à tolerância com a morte de milhares de pessoas em virtude de doenças relacionadas à pobreza.

Para Pogge $e^{67}$, então a orientação teria de ser imediata, se a humanidade já dispõe dos meios para erradicar a pobreza extrema e a fome, seria o caso de dividir responsabilidades entre os diversos envolvidos na cadeia global de valor e de distribuição para que imediatamente houvesse a supressão total dessa intolerável violação aos Direitos Humanos. Não caberia margem de adaptação numa temática tão sensível. Para ele, a lógica de servir apenas como inspiração para futuras articulações de governança multistakeholder é muito modesta dada a crueldade do tema.

\section{Considerações finais}

Em conclusão, a relevância do presente projeto para as Relações Internacionais, como um todo e do Brasil, permeia as duas questões abordadas anteriormente. A má distribuição e a falta de acesso aos alimentos por parte da população deve ser de destaque como uma resultante da insegurança alimentar no contexto das discussões sobre o tema. Por se tratar de um tema não somente de interesse nacional, mas em nível internacional, pode-se dizer que o Brasil faz parte ao construir e colaborar com a busca da erradicação da fome e se constitui inegável a pertinência do tema, no sentido de colaborar no desenvolvimento das Relações Internacionais.

Quando desenvolvido o conceito de insegurança alimentar, infelizmente a civilização mundial teve que passar por desnecessárias Guerras Mundiais e uma enorme revolução social russa, em que 12 milhões de pessoas vieram a óbito devido à fome para que o ocidente abrisse os olhos e percebesse que a fome era uma realidade. Essa questão geopolítica foi analisada no início deste artigo e com isso foi mostrado que por isso os países conscientizaram-se sobre o problema e procuraram po-

67 POGGE, Tomas. The Hunger Games. Food ethics (2016) 1: 9. June 2016, Volume 1, Issue 1. 
líticas para que começasse uma mudança em nível global para resolve-la. Essa mudança teve sua materialização jurídica nas primeiras das conferências sediadas pela ONU para a solução do tema da insegurança ambiental em um cenário de pós-guerra. A partir desse encontro, originou-se a FAO e deram início a uma série de discussões e debates sobre medidas conjuntas para um melhor resultado para as populações subnutridas.

Para que essas medidas atingissem o seu real objetivo, a FAO teve um papel ilustre, pois fomenta até os dias atuais a realização de projetos em grande parte dos países, força para que haja debates por esse problema estar em sua agenda e faz estudos e, até mesmo, relatórios sobre o real estado da segurança alimentar nos países. Embora a FAO trabalhe no plano internacional para sanar a fome e a pobreza, ela busca a melhoria da segurança alimentar e o acesso de todos aos alimentos necessários e promove o desenvolvimento agrícola como uma estratégia para aumentar a produção de alimentos para todos, a fome vem sendo causada pela má distribuição e não por falta propriamente de alimentos.

Visto que segundo especialistas a população mundial em 2050 deve alcançar os 9 bilhões de pessoas, há uma necessidade de encontrar novas soluções para lidar com a questão da fome. Estudos, referenciados neste texto mostram que há alimento suficiente no mundo para o sustento diário de todos os habitantes do planeta e hoje existe mais comida que o necessário. A FAO reconhece que os países devem estudar e examinar o porquê de milhões de pessoas ainda passarem fome em um mundo que produz comida suficientemente para alimentar todos, assim, o problema parece ser não tanto a falta de comida, mas falta de vontade política. Sob esse panorama, a FAO desempenha diferentes funções sobre a sua atuação, cooperando e auxiliando os países no que tange a suas necessidades alimentares investindo em estudos de alimentação a partir de reuniões para estimular ações nacionais e internacionais. E sobre uma hipótese negativa, tendo em vista que é essencial uma nova redistribuição dos alimentos, e um menor desperdício, visto que uma parte da população passa fome; e outra parte são clinicamente obesos.

Por ser a temática relativa a Direitos Humanos, o modelo de governança focada em objetivos, metas e compromissos voluntários talvez não seja o ideal e precise haver algo mais contundente em termos de responsabilização dos países, dos órgãos da administração pú- blica e também da iniciativa privada. Precisa haver um esforço multistakeholder para mudança de paradigma que faça com que as instituições econômicas que ganham e perenizam o modelo capitalista atual deixem de fazer com que milhares de pessoas previsível e evitavelmente não possam satisfazer suas necessidades básicas, fiquem doentes, tenham pior capacidade cognitiva, menor expectativa de vida e em pior qualidade.

A luta pela erradicação da fome é um desafio ético estrutural que só pode ser vencido com alterações sistêmicas do modelo econômico vigente. Medidas mitigatórias tímidas, condenam milhões à morte, à doença ou à falta de qualidade de vida e portanto precisam ser substituídas e fomentadas por políticas mais eficazes e arrojadas. O modelo de metas adotado pela Agenda do Milênio e agora pela Agenda 2030 geram resultados positivos, mas muito aquém do necessário.

\section{ReferênCiAs}

AMIN, S.; PATEL, R.; SCHUTTER, O. D.; STEDILE, J. P. Food Movements Unite!: Strategies to Transform Our Food System (E. Holt-Gimenez, Org.). Oakland, CA: Food First Books, 2011.

BEURLEN, Alexandra. Direito humano à alimentação adequada no Brasil. 3.ed. Curitiba: Juruá, 2008.

BUZAN, B.; WVER, O.; WILDE, J. D. Security: A New Framework for Analysis. Boulder, Colo: Lynne Rienner Pub, 1997.

CASTRO, Josué de. Geografia da fome: o dilema brasileiro: pão ou aço. 10. ed. Rio de Janeiro: Antares, 1983.

COSTA, Claudia V.; BEGNIS, Heron Sergio M. Revista de Economia \& Relações Internacionais. Fome mundial: uma análise de suas causas e da atuação da FAO. Vol. 12(24), pp. 44-60, 2014.

DEVINFO. About DevInfo. Disponível em < http:// www.devinfo.org/libraries/aspx/AboutDevInfo. aspx?T=ADI\&PN=diorg/di_about.html $>$ Acesso em 10 de outubro de 2016.

FAO, WFP and IFAD (Food and Agriculture Organization of the United Nations, World Food Programme and International Fund for Agricultural Development). 2012. The state of food insecurity in the world 2012. Rome: FAO, 2012. Disponível em: < http://www.fao. 
org/docrep/016/i3027e/i3027e.pdf>. Acesso: 20 outubro 2016.

FAO, WFP and IFAD (Food and Agriculture Organization of the United Nations, World Food Programme and International Fund for Agricultural Development). The state of food insecurity in the world 2015. Rome: FAO, 2015. Disponível em: < http://www.fao.org/3/ a4ef2d16-70a7-460a-a9ac-2a65a533269a/i4646e.pdf> . Acesso: 20 outubro 2016.

FAO. Declaração de Roma sobre segurança alimentar mundial. Disponível em: <http://www.fao. org/wfs/>. Acesso: 20 outubro 2016.

FAO. Organização das Nações Unidas para a Alimentação e a Agricultura. O desperdício alimentar tem consequências ao nível do clima, da água, da terra e da biodiversidade - novo estudo da FAO. Roma, 2013. Disponível em: <http://www.fao.org/news/ story/pt/item/204029/icode/>. Acesso: 20 outubro 2016.

FAO. Organização das Nações Unidas para a Alimentação e a Agricultura. Food wastage footprint: Impacts on natural resources. 2013. Disponível em: <http://www.fao.org/docrep/018/i3347e/i3347e. pdf>. Acesso: 20 outubro 2016.

FIEP. Portal ODM. Disponível em < http://www.portalodm.com.br > Acesso em 10 de outubro de 2016.

KEARNS, Antony P. The Right to Food Exist via Customary Internacional Law. Suffok Transnational Law Review. Vol.22, n.1, pp. 223-257,1998-1999.

KEOHANE, Robert O.; NYE, Joseph. Power and Interdependence: World Politics in Transition. Nova York: Longman, 2001.

LEÃO, Marília (Org.). O Direito Humano à Alimentação Adequada e o Sistema nacional de Segurança Alimentar e Nutricional. Brasília: ABRANDH, 2013. MRE, Ministério das Relações Exteriores. Banco Mundial. [s/d]. Disponível em: <http://www.itamaraty.gov. $\mathrm{br} / \mathrm{pt}-\mathrm{BR} /$ politica-externa/diplomacia-economica-comercial-e-financeira/120-banco-mundial>. Acesso em: 01 jun. 2016.

MÜLLER, Marcela. Direito fundamental à alimentação adequada no contexto das organizações internacionais. Curitba: Juruá, 2014.

NUNES, Mérces da Silva. O direito fundamental à alimentação: e o princípio da segurança. Rio de Janeiro: Elseiver, 2008.

ONU. The Millennium Development Goals Report. 2015. Disponível em: < http://www.un.org/millenniumgoals/2015_MDG_Report/pdf/MDG\%20 2015\%20rev\%20(July\%201).pdf > Acesso: 20 de outubro de 2016

PEARSON, Craig. A fresh look at the roots of food insecurity. In: RAYFUSE, Rosemary; WEISFELT, Nicole (Orgs.). The challenge of food seccurity: internacional policy and regulatory frameworks. Cheltennham, UK: Edward Elgar, 2012.

PIOVESAN, Flávia. Direitos humanos e o direito constitucional internacional. $13^{\circ}$ ed, p.6. São Paulo: Saraiva, 2007.

POGGE, Thomas e MEHTA, Krishen. Global tax fairness. Nova York: Oxford University Press, 2016, p. 291.

POGGE, Tomas. The Hunger Games. Food ethics (2016) 1: 9. June 2016, Volume 1, Issue 1, pp 9-27 Disponível em: < http://link.springer.com/ article/10.1007\%2Fs41055-016-0006-9\#aboutarticle > Acesso em 10 de outubro de 2016

SHAW, D. World Food Security: A History since 1945. 2007 edition ed. Basingstoke England ; New York: Palgrave Macmillan, 2007

SHIVA, V. Monoculturas Da Mente. Perspectivas Da Biodiversidade E Biotecnologia. São Paulo: Gaia, 2003; CARSON, R. Primavera silenciosa. Editora Gaia, 2015.

SISAN. Sistema Nacional de Segurança Alimentar e Nutricional. Sistema Nacional de Segurança Alimentar e Nutricional. Brasília, 2003. Disponível em: <http:/ / www4.planalto.gov.br/consea/acesso-a-informacao/ institucional/conceitos/sistema-nacional-de-seguranca-alimentar-e-nutricional>. Acesso em: 07 jun. 2016.

VALENTE, Luiz Schieck. Direito Humano à Alimentação: desafios e conquistas. São Paulo: Cortez, 2002.

VILLA, R. D. Multidimensional global security. Lua Nova: Revista de Cultura e Política, , n. 46, p. 99118. doi: 10.1590/S0102-64451999000100005, 1999.

ZIEGLER, Jean. Destruição em massa: Geopolítica da fome. São Paulo: Cortez, 2013. 


\section{OUTROS ARTIGOS}




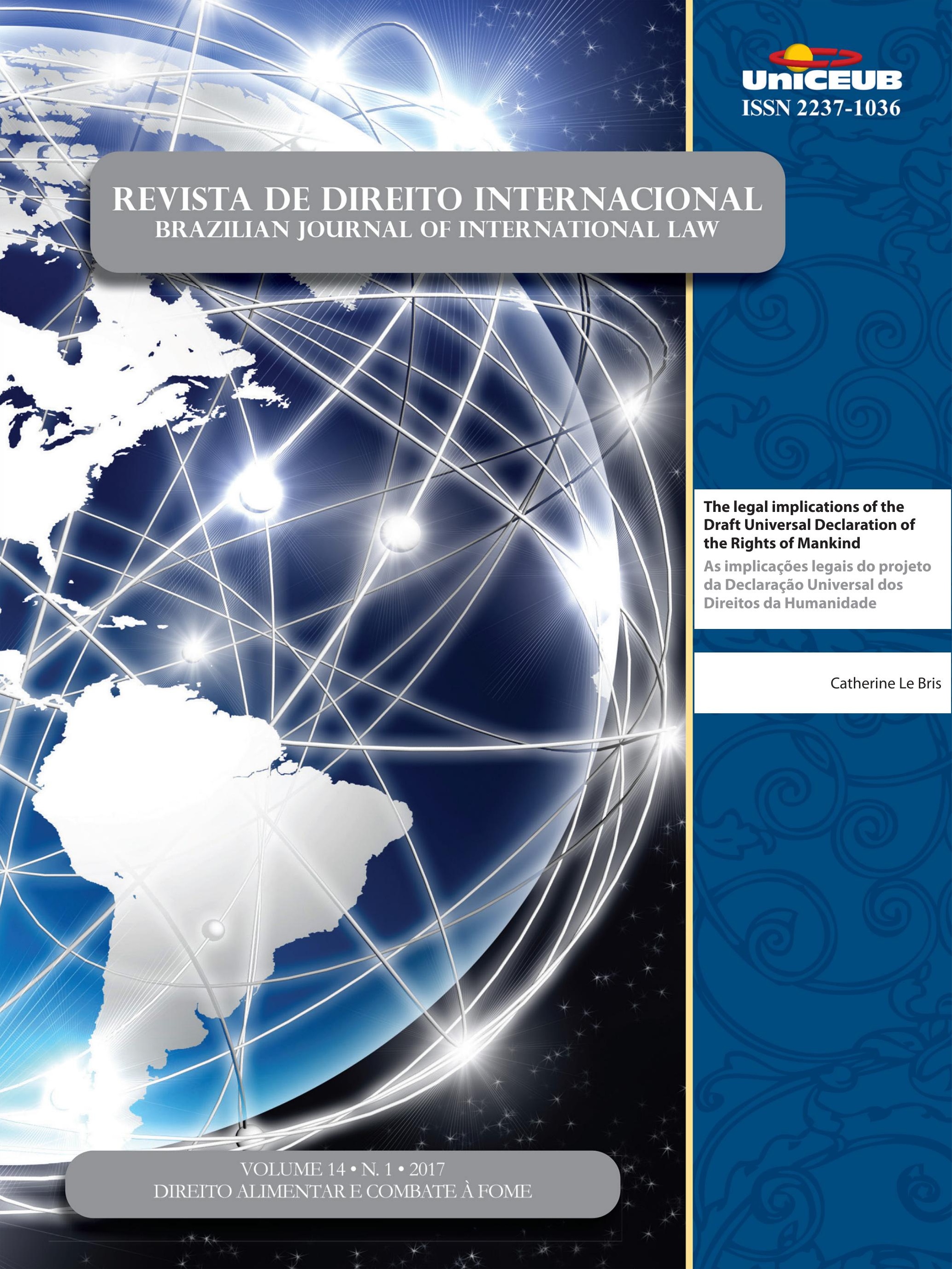




\title{
The legal implications of the Draft Universal Declaration of the Rights of Mankind*
}

\author{
As implicações legais do projeto da \\ Declaração Universal dos Direitos da \\ Humanidade
}

Catherine Le Bris**

\begin{abstract}
On 25th September 2015, the Draft Universal Declaration of the Rights of Mankind was presented to the French President François Hollande by the former Minister of Environment Mrs. Corinne Lepage and her team. What is the contribution of this Declaration? What is meant by Rights of Mankind? Are these new rights useful? This article aims to answer these questions by defining the rights of mankind, distinguishing them from human rights and putting them into perspective together with the duties towards mankind. This essay also deals with the institutional implications of this Declaration: Should mankind be represented by some sort of entity or body in order for it to exercise these rights? Who is entitled to speak on behalf of mankind?
\end{abstract}

Keywords: Universal Declaration of the Rights of Mankind. Draft. Normative and institutional implications.

\section{INTRODUCTION}

The rights of mankind ${ }^{1}$ or other human rights pertaining to the so-called "third generation rights" 2 do not have a good reputation. Skeptics consider them as being wishful thinking, ${ }^{3}$ vague ideals in respect of which attempts are made without success to make them resemble legal rights, while the bitterest skeptics only view them as a threat to freedoms. ${ }^{4}$

* Recebido em 14/02/2017

Aprovado em 21/02/2017

** Researcher at the National Centre for Scientific Research (Centre National de la Recherche Scientifique (CNRS), France) Institut des Sciences Juridique et Philosophique de la Sorbonne Université Paris 1 Panthéon-Sorbonne. Member of the Drafting Group for a Universal Declaration of the Rights of Mankind, drafed at the request of Mr. François Hollande, President of the French Republic under the lead of the Minister Mrs. Corinne Lepage. E-mail: catherinelebrisherve@gmail.com.
1 This article is a translation of an article drafted in French that was published in LE BRIS, Catherine. Le projet de déclaration universelle des droits de l'bumanité de 2015: implications et perspectives juridiques. 2016. Available in: <https://revdh.revues.org/2214\#text $>$. Access in: 4 out. 2015.

2 On a critical approach of the notion of third generation rights, see infra.

3 FRÉDÉRIC, Sudre. Droit international et européen des droits de l'homme. 9. ed. Paris: Presses universitaires de France, 2008, p. 110.

4 WECKEL, Philippe. Le rapport Lepage sur les droits de l'bumanité et le concept de l'bumanité indivisible. 2015. Available in: <www.sentinelle-droit-international.fr/?q=content/le-rapport-lepage-sur-les-droits-de-lhumanit $\% \mathrm{C} 3 \% \mathrm{~A} 9$-et-le-concept-de-lhumanit $\% \mathrm{C} 3 \% \mathrm{~A} 9$-indivisible $>$. Access in: 22 fev. 2015. "Face aux droits de la personne que vaudraient ces droits de l'espèce humaine, en tant qu'espèce vivante, attribués à une entité abstraite et globale, l'humanité? Au demeurant un catalogue des droits et devoirs suscite intuitivement l'hostilité des spécialistes des droits de l'homme". ("As far as human rights are concerned, the question arises as to what the role of these rights of mankind would be, if such rights were to be granted to an 
However, there are fewer authors who, emphasizing the potential of these rights, announce the entry in a new legal era: "With the help of mankind and that of the human aspect of international law, law should move forward and evolve without losing sight of its primary component, namely, the human society". ${ }^{5}$ Sometimes perceived as a promise and sometimes as a pipe dream, the rights of mankind give rise to conflicting lines of thought. While it is true that ideology is a system of images, ideas, philosophical or ethical principles, global stereotypes and organization of powers, ${ }^{6}$ the rights of mankind are the ideological rights par excellence: they bear a "World System" in themselves. ${ }^{7}$ Furthermore - and this also explains the aforementioned conflicting lines of thought - the rights of mankind serve as a catalyst of paradoxes. Echoing global concerns, these rights aim at solving what the philosopher Emmanuel Kant had described as "the greatest problem for the human race" and, thus, they are of an ambitious character. Yet, the realization of these rights requires, after all, the adoption of small-scale actions that, combined together, can ultimately reach their desired goal.

Historically, the ultimate goal of law has always been mankind. First, according to Stoic philosophy in Rome and subsequently, in the views of Vitoria, Suarez or Grotius, jus gentium would already be very close to a set of rights concerning mankind as a whole. ${ }^{9}$ However,

abstract and global entity (a living species) such as mankind? Moreover, an enumeration of rights and duties intuitively prompts a hostile reaction from human rights experts").

5 "L'humanité en tant qu'élément contribuant au développement progressif du droit international contemporain". SOMPONG, Sucharitkul. L'avenir du droit international dans un monde pluriculturel, colloque de l'Académie de droit international de La Haye. The Hague: Martinus Nijhoff Publishers, 1984. p. 427.

6 SERVIER, Jean. L'idéologie. Paris: PUF collection, 1982. p. 4

7 Expression forged by M. Griaule, quoted in SERVIER, Jean. L'idéologie. Paris: PUF collection, 1982.

8 See the "Fifth proposal" in KANT, Emmanuel. Idée d'une histoire universelle du point de vue cosmopolitique. Available in: <http:// classiques.uqac.ca/classiques/kant_emmanuel/idee_histoire_univ/ Idee_histoire_univ.pdf > . Access in: 21 mar. 2017. Pour la paix perpétuelle: projet philosophique, suivi d'un choix de textes sur la paix et la Guerre d'Erasme à Frend, translation, introduction, selection of texts and notes by Joël Lefebvre, Lyon, Presses universitaires de Lyon, collection "Le Livre de Poche",: "The greatest problem for the human race, to the solution of which Nature drives man, is the establishment of a universal civil society that administers law among all members of mankind". p. 121

9 The notion of jus gentium was used to name a wide variety of situations; in some of its widely varied meanings, it resembles a "general law of the universal society of mankind": see, in this regard, FORIERS, ano Apud TRUYOL Y SERRA, Antonio. Théorie this right of mankind sometimes forms an integral part of natural law and it is thus viewed not as a "small" set of rights (right of bumankind) but as a "great" set of norms ${ }^{10}$ concerning mankind (law of humankind). Only much later, when moral proved to be insufficient to protect human race from itself, mankind became the subject-matter of positive law. The "interests of humanity" and the "laws of humanity" were first used to humanize the armed conflicts. ${ }^{11}$ The prohibition of crimes against humanity itself was established in the aftermath of the Second World War in 1945. ${ }^{12}$ At that time, the main goal of the Charter of the United Nations was also to save "humankind" from the "untold sorrow" brought to it, ${ }^{13}$ this humankind being now considered as a "family" under the Universal Declaration of $\mathrm{Hu}$ man Rights. ${ }^{14}$ While Second World War contributed to an acceleration the collapse of the colonial empires, the legal aspect of mankind takes on a new dimension: in the context of the New International Economic Order, the States that emerged from decolonization call for solidarity and consider that mankind can serve as a basis for it. ${ }^{15}$ At the same time, technological discoveries rein-

du droit international public: cours general. Boston, 1981. p. 34. Available in: <http://referenceworks.brillonline.com/entries/the-hagueacademy-collected-courses/*-ej.9780792320500.009_443>. Access in: 21 mar. 2017. For further details on this matter, refer to our work: LE BRIS, Catherine. L'bumanité saisie par le droit international public. Paris: LGDJ, 2012. p. 6 et seq.

10 CARBONNIER, Jean. Flexible droit. 8. ed. Paris: LGDJ, 1995. p. 93 et seq.

11 See in particular the St. Petersburg Declaration (Declaration Renouncing the Use, in Time of War, of certain Explosive Projectiles, 11 December 1868) aimed at conciliating "the necessities of war with the laws of humanity as well as the preamble of the Convention (IV) respecting the Laws and Customs of War on Land and its annex (The Hague, 18 October 1907) where the Contracting Parties state that they are animated by the desire to serve "the interests of humanity" and to ensure that "in cases not included in the Regulations adopted [...], the inhabitants and the belligerents remain under the protection and the rule of the principles of the law of nations, as they result from the usages established among civilized peoples, from the laws of humanity, and the dictates of the public conscience".

12 See the Agreement for the Prosecution and Punishment of the Major War Criminals of the European Axis and the Charter of the International Military Tribunal.

13 Preamble of the Charter of the United Nations of 26 June 1945.

14 See the preamble of the Universal Declaration of Human Rights of 10 December 1948.

15 See in particular the recourse to the notion of "common heritage of mankind", which, on Professor Pierre-Marie Dupuy's opinion, makes reference to "normative strategies knowingly implemented by a group of States: those pertaining to the Third World, which come together in particular under the banner of the "Non-Aligned 
force the sense of belonging to the human race. The Earth is now perceived as Armstrong contemplated it from the Moon: as a unity. Astronauts are regarded as "envoys of mankind", ${ }^{16}$ outer space activities are deemed to be "province of all mankind" 17 and the moon and other celestial bodies are the "common heritage of mankind". ${ }^{18}$ The exploration of Antarctica and the discovery of the seabed areas give rise to the adoption of a similar course of action: these new spaces must also be managed in the interest of mankind. ${ }^{19}$ Everyone wants to benefit from these developments: in 1975, the Declaration on the Use of Scientific and Technological Progress in the Interests of Peace and for the Benefit of Mankind has been adopted..$^{20}$ In the course of time, as a result of the ecological disasters and the globalization of threats, solidarity becomes a necessity. Mankind is now deemed "a concrete whole". ${ }^{21}$ Furthermore, according to the terms of the Rio Declaration on Environment and Development, 1992, the "integral and interdependent nature of the Earth, our home" 22 has been recognized. Anyhow, when it comes to mankind, it is difficult to severe the object of the protection from the issue related to the subject of law, as both elements are closely linked. The Convention on the Law of the

Movement"'”: Dupuy Pierre-Marie, "Dialogue onirique avec Wolfgang Friedmann: sur les évolutions du droit international entre la fin des années soixante et la veille du XXIe siècle”. RUDA, Jose. Liber amicorum in memoriam of judge José Maria Ruda. The Hague: Kluwer law international, 2000. p.18.

16 Art. 5 of the Treaty on Principles Governing the Activities of States in the Exploration and Use of Outer Space.

17 See Art. 1 of the Treaty on Principles Governing the Activities of States in the Exploration and Use of Outer Space, including the Moon and Other Celestial Bodies, New York, 27 January 1967: "The exploration and use of outer space $[\ldots]$ shall be the province of all mankind."

18 See Art. 11(1) and Art. 1(1) of the Agreement Governing the Activities of States on the Moon and Other Celestial Bodies.

19 See in particular the preamble of the Antarctic Treaty of 1 December 1959 whereby reference is made to "the interest of all mankind", and Article 136 de la United Nations Convention on the Law of the Sea (Montego Bay, 10 December 1982, hereinafter the "United Nations Convention on the Law of the Sea") that characterizes the Area and its resources as "common heritage of mankind".

20 See resolution 3384 (XXX) of General Assembly of the United Nations of 10 November 197

21 MOREAU DEFARGES, Philippe. L'humanité, ultime "grande illusion" du XXème siècle? Politique étrangère, n. 3, 1999. p. 701.

22 UNITED NATIONS. Report of the United Nations Conference on Environment and Development. Available in: <http://www.globalforestcoalition.org/wp-content/uploads/2010/12/Rio-Declaration-onEnvironment-and-Development-principles.pdf $>$. Access in: 21 mar. 2017.
Sea confirms the foregoing: pursuant to Article 137, "all rights in the resources of the (seabed) area" ${ }^{\prime 23}$ are vested in mankind as a whole. Likewise, in the field of criminal law, according to the International Criminal Tribunal for the Former Yugoslavia, "[b]orders should not be considered [...] as a protection for those who trample underfoot the most elementary rights of humanity". ${ }^{24}$

The Draft Universal Declaration of the Rights of Mankind is an integral part of this movement towards the establishment of new rights for all human beings. It was at the Environmental Conference, organized by the French government in October 2014, that the suggestion was made when the President of the French Republic, Mr. François Hollande expressed his will that "after the rights of persons [...] it was time to lay down basis for the rights of mankind". ${ }^{25}$ Subsequently, Mrs. Corinne Lepage, former Minister for the Environment in France, ${ }^{26}$ who was responsible for allowing such a proposal to become a reality and her drafting team submitted a report on this issue to the President of the French Republic on 25 September 2015. ${ }^{27}$ This report proposes a draft Declaration recognizing six rights of mankind (the right to the environment, the right to development, the right to the common and global heritage, the right to common goods, the right to peace and the right to have freedom of choice to determine

23 Art. 137(2) of the United Nations Convention on the Law of the Sea.

24 ICTY, Prosecutor c. Tadic, case n IT-94-1, 2 October 1995, Decision, $\int 58$.

25 See the mission statement by the President of the French Republic Mr. François Hollande addressed to Mrs. Corinne Lepage dated 4 June 2015, which is contained in LEPAGE CORINNE ET EQUIPE DE RÉDACTION. Déclaration universelle des droits de l'bumanité, rapport à l'attention de Monsieur le Président de la République. 2015. p. 7 et seq. Available in: <http://www.ladocumentationfrancaise.fr/var/storage/rapports-publics/154000687.pdf>. Access in: 23 fev. 2016.

26 From 1995 to 1997.

27 LEPAGE CORINNE ET EQUIPE DE RÉDACTION. Déclaration universelle des droits de l'bumanité, rapport à l'attention de Monsieur le Président de la République. 2015. Available in: <http://www.ladocumentationfrancaise.fr/var/storage/rapports-publics/154000687. pdf $>$. Access in: 23 fev. 2016. Regarding this Draft Declaration, see in particular: DELZANGLES, Hubert. Remise de la Déclaration des droits de l'humanité: quelle place pour la protection de l'environnement?. Actu Environnement, 2015. Available in: <https:// www.actu-environnement.com/ae/news/hubert-delzangles-declaration-droits-humanite-place-protection-environnement-25834. php4> Access in: 21 mar. 2017.; DROITS de l'humanité. La Semaine Juridique - Édition Générale, n. 50, 2015. p. 2268; OTTOU, Alix; DORIS, Marion. Vers une déclaration universelle des droits de l'humanité?. Revue des droits de l'homme. 2016. Available in: <https:// revdh.revues.org/1769>. Access in: 21 mar. 2017. 
its own fate) and six duties towards mankind (the duty to ensure respect for the rights of mankind, the duty to preserve environmental heritage and resources, the duty to preserve climate equilibrium, the duty to guide scientific and technical progress, the duty to promote sustainable human development, the duty to ensure the effectiveness of the principle, rights and duties of the Declaration); these rights and duties are coupled with four guiding principles ${ }^{28}$ (the principle of responsibility, equity and solidarity, the principle of the dignity of mankind, the principle of the continuity of the existence of humanity, the principle of non-discrimination against future generations) that serve as their basis and guide their implementation. This Draft Declaration was formally presented at the Climate Conference (COP21) in Paris in 2015. ${ }^{29}$ At the time of the adoption of the Paris Agreement on 12 December 2015, President François Hollande emphasized that "to human rights we have just added the rights of mankind." ${ }^{30}$ The Agreement itself describes climate change, by linking, for the first time, such characterization to human rights, as "a common concern of humankind" ${ }^{31}$ In the long term, the Draft Declaration could be placed on the agenda of the UN General Assembly for its consideration and adoption. ${ }^{32}$ The Declaration is intended to become a soft law instrument. The use of soft law is particularly appropriate in this scenario, as the rights of mankind may disrupt the mechanisms of classical international law.

28 See the Draft Universal Declaration of Rights of Mankind reproduced in the Annex to this document. For a commentary on every article of this Declaration. LEPAGE CORINNE ET EQUIPE DE RÉDACTION. Déclaration universelle des droits de l'bumanité, rapport à l'attention de Monsieur le Président de la République. 2015. Available in: $<$ http://www.ladocumentationfrancaise.fr/var/storage/rapportspublics/154000687.pdf>. Access in: 23 fev. 2016.

29 An official side event concerning the draft Declaration was organized at the French Pavilion during the COP21.

30 L'ELYSÉE, Palais de. Tweet of 12 December 2015: Available in: $<$ https://twitter.com/elysee/status/675771304381964288>. Access in: 23 fev. 2016.

31 The Preamble of this Agreements establishes that: "Acknowledging that climate change is a common concern of humankind, Parties should, when taking action to address climate change, respect, promote and consider their respective obligations on human rights, the right to health, the rights of indigenous peoples, local communities, migrants, children, persons with disabilities and people in vulnerable situations and the right to development, as well as gender equality, empowerment of women and intergenerational equity". LE BRIS, Catherine. Les changements climatiques, une préoccupation pour l'bumanité. Available in: <https://theconversation.com/ les-changements-climatiques-une-preoccupation-pour-lhumanite-52708>. Access in:23 fev. 2016.

32 The Draft Declaration was forwarded by President François Hollande to the United Nations Secretary-General on 28/04/2016.
Indeed, in the Westphalian order, the normative space is identified with the State, the temporal power rest with sovereignties and hence the legal landscape appears relatively peaceful "under the reassuring sign of unity and stability". ${ }^{33}$ On the contrary, humanity reflects a "global notion in space and in time" 34 : it displaces the frozen time of the State in favor of the changing time of human needs and pushes back the boundaries in a quest of universality. Against this background, the rights of mankind cannot be designed to take precedence abruptly over sovereignty. However, between soft law and hard law, there are bridges: through practice and belief in these practices, the norms set forth in this Declaration could eventually become international customary law. Some of them could also eventually be included in one or more conventions. This Declaration could thus be only the first step in a relatively long process.

For this process to begin, however, several issues must first be examined: What is the meaning of this entity, mankind, in whose favor rights will be granted? How the rights of mankind can be defined? Are these rights useful? And what is the impact of the duties towards mankind in this context? All these questions are mingled with fears: concerns are raised about how these new rights will interplay with human rights ${ }^{35}$ and one can wonder who will be able to exercise these rights granted to this entity called mankind whose notion seems elusive. Therefore, the fact of underscoring the normative (I) and institutional (II) implications of this Draft Declaration will allow for its potential to be identified and, beyond the legal utopia, fully realized.

\section{RIGHTS OF MANKIND AND DUTIES TOWARDS MANKIND: NORMATIVE IMPLICATIONS OF THE Draft Declaration}

The vision of mankind as holder of rights is "as revolutionary on a global scale as the integration into the French constitutional law of the eighteenth century of the concept of Nation as holder of sovereignty re-

33 DELMAS-MARTY, Mireille. Trois défis pour un droit mondial. Paris: Éditions du Seuil, 1998. p. 92.

34 DUPUY, René-Jean. La communauté internationale entre le mythe et l'bistoire. Paris: Economica, 1986. p.169.

35 See WECKEL, Philippe. Título. Local: editora, ano. this Declaration would "intuitively prompt a hostile reaction from human rights experts". 
placing the monarch". ${ }^{36}$ This "vision" has been expressed by means of variety of terms: while some authors have sought to stress the biological unity of mankind by making reference to the "rights of the human species", 37 others have emphasized the social implications of these rights ("rights of human solidarity"), ${ }^{38}$ their scope of application ("global rights") 39 or their philosophical impact ("rights of the "human family"). ${ }^{40}$ The notion of "rights of mankind" is the most stable and widespread: it has been used since the end of the nineteenth century in official texts, ${ }^{41}$ and has been included in a number of books, ${ }^{42}$ articles $^{43}$ or academic works. ${ }^{44}$ This notion

36 PANCRACIO, ano Apud TERRÉ, François. L'humanité, un patrimoine sans personne. In: ARDANT, Philippe. Droit et politique à la croisée des cultures. Paris: LGDJ, 1999. p. 346.

37 HUBER, Gérard. Le clonage humain est-il un crime contre l'humanité. Droit et économie, n. 85, 1999. p.23.

38 NICIU, Martian I. Le patrimoine commun de l'humanité en droit international maritime et en droit spatial Annuaire de droit maritime et océanique, 1995. p. 16.

39 WEISS, Edith Brown. Justice pour les générations futures: droit international: patrimoine commun et équité intergénérations. Paris: Éditions Sang de la terre, Unesco, 1994. p. 89 et seq.

40 DELMAS-MARTY, Mireille. Europe du marché, Europe des droits de l'homme. In: GROS, François; HUBERT, Gérard. Vers un anti destin? Patrimoine génétique et droits de l'bumanité. Paris: Odile Jacob, 1992. p. 415.

41 In 1919, during the Paris Peace Conference, the British delegation stated that the offenders have trampled underfoot international law and the sacred rights of mankind [Translation]. GRAVEN, Jean. Les crimes contre l'humanité, RCADI, v. 76, 1950. p. 447.

42 See in particular the works by French Professor René-Jean Dupuy concerning the concept of mankind and, especially. DUPUY, René-Jean. La communauté internationale entre le mythe et l'histoire. Paris: Economica, 1986. p. 152 (whereby reference is made to "general rights of mankind") and DUPUY, René-Jean. L'bumanité dans l'imaginaire des nations. Paris: Julliard, 1991. p. 200. ("the recognition of mankind and their rights"). See also BEDJAOUI, Mohamed. Pour un nouvel ordre économique international. Paris: UNESCO, 1978. p. 230. "Droits de l'humanité tout entire". "The rights of mankind as a whole".

43 CARRILLO-SALCEDO, Juan Antonio. Le concept de patrimoine commun de l'humanité. In: HOMMAGE à René-Jean Dupuy, Ouvertures en droit international. Paris: Pedone, 2000. p. 61; CASSAN, Hervé. Humanité et développement: quelques remarques prospectives. In: FLORY, Maurice; HENRY, Jean-Robert. MAHIOU, Ahmed. La formation des norms en droit international du développement. Paris: CNRS, 1984. p. 200-201; DUPUY, Pierre-Marie. Humanité, communauté et efficacité du droit. In: DUPUY, René-Jean. Humanité et droit international: mélanges. Paris: Pedone, 1991. p. 137; KAMTO, Maurice. La volonté de l'État en droit international. RCADI, v. 310, 2004. p. 327; KOUASSI Kanga. Le concept de patrimoine commun de l'humanité et l'évolution du droit international public. Revue juridique et politique: indépendance et cooperation, 1995. p. 951. (la reconnaissance de droits à l'humanité); TRINDADE, Antônio Augusto Cançado. International law for humankind: towards a new jus gentium (I) et (II). General course of public international law, RCADI, v. 316, 2005. p. 328.

44 DATONOU, Dieudonné. Du concept de patrimoine commun de has also been used in international instruments ${ }^{45}$ and in court $^{46}$. Efforts to define these rights of mankind have proved to be necessary, although sometimes the resulting definitions have created some degree of confusion with notion of human rights $(A)$. It is by drawing a clear distinction between the two notions that the scope of the rights of mankind and their corollary - the duties towards mankind - can be fully assessed (B).

\subsection{Rights of mankind and human rights: between autonomy and interdependence}

Mankind, in the definition given by the French philosopher Auguste Comte, is an "immense and eternal social unity", ${ }^{47}$ bound by solidarity. It is composed of both the living and "the unborn". ${ }^{48}$ Moreover, mankind covers all individuals and groups, in particular peoples, non-governmental organizations and States and also embraces all generations. This definition is reproduced in the draft Declaration: " $[\mathrm{M}]$ ankind, which includes all human individuals and organizations, covering past, present and future generations". While according to the analyses carried out by the French historian Ernest Renan the nation relies heavily on the past legacy, the legal aspect of mankind is of a prospective nature rather than a retrospective one: it "embodies the future rather than the present day. It would represent eternity if history were not to come to an end". ${ }^{49}$

Mankind, in its capacity of holder of rights, is indivisible. It must be regarded as an inextricable and inseparable combination of individuals, groups and

l'bumanité aux droits de l'bumanité, étude historico-juridique du concept de patrimoine commun de l'bumanité em droit international, excerpta ex dissertatione ad doctoratum in utroqueiure. Roma: Pontificia Università Laternense, 1995. $145 \mathrm{p}$.

45 Regarding binding instruments, see Art. 137(2) of the United Nations Convention on the Law of the Sea: "All rights in the resources of the [...] Area are vested in mankind as a whole" (Emphasis is ours).

46 See ICTY, Prosecutor v. Tadic, 2 October 1995, cited above, $\mathbb{S}$ 58 ("the most elementary rights of humanity"). In the Barbie case, before the French courts, the Attorney-General Dontewille has made reference several times to the "rights of mankind": see Ruzié David, «Commentaire sous Cass. Crim, 6 octobre 1983, Barbie (Report by M. Le Conseiller Le Guhenec ; Conclusions de M. L’Avocat Général Dontenwille et arrêt) », La Semaine Juridique (JCP), 1983, II, 20107.

47 GRAVEN, Jean; CASSIN, René. Le difficile progrès du règne de la justice et de la paix internationales par le droit. des origines à la Société des Nations. Paris: Pedone, 1970. p. 277.

48 KOFMAN, Sarah. Penser l'humanité. Actes: droit et humanité: Les cahiers d'action juridique, n. 67-68, Sep. 1989, p. 9.

49 DUPUY, René-Jean. Réflexions sur le patrimoine commun de l'humanité. Droits, n.1, 1985. p. 69. 
generations. ${ }^{50}$ In practice, each generation does not go on the stage of history "as just one man" nor does it leave it "as a group", ${ }^{11}$ as generations intermingle. This reality has not only philosophical implications, but also legal and litigious consequences: if mankind is a unity, this means that the so-called rights of "future generations" are only one aspect of the rights of mankind and therefore, these rights are not to be understood as an autonomous notion. Against the background, "future" generations cannot, when they become "present generations" turn against "past" generations.

In the Draft Universal Declaration of the Rights of Mankind of 2015, mankind and nature are deemed to be interdependent. In other words, the Draft Declaration excludes those conceptions that separate mankind from nature: it refuses to view the environment as an object that is at the service of mankind. However, it does not characterize nature as a legal person. It establishes a third way, which is that of nature as a project ("nature-projet") ${ }^{52}$ : such a perspective reflects an eco-anthropocentric approach, according to which mankind and nature are inextricably linked. The reference to "living species" in the Declaration - which had been suggested by the American essayist Jérémy Rifkin, a member of the working group of Mrs. Corinne Lepage - aims at reflecting this interdependence between the human species and the other species.

The rights of mankind, which have been conceived along the lines of their holder, feature two major characteristics: they are of a collective and of an intergenerational nature.

The notion of "collective right" is ambiguous. It can mean that the right concerned can only be collectively exercised, particularly since the right itself - its enjoyment - is of an individual nature (along the lines of the right to strike, for instance). However, it can also mean that the holder of the right is a group and it is in this sense that it must be construed here. The rights of mankind, which are granted in favor of the human community,

50 CHEMILLIER-GENDREAU, Monique. Humanité et souveraineté, essai sur la fonction du droit international. Paris: La Découverte, 1995. p. 358.

51 OST, François. Elargir la communauté politique : par les droits ou par les responsabilités? Réflexions sur les enjeux éthiques de la crise écologique. In: BERNS, Thomas. Le droit saisi par le collectif. Bruxelles: Bruylant, 2004. p. 258.

52 OST, François. La nature hors la loi: l'écologie à l'épreuve du droit: l'écologie à l'épreuve du droit. Paris: La Découverte, 2003. p. 237 et seq. cannot be subsumed in an aggregation of individual rights; they concern all human beings and "do not belong to any of them in particular". ${ }^{53}$ The legally protected interest related to the rights of mankind is of a diffused character - as these rights concern an indefinite number of individuals or groups. ${ }^{54}$ Such interest is also indivisible, that is, it cannot be split up. ${ }^{55}$ This is the reason why the rights of mankind have sometimes been called "rights of solidarity". This solidarity, inherent to these rights, manifests itself in space (covering different groups, cultures and peoples) and in time (through succeeding generations). Indeed, the rights of mankind are also intergenerational: the principle of transmission that underpins them is one of their specific features. Under the terms of the draft Declaration, the "continuity of mankind rests on this intergenerational link". ${ }^{56}$

The rights of mankind, by virtue of their features, are distinguished from human rights. While the latter are aimed at protecting individual freedoms (freedom of expression, freedom of movement, etc.) and making these freedoms effective (economic and social rights, as well as civil and political rights such as the right not to be subjected to degrading treatment or the right to participating in public affairs), ${ }^{57}$ the rights of mankind aim to safeguard the essential interests of the human race

53 DUPUY, René-Jean. Humanité et droit international: mélanges. Paris: Pedone, 1991. p. 137.

54 DUfFRENE, Marie Pierre Camproux. La représentation de l'intérêt collectif environnemental devant le juge civil : après l'affaire Erika et avant l'introduction dans le Code civil du dommage causé à l'environnement. Vertigo, 2015. Available in: < https://vertigo.revues.org/16320>. Access in: 23 fev. 2016.

55 DUFFRENE, Marie Pierre Camproux. La représentation de l'intérêt collectif environnemental devant le juge civil : après l'affaire Erika et avant l'introduction dans le Code civil du dommage causé à l'environnement. Vertigo, 2015. Available in: < https://vertigo.revues.org/16320>. Access in: 23 fev. 2016.

56 See the Preamble of the Draft Universal Declaration of the Rights of Mankind, 2015. FRANCE. Présidence de la République. Déclaration universelle des droits de l'bumanité, rapport à l'attention de Monsieur le Président de la République. 2015. Available in: <http://www. ladocumentationfrancaise.fr/rapports-publics/154000687/index. shtml>. Access in: 23 mar. 2017.

57 For a more detailed analysis of this issue, see LE BRIS, Catherine. L'bumanité saisie par le droit international public. Paris: LGDJ, 2012. p. 81 et seq. Regarding the interplay between "human rights" and "freedoms". CHAMPEIL-DESPLATS, Véronique. Des "libertés publiques" aux "droits fondamentaux" : effets et enjeux d'un changement de denomination. Jus Politicum, n. 5, 2010. p. 3. Available in: <http://juspoliticum.com/uploads/pdf/JP5_Champeil_corr01. pdf>. Access in: 23 fev. 2016. 
(right to development, ${ }^{58}$ right to common heritage, ${ }^{59}$, right to peace, ${ }^{60}$ right to a sustainable environment, ${ }^{61}$ etc.). Both rights of mankind and human rights fall under different temporal scopes: human rights are exercised in the present time, while the rights of mankind, which also concern "future generations", are projected into the future as well. These two types of rights are also differentiated by the subject matter concerned: while the holders of human rights are individuals, ${ }^{62}$ the rights of mankind are conferred upon the human community as an autonomous entity.

This does not mean that mankind does not play a role in the human rights sphere: human nature, and therefore mankind, ${ }^{63}$ constitutes the criterion upon which human rights are recognized. ${ }^{64}$ These rights must be res-

58 See Art. 6 of the Draft Universal Declaration of the Rights of Mankind contained in the Annex.

59 See Arts. 7 and 8 of the Draft Universal Declaration of the Rights of Mankind contained in the Annex.

60 See Art. 9 of the Draft Universal Declaration of the Rights of Mankind contained in the Annex.

61 See Art. 6 of the Draft Universal Declaration of the Rights of Mankind contained in the Annex.

62 It is true that legal persons (e.g. non-governmental organizations within the framework of the European Convention on Human Rights) may also invoke human rights for their own benefit; this is a legal fiction to ensure the efficiency and effectiveness of those freedoms that are collectively exercised but the enjoyment of which is of an individual nature. The individual is not completely obliterated behind the legal person concerned in the process of recognition of fundamental rights: "first of all, at issue are here the persons who have established and are members (associates, co-owners, supporters) of the entity having been granted legal personality"; these rights "are not in principle attributes associated with the quality of the subject of law but with the rights recognized in favor of all human beings. While our legal system confers such rights upon legal entities, it does not do so only because they have been endowed with legal personality but because they are organizations pursuing lawful purposes, or furthermore, because they reflect the exercise by their founders or members of a freedom, namely, the freedom of association, of course, but also the freedom to undertake economic activities, religious freedom, etc." (BOULOIS, Xavier Dupré de. Les droits fondamentaux des personnes morales. Revue des droits et libertés fondamentaux, n. 15, 2011. Available in: <http://www.revuedlf.com/ droit-fondamentaux/les-droits-fondamentaux-des-personnes-morales- $\%$ E2\%80\%93-1ere-partie/>. Access in: 03 maio 2016.)

63 On the polysemy and the different meanings of the term "makind"("humanité"), LE BRIS, Catherine. L'bumanité saisie par le droit international public. Paris: LGDJ, 2012. p. 30 et seq.

64 Admittedly, legal persons, that is, those "cold monsters devoid of humanity", can also invoke human rights for their own benefit, but as stated above (note no. 57); the use of this legal fiction aims to guarantee the effectiveness and effectiveness of those freedoms, the exercise of which is of a collective nature, but their enjoyment is of an individual character: BOULOIS, Xavier Dupré de. Les droits fondamentaux des personnes morales. Revue des droits et libertés fondamentaux, n. 15, 2011. Available in: <http://www.revuedlf.com/ pected vis-à-vis all persons "by reason of their human structure". ${ }^{65}$ The inherent humanity of every person is a source of rights. Therefore, the rights of mankind and human rights are built on the same belief in the universality of human nature. ${ }^{66}$ This explains why both types of rights are indivisible and objective in character, that is, they fall outside the principle of reciprocity, "the golden rule for relations between States". ${ }^{67}$

However, the difference between these two types of rights lies in their very nature and not only in their importance. In the case of the rights of mankind, humanity itself is no longer a criterion for granting rights; mankind becomes the holder of those rights. From this perspective, these rights represent "a qualitative leap forwards that makes them fall outside the category of human rights". ${ }^{68}$ This difference has not always been properly understood. The cause of this confusion lies in the so-called "third-generation" human rights theory. According to this approach, it would be possible to identify three "generations" of human rights: civil-political freedoms ("libertés-aptitudes"), socio-economic rights ("droits-créances) and solidarity rights ("droits de solidarities"). ${ }^{69}$ This approach has - with good reasonbeen criticized by scholarly literature, and although it is not necessary to revisit all these criticisms, ${ }^{70}$ it should be noted that not only might it suggest that certain human rights would pertain to different "generations", and would therefore no longer be relevant today, but, moreover, such an approach dilutes the very concept of human rights: according to this theory the holder of these rights and their subject matter can no longer be clearly identified. In this context, the concept of "third-

droit-fondamentaux/les-droits-fondamentaux-des-personnes-morales-\%E2\%80\%93-1ere-partie/>. Access in: 03 maio 2016.

65 SUSTERHENN, Adolf. L'idée des droits de l'homme et sa mise en œuvre. In: MÉLANGES offerts à Henri Rolin: problèmes du droit des gens. Paris: Pedone, 1964. p. 398.

66 DUPUY, Pierre-Marie. Humanité, communauté et efficacité du droit. In: DUPUY, René-Jean. Humanité et droit international: mélanges. Paris: Pedone, 1991. p. 137.

67 DUPUY, René-Jean. L'bumanité dans l'imaginaire des nations. Paris: Julliard, 1991. p. 202.

68 DATONOU, Dieudonné. Du concept de patrimoine commun de l'bumanité aux droits de l'bumanité, étude historico-juridique du concept de patrimoine commun de l'bumanité em droit international, excerpta ex dissertatione ad doctoratum in utroqueiure. Roma: Pontificia Università Laternense, 1995. p. 125.

69 COLARD, Daniel. Le droit à la paix comme droit de l'homme. Les Cabiers du droit public, 1988. p. 33.

70 For a critical approach on this theory, LE BRIS, Catherine. L'bumanité saisie par le droit international public. Paris: LGDJ, 2012. p. 83 et seq. 
-generation rights" is likely to undermine human rights as a whole.

While human rights and the rights of mankind must be distinguished, they must not, however, be considered as opposing concepts. These two types of rights are "indivisible" as recalled in the Draft Declaration. ${ }^{71}$ The recognition of the rights of mankind is a guarantee of the effectiveness of individual rights: once the concept of mankind is accepted, humanity "must itself enjoy their rights, otherwise individuals would lose theirs". ${ }^{72}$ In this regard, the United Nations Human Rights Committee has stated that "[e]very effort they [States] make to avert the danger of war [...] constitute[s] the most important condition and guarantee for the safeguarding of the right to life", thus recalling the interdependence between the right of mankind to peace and the right of man to life. ${ }^{73}$ The links that are woven between human rights and rights of mankind are not limited to civil and political rights but also involve economic and social rights. A close relationship exists, in particular, between the individual right to health and the right of mankind to the environment. ${ }^{74}$ For example, in 2013, the Athabaskan peoples filed a petition with the Inter-American Commission on Human Rights against Canada whereby they basically allege that the inaction of that State against black carbon emissions, which contribute to climate change, violates in particular their right to life and health. ${ }^{75}$ It is likely that, as in the case of the petition filed against the United States on behalf of the Inuit

71 See Article 11 of the Draft Universal Declaration reproduced in the Annex.

72 DUPUY, René-Jean. La clôture du système international: la cité terrestre. Paris: Presses Universitaires de France, 1989. p. 156.

73 Human Rights Committee (HRC), General Comment 6, Article 6 (Sixteenth Session) on the International Covenant on Civil and Political Rights (right to life), 30 April 1982, \2, (Doc. UN HRI GEN $\backslash 1 \backslash$ Rev.1).

74 See the African Commission on Human and Peoples' Rights (ACHPR), 27 October, 2001, Social and Economic Rights Action Center (SERAC) and Center for Economic and Social Rights (CESR) c. Nigéria, aff. 155/ 96. On this subject, see also DUPUY, Pierre-Marie. Le droit à la santé et la protection de l'environnement. In: DUPUY, René-Jean. Le droit à la santé en tant que droit de l'homme. La Haye: Sijthoff\&Noordhoff, ano. p. 340 et seq. (in particular, p. 405).

75 ATHABASKAN COUNCIL. Petition to the Inter-American Commission on human rights seeking relief from violations of the rights of arctic Athabaskan peoples resulting from rapid arctic warming and melting caused by emissions of black carbon by Canada. 2013. Available in: <http:// earthjustice.org/sites/default/files/AAC_PETITION_13-04-23a. pdf $>$. Access in: 23 fev. 2016. Regarding this case, see CANALFORGUES, Eric; PERUSO, Camila. La lutte contre le changement climatique en tant qu'objet juridique identifié. LexisNexis, n. 8-9, comment 72, August 2015. p. 52. peoples in $2005,{ }^{76}$ the Commission concludes that no link between the greenhouse gas emissions and the alleged violations of human rights could be proved. ${ }^{77}$ This is precisely one of the advantages of recognizing the rights of mankind in the international legal order: this would allow for the circumvention of the issue concerning the proof of an individual and present (or imminent) violation, as that issue constitutes a barrier to the admissibility of this type of cases.

The fact remains that recognizing the interdependence between human rights and the rights of mankind does not solve everything: it is an undeniable fact that "the greater the number of rights, the greater the chances that disputes arise", and that those rights conflict with each other. ${ }^{78}$ The problem is not new: in former times, René Cassin ${ }^{79}$ explained that he had already criticized the 1948 Universal Declaration of Human Rights for establishing "an impossible conciliation" between classical freedoms and economic, social and cultural rights, which are more innovative. ${ }^{80}$ At present, there may be some concerns about the transcendent character of the rights of mankind and the possible risks of taking measures that endanger freedoms. ${ }^{81}$ It would be a mistake to consider that collective issues take precedence over the individual ones, or vice versa. An absolutist and overriding approach to the rights of mankind must be rejected. As a matter of fact, the legal aspect of mankind is not only transcendental, it is also

76 ATHABASKAN COUNCIL. Petition to the Inter-American Commission on buman rights seeking relief from violations of the rights of arctic Athabaskan peoples resulting from rapid arctic warming and melting caused by emissions of black carbon by Canada. 2013. Available in: <http://earthjustice.org/sites/default/files/AAC_PETITION_13-04-23a.pdf $>$. Access in: 23 fev. 2016.

77 WOLD Chris; HUNTER, David; POWERS, Mélissa. Climate change and the law. 2. Ed. New York: LexisNexis, 2013. p. 591 et seq.: the Inter-American Commission dismissed the petition on the grounds that it did not allow for a determination to be made as to whether the alleged facts implied a violation of the rights protected by the Inter-American Convention on Human Rights; (see p. 595). 78 WEISS, Edith Brown. Justice pour les générations futures: droit international: patrimoine commun et équité intergénérations. Paris: Éditions Sang de la terre, Unesco, 1994. p. 95.

79 René Cassin is a French Lawyer and Diplomat. He is one of the drafters of the Universal Declaration of Human Rights 1948.

80 CASSIN, René. La Déclaration universelle et la mise en œuvre des droits de l'homme. RCADI, v. 79, 1951. p. 285.

81 WECKEL, Philippe. Le rapport Lepage sur les droits de l'bumanité et le concept de l'bumanité indivisible. 2015. Available in: <www.sentinelledroit-international.fr/?q=content/le-rapport-lepage-sur-les-droitsde-lhumanit $\%$ C3\%A9-et-le-concept-de-lhumanit $\%$ C3\%A9-indivisible>. Access in: 22 fev. 2015. 
immanent: ${ }^{82}$ mankind is not more important than its members, "it is they who are its essence". ${ }^{83}$ Furthermore, "each right can only be the beginning of a right" and be capable of deferring to another right in the event of a conflict among them. ${ }^{84}$ On a practical level, it is important to identify the criteria or methods allowing for the resolution of assumptions of conflicts between the rights of mankind and human rights. A preliminary step aims at finding the causes of the conflicts, the conditions surrounding their emergence, so as to prevent them. The objective would thus be to reduce those contradictory requirements so as to avoid giving up one of the categories of rights concerned. Should the conflict be inevitable, it is necessary to seek to reconcile those competing rights without establishing a hierarchy among them. To this end, it is possible to weigh up the two competing rights; well-proven techniques based in particular upon the principles of necessity and proportionality can prove to be useful in this context. In addition, certain legal criteria such as the non-derogable nature of the right concerned should also be taken into account. In any event, it is important to avoid systematically giving priority to a right over another..$^{85}$

\subsection{Duties towards mankind and rights of mankind: between complementarity and added value}

The recognition of the rights of mankind beyond its symbolic character has both theoretical and practical interest.

From a theoretical perspective, the Draft Declaration introduces a new legal category, ${ }^{86}$ the so-called ri-

82 LE BRIS, Catherine. L'bumanité saisie par le droit international public. Paris: LGDJ, 2012. p. 41.

83 DUPUY, René-Jean. L'humanité dans l'imaginaire des nations. Paris: Julliard, 1991. p. 41.

84 Edith Brown-Weiss, ibid., p. 94. Consequently, even the right not to be subjected to inhuman or degrading treatment may defer to the freedom of individuals over their own bodies: see European Court of Human Rights, judgment delivered on 17 February 2005, K.A and A.D. v. Belgium, Applications nos. 42758/98 and 45558/99 (concerning sadomasochism).

85 On the issue related to conflicting fundamental rights, see the informal noted by Françoise Tulkens concerning «Les conflits de droits fondamentaux» of 14 April 2006. Document available online at: [http://www.ies.be/files/Fr.Tulkens.Notes_de_support_au_ cours_du_16_f\%C3\%A9vrier_2007.pdf] (last 23/02/2016).

86 It is possible to believe that a legal category exists "given that the legislation incorporates it into its own lexicon and legal consequences are attached to it": see, on this issue, Lochak Danièle, ghts of mankind. This category allows for norms, things, facts or acts focused on the interest of mankind to be dealt with as a whole and be governed by a common legal regime. Failing this, the recognition of the interests of mankind would only consist of "a jumble of heterogeneous rules", a "simple juxtaposition of diverging rules" that are impossible to be applied and that inevitably involve contradictions among them. ${ }^{87}$ As a new category, the rights of mankind emerge as a strong normative basis to ensure the connection between legal notions such as "(common/global) heritage of mankind", "common concern of mankind", "human security", "human development", "human interest" or "crime against humanity". In environmental matters, in particular the recognition of this category makes it possible to adapt the legislation to empirical developments when dealing with what is often referred to as "ecological interdependence". To take just one example, climate change, which from a legal perspective, is "a common concern of humankind" 88 having an impact on glaciers in Antarctica - a region whose environmental protection is "in the interest of mankind as a whole" ${ }^{89}$-, is also closely linked to the oceans whose seabed is the common heritage of mankind. ${ }^{90}$ Thus, climate change can deteriorate the world heritage of mankind such as the Great Barrier Reef ${ }^{91}$ and can ultimately pose a threat to human security. ${ }^{92}$ Thus, by recognizing the category of rights of mankind, the international legal order is in tune with the circumstances that it governs.

From a practical point of view, the recognition of the rights of mankind contributes to increasing res-

«La race: une catégorie juridique?», in Actes du colloque Sans distinction de... race, 27 -28 March 1992, published in Mots no. 33. Available online:[http://www.anti-rev.org/textes/Lochak92a/] (Last visited 24/02/2016).

87 Bergel Jean-Louis, Théorie générale du droit, Paris, Dalloz, 2012, p. 225 et s.

88 Preamble of the United Nations Framework Convention on Climate Change of 9 May 1992 and Preamble of the Paris Agreement of 12 December 2015.

89 Protocol Environmental Protection to the Antarctic Treaty, Madrid, 4 October 1991.

90 See Article 136 of the United Nations Convention on the Law of the Sea.

91 See the Convention for the Protection of the World Cultural and Natural Heritage, Paris, 16 November 1972. The World Cultural List is available on the Web site of Unesco at: [http://whc.unesco. $\mathrm{org} /$ en/list/154/] (Last visited 24/02/2016).

92 Regarding the notion of human security, see in particular, United Nations Development Programme, Human Development Report 1994 : New Dimensions of Human Security, Paris, Economica, 1994, p. 240. 
ponsibilities insofar as these rights are conceptualized in terms of creditors and debtors. Indeed, where a subjective right is created, its holder is granted the power to make demands and the norm concerned is thus assorted with a number of mechanisms to which recourse will be had upon its slightest contravention. ${ }^{93}$ In this respect, "subjective" rights (if it is possible to use the term "subjective right", which has traditionally been regarded as conferring a prerogative upon individuals, ${ }^{94}$ in connection with the rights of mankind that concern global interests) are more effective than the mere objective rules dealing with environmental protection, peace and development. All the more so given that the rights of mankind are of a collective nature, ${ }^{95}$ and thus those who seek to avail themselves of the above rights on behalf of mankind do not have to prove, from a theoretical point of view, that they have been individually harmed. In this context, to quote the example of petitions filed by Inuit and then the Athabaskan peoples with the Inter-American Commission on Human Rights, ${ }^{96}$ if the rights of mankind could have been invoked as a supplement to human rights, those petitions had been dealt with quite differently. Moreover, where a subjective right is recognized, a whole series of obligations derive from it. In other words, these obligations are no longer dependent on their incorporation into a specific text, but they are infinite in some way or at least as numerous as they may be necessary for the realization of the right concerned. The recognition of the rights of mankind thus leads to an extension of the scope of obligations.

While the draft Declaration rests on this "natural" dynamics existing between legal rights and duties, the decision was also made to set forth in the above Declaration the duties towards mankind. Indeed, it was established that " $[t]$ he present generations have a duty to guide scientific and technical progress towards the preservation and health of humans and other species" $" 97$ or

93 CARBONNIER, Jean. Flexible droit. 8. ed. Paris: LGDJ, 1995. p. 150.

94 See Cornu Gérard, Vocabulaire juridique, $8^{\text {th }}$ ed., 2000, item «Droit ». See also BERGEL Jean-Louis, Théorie générale du droit, Paris, Dalloz, 2012, $5^{\text {th }}$ edition, p. 39. P As a reminder, the definition of subjective rights is uncertain: for some authors, subjective rights are defined by the recognition of the power of will; for others, subjective rights are legally protected interests (Ihering).

95 See above

96 See above.

97 Article 14 of the Draft Universal Declaration of Rights of Mankind in the Annex to this document. that "the principles, rights and duties proclaimed in this Declaration should serve as a basis for learning lessons, raising awareness and taking further action for their actual implementation". ${ }^{98}$ Contrary to what prevails in the Universal Declaration of Human Rights, ${ }^{99}$ the recognition of rights does not lead to "a retraction of duties". ${ }^{100}$ This decision is explained both by reasons of legal policy and legal technique. From a legal policy perspective, the decision was motivated by the concern to account for different cultures. Indeed, while for the modern Western world, man is defined by "their constitution as an individual who must be endowed with rights", in other cultural traditions man can only be conceived as "a being integrated into communities and defined more in terms of their duties than their rights". ${ }^{101}$ From a more technical point of view, it should be recalled that if rights are always accompanied by obligations or duties, the opposite is not necessarily true. While rights are of a bilateral nature and involve reciprocity, duties, on the other hand, can be unilateral, non-reciprocal and autonomous. ${ }^{102}$ Thus, the duty to guide scientific and technical progress towards the preservation of species, ${ }^{103}$ in particular, does not lead to a right corresponding to that duty. Furthermore, duties can present an added value in relation to a given right: they "indicate more than a specific right as they are basically placed at a general level, that is, beyond the calculation of equivalences between concrete rights and duties". ${ }^{104}$ Therefore, duties cannot be reduced to the corresponding obligations. Finally, on a purely practical level, the reference to duties is likely to increase the effectiveness of the

98 Article 15 of the Draft Universal Declaration of Rights of Mankind in the Annex to this document.

99 In the Universal Declaration of Human Rights, the establishment of duties is limited to just one article (Article 29).

100 BRAGA, Valeschka. La délicate question de l'équilibre entre droits et devoirs en France. Available in: <http://www.droitconstitutionnel. org/congresParis/comC8/BragaTXT.pdf>. Access in: 24 fev. 2016. 101 ROULAND, ano Apud BISSONNETTE, Alain. L'actualité de la Déclaration universelle des droits de l'homme. Revue québécoise de droit international, v. 8, n. 1, 1993-1994. p. 55. On this respect, see for instance, Art. 27 et seq. of the African Charter on Human and Peoples' Rights (Nairobi, 27 June 1981), but also Arts. 29 et seq. of the American Declaration of the Rights and Duties of Man (Bogota, Colombia, 1948).

102 DELMAS-MARTY, Mireille. Vers une communauté de valeurs? Les droits fondamentaux. Seminar held at the Collège de France, 2008. Available in: <http://calenda.org/194353>. Access in: 23 mar. 2017.

103 Art. 14 of the Draft Universal Declaration of Rights of Mankind in the Annex to this document.

104 Braga Valeschka, «La délicate question de l'équilibre entre droits et devoirs en France », op. cit. 
rules enshrined in the Draft Declaration. Indeed, while rights are attributed to mankind, which may appear ethereal, ${ }^{105}$ duties, by contrast, must be implemented by well-identified entities such as States. The recognition of these duties thus makes it possible to anchor the Draft Declaration in reality.

The Draft Declaration specifies the list of debtors of duties towards mankind: ${ }^{106}$ while States, as primary subjects of international law, have primary responsibility in this matter, international organizations, enterprises, in particular multinational corporations, non-governmental organizations, peoples, local authorities and individuals are also targeted. This multiplicity of debtors contributes to explain the choice of using, except for exceptional cases, ${ }^{107}$ the term "duty" rather than "obligation". The reference to "duties" allows for a broad spectrum of stakeholders to be targeted (for instance, transnational corporations), while the notion of obligation could have limited the debtors to subjects of public international law, in particular to States. Undoubtedly, the notion of duties has more of a moral connotation than that of obligations. That does not mean, however, that those duties cannot have a legal dimension: the boundaries between morality and law are not hermetic and the moral nature of a norm is by no means incompatible with its legal character. On the contrary, recognition of a moral obligation is often a "step in the evolution of public awareness". ${ }^{108}$ Certain rights, in particular human rights, have a strong moral

105 On the representation of mankind, see infra (II).

106 See the preamble of the Declaration: "Considering the special responsibility of present generations, especially the States that hold primary responsibility in this area, but also that of peoples, intergovernmental organizations, corporations, including multinationals, non-governmental organizations, local authorities and individuals". An initial version of the text established as follows: "Considering that the duties towards mankind must be complied with by the present generations...". The term « responsabilité » ("responsibility") has finally been preferred to the exclusion of the term "devoir" ("duties"), initially proposed because of its broader scope: this term "responsabilité" ("responsibility") goes beyond the legal responsibility stricto sensu so that it covers the role played by actors other than States and international organizations (businesses in particular) and whose actions are governed by soft law. The concept of responsabilite (responsibility) can be understood here in the sense of accountability.

107 See Article 14 of the Draft Universal Declaration where the term "duty" rather than "obligation". The term duties was chosen instead of obligations insofar as rules of positive law concerning this field already exist.

108 WEISS, Edith Brown. Justice pour les générations futures: droit international: patrimoine commun et équité intergénérations. Paris: Éditions Sang de la terre, Unesco, 1994. p. 97. dimension, which in no way prevents them from having legal effects.

Mankind as a whole is the beneficiary of the duties enshrined in the draft Declaration. The concept of "duties towards mankind", used in this Draft Declaration, is not entirely new, as the Inter-American Convention on Human Rights itself establishes in its Article 32 that "[e]very person has responsibilities ["devoirs" (duties) in the French version] to [...] mankind". ${ }^{109}$ Similarly, in accordance with the Preamble to the Charter of Fundamental Rights of the European Union, the enjoyment of the rights recognized in this text "entails responsibilities and duties with regard to [...] the human community and to future generations". These are duties towards mankind rather than duties of mankind. In other words, they are to be complied with by the present generation, in particular by the international community, ${ }^{110}$ rather than by future generations that are included in the notion of mankind. Therefore, what has sometimes been referred to by means of a terminological shortcut as "duties of mankind" 111 are, in fact, "the duties of the present generation towards mankind", in particular vis-à-vis the future generations. Responsibility is thus not only of an intragenerational nature, but also of intergenerational one. There remains, however, the question of determining who may make a claim on behalf of mankind in case of violation of these rights.

\section{A United Mankind and a Plural MANKIND: INSTITUTIONAL PERSPECTIVES FOR the Draft Declaration}

Reference to mankind in a legal context is sometimes considered as a metaphor. Being described as

109 Convention adopted on 22 November 1969, in San Jose, Costa Rica. The Inter-American Court of Human Rights considers, however, that only States can be held responsible under the Convention to the exclusion of physical persons.

110 On the distinction between "humanité" ("mankind") and "international community", see LE BRIS, Catherine. L'bumanité saisie par le droit international public. Paris: LGDJ, 2012. p. 35.

111 LE BRIS, Catherine. Une déclaration sur les droits de l'humanité: avancée ou simple slogan? Le Huffington Post, 2015. Available in: <http://www.huffingtonpost.fr/catherine-le-bris/declaration-droits-humanite-avancee-ou-slogan_b_6735426.html>. Access in: 24 fev. 2015): in January 2015, the President of the French Republic François Hollande made reference to "duties of mankind" (devoirs de l'humanité), giving rise to some terminological hesitation. 
a "ghost" holder, ${ }^{112}$ mankind would be nothing more than a legal fiction conceived to ensure the protection of values or the transmission of goods. ${ }^{113}$ The question remains, however, as to who can speak on behalf of mankind. ${ }^{114}$ That question was purposefully dealt with only in an indirect manner in the Draft Declaration: pursuant to Article 16 "[a]ll States are under the obligation to ensure the effectiveness of the principles, rights and duties proclaimed by this Declaration, including through the organization of mechanisms to ensure their full observance". ${ }^{115}$ In other words, while the Declaration establishes the principle concerning the effectiveness of the rights of mankind, it leaves it to the States to decide how to ensure its application. Consequently, two options are left to the States: the first one, which is of a prospective nature, consists of endowing mankind with a centralized representation (A); the second one, of a more actual nature, is adapted to the structure of international society and involves the implementation of the rights of mankind by the subjects and stakeholders of international law (B).

\subsection{United Mankind: A Supranational Institution as the Custodian of Rights of Mankind}

Historically, there has always existed an ideal of a united mankind, the so-called, civitas maxima. ${ }^{116}$ This ideal serves as a basis for both legal scholarly writings and positive law. Based on what is known in national legal orders, lawyers tend to turn, quite spontaneously, to a model patterned after a united mankind represented by an institution of a centralized nature in order to address issues concerning rights of mankind. Although this model may, at first glance, seem utopian, it is the one that was used in the field of the law of the sea, in particular when dealing with issues concerning the

112 MATHIEU, Bertrand. Génome humain et droits fondamentaux. Paris: Economica, 2000. p. 92.

113 DARDOT Pierre; LAVAL, Christian. Commun: essai sur la révolution au XXIème siècle. Paris: La découverte, 2014. p. 40. For an opposite opinion, see TERRÉ, François. L'humanité, un patrimoine sans personne. In: ARDANT, Philippe. Droit et politique à la croisée des cultures. Paris: LGDJ, 1999. p. 341 : 'La gestation de l'humanité en tant que personne titulaire d'intérêts juridiquement protégés [...] se réalise lentement."

114 KISS, Alexandre Charles. La notion de patrimoine commun de l'humanité, RCADI, v. 175, 1982. p. 236.

115 No underlining in the original version of the text.

116 TASSITCH, Georges. La conscience juridique international, RCADI, v. 65, 1938. p. 311.
Area ${ }^{117}$ which is common heritage of mankind, having led to the creation of the International Seabed Authority. Pursuant to the terms of the Convention on the Law of the Sea, [a]ll rights in the resources of the Area are vested in mankind as a whole, on whose behalf the $\mathrm{Au}-$ thority shall act". ${ }^{118}$ Furthermore, the Authority shall, in particular, ensure that the activities carried out in the Area do not pollute the marine environment, including the coastline. ${ }^{119}$

In the event of damage to the Area or the marine environment, it is entirely conceivable that the Authority would claim compensation: according to the opinion of the International Tribunal for the Law of the Sea, ${ }^{120}$ even if there is no express provision in the Convention, the Authority is implicitly authorized to do so insofar as it acts "on behalf" 121 of mankind. Therefore, in such a case, the Authority could refer the matter to the Seabed Disputes Chamber of this Tribunal on the basis of the Convention on the Law of the Sea, in particular pursuant to its Article 187(b)(i). ${ }^{122}$

The question remains as to whether it would be possible to generalize this institutional model for it to be used as a mechanism for the enforcement of the rights of mankind. It should be stated that such an idea has in fact been advocated before. It was proposed in particular to extend this model to other areas of environmental protection. In 1989, the States signatories to the Declaration of The Hague on the Protection of the Atmosphere, recognizing that "climate change" is "a common concern of mankind", called for the establishment of a "new institutional authority" to address climate change. ${ }^{123}$ In the same vein, it was proposed that an

117 See Art. 1(1) of the United Nations Convention on the Law of the Sea: "Area" means the "seabed and ocean floor and subsoil thereof, beyond the limits of national jurisdiction."

118 See Arts. 137(2) and 153(1) of the Convention on the Law of the Sea.

119 See Art. 145 of the Convention on the Law of the Sea.

120 INTERNATIONAL TRIBUNAL FOR THE LAW OF

THE SEA. Responsibilities and obligations of States sponsoring persons and entities with respect to activities in the Area, 2011, Case n. 17, para. 180. Available in: <https://www.itlos.org/en/cases/list-of-cases/caseno-17/>. Access in: 23 mar. 2017.

121 See Art. 137(2) of the Convention on the Law of the Sea.

122 See also Article 37 of Annex VI to the Convention on the Law of the Sea. See, on this matter, BEURIER, Jean-Pierre. L'Autorité internationale des fonds marins, l'environnement et le juge. Vertigo, special edition 22, September 2015. Available in: $<$ https://vertigo. revues.org/16169>. Access in: 23 mar. 2017.

123 Declaration on the Protection of the Atmosphere, The Hague, 11 March 1989 (Doc. NU A/44/340). 
international authority should be created to promote the protection of genetic resources ${ }^{124}$ bearing in mind that the preservation of biological diversity is also referred to as a "common concern of humankind". ${ }^{125}$ Moreover, the establishment of a single global government representing humanity as a whole has often been considered and those jurists having put forward such a proposal are more numerous than might be expected. According to Professor Albert de Geouffre de la Pradelle, there is an urgent need to establish "an institutional community authority of a supranational nature capable of endowing mankind with the means to realize its implicit competencies". ${ }^{126}$ More recently, it has also been argued that "even if it might seem utopian in the short term, the establishment of a government representing mankind will become a pressing need in the long term". ${ }^{127}$ If these proposals were implemented, mankind would become a subject of international law, whereas at present it is only a passive subject, that is, it has rights but, given its lack of representation, except for exceptional cases, ${ }^{128}$ has no capacity to exercise them. From a legal perspective, granting mankind legal personality is quite conceivable: legal personality in law is largely of a fictitious character and if it was possible to have recourse to this technique to "optimize a market process (commercial companies), "to institutionalize political power" (States and local authorities) or "to assert collective interests (associations)", ${ }^{129}$ it is not incoherent to consider that mankind may be conferred legal personality. Fur-

124 KLEMM, Cyril de. Le patrimoine naturel de l'humanité. In: Dupuy, Renâe Jean. L'avenir du droit international de l'environnement, colloque de l'Académie de droit international de La Haye, 12-14 November 1984. The Hague: Martinus Nijhoff Publishers, 1985. p. 142 et seq. 125 Preamble of the Convention on Biological Diversity of 5 June 1992.

126 GEOUFFRE DE LA PRADELLE, Paul de. Une idée qui prend corps: la protection internationale de l'humanité. Aix-en-Provence: Presses universitaires d'Aix-Marseille, 1979. p. 103. See also DEL VECCHIO, Giorgio. Humanité et unité du droit: essai de philosophie juridique. Paris: Librairie générale de droit et de jurisprudence, 1963. p. 263. "L'acceptation d'un ordre supranational est une nécessité catégorique qui ne peut être éludée ni soumise à l'approbation de qui que ce soit". "Recognition of a supranational legal order is an imperative need that can neither be avoided nor subjected to the approval of any person or institution".

127 PAQUEROT, Sylvie. Le statut des ressources vitales en droit international: essai sur le concept de patrimoine commun de l'humanité. Bruxelles: Bruylant, 2002. p. 241.

128 See above the case concerning International Seabed Authority. 129 SOHNLE Jochen. La représentation de la nature devant le juge: Plaidoyer pour une épistémologie juridique du fictive. Vertigo, n. 22, sep. 2015. Available in: <https://vertigo.revues.org/16343>. Access in: 23 mar. 2017. thermore, in the Draft Declaration ${ }^{130}$ it is proposed on an optional basis that legal personality be recognized in favor of mankind. However, if this option were chosen, it would be more of a symbolic than a normative nature. Indeed, international legal personality does not derive from its recognition in an legal instrument but from the effective granting of rights and the real capacity to exercise them: "Even if a legal order establishes a rule stating that "X is subject of law", $\mathrm{X}$ would not become a subject of law if that legal order did not grant at least one right or obligation in favor of X'. ${ }^{131}$ Although it is possible, from a legal perspective, to confer legal personality on mankind, such recognition would require, from a political viewpoint, that a certain number of precautions be taken. Firstly, the political unity of mankind, or at least its political construction, appears to be a prerequisite for its recognition as a legal person. The creation of the League of Nations and the subsequent establishment of the United Nations were, in turn, the results of the concern to protect humanity in a universal framework. However, in spite of encouraging progress and the conclusion of a charter that may resemble a constitution, ${ }^{132}$ this organization remains an instance where the differing interests of sovereign States clash. Secondly, special attention should be given to the representativeness of this institution, which would be responsible for embodying the interests of mankind in its entirety: where collective rights are recognized to any group whatsoever, "the question as to who speaks on behalf of whom must always remain open". ${ }^{133}$ This analysis remains especially valid in relation with the establishment of a universal subject that would be responsible for the protection of the rights of mankind, a kind of "global Leviathan"134 that might run counter to hegemonic aspirations.

Moreover, other alternatives are possible. Thus, the idea of a global and/or international environmental organization, more in line with the structure of classical

130 LEPAGE CORINNE ET EQUIPE DE RÉDACTION. Déclaration universelle des droits de l'bumanité, rapport à l'attention de Monsieur le Président de la République. 2015. p. 44. Available in: <http:// www.ladocumentationfrancaise.fr/var/storage/rapports-publics/154000687.pdf>. Access in: 23 fev. 2016.

131 BARBERIS, Julio A. Nouvelles questions concernant la personnalité juridique international. RCADI, v. 179, 1983. p. 169.

132 See the Charter of the United Nations of 26 June 1945.

133 ROULAND, ano Apud BISSONNETTE, Alain. L'actualité de la Déclaration universelle des droits de l'homme. Revue québécoise de droit international, v. 8, n. 1, 1993-1994. p. 55.

134 DELMAS-MARTY, Mireille. Trois défis pour un droit mondial. Paris: Éditions du Seuil, 1998. p. 92. p. 173. 
international law than with the project of a global government, might emerge from its "winter slumber". ${ }^{135}$ Naturally, such an organization, which is confined to a specific field, would have a more limited scope. Furthermore, if that organization were of an international character rather than a supra-State or supranational nature, it could not claim to embody mankind. However, it could act on its behalf, be its representative, in particular in order to advocate the right of mankind to the environment. This could be complemented by the establishment of a global and/or international environmental Court. In this regard, the Draft Declaration contains, as an optional proposal, a provision on the establishment of an "International Criminal Tribunal for the Environment and Health". ${ }^{136}$ Such a perspective is not utopian: the draft agreement on climate negotiated at the COP21 proposed, on an optional basis, the creation of an "International Tribunal of Climate Justice" that would address cases of non-compliance with commitments undertaken by developed-country Parties. ${ }^{137}$ While this option was ultimately not adopted in the Paris Agreement, the fact that it was proposed in the framework of a draft treaty (and that it was maintained throughout the pre-negotiations phase that took place in Bonn) is, in itself, a step forward.

\subsection{Plural mankind: decentralized exercise of the rights of mankind within the international community}

Currently, international society has neither a legislative nor an executive nor a judicial branch at the service

135 BEURIER, Jean-Pierre. L'Autorité internationale des fonds marins, l'environnement et le juge. Vertigo, special edition 22, September 2015. Available in: <https://vertigo.revues.org/16169>. Access in: 23 mar. 2017. On this issue, see Also BEDJAOUI, Mohamed. L'humanité en quête de paix et de développement: cours général de droit international public. RCADI, v. 325, 2006. p. 339 et seq.

136 LEPAGE CORINNE ET EQUIPE DE RÉDACTION. Déclaration universelle des droits de l'bumanité, rapport à l'attention de Monsieur le Président de la République. 2015. p. 45. Available in: <http:// www.ladocumentationfrancaise.fr/var/storage/rapports-publics/154000687.pdf>. Access in: 23 fev. 2016.

137 See the Draft agreement and draft decision on work streams 1 and 2 of the Ad Hoc Working Group on the Durban Platform for Enhanced Action of 4 December 2015 (Art. 11, option 2): “An International Tribunal of Climate Justice is hereby established to address cases of non-compliance with the commitments of developed country Parties on mitigation, adaptation, provision of finance, technology development and transfer, capacity-building, and transparency of action and support, including through the development of an indicative list of consequences, taking into account the cause, type, degree and frequency of non-compliance." of mankind. ${ }^{138}$ Nevertheless, given that nature abhors a vacuum, "the instinctive efforts of mankind to meet the need for solidarity [...] emerge spontaneously from inter-State relations: ${ }^{139}$ the functions that should be performed by the bodies of the mankind community are then carried out by "faster, more straightforward and decisive processes than those that take place in our local and hierarchical societies that are organized on the basis of the specialization of tasks". ${ }^{140}$ In the absence of institutions representing mankind, it is the States that protect the interests of mankind and its rights. As a result of the "functional duplication" technique, where States act on their own account, they act, at the same time, on behalf of the mankind community, as described by theory developed by the French Professor Georges Scelle. While in the assumption of the aforementioned government of mankind, the representation of the entity "mankind" itself is brought into question (the government embodying mankind is, at the same time, its organ, therefore, there is only one legal person), in the case of functional duplication, States ensure the representation of the interests of mankind (two legal entities intervene in this assumption). This is the reason why it is possible to characterize States as being the representatives of mankind. Whenever a State identifies, for example, items for their inclusion in the World Heritage List or ensures compliance with environmental rules on its territory, acts like a "superintendent ("intendant") of mankind". ${ }^{141}$

In case of State interference invoking the rights of mankind (humanitarian, ecological, cultural interference, etc.), such a situation could be legitimately described as a "functional triplication" 142 of acts carried out by a State. Indeed, in that case, the State concerned acts theoretically on behalf of another State and at the same

138 For a more detailed analysis of this issue, see LE BRIS, Catherine. L'bumanité saisie par le droit international public. Paris: LGDJ, 2012. p. 409 et seq.

139 SCELLE, Georges. Le droit constitutionnel international. In: PFISTER, Christian; DUQUESNE, Joseph. Mélanges R. Carré de Malberg. Paris: Edouard Duchemin, 1977. p. 514.

140 SCELLE, Georges. Le droit constitutionnel international. In: PFISTER, Christian; DUQUESNE, Joseph. Mélanges R. Carré de Malberg. Paris: Edouard Duchemin, 1977. p. 512.

141 CHARPENTIER, Jean. L'humanité: un patrimoine mais pas de personnalité juridique. In: PRIEUR, Michel; LAMBRECHTS, Claude. Les homes et l'environnement : quels droits pour le vingt-etunième siècle? Études en hommage à Alexandre Kiss. Paris: Frison Roche, 1998. p. 19.

142 SCELLE, Georges. La notion d'ordre juridique. Revue du droit public et de la science politique en France et à l'étranger, 1944. p. 100. 
time on behalf of mankind. In practice, however, the interfering State also acts on its own account as it is often case that that State has its own interests in the matter in question... ${ }^{143}$

This decentralized protection of the rights of mankind is also present in case of litigation. In its advisory opinion of 2011 on Responsibilities and obligations of States sponsoring persons and entities with respect to activities in the Area, the International Tribunal for the Law of the Sea provided an essential clarification in this regard. It held that in the event of damage to the common heritage of mankind or damage to the marine environment, "each State Party [to the Convention on the Law of the Sea] may [...] claim compensation in light of the erga omnes character of the obligations relating to preservation of the environment of the high seas and in the Area". ${ }^{144}$ Obligations referred to as "erga omnes" are those obligations binding "any State to the international community as a whole", ${ }^{145}$ paving the way for the exercise of the "actio popularis". The rights of mankind constitute the basis of this type of obligation: as Judge Weeramantry pointed out, by taking into account "the greater interests of humanity" and "planetary welfare", "we enter the arena of obligations which operate erga omnes rather than inter partes". ${ }^{146}$ In the aforementioned opinion, the International Tribunal for the Law of the Sea makes reference to Article 48, paragraph 1 of the Draft Articles of the International Law Commission on Responsibility of States for Internationally Wrongful Acts ${ }^{147}$ according to which: "Any State other than an injured State is entitled to invoke the responsibility of another State ... if: (a) [t]he obligation breached is owed to a group of States including that State, and is established for the protection of a collective interest of the group; or (b) [t]he obligation breached is owed to the international community as a whole." The Tribunal careful targeted not only the case where

143 LE BRIS, Catherine. L'bumanité saisie par le droit international public. Paris: LGDJ, 2012. p. 447 et seq.

144 International Tribunal of the Law of the Sea, Advisory Opinion of 1 February 2011 op.cit, para.180.

145 SALMON, Jean. Dictionnaire de droit international public. Bruxelles: Bruylant, 2001. p. 368.

146 Separate opinion of Vice-President Weeramantry in the Gabčíkovo-Nagymaros Project (Hungary/Slovakia) judgment, ICJ Reports 1997, p. 118.

147 Draft Articles of the International Law Commission on Responsibility of States for Internationally Wrongful Acts, adopted by the General Assembly of the United Nations in its resolution 56/83 of 12 December 2001. there is a treaty (the case of erga omnes partes obligations referred to in paragraph (a), but also the case where, in the absence of a treaty, the obligation derives from a customary rule (the case of the erga omnes obligations referred to in paragraph (b), providing the holding of the Court with a broader scope.

While it is authoritative, the draft Articles of the International Law Commission is still only a soft law instrument. Furthermore, the question arises as to whether States would resort to this rules in the event that they were recognized. The technique of functional duplication (and, as a result, that of functional triplication) has its limitations: it is likely that, torn between their national interests and those of the human race, States will hesitate to file an application with a court or will only do that on a selective basis, which does not seem to be compatible with an effective protection of the rights of mankind. In this context, the recognition of these rights also means that a bigger share should be reserved for civil society in the international legal order. However, this is not due to the fact that that civil society embodies a "sovereign mankind", 148 but because, just like intergovernmental organizations or States, it is an integral part of the legal aspect of mankind and constitutes a counter-power to sovereignty. This interplay of powers and counter-powers is likely to enhance the efficiency and effectiveness of the rights of mankind. In particular, it could be conceivable that civil society be represented within the framework of a future global environmental organization. Likewise, some non-governmental organizations could be granted ius standi to appear before a World Environmental Court in the event that it were established. The rights of mankind imply a democratization of international society and the establishment of a "globalized forum for discussion". ${ }^{149}$ Some initiatives at the national level favor such an approach. Thus, 886 individuals and a foundation (the Urgenda Foundation)

148 Expression forged by Professeur Sandra Szurek: La société civile internationale et l'élaboration du droit international (report). GHÉRARI, Habib; SZUREK, Sandra. L'émergence de la société civile internationale: vers la privatisation du droit international? Paris: Pedone, 2003. p. 67. For an opposite opinion, see the analysis carried out by Professor Falk: in his opinion, the common rights of mankind are the rights of civil society. "The world order between inter-state and the law of humanity: the role of civil society institutions". ARCHIBUGI, Daniele; HELD, David. Cosmopolitan Democracy: an agenda for a new world order. Cambridge: Polity Press, 1995. p. 165 et. seq. 149 JOUANNET, Emmanuelle. L'idée de communauté humaine à la croisée des États et de la communauté mondiale. La mondialisation entre illusion et utopie, Archives de Philosophie du droit, v. 47, 2003. 
filed an application with the Commercial Chamber of The Hague Tribunal to require that the Dutch State be ordered to reduce its greenhouse gas emissions. The application relied both on human rights (in particular, Article 2 of the European Convention on Human Rights) and on environmental law. The Tribunal upheld the applicants' claim on the basis of the duty of care of the "environment and mankind" pursuant to Article 21 of the Dutch Constitution. ${ }^{150}$ This is a decision issued by a court of first instance against which the Government of the Netherlands has lodged an appeal, ${ }^{151}$ but this case has a strong symbolic dimension.

Could the Universal Declaration of the Rights of Mankind also be invoked by everyone before the national courts in the longer or shorter term? As a soft law instrument, this Declaration is not, in itself $\mathrm{f}^{152}$, creating rights that are likely to be directly invoked before domestic courts. However, national courts, as well as international tribunals, could fully rely on this Declaration to interpret binding texts. One of the benefits of soft law is precisely to pave the way for having recourse to hard law and to gain insight into emerging phenome$\mathrm{na}^{153}$. This is, moreover, one of the stated goals of this Draft Universal Declaration of the Rights of Mankind: to follow social, political and environmental developments, contributing in this way to the renewal of the legal protection of mankind and its interests.

Concerning the Universal Declaration of Human Rights of 1948, René Cassin stated that it can be compared "to the vast portico of a temple whose forecourt is formed by the Preamble affirming the unity of the human family and whose foundations are constituted by the general principles of freedom, equality, non-discrimination and fraternity". ${ }^{154}$ But he went on to say that

150 CANAL-FORGUES, Eric; PERUSO, Camila. La lutte contre le changement climatique en tant qu'objet juridique identifié. LexisNexis, n. 8-9, comment 72, August 2015.

151 ABONNEZ-VOUS. La Haye veut faire appel d'un jugement d'un tribunal local sur les émissions de gaz à effet de serre. Le Point International, 2015. Available in: <http://www.lepoint.fr/monde/ la-haye-veut-faire-appel-d-un-jugement-d-un-tribunal-local-sur-lesemissions-de-gaz-a-effet-de-serre-01-09-2015-1960929_24.php>. Access in: 23 fev. 2015.

152 While the Declaration has no binding force, its norms could eventually become customary rules or be enshrined in future conventions: see above.

153 CONSEIL D'ETAT. Les rapports du Conseil d'État: ancienne collection Étude et documents du Conseil d'État, Paris, 2013, p. 91. Available in: <http://www.ladocumentationfrancaise.fr/var/storage/rapports-publics/144000280.pdf>. Access in: 23 fev. 2016.

154 CASSIN, René. La Déclaration universelle et la mise en œuvre "the portico was nothing but a superb facade behind which there is nothing". ${ }^{155}$ Paraphrasing those words, it can be stated that the doors of the Draft Declaration of 2015, which make it possible to enter the temple of the rights of mankind, actually lead somewhere. ${ }^{156}$ This Draft Declaration was conceived as a text of an international nature and, therefore, the General Assembly of the United Nations, in its global capacity, constitutes the "natural instance" for its adoption. However, the legal aspect of mankind is not an issue to be dealt with exclusively by States: civil society is also called upon to take ownership of this Draft Declaration that is already supported by several non-governmental organizations. ${ }^{157}$ Furthermore, given that universal rights begin close to home, ${ }^{158}$ as Eleanor Roosevelt put it, it is important that local authorities also take ownership of this Declaration. In France, some cities, such as Strasbourg, have already taken the initiative to sign it. The rights of mankind are an invitation to circumvent and/or complement the traditional process of law-making. However, given that that law-making process has "not been completed yet, but it is in the process of becoming a reality", ${ }^{159}$ these rights contribute to the evolution of the legal thinking that, albeit becoming increasingly complex, could also be enriched by such a process.

\section{References}

ALLOT, Philip. Reconstituting humanity: new international law. European journal of international law (EJIL), v. 3, n. 2, p. 219- 252, 1992.

ALSTON, Philip. A third generation of solidarity rights: progressive development or obfuscation of internatio-

des droits de l'homme. RCADI, v. 79, 1951. p. 277/278.

155 CASSIN, René. La Déclaration universelle et la mise en œuvre des droits de l'homme. RCADI, v. 79, 1951. p. 279.

156 CASSIN, René. La Déclaration universelle et la mise en œuvre des droits de l'homme. RCADI, v. 79, 1951. "The doors of the Declaration, which make it possible to enter the temple of human rights, should actually lead somewhere."

157 Especially by the Green Cross International.

158 ROOSEVELT, 1958, Apud OFFICE OF THE HIGH COMMISSIONER FOR HUMAN RIGHTS. ABC: Teaching Human Rights: Practical Activities for Primary and Secondary Schools. New York: United Nations, 2004. p. 11 (Doc. NU A/HRC/29/40).

159 DUPUY, René-Jean. L'assistance bumanitaire comme droit de l'homme contre la souveraineté de L'État: assisting the victims of armed conflict and other disasters. Dordrecht: MartinusNijhoff Publishers, 1989. p. 34. 
nal human rights law. Netherlands international law review, v. 24, p. 307-322, 1982.

AMATO, (d') Anthony. Do we owe a duty to future generations to preserve the global environment? American journal of international law (AJIL), v. 84, n. 1, p. 190- 198, 1990.

APOSTOLIDIS CHARALAMBOS, Fritz Gérard; FRITZ Jean-Claude. L'bumanité face à la mondialisation: droits des peuples et environnement. Paris: L'harmat$\tan , 1997$.

BASLAR, Kemal. The concept of the common heritage of mankind in international law. The Hague: Martinus Nijhoff Publishers, 1998.

BEDJAOUI Mohamed. L'humanité en quête de paix et de développement: cours général de droit international public. RCADI, v. 325, 2006.

BROWN-WEIS, Edith. Fairness to Future Generations International Law: Common Patrimony and Intergenerational Equity. Tokyo: United Nations University, 1989.

BROWN-WEIS, Edith. Our rights and obligations to future generations for the environment. AJIL, v. 84, n. 1, p. 198-207, 1990.

CHEMILLIER-GENDREAU, Monique. Humanité et souveraineté, essai sur la fonction du droit international. Paris: La Découverte, 1995.

COCCA, Aldo Armando. Mankind as a new legal subject: a new juridical dimension recognized by the United Nations. In: INTERNATIONAL INSTITUTE OF SPACE LAW. Proceedings of the 13th colloquium on the law of outer space. Davis/California: University of California School of Law, 1971. p. 211-218.

COUPLAND, Robin. Humanity: what is it and how does it influence international law? International review of the Red Cross, v. 83, n. 844, p. 969-989, 2001.

DELMAS-MARTY, Mireille. Global law: a triple challenge. New York: Transnational Publishers, ano.

DELMAS-MARTY, Mireille. La refondation des pouvoirs. Paris: Éditions du Seuil, 2007. v. 3.

DELMAS-MARTY, Mireille. Le pluralisme ordonné. Paris: Éditions du Seuil, 2006. v. 2.

DELMAS-MARTY, Mireille. Les forces imaginantes $d u$ droit: Le relatif et l'universel. Paris: Éditions du Seuil, 2004. v. 1.
DELMAS-MARTY, Mireille. Vers une communauté de valeurs. Paris: Éditions du Seuil, 2011. v. 4.

DUPUY, Pierre-Marie. L'unité de l'ordre juridique international: cours général de droit international public (2000). Boston: Brill Nijhoff, 2002.

DUPUY, René-Jean. Humanité et droit international: mélanges. Paris: Pedone, 1991.

DUPUY, René-Jean. L'bumanité dans l'imaginaire des nations. Paris: Julliard, 1991.

DUPUY, René-Jean. La gestion des ressources pour l'bumanité, le droit de la mer: colloque, La Haye, 29-31 octobre 1981. The Hague: Martinus Nijhoff Publishers, 1982.

JENKS, C. Wilfred. The common law of mankind. London: Stevens and sons limited, 1958.

JONES, Harry W. Law and the Idea of Mankind. Columbia Law Review, v. 62, n. 5, p. 753-772, may 1962.

KISS, Alexandre Charles. La notion de patrimoine commun de l'humanité, RCADI, v. 175, 1982.

KISS, Alexandre. The emergence of mankind as a legal entity. In: ORWELL Colloquy "1984": Myths and realities : documents. Strasbourg: Conseil de l'Europe, 1984.

LE BRIS, Catherine. L'humanité saisie par le droit international public. Paris: LGDJ, 2012.

MAQUEDA, Ricardo. Something more about humanity as subject of law. In: INTERNATIONAL INSTITUTE OF SPACE LAW. Proceedings of the 13th colloquium on the law of outer space, october 4-10, 1970. California: University of California School of Law, 1971. p. 215-218.

MOREAU-REIBEL, Jean. Le droit de société interhumaine et le jus gentium : essai sur les origines et le développement des notions jusqu'à Grotius. CCHAIL, v. 2, p. 485-596, 1950.

NAGY, Boldizsar. Common heritage of mankind : the status of future generations. In: INTERNATIONAL INSTITUTE OF SPACE LAW. Proceedings of the 31th colloquium on the law of outer space. October 8-15, 1988, Bangalore, India, Washington/DC: American institute of aeronautics and astronautics, 1989. p. 319-325.

PAQUEROT, Sylvie. Le statut des ressources vitales en droit international: essai sur le concept de patrimoine commun de l'humanité. Bruxelles: Bruylant, 2002.

PAYOYO, Peter Bautista. Cries of the sea: world inequality, sustainable development and the common herita- 
ge of humanity. London: Martinus Nijhoff publishers, 1997. v. 33.

PETERS, Anne. Humanity as the A and $\{$ Omega $\}$ of Sovereignty. EJIL, v. 20, n. 3, 2009.

STEPHENS, Alan; WALDEN, Raphael. For the sake of bumanity: Essays in honour of Clemens N. Nathan. Leiden: Martinus Nijhoff Publishers, 2006.

TEITEL, Ruti G. Humanity's Law. Oxford: Oxford University Press, 2011.

TOMUSCHAT, Christian. International law: ensuring the survival of mankind on the eve of a new century: general course on public international law. CCHAIL, v. 281, 1999.

TRINDADE, Antônio Augusto Cançado. International law for humankind: towards a new jus gentium (I) et (II), General course of public international law. CCHAIL, v. 316, 2005.

VAN BEERS, Britta et al. Humanity across International Law and Biolaw. Cambridge: Cambridge University Press, 2014.

VARGAS, Diego Uribe. La troisième génération des droits de l'homme. CCHAIL, v. 184, p. 355-376, 1984.

ZICARDI, Capaldo Guilana. The pillars of global law. Burlington: Ashgate Publishing Company, 2008.

\section{Annex 1 - Draft Universal Declaration of the Rights of Mankind (Paris, 25 September 2015)}

1. Recalling that mankind and nature are in danger and that in particular the adverse effects of climate change, the accelerated loss of biodiversity, and the degradation of land and oceans are all violations of human rights and pose threats to the vital interests of present and future generations,

2. Noting that the extreme gravity of the situation, which is a common concern for humankind in its entirety, requires the recognition of new principles, rights and obligations,

3. Recalling its commitment to the principles and rights recognized in the Universal Declaration of Human
Rights, including gender equality, and to the purposes and principles of the Charter of the United Nations,

4. Recalling the Declaration of the United Nations Conference on the Human Environment (Stockholm Declaration, 1972), the World Charter for Nature, New York, 1982, the Rio Declaration on Environment and Development (Earth Charter), 1992, the resolutions of the General Assembly of the United Nations, namely, the Millennium Declaration, 2000, and The Future We Want, 2012,

5. Recalling that this same danger is recognized by the civil society, especially networks of people, organizations, institutions and cities in the Earth Charter 2000,

6. Recalling that mankind, which includes all human individuals and organizations, covering past, present and future generations, and that the continuity of mankind rests on this intergenerational link,

7. Reaffirming that the Earth, home to humanity, constitutes a whole characterized by interdependence and that the existence and the future of mankind are inseparable from its natural environment,

8. Convinced that the fundamental rights of human beings and the safeguarding duties to preserve nature are inherently interdependent, and that the proper conservation of the environment and the improvement of its quality is of vital importance,

\section{Considering the special responsibility of present} generations, especially the States that hold primary responsibility in this area, but also that of peoples, intergovernmental organizations, corporations, including multinationals, non-governmental organizations, local authorities and individuals,

10. Considering that this responsibility reflects particular duties vis-à-vis mankind, and that these obligations are to be fulfilled relying upon just, democratic, ecological and peaceful mechanisms,

11. Considering that recognition of the dignity inherent to mankind and its members constitute the foundation of freedom, justice and peace in the world, 12. Proclaims the following principles, rights and 
obligations and adopts the present declaration:

\subsection{The Principles}

Article 1:

The principle of responsibility, equity and solidarity, which is of intragenerational and intergenerational nature, demands of the human family and in particular of the States to work in a common but differentiated manner to safeguard and preserve mankind and Earth.

Article 2:

The principle of dignity of mankind and its members involves the satisfaction of their basic needs and the protection of their intangible rights. Each generation ensures compliance with this principle in time.

Article 3:

The principle of continuity of the existence of mankind guarantees the preservation and protection of humankind and the Earth, through prudent human activities respectful of nature, particularly of life, human and non-human, taking all necessary measures aimed at preventing any serious or irreversible consequences that may transcend generations.

Article 4:

The principle of non-discrimination against those belonging to a certain generation preserves mankind, particularly future generations and requires that the activities or measures undertaken by present generations do not have the effect of causing or perpetuating an excessive reduction of resources and choices for future generations.

\subsection{The rights of mankind}

Article 5:

Mankind, like all living species, has the right to live in a healthy and ecologically sustainable environment.

Article 6:

Mankind is entitled to a responsible, equitable, inclusive and sustainable development.

Article 7:

Mankind is entitled to the protection of the common natural, cultural, tangible and intangible heritage.
Article 8:

Mankind has the right to the preservation of common goods, especially air, water and ground, and universal and effective access to vital resources. Future generations are entitled to the transmission of the aforementioned goods.

Article 9:

Mankind has the right to peace, in particular the peaceful settlement of disputes as well as to human security concerning environmental, food, health, economic and political issues. This right aims in particular to preserve succeeding generations from the scourge of war.

Article 10:

Mankind has the freedom of choice to determine its own fate. This right is exercised by taking into account the long term, and notably the cycles inherent to mankind and nature, in collective choices.

\subsection{The duties towards mankind.}

Article 11:

The present generations have a duty to ensure respect for the rights of mankind as well as that of all living species. Respect for the rights of mankind and of man, which are indivisible, apply in respect to successive generations.

Article 12:

The present generations, who are guarantors of resources, ecological balance the common heritage and the natural, cultural, tangible and intangible heritage have a duty to ensure that this legacy is conserved and that it be used with caution, and in a responsible and equitable manner.

Article 13:

To ensure the sustainability of life on Earth, the present generations have a duty to put in every effort to preserve the atmosphere and the climatic equilibrium to prevent as much as possible the movement of people related to environmental factors and, failing this, to rescue and protect the affected people.

Article 14:

The present generations have a duty to guide scientific and technical progress towards the preservation of 
humans and their health as well as another species. To this end, they must, in particular, ensure access and use of biological and genetic resources respecting human dignity, traditional knowledge and the preservation of biodiversity.

Article 15:

All States and other subjects, public and private actors have the duty to integrate the long-term and promote sustainable human development. This as well as the principles, rights and duties proclaimed in this Declaration should serve as a basis for learning lessons, raising awareness and taking further action for their actual implementation.

Article 16:

All States are under the obligation to ensure the effectiveness of the principles, rights and duties proclaimed by this Declaration, including through the organization of mechanisms to ensure their full observance. 


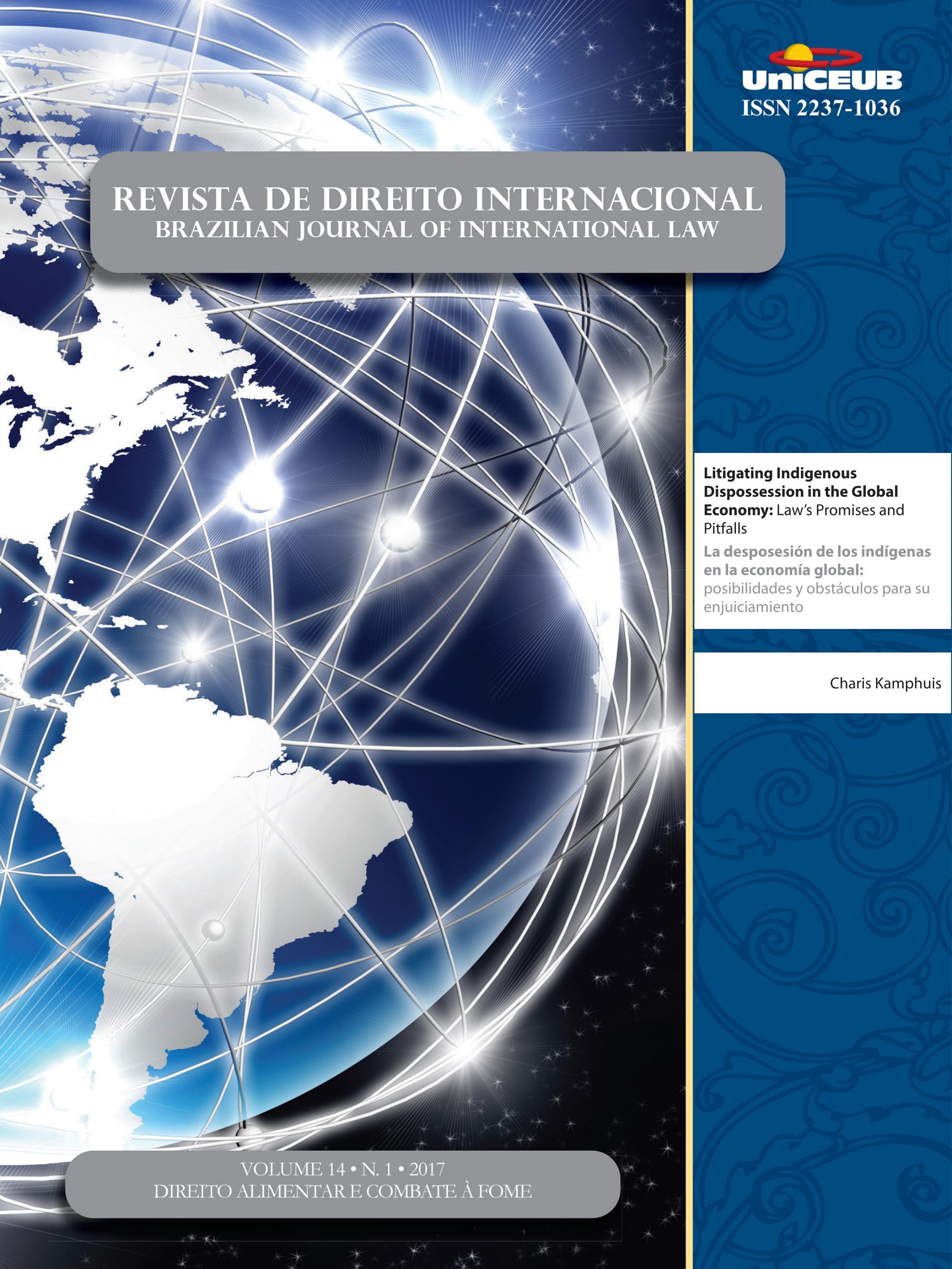




\section{Litigating Indigenous Dispossession in the Global Economy: Law's Promises and Pitfalls*}

\author{
La desposesión de los indígenas en la \\ economía global: posibilidades y obstáculos \\ para su enjuiciamiento
}

Charis Kamphuis**

\section{Abstract}

Based on documents collected with local community members and advocates over the course of more than a decade, this paper begins by describing the legal processes whereby the Campesino Community San Andres de Negritos allegedly "consented" to its own dispossession in favor of the large foreign-owned Yanacocha Mine located in Northern Peru. It frames this story within the larger unfolding story of Agrarian Reform, neoliberal globalization, transnational resource extraction, the rise of community-based activism, and the emergence of Indigenous rights in international law and domestic constitutions in Latin America. In this highly-textured context, this paper describes how advocates developed an innovative rights framework for problematizing the Negritos Community's dispossession and challenging the legality of Yanacocha's operations. This unprecedented turn to the law ultimately reveals a disjuncture between the expansion of Indigenous rights recognition at one level, and the absence of appropriate causes of action and procedures for operationalizing these rights on the ground. As the Negritos Community litigates its case against one of the most powerful mining companies in the world, it has faced numerous challenges inside and outside of the courtroom. This paper critically analyzes the response of the state, the company and the domestic legal system. It focuses in particular on the limitation period procedural rule and the formalist and discriminatory view of consent that has permeated the courts' decisions to date. In formulating this critique, the paper theorizes "the dynamics of dispossession" and reflects on human rights law's promise and pitfalls as an instrument of global economic justice. The conclusion articulates this study's findings and consequences for future research and law reform.

\section{Resumen} tice. Acknowledgment is also due to the NGO GRUFIDES in Cajamarca, Peru, to the Legal Clinic at San Marcos National University in Lima, Peru, to lawyer Jesica Karina Chuquilin Figueroa who represented the Negritos Community pro bono before the courts of first and second instance, and to Juan Carlos Ruiz Molleda who represents the Community before Peru's Constitutional Court. All translations are mine.

* Recebido em 08/03/2017

Aprovado em 05/04/2017

** Assistant Professor, Faculty of Law, phuis@tru.ca. This paper and the case that it porate Accoun you to Richard Wong, Margarita Malkina, Ivar Calixto, Carlos Alberto Quispe Davila, Jeansistance. The development of the ideas in this Imai, Juan Carlos Ruiz Molleda, Pedro Paulino Grandez Castro, Ruth Buchanan and Robert Wai. This study is only possible because of the dedication of the Campesino Community
Basado en documentación aportada por miembros y abogados de las comunidades locales en el transcurso de más de una década, este estudio comienza con la descripción de los procesos legales mediante los que la comunidad campesina San Andrés de Negritos supuestamente "consintió" su propia desposesión por la gran mina aurífera de propiedad extranjera, Yanacocha, ubicada en el norte de Perú. El texto enmarca este caso dentro 
de las historias interconectadas de la reforma agraria, la globalización neoliberal, la extracción transnacional de recursos, el crecimiento del activismo de base local y la plasmación de los derechos indígenas en el derecho internacional y en las constituciones latinoamericanas. En este contexto altamente complejo, el estudio describe cómo los abogados desarrollaron un creativo marco legal para problematizar la desposesión de la comunidad de Negritos e impugnar la legalidad de las operaciones de Yanacocha. En esencia, este novedoso uso de las leyes muestra la contradicción que se presenta entre la expansión del reconocimiento de los derechos indígenas, por una parte, y por la otra la ausencia de precedentes y procedimientos judiciales apropiados para aplicar estos derechos en la práctica. Al presentar ante la justicia su caso contra una de las más poderosas compañías mineras del mundo, la comunidad de Negritos ha enfrentado numerosos desafíos dentro y fuera de la sala del tribunal. El presente estudio analiza críticamente la respuesta del estado, la compañía y del sistema legal peruano, centrándose particularmente en la norma procesal del período de prescripción y en el criterio formalista y discriminatorio del consentimiento que ha permeado hasta hoy día las decisiones de los tribunales. Al formular esta crítica, el estudio teoriza sobre la "dinámica de la desposesión" y reflexiona sobre las posibilidades que brinda el derecho internacional de los derechos humanos como instrumento de la justicia económica global, así como los obstáculos que enfrenta su aplicación. La conclusión articula los hallazgos y las consecuencias del estudio, con vistas a futuras investigaciones y a la reforma de la ley.

\section{Introduction \& Context: Global Resource Conflicts and the Governance GAP}

In the last two decades, foreign investment in the extraction of natural resources has expanded dramatically around the world. ${ }^{1}$ Latin America in particular has become a region plagued by social conflicts between communities, resource extraction companies and the states that support them. ${ }^{2}$ These conflicts often origi-

1 Todd Gordon \& Jeffery R Webber, Blood of Extraction: Canadian Imperialism in Latin America (Fernwood Publishing, 2016).

2 OAS, Inter-American Commission on Human Rights, Criminalization of the Work of Human Rights Defenders, OROEA/Ser.L/ nate in community concerns related to control over the use of land, environmental protection and the equitable distribution of benefits. ${ }^{3}$ Social conflicts are intense, involving everything from peaceful protests, civil disobedience and sit-ins or occupations. These actions are often met with the exercise of force by public and private security forces. Activists and community members are too often defamed, threatened, surveiled, incarcerated, injured and in some instances even murdered due to their criticism of resource extraction projects. ${ }^{4}$ In Latin America as a whole, the proponents of resource extraction activities are typically foreign companies headquarter in wealthy developed countries. As of 2016, mining companies headquartered in Canada, the United States and the United Kingdom had the greatest presence in the region. ${ }^{5}$

II.Doc.49/15 (2015) at paras 48-50. Also see Observatorio de Conflictos Mineros de América Latina, "Mapa de Conflictos Mineros en América Latina", online: http://www.conflictosmineros.net/; McGill Research Group Investigating Canadian Mining in Latin America, "Canadian Mining in Ecologically Vulnerable Areas: South America”, online:http://micla.ca/wpcontent/uploads/2012/05/ CanadianMining_ecologically_vulnerable_areas.png; Environmental Justice Organization, Liabilities and Trade, "Environmental Justice Atlas", online: http://ejatlas.org/.

3 Most resource extraction is an industrial for-profit activity that fundamentally involves permanently transforming the surface and/ or subsurface of significant tracts of land with which communities have a mix of historical, cultural, economic and social relationships, along with asserted or recognized legal rights: Special Rapporteur on the Rights of Indigenous Peoples, James Anaya, Extractive industries and indigenous peoples, GA, 24 $4^{\text {th }}$ Sess, UN Doc A/HRC/24/41 (2013) [Anaya]; OAS, Inter-American Commission on Human Rights, Indigenous Peoples, Afro-Descendent Communities, and Natural Resources: Human Rights Protection in the Context of Extraction, Exploitation, and Development Activities, OROEA/Ser.L/VII.Doc.47/15 (2015) [OAS, Human Rights Protection].

4 See generally supra notes 1 and 2. Also see: Justice \& Corporate Accountability Project, The "Canada Brand": Violence and Canadian Mining Companies in Latin America (JCAP, 2016); Jen Moore, In the National Interest?: Criminalization of Land and Environment Defenders in the Americas (MiningWatch Canada, 2015); Charis Kamphuis, "Foreign Investment and the Privatization of Coercion: A Case Study of the Forza Security Company in Peru" (2012) 37(2) Brooklyn Journal of International Law 529 [Kamphuis, "Privatization of Coercion"]; Global Witness, On Dangerous Ground: The Killing and Criminalization of Land and Environmental Defenders Worldwide (London: Global Witness, 2016).

5 Half of announced investment in metal mining between 2003 and 2015 in Latin America originated in Canadian firms (50.6\%), which also accounted for $83.0 \%$ of total investment in gold and silver mining. United Kingdom-based companies made up the next largest source, representing $52.2 \%$ of investment in iron ore mining and $21.3 \%$ of investment in copper, nickel, lead and zinc mining. The United States was the main source of investment in aluminum and the second-largest investor in iron ore extraction: Economic Commission for Latin America and the Caribbean (ECLAC), Foreign 
The proliferation of these kind of social conflicts, not only in Latin America but also elsewhere in the world, has led to an extensive global debate regarding the governance of transnational resource extracting companies and their impacts on local communities in developing countries. ${ }^{6}$ As a whole, this debate tends to center on the efficacy (or not) of corporate social responsibility mechanisms ${ }^{7}$, the existence (or not) of a home state responsibility to regulate ${ }^{8}$ and the viability (or not) of a binding international treaty instrument to address these matters. ${ }^{9}$ While these conversations are prolific, they overwhelmingly focus on jurisdictions and instruments outside of the developing countries where ground-level social conflicts around resource extraction

Direct Investment in Latin America and the Caribbean, 2016, LC/G.2680$\mathrm{P}$ (Santiago, 2016) at 107.

6 John Ruggie, Special Representative of the Secretary-General on the Issue of Human Rights and Transnational Corporations and Other Business Enterprises, Guiding Principles on Business and Human Rights: Implementing the United Nations "Protect, Respect and Remedy" Framework, OHCHR, UN Doc A/HRC/17/31 (2011); Penelope Simons \& Audrey Macklin, The Governance Gap: Extractive Industries, Human Rights, and the Home State Advantage (New York: Routledge, 2014).

7 Hevina S. Dashwood, The Rise of Global Corporate Social Responsibility: Mining and the Spread of Global Norms (Cambridge University Press, 2012); Cynthia A. Williams, "Civil Society Initiatives and 'Soft Law' in the Oil and Gas Industry" (2003-2004) 36 NYU Journal of International Law and Politics 457; Luis Eslava, "Corporate Social Responsibility \& Development: A Knot of Disempowerment" (2008) 2 (2) Oñati Journal of Emergent Socio-Legal Studies 43; Ronen Shamir, "Corporate Social Responsibility: A Case of Hegemony and Counter-Hegemony" in Boaventura de Sousa Santos \& Cesar A. Rodriguez-Garavito, eds, Law and Globalization from Below: Towards a Cosmopolitan Legality (Cambridge University Press, 2005); Penelope Simons, "Corporate Voluntarism and Human Rights: The Adequacy and Effectiveness of Voluntary Self-Regulation Regimes" (2004) 59 Relations industrielles/ Industrial Relations 101.

8 Sara L. Seek, "Home State Responsibility and Local Communities: The Case of Global Mining" (2008) Yale Human Rights \& Development Law Journal 177-206; ETOS for Human Rights beyond Borders, Maastricht Principles on Extraterritorial Obligations of States in the Area of Economic, Social and Cultural Rights (February 2012); Robert McCorquodale \& Penelope Simons "Responsibility Beyond Borders: State Responsibility for Extraterritorial Violations by Corporations of International Human Rights Law" (2007) 70 Modern Law Review 598.

9 Jens Martens, Corporate Influence on the Business and Human Rights Agenda of the United Nations (Germany: Global Policy Forum, June 2014); Penelope Simons, "International law's invisible hand and the future of corporate accountability for violations of human rights" (2012) 3:1 Journal of Human Rights and the Environment; Claire A Cutler, "Private transnational governance and the crisis of global leadership" in Stephan Gill, ed, Global Crises and the Crisis of Global Leadership (Cambridge University Press, 2011); Elaboration of an international legally binding instrument on transnational corporations and other business enterprises with respect to human rights, HRC Res, UNGAOR, 26th Sess, UN Doc A/HRC/26/L.22/Rev.1 (2014). are taking place. There is relatively little debate in the global governance literature over the emerging efforts of mine-affected communities in developing countries to engage with their own domestic public law regimes in order to address their justice concerns. ${ }^{10}$ There are relatively even fewer in-depth, extended studies of this form of legal activism and its implications. ${ }^{11}$

This absence likely has more than one reasonable explanation. Developing country legal systems are routinely viewed as either incapable or unwilling to rein in transnational resource companies and subject them to the rule of law generally, much less to human rights standards more specifically. Some point to the presence of endemic inefficiencies, corruption and inadequacies in developing country legal systems, the product of some combination of a chronic lack of resources, colonial

10 References to these efforts are beginning to appear in some places, although most are cursory. For a reference to a court case in Chile, see: James S Phillips, "The rights of indigenous peoples under international law" (2015) 26(2) Global Bioethics 120; Michelle Richard, "Conflict in Latin America over Natural Resource Exploitation” (2013) 19 L \& Bus Rev Am 561. For discussions of a court case in Argentina, see Brant McGee, “The Community Referendum: Participatory Democracy and the Right to Free, Prior and Informed Consent to Development" (2009) 27 Berkeley J Intl L 570. For references to court cases in Columbia see: Viviane Weitzner, Holding Extractive Companies to Account in Columbia: An evaluation of CSR instruments through the lens of Indigenous and Afro-Descendent Rights (The North-South Institute, Proceso de Comunidades Negras, Resguardo Indígena Cañamomo Lomaprieta, 2016); Europe-Third World Centre \& International Association of Democratic Lawyers, Mining and Human Rights Violations in Colombia: The Case of Anglo Gold Ashanti us the Afro-descendant community of La Toma, UNGA, 26th Sess, Annex, Agenda Item 3, UN Doc A/HRC/26/NGO/38 (2014). For references to court cases in Guatemala, see: Rachel Sieder, "'Emancipation' or 'regulation'? Law, globalization and indigenous peoples' rights in post-war Guatemala" (2011) 40(2) Economy and Society 239; Shin Imai et al, "Breaching Indigenous Law: Canadian Mining in Guatemala" (2007) 6(1) Indigenous L J 101. For references to court cases in Ecuador, Bolivia and Costa Rica, see Begüm Özkaynak et al, Mining conflicts around the world: Common grounds from an Environmental Justice perspective, EJOLT Report No 7 (Environmental Justice Organisations, Liabilities and Trade, 2012).

11 For some recent examples of case studies of the genius, litigation and consequences of particular Indigenous rights cases see: Cesar Rodríguez-Garavito \& Diana Rodríguez-Franco, Radical Deprivation on Trial: The Impact of Judicial Activism on Socioeconomic Rights in the Global South (Cambridge University Press, 2015); Pooja Parmar, Indigeneity and Legal Pluralism in India: Claims, Histories, Meanings (Cambridge University Press, 2015); Judith Kimerling, "Habitat as Human Rights: Indigenous Huaorani in the Amazon Rainforest, Oil and Ome Yasuni" (2016) 40 Vermont Law Review 445. For a series of studies of domestic human rights litigation in the African context in an effort to challenge global poverty, see: Lucie E. White \& Jeremy Perelman, Stones of Hope: How African activists reclaim buman rights to challenge global poverty (Stanford University Press, 2011). 
histories, foreign influences, and imperial impositions. ${ }^{12}$ Other scholars point to the ways in which international trade agreements and foreign investment protection agreements circumscribe the range of public policy options available to decision makers in developing countries in relation to foreign resource companies. ${ }^{13}$ The applicable instruments of public international law are often similarly viewed as inadequate, for the reason that, even when binding, they represent a system of law that is non-enforceable vis-à-vis a developing country state that, once again, is beholden to the powerful companies that it hosts. ${ }^{14}$ Finally, logistically and conceptually, it may be difficult for the transnational solidarity networks that support mine-affected communities to engage with developing country legal systems, causing them to favor other more familiar legal options and strategies.

These explanations and characterizations are well known. They form part of the context for an important global conversation about how to address the "governance gap", a term used to refer to the systemic impunity that transnational corporations, operating in developing countries, appear to enjoy. ${ }^{15}$ This article in

12 See Simons \& Macklin, supra note X at 16-17, citing the OECD definition of weak governance zones. In a transnational tort action against a Canadian mining company, the British Columbia Court of Appeal recently decided that the risk of an unfair trial in the Guatemalan courts was a factor that weighed in favor of its determination that the province of British Columbia is the most appropriate jurisdiction to hear the Guatemalan plaintiffs' claim: Garcia v Taboe Resources Inc, 2017 BCCA 39. For critique of Canadian foreign policy in relation to resource extraction in developing countries, see generally: Stephen Brown, ed, Struggling for Effectiveness: CIDA and Canadian Foreign Aid (McGill-Queen's University Press, 2012); Yves Engler, The Black Book of Canadian Foreign Policy (Fernwood Publishing \& RED Publishing, 2009).

13 Hadrian Mertins-Kirkwood, A Losing Proposition: the Failure of Canadian ISDS Policy at Home and Abroad (Ottawa: Canadian Centre for Policy Alternatives, 2015); Gus Van Harten, "Investment Treaty Arbitration and the Policy Implications for Capital-Importing States" in Diego Sánchez-Ancochea \& Kenneth C Shadlen, eds, The Political Economy of Hemispheric Integration (New York: Palgrave Macmillan, 2008) 83; Gus Van Harten, "Investment treaties as a constraining framework" in Shahrukh R Khan \& Jens Christiansen, eds, Towards New Developmentalism: Market as means rather than master (New York: Routledge, 2011) 154; Lorenzo Cotula, Foreign investment, law and sustainable development: A bandbook on agriculture and extractive industries, $2^{\text {nd }}$ ed, IIED Natural Resources Issues Series 31 (International Institute for Environment and Development, 2016).

14 Claes Cronstedt \& Robert C Thompson, "A Proposal for an International Arbitration Tribunal on Business and Human Rights" (2016) 57 Online Symposium, Harv Intl LJ 66, online: http:// www.harvardilj.org/wp-content/uploads/Cronstedt-and-Thompson_0615.pdf.

15 Simons \& Macklin, supra note 6, Catherine Coumans, "Alternative Accountability Mechanisms and Mining: The Problems of Ef- no way aims to detract from this extremely important conversation. Law reform and new enforceable mechanisms that aim to address problematic corporate conduct are pressing. ${ }^{16}$ However, while the larger political struggle over the terms of effective transnational regulation and extra-territorial jurisdiction continues, mine-affected communities, local activists and lawyers in the Global South are deeply involved in the daily, ground-level work of attempting to engage with existing, ostensibly enforceable, domestic public law to address their ongoing social injustice concerns. ${ }^{17}$

In spite of many pitfalls, the public law regimes currently in force in developing countries maintain a certain appeal for activists and their lawyers. They offer an enforceable rights framework, which, in the Latin American context and perhaps elsewhere, increasingly incorporates international human rights law. Moreover, domestic public law represents the system of law with the closest proximity to the historical context, democratic life and political struggles of mine-affected communities. This paper departs from the assertion that the task of recognizing, tracking and analyzing mine-affected communities' engagement with applicable public law regimes in the Global South is incredibly important. To the extent that these efforts are successful (by some measure), they represent an important advance toward the aspiration that law might be an instrument of social justice in the hands of poor and marginalized communities in developing countries. ${ }^{18}$ To the extent that they are unsuccessful (by some measure), their pitfalls offer important insight into public law's shortcomings in the context of the foreign resource extraction, with the potential to feed local law reform efforts as well as the

fective Impunity, Human Rights, and Agency" (2010) 30 CJDS 27; Ruggie, supra note 6.

16 Sara L. Seck, "Canadian Mining Internationally and the UN Guiding Principles on Business and Human Rights" (2011) 49 Can YB Int'l Law 51; Charis Kamphuis, "Canadian Mining Companies and Domestic Law Reform: A Critical Legal Account" (2012) German Law Journal 1456; Penelope Simons, "Canada's Enhanced CSR Strategy: Human Rights Due Diligence and Access to Justice for Victims of Extraterritorial Corporate Human Rights Abuses" (2015) 56 Canadian Business Law Journal 167.

17 See references in supra note 10. Also see Rachel Sieder, "The judiciary and indigenous rights in Guatemala" (2007) 5(2) Int J Const L 211.

18 See María Galvis \& Ángela Ramirez, Digesto de jurisprudencia latinoamericana sobre los derechos de los pueblos indigenas a la participación, la consulta previa y la propiedad comunitaria (Washington: Fundación del Debido Proceso, 2013); Boaventura de Sousa Santos \& César Rodríguez-Garavito, eds, Law and Globalization from Below. Towards a Cosmopolitan Legality (Cambridge: Cambridge University Press, 2005). 
broader global conversation on the transnational regulation of the multinational corporation.

Using the case study method, this article will focus on one Campesino Community's engagement with the matrix of public laws enforceable in its jurisdiction of Peru. It traces this community's attempts to translate its justice concerns with respect to the actions of a large multinational mining company into terms that have traction with applicable domestic and international law regimes. This case study is particularly interesting because its substantive issues are at the heart of the contemporary resource extraction model, namely it examines the nature of communities' ownership and control over land and access to equitable compensation and benefits when resources are developed. In this connection, this study profiles another important legal issue that challenges many resource extraction projects around the world, namely the matter of how courts should respond to past injustice claims, advanced now in the language and in accordance with the procedures of constitutional rights and international human rights law. This case study reveals some of the promises and pitfalls that may emerge when Indigenous communities in Latin America attempt to bring their claims of dispossession in the global economy to their own domestic legal systems. This test of one domestic legal system's capacity as a potential instrument of justice in this context has implications for substantive and procedural law at international human rights bodies like the Inter-American Commission and Court of Human Rights, some of which I explore in this paper's conclusion. At both the domestic and the international level, what is at stake is the ability of Indigenous communities to bring claims that might benefit from, and further advance, these bodies' promising statements of collective rights.

Part A of this paper reviews, by way of background, the first leg of the unfolding story of the Peruvian Campesino Community San Andres de Negritos. Elsewhere, I have provided an account of the legal processes whereby Yanacocha Mine, majority owned by American gold mining giant Newmont, came to occupy the Negritos Community's communally titled land in the northern Andes of Peru. ${ }^{19}$ In this previous work, I

19 Charis Kamphuis, "Foreign Mining, Law and the Privatization of Property: A case study from Peru" (2012) 3:2 Journal of Human Rights and the Environment 217 [Kamphuis, "Foreign mining"]; Charis Kamphuis, "Derecho y la Convergencia del Poder Público y el Poder Empresarial: La Desposesión Campesina y La Coerción argue that these processes were a product of the convergence of Yanacocha's corporate power with the Peruvian state's public power. I described a central feature of this convergence in terms of the production of the Community's "consent" to its own dispossession and ultimately its own legal annihilation or "annulment". The present paper adds to the story by fully assessing the complex dynamics of dispossession and describing some of the Negritos Community's responses and for$\mathrm{ms}$ of resistance to the circumstances of its dispossession, setting the context for its ultimate turn toward the Peruvian courts. Further, it situates these local forms of resistance in a national and international context of Indigenous activism that has simultaneously spurred the emergence of Indigenous rights regimes while reacting to ongoing neoliberal reforms of investment and resource laws.

Whereas Part A of this paper recounts the Negritos Community's story of dispossession and resistance, Part B tells the story of the case itself; focusing on how the Community has endeavored to pursue justice through law. In 2011, the Negritos Community initiated a constitutional amparo action in local courts in an effort to seek a remedy for its dispossession. Its action challenges the legality of Yanacocha's operations on its land, attempts to compel the state and the company to respect and protect its constitutionally recognized communal property rights, and seeks to remedy the alleged violations. Part B describes the Community's legal strategies in the domestic scene, in particular that of putting the full matrix of applicable public law before the court. Importantly, in Peru, like in other Latin American countries, the constitutional rights regime applicable to Indigenous and Campesino Communities incorporates certain international Indigenous rights principles, ratcheting up the domestic legal standard and creating a matrix of rights enforceable against both public and private actors. This makes the Negritos Community's efforts to actualize these rights provisions and principles all the more interesting, especially from the perspective of the "governance gap" referenced above.

The section also analyzes the challenges that the Negritos Community has faced, both inside and outside of the courtroom. Significantly, the actualization of rights

Privatizada en el Perú" (2012) 15 Revista Latinoamericana de Derecho Social: Universidad Nacional Autónoma de México Instituto de Investigaciones Jurídicas 57 [Translation]. 
principles through local courts involves finding a suitable domestic cause of action. The Negritos case study reveals that procedural matters can become front and center in communities' struggles to frame their stories of injustice in ways that are intelligible to public law rights protecting regimes. Legal claims are successful not only with good facts and robust substantive rights frameworks. Crucially, they must also package themselves into a recognizable cause of action and navigate the associated procedural requirements. The Negritos case study reveals how the complexity of these matters is augmented in the context of resource extraction, where the lived reality of dispossession's legal and social processes may be difficult to reconcile with procedural rules. It depicts how procedural rules become a site of struggle over the meaning of consent, the subjectivity of the rights holder, and how to come to terms with past and ongoing injustice.

This overview requires a comment on the research methods that inform this paper. The story that the Negritos case tells about dispossession and resistance (Part A), as well as the story of the Negritos Community's engagement with public law (Part B), are based on hundreds of pages of primary documents collected and organized over more than a decade by Negritos community members and pro bono local lawyers and law students based in Peru, with the support of volunteer lawyers and law students in Canada. I was an active participant in this transnational team since its inception. The documents referred to in Part A were collected beginning in 2006 and up until 2011 when the Negritos community filed its amparo claim before local courts. The documents described in Part B were collected between 2011 and 2016 as the court case wound its way toward Peru's Constitutional Court, where, at the time of publication, it awaits a final decision. All of these documents were produced either by Peruvian courts, government institutions, the company in question, or the Community's own governance bodies. These materials are complemented by information published in secondary sources as well as through many conversations between myself, members of the Negritos legal team and Community leaders over the course of multiple visits to the Community and countless virtual conversations.

The strength of this method is derived from the opportunity it provides to critique the formal legal justification for Yanacocha's presence on the Negritos Community's land. The documentary record consti- tutes the formal legal underpinnings for Yanacocha's operations, primarily rooted in property and contract law. The review of this record offers an important and potentially powerful opportunity to challenge the very legality of the company's presence, using normative frameworks embedded in constitutional and international law. In order words, the Negritos case scrutinizes Yanacocha Mine's claim to legality and advances a critique that brings the dynamics of dispossession into a legal forum. However, there is no doubt that this reliance on documents, including the Community's own written records, has limitations. While myself and other members of the Negritos legal team have spent time in the Negritos Community, our work did not include ethnographic methods. As a result, the story told here can only very partially and tangentially capture the lived experiences of Community members with respect to the events surrounding the official documents and the litigation itself. It does not endeavor to account for the meanings that Community members assign to the many legal and political moments in their journey, from the hacienda system, to Agrarian Reform, through to the arrival of Yanacocha, the Community's dispossession, and its ultimate decision to pursue justice in local courts. ${ }^{20}$

In telling this story, and notwithstanding the limitations of the documentary method, my approach to law in this article resonates with the tenants of critical legal pluralism. ${ }^{21}$ I attempt to capture the multiple scales of law at play (local, national, regional and international), the interrelationship between multiple areas of law (private and public), the slippage between substantive claims and procedural requirements, and the interaction between law, politics/ideology and corruption. In this vein, this paper consciously employs the term "story" in order to make explicit the techniques used to packa-

20 For one relatively rare example of a rich ethnographic study of one community's historic and contemporary dispossession story, see Parmar, supra note 11. Writing about a "Scheduled Tribe" in India, Parmar's captures the differing interpretations among activists, lawyers and community members with respect to the nature of the injustice at issue and the significance of the domestic litigation that emerged in response.

21 See Martha-Marie Kleinhans \& Roderick A. Macdonald, "What is Critical Legal Pluralism?” (1997) 12(2) Canadian Journal of Law \& Society 25. Kleinhans and Macdonald define critical legal pluralism as an approach that sees legal subjects as "law inventing". Also see: Roderick A Macdonald, "Custom Made: For a Non-chirographic Critical Legal Pluralism” (2011) 26 Canadian Journal of Law \& Society 301 . 
ge complex social relationships into legal frameworks that serve to justify or problematize those relationships. This reflects the socio-legal insight that, in their efforts to pursue justice through law, social justice lawyers do not just find cases. Rather, they act to convert complex social realities into terms that have currency with applicable systems of law. In this article, I examine the techniques employed in a multidimensional, shifting and sometimes contradictory legal landscape in order first, to articulate the Negritos story as one of dispossession and second, to fashion a pathway for resistance using law.

This introduction reveals the fact that this article is fundamentally a product of advocacy and activism, including my own. It is also written as part of an explicit effort to support the Negritos Community's case going forward. In other words, it takes the opportunity, in an academic venue, to explore and develop the approaches to law that might enable the Negritos Community, and communities like it, to pursue justice in domestic and international courts. Beyond its practical value to communities, this advocacy oriented approach, supported by an extensive documentary record, has the potential to ground and inform a range of analytical and theoretical work going forward. The thick description of context, practices, law and legal argument in the pages that follow offers important data that is not easily or readily available to those who have not had the opportunity to work intensively and continuously with mine-affected communities in the Global South. This material has value to efforts to theorize the concepts of consent and knowledge, as well as the procedural and remedial legal forms the might govern encounters between Indigenous communities and multinational companies operating in developing countries. As such, this paper recounts an unfinished story in more than one sense. Not only does the Negritos Community's advocacy journey continue as it awaits a decision from Peru's highest court, likewise, the concepts and legal forms profiled here similarly await further in-depth analytical reflection and research.

This article's conclusion in Part $\mathrm{C}$ takes some early steps toward this larger goal. It begins by articulating the international and comparative research and potential law reform agendas that flow from this work. Reflecting on the Negritos Community's pursuit of justice, it offers insight into law, lawyering and access to justice in the context of Campesino and Indigenous legal challenges to resource extraction practices in Latin America.
This includes an incipient reflection on the transformative potential and pitfalls of collective property rights claims as a mode for articulating the justice concerns of Indigenous communities adversely affected by the global system of resource extraction.

\section{The Negritos Story: An account of DISPOSSESSION (THE CASE TELLS A STORY ABOUT LIFE)}

In many Latin American countries, struggles over land, resources and rights often occur in the context of rural property regimes characterized by a mix of communal and individual tenures. Today's legal framework is a product of a complex history of ideologically-driven land reform initiatives that stretch from protectionist/ nationalist policies enacted between the 1960s and the $1980 \mathrm{~s},{ }^{22}$ through to on-going neo-liberal reforms begun in the 1990s that aim to foster private investment including on Campesino land, ${ }^{23}$ and now, in some countries, with relatively new layers of community consultation laws and an emerging Indigenous and Campesino constitutional rights jurisprudence. ${ }^{24}$

Each of these waves are of course the product of a complex interplay between transnational and domestic trends and influences. As a practical matter though, mine-affected communities who seek to challenge the legality of a company's concession and surface property

22 Tom Griffiths, "Indigenous Peoples, Land Tenure, and Land Policy in Latin America" in P. Groppo, ed, Land Reform: Land Settlement and Cooperatives (FAO, 2004) 49; Miguel Alteri \& Andrés Yurjevic, La agroecología y el desarrollo rural, sostenible en América Latina (Santiago de Chile: Economic Commission for Latin America and the Caribbean, 1992) online: http://repositorio.cepal.org/bitstream/ handle/11362/33761/S9200648_es.pdf?sequence=1

23 See infra Section B.5 for discussion of the more recent laws that critics argue infringe Campesino and Indigenous rights.

24 See Roger Merino Acuña, "Prior Consultation: Law and the Challenges of the New Legal Indigenism in Peru" (2014) 4(1) Hendu 19; Fundación del Debido Proceso, "El derecho a la consulta de los pueblos indígenas en Perú" (Washington, DC: 2010); Raquel Yrigoyen, "El horizonte del constitucionalismo pluralista: del multiculturalismo a la decolonización" in César Rodríguez, ed, El Derecho en América Latina: Un mapa para el pensamiento jurídico del siglo XXI (Buenos Aires: Siglo XXI Editores, 2011) 139; César Rodríguez-Garavito, "Ethnicity.gov: Global Governance, Indigenous Peoples, and the Right to Prior Consultation in Social Minefields" (2010) 18 Indiana Journal of Global Legal Studies 1; Emiliano López \& Francisco Vértiz, "Extractivism, Transnational Capital, and Subaltern Struggles in Latin America" (2015) 42(5) Latin American Perspectives 152. 
rights must navigate this complex and even contradictory domestic legal matrix. The Negritos case study provides a highly-textured example of how these trends have unfolded in Peru with consequences for present day legal struggles between mine-affected communities and foreign mining companies.

\subsection{Dispossession Story: Agrarian Reform, neoliberalism, transnational mining \& corruption}

Agrarian Reform is an important historical point of departure for the Negritos Community in that for the first time it became an entity with significance in Peruvian law. Agrarian Reform came to Peru in 1969 with an agenda to transform the agrarian system by replacing the haciendas, inherited from colonial times, with a fair system of property and a legal regime that would guarantee social justice in rural areas. ${ }^{25}$ The Agrarian Reform Law also declared that "Indigenous Communities" would thereafter be called "Campesino Communities". ${ }^{26}$ The key provisions of Agrarian Reform were later constitutionalized in the 1979 Political Constitution of Peru. The program was also implemented in part through a series of statutes that purported to define Campesino Communities, their political and economic institutions, and their legal relationship with their communal lands. Most prominent among these were the 1970 Campesino Communities Special Statute, ${ }^{27}$ the 1987 Campesino Communities General Law ${ }^{28}$ and the 1987 Law for the Demarcation and Titling of the Communal Territories of Campesino Communities. ${ }^{29}$ The significance of this domestic legal regime for the Negritos case will be described more fully in the next section.

In 1971 the Peruvian state designated the inhabitants

25 Law No 17716, Agrarian Reform Law (1969), art 1. When comparing Agrarian Reform in Peru to other processes of the same name across Latin America, some authors have characterized Peru's Agrarian Reforms as "revolutionary", "massive" and "structural": see Raúl Alegrett, "Past and present land reform in Latin America" in P. Groppo, ed, Land Reform: Land Settlement and Cooperatives (FAO, 2003/2) 112 online: http://www.fao.org/docrep/006/J0415T/ j0415t0b.htm.

26 Agrarian Reform Law, ibid, art 115.

27 Supreme Decree No 37-70-AG, Campesino Communities Special Statute (1970).

28 Law No 24656, Campesino Communities General Law (1987). Also see: Supreme Decree No 008-91-TR, Regulation of the Campesino Communities General Law (1991).

29 Law No 24657, Law for the Demarcation and Titling of the Communal Territories of the Campesino Communities (1987). of an area of land called "Negritos" as beneficiaries of Agrarian Reform and in 1974 the country's President decreed that 14,375 hectares of land would be communally titled in the Community's name. The Negritos Community is located in the northern Andes of Peru in the Department of Cajamarca, relatively close to the regional capital city, also called Cajamarca. It is one of approximately 118 Campesino Communities in the entire Department. Cajamarca is a predominately rural region and has consistently ranked among the poorest in the country. In 2015 about half of the population continued to live in poverty and another one quarter struggling in extreme poverty. ${ }^{30}$ In La Encañada, the district where the Negritos Community is located, poverty levels in recent years have fluctuated between 70 and $80 \% .{ }^{31}$ The Negritos Community is located in the highlands, accessible only by a simple road. Most households do not have electricity or running water.

The practical implementation of Agrarian Reform was a complex affair, under-resourced and suffering from serious deficiencies, delays and in some cases, acts of corruption. ${ }^{32}$ The Negritos Community was not immune to these issues. For example, in 1975, in a patently illegal move, state officials purported to sell the Negritos Community's land to representatives of the neighboring Campesino Community of Tual. In 1980, the payment requirement was removed but title remained with the neighboring Community. When Negritos community members became aware of these events in 1986, they called a General Assembly and agreed to pressure Peruvian government bodies to recognize their Community and its property rights. This agreement was recorded in a handwritten resolution entitled "Act of the General Assembly of the Negritos Community":

By majority we request the separation of Negritos land from the Campesino Community of Tual and the [legal] formation of an independent community that will be called Negritos, given that among other things we are an independent socio-economic territorial unit,

30 Cajamarca is one of three regions of Peru with the highest incidence of poverty, generally fluctuating between 44.7 and $51.7 \%$. As of 2015 Cajamarca had the highest incidence of extreme poverty in Peru, with peak levels reaching $26.97 \%$ of the total population in 2013: see Instituto Nacional de Estadística e Informativa, Evolución de la Pobreza Monetaria: 2009-2015 (Lima: INEI, 2015) at 46, 50.

31 Ibid, at 61, 107.

32 Alfonso Quiroz, Historia de la corrupción en el Perú, translated by Javier Flores, Popular Collection Series No 5 (Lima: Institute for Peruvian Studies, 2014) at 320-9. Also see: Alfonso Quiroz, Corrupt Circles: A History of Unbound graft in Peru (Washington: Woodrow Wilson Center Press, 2008). 
which is why it is absurd to consider that we might be part of the Campesino Community of Tual, given that the two communities have always lived independently without any links between us. [translation]

There is a paper trail, beginning in the 1980s, of handwritten records (Acts) of decisions made at Negritos Community General Assembly meetings. To date, Community members maintain original copies of the documents produced at these meetings. In these Acts, Community members describe their communal decision-making processes regarding many practical matters of interest to their Community as a whole. They make reference to their collective political and legal institutions, elections of leaders, decisions related to communal justice, agreements regarding communal planting and harvesting of crops, and the collective management of communal property and finances.

Between 1987 and 1989, officials from the Ministry of Agriculture responded to the Negritos Community's requests for recognition in a series of field studies and meetings with community members. Based on these visits, Ministry officials wrote in their technical reports that the Negritos Community members are "natural-born" Campesinos, with their own unique characteristics and institutions, "who have been working on the communal lands in question since the time of their ancestors". Finally, in 1990, the Ministry officially recognized the Campesino Community San Andres de Negritos as a legal entity consisting of 140 families. Community members then took steps to debate their Community Statute and Internal Regulations, "article by article", which they ultimately adopted with a signature from the head of each family. Among other things, these rules allowed Negritos families to obtain "certificates of possession" of parcels of Negritos communal land. Between 1990 and 1991, Community members worked with Ministry staff to demarcate the boundaries of its territory. The agreed upon demarcations establishing a total surface area of 13,609 hectares of Community land and this was incorporated into the Community's Internal Statute. Negritos' communal title was registered in the local Public Registrar in October of 1991.

Following these events, this story of recognition and communal titling abruptly reversed itself over just a few short years. By 1995 Yanacocha Mine had established itself squarely within the boundaries of the Negritos Community's land. Moreover, according to the State and company, the Negritos Community no longer exis- ted in law and was not longer a property titleholder. The remainder of this section will describe the documentary record of how this came to be.

As the first large-scale foreign investment project of its kind in the country and perhaps even the entire region, Yanacocha was truly emblematic of the new face of neoliberal globalization in Peru, in the region and the entire world. It consisted of a joint venture between its majority shareholder, the American company Newmont Mining, and its minority shareholders, the International Finance Corporation (IFC), an arm of the World Bank, and Buenaventura, a Peruvian company owned by one of the most powerful families in Peru. ${ }^{33}$ With significant start-up financing from the IFC, Yanacocha quickly grew to be the largest gold mine in Latin America and one of the largest in the world. ${ }^{34}$ Its extraordinary profitability, due in part to extremely low production costs, has also been the subject of significant study, with some authors concluding that it quickly became the most profitable mine in the world. ${ }^{35}$ Yanacocha's size and profitability have arguably made a significant contribution to the success of its majority shareholder. In 2015 Newmont Mining was the second largest gold producer globally. ${ }^{36}$ These figures starkly contrast those that depict persistent extreme poverty in the region of Cajamarca, which marked 2015 with the highest levels of extreme poverty in Peru. ${ }^{37}$

Yanacocha established itself in Peru at a time of radical neo-liberal restructuring of the Peruvian legal and economic system, and just as neo-liberal globalization began to take a stronger hold in many countries around the world. ${ }^{38}$ Elected president of Peru in 1990, Alber-

33 Newmont Mining Company, online: http://www.newmont. com/operations-and-projects/south-america/yanacocha-peru/ overview/default.aspx.

34 Some researchers report that Yanacocha is the second largest gold mine in the world: Fabiana Li, "Contested Equivalences: Controversies over water and mining in Peru and Chile" in John Wagner, ed, The Social Life of Water (Berghahn Books, 2013) at 18 [Li, "Contested Equivalences"].

35 Raul Wiener \& Juan Torres, Large scale mining: Do they pay the taxes they should? The Yanacocha case (Latin American Network on Debt, Development and Rights, 2014) at 23, 29. These researchers allege that Yanacocha has consistently inflated its expenses to reduce its taxes owing: ibid at 73 .

36 "10 Top Gold-producing Companies", Investing News Network (20 April 2016) online: http://investingnews.com/daily/resourceinvesting/precious-metals-investing/gold-investing/barrick-newmont-anglogold-goldcorp-kinross-newcrest/.

37 Supra note 30.

38 David Harvey, “The 'New' Imperialism: Accumulation by Dis- 
to Fujimori became a champion of neo-liberal policies, immediately implementing a wide-ranging program to reduce restrictions on international trade and investment while also cutting government funding of social services, health and education. ${ }^{39}$ Fujimori immediately began to pursue policies specifically aimed at weakening Agrarian Reform and opening Campesino communal land up to foreign investment. ${ }^{40}$ In addition to this very favorable legal framework, Yanacocha's investors further benefited from a foreign investment agreement with the Peruvian government, guaranteeing it a low rate of income tax, tax-stability, and a complete exemption from royalty payments. ${ }^{41}$

The comfortable relationship between Yanacocha Mine, its majority shareholder Newmont, and the Peruvian government has, at a minimum, crossed ethical boundaries. In the mid-1990s, Newmont became embroiled in a legal dispute in Peruvian courts with a French company over the right to shares in Yanacocha. ${ }^{42}$ In the early 2000s, video evidence leaked as part of a New York. Times investigation revealed that, in the midst of the court case, in two separate meetings, a representative of the American Central Intelligence Agency (CIA) and a Newmont executive personally requested help from Vladimiro Montesinos, the head of Peru's secret intelligence agency and the most powerful official in the country at the time. ${ }^{43}$ In response, Monestinos met with one of the seven justices of Peru's Supreme Court who were presiding over the case.

possession" (2004) 40 Socialist Register 63.

39 See: Legislative Decree No 662, Granting a Legally Stable Regime to Foreign Investors through the Recognition of Certain Guarantees (1991); Legislative Decree No 757, Legal Framework for the Growth of Private Investment (1991); Legislative Decree No 674, Law for the Promotion of Private Investment in State Enterprises (1991); Legislative Decree No 708, Law for the Promotion of Investments in the Mining Sector (1991).

40 In 1991, Fujimori repealed the Agrarian Reform Law, replacing it with Legislative Decree No 653, Law for the Promotion of Investment in the Agrarian Sector (1991). He followed this with an agrarian land titling program that only contemplated individual title and a controversial law dubbed the "Land Law": Law No 26505, Law for the Promotion of Private Investment in the Development of Economic Activities on the National Territory and on Campesino and Native Community Land (1995). Fujimori's attack on Campesino land and institutions has continued with subsequent governments: see infra Part B.5.

41 Christian Aid, Undermining the Poor: Mineral Taxation Reforms in Latin America (September 2009) at 9, 16; Wiener \& Torres, supra note 35 at 42 . For a general description of the tax agreements available to the mining sector in Peru, see Wiener \& Torres, ibid at 65-6.

42 Wiener \& Torres, ibid at 11.

43 Ibid at 12. J Perlez \& L Bergman, "Tangled Strands in Fight Over Peru Gold Mine” (Series: The Cost of Gold: Treasure of Yanacocha), New York Times (25 October 2005).
Leaked videos depict Montesinos explaining to the judge that he must decide in Newmont's favor in order to improve Peru's diplomatic position in negotiations with the United States on other matters. ${ }^{44}$ Days later, the Supreme Court handed down its decision, with the judge in question making the difference in a 4-3 vote in Newmont's favor. The Yanacocha scandal was only the beginning of Fujimori and Monestinos' downfall. Beginning in 2007, and unrelated to Yanacocha, Peruvian courts found Fujimori guilty of a long list of crimes, including crimes against humanity and corruption. ${ }^{45}$ Montesinos was similarly found guilty, beginning in 2002, of numerous crimes related to corruption and abuse of public office. ${ }^{46}$ Thus, while the careers of these political leaders ended, Yanacocha's career, as a profitable mine surrounded by impoverished communities, remained in full swing.

This broad strokes description of these macro processes paints a backdrop for the micro-level legal and social processes that opened doors for Yanacocha on the ground, or more specifically, on the Negritos Community's communally titled land. ${ }^{47}$ Generally speaking, the mineral tenure system in Peru is similar to that of many other countries in that a company can begin extraction only after the state has granted it a mi-

44 Some of the leaked videos are available online. For a video of the meeting between Montesinos and a representative of the Central Intelligence Agency (CIA), see: "Vladimiro Montesinos ofreciendo mina Yanacocha a través de la CIA a cambio de millones", YouTube, online: https://www.youtube.com/watch?v=15k3GHWHHVw. For a transcript of the meeting between Montesinos and Justice of the Supreme Court of Peru, see: Segunda Legislatura Ordinaria de 2000, Transcripción del Vídeo No 892 (19 May 1998), online: http://www2.congreso.gob.pe/sicr/diariodebates/audiovideos. nsf/indice/CD180DDE013DE79805256A8E006F659A. There are a number of documentary videos about these events, including one by a New York Times journalist: Lowell Bergman, La maldición del oro inca (FRONTLINE/World, 2005), YouTube, online: https://www. youtube.com $/$ watch?v=5OdJ9eRv_LY.

45 Supreme Court of Justice of the Republic, Criminal Investigations Section, Exp No 13-03 (11 December 2007); Supreme Court of Justice of the Republic, Special Criminal Appeals Section, Exp No 10-2001 / Acumulado No 45-2003 AV (7 April 2009); Supreme Court of Justice of the Republic, Special Criminal Appeals Section, Exp No AV-33-2003 (30 September 2009); Supreme Court of Justice of the Republic, Special Criminal Appeals Section, Exp. No AV 19-2001 (7 April 2009); Supreme Court of Justice of the Republic, Special Criminal Appeals Section, No AV-23-2001 (20 July 2009).

46 Roberto Barandiaran Dempwolf \& José Antonio Nolasco Valenzuela, Jurisprudencia penal generada en el subsistema anticorrupción. Corrupción gubernamental, Vol 2 (Lima, Palestra: 2006) at 691-704, 991 1011, 712-779.

47 Some parts of this story are recounted in Kamphuis, "Foreign mining", supra note 19 at 224-31. 
neral concession, referring to a kind of property right to the subsurface minerals beneath a tract of land. ${ }^{48}$ As stated above, Newmont's acquisition of the concession rights to Yanacocha Mine are a point of controversy. However, with these rights in hand, the company faced the task of securing access to the surface land above the subsurface minerals, which of course happened to be the recently communally titled property of the Negritos Community.

In Latin America more generally, the legal processes whereby companies acquire surface property rights and access can be highly controversial for the reason that, in many cases, projects proceed without the free, prior and informed consultation or consent of Indigenous communities who either hold title, or claim title, to the surface area and perhaps even the subsurface minerals. ${ }^{49}$ Thus, for legal and practical reasons, the issue of access to surface land is often at the heart of conflicts between communities and resource companies. The Negritos case study offers a particularly stark depiction of the extraordinary difficulty of informed consultation and consent where a community is left to negotiate directly with a company in the context of immense power inequalities, which create serious risks of, among other things, the abuse of power, the breakdown of community cohesion, and the corruption of community leaders. $^{50}$

According to documents, in 1992 Yanacocha submitted a request to the Ministry of Mining for the expropriation of 609 hectares of Negritos communal land (in an area known as Pampa Larga). In 1993, the Ministry granted this request and title to this portion of land passed from the Community to the company. Official documents indicate that Yanacocha and the Community "directly agreed" to compensation in the amount of approximately $\$$ US 30,000, or just under $\$ 50$ per hectare. ${ }^{51}$ These funds were transferred directly to

48 In Peru, like in many other countries, renewable and nonrenewable natural resources, including subsurface minerals, are the property of the State and concession rights are real property rights, see: the Political Constitution of Peru, 1993, art 66; the General Law on Mining (1992) and the Organic Law for the Sustainable Use of Natural Resources (1997), art 23.

49 See generally, Anaya, supra note 3.

50 For critiques of power relationships under contemporary consultation laws in Peru and Bolivia see: Flemmer \& Schilling-Vacaflor, infra note 122.

51 Also see Wierner \& Torres, supra note 35 at 36. In their study Wierner \& Torres record that on average Yanacocha paid US\$ 52 per hectare to Campesinos in exchange for land. only three community members, including the then President, over 800 kilometers away in the national capital city of Lima. By 1995, Yanacocha had obtained two mortgages over the expropriated property in exchange for loans from the IFC and a German bank totaling US\$ $85,000,000 .^{52}$

The expropriation and the transfer of all of the compensation directly to the then Negritos President in Lima was purportedly authorized by several Acts of the Community's General Assembly. In one Act, dated just months before Yanacocha solicited the expropriation, the Community purportedly agreed to grant the President a certificate of possession to Pampa Larga, coincidently the area that would shortly become the object of expropriation. The timing and contents of this Act suggest that the President took steps to position himself to benefit from the expropriation before it was even officially requested.

Then, a few months after Yanacocha requested the expropriation, in another Act, the Community purportedly made a number of important decisions: agreeing to the expropriation; agreeing that $95 \%$ of the total compensation would be designated for the holder of the certificate of possession to the expropriated area (the then President); and granting the then President and two other community leaders the authority to act on behalf of the entire Community in all matters related to the expropriation and the transfer of funds. On the basis of these "authorizations", the President then proceeded to unilaterally agree to, and personally accept, a compensation amount. Notably, the Community's alleged agreement in this Act to the expropriation and compensation occurred before the compensation amount had been proposed.

This expropriation is only one of a number of allegedly unconstitutional and illegal transfers of Negritos' communal property to Yanacocha..$^{53}$ In 1995, in exchange for approximately US $\$ 18,000$, Yanacocha obtained a mining easement in relation to 810 hectares of Negritos communal land. The easement was tantamount to an

52 In its 2011 submissions to the First Civil Court of Cajamarca, Yanacocha claimed that the mortgage was not of the expropriated property alone, but also of other properties and all of the machinery and structures located on its property.

53 See Part B.5.b of this paper for the argument that the law of mining expropriations and easements in Peru is unconstitutional and contravenes international law with respect to Campesino and Indigenous Communities. 
expropriation given that its terms permitted the full range of mineral extraction activities. The easement was also established under the same provisions of Peruvian mining law and followed a very similar procedure to that of the expropriation.

Not surprisingly, the Negritos Community asserts that its alleged consent to the expropriation and easement was totally fraudulent. Between 1995 and 1996, the Community passed at least two General Assembly Acts condemning the Community leaders who had signed onto the expropriation and easement documents. Community members sent these Acts, along with numerous letters, to local authorities. They alleged that the Community's then President and his small group of supporters had pressured fellow Community members off of their land in anticipation of transfers of land to Yanacocha, had sold land to Yanacocha that did not belong to them, had participated in fraud and extortion in relation to the procurement of signatures on Community Acts and in the creation of certificates of possession, and had not shared any of the expropriation compensation with the rest of the Community. There is no record that state officials did anything to respond to these concerns, sent in writing. Rather, Yanacocha's operations continued to benefit from state support.

Finally, between 1992 and 1995, the Ministry of Agriculture designated the Community's communally titled land as eligible for individual title, leaving only a small portion known as the "reserve area", considered in Peruvian law to be property of the state (although this is not the Community's view). This process of individual titling culminated in an administrative act executed by the Ministry in 1995 that purported to strip the community of its legal status (legal personality) as a Campesino Community. The actions of the Ministry to convert communally titled land to individual titles and to annul the Community's legal personality were highly problematic and appear to have violated, not only the Community's constitutional rights, but also basic administrative law principles. ${ }^{54}$ The documents suggest that Ministry officials actively misinformed Negritos Community members by advising them, among other things, that their Campesino Community did not have communal property rights and that they had no other

54 See Part B.5.b of this paper for the argument that the individual titling and annulment of the Negritos Community violated the constitution and international law. choice but to accept individual title. This approach to the Community starkly contrasts the Ministry' actions, just a short few years prior, to recognize and communally title the Negritos Community.

The introduction of individual title and the purported annulment of the Negritos Community was perfectly timed with Yanacocha's arrival and occurred at a time of crisis in the Community due to the betrayal of its leaders to Yanacocha. Individual title made it even easier for the company to acquire land through direct dealings with individual Campesinos. Community members recount that transfers of property to Yanacocha were often induced by a combination of misinformation, threats, extortion and unfulfilled promises.$^{55}$ Researchers have reported that Yanacocha workers drove poor and illiterate community members to the land titles office in company vehicles in order to sign the necessary paper work. ${ }^{56}$ By 2009, Yanacocha Mine occupied approximately one third of the Negritos Community's original communally title property area. Part B.2 of this paper analyzes these events by conceptualizing the knowledge and power dynamics of dispossession in the Negritos case. Part B.5 describes the substantive rights violations that the Negritos Community attributes to these events.

As Yanacocha consolidated the surface rights necessary to initiate and quickly expand its operations, social conflict began to brew. As early as 1993, Campesinos from numerous Communities in the area had begun to complain about land usurpation, extortion, environmental impacts on animals and water and excessive use of force on the part of Yanacocha's security forces. ${ }^{57}$

55 A number of empirical studies have documented the tactics adopted by Yanacocha in purchasing land from local Campesinos: S Langdon, 'Peru's Yanacocha Gold Mine: The IFC's Midas Touch?' in Profiling Problem Projects (Project Underground, Berkeley CA 2003); Anthony Bebbington et al, "Mining and Social Movements: Struggles over Livelihood and Rural Territorial Development in the Andes" (2008) 36 World Development 2888. Wierner \& Torres accuse the company of tactics to pressure Campesinos to "sell" their land for unbelievably low prices. This includes threatening Campesinos with expropriation if they refuse to sell and hiding information about the gold deposits in order to induce them to accept lower prices for their land. These authors characterize the processes whereby Yanacocha acquired land as a "brutal fraud and pillage" of land: supra note 35 at $14-15$.

56 J Bury, "Neoliberalismo, minería y cambios rurales en Cajamarca" in A Bebbington, ed, Minería, Movimientos Sociales y Respuestas Campesinos (CEPES \& IEP, Lima 2007) 49 at 76-7.

57 Marco Arana, "El Cerro Quilish y la Mineria del Oro en Cajamarca", online: http://cajamarca.de/mine/quilish.htm; Fabiana Li, "Relating Divergent Worlds: Mines, Aquifers and Sacred Mountains in Peru" (2013) 55 Anthropologica 399 at 401 [Li, "Divergent 
These early years of protest against Yanacocha were also witness to the birth of a growing class of local NGOs in the Cajamarca region..$^{58}$ In 2000, Yanacocha's subcontracted trucking company was responsible for a serious mercury spill along a local road. ${ }^{59}$ The subsequent handling of the spill and the alleged cover up did not help the deteriorating relationship between the mine and surrounding communities. ${ }^{60}$ The community living alongside the road suffered extensive mercury poisoning and there are widespread allegations that compensation agreements between the company and victims were inadequate with many victims receiving no compensation at all. ${ }^{61}$

\subsection{The Turn to Law: An unresponsive state and the emergence of local activism}

Beginning in 2004 with a long general strike, social unrest linked to Yanacocha culminated over the years in more than one period of social crisis, widespread blockades and general strikes. ${ }^{62}$ Of course the Negritos

Worlds"]; Wierner \& Torres state that the first legal complaints about water contamination occurred in 1999: supra note 35 at 18.

58 For the influence of local NGOs, formed in the early 2000 s, on social protest and concern about mining, see: Li, "Divergent Worlds", ibid at 402.

59 Allan Ingelson, Arturo Urzúa \& William Holden, "Mine Operator Liability for the Spill of an Independent Contractor in Peru" (2006) 24(1) J Energy Nat Resources L 53.

60 The Peruvian Ombudsman reported that Yanacocha workers told community members to collect the mercury themselves and offered money rewards in proportion to the amount collected. Children and adults alike proceeded to collect the liquid mercury with their bare hands. They were not told that it was a toxic substance: Defensoría del Pueblo, El Caso del Derrame de Mercurio que afectó a las localidades de San Sebastián de Choropampa, Magdalena y San Juan, en la Provincia de Cajamarca, Informe Defensorial No 62 (2001) at 18-79. 61 Comisión de Pueblos Andinos, Amazónicos, Afroperuanos, Ambiente y Ecología, Informe del Grupo de trabajo encargado de levantar información sobre la situación ambiental y estado de salud de los afectados por el derrame de mercurio en las localidades de San Juan, Choropampa y Magdalena, Departamento de Cajamarca en junio del año 2000 (Lima: Congreso de la República del Perú, 2008). Also see documentary film: Ernesto Cabellos \& Stephanie Boyd, Choropampa: The Price of Gold (Guarango Association, 2002).

62 In 2004 protests erupted against a proposed expansion of Yanacocha Mine to a neighboring mountain called Quilish. Over a period of 15 days protestors called for a general strike, demanding that Yanacocha halt exploration activities on the mountain. At times, the protestors ranked more than 10,000 strong, uniting sections of urban and rural civil society. At the time, these protests were unprecedented in the country's history: Li, "Divergent Worlds", supra note 57. Also see: Fabiana Li, "In Defense of Water: Modern Mining, Grassroots Movements, and Corporate Strategies in Peru" (2016) 21(1) The Journal of Latin American and Caribbean Anthropology
Community, living with Yanacocha literally in its backyard, was involved in many of these protest events, which have at times implicated multiple Campesino Communities and sometimes spread to the nearby regional capital city of Cajamarca. Especially in the first decade following Yanacocha's arrival in the area, communities, including the Negritos Community, typically expressed their opposition with social protest, civil disobedience and road blockades. ${ }^{63}$ In recent years, these tactics have been increasingly accompanied by resort to local courts. ${ }^{64}$

This section describes the Negritos Community's trajectory from participation in broad-based grassroots community activism and protest to political advocacy with local officials to the articulation of collective rights claims with the support of a transnational legal team. Attention to the multiple scales of law that surround the Negritos case reveals that, at the turn of the century, growing social discontent with Yanacocha specifically, and large scale mining in Peru and the Americas more generally, occurred in conjunction with significant shifts in the international and domestic legal landscape of Indigenous rights.

Nearly two and a half decades after Agrarian Reform had declared that Peru's Indigenous peoples would thereafter be called "Campesinos", the term "Indigenous" began to reappear in Peruvian law along with a series of legal and institutional innovations with respect to peoples more generally in Peru, including Indigenous, Campesino and Afrodescendant communities. In 1993, Peru passed 1989 ILO Convention concerning Indigenous and Tribal Peoples in Independent Countries" ("Convention No 169") into domestic law, ratifying it the following year. ${ }^{66}$ Then in 1995, the National Institute for the Development

109 (referring to protests in Combayo).

63 Arana, supra note 57.

64 In 2012 local activists decided to bring a legal case against a proposed expansion of Yanacocha Mine known as the Conga Project, see: STC No 03673-2013-PA/TC (11 December 2014). Also see: Natalia Guzmán Salano, "Struggle from the margins: Juridical processes and entanglements with the Peruvian state in the era of mega-mining" (2016) 3 The Extractive Industries and Society 416; Maiah Jaskoski, "Environmental Licensing and Conflict in Peru's Mining Sector: A Path-Dependent Analysis” (2014) 64 World Development 873 (referring to protests over the proposed Conga Mine). 65 Convention concerning Indigenous and Tribal Peoples in Independent Countries, International Labour Organization, Convention No. 169, (1989) [Convention No 169].

66 Legislative Resolution No 26253, For the approval of "Convention 169 of the ILO on Indigenous and Tribal Peoples in Independent Countries" (1993). 
of Andean, Amazonian and Afro-Peruvian Peoples was created. ${ }^{67}$ These developments continued between 2003 and 2011 as the Peruvian government passed a series of laws protecting and recognizing Campesino and Indigenous peoples' rights, including in relation to Campesino traditional institutions of communal justice (2003), Indigenous groups in voluntary isolation in the Amazon (2006), Campesino and Native Communities' right to water (2009), and Indigenous Peoples' right to prior consultation (2011). ${ }^{68}$ With respect to the 2003 law on Campesino communal justice, it explicitly extended the protections of Convention No 169 to traditional justice institutions, called Rondas Campesinas. ${ }^{69}$ Between 2002 and 2005 Peru's environmental laws also added special recognition for Indigenous peoples, Campesino and Native communities, including references to rights protection, knowledge recognition, equitable compensation and consultation. ${ }^{70}$

At the same time, at the international level, and especially in the Americas, the Indigenous rights movement was making gains, catalyzed by the 2001 landmark Awas Tingni ruling where the Inter-American Court of Human Rights found that the property rights protected by the 1969 American Convention on Human Rights encompass an Indigenous right to collective property. ${ }^{71}$ Since then, the Inter-American Court has produced a notable body of jurisprudence on Indigenous property and

67 Law No 28495, Law for the National Institute for the Development of Andean, Amazonean and AfroPeruvian Peoples (1995).

68 See respectively: Law No 27908, Rondas Campesinas Law (2003); Law No 28736, Law for the protection of Indigenous and original peoples in a situation of isolation or initial contact (2006); Law No 29338, Hydro Resources Law (2009), arts 3, 64; Law No 29785, Law for the right of Indigenous and original peoples to prior constulation, recognized in Convention 169 of the International Labour Organization (2011) [Right to Consultation Law].

69 Rondas Campesinas Law, ibid: article 1 states that the recognized rights of Indigenous and Campesino Communities apply to the Rondas.

70 Law No 28611, General Law on the Environment (13 October 2005), arts 70-2; Law No 27446, National System of Environmental Impact Assessment Law (2009), art 71.

71 See Mayagna (Sumo) Awas Tingni Cmty v Nicaragua, Merits, Reparations, and Costs, Judgment, Inter-Am. Ct. H.R. (ser. C) No. 79 (Aug 31, 2001) at para 148 [Awas Tingni]. Awas Tingni was the first indigenous rights claim brought to the Inter-American Commission. The petition was filed in 1995 and the Court issued a final judgment in 2001. See Galvis \& Ramírez, supra note 18, for specific references to subsequent Indigenous rights jurisprudence in Latin American courts more generally. For a description of the emergence of the Indigenous rights movement as an international human rights movement, see Karen Engle, The Elusive Promise of Indigenous Development: Rights, Culture, Strategy (Duke University Press, 2010). cultural rights, often in response to cases brought by communities affected by resource extraction. ${ }^{72}$ These claims often echo many of the issues raised by the $\mathrm{Ne}$ gritos Community, namely that extraction activities are occurring without the consent and to the detriment of affected communities. ${ }^{73}$ This inter-American jurisprudence is important because it has the potential to influence and even direct the development of constitutional law in many Latin American countries with monist legal systems. ${ }^{74}$

It is fascinating that these national and international shifts in law and political consciousness occurred roughly in parallel to a renewal of activism and hope for justice within the Negritos Community. In 2005, following the massive 2004 regional general strike against Yanacocha (mentioned above), the Negritos Community elected a new leadership with a mandate and the capabilities to begin to investigate the past wrongs that had led to Yanacocha's entry into its territory. The Community had not forgotten about the expropriation of Pampa Larga. However, while Community members carried a strong sense of betrayal and injustice, they knew very little about how their dispossession had actually been effected in law, just over 10 years prior.

72 See generally: Maya Indigenous Communities of the Toledo District $v$ Belize, Merits Report, Case 12.053, Inter-Am Comm'n HR, Report No 40/04 (2004) [Maya Communities]; Moiwana Cmty v Suriname, Preliminary Objections, Merits, Reparations, and Costs, Judgment, Inter-Am Ct HR (ser C) No 124 (June 15, 2005); Yakye Axa Indigenous Cmty v Paraguay, Merits, Reparations, and Costs, Judgment, Inter-Am Ct HR (ser C) No 125 (17 June 2005); Sawhoyamaxa Indigenous Cmty v Paraguay, Merits, Reparations, and Costs, Judgment, Inter-Am Ct HR (ser C) No 146 (29 March 2006) [Sawhoyamaxa]; Saramaka People v Suriname, Preliminary Objections, Merits, Reparations, and Costs, Judgment, Inter-Am Ct HR (ser C) No 172 (28 November 2007) [Saramaka]; Saramaka People v Suriname, Interpretation of the Judgement on Preliminary Objections, Merits, Reparations, and Costs, Judgment, Inter-Am Ct HR (ser C) No 185 (12 August 2008); Xákmok Kásek Indigenous Cmty v Paraguay, Merits, Reparations, and Costs, Judgment, Inter-Am Ct HR (ser C) No 214 (24 August 2010); Pueblo Indígena Kichwa de Sarayaku v Ecuador, Merits and Reparations, Judgment, Inter-Am Ct HR (ser C) No 245 (27 June 2012); Communities of the Sipakepense and Mam Mayan People of the Municipalities of Sipacapa and San Miguel Ixtabuacan v Guatemala, Report on Admissibility, Inter-Am Comm'n HR, Report No. 20/14 Petition 1566-07 (3 April 2014); Comunidad Garifuna de Punta Piedra v Honduras, Preliminary Objections, Merits, Reparations, and Costs, Judgment, InterAm Ct HR (ser C) No 304 (8 October 2015); Comunidad Garifuna de Triunfo de la Cruz v Honduras, Merits, Reparations, and Costs, Judgment, Inter-Am Ct HR (ser C) No 305 (8 October 2015); Kalina and Lokono Peoples v Suriname, Merits, Reparations, and Costs, Judgment, Inter-Am Ct HR (ser C) No 309 (25 November 2015).

73 OAS, Human Rights Protection, supra note 3.

74 Galvis \& Ramírez, supra note 18 at 256-7. 
In this context, Negritos Community leaders began to collect volumes of official documents pertaining to the legal status of their Community and its property rights. These documents, spanning from the 1970s to the mid-1990s, were primarily collected from government entities such as the Public Registrar and government ministries, but they also included the handwritten record of communal decisions (Acts) made at countless community General Assemblies. These documents ultimately formed the basis of the Community's legal case and the allegations described throughout this paper. The Community's internal decision to investigate its own case in order to understand it and pursue some form of justice underscores the assertion that the elimination of the Community's property rights and its very existence, as described in the previous section, occurred without the informed consent or even knowledge of the Community. While in the eyes of the company and the Peruvian state the Community no longer existed in law, it certainly existed as a sociological fact.

Bolstered by what they saw in these documents, Community leaders initiated a series of formal and informal appeals with a wide range of administrative and political decision makers, as well as Yanacocha itself. In 2006, the Community found a local lawyer who helped them file civil law proceedings against a group of third parties (non-community member), who were apparently attempting to occupy and illegally obtain title to a portion of the Community's land, known to the Peruvian state as the "Reserve Area" and to the Community as "Llagaden". Community members believed that these "invaders" were receiving informal support from Yanacocha. In order to better investigate and document the situation, the Community resolved to undertake a traditional communal inspection of the area. However, it feared that these third parties were armed and violent and made numerous requests for protection from local authorities, including to the regional Governor, the prosecutions office and the police. After these requests went unanswered, the Community resolved to undertake the inspection anyway with over 250 community members in attendance. Unfortunately, during the inspection unknown assailants shot at the Community members and one person was injured.

This new threat to communal property appears to have catalyzed yet another series of appeals to state and company officials. It also starkly revealed that without state recognition, the Negritos Community's capacity to protect its communal property interests would be limited. Between 2006 and 2009 the Community sent at least eight letters to the regional office of the Ministry of Agriculture requesting official recognition as a Campesino Community and title to Llagaden (the Reserve Area). In response, the Ministry consistently took a number of problematic positions in its communications to the Community, from claiming that the Reserve Area is state-owned property, to stating that the Community does not exist, to denying that the matter is in its jurisdiction, to proposing that the area could only be demarcated and titled in exchange for thousands of dollars. The Ministry's responses to the Community's letters were less than timely, often delayed by months, and sometimes up to a year at a time. Community leaders' frequent requests to meet with officials in person yielded similarly sparse results.

In the same time period, the Negritos Community sent complaints to the Ministry of Energy and Mining and at least thirty letters to Yanacocha. In these letters, the Community advised that a recent expansion of the Mine had occurred without consulting the Community and it detailed the impact of mining activities on ongoing traditional communal uses of land and livelihood. The Community requested that Yanacocha negotiate matters related to the acquisition of communal property with the recognized and elected leaders of the Community and that the company cease to use and occupy communal property without permission. In written responses Yanacocha consistently denied the Community's existence and stated that it had fulfilled all of its commitments. Yanacocha refused to meet with Community leaders, stating that its operations take place exclusively on property owned by the company and threatened to initiate legal action against anyone who failed to respect its property rights.

\subsection{Developing a Legal Strategy: Putting dispossession into a rights framework}

In 2007 the Community solicited the support and legal representation of a local NGO who in turn sought support from international partners. Beginning in 2008, a transnational team of pro bono Canadian and Peruvian lawyers and academics began to organize and analyze the documents collected by Community members. Working with hundreds of pages of documents, these lawyers reconstructed the historical record of the 
Negritos Community's land title and status as a Campesino Community. The documents detailed the story recounted in the previous section, of how, after granting Yanacocha the concession rights to the minerals beneath the Negritos Community's land, the Peruvian state had proceeded to expropriate a portion of the Community's communal land, designate its communally titled land as eligible for individual titling, and strip the Community of its legal status.

The Negritos legal team undertook to analyze these documents in light of applicable domestic, constitutional and public international laws. Their starting point was the status of Campesino Communities in Peruvian law. As referenced above, the first mention of Campesino Communities in Peruvian law occurred in 1969 with the promulgation of the Agrarian Reform Law, which declared that Indigenous Communities were to be denominated Campesino Communities from that point forward. Previously, Indigenous Communities were recognized in the 1920 Constitution, which specified that the State had a duty to protect the "indigenous race" and to pass special laws to support its development in harmony with its needs. ${ }^{75}$ This now historic Constitution also afforded Indigenous communal property special protections, stating that Indigenous property interests may not be diminished by prescription, that Indigenous property can only be transferred to the state and that such transfers may occur only as prescribed by law.

Following Agrarian Reform, Campesino Communities were recognized in the 1979 Constitution. This legal text is relevant to the Negritos Community's case because it applies to those events that took place prior to the introduction of the subsequent 1993 Constitution. This includes for example the expropriation of the Community's land and the conversion of a portion of its communal property interest into individual interests. The 1976 Constitution states that Campesino Communities have legal existence and legal personhood, that they are autonomous in their communal organizations, work, land uses, economy and administration, and that the State must respect and protect their traditions. ${ }^{76}$ It also creates a state duty to promote Campesino Communities' development and communal enterprises. ${ }^{77} \mathrm{Fi}$ nally, it provides special protections for communal pro-

75 Agrarian Reform Law, supra note 25, art 58.

76 Political Constitution of Peru, 1979, art 161.

77 Ibid, art 162. perty, stating that Campesino land is unalienable except in one of two circumstances: either by a law based in the Community's interest and approved by two-thirds of community members; or in the case of an expropriation, by a law based on public need and utility. ${ }^{78}$ These 1970s Campesino rights and protections are relatively progressive for their time, especially due to their recognition of political and economic autonomy and rights.

Fujimori's 1993 Constitution, which remains in place today, significantly weakened these constitutional recognitions and protections for Campesino Communities. It recognizes the right to communal property but controversially allows the state to claim rights over "abandoned" lands. ${ }^{79}$ In a context where so many communities remain unable to acquire communal title due to deficiencies in domestic land laws, this provision puts untitled communities at risk. Like its predecessor, the 1993 Constitution recognizes the legal existence of Campesino Communities, their autonomy, and some property protections. However, it very significantly removed the requirement that communal property might only be alienated on the basis of a two-thirds majority vote of Community members. ${ }^{80}$

The 1993 constitutional changes were consistent with Fujimori's wide-sweeping program of law reform that aimed to weaken communal property rights and facilitate private foreign investment in natural resource extraction. Of interest though, is the fact that Fujimori's reforms left the most important Agrarian Reform statutes in place, including the 1987 Campesino Communities General Law and the 1987 Law for the Demarcation and Titling of Communal Territories of Campesino Communities. Importantly, these statutes, which remain in place to date, maintain the property protections that Fujimori eliminated from the Constitution, including the requirement for a two-thirds majority vote. ${ }^{81}$

Taken together, these Constitutional and statutory laws referring to Campesino Communities formed the

\footnotetext{
78 Ibid, art 163.

79 Political Constitution of Peru, 1993, art 88.

80 Ibid, art 89.

81 See Campesino Communities General Law, supra note 28 at art 7. These Agrarian Reform statutes remain in place today, even in the midst of the ongoing roll out of neo-liberal reforms that aim to further facilitate foreign investors' access to land and resources. Many of these laws arguably violate different aspects of Indigenous peoples' rights as recognized in international law and the Peruvian Constitution. See Part B.5.b for more detail on some of these contemporary reforms and their relevance to the Negritos case.
} 
basic starting point for the Negritos legal team's in-depth analysis of the documents that the Community had been collecting. However, key features of the Peruvian constitutional system allowed the Negritos legal team to complement these domestic rights provisions by drawing upon international legal principles on the rights of Indigenous peoples. ${ }^{82}$ Doctrinally, this was possible due to the combined operation of two rules, one domestic and the other international.

Beginning with the domestic rule, Peru, like many Latin American countries, is a monist legal system in that article 55 of its 1993 Constitution explicitly incorporates international treaties into national law upon ratification by the Peruvian state. In 2005 Peru's Constitutional Court interpreted this provision to include international human rights treaties such as the 1969 American Convention. ${ }^{83}$ In 2009 the Court acknowledged that ILO Convention No 169 and the jurisprudence of the Inter-American Court also have the status of enforceable law in Peru. ${ }^{84}$

This recognition of the constitutional status of international human rights treaties and jurisprudence in Peru requires some clarification regarding the applicability of these sources of law to past events. In international law, the rights recognized in any given treaty become binding on a state after it ratifies the treaty. In Peru, these rights become binding domestically once the treaty is specifically incorporated into Peruvian law by legislation. For example, ILO Convention No 169, first available for ratification in 1989, was not incorporated into Peruvian law until November 1993, just months after the expropriation of Negritos land but nearly two years before the mining easement was established. As such, its provisions would apply to the latter but not the former.

The temporal applicability of the jurisprudence of the Inter-American Court in Peru also merits comment. When the Inter-American Court considers provisions of the 1969 American Convention in any given case, its interpretation of the content and meaning of specific

82 The Negritos legal claim asserted that Campesino Communities in Peru are analogous to Indigenous Communities for the purposes of the application of international human rights law protections. The details of this argument are described in Part B.5.a of this paper.

83 STC No 4587-2004-AA/TC (29 November 2005) at para 44. STC No 0025-2005-PI/TC (25 April 2006) at para 30.

84 STC No 00007-2007-PI/TC (19 June 2007) at para 36. rights are available to analyze facts that pre-date the case at hand. This is due to the nature of rights jurisprudence in international as well as domestic public law. Part of a court's judicial function is to interpret the rights statements contained in the constitution or treaty within its jurisdiction. In other words, public law rights jurisprudence interprets and applies existing rights, it does not create new rights. This is precisely what makes it such an important and powerful tool for analyzing the present-day legal significance of past injustice. On this basis, the Negritos legal team invoked the Indigenous rights jurisprudence of the Inter-American Court to analyze the earlier facts of the Community's case.

With this framework, the Negritos team advanced the proposition that the above-named sources of international law (Convention No 169, the American Convention and decisions of the Inter-American Court) should be relied on, together with the constitutional and legislative provisions pertaining to Campesino Communities in Peru, to analyze the facts of the Negritos case. Indeed, there are remarkable parallels between Peru's 1970s and 80s Campesino Community laws, and the Indigenous rights principles developed in international law beginning with ILO Convention 169 in 1989 and continuing with the Inter-American Indigenous rights jurisprudence beginning in 2001. These parallels allowed the Negritos legal team to create a robust and coherent substantive rights framework by effectively weaving these international sources of Indigenous rights law together with the Campesino rights provisions already present in the Peruvian Constitution and domestic law.

The impact of this approach was further complimented by the operation of another rule, this time emanating from an international source. Article 29(b) of the American Convention establishes that its provisions cannot be interpreted to limit the enjoyment and exercise of any right or freedom recognized under the domestic law of the state in question or recognized by an international treaty ratified by that state. In the context of the Negritos case, this principle infuses the Indigenous property rights jurisprudence of the Inter-American Court with the rule from the Campesino Communities General Law that Campesino land cannot be alienated without a two-thirds majority vote. Given that this jurisprudence has constitutional status in Peru, the operation of article 29(b) in the context of Peru's Constitutional framework creates a kind of feedback loop, elevating the property rights-related provisions of the Campesino Communities 
General Law to constitutional status on their own terms. This also accords with the principle that rights recognized in domestic statutes should be taken into account when interpreting related constitutional rights.

As a result, the two-thirds majority vote rule should retain significant legal weight in Peru, even after Fujimori's 1993 Constitution removed it. This is relevant to the conversion of the Negritos Community's communally titled land into individually titled land (one form of alienation), which occurred both before and after this constitutional amendment. It is also helpful due to the fact that the sources of international law applicable to the Negritos facts have only recognized a limited Indigenous right to free, prior and informed consent to the alienation of communally-held land. ${ }^{85}$ As a result, the two-third majority rule arguably has the potentially to create a higher standard than international sources, at least in the context of the potential alienation of communally titled land.

In sum, article 55 of the Peruvian Constitution and article 29(c) of the American Convention allow for the integration of the rights protection offered by applicable international human rights treaties and Peruvian domestic law in order to assemble a rights framework that contains the most robust and comprehensive level of protection available. Consequently, the sources of law relevant to the Negritos case are: the American Convention, Convention No 169, the Peruvian Constitution, Peruvian domestic law, the jurisprudence of the Inter-American Court on Human Rights, and the jurisprudence of the Peruvian Constitutional Court. The Negritos legal team considered these sources holistically to identify the substantive rights available to the Negritos community. In other words, the focus of the rights analysis was not on each relevant article and statements of law, which taken together are numerous. Rather, the Negritos legal team synthesized the relevant articles and their interpretations to identify the substantive rights

85 The Inter-American Court has recognized that the state must obtain the free, prior, and informed consent of affected communities before proceeding with certain types of projects such as where the project may endanger the physical or cultural survival of a community: Saramaka, supra note 72. See: Forest Peoples Programme, Indigenous Peoples' Rights and Reduced Emissions from Reduced Deforestation and Forest Degradation: The Case of the Saramaka People v. Suriname (UK: Forest Peoples Programme, 2009). The UN Declaration is not directly applicable to the Negritos facts since it came into being much later: United Nations Declaration on the Rights of Indigenous Peoples, UNGAOR, 62 Sess., Annex, Agenda Item 68 UN Doc. A/61/L.67 (2007). that these provisions, taken together as a whole, recognize in relation to the facts of the Negritos case.

Applying this holistic method, Community's legal team ultimately concluded that there was strong documentary evidence that the actions of the Peruvian state and Yanacocha Mine had violated the Negritos Community's rights, as protected by Peruvian constitutional and international laws applicable at the time of the acts in question. It identified violations of the following substantive rights: (1) the right to collective property; (2) the right to free, prior and informed consent prior to a change in the status of the Community's property title from communal to individual; (3) the right to the recognition of the Community and its legal personhood; (4) the right to free, prior and informed consent prior to a change in the Community's legal status or personhood; (5) the right to free, prior and informed consultation prior to the expropriation of the Community's land; (6) the right to equitable indemnification in exchange for the expropriation of the Community's land; (7) the right to benefit equitably from the benefits generated by mining activity on the Community's land; and (8) the State's obligation to take special measures to protect the aforementioned rights. The alleged violation of these rights stems primarily from the State's actions, detailed in the previous section, to expropriate communal land and strip the community of communal title and legal status, concurrently with the establishment of Yanacocha Mine squarely within the boundaries of the Negritos Community's communally titled property. ${ }^{86}$

The articulation of these rights arguments was a watershed moment for Negritos community members because it represented a significant reframing of their concerns into a legal framework that they had been largely unaware of. Community members previously had very limited knowledge of their legal rights as a Campesino Community and even less information about how the state and the company had purported to diminish or eliminate those rights in law. As such, they had expressed their sense of injustice primarily in the language of a general demand for recognition as a Campesino Community and in reference to a raft of specific practical grievances with the Yanacocha and the impact of

86 A full and methodical analysis of each state and company impugned action in the Negritos case and the complete argumentation with respect to these alleged violations is beyond the scope of this paper. However, for more discussion on the alleged violations mentioned here, see Part B.5 of this paper. 
its operations on daily subsistence life. Community members welcomed and celebrated the proposition that international law and Peruvian constitutional law recognize that their Community has special status, including special property rights, that should command the attention and respect of company and state alike. However, given that the state and company were certainly not listening, the Community's last resort was to approach a court of law that could recognize and enforce its rights claims. Crucially, this was contingent on the identification of an appropriate legal forum and a cause of action. The next part of this paper turns to this issue.

\section{The Negritos Case: Litigating a DISPOSSESSION CLAIM (THE STORY OF THE CASE ITSELF)}

This part begins with the practical question of what would be required to operationalize the statements of international and constitutional Campesino rights described above. The Inter-American Commission for Human Rights can admit a petition only when claimants have complied with a number of procedural requirements, including the "exhaustion of domestic remedies" rule. ${ }^{87}$ The Negritos volunteer legal team ultimately determined that a domestic constitutional cause of action called amparo was in principle available in Peru to protect the Community's constitutionally enshrined rights, as set out in the previous section. If the amparo action were to fail, the Negritos Community would be in a position to present a petition to the Inter-American Commission alleging violations of the American Convention on the part of the Peruvian State.

In general, once the Commission deems a petition admissible, it evaluates the claim on the merits. If it finds one or more human rights violations, the Commission can refer the case to the Inter-American Court where claimants can seek a binding judgment against their home state. ${ }^{88}$ As such, if the Negritos Community were to have any chance of pursuing justice with either international or domestic public law, it would have to navigate its own domestic regimes by fitting the particularities of its Campesino rights claim into the pa-

87 Rules of Procedure of the Inter-American Commission on Human Rights, art 31(1).

88 Ibid, art 45. rameters and logic of Peru's amparo domestic cause of action. The following section describes the Negritos amparo action and touches on its significance in terms of the global debate on the regulation of the transnational corporation, referred to in this paper's introduction.

\subsection{The Amparo: A cause of action for dispossession in Peru?}

Peru's Constitutional Procedural Code establishes three potential causes of action for rights protection. The habeas corpus action is linked to the protection of individual freedoms, typically in the realm of criminal law, and the habeas data action typically relates to the right to receive information from any public office. ${ }^{89}$ The amparo action is available to protect all other constitutional rights not covered by these first two, including presumably Campesino rights. In this sense, it is considered a "residual" cause of action. ${ }^{90}$

The Peruvian amparo shares common features with the cause of action by the same name in a number of other countries in the region. ${ }^{91}$ It is a civil law procedure that enables a plaintiff to request a court order requiring the defendant to cease any actions or omissions that the court finds responsible for violating the plaintiff's constitutional rights. ${ }^{92}$ An amparo action can be brought against a private party and/or a state defendant. In the sense that it offers judicial protection of constitutional rights, the amparo resembles the procedure known as judicial review in common law countries, with one significant difference being that the Peruvian amparo is not available to challenge the constitutionality of statutes or legislation. ${ }^{93}$

An amparo claim in Peru must allege violations of the constitutionally protected aspects of the rights claimed. ${ }^{94}$ In this regard, the Code specifies twenty-four di-

89 Allan R Brewer-Carías, Constitutional Protection of Human Rights in Latin America: A Comparative Study of Amparo Proceedings (Cambridge University Press, 2008) at 159.

90 See Omar Cairo Roldán, "El panorama general del proceso de amparo en el Perú" 3(8) (2008) Palestra Tribunal Constitucional: Revista de doctrina y jurisprudencia 153 at 157.

91 Peru's amparo is similar to that in Brazil, Colombia, the Dominican Republic, Ecuador, Guatemala and Nicaragua: see BrewerCarías, supra note 89 at 139.

92 Law No 28237, Constitutional Procedural Code, art 2.

93 In Peru, judicial oversight of legislation for constitutional compliance is triggered by a distinct cause of action known as the action of unconstitutionality: at Brewer-Carías, supra note 89 at 161, 175.

94 Constitutional Procedural Code, art 5(1). 
fferent constitutional rights that the amparo protects. ${ }^{95}$ Campesino rights are not mentioned anywhere in this long list. As such, they necessarily fall under the twenty-fifth and final item listed, namely "other rights that the constitution recognizes." ${ }^{\prime}$ Notably then, while Peru's 1979 and 1993 Constitutions both set out Campesino rights in some detail, the accompanying Constitutional Procedural Code does not provide for a cause of action specifically tailored to these rights, nor does it even mention them explicitly. ${ }^{97}$ This general absence of Campesino Communities from Peru's procedural code led the Negritos legal team to undertake intensive consultations with Peruvian constitutional experts before determining that the amparo cause of action was in principle available to the Negritos Community.

The Negritos Community began the process of assembling its legal claim in 2008 and in 2011 it filed its amparo action before a local court of first instance in the city of Cajamarca, Peru. Interestingly, this period of time coincided with an unprecedented series of decisions from Peru's Constitutional Court. Between 2008 and 2012, the Constitutional Court issued eight decisions that addressed the issue of Indigenous peoples' constitutional rights in Peru for the first time. ${ }^{98}$ Seven of the eight cases were initiated between 2008 and 2009 and as of the date of publication, there have been no further decisions on Indigenous constitutional issues at the Constitutional Court level since 2012.99 In only three of these eight decided cases did the Court find in favor of the claimant. ${ }^{100}$ Nonetheless, as a group, these

\section{Ibid, art 37.}

96 Ibid, art 37(25).

97 The Constitutional Court has stated that the amparo is not the appropriate proceeding for determining whether or not claimant is a rights-holder. Rather, it is available solely for the purpose of alleging a rights violation: STC No 4762-2007-PA/TC (22 September 2008) at para 10-11. As such, it appears that the Peruvian legal system lacks a constitutional process whereby an Indigenous community can bring a claim seeking constitutional rights recognition. 98 STC No 03343-2007-PA/TA (19 February 2009); STC No 06316-2008-PA/TC (11 November 2009 and clarification decision 24 August 2010); STC No 00027-2009-PI/TC (5 January 2010); STC No 0022-2009-PI/TC (9 June 2010); STC No 05427-2009-PC/ TC (30 June 2010); STC No 00025-2009-PI/TC (17 March 2011); STC No 00024-2009-PI/TC (26 July 2011); STC No 01126-2011HC/TC (11 September 2012).

99 The only Constitutional Court decision after 2012 is STC No 01931-2013-HC (30 July 2015). However, this decision relates to a Native Community's request for clarification of a judgement previously obtained. As such, it is linked with one of the eight cases already mentioned.

100 STC No 03343, supra note 98; STC No 05427, supra note 98; cases are important because they pushed the Constitutional Court to recognize, as mentioned earlier, that both ILO Convention No 169 and the Inter-American Court's jurisprudence on Indigenous peoples rights have constitutional force in Peru. ${ }^{101}$

Notwithstanding their achievements, the substantive rights claims advanced in these cases have limited precedential value for the purposes of the Negritos claim. For the most part, these cases have focused on asserting an Indigenous right to consultation prior to enacting national legislation that impacts Indigenous communities. ${ }^{102}$ In this sense these cases can be understood as an attempt to address some of the neo-liberal investment oriented reforms referred to earlier. A smaller subsection of these eight cases focused on rights related to a healthy environment. ${ }^{103}$ Only one case advanced a claim to an Indigenous right to communal property. However, the allegations in that case related to trespass and hold little resemblance to those of the Negritos case in that they do not involve allegations of elimination of title and illegal property transfers to a foreign mining company. ${ }^{104}$ As a result, to date, there is not a single case on record in Peru's highest court whereby a Campesino Community has initiated a constitutional rights claim that resembles that of the Negritos Community, claiming violations of communal property title, recognition, consent and compensation for violations.

The total absence of a Campesino or Indigenous rights jurisprudence in Peru until 2009 is striking in light of the fact that the contemporary recognition and protection of Campesino and Native communal property, social, economic and cultural institutions first occurred in the 1979 Constitution. Indeed, even among the Indigenous rights cases decided since 2009, five of the eight to date were brought by civil society groups impugning national legislation on behalf of Indigenous communities generally. ${ }^{105}$ In only two cases were the claims on

STC No 01126, supra note 98.

101 See supra note 98 and accompanying text. See specifically STC No 00024, supra note 98 at para 12.

102 STC No 00027, supra note 98; STC No 0022, supra note 98; STC No 05427, supra note 98; STC No 00025, supra note 98; STC No 00024, supra note 98.

103 STC No 03343, supra note 98; STC No 06316, supra note 98. In this second case, the right to property was raised among a long list of environmental rights but it was not considered because the court concluded that there was insufficient evidence that the communities in voluntary isolation in fact existed.

104 STC No 01126, supra note 98.

105 STC No 00027, supra note 98; STC No 0022, supra note 98; 
behalf of a named community or group of communities and in only one case (the trespass case) was the community itself the claimant. ${ }^{106}$

Notwithstanding the constitutionalization of Campesino rights since 1979 in Peru, this overview points to three absences. First, Campesino rights are absent from Peru's Constitutional Procedural Code. Second, Campesino and Indigenous rights are absent from the Constitutional Court's jurisprudence before 2009. And finally, at least to date, Campesino and Indigenous communities as claimants are almost totally absent from the Court's jurisprudence on their rights. Arguably, these absences suggest that there are barriers that prevent these communities from accessing Peruvian courts to advance their interests though constitutional rights protection claims. This highlights the importance of tracking the barriers that arose in the Negritos case as well as the strategies employed over the course of the case's journey in the Peruvian court system.

While the shortage of comparable precedents on point certainly presents a challenge for the Negritos claim, it is not fatal to its pursuit of justice. As lawyers well know, an absence of comparable case law does not necessarily mean that innovative claims are not legitimate, viable and even a necessary part of broader efforts to push the law to respond to social realities. Moreover, in spite of the absences described above, the Peruvian amparo has two feature that are particularly promising for a community like Negritos, seeking to advance a legal claim against a foreign resource company for violations of its Campesino rights, including communal property rights.

First, the Peruvian amparo permits a plaintiff to bring a constitutional rights action against a public authority, functionary and/or a private person, which includes a corporation. ${ }^{107}$ As such, in the Negritos amparo action, the Community named Yanacocha as a co-defendant

STC No 00025, supra note 98; STC No 00024, supra note 98; STC No 03343, supra note 98.

106 STC No 05427, supra note 98; STC No 06316, supra note 98; STC No 01126, supra note 98. There are a handful of examples where an single Campesino Community has brought an claim to the Constitutional Court for protection of constitutional right other than Campesino constitutional rights. See for example: STC No 046112007-PA/TC (9 April 2010); STC No 09874-2006-PA/TC (20 December 2007); STC No 03215-2008-PA/TC (19 August 2009).

107 Constitutional Procedural Code, art 2. The amparo action against individuals is expressly referred to in the constitutions of Argentina, Bolivia, Paraguay and Peru: see Brewer-Carías, supra note 89 at 174. alongside the Peruvian Ministry of Energy and Mining. The Community was able to allege that the actions and omissions of state authorities and the mining company, often in combination, had violated the Community's collective rights.

Second, a successful amparo claimant obtains an enforceable remedy from the Peruvian courts. The available remedy aligns with the purpose of the amparo as a cause of action, namely to protect constitutional rights. ${ }^{108}$ As such, the court will attempt to return the plaintiff to the state in which they were before the violation occurred. To this end, the judge may order a defendant to fulfil its legal obligations or, in the case of a public authority, to perform an administrative act. ${ }^{109}$ The court may issue a declaration requiring the defendant(s) to cease rights violating actions, or in the case of omissions, requiring the defendant(s) to undertake some form of positive action in order to respect the claimant's rights. ${ }^{110}$ The court has the power to impose fines or other penalties on a defendant who refuses to comply with court orders. ${ }^{111}$

These two features are significant especially when considered together with the incorporation of international human rights law into the Peruvian constitutional framework, as described in the previous section. In summary, the amparo creates a domestic cause of action, with an enforceable remedy, against a public or private actor who violates constitutionally protected Campesino rights, which includes certain Indigenous rights recognized in international human rights law. Within this framework, the Negritos Community's amparo claim is fundamentally about the pursuit of an enforceable remedy via a domestic cause of action in Peru directly against a foreign resource company for the violation of its constitutional and international human rights as a Campesino Community.

As such, the Negritos claim brings together a constellation of rights, remedies and actors that is of particular interest in the context of the global conversation, referred to in this paper's introduction, regarding the problem of the "governance gap" in the effective re-

108 Constitutional Procedural Code, art 1.

109 Ibid.

110 Part B.5.c provides a detailed description of the specific remedies requested in the Negritos action.

111 Constitutional Procedural Code, art 22. The defendant may be obligated to pay fixed or accumulative fines. The judge may also order the dismissal of a responsible public authority. 
gulation of the human rights impacts of transnational corporations operating in developing countries. The techniques described here are fascinating in light of the widely-observed fact that communities in developing countries often lack a forum and an enforceable cause of action when seeking to mount rights claims, and in particular international human rights claims, against foreign resource companies. While this paper undoubtedly explores the problems that the Negritos Community has faced in the course of its efforts to access this regime in practice, the mere fact of its existence is significant. In light of the governance gap, the Negritos amparo action appears to represent a relatively unusual opportunity, at least to date. Human rights lawyers in Peru report that there is now a handful of Indigenous property claims of various kinds against foreign resource companies in progress in the lower courts in Peru. However, the Negritos claim remains the only one of its kind now before Peru's Constitutional Court. ${ }^{12}$

\subsection{Dispossession as Knowledge and Power: An equitable approach to the limitation period}

The previous section described how the amparo offers the Negritos Community an avenue for constitutional rights protection and remedy in that it applies to the substance of its case, framed in terms of violations of its Campesino constitutional rights. However, like most civil causes of action, the amparo imposes various procedural rules on claimants. While several of these requirements presented challenges to the Negritos Community, the limitation period rule ultimately became its biggest obstacle. The Peruvian Constitutional Procedural Code requires that an amparo claim be filed before a court of first instance within sixty days of the time that the claimant's rights were first violated. ${ }^{113}$ The rationale for this rule appears to be rooted in the amparo's conception as a simple and prompt remedy for the urgent protection of rights. ${ }^{114}$

The limitation period rule as set out in the Code includes two important qualifiers, first the claimant must have knowledge of the violating act, and second, the

112 Instituto de Defensa Legal, "Listado de casos patrocinados por el Área de Litigio Constitucional” (July 1, 2016), document on file with the author.

113 Constitutional Procedural Code, art 44.

114 Brewer-Carías, supra note 89 at 165; Cairo Roldán, supra note 92 at $179,230$. claimant must have the ability to present the claim to the courts. The rule states that if either of these obstacles exist, the limitation period will be calculated from the moment that the impediment is removed. ${ }^{115}$ Thus the limitation period rule as it appears in the Code exists in the form of a strict rule ( 60 days) accompanied by a kind of equitable exception, internal to the rule itself, that gives the court the discretion to account for the claimant's knowledge and ability in relation to the alleged violation and, arguably, the legal system itself. This general statement of the limitation rule in the Code precedes a list of numbered exceptions to the rule, to be considered in the next section of this paper.

The Inter-American Court has indirectly addressed procedural questions in relation to Indigenous peoples' rights claims with an important statement regarding the right to remedy. The Court has stated that Indigenous peoples who have unwillingly lost their lands are entitled to a legal remedy and that the right to a remedy persists so long as their relationship with the land exists, or where there are impediments to the maintenance of this relationship, so long as those impediments exist. ${ }^{116}$ Notably, this statement regarding the right to a remedy is qualified with the requirement that the loss of land must have occurred "unwillingly", in other words, without their consent.

These statements from the Inter-American Court can be read together with the statement of the limitation period rule in Peru's Constitutional Code to identify at least some of the general principles that might apply to the question of the admissibility of the Negritos Community's claim. First, the Negritos Community's right to a legal remedy persists so long as the loss of its legal interests occurred unwillingly, meaning without its consent; and second, the limitation period for seeking a legal remedy will be triggered at the point in time when the Community has knowledge of the violating acts and the ability to bring its claim forward. In this light, consent, knowledge and ability all emerge as central concepts in the admissibility and right to remedy analysis. At the same time, Parts A.3 and B.5.b of this paper both describe how the concept of consent, which is of course inextricably linked with knowledge, is also at the core of the alleged rights violations in the Negritos case.

115 Supra note 113.

116 Sawhoyamaxa, supra note 72, at paras 128, 131-132 [emphasis added]. 
Taking all this together, an interesting situation comes into sharper focus, with potential implications for the litigation of other Indigenous dispossession claims. In the Negritos amparo claim, the concepts of knowledge and ability/power are engaged in the analysis of procedural questions related to admissibility, as well as in the analysis of the Community's substantive right to consultation and consent.

Arguably, at both the procedural and substantive phases, these concepts must be considered in context. ${ }^{117}$ Given that the amparo is in place to protect constitutional rights, including Campesino rights, it is critical that its procedural requirements, including the limitation period requirement, be interpreted in context. This refers to the lived reality of those rights and by extension, rights violations. In the Negritos case, searching for the lived reality of rights violations requires a brief review of the factual story, told in Part A of this paper, of the social and legal processes that led to the elimination of the Community's Campesino property title and legal status, as well as the processes whereby the Community came to assert rights and claim rights violations.

The Negritos legal claim arises from contemporary processes of dispossession and lack of recognition that are rooted in a history of colonial relations and the subsequent inadequacies of Agrarian Reform. Part A of this paper described how in the early 1990s, newer legal and economic forms of globalization mapped onto a preexisting context of disadvantage and social exclusion that was only partially addressed by Agrarian Reform. As a result, the processes of dispossession in the Negritos case unfolded in the context of fundamentally unequal power relationships, between the Campesino Community on one side and the state and the foreign company on the other. Indeed, the interests and actions of the state and the corporation (Yanacocha) were at times so highly coordinated that the exercise of public and private power seemed to converge. The Peruvian state and the company often appeared to operate in a complementary fashion toward achieving a common objective. This occurred in part through the exchange of roles, responsibility, resources and information and through the mutual facilitation of the social and legal processes necessary to ostensibly eliminate the Negritos

117 See for example: Jeremy Webber, "The Meanings of Consent" in Jeremy Webber and Colin Macleod, eds, Between Consenting Peoples: Political Community and the Meaning of Consent (Vancouver: UBC Press, 2010) 3-41.
Community's legal interests. ${ }^{118}$

When the state and company's interests prevailed, this occurred formally through processes that engaged the legal constructs of property, contract and consent. For example, the name of the titleholder in the state registry changed from that of the Community to the mining corporation, purportedly on the basis of an expropriation "agreement" between Yanacocha and the Community. Other pivotal moments involved the elimination of the Community's legal personhood and its communal property title in favor of the opportunity to obtain individual titles. Legal title to many individually titled properties was also transferred to the Mine. Critically, these changes to the Community's status and property interests in law all occurred with the signatures of some (but not all) Community members, procured at different intervals between 1991 and 1995, and just as Yanacocha began to produce its first bars of gold. Part A of this paper described how in 1995 and 1996 the Community publically denounced, including in letters to state officials, the legitimacy of these legal processes along with the allegedly corrupt leaders that facilitated them. However, and of particular importance for the limitation period discussion, the Community did not respond to these events with an immediate and coordinated turn to the law, much less with a formulated constitutional claim. Indeed, the Negrito amparo action was only filed much later, in 2011 with the support of a transnational team of lawyers and law students.

On a socio-historical level, the Negritos Community's delayed turn to the law might be understood in light of the long history of indifference (or even animosity) on the part of Peru's Campesino Communities toward laws emanating from the Peruvian state. ${ }^{119}$ This may

118 For a detailed description of the convergence of private and public power in the Negritos case and the links with the exercise of coercive force, see: Kamphuis, "Foreign mining", supra note 19 at 239-242.

119 For example, Campesino Communities in Peru have long standing communal institutions of justice called "Rondas" that applied communal laws. The Rondas historically operated with disregard for state-based law in part because it was either unknown, inappropriate or unenforced: see Antonio Peña Jumpa, Justicia comunal en los Andes del Perú: El caso de Calabuyo (Lima: Pontificia Universidad Católica del Perú, Fondo Editorial, 1998). In 2003, legislation was enacted to protect the Rondas as Campesino institutions and give them special status as indigenous rights holders: Alejandro Laos Fernández et al, Rondando por Nuestra Ley (Lima: Asociación Servicios Educativos Rurales, Red Interamericana para la Democracia, 2003). 
explain in part the many absences, described previously, of Campesino and Indigenous communities from Peruvian constitutional jurisprudence. However, turning to the specific facts at issue in the Negritos case, the amparo action alleges that unequal power relations enabled illegal practices such as fraud, corruption, extortion and misrepresentation, which in turn reinforced or deepened these power relations. Although the state and the company purported to procure signatures from Community members, there are many unresolved questions surrounding the validity of these signatures. Community members allege that signatures were falsified, extorted or otherwise uninformed. Moreover, even the number of (contested) signatures was insufficient to comply with the constitutional requirement in Peruvian law that the agreement of two-thirds of the Community is required before communal land can be alienated.

Nonetheless, the signatures of some Community members on the documents that purported to transfer title and eliminate rights in the Negritos case raises the possibility that, at a preliminary procedural phase, an uninformed observer (or even a court judge) might presume that if at least some Community members signed documents that purported to extinguish their communal rights, the fact of these signatures should constitute knowledge of the alleged violations and capacity to act, thereby triggering the sixty-day limitation period. This reveals that the concept of knowledge and capacity employed in the limitation period analysis is a crucial matter and requires critical interrogation. Beyond the allegations of dubious dealings described above, the Negritos amparo action alleges that, even if these signatures are taken at face value, the facts reveal that Community members did not know what they were signing due to lack of adequate information and inappropriate procedures. At this juncture, an important argument emerges with respect to how the court should approach the limitation period. The assertion here is that where the substantive rights issues in amparo proceedings raise questions of consent, the court cannot avoid a careful consideration of the plaintiff's knowledge and capacity for the purposes of the limitation period analysis. Moreover, in order to properly interpret the legal standards of knowledge applicable to an Indigenous community, the courts must consult with the case law on point.

As stated previously, the Negritos amparo action argues that the Community has a right to free, prior and informed consent prior to the alienation of its com- munal property, and in the case of expropriation, a right to free, prior and informed consultation. ${ }^{120}$ The Inter-American Commission has stated that consent requires, at a minimum, that all members of the Community be fully and precisely informed of the nature and consequences of the proposed project and of the decision-making process; and that they be afforded the opportunity to effectively participate individually and collectively. ${ }^{121}$ For its part, Peru's Constitutional Court has stated that access to "true information" is not only a fundamental human right, but also an essential condition for free choice. ${ }^{122}$ Drawing on Inter-American jurisprudence, the Constitutional Court has recognized that the appropriate methodology for consultation is case specific, considering the needs and circumstances of each community. However, at a basic level, the information required in relation to a proposed resource project would include information about the company proposing the project, the kind of resource, the exploitation area and the potential environmental and health impact. ${ }^{123}$ Moreover, communities should have adequate time to digest this information during the consultation process and the process itself should aim to achieve an agreement that protects the legitimate interests of the community, including the preservation of its economic and cultural activities and the environmental integrity of its territory. ${ }^{124}$

The work of legal anthropologists in the Peruvian context offers critical insights that help illuminate the complexity of the concepts of adequate information and appropriate procedures as described in the case law above. They have accumulated a rich body of research that reveals that consultation and consent processes with Indigenous peoples will only be effective if they are designed to account for information and knowledge differences and power disparities. ${ }^{125}$ Anthropological

120 This assertion is grounded in the following legal instruments and jurisprudence: Political Constitution of Peru, 1979, art 163; Campesino Communities General Law, art 7, supra note 28; American Convention, art 2(2), 2(14), 21; Convention No 169, arts 6(1), 6(2), 17(2); Awas Tingni, supra note 71; Yake Axa, supra note 72; Saramaka, supra note 72. It is supported by the following legal instruments: Political Constitution of Peru, 1979, art 161; Political Constitution of Peru, 1993, art 89. 121 Maya Communities, supra note 72 at para 142.

122 STC No 1776-200-AA/TC (26 January 2007) at paras 39-40.

123 STC No 0022, supra note 98 at paras 26-8, 32, 34, 35, 51; STC No 03343, supra note 98 at para 35. Also see Saramaka, supra note 72 at para 134 .

124 STC No 0022, supra note 98 at paras 30, 33, 39.

125 See for example: David Szablowski, “Operationalizing Free, Prior and Informed Consent in the Extractive Industry Sector? Ex- 
work with Campesino Communities in Peru suggests that these inequities are exacerbated by deeper epistemological differences between the parties regarding the meaning of community, property, livelihood, development, and the environment. ${ }^{126}$ A number of studies have observed that Communities have complex, mixed and multilayered conceptions of property that blend communal and familiar rights into different and variable arrangements that do not coincide with state-based legislation or legal concepts. ${ }^{127}$ One researcher who did ethnographic work with Negritos Community members reports that when Yanacocha arrived in the early 1990s most of the adults in the Community were illiterate and did not understand exactly what a "mine" was. ${ }^{128}$

As stated, the Negritos amparo action alleges that for most Negritos Community members the legal processes that lead to their dispossession in law (on the books) were initially either entirely unknown or, if known, their significance was not understood. Much less did they conceive of what had occurred as a violation of their constitutional rights, bolstered by international law, with a potential domestic remedy called amparo. Moreover, there is continuity between the formal legal processes of dispossession and the material outcomes of the mining project that these processes purport to legalize. The adverse material impact of the project on the Negritos Community embodies the fundamentally different understandings and worldviews (at best), and

amining the Challenges of a Negotiated Model of Justice" (2010) 30:1-2 Canadian Journal of Development Studies 111; Riccarda Flemmer \& Almut Schilling-Vacaflor, "Unfulfilled promises of the consultation approach: the limits to effective indigenous participation in Bolivia's and Peru's extractive industries" (2015) Third World Quarterly.

126 One researcher working with Campesino Communities in Cajamarca has observed the impact of divergent epistemologies on conflicts related to the management of water resources impacted by Yanacocha Mine: Li, "Contested Equivalences", supra note 34.

127 See Alejandro Diez, "Interculturalidad y Comunidades: Propiedad Colectiva y Propiedad Individual” (2003) 36 Debate Agrario 71; Laureano del Castillo, "Titulación de las Comunidades Campesinas: CEPES, ALLPA y la Problemática Comunal” (2003) 36 Debate Agrario 89; Cletus Gregor Barié, Pueblos Indígenas y derechos constitucionales en América Latina: un panorama, 2d ed (La Paz, Bolivia: Génesis, 2003) at 492-3; R Plant \& S Havlkof, Land Titling and Indigenous Peoples in Latin America (Inter-American Development Bank, Washington DC, 2001) at 15.

128 Richard André O’Diana Rocca, Las limitaciones del sistema de dominio minero vigente en el Perú y las consecuencias negativas que genera a las comunidades campesinas: un estudio a partir del caso de la Comunidad Campesina San Adres de Negritos de Cajamarca, Thesis for the degree of Bachelor of Law, Faculty of Law, Pontifical Catholic University of Peru (Lima, 2014) at 120, 144. fraud, extortion and misrepresentation (at worst), that characterized the initial legal processes that presumed to eliminate the Community's property title and status with its "consent".

The Negritos Community's dispossession was consolidated by the subsequent deepening of its relative marginalization as Yanacocha's operations picked up speed and it became grossly unable to equitably benefit from the mining project. This occurred as a result of a two-fold process. First, the Community was substantively excluded from the model of mining "development" initiated by the changes to its property title. Community members did not obtain meaningful employment and otherwise meaningfully share in Yanacocha's wealth production. Second, Yanacocha's operations diminished Community members' capacity to engage in their land-based livelihoods. They allege that their natural sources of water have been contaminated, that their traditional pathways for moving animals have been destroyed and that their homes have suffered the consequences of blasting. In the Negritos case the subsequent wealth disparities are stark: Part A referred to the fact that after more than twenty years of Yanacocha's operations, members of the Negritos Community remain among the poorest inhabitants of one of the poorest regions of Peru while Yanacocha's wealth has consistently topped the charts globally. Its success is arguably due in part to the way that it originally leveraged its title to Negritos' land to obtain start-up financing loans in the amount of US\$ 85,000,000.

This account of the Negritos Community's knowledge and ability for the purposes of the limitation period analysis must also account for its processes of resistance and its ultimate turn to law. Gradually Community members became aware of the stark material consequences of their dispossession, the grossly unequal and disadvantageous conditions in their midst, and the adverse impact of the mine's operations on their livelihood. As mentioned earlier, explicit or open conflict between Yanacocha, the Negritos Community and other neighboring communities emerged toward the end of the 1990s, once the mine was well into the operations phase and the reality of its potential and actual environmental, social and economic consequences were felt. Part A of this paper described how these initial conflicts occurred primarily in the form of social protests as opposed to claims brought to the courts. 
As the Negritos Community came together in the years that followed to seek solutions for a variety of problems, it encountered the consistent message from state and company officials that it lacked the status to make demands as a Community, in other words, that it did not exist. All of this served as a catalyst for renewed Community mobilization and search for justice. However, it took a period of years for the Community to explore its options. The previous section described how following several episodes of protest in the region, in 2005 the Negritos Community began to intensify its pursuit of potential avenues of recourse, directly appealing to political actors, administrative decision makers and the corporation itself.

When these avenues consistently failed, the Community ultimately turned to the law, searching for legal mechanisms that might govern the public and private actions and inactions in question. In the process, it faced serious hurdles as it sought to collect hundreds of pages of documentation from state authorities in order to understand what had happened to its legal interests. Finally, it turned to the only legal counsel willing to assist, a team of volunteer lawyers, law students and local NGO workers, who in turn received support from national and international allies. This team was ultimately able to file the Community's claim in local courts in early 2011. This brief recap of the Community's pursuit of justice signals that a final condition of inequity has reinforced its dispossession, namely its lack of access to legal counsel and the resources necessary to efficiently bring its claims to local courts.

In sum, the Negritos Community's dispossession fundamentally involved the non-consensual loss of land and status, resulting in the enrichment of Yanacocha, growing economic disparity and the deprivation of the Community. The processes that purported to imbue dispossession with a veneer of legality and consent were underpinned by vast inequalities in economic and political power. The impossibility of meaningful consent in this context is a consequence of at least four conditions of inequity or what I refer to as the "dynamics of dispossession": (1) lack of meaningful access to information about material fact and law, (2) inaccessible, inappropriate, inefficient or unfair administrative procedures, (3) epistemological differences with respect to the meaning of legal categories and events, and (4) lack of access to appropriate legal support.
This account emphasizes the temporal aspect of these legal and social process in order to explain why the Negritos Community's turn to the courts took place gradually, over a period of years, and far beyond the 60-day limitation period required by statute. The dynamics of dispossession help explain why the Negritos Community did not have the knowledge or ability to mount a legal challenge to the alleged rights violations, which began between 1991 and 1995, until it finally presented its case to local courts in 2011, a decade and a half later. As I have noted, this examination of the specific features of knowledge, ability and consent in the Negritos case raises important questions regarding how the courts should interpret and apply limitations period rules in the context of Indigenous rights claims like that of the Negritos Community.

Importantly, the above account signals that the inequities that enable the legal processes of dispossession can be the same factors that prevent the community from promptly understanding the full significance of these processes and bringing legal action. For example, not only does a lack of access to information and fair process make meaningful consent impossible, it can also prevent a timely response from the Community. The Negritos story reveals that, due to the dynamics of the unequal power relationships that inform the processes of dispossession, the legal underpinning of the impugned act or omission is often consolidated without the full knowledge or participation of the Community and according to the terms of a system of law that the Community is not familiar with. As a result, it may take a period of years or even decades for a Community to become aware of the loss of its rights in the eyes of state-based law, as well as the possibility, and potentially the necessity, of seeking redress through the state's legal system.

The Negritos Community's experience in this regard supports a more general argument, namely, that where an Indigenous community's constitutional claim alleges the nonconsensual loss of property and rights, for the purposes of the limitation period rule the claimant's knowledge and ability must be considered in the full context of each case and on the basis of relevant principles in the applicable Indigenous rights jurisprudence. Strict adherence to the sixty-day limitation period requirement on the basis of formal signatures would put the law dramatically out of touch with the ways in which Indigenous property rights are often lived and lost on 
the ground. To demand by way of a generic procedural requirement that the Negritos Community, and communities like it, should mobilize within sixty days of the impugned act or omission would be to perpetuate the very dynamics of dispossession that form the basis of the claim. Especially where questions of dispossession and consent are at issue, to assume at the admissibility stage that the Community's knowledge and ability was sufficient to launch a legal challenge within sixty days of the alleged violations would amount to a premature and formalistic determination of the substantive issues. Indeed, issues such as what the Community knew are central to the allegations of rights violations. Thus, a strict application of the limitation period criterion in the context of Negritos case, and cases of a similar nature, would risk creating a de facto bar in Peru to Indigenous communities seeking constitutional redress for constitutional wrongs that fall outside of a 60 -day period.

\subsection{Dispossession as Actions and Omissions: A doctrinal approach to the limitation period}

The previous section set out the amparo's limitation period rule as stated in the Constitutional Procedural Code. It observed that the 60-day limitation rule contains a qualification, internal to the rule itself, that references a claimants' knowledge and capacity. This grounded the argument that the rights violations alleged in the Negritos case, rooted in the dynamics of dispossession, are a direct result of inequities related to knowledge and capacity, thereby explaining the fact that the Community did not turn to the law for several years. While this equitable argument makes an important contribution to a critical analysis of the limitation period, it also faces important evidentiary obstacles. The substantive arguments in the Negritos action rely on the available documentary record to argue that the Community's loss of title and status was non-consensual. However, further evidence would be required to prove that the Community lacked sufficient knowledge and capacity to bring its claim in the years between the initial loss of its rights (1992-1995) and the moment when it filed its claim (2011). This would likely be difficult to prove in light of the strict evidentiary requirements of the amparo action. The amparo procedures do not typically allow forms of evidence that would need to be tested and weighed by the court, such as witness testimony in the form of affi- davit evidence. ${ }^{129}$

In this context, the Negritos legal team sought an alternative approach to overcoming the limitation period hurdle, one that would not raise complex evidentiary questions and equitable arguments. It turned to a list of specified exceptions that appear in the Constitutional Procedural Code immediately following the statement of the rule. In this regard, articles 44(3) and 44(5) were particularly promising. These two provisions permit exceptions to the amparo's sixty-day limitation period rule in circumstances where the alleged violations are generated by omissions and/or ongoing actions. Relying on these provisions, the Negritos amparo asserted that the courts should admit the claim and exempt the Community from the application of the 60-day limitation period requirement on the basis that the alleged rights violations are the result of continuous actions or omissions. Continuous actions are actions that have been occurring, that continue to occur, and that will certainly continue to occur. ${ }^{130}$ Another way to identify continuous actions is by their effects. Decisions of Peru's Constitutional Court state that the effects of a continuous action are periodically produced and reproduced, leaving the rights holder constantly unable to exercise the right. ${ }^{131}$

On the basis of these provisions and their interpretation, the Community argued that the rights violations it attributes to the mining company and the state did not end with the initial changes in law to the Community's status and its property title, such as for example through the expropriation of Pampa Larga. Rather, the Community asserted that the violations of the rights in question, the right to property, the right to recognition, the right to consultation and consent, and the right to equitable compensation and an equitable share of the benefits of resource development, should all be characterized as the product of continuous actions and omissions. However, given the absence already noted of decided constitutional cases in Peru with facts comparable to those of the Negritos case, it is not surprising that

129 Constitutional Procedural Code, art 9. This evidentiary rule is a result of the amparo's intended status as a rapid constitutional procedure designated for urgent rights issues. However, judges have the discretion to accept other forms of evidence if it will not compromise the expediency of the process: Cairo Roldán, supra note 92 at 161.

130 Samuel Abad Yupanqui, El Proceso Constitucional de Amparo (Gaceta Jurídica: Lima, 2008) at 127.

131 STC No 3283-2003-AA/TC (15 June 2004) at para 4. 
there is a similar absence of guidance in the case law with regard to how limitation period exceptions should be interpreted in the context of Campesino constitutional rights claims. As a result, in order to support the argument that the rights violations in the Negritos claim are continuous, the Community's legal team sought analogies with continuous actions and omission in other contexts already recognized by Peru's Constitutional Court.

The Negritos submissions developed two main analogies with established case law interpreting the meaning of continuous actions and omissions. The first related to the allegations in the Negritos claim that the state and company had violated the Community's right to equitable compensation for the loss of its property interest and the right to benefit equitably from mining activity on its land. The amparo claim argued that these violations were generated by the company's continual failure to transfer compensation and benefits and by the state's failure to ensure that these rights are respected. In developing this argument, the Negritos action put forward the view that the deprivation of one's right to a constitutionally protected economic entitlement is an ongoing violation of that right. To support this assertion, it drew upon the fact that Peru's Constitutional Court had upheld this principle in a series of pension benefits cases, where the court found that the failure to provide these benefits constituted an ongoing violation of the claimants' rights. ${ }^{132}$

The second analogy drew on the allegations in the Negritos case that any purported consent or consultation was invalid because the Community lacked the information necessary to make a free and informed decision with regard to changes made to its status and property title. The Community's amparo action argued that this deficiency constituted a failure (omission) on the part of the state and the company to provide appropriate information. In making this argument, it drew on Peruvian jurisprudence that accepts that a lack of access to adequate information is an ongoing omission that exempts a claimant from the limitation period requirement. ${ }^{133}$

Moving beyond these doctrinal analogies, the Ne-

132 STC No 2574-2005-AA/TC (27 May 2005) at para 1. This case relates to article 11 of the 1993 Constitution which guarantees access to pension and health services.

133 STC No 00014-2007-PI/TC (4 May 2009) at para 16. This case relates to the fundamental right to information, established in article 5 of the 1993 Constitution. gritos amparo claim extended the concept of ongoing violations and omissions to the case's core rights issues of Campesino communal property title and status. Referring to Yanacocha's alleged illegal acquisitions of the Community's property for its mining operations, the Negritos claim asserted that the physical act of Yanacocha's occupation is an ongoing action, thereby constituting a continuing violation of the Community's communal property rights. With regard to the state's purported elimination of the Negritos Community's legal status, the amparo claim asserted that the failure of the state to fulfill its duty to recognize the Negritos Campesino Community as such is an ongoing omission. On the facts of the Negritos case, this omission has become an active violation of the Community's right to recognition due to the state's consistent rejection of the Community's requests for recognition. ${ }^{134}$ Moreover, this sustained refusal to recognize the Community has made it vulnerable to new and ongoing impacts on its rights. Part A of this paper described how Yanacocha and other third parties have taken advantage of the Community's uncertain legal status. It recounted how in one instance, when non-community members invaded tracts of land which were formally communally titled, the Community's efforts to confront these invaders and obtain protection from the police were frustrated in part by the state's continued denial of the Community's very existence.

The Negritos legal team ultimately made a strategic decision to invoke the "ongoing actions" and "omissions" exceptions to the limitation period, rather than focusing its limitations argument on the conditions of knowledge and capacity referred to within the rule itself. In doing so, it appealed to doctrine, as described in this section, rather than the equitable arguments put forward in the previous section. There were two reasons for this. First, the team calculated that the courts would be more likely to accept arguments based on analogies with established doctrine than arguments rooted in a social analysis of the inequities that inform the dynamics of dispossession. Second, even if successful in the Negritos case, going forward, arguments regarding any given community's knowledge and ability at the time of dispossession would need to be proven on a case by case basis, thereby maintaining procedural and evidentiary obstacles for other communities in a similar situation. In contrast, if the Negritos Community were successful

134 See Part A.2. of this paper. 
with a doctrinal argument that constructs relations of dispossession in terms of ongoing actions and omissions, this could potentially be useful to communities facing similar hurdles at the limitation period stage.

The viability of any doctrinal argument depends considerably on the willingness of the Court to accept the proposed construction of law. At the admissibility stage of the Negritos case, this refers to the proposed construction of the alleged rights violations as ongoing actions and omissions. Arguably, the distinction between rights violating actions that have ceased, are continuous or qualify as omissions, is not self-evident, but rather can only be resolved by making analytical choices. As with any application of law to fact, and particularly when adjudicating rights claims, there is often more than one reasonable construction and the ultimate path chosen will be informed by the courts' underlying political and social values. ${ }^{135}$

Ultimately then, the outcome in the Negritos case would depend on the importance, in the eyes of Peruvian courts, of making the amparo cause of action accessible to Communities whose dispossession has occurred over time and under conditions of gross inequality. Absent such a willingness, the limitation period requirement stands to perpetuate the factors of inequity and risks creating an absolute bar to any Campesino justice claim that is not brought within sixty days of the first occurrence of rights violating acts. As argued above, the very circumstances that inform rights violations in contexts like the Negritos case often serve to prevent Communities from presenting their claims to the courts within such a narrow timeframe. With all of this in the background, the next section will critically examine the Peruvian courts' responses to the Negritos amparo to date, with particular attention to their treatment of the limitation period issue.

\subsection{San Andres de Negritos Campesino Community $v$ Yanacocha Mine}

This section is divided into three parts. The first recounts the Negritos Community's experience in the courtroom to date litigating its constitutional claim against Yanacocha Mine and the Peruvian State. The

135 See for example Allan Hutchinson, "Looking for the Good Judge: Merit and Ideology" in Nadia Verrelli, ed, The Democratic Dilemma: Reforming Canada's Supreme Court (McGill-Queen's University Press, 2013) 99. second offers a critical analysis of this experience. The third describes some of the challenges that the Community has faced outside of the courtroom.

\subsubsection{The Litigation}

The Negritos legal team filed the Community's amparo claim in civil court in the regional capital city of Cajamarca, Peru in March 2011. In its response submissions, Yanacocha made four objections to the admissibility of the claim. It argued that the Community did not have the legal capacity to present an amparo claim because it did not have legal personhood, meaning it did not exist in law. Adding to this, the company argued that the Community could not claim property rights violations because it was not a property titleholder. It further asserted that the Community had failed to exhaust administrative remedies and that the claim was outside the limitation period. ${ }^{136}$

Yanacocha and the Community's lawyers made a series of written and oral submissions with regard to these objections over the course of nearly six months before the proceedings ran into procedural delays. Three distinct procedural disputes emerged and each was only resolved on appeal, leading to considerable delays as the case was transferred back and forth between two levels of court each time. Confusion over the proper service of documents and the timeliness of the Ministry of Energy and Mining's written submissions caused the first procedural delay. This issue arose in part because the Ministry's response to the Negritos claim was filed outside of the timeframe required in the Procedural Code. The Ministry had also failed to specify an address in the regional capital city of Cajamarca for the service of documents, instead insisting on service at its headquarters in the national capital city of Lima. The service issue was significant for the Community given that its pro bono lawyer at the time was located in the city of Cajamarca and without a budget for executing service in the nation's capital, hundreds of kilometers away.

In the final weeks of 2012, an appeal court resolved

136 On matters of substance, Yanacocha took the position that the Community had freely consented its own elimination and to the transfers of its property to the company. It also argued that, in any case, the Negritos Community could not avail itself of rights regimes applicable to Campesino and Indigenous Communities because it does not fulfill the definition in Peruvian law of a Campesino Community. 
the matter, ordering the Ministry to accept service at its regional office. ${ }^{137}$ Although the Ministry remains a named defendant and continues to be served with documents in the proceedings, it has declined to make a single submission to the courts on any of the substantive or admissibility issues raised by the other two parties. In light of all this, it seems fair to describe the Ministry's role in the proceedings as one of indifference, at the very least, and less charitably, perhaps even incompetence. Without a doubt, the Ministry's errors added to the delays in the process and created further challenges for the Community.

The second procedural issue arose when Yanacocha challenged a resolution of the court of first instance allowing the Community to make audio recordings of oral submissions at hearings. Yanacocha argued that such recordings would violate its lawyers' rights to free expression and to preserve their "image and good reputations". The finagling over this issue continued (in parallel to other issues) for nearly two years until an appeal court sided with the Community in 2013 and awarded it the right to make the recordings requested. ${ }^{138}$ In spite of this win, on the day of the hearing, the presiding judge nonetheless failed to ensure that the courtroom was furnished with the necessary audio video equipment. Community members were forced to record what they could with their cellular phones.

The third issue arose in 2013 when a Canadian NGO, the Justice and Corporate Accountability Project (JCAP), sought permission to participate in the Negritos amparo proceedings as an intervenor in order to make written submissions to the court on points of law (known in Peru as an amicus curiae). Yanacocha argued that the court should refuse to grant JCAP amicus status. The company asserted that JCAP was not objective or impartial and that, in any case, in the company's view the subject matter of the litigation did not raise any public interest issues that would merit intervener participation. This issue was temporarily addressed on appeal, when the court decided that JCAP's amicus request would be determined together with the issue of the admissibility of the amparo action itself.

137 Specialized Civil Appeal Court of Cajamarca, Exp No 00315-2011-1-0601-JR-CI-01, Resolution No 2 (14 December 2012).

138 Specialized Civil Appeal Court of Cajamarca, Exp No 00315-2011-1-0601-JR-CI-01, Resolution No 1 (19 March 2013).
These three procedural disputes created additional obstacles and distractions from the threshold issue of the Negritos amparo's admissibility in light of Yanacocha's objections. In June 2014, more than three years after the amparo claim was first filed, the local court of first instance finally issued a decision, declaring the Community's claim inadmissible. It reached this conclusion by finding in favor of two of Yanacocha's four objections. ${ }^{139}$ It agreed with Yanacocha that the Community did not have the legal status to present its claim (it did not exist in law) and that its claim was beyond the limitation period. In coming to this latter conclusion, the court relied on the principle that, absent evidence to the contrary, there is a presumption that both natural and legal persons have knowledge of the records contained in the Public Registry. ${ }^{140}$ This refers to the official repository of documentation where the changes to the Negritos Community's property title and legal status were registered. In its judgement, the lower court failed to address the Community's doctrinal arguments that the codified exception to the limitation period should apply on the basis that the alleged violations are ongoing actions and omissions.

The Negritos Community appealed this lower court decision to Cajamarca's regional appeal court for civil matters and the appeal court issued its decision in May 2015. ${ }^{141}$ It rejected three of Yanacocha's four objections, overturning the lower court's conclusion that the Community did not have the legal status to present its claim. However, it agreed with the lower court's conclusion that the claim was outside of the limitation period. On this basis, the appeal court upheld the lower court decision to rule the Negritos amparo claim inadmissible. At the same time, it denied JCAP's request to act as an amicus curiae in the proceedings. The Community sought and received leave to challenge the appeal court's decision before Peru's Constitutional Court. The Community continues to wait for a hearing date, knowing that delays are notorious due to a heavy backlog of cases at the highest Court. The legal questions that frame the Negritos Community's appeal to the Constitutional Court will be addressed in the final section of this paper.

139 First Specialized Civil Court of Cajamarca, Exp No 00315-2011-1-0601-JR-CI-01, Resolution No 25 (16 June 2014). 140 Legislative Decree No 295, Civil Code (2015), art 2012 [emphasis added].

141 Superior Court of Justice of Cajamarca, Permanent Civil Appeal Court, Exp 00315-2011-0-0601-JR-CI-01, Resolution No 33 (5 May 2014). 


\subsubsection{Critical Analysis of the Appeal Court Decision}

There are at least two important observations to make of the Negritos Community's experience in the courtroom to date litigating against Yanacocha and the Peruvian state. The first, and most obvious, relates to process, and the second, and more complex, addresses the appeal court's admissibility analysis of the Negritos claim. A final point of analysis focuses on the appeal court's treatment of JCAP's amicus curiae request.

Turning to issues of process, the proceedings notably suffered from significant procedural delays. This is evident from the fact that it took more than four years for the Community to receive an admissibility decision from Cajamarca's appeal court and the Community continues to wait for a hearing before the Constitutional Court. Much of this delay was caused by procedural issues triggered by either the company or the Ministry of Energy and Mining. This ranged from the Ministry's failure to properly participate in the proceedings to Yanacocha's objections to increased transparency and public participation in connection to the Community's attempt to film the proceedings and JCAP's request to submit an amicus. Undoubtedly, a four-year court battle on the threshold issue of admissibility took a toll on the Negritos Community, especially where it spent much of that time fighting to make the proceedings more transparent and open to public participation.

A second observation arises from a concerning set of developments at the core of the court's treatment of the limitation period issue. Yanacocha has challenged the claim's admissibility by adopting a strategy of conflating the substantive legal issues in the case with admissibility questions. Critical analysis of this strategy reveals that it is predicated on a formalistic concept of consent and an abstract universalizing construction of the legal subject. These two approaches to consent and subjectivity have infiltrated the court's admissibility analysis in the form of formalist assumptions that have the effect of decontextualizing the Community's dispossession claim, rending its experience invisible or irrelevant, and ultimately excluding its justice claims from the courts. This section will examine how this has occurred.

As stated, in its objections to the Negritos claim's admissibility, Yanacocha took the position that the
Community does not exist and does not have a property right to defend. Both assertions rely on a common sense formal notion of consent to the legal events that lead to the elimination of the community's legal status and property title. They ask the court to presume that the signature of some community members on the relevant documents is a full and sufficient answer to the Negritos claim. This ignores the fact that the question of free and informed consent to these legal events is precisely at the heart of the case. It is problematic to implicitly presume informed consent at a preliminary stage when the alleged absence of informed consent is central to the substantive issues in the case.

Although the appeal court's admissibility decision rejected these two objections, it accepted another of Yanacocha's objections, namely that the Community's claim is barred because it is outside of the limitation period. Crucially, the limitation period objection depends on the same problematic formalist notion of consent and knowledge. The reasoning of the appeal court on this point is revealing. The court began its discussion of the limitation period objection by emphasizing that constitutional rights are not absolute and must be balanced with other objectives, presumably referring to the objective of legal certainty generally associated with limitation period rules. ${ }^{142}$ It rejected the theory of continuous rights violations and omissions, instead taking the position that any alleged rights violations would have concluded with the finalization of the legal transactions in question, referring to the transfer of property interests from the Community to the company. The court seems to have relied on "common sense" reasoning to support this conclusion, as it did not point to any supporting case law, nor did it directly address the Community's submissions on point.

In reaching these conclusions, the appeal court explicitly assumed that these legal processes occurred with the consent of the Community. The court stated that as soon as these property transfers occurred, the Community is presumed to have had the ability to act in defense of its own rights. ${ }^{143}$ It reasoned that the Community cannot argue that it did not have the technical or economic capacity to do so given that it had previously registered itself as a Campesino Community, therefore interacting with the Public Registry. The court conclu-

142 Ibid at para 8.

143 Ibid at paras 10-11 [emphasis added]. 
ded that any argument that the Community leaders who signed the property transfer documents were corrupt is unsupported and merely serves as a convenient reason for bringing a claim after the expiry of the limitation period. The court further observed that it would be impossible for the Community not to know that there was a mine operating in its midst on the basis of these property transfers.

The appeal court's reasoning on the limitation period issue made dramatic presumptions about the Negritos Community's knowledge and consent, without acknowledging that these issues are directly related to the Community's substantive arguments on the merits of the case. In doing so, the court avoided the need to consider documentation suggesting misrepresentation, corruption, fraud and extortion. It failed to consider alternative approaches to the limitation period and Peruvian and international jurisprudence elaborating on the right to remedy and the meaning of informed consent and consultation. Further, it ignored the social context of the Negritos Community, its poverty, isolation, limited literacy, lack of legal knowledge, and lack of access to competent lawyers capable of taking on a case against the most powerful foreign company in Peru.

Rather, the appeal court implicitly held the Negritos Community to a standard that would require it to engage with Yanacocha as though it were also a legally sophisticated, knowledgeable and resourced actor. The court conflated the obvious fact of the Community's knowledge of the physical existence of the Mine, with knowledge of its legal rights, alleged violations and available causes of action. It presumed that since the Mine's presence is based on official documents and publically registered title, then the Community should have had knowledge of these documents and of its legal rights and remedies in this respect. In this way, the court measured the Community's conduct against the standard of an ideal subject, with qualities that do not reflect the Community's actual social experience. To the extent that the Community cannot meet this standard due to its social disadvantage, the appeal court's approach is exclusionary and discriminatory. This reasoning effectively transforms the limitation period rule into an absolute bar to the pursuit of justice through law for the Negritos Community and communities like it.

The appeal court's reasoning leaves unanswered the question of what kind of information and consultative community processes would be required for the Negritos Community to make a free and informed collective choice, in the early 1990s, to transfer large portions of its communal land to one of the largest and most powerful mining companies in the world, in order to build one of the largest and most profitable gold mines in the world, such that its members would live with this mammoth open pit mine as their neighbor for decades and generations to come. In this context, and putting aside questions of allegedly illegal acts in procuring signatures, it does not seem reasonable to presume that the Community made a free and informed choice to extinguish all of its rights and its very existence in law in exchange for a few thousand dollars. This is highlighted by the apparent contradiction between the Community purported agreement to annul its legal existence and the fact that it continued with its communal economic, cultural and governance practices as before. Given the high indicators of poverty among Campesino Communities in the region, combined with limited to no access to basic education, much less legal advice, it seems unlikely that the Community had meaningful knowledge in the early 1990s that it had collective rights protected in Peruvian constitutional and international law. This all casts in serious doubt the appeal court's conclusion that the Community had the capacity to marshal the knowledge and the resources necessary to bring its case to court within sixty days (the limitation period) following the events in question.

When the appeal court rejected the community's doctrinal arguments with respect to the application of the codified exceptions of continuous actions and omissions, it appeared to do so offhandedly, and not on the basis of doctrinal reasoning. Rather, it chose to rest its decision on presumptions about the Community's consent and knowledge. In choosing to go down this path, it was incumbent on the court to consider a contextualized equitable approach to the limitation period as well as the case law on Indigenous knowledge and consent in an effort. These sources would have certainly complicated the formalist notion of consent and knowledge that the appeal court ultimately adopted. It is discriminatory for the court to adopt an interpretation of the limitation period rule and presumptions about the Community's consent and knowledge that do not take the Negritos Community social context of historical disadvantage into account.

In the final portion of its decision, the appeal court 
rejected JCAP's amicus curiae, presented earlier in the proceedings. The controversy regarding the admission of the JCAP amicus arose due to some uncertainty in the law on this area. As a starting point, the regulations of the Constitutional Court give it the discretion to directly invite a third-party to act as an amicus curiae. ${ }^{144}$ However, according to some legal experts, the right to proactively request amicus curiae status (without an invitation from the court) is rooted in Peru's constitutional provisions establishing the right to make legal submission to public authorities, the right to publicize legal proceedings and the right to participate in the political life of the nation. ${ }^{145}$ In practice, it has become increasingly common practice for Peru's Constitutional Court, as well as lower courts, to accept amici curiae from third parties without previous invitation from the court, although there are some notable (and arguably politicized) exceptions. ${ }^{146}$ Nonetheless, the increasing participation of amici curiae in public interest cases in Latin America is widely seen as part of a trend toward greater democratization, transparency in legal debate and judicial decision making that takes into account the broader public and social impacts of individual cases. ${ }^{147}$ The Inter-American Court has emphasized the importance of amici curiae because of their capacity to represent relevant public interests and contribute to debate in cases with broad social consequences that require greater public and democratic deliberation. ${ }^{148}$ Peru's Constitutional Court has reiterated this perspective in a number of cases. ${ }^{149}$

The court of appeal in the Negritos case ultimately concluded that the JCAP amicus was inadmissible be-

144 Administrative Resolution No 095-2004-P-TC, Normative Regulation of the Constitutional Court (14 September 2004) art 13-A.

145 Political Constitution of Peru, 1993, arts 2.17, 2.20, 31, 139.4. See: Juan Carlos Ruiz Molleda, "Para que sirven los amicus curiae?: TC rechaza el amicus del IDL sobre el derecho a la consulta de pueblos indígenas" (Instituto de Defensa Legal, 2010) online: http://www. justiciaviva.org.pe/notihome/notihome01.php?noti=221.

146 Ruiz Molleda, ibid.

147 Martín Abregu \& Christian Courtis, "Perspectivas y posibilidades del amicus curiae en el derecho argentino" in La aplicación de los tratados sobre derechos humanos por los tribunales locales (CELS, Editores del Puerto, 1997) at 388, cited in Ruiz Molleda, supra note 145; Peter Haberle, ElEstado Constitucional (Autonomous University of Mexico, 2003) at 149, cited in Ruiz Molleda, ibid.

148 Castañeda Gutman v Mexico, Preliminary Objections, Merits, Reparations, and Costs, Judgment, Inter-Am Ct HR (ser C) No 184 (August 6, 2008).

149 Some examples are: STC No 3081-2007-PA/TC (9 November 2007); STC No 0017-2003-AI/TC (16 March 2004); STC No 7435-2006-PC/TC (13 November 2006); STC No 00027-2006-PI/ TC (21 November 2007). cause the court had not directly requested it from the NGO. As such, it adopted a conservative interpretation of the law on point, converting the court's discretion to solicit an amicus into a strict rule that an amicus is only admissible if it is solicited. In doing so, the appeal court ignored the public interest purposes of the amicus. However, the court went further, reasoning that the fact that the amicus' authors had presented it on their own initiative made it evident that they were not impartial and objective. The court then went on to say that JCAP's interest in the case reveals that the case itself is a product of third party NGO interests, aimed at generating instability in the country by taking advantage of a difficult social context on mining issues. ${ }^{150}$

As such, the appeal court's reasoning and conclusion in relation to the amicus appears to be based on ideological rather than legal considerations. It does not offer any support for its statement that JCAP aims to cause social instability in the country. This conclusion appears to be based on unfounded assumptions and a suspicious view of the Negritos Community's decision to resort to the courts with the help of civil society actors. The court's comments with respect to JCAP's amicus are consistent with a conservative strand of thinking in some circles in Peru that delegitimizes, and in some cases, even dehumanizes and criminalizes, Campesino Communities and NGOs for their concerns and critiques of resource extraction in the country. ${ }^{151}$ In doing so, the appeal court ignored accepted practice and relevant jurisprudence with regard to the public policy and democratic function of an amicus curiae in human rights cases.

The forgoing analysis of the appeal court's comments on the JCAP amicus, taken together with the rea-

$150 \quad$ Ibid at para 14.

151 This ideology is best described by the concept of "perro de hortelano" or "the dog in the manger". In 2007, then President of Peru Alan Garcia published an editorial in a major Peruvian newspaper where he described the "syndrome" of "the dog in the manger", to refer to Indigenous and Campesino communities who oppose resource extraction on their land, thereby creating obstacles to national prosperity for all. He accused them of being irrationally attached to a way of life that only traps them in poverty and prevents progress. This discourse is used to justify militarized responses to opposition and protest. For commentary see: Moore, supra note 4 at 12-3; Roger Merino Acuna, "The politics of extractive governance: Indigenous peoples and socio-environmental conflicts" (2015) 2 The Extractive Industries and Society 85; Kamphuis, "Foreign mining", supra note 19 at 135; Anthony Bebbington \& Denise Humphreys Bebbington, "Actores y ambientalismos: Continuidades y cambios en los conflictos socio-ambientales en el Perú" (2009) 35 Iconos 117. 
soning in its admissibility decision and the procedural delays in the Negritos legal proceedings to date, paint a bleak access to justice scenario for Campesino Communities in Peru. First, the appeal court was willing to ignore evidence, jurisprudence and social context in order to rule the Negritos claim inadmissible on the basis of a formalist and exclusionary notion of consent and knowledge. It implicitly evaluated the Community's conduct against the standard of a legally sophisticated and resourced subject, thereby turning the limitation period rule into an absolute bar to justice for Campesino Communities in a position similar to that of the $\mathrm{Ne}$ gritos Community. This obstacle was augmented in the proceedings themselves when both the company and the Ministry generated delays on procedural matters. Ultimately, this has forced the Community to somehow marshal the resilience and the resources to advocate in a process that has continued for nearly six years and counting.

Finally, the appeal court's reasoning on the admissibility of the amicus seals the Community's fate. To the extent that the Community receives support from civil society actors, include foreign lawyers, the court presumes that the claim is illegitimate and animated by nefarious goals, as opposed to a bona fide concern to defend the rights in question. Following the logic of the appeal court, not only must the Community have the ability to mount its legal case extremely quickly, with full knowledge of the law, it must do so without the support of civil society organizations, lest its intentions be called into question. This paper's conclusion will explore the wider implications of the Peruvian courts' treatment to date of the Negritos claim.

\subsubsection{Challenges outside the Courtroom}

The previous sections recounted the challenges that the Negritos Community faced inside of the courtroom over the course of its litigation journey. This captures only one dimension of the complex set of economic, political, cultural and social challenges that Campesino and Indigenous communities face when they choose to engage with state law against a powerful foreign company. This section will profile some of the additional challenges that the Community faced in relation to its litigation efforts. Just as Part A of this paper contextualized the Negritos Community's dispossession story, this section sketches some of the social context details that have characterized the Community's litigation experience to date.

The Negritos Community litigated its case in a broader social context where the corruption of public officials in Peru is an ongoing concern. Unfortunately, it seems that corruption concerns and allegations continue to maintain close proximity to both Yanacocha and the Negritos case. The lower court decision in the Negritos amparo action in favor of Yanacocha's admissibility objections was issued by a judge of the Superior Court of Cajamarca by the name of Guhtember Pacherres Pérez. This is the same judge who neglected to duly organize audio recordings of certain hearings. Throughout the proceedings, the Negritos Community members and their local lawyer strongly suspected that Justice Pacherres Pérez was not an ethical judge and they believed that he was intentionally delaying the proceedings. It appears that they may have had good reason to suspect as much. Coincidentally, the day after Justice Parcherres Perez issued his decision dismissing the Negritos' amparo claim, he was filmed accepting a bribe in another case and was subsequently arrested, tried, and sentenced to a nine-month prison term. ${ }^{152} \mathrm{He}$ admitted his guilt, and the evidence revealed that he had solicited the bribe on July 11, 2014, just days before he issued his admissibility decision in the Negritos case.

The Negritos Community has no direct evidence that Justice Pacherres Perez accepted bribes from Yanacocha in relation to the Negritos amparo proceedings. There is no doubt though that this lower court judge was engaged in acts of corruption while he presided over the Negritos proceedings. The uncertainty about whether or not corruption has influenced outcomes to date in the Negritos case is heightened by the grim reminder of the high-profile corruption allegations that plagued the decision of the Supreme Court of Peru in favor of Newmont in Yanacocha's early days. ${ }^{153}$ Moreover, just a few months before the Pacherres Pérez

152 "La intervención a Juez Titular Gutenberg Pacherres Pérez por coima" (21 July 2014) online: https://www.youtube.com/ watch?v=PCOtbyBTHZU; "Juez Titular Guhtember Pacheres Pérez al penal de Huacariz en Cajamarca" (19 July 2014), online: https:// www.youtube.com/watch?v=-W9hKrF_C8 ; "Si, soy corrupto: El reo Pacherres aceptó recibir coima, ahora sufridos litigantes piden revisión de casos", El Mercurio (21 July 2014) 2, online: https:// issuu.com/elmercurio/docs/21-07-2014; "Cajamarca: encarcelan a juez acusado de recibir coima de 4 mil dólares”, Canal N (18 July 2014), online: http://canaln.pe/peru/cajamarca-encarcelan-juezacusado-recibir-coima-4-mil-dolares-n145767.

153 See supra Part A.1. 
corruption scandal broke, Yanacocha was implicated in yet another high-profile corruption story. In May 2014, Peruvian journalists reported on a leaked audio recording of conversations that took place in 2012 between Yanacocha's governmental affairs manager and three elected public officials in Cajamarca. In the recordin$\mathrm{gs}$, the public officials requested a financial contribution from the company in return for their support of its controversial mine expansion project, known as Minas Conga. In response, Yanacocha's manger promised to raise the issue of "economic support" with senior management. Following the publication of these recordings, Yanacocha promised to investigate and reiterated its commitment to transparency. ${ }^{154}$

There can be little doubt that the challenges associated with litigating a case like that of the Negritos Community's has taken a personal toll on the Community and its allies. In 2014, the local NGO that had been providing legal representation for the Negritos Community since 2007 withdrew from the case without an official explanation. As a result, for much of the litigation process, the Community was represented by a young local lawyer, working pro bono, with the distant help of a volunteer group of students and lawyers in Lima, Peru and in Canada. Just like the mine that sits on its land, the Negritos Community's case is mammoth, involving hundreds of pages of documents and complex arguments of fact and law. Dispossession cases are often complicated by nature, making them difficult to for NGO workers and pro bono lawyers to sustain.

The logistical, social and human conditions of the Negritos Community itself has added to these challenges. This paper has already referred to the Community's relatively low levels of education and continued high levels of poverty and exclusion from basic services. Community members live high up in the mountains, making communication very difficult with limited telephone access or electricity. In order to meet with Community members, lawyers must wait for regularly scheduled monthly General Assembly meetings. Community members walk long distances to attend meetings

154 "Peru: Miners in bribery risks, Yanacocha probes case", Latin IQ (21 May 2014), online: http://latin-iq.com/blog/peru-minersin-bribery-risks-yanacocha-probes-case/; "Consejeros de Cajamarca pidieron plata a Yanacocha para apoyar proyecto Conga", La Republica (21 May 2014), online: http://www.larepublica.pe/21-05-2014/ consejeros-de-cajamarca-pidieron-plata-a-yanacocha-para-apoyarproyecto-conga. and it is often difficult for lawyers to find and pay for transportation for the trip up into the mountains. Meetings take place in the open air, sitting under the hot Andean sun. Community leaders and members come to nearby Cajamarca only periodically and can sometimes be hard to locate with inconsistent access to a telephone. The Community's isolation, lack of resources and logistical challenges are just some of the obstacles that have made it difficult for Community members and pro bono lawyers alike to engage in a court process against a powerful company over a period of years.

These observations offer only a very partial picture of the social context that framed the Negritos Community members' experiences of the legal arguments, procedures and decisions taking place in the courtroom. Importantly, the documentary record does not capture the social and cultural impact of the case on the $\mathrm{Ne}$ gritos Community itself. Whenever a community decides to bring its justice concerns to the dominant legal system, it will undoubtedly face stresses and strains on community relationships and political leadership. ${ }^{155} \mathrm{Li}-$ tigation inevitably triggers a complex array of internal and external pressures that may create or exacerbate divisions within the Community. Community members and leaders may come under enormous pressure to drop or settle the case, sometimes they are offered bribes, sometimes they are threatened and sometimes they are actually harmed. ${ }^{156}$ It is well documented that Yanacocha's operations are increasingly militarized with may reported incidences of its security services threatening, harming or surveilling the company's critics. ${ }^{157}$

155 For one example of a detailed account of the negative impact of litigation on community relationships, see Parmar, supra note 11. 156 See generally commentary on criminalization of environmental and human rights defenders in Latin America: supra notes 2 and 4.

157 Kamphuis, "Privatization of Coercion", supra note 4; Guzmán Salano, supra note 64; Tim Martin et al, "Tragadero Grande: Land, Human Rights, and International Standards in the Conflict Between the Chaupe Family and Minera Yanacocha", Report of the Independent Fact Finding Mission (Washington, DC: Resolve, 2016); Inter-American Commission on Human Rights, Resolution, Resolución 9/2014, Lideres y Lideresas de Comunidades Campesinas y Rondas Campesinas de Cajamarca Respecto de la República de Perú, Precautionary Measure No 452-11 (2014), online: http://www.oas.org/es/cidh/decisiones/ pdf/2014/MC452-11-ES.pdf; Roxana Olivera, “'I Will Never Give Up My Land”", New Internationalist (July 2016), online: https:/ / newint. org/features/2016/07/01/interview-maxima-acuna/; EarthRights International, Media Release, "Factsheet: Campos-Alvarez v Newmont Mining Corp", online: https://www.earthrights.org/sites/ default/files/documents/Factsheet-Campos-Alvarez-v-Newmont. pdf; “Máxima Acuña: 2016 Goldman Prize Recipient” (2016) The 
Further in-depth fieldwork is required to fully document the Negritos Community's social experience with respect to the litigation to date and as it continues to unfold.

In sum, the Negritos Community has faced multiple challenges in its efforts to use the domestic Peruvian legal system to advance communal property claims grounded in international human rights law and the Constitution. Outside of the courtroom, these challenges have included the risk of corruption and bias in the local judiciary and a lack of access to trained and funded legal counsel. Inside the courtroom, the Community faces the formalist application of procedural rules to justify the dismissal of its case on the basis of a concept of consent and subjectivity that is arguably discriminatory. This live legal issue is the focus of the Negritos Community's current appeal to Peru's highest court.

\subsection{Negritos Case Next Steps: Precedents \& Remedies}

As stated, the Negritos Community has appealed the dismissal of its amparo action to Peru's Constitutional Court. In Peruvian constitutional law, this type of appeal is called a recurso de agravio. The Constitutional Procedural Code grants an amparo claimant a general procedural right to appeal a negative decision of a court of second instance to Peru's highest court. ${ }^{158}$ Thus, according to the Code, the Peruvian Constitutional Court is required to consider all recurso de agravio petitions if they are presented according to the specified rules.

However, recent developments in Peruvian constitutional jurisprudence have expanded the grounds upon which the Constitutional Court may refuse to grant a full hearing to such an applicant. In 2014, the Court issued the Vásquez Romero precedent, which established a special expedited procedure for dismissing recurso de agravio claims in certain situations. ${ }^{159}$ The decision identifies a list of deficiencies that could, alone or in combination, form the basis for the Court's decision to summarily

Goldman Environmental Prize, online: http://www.goldmanprize.org/ recipient/maxima-acuna/.

158 Constitutional Procedural Code, art 18.

159 STC No 00987-2014-PA/TC (6 August 2014) at para 49. This decision attempted to refine earlier decisions with a similar orientation: César Landa Arroyo, "Límites y alcances de la 'especial transcendencia constitucional”" (2015) 8 Revista Peruana de Derecho Constitucional 89 at $91-96$. dismiss the case: the alleged violations are manifestly unsubstantiated; the question of law at issue does not have "special constitutional importance"; the claim relies on law that clearly contradicts an established precedent of the Court; and finally, cases with substantially similar legal issues have been unsuccessful. ${ }^{160}$ Referring to the criterion of "special constitutional importance", the Vásquez Romero decision states that this threshold is met when a case requires the court to consider the content or scope of a fundamental right, when the alleged violations affect the constitutionally protected aspects of the rights in question, or when the issues at stake require especially urgent rights protection. ${ }^{161}$ Commentators have observed that the Vásquez. Romero criteria are highly subjective and they speculate that the Constitutional Court will likely be forced to provide further precision on their meaning in subsequent decisions. ${ }^{162}$

Importantly, the Court's inquiry into the "constitutional importance" of the case is expeditious, in that the Court makes this assessment without an in-depth review of the proceedings. Rather, the claimant must make a written submission to the court addressing the issue of constitutional importance. This is a function of the fact that the Vásquez Romero criteria were introduced, at least in part, to help reduce the unmanageable case load that the Constitutional Court faces. In 2013, the Court had an accumulated load of over six thousand and six hundred cases pending. ${ }^{163}$ This situation obviously impedes the Court's ability to attend to urgent and important cases in a timely manner.

Given the centrality of the "constitutional importance" criteria, the remainder of this section will describe the legal significance of the Negritos case in the context of the ongoing tension in Peru between neoliberal reforms and Indigenous rights. If the Constitutional Court agrees to consider the case on the merits, it would have the opportunity to develop jurisprudence in three distinct aspects of Indigenous and Campesino rights law with respect to resource extraction. First, admitting the case would give the Court the opportunity to clarify the status of Peru's Campesino Communities

\footnotetext{
160 STC No 00987, ibid.

161 Ibid at para 50. Also see: Eloy Espinosa-Saldaña Barrera, "La "especial trascendencia constitucional" como causal para el rechazo liminar de recursos de agravio en el Perú” (2015) 8 Revista Peruana de Derecho Constitucional 41 at 48-49, 52.

162 Landa Arroyo, supra note 159 at 101.

163 Ibid.
} 
vis-à-vis the incorporation of international Indigenous rights norms into Peru's constitutional order. Second, the substantive arguments in the case address matters relating to the nature of Campesino constitutional rights, including norms governing: the conversion of communal property into individual property; the legal recognition of Campesino communities; the expropriation of Campesino communal property, and meaning of fair and equitable compensation. Finally, if successful on the merits, the case would give the Constitutional Court the opportunity to explore law's capacity to remedy dispossession claims.

Due to its focus on the ongoing Negritos amparo litigation, this section of the paper frames the important questions and arguments advanced in the case in terms of their potential contribution to Peruvian law. However, many of the issues in the Negritos case are arguably a microcosm of the tensions between Indigenous communities around the world and the globalized model of foreign resource extraction. As such, the discussion in this section, while situated in the Peruvian context, arguably transcend the Negritos case. Controversy over the foreign resource extraction model are very often about the legal status of rights holders, the meaning of consent, the terms of property ownership, transfer and compensation, the tension between private and public law, as well as the nature of available legal remedies. At the same time, exploring these themes in a discrete case study is helpful because it illuminates law's potential and limitations as a tool for responding to the underlying justice concerns that the Negritos case represents. I will take this topic up again in this paper's conclusion.

\subsubsection{The Indigenous Status of Campesino Communities in International Law}

Part A of this paper described briefly how in the 1920 and 1933 Peruvian Constitutions, "Indigenous Communities" were given special status and rights. The 1969 Agrarian Reform Law changed this terminology when it declared that from that moment forward, the Indigenous Communities of Peru would be denominated "Campesino Communities". ${ }^{164}$ The Peruvian state subsequently developed an elaborate statutory regime pertaining to Campesino Communities and in the 1979 and 1993 Constitutions they were granted special status

164 Agrarian Reform Law, supra note 25 at art 115. and rights. In each of these Constitutions, the term "Campesino Community" was used together with "Native Community" in reference to the same set of cultural, political, and property rights. Specific legislation clarifies that Campesino Communities are those located in the Andes while Native Communities are found in the Amazon region of Peru.

Part A also referred to the fact that at the international level, Indigenous peoples began to make significant gains beginning in the early 1990s. In 1989 the ILO revised its earlier 1957 Convention $^{165}$ to approve Convention No 169, which remains the only binding international treaty on the subject of Indigenous peoples' rights. In 2001 the Inter-American Court pronounced in its first Indigenous land rights case, interpreting existing provisions of the 1969 American Convention to include an Indigenous right to communal property. ${ }^{166}$ Finally, in 2007, the United Nations Declaration on the Rights of Indigenous Peoples was broadly endorsed by the international community. Part B of this paper described the legal significance of these international law developments in Peru. Peru's Constitutional Court has held that it is bound by the jurisprudence of the Inter-American Court, including its interpretations of Indigenous rights, while Convention No 169 is similarly part of Peruvian Constitutional law, acquiring constitutional status after it was approved by Peru's Congress in 1993.

This brief recap reveals that a curious situation has arisen in Peruvian law. While relatively recent international statements of Indigenous rights have been incorporated into Peruvian Constitutional law, the category of "Indigenous Communities" disappeared from the 1979 Constitution in favour of the terms Campesino and Native Communities. Thus, while international and domestic law have converged in Peruvian constitutional law, the legal categories employed in these two spheres have diverged. In this context, the status of Peru's Campesino Communities vis-à-vis international law has become an important question. In other words, do the rights of Indigenous peoples, as incorporated into the Peruvian Constitution through various international instruments, apply to Campesino Communities? This question is pressing. There are over 5000 Campesino Communities in Peru and a significant portion of mi-

165 Indigenous and Tribal Populations Convention, International Labour Organization, Convention No 169, (1957).

166 Awas Tingni, supra note 71. 
ning activity affects land belonging to these Communities. $^{167}$

Human rights institutions, both inside of Peru and internationally, have consistently treated Campesino Communities, either implicitly or explicitly, as Indigenous for the purposes of the application of the Peruvian Constitution and international law. ${ }^{168}$ Certain domestic statutes have also treated Campesino Communities and Indigenous peoples as a single grouping for the purposes of describing their rights. ${ }^{169}$ However, the Peruvian State's official position on this issue is inconsistent at best and it has tended to deny that Campesino Communities have Indigenous rights. In 2009 the Peruvian State informed the ILO Expert Committee that it intended to treat Campesino Communities as collectivities similar to Indigenous Peoples in the recognition of their ethnic and cultural rights. ${ }^{170}$ Yet in a 2011 decision, the Constitutional Court took note of the Peruvian government's submissions that Convention No 169 does not apply because Peru has very few Indigenous peoples and Campesino and Native Communities are fundamentally mestizo or 'mixed'. ${ }^{171}$

Also in 2011, the Peruvian state legislated a controversial set of objective and subjective criteria for the recognition of Indigenous peoples, including that they must be "direct descendants" of the country's "original inhabitants" and that they must self-identify as Indigenous. ${ }^{172}$ This definition directly contradicts statements

167 See Laureano del Castillo, "Propiedad Rural, Titulación de Tierras y Propiedad Comunal” (1997) 26 Debate Agrario 59.

168 For domestic examples, see: the Peruvian Commission for the Environment, Ecology and Andean, Amazonian and AfroPeruvian Peoples: Comisión de Pueblos Andinos, Amazónicos y Afroperuanos, Ambiente y Ecología, Proyecto de Ley de Reforma de la Constitución, Título II, Capítulo VII "Derechos de los Pueblos Indígenas", art 96. Also see the National Institute for the Development of Andean, Amazonian and Afro-Peruvian Peoples: Supreme Decree No 065-2005-PCM, Regulation of the National Institute for the Development of Andean, Amazonean and AfroPeruvian Peoples (2005), art 2. For international examples, see: OAS, Inter-American Commission on Human Rights, Second Report on the Situation of Human Rights in Peru, OR OEA/Ser.L/V/II.106/Doc 59, rev (2000) at Chapter $\mathrm{X}$, “Indigenous Communities' Rights". Also see: ILO, Committee of Experts on the Application of Conventions and Recommendations, Indigenous and tribal peoples: Observations of Peru, Indigenous and Tribal Peoples Convention, 1989 (No 169), ILC.98/III/1A (ILO: 2009), 686-687 at paras 3, 4 [CEACR 2009].

169 See Rondas Campesinas Law, supra note 69; See environmental laws (Law No 28611 and Law No 27446), supra note 70.

170 CEACR 2009, supra note 168.

171 STC No 00024, supra note 98.

172 Right to Consultation Law, supra note 69 at art 7. of the ILO Expert Committee on the application of Convention No 169 in Peru. ${ }^{173}$ The Committee has clearly stated that if Campesino Communities fulfill the requirements of the Convention, they should receive the full protection of its provisions. Notably the language of the Convention is significantly broader than the concepts of "direct descendant" of "original inhabitants". ${ }^{174}$ Moreover, the ILO has stated that the use of the term "Indigenous" by a community in the Peruvian context is not a requirement and its absence should not be used to preclude the application of the Convention. ${ }^{175}$ In spite of this, in 2012, Peru's Ministry of Culture adopted an even more restrictive definition to the effect that, in order to be registered in the Official Indigenous Peoples' Database, communities must speak an Indigenous language and remain in their ancestral territory. ${ }^{176}$ Local lawyers have documented instances where the Ministry of Energy and Mining has used this restrictive definition to avoid consulting with Campesino Communities impacted by proposed mining projects. ${ }^{177}$

In spite of the controversy and importance of this issue, Peru's Constitutional Court has declined to offer any meaningful guidance in its decisions to date. It has referenced the issue only once by way of comments

173 The ILO Expert Committee expressed disapproval of Peru's definition of Indigenous peoples in its Law for the Right to Consultation: see ILO, Committee of Experts on the Application of Conventions and Recommendations, Indigenous and tribal peoples: Observations of Peru, Indigenous and Tribal Peoples Convention, 1989 (No. 169), ILC.100/ III/1A (ILO: 2011), at 794-795 [CEACR 2011].

174 The Expert Committee stated that if Campesino Communities comply with either (a) or (b) of article 1, Convention No 169 will apply: CEACR 2009, supra note 168. The text of article 1 is as follows: 1. This Convention applies to: (a) tribal peoples in independent countries whose social, cultural and economic conditions distinguish them from other sections of the national community, and whose status is regulated wholly or partially by their own customs or traditions or by special laws or regulations; (b) peoples in independent countries who are regarded as indigenous on account of their descent from the populations which inhabited the country, or a geographical region to which the country belongs, at the time of conquest or colonisation or the establishment of present state boundaries and who, irrespective of their legal status, retain some or all of their own social, economic, cultural and political institutions: Convention No 169, art 1.

175 CEACR 2009, supra note 168; CEACR 2011, supra note 173 at 872 .

176 Directive No 03-2012/MC at arts 7.1, adopted by Ministry of Culture, Ministerial Resolution No 202-2012-MC (2012).

177 Juan Carlos Ruiz Molleda, "Ministerio de Cultura bloquea la consulta previa de las concesiones mineras e invisibiliza a los PPII en Espinar", Instituto de Defensa Legal: Justicia Viva, (16 April 2015), online: http://www.justiciaviva.org.pe/notihome/notihome01. php?noti=1597. 
that were tangential to its ultimate decision. On this occasion, the Court stated that the Indigenous status of Campesino Communities for the purposes of the application of Convention No 169 in Peru must be considered on a case-by-case basis. ${ }^{178}$ Unfortunately, the Court refrained from offering any additional guidance regarding this form of individualized consideration.

Taken together, the legislation described above and the Court's decision ostensibly create a situation where, prior to invoking the rights and protection of Convention No 169, each individual Campesino Community must somehow prove its status as an Indigenous community. As a result, Campesino Communities in Peru exist in a legal context where there is a presumption that they are not Indigenous and where the onus is on them to prove their indigeneity. When making a legal claim in a court, this amounts to an additional threshold evidentiary burden on Campesino Communities who claim Indigenous rights as recognized in international law. Given that the 1969 Agrarian Reform in Peru declared that Indigenous Communities would thereafter be dominated Campesino Communities, the Peruvian State's contemporary approach to the legal category of Indigenous converts this change in terminology into a presumption in favor of Campesino Communities' loss of Indigenous status and the concomitant reduction of their rights in international law. Not only does this contradict the professed social justice purpose and spirit of the Agrarian Reform Law and its implementing legislation, it converts Agrarian Reform into a fundamentally assimilationist rights-reducing project.

In the context of the ongoing controversy in Peru over the legal definition of Indigenous communities, the Negritos amparo claim takes the position that Campesino Communities as such have the legal status of Indigenous communities under international law. This argument is legalistic as opposed to anthropological. It begins with the historical progression in Peru's Agrarian Reform Law from the term Indigenous to Campesino. It further points to the significant conceptual similarities between international Indigenous rights regimes and the Peruvian domestic legal regime with respect to Campesino Communities. Peruvian laws recognize Campesino Communities' legal personhood, their culturally specific characteristics as a group, their communal political and economic institutions and their special

178 STC No 0022, supra note 98 at para 10. relationship to a specific area of land or territory. On this basis, the Negritos amparo claim argues that to identify oneself as part of a Campesino Community in Peru is the equivalent, for the purposes of the application of international law, to identifying oneself as a member of an Indigenous group.

This argument attempts to counteract the State's assimilationist approaches by intentionally relying on legal histories and facts available to all Campesino Communities in order to construct a broad claim for their international status as Indigenous people. The value of this approach is that Campesino Communities are not required to marshal complex historical anthropological evidence before invoking international Indigenous rights statements to support their claims. This avoids the imposition of a heavy evidentiary burden on Campesino Communities, which in practical terms may be insurmountable. In the context of litigation, such a burden would only exacerbate the existing procedural and practical obstacles described in the previous sections of this paper. In this way, the Negritos amparo action has the potential to set an important precedent by advancing an approach that would clarify some of the legal uncertainties and alleviate some of the evidentiary burdens that presently plague Peru's Campesino Communities who assert Indigenous rights in local courts.

\subsubsection{Substantive Rights Precedents}

Previous sections of this paper described how the Negritos amparo action draws on domestic and international law and jurisprudence to advance four substantive rights claims of precedent setting value. Each claim speaks to an unresolved point of law in the Peruvian context and, if accepted, would make an important contribution to the advancement of Campesino and Indigenous rights in Peru. Beyond their legal significance, these claims have political significance in that they confront a suite of neoliberal state policies and company practices that continue to pose a threat to Campesino Communities' land and legal status. While certain events in the Negritos case occurred decades ago, they remain emblematic of the vulnerabilities and pressures that Campesino Communities in Peru continue to face vis-à-vis legal regimes designed to promote foreign investment at the expense of rights protection. This highlights the need for strategic Campesino rights litigation like the Negritos case to push the political de- 
bate and legislative agenda.

The first significant substantive rights claim in the Negritos action is that the communal property of a Campesino Community cannot be alienated or converted into individual property without the free, prior and informed consent of the majority of the Community. ${ }^{179}$ This assertion is grounded in the 1979 Constitution and 1987 Campesino Communities General Law which require a vote of two-thirds of the community in these circumstances. ${ }^{180}$ Part B of this paper described how international and domestic law principles imbue this provision of the Campesino Communities General Law with constitutional significance even after it was dropped from the 1993 Constitution. International sources of law support the proposition that this vote should be free, prior and informed, emphasizing (among other things) that information should be meaningful, appropriate and allow for effective decision-making. ${ }^{181}$

This argument is important because of consistent efforts of the Peruvian State since the early 1990s to introduce policies that attempt to facilitate and expedite the conversion of communally titled property into individual property. ${ }^{182}$ The expressed goal of these policies has often been to facilitate the disposition of (formerly) communal property to private, often foreign, investment. While the state has repealed some of these policies due to their controversial and allegedly unconstitutional status, this has only occurred after significant social conflict. ${ }^{183}$ As recently as 2015 , the Peruvian go-

179 This right is part of a suite of interrelated Indigenous property rights, including the right to collective property, the right to state recognition of collective property and the state's duty to take special measures to protect communal property related rights. The conversion of Negritos communal land into individually titled land occurred between 1991 and 1995. As such, both the 1979 and 1993 Political Constitutions of Peru apply, as well as Convention No 169 and the American Convention.

180 In domestic law, this right is based on articles 163 and 161 of the Political Constitution of Peru, 1979, article 7 of the Campesino Communities General Law, and article 89 of the Political Constitution of Peru, 1993.

181 See American Convention, art 21 and relevant jurisprudence of the Inter-American Court: Awas Tingni, supra note 71 at para 149; Yakye Axa, supra note 72; Saramaka, supra note 72. Also see: Convention No 169, arts 6(1), 6(2), 17(2).

182 Part A above referred to the Fujimori era laws associated with this tendency.

183 In 2007, the Executive Branch, endowed with special new powers, introduced new laws to facilitate Peru's Free Trade Agreement with the United States. Five decrees in particular endeavored to reduce the property rights of Campesino and Native Communities. After one year of widespread protest against the new laws, four vernment passed laws purporting to allow a small number of Campesino Community leaders to approve mining projects without bringing the proposal to a General Assembly, ${ }^{184}$ thereby expediting the sale of communally owned Campesino and Indigenous property to private investors. ${ }^{185}$ Notably, these laws presume to legalize the very type of process that was actually followed in the Negritos case in the early 1990s. Commentators have denounced these 2015 laws for contravening provisions of the Campesino Communities General Law and international law regarding consultation and consent and for interfering with Communities' political autonomy and rights under national and international law to establish their own governance structures and decision-making procedures. $^{186}$

In sum, the Peruvian state and the private sector have consistently pursued legal frameworks that help expedite the commodification of communal land. This has led to policies and practices on the ground that generate significant pressure on Campesino Communities to individually parcel and/or sell their land to companies. In this context, the facts of the Negritos case remain extremely relevant. Their judicial treatment would give the courts an opportunity to make a clear statement that informed consent with the meaningful participation of the majority of Community members is the standard in relation to the alienation of communal land.

The second substantive claim of constitutional significance in the Negritos action arises from the state's administrative action purporting to eliminate the Community's legal existence. ${ }^{187}$ As a result, the Negri-

of the five decrees were repealed: see Pedro Castillo Castañeda, El Derecho a la Tierra y los Acuerdos Internacionales: el Caso de Perú (Lima, CEPES \& International Land Coalition: 2009) at 74-75.

184 Supreme Decree No 001-2015-EM, Provisions for mining procedures that encourage investment projects (2015).

185 Legislative Decree No 1192, Law for the acquisition and expropriation of real property, transfer of state real property, removal of interferences and other measures for the execution of infrastructure projects (2015).

186 Álvaro Másquez Salvador \& Juan Carlos Ruiz Molleda, "Gobierno aprueba norma que consagra intromisión en autonomía de Comunidades Campesinas", Instituto de Defensa Legal: Justicia Viva (15 January 2015), online: http://www.justiciaviva.org.pe/notihome/ notihome01.php?noti=1526; Juan Carlos Ruiz Molleda, “¿El sexto paquetazo normativo? La aprobación de los DL $\mathrm{N}^{\circ} 1192$ y $\mathrm{N}^{\circ}$ 1210" Instituto de Defensa Legal: Justicia Viva (1 October 2015), online: http://www.justiciaviva.org.pe/blog/el-sexto-paquetazo-normativo-la-aprobacion-de-los-dl-n-1191-y-n-1210/ [Ruiz Molleda, "Sexto paquetazo"].

187 A regional branch of the Ministry of Agriculture issued a resolution purporting to annul the legal personhood of the Negritos Community in 1995. As a result, the Political Constitution of Peru, 
tos amparo action offers the courts the opportunity to pronounce on Indigenous and Campesino rights to political and legal recognition. This directly relates to the first legal claim in the Negritos case in that the state's efforts to eliminate communal land rights were directly linked with its efforts to eliminate the legal personhood of the Community itself. Domestic and international tribunals are clear that state recognition of Campesino and Indigenous communities is declaratory and not constitutive. ${ }^{188}$ The Negritos case builds on this to argue that, following recognition, any change in the legal status of a Campesino Community may only take place with the free, prior and informed consent of the majority of the Community. Given that the recognition of the Community as such strengthens its capacity to assert rights claims in legal and political arenas, establishing a standard of informed consent prior to any changes to the Community's legal personhood is a fundamental first step toward securing robust rights protection for Campesino Communities. ${ }^{189}$

The third claim of constitutional importance in the Negritos amparo action relates to the domestic regulatory regime that governs the expropriation of Campesino communally owned land in favour of private mining interests. The Peruvian Constitution allows the state to expropriate both communal and individually titled land in situations of public necessity and utility or for a social interest, in accordance with law and with fair monetary compensation. ${ }^{190}$ Peru’s 1992 Mining Law gives

1993, Convention No 169 and the American Convention all apply to this event.

188 In domestic law, the Constitutional Court has interpreted article 89 of the Political Constitution of Peru, 1993 to conclude that Campesino Communities have exceptional and privileged legal existence and legal personhood, that state recognition is declaratory and not constitutive of their existence, and that their existence should not depend on formalities: see STC No 02939-2008-PA/TC (13 May 2009) at para 9; STC No 04611, supra note 106 at para 22; STC No 00042-2004-AI/TC (13 April 2005) at para 1. In international law, the Inter-American Court has held that the legal personhood of Indigenous Peoples makes existing rights operational and that Indigenous rights do not originate in the act of State recognition: Yakye Axa, supra note 72 at para 82.

189 The Inter-American Court has stated that Indigenous peoples' right to the recognition and legal personhood is connected to communal property rights, the right to legal protection and the state's duty to take measures to effectively protect Indigenous rights: Saramaka, supra note 72 at paras 174-5.

190 Political Constitution of Peru, 1979, art 125; Political Constitution of Peru, 1993, art 70. While, international law principles tend to support the existence of this power, it is controversial. Convention No. 169 recognizes the state's right to expropriate Indigenous land upon realizing a consultation process with the Indigenous community (art mineral concession owners the right to submit a request to the Ministry of Mining to expropriate property for the purposes of mining activities. ${ }^{191}$ This law does not distinguish between individually titled and Campesino communally titled property.

The Mining Law also specifies the resulting procedures, which apply equally to all property titleholders. ${ }^{192}$ It requires that, within fifteen days of receiving notice from the Ministry of Mining, the titleholder must attend a "negotiation meeting" with the mineral concession holder in order to reach an agreement regarding the expropriation. If the property owner fails to attend, the process will continue in its absence. If the owner does attend but an agreement cannot be reached at the meeting, the Ministry will designate an expert official to impose a final decision regarding the process and the compensation. ${ }^{193}$ In all cases, whether the property owner agrees or not to the expropriation, a visual inspection of the property must occur within sixty days of the meeting and a report must be issued in the thirty days following. Upon receiving the report, the Ministry must, within thirty days, issue a final resolution approving or not the expropriation request. ${ }^{194}$ Thus the entire expropriation process is designed to wrap up in approximately four and half months and property owners, including Campesino Communities, are legally entitled to only fifteen days at the outset to participate in the process and negotiate an agreement. If they are unable to agree in this period, the Ministry has the power to impose an agreement upon them.

The Mining Law contemplates an identical process in order to establish an easement in favor of a concession holder over privately owned property, including Campesino property. ${ }^{195}$ The substantive effect of the mining easement on Campesino communal land interests is tantamount to that of an expropriation. In other words, just like the expropriation, the easement allows for the involuntary and potentially permanent transfer of the right to use the surface of a particular piece of land. Although an easement does not transfer title, mining

6) while the UN Declaration states that Indigenous peoples cannot be forcefully displaced from their land and that any relocation must occur after the consent of the community (art 10).

191 Supreme Decree No 014-92-EM, General Mining Law (1992), art 37.

192 Ibid, arts 130-1.

193 Ibid.

194 Ibid.

195 Ibid. 
easements in Peru allow for activities that permanently and radically alter the land. For example, in the Negritos case the easement afforded Yanacocha the open-ended right to undertake work related to mining exploration and exploitation, broadly defined.

The expropriation of a portion of Negitos communal land known as Pampa Larga was executed in 1993 and the establishment of a mining easement in favor of Yanacocha over another portion of Negritos land occurred in 1995. Both processes occurred in accordance with the procedures dictated by the Mining Law, as outlined above. The now discredited Community leaders agreed to the expropriation and the easement at a negotiation meeting with Yanacocha, with no further consultation with the rest of the Negritos Community and even before many key details of the transaction were specified, including the compensation amount. As stated earlier, there is no evidence that the Community received any information about its legal rights and the anticipated consequences of the mining activities contemplated. Part A outlined the dubious dealings that occurred in relation to both transactions and the grossly inequitable final arrangement.

The Negritos amparo action claims that, while the expropriation and easement procedures with respect to the Negritos Community's land may have followed the provisions of the Mining Law, they did not conform to the constitutional standard of free, prior and informed consultation with at least two thirds of Community members. ${ }^{196}$ It is inconceivable that a Campesino Community could participate in meaningful consultation with respect to the expropriation of its land for the purposes of a large mining project within fifteen days and in the absence of basic information regarding the expropriation and the project. The imposition of such a severe timeframe effectively subverts Communities' right to engage in decision making in accordance with their customs and traditions and in light of their social and economic constraints. ${ }^{197}$ The Negritos action ar-

196 The Negritos Community's communal property was expropriated and title was transferred to Yanacocha in April of 1993. As a result, the Political Constitution of Peru, 1979 and the American Convention both apply to this event. An easement was established in favor of Yanacocha over Negritos communal land in 1995. As a result, the Political Constitution of Peru, 1993, the American Convention and Convention No 169 all apply to this event.

197 See STC No 0022, supra note 98 at paras 26, 28, 34, 39, 51; STC No 003343, supra note 98 at para 97; Saramaka, supra note 72 at paras 129, 134. Also see: Campesino Communities General Law, supra gues that respect for the Campesino right to meaningful consultation is part of the constitutional framework of due process and legality that constrains the state's power to expropriate communally-held land. ${ }^{198}$ In this respect, Peru's Constitutional Court has stated that the right to consultation is engaged by the expropriation of Indigenous land and that the content of that right is elevated where the impact of the expropriation will be significant. ${ }^{199}$ For its part, the Inter-American Court has stated that in the case of large scale projects with a significant impact on an Indigenous group's territory, the state must obtain their consent. ${ }^{200}$

Within the scope of the Negritos amparo action, the assertion that the expropriation and easement in the Negritos case was unconstitutional has only indirect implications for the relevant provisions of the Mining Law. It is not open to a court in amparo proceedings to find that the Mining Law's expropriation provisions are themselves unconstitutional as they apply to Campesino land. This is due to the fact that the amparo is a cause of action against public and/or private actions/omissions, and not legislation. ${ }^{201}$ However, in spite of these constraints, the Negritos action marshals a claim with considerable impact. It argues that while the conduct of the state and the company may have formally occurred in conformity with the Mining Law, this conduct is nevertheless unconstitutional (and therefore illegal) because did not comply with the constitutional requirement of free, prior and informed consultation. ${ }^{202}$

Judicial treatment of the Negritos claim in this regard is pressing since the status quo in Peru on this is-

note 28 , art 15.

198 In Peru's constitutional framework, the state's power to expropriate occurs by definition against a property owner's will and as such is an exception to the constitutionally recognized right to property. As such, an expropriation must comply with certain conditions, including it may only be done: in accordance with law, when necessary, proportional, and in order to pursue a legitimate objective in a democratic society: STC No 05614-2007-PA/TC (20 March 2009) at paras 8-9.

199 STC No 0022, supra note 98 at paras 32, 51.

200 Saramaka, supra note 72 at paras 134, 137. The Inter-American Court has also added that any restriction on Indigenous peoples' property cannot put their subsistence into jeopardy: Yake Axa, supra note 72 at paras $145-8$.

201 See discussion in Part B.1.

202 The Constitutional Court has stated that where there are gaps in the law with respect to the regulation of consultation with Indigenous peoples, the state must proceed in accordance with constitutional standards lest its actions be deemed unconstitutional even if it has complied with applicable statutes: STC No 0022, supra note 98 at para 26. Also see infra note 213. 
sue remains deeply problematic. The 1992 expropriation provisions of the Mining Law were not modified following the 2011 Right to Consultation Law, thereby contributing to a situation of regulatory incoherence that puts Campesino Communities' rights at risk. ${ }^{203}$ Moreover, recent expropriation laws that aim to support large development projects have failed to include provisions that would protect Indigenous and Campesino land. ${ }^{204}$ In 2015 a law regulating expropriation more generally was modified so that it could be read to apply to Campesino and Native Communities' lands. ${ }^{205}$ Like the 1992 Mining Law, the 2015 general expropriation law fails to stipulate appropriate conditions and procedures for meaningful consultation with Campesino Communities. It also implements nearly identical expedited procedures, including the extraordinarily limited fifteen-day window for negotiating compensation followed, failing this, by the imposition of an agreement. ${ }^{206}$ In this context, Indigenous and Campesino communities in Peru continue to demand that the state must, at a minimum, undertake free, prior and informed consultation with them prior to transferring their land interests over to resource companies. ${ }^{207}$

In sum, the legal status quo in Peru continues to be

203 This situation is described in greater detail in Part A.1.

204 See: Law No 30025, Law that facilitates the acquisition, expropriation and possession of real property for infrastructure works and declares the public need for the acquisition or expropriation of real property affected by the execution of diverse infrastructure works (2013). This law allows private investors to acquire land for infrastructure projects and permits special procedures for expropriation. Also see: Law No 30327, Law for the promotion of investment for economic growth and sustainable development (2015). This law simplifies the procedures for obtaining easements and expropriations of "unoccupied" land, which could include the untitled land of Campesino Communities.

205 Legislative Decree No 1192, supra note 185 as modified by Legislative Decree No 1210, Modification of the Tenth Final Complementary Disposition of Legislative Decree No 1192 (2015).. The modification retains an exemption for Indigenous peoples from the law's expropriation provisions but changes the earlier version by removing Campesino Communities from this exemption, presumably in accordance with the state's position that Campesino Communities are not Indigenous: see Ruiz Molleda, "Sexto paquetazo", supra note X. 206 Decreto Legislativo No 1192, supra note 185, art 20.

207 See for example: "Reconocen que servidumbres petroleras están sobre territorios indígenas", Servicios de Comunicación Intercultural, (28 November 2016), online: https://www.servindi.org/actualidadopinion/28/11/2016/reconocen-que-servidumbres-petroleras-seencuentran-sobre-territorios. Communities are also demanding that consultation occur prior to granting mineral concessions: "Todas las concesiones mineras deberán ser consultadas a las comunidades" Servicios de Comunicación Intercultural (24 November 2016), online: https://www.servindi.org/actualidad-noticias/24/11/2016/todaslas-concesiones-mineras-deberan-ser-consultadas-las-comunidades. one where Campesino and Native land are subject to expropriation laws that do not account in any way for their right to meaningful free prior and informed consultation. In light of this reality, the questions raised in the Negritos action are certainly constitutionally significant and require urgent judicial consideration.

The fourth contribution of the Negritos amparo action to substantive law in Peru moves beyond the process required before expropriating Campesino Community land (consultation and in some cases consent) to address the matter of Campesino Communities' rights to equitable compensation. Part A.1 told the story of how, using the legal instruments of expropriation and easement, Yanacocha received title and/or full access rights to a combined total of just over 1200 hectares of Negritos communally titled land in exchange for a total payment of approximately US $\$ 48,000$. The company subsequently mortgaged the expropriated property for financing loans totaling US $\$ 85$ million.

At a minimum, Peruvian and international law requires fair compensation where Campesino communal land is expropriated. ${ }^{208}$ As such, the meaning of fair compensation in this context must be explored. Clearly a meaningful process of free and informed consultation prior to a proposed expropriation is essential to determining the terms of fair compensation. According to the Inter-American Court, fair compensation for any limitation on Indigenous property rights in favor of private investment includes the right to participate in the creation of a "development plan". ${ }^{209}$ Moreover, the state must guarantee that Indigenous communities' reasonably benefit from the plan. ${ }^{210}$ Peru's Constitutional Court has similarly stated that where expropriation occurs to facilitate resource extraction, Indigenous peoples' right to compensation includes the right to an equitable share in the profits and benefits ${ }^{211}$ and that

208 See Constitution Political del Peru, 1979, arts 2(2), 2(15), 125, 163; Supreme Decree No 004-92-TR, Regulation of Chapter VII - Economic Regime for the Campesino Communities General Law (1992), art 167; American Convention, art 21(2).

209 Saramaka, supra note 72 at para 129, interpreting article 21(2) of the American Convention.

210 Ibid [emphasis added]. This fits with a line of jurisprudence at Peru's Constitutional Court to the effect that the state has an obligation to correct inequalities generated by the free market, while private parties have an obligation to exercise their freedoms with social responsibility: STN No 03343, supra note 98 at para 22; STC No 00020-2005-PI/TC and 00021-2005-PI/TC (27 September 2005) at para 17; STC No 0008-2003-AI/TC (11 November 2003) at para 4. 211 STC No 03343, supra note 98 at para 34. Equitable benefit in- 
a failure to ensure equitable compensation is actionable. $^{212}$ These standards are rooted in the recognition that land has a special spiritual and cultural significance for Campesino Communities and its loss can put their very existence as such into jeopardy. ${ }^{213}$

Drawing on this international and domestic jurisprudence, the Negritos amparo action argues that the expropriation and easement in favor of Yanacocha violated, not only the Community's right to consultation, but also its right to fair and equitable compensation. Part A.1 of this paper recounted the Negritos Community's continued social and economic deprivation in the face of Yanacocha's extraordinary profitability over more than two decades. Moreover, the meaning of fair and equitable compensation remains pertinent in Peru. While the mining laws, consultation law, and expropriation laws referenced throughout this section all regulate in some regard the potential transfer of communal land interests to private companies, none of these laws have addressed Indigenous and Campesino rights to equitable compensation.

Unfortunately, the legislative trend in Peru is to specifically curtail the concept of equitable compensation. The most explicit example of this is the recent 2015 expropriation law. It expressly states that property, including Campesino and Indigenous property, can only be valued in terms of its commercial value, fixed by the value, present and future, of any existing improvements and crops being cultivated at the time that the acquisition or the expropriation is solicited. ${ }^{214}$ This provision has the effect of precluding any consideration of the post-expropriation profitability of the property. Moreover, this same law specifically prohibits calculating compensation by taking into account "non-economic" valuations, such a property's cultural, social and spiritual significance to its owner. ${ }^{215}$

Undoubtedly, this economic approach is a disadvantage for Peru's Indigenous and Campesino Communities who generally do not have large amounts of capital

cludes participation in the extractive activities and sharing of profits: ibid at para 39; STC No 0022, supra note 98 at para 33.

212 STC No 0022, ibid at para 52. A 2005 environmental law also provides that Indigenous peoples, Campesino and Native Communities have the right to equitable compensation when the state grants third parties the right to exploit resources on their land: Law No 28611, supra note 70, art 72.3 .

213 Ibid.

214 Decreto Legislativo No 1192, supra note 185, art 13.1.

215 Ibid. and who mostly use their land for subsistence purposes. It also directly disadvantages Communities if they chose not to cultivate certain tracts of land for conservation or other reasons. Most importantly, the preclusion of equitable compensation and non-economic valuations flies in the face of the jurisprudence of Peru's Constitutional Court and the Inter-American Court, which have both directly prohibited a purely economic approach to compensating Indigenous peoples for limitations or losses of property interests. ${ }^{216}$ In this context, the Negritos case stands to make an important contribution by presenting the court with the opportunity to analyze the right to equitable benefit in a well-documented factual matrix.

\subsubsection{Legal Remedies for Dispossession}

The claims made in the Negritos action ultimately require inquiry into the nature of the remedies available in an amparo proceeding in response to a dispossession claim such as that of the Negritos Community. The question of remedy is of major constitutional significance given the lack of jurisprudence in this area in Peru. It critically goes to the heart of law's potential as an instrument of justice in these circumstances. Especially given the significance of the procedural, substantive and practical obstacles to the Negritos claim, it is important to be clear about what is at stake and what might be accomplished by the Community's decision to resort to domestic courts against the odds. In this light, questions of remedies in the context of the Negritos claim allow for an important reflection on the possibilities and limitations that shape law's ability to redress Indigenous dispossession in the global economy.

In its written submissions, the Negritos Community must request action from the court (petitorio) on the basis of the facts and allegations presented in its case. Section B.1 of this paper explained that the remedial focus of Peru's amparo cause of action is on the protection and restoration of constitutional rights. As such, the Procedural Code neither mandates nor prohibits a monetary damages award to the claimant as compensation for violations. Rather, it empowers the Court to issue a declaration ordering the cessation of the offending action and the restoration of the claimant to its original position prior to the violation. The amparo process is

216 See supra notes 208 through 213. 
restorative in that the objective is "to restore the enjoyment of the plaintiff's injured right, reestablishing the situation existing when the right was harmed, by eliminating or suspending, if necessary, the detrimental act or fact." ${ }^{217}$ To this end, the Court may also order the defendant to perform a positive action in the case of proven omissions.

These are the statutory parameters that shape the nature of the remedies that the Negritos Community may request if the Constitutional Court finds in its favor on the merits of its case. Within this framework, the Negritos legal team fashioned four specific remedies that attempt to redress the injustice of the Community's dispossession in terms that fit the scope of the court's remedial power in an amparo action. These proposed remedies reflect a preliminary effort to explore the question of what might be required, practically speaking, in order to take the Negritos Community's justice claims and its right to remedy seriously. Given the Peruvian courts' limited consideration of Indigenous property rights to date, there does not appear to be any domestic case law directly on point. As such, this discussion of remedies refers to relevant Peruvian commentary as well as statements of international human rights bodies.

The first available remedy would be a declaration that the Ministry of Energy and Mining and Yanacocha Mine violated the Negrtios Community's rights (as described above) and failed to fulfil their obligations to the Community under the Peruvian Constitution and international law. This first step would form the basis for the second remedy, namely a declaration that the administrative decisions that purported to eliminate or diminish the Community's communal property rights and legal existence are null and void. This includes the Ministry's approval of the expropriation and mining easement.

Building on these first two remedies, as a third step, the court could restore the Negritos Community to its original position before the violations by declaring that it remains a legal person and rightful property owner of the Reserve Area (Llagaden), the expropriated area (Pampa Larga) and the area subjected to a mining easement in favor of Yanacocha. This third order could include recognition of the Community's right to participate in the benefits of the mining activity taking place on its land and to be equitably indemnified for the damage it has suffered due to past violations of it proper-

217 Brewer-Carías, supra note 89 at 279. ty rights and the illegal occupation of its property since the early 1990s for the purposes of mining activity. ${ }^{218}$

Finally, to secure the ongoing protection of the Negritos Community's rights in light of Yanacocha's occupation of its land, the court could add a fourth order requiring the company to negotiate an agreement with the Community. Such an agreement would govern the ter$\mathrm{ms}$ of the co-existence of the mining company and the Community in light of the Community's rightful ownership of the land upon which the company conducts some of its key operations. ${ }^{219}$ The court should specify that the negotiation of this agreement must be conducted in accordance with the principles of constitutional and international law that define the Community's right to equitable compensation and equitable benefit in return for the loss of its land to mining activity.

To ensure that the company commits to such negotiations, the court could impose a fine or penalty if the company refuses to comply. ${ }^{220}$ However, it could also take a more proactive approach, by ordering the suspension of all mining activities that impact the Community's property interests until such an agreement is reached. ${ }^{221}$ A proactive approach may be important in light of the severe nature of the rights violations and the extraordinary power imbalance between the parties. It would incentivize Yanacocha to take its negotiations with the

218 Citing a report of the Peruvian national Ombudsmen, Sulca Huamaní also concludes that mining operations, even when authorized by the Ministry of Mining, are illegal if they have not met the constitutional standard of free, prior and informed consent or consultation, as the case may be: Daniyar Sulca Huamaní, "Acceso a las tierras comunales y le conflicto sociambiental: el Caso Majaz" (2008) Palestra del Tribunal Constitucional: Revista de Doctrina y Jurisprudencia 3(9) 135 at 145 . Also see supra note 202.

219 The Community may decide to negotiate an agreement to govern present day operations given that the mine is already established and its impacts can only be mitigated. The Peruvian State could of course elect to re-expropriate the Community's property but this would require conformity with the general rules that govern expropriation in addition to due regard for the Community's status as a Campesino property holder under Peruvian Constitutional and international law.

220 Constitutional Procedural Code, art 22.

221 There is at least one example of an international human rights body ordering the temporary suspension of a foreign-owned mine in response to a petition brought by Indigenous communities in Guatemala alleging rights violations, including property rights violations: Inter-American Commission on Human Rights, PM 260-07 "Communities of the Maya People (Sipakepense and Mam) of the Sipacapa and San Miguel Ixtahuacan Municipalities in the Department of San Marcos, Guatemala" (May 20, 2010 revised December 7, 2011), online: http://www.oas.org/en/iachr/decisions/precautionary.asp under 2010, PM 260-07. 
Community seriously and reach an agreement, thereby protecting the Community's right to property and equitable compensation. Of course, if it is difficult to reach an agreement expeditiously, at the Community's discretion the suspension of mining operations could be lifted by way of an interim agreement predicated on the consolidation of a longer-term agreement.

These proposed remedies are structured to acknowledge that, while the amparo is a public law rights-protecting cause of action, some of the Negritos Community's specific rights claims have distributive consequences. In particular, this refers to the right to equitable compensation for damage to its property and to an equitably share of the profits generated by resource extraction. The legal remedies described above address this through a combination of orders that recognize rights, restore rights and require the company to do the same, including by applying economic pressure on the company through a suspension order.

This discussion of remedies makes apparent the fact that, in problematizing the Negritos story of dispossession by raising rights claims rooted in constitutional and international human rights law, the Negritos case taps into deeper questions regarding judicial remedies for past wrongs. More specifically, in fashioning a remedy for dispossession, courts are often forced to address a material conflict between rights rooted in public law, due in this case to the claimant's special status as a Campesino Community, and rights rooted in private law, acquired here by the mining company through the law of contract and property. ${ }^{222}$ In this context, Peruvian constitutional experts have advocated for the principle that private law rights must give way to constitutional rights where there is a conflict. ${ }^{223}$ Statements from international human rights bodies have similarly concluded that the state should suspend a company's private rights to exploit a natural resource where its operations have been approved and undertaken without fully respecting

222 While contract and property rights enjoy constitutional protection in Peru, they nonetheless originate in private law: see Political Constitution of Peru, 1993, arts 62, 70. The constitutional right to property in Peru is limited by the state's power to expropriate property for reasons of national security or public necessity.

223 Roger Arturo Merino Acuña, "La Tutela Constitucional de la Autonomía Contractual. El Contracto Entre Poder Público y Poder Privado" in El Derecho Civil Patrimonial y Derecho Constitucional (Gaceta Jurídica, 2009) 43; Roger Arturo Merino Acuña, "Legitimando el Abuso en el Contrato: El Pleno Casatorio Sobre Transacción Extrajudicial y los Contratos Contaminados" (2010) Actualidad Civil y Procesal Civil, Normas Legales 221. the rights of affected Indigenous communities. ${ }^{224}$ Even those who argue that private rights should be insulated from public law remedies for historic injustice nonetheless qualify their argument to those cases where the private rights-holders are "morally innocent", having acquired their rights many years after the original violations. ${ }^{225}$ Undoubtedly where the private rights-holder is also the original rights violator, as alleged in the Negritos Community's action against Yanacocha, this reasoning should not apply.

\section{Conclusion: Dispossession Research and Law Reform Agenda}

This case study told the story of how one domestic legal system in Latin America responded to an Indigenous dispossession claim that fundamentally challenges the legal arrangements underpinning the operations of a large and profitable foreign-owned gold mine. In conclusion, I will summarize the practical consequences of this study for those who seek to continue the work of studying and problematizing Indigenous dispossession in the global economy. This includes by advancing rights claims in domestic and international legal fora in order to support Indigenous communities confronted with unwanted models of resource extraction. In this section, I outline this study's two most significant findings, along with their potential consequences for national and international law reform and future comparative research. The first set of findings relate to the study and problematization of dispossession using human rights law. The second set speak to the litigation of dispossession in domestic and international courts. I

224 In 2010, the Committee of Experts on the Application of Conventions and Recommendations (CEACR) of the International Labour Organization (ILO) recommended that the Peruvian State "suspend the exploration and exploitation of natural resources which are affecting peoples covered by the Convention until such time as the participation and consultation of the peoples concerned is ensured through their representative institutions in a climate of full respect and trust, in accordance with Articles 6, 7 and 15 of the Convention", see: ILO, Committee of Experts on the Application of Conventions and Recommendations, Report of the Committee of Experts on the Application of Conventions and Recommendations (Report III, Part 1A), International Labour Conference, 99 ${ }^{\text {th }}$ Session, 2010 (ILO: 2010) at 784 .

225 One example is Jeremy Waldron concept of supersession: Burke A. Hendrix, "Historical Injustice, Rawlsian Egalitarianism, and Political Contestation" (2014) 27 Canadian Journal of Law \& Jurisprudence 73 at 74 . 
will describe each area in turn.

First, this paper demonstrates the strategic value of accumulating a critical mass of empirically informed systematic studies of the legal processes of Indigenous dispossession in the global economy. In the preceding pages, I relayed the story of the Negritos Community's dispossession and resistance, making an effort to tell this story in its larger social, legal, economic and political context. I also analyzed this story systematically in order to describe the "dynamics of dispossession". While this description is rooted in the Negritos Community's experience, it has the potential to contribute to further comparative study and theorizing of dispossession in the global economy. Although every Indigenous community's dispossession story has its own specificities, systematic and comparative studies may reveal patterns. More studies are needed of the mechanics of how legal processes facilitate, maintain and enforce the dispossession of local communities in the global economy and a comparative review of existing studies may be in order. ${ }^{226}$

Not only can this mode of inquiry be useful for specific communities, studies of this kind can present a powerful challenge to the contemporary model of global resource extraction, revealing the extent to whi$\mathrm{ch}$ it is predicated on relations of dispossession. The strength of communities' efforts to challenge the ethics and legality of the relations that underlie global resource extraction will depend in part on the quality of the evidence behind each dispossession story. Uncovering (and interrogating) a company's official claim to legality is a critical starting point.

This paper also described how the Negritos legal team drew on constitutional and international human rights law to develop a legal framework for problematizing the Negritos Community's dispossession. It depicts how the expansion of Indigenous rights principles in international law complements existing constitutional frameworks and jurisprudence in Peru to create a relatively robust set of standards and rights for problematizing dispossession and making a claim for remedy. These principles, enforceable in the jurisdiction, include the right to communal property, the right to free, prior and informed consultation and in some cases consent, the right to legal personhood, and the right to bene-

226 See Anaya, supra note 3; Engle, supra note 71; Rodríguez-Garavito \& Rodríguez-Franco, supra note 11; Parmar, supra note 11. fit equitably from resource extraction activities. Most importantly from the perspective of Negritos Community members, these principles speak to their lived experience of dispossession and they offer a language for challenging their material loss of property and legal personhood, as well as their alleged consent to these processes. Thus, at least at the level of principle, the Negritos experience suggests that human rights law can be a useful frame for translating dispossession concerns into legal and political claims.

Despite this, the state has failed to respond to the Negritos Community's claims and the domestic courts have become the Community's last resort. This paper tells the story of how the Negritos Community has attempted to give practical effect to its Campesino Community rights. This provides an important opportunity to examine the available causes of action that might channel dispossession claims to local (and international) courts. While much is known about the expansion of Indigenous peoples' substantive rights internationally, much less is known about how these rights are operationalized in domestic legal systems. As the Negritos Community discovered, Peru's domestic legal system offers a single cause of action, the amparo action, for presenting a claim to local courts alleging violations of constitutional Campesino rights and international human rights law.

Rights are only meaningful if processes and mechanisms exist whereby communities can advance their substantive claims before legal decision makers. In the process of litigating its case, the Negritos Community encountered multiple hurdles in the courtroom. Among these, the limitation period has emerged as the most significant procedural obstacle. To date, domestic courts in the Negritos case have ignored other possible approaches to the limitation period requirement, opting for an interpretation that would have required the Community to bring its legal claim within sixty days of purportedly signing the documents that transferred its land to the company. I have argued that the courts' interpretation of the limitation period requirement in the Negritos case is doctrinally unnecessary in that it was open to the court to conceptualize the impugned rights violations as ongoing actions or omissions. Perhaps more importantly, I have argued that if the court decides to draw conclusions with respect to an Indigenous claimant's knowledge and capacity at the admissibility phase of a dispossession claim, it must consider the- 
se concepts in context and in light of Indigenous rights case law. To do otherwise is problematic from an equitable perspective because it ignores the power dynamics that characterized the processes that lead to the Community's dispossession. To date, the courts in the Negritos case have been unwilling to substantively consider the factors that impacted the Community's knowledge and capacity to bring its claim in a timely fashion.

Rather, the courts in the Negritos case have ultimately relied (at least to date) on the same formalist, superficial view of consent that Yanacocha put forward in its submissions. Thus, a certain irony emerges. The Community is attempting to access the court in order to assert a rights framework that includes the right to free and informed consultation, and in some cases, consent. The facts of the case provide strong evidence suggesting that the signatures procured on the documents in question fall far short of meeting the free and informed standard being developed in international law and in Peruvian domestic law. The irony is that the Community is precluded from a substantive consideration of its consent-related allegations due to the operation of a formalist notion of consent in the limitation period analysis at the admissibility stage.

This observation lays the groundwork for this paper's second major finding. The expansion of Indigenous rights frameworks in both domestic and international law is undoubtedly important and, as described above, these statements of principle seem capable of effectively problematizing relations of dispossession. However, this expansion of substantive rights recognition has not been accompanied by a parallel concern for the development of appropriate and accessible judicial procedures and legal remedies. Communities' legal claims are successful not only because they have good facts and are decided with robust substantive rights frameworks. Crucially, they must also be able to package themselves into a recognizable domestic cause of action and navigate the associated procedural requirements. Access to justice is of course as contingent on appropriate procedures as it is on rights statements and enforcement. Arguably international and domestic lawmakers have been insufficiently attentive to the procedural aspects of the assertion of Indigenous and Campesino rights, and particularly property rights, in domestic courts. This observation applies in particular to contexts where the claims relate to past violations associated with established projects.
In Peru, despite the existence of promising statements of law, there is no specific constitutional procedure for the litigation of Campesino and Indigenous rights claims. When the Negritos Community attempted to bring its rights claim using the only cause of action that ostensibly applied, the associated procedural rules proved susceptible to the re-introduction of formalist concepts of consent. Thus, the rules of procedure themselves have become a new site of political and legal struggle. This suggests that appropriate public law mechanisms, procedures and principles must be developed to prevent courts from dismissing Indigenous rights claims at the procedural phase of legal proceedings on the basis of formalistic notions of consent. More research is needed to identify whether or not substantive Indigenous rights frameworks and remedies are similarly inaccessible in other domestic legal systems in the Americas. There may be good reason to believe that this issue is systemic given that the Peruvian amparo as a cause of action is similar to amparo proceedings in other countries across Latin America. ${ }^{227}$ Law reform may be needed to design new mechanisms, or to make available mechanisms more accessible and responsive to the reality of Indigenous claims, especially claims of past rights violations. If this does not happen, the Negritos experience teaches that existing domestic rights protection mechanisms will work to simply reinforce the dynamics of power and exclusion that give rise to rights violations.

Importantly, this Indigenous rights-based critique of domestic procedure and access to justice in Peru has its international counterpart with international consequences. This paper has described how the Negritos case unfolded in parallel with the emergence, at the turn of the millennium, of a body of inter-American jurisprudence that acknowledges Indigenous rights. However, these rights might only be claimed before the Inter-American Commission or Court in accordance with certain procedural requirements. Perhaps most significant is the long-standing exhaustion of remedies requirement: all claimants must exhaust available remedies in their domestic legal system, albeit with some exceptions. ${ }^{228}$ Thus, the expansion of Indigenous rights

227 See generally Brewer-Carías' comparative study of the amparo proceedings across numerous Latin American countries: supra note 89.

228 Rules of Procedure of the Inter-American Commission on Human Rights, art 31(1). The exceptions to the exhaustion of remedy requirement are: (i) the domestic legislation does not afford due pro- 
recognition in the inter-American system has not been accompanied by, at least on its face, any changes to the procedural requirements that Indigenous groups must meet in order to operationalize these rights.

Yet the Negritos case study reveals that an ostensible domestic cause of action may in practice include procedural requirements that are interpreted to create an insurmountable obstacle for Indigenous dispossession claims. The Negritos example is important because it documents how a community can become caught in a web of procedural requirements that threaten to effectively frustrate its capacity to assert its substantive rights claims before any court of law, either domestically or internationally. There is potentially a kind of misalignment between inter-American procedures and statements of Indigenous rights on one hand, and on the other, the complex domestic legal and political terrain that Campesino and Indigenous communities must navigate in an effort to simply identify a cause of action and convince a court to admit their claim and consider it on the merits. Due to the exhaustion of remedies requirement, where an ostensible cause of action exits these domestic efforts are a necessary prerequisite, even if they are ultimately fruitless, before a community may appeal to an international human rights body, like the Inter-American Commission.

This points to a potential area of future public international law research focused on the admissibility decisions of the Inter-American Commission in response to Indigenous rights related petitions. If the domestic mechanisms available for actualizing Indigenous rights in the region are systematically and seriously deficient, more research is needed to identify how this reality is informing, or should inform, admissibility rules at the inter-American level. For example, how has the Inter-American Commission applied the exhaustion of remedies requirement (and its exceptions) to petitions presented by Indigenous communities in the Americas? Can a systematic pattern of deficient local remedies be observed across the petitions presented to date? If so, how should the Commission respond in its admissibility determinations? Are specialized admissibility considerations or rules warranted for Indigenous rights pe-

cess of law [art 31(2)(a)]; (ii) the party alleging violation has been denied access to the remedies under domestic law or has been prevented from exhausting them [art 31(2)(b)]; (iii) there has been unwarranted delay in rendering a final judgment under the aforementioned remedies [art 31(2)(c)]. titions? Should the Commission develop substantive principles to inform debate over the domestic causes of action and procedural rules that would ensure Indigenous communities meaningful access to their local courts?

As a stand-alone case study, the Negritos case cannot answer these questions; rather it can only help to pose them. While a single case study will always have inherent limitations, one of the strengths of the Negritos study is the depth and detail of information compiled over more than a decade. As such, it offers a unique window into the interaction between the domestic legal system, a Campesino Community, and a transnational mining company, where enforceable Constitutional rights and international human rights are at stake. It tells us that the incorporation of international public law, and specifically rights related to Indigenous communal property, into the domestic sphere, can trigger important access to justice problems due to the absence of appropriate procedural rules. More detailed empirical and longitudinal studies of other cases and contexts are needed to identify the extent to which these problems extend beyond Peru. ${ }^{229}$ In this work, it would be important to distinguish between the proactive use of the courts to resist the imposition of a project, and recourse to the courts in order to remedy past violations and dispossession.

The Negritos case study depicts a particular form of legal practice in contemporary conditions of economic globalization. At the broadest level, it represents an attempt by activists to use international human rights concepts to address issues of global economic justice. This activism must be informed by a conception of the nature of the problem it seeks to address and of course such an exercise is always contentious and complex..$^{230}$

229 Although there are a number of studies of Indigenous and other communities in Latin American using domestic courts to address concerns related to resource extraction, none of these offer the detail and depth described here. Moreover, many of these depict examples of communities resorting to the courts in order to proactively prevent a proposed mining project, rather than examples of efforts to remedy past violations: see generally supra note 10 .

230 Karen Engle published an extensive study of the struggle within the Indigenous rights movement over international law strategies for addressing "the problem". She sees the history of the movement primarily in terms of a struggle between framing the problem as the right to self-determination and the right to culture. While she understands the right to property as a derivative of the right to culture, she also observes how the property frame has the potential to advance certain elements of the self-determination 
In the amparo action, the Negritos Community's concerns were primarily framed as violations of communal property rights. This was in part due to the nature of the available documentary evidence. Perhaps with other forms of evidence, other legal frames could have been adopted, such as cultural rights or environmental rights. However, as stated above, the Negritos experience suggests that there is significant value in framing cases of this kind as struggles over property in particular. The property lens reveals the material, corporeal, aspect of foreign mining activities, where land is taken, transferred, occupied and exploited in the midst of people, communities and livelihoods. In the Negritos case, the property lens was powerful because it allowed the Community to challenge the very legality and the legitimacy of Yanacocha's mining operations, and arguably by extension, the global status quo of transnational resource extraction as described in this paper's introduction.

In the first paragraphs of this conclusion I referred to the importance of studying dispossession in the global economy and the promise that human rights law seems to hold as one problematizing frame for this endeavor. However, at the same time, the procedural obstacles in the Negritos case point to a potential weakness or irony of property claims as a human rights claims. In a market economy, property is traded through contracts, usually in exchange for money. This exchange of course is predicated on some notion of consent. Legitimate property transfers must be consensual. Where they are not consensual, they must be justified in the national public interest, as in the case of expropriation. ${ }^{231}$ The Negritos study reveals how slippery the notion of consent can be, not only in relation to substantive rights matters, but also at the procedural stage of legal proceedings. The case law and literature cited in Part B.3 of this paper emphasize that for Indigenous communities the question of consent is never merely a matter of formal information transfer, but can only be understood in a cultural, social, historical context and with attention to different ways of knowing. In the Negritos case, to date the courts, the state and the company have all accepted the idea that, in exchange for practically nothing, the Community consented to the elimination of all of its communal land interests, any other community right or

agenda, namely control over land and resources: see Engle, supra note 71 .

231 Political Constitution of Peru, 1993, art 70; American Convention, art 21(2). interest, and its very existence in law.

In one view, the Negritos case study is perhaps an extreme example due to the time period of the property acquisitions in question. In today's Latin America, arguably few communities occupy a position comparable to that of the Negritos Community in the early 90s: most have at least heard about the pitfalls of large scale foreign mining and many have relatively greater access to information and supportive civil society actors. However, these changes are a matter of degree. Communities in Latin America and foreign resource companies continue to encounter each other in the context of vastly unequal power relations. The widespread resource related social conflicts described in this paper's introduction reveal that, politically speaking, the terms and meaning of consent remain very much unsettled, notwithstanding the growing international Indigenous rights case law.

In this light, many of the deeper questions in the Negritos case maintain their relevance. Of particular importance is the question of just how free consent can be under current conditions, not only of unequal power relations, but where the rules of property and contract that ultimately govern these relations remain squarely in the political economy of neoliberal capitalism. Even where Communities are relatively better resourced and equipped to negotiate with companies, it can be difficult to escape a model that pushes toward the commodification of rights, exchanging monetary compensation in return for permission to exploit resources. ${ }^{232}$ One important commonality between the Negritos case and the circumstances of present day resource conflicts is that few communities have real choices and control over outcomes when it comes to proposed resource projects and the legal frameworks that determine who has ultimate decision making power. ${ }^{233}$

232 See for example: Ibironke Odumosu-Ayanu, "Foreign Direct Investment Catalysts in West Africa: Interactions with Local Content Law and Industry-Community Agreements" (2012) 35 North Carolina Central Law Review 65; Colin Samson, "Canada's Strategy of Dispossession: Aboriginal Land and Rights Cessions in Comprehensive Land Claims" (2016) 31(1) Canadian Journal of Law and Society 87.

233 For an Indigenous rights critique of the dominant global resource extraction model, see Anaya, supra note 3. Popular referenda in Latin America represent one attempt to establish and advocate for another source of law and decision making power. For just two of many examples see: McGee, supra note 10; Shin Imai et al, supra note 10. This is not just a developing country issue. Indigenous controlled project assessments and decision-making processes that 
Property has come to occupy this ambivalent space, as a foundational right in Indigenous rights frameworks as well as in the neoliberal economic system. This paper previously described how, in Peru and in many other countries in the region and around the world, Indigenous rights and neoliberal legal (foreign investment) projects have unfolded almost in parallel. The Negritos case study reveals that the slippage between these two worlds often occurs in the context of the struggle over the meaning of consent, crystalized in this study in arguments over how to apply the limitation period. While this paper has advocated for progressive interpretations of limitation period laws, or other Indigenous appropriate procedural reforms, in the background we are always confronted with the possibility that in order to approximate global social justice, we must address and transform the system of property that generates the very injustices we seek to redress. ${ }^{234}$ This raises questions about whether or not, or under what conditions, human rights, and Indigenous property rights more specifically, can be liberating, or conversely, whether or not even the most robust procedural reforms will nonetheless somehow fail to convert law into an instrument of justice for the dispossessed.

In the meantime, while we contemplate how we might change the legal structures of the global economic system, or while we strategize legal responses to the global governance gap described in this paper's introduction, we must bear in mind one final lesson from this study. As we reach to global debates and work toward structural changes, we must nonetheless remain grounded in the struggles of the dispossessed. This involves thinking critically, conscientiously and consulting as we

situate themselves outside of the state's jurisdiction are also growing in Canada. For two examples see: Stk'emlupsemc te Secwepemc Nation, Media Release, "Stk'emlupsemc te Secwepemc Nation (SSN) says No to KGHM Ajax Mine and Yes to Healthy People and Environment" (4 March 2017), online: http://miningwatch. $\mathrm{ca} /$ sites/default/files/2017-03-ssnajaxdecisionrelease_0.pdf; TsleilWaututh Nation, Media Legal Backgrounder, "Tsleil-Waututh Nation (TWN) Legal Challenge to the National Energy Board's (NEB) review of Kinder Morgan Trans Mountain Pipeline and Tanker Project" (2 May 2014), online: http://www.twnation.ca/en/ /media/ Files/Press\%20Releases/TWN\%20-\%20NEB\%20-\%20Legal $\% 20$ Backgrounder\%20-\%20CLEAN_VAN_LAW-1461360-v4.ashx.

234 Engle, supra note 71 at 274-8; David Kennedy, "The international human rights movement: part of the problem?" European Human Rights Law Review 3 (2001) 245; David Kennedy, "The International Human Rights Regime: Still Part of the Problem?" in Ole Windahl Pedersen, ed, Examining Critical Perspectives on Human Rights (Cambridge University Press, 2013) 19. craft legal frames for problematizing relations of dispossession. It requires using law to fight practices and ideologies that would treat the dispossessed as irrelevant, nonexistent, invisible, or deserving of their fate. At the same time, we must be realistic that even the most committed communities may become weak and divided after decades (or centuries) confronting relations of power and exploitation. And even when our efforts feel futile in the face of what we confront (delays, corruption, formalism), we must continue to support communities' demands that their local legal syste$\mathrm{ms}$ be efficient, fair, equitable and accessible. May we be creative and courageous in our pursuit of remedies, reparations and a new order of legal relations.

\section{References}

\section{International conventions $\&$ declarations}

American Convention on Human Rights, 1144 UNTS 123 (1969).

Convention concerning Indigenous and Tribal Peoples in Independent Countries, International

Labour Organization, Convention No 169, (1989).

Elaboration of an international legally binding instrument on transnational corporations and other business enterprises with respect to human rights, HRC Res, UNGAOR, 26th Sess, UN Doc A/HRC/26/L.22/Rev.1 (2014).

Indigenous and Tribal Populations Convention, International Labour Organization, Convention No 169 , (1957).

Rules of Procedure of the Inter-American Commission on Human Rights (2013).

United Nations Declaration on the Rights of Indigenous Peoples, UNGAOR, 62 Sess., Annex, Agenda Item 68 UN Doc. A/61/L.67 (2007).

\section{Peruvian legislation}

Administrative Resolution No 095-2004-P-TC, Normative Regulation of the Constitutional Tribunal (14 September 2004).

Comisión de Pueblos Andinos, Amazónicos y Afroperuanos, Ambiente y Ecología, Proyecto de Ley de Reforma de la Constitución, Título II, Capítulo VII "Derechos de los Pueblos Indígenas". 
Directive No 03-2012/MC, Ministry of Culture, Ministerial Resolution No 202-2012-MC (2012).

Law No 30327, Law for the promotion of investment for economic growth and sustainable development (2015).

Law No 30025, Law that facilitates the acquisition, expropriation and possession of real property for infrastructure works and declares the public need for the acquisition or expropriation of real property affected by the execution of diverse infrastructure works (2013).

Law No 29785, Law for the right of Indigenous and original peoples to prior consultation, recognized in Convention 169 of the International Labour Organization (2011).

Law No 29338, Hydro Resources Law (2009).

Law No 27446, National System of Environmental Impact Assessment Law (2009).

Law No 28736, Law for the protection of Indigenous and original peoples in a situation of isolation or initial contact (2006).

Law No 28611, General Law on the Environment (13 October 2005).

Law No 28237, Constitutional Procedural Code (2004).

Law No 27908, Rondas Campesinas Law (2003).

Law No 26821, Organic Law for the Sustainable Use of Natural Resources (1997).

Law No 28495, Law for the National Institute for the Development of Andean, Amazonean and AfroPeruvian Peoples (1995).

Law No 26505, Law for the Promotion of Private Investment in the Development of Economic Activities on the National Territory and on Campesino and Native Community Land (1995).

Law No 24656, Campesino Communities General Law (1987).

Law No 24657, Law for the Demarcation and Titling of the Communal Territories of the Campesino Communities (1987).

Law No 17716, Agrarian Reform Law (1969).

Legislative Decree No 295, Civil Code (2015).

Legislative Decree No 1192, Law for the acquisition and expropriation of real property, transfer of state real property, removal of interferences and other measures for the execution of infrastructure projects (2015).

Legislative Decree No 1210, Modification of the Tenth Final Complementary Disposition of Legislative Decree No 1192
(2015).

Legislative Decree No 662, Granting a Legally Stable Regime to Foreign Investors through the Recognition of Certain Guarantees (1991).

Legislative Decree No 674, Law for the Promotion of Private Investment in State Enterprises (1991).

Legislative Decree No 708, Law for the Promotion of Investments in the Mining Sector (1991).

Legislative Decree No 653, Law for the Promotion of Investment in the Agrarian Sector (1991).

Legislative Decree No 757, Legal Framework. for the Growth of Private Investment (1991).

Legislative Resolution No 26253, For the approval of "Convention 169 of the ILO on Indigenous and Tribal Peoples in Independent Countries" (1993).

Political Constitution of Peru, 1993.

Political Constitution of Peru, 1979.

Supreme Decree No 001-2015-EM, Provisions for mining procedures that encourage investment projects (2015).

Supreme Decree No 065-2005-PCM, Regulation of the National Institute for the Development of Andean, Amazonean and AfroPeruvian Peoples (2005).

Supreme Decree No 014-92-EM, General Mining Law (1992).

Supreme Decree No 004-92-TR, Regulation of Chapter VII - Economic Regime for the Campesino Communities General Law (1992).

Supreme Decree No 008-91-TR, Regulation of the Campesino Communities General Law (1991).

Supreme Decree No 37-70-AG, Campesino Communities Special Statute (1970).

\section{Jurisprudence}

\section{International jurisprudence}

Castañeda Gutman v. Mexico, (2008) Preliminary Objections, Merits, Reparations, and Costs, Judgment, InterAm Ct HR (ser C) No 184.

Comunidad Garifuna de Punta Piedra v Honduras, Preliminary Objections, Merits, Reparations, and Costs, Judg- 
ment, Inter-Am Ct HR (ser C) No 304 (8 October 2015).

Comunidad Garifuna de Triunfo de la Cruzv Honduras, Merits, Reparations, and Costs, Judgment, InterAm Ct HR (ser C) No 305 (8 October 2015).

Communities of the Sipakepense and Mam Mayan People of the Municipalities of Sipacapa and San Miguel Ixtabuacan v Guatemala, Report on Admissibility, Inter-Am Comm'n HR, Report No. 20/14 Petition 1566-07 (3 April 2014).

Inter-American Commission on Human Rights, PM 260-07 "Communities of the Maya People (Sipakepense and Mam) of the Sipacapa and San Miguel Ixtahuacan Municipalities in the Department of San Marcos, Guatemala" (May 20, 2010 revised December 7, 2011), online: http://www.oas.org/en/iachr/decisions/precautionary.asp under 2010, PM 260-07.

Inter-American Commission on Human Rights, Resolution 9/2014, Lideres y Lideresas de Comunidades Campesinas y Rondas Campesinas de Cajamarca Respecto de la República de Perú, Precautionary Measure No 452-11 (2014), online: http://www.oas.org/es/cidh/decisiones/pdf/2014/ MC452-11-ES.pdf.

Kaliña and Lokono Peoples v Suriname, Merits, Reparations, and Costs, Judgment, Inter-Am Ct HR (ser C) No 309 (25 November 2015).

Maya Indigenous Communities of the Toledo District v Beli$z e$, Merits Report, Case 12.053, Inter-Am Comm'n HR, Report No 40/04 (2004).

Mayagna (Sumo) Awas Tingni Cmty v Nicaragua, Merits, Reparations, and Costs, Judgment, Inter-Am. Ct. H.R. (ser. C) No. 79 (31 August 2001).

Moiwana Cmty v Suriname, Preliminary Objections, Merits, Reparations, and Costs, Judgment, Inter-Am Ct HR (ser C) No 124 (June 15, 2005).

Pueblo Indigena Kichwa de Sarayaku v Ecuador, Merits and Reparations, Judgment, Inter-Am Ct HR (ser C) No 245 (27 June 2012).

Saramaka People v Suriname, Preliminary Objections, Merits, Reparations, and Costs, Judgment, Inter-Am Ct HR (ser C) No 172 (28 November 2007).

Saramaka People $v$ Suriname, Interpretation of the Judgement on Preliminary Objections, Merits, Reparations, and Costs, Judgment, Inter-Am Ct HR (ser C) No 185 (12 August 2008).
Sawhoyamaxa Indigenous Cmty v Paraguay, Merits, Reparations, and Costs, Judgment, Inter-Am Ct HR (ser C) No 146 (29 March 2006).

Xákmok Kásek. Indigenous Cmty v Paraguay, Merits, Reparations, and Costs, Judgment, Inter-Am Ct HR (ser C) No 214 (24 August 2010).

Yakye Axa Indigenous Cmty v Paraguay, Merits, Reparations, and Costs, Judgment, Inter-Am Ct HR (ser C) No 125 (17 June 2005).

\section{Domestic jurisprudence}

British Columbia Court of Appeal, Garcia v Taboe Resources Inc, 2017 BCCA 39.

Constitutional Court of Peru, STC No 01931-2013-HC (30 July 2015).

Constitutional Court of Peru, STC No 03673-2013PA/TC (11 December 2014).

Constitutional Court of Peru, STC No 00987-2014PA/TC (6 August 2014).

Constitutional Court of Peru, STC No 01126-2011HC/TC (11 September 2012).

Constitutional Court of Peru, STC No 00024-2009-PI/ TC (26 July 2011).

Constitutional Court of Peru, STC No 00025-2009-PI/ TC (17 March 2011).

Constitutional Court of Peru, STC No 05427-2009PC/TC (30 June 2010).

Constitutional Court of Peru, STC No 0022-2009-PI/ TC (9 June 2010).

Constitutional Court of Peru, STC No 04611-2007PA/TC (9 April 2010).

Constitutional Court of Peru, STC No 00027-2009-PI/ TC (5 January 2010).

Constitutional Court of Peru, STC No 06316-2008PA/TC (11 November 2009 and clarification decision 24 August 2010).

Constitutional Court of Peru, STC No 03215-2008PA/TC (19 August 2009).

Constitutional Court of Peru, STC No 02939-2008PA/TC (13 May 2009).

Constitutional Court of Peru, STC No 00014-2007-PI/ 
TC (4 May 2009).

Constitutional Court of Peru, STC No 05614-2007PA/TC (20 March 2009).

Constitutional Court of Peru, STC No 03343-2007PA/TA (19 February 2009).

Constitutional Court of Peru, STC No 4762-2007-PA/ TC (22 September 2008).

Constitutional Court of Peru, STC No 09874-2006PA/TC (20 December 2007).

Constitutional Court of Peru, STC No 00027-2006-PI/ TC (21 November 2007).

Constitutional Court of Peru, STC No 3081-2007-PA/ TC (9 November 2007).

Constitutional Court of Peru, STC No 00007-2007-PI/ TC (19 June 2007).

Constitutional Court of Peru, STC No 1776-200-AA/ TC (26 January 2007).

Constitutional Court of Peru, STC No 7435-2006-PC/ TC (13 November 2006).

Constitutional Court of Peru, STC No 0025-2005-PI/ TC (25 April 2006).

Constitutional Court of Peru, STC No 4587-2004-AA/ TC (29 November 2005).

Constitutional Court of Peru, STC No 00020-2005-PI/ TC and 00021-2005-PI/TC (27 September 2005).

Constitutional Court of Peru, STC No 2574-2005-AA/ TC (27 May 2005).

Constitutional Court of Peru, STC No 00042-2004-AI/ TC (13 April 2005).

Constitutional Court of Peru, STC No 0017-2003-AI/ TC (16 March 2004).

Constitutional Court of Peru, STC No 3283-2003-AA/ TC (15 June 2004).

Constitutional Court of Peru, STC No 0008-2003-AI/ TC (11 November 2003).

First Specialized Civil Court of Cajamarca, Exp No 00315-2011-1-0601-JR-CI-01, Resolution No 25 (16 June 2014).

Specialized Civil Appeal Court of Cajamarca, Exp No 00315-2011-1-0601-JR-CI-01, Resolution No 1 (19 March 2013).
Specialized Civil Appeal Court of Cajamarca, Exp No 00315-2011-1-0601-JR-CI-01, Resolution No 2 (14 December 2012).

Superior Court of Justice of Cajamarca, Permanent Civil Appeal Court, File 00315-2011-0-0601-JR-CI-01, Resolution No 33 (5 May 2014).

Supreme Court of Justice of the Republic, Criminal Investigations Section, Exp No 13-03 (11 December 2007).

Supreme Court of Justice of the Republic, Special Criminal Appeals Section, Exp No 10-2001 / Acumulado No 45-2003 AV (7 April 2009).

Supreme Court of Justice of the Republic, Special Criminal Appeals Section, Exp No AV-33-2003 (30 September 2009).

Supreme Court of Justice of the Republic, Special Criminal Appeals Section, Exp No AV 19-2001 (7 April 2009).

Supreme Court of Justice of the Republic, Special Criminal Appeals Section, Exp No AV-23-2001 (20 July 2009).

\section{Secondary materials: book chapters \& monographs}

Abad Yupanqui, Samuel. El Proceso Constitucional de Amparo (Gaceta Jurídica: Lima, 2008).

Alegrett, Raúl. "Past and present land reform in Latin America" in P. Groppo, ed, Land Reform: Land Settlement and Cooperatives (FAO, 2003/2) 112.

Alteri, Miguel \& Andrés Yurjevic, La agroecología y el desarrollo rural, sostenible en América Latina (Santiago de Chile: Economic Commission for Latin America and the Caribbean, 1992).

Barandiaran Dempwolf, Roberto \& José Antonio Nolasco Valenzuela. Jurisprudencia penal generada en el subsistema anticorrupción. Corrupción gubernamental, Vol 2 (Lima, Palestra: 2006).

Bury, J. "Neoliberalismo, minería y cambios rurales en Cajamarca" in A Bebbington, ed, Minería, Movimientos Sociales y Respuestas Campesinos (CEPES \& IEP, Lima 2007) 49.

Brewer-Carías, Allan R. Constitutional Protection of Human Rights in Latin America: A Comparative Study of Amparo Proceedings (Cambridge University Press, 2008). 
Brown, Stephen, ed. Struggling for Effectiveness: CID $A$ and Canadian Foreign Aid (McGill-Queen's University Press, 2012).

Castillo Castañeda, Pedro. El Derecho a la Tierra y los Acuerdos Internacionales: el Caso de Perú (Lima, CEPES \& International Land Coalition: 2009).

Cutler, A. Claire. "Private transnational governance and the crisis of global leadership" in Stephan Gill, ed, Global Crises and the Crisis of Global Leadership (Cambridge University Press, 2011).

Dashwood, Hevina S. The Rise of Global Corporate Social Responsibility: Mining and the Spread of Global Norms (Cambridge University Press, 2012).

Engle, Karen. The Elusive Promise of Indigenous Development: Rights, Culture, Strategy (Duke University Press, 2010).

Engler, Yves. The Black Book of Canadian Foreign Policy (Fernwood Publishing \& RED Publishing, 2009).

Gregor Barié, Cletus. Pueblos Indígenas y derechos constitucionales en América Latina: un panorama, 2d ed (La Paz, Bolivia: Génesis, 2003).

Griffiths, Tom. "Indigenous Peoples, Land Tenure, and Land Policy in Latin America" in P. Groppo, ed, Land Reform: Land Settlement and Cooperatives (FAO, 2004) 49.

Gordon, Todd \& Jeffery R Webber. Blood of Extraction: Canadian Imperialism in Latin America (Fernwood Publishing, 2016).

Haberle, Peter. El Estado Constitucional (Autonomous University of Mexico, 2003).

Hutchinson, Allan. "Looking for the Good Judge: Merit and Ideology" in Nadia Verrelli, ed, The Democratic Dilemma: Reforming Canada's Supreme Court (McGill-Queen's University Press, 2013) 99.

Kennedy, David. "The International Human Rights Regime: Still Part of the Problem?" in Ole Windahl Pedersen, ed, Examining Critical Perspectives on Human Rights (Cambridge University Press, 2013) 19.

Laos Fernández, Alejandro et al. Rondando por Nuestra Ley (Lima: Asociación Servicios Educativos Rurales, Red Interamericana para la Democracia, 2003).

Merino Acuña, Roger Arturo. "La Tutela Constitucional de la Autonomía Contractual. El Contracto Entre Poder Público y Poder Privado" in El Derecho Civil Patri- monial y Derecho Constitucional (Gaceta Jurídica, 2009) 43.

O'Diana Rocca, Richard André. Las limitaciones del sistema de dominio minero vigente en el Perú y las consecuencias negativas que genera a las comunidades campesinas: un estudio a partir del caso de la Comunidad Campesina San Adres de Negritos de Cajamarca, Thesis for the degree of Bachelor of Law, Faculty of Law, Pontifical Catholic University of Peru (Lima, 2014).

Odumosu-Ayanu, Ibironke. "Foreign Direct Investment Catalysts in West Africa: Interactions with Local Content Law and Industry-Community Agreements" (2012) 35 North Carolina Central Law Review 65.

Parmar, Pooja. Indigeneity and Legal Pluralism in India: Claims, Histories, Meanings (Cambridge University Press, 2015).

Peña Jumpa, Antonio. Justicia comunal en los Andes del Perú: El caso de Calabuyo (Lima: Pontificia Universidad Católica del Perú, Fondo Editorial, 1998).

Plant, R \& S Havlkof. Land Titling and Indigenous Peoples in Latin America (Inter-American Development Bank, Washington DC, 2001).

Quiroz, Alfonso. Historia de la corrupción en el Perú, translated by Javier Flores, Popular Collection Series No 5 (Lima: Institute for Peruvian Studies, 2014).

Quiroz, Alfonso. Corrupt Circles: A History of Unbound graft in Peru (Washington: Woodrow Wilson Center Press, 2008).

Rodríguez-Garavito Cesar \& Diana Rodríguez-Franco. Radical Deprivation on Trial: The Impact of Judicial Activism on Socioeconomic Rights in the Global South (Cambridge University Press, 2015).

Shamir, Ronen. "Corporate Social Responsibility: A Case of Hegemony and Counter-Hegemony" in Boaventura de Sousa Santos \& Cesar A. Rodriguez-Garavito, eds, Law and Globalization from Below: Towards a Cosmopolitan Legality (Cambridge University Press, 2005).

Simons, Penelope \& Audrey Macklin. The Governance Gap: Extractive Industries, Human Rights, and the Home State Advantage (New York: Routledge, 2014).

de Sousa Santos Boaventura \& César Rodríguez-Garavito, eds. Law and Globalization from Below. Towards a Cosmopolitan Legality (Cambridge: Cambridge University Press, 2005).

Van Harten, Gus. "Investment treaties as a constraining 
framework" in Shahrukh R Khan \& Jens Christiansen, eds, Towards New Developmentalism: Market as means rather than master (New York: Routledge, 2011) 154.

Van Harten, Gus. "Investment Treaty Arbitration and the Policy Implications for Capital-Importing States" in Diego Sánchez-Ancochea \& Kenneth C Shadlen, eds, The Political Economy of Hemispheric Integration (New York: Palgrave Macmillan, 2008) 83.

Webber, Jeremy. "The Meanings of Consent" in Jeremy Webber and Colin Macleod, eds, Between Consenting Peoples: Political Community and the Meaning of Consent (Vancouver: UBC Press, 2010) 3.

White, Lucie E. \& Jeremy Perelman. Stones of Hope: How African activists reclaim human rights to challenge global poverty (Stanford University Press, 2011).

Yrigoyen, Raquel. "El horizonte del constitucionalismo pluralista: del multiculturalismo a la decolonización" in César Rodríguez, ed, El Derecho en América Latina: Un mapa para el pensamiento jurídico del siglo XXI (Buenos Aires: Siglo XXI Editores, 2011) 139.

\section{Secondary materials: academic articles}

Bebbington, Anthony et al. "Mining and Social Movements: Struggles over Livelihood and Rural Territorial Development in the Andes" (2008) 36 World Development 2888.

Bebbington, Anthony \& Denise Humphreys Bebbington. "Actores y ambientalismos: Continuidades y cambios en los conflictos socio-ambientales en el Perú" (2009) 35 Iconos 117.

Cairo Roldán, Omar. "El panorama general del proceso de amparo en el Perú" 3(8) (2008) Palestra Tribunal Constitucional: Revista de doctrina y jurisprudencia 153.

del Castillo, Laureano. "Titulación de las Comunidades Campesinas: CEPES, ALLPA y la Problemática Comunal" (2003) 36 Debate Agrario 89.

------. "Propiedad Rural, Titulación de Tierras y Propiedad Comunal" (1997) 26 Debate Agrario 59.

Coumans, Catherine. "Alternative Accountability Mechanisms and Mining: The Problems of Effective Impunity, Human Rights, and Agency" (2010) 30 Canadian Journal of Development Studies 27.
Cronstedt, Claes \& Robert C Thompson. "A Proposal for an International Arbitration Tribunal on Business and Human Rights" (2016) 57 Online Symposium, Harvard International Law Journal 66, online: http://www. harvardilj.org/wp-content/uploads/Cronstedt-andThompson_0615.pdf.

Diez, Alejandro. "Interculturalidad y Comunidades: Propiedad Colectiva y Propiedad Individual" (2003) 36 Debate Agrario 71.

Eslava, Luis. "Corporate Social Responsibility \& Development: A Knot of Disempowerment" (2008) 2 (2) Oñati Journal of Emergent Socio-Legal Studies 43.

Espinosa-Saldaña Barrera, Eloy. "La "especial trascendencia constitucional" como causal para el rechazo liminar de recursos de agravio en el Perú" (2015) 8 Revista Peruana de Derecho Constitucional 41.

Flemmer, Riccarda \& Almut Schilling-Vacaflor. "Unfulfilled promises of the consultation approach: the limits to effective indigenous participation in Bolivia's and Peru's extractive industries" (2016) 37(1) Third World Quarterly.

Guzmán Salano, Natalia. "Struggle from the margins: Juridical processes and entanglements with the Peruvian state in the era of mega-mining" (2016) 3 The Extractive Industries and Society 416.

Harvey, David. 'The 'New' Imperialism: Accumulation by Dispossession" (2004) 40 Socialist Register 63.

Hendrix, Burke A. "Historical Injustice, Rawlsian Egalitarianism, and Political Contestation” (2014) 27 Canadian Journal of Law \& Jurisprudence 73.

Ingelson, Allan, Arturo Urzúa \& William Holden. "Mine Operator Liability for the Spill of an Independent Contractor in Peru” (2006) 24(1) J Energy Nat Resources L 53.

Imai, Shin et al. "Breaching Indigenous Law: Canadian Mining in Guatemala” (2007) 6(1) Indigenous L J 101.

Jaskoski, Maiah. "Environmental Licensing and Conflict in Peru's Mining Sector: A Path-Dependent Analysis" (2014) 64 World Development 873.

Kamphuis, Charis. "Canadian Mining Companies and Domestic Law Reform: A Critical Legal Account" (2012) German Law Journal 1456.

. "Foreign Investment and the Privatization of Coercion: A Case Study of the Forza Security 
Company in Peru" (2012) 37(2) Brooklyn Journal of International Law 529.

------. "Foreign Mining, Law and the Privatization of Property: A case study from Peru" (2012)

3:2 Journal of Human Rights and the Environment 217.

------. "Derecho y la Convergencia del Poder Público y el Poder Empresarial: La Desposesión Campesina y La Coerción Privatizada en el Perú" (2012) 15 Revista Latinoamericana de Derecho Social: Universidad Nacional Autónoma de México Instituto de Investigaciones Jurídicas 57.

Kennedy, David. "The international human rights movement: part of the problem?" European Human Rights Law Review 3 (2001) 245.

Kimerling, Judith. "Habitat as Human Rights: Indigenous Huaorani in the Amazon Rainforest, Oil and Ome Yasuni” (2016) 40 Vermont Law Review 445.

Landa Arroyo, César. "Límites y alcances de la 'especial transcendencia constitucional”' (2015) 8 Revista Peruana de Derecho Constitucional 89.

Li, Fabiana. "In Defense of Water: Modern Mining, Grassroots Movements, and Corporate Strategies in Peru" (2016) 21(1) The Journal of Latin American and Caribbean Anthropology 109.

-------. "Contested Equivalences: Controversies over water and mining in Peru and Chile" in John Wagner, ed, The Social Life of Water (Berghahn Books, 2013).

. "Relating Divergent Worlds: Mines, Aquifers and Sacred Mountains in Peru" (2013) 55 Anthropologica 399.

López, Emiliano \& Francisco Vértiz. "Extractivism, Transnational Capital, and Subaltern Struggles in Latin America" (2015) 42(5) Latin American Perspectives 152.

McCorquodale, Robert \& Penelope Simons. "Responsibility Beyond Borders: State Responsibility for Extraterritorial Violations by Corporations of International Human Rights Law” (2007) 70 Modern Law Review 598.

McGee, Brant. "The Community Referendum: Participatory Democracy and the Right to Free, Prior and Informed Consent to Development" (2009) 27 Berkeley J Intl L 570.

Merino Acuna, Roger. "The politics of extractive go- vernance: Indigenous peoples and socio-environmental conflicts" (2015) 2 The Extractive Industries and Society 85 .

"Prior Consultation: Law and the Challenges of the New Legal Indigenism in Peru" (2014) 4(1) Hendu 19.

"Legitimando el Abuso en el Contrato: El Pleno Casatorio Sobre Transacción Extrajudicial y los Contratos Contaminados" (2010) Actualidad Civil y Procesal Civil, Normas Legales 221.

Phillips, James S. "The rights of indigenous peoples under international law" (2015) 26(2) Global Bioethics 120.

Richard, Michelle. "Conflict in Latin America over Natural Resource Exploitation” (2013) 19 L \& Bus Rev Am 561.

Rodríguez-Garavito, César. "Ethnicity.gov: Global Governance, Indigenous Peoples, and the Right to Prior Consultation in Social Minefields" (2010) 18 Indiana Journal of Global Legal Studies 1.

Samson, Colin. "Canada's Strategy of Dispossession: Aboriginal Land and Rights Cessions in Comprehensive Land Claims" (2016) 31(1) Canadian Journal of Law and Society 87.

Seck, Sara L. "Canadian Mining Internationally and the UN Guiding Principles on Business and Human Rights" (2011) 49 Can YB Int'l Law 51.

"Home State Responsibility and Local Communities: The Case of Global Mining" (2008)

Yale Human Rights \& Development Law Journal 177.

Sieder, Rachel. “'Emancipation' or 'regulation'? Law, globalization and indigenous peoples' rights in post-war Guatemala" (2011) 40(2) Economy and Society 239.

------. "The judiciary and indigenous rights in Guatemala” (2007) 5(2) Int J Const L 211.

Simons, Penelope. “Canada's Enhanced CSR Strategy: Human Rights Due Diligence and Access to Justice for Victims of Extraterritorial Corporate Human Rights Abuses" (2015) 56 Canadian Business Law Journal 167. ------. "International law's invisible hand and the future of corporate accountability for violations of human rights" (2012) 3:1 Journal of Human Rights and the Environment. 
------. "Corporate Voluntarism and Human Rights: The Adequacy and Effectiveness of Voluntary

Self-Regulation Regimes" (2004) 59 Relations industrielles/ Industrial Relations 101. Sulca Huamaní, Daniyar. "Acceso a las tierras comunales y le conflicto sociambiental: el Caso Majaz" (2008) Palestra del Tribunal Constitucional: Revista de Doctrina y Jurisprudencia 3(9) 135.

Szablowski, David. "Operationalizing Free, Prior and Informed Consent in the Extractive Industry Sector? Examining the Challenges of a Negotiated Model of Justice" (2010) 30:1-2 Canadian Journal of Development Studies 111.

Williams, Cynthia A. "Civil Society Initiatives and 'Soft Law' in the Oil and Gas Industry” (2003-2004) 36 NYU Journal of International Law and Politics 457.

\section{Reports}

Christian Aid. Undermining the Poor: Mineral Taxation Reforms in Latin America (September 2009).

Comisión de Pueblos Andinos, Amazónicos, Afroperuanos, Ambiente y Ecología. Informe del Grupo de trabajo encargado de levantar información sobre la situación ambientaly estado de salud de los afectados por el derrame de mercurio en las localidades de San Juan, Choropampa y Magdalena, Departamento de Cajamarca en junio del año 2000 (Lima: Congreso de la República del Perú, 2008).

Cotula, Lorenzo. Foreign investment, law and sustainable development: $A$ bandbook on agriculture and extractive industries, $2^{\text {nd }}$ ed, IIED Natural Resources Issues Series 31 (International Institute for Environment and Development, 2016).

Defensoría del Pueblo. El Caso del Derrame de Mercurio que afectó a las localidades de San Sebastián de Choropampa, Magdalena y San Juan, en la Provincia de Cajamarca, Informe Defensorial No 62 (2001).

Economic Commission for Latin America and the Caribbean (ECLAC). Foreign Direct Investment in Latin America and the Caribbean, 2016, LC/G.2680-P (Santiago: ECLAC, 2016).

ETOS for Human Rights beyond Borders, Maastricht Principles on Extraterritorial Obligations of States in the Area of Economic, Social and Cultural Rights (February 2012).

Europe-Third World Centre \& International Associa- tion of Democratic Lawyers. Mining and Human Rights Violations in Colombia: The Case of Anglo Gold Ashanti vs the Afro-descendant community of La Toma, UNGA, 26th Sess, Annex, Agenda Item 3, UN Doc A/HRC/26/ NGO/38 (2014).

Forest Peoples Programme. Indigenous Peoples' Rights and Reduced Emissions from Reduced Deforestation and Forest Degradation: The Case of the Saramaka People v. Suriname (UK: Forest Peoples Programme, 2009).

Fundación del Debido Proceso. "El derecho a la consulta de los pueblos indígenas en Perú" (Washington, DC: 2010).

Galvis, María \& Ángela Ramírez. Digesto de jurisprudencia latinoamericana sobre los derechos de los pueblos indígenas a la participación, la consulta previa y la propiedad comunitaria (Washington, DC: Fundación del Debido Proceso, 2013).

Global Witness. On Dangerous Ground: The Killing and Criminalization of Land and Environmental Defenders Worldwide (London: Global Witness, 2016).

ILO, Committee of Experts on the Application of Conventions and Recommendations. Indigenous and tribal peoples: Observations of Peru, Indigenous and Tribal Peoples Convention, 1989 (No. 169), ILC.100/III/1A (ILO: 2011).

ILO, Committee of Experts on the Application of Conventions and Recommendations. Report of the Committee of Experts on the Application of Conventions and Recommendations (Report III, Part 1A), International Labour Conference, 99 $9^{\text {th }}$ Session, 2010 (ILO: 2010).

ILO, Committee of Experts on the Application of Conventions and Recommendations. Indigenous and tribalpeoples: Observations of Peru, Indigenous and Tribal Peoples Convention, 1989 (No 169), ILC.98/III/1A (ILO: 2009).

Instituto de Defensa Legal. "Listado de casos patrocinados por el Área de Litigio Constitucional” (2016).

Instituto Nacional de Estadística e Informativa. Evolución de la Pobreza Monetaria: 2009-2015 (Lima: INEI, 2015).

Justice \& Corporate Accountability Project. The "Canada Brand": Violence and Canadian Mining Companies in Latin America (Toronto: JCAP, 2016).

Langdon, S. "Peru's Yanacocha Gold Mine: The IFC's Midas Touch?" in Profiling Problem Projects (Berkeley, CA: Project Underground, 2003). 
Martens, Jens. Corporate Influence on the Business and Human Rights Agenda of the United Nations (Germany: Global Policy Forum, 2014).

Martin, Tim et al. "Tragadero Grande: Land, Human Rights, and International Standards in the Conflict Between the Chaupe Family and Minera Yanacocha", Report of the Independent Fact Finding Mission (Washington, DC: Resolve, 2016).

Mertins-Kirkwood, Hadrian. A Losing Proposition: the Failure of Canadian ISDS Policy at Home and Abroad (Ottawa: Canadian Centre for Policy Alternatives, 2015).

Moore, Jen. In the National Interest?: Criminalization of Land and Environment Defenders in the Americas (MiningWatch Canada, 2015).

OAS, Inter-American Commission on Human Rights. Indigenous Peoples, Afro-Descendent Communities, and Natural Resources: Human Rights Protection in the Context of Extraction, Exploitation, and Development Activities, OROEA/ Ser.L/VII.Doc.47/15 (2015).

------. Criminalization of the Work of Human Rights Defenders, OROEA/Ser.L/II.Doc.49/15 (2015).

------. Second Report on the Situation of Human Rights in Peru, OR OEA/Ser.L/V/II.106/Doc. 59, rev (2000).

Özkaynak, Begüm et al. Mining conflicts around the world: Common grounds from an Environmental Justice perspective, EJOLT Report No 7 (Environmental Justice Organisations, Liabilities and Trade, 2012).

Special Rapporteur on the Rights of Indigenous Peoples, James Anaya. Extractive industries and indigenous peoples, GA, 24 $4^{\text {th }}$ Sess, UN Doc A/HRC/24/41 (2013).

Special Representative of the Secretary-General on the Issue of Human Rights and Transnational Corporations and Other Business Enterprises, John Ruggie. Guiding Principles on Business and Human Rights: Implementing the United Nations "Protect, Respect and Remedy" Framework, OHCHR UN Doc A/HRC/17/31 (2011).

Weitzner, Viviane. Holding Extractive Companies to Account in Columbia: An evaluation of CSR instruments through the lens of Indigenous and Afro-Descendent Rights (The NorthSouth Institute, Proceso de Comunidades Negras, Resguardo Indígena Cañamomo Lomaprieta, 2016).

Wiener, Raul \& Juan Torres. Large scale mining: Do they pay the taxes they should? The Yanacocha case (Latin American Network on Debt, Development and Rights, 2014).

\section{Print \& visual media}

Arana, Marco. "El Cerro Quilish y la Mineria del Oro en Cajamarca", online: http://cajamarca.de/mine/quilish. htm.

Bergman, Lowell. La maldición del oro inca (FRONTLINE/World, 2005), YouTube, online: https://www.youtube.com $/$ watch?v $=5 \mathrm{OdJ} 9 \mathrm{eRv} \_$LY.

Cabellos, Ernesto \& Stephanie Boyd. Choropampa: The Price of Gold (Guarango Association, 2002).

"Cajamarca: encarcelan a juez acusado de recibir coima de 4 mil dólares", Canal N (18 July 2014), online: http://canaln.pe/peru/cajamarca-encarcelan-juez-acusado-recibir-coima-4-mil-dolares-n145767.

"Consejeros de Cajamarca pidieron plata a Yanacocha para apoyar proyecto Conga", La Republica (21 May 2014), online: http://www.larepublica.pe/21-05-2014/ consejeros-de-cajamarca-pidieron-plata-a-yanacochapara-apoyar-proyecto-conga.

EarthRights International, "Factsheet: Campos-Alvarez v Newmont Mining Corp", online: https:// www.earthrights.org/sites/default/ files/documents / Factsheet-Campos-Alvarez-v-Newmont.pdf.

The Goldman Environmental Prize, "Máxima Acuña: 2016 Goldman Prize Recipient South and Central America" (2016), online: http://www.goldmanprize.org/recipient/maxima-acuna/.

"Juez Titular Guhtember Pacheres Pérez al penal de Huacariz en Cajamarca" (19 July 2014), YouTube online: https://www.youtube.com/watch?v=-W9hKrF_C8.

"La intervención a Juez Titular Gutenberg Pacherres Pérez por coima" (21 July 2014), online: YouTube https://www.youtube.com/watch?v=PCOtbyBTHZU.

Olivera, Roxana. "II Will Never Give Up My Land”, New Internationalist (July 2016), online: https://newint. org/features/2016/07/01/interview-maxima-acuna/.

Perlez, J \& L Bergman. “Tangled Strands in Fight Over Peru Gold Mine” (Series: The Cost of

Gold: Treasure of Yanacocha) New York Times (25 October 2005).

"Peru: Miners in bribery risks, Yanacocha probes case", Latin IQ (21 May 2014), online: http://latin-iq.com/ $\mathrm{blog} /$ peru-miners-in-bribery-risks-yanacocha-probes- 
case/.

"Reconocen que servidumbres petroleras están sobre territorios indígenas", Servicios de Comunicación Intercultural, (28 November 2016), online: https:/ /www.servindi. org/actualidad-opinion/28/11/2016/reconocen-queservidumbres-petroleras-se-encuentran-sobre-territorios.

Ruiz Molleda, Juan Carlos. "¿El sexto paquetazo normativo? La aprobación de los DL N 1192 y N 1210" Instituto de Defensa Legal: Justicia Viva (1 October 2015), online: http://www.justiciaviva.org.pe/blog/el-sextopaquetazo-normativo-la-aprobacion-de-los-dl-n$1191-\mathrm{y}-\mathrm{n}-1210 /$.

------. "Ministerio de Cultura bloquea la consulta previa de las concesiones mineras e invisibiliza a los PPII en Espinar", Instituto de Defensa Legal: Justicia Viva, (16 April 2015), online: http:/ /www.justiciaviva.org.pe/notihome/notihome01.php?noti=1597.

------. "Para que sirven los amicus curiae?: TC rechaza el amicus del IDL sobre el derecho a la consulta de pueblos indígenas" (Instituto de Defensa Legal, 2010), online: http://www.justiciaviva.org.pe/notihome/notihome01.php?noti=221.

"Si, soy corrupto: El reo Pacherres aceptó recibir coima, ahora sufridos litigantes piden revisión de casos", ElMercurio (21 July 2014) 2, online: https:/ /issuu.com/ elmercurio/docs/21-07-2014.

Stk'emlupsemc te Secwepemc Nation, Media Release, "Stk'emlupsemc te Secwepemc Nation (SSN) says No to KGHM Ajax Mine and Yes to Healthy People and Environment" (4 March 2017), online: http://miningwatch.ca/sites/default/files/2017-03-ssnajaxdecisionrelease_0.pdf;

"Todas las concesiones mineras deberán ser consultadas a las comunidades" Servicios de Comunicación Intercultural (24 November 2016), online: https:/ /www.servindi.org/ actualidad-noticias/24/11/2016/todas-las-concesionesmineras-deberan-ser-consultadas-las-comunidades.

"10 Top Gold-producing Companies", Investing News Network (20 April 2016) online: http://investingnews. $\mathrm{com} /$ daily/resource-investing/precious-metals-investing/gold-investing/barrick-newmont-anglogoldgoldcorp-kinross-newcrest/.
Tsleil-Waututh Nation, Media Legal Backgrounder, "Tsleil-Waututh Nation (TWN) Legal Challenge to the National Energy Board's (NEB) review of Kinder Morgan Trans Mountain Pipeline and Tanker Project" (2 May 2014), online: http://www.twnation.ca/en/ / media/Files/Press\%20Releases/TWN\%20-\%20 NEB\%20-\%20Legal\%20Backgrounder\%20-\%20CLEAN_VAN_LAW-1461360-v4.ashx

"Vladimiro Montesinos ofreciendo mina Yanacocha a través de la CIA a cambio de millones", YouTube, online: https:/ www.youtube.com/ watch? $=15 \mathrm{k} 3 \mathrm{GHWHHVw}$.

\section{Internet sites}

Environmental Justice Organization, Liabilities and Trade, "Environmental Justice Atlas", online: http:// ejatlas.org/.

Másquez Salvador, Álvaro \& Juan Carlos Ruiz Molleda. "Gobierno aprueba norma que consagra intromisión en autonomía de Comunidades Campesinas", Instituto de Defensa Legal: Justicia Viva (15 January 2015), online: http://www.justiciaviva.org.pe/notihome/notihome01.php?noti $=1526$.

McGill Research Group Investigating Canadian Mining in Latin America, "Canadian Mining in Ecologically Vulnerable Areas: South America”, online: http:/ / micla.ca/wpcontent/uploads/2012/05/CanadianMining_ecologically_vulnerable_areas.png.

Newmont Mining Company, online: http://www.newmont.com/operations-and-projects/south-america/ yanacocha-peru/overview/default.aspx.

Observatorio de Conflictos Mineros de América Latina, "Mapa de Conflictos Mineros en América Latina", online: http://www.conflictosmineros.net/.

Segunda Legislatura Ordinaria de 2000, Transcripción del Vídeo No 892 (19 May 1998), online: http:/ /www2. congreso.gob.pe/sicr/diariodebates/audiovideos.nsf/ indice/CD180DDE013DE79805256A8E006F659A. 


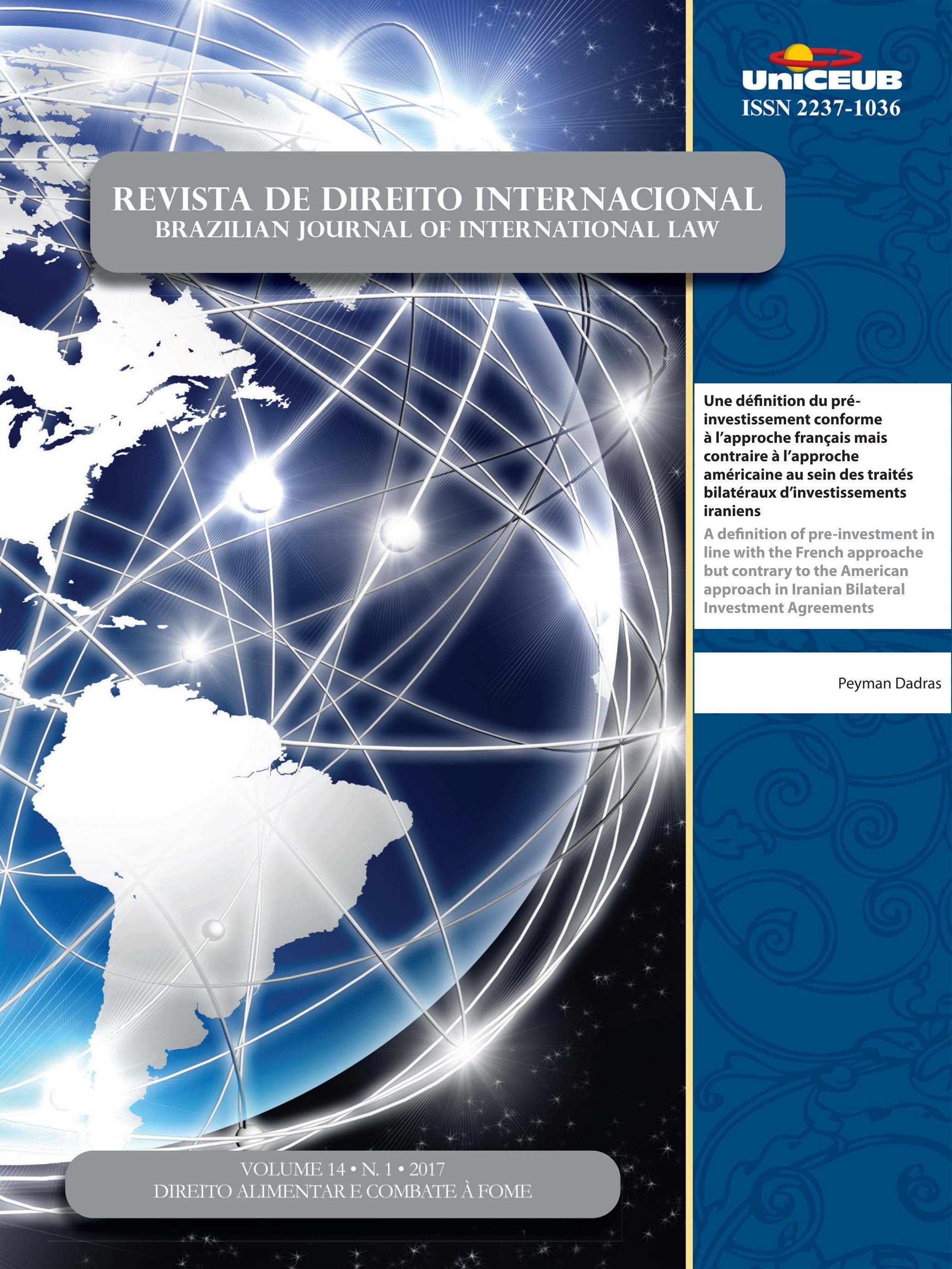




\title{
Une définition du pré-investissement conforme à l'approche français mais contraire à l'approche américaine au sein des traités bilatéraux d'investissements iraniens*
}

\author{
A definition of pre-investment in line with \\ the French approache but contrary to the \\ American approach in Iranian Bilateral \\ Investment Agreements
}

Peyman Dadras**

\section{RÉSUMÉ}

Le rôle du droit international des investissements est bien connu dans le monde entier. Afin de développer l'économie interne d'un pays, il est nécessaire d'obtenir des fonds étrangers dans le cadre d'un investissement quelle que soit la nature de l'activité. Les législations nationales concernant l'investissement étranger, très souvent désignées sous l'appellation « codes d'investissements », continuent sans doute à avoir une importance concrète sur le traitement des investissements étrangers, dans la mesure où l'Etat demeure compétent pour réglementer l'entrée et le développement des investissements sur son territoire, même en présence d'une convention international. A cet égard, Le pré-investissement, se definit comme l'ensemble des opérations en rapport avec un investissement en train de se réaliser sur le territoire de l'État d'accueil, concerne des normes sur l'admission et l'établissement dudit investissement. Dans le cadre d'une comparaison entre les États-Unis, la France et l'Iran sur l'admission des investissements étrangers (pré-investissement) est très remarquable de point de vue de la souveraineté de l'État où l'investissement va se développer.

Mots clés: Investissement. L'admission. Pré-investissement. Le traitement. Etranger

\section{Abstract}

The role of international investment law is well known throughout the world. In order to develop the internal economy of a country, it is necessary to obtain foreign funds in the context of an investment whatever the nature of the activity. National laws on foreign investment, often referred to as the «investments code», still probably have practical importance on the treatment of foreign investment to the extent that the state remains competent to regulate Entry and development of investment in its territory, even in the presence of an international convention. In this regard, the pre-investment, defined as all operations in connection with an investment in being realized

** Docteur en droit privé de l'Université Paris 1 Panthéon-Sorbonne, Maitre de conférences de l'Université SRBIAU. Email: peyman_hamc@yahoo.com
Recebido em 14/02/2017

Aprovado em 20/02/2017 
on the territory of the host State, respects standards for the admission and establishment of that investment. In the context of a comparison between the United States, France and Iran on the admission of foreign investment (pre-investment) it is very remarkable in the view of the sovereignty of the state of the point where the investment will develop.

Keywords : Investment. Admission. Pre investment. Treatment

\section{INTRODUCTION}

Le droit international de l'investissement est sans doute aujourd'hui l'une des matières les plus importantes du droit international. Le rôle du droit international des investissements est bien connu dans le monde entier. Afin de développer l'économie interne d'un pays, il est nécessaire d'obtenir des fonds étrangers dans le cadre d'un investissement quelle que soit la nature de l'activité (construction, extraction, mise en place de réseaux de distribution d'eau ou d'électricité, mais aussi assurance, tourisme, etc.). Malgré cette nécessité, un regard rétrospectif sur l'évolution des investissements internationaux suffit à démontrer que le cadre juridique de ces investissements comprend une variété de normes à la fois nationales et internationales. Les législations nationales concernant l'investissement étranger, très souvent désignées sous l'appellation « codes d'investissements », continuent sans doute à avoir une importance concrète sur le traitement des investissements étrangers, dans la mesure où l'Etat demeure compétent pour réglementer l'entrée et le développement des investissements sur son territoire, même en présence d'une convention international ${ }^{1}$. Le pré-investissement, c'est-à-dire l'ensemble des opérations en rapport avec un investissement en train de se réaliser sur le territoire de l'État d'accueil, concerne des normes sur l'admission et l'établissement dudit investissement. A ce sujet, on ne saurait s'étonner que la considération de la souveraineté de l'État où l'investissement va se développer, soit invoquée ${ }^{2}$.En effet, tout État est

1 LEBEN, (Ch.). Le droit international des affaires. Paris:PUF Gème édition. 2003. p.114-115.

2 CARREAU, (D); JUILLARD, (P). Droit international économique. Paris: Dalloz, 2010. p. 402-407; dans ce sens, on peut donner l'exemple de « Foreign Investment and National Securtiy Act» adopté le 28 février 2007 en droit américaine. Cette normativité a apporté beaucoup de changement vis-à-vis du CFIUS («the committe on foreign souverain pour définir sa politique économique et organiser son espace économique, ce qui demande un strict contrôle de l'admission des investissements ayant leur origine à l'étranger. Cela peut certainement être effectué par l'établissement de certaines obligations particulières à faire par les investisseurs étrangers qui veulent se placer sur le territoire (licences ou permis d'autorisation ou d'habilitation préalables), en vertu du droit interne de l'État. Mais les exigences de l'économie internationale ainsi que les exigences de la promotion des investissements ont pourtant conduit les États vers une atténuation de l'exercice de leur souveraineté.

A cet égard le rôle des Etats-Unis représentant d'un pays de système juridique de Common Law est très remarquable.

Dans le cadre d'une comparaison entre les États-Unis et la France s'appuyant sur le droit international de l'investissement, et plus précisément sur l'admission des investissements étrangers (pré-investissement), nous pourrions donc poser l'idée d'une opposition entre une Amérique libérale et une France protectionniste ${ }^{3}$.

Aujourd'hui, aux États-Unis comme en France, la question de l'admission des investissements étrangers paraît principalement se poser autour de la question plus ou moins concernée de la sécurité nationale.

Néanmoins, si en France il ne s'agit que de quelques articles -auxquels il est d'ailleurs assez peu fait référence -du Code monétaire et financier, aux États-Unis cette problématique est parfaitement centrale. Elle a été l'objet d'une succession de lois et d'affaires d'État, véritable champs de bataille politique et lieu de toutes les crispations ${ }^{4}$.

A cet égard le CFIUS (Committee on Foreign Investment in the United States), a originellement été créé

investment in the united states»), lequel, à la suite d'une enquête, doit faire une recommandation au président, qui dispose de 15 jours pour prendre une décision. Le CIFUS soit convaincre, le président qu'il existe des preuves tangibles que l'investissement étranger est susceptible de menacer la sécurité nationale. Enfin, sur le fond, le «Foreign Investment and National Security Act» élargit la notion de "sécurité national» afin d'y inclure celle de «sécurité national». Voir MILSTAJN, (A). l'admissibilité des investissements étrangers: comparaison Etats-Unis/France. Paris: université paris 1, p. 44-45

3 SERVAN-SCHREIBER, Pierre. Approche comparée des investissements internationaux entre la France et les EtatsUnis. Paris: l'Université Paris 2 Panthéon-Assas, 2012

4 MILSTAJN (A), L'admission des investissements étrangers. Comparaison Etats-Unis/France, Mémoire du Master 2. Paris: Université Paris 1 Panthéon Sorbonne, 2011. p.16 
par l'Executive Order n 11,858 de 1975 afin de surveiller et d'évaluer l'impact des investissements étrangers aux États-Unis. La particularité du CFIUS en tant que comité inter-agences est que ces agences ont initialement des vocations différentes et parfois même opposées puisque l'on en retrouve aussi bien certaines dont le champ d'action concerne la défense ou la sécurité intérieure, alors que d'autres ont vocation à promouvoir et à favoriser l'ouverture du commerce et des politiques d'investissement ${ }^{5}$.

En 2014, les États-Unis confirment leur position de premier émetteur mondial d'investissement direct étranger (désormais IDE). L'Union européenne, malgré les difficultés qu'elle traverse, demeure la destination privilégiée des IDE américains. Les États-Unis perdent en 2014 leur position de principale destination des IDE au monde, en faveur de la Chine. La baisse notable de l'attractivité des États-Unis sur la dernière décennie inquiète l'administration américaine qui développe des opérations de promotion du territoire américain comme terre d'accueil des investissements étrangers ${ }^{6}$.

De l'autre côté la France accueille sur son sol le $7^{\text {ème }}$ stock mondial d'IDE entrants $(729 \mathrm{Md} \$$ à la fin 2014 selon la CNUCED), derrière les États-Unis, la Chine et le Royaume-Uni. En 2015, les entrées d'IDE en France progressent très fortement, à $40 \mathrm{Md} €$ (après 11 Md€ en 2014), atteignant leur niveau le plus élevé depuis 2008. Cette hausse est liée à la réalisation en 2015 de plusieurs opérations importantes, au premier rang desquelles la fusion Lafarge-Holcim ${ }^{7}$. Selon Mathias Audit, le droit français en matière d'investissement international serait généralement attaché à une «situation géopolitique particulière, notamment l'existence larvée ou déclarée d'un conflit armé ou d'une crise économique $»^{8}$. La première loi française concernant de l'investissement international est édictée le 28 décem-

5 THE COMMITTEE on Foreign Investment in the United States. Disponível em:<https://www.treasury.gov/resource-center/ international/Pages/Committee-on-Foreign-Investment-in-US. aspx>.

6 DOSSIER Investissement direct étranger des États-Unis en 2014. Disponível em: <http://www.tresor.economie.gouv. fr/12904_les-investissements-directs-etrangers-des-Etats-Unisen-2014>.

7 INVESTISSEMENTS étrangers en France. Disponível em: $<$ http://www.tresor.economie.gouv.fr/investissements-etrangersen-france $>$.

8 Droit des investissements internationaux. Régime du droit interne », Jurisclasseur de droit international, fasc. 572-55. bre $1966^{\circ}$. Elle est liée aux relations financières avec l'étranger. Ses modalités d'application ont d'abord été déterminées par le décret n67-78 du 27 janvier 1967 supportant spécialement des investissements étrangers en France et des investissements français à l'étranger soumis à déclaration ou à autorisation préalable ${ }^{10}$.

En Iran, l'investissement étranger s'est formé plus ou moins parallèlement aux évolutions de l'investissement dans les autres pays. Toutefois, le processus d'évolution de l'investissement direct de l'étranger en Iran a été confronté à des difficultés résultant des changements politiques mouvementés connus dans ce pays. Malgré la grande variation du prix du pétrole aux cours de ces dernières années, le niveau de l'épargne nationale ne suffisait pas et les ressources suffisantes en vue de l'investissement en Iran n'avaient pas un niveau satisfaisant. Par conséquent, faute des sources financières suffisantes et en raison du besoin de technologies en Iran, l'attraction des investissements directs étrangers a dû être prise en compte. Avant 1932, l'investissement étranger en Iran se faisait souvent sous la forme de concession de privilèges aux étrangers. Après la nationalisation du pétrole en Iran et jusqu'en 1955, les Iraniens n'avaient pratiquement enregistré aucun investissement étranger, à cause de la crainte de la nationalisation et de l'instabilité de la loi. La donne en la matière changera ensuite avec l'adoption par le parlement, fortement encouragé en ce sens par les investisseurs étrangers, d'une loi ${ }^{11}$. A l'appui de cette loi, le nombre des investissements étrangers entrants en Iran s'est accru. A partir de 1956, l'activité des sociétés multinationales a connu une véritable progression. Après la Révolution iranienne, et en raison de certaines évolutions comme la guerre, la nationalisation et la confiscation des investissements, l'approbation de la nouvelle loi constitutionnelle et l'apparition des ambiguïtés et des doutes en matière

9 FRANÇA. Loi n ${ }^{\circ}$ 66-1008 du 28 décembre 1966. relative aux relations financières avec l'étranger. Disponível em: <https://www. legifrance.gouv.fr/affichTexte.do?cidTexte=JORFTEXT000000880 207\&categorieLien $=$ cid $>$

10 FRANÇA. Décret nº7-78 du 27 janvier 1967. FIXANT LES MODALITES D'APPLICATION DE LA LOI 661008 DU 28-121966 RELATIVES AUX RELATIONS FINANCIERES AVEC L'ETRANGER. Disponível em: <https://www.legifrance.gouv.fr/ affichTexteArticle.do?idArticle=LEGIARTI000006637286\&cidTex te=JORFTEXT000000877280>.

11 LA LOI de 1955 concernant de la promotion et la protection de l'investisseur étranger en Iran. In: EFTEKHAR, (R.). les modifications des traités bilatéraux d'investissement de l'Iran à la lumière des développements récentes du droit de l'investissement, Mémoire du Master 2. Téhéran: Université Shahid Beheshti, 2009. p.10-13 
d'investissement étranger, l'environnement a changé au détriment de l'investissement étranger. A cette époque, non seulement l'Iran n'avait pas réussi à attirer les investissements étrangers, mais en plus, certains investissements des précédentes années avaient été annulés et restitués aux pays investisseurs. Il existait depuis longtemps des traités d'amitié, de commerce et de navigation avant la naissance des traités bilatéraux de l'investissement. Le premier traité d'amitié, de commerce et de navigation a été conclu entre la France et les Etats-Unis en $1788^{12}$. Le premier traité bilatéral d'investissement a quant à lui été conclu entre l'Allemagne et la République Dominicaine en $1959^{13}$. L'Iran a signé avec plusieurs Etats un traité d'amitié, de commerce et de navigation ${ }^{14}$. Aujourd'hui, il existe toujours une relation économique avec ces Etats mais sous la forme d'un traité bilatéral. C'est avec l'Allemagne que l'Iran conclut son premier traité bilatéral de l'investissement le 6 avril 1968. Cependant, après ce traité, l'Iran n'a pas été très actif dans ce domaine sur la scène internationale jusqu'en 1995 ; année à partir de laquelle il signera plusieurs traités bilatéraux d'investissements ${ }^{15}$ (désormais TBI).

12 VANDEVELDE, (K. J.). United States treaties. Oxford: Oxford university press, 2009. p.19-20

13 DOLZER, (R); STEVENS (M). Bilateral Investment Treaties. Boston: Martinus Nijhoff Publishers the Hague, 1995. p. 1

14 Le traité de l'Iran avec la Chine en 1920, le traité de l'Iran avec la Pologne en 1927, le traité de l'Iran avec l'Allemagne en 1929, le traité de l'Iran avec la France en 1929, le traité de l'Iran avec l'Italie en 1929 et en 1950 aussi, le traité de l'Iran avec Finlande en 1931, le traité de l'Iran avec la Suisse en 1934, le traité de l'Iran avec l'Autriche en 1959, le traité de l'Iran avec le Pakistan en 1950, le traité de l'Iran avec le Liban en 1953, le traité de l'Iran avec la Syrie en 1954, le traité de l'Iran avec l'Espagne en 1956, le traité de l'Iran avec l'Éthiopie en 1968, le traité de l'Iran avec le Malaisie en 1968, le traité de l'Iran avec la Corée du sud en 1969, le traité de l'Iran avec la Turquie en 1969.

15 Le TBI de l'Iran avec l'Arménie en 1995, le TBI de l'Iran avec le Belarus en 1995, le TBI de l'Iran avec le Tadjikistan en 1995, le TBI de l'Iran avec le Pakistan en 1995, le TBI de l'Iran avec le Kazakhstan en 1996, le TBI de l'Iran avec le Turkménistan en 1996, le TBI de l'Iran avec l'Ukraine en 1996, le TBI de l'Iran avec le Yémen en 1996, le TBI de l'Iran avec le Bosnie-Herzégovine en 1996, le TBI de l'Iran avec le Kirghizstan en 1996, le TBI de l'Iran avec l'Azerbaïdjan en 1996, le TBI de l'Iran avec la Turquie en 1996, le TBI de l'Iran avec le Liban en 1997, le TBI de l'Iran avec l'Afrique du Sud en 1997, le TBI de l'Iran avec la Syrie en 1998, le TBI de l'Iran avec la Suisse en 1998, le TBI de l'Iran avec la Pologne en 1998, le TBI de l'Iran avec le Coré du sud en 1998, le TBI de l'Iran avec la Bulgarie en 1998, le TBI de l'Iran avec l'Italie en 1999, le TBI de l'Iran avec le Qatar en 1999, le TBI de l'Iran avec le Soudan en 1999, le TBI de l'Iran avec le Croatie en 2000, le TBI de l'Iran avec l'Ouzbékistan en 2000, le TBI de l'Iran avec la Chine en 2000, le TBI de l'Iran avec la Macédoine en 2000, le TBI de l'Iran avec le Maroc en 2001, le TBI de l'Iran avec l'Autriche en 2001, le TBI de l'Iran avec la Tunisie en 2001, le TBI
Normalement, les TBI sont adoptées sur une base de réciprocité, ce qui suppose l'existence de flux croisés d'investissements entre les parties contractantes. Par exemple, le modèle européen de TBI comporte souvent une clause dite « d'encouragement » (article 2) des investissements à la manière suivante : "Chacune des parties contractantes autorise et encourage, dans le cadre de sa législation et des dispositions du présent accord, les investissements effectués par les nationaux et sociétés de l'autre partie sur son territoire et dans sa zone maritime».

Cette clause d'encouragement des investissements n'a pas la portée de libérer l'admission des investissements des ressortissants d'une partie contractante sur le territoire de l'autre partie contractante. En fait, cet article permet à chaque législation le soin de réglementer les formalités exigées à l'admission des investissements étrangers.

Compte tenu de l'accord de Vienne entre l'Iran et les Pays de 5+1 sur la question nucléaire en 2015, l'adoption une approche libérale comme celle les Etats-Unis pour l'admission des investissements étrangers est plus favorable en droit international de l'investissement car ça apporterai une protection plus vaste aux investisseurs étrangers sur la base des normes international comme le traitement national et la clause de la nation plus favorisé. Tandis que l'approche française serai encadré de plus en plus avec l'idée de protectionnisme.

\section{L'IMPACT DES TBI SUR LA QUESTION DE PRÉ- INVESTISSEMENT}

Dans presque la moitié des TBI iraniens, les parties se sont engagées à fournir à l'investisseur étranger des

de l'Iran avec le Bangladesh en 2001, le TBI de l'Iran avec l'Oman en 2001, le TBI de l'Iran avec la Romani en 2002, le TBI de l'Iran avec la Malaisie en 2002, le TBI de l'Iran avec l'Allemagne en 2002, le TBI de l'Iran avec le Coré du nord en 2002, le TBI de l'Iran avec le Bahreïn en 2002, le TBI de l'Iran avec l'Espagne en 2002, le TBI de l'Iran avec le Finlande en 2002, le TBI de l'Iran avec la France en 2003, le TBI de l'Iran avec l'Algérie en 2003, le TBI de l'Iran avec l'Éthiopie en 2003, le TBI de l'Iran avec la Serbie en 2003, le TBI de l'Iran avec le Monténégro en 2003, le TBI de l'Iran avec le Venezuela en 2005, le TBI de l'Iran avec le Moldavie en 1995, le TBI de l'Iran avec le Philippine en 1995, le TBI de l'Iran avec le Zimbabwe en 1999, le TBI de l'Iran avec le Sri Lanka en 2000, le TBI de l'Iran avec la Grèce en 2002, le TBI de l'Iran avec l'Indonésie en 2005, le TBI de l'Iran avec la Suède en 2005, le TBI de l'Iran avec la Koweit en 2006, le TBI de l'Iran avec l'Afghanistan en 2006, le TBI de l'Iran avec le Libye en 2006, le TBI de l'Iran avec le Chypre en 2009, le TBI de l'Iran avec le Viêt Nam en 2009. 
conditions appropriées ${ }^{16}$. Dans certains des TBI iraniens, cet engagement a été manifesté dans le cadre des lois des pays d'accueils ${ }^{17}$.

Dans le TBI entre l'Iran et la France, les parties n’ont pas précisé ce type d'engagement mais ont opté pour des mécanismes pratiques pour l'investisseur étranger. Il s'agit par exemple de l'engagement relatif à l'autorisation d'entrée, de séjour, de voyage, de travail et d'embauche. Ce type de disposition peut apporter des nouveaux concepts pour le future et nous pouvons proposer ces types de la clause au sein des TBI avec les autre pays et surtout après la conclusion de l'accord de Genève à la suite du programme nucléaire.

Dans tous les TBI iraniens les parties s'engagent aussi à accueillir l'investisseur étranger sauf dans un TBI où les deux Etats n'ont pas manifesté leur intention $^{18}$. Pourtant dans le protocole de ce traité les parties s'engageaient à donner l'autorisation à l'investisseur étranger. Dans le TBI de l'Iran avec l'Allemagne et la France, les parties précisent que l'accueil de l'investisseur étranger sera effectué par l'autorité compétente de pays d'accueil en espèce OIETAI (Organisation d'investissement et d'assistance économique et technique de l'Iran). Dans le TBI entre l'Iran et la Turquie, les deux Etats déclarent leur intention d'accueillir l'investisseur étranger à la condition que soit garantie une protection égale vis-à-vis les investisseurs des pays tiers. Autrement dit, ils demandent une protection absolue conformément aux normes du droit international et la clause du traitement de la notion plus favorisé.

Dans tout les TBI iraniens, la question de l'autorisation de l'investissement a été précisée sauf dans les deux $\mathrm{TBI}^{19}$, que les parties n'ont pas abordé à ce sujet. Les TBI iraniens, ont toujours eu pour référence, la loi interne pour la demande de l'autorisation de l'investissement étranger. ${ }^{20}$ Dans le TBI de l'Iran avec

16 Les TBI de l'Iran avec Corée du sud, l'Ethiopie, le Venezuela, l'Algérie, l'Autriche, la Corée du nord, le Qatar, la Chine, l'Allemagne, le Bahreïn, l'Ouzbékistan, le Malaisie, la Tunisie, l'Italie, le Bangladesh, le Soudan, le Liban, la Serbie, le Monténégro, l'Oman, l'Afrique du sud.

17 Les TBI de l'Iran avec la Suisse, la Macédoine, la Corée du sud, l'Ethiopie, le Venezuela, l'Algérie, l'Autriche, la Coré du nord, le Qatar, la Chine, l'Allemagne, le Bahreïn, l'Ouzbékistan, la Tunisie, l'Italie, Bangladesh, le Liban, la Serbie, le Monténégro, l'Afrique du sud.

18 Le TBI de l'Iran avec l'Arménie en 1995.

19 Le TBI de l'Iran avec le Malaisie en 2002 et Le TBI de l'Iran avec l'Ukraine en 1996.

20 Les TBI de l'Iran avec l'Ethiopie, l'Algérie, la Corée de nord, le Bahreïn, l'Ouzbékistan, la Tunisie, la France, l'Allemagne, la Corée certains Etats, les parties ont donné quelques exemples pour présenter les différents types de l'autorisation ${ }^{21}$.

Dans le TBI entre l'Iran et la Finlande, les deux Etats soulignent que l'autorisation de l'investissement étranger doit être en conformité avec la politique nationale du pays d'accueil. Afin d'illustrer le sujet, on peut donner quelques exemples qui peuvent être intéressants pour l'investisseur étranger dans le futur TBI, par exemple l'autorisation pour embaucher des personnes qualifiées de nationalité étrangère pour le poste de PGD, ou distribuer une licence, ou l'autorisation pour la conclusion des contrats transferts de technologie ou les contrats commerciaux ou administratifs. On peut également rajouter l'autorisation pour le séjour et l'administration de projet de l'investissement.

Mais, les TBI conclus par les États-Unis, en considération du principe du traitement national (TN) et du traitement national plus favorisé (TNF), prévoient normalement la liberté d'admission des investissements dans les termes suivants : "Chaque partie s'engage à maintenir un climat favorable, sur son territoire, aux investissements des nationaux et sociétés de l'autre partie contractante; Chaque partie contractante permettra, notamment, l'établissement et l'acquisition de ces investissements à des termes et conditions qui leur garantiront un traitement non moins favorable que le traitement qu'elle garantit, dans des circonstances analogues, à ses propres nationaux et sociétés, on aux nationaux et sociétés de pays tiers, si ce dernier traitement est plus favorable $»^{22}$.

En vertu de cet article, et au contraire du modèle européen, les États contractants appliquent le principe de TN traitement national et de la NPF tant à la phase de pré-investissement qu'à la phase de l'investissement elle-même (post-établissement). En fait, ces différences de systèmes ont été l'un des raisons importantes pour arriver à la création de l'AMI ${ }^{23}$.

du sud, le Qatar, l'Afrique du sud, la Macédoine, l'Oman, la Serbie, le Monténégro, la Pologne, le Liban, le Bangladesh, l'Italie, le Maroc, l'Espagne, la Roumanie, le Bosnie, Herzégovine, le Tadjikistan, le Turkménistan, le Kirghizstan, le Venezuela, l'Azerbaïdjan, la Croatie, la Bulgarie, la Corée du sud.

21 Les TBI de l'Iran avec l'Azerbaïdjan, la Corée du sud, la Suisse, la Finlande, la Roumanie, l'Allemagne, la France.

22 U. S DEPARTAMENT OF STATE. Farmers Begin a new Season with hope. Disponível em: <Www.state.gov>.

23 JUILLARD, (P).A propos du décès de l'AMI. AFDI, 1998. p. 595-612; VADCAR, (C).Le projet d'Accord multilatéral sur l'investissement. problématique de l'adhésion des pays du Sud. JDI, 1998. p. 9-44; KODAMA, (Y). The Multilateral Agreement on Investment and its legal implication for newly industrializing economies. JW'T, v. 32, n. 4, p. 21-40, 1998. 
En ce qui concerne le droit français, les relations financières entre la France et l'étranger sont libres conformément à l'article L.151-1 du code monétaire et financière. Toutefois, conformément aux dispositions de l'article L.151-3 du code précité, sont soumis à l'autorisation préalable du ministre chargé de l'économie, les investissements en France qui participent à l'exercice de l'autorité publique ou relèvent des activités de nature à porter atteinte à l'ordre public, à la sécurité publique ou aux intérêts de la défense nationale ou des recherche, de production ou de commercialisation d'armes, de munitions, de poudres et substances explosives. Le code monétaire et financier (article R.151-1 et suivant) définit précisément la nature de ces activités.

Cette disposition nous démontre une approche restrictive et semblable au droit iranien par rapport au modèle américain qui est basé sur une liberté plus avantageuse pour l'investisseur étranger. Parce que selon l'article 5-7 de la loi 2001 sur l'encouragement et la protection de l'investisseur étranger, la demande d'acceptation et l'autorisation de l'investissement sera délivrée après l'approbation du Conseil de l'investissement étranger dans le cadre de l'OIETAI ${ }^{24}$. Nous pensons qu'une

24 ARTICLE 5. - L'Organisation est l'unique instance officielle responsable de l'encouragement des investissements étrangers en Iran et de la vérification de toutes les questions relatives aux investissements étrangers. Toutes les demandes des investisseurs étrangers relatives à la réception, à l'entrée, à l'emploi et à la sortie des capitaux doivent y être soumises; ARTICLE 6. - Pour vérifier les demandes objet de l'article (5) et en décider, se réunit un conseil dit le Conseil de l'investissement étranger préside par le Vice-ministre de l'économie et des finances, qui se charge en même temps de la direction générale de l'Organisation, et compose du Vice-ministre des Affaires étrangères, du Vice-président de l'Organisation nationale de la gestion et du plan, du Vice - gouverneur de la Banque de la République islamique d'Iran et, le cas échéant, des adjoints des ministères concernes. Quant à la demande d'acceptation, l'autorisation de l'investissement est délivrée après 1'approbation du Conseil et la confirmation et la signature du Ministre de l'économie et des finances. Lors de l'acceptation de l'investissement étranger, le Conseil doit respecter les termes de l'article 2 de la présente loi; Remarque. - L'Organisation est tenue, après une étude préliminaire, de mettre les demandes d'investissement, accompagnées de son avis, en discussion au Conseil au plus dans un délai de 15 jours suivant leur réception. Le Conseil doit étudier lesdites demandes et notifier par écrit sa décision définitive au plus tard dans un délai de 1 mois à compter de leur mise en discussion; ARTICLE 7. - En vue de faciliter et d'accélérer la procédure relative à l'acceptation et a l'activité des investissements étrangers dans le pays, tous les organismes concernes tels que le Ministère de l'économie et des finances, le Ministère des Affaires étrangères, le Ministère du commerce, le Ministère du travail et des affaires sociales, la Banque d'Iran, 1'Administration des douanes, le Registre des sociétés et de la propriété industrielle et le Département de la protection de l'environnement approche américain sera dans l'intérêt des futurs TBI iraniens parce que l'investisseur étranger sera traité avec des normes internationaux et en égalité de traitement avec les investisseurs internes de l'Etat d'accueil.

Certains TMI ont autorisé cependant de garantir la tendance vers l'assouplissement des mesures d'admission des investissements internationaux dans l'optique de les encourager. Ainsi, le traité sur la Charte de l'énergie protège aussi bien la phase de l'établissement que la phase post-établissement, si bien que le système ne prévoit pas une obligation de résultat pour ce qui examine l'étape d'admission des investissements.

L'article 10 du traité sur la Charte de l'énergie précise en effet que chaque partie contractante encourage et crée des conditions stables, équitables, favorables et transparentes pour la réalisation d'investissement. Ces conditions contiennent l'engagement d'accorder, à tout instant, un traitement loyal et équitable, une protection et une sécurité constante ne comportant aucune entrave résultant notamment de mesures déraisonnables ou discriminatoires.

Le traité dispose en outre que Chaque partie doit essayer d'accorder aux investisseurs des autres parties contractantes, la réalisation d'investissements dans sa zone, le bénéfice du traitement national ou du traitement le plus favorable réservé à des investisseurs tiers. Nous pensons que les obligations du traitement national et du TNF restent d'application restreinte dans la mesure où les parties contractantes n'ont pas vraiment une obligation de résultat, et ils doivent faire tous des efforts possibles et ils ont seulement un devoir d'encouragement à l'égard de l'investisseur étranger. Compte tenu de la position actuelle de l'Iran qui est membre observateur de ce traité, il faut une modification dans le cadre de la loi 2001 concernant la loi sur l'encouragement et la protection de l'investissement étranger en particulière l'article 5 et 7 de cette loi afin d'attirer de plus les investisseurs étrangers dans les domaines d'énergies.

En revanche, les dispositions relatives au traitement national (article 1102) et au traitement de la NPF (article 1103) contenues dans l'ALENA, ont un caractère plus contraignant. Parce qu'ils prévoient que cha-

sont tenus de nommer, par la signature de la plus haute autorité, un représentant muni de pleins pouvoirs auprès de l'Organisation. Les représentants ainsi nommes seront reconnus comme agent de relation et coordinateur des affaires entre l'organisme d'origine et l'Organisation. 
que partie accordera ledit traitement aux investisseurs et aux investissements d'une autre partie, concernant l'établissement, l'acquisition, l'expansion, la gestion, la direction, l'exploitation et la vente ou autre aliénation de ces investisseurs ou investissements. Également, l'article 1106 interdit aux États parties d'imposer des obligations propres en rapport avec l'établissement ou à l'acquisition d'un investissement dans le territoire de l'État d'accueil. Ceci a évidemment pour effet de diminuer les entraves possibles que le droit interne des États pourrait imposer à l'établissement d'un investissement provenant de l'étranger ${ }^{25}$.

Parmi les autres traités multilatéraux et régionaux contenant des dispositions similaires, peuvent être cités :

- Le Traité de libre-échange ci-après (TLE) de 1994 entre la Colombie, le Mexique et le Venezuela (Article 17-03), par lequel le TN et le TNF sont accordés aux investisseurs et investissements de l'autre partie, le droit de chaque partie d'exiger certaines formalités en matière d'établissement de l'investissement.

- Le cadre légal de l'ASENA (L'Association des nations de l'Asie du Sud-est) sur la création d'une zone pour le libre-échange et l'investissement international indique le TN à tous les investisseurs, alors que le TNF seulement aux États membres. Et enfin les principes APEC (Asie-Pacifique economic cooperation) sur l'investissement comportent aussi des droits à l'établissement sur la base du TN et du TNF, si bien qu'ils ne sont pas revêtus d'un caractère obligatoire ${ }^{26}$.

\section{L'APPORT DE LA JURISPRUDENCE ARBITRALE SUR CETTE QUESTION}

Afin de bien comprendre la question il nous convient de voir la position de la jurisprudence et les tribunaux arbitraux, à ce propos l'affaire Mihaly c. / Sri Lanka, un tribunal CIRDI a dû pour la première fois expliquer si certaines dépenses pré-contractuelles constituaient un investissement. En d'autres termes, cela

25 Les différentes exemples de contrôles exercés par les pays sur l'accès à leur économie national cités par cites par la CNUCED. Admission and establishment, UNCTAD Series on issues in international investment agreements, 1999, p.8-10; L'ALENA prévoit toutefois certaines réserve et exception citées à l'article 1108 .

26 UNCTAD, 1996 a, vol. II, p. 536. consistait à savoir si certaines dépenses dans la période du pré-investissement pouvaient relever de la compétence du Centre ${ }^{27}$. En l'espèce, la société américaine Mihaly international Corporation avait acquis le bénéfice de plusieurs lettres d'intention de la part de l'État du Sri Lanka, relatif à un appel d'offres pour la construction et l'exploitation d'une centrale électrique, sous la forme d'un contrat BOT (Build, operate, transfer) ${ }^{28}$.

Pendant des négociations la société avait fait de fortes dépenses afin de réaliser le contrat avec l'État du Sri Lanka. Toutefois à la suite de son exclusion définitive du projet, la société a intenté une action contre l'État devant un tribunal CIRDI sur le fondement du TBI entre les États-Unis et l'État du Sri Lanka, en réclamant le remboursement des sommes engagées dans la phase de négociation du projet. Le tribunal s'était déclaré incompétent pour résoudre l'affaire, en considérant que les sommes dépensées par la société ne constituaient pas un investissement dans le cadre du TBI.

Pour parvenir à cette conclusion, la juridiction arbitrale avait en premier lieu analysé le caractère contraignant des lettres d'intention émises par l'État. Dans la première lettre (letter of intent) l'État acceptait un certain nombre de principes concernant les bases de la négociation et donnait à la société américaine une période d'exclusivité de six mois pendant laquelle les parties devaient arriver à un projet d'accord. La période d'exclusivité écoulée, une nouvelle lettre fut envoyée à la société américaine (lettre of agreement), dans laquelle les représentants du Secrétariat pour l'infrastructure et le développement et l'investissement (SIDI) et le Conseil de l'électricité (Ceylon Electricity Board-CEB), lui affirmaient leur sanction des progrès faits afin de compléter les conditions résultant de la première lettre d'intention (lettre of intent).

Cependant ce nouveau document démontrait que l'efficacité de la lettre en question (lettre of agreement) était exposés à ce que le CEB puisse accorder avec la société SAEC (South Asia Electricity company, c'est-à-dire avec la société enregistré au Sri Lanka pour négocier et administrer la distribution de l'électricité. Enfin, une troisième lettre (letter of extension), a été émise en répon-

27 Mihaly international corrporation c./ République démocratique socialiste de Sri Lanka, l'affaire précité à la note $n^{\circ} 91$.

28 BEN HAMIDA (W). Les contrats BOT à l'épreuve du nouveau droits des investissements internationaux, in Travaux du Centre d'étude et de recherche de droit international à l'accadémie de droit international de la Haye. TDM, v. 4, issue 4, juillet 2007. Disponível em: <www.transnational-dispute-management.com> 
se à la demande faite par la société américaine pour le rétablissement de l'exclusivité du projet.

Cette troisième lettre indiquait que le document ne constituait en soi une obligation pour aucune des parties, en dépit du fait qu'elle manifestait l'intention de s'efforcer, autant que possible, à se conformer aux lois et règlements applicables au Sri Lanka, afin d'aboutir à un accord avec la société américaine. Après l'analyse de ces documents, le tribunal avait estimé qu'il n'y a jamais eu de contrat entre les parties pour la construction, l'acquisition ou l'exploitation de l'usine électrique.

Concernant le TBI entre les États-Unis et le Sri Lanka du 20 septembre 1991, le tribunal précise que celui-ci comporte des normes relatives à la définition de l'investissement ainsi que sur les conditions pour son admission. Pourtant, comme remarqué par le tribunal, la société demanderesse n'avait pas apporté de preuve de l'interprétation du traité ou de la pratique des États sur la possibilité que le pré-investissement et les dépenses pour le développement soient acceptés comme un investissement, en l'absence du consentement de l'État d'accueil à la mise en œuvre du projet. En d'autres termes, le tribunal n'avait pas exclu la possibilité qu'un pré-investissement puisse être protégé par le traité dans certaines circonstances, sauf exclusion expresse prévue par le traité29.

Au regard du texte du TBI, rien n'exclut la possibilité de protéger les investissements dans leur phase d'établissement et acquisition. De plus, l'article 1 prévoyait une définition large de l'investissement, incluant : "(ii) une entreprise ou des actions ou d'autres intérêts dans une société ou dans les actifs de celle-ci; (iii) une demande d'argent on une demande de prestations ayant une valeur économique, et associée à un investissement; tout droit conféré par la loi ou le contrat, les licences et les permis, conformément à la loi ».

Il ne fait donc aucun doute que la protection accordée par le traité n'était pas limitée à l'existence d'un lien contractuel et que la société demanderesse aurait pu demander une indemnisation sur le fondement, soit de la création de la société $S A E C$, soit des dépenses associées à l'établissement de son investissement, sous la loi de l'État de Sri Lanka. Cette décision a été très critiquée par la doctrine, mais en réalité il ne pourrait être reproché au tribunal de ne pas avoir cherché à prouver que

29 Ph. Gruslin c./ Malasie, ICSID Case n ${ }^{\circ}$ ARB/99/3, Sentence du 27 novembre 2000, 5 ICSID Report, 2002,p. 484. les dépenses réalisées par la société américaine étaient couvertes par le traité.

Car il appartenait à cette société et non au tribunal d'apporter la preuve que dans la mise en place d'un contrat de BOT, les dépenses avaient une valeur économique lié avec un investissement, y compris la création de la société au Sri Lanka ${ }^{30}$. De plus, même si le tribunal arbitral s'était déclaré compétent sur le fondement d'une définition large de l'investissement, il n'est pas sûr que l'État eusse été condamné sur le fond.

En effet, pour que l'État d'accueil engage internationalement sa responsabilité, son comportement doit être contraire aux droits protégés par le traité. En l'espèce, il s'agissait de prouver qu'il n'avait pas consacré un traitement juste et équitable vis-à-vis de l'investisseur, ou qu'il aurait manqué à l'obligation du traitement national (ou du TNF) au moment de l'étape de l'établissement et de l'acquisition de l'investissement ; ce qui n'était pas démontré en l'espèce. Au contraire, il apparait que le Sri Lanka lui avait donné un traitement conformément à la pratique des États en matière des contrats ou concession BOT.

L'article II du TBI entre les États-Unis et le Sri Lanka portant sur l'application du traitement juste et équitable, du traitement national et du NPF précise : " Aucune des parties ne pourra en aucune manière altérer par des mesures arbitraires et discriminatoires la gestion, l'opération, l'entretien, l'utilisation, la jouissance, l'acquisition, l'expansion ou la disposition des investissements ..... sujet au droit relatif à l'entrée et au séjour des étrangers, ressortissants de l'une des parties doivent être autorisés à entrer et à rester sur le territoire de l'autre partie dans le but d'établir, développer, administrer ou conseiller sur l'exploitation d'un investissement auquel ils, ou une entreprise de la première partie qui les emploie, ont engagé ou sont sur le point d'engager une quantité importante de capitaux ou d'autres ressources .... Aucune des parties ne doit imposer des exigences de performance en tant que condition de création, d'expansion ou de maintien des investissements, qui exigent ou exécutent les engagements aux biens d'experts produits, ou qui précisent que les biens ou les services doivent être achetés sur place, ou qui imposent d'autres

30 BEN HAMIDA (W). The Mihaly v. Sri Lanka Case : some thoughts relating to the status of pre investments expenditure. International investment law and arbitration, Cameron, , p. 47-66, May, 2005. 
conditions nécessaires similaires $»^{31}$.

Dans l'affaire W. Nagel c. / République tchèque, résolue sous l'égide de l'Institut de la Chambre de Commerce de Stockholm, le tribunal arbitral avait refusé de qualifier d'investissement un accord de coopération ${ }^{32}$. L'investisseur avait alors introduit une instance d'appel devant les juridictions suédoises (Svea Court of Appeal). Ladite cour d'appel rejeta toutefois la demande sur la base des mêmes motifs que ceux retenus par le tribunal arbitral, à savoir que l'accord ne conférait à l'investisseur aucun droit pour l'obtention de la licence d'exploitation du service de téléphonie mobile $\mathrm{GSM}^{33}$.

En l'espèce, il s'agissait d'un accord conclu entre W. Nagel de nationalité britannique et l'une entreprise publique tchèque en charge des télécommunications ( $S R A$ ), concernant l'obtention d'une licence de téléphonie mobile GSM. Exclu du projet, W. Nagel, a engagé une action contre la République tchèque sur le fondement du TBI signé entre cet État et le Royaume Uni le 10 juillet 1990. W. Nagel indiquait que la République tchèque avait dérogé les obligations conventionnelles car son investissement rentrait dans la catégorie des créances de sommes d'argent ou des droit à la prestation effectuée en vertu d'un contrat (Article 1(a)iii du TBI) et ayant une valeur financière.

Le tribunal arbitral s'était limité alors à l'analyse du texte de l'accord de coopération pour déterminer si celui-ci pouvait être considéré comme un contrat avec l'État par lequel il serait accordé des droits ayant une valeur économique ou financière. Le tribunal avait noté que l'accord n'obligeait pas les parties à une contribution financière au projet. Il exposait seulement que des actions, des contributions de capital et des prêts seraient exigés une fois le consortium formé. La juridiction en conclut donc que l'accord n'était qu'une étape préparatoire du projet qui était non contraignante pour les parties. Par conséquent, il ne créait aucun droit ayant une valeur économique pour le demandeur ${ }^{34}$.

31 U. S DEPARTAMENT OF STATE. Farmers Begin a new Season with hope. Disponível em: <Www.state.gov $>$.

32 WILLIAM, Nagel c. / République tchèque, Sentence du 9 septembre 2003, SCC Case n 49/2002, 1 SAR, 2004, p. 145. Disponível em: <www.sccinstitute.com/uk>

33 WOLTERS $(\mathrm{Y})$. The meaning of « investment in treaty disputes: substantive or jurisdictional? Lessons from Nagel v. Czech Republic and S.D. Myers v. Canada. JWI \& T, v. 8, n. 1, p. 175-185, 2007.

34 Selon le tribunal, "Comme indiqué plus haut, l'engagement fondamental dans l'accord de coopération a été que les parties devraient travailler ensemble
Dès lors, il semble approprié de s'interroger sur les conditions dans lesquelles une attente légitime de la part de l'investisseur peut exposer la responsabilité internationale de l'État. Est-ce que cette atteinte légitime répond à un principe général de droit ou est-ce qu'elle doit être envisagée selon du TBI ou TMI en question ${ }^{35}$ ? Dans l'affaire S.D. Myers c. / Canada, le Canada affirmait que Myers n'était pas véritablement un investisseur car les sommes d'argent dépensées ne l'avaient été que pour la publicité de ses services au Canada.

Et ladite société n'avait pas encore développé son investissement au Canada. En d'autre terme, l'entreprise était dans une étape de préparation pour l'établissement de son investissement au Canada. Écartant cette argumentation, le tribunal arbitral avait estimé que Myers (SDMI) représentait bel et bien un investisseur ayant réalisé un investissement au Canada sur la base de l'ALENA ${ }^{36}$.

En outre, la solution de cette affaire amène à s'interroger sur les raisons pour lesquelles il fut considéré que Myers avait une attente lui donnant le droit de réclamer une indemnisation à l'égard de l'État canadien. Dans le cas de Nagel, l'accord de coopération n'était pas suffisant pour prouver la responsabilité internationale de la République tchèque. En effet en l'espèce, l'investissement été effectué par le moyen d'une société de droit local (Myers Canada), alors que dans l'affaire $\mathrm{Na}$ gel l'accord de coopération ne remplissait pas la notion de bien ou d'investissement donné par le traité.

Également, il convient de préciser comme dans l'affaire Mihaly, que le demandeur dans l'affaire Nagel

dans le but d'obtenir une ..... licence. Il n'y avait pas, et ne pouvait pas, de garantie que la licence serait en fait obtenue. Cela dépendrait du gouvernement, et le gouvernement n'avait fait aucun engagement à cet égard. $M$. Nagel ne pouvait faire plus que d'espérer que sa collaboration avec la société d'État angmente ses chances de participer à l'opération en République Tchèque, mais il ne pouvait pas être certain d'obtenir une licence. Bien qu'il ait été encouragé par diverses remarques des ministres ou des fonctionnaires du gouvernement ou par l'intérêt général qu'ils ont démontré dans ses plans, ce n'était pas suffisant pour élever ses perspectives sur la base de l'accord de coopération au niveau d'une «attente légitime» avec une valeur financière ».

35 SNODGRASS (E). Protecting investor's legitimate expectations: recognizing and delimiting a general principle. ICSID Rev, p. $1-58,2006$.

36 «Lors de la procédure, il y a eu un débat considérable quant à savoir si Myers Canada rentrait dans une des catégories de la définition d'investissement. Preuve a été présentée pour démontrer que SMDI a prêté de l'argent à Myers Canada et que SMDI avait un espoir qu'elle aurait part aux revenus ou aux bénéfices, s'il y en avait. En fait, certains paiements pour les services ont été faits par Myers Canada à SMDI ». 
n'avait pas présenté la preuve des apports en capitaux ou en nature, à un projet d'investissement. Pourtant, même si des contributions et de dépenses dans l'étape d'établissement de l'investissement, c'est-à-dire du pré-investissement, avaient été démontrées, on pense que le TBI entre la République tchèque et le Royaume Uni n'accordait pas une protection effective dans cette période.

En effet, le TBI en question suit le modèle français du $\mathrm{TBI}^{37}$, en ce qu'il comporte seulement une clause d'encouragement des investissements, qui ne crée pas une vraie obligation de résultat pour l'État. L'article II est rédigé de la façon suivante: «Chaque partie contractante encourage et doit créer des conditions favorables pour les investisseurs de l'autre Partie contractante à investir des capitaux sur son territoire sous réserve de son droit d'exercer les pouvoirs conférés par ses lois».

Il nous convient de rappeler que les normes concernant le traitement national et le TNF (article III) sont seulement applicables à la gestion, la maintenance, l'usage et la jouissance des investissements. Rien n'est dit concernant l'établissement et l'acquisition des investissements. En revanche, dans l'affaire Myers, l'ALENA était applicable et tout dépendait des dispositions du traité. On peut avouer l'effet des traités bilatéraux, multilatéraux et régionaux sur la voie de la libéralisation des normes qui régissent les investissements internationaux du présent et du futur.

\section{Conclusion}

Les TBI iraniens sont proches aux TBI français parce que selon le code monétaire et financière (l'article 151), il appartient aux autorités nationales de décider l'intervention et l'autorisation de l'investisseur étranger. Ce rôle en Iran est conféré au OIETAI (Organisation d'investissement et d'assistance économique et technique de l'Iran) qui décide selon les dispositions internes, alors que dans les TBI américains cette question est traitée sur la base des normes TN et TNF dans la phase de pré-investissement et l'oblige l'Etat d'accueil à envisager la question de pré-investissement avec une

37 DRAFT agreement between the government of the republic of france and the government of the republic of (...) on the reciprocal promotion and protection of investments. Disponível em: $<$ http://italaw.com/documents/ModelTreatyFrance2006.pdf $>$. approche plus large. Cette approche va attirer les investisseurs étrangers au sein des TBI iraniens compte tenu de l'accord de Vienne entre l'Iran et le groupe de 5+1 sur la question nucléaire.

\section{BibILOGRAPHIE}

BEN HAMIDA (W). The Mihaly v. Sri Lanka Case : some thoughts relating to the status of pre investments expenditure. International investment law and arbitration, $\mathrm{Ca}-$ meron, , p. 47-66, May, 2005.

BEN HAMIDA (W). Les contrats BOT à l'épreuve du nouveau droits des investissements internationaux, in Travaux du Centre d'étude et de recherche de droit international à l'accadémie de droit international de la Haye. TDM, v. 4, issue 4, juillet 2007. Disponível em: $<$ www.transnational-dispute-management.com>.

CARREAU, (D); JUILLARD, (P). Droit international économique. Paris : Dalloz, 2010.

DOLZER, (R); STEVENS (M). Bilateral Investment Treaties. Boston: Martinus Nijhoff Publishers the $\mathrm{Ha}-$ gue, 1995.

DOSSIER Investissement direct étranger des ÉtatsUnis en 2014. Disponível em: <http://www.tresor. economie.gouv.fr/12904_les-investissements-directsetrangers-des-Etats-Unis-en-2014>.

DRAFT agreement between the government of the republic of france and the government of the republic of (...) on the reciprocal promotion and protection of investments. Disponível em: <http://italaw.com/documents/ModelTreatyFrance2006.pdf $>$.

Droit des investissements internationaux. Régime du droit interne ", Jurisclasseur de droit international, fasc. $572-55$.

FRANÇA. Décret nº7-78 du 27 janvier 1967. FIXANT LES MODALITES D'APPLICATION DE LA LOI 661008 DU 28-12-1966 RELATIVES AUX RELATIONS FINANCIERES AVEC L'ETRANGER. Disponível em: <https://www.legifrance.gouv.fr/affichTexteArticle.do?idArticle=LEGIARTI0000066372 86\&cidTexte=JORFTEXT000000877280 $>$.

FRANÇA. Loi no 66-1008 du 28 décembre 1966. relative aux relations financières avec l'étranger. Disponível em: $<$ https://www.legifrance.gouv.fr/affichTexte.do?cidTe 
xte=JORFTEXT000000880207\&categorieLien $=$ cid $>$.

INVEST IN IRAN. [Homepage]. Disponível em: <http://www.investiniran.ir/en/home>.

INVESTISSEMENTS étrangers en France. Disponível em: <http://www.tresor.economie.gouv.fr/investissements-etrangers-en-france $>$.

JUILLARD, (P). A propos du décès de l'AMI. AFDI, 1998.

KODAMA, (Y). The Multilateral Agreement on Investment and its legal implication for newly industrializing economies. JWT, v. 32, n. 4, p. 21-40, 1998.

LA LOI de 1955 concernant de la promotion et la protection de l'investisseur étranger en Iran. In: EFTEKHAR, (R.). les modifications des traités bilatéraux d'investissement de l'Iran à la lumière des développements récentes du droit de l'investissement, Mémoire du Master 2. Téhéran: Université Shahid Beheshti, 2009. p.10-13

LEBEN, (Ch.). Le droit international des affaires. PUF Gème édition. Cidade: editora, 2003.

Mihaly international corrporation c./ République démocratique socialiste de Sri Lanka, l'affaire précité à la note $\mathrm{n}^{\circ} 91$.

MILSTAJN, (A). l'admissibilité des investissements étrangers: comparaison Etats-Unis/France. Paris: université paris 1 , ano.

NAFTA. Disponível em: <http://www.naftanow.org/ l'article 1108>.

Ph. Gruslin c./ Malasie, ICSID Case n ${ }^{\circ}$ ARB/99/3, Sentence du 27 novembre 2000, 5 ICSID Report, 2002,p. 484.

SERVAN-SCHREIBER, Pierre. Approche comparée des investissements internationaux entre la France et les EtatsUnis. Paris: l’Université Paris 2 Panthéon-Assas, 2012.

SNODGRASS (E). Protecting investor's legitimate expectations: recognizing and delimiting a general principle. ICSID Rev, p. 1-58, 2006.

SUR les lois d'investissement étranger. Disponível em: $<$ http://www.investiniran.ir/fr/foreigninvestment/ laws $>$.

THE COMMITTEE on Foreign Investment in the United States. Disponível em : < https://www.treasury. gov/resource-center/international/Pages/Committeeon-Foreign-Investment-in-US.aspx>.

U.S DEPSRTAMENT OF STATE. Celebrating International womens day. Disponível em: <https://Www.State. Gov/>.

UNITED NATIONS CONFERENCE ON TRADE AND DEVELOPMENT. World Consumer Rights Day. Disponível em: < http://unctad.org/en/pages/DIAE/ International $\% 20$ Investment $\% 20$ Agreements $\% 20$ (IIA)/UNCTAD-Series-on-issues-on-international-investment-agreements.aspx $>$.

VADCAR, (C). Le projet d'Accord multilatéral sur l'investissement: problématique de l'adhésion des pays du Sud. JDI, 1998.

VANDEVELDE, (K. J.). United States treaties. Oxford: Oxford university press, 2009.

WILLIAM, Nagel c. / République tchèque, Sentence du 9 septembre 2003, SCC Case $n^{\circ}$ 49/2002, 1 SAR, 2004, p. 145. Disponível em: <www.sccinstitute.com/uk>.

WOLTERS $(Y)$. The meaning of « investment in treaty disputes: substantive or jurisdictional? Lessons from Nagel v. Czech Republic and S.D. Myers v. Canada. JWI \&T, v. 8, n. 1, p. 175-185, 2007. 


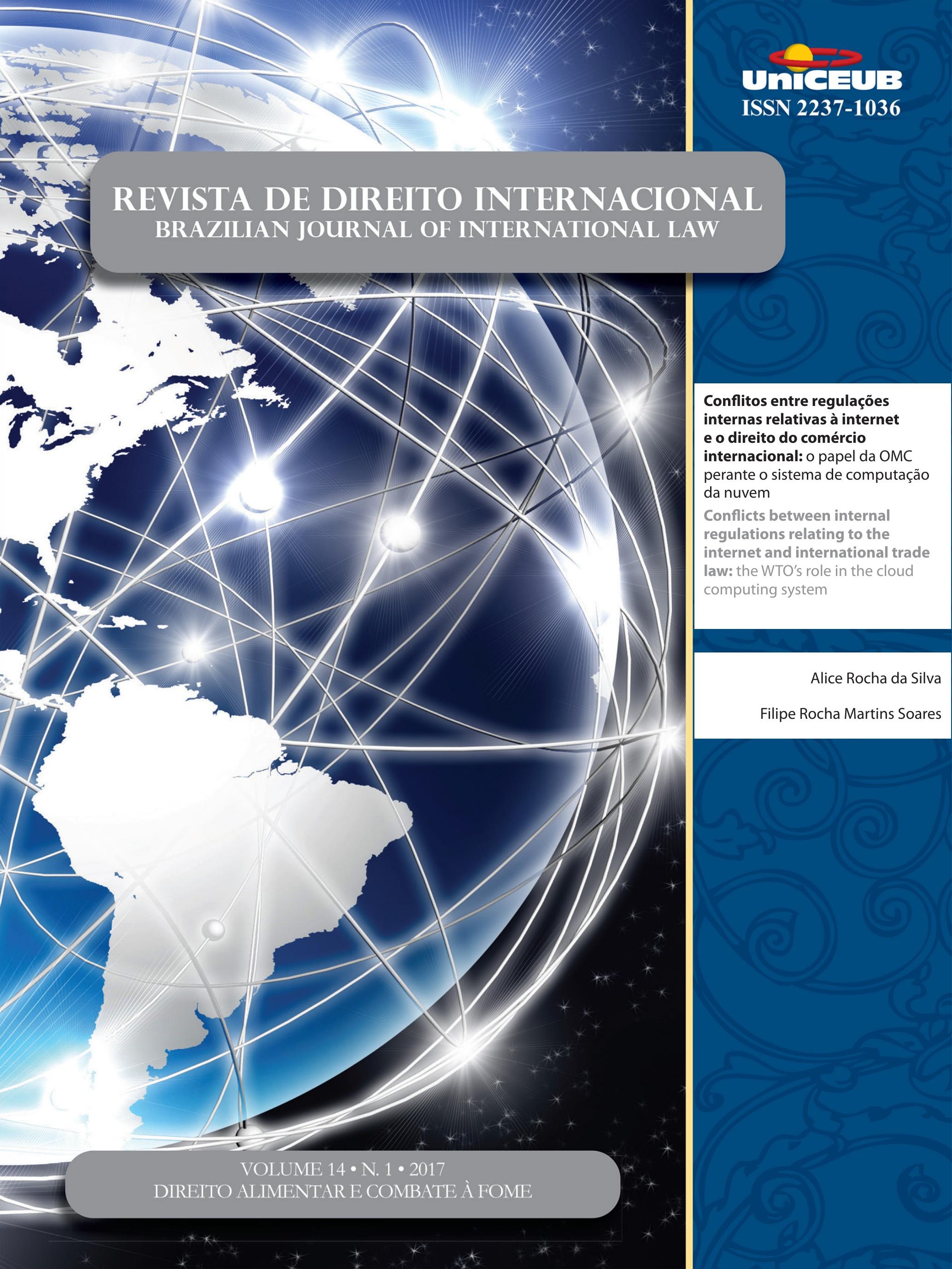




\title{
Conflitos entre regulações internas relativas à internet $\mathrm{e} o$ direito do comércio internacional: o papel da OMC perante 0 sistema de computação da nuvem*
}

\author{
Conflicts between internal regulations \\ relating to the internet and international \\ trade law: the WTO's role in the cloud \\ computing system
}

Alice Rocha da Silva**

Filipe Rocha Martins Soares***

\section{Resumo}

A OMC tem um papel importante no aprimoramento da governança dos mecanismos de computação na plataforma de comercialização de bens e serviços, de modo específico a nuvem cibernética. Ao impor medidas como a censura, normas de proteção de dados privados ou a exigência de licenças prévias para o funcionamento de empresas, governos costumam fundamentar suas decisões no imperativo de garantir a segurança pública e assegurar a defesa nacional. Os Estados geralmente optam por limitar os fluxos internacionais de dados ao promoverem esse tipo de regulação sobre a internet. Ocorre que, ao fazê-lo, podem acabar por sufocar a rede, uma vez que a economia que se desenvolveu em torno dela é baseada na movimentação de informações. Ademais, não é raro que se promovam medidas protecionistas camufladas, o que afronta as regras do comércio internacional.

Palavras-chave: OMC. Nuvem cibernética. Governança. Barreiras comerciais.

* Autores convidados

** Professora do Programa de Mestrado e Doutorado em Direito do UniCEUB. Doutora em Direito pela Universite d'Aix-Marseille III, Franca. Mestre em Direito pelo Uniceub. Graduada em Direito pelo UniCEUB e em Ciencia Politica e Relacoes Internacionais pela Universidade de Brasilia. E-mail: rochaalice@yahoo. com.br

*** Mestrando em Direito pelo Centro Universitário de Brasília - UniCEUB. Bacharel em direito pela Universidade Federal do Piaui UFPI. Servidor Público. E-mail: filipe.soares@ protonmail.ch

\begin{abstract}
When imposing measures such as censorship, data protection laws or licensing requirements, governments tend to base those decisions on matters of law enforcement or national security. States usually choose the option of limiting the international flow of data when enforcing this sort of regulation over the internet. It so happens that, by behaving that way, they may end up chocking the network, once the economic model developed around it is based on the information flows. Also, it not unusual that protectionist measures are camouflaged, what represents an affront to the rules of international trade. In that sense, it is worth investigating how the WTO can act so as to improve the governance of cloud computing mechanisms.
\end{abstract}

Keywords: WTO. Cybernetic cloud. Governance. Trade barriers. 


\section{INTRODUÇÃO}

O direito da Organização Mundial do Comércio (OMC) advêm de uma série de acordos firmados no âmbito da instituição, cujo principal escopo é a liberalização do comércio internacional. As decisões dos painéis e dos órgãos de apelação estabelecem princípios, regras e métodos de interpretação deste Direito, ao passo que sua evolução é impulsionada por entendimentos entre todos os membros, por acordos multilaterais e pelas normas negociadas no momento em que novos países aderem à organização ${ }^{1}$.

O GATT (do inglês General Agreement on Tariffs and Trade) e o GATS (do inglês The General Agreement on Trade in Services) regulam, respectivamente, o comércio de bens e de serviços. Ambos os acordos refletem os cânones do Direito da OMC: o Tratamento Nacional e a cláusula da Nação Mais Favorecida. Além disso, os dois textos contribuem para o equacionamento de eventuais desacordos entre regulações nacionais e as regras do comércio internacional. Tal conflito, no que se refere ao comércio de bens e serviços na internet e aos fluxos internacionais de dados cibernéticos, é o objeto deste artigo.

$\mathrm{O}$ artigo XI do GATT estabelece que não haverá restrições ao comércio "além de impostos, taxas ou outros encargos", inobstante o método pelo qual se efetivem tais limitações - "seja por quotas, licenças de importação ou exportação ou por outras medidas". Já o artigo XVII do GATS estatui, inequivocamente, a regra do tratamento nacional: os integrantes da OMC assegurarão a prestadores de serviços de outros membros "tratamento não menos favorável que o oferecido aos seus próprios serviços e fornecedores de serviço equivalentes". ${ }^{3}$

1 Sobre o tema OSAKWE assevera: "Real Market access improvements in the WTO have resulted from accession negotiations. [...] The Organization has been able to update its rules steadly but quietly through the accession negotiations". OSAKWE, C. Future of the Multilateral Trading System: Why the Wto Remains Indispensable? Asian Journal of W to \& International Health Law and Policy, v. 10, n. 1, p. 1-25, 2015. at. p. 22.

2 Tradução Nossa. Texto original: "No prohibitions or restrictions other than duties, taxes or other charges, whether made effective through quotas, import or export licences or other measures, shall be instituted or maintained by any contracting party on the importation of any product of the territory of any other contracting party or on the exportation or sale for export of any product destined for the territory of any other contracting party".

3 Tradução nossa. Texto parcial do artigo: "In the sectors inscribed
Ambos os acordos, porém, trazem exceções à regra geral de liberalização. Trata-se de situações em que, por razões atinentes à segurança nacional ou à ordem públi$\mathrm{ca}$, as normas internacionais capitulam perante o Direito interno. Nesse sentido, redigiram-se o artigo XX do GATTT e o artigo XIV do GATS. Nos dois casos, prevê-se que a moral e a ordem pública podem ser invocadas como subterfúgios para a não-aplicação do Direito da OMC. O mesmo artigo XX do GATT e o artigo VI do GATS, contudo, determinam que a regulação local não seja imposta de forma arbitrária, injustificável, desarrazoada ou tendenciosa.

Com a internet, desenvolveu-se um novo entreposto que é, concomitantemente, uma plataforma de comercialização de bens e serviços, e um serviço em si mesma: a nuvem cibernética. Servidores de informática espalhados pelos mais diversos locais distribuem conteúdos e alojam dados cuja guarda lhes é confiada. A redução de custos decorrente da possibilidade de oferecer bens e serviços a todo o planeta sem a necessidade de presença física em múltiplas sedes é a principal atratividade da nuvem. Por ela, distribui-se vasta gama de produtos, como softwares, jogos eletrônicos, livros digitais, e serviços que possam ser oferecidos remotamente. Ao mesmo tempo, é comum que se contratem espaços em servidores fisicamente situados em outros países para alojar dados produzidos por clientes de empresas atuantes tanto no mundo físico como exclusivamente no âmbito cibernético.

O instituto estatal de padrões e tecnologia dos Estados Unidos (National Institute of Standards and Technology - NIST") formulou uma definição de "computação na nuvem" amplamente aceita pela doutrina:

Computação na nuvem é um modelo apto a
possibilitar acesso em rede ubíquo, conveniente e
sob demanda a um pool de recursos de computação
configuráveis (redes, servidores, alojamento,
aplicações e serviços, por exemplo) que podem
ser rapidamente provisionados e liberados com
o mínimo esforço gerencial ou interação com o
provedor do serviço 5

in its Schedule, and subject to any conditions and qualifications set out therein, each Member shall accord to services and service suppliers of any other Member, in respect of all measures affecting the supply of services, treatment no less favourable than that it accords to its own like services and service suppliers".

4 O órgão homólogo ao NIST, no Brasil, é o Inmetro.

5 No original: "Cloud computing is a model for enabling ubiquitous, convenient, on-demand network access to a shared pool of configurable computing resources (e.g., networks, servers, storage, 
O NIST aponta, ainda, cinco características essenciais ao modelo: o autoatendimento sob demanda do cliente; a ampla acessibilidade da rede; o agrupamento de recursos computacionais para atender a múltiplos consumidores simultaneamente; a possibilidade de aumentos em escala dos serviços oferecidos sem a necessidade de ajustes bruscos; a interação com o consumidor de modo a otimizar os recursos disponibilizados conforme o seu interesse.

Um exemplo simples pode auxiliar o leitor leigo a compreender o funcionamento da nuvem: o Google. Os diversos produtos e serviços oferecidos pela empresa estadunidense estão permanentemente disponíveis ao consumidor; os servidores da companhia estão espalhados em diferentes locais do mundo, com o intuito de atender a múltiplas demandas simultaneamente e a potenciais aumentos súbitos de requisições sem interrupção dos serviços. Ademais, o Google monitora os hábitos de seus clientes com o fim de aprimorar, tanto em tempo real como no longo prazo, a qualidade dos recursos oferecidos. A contrapartida que a empresa obtém decorre igualmente deste monitoramento: os dados privados de seus clientes são utilizados, dentre outros fins, para a elaboração de publicidade personalizada.

A rápida expansão da nuvem, na condição de plataforma e de serviço, não tem ocorrido sem provocar alvoroço na disciplina dos fluxos internacionais de dados. Se a preocupação dos governos, anteriormente, era a garantia da segurança e do acesso, em caso de necessidade, a dados bancários ou a registros telefônicos (por exemplo) produzidos por seus cidadãos, mas alojados em outro país, a nuvem aumenta sobremaneira as interações necessárias. Do mesmo modo, regimes autoritários veem tolhida sua capacidade de controlar as informações - tanto dados privados quanto conteúdos jornalísticos ou propagandísticos - que entram e saem de suas fronteiras.

Com o modelo de distribuição em nuvem, o fluxo dos dados se torna mais rápido, volumoso e difícil de monitorar. Os conteúdos na internet não se deslocam de maneira retilínea; ao contrário, atendem a complicados padrões que dependem da arquitetura da rede e

applications, and services) that can be rapidly provisioned and released with minimal management effort or service provider interaction" (Tradução Nossa) MELL, P.; GRANCE, T. The NIST definition of cloud computingNIST Special Publication. Disponível em: <http:// www.mendeley.com/research/the-nist-definition-about-cloud-computing/>. At. p. 6. são pautados principalmente pela economia de custos. Assim, uma informação produzida em um determinado país pode passar por múltiplos territórios antes de atingir seu destino final - um servidor situado em outro local. Nesse sentido, aduz que:

A geografia e a territorialidade [...] tornaram-se
menos importantes do ponto de vista negocial e
tecnológico. Muitas companhias estruturam suas
operações com base em linhas de negócios ao invés
de critérios geográficos, e a tecnologia permite
a transferência de dados pessoas sem considerar
fronteiras nacionais." (Tradução nossa, com
adaptações ao texto original) ${ }^{6}$.

Esta revolução possibilitou o surgimento de uma infinidade de novos modelos de negócios, reduziu custos - no que propiciou oportunidades de crescimento a outrora pequenas startups - e permitiu o acesso a produtos, serviços e informações a pessoas isoladas nos mais recônditos locais do planeta. No entanto, despertou reações de governos que, pela primeira vez, viram-se alijados do controle sobre o fluxo internacional de dados.

A resposta da maioria dos Estados tem consistido na busca por maior inserção de mecanismos de controle sobre o domínio cibernético. Tal processo encontra-se em período de expansão, sob o estímulo de fenômenos que favorecem a desconfiança entre os países, como a espionagem internacional e a elaboração, em nível local, de rigorosas normas de proteção de dados - o que dificulta o compartilhamento. O problema manifesta-se por meio de regulações nacionais elaboradas com o intuito de ampliar o poder do Estado sobre a internet e a nuvem cibernética, mas que, por causa da ubiquidade destas inovações, atingem diretamente a dinâmica do fluxo internacional de dados. Ademais, não se descarta que razões mais prosaicas motivem as limitações à internet, como o interesse em proteger empresas locais da concorrência externa.

A despeito da motivação, é possível que, em determinadas circunstâncias, as normas locais afrontem o Direito da OMC. Outrossim, têm o condão de desvirtuar a internet, por duas razões. A primeira é que a rede mundial de computadores tem como premissa básica o

6 Do original: “... geography and territoriality [...] have become less important from the business and technological points of view. Many companies structure their operations based on lines of business rather than geography, and technology allows the transfer of personal data without regard to national boundaries." KUNER, C. Regulation of Transborder Data Flows under Data Protection and Privacy Law : Past, Present, and Future. OECD Digital Economy Papers, n. 187, 2011. p. 12. 
livre fluxo de informações e o amplo acesso. As restrições encaminham o cenário para uma balcanização da rede, cuja manifestação mais extrema - e indesejável produziria uma versão própria da internet por país.

O segundo motivo é o fato de a internet ser caracteriza pela sua governança difusa, compartilhada entre governos, empresas, consumidores e instituições privadas sem fins lucrativos. $\mathrm{O}$ fortalecimento de um modelo gestado por órgãos estatais pode repelir os demais atores e reproduzir, na internet, as tensões e disputas entre os países, o que, novamente, levaria à fragmentação da rede.

Ao estabelecer parâmetros para que os Estados imponham normas locais em detrimento dos acordos internacionais, o Direito da OMC pode ser uma ferramenta útil no sentido de evitar a balcanização da internet. À medida que a organização se abre para agentes não-estatais, ela também tem o potencial de tornar-se foro de rediscussão do sistema de governança global da internet.

\section{A tensão entre Regulações locais e 0 COMÉRCIO INTERNACIONAL}

Pode-se destacar duas dificuldades que se apresentam perante os reguladores estatais no tocante à internet. A primeira é a possibilidade de o usuário tornar-se anônimo no ambiente virtual. Por um lado, isso permite que cidadãos se esquivem de censura ou perseguição política em regimes ditatoriais. Por outro, cria facilidades para o cometimento de crimes cibernéticos.

Em ambos os casos, interessa aos Estados - autoritários ou democráticos - controlar de modo mais assertivo a internet. Um dos caminhos de que dispõem é a criação de filtros a determinados conteúdos, os quais, eventualmente extremados, confundem-se com censura. Nesse sentido, do mesmo modo que um cidadão chinês é incapaz de encontrar referências ao Falun Gong nos buscadores da internet - prática proscrita pelo regime daquele país -, um francês tampouco consegue acesso a determinados sites de leilão de produtos de memória nazista ${ }^{7}$.

7 Sobre o tema, é interessante a análise do caso: LICRA ET UEJF CONTRE YAHOO! Inc. et YAHOO FRANCE. A decisão da corte francesa está disponível em: <http://www.lapres.net/yahfr.html>. Acesso em 17 dez. 2016.
No entanto, a mesma tecnologia que possibilita o anonimato permite, em condições normais, que o usuário, sub-repticiamente, altere sua localização. Vislumbram-se, então, outras duas alternativas para os órgãos estatais; ambas, porém, drásticas.

O regime chinês desenvolveu algo que se aproxima muito de uma versão própria da internet, com o uso de tecnologias que inviabilizam o anonimato e garantem a imposição de filtros ${ }^{8}$. Já nos Estados Unidos, recentemente, o Federal Bureau of Investigations (FBI) obteve poderes para utilizar recursos avançados de invasão a sistemas de informática quando se percebe a aparência de que o alvo de determinada ação pretende camuflar sua verdadeira localização, estando o usuário, ao final, em território estadunidense ou não? .

Trata-se, no primeiro caso, de rigorosa limitação às liberdades individuais e, no segundo, de projeção extraterritorial de normas e da jurisdição local, potencialmente atentatórias ao Direito Internacional. Note-se, então, que são escassas e, porventura, tortuosas as opções de que os Estados dispõem para imposição de sua ordem pública no domínio cibernético. O fato é agravado pelos empecilhos ao acesso a dados, mesmo quando é possível individualizar e localizar determinado usuário.

Neste ponto reside a segunda dificuldade com que se deparam os reguladores estatais: o conflito entre normas internas de proteção de dados e o interesse de acesso, por outros Estados, a informações. O problema é uma decorrência da estrutura da nuvem cibernética, mas já existia, conforme se aludiu acima, relativamente, por exemplo, ao acesso a dados bancários no âmbito de investigações criminais. $\mathrm{O}$ fato é apenas agravado porque, ao invés de envolver, normalmente, apenas duas jurisdições (a do país interessado e a do Estado onde estão armazenadas as informações), devido à arquitetura da internet, múltiplas nações podem ter interesse em aplicar suas leis com base em diferentes critérios - territorialidade objetiva, nacionalidade passiva, princípio da segurança nacional ou local onde se percebam os efeitos de determinada ação. Além disso, a estrutura de informações entre empresas e usuários é assimétrica: estes

8 Internamente, as autoridades chinesas referem-se ao projeto como "Golden Shield". No exterior, pejorativamente, e em alusão à muralha da China, ele é conhecido como "Great Firewall of China". 9 A alteração, que atribui poderes de investigação extraterritoriais ao FBI, passou a viger a partir de $1^{\circ}$ de dezembro de 2016. Trata-se de mudança nas "regras federais de processo penal". 
normalmente sequer sabem onde suas informações estão armazenadas.

Normas de proteção de dados tendem a dificultar o acesso por outros Estados a informações que a estes interessam. Ocorre que uma informação produzida em um país, se armazenada em outro, estará sujeita às regras de proteção deste, ainda que seja de grande relevância para investigações criminais, por exemplo, naquele. A dificuldade que se impõe aos fluxos internacionais de dados, nestes casos, é justificada tanto pela aspiração de garantia de maior privacidade aos cidadãos contra ações de governos e empresas estrangeiros quanto pelo interesse dos países onde as informações estiverem alojadas de acessá-las em caráter exclusivo. No caso de persecução penal, não havendo acordo bilateral de assistência judiciária mútua, o país onde o dado gere efeitos pode não ser capaz de acessá-lo.

Os Estados têm reagido a este fenômeno de duas maneiras: ora tentam projetar suas normas para além de seu território, ora restringem a saída de dados do país (ou seja, limitam os fluxos).

Os casos de tentativa de projeção extraterritorial de normas são múltiplos, e o Brasil não é exceção neste cenário. Já se registraram imbróglios entre o poder judiciário brasileiro e a rede social Facebook ${ }^{10}$, o aplicativo Whatsapp ${ }^{11}$ e a plataforma de vídeos Youtube ${ }^{12}$, apenas para citar alguns exemplos. Em todas as situações, o poder público nacional almejava o acesso a dados ou o cumprimento de ordens judiciais que colidiam com o direito estrangeiro, no que dizia respeito à proteção de informações ou à liberdade de expressão.

O Marco Civil da Internet (lei no 12.965/2014) prevê, expressamente, em seu artigo 11, a aplicação do Direito brasileiro sobre situações em que dados tenham sido produzidos ou processados em território nacional, ainda que estejam alojados em outros países. A norma colide com regras de proteção estrangeiras, e, portanto,

10 Justiça do AM bloqueia R $\$ 38$ milhões do Facebook por não liberar dados. Disponível em: <http://g1.globo.com/am/amazonas/noticia/2016/07/mpf-am-bloqueia-r-38-milhoes-do-facebookpor-nao-liberar-dados.html>. Acesso em: 17 dez. 2016.

11 WhatsApp: Justiça do RJ manda bloquear aplicativo em todo o Brasil. Disponível em: <http://g1.globo.com/tecnologia/noticia/2016/07/whatsapp-deve-ser-bloqueado-decide-justica-do-rio. html>. Acesso em: 17 dez. 2016.

12 Justiça solicita bloqueio de site YouTube por veicular vídeo de Cicarelli. Disponível em: <http://www1.folha.uol.com.br/folha/ informatica/ult124u21292.shtml>. Acesso em: 17 dez. 2016. está longe de ser uma solução ideal para a disciplina dos fluxos de dados ${ }^{13}$.

Além da tentativa de projeção extraterritorial do Direito interno, a regulação estatal pode limitar os fluxos de informações pela restrição dos países aos quais é possível remeter dados cibernéticos - como o faz a União Europeia -; pela imposição de padrões rigorosos para o compartilhamento; pela exigência de licenças para atuar em determinado país e captar dados de seus cidadãos; ou por regras de localização. Neste caso, as empresas seriam obrigadas a manter suas centrais de processamento e armazenamento de dados (conhecidas como Data Centers) dentro do território do país onde ocorre a captura.

Após o início das revelações, em 2013, sobre a amplitude dos programas de espionagem estadunidenses ${ }^{14}$, China, Irã e Rússia já elaboraram leis de nacionalização forçada de data centers. Conseguem, assim, cumprir o citado duplo propósito: evitam o acesso aos dados de seus cidadãos por outros governos e, ao mesmo tempo, garantem a imposição de suas normas quando lhes interessar a obtenção dos dados contidos em servidores situados em seu território.

Existe uma linha muito tênue entre o que seriam interesses legítimos e medidas que representariam barreiras comerciais injustificáveis por trás de regulações como as descritas acima; por essa razão, é difícil determinar, em alguns casos, qual a real motivação das autoridades públicas.

Em relação à censura, reconhece-se que se trata de forma de expressão da ordem pública, não apenas em locais de tradição autoritária, pois, conforme se viu, a França proíbe a venda online de objetos alusivos ao ideário nazista, e o Brasil limita a divulgação de vídeos que atentem contra a honra das pessoas, mesmo que,

13 Marco Civil da Internet (lei $\left.n^{\circ} 12.965 / 2014\right)$. Art. 11. Em qualquer operação de coleta, armazenamento, guarda e tratamento de registros, de dados pessoais ou de comunicações por provedores de conexão e de aplicações de internet em que pelo menos um desses atos ocorra em território nacional, deverão ser obrigatoriamente respeitados a legislação brasileira e os direitos à privacidade, à proteção dos dados pessoais e ao sigilo das comunicações privadas e dos registros.

14 Em junho de 2013, Edward Snowden, que fora prestador de serviços a agências de Inteligência estadunidenses, deu início a uma série de vazamentos de documentos que obtivera principalmente no período em que trabalhou para a National Security Agency (NSA). As revelações de Snowden representam, provavelmente, o maior vazamento de informações sigilosas em toda a história. 
para tal, restrinja a liberdade de expressão. Contudo, a censura pode ser, também, uma forma velada de repelir concorrentes estrangeiros.

As investidas do governo chinês contra o Google $e^{15}$, por exemplo, fizeram que a empresa desistisse da maior parte de suas operações no país. Ao mesmo tempo, possibilitaram o vertiginoso crescimento de ferramenta de busca concorrente, o Baidu, pertencente a uma companhia local. estimam que "caso se imponha a um site que se mantenha fora de serviço por sete dias, ocorrerá um impacto em sua receita equivalente a $2 \%$ do faturamento anual. Em um mercado com margens estreitas, duas semanas de bloqueio são suficientes para erradicar todo o lucro anual ${ }^{16 "}$. Tal fato ocorreria justamente porque, após algum tempo, os consumidores buscariam produtos alternativos para suprir a ausência - ainda que temporária - do fornecedor excluído.

$\mathrm{Na}$ mesma linha do que se expôs até o momento, assevera que:

Com relação ao aumentado nível de medidas adotas domesticamente para proteger interesses públicos chave, como privacidade e segurança nacional, tem havido um amplo reconhecimento de que alguns deles podem ser legítimos e completamente justificáveis. Também é claro, no entanto, que outras medidas inibem o comércio digital indevidamente. Infelizmente, os Estados ainda estão tentando descobrir quais os níveis apropriados de proteção e qual o equilíbrio entre objetivos discrepantes, como a inovação do mercado e a proteção à privacidade, e ainda não há uma abordagem bem definida nem internamente e tampouco internacionalmente para a resolução destes dilemas da era digital. ${ }^{17}$. (Tradução Nossa)

15 Durante todo o imbróglio, o governo chinês manteve a alegação de que seu principal interesse seria acessar informações de dissidentes políticos cujos dados encontravam-se na nuvem cibernética administrada pelo Google. Na maioria das situações, a empresa recusou-se a fornecer os dados.

16 ERIXON, F.; HINDLEY, B.; LEE-MAKIYAMA, H. Protectionism Online: Internet Censorship and International Trade Law. Disponível em: <http://62.58.77.233/library/files/Brian and Hosuk_ EN_071109_ECIPE_Protectionism Online Internet Censorship and International Trade Law.pdf>. p. 6. Tradução nossa Texto original: "If a web site is taken out of service for seven days, it will have an impact on revenue equivalent to $2 \%$ of totalannual turnover. In a developing, low-margin market, a couple of weeks of blockage are enough to eradicate the entire annual profit".

17 BURRI, M. The international economic law framework for digital trade. Zeitschrift für Schweizerisches Recht, v. 135, n. 2, p. 10-72, 2015. p. 50. Do original: With regard to the increased level of measures adopted domestically to protect key public interests, such as privacy and national security, there has been a broad recognition that some of them may be legitimate and fully justified. It is also clear, however, that others inhibit digital trade unduly. It is unfortunate that nation states are still in the process of figuring out the appropri-
Logo, é difícil estabelecer, ao certo, qual o equilíbrio entre o autêntico interesse de defesa da ordem pública - desprovendo-se de juízo de valor quanto a diferenças entre os regimes de governo adotados pelos países e potenciais empecilhos ao comércio internacional. A formulação de uma regra geral que abranja todos os possíveis casos e esteja apta a diferenciar os fenômenos parece impossível; ao invés disso, a análise casuística das regulações é capaz de melhor elucidar o problema, na busca por sutilezas que mascarem barreiras ao comércio.

Ao se analisarem situações específicas, pode-se observar que a censura, eventualmente, é uma barreira velada. Os atritos entre o Google e o governo chinês, conforme exposto, possibilitaram o crescimento do concorrente local. A projeção extraterritorial de normas pode ser, igualmente, uma maneira de obtenção de ganhos comerciais indevidos. Ao se atribuírem poderes extraterritoriais aos órgãos investigativos - como o fizeram os Estados Unidos - cria-se a possibilidade de o aparato de Inteligência estatal ser empregado com o fim de obter informações privilegiadas sobre os processos produtivos de empresas sediadas em outros países ${ }^{18}$. Do mesmo modo, rigorosas normas locais de proteção de dados têm o condão de criar dificuldades para o acesso de empresas a mercados. ${ }^{19}$

O modelo de negócios encetado pela nuvem é, então, ameaçado por normas locais de restrição de fluxos, decorrentes do interesse declarado de proteção de dados. Em um relatório elaborado por sua assessoria jurídica, o resume o problema nos seguintes termos: "a informação é a moeda da Internet e da economia de inovações. O poder e a habilidade da internet de prover

ate levels of protection and the balance between conflicting objectives, such as market innovation and protection of privacy,and there is yet no clear-cut approach even within nation states and much less so internationally on the appropriate approach to solving these dilemmas of the digital age.

18 obre o tema: LIMA, H. A. V.; CUNHA, N. M. R. O problema da espionagem econômica internacional: seria a Organização Mundial do Comércio o foro adequado para sua apreciação? Revista Brasileira de Direito Internacional, v. 12, n. 2, p. 5-18, 2014.

19 Nesse sentido BERRY, R.; REISMAN, M. Policy Challenges of Cross-Border Cloud Computing. Journal of International Commerce, v. 4, n. 2, p. 1-38, 2012. p. 13. "Cloud providers must ensure that data storage and processing complies with laws in all relevant jurisdictions, and this can become even more complicated when data are stored and processed globally, not just in the cloud provider's home country or the customer's home country. In some cases, this complexity may limit a provider's ability to do business in multiple markets." 
benefícios, inclusive para o sistema de comércio internacional, depende do livre fluxo de informações através de toda a rede global" 20 .

Ao desconsiderar fronteiras nacionais e privilegiar a redução de custos, a metodologia de distribuição e armazenamento de conteúdos descentralizada é gravemente prejudicada por normas que restringem os fluxos de informações. Isso obriga as empresas a reorganizarem todo o processo produtivo, a incorrerem em gastos para o estabelecimento de data centers em várias jurisdições e para se adaptarem às especificidades dos diferentes ordenamentos jurídicos. Embora a motivação destas regulações nem sempre seja a imposição de barreiras comerciais, estas acabam por se tornar uma consequência, sobretudo se consideradas pequenas empresas, para as quais os custos inviabilizariam as operações em determinados países.

A mais drástica de todas as regulações restritivas é, sem dúvidas, a imposição de normas de localização de Data Centers. Em um hipotético cenário no qual todos os países as adotassem, as empresas teriam de incorrer em enormes custos para instalação de uma central de processamento de dados por país. Esse tipo de norma repele investidores estrangeiros - exceto em locais com mercados consumidores importantes - e tolhe a inovação.

\section{O Direito da OMC aplicável Às REGULAÇÕES LOCAIS SOBRE COMPUTAÇÃO NA NUVEM}

Regulações estatais não são construídas em ambientes neutros. Ao contrário, resultam de múltiplas pressões: dos cidadãos, de autoridades e órgãos públicos, da sociedade civil organizada, do setor privado interno, de investidores estrangeiros e da comunidade internacional. ${ }^{21}$

20 GOOGLE. Enabling Trade in the Era of Information Technologies: Breaking Down Barriers to the Free Flow of Information. Internet World, p. 1-25, 2010. Texto original: "information is the currency of the Internet and the innovation economy. The Internet's power and ability to deliver benefits, including to the international trading system, depends on the free flow of information across the entire global network".

21 OGUS, A. Regulation: Legal Form and Economic Theory. Portland: Hart Publishing, 2004. p. 117. "Regulatory rule-making often gives rise to what has been described as the 'polycentric problem':
Não é raro, entretanto, que aconteça o fenômeno da captura regulatória: normas estatais passam a ser elaboradas para atender majoritariamente a interesses de grupos privados imbuídos de grande poder de pressão. Neste contexto, eclodem regulações que repelem concorrentes estrangeiros em benefício de produtores nacionais. O fenômeno, embora antigo, é particularizado em relação à nuvem porque, em decorrência de sua construção dispersa, é fácil camuflar uma barreira sob o argumento da proteção à privacidade ou à segurança nacional, conforme já se explicou acima.

É na diferenciação entre a segurança e o protecionismo que se destaca o papel da OMC. A já defendida abordagem casuística do problema, por exemplo, é beneficiada pela existência de uma sistemática muito bem estabelecida de solução de controvérsias.

O Direito da OMC também provê métodos para prevenir a imposição arbitrária da regulação interna em detrimento do comércio internacional. Além das regras de Tratamento Nacional e Nação Mais Favorecida, e das regras apresentadas na introdução a este artigo, preveem-se medidas que visam a evitar o recurso ao argumento de defesa da ordem pública em caráter reiterado e, amiúde, desnecessário.

A nota de rodapé $n^{\circ} 5$ do GATS, por exemplo, é bastante lembrada pela doutrina: "A exceção de ordem pública pode ser invocada apenas quando uma ameaça genuína e suficientemente séria se apresenta perante um dos interesses fundamentais da sociedade "'n2. Nota-se a tentativa de se estabelecerem critérios para a restrição ao comércio fundada na ordem pública. O problema é que os parâmetros são abstratos ("ameaça genuína e suficientemente séria"); logo, não se prescinde da análise casuística.

Os já citados artigos XIV do GATS e XX do GATT revestem-se do mesmo espírito, ao rechaçar regulações que constituam "diferenciação arbitrária ou injustificável entre países onde condições análogas prevaleçam"²3.

issues cannot be resolved independently and sequentially; they are, rather, interdependent, and a choice from one set of alternatives has implications for preferences within other sets of alternatives. The decision-maker must take into account the whole network before she can reach a single decision."

22 Do original: "the public order exception may be invoked only where a genuine and sufficiently serious threat is posed to one of the fundamental interests of society".

23 Os textos são praticamente idênticos. Fragmentos originais: GATS, Article XIV -"Subject to the requirement that such measures 
Decisões de painéis e de órgãos de apelação já reforçaram tais regras, no sentido de atribuir ao país que impôs determinada regulação a necessidade de justificá-la e de demonstrarque as normas internas atendem aos cânones do Direito da OMC. No caso Gambling, por exemplo, entre os Estados Unidos e o arquipélago de Antigua e Barbuda, embora, ao final, o órgão de apelação tenha tolerado a filtragem de conteúdos online, determinou-se que restrições à neutralidade da rede teriam de ser justificadas pelos Estados Unidos e que não poderia haver diferenciação entre fornecedores locais e estrangeiros.

Além da imposição de filtros, outra forma que os países encontram para camuflar medidas protecionistas é a exigência de licenças prévias ao acesso a mercados por fornecedores estrangeiros. Os padrões estabelecidosterão de ser iguais para empresas nacionais e estrangeiras; contudo, ainda assim pode ser mais fácil para uma companhia adaptar-se localmente, ao passo que as firmas regionais podem, como expressão do fenômeno da captura regulatória, contribuir na formulação de normas que favoreçam seus processos produtivos específicos.

A OMC aparece, então, como importante instância para a garantia do funcionamento do modelo de computação em nuvem e de todas as vantagens que dele decorrem. Uma vez que se faz necessária a existência de acordos internacionais impositivos para, de algum modo, limita-se a discricionariedade que a soberania assegura às nações sobre seu direito interno, e dada a capilaridade da OMC, que hoje abrange a grande maioria dos países, a instituição desponta como o foro ideal. Logo, faz-se muito importante delinear com maior precisão as diferenças entre interesses estatais legítimos e o protecionismo comercial.

Também se defende a atualização das normas da OMC, para se adaptarem aos novos desafios. Tanto o GATT como o GATS foram idealizados em uma era pré-internet. Embora não sejam necessárias mudanças bruscas, sobretudo no GATT, dado seu caráter genera-

are not applied in a manner which would constitute a means of arbitrary or unjustifiable discrimination between countries where like conditions prevail, or a disguised restriction on trade in services".

GATT, article XX: "Subject to the requirement that such measures are not applied in amanner which would constitute a means of arbitrary or unjustifiablediscrimination between countries where the same conditions prevail, or adisguised restriction on international trade". lista, o GATS poderia ser atualizado para abranger mais claramente os serviços de internet. A problemática é exposta por nos seguintes termos:

A maioria das regras do GATS apenas se aplicam a setores nos quais os membros tenham firmado compromissos liberalizantes e há incertezas quanto à aplicação destes compromissos a novos serviços online. Em contraste, todas as normas do GATT, como a NMF e o Tratamento Nacional aplicam-se a todos os bens, a despeito de suas determinações tarifárias, fazendo deste um conjunto de regras mais abrangente para a regulação do comércio online. ${ }^{24}$.

Existem dificuldades para definir determinadas categorias de produtos disponíveis na internet como bens ou serviços. O exemplo mais notório, novamente, são as ferramentas de busca. Se entendidas como bens, estão sujeitas ao GATT e, por conseguinte, aos princípios da OMC. Se consideradas serviços, gerarão obrigações liberalizantes apenas para os países que se comprometeram a fazê-lo e, pior, que entendam que as ferramentas de busca se enquadram em alguma das categorias delimitadas pelo GATS em 1994.

De forma utópica, tendo em vista ser uma mudança muito brusca, poderia ser defendida que a sistemática do GATS seja alterada para uma metodologia de adesão semelhante à do GATT. ${ }^{25}$ Ao invés de listarem os setores com os quais se comprometem, os países excluiriam aqueles em relação aos quais não estariam dispostos a liberalizar o comércio. $O$ consenso entre os membros autorizaria as medidas.

Uma fórmula interessante e mais genérica foi empregada, por exemplo, no acordo bilateral de livre comércio entre Estados Unidos e Coréia do Sul:

Em reconhecimento da importância do livre fluxo
de informações na facilitação do comércio, e
cientes da importância da proteção de informações
pessoais, as partes devem esforçar-se no sentido
de evitar a imposição ou manutenção de barreiras
aos fluxos eletrônicos de informações além das
fronteiras. (Tradução nossa)

24 MELTZER, J. P. The Internet, Cross-Border Data Flows and International Trade. Issues in Technology Innovation, v. 22, p. 1-21, 2013. Do original: "most GATS rules only apply to sectors where Members have made liberalizing commitments and there is uncertainty about the application of these commitments to new online services. In contrast, all GATT rules such as the MFN and National Treatment commitments apply to all goods irrespective of their tariff bindings, making it a more comprehensive set of rules for regulating online trade".

25 WU, T. The World Trade Law of Censorshop and Internet Filtering. Chicago Journal of International Law, v. 7, n. 1, p. 263-287, 2006. 26 Do original: "Recognizing the importance of the free flow of 
Embora ainda se trate de um compromisso vago, desprovido de sanção decorrente do descumprimento, nota-se um caminho para o avanço da matéria, de uma maneira com a qual a maioria dos países poderia aquiescer. Logo, a proposição de fórmula semelhante no âmbito da OMC poderia gerar resultados positivos.

Um último ponto a se destacar é a possível contribuição da OMC à governança da internet, à medida que a organização, concebida sob caráter exclusivamente estatal, abre-se para a participação de agentes privados. Vislumbra-se o futuro deste processo como um movimento coordenado pelos Estados, mas com ampla participação dos atores não-estatais, dotados de capacidade para influenciar ativamente as decisões. ${ }^{27}$

Existem diferentes estágios de participação de ONGs na OMC. Na fase de criação de normas, as ONGs podem atuar como instituições consultivas e cooperativas, enquanto relativamente à solução de controvérsias, tem-se aceitado sua intervenção na condição de amici curiae, o que, para a autora, "abre a possibilidade não apenas de ONGs atuarem no mecanismo de solução de controvérsias, mas também permitem a introdução de novas leituras dos acordos da OMC", ${ }^{28}$

Esse modelo pode ser estendido a todos os outros agentes envolvidos na governança da internet, com o fim de propiciar-lhes efetiva participação na formulação de regras que impeçam restrição ao livre fluxo de dados - ou, ao menos, que mitiguem essas limitações quando as regulações internas forem arbitrárias ou pouco razoáveis.

\section{Considerações finais}

A discricionariedade dos países para regular a internet deve ser pautada pelas normas do comércio inter-

information in facilitating trade, andacknowledging the importance of protecting personal information, the Parties shallendeavor to refrain from imposing or maintaining unnecessary barriers to electronicinformation flows across borders." Korea-U.S. Free Trade Agreement [KORUS] art. 15.8 (Cross Border Information Flows), assinado em $1^{\circ}$ jun. 2007. Disponível em: <https://ustr.gov/tradeagreements/free-trade-agreements/korus-fta/final-text $>$. Acesso em: 17 dez. 2016.

27 Nesse sentido https://www.wto.org/french/forums_f/public_forum09_f/public_forum09_f.htm Acesso em: 04 abr. 2017. 28 SANCHEZ, M. R. Breves Considerações Sobre os Mecanismos de Participação para Ongs na Omc. Revista Internacional de Direitos Humanos, v. 4, n. 3, p. 102-125, 2006. nacional. A internet é, em essência, uma rede global, em que as informações se deslocam em ritmo acelerado e difícil de controlar. O estabelecimento de limites aos fluxos de dados, portanto, pode desvirtuar o funcionamento e a estrutura da nuvem cibernética, convertendo-a em uma série de redes isoladas. É possível conjecturar acerca de um futuro, caso o processo não seja revertido, no qual se perderão muitas das inovações e dos benefícios a elas associados que derivam do modelo de computação na nuvem.

À medida que as regulações internas mascarem mesmo que de forma não deliberada - as normas do comércio internacional, a OMC pode se afigurar como importante defesa do livre fluxo de dados. Logo, tal instituição tem um papel de grande importância na governança da internet - pode, e deve, ser mais frequentemente acionada por Estados ou, de algum modo, provocada por agentes privados, em oposição à balcanização da internet.

Os estudos, a partir desta constatação, devem centrar-se, de forma essencialmente jurídica e desprovida da influência de ideologias, no estabelecimento de limites claros, e tão concretos quanto possível, entre regulações formuladas com fins autênticos e toleradas pelo Direito da OMC, e barreiras disfarçadas ao comércio.

\section{ReferênCias}

BERRY, R.; REISMAN, M. Policy Challenges of CrossBorder Cloud Computing. Journal of International Commerce, v. 4, n. 2, p. 1-38, 2012.

BURRI, M. The international economic law framework for digital trade. Zeitschrift für Schweizerisches Recht, v. 135, n. 2, p. 10-72, 2015.

ERIXON, F.; HINDLEY, B.; LEE-MAKIYAMA, H. Protectionism Online: Internet Censorship and International Trade Law. Disponível em: <http://62.58.77.233/ library/files/Brian and Hosuk_EN_071109_ECIPE_ Protectionism Online Internet Censorship and International Trade Law.pdf $>$.

GOOGLE. Enabling Trade in the Era of Information Technologies: Breaking Down Barriers to the Free Flow of Information. Internet World, p. 1-25, 2010.

KUNER, C. Regulation of Transborder Data Flows under Data Protection and Privacy Law : Past, Present, 
and Future. OECD Digital Economy Papers, n. 187, 2011. LIMA, H. A. V.; CUNHA, N. M. R. O problema da espionagem econômica internacional: seria a Organização Mundial do Comércio o foro adequado para sua apreciação? Revista Brasileira de Direito Internacional, v. 12, n. 2, p. 5-18, 2014.

MELL, P.; GRANCE, T. The NIST definition of cloud computingNIST Special Publication. Disponível em: <http:// www.mendeley.com/research/the-nist-definitionabout-cloud-computing/>.

MELTZER, J. P. The Internet, Cross-Border Data Flows and International Trade. Issues in Technology Innovation, v. 22, p. 1-21, 2013.
OGUS, A. Regulation: Legal Form and Economic Theory. Portland: Hart Publishing, 2004.

OSAKWE, C. Future of the Multilateral Trading System: Why the Wto Remains Indispensable? Asian Journal of Wto \& International Health Law and Policy, v. 10, n. 1, p. 1-25, 2015.

SANCHEZ, M. R. Breves Considerações Sobre os Mecanismos de Participação para Ongs na Omc. Revista Internacional de Direitos Humanos, v. 4, n. 3, p. 102-125, 2006.

WU, T. The World Trade Law of Censorshop and Internet Filtering. Chicago Journal of International Law, v. 7, n. 1, p. 263-287, 2006. 


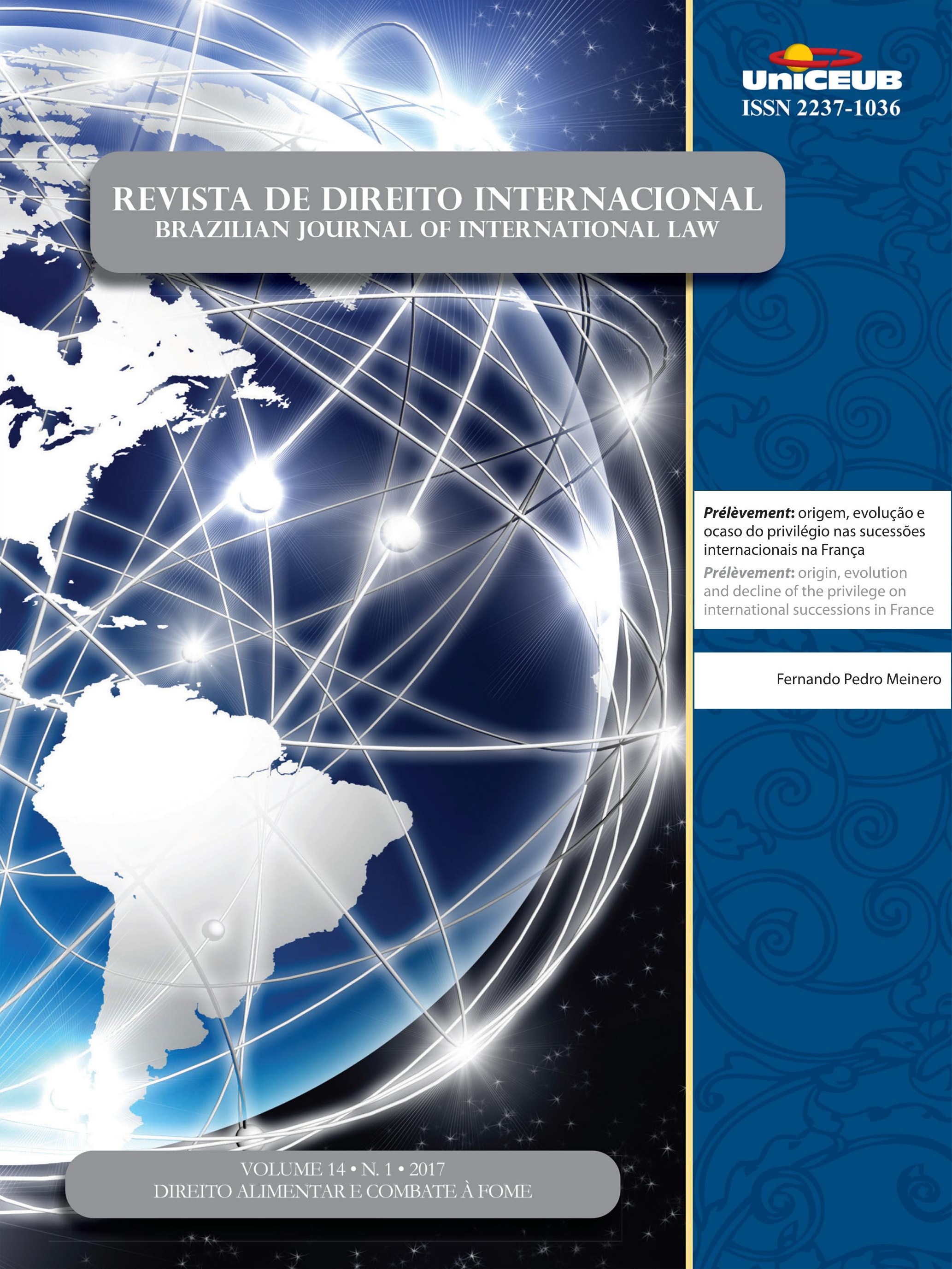




\section{Prélèvement: origem, evolução e ocaso do privilégio nas sucessões internacionais na França*}

\section{Prélèvement: origin, evolution and decline of the privilege on international successions in France}

Fernando Pedro Meinero**
* Recebido em 12/10/2016

Aprovado em 12/01/2017

** Doutor em Direito Internacional Privado pelo Programa de Pós-graduação em Direito da Universidade Federal do Rio Grande do Sul (2016). Mestre em Integração Latino-Americana pela Universidade Federal de Santa Maria (2005). Graduação em Abogacía pela Universidad Nacional del Litoral (2003), com Revalidação do Título pela Universidade Federal de Pelotas (2011). Professor Adjunto da Carreira do Magistério Superior, Classe A, Nível I, da Universidade Federal do Pampa (Campus Santana do Livramento). Participa como professor convidado do Curso de Especialização Lato Sensu "O novo Direito Internacional", da Universidade Federal do Rio Grande do Sul. Participa como professor do Curso de Especialização em Direito Empresarial na Universidade do Vale do Rio dos Sinos. Membro do Corpo Editorial da Revista Direito e Justiça Social (UVV-ES). Membro da Academia Brasileira de Direito Internacional (ABDI). Foi professor dos Cursos de Direito, Administração de Empresas e Relações Internacionais do Centro Universitário FSG, em nível de graduação e pós-graduação. Foi professor dos Cursos de Direito e Comércio Internacional da Universidade de Caxias do Sul, em nível de graduação. Tem experiência na área de Direito Internacional, com ênfase em Direito Internacional Privado, Direito da Integração Econômica, Comércio Internacional e Direito Aduaneiro. Participou do Summer Course on International Private Law 2015 - Prof. Ives Lequette - Academia de Direito Internacional de Haia - Países Baixos. Tem experiencia na Advocacia Civil, Empresarial, do Comércio Internacional e de Direito Aduaneiro. E-mail: fernandomeinero@gmail. com

\section{Resumo}

O presente artigo visa mostrar a evolução de um mecanismo de proteção a herdeiros nacionais denominado prelévèment, vigente até pouco tempo atrás no Código Civil francês. Com alguma semelhança com o benefício da lei mais favorável na legislação brasileira, o prélèvement permitia que os herdeiros franceses que tivessem sido excluídos em sucessões abertas no estrangeiro pudessem compensar esse prejuízo tomando uma porção equivalente sobre a herança aberta em território francês. Para atingir o objetivo, utiliza-se do método histórico e analisa-se o contexto em que a norma surgiu, como ela foi interpretada pela doutrina e pela jurisprudência daquele país e, finalmente, os motivos que levaram a ser declarada inconstitucional pelo Conselho Constitucional francês no ano de 2011. A análise revela uma deturpação da ideia original de proteção patrimonial de determinados herdeiros, transformado em um privilégio baseado na nacionalidade destes, contrária ao princípio da igualdade.

Palavras-chave: Evolução. Prélèvement. Princípio de igualdade. Sucessões internacionais.

\section{Abstract}

This paper deals to the evolution of the prélèvement, a legal mechanism to protect national heirs, for many years in force in the French Civil Code. With some similarity to the benefit of the more favorable law provided by the Brazilian legislation, the prélèvement allowed the French heirs who had been excluded in successions abroad, to compensate that loss by taking an equivalent portion on the assets located in the French territory. For this purpose, this paper uses the historical method and analyzes the context in which the prélèvement rule has emerged, how it was interpreted by the doctrine and the case law of the French Courts. Finally, it discusses the reasons to be declared unconstitutional by the French Constitutional Council in 2011. The analysis discloses a distortion of the original idea of patrimonial protection to certain heirs, turned into a privilege based on their nationalities, contrary to the principle of equality. 
Keywords: Evolution. International succession. Prélèvement. Principle of equality.

\section{INTRODUÇão}

No ordenamento jurídico brasileiro, uma das normas de solução de conflito de leis mais interessantes, quanto à sua natureza e os seus efeitos, é a do art. 10, $\S 1^{\circ}$, da Lei de Introdução às Normas do Direito Brasileiro (LINDB), presente, também, no art. $5^{\circ}$, inc. XXXI, da Constituição Federal de 1988. Esse último assim reza: "a sucessão de bens de estrangeiros situados no País será regulada pela lei brasileira em benefício do cônjuge ou dos filhos brasileiros, sempre que não lhes seja mais favorável a lei pessoal do 'de cujus"'. Trata-se de uma forma de proteger economicamente a família brasileira do de cujus, diante da possibilidade de que, pela aplicação lei do último domićlio ? em virtude do disposto no caput do art. 10 da LINDB, estes venham ser prejudicados na expectativa de herdar pela aplicação de uma lei estrangeira.

São muitas as críticas que podem ser direcionadas a tal regra, mas, basicamente, se ressumem ao fato de tratar-se de uma regra que promove uma discriminação entre herdeiros de diversa nacionalidade.

Tal regra não é uma originalidade do legislador brasileiro de 1942, nem da Assembleia Constituinte de 1988. De fato, ela já se fazia presente em convenções consulares celebradas pelo Brasil nos últimos anos do Império e consta nos textos constitucionais desde 1934, a despeito de algumas alterações na sua redação. Contudo, a existência de uma norma que favoreça os nacionais, na sucessão que envolve elementos estrangeiros, sobre bens situados no país, tampouco é uma originalidade brasileira. Ela encontra seu antecedente no prélèvement francês, surgido no cenário da Restauração monárquica daquele país, no ano de 1819 e inserido no Code Civil. Quase dois séculos depois, no ano de 2011, o prélèvement foi declarado inconstitucional pelo Conselho Constitucional francês.

Conduzido com apoio no método histórico, o presente estudo indaga acerca de como foi a evolução do prélèvement francês. Para tanto, busca determinar quais fatores dispararam a sua adoção na legislação civil sucessória, como ele foi interpretado pela jurisprudência francesa e quais os motivos que levaram à sua declara- ção de inconstitucionalidade.

Primeiramente, é necessário compreender o contexto e o caminho percorrido até a positivação do prélèvement em 1819. Isto ajudará a entender os motivos da sua adoção, em que se passou de um instituto destinado a marcar uma diferença entre nacional e estrangeiro a um mecanismo preocupado com a compensação dos efeitos da discriminação praticada alhures. Em um segundo momento, será possível ver que, uma vez positivada, os tribunais franceses deram uma interpretação ampla à regra, reavivando um tratamento discriminatório do estrangeiro em sucessões internacionais. Em terceiro lugar, estudar-se-á a declaração de inconstitucionalidade do instituto na França, como um claro sinal da necessidade de abandoná-lo em virtude do caráter discriminatório.

A referência às origens externas do instituto brasileiro se justifica. Coincide-se com Sixto Sanchez Lorenzo quando destaca a importância do direito comparado como ramo da ciência jurídica, especialmente quando temperado pelo método histórico, pois permite, em sua concepção clássica, um autoconhecimento de nós mesmos e do sistema jurídico nacional. ${ }^{1}$ É precisamente o que se pretende.

\section{Do diREITO dE ALBINÁGIO AO SURGIMENTO PRÉLĖVEMENT}

O prélèvement, introduzido em uma reforma ao Código Civil de Napoleão em 1819, surge após o predomínio secular de um instituto antecedente, o direito de albinágio (droit d'aubaine). ${ }^{2}$ Como será possível observar, esse último, de ser um instrumento tipicamente feudal de controle da transmissão dos direitos hereditários sobre as terras do reino, transformou-se, na França pré-revolucionária, em uma peça fundamental para a formação do Estado, servindo, internamente, para a imposição de uma submissão dos estrangeiros ao soberano pela via da naturalização e, externamente, como uma das manifestações da política externa a respeito de determinadas potências.

1 SANCHEZ LORENZO, Sixto. El derecho comparado del siglo XXI. Boletin Mexicano de Derecho Comparado, México, p. 10991107, 2008. p. 1101. Disponível em: <http://redalyc.org/articulo. oa?id=42723039034> . Acesso em: 20 mar. 2015.

2 LEWALD, Hans. Questions de droit international des successions. Recueil des cours, La Haye, v. 9, p. 1-126, 1925. p. 47-48. 


\subsection{Direito de albinágio como anti-privilégio}

Ao longo da Teoria da Soberania do Estado Moderno, proposta na obra "Os seis livros da República", Jean Bodin apresentou uma marcada distinção entre cidadão e estrangeiro. ${ }^{3}$ Encontraria, porém, dificuldades em definir o que seria um cidadão, pois deveria fazer referência a uma diversidade de prerrogativas que estes tinham, uns sobre outros. ${ }^{4}$ Era comum a presença de estamentos privilegiados e corporações em que indivíduos não partilhavam outro estatuto comum a não ser o de todos estarem sujeitos ao mesmo Rei. Maior unidade que essa não seria necessária para conformar uma República na concepção de Bodin. ${ }^{5}$ Não havia uma identidade nacional, étnica ou linguística, que pudesse servir de base ou justificativa ideológica para essa pertença e que pudesse comportar uma conotação análoga ao de cidadania contemporânea. Somente a Revolução Francesa de 1789 conseguiu eliminar o emaranhado conjunto de privilégios, liberdades, imunidades e isenções fiscais, para criar uma classe de pessoas que gozassem de direitos comuns, mudando da condição de privilegiados para cidadãos e passando de um conceito antigo a um conceito moderno de cidadania. ${ }^{6}$

A cidadania não estava definida por estatutos legais, mas ia se modelando pela via pretoriana, em processos judiciais envolvendo disputas entre cidadãos e estrangeiros nas quais se marcavam as diferenças. ${ }^{7}$ Por isso, mais do que descrever os direitos políticos e civis do

3 Para Bodin, a nota característica da cidadania é a obediência e o reconhecimento do súdito livre ao seu príncipe soberano, e a tutela, justiça e defesa do príncipe ao súdito. BODIN, Jean. Los seis libros de la República. Selección, traducción y estudio preliminar de Pedro Bravo Gala. 3. ed. Madrid: Tecnos, [1576] 1997. p. 41. Arno Dal Ri Júnior entende que na constituição da sua teoria sobre a cidadania, a pretensão de Bodin estava intimamente ligada à necessidade de instituir uma noção de poder público que viesse dar suporte à ideia de Estado absoluto. DAL RI JÚNIOR, Arno. Evolução histórica e fundamentos político-jurídicos da Cidadania. In: OLIVEIRA, Odete M.; DAL RI JÚNIOR, Arno (Org.). Cidadania e nacionalidade. Efeitos e perspectivas nacionais - regionais - globais. Ijuí: Unijuí, 2002. p. 25-84. p. 47.

4 SAHLINS, Peter. Sur la citoyenneté et le droit d'aubaine à l'époque moderne: Réponse à Simona Cerutti. Annales: Histoire, Sciences Sociales, Paris, v. 2, n. 63, p. 385-398, 2008. p. 385.

5 BODIN, Jean. Los seis libros de la República. Selección, traducción y estudio preliminar de Pedro Bravo Gala. 3. ed. Madrid: Tecnos, [1576] 1997. p. 37.

6 Etimologicamente, a palavra privilégio significa "lei particular". SAHLINS, Peter. Unnaturally French: foreign citizens in the Old Regime and After. Ithaca, NY: Cornell University Press, 2004. p. 1-3. 7 SAHLINS, Peter. Unnaturally French: foreign citizens in the Old Regime and After. Ithaca, NY: Cornell University Press, 2004. p. 1-3. cidadão no seu vínculo com o soberano como o fariam as definições dos textos constitucionais surgidos depois de 1789 - o teórico francês centrou sua distinção nas consequências negativas, nos "anti-privilégios" do estrangeiro. Assim, o cidadão seria, do ponto de vista prático, todo aquele não sujeito às incapacidades impostas aos estrangeiros residentes no território. ${ }^{8}$

De fato, os estrangeiros estavam sujeitos a diversas incapacidades. Às restrições econômicas e políticas como celebrar contrato de mútuo ou de ocupar cargos públicos - somavam-se incapacidades civis. A mais significativa dessas últimas estava representada pelo direito de albinágio (droit d'aubaine). ${ }^{9}$ Por este, dava-se ao soberano o direito de confiscar os bens de estrangeiros que falecessem no território sem deixar herdeiros nacionais..$^{10}$ Assim, uma das diferenças mais marcantes entre cidadão e estrangeiro estava dada pela possibilidade de o primeiro de transmitir seus bens de acordo com o seu direito costumeiro, ou de deixar patrimônio aos seus próximos por meio de um ato de última vontade. O estrangeiro não possuía nem um nem outro direito, pois seus herdeiros eram afastados por um ato do Estado que tomava para si o acervo hereditário, da mesma forma que o fazia diante de navios naufragados nas suas águas. ${ }^{11}$

Era lógico que fosse assim, levando-se em conta a existência de governos constituídos pelo poder político baseado em instituições familiares, ligadas ao domínio das terras. Logo, era inerente ao sistema de organização feudal impedir que estrangeiros tivessem acesso às terras locais, tendo em vista a possibilidade de uma in-

8 SAHLINS, Peter. Sur la citoyenneté et le droit d'aubaine à l'époque moderne: Réponse à Simona Cerutti. Annales: Histoire, Sciences Sociales, Paris, v. 2, n. 63, p. 385-398, 2008. p. 385; Vide também DEMANGEAT, Charles. Histoire de la condition civile des étrangers en France dans l'ancien et le nowveau droit. Paris: Joubert, Librairie da la Cour de Cassation, 1844. p. 22.

9 LEWALD, Hans. Questions de droit international des successions. Recueil des cours, La Haye, v. 9, p. 1-126, 1925. p. 47-48.

10 CERUTTI, Simona. À qui appartiennent les biens qui n'appartiennent à personne? Citoyenneté et droit d'aubaine à l'époque moderne. Annales: Histoire, Sciences Sociales, Paris, ano 62, v. 2, p. 355-383, 2007. p. 356.

11 Uma correspondência pode encontrar-se no droit de naufrage, pelo qual o senhor feudal podia se apropriar do que for salvo de navios naufragados nas proximidades das costas do seu território. A tripulação não possuía qualquer direito de reclamar por eventuais danos. Pelo contrário, a sua vida ficava à mercê do monarca, que poderia eventualmente vendê-los como escravos. BALDWIN, Simeon E. The modern 'Droit D'aubaine'. Science, Washington, v. 21, n. 532, p. 361-373, mar. 1905. p. 361. Disponível em: <http://www.jstor. org/stable/1631663?seq=1>. Acesso em: 14 fev. 2016. 
gerência política por essa via. ${ }^{12}$ Foi precisamente Jean Bodin quem destacou o direito de livre dispor dos bens ao momento da morte como o mais importante privilégio dos cidadãos perante os estrangeiros:

El más notable privilegio que tiene el ciudadano sobre el extranjero es poder hacer testamento y disponer de sus bienes según la costumbre, o dejar por herederos a sus parientes más cercanos. El extranjero no puede hacer ninguna de ambas cosas y sus bienes van a parar al señor del lugar donde muere. ${ }^{13}$

Hugo Grotius, em 1625, na sua obra basilar do direito internacional moderno "De Jure Belli ac Pacis", defenderia o direito de fazer testamento como um direito intimamente ligado ao direito de propriedade e, por sua vez, entenderia que as restrições a ele não decorriam do direito natural, mas de restrições de determinados Estados que percebiam ao estrangeiro como um inimigo. Assim, para o autor holandês, tal restrição não estava de acordo com as práticas atuais de nações civilizadas. ${ }^{14}$

\subsection{Direito de albinágio como pilar da política externa francesa}

A monarquia francesa converteu o direito de albinágio em um poderoso pilar de sua política de Estado. $\mathrm{O}$ fundamento nas antigas pretensões feudais e senhoriais se mantinha, mas, dessa vez, com uma forte conotação de reafirmação de sua soberania. Assim, Sahlins destaca:

[...] no "national" patterns of civil disabilities in the early modern period reeked as much of the feudal world as did those of France. [...] In sixteenth- and seventeenth-century France, inheritance restrictions and seigneurial prerogatives that had initially been practiced in the customary and feudal law of northern and eastern France found a renewed and revitalized existence when deployed in the

12 BALDWIN, Simeon E. The modern 'Droit D'aubaine'. Science, Washington, v. 21, n. 532, p. 361-373, mar. 1905. p. 361. Disponível em: <http://www.jstor.org/stable/1631663?seq=1>. Acesso em: 14 fev. 2016. Cabe lembrar que, conforme foi exposto no momento de tratar dos sistemas para a determinação da lei aplicável à sucessão, os estatutários franceses entendiam que a sucessão devia ser governada pela lex rei sitae. Dessa forma, o sistema conflitual sucessório era propício para a aplicação do direito de albinágio.

13 BODIN, Jean. Los seis libros de la República. Selección, traducción y estudio preliminar de Pedro Bravo Gala. 3. ed. Madrid: Tecnos, [1576] 1997. p. 41; SAHLINS, Peter. La nationalité avant la lettre. Les pratiques de naturalisation en France sous l'Ancien Régime. Annales: Histoire, Sciences Sociales, Paris, ano 55, v. 5, p. 1081-1108, 2000. p. 1084.

14 GROTIUS, Hugo. De Jure Belli ac Pacis. Oxford: Oxford University Press, [1643] 1925, v. 2. p. 266 state-building projects of the absolutist monarchy. The droit d'aubaine, in an expansive and political definition of the practice, became the centerpiece of French nationality law. This was the case in practice, in the bureaucracy of naturalization. But it was also the case in politics, where the crown appropriated the droit d'aubaine to tax the alien population of the kingdom, and thus to mark the divisions of citizens and foreigners". ${ }^{15}$

Ao ser a Coroa francesa a única competente a outorgar cartas de naturalização (lettres de naturalisation), potencializaria os efeitos do direito de albinágio, constituindo a aquisição da nacionalidade ${ }^{16}$ francesa a única via de escape. Para Peter Sahlins, é por meio do direito de albinágio que se conforma a construção do "cidadão absoluto", pois suas prerrogativas são definidas a contrario, por ser isento das restrições próprias do estrangeiro. ${ }^{17}$

Essa concepção fortalecida do direito de albinágio começa a tomar corpo ao final do S. XVI e, para o reinado absolutista de Luís XIV, já estaria, plenamente, institucionalizado e operativo desde o ponto de vista administrativo. Os anti-privilégios não se resumiriam, apenas, a questões sucessórias: consistiam em restrições econômicas, taxas especiais, limitações de cunho civil e familiar, impossibilidade de ocupar cargos, e de gozar de benefícios religiosos. ${ }^{18}$ Todo esse quadro levou milhares de estrangeiros a requererem "voluntariamente" a naturalização entre 1660 e $1789 .{ }^{19} \mathrm{O}$ valor do imposto

15 SAHLINS, Peter. Unnaturally French: foreign citizens in the Old Regime and After. Ithaca, NY: Cornell University Press, 2004. p. 6.

16 Na França, o termo "nacionalidade" aparece em primeiro lugar com os escritores românticos como Lamartine e Victor Hugo, e os historiadores de 1830 como Guizot, Thierry e Michelet, com uma conotação antropológica, pela ideia de pertença a uma comunidade definida por um conjunto de caraterísticas culturais e como uma ideia política. Por outro lado, o termo é ausente nos juristas, até o fim do S. XIX. SAHLINS, Peter. La nationalité avant la lettre. Les pratiques de naturalisation en France sous l'Ancien Régime. Annales: Histoire, Sciences Sociales, Paris, ano 55, v. 5, p. 1081-1108, 2000. p. 1082. A primeira vez que o termo apareceria no título de uma lei francesa seria com a "Loi sur la nationalité du 26 juin 1889". Para comentários sobre essa lei, vide LE SEUR, Louis; DREYFUS, Eugène. La nationalité. (droit interne): commentaire de la loi du 26 juin 1889. Paris: G. Pedone-Lauriel, 1890. p. 304

17 SAHLINS, Peter. Sur la citoyenneté et le droit d'aubaine à l'époque moderne: Réponse à Simona Cerutti. Annales: Histoire, Sciences Sociales, Paris, v. 2, n. 63, p. 385-398, 2008. p. 387.

18 De fato, em sentido amplo, a expressão droit d'aubaine compreenderia todas as disposições que governariam a condição especial do estrangeiro. WEISS, André. Manuel de droit international privé. Paris: Recueil Sirey, 1909. p. 228.

19 SAHLINS, Peter. Sur la citoyenneté et le droit d'aubaine à l'époque moderne: Réponse à Simona Cerutti. Annales: Histoire, Sciences Sociales, Paris, v. 2, n. 63, p. 385-398, 2008. p. 388. 
que o requerente devia abonar por tal naturalização seria proporcional a sua fortuna, como forma de indenizar o soberano pela perda do seu direito de albinágio. ${ }^{20}$ Assim, a carta de naturalização seria mais uma "renúncia soberana", ${ }^{21}$ do que um ato de acolhimento no território. ${ }^{22}$ É por isso que, como Peter Sahlins destaca, não houve em outro país, a não ser na França, um vínculo tão estreito entre direito de albinágio e naturalização:

Il n'y a qu'en France que le droit d'aubaine était
si intimement lié à l'exercice de la souveraineté
royale. Par conséquent, il n'y a qu'en France que la
pratique de la naturalisation était si fortement liée
au droit d'aubaine. Le «modèle français» implique
par conséquent un monopole royal sur l'octroi de
la 'nationalité' prémoderne, en théorie comme en
pratique. ${ }^{23}$

A expansão do direito de albinágio aos Estados vizinhos do território francês explica-se pelas pretensões absolutistas da Coroa. A partir do S. XVI, além de impor o direito real às províncias do Sul e do Leste, baseadas no direito romano, que reconheciam a capacidade sucessória aos estrangeiros, a França buscaria impor o direito de albinágio a outros países conquistados, a exemplo da Savoia. Se a prática foi adotada por outros Estados, o foi a modo de uma reciprocidade negativa, como represália à política expansionista da Coroa francesa. Contudo, as restrições impostas não chegavam a ser tão amplas como na França. ${ }^{24}$

Nos últimos anos do absolutismo, o direito de albinágio foi dando lugar em matéria sucessória ao direito de detração (droit de détraction). Por este, o soberano tomaria os bens do falecido se este não tivesse deixado um testamento ou se não tivesse herdeiros conhecidos no Reino. Em caso de esses últimos existirem, o soberano exerceria a detração, ou seja, retiraria, apenas, uma parte do acervo em seu favor, na forma de um imposto cobrado ao estrangeiro. Com o passar do tempo os

20 WEISS, André. Manuel de droit international privé. Paris: Recueil Sirey, 1909. p. 87; SPIRE, Alexis. Faire payer les étrangers. L'avenir d'une vieille idée. Plein droit, n. 67, p. 3-5, 2005/4. p. 3.

21 WEISS, André. Manuel de droit international privé. Paris: Recueil Sirey, 1909. p. 229.

22 CERUTTI, Simona. À qui appartiennent les biens qui n'appartiennent à personne? Citoyenneté et droit d'aubaine à l'époque moderne. Annales: Histoire, Sciences Sociales, Paris, ano 62 , v. 2, p. 355-383, 2007. p. 357.

23 SAHLINS, Peter. Sur la citoyenneté et le droit d'aubaine à l'époque moderne: Réponse à Simona Cerutti. Annales: Histoire, Sciences Sociales, Paris, v. 2, n. 63, p. 385-398, 2008. p. 389.

24 SAHLINS, Peter. Sur la citoyenneté et le droit d'aubaine à l'époque moderne: Réponse à Simona Cerutti. Annales: Histoire, Sciences Sociales, Paris, v. 2, n. 63, p. 385-398, 2008. p. 385. percentuais retidos foram se tornando mais modestos. ${ }^{25}$ Além do mais, de acordo com sua conveniência, a França, também, optou por realizar isenções coletivas desse direito de albinágio a cidadãos de determinada origem. Assim, as concedeu para certos grupos nacionais aliados - como a Escócia, aos cantões suíços católicos, ou às Províncias Unidas dos Países Baixos - ou de acordo com o lugar em que viessem a se fixar no país - para cidades como Bordeaux, Metz, Lyon, Calais, Dunkerque, Marseille ou Sarrelouis. Também se utilizaria a isenção para atrair mão de obra especializada e para povoar cidades fronteiriças ou portuárias. ${ }^{26}$

Com o aumento do comércio internacional, os países se viram na obrigação de oferecer garantias para aqueles dispostos a estabelecer relações comerciais. As garantias dadas aos mercadores mostravam a preferência dos monarcas pelos ganhos oriundos do comércio ao que pudessem obter esporadicamente por força dessa particular modalidade de aquisição de propriedade, isto é, o direito de albinágio. Entre os anos 1713 e 1802, a França celebrou numerosos tratados específicos de abolição recíproca do direito de albinágio - incluindo-se o direito de detração $-{ }^{27}$ ou como parte de tratados de Amizade, Comércio e Navegação. ${ }^{28}$

\subsection{Abolição do direito de albinágio e o surgimento do droit de prélèvement}

Para a época da Revolução Francesa, o direito de albinágio já tinha perdido importância prática por conta dos tratados bilaterais e dos decretos especiais de aboli-

25 BALDWIN, Simeon E. The modern 'Droit D'aubaine'. Science, Washington, v. 21, n. 532, p. 361-373, mar. 1905. p. 362. Disponível em: <http://www.jstor.org/stable/1631663?seq=1>. Acesso em: 14 fev. 2016.

26 SAHLINS, Peter. La nationalité avant la lettre. Les pratiques de naturalisation en France sous l'Ancien Régime. Annales: Histoire, Sciences Sociales, Paris, ano 55, v. 5, p. 1081-1108, 2000. p. 1082. Entre 1750 e 1789 o Ministério de Assuntos Exteriores francês celebraria mais de sessenta tratados bilaterais de isenção com os principais Estados da Europa. SAHLINS, Peter. Sur la citoyenneté et le droit d'aubaine à l'époque moderne: Réponse à Simona Cerutti. $A n$ nales: Histoire, Sciences Sociales, Paris, v. 2, n. 63, p. 385-398, 2008. p. 391. WEISS, André. Manuel de droit international privé. Paris: Recueil Sirey, 1909. p. 232.

27 A relação de Tratados celebrados pela França nesse período pode ser consultada em DE CLERQ, Jules. Recueil des traités de la France (1713-1802). Paris: Amyot, 1864. v. 1.

28 Assim o dispõe o art. 7 do Tratado com os Estados Unidos Amizade, Comércio e Navegação de 1880. DE CLERQ, Jules. Recueil des traités de la France. t. I. (1713-1802). Paris: Amyot, 1864. p. 402-403. 
ção para determinados estrangeiros. A sua subsistência no mundo jurídico seria considerada incompatível com o princípio de fraternidade, consagrado na Declaração de Direitos do Homem e do Cidadão. A Assembleia surgida da Revolução não poderia deixar subsistir tais incapacidades tão próprias do Antigo Regime. Por isso, pelo Decreto de 6 de agosto de 1790, se dispôs:

L'Assemblée nationale, considérant que le droit
d'aubaine est contraire aux principes de fraternité
qui doivent lier tous les hommes, quels que soient
leur pays et leur gouvernement; que ce droit, établi
dans des temps barbares, doit être proscrit chez un
peuple qui a fondé sa constitution sur les droits de
l'homme et du citoyen, et que la France libre doit,
ouvrir son sein a tous les peuples de la terre, on
les invitant à jouir sous un gouvernement libre des
droits sacres et inviolables de l'humanité, a décrété:
$1^{\circ}$ Le droit d'aubaine et celui de détraction sont
abolis pour toujours.

O mencionado decreto, focado na antiga incapacidade de transmitir do de cujus estrangeiro, não contemplava o caso de herdeiros estrangeiros que reclamassem herança no território francês, em sucessões de franceses, lacuna que seria preenchida pelo Decreto de 8 de abril de $1791 .{ }^{30}$ Finalmente, a garantia do direito dos estrangeiros de transmitir e suceder se completaria com a consagração expressa da abolição do direito de albinágio no Título VI da Constituição de 1791. ${ }^{31}$

A abolição do direito de albinágio por parte dos textos citados não fez perder de vista a possibilidade de que os nacionais franceses continuassem, no estrangeiro, a serem tratados da forma que o eram os estrangeiros na França durante o Antigo Regime. Este foi um dos aspectos a serem considerados para admitir uma igualdade de tratamento aos estrangeiros na França com base da reciprocidade. Em outras palavras, a França teria sido demasiado generosa ao abolir o direito de albinágio, consagrando o direito à sucessão hereditária como algo destinado a todos os homens, sem distinções, com

29 DEMANGEAT, Charles. Histoire de la condition civile des étrangers en France dans l'ancien et le nouveau droit. Paris: Joubert, Librairie da la Cour de Cassation, 1844. p. 239.

30 WEISS, André. Manuel de droit international privé. Paris: Recueil Sirey, 1909. p. 234.

31 FRANCE. Constitution française de 1791. Disponível em: <http://www.conseil-constitutionnel.fr/conseil-constitutionnel/ francais/la-constitution/les-constitutions-de-la-france/constitution-de-1791.5082.html.>. Acesso em: 14 fev. 2016. DEMANGEAT, Charles. Histoire de la condition civile des étrangers en France dans l'ancien et le nowveau droit. Paris: Joubert, Librairie da la Cour de Cassation, 1844. p. 242. fundamento na fraternidade. ${ }^{32}$

Essa preocupação seria, claramente, exposta nos trabalhos preparatórios do Código Civil de $1804^{33}$ e resultou no art. 11 do Código Civil de Napoleão, instalando uma igualdade condicionada que perdura na sua redação atual: «L'étranger jouira en France des mêmes droits civils que ceux qui sont ou seront accordés aux Français par les traités de la nation à laquelle cet étranger appartiendra ${ }^{34}$. Em matéria sucessória, o artigo 11 do Código Civil francês de 1804 se combinou com os art. 726 e 912 do mesmo diploma legal, de maneira tal que a faculdade do estrangeiro de realizar inventário e de receber por herança no país, ficou restrita a uma condição de reciprocidade. Isto representou um retorno sobre as concessões "imprudentemente generosas" feitas aos estrangeiros pelas Assembleias do período revolucionário, eis que as nações estrangeiras foram mais conservadoras, em vez de seguir o exemplo francês: enquanto na França os estrangeiros viram-se com plena capacidade, franceses residentes em outros países continuavam a sofrer as restrições do período pré-revolucionário. A reciprocidade estabelecida pelos art. 11, 726 e 912 era diplomática, e condicionava o tratamento do estrangeiro ao que fosse estabelecido nos tratados celebrados pela França com o seu país. Por isso, embora não se produzisse um restabelecimento do direito de albinágio, o Código de Napoleão foi menos liberal do que o direito intermediário a este respeito. ${ }^{35}$

Já no período da Restauração, a discussão dos direitos hereditários dos estrangeiros foi levantada pelo relatório de Boissy D'Anglas, apresentado à Câmara dos Pares em 22 de maio de 1819, questionando-se, por um lado, a conveniência da reciprocidade diplomática aplicável a questões da vida civil e, por outro, a possibilidade de um sistema que permita, verdadeiramente, eliminar, de forma definitiva, os resquícios do direito de albinágio. ${ }^{36}$ Meses depois, com base nessa proposta, a lei

32 WEISS, André. Manuel de droit international privé. Paris: Recueil Sirey, 1909. p. 234.

33 FENET, Pierre A. Recueil complet des travaux préparatoires du Code Civil. Paris: Marchand du Breuil, 1827. v. 7. p. 69-76.

34 FRANÇA. Code Civil. Disponível em: < http://www.legifrance. gouv.fr/telecharger_ pdf.do?cidTexte=LEGITEXT00000607072>. Acesso em: 14 fev. 2016.

35 WEISS, André. Manuel de droit international privé. Paris: Recueil Sirey, 1909. p. 237 ; LEWALD, Hans. Questions de droit international des successions. Recueil des cours, La Haye, v. 9, p. 1-126, 1925. p. 48.

36 Vide a apresentação do relatório feita por Boissy d'Anglas na sessão de 22 de maio de 1819 em MAVIDAL, M. J. Archives parlementaires de 1787 à 1860: recueil complet des débats. Deuxième série 
de 14 de julho de 1819 introduziu o prélèvement sucessório francês, permanecendo vigente por quase duzentos anos. No ano de 2011, o instituto foi declarado inconstitucional pelo Conselho Constitucional desse país.

O instituto em comento teve, na base do seu funcionamento, a observação do direito estrangeiro, incluindo suas leis, estatutos e costumes locais. A lei de 14 de julho de 1819 assim dispôs:

Article 1. Les articles 726 et 912 du Code civil sont abrogés: en conséquence, les étrangers auront le droit de succéder, de disposer et de recevoir de la même manière que les Français dans toute l'étendue du Royaume.

Article 2. Dans le cas de partage d'une même succession entre des cohéritiers étrangers et français, ceux-ci prélèveront sur les biens situés en France une portion égale à la valeur des biens situés en pays étranger dont ils seraient exclus, à quelque titre que ce soit, en vertu des lois et coutumes locales. ${ }^{37}$

O prélèvement consistiu na outorga ao herdeiro francês de uma parte da sucessão nos bens situados na França, que compensasse a exclusão que os franceses sofriam no estrangeiro, em virtude de um direito de albinágio ainda não revogado. ${ }^{38}$

$\mathrm{Na}$ sua forma de operar, para chegar ao resultado da aplicação do prélèvement, calcular-se-ia a parte que deveria receber o herdeiro francês de acordo com o direito francês, sem distinção dos bens que compusessem o patrimônio. Posteriormente, atribuir-se-ia, sobre os bens situados na França, a diferença entre essa porção e a que receberia de acordo com a lei estrangeira, considerando-se todo o patrimônio do de cujus como uma universalidade, qualquer que seja a natureza e situação dos bens. ${ }^{39}$ É por isso que o prélèvement representou, nesse aspecto, uma aproximação à unidade sucessória, contrariando a tradição francesa do fracionamento (lex rei sitae para imóveis e lexpatriae para móveis) e de incomunicabilidade das massas. ${ }^{40}$

(1800-1860). Paris: Librairie Administrative de Paul Dupont, 1873. v. 34.p. 505 e sgtes.

37 FRANÇA. Loi du 14 juillet 1819 relative à l'abolition du droit d'aubaine et de détraction. Disponível em: < http://www.legifrance. gouv.fr/affichTexte.do?cidTexte=LEGITEXT00000 6069447\&dateTexte $=20110805>$. Acesso em: 15 mars 2014 .

38 ANCEL, Bernard. Inconstitutionnalité du droit de prélèvement de l'heritier français dans les successions internationales. Revue critique de droit international privé, Paris, n. 2, p. 457-463, avr.-jun. 2013. p. 461.

39 LEWALD, Hans. Questions de droit international des successions. Recueil des cours, La Haye, v. 9, p. 1-126, 1925. p. 51.

40 BONOMI, Andrea. Successions internationales: conflits de

\subsection{O prélèvement fora da França}

Após a promulgação da lei de 14 de julho de 1819, outros países europeus adotaram mecanismos para favorecer os herdeiros nacionais em casos de albinágio. $\mathrm{Na}$ Europa, são os casos da Bélgica, ${ }^{41}$ Luxemburgo ${ }^{42} \mathrm{e}$ Alemanha. Em todos estes, o prélèvement não subsiste. ${ }^{43}$

A antiga Lei de Introdução ao Código Civil Alemão (EGBGB) continha, no seu art. 25, uma disposição de prélèvement, mas operava, de forma diferente, ainda tendo o mesmo objetivo de beneficiar os cidadãos alemães. Após estipular que um estrangeiro falecido com domicílio na Alemanha teria sua sucessão regida pelo direito da sua nacionalidade, declarava, no segundo parágrafo, que um alemão poderia fazer valer seus direitos hereditários, ainda que apenas se justifiquem de acordo com a lei alemã, a menos que, de acordo com o Direito do Estado, a que o de cujus pertencia, as leis alemãs sejam, exclusivamente, decisivas à sucessão de um alemão que tenha domicílio nesse Estado. ${ }^{44}$ Coester denominou o instituto como "privilegium germanicum" 45

Fora da Europa, ainda se encontra um prélèvement com similar redação ao original francês nos Códigos Civis de Gabão (art. 54), do Equador (art. 1036, inc. 2), do Chile (art. 998, inc. 2), de Honduras (art. 978), de El Salvador (art. 995), de Nicarágua (art. 1024). ${ }^{46}$

lois et de juridictions. Recueil des cours, La Haye, v. 350, p. 71-418, 2010. p. 159. Vide também WEISS, André. Manuel de droit international privé. Paris: Recueil Sirey, 1909. p. 296.

41 Lei de 26 abril de 1865 , relativa à reciprocidade internacional em matéria de sucessões.

42 Art. 2 da Lei de 29 de fevereiro de 1872, relativa à abolição do direito de albinágio e de détraction.

43 Em Luxemburgo o instituto foi abolido em 1951, com a adoção de uma Lei Uniforme de Direito Internacional Privado, enquanto na Bélgica foi abolido em 2004, com a adoção do Código de Direito Internacional Privado.

44 "Art. 25: Ein Ausländer, der zur Zeit seines Todes seinen Wohnsitz im Inlande hatte, wird nach den Gesetzen des Staates beerbt, dem er zur Zeit seines Todes angehörte. Ein Deutscher kann jedoch erbrechtliche Ansprüche auch dann geltend machen, wenn sie nur nach den deutschen Gesetzen begründet sind, es sei denn, daß nach dem Rechte des Staates, dem der Erblasser angehörte, für die Beerbung eines Deutschen, welcher seinen Wohnsitz in diesem Staate hatte, die deutschen Gesetze ausschließlich maßgebend sind.” WENGLER. Wilhelm. Internationales privatrecht. Berlin: de Gruyter, 1981. p. 1115. Também vide LEWALD, Hans. Questions de droit international des successions. Recueil des cours, La Haye, v. 9, p. 1-126, 1925. p. 52.

45 COESTER, Michael. International aspects on German estate law. Loyola of Los Angeles International and Comparative Law Review, Los Angeles, v. 4, p. 53-86, jan. 1981. p. 56.

46 UNION INTERNATIONAL DU NOTARIAT. World Map: 
Maiores variantes da norma se encontram nos Códigos de Civis da Argentina de 1871 (art. 3.470), do Paraguai (art. 2.448), da Colômbia (art. 1054), do Quebec (art. 3100) e na Lei de Direito Internacional Privado da Venezuela (art. 35). Nesses países, o benefício não se reduz aos nacionais, mas se estende aos estrangeiros domiciliados no país.

No caso da Argentina, o codificador Vélez Sarsfield propôs uma pequena, embora importante, alteração na regra original, valendo-se dos conceitos e críticas de Aubry e Rau à lei de 14 de julho de 1819, tal como mencionado infra. ${ }^{47}$. O art. 3.470 do anterior Código Civil daquele país ficou assim redigido:

\begin{abstract}
En el caso de división de una misma sucesión entre herederos extranjeros y argentinos, o extranjeros domiciliados en el Estado, estos últimos tomarán de los bienes situados en la República, una porción igual al valor de los bienes situados en el país extranjero de que ellos fuesen excluidos por cualquier título que sea, en virtud de leyes o costumbres locales. ${ }^{48}$
\end{abstract}

A regra, mais acorde à realidade de um país de imigração, permitia que os estrangeiros domiciliados no Estado pudessem reclamar o benefício sobre os bens situados no país, o que justificava, também, a competência dos seus tribunais de caráter forum rei sitae. ${ }^{49}$

Feldstein de Cárdenas estima que o legislador, prevendo que nem todos os ordenamentos adotariam o princípio da unidade da legislação, quis compensar os eventualmente excluídos por aqueles países cuja lei sucessória fosse a da localização dos bens e não a do último domicílio do de cujus. Por isso sustenta que, longe de ser uma exceção, trata-se de um complemento à regra da unidade. ${ }^{50}$ Em outra posição, se encontram aqueles que sustentam que o art. 3.470 traslada à Argentina o prélèvement como uma disposição totalmente independente da

Conflict of Laws in Successions. Mappemonde du rattachement en matière successorale. Notarius International, Würzburg, v. 10, n. 3, p. 3-4, 2005. Disponível em: <http://212.63.69.85/DataBase/2005/ notarius_2005_03_last.pdf $>$. Acesso em: 14 fev. 2016.

47 A nota de rodapé do art. 3.470 diz: "ley de Francia del 14 de julio de 1819", acrescentando que "sobre las razones y conceptos del artículo, véase Aubry y Rau, párrafo 592”.

48 ARGENTINA. Código Civil de la República Argentina de 1871. Con notas del Codificador Vélez Sarsfield. Disponível em: <http://www.consejosdederecho.com.ar/codigocivilanotado. htm>. Acesso em: 14 fev. 2016.

49 SCOTTI, Luciana. Derecho internacional privado. Incidencias del Código Civil y Comercial. Buenos Aires: Hammurabi, 2015. p. 245.

50 FELDSTEIN DE CÁRDENAS, Sara L. La obsolescencia del artículo 3.470 del Código Civil en materia de sucesiones internacionales. Urbi Et Ius, Buenos Aires, v. 1, n. 13, p. 63-74, jun. 2014, p. 73. luta entre os sistemas da unidade e do fracionamento. $\mathrm{O}$ artigo devia reconduzir-se à sua função histórica, que é a que teve em 1819: uma represália contra o direito estrangeiro xenófobo. ${ }^{51}$

De qualquer modo, tanto Boggiano ${ }^{52}$ como Feldstein de Cárdenas compartilham a opinião acerca do caráter anacrônico, obsoleto, do instituto. Feldstein de Cárdenas recomendou a sua derrogação em futura reforma do Código Civil, ${ }^{53}$ algo que de fato aconteceu: no CCArg./2015 o prélèvement que trazia o art. 3.470 não foi reeditado.

Nos próximos pontos, será possível observar como o prélèvement foi sendo interpretado pela doutrina e a jurisprudência francesa, uma interpretação que foi muito além do texto legal.

\section{Interpretação do Prélèvement na DOUTRINA E NA JURISPRUDÊNCIA FRANCESA}

Deixado atrás o contexto histórico que motivou sua introdução no ordenamento francês - e seu replique em outros ordenamentos do Velho e Novo Mundo -, os questionamentos que o prélèvement levantou nos tribunais já não diziam respeito a situações em que os herdeiros franceses eram, em sucessões abertas no estrangeiro, prejudicados pela aplicação do direito de albinágio. Tratava-se, de fato, de casos em que o prejuízo decorria da simples aplicação das normas de conflito de leis sucessórias, sem consideração da nacionalidade do herdeiro. Assim, a aplicação do prélèvement extravasou a hipótese de discriminação sofrida pelo francês enquanto tal em juízos sucessórios promovidos no exterior, ganhando força a sua aplicação sempre que este recebesse melhor tratamento pela lei francesa do que pela lei estrangeira. ${ }^{54}$

51 GOLDSCHMIDT, Werner. Derecho Internacional Privado. Derecho de la Tolerancia. 7. ed. Buenos Aires: Depalma, 1997. p. 371372.

52 BOGGIANO, Antonio. Derecho internacional privado. En la estructura jurídica del mundo actual. 6. ed. Buenos Aires: Abeledo Perrot, 2011. p. 412.

53 FELDSTEIN DE CÁRDENAS, Sara L. La obsolescencia del artículo 3.470 del Código Civil en materia de sucesiones internacionales. Urbi Et Ius, Buenos Aires, v. 1, n. 13, p. 63-74, jun. 2014, p. 73. 54 ANCEL, Bernard. Inconstitutionnalité du droit de prélèvement de l'heritier français dans les successions internationales. Revue critique de droit international privé, Paris, n. 2, p. 457-463, avr./jun. 2013. p. 461. 
Para entender como foi a interpretação dos tribunais franceses do dispositivo estudado, parte-se do exemplo proposto por Weiss. Imagine-se que o de cujus, ao morrer, deixou 100.000 francos em imóveis na França e 100.000 francos em imóveis na Itália. Seus herdeiros são seu pai italiano e seu irmão francês. Pelos termos da lei francesa, o pai teria direito a um quarto da sucessão e o irmão a três quartos. Já pelos termos da lei italiana, eles receberiam a metade cada um. Na partilha feita na Itália, o pai toma 50.000 francos sobre os imóveis deixados naquele país e deixa os restantes 50.000 ao seu coerdeiro. Esse último poderá reclamar a totalidade dos bens situados na França, sob o argumento de que, segundo a lei francesa, três quartos dos bens lhe pertenceriam, considerando que na Itália lhe foram negados 25.000 francos? O direito de prélèvement deveria ter lugar? Poder-se-ia dizer que o herdeiro francês foi excluído? ${ }^{55}$ Segundo o autor, três respostas poderiam ser dadas.

A primeira resposta entendeu que o prélèvement podia ser invocado sempre que o herdeiro francês fosse excluído pela sua condição de francês, tomando por base a intenção do legislador com a introdução da regra. A isso se refere quando menciona "leis e costumes locais" ("lois et contumes locales"). Como se viu, o objetivo da lei de 14 de julho de 1819 foi compensar o francês que tivesse sofrido uma exclusão no estrangeiro, por conta de um direito de albinágio ainda não revogado. Interpretar nesse caso concreto que o herdeiro francês foi excluído da sucessão resulta numa usurpação por parte da lei francesa do direito de cada Estado (no caso a Itália) de governar as sucessões de acordo com as suas leis. ${ }^{56} \mathrm{O}$ herdeiro francês foi tratado, segundo o direito italiano, como se italiano fosse, embora recebesse uma porção inferior àquela que lhe corresponderia em caso de aplicar-se à lei francesa. Ainda, seria injusto favorecer o herdeiro francês, quando o próprio sistema de direito internacional privado francês submeteu a sucessão ao direito italiano. ${ }^{57}$

Uma opinião intermediária, apoiada por Weiss, entendeu que era necessário saber qual lei devia governar a sucessão. Se fosse a lei estrangeira, não deveria invocar-se benefício. Nesse caso, o legislador francês não tinha

55 WEISS, André. Manuel de droit international privé. Paris: Recueil Sirey, 1909. p. 290.

56 WEISS, André. Manuel de droit international privé. Paris: Recueil Sirey, 1909. p. 291.

57 LEWALD, Hans. Questions de droit international des successions. Recueil des cours, La Haye, v. 9, p. 1-126, 1925. p. 50. competência para corrigir os efeitos de uma norma que não tivesse ultrapassado os limites da sua soberania. Contrariamente, se a lei francesa fosse aplicável à sucessão, o legislador deveria garantir sua plena eficácia, indenizando o herdeiro francês pelo prejuízo que lhe provocou a aplicação da lei estrangeira alhures, mediante a aplicação do instituto. ${ }^{58}$

A terceira posição é a que adotou a jurisprudência francesa, interpretando a regra de forma ampla, com base no seu texto: "por qualquer título que seja" ("a quelque titre que ce soit"). Entendeu que, pela aplicação da lei estrangeira, haveria uma exclusão do herdeiro francês nesses casos e, para corrigir essa desigualdade, esse último deveria receber na França o valor que receberia de acordo com a lei francesa. Em definitiva, operaria uma substituição da lei eventualmente aplicável pela lei francesa. ${ }^{59}$

A fração da sucessão sobre a qual o prélèvement incidiria estaria conformada, apenas, pelos bens situados na França, ou seja, pelos bens sobre os quais a ordem jurídica francesa mantém um poder de execução e sobre os quais pode evitar a aplicação do direito estrangeiro. ${ }^{60}$

No que respeita à aplicação somente em casos de concorrência entre herdeiros franceses e estrangeiros, o texto do artigo parece exigi-lo. Contrariamente, a jurisprudência admitiu o prélèvement caso apenas concorressem herdeiros franceses, e com o intuito de preservar a reserva de legítima prevista pela lei francesa. ${ }^{61} \mathrm{O}$ benefício foi admitido como fundamento para uma ação de redução por parte de um nacional francês contra o Estado francês que, apesar de não ser coerdeiro, foi beneficiado com uma doação feita pelo de cujus. ${ }^{62}$

58 WEISS, André. Manuel de droit international privé. Paris: Recueil Sirey, 1909. p. 292-293.

59 FRANÇA. Tribunal de Seine. Arrêt Alfaro. Julgamento: 26/04/1911. Paris: Clunet, 1911. p. 254-278; LEWALD, Hans. Questions de droit international des successions. Recueil des cours, La Haye, v. 9, p. 1-126, 1925. p. 50.

60 ANCEL, Bernard. Inconstitutionnalité du droit de prélèvement de l'heritier français dans les successions internationales. Revue critique de droit international privé, Paris, n. 2, p. 457-463, avr./jun. 2013. p. 460.

61 FRANÇA. Cour de Cassation. Arrêt Jeannin. Chambre civile. Julgamento: 27/04/1868. Publicação: Dalloz, 1868, p. 302. Mais recentemente esse posicionamento foi mantido em FRANÇA. Cour de Cassation. Chambre des requêtes. Julgamento: 10/05/1937. Publicação: Revue Critique de Droit International Privé, 1937, p. 637. 62 FRANÇA. Cour de Cassation. 82-15033. Première Chambre Civile. Julgamento: 20/03/1985. Paris: Bulletin, n. 103, p. 93, 1985 I. Também FRANÇA. Cour de Cassation. Première Chambre Civile. n. 95-18006. Julgamento: 03/06/1997. Paris: Bulletin, n. 180, p. 121, 
Esse posicionamento amplo do prélèvement já era alvo de críticas por parte de Weiss, no sentido de que com o pretexto da igualdade entre os herdeiros, exclui-se a aplicação de leis estrangeiras que possam governar a sucessão. ${ }^{63}$ Desse modo, o art. 2 da lei de 14 de julho 1819 foi interpretado no sentido de manter a igualdade hereditária fixada pelo Código Civil francês, confundindo-se essa igualdade com a ordem sucessória estabelecida pelo direito material francês. Aplicar-se-ia a lei francesa para corrigir os efeitos da lei sucessória estrangeira. ${ }^{64} \mathrm{~A}$ lei da nacionalidade do herdeiro, que é a lei do foro, prevaleceria sobre os princípios do DIPr sucessório.

O prélèvement interpretou-se como uma norma de DIPr que submete a sucessão ao império do direito francês, toda vez que se trate de preservar os interesses de uma pessoa de nacionalidade francesa com vocação hereditária de acordo com o direito francês. Determina-se a lei sucessória de acordo com a nacionalidade do herdeiro. ${ }^{65}$ Não foi outra a concepção dos tribunais franceses, como deixa clara a seguinte passagem de uma decisão da Corte de Apelações de Lyon: «En effet, le droit à prélèvement constitue bien un substitut de la protection de la réserve, applicable lorsque l'application d'une loi étrangère prive les héritiers réservataires français de leur droit à réserve» ${ }^{66}$.

Quanto a quem correspondia a invocação do benefício, a interpretação sempre foi restritiva, dando essa possibilidade apenas aos franceses, reforçando dessa forma a tese do privilégio. Não poderia ser alegado por estrangeiros mesmo que residentes permanentes no país. Em contrapartida, poderia ser alegado por franceses residentes no exterior ${ }^{67}$ e ainda chegou a ser admitido para um nacional francês que reclamou herança

1997 I.

63 WEISS, André. Manuel de droit international privé. Paris: Recueil Sirey, 1909. p. 295. FRANÇA. Cour de Cassation. Première Chambre Civile. n. 70-11911. Julgamento: 01/02/1972. Paris: Bulletin 1972, n. 36, p. 33; FRANÇA. Cour de Cassation. 82-15033. Première Chambre Civile. Julgamento: 20/03/1985. Paris: Bulletin 1985 I, n. 103 p. 93; FRANÇA. Cour de Cassation. Arrêt Holžberg. n. 84-16168. Première Chambre Civile. Julgamento: 04/02/1986. Paris: Bulletin, , v. 2, n. 103, 1985 I. p. 94.

64 LEWALD, Hans. Questions de droit international des successions. Recueil des cours, La Haye, v. 9, p. 1-126, 1925. p. 51.

65 LEWALD, Hans. Questions de droit international des successions. Recueil des cours, La Haye, v. 9, p. 1-126, 1925. p. 51.

66 FRANÇA. Cour d'Appel de Lyon. 10/04742. Première Chambre Civile. Julgamento: 23/12/2011. Disponível em: <http:// www.legifrance.gouv.fr/affichJuriJudi.do?idTexte=JURITE XT000025572496.>. Acesso em: 14 févr. 2016.

67 FRANÇA. Tribunal de St. Palais. Julgamento: 19/01/1884. Publicação: Clunet, 1885. p. 447. exercendo o direito de representação de um estrangeiro. ${ }^{68}$ Esse foi um dos alvos de crítica de Aubry et Rau:

Si le législateur n'avait vu, dans le prélèvement établi en faveur des Français, qu'un droit ordinaire de succession, il n'aurait pas eu de motifs pour en refuser la jouissance aux étrangers, désormais placés, quant au droit de succéder, sur la même ligne que les Français. Ce refus ne peut s'expliquer qu'en partant de l'idée que ce prélèvement constitue, d'après l'esprit de la loi du 14 juillet 1819, un privilège exclusivement attaché à la nationalité française, privilège à la jouissance duquel les étrangers ne peuvent dès lors prétendre, par cela seul qu'ils auraient été admis à établir leur domicile en France, et à y jouir des droits civils ordinaires. Si, contrairement à notre manière de voir, on voulait, à raison de cette circonstance, autoriser le prélèvement en faveur des étrangers, il faudrait les admettre à l'exercer, non seulement contre d'autres étrangers, mais même contre des Français. Cette conséquence nous paraissant inacceptable, condamne péremptoirement, à notre avis, le système qui y conduit». ${ }^{69}$

Para o exercício do prélèvement, deviam reunir-se quatro condições: o herdeiro devia ter sido excluído em todo ou em parte de uma sucessão no estrangeiro; devia ser herdeiro legítimo de acordo com a lei francesa; o prélèvement se exerceria apenas sobre os bens situados na França; quem o exercesse devia ser nacional francêss. ${ }^{70}$

Nas decisões mais recentes, todas, sem exceção, fazem referência ao benefício ser sempre em favor de nacionais franceses. É precisamente por isso que, embora procure a compensação em favor do herdeiro francês, somente visa proteger a ele, o que o torna um prélèvement nacionalista ou discriminatório. ${ }^{71}$

Paul Lagarde, no comentário ao Acórdão da $1^{\circ}$ Câmara Civil da Corte de Cassação, de 1972, já criticava fortemente esse instituto, por arcaico, recomendando a sua derrogação. ${ }^{72}$ Droz o qualificaria de "um anacronis-

68 FRANÇA. Cour de cassation. Julgamento: 20/02/1882. Paris: Sirey, 1882. p. 146.

69 AUBRY, Charles; RAU, Charles-Frederic. Cours de droit civil français. 5 ed. Paris: Marchal et Billard, 1917. v. 9. p. 408-409. (sem destaque no original).

70 FRANÇA. Conseil Constitutionnel. Décision n. 2011159 QPC. Julgamento: 05/08/2011. Journal Officiel 06/08/2011, p. 13.478. Disponível em: <www.conseil-constitutionnel.fr/ decision/2011/2011159qpc.htm.>. Acesso em: 14 févr. 2016.

71 BONOMI, Andrea. Successions internationales: conflits de lois et de juridictions. Recueil des cours, La Haye, v. 350, p. 71-418, 2010. p. 158-160.

72 LAGARDE, Paul apud FELDSTEIN DE CÁRDENAS, Sara L. La obsolescencia del artículo 3.470 del Código Civil en materia de sucesiones internacionales. Urbi Et Ius, Buenos Aires, v. 1, n. 13, p. 
mo vergonhoso", representado por uma norma que tal como foi interpretada pela jurisprudência teve seu objeto desviado. ${ }^{73}$ Afirma:

Le droit de prélèvement «nationaliste» apporte un trouble que l'on peut considérer aujourd'hui comme intolérable dans le règlement des situations internationales. Ce n'est pas l'application de la loi nationale qui nous choque car ce rattachement est suivi dans de nombreux systèmes, mais c'est l'attitude discriminatoire qui est inadmissible: l'étranger domicilié en France verra sa succession soumise à la loi française du domicile pour les meubles alors que l'héritier français pourra exiger l'application de la loi française sur la succession mobilière d'un Français domicilié á l'étranger. ${ }^{74}$

Foi essa última questão decisiva na sua declaração de inconstitucionalidade e em propostas para substituir o texto.

\section{A DECLARAÇÃo DE INCONSTITUCIONALIDADE DO PRÉLĖVEMENT}

Em data 5 de agosto de 2011, o Conselho Constitucional Francês tratou da constitucionalidade do art. 2 da lei de 14 de julho de 1819, na Decisão n. 2011 159 QPC, pela resolução de uma questão prioritária de constitucionalidade (question prioritaire de constitutionnalitê) suscitada nos casos Elke B. e La Houssaye/ sucessão de René Argereau $^{75}$ e Dana Colombier e outros/sucessão de Michel Co-

63-74, jun. 2014. p. 71.

73 DROZ, Georges A. Regards sur le droit international privé. Recueil des cours, La Haye, v. 229, 1991. p. 232.

74 DROZ, Georges A. Regards sur le droit international privé. Recueil des cours, La Haye, v. 229, 1991. p. 232.

75 O caso originou-se nos tribunais de Nice. O litígio se estabeleceu em torno da sucessão de René Argereau, falecido na Suíça no ano de 2007, país onde estava domiciliado. À sucessão concorriam a Sra. Elke Berg, viúva, e o Sr. Pierre Argereau, filho do de cujus de um anterior matrimônio. Ambos os herdeiros eram de nacionalidade francesa. O de cujus, por testamento ológrafo firmado em 1999, deixava a sua esposa tudo o que a lei suíça permitisse em seu favor. Em 1986, os esposos Argereau tinham constituído a sociedade La Houssaye, para a qual o de cujus tinha feito um aporte de capital, permitindo a compra por parte desta última de uma propriedade imobiliária em Cannes. Em 1994 o de cujus doou à Sra. Argereau as quotas que possuía nessa sociedade bem como o mobiliário e obras de arte nela existentes. $\mathrm{Na}$ perspectiva de se ver prejudicado pela aplicação da lei suíça à sucessão - em virtude de ser a lei do último domicílio do de cujus aplicável para a sucessão de bens móveis o Sr. Pierre Argereau solicitou medidas conservatórias desses bens perante os tribunais de Nice, com base no direito de prélèvement. Tais medidas foram admitidas em primeira instância. Na Corte de Apelações de Aix-en-Provence, a viúva suscitou o reenvio à Corte lombier $^{76}$.

Ambos os casos apresentam como caraterística comum a existência de herdeiros franceses em disputa com o cônjuge sobrevivente e a existência de bens móveis no território francês a serem regulados pela lei sucessória estrangeira, em virtude da última residência do de cujus. As teses sustentadas de um e outro lado não diferem das questões que a jurisprudência apreciou desde a criação dos institutos. De um lado, está quem alega que o droit de prélèvement serve para garantir a aplicação da lei francesa à sucessão, de forma a assegurar o direito dos herdeiros franceses àquilo que, por aplicação da lei estrangeira, lhes foi tirado. De outro está quem sustenta que o prélèvement desconhece o princípio da igualdade ao promover um tratamento diferente em favor dos herdeiros franceses, apenas pelo fato de serem franceses.

No caso Elke B./La Houssaye, ${ }^{77}$ a Corte de Cassação reenviou o caso ao Conselho Constitucional com a seguinte questão: se o prélèvement, instituído pelo art. 2 da lei de 14 de julho de 1819, representa um menosprezo do princípio da igualdade garantido pelo art. 6 da De-

de Cassação da Questão Prioritária de Inconstitucionalidade do prélèvement. FRANÇA. Cour d'Appel d'Aix-en-Provence. RG. n. 11/00780. Première Chambre Civile - Section C. Relator: MarieAnnick Varlamoff. Julgamento: 03/03/2011. Sem publicação.

76 Neste caso, tratou-se da sucessão do famoso compositor francês Michel Colombier, falecido em 2004 em Santa Monica, Estados Unidos, onde estava domiciliado há mais de trinta anos. Concorreram à sucessão a sua viúva, com a qual estava casado em terceiras núpcias, e seis filhos, dos quais quatro eram de relacionamentos anteriores. Em 1999 os esposos Colombier organizaram a gestão de seu patrimônio sob a forma de um trust comum, pelo qual o esposo que sobrevivesse seria único beneficiário da integralidade dos bens do casal. Na sequência, Michel Colombier registrou um testamento pelo qual outorgava todos seus bens ao trust. O patrimônio, avaliado em oito milhões de dólares, estava composto por bens móveis localizados na França e nos Estados Unidos, e imóveis situados, apenas, nesse último país. Quando da abertura da sucessão na França, os filhos exclusivos do de cujus opuseram, diante do Tribunal de Grande Instância de Paris, a reclamação de que estavam sendo deserdados pela aplicação da lei californiana, e que lhes correspondia o exercício do prélèvement sobre os bens localizados no território francês. Assim, as cessões feitas pelo de cujus em favor do trust não lhes seriam oponíveis. Em contraposição, a viúva, por direito próprio e em representação das filhas comuns com o de cujus, suscitou a inconstitucionalidade do prélèvement. FRANÇA. Tribunal de Grande Instance de Paris. RG. n. 10/14437. Deuxième Chambre Civile Section 1. Relator: Françoise Lucat. Julgamento: 15/02/2011. Sem publicação.

77 FRANÇA. Cour de Cassation. 11-40008. Julgamento: 01/06/2011. Sem publicação. Disponível em: < http://www.legifrance.gouv.fr/affichJuriJudi.do?oldAction $=$ rechJuriJudi\&idTexte $=$ JURITEXT000024119771\&fastReqId=518771874\&fastPos=1. $>$. Acesso em: 14 févr. 2016. 
claração de Direitos do Homem e do Cidadão de 1789, bem como um detrimento contra o direito de propriedade, protegido pelos arts. 2 e 17 da mesma Declaração. $\mathrm{Na}$ mesma audiência, ao tratar o caso Dana Colombier ${ }^{\text {, }}$, a Corte questionou se o prélèvement violava as liberdades e garantias previstas nos arts. 1 e 6 da Declaração de Direitos do Homem e do Cidadão de $1789^{79}$ e o art. 2 da Constituição de $1958 .{ }^{80}$

Ao responder, o Conselho Constitucional fez considerações, sendo as mais importantes as que seguem:

3. [...] que le principe d'égalité ne s'oppose ni à
ce que le législateur règle de façon différente des
situations différentes, ni à ce quil déroge à l'égalité
pour des raisons d'intérêt général pourvu que, dans
l'un et l'autre cas, la différence de traitement qui en
résulte soit en rapport direct avec l'objet de la loi
qui l'établit;»
6. Considérant qu'afin de rétablir l'égalité entre les
héritiers garantie par la loi française, le législateur
pouvait fonder une différence de traitement sur la
circonstance que la loi étrangère privilégie l'héritier
étranger au détriment de l'héritier français; que,
toutefois, le droit de prélèvement sur la succession
est réservé au seul héritier français; que la
disposition contestée établit ainsi une différence de
traitement entre les héritiers venant également à la
succession d'après la loi française et qui ne sont pas
privilégiés par la loi étrangère; que cette différence
de traitement n'est pas en rapport direct avec l'objet
de la loi qui tend, notamment, à protéger la réserve
héréditaire et l'égalité entre héritiers garanties par
la loi française; que, par suite, elle méconnait le
principe d'égalité devant la loi; ${ }^{81}$

78 FRANÇA. Cour de Cassation. 11-40010. Julgamento: 01/06/2011. Sem publicação. Disponível em: < http://www.legifrance.gouv.fr/affichJuriJudi.do?oldAction $=$ rechJuriJudi\&idTexte $=$ JURITEXT000024119772\&fastReqId $=2006219195 \&$ fastPos $=1$. $>$. Acesso em: 14 févr. 2016.

79 Dispõem tais artigos: "Art.1․ Os homens nascem e são livres e iguais em direitos. As distinções sociais só podem ter como fundamento a utilidade comum". [...] "Art. $6^{\circ}$. A lei é a expressão da vontade geral. Todos os cidadãos têm o direito de concorrer, pessoalmente ou através de mandatários, para a sua formação. Ela deve ser a mesma para todos, seja para proteger, seja para punir. Todos os cidadãos são iguais a seus olhos e igualmente admissíveis a todas as dignidades, lugares e empregos públicos, segundo a sua capacidade e sem outra distinção que não seja a das suas virtudes e dos seus talentos". FRANÇA. A Declaração dos Direitos do Homem e do Cidadão, 1789. Disponível em: <http://www.senat.fr/lng/ pt/declaration_droits_homme.html.>. Acesso em: 14 févr. 2016.

80 "Art. 2: O lema da República é "Liberdade, Igualdade e Fraternidade”. FRANÇA. Constituição de 1958. Disponível em: < http:// www.conseil-constitutionnel.fr/conseil-constitutionnel/root/bank_ $\mathrm{mm} /$ portugais / constitution_portugais.pdf.>. Acesso em: 14 févr. 2016.

81 FRANÇA. Conseil Constitutionnel. Décision n. 2011159 QPC. Julgamento: 05/08/2011. Journal Officiel 06/08/2011,
Assim, o Conselho Constitucional considerou que o art. 2 da lei de 14 de julho de 1819 é contrário à Constituição, por contrariar o princípio da igualdade de tratamento. ${ }^{82}$

Segundo Bertrand Ancel, a decisão se deu em um momento oportuno, tendo em vista os trabalhos preparatórios do R650/2012 - lembrando que o R650/2012 foi aprovado em 4 de julho de 2012 - e sobretudo a proibição de discriminação em razão da nacionalidade prevista pelo art. 18 do Tratado de Funcionamento da União Europeia. ${ }^{83}$

Em virtude da decisão do Conselho Constitucional de declarar inconstitucional o prélèvement, o Deputado Thierry Braillard apresentou, na Assembleia Nacional, o Projeto de lei n. 645, relativo à igualdade em matéria sucessória. A proposta consistia na inserção de uma Seção 1 bis "Do princípio da igualdade em matéria sucessória", propondo uma redação ao dispositivo similar à de 1819, mas estendendo o seu exercício a qualquer herdeiro, quer seja nacional, quer seja estrangeiro. ${ }^{84}$

De ponto de vista da técnica, não deixa de ser válida a constatação de Bonomi quando entende que este prélèvement "neutro" não deixa de ser um remédio excessivo e contraditório em casos de sistemas do fracionamento, como o caso da França, pois na proposta a sucessão é vista como uma unidade, algo que não seria coerente com tal sistema. ${ }^{85}$

p. 13478. Disponível em: <www.conseil-constitutionnel.fr/ decision/2011/2011159qpc.htm>. Acesso em: 14 févr. 2016.

82 FRANÇA. Conseil Constitutionnel. Décision n. 2011159 QPC. Julgamento: 05/08/2011. Journal Officiel 06/08/2011, p. 13478. Disponível em: <www.conseil-constitutionnel.fr/ decision/2011/2011159qpc.htm. > . Acesso em: 14 févr. 2016.

83 ANCEL, Bernard. Inconstitutionnalité du droit de prélèvement de l'heritier français dans les successions internationales. Revue critique de droit international privé, Paris, n. 2, p. 457-463, avr./jun. 2013. p. 459.

84 FRANÇA. Proposition de loi n. 645 relative au principe d'égalité en matière successorale. (Thierry Braillard - RDPP). Assemblée Nationale, 23/01/2013. Disponível em: <http://www. assemblee-nationale.fr/14/propositions/pion0645.asp.>. Acesso em: 23 févr. 2015.

85 O caráter excessivo se observa em sucessões envolvendo países que adotam o sistema do fracionamento, pois dá lugar a uma correção não apenas quando o sistema conduz a resultados injustos, mas em qualquer caso. Pode pensar-se no caso de uma sucessão de uma pessoa que, para manter o equilíbrio na sucessão deixa um imóvel situado na Inglaterra a um filho A, e um imóvel na França ao filho B. Em tal caso, o reparto equitativo poderia se ver desvirtuado, pois o filho A poderia reclamar seu direito à legítima determinado pela lei francesa sobre o imóvel situado nesse país. Para evitar isso, o filho B oporia o prélèvement no seu aspecto compensatório, considerando que foi excluído da sucessão sobre o imóvel na Inglaterra, e assim reequilibrar a partilha. Caso o de cujus tenha disposto deixar ao 
Pela contundência das críticas - históricas e atuais -, estima-se que não se encontrará muita receptividade em tal reforma, para um instituto, claramente, necessário em outras circunstâncias, mas que, quando o cenário original mudou, colheu muitas objeções. Feldstein de Cárdenas confirma essa posição, lendo no resultado decorrente da declaração de inconstitucionalidade uma tendência contemporânea à derrogação de institutos anacrônicos suscetíveis de provocarem uma discriminação. ${ }^{86}$

\section{Considerações Finais}

O presente estudo apresentou a evolução do prélèvement, um instituto criado a partir da necessidade de compensar o cidadão francês da prática do direito de albinágio fora da França. Por meio daquele, o herdeiro de nacionalidade francesa podia, na sucessão aberta em território francês, obter um direito igual ao que se visse privado em uma sucessão aberta no estrangeiro. A condição de nacional francês para a obtenção do benefício apoiava-se, precisamente, na condição de estrangeiro do herdeiro na sucessão aberta em outro país.

Se a ideia original do instituto era apenas uma compensação para evitar injustiças, a doutrina e a jurisprudência francesa o interpretaram de forma muito diferente da ideia original. Em verdade admitiram que, se o francês obtivesse na sucessão aberta na França menos direitos em virtude da aplicação da lei estrangeira, aplicar-se-ia a lei material francesa diretamente. A menção a uma exclusão "por qualquer título que seja" em virtude de leis e costumes locais, daria ensejo a um total afastamento da lei material estrangeira aplicável à sucessão pelas regras materiais do Code Civil. E essa substituição operaria independentemente da existência de uma sucessão aberta no estrangeiro em que o francês tivesse sido prejudicado pela sua condição de francês.

filho A todos os bens imóveis, tanto na França quanto na Inglaterra, e deserdar B, esse último reclamaria na França sua parte da herança em conceito de reserva conforme determina a lei francesa, permitindo a $\mathrm{B}$ se valer do direito francês ainda que uma parte dos bens seja em princípio governada pela lei inglesa, sem que esse corretivo seja necessário para evitar um resultado injusto. BONOMI, Andrea. Successions internationales: conflits de lois et de juridictions. Recueil des cours, La Haye, v. 350, p. 71-418, 2010. p. 125-127 e 160-161.

86 FELDSTEIN DE CÁRDENAS, Sara L. La obsolescencia del artículo 3.470 del Código Civil en materia de sucesiones internacionales. Urbi Et Ius, Buenos Aires, v. 1, n. 13, p. 63-74, jun. 2014. p. 73.
A declaração de inconstitucionalidade do prélèvement em 2011 pelo Conselho Constitucional francês provou tratar-se de um instrumento discriminatório, ou seja, contrário ao princípio da igualdade previsto no ordenamento francês e em tratados internacionais. Uma das condições de aplicação do benefício era a concorrência entre herdeiros franceses e estrangeiros. Ao apenas favorecer os primeiros, a norma convertia-se em um mecanismo de discriminação entre herdeiros, provavelmente irmãos de diversa nacionalidade. Os casos em que inconstitucionalidade foi declarada foram bastante elucidativos a esse respeito.

\section{RefERÊNCIAS}

ANCEL, Bernard. Inconstitutionnalité du droit de prélèvement de l'heritier français dans les successions internationales. Revue critique de droit international privé, $\mathrm{Pa}-$ ris, n. 2, p. 457-463, avr./juin. 2013.

ARGENTINA. Código Civil de la República Argentina de 1871. Con notas del Codificador Vélez Sarsfield. Disponível em: <http://www.consejosdederecho.com.ar/ codigocivilanotado.htm>. Acesso em: 14 févr. 2016.

AUBRY, Charles; RAU, Charles-Frederic. Cours de droit civil français. 5. ed. Paris: Marchal et Billard, 1917. t. 9.

BALDWIN, Simeon E. The modern 'Droit D'aubaine'. Science, Washington, v. 21, n. 532, p. 361-373, mar. 1905. p. 361. Disponível em: <http://www.jstor.org/ stable/1631663?seq=1 >. Acesso em: 14 févr. 2016.

BODIN, Jean. Los seis libros de la República. Selección, traducción y estudio preliminar de Pedro Bravo Gala. 3. ed. Madrid: Tecnos, [1576] 1997.

BOGGIANO, Antonio. Derecho internacional privado. En la estructura jurídica del mundo actual. 6. ed. Buenos Aires: Abeledo Perrot, 2011.

BONOMI, Andrea. Successions internationales: conflits de lois et de juridictions. Recueil des cours, La Haye, v. 350, p. 71-418, 2010.

CERUTTI, Simona. À qui appartiennent les biens qui n’appartiennent à personne? Citoyenneté et droit d'aubaine à l'époque moderne. Annales: Histoire, Sciences Sociales, Paris, ano 62, v. 2, p. 355-383, 2007.

COESTER, Michael. International aspects on German estate law. Loyola of Los Angeles International and Compa- 
rative Law Review, Los Angeles, v. 4, p. 53-86, jan. 1981.

DAL RI JÚNIOR, Arno. Evolução histórica e fundamentos político-jurídicos da Cidadania. In: OLIVEIRA, Odete M.; DAL RI JÚNIOR, Arno (Org.). Cidadania e nacionalidade: efeitos e perspectivas nacionais - regionais - globais. Ijuí: Unijuí, 2002. p. 25-84

DE CLERQ, Jules. Recueil des traités de la France: (17131802). Paris: Amyot, 1864. t. 1

DEMANGEAT, Charles. Histoire de la condition civile des étrangers en France dans l'ancien et le nouveau droit. Paris: Joubert, Librairie da la Cour de Cassation, 1844.

DROZ, Georges A. Regards sur le droit international privé. Recueil des cours, La Haye, v. 229, 1991.

FELDSTEIN DE CÁRDENAS, Sara L. La obsolescencia del artículo 3.470 del Código Civil en materia de sucesiones internacionales. Urbi Et Ius, Buenos Aires, v. 1, n. 13, p. 63-74, jun. 2014.

FENET, Pierre A. Recueil complet des travaux préparatoires $d u$ Code Civil. t. 7. Paris: Marchand du Breuil, 1827.

FRANÇA. A Declaração dos Direitos do Homem e do Cidadão, 1789. Disponível em: <http://www.senat.fr/lng/ pt/declaration_droits_homme.html>. Acesso em: 14 fev. 2016.

FRANÇA. Code civil. Disponível em: < http://www.legifrance.gouv.fr/telecharger $\_$pdf.do?cidTexte=LEGITE XT00000607072.> Acesso em: 14 févr 2016.

FRANÇA. Conseil Constitutionnel. Décision n. 2011159 QPC. Julgamento: 05/08/2011. Publicação: Journal Officiel 06/08/2011, p. 13.478. Disponível em: <www. conseil-constitutionnel.fr/decision/2011/2011159qpc. htm. >. Acesso em: 14 févr 2016.

FRANÇA. Constituição (1958). Disponível em: $<$ http://www.conseil-constitutionnel.fr/conseil-constitutionnel/root/bank_mm/portugais /constitution_ portugais.pdf.> Acesso em: 14 févr 2016.

FRANÇA. Cour d'Appel d'Aix-en-Provence. RG. n. 11/00780. Première Chambre Civile - Section C. Relator: Marie-Annick Varlamoff. Julgamento: 03/03/2011. Sem publicação.

FRANÇA. Cour d'Appel de Lyon. 10/04742. Première Chambre Civile. Julgamento: 23/12/2011. Disponível em: <http://www.legifrance.gouv.fr/affichJuriJudi.do? idTexte=JURITEXT000025572496. $>$. Acesso em: 14 févr 2016.
FRANÇA. Cour de Cassation. 11-40008. Julgamento: 01/06/2011. Sem publicação. Disponível em: <http:/ / www.legifrance.gouv.fr/affichJuriJudi.do?oldAction $=\mathrm{r}$ echJuriJudi\&idTexte $=$ JURITEXT000024119771\&fas tReqId $=518771874 \&$ fastPos $=1>$. Acesso em: 14 févr 2016.

FRANÇA. Cour de Cassation. 11-40010. Julgamento: 01/06/2011. Disponível em: <http://www.legifrance. gouv.fr/affichJuriJudi.do?oldAction $=$ rechJuriJudi\&idT exte=JURITEXT000024119772\&fastReqId $=2006219$ 195\&fastPos=1>. Acesso em: 14 févr 2016.

FRANÇA. Cour de Cassation. 82-15033. Première Chambre Civile. Julgamento: 20/03/1985. Bulletin 1985 I, n. 103 p. 93.

FRANÇA. Cour de Cassation. Arrêt Holźberg. n. 84-16168. Première Chambre Civile. Julgamento: 04/02/1986. Bulletin I, v. 2, n. 103, p. 94, 1985.

FRANÇA. Cour de Cassation. Arrêt Jeannin. Chambre civile. Julgamento: 27/04/1868. Dalloz, 1868, p. 302.

FRANÇA. Cour de Cassation. Chambre des requêtes. Julgamento: 10/05/1937. Publicação: Revue Critique de Droit International Privé, p. 637.1937.

FRANÇA. Cour de cassation. Julgamento: 20/02/1882. Sirey, v. 1, p. 146, 1882.

FRANÇA. Cour de Cassation. Première Chambre Civile. n. 70-11911. Julgamento: 01/02/1972. Bulletin, n. 36, p. 33, 1972.

FRANÇA. Loi du 14 juillet 1819 relative à l'abolition du droit d'aubaine et de détraction. Disponível em: $\quad<$ http://www.legifrance.gouv.fr/affichTexte. do?cidTexte=LEGITEXT00000 6069447\&dateTexte= 20110805 >. Acesso em: 15 mars 2014.

FRANÇA. Proposition de loi n. 645 relative au principe d'égalité en matière successorale. (Thierry Braillard RDPP). Assemblée Nationale, 23/01/2013. Disponível em: <http://www.assemblee-nationale.fr/14/propositions/pion0645.asp>. Acesso em: 23 févr. 2015.

FRANÇA. Tribunal de Grande Instance de Paris. RG. n. 10/14437. Deuxième Chambre Civile - Section 1. Relator: Françoise Lucat. Julgamento: 15/02/2011. Sem publicação.

FRANÇA. Tribunal de Seine. Arrêt Alfaro. Julgamento: 26/04/1911. Clunet, 1911.

FRANÇA. Tribunal de St. Palais. Julgamento: 
19/01/1884. Clunet, 1885.

FRANCE. Constitution française de 1791. Disponível em: $<$ http://www.conseil-constitutionnel.fr/conseil-constitutionnel/francais/la-constitution/les-constitutionsde-la-france/constitution-de-1791.5082.html>. Acesso em: 14 févr. 2016.

GOLDSCHMIDT, Werner. Derecho Internacional Privado. Derecho de la Tolerancia. 7. ed. Buenos Aires: Depalma, 1997.

GROTIUS, Hugo. De Jure Belli ac Pacis. Oxford: Oxford University Press, [1643] 1925. v. 2.

LE SEUR, Louis; DREYFUS, Eugène. La nationalité. (droit interne): commentaire de la loi du 26 juin 1889. Paris: G. Pedone-Lauriel, 1890.

LEWALD, Hans. Questions de droit international des successions. Recueil des cours, La Haye, v. 9, p. 1-126, 1925.

MAVIDAL, M. J. Archives parlementaires de 1787 à 1860: recueil complet des débats. Deuxième série (18001860). Paris: Librairie Administrative de Paul Dupont, 1873. v. 24.

SAHLINS, Peter. La nationalité avant la lettre. Les pratiques de naturalisation en France sous l'Ancien Régime. Annales: Histoire, Sciences Sociales, Paris, ano 55, v. 5, p. 1081-1108, 2000.

SAHLINS, Peter. Sur la citoyenneté et le droit d'aubaine à l'époque moderne: Réponse à Simona Cerutti. Annales: Histoire, Sciences Sociales, Paris, v. 2, n. 63, p. 385398, 2008.

SAHLINS, Peter. Unnaturally French: foreign citizens in the Old Regime and After. Ithaca, NY: Cornell University Press, 2004.

SANCHEZ LORENZO, Sixto. El derecho comparado del siglo XXI. Boletin Mexicano de Derecho Comparado, México, p. 1099-1107, 2008. p. 1101. Disponível em: http:/ / redalyc.org/articulo.oa?id $=42723039034$. Acesso em: 20 marzo 2015.

SCOTTI, Luciana. Derecho internacional privado. Incidencias del Código Civil y Comercial. Buenos Aires: Hammurabi, 2015.

SPIRE, Alexis. Faire payer les étrangers. L'avenir d'une vieille idée. Plein droit, n. 67, p. 3-5, 2005/4.

UNION INTERNATIONAL DU NOTARIAT. World Map: Conflict of Laws in Successions. Mappemonde du rattachement en matière successorale. Notarius International, Würzburg, v. 10, n. 3, p. 3-4, 2005. Disponível em: http://212.63.69.85/DataBase/2005/ notarius_2005_03_last.pdf. Acesso em: 14/02/2016.

WEISS, André. Manuel de droit international privé. Paris: Recueil Sirey, 1909.

WENGLER. Wilhelm. Internationales privatrecht. Berlin, New York: de Gruyter, 1981. 


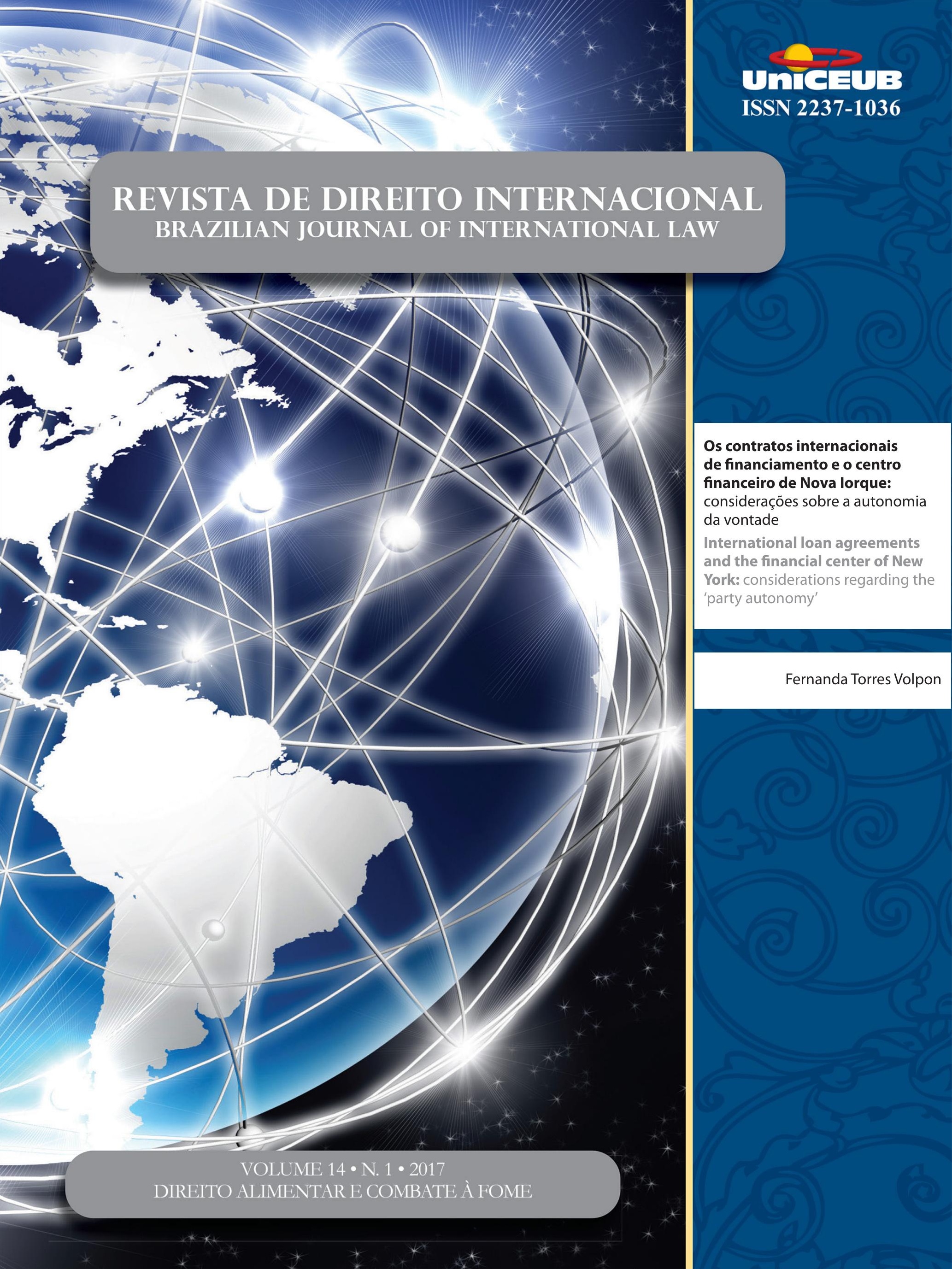




\title{
Os contratos internacionais de financiamento e o centro financeiro de Nova Iorque: considerações sobre a autonomia da vontade*
}

\author{
International loan agreements and the \\ financial center of New York: considerations \\ regarding the 'party autonomy'
}

Fernanda Torres Volpon **

\section{Resumo}

Este artigo possui como objetivo analisar o exercício da autonomia privada nos contratos internacionais de financiamento, verificando a hipótese de uma possível preferência pelo foro e leis de Nova Iorque e, caso exista, as razões para essa escolha e o problema do posicionamento dos tribunais norte-americanos em relação ao exercício da autonomia da vontade nessa espécie contratual. Aplica-se a metodologia jurídico-dogmática, utilizando-se como marco teórico a construção de um estudo dos temas da escolha da lei aplicável e eleição de foro permeado por uma análise empírica realizada pelos autores norte-americanos Theodore Eisenberg e Geoffrey Miller. Conclui-se que, não por acaso, os contratos internacionais de financiamento apresentam cláusulas de eleição de foro com competência para os tribunais de Nova Iorque, mesmo sem qualquer elemento de conexão com este território, tradicionais do Direito Internacional Privado. Evidencia-se, na verdade, uma 'corrida' dos atores privados para o centro financeiro de Nova Iorque influenciado, entre outros fatores, pelo resultado de um esforço político-regulatório do próprio Estado de Nova Iorque. O exercício da autonomia da vontade, nesse sentido, resulta de um processo de interesse econômico e desejo por segurança jurídica que os atores privados buscam na aplicação das leis de Nova Iorque nas suas controvérsias financeiras. $\mathrm{O}$ posicionamento dos tribunais de Nova Iorque coaduna com o interesse dos atores privados ao se auto-afirmarem como centro 'financeiro-judicial' e consagrarem o respeito pela escolha da lei e eleição do foro por partes estrangeiras sem apresentar um elemento de conexão, posicionamento este inovador em relação à tradicional doutrina do método de conflito de leis.

Palavras-Chave: Lei Aplicável. Eleição de Foro. Contratos de Financiamento. Autonomia da Vontade.

Recebido em 12/11/2016

Aprovado em 19/01/2017

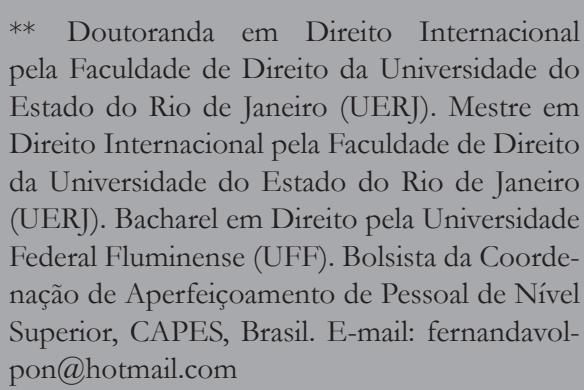

\section{Abstract}

This paper is focused on the analysis of the exercise of party autonomy in the international loan agreements, looking at the hypothesis of a real 
inclination for the forum and laws of New York by the contractual parties and, if existent, the reasons for such preference and the position of American courts in relation to the exercise of party autonomy in this type of agreements. The methodology applied in this paper is the dogmatic legal method, using the theory constructed by the study of choice of law and choice of forum influenced by the empirical analysis produced by the American authors Theodore Eisenberg e Geoffrey Miller. The conclusion demonstrates that, not by chance the international loan agreements include choice of forum clauses electing the New York State Courts without any relationship to the American territory a traditional element of international private law doctrine. In reality, it is possible to verify a 'race' by the private actors directed to the financial center of New. On the one hand, the exercise of party autonomy results in a process of economic interest and hunger for legal security that the private actors look for when applying the laws of New York to their financial disputes. On the other hand, New York Courts have positioned themselves in the same sense of private actors by auto declaring as the center of financial-judicial matters reaffirming that choice of law and choice of forum clauses made by foreign parties will prevail in the New York Courts without presenting a relationship with the American territory, an innovative position in relation to the traditional conflict of laws method.

Keywords: Governing Law. Choice of Forum. Loan Agreements. Party Autonomy.

\section{INTRODUÇÃO}

A negociação de contratos internacionais envolvendo vultuosas quantias e alto risco de retorno acabam por levar a um caminho tortuoso das batalhas das formas. ${ }^{1}$ As discussões negociais começam desde a proposta e perduram ao longo de toda a fase contratual. Trata-se de um embate dificultoso, que pode gerar consequências jurídicas relevantes para ambas as partes. ${ }^{2}$

1 RIBEIRO, Marilda Rosado de Sá. Batalha das formas e negociação prolongada nos contratos internacionais. In: RODAS, João Grandino (Coord.). Contratos Internacionais. 3. ed. rev. atual. e ampl. São Paulo: Revista dos Tribunais, 2002. p. 251-282, p. 264.

2 RIBEIRO, Marilda Rosado de Sá. Batalha das formas e negociação prolongada nos contratos internacionais. In: RODAS, João Grandino (Coord.). Contratos Internacionais. 3. ed. rev. atual. e ampl.
Ao longo do tempo, a conscientização dos operadores de mercado diante das dificuldades negociais culminou em uma necessária uniformização. Entende-se que trazer uniformidade para os contratos e suas cláusulas resultaria em eficiência, reduzindo custos para os envolvidos. Nessa esteira, conclui-se que a escolha de leis eficazes, sofisticadas e práticas gerariam segurança jurídica para que as partes tivessem a tão desejada previsibilidade nas suas transações comerciais. O impacto econômico dessas escolhas é evidente, tornando-se fator relevante não só para o departamento jurídico de diversas empresas, mas também para as suas áreas comerciais.

Compreendendo a necessidade do mercado, o Estado de Nova Iorque soube atrair as negociações e as discussões judiciais para o seu foro. Nova Iorque se tornou não só o centro financeiro, como também o centro judicial para as controvérsias no âmbito dos contratos internacionais de financiamento.

Assim, consolidaram-se as cláusulas de 'governing law'3 $^{3}$ e 'jurisdiction'4 para se aplicar as leis de Nova Iorque e se eleger o foro de Nova Iorque na grande maioria dos contratos comerciais. Essas Cláusulas se tornaram parte dos contratos padronizados das associações privadas para financiamentos internacionais. Além das instituições norte-americanas, diversos atores privados estrangeiros passaram a incluir essas cláusulas em seus contratos, sem que houvesse qualquer elemento de conexão com os Estados Unidos. Surgiu, então, o receio fundado sobre a reação dos tribunais a respeito do exercício da autonomia privada, problemática jurídica integrante deste trabalho. Surgiu o questionamento se os tribunais de Nova Iorque iriam respeitar a escolha das partes: valeria a autonomia da vontade mesmo quando não fosse identificado qualquer elemento de conexão na relação contratual com o território norte-americano?

Portanto, o objetivo deste trabalho consiste em (i) tratar das razões para os contraentes de transações "cross-border" ${ }^{5}$ optarem pelas cláusulas de lei aplicável

São Paulo: Revista dos Tribunais, 2002. p. 251-252.

3 Cláusula de lei aplicável (tradução livre).

4 Cláusula de eleição de foro (tradução livre).

5 No contexto desse trabalho, utiliza-se o termo "cross-border" para transações de financiamento envolvendo partes estrangeiras, sem elemento de conexão com o território norte-americano, caracterizadas como transfronteiriças. Neste caso, o credor e o devedor estariam fora dos Estados Unidos, mas a cláusula de eleição de foro e a escolha da lei aplicável seriam de Nova Iorque. "Como os contratos internacionais de empréstimo envolvem mais de uma jurisdição, os credores, na maioria das vezes, vão escolher a lei que eles consid- 
e eleição de foro integrantes nos modelos contratuais modernos, assim como (ii) analisar o posicionamento atual dos tribunais de Nova Iorque perante o exercício da autonomia da vontade nesses tipos contratuais.

Para tanto, esse trabalho foi dividido em três partes principais. Na primeira seção, procurou-se traçar um panorama sobre a autonomia da vontade na escolha da lei aplicável e eleição de foro. Neste primeiro momento, foram feitas breves considerações sobre como o tema é tratado no Brasil e no direito internacional para melhor compreensão do mesmo. A segunda seção discorre sobre a visão econômica determinante para escolha da lei aplicável aos contratos internacionais e eleição do foro. Ao contrário de se entender como uma decisão meramente jurídica, trata-se de um debate que alcança o nível comercial diante dos impactos financeiros que essa escolha pode causar. A terceira seção, por fim, traça os aspectos gerais sobre o direito norte-americano para definição de competência dos seus tribunais e se a autonomia da vontade na escolha da lei aplicável e eleição de foro do Estado de Nova Iorque é respeitada pelos tribunais nova-iorquinos. Procura-se traçar uma perspectiva sobre a motivação legislativa e reforma institucional realizada em Nova Iorque para atrair negócios e garantir a segurança jurídica para os operadores de mercado.

\section{Breves Considerações sobre Lei Aplicável e Eleição de Foro na Doutrina Brasileira}

O estudo mais aprofundado dos contratos internacionais de financiamento depende de algumas reflexões prévias sobre os aspectos fundamentais dos contratos internacionais: a escolha da lei aplicável e a eleição de foro. Não se objetiva travar discussões sobre a possibilidade de se exercer, no âmbito do direito brasileiro, a autonomia da vontade na celebração dos contratos internacionais, tema de antigo debate na doutrina, ${ }^{6}$ mas

eram mais benéfica". ROCHA, Dinir Salvador Rios de. Contrato de empréstimo internacional. São Paulo: Saraiva, 2013. p. 170. Observa-se, ainda, que as partes envolvidas nesses tipos de contratos são sofisticadas e não envolvem consumidores.

6 Nesse sentido, ver "uma das questões mais candentes no autal estágio de desenvolvimento do Direito Internacional Privado, notadamente no Brasil, é a incorporação do princípio da autonomia da vontade na celebração dos contratos internacionais, de forma a permitir aos contratantes a escolha da lei de regência de seu acordo, independentemente de outros elementos de conexão." NARDI, Marcelo de. Eleição de foro: Uma visão brasileira. In: RODAS, João sim apresentar seus aspectos fundamentais e posicionar esse tema de forma introdutória.

Preliminarmente, destaca-se que a escolha da lei aplicável não se confunde com a eleição de foro, já que a lei aplicável se refere ao direito que regerá a relação entre as partes e a interpretação das cláusulas contratuais. ${ }^{7} \mathrm{O}$ foro eleito, por sua vez, será aquele determinado para solucionar eventual controvérsia a respeito do contrato submetido a litígio, onde tramitará ação judicial. ${ }^{8}$ Os dois temas formam parte do núcleo da disciplina do direito internacional privado, ${ }^{9}$ disciplina esta que se preocupa em tratar dos conflitos de jurisdição em casos que apresentam elementos de estraneidade e conflitos de lei. Ambos os tópicos são de vital importância para que se determine "em que local acionar" e "qual a lei aplicável” ao caso vertente. ${ }^{10}$

Grandino (Coord.). Contratos Internacionais. 3. ed. rev. atual. e ampl. São Paulo: Revista dos Tribunais, 2002. p. 125. "Uma das questões mais discutidas em DIPr diz respeito à determinação da lei aplicável aos contratos internacionais". ARAUJO, Nadia de. A necessária mudança do artigo 9o da LINDB: o avanço que faltava para a consagração da autonomia da vontade no DIPr brasileiro. In: RAMOS, André de Carvalho (Org.). Direito Internacional Privado: Questões Controvertidas. Belo Horizonte: Arraes Editores, 2015. p. 289-309, p. 289. Sobre a controvérsia, ver também: FRANCESCHINI, José Inácio. A lei e o foro de eleição em tema de contratos internacionais. In: RODAS, João Grandino (Coord.). Contratos Internacionais. 3. ed. rev. atual. e ampl. São Paulo: Revista dos Tribunais, 2002. p. 6775. Nadia de Araujo trata do aspecto jurisprudencial em seu artigo. ARAUJO, Nadia de. Contratos Internacionais e a jurisprudência brasileira: Lei aplicável, ordem pública e cláusula de eleição de foro. In: RODAS, João Grandino (Coord.). Contratos Internacionais. 3. ed. rev. atual. e ampl. São Paulo: Revista dos Tribunais, 2002. p. 202-208. 7 "Curial é constatar a existência de duas liberdades essenciais na contratação internacional: 1.) a de escolher a lei aplicável ao contrato; e 2.) a de escolher o foro a que as partes submeter-se-ão para dirimir as disputas que possam surgir". Equanto a primeira é de direito material, a segunda é eminentemente de conotação processual. NARDI, Marcelo de. Eleição de foro: Uma visão brasileira. In: RODAS, João Grandino (Coord.). Contratos Internacionais. 3. ed. rev. atual. e ampl. São Paulo: Revista dos Tribunais, 2002. p. 129. Carmen Tiburcio e Jacob Dolinger também ressaltam que "a determinação da lei aplicável é, portanto, assunto distinto da competência jurisdicional e não se podem confundir esses dois objetos". DOLINGER, Jacob; TIBURCIO, Carmen. Direito Internacional Privado: Parte Geral e Processo Internacional. 12. ed. rev. atual. e ampl. Rio de Janeiro: Forense, 2016. p. 556.

8 GARCIA JUNIOR, Armando Alvares. Lei aplicável aos contratos internacionais. 2. ed. São Paulo: Aduaneiras, 2004. p. 6-7.

9 "O Direito Internacional Privado possui, como visto anteriormente, quatro objetos de estudo distintos. Entre estes destacam-se a determinação da lei aplicável às relações jurídicas interjurisdicionais e, no âmbito do direito processual internacional, a fixação da competência internacional da autoridade judiciaria local”. DOLINGER, Jacob; TIBURCIO, Carmen. Direito Internacional Privado: Parte Geral e Processo Internacional. 12. ed. rev. atual. e ampl. Rio de Janeiro: Forense, 2016. p. 556.

10 ARAUJO, Nadia de. Direito Internacional Privado: Teoria e 
Respeitando o critério cronológico da disciplina de processo civil internacional, ${ }^{11}$ decidiu-se por realizar a análise, em primeiro lugar, da "fixação da competência internacional" e, em segundo lugar, da determinação da lei aplicável.

A dificuldade de se tratar do tema da eleição de foro se deve ao fato de que esse tema encontra-se na "seara do direito público, na medida em que se cuida do exercício da atividade jurisdicional, uma das funções da soberania do Estado". ${ }^{12}$ No entanto, não se pode deixar de reconhecer a importância do exercício da autonomia da vontade dos atores privados nesse cenário.

Quanto à eleição de foro, destaca-se que existem duas possibilidades de exercício da autonomia da partes: positiva e negativa. Nesse sentido, esclarecem Jacob Dolinger e Carmen Tibúrcio:

as partes podem atuar tanto inserindo hipótese não prevista na norma interna sobre o exercício da função jurisdicional (efeitos positivos) quanto afastando a jurisdição, em hipótese prevista na legislação local, com escolha de foro estrangeiro para conhecer do litígio (efeitos negativos. ${ }^{13}$

No direito brasileiro, o legislador determinou as hipóteses de competência internacional concorrente da jurisdição brasileira nos artigos 21 e 22 do Código de Processo Civil de $2015^{14}$ e competência internacional exclusiva no artigo 23 do mesmo diploma legal. Nádia de Araújo destaca que, a cláusula de eleição de foro deve ser analisada juntamente com as regras de competência internacional previstas no Código de Processo Civil brasileiro (CPC).$^{15}$ Isto porque, nos casos de competência internacional exclusiva da jurisdição brasileira, a de-

Prática Brasileira. 6a ed., atual. e ampl. Porto Alegre: Revolução eBook, 2016, p. 77-78.

11 DOLINGER, Jacob; TIBURCIO, Carmen. Direito Internacional Privado: Parte Geral e Processo Internacional. 12. ed. rev. atual. e ampl. Rio de Janeiro: Forense, 2016. p. 556.

12 DOLINGER, Jacob; TIBURCIO, Carmen. Direito Internacional Privado: Parte Geral e Processo Internacional. 12. ed. rev. atual. e ampl. Rio de Janeiro: Forense, 2016. p. 570.

13 DOLINGER, Jacob; TIBURCIO, Carmen. Direito Internacional Privado: Parte Geral e Processo Internacional. 12. ed. rev. atual. e ampl. Rio de Janeiro: Forense, 2016. p. 570.

14 Destaca-se que as hipóteses do artigo 88 do Código de Processo Civil de 1973 foram fielmente reproduzidas no art. 21 do Código de Processo Civil de 2015 (CPC de 2015). No entanto, novas hipóteses foram acrescentadas no art. 22 do CPC de 2015 sem correspondência com o CPC anterior.

15 ARAUJO, Nadia de. Contratos Internacionais e a jurisprudência brasileira: Lei aplicável, ordem pública e cláusula de eleição de foro. In: RODAS, João Grandino (Coord.). Contratos Internacionais. 3. ed. rev. atual. e ampl. São Paulo: Revista dos Tribunais, 2002. p. 213. cisão estrangeira não terá eficácia. ${ }^{16}$

Nos casos de competência internacional concorrente, a doutrina brasileira, de forma majoritária, admitia a eleição de foro indistintamente quanto àquelas com efeitos positivos e negativos. ${ }^{17}$ Por outro lado, a jurisprudência tomou posicionamentos controvertidos no momento de julgar contratos que apresentavam cláusula de eleição de foro. ${ }^{18}$ Diante da instabilidade das decisões do Superior Tribunal de Justiça (STJ), as partes acaba-

16 "se a cláusula referente à escolha de outro foro for pactuada considerando alguma das competências arroladas no artigo 89, a cláusula não seria válida, pois estaria usurpando do Estado o seu exercício de atividade jurisdicional". XAVIER JUNIOR, Ely Caetano; CASTRO, Emília Lana de Freitas. A competência internacional e a eleição de foro no projeto do novo código de processo civil brasileiro. Revista do Instituto do Direito Brasileiro, Lisboa, ano 2, n. 8, p. 79858022, 2013. Disponível em: < http://www.cidp.pt/publicacoes/ revistas/ridb/2013/08/2013_08_07985_08022.pdf>. Acesso em: 03 out. 2016. p. 8012.

17 Luiz Olavo Baptista trata de aspectos teoricos e práticos do tema. BAPTISTA, Luiz Olavo. Dos contratos internacionais: uma visão teórica e prática. São Paulo: Saraiva, 1994. p. 48-49. SOUZA JUNIOR, Lauro da Gama. Autonomia da vontade nos contratos internacionais no Direito Internacional Privado brasileiro: Uma leitura constitucional do artigo $9^{\circ}$ da Lei de Introdução ao Código Civil em favor da liberdade de escolha do direito aplicável. In: TIBURCIO, Carmen; BARROSO, Luís Roberto (Org.). O direito internacional contemporâneo: estudos em homenagem ao professor Jacob Dolinger. Rio de Janeiro: Renovar, 2006. p. 605-608. Carmen Tiburcio cita os doutrinadores Serpa Lopes, Haroldo Valladão, Helio Tornaghi, Irineu Strenger, Arruda Alvim, Nadia de Araújo, entre outros, como favoráveis à cláusula de eleição de foro. TIBURCIO, Carmen. A eleição de foro estrangeiro e o judiciario brasileiro. Revista de Arbitragem e Mediação, São Paulo, v. 6, n. 21, p. 84-113, abr./jun. 2009. Lembra, ainda, que em posição oposta, contrariamente à admissão da cláusula de eleição de foro. DOLINGER, Jacob; TIBURCIO, Carmen. Direito Internacional Privado: Parte Geral e Processo Internacional. $12^{\mathrm{a}}$ ed. rev., atual. e ampl. Rio de Janeiro: Forense, 2016, p. 575 .

18 Destacam os autores que, na década de 50, o Supremo Tribunal Federal "assumiu posição inovadaora e admitiu expressamente a escolha de foro uruguaio em contrato celebrado para ser cumprido no Brasil". No entanto, como ressaltam os autores, diversas decisões do STJ posteriores desconsideraram a eleição de foro estrangeiro. DOLINGER, Jacob; TIBURCIO, Carmen. Direito Internacional Privado: Parte Geral e Processo Internacional. 12. ed. rev. atual. e ampl. Rio de Janeiro: Forense, 2016. p. 575. Nádia de Araújo destaca o posicionamento incerto da jurisprudência brasileira no tocante à consagração da cláusula de eleição de foro: "Até então, a possibilidade de a Justiça brasileira ceder ou não espaço a um foro estrangeiro escolhido pelas partes era objeto de controvérsias, adotando os tribunais um posicionamento vacilante, que ora aceitava a escolha das partes e ora decidia que as regras do artigo 88 não autorizavam o afastamento da atuação da Justiça nacional diante de uma das hipóteses de competência concorrente". ARAUJO, Nadia; SPTIZ, Lidia; NORONHA, Carolina. O novo CPC nas relações internacionais. Jornal Valor Econômico, 13 de jan. de 2015. Disponível em: <http://www.valor.com.br/legislacao/3856442/o-novo-cpc-nasrelacoes-internacionais>. Acesso em 04 out. 2016. 
vam por se sentirem inseguras "no momento da celebração de contratos com elementos de estraneidade", 19 uma vez que não saberiam assegurar se a eleição de foro seria respeitada ou não pelo judiciário brasileiro.

O CPC de 2015, por sua vez, consagrou a possibilidade do exercício da autonomia privada no tocante à eleição de foro. ${ }^{20}$ Dessa forma, o referido diploma permitiu a eleição de foro com efeitos positivos no âmbito do artigo 22, "acarretando a competência concorrente do Judiciário brasileiro" 21 e, com efeitos negativos no âmbito do artigo 25 "que ensejam a incompetência do Judiciário brasileiro quando houver foro eleito no exterior". ${ }^{22}$ Observa-se que, a escolha do foro deve ser exclusiva, nos termos do artigo 25 do CPC de 2015. Assim, existem dois requisitos para a validade da cláusula de eleição de foro: "o acordo seja expresso e ainda explicite que se trata de uma cláusula exclusiva", ${ }^{23}$ com objetivo de se evitar que a eleição de foro seja interpretada como "mera obrigação de fazer".

Portanto, conclui-se que o tema da possibilidade de as partes determinarem de forma prévia o foro ao qual consideram mais conveniente submeter sua controvérsia, encontra-se, nesse momento, sanado pelo advento do CPC de 2015. Deve-se acompanhar o posicionamento da jurisprudência para verificar se o tema será consagrado também nessa seara.

Em paralelo, destaca-se a aceitação da eleição de foro no plano internacional, preceito consagrado na

19 XAVIER JUNIOR, Ely Caetano; CASTRO, Emília Lana de Freitas. A competência internacional e a eleição de foro no projeto do novo código de processo civil brasileiro. Revista do Instituto do Direito Brasileiro, Lisboa, ano 2, n. 8, p. 7985-8022, 2013. Disponível em: < http://www.cidp.pt/publicacoes/revistas/ridb/2013/08/20 13_08_07985_08022.pdf>. Acesso em: 03 out. 2016. p. 8017.

20 "A grande novidade é a inclusão de um relevante permissivo: agora, é inconteste a possibilidade de as partes afastarem a competência da Justiça brasileira por meio da eleição de foro estrangeiro exclusivo em seus contratos". ARAUJO, Nadia; SPTIZ, Lidia; NORONHA, Carolina. O novo CPC nas relações internacionais. Jornal Valor Econômico, 13 de jan. de 2015. Disponível em: $<$ http://www.valor.com.br/legislacao/3856442/o-novo-cpc-nasrelacoes-internacionais>. Acesso em 04 out. 2016.

21 DOLINGER, Jacob; TIBURCIO, Carmen. Direito Internacional Privado: Parte Geral e Processo Internacional. 12. ed. rev. atual. e ampl. Rio de Janeiro: Forense, 2016. p. 577.

22 DOLINGER, Jacob; TIBURCIO, Carmen. Direito Internacional Privado: Parte Geral e Processo Internacional. 12. ed. rev. atual. e ampl. Rio de Janeiro: Forense, 2016. p. 577.

23 ARAUJO, Nadia de. Direito Internacional Privado: Teoria e Prática Brasileira. 6. ed. atual. e ampl. Porto Alegre: Revolução eBook, 2016. p. $367-268$
Convenção de Haia sobre Eleição de Foro de $2005,{ }^{24}$ assim como em outros instrumentos. O Regulamento $\mathrm{n}^{\circ}$ 1215 de 2012 da União Europeia estabeleceu a competência exclusiva do tribunal de um Estado-membro "se as partes, independentemente do seu domicílio, tiverem convencionado que um tribunal ou os tribunais de um Estado-Membro têm competência para decidir quaisquer litígios que tenham surgido ou que possam surgir de uma determinada relação jurídica". ${ }^{25}$ No âmbito do Mercosul, o artigo $4^{\circ}$ do Protocolo de Buenos Aires sobre Jurisdição Internacional em Matéria Contratual, promulgado pelo Decreto no. 2.095/1996, ${ }^{26}$ também consagrou a possibilidade de acordo para submissão à jurisdição dos tribunais de Estados-Partes do Mercosul no âmbito dos contratos internacionais em matéria civil ou comercial. Nos Estados Unidos, já na década de 1970, a Suprema Corte dos Estados Unidos entendeu no caso Bremen v. Zapata Off-Shore Company, pelo respeito de uma cláusula de eleição de foro com jurisdição exclusiva para os tribunais norte-americanos. ${ }^{27}$

24 HCCH. Convention of 30 June 2005 on Choice of Court Agreements. Disponível em: <https://www.hcch.net/en/instruments/conventions $/$ full-text $/$ ?cid=98>. Acesso em: 04 out. 2016. Destaca-se que tal Convenção "procurou conferir previsibilidade em questão de jurisdição internacional, mas assegurar igualdade de condições à cláusula de escolha de foro [...], privilegiando o princípio da autonomia da vontade". CASTRO, Joana Holzmeister. Cláusula de Eleição de Foro em Contratos Internacionais: o que muda com o novo Código de Processo Civil. 2015. 57 f. Monografia (Graduação em Direito) - Faculdade de Direito, Pontifícia Universidade Católica do Rio de Janeiro, Rio de Janeiro, 2005. p. 30.

25 Exceções para a competência exclusiva do foro eleito estão previstas no próprio artigo 25 (1) do Regulamento "a menos que o pacto seja, nos termos da lei desse Estado-Membro, substantivamente nulo. Essa competência é exclusiva, salvo acordo das partes em contrário." UNIÃO EUROPÉIA. Regulamento (UE) no 1215 do Parlamento Europeu e do Conselho de 12 de dezembro 2012. Disponível em: <http://eur-lex.europa.eu/LexUriServ/LexUriServ.do?uri=OJ :L:2012:351:0001:0032:pt:PDF>. Acesso em: 04 out. 2016.

26 BRASIL. Protocolo de Buenos Aires sobre Jurisdição Internacional em Matéria Contratual. Disponível em: <http://www.camara.leg.br/ mercosul/Protocolos/BUENOS_AIRES.htm>. Acesso em: 04 out. 2016.

27407 U.S. 1 (1972). As partes (uma empresa alemã e norteamericana) celebraram um contrato para rebocar um equipamento de perfuração de Louisiana para Itália que incluía uma cláusula determinando que qualquer disputa seria submetida aos tribunais da Inglaterra. Durante o transporte, uma tempestade danificou o equipamento e forçou a companhia rebocadora a atracar na Florida. Com isso, a empresa norte-americana processou no tribunal da Florida. A empresa alemã demandou que a cláusula determinando a competência exclusiva dos tribunais ingleses fosse respeitada. A Suprema Corte entendeu que era válida a cláusula, a não ser que a parte ré demonstrasse que declarar a cláusula válida seria injusto ou desproporcional. Disponível: <http://caselaw.findlaw.com/ussupreme-court/407/1.html>. Acesso em 06 out. 2016. 
A escolha da lei aplicável é um tema submetido à debate doutrinário com semelhante controvérsia presente no caso da eleição de foro. Deve-se esclarecer que a determinação da lei aplicável se faz a partir das regras de conexão, após tenha sido determinada a jurisdição competente. Carmen Tibúrcio e Jacob Dolinger as definem como "normas solucionadoras de conflitos de leis". ${ }^{28}$ Cada país tem o seu conjunto de regras para determinar qual a lei aplicável de acordo com os seus critérios de conexão.

No âmbito dos contratos internacionais, a regra de conexão brasileira é aquela elencada no artigo $9^{\circ}$ do Decreto-Lei 4.657 de 4 de setembro de 1942 (Lei de Introdução às Normas do Direito Brasileiro - LINDB) ${ }^{29}$, a qual estabelece a lei do local de celebração (lex loci contractus) para qualificar e reger as obrigações. ${ }^{30}{ }^{31}$

No entanto, a controvérsia no direito brasileiro versa

28 DOLINGER, Jacob; TIBURCIO, Carmen. Direito Internacional Privado: Parte Geral e Processo Internacional. 12. ed. rev. atual. e ampl. Rio de Janeiro: Forense, 2016. p. 557.

29 BRASIL. Decreto-Lei no 4.657, 4 de Setembro de 1942 (Redação dada pela Lei $n^{\circ} 12.376$, de 2010). Disponível em: < http://www. planalto.gov.br/ccivil_03/decreto-lei/Del4657compilado.htm>. Acesso em 04 out. 2016.

30 ARAUJO, Nadia de. Direito Internacional Privado: Teoria e Prática Brasileira. 6. ed. atual. e ampl. Porto Alegre: Revolução eBook, 2016. p. 81.

31 A título de esclarecimento, o artigo 21, III do CPC 2015 menciona "ato ocorrido no Brasil". "Art. 21. Compete à autoridade judiciária brasileira processar e julgar as ações em que: III - o fundamento seja fato ocorrido ou ato praticado no Brasil.”. Jacob Dolinger e Carmen Tiburcio fazem uma interpretação deste artigo para considerar a competência internacional concorrente no caso de contrato celebrado no Brasil. DOLINGER, Jacob; TIBURCIO, Carmen. Direito Internacional Privado: Parte Geral e Processo Internacional. 12. ed. rev. atual. e ampl. Rio de Janeiro: Forense, 2016. p. 563. Nessa esfera, importante traçar um paralelo para a previsão competência internacional (jurisdição) concorrente consubstanciada nos termos do artigo 21, III do CPC de 2015. Essa disposição prevê que a competência da jurisdição brasileira no caso de o contrato ter sido celebrado no território brasileiro. Destaca-se que, o Brasil é visto isoladamente no tocante a essa previsão. Foram realizadas pesquisas no âmbito da União Europeia (Regulamento no. 1215/2012), Portugal (Código de Processo Civil de 2013), França (Código de Processo Civil e Código Civil) e Estados Unidos (Jurisprudência) não possuem disposição equivalente para competência internacional. UNIÃO EUROPÉIA. Regulamento (UE) $n^{\circ} 1215$ do Parlamento Europeu e do Conselho de 12 de dezembro 2012. Disponível em: <http:/ / eur-lex.europa.eu/LexUriServ/LexUriServ.do?uri=OJ:L:2012:351: 0001:0032:pt:PDF>. Acesso em: 04 out. 2016; PORTUGAL. Lei $n^{\circ}$ 41/2013, de 26 de junbo. Disponível em: <http://www.pgdlisboa. pt/leis/lei_mostra_articulado.php?nid=1959\&tabela=leis $>$. Acesso em: 04 out. 2016; FRANÇA. Code de Procédure Civile. <https:// www.legifrance.gouv.fr $/$ affichCode.do;jsessionid $=0$ F2723F52018 03CF911ECAB5A3705687.tpdila13v_3?idSectionTA=LEGISCT A000006135862\&cidTexte $=$ LEGITEXT000006070716\&dateTex te $=20161004>$. Acesso em: 04 out. 2016 . sobre o fato de as partes deterem ou não autonomia da vontade no tocante à escolha da lei aplicável ou se deverá ser aplicada a lei onde a obrigação foi constituída, ${ }^{32}$ já que "essa autonomia é vista de forma controversa na doutrina brasileira e jurisprudência". ${ }^{33}$ Uma das razões para essa discussão se consolidou no fato de que o artigo $9^{\circ}$ da LINDB omite o termo "salvo estipulação em contrário" presente no texto do artigo 13 da antiga Lei de Introdução ao Código Civil. ${ }^{34}$

Enquanto no direito brasileiro, muito se discutiu acerca da possibilidade do exercício da autonomia da vontade na escolha da lei aplicável, "no plano internacional, pode-se dizer que há um consenso de que cabe às partes escolher o direito aplicável, consagrado o princípio da autonomia da vontade". ${ }^{35}$ Os princípios da Conferência da Haia sobre escolha da lei aplicável em contratos comerciais aplica a autonomia da vontade, demonstrando a amplitude da aceitação desse princípio

32 RIBEIRO, Marilda Rosado de Sá. Batalha das formas e negociação prolongada nos contratos internacionais. In: RODAS, João Grandino (Coord.). Contratos Internacionais. 3. ed. rev. atual. e ampl. São Paulo: Revista dos Tribunais, 2002. p. 253.

33 Nesse sentido, "a autonomia da vontade não pode ser reconhecida como elemento de conexão contratual". FRANCESCHINI, José Inácio. A lei e o foro de eleição em tema de contratos internacionais. In: RODAS, João Grandino (Coord.). Contratos Internacionais. 3. ed. rev. atual. e ampl. São Paulo: Revista dos Tribunais, 2002. p. 71. Nesse sentido, ver o Artigo 9 da atual Lei de Introdução às normas do Direito Brasileiro "Art. $9^{\circ}$ Para qualificar e reger as obrigações, aplicar-se-á a lei do país em que se constituirem. $\$ 1^{\circ}$ Destinando-se a obrigação a ser executada no Brasil e dependendo de forma essencial, será esta observada, admitidas as peculiaridades da lei estrangeira quanto aos requisitos extrínsecos do ato. $\$ 2^{\circ}$ A obrigação resultante do contrato reputa-se constituida no lugar em que residir o proponente." Carmen Tiburcio ressalta que "No Brasil, como regra, os contratos são regidos pela lei do lugar da sua celebração - lex loci celebrationis - havendo controvérsia na doutrina acerca da possibilidade de escolha pelas partes da lei aplicável - lex voluntatis.". Para tanto, cita na doutrina que, enquanto alguns entendem que a doutrina da autonomia da vontade é inadmissível - Amilcar de Castro, Irineu Strenger, Oscar Tenório - outros entendem que a autonomia da vontade é consagrada no direito internacional privado brasileira - Haroldo Valladão. TIBURCIO, Carmen. A arbitragem como meio de solução de litígios comerciais internacionais envolvendo o petróleo e uma breve análise da cláusula arbitral da sétima rodada de licitações da ANP. Revista de Arbitragem e Mediação, São Paulo, v. 3, n. 9, p. 78-98, abr./jun. 2006. p.84-85.

34 "Art. 13. Regulará, salvo estipulação em contrário, quanto á substância e aos efeitos das obrigações, a lei do lugar, onde forem contraídas." BRASIL. Lei $n^{\circ} 3.071$, de $1^{\circ}$ de janeiro de 1916. Disponível em: <http://www.planalto.gov.br/ccivil_03/leis/L3071.htm>. Acesso em 03 out 2016.

35 ARAUJO, Nadia de. A necessária mudança do artigo 9o da LINDB: o avanço que faltava para a consagração da autonomia da vontade no DIPr brasileiro. In: RAMOS, André de Carvalho (Org.). Direito Internacional Privado: Questões Controvertidas. Belo Horizonte: Arraes Editores, 2015. p. 289. 
pelos Estados-contratantes. ${ }^{36}$ A Convenção Interamericana sobre Direito Aplicável aos Contratos Internacionais também consagrou em seu artigo $7^{\circ}$ a possibilidade de escolha aplicável pelas partes, determinando que "O contrato rege-se pelo direito escolhido pelas partes". ${ }^{37}$ No plano europeu, o Regulamento nº 593/2008 da União Europeia sobre a lei aplicável às obrigações contratuais (Roma I), prevê a possibilidade de escolha da lei aplicável pelas partes no seu artigo $3^{\circ}$. Nesse caso, a escolha também deverá "ser expressa ou resultar de forma clara das disposições do contrato, ou das circunstâncias do caso". ${ }^{38}$ Nos Estados Unidos, a supremacia da autonomia da vontade foi resultado de um debate que durou anos e se encerrou algumas décadas atrás ${ }^{39}$ sendo que, atualmente, o seu exercício encontra-se consagrado no Restatement (Second) $\int 187$ e UCC $\int 1-105 . .^{40}$

Nessa esteira, defende-se a necessidade de revisitação das normas sobre a escolha da lei aplicável no direito brasileiro. Nádia de Araújo trata da proposta de mudança do artigo $9^{\circ}$ da LINDB introduzida pelas emendas ao Projeto de Lei nº. 281 de 2012 aprovado no Senado Federal e encaminhado para aprovação da Câmara de Deputados em novembro de 2015.

Essa proposta insere o artigo $9^{\circ}-\mathrm{A}$ na LINDB, em que se permite que "o contrato internacional entre profissionais, empresários e comerciantes reger-se-á pela lei escolhida pelas partes, devendo esta escolha referir-se à

36 "Many States have reached this conclusion and, as a result, giving effect to party autonomy is the predominant view today.". HCCH. Convention of 30 June 2005 on Choice of Court Agreements. Disponível em: <https:/ / www.hcch.net/en/instruments/conventions/full-text/?cid=98>. Acesso em: 04 out. 2016.

37 "O acordo das partes sobre esta escolha deve ser expresso ou, em caso de inexistência de acordo expresso, depreender-se de forma evidente da conduta das partes e das cláusulas contratuais, consideradas em seu conjunto. Essa escolha poderá referir-se à totalidade do contrato ou a uma parte do mesmo." ORGANIZAÇÃO DOS ESTAOS AMERICANOS. Convenção Interamericana sobre Direito Aplicável aos Contratos Internacionais. Disponível em: <http:// www.oas.org/juridico/portuguese/treaties/b-56.htm>. Acesso em: 04 out. 2016. Ressalta-se que essa Convenção encontra-se ratificada apenas pelo México e Venezuela.

38 UNIAO EUROPEIA. Regulamento (ce) n.o 593/2008 do Parlamento Europeu e do Conselho de 17 de junbo de 2008. Disponível em: $<$ http://eur-lex.europa.eu/LexUriServ/LexUriServ.do?uri=OJ:L:2 008:177:0006:0016:PT:PDF>. Acesso em: 04 out. 2016.

39 RUHL, Giesela. Party Autonomy in the Private International Law of Contracts: Transatlantic Convergence and Economic Efficiency. CLPE Research Paper 4/2007, v. 3, n. 1, p. 1-41, 2007. p. 4.

40 RUHL, Giesela. Party Autonomy in the Private International Law of Contracts: Transatlantic Convergence and Economic Efficiency. CLPE Research Paper 4/2007, v. 3, n. 1, p. 1-41, 2007. p. 4. totalidade do contrato e ser efetuada mediante acordo expresso entre as partes". ${ }^{41}$

Dessa forma, observa-se que o caput do artigo $9^{\circ}$-A reproduzido acima "adotou expressamente o princípio da autonomia da vontade, ao dispor ser a lei aplicável ao contrato internacional aquelas escolhida pelas partes". ${ }^{42}$ Nesse sentido, caso seja aprovado o referido Projeto de Lei, consagra-se a autonomia da vontade entre as partes contratantes no direito brasileiro, mesmo que "sem conexão com as partes ou a transação. Isso reforça o princípio da autonomia das partes no sentido de ser escolhida uma lei neutra ou especializada, mais adequada à transação e não tão somente uma lei que seja próxima das partes". ${ }^{43}$ Por fim, é preciso destacar que a nova disposição se aplicaria a contratos internacionais destinados às relações comerciais e não se aplicaria às relações de consumo e de trabalho.

Essa previsão, juntamente com a nova disposição do CPC de 2015 para eleição de foro, permitiria que o Brasil se aproximasse das jurisdições que possuem uma visão mais consolidada da autonomia da vontade, estimulando o fluxo de comércio internacional e investimento estrangeiro. A consagração da autonomia da vontade no ordenamento jurídico brasileiro permitirá que as partes brasileiras e estrangeiras sintam maior segurança jurídica quanto ao sistema brasileiro. Na próxima seção, será tratado do aspecto econômico que fundamenta a escolha da lei aplicável e eleição de foro nos contratos internacionais.

\section{VISÃo ECONÔMICA dA ESCOLHA DA LEI APLICÁVEL E ELEIÇÃO DE FORO NOS CONTRATOS INTERNACIONAIS}

Com a mundialização da economia, a expansão do comércio internacional, mobilidade de pessoas, transfe-

41 BRASIL. Projeto de Lei $n^{\circ} .281$ de 2012. Disponível em: <http://www.senado.leg.br/atividade/rotinas/materia/getPDF. asp?t=182349\&tp=1>. Acesso em: 04 out. 2016. p. 9.

42 ARAUJO, Nadia de. A necessária mudança do artigo 9o da LINDB: o avanço que faltava para a consagração da autonomia da vontade no DIPr brasileiro. In: RAMOS, André de Carvalho (Org.). Direito Internacional Privado: Questões Controvertidas. Belo Horizonte: Arraes Editores, 2015. p. 301.

43 ARAUJO, Nadia de. A necessária mudança do artigo 9o da LINDB: o avanço que faltava para a consagração da autonomia da vontade no DIPr brasileiro. In: RAMOS, André de Carvalho (Org.). Direito Internacional Privado: Questões Controvertidas. Belo Horizonte: Arraes Editores, 2015. p. 303. 
rências de tecnologia e ampliação da capacidade de investimento, se desenvolveu o processo de globalização, alcançando diversos setores da economia.

De certa forma, a globalização estreitou os laços entre atores do mercado internacional, consolidando-se como um fenômeno que

\begin{abstract}
aproximou os mercados, o comércio realiza-se agora - cada vez mais - entre pessoas e empresas de diversos países, com diversas sedes e filiais, com marcas e imagens consolidadas, com empresas de capital muitas vezes disperso entre acionistas de muitas nacionalidades e países, mas de atuação e produção realmente multinacional. ${ }^{44}$
\end{abstract}

Todavia, esse fenômeno incorpora-se através do seu caráter "multidimensional", ${ }^{45}$ que apresenta um alto nível de complexidade e relaciona diferentes "domínios da atividade e das interações humanas" ${ }^{46}$ Globalização é um processo híbrido e complexo. Os seus efeitos jurídicos não podem ser justificados a partir de um simples argumento fático ou legal. ${ }^{47}$

O resultado natural do processo globalizante culminou em aumento significativo no número de empresas que, através de suas subsidiárias e filiais, permeiam os polos econômicos de diversos países, dos menos aos mais desenvolvidos. Desse modo, o processo de múltiplas conexões e aproximação das relações empresariais impulsionou uma expansão além-fronteiras das sociedades que se globalizaram e ampliaram suas atividades "para além das barreiras territoriais de seu Estado de origem". ${ }^{48}$

44 MARQUES, Cláudia Lima. Ensaio para uma introdução ao Direito Internacional Privado. In: DIREITO, Carlos Alberto Menezes; TRINDADE, Antônio Augusto Cançado; PEREIRA, Antonio Celso Alves. (Coord.). Novas perspectivas do direito internacional contemporâneo: Estudos em homenagem ao professor Celso D. de Albuquerque Mello. Rio de Janeiro: Renovar, 2008. p. 326.

45 BARRETTO, Vincente de Paulo. Globalização, direito cosmopolítico e direitos humanos. In: DIREITO, Carlos Alberto Menezes; TRINDADE, Antônio Augusto Cançado; PEREIRA, Antônio Celso Alves. Novas perspectivas do direito internacional contemporâneo: Estudos em homenagem ao Professor Celso D. de Albuquerque Mello. Rio de Janeiro: Renovar, 2008. p. 943.

46 BARRETTO, Vincente de Paulo. Globalização, direito cosmopolítico e direitos humanos. In: DIREITO, Carlos Alberto Menezes; TRINDADE, Antônio Augusto Cançado; PEREIRA, Antônio Celso Alves. Novas perspectivas do direito internacional contemporaneo: Estudos em homenagem ao Professor Celso D. de Albuquerque Mello. Rio de Janeiro: Renovar, 2008. p. 943.

47 BERGER, Klaus Peter. Transnational Commercial Law in the Age of Globalization. In: SAGGI, CONFERENZE E SEMINARI 42, Disponível em: < http://cisgw3.law.pace.edu/cisg/biblio/berger1.html>. Acesso em 03 out. 2016. p. 3.

48 XAVIER, Mônica Antão. Internacionalização de Empresas e
No seio de uma economia transnacionalizada, se torna um tema de fundamental análise: o caráter econômico das decisões dos atores privados sobre a lei aplicável e eleição de foro, escolhas fundamentais nos contratos internacionais. Nesse cenário, verifica-se um fenômeno recorrente em que se busca a redução dos custos das transações e aumento da sua eficiência. ${ }^{49}$ Klaus Berger ressalta que a aplicação das leis nacionais em transações comerciais transnacionais sempre foi analisada como um obstáculo imposto ao mercado globalizado devido ao seu custo: "the application of foreign law is regarded as the 'globalization trap', the devision of the world into different legal systems can be regarded as a non-tariff trade barrier". ${ }^{50}$

Dentre um dos desenvolvimentos jurídicos relevantes para a transnacionalização do direito comercial, destaca-se a consagração da autonomia da vontade no direito internacional, além da consolidação do entendimento de que as tecnicidades da legislação doméstica não se adequam ao comércio internacional..$^{51}$

Nesse sentido, deve-se fazer uma leitura econômica das decisões dos atores privados no tocante à submissão de eventuais controvérsias à determinada jurisdição e regulação do direito material por determinada lei escolhida pelas partes. Em primeiro lugar, antes de se propor cláusulas de eleição de foro e lei aplicável às contrapartes, os atores privados fazem uma análise econômica dos riscos da jurisdição a que se está submetendo e se o contrato internacional a ser celebrado possui um custo-benefício válido. Após essa definição, incorporam-se ao contrato as cláusulas que cada parte encontra conforto, submetendo-as à negociação com a contraparte.

De forma genérica, a importância econômica da

o Direito Internacional dos Investimentos. In: ROSADO, Marilda (Org.). Direito Internacional dos Investimentos. Rio de Janeiro: Renovar, 2014. v. 1, p. 303-328. p. 303.

49 BERGER, Klaus Peter. Transnational Commercial Law in the Age of Globalization. In: SAGGI, CONFERENZE E SEMINARI 42, Disponível em: < http://cisgw3.law.pace.edu/cisg/biblio/berger1.html>. Acesso em 03 out. 2016. p. 2.

50 "A aplicabilidade do direito estrangeiro é vista como uma "armadilha da globalização", a divisão do mundo em diferentes sistemas jurídicos pode ser vista como uma barreira não tarifária" (tradução livre). BERGER, Klaus Peter. Transnational Commercial Law in the Age of Globalization. In: SAGGI, CONFERENZE E SEMINARI 42, Disponível em: < http:/ / cisgw3.law.pace.edu/cisg/ biblio/berger1.html>. Acesso em 03 out. 2016. p. 2.

51 BERGER, Klaus Peter. Transnational Commercial Law in the Age of Globalization. In: SAGGI, CONFERENZE E SEMINARI 42, Disponível em: < http://cisgw3.law.pace.edu/cisg/biblio/berger1.html>. Acesso em 03 out. 2016. p. 2. 
definição prévia de uma cláusula de eleição de foro se destaca no momento em que a controvérsia surge, isto porque

\begin{abstract}
Quando o litígio surge, há uma corrida para diversos locais como foros competentes, porque as partes procuram utilizar o tribunal do país em que sintam poder ser mais beneficiadas. Analisam as vantagens das regras relativas aos aspectos processuais da questão, da lei aplicável, dos custos para a contratação de advogados, entre outros. Essa busca é denominada forum shopping. ${ }^{52}$
\end{abstract}

A incerteza gerada pelo forum shopping pode afetar de forma direta os custos e as condições das transações "cross-border". É possível, ainda, afirmar que tal incerteza pode acarretar o desencorajamento de "certos negócios somente em razão da análise das condições dos tribunais com possibilidades de julgarem a questão". ${ }^{53}$

No tocante ao direito material, os princípios da Conferência da Haia sobre a escolha da lei aplicável em contratos internacionais consagram o entendimento sobre a importância da determinação das regras aplicáveis aos contratos com elementos de conexão com mais de um Estado. ${ }^{54}$ Nessa mesma linha, o Protocolo de Buenos Aires incluiu uma premissa em seu considerando, qual seja: "a necessidade de proporcionar ao setor privado dos Estados-Partes um quadro de segurança jurídica que garanta justas soluções e a harmonia internacional das decisões judiciais e arbitrais vinculadas à contratação no âmbito do Tratado de Assunção". ${ }^{5}$

Certeza, previsibilidade e segurança jurídica são fatores determinantes para as partes decidirem previamente a lei que desejam reger as disposições contratuais e prever as consequências jurídicas das suas escolhas. ${ }^{56}$

52 ARAUJO, Nádia; GAMA JUNIOR, Lauro; VARGAS, Daniela. Temas de Direito Internacional Privado no Projeto de Novo Código de Processo Civil. Revista de Arbitragem e Mediação, São Paulo, v. 28, n. 28, p. 147-158, jan./mar. 2011. p. 147.

53 ARAUJO, Nádia; GAMA JUNIOR, Lauro; VARGAS, Daniela. Temas de Direito Internacional Privado no Projeto de Novo Código de Processo Civil. Revista de Arbitragem e Mediação, São Paulo, v. 28, n. 28, p. 147-158, jan./mar. 2011. p. 148.

54 "When parties enter into a contract that has connections with more than one State, the question of which set of legal rules governs the transaction necessarily arises." HCCH. Convention of 30 June 2005 on Choice of Court Agreements. Disponível em: <https://www. hcch.net/en/instruments/conventions/full-text/?cid=98>. Acesso em: 04 out. 2016.

55 BRASIL. Protocolo de Buenos Aires sobre Jurisdição Internacional em Matéria Contratual. Disponível em: <http://www.camara.leg.br/ mercosul/Protocolos/BUENOS_AIRES.htm>. Acesso em: 04 out. 2016.

56 "Certainty and predictability are of particular importance in
Compreender as normas aplicáveis e como serão regidas as controvérsias oriundas da vertente contratual gera economia de recursos despendidos na recuperação dos créditos oriundos dos contratos internacionais de financiamento e alinha expectativas entre a área negocial e o jurídico das entidades financiadoras. A determinação da lei aplicável e consagração da autonomia da vontade são importantes não somente para o judiciário em solucionar a disputa, mas se configuram como sendo de maior relevância ainda para as partes envolvidas na transação. ${ }^{57}$

Estar na situação de negociar um contrato internacional e não saber quais os custos e consequências de litigá-lo em um tribunal que aplicará a lei obtida através da utilização do seu próprio método de DIPr certamente traz insegurança jurídica. Pode ser inclusive um fator de impedimento da contratação, pois os custos da incerteza podem não compensar as vantagens que seriam auferidas a partir da conclusão do contrato. ${ }^{58}$

Conclui-se que as partes devem agir com cautela e conhecimento da jurisdição e das leis que as negociações resultam por escolher aplicáveis à relação contratual. Não se trata de mera ocasião, mas sim de estratégia jurídica que pode gerar reflexos econômicos relevantes para quaisquer das partes. No âmbito dos contratos internacionais de financiamento, as cláusulas consagradas nos contratos internacionais são consideravelmente uniformizadas quando se trata de transações comerciais com relevante volume financeiro. Diante da particularidade dessas transações, parte-se para a análise específica desses contratos na próxima seção.

areas where the parties are likely to give advance thought to the legal consequences of their transactions." REESE, Willis. Conflict of Laws and the Restatement Second. 28 Law and Contemporary Problems. p. 679-699, 1963. Disponível em: < http://scholarship.law.duke. edu/lcp/vol28/iss4/2>. Acesso em: 04 out. 2016.

57 "The answer to this question is obviously important to a court or arbitral tribunal that must resolve a dispute between the parties but it is also important for the parties themselves, in planning the transaction and performing the contract, to know the set of rules that governs their obligations." HCCH. Convention of 30 June 2005 on Choice of Court Agreements. Disponível em: <https://www.hcch. net/en/instruments/conventions/full-text/?cid=98>. Acesso em: 04 out. 2016.

58 ARAUJO, Nadia de. Direito Internacional Privado: Teoria e Prática Brasileira. 6. ed. atual. e ampl. Porto Alegre: Revolução eBook, 2016. p. 735 . 


\section{O CASO DOS CONTRATOS INTERNACIONAIS DE FINANCIAMENTO: O CENTRO 'FINANCEIRO-JUDICIAL' DE Nova lorQue}

No âmbito dos contratos internacionais de financiamento, a lei de Nova Iorque é amplamente eleita como lei aplicável para reger as previsões contratuais. Do mesmo modo, os tribunais estaduais e federais de Nova Iorque são escolhidos, com frequência, como competentes para solução de controvérsias. Esse fenômeno ocorre tanto em negócios jurídicos bilaterais, quanto os multilaterais entre estrangeiros, sem qualquer elemento de conexão com o território norte-americano: $:^{59}$ as chamadas transações "cross-border". ${ }^{00}$

Nesse sentido, Nádia de Araújo corrobora o entendimento sobre como a escolha da lei aplicável de Nova Iorque se encontra presente nos contratos internacionais de financiamento:

\begin{abstract}
nos Estados Unidos, onde essas regras são de caráter estadual, a maioria dos contratos de financiamento contém cláusula elegendo a lei de Nova York como aplicável, já que a legislação desse estado sempre teve a preocupação de adequar-se às necessidades do comércio, transformando Nova York na capital dos negócios a partir da adoção de um aparato legislativo adequado. ${ }^{61}$
\end{abstract}

Esse fenômeno se evidencia pela própria uniformidade presentes nas cláusulas de 'jurisdiction' ${ }^{62} \mathrm{e}$ 'governing law ${ }^{93}$ dos contratos padronizados pelas associações privadas e amplamente utilizados pelos operadores do mercado financeiro internacional. Contratos internacionais de financiamento apresentam cláusulas de eleição de foro com competência (exclusiva ou não-exclusiva) ${ }^{64}$ para os tribunais de Nova Iorque, mesmo sem qualquer

59 "A dispute under a credit agreement with a non-U.S. borrower and a group of non-U.S. lenders could be heard in New York State courts even though there are "aliens" on both sides of the dispute". WIGHT, Richard; COOKE, Warren; GRAY, Richard. The LSTA's Complete Credit Agreement Guide. Nova York: McGraw Hill, 2009. p. 552. 60 A definição nesse termo encontra-se na nota de rodapé no. 3.

61 ARAUJO, Nadia de. Direito Internacional Privado: Teoria e Prática Brasileira. 6. ed. atual. e ampl. Porto Alegre: Revolução eBook, 2016. p. 735

62 Cláusula de eleição de foro (tradução livre).

63 Cláusula de lei aplicável (tradução livre).

64 'The submission is customarily 'nonexclusive;' the parties are, in other words, not forced to litigate in the selected jurisdiction [...]. This preserves for the lenders the right to sue the borrower in its home jurisdiction or elsewhere". WIGHT, Richard; COOKE, Warren; GRAY, Richard. The LSTA's Complete Credit Agreement Guide. Nova York: McGraw Hill, 2009. p. 552-553. elemento de conexão com este território.

A cláusula de eleição de foro ('submission to jurisdiction') dos contratos elaborados por associações privadas ${ }^{65}$ produzem instrumentos contratuais "tipo" para serem utilizados pelos operadores do mercado:

\begin{abstract}
the Borrower agrees that any action or proceeding with respect to this Agreement or any judgment entered by any court in respect thereof may be brought in the United States District Court for the Southern District of New York, in the Supreme Court of the State of New York sitting in New York County (including its Appellate Division), or in any other appellate court in the State of New York, as the party commencing such suit, action or proceeding may elect in its sole discretion" ${ }^{66}$
\end{abstract}

A cláusula de escolha da lei aplicável ('governing law'), por sua vez, dispõe: "This Agreement shall be construed in accordance with and governed by the law of the State of New York." ${ }^{67}$

O fundamento para essa escolha consubstancia-se no fato de Nova Iorque ter se consolidado como centro internacional financeiro e comercial. Assim, a legislação de Nova Iorque seria considerada pelos atores privados como mais sofisticada e capaz de solucionar casos predominantemente financeiros. ${ }^{68}$ Por outro lado, os tri-

65 Exemplos de associações privadas: Loan Market Association. Disponível em: <http://www.lma.eu.com/>. Acesso em 05 out. 2016. Assim como, The Loan Syndications and Trading Association Disponível em: <http://www.lsta.org/>. Acesso em 05 out. 2016.

66 "O devedor concordar que qualquer ação ou procedimento em relação a esse contrato ou qualquer julgamento iniciado por qualquer tribunal em relação ao mesmo pode ser levada ao Tribunal Distritual dos Estdos Unidos para o Distrito Sul de Nova Iorque na Suprema Corte do Estado de Nova Iorque no Condado de Nova Iorque (inclusive sua Divisão de Apelação) ou em qualquer outro tribunal de apelação do de Nova Iorque que a parte autora da ação ou procedimento venha a eleger a seu critério" (tradução livre). WIGHT, Richard; COOKE, Warren; GRAY, Richard. The LSTA's Complete Credit Agreement Guide. Nova York: McGraw Hill, 2009. p. 552.

67 "Esse contrato deverá ser regido de acordo com as leis do Estado de Nova Iorque" (tradução livre). WIGHT, Richard; COOKE, Warren; GRAY, Richard. The LSTA's Complete Credit Agreement Guide. Nova York: McGraw Hill, 2009. p. 548.

68 "Since New York is a leading center of international finance and commerce, parties to significant domestic and international commercial transactions widely regard New York law as a body of stable and reasonably sophisticated commercial law which might be appropriate to govern their arrangements and view the courts of New York or arbitration in New York as an appropriate forum for resolution of any disputes. However, the case law has left room for some differences of opinion concerning the extent to which such choices of law or choices of forum will be enforced in situations in which the transaction has little or no connection with New York." CARTER, James H. United States: New York Statute Amendments concerning reference to New York Law and New York Arbitration in international agreements. International Legal Materials, n. 24, p. 1019, 1985. Note que esse entendimento 
bunais de Nova Iorque teriam expertise para analisar a complexidade das cláusulas desses tipos de contratos, diferentemente de outros tribunais estrangeiros.

Ocorre que, nos Estados Unidos, diferentemente dos países de civil law, o método conflitual concede maior discricionariedade ao juiz ${ }^{69}$, sendo que a flexibilidade permitida no processo decisório do sistema conflitual norte-americano atual pode ensejar certa sensação de insegurança jurídica entre as partes. ${ }^{70}$

vigora desde 1984, momento em que foi codificado o Título 14 da Lei das Obrigações Gerais, modificando a doutrina do conflitos de leis que exigia, anteriormente, um elemento de conexão entre Nova York e o contrato. "On July 19, 1984, New York Governor Mario Cuomo signed into law Assembly Bill 7307-A,' codified primarily as title 14 of the New York Law of General Obligations. The new statute modifies New York's conflicts of law doctrine. Prior to title 14, New York courts generally enforced contracting parties' choice of New York. law to govern an agreement only if the state maintained a reason-able relationship with the agreement." RASHKOVER, Barry W. Title 14 New York Choice of Law Rule for Contractual Disputes: Avoiding the Unreasonable Results. Cornell Law Review, v. 71, p. 227-248, 1985. p. 227.

69 Apesar do sistema norte-americano se reger pelo mecanismo de "stare decisis", em que as decisões são fundamentadas a partir da vinculação ao precedente, instrumento este utilizando para conferir legitimidade, confiança e compliance às decisões judiciais, nota-se ainda se verificar o elemento da discricionariedade nas decisões judiciais figurando em paralelo ao mecanismo do "stare decisis". "Scholars (see Carter 1988; Dworkin 1978; Murphy, Fleming, and Barber 1995, 3033; Shapiro 1965) and jurists (Cardozo [1921] 1964; Wald 1995) recognize that judges continue to bave discretion even in the face of the norm of 'stare decisis'. For example, Supreme Court justices rarely decide two cases on the merits with precisely the same facts, and in many cases there may be conflicting precedent on an issue. Thus, there is often decisional leeway in determining whether a precedent governs a case (see Carter 1988; Schauer 1987)". No processo decisório de um caso concreto, os precedentes devem ser considerados e incorporados à fundamentação da decisão como instrumento para se consagrar fundamentos neutros, jurídicos e aumentar a sua legitimidade. Esse mecanismo, entretanto, ainda permite que se tenha certa discricionariedade nas decisões. HANSFORD, Thomas G.; SPRIGGS II, James F. The Politics of Precedent on the U.S. Supreme Court. Princeton: Princeton University Press, 2006. p. 22-23. O leitor deve observar, entretanto, que a discricionariedade mencionada trata da discricionariedade presente nas decisões do método conflitual norte-americano, existente mesmo após a chamada "revolução" no direito internacional privado norte-americano, conforme ressaltado por Symeon C. Symeonides. O autor faz uma crítica à flexibilidade resultante dessa revolução: "One of the consequences of these developments was an unprecedented degree of judicial flexibility in choiceof-law decisions. To be sure, flexibility is preferable to uncritical rigidity, but too much flexibility can be as bad as no flexibility at all. When each case is decided ad hoc as if it were a case of first impression, multiple problems arise, including increased litigation costs, waste of judicial resources, and an increased danger of judicial subjectivism, which has been aptly described as 'judicial particularistic intuitionism' or 'impressionnisme juridique". SYMEONIDES, Symeon C. The American choice-of-law revolution in the courts: today and tomorrow. Recueil des Cours de la Académie de Droit International, tome 35, p. 418-418, 2002.

70 "O incremento da discricionariedade tende a reduzir a segurança e a previsibilidade das decisões e a permitir maior exercício de
"No sistema americano, a questão deve ser vista a partir de seu resultado, sendo a seleção feita de acordo com o conteúdo do problema em questão, procurando-se a melhor norma material para solucioná-lo". ${ }^{71}$ Além da particularidade e flexibilidade da solução conflitual a cada caso, deve-se acrescentar, ainda, que o sistema norte-americano é híbrido, pois "evoluiria conforme o common law", no tocante às decisões casuísticas, mas estaria limitado aos dispositivos constitucionais "típicos do civil law". ${ }^{72}$

Para determinar a competência de um Estado norte-americano para julgar uma ação, deve-se considerar dois critérios: "subject-matter" e "personal jurisdiction". ${ }^{73}$ Enquanto que a "subject-matter" encontra-se baseada na competência em razão da matéria e de reduzida possibilidade de alteração, a jurisdição pessoal consolida-se no fato de que "a jurisdição de uma corte in personam fundava-se num poder de fato sobre a pessoa" ${ }^{74}$ tornando possível que as partes criem jurisdição pessoal no contrato. Nesse sentido, José Maria Tesheiner esclarece:

Trata-se de determinar o Estado-membro em que pode ser proposta uma ação, seja na Justiça do próprio Estado, ou na Justiça Federal ou, em outras palavras, de determinar, de conformidade com a Constituição, qual Estado-membro tem jurisdição no caso concreto. A jurisdição pode ser geral (por

concretude por aquele que deveria apenas aplicar o direito posto". VASCONCELOS, Raphael. Premissas Fundamentais do Direito Internacional Privado. In: TIBURCIO, Carmen; MENEZES, Wagner; VASCONCELOS, Raphael (Org.). Panorama do Direito Internacional Privado Atual e outros Temas Contemporâneos. Belo Horizonte: Arraes Editores, 2015. p. 39-40.

71 ARAUJO, Nadia de. Direito Internacional Privado: Teoria e Prática Brasileira. 6. ed. atual. e ampl. Porto Alegre: Revolução eBook, 2016. p. 106.

72 VASCONCELOS, Raphael. Premissas Fundamentais do Direito Internacional Privado. In: TIBURCIO, Carmen; MENEZES, Wagner; VASCONCELOS, Raphael (Org.). Panorama do Direito Internacional Privado Atual e outros Temas Contemporâneos. Belo Horizonte: Arraes Editores, 2015. p. 44.

73 Trata-se da competência em razão da matéria, como esclarece os autores "subject-matter jurisdiction refers to the power of a particular court to bear a particular kind of case". Enquanto que "personal jurisdiction" é aquela competência em razão da pessoa "Personal jurisdiction refers to the power of a court over a particular entity". Como a jurisdição em razão da material não pode ser criada por contrato entre as partes, WIGHT, Richard; COOKE, Warren; GRAY, Richard. The LSTA's Complete Credit Agreement Guide. Nova York: McGraw Hill, 2009. p. 551.

74 Artigo 12 (b)(2) do Código de Processo Civil Federal: "personal jurisdiction is the power of a court to exercise control over a particular person or item of property". TESHEINER, José Maria. Jurisdição territorial nos Estados Unidos da América do Norte e Competência Internacional e de Foro no Brasil. Revista Eletrônica de Direito Processual, Rio de Janeiro, v. 13, p. 259-274, 2014. p. 265. 
exemplo, qualquer causa contra réu domiciliado no Estado) ou específica (por exemplo, causa derivada de ato ilícito praticado pelo réu no território do Estado). ${ }^{75}$

Para que as partes possam criar jurisdição pessoal no contrato, é preciso que exista uma "base" para a jurisdição e que o réu tenha sido notificado. O critério de "base" funda-se na declaração das partes em consentirem na submissão, no âmbito do contrato, à jurisdição escolhida. Por essa razão que os contratos internacionais de financiamento estabelecem cláusulas de eleição de foro com competência (exclusiva ou não-exclusiva) para os tribunais de Nova Iorque, ${ }^{76}$ declarando as partes que consentem com a jurisdição eleita.

Destaca-se, ainda, que para determinar se a jurisdição do Estado é competente ou não, a jurisprudência norte-americana estabeleceu alguns critérios segundo o regramento da jurisdição pessoal. O primeiro deles "minimum contacts with forum", foi estabelecido no âmbito da decisão International Shoe Co. v. Washington 77 de 1945. Nesse julgado, derrogou-se a concepção histórica de que o requisito para exercício da jurisdição in personam era "presença [do réu] no território sob jurisdição da corte", ${ }^{78}$ ampliando-se o escopo da jurisdição pessoal para a concepção de que bastaria que o réu tivesse contatos mínimos ("minimum contacts") com o tribunal para este se considerar competente. A verificação dos contatos mínimos se consolida através do contato sistemático e contínuo do réu com o território do Estado. Outro teste seria o "long Arm jurisdiction with forum state", critério que determina que, para o tribunal exercer "personal jurisdiction" sobre um réu, deverá existir um regulamento que permita que o tribunal explicitamente o autorize a

75 TESHEINER, José Maria. Jurisdição territorial nos Estados Unidos da América do Norte e Competência Internacional e de Foro no Brasil. Revista Eletrônica de Direito Processual, Rio de Janeiro, v. 13, p. 259-274, 2014. p. 260.

76 "New York's dominant thrust bas been in the area of finance contracts.". Os autores fazem apresentam um série de resultados empíricos que evidenciam que as partes de contratos financeiros preferem as leis de Nova Iorque e a eleição de foro para esse Estado. EISENBERG, Theodore; MILLER, Geoffrey. The Flight to New York: An Empirical Study of Choice of Law and Choice of Forum Clauses in Publicly-Held Companies' Contracts. New York University Law and Economics Working Papers, Paper 124, p. 1-42, 2008. p. 21.

77 Cornell University Law School. International Shoe v. State of Washington. 326 U.S. 310. Disponível: <https://www.law.cornell. edu/supremecourt/text/326/310>. Acesso em: 05 out. 2016.

78 TESHEINER, José Maria. Jurisdição territorial nos Estados Unidos da América do Norte e Competência Internacional e de Foro no Brasil. Revista Eletrônica de Direito Processual, Rio de Janeiro, v. 13, p. 259-274, 2014. p. 265. exercer tal jurisdição. ${ }^{79}$

Para que a escolha da lei pelas partes seja considerada válida e o tribunal considerado competente, estabeleceu-se um teste da relação razoável com a transação ("reasonable relation") ${ }^{80}$ e violação da ordem pública. Caso não houvesse relação mínima ou caso se caracterizasse a violação da ordem pública, os tribunais de Nova Iorque tendiam a não considerar válida a escolha da lei aplicável. ${ }^{81} \mathrm{Na}$ realidade, o requisito do "reasonable relation" 82 é facilmente preenchido com o consentimento das partes em aplicar as leis de Nova Iorque e em submeter o seu litígio a esse foro. ${ }^{83}$ Quanto à ordem pública, este argumento dificilmente é considerado, pois o pressuposto principal considerado para o Estado de Nova Iorque se consagrar como centro financeiro comercial é respeitar a autonomia da vontade das partes. ${ }^{84}$

Como nos Estados Unidos a discricionariedade do método conflitual do juiz é latente ${ }^{85} \mathrm{e}$ as decisões sobre

79 No caso dos contratos internacionais de financiamento, esse regramento está previsto no "General Obligations Law" (GOL) editado pelo Estado de Nova Iorque.

80 No âmbito contratual, section 187 do Restatement (Second) of Conflicts of Law prevê "the chosen state has no substantial relationship to the parties or the transaction and there is no other reasonable basis for the parties' choice". U.S. Restatement (Second) of Conflicts of Law. Disponível em: <http://www.kentlaw.edu/perritt/conflicts/rest187. html>. Acesso em 05 out. 2016.

81 "The chosen law had to have a reasonable relationship with the contract itself.”. EISENBERG, Theodore; MILLER, Geoffrey. The Flight to New York: An Empirical Study of Choice of Law and Choice of Forum Clauses in Publicly-Held Companies' Contracts. New York University Law and Economics Working Papers, Paper 124, p. 1-42, 2008. p. 10 .

82 Esse critério não é bem definido, mas alguns parâmetros podem guiar os contraentes para considerar que essa relação existe, são eles: (i) quando o desembolso do financiamento ocorrer no território norte-americano, (ii) o pagamento ser realizado nos Estados Unidos e (iii) o credor se encontrar domiciliado neste território. WIGHT, Richard; COOKE, Warren; GRAY, Richard. The LSTA's Complete Credit Agreement Guide. Nova York: McGraw Hill, 2009. p. 549.

83 "A contract may bear a reasonable relationship to New York merely because of the parties' decision to select New York law". EISENBERG, Theodore; MILLER, Geoffrey. The Flight to New York: An Empirical Study of Choice of Law and Choice of Forum Clauses in Publicly-Held Companies' Contracts. New York University Law and Economics Working Papers, Paper 124, p. 1-42, 2008. p. 12.

84 EISENBERG, Theodore; MILLER, Geoffrey. The Market for Contracts. New York University, Law \& Economics Research Paper, n. 06-45, p. 1-49, 2007. p. 34.

85 Como mencionado na nota de rodapé n. 69, um dos resultados da revolução do direito internacional privado norte-americano citada por Symeon Symeonides foi a flexibilidade judicial nas decisões no âmbito do método conflitual norte-americano. SYMEONIDES, Symeon C. The American choice-of-law revolution in the courts: 
escolha da lei aplicável e eleição de foro são decididas de forma casuística, ${ }^{86}$ os celebrantes de contratos internacionais de financiamento poderiam acabar por se sentir inseguros quanto ao exercício da autonomia da vontade, visto os diversos critérios utilizados pela jurisprudência.

Essa premissa, no entanto, foi sendo desconstruída pelas alterações legislativas em 1984 e pelos precedentes dos tribunais de Nova Iorque voltados para esse tema, que tem fortemente assegurado aos contratantes que a escolha da lei aplicável e eleição de foro serão respeitadas. ${ }^{87}$ Houve, assim, um esforço programado das autoridades públicas em construir uma imagem de Nova Iorque como centro 'financeiro-judicial' dos contratos internacionais. ${ }^{88}$

\section{Nesse sentido, Eisenberg e Miller destacam:}

The upshot of these intertwining provisions is that parties to major commercial contracts received a guarantee that New York courts will respect clauses selecting New York as the law or forum, regardless of whether the parties have any other connections with New York State. ${ }^{89}$

Assim, em 1984 foram editados os artigos 5-1401 e 5-1402 da "General Obligations Law" (GOL). ${ }^{90}$ A regra

today and tomorrow. Recueil des Cours de la Académie de Droit International, tome 35, p. 417-418, 2002.

86 "because they are not legislative in nature, and because they technically admit the possibility of exceptions, New York case law does not provide absolute assurance to attorneys drafting major commercial contracts." EISENBERG, Theodore; MILLER, Geoffrey. The Market for Contracts. New York University, Law \& Economics Research Paper, n. 06-45, p. 1-49, 2007. p. 37.

87 Os autores defendem que existe uma corrida estimulada pelo próprio Estado de Nova Iorque para atrair a aplicação das suas leis e eleição de foro. EISENBERG, Theodore; MILLER, Geoffrey. The Market for Contracts. New York University, Law \& Economics Research Paper, n. 06-45, p. 1-49, 2007. p. 33.

88 "New York and other states compete for litigation and forum selection clauses by offering attractive judicial services to major commercial parties". EISENBERG, Theodore; MILLER, Geoffrey. The Flight to New York: An Empirical Study of Choice of Law and Choice of Forum Clauses in Publicly-Held Companies' Contracts. New York University Law and Economics Working Papers, Paper 124, p. 1-42, 2008. p. 13.

89 "O resultado dessas previsões interligadas consubstancia no fato de que as partes dos principais contratos comerciais recebem uma garantia de que os tribunais de Nova Iorque vão respeitar as cláusulas que selecionam Nova Iorque como foro e como lei aplicável, independentemente se as partes possuem ou não qualuqer conexão com o Estado de Nova Iorque". (tradução livre). EISENBERG, Theodore; MILLER, Geoffrey. The Market for Contracts. New York University, Law \& Economics Research Paper, n. 06-45, p. 1-49, 2007. p. 39.

90 US NY COURTS. IRB-Brasil Resseguros, S.A. v. Inepar Investments, S.A. Opinion of Chief Juge, Lippman, p. 1-8, 2012. Disponível em: <http://www.nycourts.gov/ctapps/Decisions/2012/ do artigo 5-140191 da GOL permite a escolha da lei aplicável e eleição de foro de Nova Iorque pelas partes, independentemente do cumprimento do critério "reasonable relation", no caso de contratos comerciais com valor igual ou maior de 250 mil dólares. ${ }^{92}$ A regra do artigo 5-1402 $2^{93}$ permite a eleição de foro em contratos em que houve escolha de lei aplicável nos termos do artigo 5-1401 da GOL, cujo montante da obrigação seja igual ou maior que 1 milhão de dólares e tenha uma cláusula de eleição de foro, em que a empresa estrangeira ou não-residente concorda em submeter eventual controvérsia à jurisdição dos tribunais de Nova Iorque.

Desse modo, os critérios que devem ser observados para que a escolha das partes seja considerada válida

Dec12/191opn12.pdf>. Acesso em: 03 out. 2016. p. 4-5.

91 "N.Y. GOB. LAW \5-1401: "Choice of law 1. The parties to any contract, agreement or undertaking, contingent or otherwise, in consideration of, or relating to any obligation arising out of a transaction covering in the aggregate not less than two hundred fifty thousand dollars, including a transaction otherwise covered by subsection one of section 1-105 of the uniform commercial code, may agree that the law of this state shall govern their rights and duties in whole or in part, whether or not such contract, agreement or undertaking bears a reasonable relation to this state. This section shall not apply to any contract, agreement or undertaking (a) for labor or personal services, (b) relating to any transaction for personal, family or household services, or (c) to the extent provided to the contrary in subsection two of section 1-105 of the uniform commercial code. 2. Nothing contained in this section shall be construed to limit or deny the enforcement of any provision respecting choice of law in any other contract, agreement or undertaking". FINDLAW. New York General Obligations Law \5-1401. Choice of law. Disponível em: <http://codes.findlaw.com/ny/general-obligations-law/gobsect-5-1401.html>. Acesso em: 03 out. 2016.

92 WIGHT, Richard; COOKE, Warren; GRAY, Richard. The LSTA's Complete Credit Agreement Guide. McGraw Hill, 2009, p. 549. 93 "N.Y. GOB. LAW \ 5-1402: 1. Notwithstanding any act which limits or affects the right of a person to maintain an action or proceeding, including, but not limited to, paragraph (b) of section thirteen hundred fourteen of the business corporation law and subdivision two of section two hundred-b of the banking law, any person may maintain an action or proceeding against a foreign corporation, non-resident, or foreign state where the action or proceeding arises out of or relates to any contract, agreement or undertaking for which a choice of New York law has been made in whole or in part pursuant to section 5-1401 and which (a) is a contract, agreement or undertaking, contingent or otherwise, in consideration of, or relating to any obligation arising out of a transaction covering in the aggregate, not less than one million dollars, and (b) which contains a provision or provisions whereby such foreign corporation or non-resident agrees to submit to the jurisdiction of the courts of this state. 2. Nothing contained in this section shall be construed to affect the enforcement of any provision respecting choice of forum in any other contract, agreement or undertaking." FINDLAW. New York General Obligations Law $\int 5-1402$. Choice of forum. Disponível em: <http://codes.lp.findlaw.com/nycode/GOB/5/14/5-1402 sthash.j4njByf7.dpuf>. Acesso em: 03 out. 2016. 
nos contratos comerciais internacionais se consolidaram de forma objetiva. ${ }^{94}$ Esses critérios são (i) transação no montante igual ou maior que 1 milhão de dólares; (ii) as partes devem ter concordado em submeter eventual controvérsia à jurisdição dos tribunais de Nova Iorque e; (iii) escolha da lei de Nova Iorque como aplicável de acordo com o critério do artigo 5-1401 da GOL. ${ }^{95}$

Estabeleceu-se, também, a proibição aos tribunais de Nova Iorque em negar competência com base no forum non conveniens, quando a ação fundar-se em contrato com eleição de foro baseado no artigo 5-1402 da GOL e leis aplicáveis de Nova Iorque. ${ }^{96}$ Em 1995, criou-se um departamento comercial permanente na Suprema Corte, ${ }^{97}$ altamente especializado para lidar com as controvérsias comerciais de alta complexidade.

$\mathrm{Na}$ espreita de se consolidar como um centro 'financeiro-judicial', os tribunais de Nova Iorque presumem que a autonomia da vontade deverá prevalecer quanto à escolha da lei aplicável.

Esse entendimento foi consagrado no julgamento IRB-Brasil Resseguros, S.A. v. Inepar Investments, S.A., envolvendo o tema da escolha da lei aplicável e eleição de foro. O julgado teve por objeto um contrato, no qual os contraentes consentiram em eleger o foro de Nova Iorque. Além disso, as partes escolheram aplicar as leis de Nova Iorque, porém não incluíram a expressão "without regard to conflict of laws principles' $\$ 8$ na cláusula de 'governing law'. O tribunal de Nova Iorque entendeu que "express

94 Ressalta-se que "in the tort and antitrust context, the ability to access the New York courts is not so clear". KUCK, Lea; HELLMANN, Betsy. International Cases Court of Appeals Decided in 2012, Looking Ahead to 2013. New York Law Journal, v. 49, n. 46, p. 1-3, 2013. p. 2. 95 US NY COURTS. IRB-Brasil Resseguros, S.A. v. Inepar Investments, S.A. Opinion of Chief Juge, Lippman, p. 1-8, 2012. Disponível em: <http://www.nycourts.gov/ctapps/Decisions/2012/ Dec12/191opn12.pdf $>$. Acesso em: 03 out. 2016. p. 6.

96 EISENBERG, Theodore; MILLER, Geoffrey. The Market for Contracts. New York University, Law \& Economics Research Paper, n. 06-45, p. 1-49, 2007. p. 39.

97 "The bad repute of the New York state court system posed an obvious threat to New York's ability to compete for contracts [...] In 1993 the state instituted a pilot commercial court program in the New York County (Manhattan) Supreme Court (...)the state established a permanent Commercial Division of the Supreme Court in 1995". EISENBERG, Theodore; MILLER, Geoffrey. The Market for Contracts. New York University, Law \& Economics Research Paper, n. 06-45, p. 1-49, 2007. p. 41; 42.

98 "sem observar os princípios de conflitos de leis" (tradução livre). US NY COURTS. IRB-Brasil Resseguros, S.A. v. Inepar Investments, S.A. Opinion of Chief Juge, Lippman, p. 1-8, 2012. Disponível em: <http://www.nycourts.gov/ctapps/Decisions/2012/ Dec12/191opn12.pdf>. Acesso em: 03 out. 2016. p. 2. contract language excluding New York's conflict-of-laws principles is not necessary", "99 uma vez que as partes expressaram claramente seu intuito em aplicar as leis de Nova Iorque.

No voto do Chief Juge Lippman na decisão IRB-Brasil Resseguros, S.A. v. Inepar Investments, S.A., evidencia-se o fundamento para consagrar a autonomia da vontade nos termos do histórico desenvolvimento legislativo e jurisprudencial nova-iorquino:

The Legislature passed the statute in 1984 in order to allow parties without New York contacts to choose New York law to govern their contracts. Prior to the enactment of $\int 5-1401$, the Legislature feared that New York courts would not recognize "a choice of New York law [in certain contracts] on the ground that the particular contract had insufficient 'contact' or 'relationship' with New York" (Sponsor's Mem, Bill Jacket, L 1984, ch 421). Instead of applying New York law, the courts would conduct a conflicts analysis and apply the law of the jurisdiction with "'the most significant relationship to the transaction and the parties [...] As a result, parties would be deterred from choosing the law of New York in their contracts, and the Legislature was concerned about how that would affect the standing of New York as a commercial and financial center". ${ }^{100}$

Importante esclarecer, por fim, que no âmbito dos contratos de financiamento, a escolha das partes se volta para Nova Iorque, pois o seu aparato normativo se

99 "linguagem contratual expressa excluindo os princípios de conflitos de leis não é necessária" (tradução livre.) Além disso, o julgado corroborou "To find here that courts must engage in a conflict-of-law analysis despite the parties' plainly expressed desire to apply New York. law would frustrate the Legislature's purpose of encouraging a predictable contractual choice of New York commercial law and, crucially, of eliminating uncertainty regarding the governing law." US NY COURTS. IRB-Brasil Resseguros, S.A. v. Inepar Investments, S.A. Opinion of Chief Juge, Lippman, p. 1-8, 2012. Disponível em: <http://www.nycourts.gov/ctapps/Decisions/2012/Dec12/191opn12.pdf>. Acesso em: 03 out. 2016. p. 7. 100 "O poder legislativo editou o estatuto em 1984 com objetivo de permitir às partes sem contato com Nova Iorque que escolhessem as leis de Nova Iorque para reger seus contratos. Antes da edição do artigo 5-1401, o poder legislativo temia que os tribunais de Nova Iorque não reconheceriam "a escolha da Lei de Nova Iorque como aplicável em certos contratos com fundamento no fato de que um contrato particular não teria suficiente contato ou relação com Nova Iorque". Ao invés de se aplicar a lei de Nova Iorque, os tribunais iriam conduzir uma análise de conflitos de lei e aplicar a lei da jurisdição que tivesse a relação mais substancial com a transação e com as partes [...]. Como resultado, as partes iriam se dissuadir de escolher as lei de Nova Iorque em seus contratos. Assim, o poder legislativo se preocupou sobre como esse fenômeno iria afetar a posição de Nova Iorque como um centro financeiro e comercial" (tradução livre). US NY COURTS. IRB-Brasil Resseguros, S.A. v. Inepar Investments, S.A. Opinion of Chief Juge, Lippman, p. 1-8, 2012. Disponível em: <http://www.nycourts.gov/ctapps/Decisions/2012/Dec12/191opn12.pdf>. Acesso em: 03 out. 2016. p. 4-5. 
consagra como sendo o preferido entre os atores privados para reger esses tipos de contrato, cuja aplicação é especialmente requerida pelos credores. ${ }^{101}$ "New York commercial law is relatively extensive, stable, and "creditor-frien$d y$," and this fact, coupled with Section 5-1401 of the General Obligations Law, makes it favored choice as the governing law for credit agreements". ${ }^{102}$ Até porque, a escolha equivocada do foro para dirimir eventuais controvérsias contratuais de financiamento pode gerar prejuízos financeiros de grande monta para o credor. ${ }^{103}$ Assim, a regulamentação dos artigos 5-1401 e 5-1402 da GOL, a proibição de se aplicar a doutrina do forum non conveniens e os precedentes consagrados, como o IRB-Brasil Resseguros, S.A. v. Inepar Investments, S.A., trouxeram conforto para as partes estrangeiras nesses tipos contratuais. Esses 'instrumentos' foram sendo amplamente utilizados pelos juristas como forma de demonstrar a segurança que os tribunais de Nova Iorque tem buscado conceder aos atores privados como forma de atração de uma gama de contratos comerciais e partes sofisticadas para seus foros de competência.

Os esforços do Estado de Nova Iorque realizados através de mecanismos legislativos e judiciais resultaram em um fenômeno de clara preferência pela escolha dos atores privados nas negociações contratuais. Em uma pesquisa realizada em 2002 pelos autores Eisenberg e Miller, ${ }^{104}$ verificou-se que dos 2.865 contratos comer-

101 Deve-se ressaltar que não é recomendável escolher a lei onde se situa o devedor como lei aplicável. Esse tipo de escolha pode se tornar um risco por algumas razões: dificuldade em se compreender o ordenamento jurídico aplicável, além da hipótese de ser contra as políticas internas do credor. WIGHT, Richard; COOKE, Warren; GRAY, Richard. The LSTA's Complete Credit Agreement Guide. Nova York: McGraw Hill, 2009. p. 549.

102 "o direito empresarial de Nova Iorque é relativamente extenso, estável e favorável ao credor e esse fato, juntamente com o artigo 5-1401 da Lei geral de obrigações, faz com que seja a escolha preferida como lei aplicável nos contratos de crédito" (tradução livre). WIGHT, Richard; COOKE, Warren; GRAY, Richard. The LSTA's Complete Credit Agreement Guide. Nova York: McGraw Hill, 2009. p. 549.

103 Deve-se ficar muito atento para os prejuízos de se eleger uma jurisdição estrangeira para o caso vertente: "Commeencing litigation in the borrower's jurisdiction can entail incremental travel and other expenses, be less certain of a proper outcome, and, of course, eat up more loan officer time". Além disso, deve-se levar em consideração "the possibility that a local court would favor a local company and perhaps misconstrue New York law". WIGHT, Richard; COOKE, Warren; GRAY, Richard. The LSTA's Complete Credit Agreement Guide. Nova York: McGraw Hill, 2009. p. 551.

104 EISENBERG, Theodore; MILLER, Geoffrey. The Flight to New York: An Empirical Study of Choice of Law and Choice of Forum Clauses in Publicly-Held Companies' Contracts. New York ciais analisados, $46 \%$ dos contratos continham escolha da lei aplicável para Nova York. ${ }^{105}$ A grande maioria dos contratos eram financeiros, incluindo os financiamentos: "New York's dominant thrust has been in the area of finance contracts", ${ }^{106}$ fator este resultante em um alto número de instituições financeiras no território deste Estado. Para a eleição do foro, identificou-se o padrão da escolha da lei aplicável como parâmetro. Assim, o foro eleito usualmente é aquele, cuja lei foi escolhida para se aplicar ao contrato. Portanto, para os contratos que designavam as leis de Nova Iorque como aplicáveis, 95\% elegiam o foro de Nova Iorque como competente. ${ }^{107}$

\section{Considerações Finais}

Neste trabalho, buscou-se fazer uma análise sobre os aspectos relevantes do exercício da autonomia da vontade na escolha da lei aplicável e eleição de foro nos contratos internacionais de financiamento. Por um lado, foram abordadas questões controversas no âmbito do ordenamento jurídico brasileiro para ressaltar as discussões colocadas pela doutrina, a inconsistência das decisões judiciais e alterações legislativas editadas com objetivo de solucionar a controvérsia. Muito se aclamou pela consagração do exercício da autonomia da vontade no direito brasileiro à luz dos exemplos dos ordenamentos jurídicos estrangeiros.

Em segundo lugar, procurou-se evidenciar a visão econômica que os atores privados adotam no momento da escolha da lei aplicável e eleição de foro nos contratos internacionais. Medida esta que evidencia a importância de uma discussão sobre a possibilidade do exercício da

University Law and Economics Working Papers, Paper 124, p. 1-42, 2008. p. 16-.

105 EISENBERG, Theodore; MILLER, Geoffrey. The Flight to New York: An Empirical Study of Choice of Law and Choice of Forum Clauses in Publicly-Held Companies' Contracts. New York University Law and Economics Working Papers, Paper 124, p. 1-42, 2008. p. 19.

106 "o impulso dominante de Nova Iorque tem sido na área de contratos" (tradução livre). EISENBERG, Theodore; MILLER, Geoffrey. The Flight to New York: An Empirical Study of Choice of Law and Choice of Forum Clauses in Publicly-Held Companies' Contracts. New York University Law and Economics Working Papers, Paper 124, p. 1-42, 2008. p. 21.

107 EISENBERG, Theodore; MILLER, Geoffrey. The Flight to New York: An Empirical Study of Choice of Law and Choice of Forum Clauses in Publicly-Held Companies' Contracts. New York University Law and Economics Working Papers, Paper 124, p. 1-42, 2008. p. 35. 
autonomia da vontade. Os fundamentos econômicos se demonstraram capazes de reverberar a necessidade de se permitir que os atores privados tenham liberdade na negociação contratual e escolham a lei que mais lhe favorecem e o tribunal mais conveniente para julgar suas controvérsias contratuais.

O fenômeno que ocorre no âmbito dos contratos internacionais de financiamento demonstra que a prática contratual está permeada pela autonomia da vontade. Trata-se de um desejo claro de se escolher o centro financeiro internacional - Nova Iorque - para solucionar as controvérsias dos financiamentos. Essa decisão não se resume aos contraentes norte-americanos, mas incontáveis partes estrangeiras que desejam se beneficiar do arcabouço jurídico sofisticado e expertise desses juízes para dirimir os seus conflitos financeiros sem qualquer contato com os Estados-Unidos.

Dessa forma, decidiu-se por esclarecer como o sistema norte-americano conduz o mecanismo de escolha de lei aplicável e eleição de foro no âmbito dos financiamentos. Demonstrou-se que o Estado de Nova Iorque promoveu uma verdadeira corrida para atração dos contratos comerciais. Ao longo dos anos, deixou-se para trás a incredulidade de que a escolha das partes seria consagrada e o problema jurídico que a desconsideração da autonomia da vontade causaria para os atores privados, a fim de se consagrar o posicionamento de que dificilmente se derrogaria a eleição de foro e escolha da lei de Nova Iorque pelos atores privados, mesmo sem qualquer relação razoável com o território deste Estado norte-americano.

Portanto, consagrou-se a autonomia da vontade nos tribunais de Nova Iorque. Esse posicionamento passou por uma evolução histórica, mudança de paradigma nesses tribunais, já que não se estabeleceu dessa forma desde o início. O caso de Nova Iorque pode servir, portanto, como exemplo para o sistema jurídico brasileiro e outros ordenamentos jurídicos. Exemplo para um mecanismo que pode atrair recursos financeiros e permitir segurança jurídica às partes que eventualmente venham ao território local de um país com objetivo de contratar e, eventualmente, litigar. A segurança jurídica só tende a trazer resultados benéficos, especialmente, a atração de um volume maior de investimento estrangeiro para o país.

\section{REFERÊNCIAS}

ARAUJO, Nadia de. A necessária mudança do artigo 9o da LINDB: o avanço que faltava para a consagração da autonomia da vontade no DIPr brasileiro. In: RAMOS, André de Carvalho (Org.). Direito Internacional Privado: Questões Controvertidas. Belo Horizonte: Arraes Editores, 2015. p. 289-309.

ARAUJO, Nadia de. Contratos Internacionais e a jurisprudência brasileira: Lei aplicável, ordem pública e cláusula de eleição de foro. In: RODAS, João Grandino (Coord.). Contratos Internacionais. 3. ed. rev. atual. e ampl. São Paulo: Revista dos Tribunais, 2002. p. 202-208.

ARAUJO, Nadia de. Direito Internacional Privado: Teoria e Prática Brasileira. 6. ed. atual. e ampl. Porto Alegre: Revolução eBook, 2016.

ARAUJO, Nádia; GAMA JUNIOR, Lauro; VARGAS, Daniela. Temas de Direito Internacional Privado no Projeto de Novo Código de Processo Civil. Revista de Arbitragem e Mediação, São Paulo, v. 28, n. 28, p. 147-158, jan./mar. 2011.

ARAUJO, Nadia; SPTIZ, Lidia; NORONHA, Carolina. $\mathrm{O}$ novo $\mathrm{CPC}$ nas relações internacionais. Jornal Valor Econômico, 13 de jan. de 2015. Disponível em: <http://www.valor.com.br/legislacao/3856442/onovo-cpc-nas-relacoes-internacionais $>$. Acesso em 04 out. 2016.

BAPTISTA, Luiz Olavo. Dos contratos internacionais: uma visão teórica e prática. São Paulo: Saraiva, 1994.

BARRETTO, Vincente de Paulo. Globalização, direito cosmopolítico e direitos humanos. In: DIREITO, Carlos Alberto Menezes; TRINDADE, Antônio Augusto Cançado; PEREIRA, Antônio Celso Alves. Novas perspectivas do direito internacional contemporâneo: Estudos em homenagem ao Professor Celso D. de Albuquerque Mello. Rio de Janeiro: Renovar, 2008.

BERGER, Klaus Peter. Transnational Commercial Law in the Age of Globalization. In: SAGGI, CONFERENZE E SEMINARI 42, Disponível em: <http:// cisgw3.law.pace.edu/cisg/biblio/berger1.html>. Acesso em 03 out. 2016.

BRASIL. Decreto-Lei no 4.657, 4 de Setembro de 1942 (Redação dada pela Lei no 12.376 , de 2010). Disponível em: <http://www.planalto.gov.br/ccivil_03/decreto-lei/ Del4657compilado.htm>. Acesso em 04 out. 2016. 
BRASIL. Lei $n^{0}$ 3.071, de $1^{\circ}$ de janeiro de 1916. Disponível em: <http://www.planalto.gov.br/ccivil_03/leis/ L3071.htm>. Acesso em 03 out 2016.

BRASIL. Projeto de Lei no 281 de 2012. Disponível em: <http://www.senado.leg.br/atividade/rotinas/materia/getPDF.asp?t=182349\&tp=1>. Acesso em: 04 out. 2016.

BRASIL. Protocolo de Buenos Aires sobre Jurisdição Internacional em Matéria Contratual. Disponível em: <http://www. camara.leg.br/mercosul/Protocolos/BUENOS_AIRES.htm>. Acesso em: 04 out. 2016.

CARTER, James H. United States: New York Statute Amendments concerning reference to New York Law and New York Arbitration in international agreements. International Legal Materials, n. 24, 1985.

CASTRO, Joana Holzmeister. Cláusula de Eleição de Foro em Contratos Internacionais: o que muda com o novo Código de Processo Civil. 2015. 57 f. Monografia (Graduação em Direito) - Faculdade de Direito, Pontifícia Universidade Católica do Rio de Janeiro, Rio de Janeiro, 2005.

CORNELL UNIVERSITY LAW SCHOOL. International Shoe v. State of Washington. 326 U.S. 310. Disponível: <https://www.law.cornell.edu/supremecourt/ text/326/310>. Acesso em: 05 out. 2016.

DOLINGER, Jacob; TIBURCIO, Carmen. Direito Internacional Privado: Parte Geral e Processo Internacional. 12. ed. rev. atual. e ampl. Rio de Janeiro: Forense, 2016.

EISENBERG, Theodore; MILLER, Geoffrey. The Flight to New York: An Empirical Study of Choice of Law and Choice of Forum Clauses in Publicly-Held Companies' Contracts. New York University Law and Economics Working Papers, Paper 124, p. 1-42, 2008.

EISENBERG, Theodore; MILLER, Geoffrey. The Market for Contracts. New York University, Law \& Economics Research Paper, n. 06-45, p. 1-49, 2007.

FINDLAW. New York General Obligations Law \5-1401. Choice of law. Disponível em: <http://codes.findlaw. com/ny/general-obligations-law/gob-sect-5-1401. html>. Acesso em: 03 out. 2016.

FINDLAW. New York General Obligations Law \5-1402. Choice of forum. Disponível em: <http://codes. lp.findlaw.com/nycode/GOB/5/14/5-1402 - sthash. j4njByf7.dpuf>. Acesso em: 03 out. 2016.
FRANÇA. Code de Procédure Civile. <https://www.legifrance.gouv.fr $/$ affichCode.do;jsessionid=0F2723F5201 803CF911ECAB5A3705687.tpdila13v_3?idSectionTA $=$ LEGISCTA000006135862\&cidTexte $=$ LEGITEXT0 00006070716\&dateTexte $=20161004>$. Acesso em: 04 out. 2016.

FRANCESCHINI, José Inácio. A lei e o foro de eleição em tema de contratos internacionais. In: RODAS, João Grandino (Coord.). Contratos Internacionais. 3. ed. rev. atual. e ampl. São Paulo: Revista dos Tribunais, 2002. p. 67-75.

GARCIA JUNIOR, Armando Alvares. Lei aplicável aos contratos internacionais. 2. ed. São Paulo: Aduaneiras, 2004.

HANSFORD, Thomas G.; SPRIGGS II, James F. The Politics of Precedent on the U.S. Supreme Court. Princeton: Princeton University Press, 2006.

HCCH. Convention of 30 June 2005 on Choice of Court Agreements. Disponível em: <https://www.hcch.net/ en $/$ instruments $/$ conventions $/$ full-text $/$ ?cid $=98>$. Acesso em: 04 out. 2016.

$\mathrm{HCCH}$. Introduction to the Hague Principles on Choice of Law in International Commercial Contracts. Disponível em: $<$ https://www.hcch.net/pt/instruments/conventions/ full-text/?cid=135>. Acesso em: 04 out. 2016.

KUCK, Lea; HELLMANN, Betsy. International Cases Court of Appeals Decided in 2012, Looking Ahead to 2013. New York Law Journal, v. 49, n. 46, p. 1-3, 2013.

LOAN MARKET ASSOCIATION. Disponível em: <http://www.lma.eu.com>. Acesso em: 05 out. 2016.

MARQUES, Cláudia Lima. Ensaio para uma introdução ao Direito Internacional Privado. In: DIREITO, Carlos Alberto Menezes; TRINDADE, Antônio Augusto Cançado; PEREIRA, Antonio Celso Alves. (Coord.). Novas perspectivas do direito internacional contemporâneo: Estudos em homenagem ao professor Celso D. de Albuquerque Mello. Rio de Janeiro: Renovar, 2008.

NARDI, Marcelo de. Eleição de foro: Uma visão brasileira. In: RODAS, João Grandino (Coord.). Contratos Internacionais. 3. ed. rev. atual. e ampl. São Paulo: Revista dos Tribunais, 2002.

ORGANIZAÇÃO DOS ESTAOS AMERICANOS. Convenção Interamericana sobre Direito Aplicável aos Contratos Internacionais. Disponível em: <http://www.oas.org/juridico/portuguese/treaties/b-56.htm>. Acesso em: 04 out. 2016. 
PORTUGAL. Lei n. ${ }^{\circ}$ 41/2013, de 26 de junho. Disponível em: <http://www.pgdlisboa.pt/leis/lei_mostra_articulado.php?nid=1959\&tabela=leis $>$. Acesso em: 04 out. 2016.

RASHKOVER, Barry W. Title 14 New York Choice of Law Rule for Contractual Disputes: Avoiding the Unreasonable Results. Cornell Law Review, v. 71, p. 227-248, 1985.

REESE, Willis. Conflict of Laws and the Restatement Second. 28 Law and Contemporary Problems. p. 679-699, 1963. Disponível em: <http://scholarship.law.duke. edu/lcp/vol28/iss4/2>. Acesso em: 04 out. 2016.

RIBEIRO, Marilda Rosado de Sá. Batalha das formas e negociação prolongada nos contratos internacionais. In: RODAS, João Grandino (Coord.). Contratos Internacionais. 3. ed. rev. atual. e ampl. São Paulo: Revista dos Tribunais, 2002. p. 251-282.

ROCHA, Dinir Salvador Rios de. Contrato de empréstimo internacional. São Paulo: Saraiva, 2013.

RUHL, Giesela. Party Autonomy in the Private International Law of Contracts: Transatlantic Convergence and Economic Efficiency. CLPE Research Paper 4/2007, v. 3, n. 1, p. 1-41, 2007.

SOUZA JUNIOR, Lauro da Gama. Autonomia da vontade nos contratos internacionais no Direito Internacional Privado brasileiro: Uma leitura constitucional do artigo $9^{\circ}$ da Lei de Introdução ao Código Civil em favor da liberdade de escolha do direito aplicável. In: TIBURCIO, Carmen; BARROSO, Luís Roberto (Org.). O direito internacional contemporâneo: estudos em homenagem ao professor Jacob Dolinger. Rio de Janeiro: Renovar, 2006.

SYMEONIDES, Symeon C. The American choice-of-law revolution in the courts: today and tomorrow. Recueil des Cours de la Académie de Droit International, tome 35, 2002.

TESHEINER, José Maria. Jurisdição territorial nos Estados Unidos da América do Norte e Competência Internacional e de Foro no Brasil. Revista Eletrônica de Direito Processual, Rio de Janeiro, v. 13, p. 259-274, 2014.

THE LOAN SYNDICATIONS AND TRADING ASSOCIATION. Disponível em: <http://www.lsta. org >.Acesso em: 05 out. 2016.

TIBURCIO, Carmen. A arbitragem como meio de solução de litígios comerciais internacionais envolvendo o petróleo e uma breve análise da cláusula arbitral da sétima rodada de licitações da ANP. Revista de Arbitragem e Mediação, São Paulo, v. 3, n. 9, p. 78-98, abr./jun. 2006. TIBURCIO, Carmen. A eleição de foro estrangeiro e o judiciario brasileiro. Revista de Arbitragem e Mediação, São Paulo, v. 6, n. 21, p. 84-113, abr./jun. 2009.

U.S. Restatement (Second) of Conflicts of Law. Disponível em: <http://www.kentlaw.edu/perritt/conflicts/rest187.html>. Acesso em: 05 out. 2016.

UNIAO EUROPEIA. Regulamento (ce) n.o 593/2008 do Parlamento Europeu e do Conselho de 17 de junho de 2008. Disponível em: <http://eur-lex.europa.eu/LexUriServ/LexUriServ.do?uri=OJ:L:2008:177:0006:0016:PT: PDF>. Acesso em: 04 out. 2016.

UNIÃO EUROPÉIA. Regulamento (UE) $n^{\circ} 1215$ do Parlamento Europeu e do Conselho de 12 de dezembro 2012. Disponível em: <http://eur-lex.europa.eu/LexUriServ/LexUriServ.do?uri=OJ:L:2012:351:0001:0032:pt: PDF>. Acesso em: 04 out. 2016.

US NY COURTS. IRB-Brasil Resseguros, S.A. v. Inepar Investments, S.A. Opinion of Chief Juge, Lippman, p. 1-8, 2012. Disponível em: <http://www.nycourts. gov/ctapps/Decisions/2012/Dec12/191opn12.pdf>. Acesso em: 03 out. 2016.

VASCONCELOS, Raphael. Premissas Fundamentais do Direito Internacional Privado. In: TIBURCIO, Carmen; MENEZES, Wagner; VASCONCELOS, Raphael (Org.). Panorama do Direito Internacional Privado Atual e outros Temas Contemporâneos. Belo Horizonte: Arraes Editores, 2015. p. 34-54.

WIGHT, Richard; COOKE, Warren; GRAY, Richard. The LSTA's Complete Credit Agreement Guide. Nova York: McGraw Hill, 2009.

XAVIER JUNIOR, Ely Caetano; CASTRO, Emília Lana de Freitas. A competência internacional e a eleição de foro no projeto do novo código de processo civil brasileiro. Revista do Instituto do Direito Brasileiro, Lisboa, ano 2, n. 8, p. 7985-8022, 2013. Disponível em: < http:// www.cidp.pt/publicacoes/revistas/ridb/2013/08/201 3_08_07985_08022.pdf>. Acesso em: 03 out. 2016.

XAVIER, Mônica Antão. Internacionalização de Empresas e o Direito Internacional dos Investimentos. In: ROSADO, Marilda (Org.). Direito Internacional dos Investimentos. Rio de Janeiro: Renovar, 2014. v. 1, p. 303-328. 


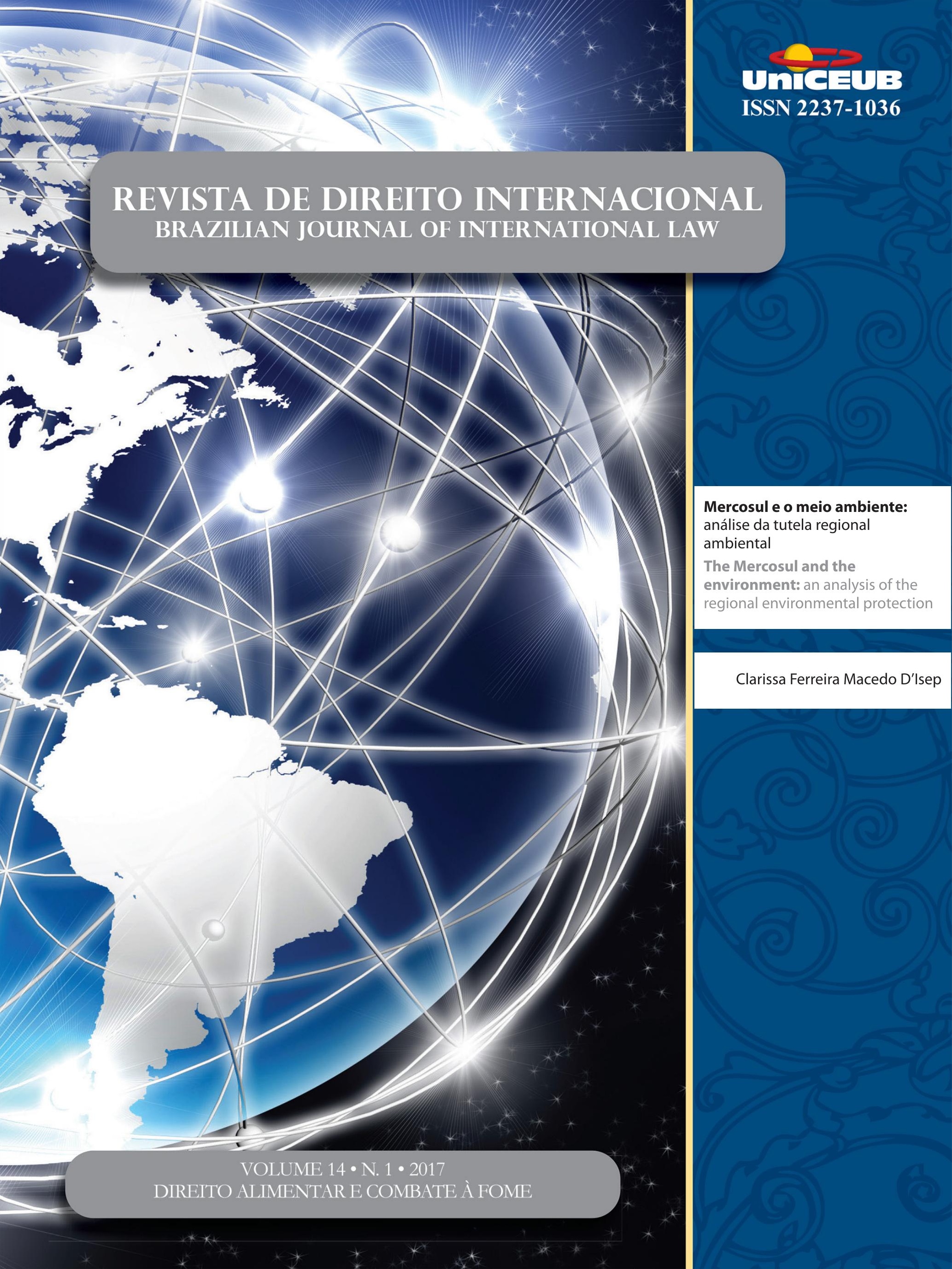




\section{Mercosul e o meio ambiente: análise da tutela regional ambiental*}

\author{
The Mercosul and the environment: an \\ analysis of the regional environmental \\ protection
}

* Recebido em 28/10/2016

Aprovado em 24/12/2016

** Advogada, parecerista e consultora. Possui doutorado em Direito Ambiental pela Université de Limoges - França (2006), doutorado em Direito das Relações Sociais pela Pontifícia Universidade Católica de São Paulo (2006), mestrado em Direito pela Pontifícia Universidade Católica de São Paulo (1998) e graduação pela Universidade Federal do Espírito Santo (1994). Professora de Direito do Programa de Pós Graduação Stricto Sensu de Direito e Professora Assistente Doutora da Graduação da Pontificia Universidade Católica de São Paulo PUC/SP. Coordenadora do Curso de Pós-graduação "lato sensu" Direitos Difusos e Coletivos da PUC/SP. Coordenadora Executiva do Curso de Pós-graduação "lato sensu" de Direito Contratual da PUC/SP. Tem experiência na área de Direito, com ênfase em Direito Ambiental, Direito Civil - Contratos, Direito Econômico, Direito do Consumidor, Direitos Difusos e Coletivos, atuando principalmente nos seguintes temas: meio ambiente, contratos, cláusulas sociais e ambientais, comércio de carbono, águas, ISO 14000, resíduos sólidos, desenvolvimento sustentavel, gestão jurídica ambiental, políticas públicas; TAC - Termo de Ajustamento de Conduta, compensação ambiental, mediação, conciliação, arbitragem, projetos de lei, metodologia, indicadores jurídicos, pagamento por serviços ambientais, meio ambiente industrial, biodiversidade, energia, novas tecnologias, planos e projetos na área de sustentabilidade. Análise de aplicação e investigação de princípios de não retrocesso em matéria ambiental, de informação, usuário-pagador, poluidor-pagador, dentre outros. É membro efetiva da Comissão de Biotecnologia e Biodireito da OAB/SP. É membro da Sociedade Francesa de Direito Ambiental. Membro da Associação de Professores de Direito Ambiental do Brasil - APRODAB. E-mail: administrativo@cmd.adv.br

\author{
Clarissa Ferreira Macedo D'Isep ${ }^{* *}$
}

\section{Resumo}

O Mercosul, mediante a aprovação do Acordo-Quadro sobre Meio Ambiente do Mercosul (AQMAM), instituiu o comando de promoção do "desenvolvimento sustentável" e de "proteção do meio ambiente", inaugurando a tutela ambiental regional do Cone Sul. Este artigo trata dos efeitos jurídicos que se podem extrair do Acordo-Quadro do Meio Ambiente do Mercosul, como a identificação da proteção ambiental integrada e a proteção ambiental autônoma, que formam o Direito Ambiental Regional do bloco, que deverá orientar a gestão ambiental, notadamente dos recursos naturais compartilhados. Tem-se evidenciado uma nova fase no direito das integrações, que possibilitará às partes de exercitar a cooperação na gestão da coisa comum e, quiça, colaborar para o avanço na cooperação socioeconômica. São analisados alguns dos desafios de implementação evidenciados neste estudo. É promovida uma análise jurídica da temática - Comércio e Meio ambiente, em que se propôs avaliar a realidade hordiena à luz do AQMAM, que prima pela construção de um sistema integrado de comércio, em que as variáveis da sustentabilidade devem ser contempladas.

Palavras-chave: Desenvolvimento sustentável. Proteção ambiental do Mercosul. Meio ambiente. Comércio Internacional e Meio Ambiente.

\section{Abstract}

Mercosul in face of the approval of the Board - The agreement about the environment of Mercosul (AQMAM), has instituted the promotion command of the "Sustainable Development " and of "the environment protection", so opening the regional environmental guardianship of the Southern Cone. The present article deals with the juridical effects which can be extracted, such as the identification of the integrated environmental protection and the autonomous environmental protection which make up the Regional Environmental Law of the block which should guide the environmental management, mainly that of the shared natural resources. A new phase has been evidenced in the law of integrations, which will enable the parts to exercise the cooperation in the management of the common property and, maybe, cooperate for the advance in the socio-economic cooperation. Some of the implementation challenges are analysed in the present 
study. A juridical analysis of the thematic - Trading and the Environment, in which it was proposed to assess the current reality on the light of the AQMAM, which aims at the construction of an integrated trading system in which the variables of sustainability must be acknowledged.

Keywords: Sustainable development. Mercosul environmental protection. Environment. International Trading and the Environment.

\section{INTRODUÇÃo}

O Acordo-Quadro sobre Meio Ambiente do Mercosul (AQMAM) foi aprovado em de 22 de junho de 2001, aditado em 7 de julho de 2004, ambos por decisões do Conselho do Mercado Comum (CMC), inaugurando a regulamentação da tutela ambiental regional. Imperiosa a necessidade de implementá-lo e, para tanto, promove-se a sua recepção normativa ao identificar os seus efeitos jurídicos regionais e a sua sistematização no ordenamento jurídico interno dos Países Membros (Brasil, Argentina, Paraguai, Uruguai, Venezuela e Bolívia), ${ }^{1}$ assim como os seus reflexos nos países associados (Chile, Peru, Colômbia, Equador, Guiania e Suriname) e nas tratativas em vigor, o que traz à baila a política ambiental do bloco.

O AQMAM normatiza, no seio do Cone Sul, o "desenvolvimento sustentável" e a "proteção do meio ambiente" (objetivos externados no art. $4^{\circ}$ ) e, por conseguinte, a qualificação do desenvolvimento pretendido em suas relações qual seja, o sustentável, também implementa o comando de efetividade da proteção ambiental regional. Destarte é estabelecido o princípio de desenvolvimento sustentável regional do Mercosul, que condicionará todas as tratativas do bloco, bem como é criado o Direito Ambiental do Mercosul, mediante a regulamentação da promoção da proteção ambiental e incentivo à ccordenação de políticas setoriais.

A promoção de uma retrospectiva descritiva da origem do bloco, visualizando, em cada uma de suas etapas, a finalidade pretendida, a filosofia aplicada e os resultados obtidos - todos vetores da sistemática que denuncia o contexto jurídico-político da temática ambiental do bloco - se faz necessária para melhor evi-

1 Ressalta-se que a Bolívia é Estado Parte em processo de adesão. denciar os efeitos do AQMAM. O que se destaca, até a aprovação do mencionado instrumento, é a existência de um regime jurídico de proteção ambiental integrada, consubstanciada na análise retrospectiva da normativa até então existente.

Indagamos: em que medida essa iniciativa de proteção autônoma do meio ambiente concretizada no AQMAM se estenderá e afetará as relações em curso firmadas pelo bloco? Também tecemos uma breve análise prospectiva do processo evolutivo ambiental no Cone Sul e da legitimação da adoção de gestão ambiental regional.

\section{O Mercosul e o meio ambiente: uma RETROSPECTIVA E A PROTEÇÃO AMBIENTAL INTEGRADA}

\subsection{Aspectos estruturais do Mercosul}

Por iniciativa dos dirigentes do Brasil e da Argentina, foi firmado, em 1985, o compromisso de acelerar o processo de integração bilateral, na chamada, Declaração de Ignaçu, sucedido, em 1986, por uma Ata para a Integração Brasil-Argentina e, em 1988, pelo Tratado de Integração, Cooperação e Desenvolvimento (TICD).

Em 1990, novo e decisivo passo é dado rumo à concretização da criação de um processo de integração e cooperação econômica, com a assinatura da Ata de Buenos Aires. Logo depois, em 26-3-1991, o processo conta com o apoio e a participação do Uruguai e do Paraguai, mediante a assinatura do Tratado de Assunção (TA), que entra em vigor em 29-9-1991, tendo-se, assim, constituído o mercado comum entre a República Argentina, a República Federativa do Brasil, a República do Paraguai e a República Oriental do Uruguai, que passa a ser denominado: "Mercado Comum do Sul" (Mercosul) (Art. 1", TA). Em 17-12-1994, é firmado o Protocolo Adicional ao Tratado de Assunção sobre a Estrutura Institucional do Mercosul, que lhe atribuiu personalidade jurídica de Direito Internacional (art. 34) e formalizou sua estrutura institucional em Ouro Preto (Minas Gerais/Brasil), razão pela qual passa a ser conhecido por Protocolo de Ouro Preto (POP).

A sua estrutura institucional conta com os seguintes órgãos: a) o Conselho do Mercado Comum (CMC), órgão superior, com a função de condução política 
e tomada de decisões; b) o Grupo Mercado Comum (GMC), órgão executivo; b) a Comissão de Comércio do Mercosul (CCM), que vela pela aplicação dos instrumentos de política comercial; d) a Comissão Parlamentar Conjunta (CPC), órgão representativo dos Parlamentos dos Estados Partes no âmbito do Mercosul e com o ônus de acelerar os procedimentos internos; e) o Foro Consultivo Econômico-Social (FCES), órgão representativo dos setores econômicos e sociais; f) a Secretaria Administrativa do Mercosul (SAM), órgão de apoio operacional. Foi atribuída capacidade decisória, de natureza intergovernamental, aos três primeiros, quais sejam: CMC, GMC e CCM.

O bloco do Cone Sul tem nos TA e POP a base de seu arcabouço normativo material. Somado àqueles $O$ "Protocolo de Olivos para solução de controvérsias," tem-se formada a normativa procedimental. Além das disposições próprias, o funcionamento do bloco é pautado nas normas costumeiras de Direito Internacional, o que é enfatizado em face da ausência de um órgão de controle e fiscalização de natureza executiva supranacional.

Em 1996, o Chile e a Bolívia integram o Mercosul, estabelecendo uma Zona Livre de Comércio, figurando, portanto, como Membros Associados. Ainda como Membros Associados o Peru, a Colômbia, o Equador, a Guiânia e o Suriname. Posteriormente, tem-se a adesão, na qualidade de Estado Parte, da Venezuela e da Bolívia.

A diferença de relações mantidas no Mercosul entre Estados Partes de União Adnaneira e os Membros Associados de Zona Livre de Comércio caracteriza, já na sua fase embrionária, a sua particularidade e busca de caminho próprio, diversamente daquele trilhado pela União Europeia, atualmente, referencial expressivo de processo de integração, que até então revela as seguintes etapas: Zona de Livre Comércio, União Aduaneira, Mercado Comum, União Econômica e Monetária e, ulteriormente, a busca da União Política.

É nessa estrutura e contexto econômico-comercial que a matéria ambiental é abordada, já no Preâmbulo do TA, condicionando, expressamente, a ampliação de seus mercados ao "[...] aproveitamento mais eficaz dos recursos disponíveis e a preservação do meio ambiente".

2 O Protocolo de Olivos data de 18-2-2002. Aprovado pelo Conresso Nacional Brasileiro, pelo do Decreto Legisltivo $\mathrm{n}^{\circ} 712$, de 14 de coutubro de 2003, e promulgado pelo Decreto ${ }^{\circ} 4.982$, de 9 de fevereiro de 2004.
Por conseguinte, o comando de conservação do meio ambiente - nos espaços fronteiriços e internos dos países membros - passa a figurar como condicionante, logo princípio da política econômica comercial do bloco e em todos os seus processos decisórios, o que revela o regime jurídico de proteção integrada do meio ambiente. Proteção esta que, por sua vez, evidencia o Princípio da Integração Ambiental previsto na Declaração do Rio de Janeiro/92 (Princípio 4), reafirmado no Acordo-Quadro Ambiental, de forma expressa no art. $3^{\circ}$, b, que dispõe acerca da "[...] incorporação da componente ambiental nas políticas setoriais e inclusão das considerações ambientais na tomada de decisões que se adote no âmbito do MERCOSUL para o fortalecimento da integração" e, de forma implícita, ao se estabelecer o desenvolvimento sustentável como objetivo, uma vez que ele por si só concretiza a integração da proteção ambiental em seu conceito e propósito.

\subsection{Tutela Ambiental Regional: da proteção ambiental integrada à proteção ambiental autônoma, interação recíproca}

Em 20 e 21-2-1992, em Canela (Rio Grande do Sul/ Brasil), é realizado um encontro do qual adveio a $D e-$ claração de Canela, documento que consagrou as condicionantes - utilização eficaz dos recursos disponiveis e proteção do meio ambiente. O contexto sociopolítico criado com os preparativos para a Reunião da Conferência do Rio de Janeiro, em 1992, propiciou a postura homogêna e participativa que viabilizou a sua aprovação, do que resultou: a determinação da responsabilidade comum atinente à matéria ambiental; a busca da implementação de ações solidárias destinadas a reverter o processo de degradação do meio ambiente; o reconhecimento da complementaridade dos conceitos: "preservação de recursos naturais", "progresso material" e "desenvolvimento econômico"; o reconhecimento da necessidade de codificação gradual do Direito Ambiental Internacional, enfatizando a cooperação internacional com vistas à Conferência das Nações Unidas sobre Meio Ambiente. Nesse sentido, em 27 de junho de 1992 (CMC - Decisão no 01/92), são atribuídos programas de trabalho ambiental aos grupos SGT 7 - política industrial e tecnologia, SGT 8 - política agrícola; SGT 9 - política energética. Em 1993, é implementada, no SGT n ${ }^{\circ} 7$, a Comissão sobre Meio Ambiente, que recomenda ( $\mathrm{n}^{\circ}$ 20/93) a adoção de Projeto de Cooperação para o Meio Ambiente. 
O GMC, considerando que o tema ambiental é trabalhado de forma transversal e setorizada nos SGT 7, 8 e 9, mediante Resolução GMC no 22/92, resolve criar as chamadas Remas - reuniões especializadas de meio ambiente - que, com o escopo de: promover a análise da legislação ambiental vigente nos Estados Partes, para posterior harmonização ${ }^{3}$; de análisar o impacto relativo às normas ISO 14000 e de proporcionar ações de proteção ao meio ambiente etc., passam, então, a acontecer periodicamente. Nesse sentido, é elaborada a Recomendação n $1 / 94$ ao GMC que, ao ser aprovada (Resolução GMC no 10/94), gera o documento Diretrizes Básicas em Matéria de Politica Ambiental.

A preocupação ambiental volta à pauta em 20 e 21 de junho de 1995, mediante reunião dos ministros, formalizada na Declaração de Taranco, quando reafirmam a prioridade dos acordos internacionais e do reconhecimento da temática ambiental do Mercosul. Essa temática é materializada na proposta e concretização de transformação das Remas em subgrupo de trabalho específico, o que acontece com a edição da Resolução $n^{\circ}$ 20/95. Estabelece-se, então, um subgrupo de trabalho consagrado exclusivamente ao meio ambiente, o SGT-6 - subgrupo de trabalho 6 do Grupo Mercado Comum - com a missão de: a) gerar um sistema de informação ambiental; b) implementar o projeto de cooperação: competitividade e meio ambiente; c) promover a gestão integrada dos resíduos de portos, aeroportos e postos de fronteira; d) desenvolver uma gestão ambientalmente adequada de substâncias e produtos químicos, dentre outros.

A dificuldade de harmonização das legislações ambientais se faz presente tendo em vista o desnível entre elas, notadamente o avanço e sofisticação da legislação ambiental brasileira comparada com a todos outros Países Partes. Embora criticada pela Argentina ${ }^{4}$ quanto à sua pouca efetividade, ganha, paulatinamente, força nos tribunais do País que começam a incorporar a cultura ambiental. O contexto é de dificuldades - o que é compreensível toda vez que se tenta definir uma política comum em universos diferentes, como foi o caso da ela-

\footnotetext{
3 Trazemos à baila a clássica observação já tecida quando da iniciativa das atividades da atual União Europeia, no sentido de que "Harmonizar não implica estabelecer uma legislação única e sim eliminar eventuais assimetrias e dirimir divergências".

4 AVIS ET RAPPORTS DU CONSEIL ECONOMIQUE ET SOCIAL. Relations entre L'Union Européenne et le Mercosur, 2002. (Rapport présenté par M. Lucien Bouis).
}

boração e transposições de várias diretivas ambientais da União Europeia, assim como da padronização do modelo de gestão ambiental promovida com a criação da norma ISO série $14000^{5}$ etc.

Ainda assim, o Conselho de Mercado Comum, pela Recomendação no 01/01 do SGT no 6 "Meio Ambiente", em Decisão no 02/01, de 22 de junho de 2001, em Assunção, aprova o Acordo-Quadro sobre Meio Ambiente do Mercosul (AQMAM), criando, conforme dispõe em seu preâmbulo, um "[...] macro jurídico que facilite a efetiva proteção do meio ambiente e o uso sustentável dos recursos naturais dos Estados Parte". Ao fazê-lo, o Mercosul, diante de todas as dificuldades e crises consideráveis em que se encontram os países integrantes, especialmente a Argentina, dá sinal de vida, contrariando aqueles que o tinham como morto e dando um importante passo para a concretização do processo de integração e cooperação que tem anseios que devem ir muito além da equidade comercial, ou ao menos de alcançá-la de maneira sustentável. Fato é que, com o AQMAM, é concretizado o que denominamos de política ambiental regional, redirecionando e ampliando o processo de cooperação e, sobretudo, efetivando, juridicamente, a proteção autônoma do meio ambiente, e revelando o $o$ direito ambiental regional do Mercosul.

\subsection{Desenvolvimento sustentável: conceito integrador de matérias e de sujeitos dotado de pluralidade de efeitos}

O desenvolvimento sustentável se constitui em objetivo a ser perquirido pelo Cone Sul, conforme preleciona o $\operatorname{art.~} 4^{\circ}$ do AQMAM. A orientação é embrionária à existência do bloco, ainda que de forma indireta e parcial, uma vez que o preâmbulo do TA, ao expor seus motivos e objetivos, elenca vertentes, tais quais: "[...] acelerar seus processos de desenvolvimento econômico com justiça social; aproveitamento mais eficaz dos recursos disponiveis, preservação do meio ambiente, [...] desenvolvimento científico e tecnológico"; [...] modernizar a economia a fim de melhorar as condições de vida de seus habitantes".

Destarte, por não ter se utilizado da nomeclatura e, por conseguinte, do "desenvolvimento sustentável", a evocação de seu conceito, efeitos e implicações, a exemplo

5 Acerca do tema: D'ISEP, Clarissa Ferreira Macedo. Direito ambiental econômico e a ISO 14000: análise jurídica do modelo de gestão ambiental ISO 14001. 2. ed. rev. atual. e amp. São Paulo: Revista dos Tribunais, 2009. 
da sua extensão subjetiva às futuras gerações, implicaria interpretação extensiva do TA.

Em face do atual contexto de degradação socioambiental e do nível de desenvolvimento econômico e tecnológico, não mais se pode visualizar o desenvolvimento legítimo dissociado da exigência de sua sustentabilidade. Essa qualificação - sustentável - o empregnou de tal modo que se busca desenvolvê-la de forma setorial, a fim de garantir-lhe a máxima efetividade e aplicação, a exemplo da dita pesca sustentável, agricultura sustentável, comércio sustentável, cidade sustentável etc. Dessa forma, estar-se-á concretizando o Princípio 27 da Declaração Rio/92 e o capítulo 39 da Agenda 21 da Conferência das Nações Unidas, assim como aplicando o Princípio da Integração.

A vertente desenvolvimento sustentável regional do Mercosul, agora expressa, passa a ser regida pelo microssistema normativo composto por: $\mathrm{TA}+\mathrm{POP}+\mathrm{PO}+\mathrm{AQ}-$ MAM + Princípios da Declaração Rio/92, fontes que, ao dialogarem, formam a unidade geral, abstrata e objetiva de regramento. Quando evocada, ou seja, aplicada ao caso real, a subsunção se dará de forma especifica, concreta e subjetiva, uma vez que interage com as disposições setoriais, reguladoras da matéria em questão, e, ainda, com o Direito interno dos Países Membros e Associados, conforme o caso.

Para ilustrar a afirmativa, tomemos como exemplo a iniciativa de cooperação firmada entre o Mercado Comum do Sul e a República Federal da Alemanha, em 18-2-2002, no Acordo sobre o projeto de "[...] fomento de gestão ambiental e produção mais limpa em pequenas e médias empresas", por Decisão de no 03/02 do CMC, que tem por objetivo: “[...] fomentar a gestão empresarial ecológica e os processos de produção mais limpa em pequenas e médias empresas mediante a cooperação entre instituições relevantes dos setores público e privado dos estados Partes do MERCOSUL". Esse projeto encontra sustentação normativa geral, abstrata e objetiva na política de desenvolvimento sustentável regional, portanto no microssistema supramencionado; e, de forma especifica, concreta e subjetiva na legislação reguladora da atividade econômica e ambiental do País Membro que for sediar a pequena ou média empresa que vier a ser fomentada pelo projeto em questão. Isso somado à regulamentação material específica do setor de atuação dessa empresa.

A política do desenvolvimento sustentável regional é o instituto responsável pelo movimento e coesão, portanto de ação e interação dessa rede normativa que, ao mesmo tempo em que é provida de caráter bidimensional, no tocante à matéria (geral e setorial), e de caráter tridimensional, quanto à origem das normas (internacional, regional e nacional), adquire, no caso concreto, forma unidimensional, por revelar a intersecção entre diferentes conceitos, matérias e princípios.

O desafio na delimitação de efeitos e extensão de tal instituto, "desenvolvimento sustentável", que comporta, ainda, o debate quanto ao seu valor jurídico, é uma constante que se intensifica e se efetiva cada vez que é ratificado em novo acordo ou texto de lei, o que nos remete a reavaliar e atualizar, numa relação direta de tempo e espaço, a proposta de seu conteúdo, sentido e alcance. $^{6}$

A iniciativa se coaduna com o cenário internacional, evidenciado pela "Declaração de New Delhi sobre os Princípios de Direito Internacional Relativos ao Desenvolvimento Sustentável", documento aprovado na conferência de 2 a 6-4-2002, por ela recepcionado. Tem como proposta a observância dos princípios de direito internacional aplicados à ideia do desenvolvimento sustentável, com o fim de concretizar os seguintes objetivos: a) o dever dos Estados de velar pela utilização sustentável dos recursos naturais; b) o princípio da igualdade e eliminação da pobreza; c) o princípio da responsabilidade comum mais diferenciada; d) o princípio da precaução aplicado à saúde, aos recursos naturais e aos ecossitemas; e) o princípio da participação do público e acesso à informação e à justiça; f) o princípio da boa governância; g) o princípio da integração e interdependência, em particular no que concerne aos direitos humanos, objetivos sociais, econômicos e ambientais.

A proteção ambiental integrada é uma vertente internacional, que orienta o Mercosul, como sujeito de direito internacional. Diversa não poderia ser a orientação do AQMAM, que privilegiou, exaustivamente, as duas espécies de proteção: a autônoma, ao direcionar os rumos da cooperação para uma política ambiental comum; a integrada, que é reafirmada no art. $3^{\circ}$, b, figurando como princípio e como objetivo (art. 4), quando da imposição do desenvolvimento sustentável, que permeia todo o Acordo Ambiental. Isso sem mencio-

6 Cumpre ressaltar que o Princípio do Desenvolviemento Sustentável foi declarado Princípio Geral de Direito por decisão arbitral da Corte de Paris. In: D’ISEP, Clarissa Ferreira Macedo. Agua juridicamente sustentável. São Paulo: Revista dos Tribunais, 2010. 
nar a ratificação expressa aos princípios da Declaração Rio/92, que a eles (princípio da integração e do desenvolvimento sustentável) se reportam.

Entendemos estar superada a ideia de que a proteção ambiental constitua uma restrição ao comércio ou às atividades econômicas de forma geral, pela simples razão de que visualizamos a economia como sendo a ecologia humana. ${ }^{7}$

Nesse sentido, foram as orientações do Comitê Independente de Revisão do "Acordo Norte-Americano de Cooperação Ambiental" (em inglês: North American Agreement on Environmental Coorperation NAAEC), celebrado em 13-9-93, entre Canadá, México e Estados Unidos, que, resumidamente, enfatizaram a necessidade de a Comissão de Cooperação intervir para ampliar e especificar o nexo que liga "comércio e meio ambiente"; assim como a necessidade de enfrentar o problema ligado à "[...] melhoria da capacidade analítica dos países no estabelecer o relacionamento sistemático entre a expansão do comércio e a qualidade ambiental na área pertinente". ${ }^{8}$

A Declaração de New Delhi constata que “[...] o objetivo do desenvolvimento sustentável implica numa abordagem exaustiva e integrada entre processo econômico, social e político [...]”. A proteção integrada é um forte e eficaz princípio na defesa da qualidade ambiental que ganha força e necessita de sua instrumentalização e fiscalização. Diverso não foi o ocorrido na União Europeia até a implantação do Direito Comunitário Ambiental.

\section{O ACORDO-QUADRO SOBRE O MEIO AMBIENTE DO MERCOSUL (AQMAM): DA ANÁLISE DA PROTEÇÃO AUTÔNOMA DO MEIO AMBIENTE REGIONAL A UMA ABORDAGEM PROSPECTIVA DO Direito ambiental regional do Mercosul}

O Acordo-Quadro sobre Meio Ambiente do Mercosul $(A Q M A M)^{9}$ foi sistematizado, além do Prêambulo, em

\footnotetext{
7 A respeito veja, D’ISEP, Clarissa Ferreira Macedo. Direito ambiental econômico e a ISO 14000: análise jurídica do modelo de gestão ambiental ISO 14001. 2. ed. rev. atual. e amp. São Paulo: Revista dos Tribunais, 2009. p. 53 e ss.

8 MACHADO, Paulo Afonso Leme. Direito Ambiental Brasileiro. 19. ed. rev., atual. e ampl. São Paulo: Malheiros, 2011. p. 1170 e 1171.

9 A aprovação do Acordo-Quadro no Brasil pelo Congresso Na-
}

quatro capítulos (I - Princípios; II - Objetivo; III Cooperação em Matéria Ambiental; e IV - Disposições Gerais) e em um anexo (Áreas Temáticas). Trata-se de instrumento normativo específico, que tem por objetivo a concretização do desenvolvimento sustentável e da proteção do meio ambiente (cf. art. $4^{\circ}$ ), colocado à disposição de particulares e dos Estados Partes para pautarem suas relações, comerciais ou não, entre si e o bloco com terceiros.

A regulamentação concretizada promove a confirmação do valor ambiental no seio do Mercosul, tendo em vista que a função normativa coloca em evidência os seus fundamentos, situação bem ilustrada na afirmativa de que se "[...] a norma é o instituto, o valor é o instituidor". ${ }^{10}$ Todo esse processo buscou alcançar a eqüidade ambiental interna e a competitividade ambiental exter$n a$, uma vez que a tutela se dá de forma integrada ao anseio de desenvolvimento e no contexto de um processo de cooperação econômica, donde se tem por selada a proteção ambiental como premissa, logo fundamento de suas atividades. Nesse sentido, ilustramos com a Constituição Federal Brasileira de 1988 que, expressamente, já estabelece, em seu artigo 170, a proteção do meio ambiente e a defesa do consumidor como princípios da atividade econômica.

\subsection{O significado e a abrangência de um Acordo-Quadro Ambiental Regional: efeitos jurídicos}

Pautando-nos nos sujeitos alcançados, no objetivo pretendido e no status jurídico do bloco, podemos atribuir uma multiplicidade de efeitos jurídicos ao AQMAM, que podem ser analisados por variados critérios, devido à complexidade do seu escopo e à pluralidade de possibilidades de atividades do Cone Sul.

Mesmo que não tenha aplicação imediata, revela um efeito vinculante, pelo fato de resultar numa manifestação unilateral de vontade, pois o Mercosul é provido de personalidade jurídica de direito internacional, portanto sujeito de direito internacional ${ }^{11}$ que, ao emitir uma decla-

cional pelo Congresso Nacional se deu por meio do Decreto Legislativo $\mathrm{n}^{\circ} 333$, de 24 de julho de 2003.

10 SOUBIRAN-PAILLET, Francine; VAN DE KERCHOVE, Michel. Normativités et inormativités. Paris: LGDJ, 2000. p. 17.

11 Ilustramos com a definição de sujeito de direito internacional oferecida por DUPUY, como segue: "On dit d'une entité qu'elle constitue un sujet de droit lorsqu'elle est dotée par les normes d'un 
ração, tem por constituída a obrigação de fazê-lo perante a sociedade internacional e, por conseguinte, a obrigação de resultado entre os Estados Partes, ainda que livres quando à forma.

No tocante aos Estados Partes, conforme o prisma e situação analisados, ter-se-ão as disposições do acordo figurando com natureza jurídica contratual, mas precisamente na condição de cláusula geral na matéria ambiental, quanto ao comando de "proteção do meio ambiente", e instituído um conceito determinado pela função, ${ }^{12}$ quanto à promoção do "desenvolvimento sustentável".

O AQMAM figura, ainda, como uma importante fonte formal de direito, notadamente para o Paraguai e o Uruguai, que nele poderão lastrear suas decisões, arbitrais ou jurisdicionais, atinentes à matéria ambiental.

Por derradeiro, evidencia-se, como efeito jurídico do AQMA, a capacidade de vedar disposições diversas e, como supramencionado, de promover a eqüidade ambiental, confirmando assim o valor ambiental, estendendo a cooperação promovida pelo bloco e ratificando a intenção, anteriormente exposta de forma menos acentuada, de proteger o meio ambiente e qualificar 0 desenvolvimento, regulando o comércio ao condicioná-lo à premissa ambiental.

\subsection{A proteção regional autônoma do meio ambiente: 0 alvorecer do direito ambiental regional do Mercosul}

Ao promover a proteção do meio ambiente, objeto de Acordo-Quadro (art. 4\% ACMAM), tem-se estabelecida a sua proteção ambiental autônoma e instaurada a tutela ambiental regional no Cone Sul, conforme já disposto, bem como definido o seu "status" jurídico, ou seja, foi-lhe atribuído um valor jurídico determinado, que não foi outro senão o de princípio fundamental regional.

As tratativas do Mercosul têm, sob a ótica do direito de integração, natureza jurídica contratual, portanto sujeita ao efeito vinculativo do princípio geral contratual,

ordre juridique déterminé d'un ensemble de droits et d'obligations, ainsi que des capacités nécessaires à leur exercice. » DUPUY, JeanMarie. Droit international public. 4. ed. Paris: Dalloz, 1988.

12 NERY JUNIOR, Nelson; NERY, Rosa Maria de Andrade. Novo Código Civil e Legislação Extravagante Anotados. São Paulo: Revista dos Tribunais, 2002. p. 6 . "Conceitos determinados pela função (funktionsbestimmte Rechtsbegriffe) Os conceitos legais indeterminados se transmudam em conceitos determinados pela função que têm de exercer no caso concreto". o pacta sunt servanda. Sendo assim, ignorado o comando de proteção ambiental, quando das atividades regionais do Mercosul, ter-se-á a sua ilegitimidade, tendo em vista o descumprimento contratual.

O AQMAM passa a integrar o microssistema jurídico-ambiental interno dos Países Membros e reconhece a legislação ambiental como um instrumento da política ambiental, assim como prevê o intercâmbio de informações sobre leis, regulamentos, procedimentos, políticas e práticas ambientais (art. 6० AQMAM), inclusive no fito de harmoniza-las.

Ressalta-se que o comando geral de proteção ambiental somado ao comando expresso de busca da instrumentalização dos Princípios da Declaração do Rio de Janeiro sobre Meio Ambiente, de 1992, trazido pelo acordo (art. $2^{\circ}$, AQMAM) e interpretado, sistematicamente, com disposições setoriais existentes, tem formado o microssistema normativo do meio ambiente do Mercosul, do qual resulta o direito ambiental do Mercosul. Isso indica que a tais disposições foi atribuído caráter transversal, não as limitando à temática regulada, o que significa que as disposições estabelecidas, por exemplo, em instrumentos como o "Acordo de Cooperação e Facilitação sobre a Proteção das Obtenções Vegetais nos Estados Partes do MERCOSUL" (Dec. n¹/99) ou, ainda, a "Complementação do Plano Geral de Cooperação Recíproca para a Segurança Regional em Matéria de Ilícitos Ambientais" (Dec. no 10/00) trazem instrumental que pode ser disponibilizado para a proteção do meio ambiente de forma geral.

A existência do AQMAM aponta que o Mercosul pretende buscar harmonizar vertentes de um mesmo ecossistema, meio ambiente e comércio, e, também, contribuir para a promoção da cooperação ambiental regional e internacional.

Ao promover a proteção autônoma do meio ambiente, o Acordo ocasionou efeitos, tais quais: a) a proteção preventiva e integral do meio ambiente, que conduzirá à agestão ambiental regional; b) a cooperação entre governos na busca de harmonização das legislações; c) a parceria com a sociedade civil organizada, que passa a figurar como sujeito indispensável na gestão ambiental.

A proteção autônoma se faz preventiva, pois permite uma atuação independente e, por certo, de maneira a considerar o meio ambiente como um todo e ao mesmo tempo aperfeiçoando a proteção setorial, logo integral. 
Vale notar a aplicação do princípio da informação e participação no AQMAM, dado o destaque atribuído ao governo pelos organismos nacionais competentes e à sociedade civil organizada (art. $6^{\circ}$, caput) que deverão auxiliar na análise dos problemas ambientais, incrementando o intercâmbio de informações, incentivando a pesquisa científica, contribuindo para a promoção de trabalho ambientalmente saudável etc. (art. $6^{\circ}$, a-n).

Entretanto, para concretizá-los, será necessária a criação de um conceito de meio ambiente comum, o que se dará com a harmonização legislativa e, sobretudo, a instrumentalização dessa defesa transfronteriça, ou seja, o Estudo de Impacto Ambiental Regional, a licença ambiental regional, o monitoramento ambiental regional, a auditoria ambiental regional, etc. Também é preciso a criação de instrumentos de fiscalização da proteção integrada, que poderão ser uma certificação, etiqueta ambiental do bloco, cláusulas ambientais, auditoria ambiental, etc.

Além dos efeitos supramencionados, ter-se-á, cada vez que for instaurado, um acordo-quadro, estabelecido e atribuído o valor jurídico de princípios fundamentais à matéria regulada, devendo essa matéria refletir de forma autônoma e integrada nas matérias setoriais, revelando a gestão ambiental do bloco.

\subsection{O Acordo-Quadro Ambiental do Mercosul: entre prognósticos e prospectivas.}

O AQMAM estabelece um divisor de águas na temática ambiental do Mercosul, dados os seus efeitos inovadores.

Esse acordo tem o condão de firmar o compromisso do desenvolvimento da política ambiental do Mercado Comum do Sul, em que o meio ambiente do Mercosul - espaço geográfico dos Países Membros e associados, nos limites do objeto de suas relações, reguladas nos tratados - partilha da obrigação e responsabilidade de instrumentalizar e concretizar a tutela do espaço ora protegido que, dados os efeitos difusos, ainda que de origem comum, passa a ter natureza jurídica análoga à de "ressource naturel partagée", ou seja, em tradução literal e significativa do termo, "recursos naturais partilhados". Neste sentido, o Acordo do Aquífero Guarani, firmado na Argentina em 2-8-2010, em que o status jurídico é de recurso hídrico transfronteiriço.

Inaugurada, pela norma em comento, a política am- biental regional, que se instrumentaliza na gestão regional ambiental do Cone Sul, traz diversas disposiçoes que sintetizamos.

Ratifica a proteção ambiental integrada, em seu art. $3^{\circ}$, b e quando estabelece o objetivo de "desenvolvimento sustentável"; e inova, com a imposição de uma proteção ambiental autônoma que se exterioriza no comando expresso de "proteção do meio ambiente".

A proteção integrada e a autônoma revelam um microssistema de normas ambientais que inaugura a tutela ambiental regional no âmbito do Mercosul, o que deverá permear todas as suas normas e tratativas, o que, por conseguinte, faz emergir o direito ambiental regional do Mercosul.

O objeto do AQMAM produz efeitos subjetivos em diferentes níveis: nas relações do bloco propriamente dito, isto é, do Mercosul com terceiros; dos Países Membros e Países Associados entre si; e, ainda, no interior dos Países Membros, visando, com isso, a garantir a equidade ambiental entre e intergerações.

Efeitos materiais estão evidenciados nos objetivos externados no art. $4^{\circ}$., que qualifica o desenvolvimento, já normatizado no TA, como sustentável, almejando equidade nas relações comerciais. Ao impor a proteção do meio ambiente, objetivando a conservação dos recursos naturais do bloco, inspira um sistema análago ao de "recursos naturais compartilhados", que terá sua implementação em função do estágio político regional do bloco no tocante aos diferentes estágios de integração. O Mercosul trilha, até então o modelo societário, em que, de acordo com Ferdinand Tonies, os fatores de desagregação do grupo social são mais fortes que os de aproximação"13 - o regime jurídico dos "recursos naturais compartilhados" seria o de condomínio; ao posso que o da União Europeia, modelo comunitário, em que os fatores de aderência são mais fortes, a gestão do bem comum se dá no regime jurídico da copropriedade.

Por certo, a força dos fatores de desagregação, no âmbito econômico-financeiro-comercial do Mercosul, tem se revelado em grande entrave para avanço de cooperação e integração do bloco. A seara ambiental, por meio do ACMAM, revela-se como uma nova alternativa e oportunidade de exercicio de cooperação para os Estados Partes e Países Associados, dada a unidade

13 ACCIOLY, Elisabeth. Mercosul \& União Européia: estrutura jurídico-institucional. Curitiba: Juruá, 1996. p. 17. 
de interesse na gestão do bem comum, que é provido de caráter unitário, a exemplo do já mencionado Aquifero do Guarani. As searas em que se conseguir capturar a predominância do interesse comum devem ser priorizada para que seja superada a imaturidade no âmbito da cooperação e assegurado o avanço a estágios mais elevados no direito de integração. E, quiça, a seara social e, por derradeiro à econômica se tornariam mais ágeis. Espera-se que a presente colocação não seja razão de frustações aos empreendedores e às tratativas originárias do Cone Sul, - ao revés, que o AQMAM seja instrumento de motivação para alcançar o avanço econômico, na lógica do sábio ditado popular: "Um passo atrás para um salto na frente". Até porque a tutela ambiental jamais será "Um passo atrás", ao contrário, torna legitima a atividade econômica. O que se pretende, tão e somente, é afastar o pessimismo que circunda o Mercosul e estimular os seus defensores.

Espera-se que os atores do Mercosul coloquem em prática a força e o alcance de que é provido o acordo analisado, dada a abrangência de seus conceitos e sistemática normativa que sugere, concretizando no dizer de Lipietz, "un compromisse socio-éco-democráte". ${ }^{14}$

\section{O Acordo-quadro sobre Meio Ambiente do Mercosul (AQMAM) e o Comércio INTERNACIONAL: UMA ANÁLISE APLICADA}

O AQMAM figura, ao menos no âmbito teórico, como um divisor de águas nas relações do bloco. O escopo originário de livre comércio, por certo, se mantém, entretanto, passa a ser um comércio qualificado, qual seja: comércio sustentável.

Em que pese a previsão declinada, no preâmbulo do TA, de "utilização eficaz dos recursos disponíveis e proteção do meio ambiente", a mudança de paradigma exige uma tônica mais expressiva nas relações e decisões do bloco, o que requer, inicialmente, mudanças cultural, ideológica, ética e econômica. E, por certo, exige a adoção de políticas, instrumentos e mecanismos de sua implementação.

As decisões das cortes de solução de conflitos, seja no âmbito do Mercosul, seja, no âmbito da OMC (Painel e órgão de Apelação), não recepcionaram a susten-

14 L’Europe en Bref, p.26. tabilidade de forma dinâmica como pretendido pelo o AQMAM e pelo Direito ambiental internacional, construído por tratados.

Nesse sentindo, observa-se alguns dos pontos que permeiam a temática:

(i) regulação ambiental x liberdade de comércio: No dizer de Bernard Remiche ${ }^{15}$, "quanto mais Direito, mas economia, mais comércio...", uma vez que quanto mais regulação, mais segurança jurídica e, logo, maior circulação de bens e riquezas. Foi a lógica vislumbrada no instituto jurídico da 'Propriedade Intelectual', que uma vez que ela regulamentada, sua circulação se fez dinâmica.

A regulação tem por efeito a democratização; a possibilidade de criação de mecanismos jurídicos de aplicação, de comunicação, de transparência e de gestão. A liberdade só se faz legitima quando exercida com responsabilidade. Destarte, regulamentar a temática comércio-meio ambiente de forma mais pontual, colabora para a proteção ambiental, em que o comércio se faz instrumento de gestão ambiental. E, a contrario sensu, coíbe práticas discriminatórias e restritivas ao comércio por pretexto ambiental, seja pelo regramento do bem comercializado, seja proteção ambiental implementada.

Da mesma forma, conforme destaca Morosine ${ }^{16}$, busca-se evitar "a concorrência normativa e jurisdicional entre os regimes ambiental e comercial" e a inibir práticas discriminatórias, e assegura o comércio aberto, previsível e equitativo.

Pode-se registrar um avanço técnico, de grande valia para a interpretação e integração dos conceitos e noções, objeto de demanda de comércio transnacional, regional e internacional. A exemplo da OMC, que adotou a preservação ambiental como uma das diretrizes do seu sistema, aplicando a interpretação extensiva do art. XX, do GATT, notadamente, das alíneas b" e "g". No mesmo sentido, é a posição normativa do Mercosul, através da implementação do AQMAM. Do que se extraí que a natureza jurídica de que é provido o comendo de "proteção ambiental" e de "promoção do desenvolvimento sustentável”, no âmbito das relações de comércio inter-

15 RENICHE, Bernard. Révolution technologique, mondialisation et droit des brevets. Revue Internationale Droit Economique. Bruxelas: De Boeck Université, 2002. p. 83-124. Numéro anniversaire. 16 MOROSINI, F. C.; NIENCHESKI, L. Z. . A relação entre os tratados multilaterais ambientais e os acordos da OMC: é possível conciliar o conflito? Revista de Direito Internacional, v. 11, p. 151-168, 2014. 
nacional com os países do Mercosul, são, no aspecto instrumental, de cláusula geral e, no aspecto material, de cláusula ambiental e de cláusula de sustentabilidade, reciprocamente.

Fato é, que a proteção ambiental é uma nova vertente, em que permite a releitura de propósitos, adequação de condutas e instrumentalização de comandos do Cone Sul.

\subsection{O desenvolvimento sustentável: um caminho sem volta}

O mundo clama por um desenvolvimento sustentável, pela economia verde, e erradicação da pobreza, conforme consignado no documento "The future, we want", na Conferência das Nações Unidas no Rio em 2020. É um avanço e redesenho da integração mercosulina, que se analisada sob a lupa do comércio, pretende-se que a política socioeconômica-ambiental seja implementada, regulamentando mecanismos de viabilização e facilitação do comércio como, por exemplo:

(i) compensação ambiental;

(ii) compliance mechanisms em matéria ambiental;

(iii) cláusulas ambientais padronizadas e gerenciadas;

(iv) criação de mecanismos de incentivo flexíveis e não vinculativos de proteção ambiental no âmbito do comércio e das demais relações do bloco.

Não se pode olvidar que a política de integração mercosulina foi renovada, ampliada e, senão, redirecionada, ao menos, qualificada, posto que foi pactuada a adoção do Princípio do Desenvolvimento Sustentável em que as vertentes - social-ambiental-econômica primam por harmonização, implementação, não retrocesso e, ainda, melhoria contínua, mediante atuação pro-ativa.

Acreditar no Princípio do livre comércio como vertente e a proteção ambiental como exceção, como impregnadas as decisões de soluções de controvérsias, notadamente no caso dos pneus remodelados, é, no mínimo, ignorar a técnica jurídico-normativa que circunda o AQMAM.

A política de comércio deixa de ser um temática autônoma e isolada para agir e interagir com políticas ambientais e sociais, que devem ser implementadas. As operações comercias devem acontecer no contexto regional de política econômica, que não deve ser sustentá- vel. A complexidade do diálogo das políticas públicas de direito interno e as de direito regional e internacional, além de interagirem devem se harmonizar e serem monitorados por sistema de gestão autônomo. Desafio da nova era do bloco.

\section{REFERÊNCIAS}

ACCIOLY, Elisabeth. Mercosul \& União Européia: estrutura jurídico-institucional. Curitiba: Juruá, 1996.

AVIS ET RAPPORTS DU CONSEIL ECONOMIQUE ET SOCIAL. Relations entre L'Union Européenne et le Mercosur, 2002. (Rapport présenté par M. Lucien Bouis).

D’ISEP, Clarissa Ferreira Macedo. Agua juridicamente sustentável. São Paulo: Revista dos Tribunais, 2010.

D’ISEP, Clarissa Ferreira Macedo. Direito ambiental econômico e a ISO 14000: análise jurídica do modelo de gestão ambiental ISO 14001. 2. ed. rev. atual. e amp. São Paulo: Revista dos Tribunais, 2009.

DUPUY, Jean-Marie. Droit international public. 4. ed. Paris: Dalloz, 1988.

LIPIETZ . Alain. L'Europe en Bref.

MACHADO, Paulo Afonso Leme. Direito Ambiental Brasileiro. 19. ed. rev., atual. e ampl. São Paulo: Malheiros, 2011.

MOROSINI, F. C. The MERCOSUR and WTO retreaded tires dispute: Rehabilitating regulatory competition in international trade and environmental regulation. 2008. Doutorado (Tese de Ph.D.). The University of Texas Libraries, Austin, 2008.

MOROSINI, F. C. O Caso dos Pneus no Mercosul e na OMC: Reabilitando a Competição Regulatória em Disputas de Comércio Internacional e Meio Ambiente. In: RIEDRICH, Tatyana F. (Org.). Direito e Desenvolvimento. Curitiba: 2009.

NERY JUNIOR, Nelson; NERY, Rosa Maria de Andrade. Novo Código Civil e Legislação Extravagante Anotados. São Paulo: Revista dos Tribunais, 2002.

SOUBIRAN-PAILLET, Francine; VAN DE KERCHOVE, Michel. Normativités et inormativités. Paris: LGDJ, 2000. 


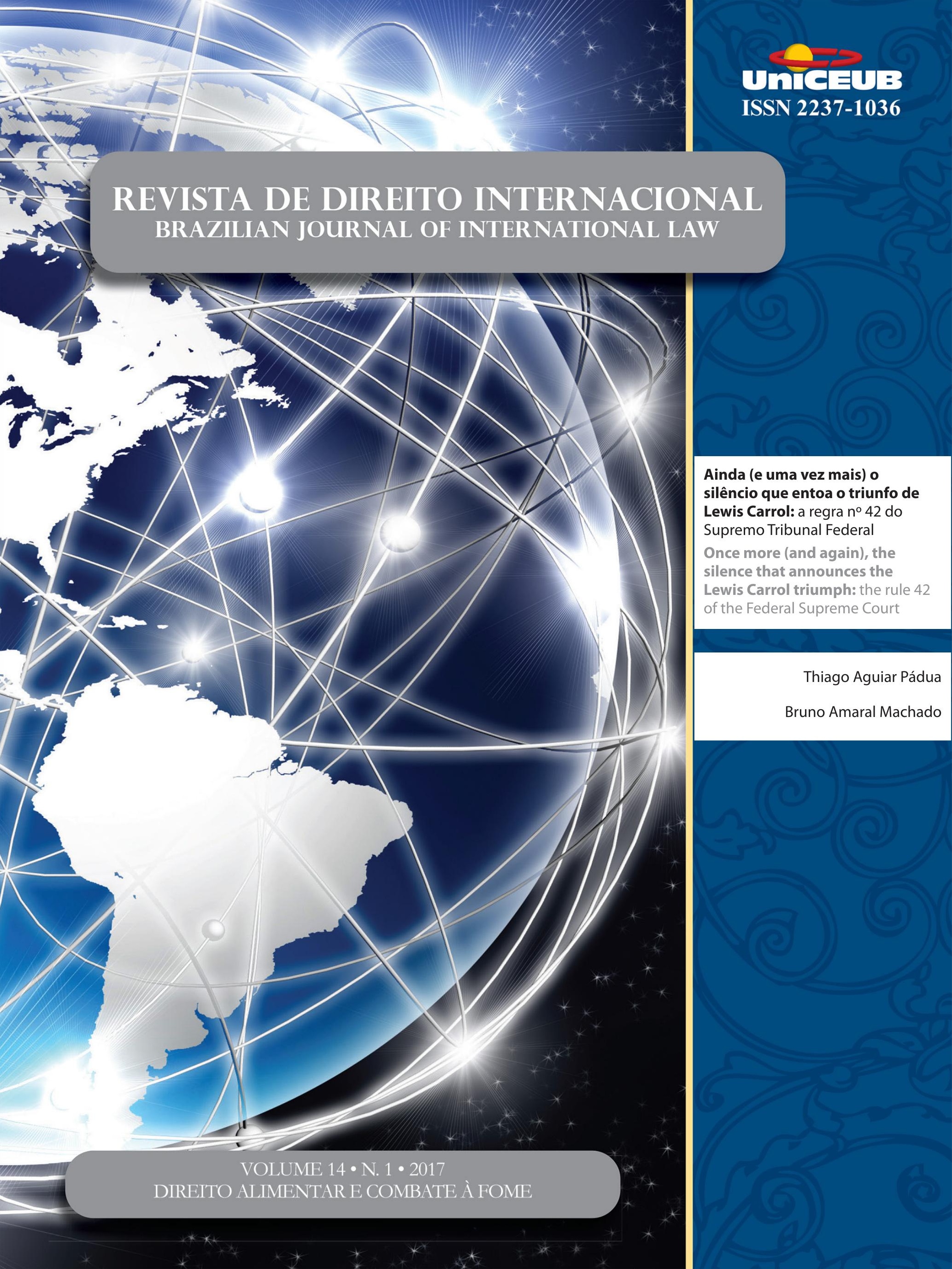




\section{Ainda (e uma vez mais) o silêncio que entoa o triunfo de Lewis Carrol: a regra $n^{\circ} 42$ do Supremo Tribunal Federal*}

\author{
Once more (and again), the silence that \\ announces the Lewis Carrol triumph: the rule \\ 42 of the Federal Supreme Court
}

\section{Resumo}

No presente artigo, discutimos dois recentes julgamentos do Supremo Tribunal Federal do Brasil em relação aos crimes praticados durante a ditadura civil-militar: a Arguição de Descumprimento de Preceito Fundamental $n^{\circ} 153$ (constitucionalidade da lei de anistia de 1979) e a Extradição no 1362 (requerimento de extradição de cidadão argentino que foi condenado pelo cometimento de crime de lesa-humanidade durante a ditadura argentina). Analisamos o papel do Supremo Tribunal Federal na (re) construção do "problema criminal" e do "controle penal", em relação a crimes contra a humanidade perpetrados nos períodos da ditadura argentina (1978-1983) e brasileira (1964-1985). Buscamos inspiração no pensamento de Lola Aniyar de Castro, para quem a criminologia do Século XXI é a "criminologia dos direitos humanos" e o controle penal é o termômetro dos direitos humanos. Ao final discutimos que parece ter havido o triunfo de Lewis Carrol, na metáfora de inversão de sentidos: quando proteger os direitos humanos passa a ser não proteger os direitos humanos, com criação de uma regra decisória ad hoc, em que "lembrar é esquecer", e "esquecer é recordar", desde que, em peculiar Regra n ${ }^{\circ} 42$, não se autorizem a investigação e a responsabilização pela prática de crimes de lesa-humanidade.

Palavras-chave: Controle Penal na Ditadura. Supremo Tribunal Federal. ADPF 153. Anistia. Extradição 1362. Lesa-humanidade.

* Autores convidados

** Doutorando em Direito pelo Centro Universitário de Brasília. Emails: sapadua@gmail. com

*** Professor do Programa de Mestrado e Doutorado em Direito do Centro Universitário de Brasília. Emails: sapadua@gmail.com e brunoamachado@hotmail.com

\section{Abstract}

In this article we discuss two recent Brazilian Federal Supreme Court judgments about crimes committed during the civil-military dictatorship: Allegation of Disobedience of Fundamental Precept suit n. 153 (constitutionality of the 1979 amnesty law), and Extradition suit n. 1362, that discussed the extradition of an Argentine citizen who was convicted of committing crimes against humanity during the Argentine dictatorship). We analyze the role of the Brazilian Federal Supreme Court in the (re) construction of the "criminal problem" and "criminal control" in relation to crimes against 
humanity perpetrated during the periods of the Argentine (1978-1983) and Brazilian (1964-1985) dictatorship. We take Lola Aniyar de Castro Thought's, seeking some inspiration, for whom the criminology of the 21st Century is the "criminology of human rights", and criminal control would be the thermometer of human rights. In the last part of this article, we discussed what seems to have been "the triumph of Lewis Carroll", in the metaphor of reversing meanings: when protecting human rights is not to protect human rights, by creating an ad hoc decision-making rule from which "remembering is to forget", and "forgetting is to remember", since then, from the peculiar Rule n. 42, the investigation and accountability for crimes against humanity are not allowed.

Keywords: Criminal Control in the Dictatorship. Brazilian Federal Supreme Court. ADPF 153. Amnesty. Extradition 1362. Lesa-humanity.

\section{INTRODUÇão}

Hello darkness, my old friend, I've come to talk with you again, Because a vision softly creeping, Left its seeds while I was sleeping, And the vision that was planted in my brain Still remains, Within the sound of silence. [...] People talking without speaking, People hearing without listening. ${ }^{1}$

O "Som do Silêncio", música de autoria da dupla Simon e Garfunkel, narra o apelo que alguém faz à escuridão, tratando-a como velha amiga, dizendo-lhe que as pessoas escutam, mas não ouvem. A releitura da música, na versão do grupo Disturbed, continua atual, tocante e melancólica. Falar para auditórios cansados, inventados (ou imaginários) pode trazer a mesma sensação.

Thiago de Mello, escritor amazonense, a despeito da escuridão e por causa dela, anunciou, poeticamente, que é preciso continuar cantando; visão sublime que ganha mais colorido quando justaposta aos 13 artigos (e mais o artigo final) de seus "Estatutos do Homem" (como Ato Institucional Permanente), nos quais fica proibido o uso da palavra "liberdade", que deveria ser suprimida dos dicionários (e do pântano enganoso das bocas). Deveria ser tornada algo "vivo e transparente", assim como um fogo ou um rio e cuja morada deveria ser

1 Cfr. SIMON, Paul; GARFUNKEL, Art. The Sounds of Silence. Sounds of Silence. Washington: Columbia, 1965. (sempre) o coração do homem. Ao denunciar a limitação da normatividade ${ }^{2}$ como condicionante e limitadora da conduta (mas também como resposta à normatividade permissiva da massiva violação dos direitos), disse, na escuridão, que ficava decretado que nada seria obrigatório (e nem proibido); que tudo seria permitido, mesmo - e inclusive - brincar com os rinocerontes e caminhar pelas tardes com uma imensa begônia na lapela. E que, por decreto irrevogável, ficava estabelecido o reinado permanente da justiça e da claridade, no qual a alegria deveria ser uma bandeira generosa, para sempre desfraldada na alma do povo.

O debate sobre o potencial da arte na hermenêutica jurídica tem despertado o interesse de pesquisadores na área Assim como as ciências sociais (sociologia, criminologia, antropologia, psicanálise, ciência política), a literatura, a música e o cinema propiciam um arsenal de artefatos semânticos para repensarmos a teoria e a prática do direito ${ }^{3}$ Nesse ensaio, a poesia e a música recordam-nos o apelo de Lola Aniyar de Castro (doravante apenas Lola), criminóloga venezuelana, falecida em 2016, à literatura de Lewis Carrol, ao alertar-nos sobre o seu perigoso triunfo na "mirada criminológica": era estranho correr tanto para chegar ao "outro lado", quando no País das Maravilhas se corre para ficar no mesmo lugar.

Para saber o resultado da soma de uma operação simples $(2+2)$, seria preciso perguntar a "quem

2 Ver entrevista recente ao poeta, por ocasião de seus 90 anos. MELLO, Thiago de. Entrevista: Autor de 'Faz Escuro Mas Eu Canto', Thiago de Mello comemora 90 anos em São Paulo. Estadão. Caderno Cultura, de 15 de março de 2016. Disponível em: $<$ http://cultura.estadao.com.br/noticias/literatura,autor-de-fazescuro-mas-eu-canto--thiago-de-mello-comemora-90-anos-em-saopaulo,10000021236>. Acesso em: 21 nov. 2016. Confira-se, ainda: MELLO, Thiago de. Faz Escuro, mas eu canto. 21. ed. São Paulo: Bertrand Brasil, 2003.

3 A arte constitui-se em manancial importante de significantes para outras áreas, como as ciências sociais. Sobre direito e literatura, ver POSNER, Richard A. Remarks on Law and Literature. Loyola University Law Journal, v. 23, p. 181-195, 1991-1992. Sobre direito e literatura no Brasil, ver TRINDADE, André Karam; GUBERT, Roberta Magalhães; COPETTI NETO, Alfredo. Direito \& Literatura: Discurso, Imaginário e Normatividade. Porto Alegre: Nuria Fabris, 2010. Sobre as interconexões entre cinema e criminologia, ver MACHADO, Bruno Amaral; ZACKSESKI, Cristina; PIZA, Evandro C. Cinema e Criminologia: narrativas sobre a violência. São Paulo: Marcial Pons, 2016. Sobre arte e psicanálise, ver RIVERA, Tânia. Arte e psicanálise. Rio de Janeiro: J. Zahar, 2002. Em relação ao tema, sob a perspectiva sistêmica, conferir BEEBEE, Thomas. Can Lawand-Humanities survive Systems Theory? Law \& Literature, n. 244, 2010. 
manda" ${ }^{4}$. A inversão de sentidos, abundante na literatura de Carrol, faz com que pensemos em um silêncio ensurdecedor, que continua a entoar, a partir do primeiro "desabafo" de Lola, o triunfo da retórica jurídica que "chancela" a violação massiva aos direitos humanos. A reflexão leva-nos a questionamento inicial, fio condutor do nosso texto: os direitos humanos não são vulnerados pela validação jurídica das Leis de Anistia e pelo reconhecimento da prescritibilidade dos crimes de lesa-humanidade (casos no Brasil das decisões do Supremo Tribunal Federal, respectivamente, nos julgamentos da ADPF no 153 , e da Extradição no 1362)?

Como narrativa, não (re)apresentaremos "a verdade", mas "possibilidades" ou "leituras alternativas", tal como observado por Lola ao contestar Rosa del Olmo em "America Latina y su criminologia". Uma história pode ser uma simples narrativa de acontecimentos, uma relação de documentos, datas, listas, livros, nomes [...] o que certa vez já se chamou de "o peso morto da história". Mas também pode ser uma interpretação em sintonia com o paradigma selecionado para compreender a sociedade. Muitas vezes são caminhos que se interpenetrem, com a presença do risco sempre possível e nem sempre calculado, da parcialidade, tanto na valoração sobre a seleção dos documentos, com base em pautas epistemológicas e pessoais, quanto da limitação das fórmulas hermenêuticas que levam aos arranjos desejados ${ }^{5}$.

As duas "verdades" de Lewis Carrol pareciam imutáveis aos olhos de Lola, considerada a experiência dos países latino-americanos com os fatores de poder e o "problema delitivo" nos regimes ditatoriais. Em homenagem ao legado crítico da pensadora venezuelana e a esse importante fragmento provocativo, retomaremos outras duas "verdades" de Lewis Carrol para homenageá-la. Vale recordar o destaque dado à participação do Brasil no $23^{\circ}$ Curso Internacional de Criminologia realizado em Maracaibo, Venezuela, em agosto de $1974^{6}$. Quando nossos representantes, presentes ao evento, optaram por falar sobre delitos de trânsito, num momento em que ecoava a violência política no país, preferimos correr e ficar no mesmo lugar, ao tempo em que

4 CASTRO, Lola Aniyar de. O triunfo de Lewis Carroll. In: A NOVA criminologia latino-americana. Discursos sediciosos: crime, direito e sociedade. Rio de Janeiro: F. Bastos, 2000. p. 137.

5 CASTRO, Lola Aniyar de. Criminologia da Libertação. Rio de Janeiro: Revan, 2005. p. 19.

6 CASTRO, Lola Aniyar de. Criminologia da Libertação. Rio de Janeiro: Revan, 2005. p. 24-25. demos a impressão de haver indagado a quem mandava para saber quanto era o resultado da soma de $2+2$. Transcorridos mais de 40 anos, em razão do ensurdecedor "silêncio", retomamos a reflexão com uma finalidade similar: dizer que a escrita de Lewis Carrol continua atual e instigante. Uma espécie de "arauto das contingências das garantias aos direitos humanos".

A nossa escrita inspira-se na metáfora contida na "regra no 42", do "País das maravilhas", e, ainda, em um fragmento de "A Caçada de Snark", para uma reflexão sobre um apelo à verdade por repetição. Na narrativa, quando se repete uma "coisa" por três vezes, é porque ela deve ser verdadeira, num processo de "autofertilização", que invoca a personagem do capitão Bellman, em "The Hunting of the Snark", que descreve "uma viagem impossivel, de uma tripulação improvável, em busca de uma criatura inconcebivel". No caso do julgamento sobre o "roubo das tortas", em relação ao depoimento de Alice, uma singular cena surge da pluma de Carrol, na forma de crítica aos julgamentos, quando regras são criadas para favorecer ou desfavorecer determinadas pessoas, em dadas circunstâncias. O fragmento remete, implicitamente, à "denúncia" à seletividade das agências do controle penal. A "regra no 42 " bem materializa me-

7 Fragmento da "Caçada" descrita em genuíno "non sense" por Lewis Carrol:

"Este é o local de Snark, gritou o capitão Bellman, enquanto desembarcava com cuidado sua tripulação, mantendo cada homem por cima das ondas, com a ajuda de um dedo emaranhado em seus cabelos, Este é o lugar de Snark! Ele disse duas vezes: Isso por si só encorajará a tripulação. Este é o lugar de Snark! Disse pela $3^{\mathrm{a}}$ vez: $\mathrm{O}$ que eu diga três vezes é verdade" (Tradução Livre). Cfr. CARROL, Lewis. The Hunting of the Snark. Cidade: Lightning Source, 2007.

8 WILLIAMS, Sidney; MADAN, Falconer. Handbook of the Literature of the Rev. Cidade: Penguin Books, 1974.

9 Fragmento da "regra no 42 ", inventada pelo julgador na explícita denúncia de Lewis Carrol: “[...] Tão logo o júri recuperou-se do choque e que suas lousas e lápis foram encontrados e devolvidos, eles sentaram-se e começaram a trabalhar diligentemente no relato do acidente. Todos, exceto o Lagarto, que parecia muito chocado para fazer outra coisa que ficar com a boca aberta, olhando para o teto da corte com os olhos esgazeados. "Que você sabe a respeito do caso?", o Rei perguntou a Alice. "Nada", respondeu Alice. "Nada de nada?", insistiu o Rei. "Nada de nada", disse Alice. "Isso é muito importante", disse o Rei, voltando-se para o júri. Os jurados estavam começando a escrever em suas lousas quando o Coelho interrompeu: "Desimportante, é o que Vossa Majestade quer dizer, claro", ele disse, em um tom respeitoso, mas franzindo o cenho e fazendo caretas. "Desimportante, é claro, foi o que eu quis dizer", o Rei retomou rapidamente, e continuou falando consigo mesmo a meia-voz "importante... desimportante... desimportante... importante..." como se estivesse procurando qual palavra soava melhor. Alguns dos jurados escreveram "importante" e alguns "desimportante". Alice pôde ver porque estava perto o suficiente para ver as 
táfora do "problema criminal" e do "controle penal", e da articulação entre ambos, centrais para repensar o potencial da contribuição de Lola para analisar nossas realidades periféricas ${ }^{10}$.

A inspiração no legado de Lola revela-se útil para refletirmos sobre diferentes manifestações do controle penal. Neste artigo, utilizamos o estudo de caso para analisar duas decisões do STF. Sugerimos que o Supremo Tribunal Federal do Brasil, ao se deparar com um possível momento de ajuste de contas com o passado, ao apreciar a constitucionalidade da lei da Anistia ${ }^{11}$, em abril de 2010, julgou a ADPF 153 e, ao avaliar a imprescritibilidade dos crimes de lesa-humanidade (Extradição 1362), optou não apenas por "correr para ficar no mesmo lugar", indagando ao legislador do regime ditatorial quanto era a soma do momento, mas também - como parece evidente - optou por repetir a história que, pela só repetição, pretendeu que fosse tornada verdadeira, criando, com isso, a sua própria "regra no 42".

Discorrer sobre o tratamento que os tribunais concedem ao esquecimento (seja na noção relativa à anistia ou à prescrição), pode nos levar a falar dele (esquecimento) com base em diferentes arranjos teóricos e imagéticos, seja do esquecimento como antípoda à recordação (!?), do esquecimento como punição (!?), do esquecimento como limite e proteção. Mas sempre serão inevitáveis nos quadros e imagens o surgimento de algumas perguntas incômodas:

lousas. "Mas isso não tem a menor importância", ela pensou consigo mesma." Nesse momento o Rei, que estivera ocupado por algum tempo escrevendo alguma coisa em um caderno de anotações, gritou: "Silêncio!" e leu o que estava escrito. "Artigo Quarenta e dois. Todas as pessoas com mais de um quilômetro e meio de altura devem abandonar o tribunal." Todo mundo olhou para Alice. "Eu não tenho mais de um quilômetro e meio", disse Alice. "Tem sim", disse o Rei. "Quase três quilômetros", completou a Rainha. "Bem, de qualquer jeito, não vou embora", disse Alice. "Além do mais, esse artigo não é legal, pois vocês acabaram de inventá-lo." "É o artigo mais antigo do código", retrucou o Rei. "Então deveria ser o Número Um", argumentou Alice. O Rei empalideceu, fechando seu livro de notas rapidamente [...]". Cfr. CARROL, Lewis. Alice no País das Maravilhas. Trad. Clélia Regina Ramos. São Paulo: Universo dos Livros, 2014. p 125-126.

10 CASTRO, Lola Aniyar de. Criminologia da Libertação. Rio de Janeiro: Revan, 2005. p. 237 e ss.

11 Foi ajuizada, posteriormente (em 2014), a ADPF $\mathbf{n}^{\mathbf{0}} \mathbf{3 2 0}$ perante o mesmo STF, na qual se postulou que a referida Lei de Anistia (Lei 6.683, de 28 de agosto de 1979), não fosse aplicada "aos crimes de graves violações de direitos humanos cometidos por agentes públicos, militares ou civis", em razão da decisão emitida pela Corte Interamericana de Direitos Humanos, no caso Gomes Lund. Mas a resposta poderá ser a mesma, numa corrida em que se permanece no mesmo lugar.
Recordar (Esquecer) de que? Por quê? De quem? De que? Pra que? Nossa proposta é discutir as concepções de controle penal ${ }^{12}$ do STF, a partir do pensamento criminológico crítico de Lola, em dois julgamentos cujo objeto foram os atos praticados nos períodos ditatoriais brasileiro (19641985) e argentino (1976-1983).

\section{Fragmentos do pensamento criminológico LATINO-AMERICANO: VETORES PARA UMA RELEITURA DO CONTROLE PENAL DOS CRIMES CONTRA A HUMANIDADE}

No final da década de 1960, os movimentos criminológicos críticos, iniciados na Europa e nos Estados Unidos, promoveram radical crítica às criminologias etiológicas (biocriminologias e sociologia criminal), cujo objeto, historicamente, recaiu sobre as causas dos crimes. A releitura, orientada pela lente marxista, levou à reconfiguração do paradigma da reação social, agora voltado para as estruturas, especialmente econômicas, que moldam a ideologia de defesa social, justificam o direito penal e os pensamentos criminológicos que, tradicionalmente, legitimaram o exercício do poder punitivo ${ }^{13}$.

O movimento crítico na América Latina, impulsionado pelo Congresso realizado na Venezuela, em 1974, capitaneado por Lola e Rosa de Olmo, constitui-se em marco histórico na construção da agenda crítica latino-americana, ao redirecionar o foco para a violência institucional exercida pelas elites. O enfoque multidisciplinar, articulado a projeto de transformação política e social, contou com representantes na Colômbia, Argentina, Chi-

12 Sobre a origem do conceito de controle social e a distinção com o controle político e penal, bem como as tipologias (controle formal e informal), conferir: MELOSSI, Dario. El estado del comtrol social. Un estudio sociológico de los cOnceptos de estado y de control social en la conformación de la democracia. México: Siglo XXI, 1992. Vale conferir a crítica ao uso, nem sempre adequado, feito pelos penalistas, do conceito de controle social: BERGALLI, Roberto et al. Control Social Punitivo. Sistema penal e instancias de aplicación (Policía, Jurisdicción y Cárcel). Barcelona: Editorial María Jesús Bosch, 1996. 13 Conferir seminal obra de BARATTA, Alessandro. Criminología crítica e crítica do direito penal: Introdução à sociologia do direito penal. 2. ed. Trad: Juarez Cirino dos Santos. Rio de Janeiro: F. Bastos, 1999. Conferir extensa referência ao movimento e como foram articuladas as reflexões sobre os novos caminhos para a pesquisa criminológica: VAN SWAANINGEN, René. Critical Criminology: Visions from Europe. London: Sage, 1997. p. 51-107 e 97-207; LARRAURI, E. La Herencia de la Criminología Crítica. 3. ed. Madri: Siglo Veintiuno de España Editores, 2000. p. 67-75. 
le, Venezuela e Brasil (entre outros países) e dedicou-se a debater as raízes da grande desigualdade social e econômica nos países da região e, especialmente, a denunciar a violência do Estado, na forma de práticas criminosas como a tortura, os desaparecimentos forçados e a morte.

No transcorrer da década de 1980, um dos temas relevantes na agenda da criminologia crítica latino-americana foi o julgamento e a responsabilização dos autores dos crimes de lesa-humanidade, praticados pelos regimes ditatoriais. ${ }^{14}$ Um momento importante no debate crítico transcorreu a partir de 1985. Lola é interpelada e responde a artigo de Novoa Monreal, quem apontou suposta "confusão" dos críticos latino-americanos entre os campos da pesquisa científica e o da luta social. Inspirada pelo romance "El jardín de al lado", de Donoso, escritor chileno, Lola reafirma a posição crítica de engajamento na luta pela transformação social e rebate a acusação, considerada distante e alheia à realidade vivenciada pelas sociedades periféricas ${ }^{15}$.
A diversidade dos pensamentos criminológicos, a configuração de campos e objetos de pesquisa diferenciados, vem despertando a atenção de especialistas há muitos anos. Em pesquisa recente sustentamos que as criminologias podem ser descritas como subsistemas científicos concorrentes. Os paradigmas não são sucessivos, estão em constante adaptação, com novos programas teóricos e metodológicos ${ }^{16 .}$ Neste artigo preferimos retomar os modelos analíticos propostos pela criminóloga venezuelana, inspiradores para pensar uma matriz teórica para refletir sobre os crimes contra a humanidade.

As criminologias, como pluralisticamente classificadas na taxonomia proposta por Lola ${ }^{17}$, se ocupam - cada uma delas - de objetos de estudo específicos: a criminologia clássica (delito), a criminologia positivista (delinquente), a criminologia organizacional (delinquência), a criminologia interacionista (reação social), e, a criminologia radical ou crítica dos Direitos Humanos (controle sociah), com atributos e descrições bastante marcadas:

\begin{tabular}{|c|c|c|c|c|c|}
\hline Clássica & Positivista & Organizacional & Interacionista & $\begin{array}{l}\text { Radical Crítica e } \\
\text { da Libertação }\end{array}$ & $\begin{array}{l}\text { Dos Direitos } \\
\text { Humanos } \\
\end{array}$ \\
\hline Especulativa, legal. & $\begin{array}{l}\text { Criminologia clássica, } \\
\text { sociologia criminal, } \\
\text { sociologia da conduta } \\
\text { desviada. }\end{array}$ & $\begin{array}{l}\text { Criminal Justice. } \\
\text { Criminologia } \\
\text { Sistêmica. }\end{array}$ & Reação social. & Poder e interesses. & $\begin{array}{l}\text { Interesses } \\
\text { emancipadores e } \\
\text { generalizáveis. }\end{array}$ \\
\hline $\begin{array}{l}\text { Não retroatividade, } \\
\text { reserva legal, } \\
\text { codificação, } \\
\text { interpretação } \\
\text { disciplinada, } \\
\text { proporcionalidade. }\end{array}$ & $\begin{array}{l}\text { Enfoque nas "causas" } \\
\text { da ação delitiva. }\end{array}$ & Política Criminal. & $\begin{array}{l}\text { Etiquetamento } \\
\text { (Labelling } \\
\text { Approach). }\end{array}$ & $\begin{array}{l}\text { Politologia do } \\
\text { delito normativa. } \\
\text { Compromisso } \\
\text { social. }\end{array}$ & $\begin{array}{l}\text { Primazia da vítima; } \\
\text { Direito penal } \\
\text { mínimo. }\end{array}$ \\
\hline Direito Penal & $\begin{array}{l}\text { Indivíduo (indivíduo } \\
\text { em sociedade). }\end{array}$ & $\begin{array}{l}\text { Aparelhos da Justiça } \\
\text { penal: criminologia } \\
\text { penitenciária, polícia, } \\
\text { Tribunais, pós- } \\
\text { penitenciária. }\end{array}$ & $\begin{array}{l}\text { Relatividade } \\
\text { valorativa. }\end{array}$ & $\begin{array}{l}\text { Procura a essência } \\
\text { atrás da aparência. }\end{array}$ & $\begin{array}{l}\text { Medidas e penas } \\
\text { alternativas } \\
\text { à privação } \\
\text { de liberdade. } \\
\text { Participação. Os } \\
\text { Direitos Humanos } \\
\text { como objeto e como } \\
\text { limite. }\end{array}$ \\
\hline $\begin{array}{l}\text { Repressão: Controle } \\
\text { legal. }\end{array}$ & $\begin{array}{l}\text { Reintegração, reforma } \\
\text { da sociedade. }\end{array}$ & $\begin{array}{l}\text { Eficiência na } \\
\text { reintegração. }\end{array}$ & & & \\
\hline
\end{tabular}

14 Conferir: BERGALLI, Roberto. Argentina: cueestión militar y discurso jurídico del olvido. Doxa, Cuadernos de Filosofía del Derecho, n. 4, p. 381-402, 1987. BERGALLI, Roberto. Una sociología del control penal para América Latina: la superación de la criminología. In: BERGALLI, Roberto; BUSTOS RAMÍREZ, Juan (Comp.). E/ poder penal del Estado. Buenos Aires: Depalma, 1985. p. 3-23. Para uma extensa e detalhada análise dos pensamentos criminológicos na América Latina, ver ANITUA, Gabriel Ignacio. Historia de los pensamientos criminológicos. Buenos Aires: Del Puerto, 2005. p. 418-426.

15 Conferir: NOVA MONREAL, Eduardo. Desorientación epistemológica en la criminología crítica? Revista Doctrina Penal, n. 8, Buenos Aires, 1985. Conferir réplica de CASTRO, Lola Anyiar de. El Jardín de al lado. Revista Doctrina Penal, Buenos Aires, n. 8, 1985. E sucessivos artigos: NOVA MONREAL, Eduardo. Lo que hay al lado no es un jardín: mi réplica a Lola Aniyar de Castro, Revista Doctrina Penal, n. 9, Buenos Aires, 1986. Conferir réplica de CASTRO, Lola Anyiar de. Un debate sin punto final. Revista Doctrina Penal, Buenos Aires, n. 11, 1988.

16 MACHADO, Bruno Amaral. Discursos criminológicos sobre o crime e o direito penal: comunicação e diferenciação funcional. Revista de Estudos Criminais, n. 45, p. 77-116, abr./jun. 2012.

17 CASTRO, Lola Aniyar de. Pensamento Criminológico. Da Criminologia Clássica à Criminologia dos Direitos Humanos. Belo Horizonte: Mandamentos, 2004. 
No modelo proposto por Lola ${ }^{18}$, há sequência lógica de análise da chamada "questão criminal", que nos remete ao "controle social" como o ponto de partida. Em sua concepção, o controle social seria o instrumento definidor dos conceitos de delito, delinquente e delinquência, primordiais para os "processos de criminalização", que são seletivos e de natureza política.

A reflexão interpela o ideário difundido pela Jurisprudência dos Conceitos, no século XIX. No "paraíso dos conceitos jurídicos" de Jhering ${ }^{19}$, repleto de expressões caricaturais, certamente haveria uma "máquina de produzir delitos e delinquentes" além dos já conhecidos "pau de sebo dos problemas jurídicos", da "máquina de partir cabelos", da "máquina da ficção", da "máquina de construir", da "máquina de conciliar passagens contraditórias", da "furadeira dialética", e do "muro da vertigem". No entanto, não estaríamos falando de um "paraíso", mas muito apropriadamente de um "inferno" ou "purgatório", mais próximo daquilo que Robert Ferguson ${ }^{20}$ concebeu ao se referir aos dois primeiros livros da comédia de Dante. Em outras palavras, para pensarmos sobre um "inferno ou purgatório dos conceitos jurídicos", no qual, certamente, a tal "máquina de produzir delitos e delinquentes" ocuparia lugar de destaque.

$\mathrm{Na}$ síntese de Lola, inspirada por longa tradição do pensamento criminológico crítico, tanto europeu quanto norte-americano, marcado pela reinterpretação das tradições conhecidas como Abordagens do Etiquetamento sob o enfoque marxista, o "controle social" cria os delitos quando os define (sentido legislativo), bem como produz o delinquente ao etiquetar, seletivamente, quem são os desviados que receberão o rótulo (nível policial-judiciário), além de instituir a criminalidade oficial (aparente) quando define o delito e seleciona os ca-

18 CASTRO, Lola Aniyar de. Criminologia da Libertação. Rio de Janeiro: Revan, 2005. p. 237 e ss.

19 Publicado originalmente como "Im juristichen Begriffshimmel. Ein Phantastiebild”, em: R. VON JHERING. Scherz Und Ernst In Der Jurisprudenz, 1884 by Breitkopf \& Hartel, Leipzig. Traduzido para o inglês por Charlotte L. Levy, como "In The Heaven for Legal Concepts: A Fantasy", Temple Law Quarterly, vol. 58, 1985, para o italiano por F. Vassalli, como "Nel cielo dei concetti giuridici", em: VON JHERING, R. Serio e faceto nella giurisprudenza, trad. di F. Vassalli, Firenze, 1954; e, para o espanhol por Tomás A. Banzhaf, como: "En el cielo de los conceptos jurídicos. Una fantasía", em: VON JHERING, R. Bromas y Veras en la jurisprudencia. trad. Tomás A. Banzhaf. Buenos Aires: EJEA, 1974.

20 FERGUSON, Robert. Inferno: An Anatomy of American Punishment. New Haven: Harvard University Press, 2014. sos incluídos nos registros dos órgãos oficiais, operando em níveis de controle penal formal (polícia, tribunais, prisões etc.) e controle não penal (religião, escola, família, meios de comunicação, partidos políticos, opinião pública etc. $)^{21}$.

Nenhum enfoque criminológico de natureza crítica poderia prescindir das formas de socialização primária (educação), uma vez que institui as condições apropriadas de consenso e de legitimação, observando-se, ainda, o fato de que o tratamento e a repressão (reeducação) são formas de socialização substitutas. Muito especialmente, ocupou lugar de destaque nas pesquisas de Lola a busca por compreender a correlação entre os meios de comunicação, o poder político-econômico e a construção do medo ${ }^{22}$, que nos conduz ao foco deste artigo. É que tais aparatos de doutrinação e produção da caricáture do inimigo interno foram postas em pleno funcionamento pelo regime ditatorial de 1964, no Brasil e de 1976, na Argentina.

Propomos observar, criticamente, parte do legado de dois regimes ditatoriais recentes, como os mantidos no Brasil (1964-1985) e na Argentina (1976-1983), que teriam seguido caminhos semelhantes no que se refere à construção do "problema delitivo", no desenho de um inimigo comum (por meio de formas de controle formais e informais).

\section{STF E O JULGAMENTO DOS CRIMES CONTRA A HUMANIDADE: CONTROLE PENAL E O LARGO TERMIDOR}

O controle penal é o "termômetro dos direitos humanos". Constitui-se em um dos elementos constitutivos das democracias e, de alguma forma, todos os governos buscam legitimar suas ideologias pela retórica jurídica $^{23}$. Lola, em perspectiva madura como teórica e

21 CASTRO, Lola Aniyar de. Criminologia da Libertação. Rio de Janeiro: Revan, 2005. p. 237 e ss.

22 CASTRO, Lola Aniyar de. Seguridad: Propuestas para una vida sin miedo y sin violencia con respecto a los derechos humanos. Revista Pensamiento Penal, abr. 2007.

23 No Cone Sul, países com distintas tradições históricas como o Brasil, a Argentina, o Chile e o Uruguai, passaram por problemas similares, com distintos posicionamentos dos tribunais no período de transição democrática, na busca de responsabilização dos autores de crimes durante as respectivas ditaduras. Cfr. REQUA, Marny. A Human Rights Triumph? Dictatorship-era Crimes and the Chilean Supreme Court. Human Rights Law Review, v. 12, n. 1, 2012. COR- 
militante, sustenta, em seus escritos da década de 2000, que a criminologia do século XXI seria a criminologia dos direitos humanos ${ }^{24}$. Em sua proposta, deveriam ser criminalizados e responsabilizados os autores dos crimes contra a humanidade, sobretudo nos períodos de ditadura, quando ocorreram massivas violações de direitos ${ }^{25}$.

Os escritos da criminóloga venezuelana são inspiradores para recordar e refletir sobre a recente história da nossa região. Nesse sentido, falar sobre a ditadura brasileira (1964-1985) e sobre a ditadura argentina (19761983), com base no controle penal como termômetro dos direitos humanos, tal como observado por Lola, equivale a dizer que o controle penal nesses regimes (formal e subterrâneo ${ }^{26}$ ) violou, sistematicamente, os direitos humanos, em busca da legitimação dos seus objetivos. A posição de Lola parece aproximar-se da leitura de Joaquín Herrera Flores, para quem os direitos humanos devem ser situados dentro da realidade social, conformada por diferentes campos (econômico, jurídico e cultural), cada um deles composto de um conjunto de capitais simbólicos, institucionais etc., distribuídos hierárquica e desigualmente em função das relações de força e poder ${ }^{27}$.

A tensão entre essas forças - seja no campo criminológico ou no campo da filosofia constitucional, quando enfrentamos rupturas institucionais, permite

REA S, Jorge. Dealing with Past Human Rights Violations: The Chilean Case After Dictatorship. Notre Dame Law Review, v. 67, 1992; MEZAROBBA, Glenda. Between Reparations, Half Truths And Impunity: The Difficult Break With The Legacy Of The Dictatorship In Brazil. SUR - UR - Int'l J. on Hum Rts. v. 7, n. 13, Dec. 2010; SOITMAN, Daniel. Applauding Uruguay's Quest for Justice: Dictatorship, Amnesty, and Repeal of Uruguay Law no. 15.848. Washington University Global Studies Law Review, v. 12, 2013; GUEMBE, Maria Jose. Reopening of Trials for Crimes Committed by the Argentine Military Dictatorship. SUR - Int'l J. on Hum Rts. v. 115, 2005; MIGNONET, Emilio Fermin; ESTLUNDTT, Cynthia L.; ISSACHAROFFTTT, Samuel. Dictatorship on Trial: Prosecution of Human Rights Violations in Argentina. 10 Yale J. Int'l L. v. 118, 1984.

24 CASTRO, Lola Aniyar de. La Criminologia Crítica em Siglo XXI como criminologia de los derechos humanos y contra-reforma humanística o las teorias criminológicas no son inocentes. Revista Interferencia - Derechos y seguridade humana, p. 15, 2009.

25 CASTRO, Lola Aniyar de. Pensamento Criminológico. Da Criminologia Clássica à Criminologia dos Direitos Humanos. Belo Horizonte: Mandamentos, 2004.

26 Sobre o conceito de direito penal subterrâneo, conferir: ZAFFARONI, Eugenio Raul. BATISTA, Nilo. SLOKAR, Alejandro. ALAGIA, Alejandro. Direito Penal Brasileiro: Teoria Geral do Direito Penal. Rio de Janeiro: Revan, 2003.

27 HERRERA FLORES, Joaquín. La Reinvencion de los derechos bumanos. Andalucía: Colecíon Ensayando, 2008. p. 83. que falemos de um "Largo Termidor", conforme sugerido por Gerardo Pisarello ${ }^{28}$, em alusão ao mês do calendário republicano instituído pela revolução francesa em que teve lugar o golpe de Estado de 1794, contra o governo democrático surgido após a queda da Monarquia e da proclamação da República. A expressão alude, ainda hoje, às rupturas das experiências democráticas. Falemos, então, de uma "Criminologia Termidoriana", se, por algum motivo, forem perpetuadas (para além do ciclo do regime ditatorial) as noções tradicionais de delito, delinquente e delinquência, no que se refere à "questão criminal", atrelados aos "controles sociais e políticos" (formal e informal), gestados nos regimes ditatoriais, com a prática de massivas violações de direitos humanos e que mesmo depois da abertura democrática são observados por organizações do sistema de justiça como atos imunes ao poder punitivo.

Tomemos como exemplo, a propósito, quatro elementos fático-conceituais para a classificação de tais atos como crimes de lesa-humanidade ${ }^{29}$, que foram cometidos pelos regimes ditatoriais brasileiro e argentino: (1) ao sujeito ativo; (2) a ação violadora da dignidade humana; (3) em alguns casos, a expectativa do amparo na impunidade; e, (4) a transcendência social do ato praticado. No que se refere ao sujeito ativo, mencionem-se aqueles atos praticados por agentes do Estado ditatorial pela participação direta, ou, de forma indireta, por simpatizantes (mas com sua tolerância), de maneira pública e explícita ou mesmo clandestina. Com relação à ação violadora da dignidade humana, trata-se de ação que visa denegrir a dignidade da pessoa para alcançar um fim político, com violação física ou moral. De um lado, observamos que os autores dos atos mencionados estão amparados, institucionalmente, por um sistema de fato ou de direito que permite, favorece ou garante sua impunidade. De outro lado, o ato praticado transcende as pessoas vitimadas, atingindo toda a comunidade, inclusive em um contexto internacional, em grave violação à dignidade humana ${ }^{30}$.

28 PISARELLO, Gerardo. Un largo Termidor: historia y crítica del constitucionalismo antidemocrático. Quito: Corte Constitucional para el Período de Transición, 2012.

29 Destaque-se, a propósito, o instrumento normativo contido na Convenção sobre a imprescritibilidade dos crimes de guerra e dos crimes de lesa humanidade, adotada pela Assembleia Geral da Organização das Nações Unidas (resolução 2391), em 26 de novembro de 1968

30 ROJAS, Gerardo Bernales. La Imprescriptibilidad de la Acción Penal en Procesos por Violaciones a los Derechos Humanos. Revista Ius et Praxis, v. 13, n. 1, p. 245 - 265, 2007. 
No Brasil, deparamo-nos com vestígios (alguns deles evidentes) desse largo "Termidor", especialmente se observarmos a ruptura institucional ocorrida em março de 1964, realizada a partir de um concerto entre civis, militares, empresários, meios de comunicação. O Ato Institucional de 1964 criou o inimigo interno que se procurava combater, expresso em sua exposição de motivos. Eis um fragmento do AI no 1: “[...] cumprir a missão de restaurar no Brasil a ordem econômica e financeira e tomar as urgentes medidas destinadas a drenar o bolsão comunista, cuja purulência já se havia infiltrado não só na cúpula do governo como nas suas dependências administrativas". Com a outorga posterior do Ato Institucional $\mathrm{n}^{\circ} 5$, de 1968, houve recrudescimento do regime, com a suspensão da garantia do habeas corpus contra crime político e contra ato praticado contra a segurança nacional, bem como a exclusão da apreciação pelo poder judiciário dos atos praticados sob sua vigência. A historiografia nacional descreve assassinatos, torturas, lesões corporais e psicológicas permanentes, estupros, violência de gênero como instrumento de poder e dominação (crimes de lesa-humanidade), largamente documentados em várias publicações, sobretudo nos relatórios da Comissão Nacional da Verdade ${ }^{31}$ e na pesquisa "Brasil Nunca Mais" ${ }^{32}$. As Leis do regime ditatorial brasileiro tipificaram crimes, cominando penas (inclusive perpétua e de morte), ensejou a instrumentalização do aparato penal para alcançar os fins da ditadura, de eliminação do inimigo eleito. Exemplifiquem-se, a propósito, com os seguintes instrumentos normativos: a Lei $\mathrm{n}^{\circ} 1802$, de 5 de janeiro de 1953; o Decreto-Lei $\mathrm{n}^{\circ}$ 314, de 13 de março de 1967; o Decreto-Lei no 510, de 20 de março de 1967; o Decreto-Lei no 898, de 29 de setembro de 1969, e a Lei $n^{\circ}$ 6620, de 17 de dezembro de 1978.

A experiência foi similar ao que ocorreu na Argentina, onde já se fala, abertamente, da faceta civil da ditadura: "Esa dimensión civil incluye a actores económicos, funcionarios civiles (judiciales incluidos), la iglesia, periodistas, medios de comunicación e intelectuales" ${ }^{\prime 3}$.

31 BRASIL. Comissão Nacional da Verdade: Relatório. Brasília: CNV, 2014. São três volumes, reunidos em 976 páginas (I), 416 páginas (II), e, 1996 páginas (III).

32 BRASIL. Pesquisa Brasil Nunca Mais. São Paulo: Arquidiocese de São Paulo, 1985. São 12 volumes (Projeto A), compostas de 6891 páginas, resumidas no Projeto B (livro Brasil Nunca Mais).

33 BOHOSLAVSKY, Juan Pablo. ¿Usted también, doctor?: Complicidad de jueces, fiscales y abogados durante la dictadura. Buenos Aires: Siglo Veintiuno Editores, 2015. p. 21.
Entre nós, pesquisa empírica que adensa nosso argumento sobre o nosso largo Termidor, projetado em 1964, encontra-se na obra do cientista político e historiador uruguaio René Armand Dryfus ${ }^{34}$, escrita, originalmente, em inglês (State, class and lhe organic elite: the formation of an entrepreneurial order in Brazil 1961-1965), que bem registou o golpe de Estado Civil-Militar, o qual contou com apoio de estruturas de poder, incluindo-se os poderes legislativo, executivo e judiciário. Certamente, há necessidade de estudos que evidenciem as especificidades das distintas instituições e suas práticas que legitimaram os atos de exceção.

Especificamente sobre o papel Supremo Tribunal Federal $^{35}$, José Afonso da Silva, em obra relativamente recente, observou que a Corte Suprema apoiou, profundamente, o duplo centralismo ditatorial (federativo e orgânico). A corte considerou inconstitucionais expressões por "turvarem a limpidez do texto constitucional", dado observado em, aproximadamente, 80 Representações de Inconstitucionalidade ajuizadas pelo Procurador-Geral da República ${ }^{36}$. A chancela jurídica que o STF concedeu ao regime ditatorial (1964-1985) reflete-se em todas as estruturas de poder, seja quando cedeu aos objetivos explícitos do golpe de estado, que incluíam censura aos meios de comunicação ${ }^{37}$, seja

34 DREYFUSS, René Armand. 1964: A Conquista do Estado. Ação Política, Poder e Golpe de Classe. Trad. Laboratório de Tradução da Faculdade de Letras da UFMG. 5. ed. Petropolis: editora, 1987.

35 O referido autor citou dois (de três) volumes que reúnem as Representações de Inconstitucionalidade julgadas pelo STF. Cfr. ALBUQUERQUE, Aluísio Xavier de; ABREU, Iduna Weinert de. Representações por Inconstitucionalidade: Dispositivos de Constituições Estaduais. Brasília: Subsecretaria de Edições Técnicas do Senado Federal, 1976; ALBUQUERQUE, Aluísio Xavier de; ABREU, Iduna Weinert de. Representações por Inconstitucionalidade: Dispositivos de Constituições Estaduais. Brasília: Subsecretaria de Edições Técnicas do Senado Federal, 1976; ALBUQUERQUE, Aluísio Xavier de; ABREU, Iduna Weinert de. Representações por Inconstitucionalidade: Dispositivos de Constituições Estaduais (Tomo III - Alagoas a Sergipe). Brasília: Centro de Documentação e Informação Coordenação de Publicações, 1984.

36 SILVA, José Afonso da. O Constitucionalismo Brasileiro: Evolução Institucional. São Paulo: Malheiros, 2011. p. 151.

37 Em termos de representatividade da "engenharia institucional" de apoio à ditadura, a propósito, observe-se que a sistemática jurídica permitia ao Procurador-Geral da República ajuizar perante o STF (com exclusividade), Representações de Inconstitucionalidade de lei em face da Constituição Federal. Tais representações deveriam ser julgas pelo Supremo Tribunal Federal, e seu funcionamento era relativamente simples: os interessados apresentavam requerimento ao Procurador-Geral da República, que apresentaria a demanda perante a Suprema Corte, nos termos da Lei Federal no 4337/1964. A Lei silenciava para o caso de ocorrer arquivamento da represen- 
quando validou, juridicamente, a radicalização da luta contra o inimigo estabelecido e as consequências, observáveis muitos anos depois, quando veio a julgar tanto a ADPF 153 quanto a Extradição 1362, que sugerem juízo de valor sobre a legitimidade do período ditatorial, quando a Suprema Corte foi "empacotada" de maneira similar ao "court-packing plan" do presidente Roosevelt contra a Suprema Corte Americana na década de 1930, durante o New Deal ${ }^{38}$.

O paralelo é importante ${ }^{39}$. No caso brasileiro, a Emenda Constitucional no 16, de 1965, instituiu o controle abstrato de normas, que passou a permitir o julgamento de leis em tese, em face da Constituição Federal (sem a necessidade de um caso concreto como pano de fundo), mecanismo instituído durante a ditadura, e o Ato Institucional n ${ }^{\circ}$ 2, de 1965, aumentou de 11 para 16 a quantidade de juízes do Supremo Tribunal Federal, todos eles por indicação direta do Presidente da República. Na sua entrevista para a "História oral do Supremo Tribunal Federal”, Rafael Mayer, juiz aposentado do STF, relembrou sua indicação para a Corte em 1978, observando que nessa época o Tribunal já tinha voltado a contar com 11 Juízes novamente, porque "[e]m um periodo ai, o Supremo, justamente por que o governo militar queria se livrar de certas coisas, tinha criado 16 vagas no Supremo"

O "empacotamento" do Supremo Tribunal Federal representou o ato inicial de alinhamento com regime, a partir da indicação de novos juízes, mas a engenharia só seria finalizada com a posterior aposentadoria de ministros que, aparentemente, não apoiavam os postulados

tação pelo PGR.

38 Essa expressão refere-se a uma "chantagem política" que remonta ao "The Judicial Procedures Reform Bill", de 1937, frequentemente mencionado como "court-packing plan", medida ligada à proposta do então presidente dos Estados Unidos da América, Franklin D. Roosevelt, que pretendia aumentar o número de juízes da Suprema Corte Americana, pois a composição anterior ao início do exercício de seu mandato havia declarado inconstitucionais a maioria de suas propostas políticas (a legislação do New Deal). Confira-se: FRIEDMAN, Barry. The Will of the people: how public opinion has influenced the Supreme Court and shaped the Constitution. New York: FSG, 2009. p. 376.

39 Em entrevista que Aliomar Baleeiro, então ministro do STF (1965-1975), concedeu ao pesquisador Osvaldo Trigueiro do Vale, esclareceu-se que o então presidente militar Castelo Branco conhecia bem o "Packing Cout Plan" de Roosevelt, detalhando o arranjo que preferiu usar no Brasil. Cfr. VALE, Osvaldo Trigueiro do. O Supremo Tribunal Federal e a instabilidade politico institucional. 1975. Dissertação (Mestrado). Escola de Administração Pública da FGV, Fundação Getúlio Vargas, Rio de Janeiro, 1975. p. 176.

40 MAYER, Rafael. Entrevista: História Oral do Supremo [19882013]. Rio de Janeiro: Escola de Direito da FGV, 2015. p. 60. da ditadura, o que podemos chamar de "desempacotamento" dos juízes não alinhados. Foram os casos das aposentadorias de Evandro Lins e Silva, Victor Nunes Leal e Hermes Lima, afastados pelo Ato Institucional $\mathrm{n}^{\circ}$ 5, de 1968, considerando-se ainda as aposentadorias "voluntárias" de outros dois ministros, Laffayette de Andrada e Gonçalves de Oliveira ${ }^{41}$, que protagonizaram o que foi retratado como "teatro" de renúncias ${ }^{42}$, recordando episódios prévios (em 1863 e 1931) ${ }^{43}$ que marcaram a história da Corte.

Em lógica aritmética simples, os presidentes da ditadura nomearam, inicialmente, 5 juízes (com o aumento de 11 para 16) e depois forçaram o afastamento de 5 juízes, quando a Corte voltou a contar com 11 membros, sem esquecermos, ainda, as aposentadorias de mais 5 juízes que integravam a Corte antes do aumento do número de vagas. Importante observar que são dados importantes, pois, se não houvesse ocorrido o golpe de Estado civil-militar em 1964, em 1965 seriam realizadas eleições gerais e o eventual presidente eleito poderia indicar ao menos 5 Juízes (de um total de 11) para o Tribunal, o que sugere intensa disputa pelo controle da Corte. Registramos nesse sentido, a composição do STF com base na alteração realizada com a outorga do Ato Institucional n⿳2 2, de 1965, de juízes indicados por presidentes do regime ditatorial.

41 Para maiores detalhes sobre os episódios de aposentadoria de juízes em 1968, observe-se a reveladora narrativa de Evandro Lins e Silva, um dos Juízes aposentados compulsoriamente do STF. Cfr. SILVA, Evandro Lins e. O Salão dos passos perdidos: Depoimento ao CPDOC. Rio de Janeiro: Nova Fronteira; FGV, 1997. p. 400.

42 Remetemos à leitura das Cartas trocadas, em que os Juízes Laffayette de Andrada e Gonçalves de Oliveira renunciam sequencialmente aos cargos de Ministro do STF. Cfr.: GALLOTTI, Luiz. Discurso do Ministro Luiz Gallotti ao transmitir a presidência do Supremo Tribunal Federal. Diário da Justiça, 16 dez, Brasília: Diário Oficial da União, 1968. p. 5365-5366; e: GALLOTTI, Luiz. [Discurso]. In: Sessão Solene do Plenário do Supremo Tribunal Federal, 1., 1969, Brasília, em 5 de fevereiro de 1969: homenagem aos Senhores Ministros Aposentados, Brasília: Diário da Justiça, 1969, p. 285-286. 43 É longínqua a ingerência política de aposentadoria forçada, chantagens e tentativas de empacotamento de juízes do STF. Confiram-se antecedentes históricos, desde 1863, nas narrativas de Pedro Calmon, Flávio Galvão, Maurício Lacerda, Rodrigo Lacerda, e de Pires e Albuquerque: CALMON, Pedro. O Rei filósofo: vida de D. Pedro II. São Paulo: Companhia Editora Nacional, 1938. p. 123124; LACERDA, Mauricio. Historia de uma covardia. Rio de Janeiro: F. Bastos, 1927; GALVÃO, Flávio. Sebastião de Lacerda, juiz do Supremo Tribunal Federal. Revista do Tribunal de Contas do Município de São Paulo, n. 25, ano 8, abr. 1979; LACERDA, Rodrigo. A República das Abelhas. São Paulo: Companhia das Letras, 2013. p. 158-159; ALBUQUERQUE, A. Pires e. Culpa e Castigo de um Magistrado. 3. ed. Rio de Janeiro: Hunos, 1972. p. 128. 
Os presidentes do regime de exceção nomearam 32 Juízes para o STF, muitos dos quais permaneceram na Suprema Corte por longos anos depois do término da ditadura, tendo influído na jurisprudência mesmo depois do advento de uma nova Constituição, ajudando a conformar um modelo interpretativo no qual um dispositivo constitucional novo é interpretado à luz - e sob a perspectiva - do ordenamento constitucional anterior, o que se convencionou chamar de "interpretação retrospectiva" ${ }^{\prime 4}$, trazendo a lume a advertência de que o legado político mais decisivo e duradouro dos Presidentes da República são as indicações que fazem para a Suprema Corte ${ }^{45}$.

Em pioneiro estudo sobre as decisões do Supremo Tribunal Federal em momentos de instabilidade política, compreendido o período de 1964-1975, Osvaldo Trigueiro do Vale realizou questionário com alguns dos juízes do Tribunal, alguns deles aposentados compulsoriamente em decorrência de ato de força do regime, chegando à conclusão de que no Brasil, nos períodos de ditadura e rompimento com a experiência democrática se fecha o legislativo, mas "não se fecham os tribunais", embora ocorram manipulações no que se refere ao número de juízes, com substituições por julgadores alinhados ao regime, e aposentadoria daqueles que causam algum incômodo, fato também bastante documentado na obra "A História não Contada do Supremo Tribunal Federal'46.

44 BARROSO, Luis Roberto. Interpretação e Aplicação da Constituição. 4. ed. Rio de Janeiro: Saraiva, 2001. p. 71.

45 Conforme carta enviada pelo Presidente norte-americano Gerald Ford a um amigo, reveladora da ambição de perpetuação do legado presidencial através dos ministros da Suprema Corte. Ver TREANOR, William Michael. Lesson for Obama in Ford's selection of Stevens. Disponível em: <http://law.fordham.edu/17791.htm>. Acesso em: 22 nov. 2016.

46 Confira-se a fecunda análise do Supremo Tribunal Federal sob a presidência dos ministros Ribeiro da Costa (1964-1966), Presidência do ministro Luiz Gallotti (1966-1968), Presidência do ministro Gonçalves de Oliveira (11 de dezembro de 1968 à 18 de janeiro de 1969), Presidência interina de Luiz Gallotti (janeiro a fevereiro de 1969), Presidência do ministro Oswaldo Trigueiro (1969-1971), Presidência do ministro Aliomar Baleeiro (1971-1973), Presidência do ministro Eloy da Rocha (1973-1975), Presidência do ministro Djaci Falcão (1975-1977), Presidência do ministro Thompson Flores (1977-1979), Presidência do ministro Antônio Neder (19791981), Presidência do ministro Xavier de Albuquerque (1981-1983), Presidência do ministro Cordeiro Guerra (1983-1985), Presidência do ministro Moreira Alves (1985-1987), e Presidência do ministro Rafael Mayer (1987-1989). Cfr. SANTOS, Marcelo Paiva dos. A História Não Contada do Supremo Tribunal Federal. Porto Alegre: Safe, 2009. p. 115-361.
É fato relativamente pouco divulgado que, em abril de 1978, o governo militar pretendeu transformar o Supremo Tribunal Federal num Conselho Constitucional, "cujas funções políticas substituiriam a ação discricionária do governo revolucionário", em projeto de reforma política ${ }^{47}$. Em certo sentido, se o Tribunal mantém inabaladas as estruturas do regime ditatorial, mesmo depois de sua derrocada, ele não só assume a face do regime, como parece mostrar que não possui inconveniente algum em tê-lo apoiado. Ele substitui a ação discricionária da ditadura, numa transição silenciosa, informal e normativa ${ }^{48}$.

Um indicativo de que a retórica legitimadora de algumas decisões da Suprema Corte brasileira à ditadura de 1964-1985 foi o que o regime esperava do STF, como se infere das alterações de sua composição ao longo da história, repetições de empacotamento ("packing Court" ${ }^{\text {"99 }}$, com 16 juízes aposentados em decorrência de atos de força em três momentos distintos (1863, 1931, e, 1968). Com base em teses e argumentos jurídicos, o Supremo Tribunal Federal, após a abertura democrática e posteriormente à Constituição de 1988, permanece chancelando atos praticados na ditadura, como o reconhecimento da impunidade dos acusados de violações a

47 CAVALCANTI, Themístocles. O Supremo Tribunal Federal e a Constituição. In: MARINHO, Josaphat; ROSAS, Roberto (Coord). Sesquicentenário do Supremo Tribunal Federal. Brasília: UnB, 1982. p. 105. 48 Alias, é bastante significativo o fato de a participação do Supremo Tribunal Federal na ditadura não receber nenhuma atribuição de relevo, e não integrar nenhuma das 6 fases (constituídas de 22 etapas) comumente descritas na cronologia que analisa a ditadura e a posterior transição democrática. Cfr. CODATO, Adriano Nervo. Uma história política da transição brasileira: da ditadura militar à democracia. Rev. Sociol. Polit. n. 25, p. 83-106, 2005.

49 Sobre o empacotamento, registre-se que, algumas semanas depois do início do segundo mandato de Roosevelt, ele enviou proposta de alteração da composição da Suprema Corte americana, sob o pretexto de que os Juízes estavam velhos demais para o ofício, mas não teriam requerido aposentadoria. O Presidente pretendia indicar um novo membro da Corte (então composta de 9 juízes) para cada juiz que tivesse mais de 70 anos, até o máximo de 15. A medida ocorreu porque a Suprema Corte, até então, estava invalidando as propostas políticas do New Deal, mas com a pressão da alteração da composição da Corte, que não chegou a ser implementada, a Suprema Corte passou a "apoiar" os planos políticos de Roosevelt. Estava no centro da discussão a popularidade do Presidente Roosevelt, e uma pressão para que o aumento de juízes da Corte Suprema poderia permitir o "elastecimento da Constituição", ensejando a criação de empregos e a melhora das condições de vida da população, atingida pela grave crise financeira norte-americana, para os quais o New Deal era mais do que uma promessa. Cfr. HODAK, George. FDR Unveils Court-Packing Plan. ABA Journal, v. 93, Issue 2, p. 72, Feb. 2007; e, LEUCHTENBURG, William E. The Origins of Franklin D. Roosevelt's Court-Packing Plan. Supreme Court Review, v. 1966, p. 347-400. 
direitos humanos no regime civil-militar, especialmente no caso do julgamento da constitucionalidade da Lei de Anistia de 1979 (ADPF 153), ou da recusa em cooperar com outros países para viabilizar o processo e julgamento daqueles acusados pela prática de tortura e outros crimes de lesa-humanidade em regimes ditatoriais, como no caso da Extradição 1362, requerida pelo Estado da Argentina.

Ressaltamos que não houve alteração da composição do Supremo Tribunal Federal de maneira substantiva, mantendo-se o quadro de ministros por longos anos ainda, mesmo após a abertura democrática; os mesmos julgadores que se indicavam que deveriam ser substituídos em decorrência da ação do governo ditatorial. Também, por esse motivo, parecem ter permanecido intocadas as fidelidades que possuíam aos postulados do regime anterior, inclusive com relação à "máquina de produzir delinquentes" ${ }^{\prime 50}$, gestada no regime, incluída a eleição do inimigo, as noções de delito, delinquente e delinquência, para o quadro dos "processos de criminalização", inerentes ao "problema delitivo", e "controle social", usados como pano de fundo para atingir os objetivos do regime, com o cometimento de crimes de lesa-humanidade ${ }^{51}$.

50 Sobre isso, o raciocínio que será retomado na sequência do artigo, que invoca a noção de "paraíso dos conceitos jurídicos", de Jhering.

51 Sobre o caso Argentino, não menos documentado, merece destaque a obra de NINO, Carlos Santiago. Radical Evil on Trial. New Haven: Yale University Press, 1996 e o relatório contido na publicação "Nunca Mas", dando conta de massivas violações de direitos humanos. Igualmente, inúmeras ações foram praticadas com base na lei e mesmo à margem dela, igualmente crimes de lesa-humanidade. A despeito de ter ficado marcado pelos seus estudos de filosofia constitucional e teoria da constituição, Nino merece ser recordado também por sua tese de doutoramento, perante a Universidade de Oxford - "Los Limites de la responsabilidad penal - una teoría liberal del delito", pois nela se funda seu argumento sobre os limites e os desafios do direito de punir. Algumas obras são seminais para reflexão sobre a Suprema Corte Argentina, como as pesquisas do professor da Universidade Federal Fluminense Andres del Rio Roldan. Cfr. DEL RÍO, Andrés. La dictadura argentina en el banquillo: la trayectoria de la justicia y punición a los responsables por los crímenes de lesa humanidad. Política, globalidad y ciudadanía, v. 1, p. 1, 2015; DEL RÍO, Andrés. A Corte Suprema de Justiça Argentina e a Ordem Conservadora: Uma Análise de Trajetórias (1853-1930). Passagens: Revista Internacional de História Política e Cultura Jurídica, v. 1, p. 132-152, 2012; DEL RÍO, Andrés. El desarrollo Institucional de la Corte Suprema de Justicia Nacional y del Supremo Tribunal Federal: Trayectorias comparadas desde el estableciemiento a la democratización. Curitiba: CVR, 2014.

\section{Tempo, Direito e Memória}

Em pesquisas recentes, abordamos a relevância do tempo e da memória como dispositivos hermenêuticos, também adequados para a pesquisa empírica ${ }^{52}$. As relações entre tempo e direito inspiram discussões filosóficas e vêm assumindo lugar relevante nas análises teóricas contemporâneas. Uma das teses centrais na análise de Ost é a de que o tempo deve ser concebido, fundamentalmente, como instituição social e não um dado físico ou psíquico. $\mathrm{O}$ autor investe no que identifica como fragilidades do direito como fenômeno que institui o tempo. Assim, relaciona formas de "destemporalização", tais como, para mencionar uma delas, o rechaço ao caráter evolutivo e finito do tempo, descrito como linear (sem fissuras)..$^{53}$

$\mathrm{Na}$ abordagem sistêmica, o tempo articula-se, diretamente, à função do direito em relação ao passado: estabilização de expectativas normativas. A determinação das comunicações individuais depende de complexo comunicativo que recorre ao tempo. Em outras palavras, funda-se em comunicações passadas e potenciais conexões futuras. Nesse sentido, as normas jurídicas configuram um conjunto de expectativas, simbolicamente, generalizadas. A relação indica a função do direito quanto ao futuro: esforço de preparação para um futuro incerto. ${ }^{54}$ Ao contemplar o tempo como unidade relevante de análise, a abordagem sistêmica distancia-se tanto do abistoricismo vazio quanto do relativismo estéril. O foco orienta-se para os sistemas sociais diferenciados funcionalmente. As mudanças historicamente operadas nos diferentes sistemas sociais geram permanente atua-

52 Conferir a discussão sobre os efeitos do tempo na investigação criminal em pesquisa que coordenamos sobre o transcurso do inquérito policial no sistema de justiça federal: MACHADO, Bruno Amaral; ZACKSESKI, Cristina; RAUPP, Rene Mallet. Tempos da investigação: o transcurso do inquérito policial no sistema de Justiça Federal. Revista Brasileira de Cienncias Criminais, São Paulo, ano 24, v. 124, p. 143-181, out. 2016. Em abordagem teórica próxima à que sugerimos neste ensaio, confira, sob o enfoque sistêmico, o julgamento dos crimes contra a humanidade e seus registros na memória da criminologia crítica contemporânea. Em: MACHADO, Bruno Amaral: TAQUARY, Eneida Orbage. A tipificação do crime de desaparecimento forçado de pessoas: construção jus internacional e a memória como categoria criminológica crítica. Revista de Estudos Criminais, n. 63, p. 59-94, dez. 2016.

53 OST, François. O tempo do Direito. Tradução: Elcio Fernandes. Bauru: Edusc, 2005. p. 12-20.

54 LUHMANN, Niklas. El derecho de la sociedad. Trad: Javier Torres Nafarrate. Cidade do México: Herder, 2005. p. 183-187. 
lização de sentido ${ }^{55}$. Perde relevância central a memória como categoria psíquica ou coletiva. Mais adequado falar-se em memória social, na forma de comunicações apoiadas na diferença entre recordar e esquecer, segundo os códigos e programas de cada sistema social diferenciado funcionalmente ${ }^{56}$.

A função da memória é liberar a capacidade de informação a fim de que o sistema se abra a novas irritações, sintetizada no duplo binário recordar/ esquecer. O esquecimento não é a perda de acesso ao passado, o que equivaleria à reversibilidade do tempo, mas consiste na condição para a aprendizagem e evolução ${ }^{57}$. A memória social não é o que as comunicações deixam como rastro nas consciências individuais, mas sim o resultado das próprias operações comunicativas. Toda comunicação atualiza determinado sentido (razão da memória social $)^{58}$. O uso repetido das mesmas referências permite inferir que, assim, será em casos futuros. Em síntese, se a evolução ocorre na forma variação - seleção - reestabilização, a memória operativa do sistema ocupa-se de acoplar o passado ao futuro, por meio de distinções ${ }^{59}$.

A partir do mecanismo recursivo de novas operações autopoiéticas, o observador pode identificar as mudanças estruturais historicamente atualizadas, ou reestabilizadas. E permite-se, assim, observar as diferentes semânticas sociais. Quando o foco se dirige aos sistemas sociais, privilegiam-se os sentidos que os eventos sugerem (irritação) aos distintos sistemas sociais ${ }^{60}$.

\subsection{Semânticas do esquecimento}

Etimologicamente, a palavra "pardon" é constituída pela junção de "per", ligada a "perfeitamente", e "dona$r e$ ", relacionada a dar ou prevenir, utilizada no sentido de "perdoar", e Anistia (Amnesty), de origem grega,

55 LUHMANN, Niklas. El derecho de la sociedad. Trad: Javier Torres Nafarrate. Cidade do México: Herder, 2005. p. 335-336.

56 LUHMANN, Niklas. El derecho de la sociedad. Trad: Javier Torres Nafarrate. Cidade do México: Herder, 2005. p. 461.

57 LUHMANN, Niklas. El derecho de la sociedad. Trad: Javier Torres Nafarrate. Cidade do México: Herder, 2005. p. 457-458.

$58 \mathrm{O}$ autor indaga porque a sociedade inventa o conceito de cultura para designar sua memória. Cultura não seria outra coisa que a memória da sociedade, uma espécie de filtro que permite recordar/ esquecer LUHMANN, N. La sociedad de la sociedad. Trad: Javier Torres Nafarrate. Cidade do México: Herder, 2007. p. 464.

59 LUHMANN, N. La sociedad de la sociedad. Trad: Javier Torres Nafarrate. Cidade do México: Herder, 2007. p. 461-464

60 LUHMANN, N. La sociedad de la sociedad. Trad: Javier Torres Nafarrate. Cidade do México: Herder, 2007. p. 438-440 com um sentido similar. A primeira é utilizada como "remissão da culpa" e a última remete à "remoção da memória" ${ }^{61}$. De igual maneira, tal qual a prescrição, adotada no sistema romano-germânico, significam extinção da punibilidade pelo efeito do tempo, com a mensagem de que determinados atos devem ser esquecidos.

No léxico jurídico, constitui-se em mensagem do Estado de que estamos "esquecendo" que os perpetradores de atos massivos e brutalmente criminosos cometeram massivas e brutais violações de direitos humanos, como a tortura, estupros, assassinatos ${ }^{62}$. No sentido proposto por Cherif Bassiouni, tais atos de esquecimento (impunidade) configuram espécie de traição à solidariedade humana com relação às vítimas dos conflitos com as quais todos possuímos dever de justiça, memória e compensação ${ }^{63}$.

Carlos $\mathrm{Nino}^{64}$, em análise do julgamento do mal radical, aborda o aspecto central da temática com uma pergunta incômoda: como devemos responder às massivas violações dos direitos humanos cometidas, seja por agentes estatais ou por outras pessoas com a tolerância ou consentimento de seus governantes? A resposta passa por dois posicionamentos: ao se deparar com tais atrocidades, os governos que sucedem os regimes de terror devem optar entre julgar e punir os autores de crimes contra a humanidade, ou alternativamente, se não tomarem nenhuma medida ou providência, os deixarão impunes.

As massivas violações dos direitos humanos são aquilo que Kant considerou como "mal radical” (Radical Evi), de uma maneira que contempla não apenas as atrocidades cometidas durante o holocausto, mas toda e qualquer situação fática similar em termos de violações massivas aos direitos humanos ${ }^{65}$. As reflexões do juris-

61 THORNTON. Pardon and Amnesty. Criminal Law Magazine, v. 6, n. 4, July, 1885.

62 YOUNG, Gwen K. Amnesty and Accountability. 35 U.C. Davis L. Rev. v. 427, 2002.

63 BASSIOUNI M. Cherif. Searching for Peace and Achieving Justice: The Need for Accountability, 59 Law \& contemp. Probs. v. 9, n. 27, 1996.

64 NINO, Carlos Santiago. Radical Evil on Trial. New Haven: Yale University Press, 1996. p. xii-xii.

65 Nas Palavras de Carlos Nino: "Se alguém confrontasse Adolf Hitler, e dissesse a ele que seus atos foram errados, isso teria soado quase risível. "Errado" é um adjetivo muito fraco para descrever reconhecidas ações que causaram a morte de mais de 20 milhões de pessoas, e o sofrimento inimaginável de tantos outros milhões". Cfr. NINO, Carlos Santiago. Radical Evil on Trial. New Haven: Yale University Press, 1996. 
ta argentino recordam Hanna Arendt sobre a natureza do "mal radical" (radical evil), e que somos "incapazes de perdoar aquilo que não podemos punir", além de sermos "incapazes de punir aquilo que se tornou imperdoável', pois o mal radical (radical evil) não pode ser punido ou perdoado, fazendo com que tais atos transcendam o reino das coisas humanas conhecidas ${ }^{66}$.

A proposta vai além de um mero jogo de palavras. Remete à noção de que, para alguns tipos de crimes, como os de lesa-humanidade, para pensar em perdoar, devemos antes investigar, processar e responsabilizar. Além de tudo, recordar para que seu cometimento não volte a ser uma opção possível. E, especialmente, para que não transformemos atos excepcionais em atos ordinários, para utilizar a terminologia jurídica conhecida e compartilhada pelos juristas.

\section{2. $O$ esquecimento como punição (de quem? por que?)}

Em outra perspectiva, a propósito, também podemos observar o esquecimento como forma de punição (pena), tal como indicam Zackseski e Freitas, ao discutirem sobre o efeito do tempo no caso justificador do revisionismo histórico de Wilson Simonal ${ }^{67}$. Os efeitos do esquecimento imposto (ou causado), vinculados a alguma noção helênica de ostracismo, seriam mais cruéis do que uma condenação criminal, pois mais duradoras que a maior pena prevista na legislação.

Como se sabe, Wilson Simonal era um cantor de sucesso, mas teve sua história bruscamente marcada por eventos que o vincularam como delator e aliado da ditadura militar, quando deixou de ser convidado para programas de televisão, talk shows e apresentações em eventos musicais. A trajetória do cantor foi narrada na

66 Ainda com Carlos Nino: "Esta imagem de impotência, frente ao mal radical (radical evil) inicialmente pode parecer como nada além de um artifício literário, como uma maneira de expressar a inadequação da evolução da humanidade, da justiça humana, ou de nossa capacidade de punir. Mas de modo mais substantivo, significa a dificuldade de responder ao mal radical (radical evil) com meios ordinários que comumente são aplicados a criminosos comuns." Cfr. NINO, Carlos Santiago. Radical Evil on Trial. New Haven: Yale University Press, 1996. p. xii.

67 ZACKSESKI, Cristina; FREITAS, Felipe da Silva. O esquecimento como pena a partir da trajetória de Wilson Simonal. In: MACHADO, Bruno Amaral; ZACKSESKI, Cristina; DUARTE, Evandro Piza. Criminologia e Cinema: narrativas sobre a violência. São Paulo: Marcial Pons/Fundação Escola Superior do Ministério Público do Distrito Federal e Territórios, 2016. cinebiografia em resgate de sua imagem, denunciando-se os perversos efeitos daquelas acusações que o empurraram do estrelato para o brutal esquecimento ${ }^{68}$.

$\mathrm{O}$ evento sugere pensarmos o esquecimento como pena, pois os esquecimentos impostos pela anistia, prescrição ou perdão equivalem a penalizar a memória das vítimas de massivas violações de direitos humanos, bem como prolongar seus efeitos para suas famílias.

\subsection{O esquecimento como limite e como proteção (de que? por que?)}

Por outro lado, também podemos observar os efeitos do tempo, quando vinculados ao esquecimento normativamente determinado (e forçado) como limites à punição. Os limites à punição, evidentemente, ajustam-se a opções de política criminal, mas também equivalem a tratar massivas violações de direitos humanos como crimes comuns, ordinários.

Quais seriam os fundamentos mínimos que legitimam a igualdade de tratamento entre massivas violações de direitos humanos e os crimes comuns? Essa pergunta coloca em evidência o sistema de proteção dos direitos humanos e a perspectiva a ser adotada por determinado grupo social. Mas, acima de tudo, expõe o uso retórico do princípio da igualdade.

Finalmente, podemos refletir sobre o esquecimento como proteção. Quando tomamos normativamente os efeitos do tempo como mecanismo de proteção para alguém, precisamos nos perguntar: de quem? E para que? Na hipótese de massivas violações de direitos humanos, a proteção se volta para favorecer, em larga medida, torturadores, estupradores e assassinos em massa. Isso responde à primeira pergunta, mas torna incômoda a abordagem da segunda.

Qual seria o fundamento de se proteger os autores de tais atos? Em uma perspectiva inicial, podemos pensar numa mensagem que chancela (implicitamente) a prática de massivas violações de direitos, pois há um pano de fundo igualmente desconfortável: punir tais atos equivaleria a dizer que o regime ditatorial errou e deixá-los impunes equivale a dizer que se concorda com os atos praticados. Em outras palavras, os fins justificando os meios (sejam quais tenham sido).

68 Confira-se, para maiores detalhes, a cinebiografia (documentário): "Ninguém sabe o duro que dei", 86 minutos, 2009. 
A partir das referidas possibilidades de leitura dos efeitos do tempo, como extintivas da punibilidade, com o consequente esquecimento, observemos brevemente, em síntese, os casos da ADPF 153 e da Extradição 1362, julgados pelo Supremo Tribunal Federal, para uma reflexão global sobre o tema.

\section{A ADPF 153: QUANDO PERDOAR É CHANCELAR}

O Conselho Federal da Ordem dos Advogados do Brasil ajuizou, em 2008, a Arguição de Descumprimento de Preceito Fundamental perante o Supremo Tribunal Federal (ADPF 153), postulando a inconstitucionalidade de dispositivos da Lei de Anistia (Lei no 6.683, de 19 de dezembro de 1979), a fim de que se procedesse à "interpretação conforme a Constituição", para que se declarasse que a anistia concedida aos crimes políticos ou conexos não deveriam se estender aos crimes comuns praticados pelos agentes da repressão contra opositores políticos, durante o regime ditatorial (1964-1985).

Buscava-se, com isso, é certo, evitar a extinção da punibilidade dos agentes do Estado ou outros agentes com a conivência do Estado brasileiro que tivessem praticado graves violações de direitos humanos durante a ditadura, conforme se observa da petição inicial, elaborada e subscrita por Fabio Konder Komparato e por Maurício Gentil Monteiro.

O Supremo Tribunal Federal, em abril de 2010, capitaneado pelo voto do Ministro Eros Grau, por maioria de votos (vencidos os ministros Carlos Ayres Britto e Ricardo Lewandowski, e, ausente o ministro Joaquim Barbosa, e impedido o ministro Dias Toffolli), julgou improcedentes os pedidos, sob o fundamento de que era preciso "não esquecer", para que as coisas não voltem a ser como no passado, concluindo com a decisão final: "Julgo improcedente a ação". Certamente, fundamentar a constitucionalidade da Lei de Anistia na necessidade de "não esquecimento" dos atos que ela busca "apagar", remete às metáforas literárias de Carrol. Quando o tribunal chancela ato jurídico do regime ditatorial, de 1979, reconhece validade jurídica a todos os atos praticados no regime de exceção: eleição de inimigos do regime, definição dos crimes e dos criminosos.

Nesse sentido, argumentamos que anistiar foi chancelar os atos do regime de exceção. Quando a decisão busca fundamento contrário ao que deveria ter sido ("não esquecer" para "esquecer"), transmite-se mensagem cifrada de que as massivas violações de direitos humanos, praticadas durante o regime, podem ser menos relevantes do que definir se entrar no cinema com pipocas e refrigerantes comprados fora do estabelecimento fere a Constituição (ADPF 398), ou se a briga de galos também viola a Constituição (ADI 1856). Assim, triunfa Lewis Carrol, seja pela corrida que se faz no mesmo lugar, pela necessidade de perguntar a quem manda quanto é $2+2$, ou pela repetição de uma narrativa, que se torna verdadeira pela sua simples repetição, que representam, também, a Regra $n^{\circ}$ 42: esquecer é não esquecer, e vice-versa.

\section{A EXTRAdIÇÃO No 1362: QUANDO NÃO EXTRADITAR É PERPETUAR A VIOLAÇão}

No caso da Extradição no 1362, o Estado Argentino solicitou ao Brasil que nacional argentino fosse encaminhado ao Estado requerente para que fosse processado pela prática de crime de lesa-humanidade, por ter participado da organização terrorista Triple A (Aliança Argentina Anticomunista), causando a morte de várias pessoas, bem como por sua participação efetiva no projeto político de terrorismo de Estado argentino, durante a ditadura.

O procedimento remete a alguns fragmentos da história argentina. Conforme narrativa histórica sobre os movimentos políticos que se alteraram no poder na Argentina, considerados os seus mais marcantes ciclos históricos (o primeiro de 1810-1860, o segundo de 1860-1930, e, o terceiro de 1930-1983) ${ }^{69}$, Juan Péron foi deposto pelos militares em 1955 e se exilou na Espanha, mantendo influência significativa sobre a política a partir de Madrid $^{70}$. Os militares permitiram, em um momento posterior, que o partido peronista disputasse as eleições de 1973, embora Perón não tenha obtido autorização legal para tanto. As eleições daquele ano foram vencidas por Hector Cámpora, quem acabou renunciando após perder o apoio político de Perón. Nova eleição foi reali-

69 Conforme Carlos Nino, durante os três ciclos históricos argentinos, observa-se a recorrência de 4 fatores que auxiliam a explicar a violação massiva dos direitos humanos naquele país: dualismo ideológico, corporativismo, concentração de poder e anomia.

70 NINO, Carlos Santiago. Radical Evil on Trial. New Haven: Yale University Press, 1996. p. 42. 
zada, culminando com a eleição de Perón, que veio a falecer alguns meses depois, quando Isabela, sua terceira esposa, assumiu as funções presidenciais, tendo ficado conhecida por sofrer profundas influências do ministro do Bem Estar Social, José Lopez Rega, policial aposentado reconhecido por criar o grupo terrorista intitulado Aliança Argentina Anticomunista (AAA), grupo do qual fez parte o extraditando.

Passando por profunda crise econômica, acusações de corrupção e a explosão da violência, os militares depuseram Isabela Perón do poder, em março de 1976, quando foi institucionalizado, nas palavras de Carlos Nino, o regime autoritário repressivo mais violento da história da Argentina. A junta militar, encabeçada pelo General Videla, o Almirante Emílio Eduardo Massera, e o Brigadeiro Orlando Ramón Agosti, lideraram onda de violência sem precedentes, conduzindo à abdução daqueles que eram contrários ao regime, considerados, portanto, como subversivos, com atos de tortura e assassinatos, e respectivas ocultações de seus cadáveres. Algumas das atrocidades foram reconhecidas internacionalmente $^{71}$. O regime de terror na Argentina contabilizou mais de 30.000 (trinta mil) vítimas, entre mortos, desaparecidos, vítimas de estupro, torturados, mulheres mortas ainda grávidas, ou sequestro de seus filhos. Um regime de terror que, certamente, impõe reconhecer os atos nele praticados como crimes de lesa-humanidade ${ }^{72}$.

A despeito disso, em novembro de 2016, o Supremo Tribunal Federal negou o pedido de extradição, por 6 votos a 5 , sob o fundamento de que teria ocorrido a prescrição dos crimes praticados pelo extraditando, com

71 Conforme narrativa largamente documentada de Carlos Nino: "Nos centros de detenção as vítimas eram submetidas a tortura, humilhação, e abusos sexuais. Os militares utilizaram técnicas como choques elétricos, imersão em água gelada, aglomeração de prisioneiros em celas junto com cachorros violentos. Prática de estupros na presença de parentes das vítimas, e com as vítimas judias sendo colocadas em posição de humilhação ao serem inseridas em salas decoradas com suásticas Nazistas. [...] Os detentos judeus eram obrigados a gritar "Eu amo Hitler", e tinham seus corpos pintados com suásticas.". Cfr. NINO, Carlos Santiago. Radical Evil on Trial. New Haven: Yale University Press, 1996. p. 55-56.

72 MALLIMACI, Fortunato. La Dictadura Argentina: Terrorismo de Estado e Imaginário de la Muerte. Buenos Aires, 2006. Observese, ainda, os relatórios inseridos nos documentos "Nunca Mas", oriundo de uma expressão argentina para repudiar o terrorismo de Estado, ocorrido durante o regime autodenomidado de "Processo de Reorganização Nacional", e também utilizada com frequência por ativistas políticos, e cuja popularização se deve ao fato de ter sido o nome adotado em 1984 pela Comissão Nacional sobre o Desaparecimento de Pessoas (CONADEP) para edição de relatório investigativo sobre os crimes praticados. base no Estatuto do Estrangeiro (considerado o artigo 77, inciso VI, da Lei Federal no 6.815/80, que veda a extradição em caso de extinção da punibilidade pela prescrição). Sem ingressar nos fundamentos dos votos dos juízes do STF, o que foge dos objetivos deste ensaio, observamos peculiar referência ao esquecimento. O Tribunal optou por considerar o esquecimento como limite e como proteção do extraditando, a despeito da posição consolidada de organismos internacionais, que consideram imprescritíveis os crimes de lesa-humanidade. Assim, chancelou os atos praticados, perpetuando a violação massiva dos direitos humanos. Uma vez mais ressurge a "regra no 42", repetindo a caçada de Snark: os crimes de lesa-humanidade são passíveis de prescrição, ou, subliminarmente, os atos praticados no regime ditatorial argentino não foram graves a ponto de serem assim considerados como crimes contra a humanidade.

A historiografia indica que as ditaduras da Argentina e Brasileira agiram de maneira conjunta em muitos casos, sob o signo da operação Condor. Na ADPF 153, o Supremo Tribunal Federal brasileiro optou, ao que parece, por chancelar (perpetuar) massivas violações de direitos humanos a protegê-los. A concepção jurídica do tempo, selecionada pelo Tribunal, parece ter sido esquecer para recordar ${ }^{73}$. As decisões sugerem reflexões sob a ótica luhmanniana. Se a função da memória é liberar a capacidade de informação para novas irritações, o esquecimento pressupõe o acesso ao passado: condição para a aprendizagem e a evolução ${ }^{74}$. Certamente, não foram essas as mensagens do STF em relação aos crimes contra a humanidade submetidos à análise.

73 A dignidade humana parece ter muitas moradas e o STF brasileiro sugere que a observemos por meio das lentes de personagens literários, como aqueles que povoam o universo de Alice, no "País das Maravilhas". Assim podemos inferir quando o STF, ao decidir a partir de pressupostos fáticos relativamente similares, sobretudo no caso da extradição de dois argentinos solicitados pelo Estado argentino, em momentos diferentes, e que ora convém recordar. Em 1984, ao apreciar o pedido de Extradição no 417, de Mário Eduardo Firmenich, acusado de ser autor de vários crimes, e integrante da esquerda argentina, liderança do movimento Montonero, o Supremo Tribunal Federal deferiu a extradição, reconhecendo legítima a declaração de inconstitucionalidade da Lei de Anistia argentina, e, portanto acolhendo a não extinção da punibilidade. Conferir a discussão sobre a inconstitucionalidade da lei de anistia argentina, no acórdão da Extradição 417, especialmente o voto do ministro Alfredo Buzaid.

74 LUHMANN, Niklas. El derecho de la sociedad. Trad: Javier Torres Nafarrate. Cidade do México: Herder, 2005. p. 457-458. 


\section{Considerações finais}

O enfoque sistêmico permite aprofundar a discussão sobre as decisões (comunicações) do STF. De um lado, ao cotejarmos os programas atualizados do sistema jurídico, na forma de tratados e convenções internacionais dos direitos humanos, bem como os direitos e garantias constitucionais, argumentamos que as decisões analisadas não se ajustam ao direito válido. $\mathrm{O}$ ponto de observação que adotamos (criminologia dos direitos humanos) evidenciou que a retórica jurídica constitui-se em mecanismo legitimador dos processos seletivos das organizações do controle penal (no caso o STF).

No processo de definição do crime e dos criminosos, a chancela aos atos de lesa-humanidade dos regimes ditatoriais remete ao que Zaffaroni descreve como Criminologia Negacionista ${ }^{75}$. Propomos, assim, que o nosso olhar, orientado pela memória social da criminologia crítica, deve contemplar estratégias discursivas para desvelar a argumentação jurídica que neutraliza e justifica os crimes contra a humanidade (Criminologia Cautelar) ${ }^{76}$.

Retomamos Lola, para observar que, ainda, e uma vez mais, persiste o triunfo de Lewis Carrol. Não apenas pela imagem de que se corre para permanecer no mesmo local, ou que para saber quanto é a soma de $2+$ 2 ainda se requer conhecer a vontade de quem manda. Materializa-se a "regra no 42", cuja repetição, como na caçada de Snark, pretende torná-la verdadeira apenas pelo simples fato de tê-la repetido. Como repetidas foram, e continuam a ser, as massivas violações de direitos humanos provocadas por regimes de exceção.

Quando as organizações de controle penal perpetuam as pautas criadas pelos órgãos de controle extrapenal, eterniza-se forma peculiar de estado de exceção. E que logo adquire o desconfortável status de regra, ainda que seja do tipo cunhado na metáfora na "regra no 42". Lola advertiu-nos constantemente sobre o triunfo de Lewis Carrol. Quando a realidade confirma a ficção, talvez sejamos exímios fingidores, amantes da ficção, e mereçamos a crítica de Bentham: "Por fanatismo ou artifício

75 ZAFFARONI, Eugenio Raúl. A palavra dos mortos. São Paulo: Saraiva, 2012.

76 Sobre a memória social da criminologia crítica e o julgamento dos crimes contra a humanidade, conferir MACHADO, Bruno Amaral: TAQUARY, Eneida Orbage. A tipificação do crime de desaparecimento forçado de pessoas: construção jus internacional e a memória como categoria criminológica crítica. Revista de Estudos Criminais, n. 63, p. 59-94, dez. 2016. de juristas, uma grande parte do ordenamento jurídico estava trancada em caracteres ilegíveis e em uma língua estrangeira. Ficções, tautologias, tecnicalidade, circularidade, irregularidade e inconsistência permanecem"'77. Se a ficção se apresenta como poderoso artefato semântico para a hermenêutica jurídica, é porque nos inspira e instiga a ampliar os horizontes de sentido em relação à normatividade e aos fatos. A memória da criminologia crítica dos direitos humanos, aqui representada nos escritos de Lola, nos alerta sobre a faticidade ${ }^{78}$ dos atos judiciais fundados em uma espécie de solipsismo, indiferente e avesso à história, em peculiar forma de esquecimento, que bloqueia o acesso ao passado.

\section{REFERÊNCIAS}

ALBUQUERQUE, A. Pires e. Culpa e Castigo de um Magistrado. 3. ed. Rio de Janeiro: Hunos, 1972.

ALBUQUERQUE, Aluísio Xavier de; ABREU, Iduna Weinert de. Representações por Inconstitucionalidade: Dispositivos de Constituições Estaduais. Brasília: Subsecretaria de Edições Técnicas do Senado Federal, 1976.

ANITUA, Gabriel Ignacio. Historia de los pensamientos criminológicos. Buenos Aires: Del Puerto, 2005.

BARATTA, Alessandro. Criminología crítica e crítica do direito penal: Introdução à sociologia do direito penal. 2 . ed. Trad: Juarez Cirino dos Santos. Rio de Janeiro: F. Bastos, 1999.

BASSIOUNI M. Cherif. Searching for Peace and Achieving Justice: The Need for Accountability, 59 Law \& contemp. Probs. v. 9, n. 27, 1996.

BEEBEE, Thomas. Can Law-and-Humanities survive Systems Theory? Law \& Literature, n. 244, 2010.

BENTHAM, Jeremy. Constitutional Code, Works. Bowring, 1843.

77 BENTHAM, Jeremy. Constitutional Code, Works. Cidade: Bowring, 1843. p. 77-78; também na versão reimpressa: OGDEN, C.K. Bentham' Theory of Fictions. New York: Kegan Paul, 1932; Também a tradução espanhola: BENTHAM, Jeremy. Teoría de las Ficciones Jurídicas. Madrid: Marcial Pons, 2005.

78 Conferir análise sobre imperativos funcionais do sistema econômico e a via pela qual o direito positivado pode emprestar legitimidade a poderes ilegítimos: HABERMAS, Jürgen. Facticidad y validez: sobre el derecho y el Estado democrático de derecho em términos de teoría del discurso. 4. ed. Madrid: Trotta, 2005. p. 103. 
BENTHAM, Jeremy. Teoría de las Ficciones Jurídicas. Madrid: Marcial Pons, 2005.

BERGALLI, Roberto et al. Control Social Punitivo. Sistema penal e instancias de aplicación (Policía, Jurisdicción y Cárcel). Barcelona: Editorial María Jesús Bosch, 1996.

BERGALLI, Roberto. Argentina: cueestión militar y discurso jurídico del olvido. Doxa, Cuadernos de Filosofía del Derecho, n. 4, p. 381-402, 1987.

BERGALLI, Roberto. Una sociología del control penal para América Latina: la superación de la criminología. In: BERGALLI, Roberto; BUSTOS RAMÍREZ, Juan (Comp.). El poder penal del Estado. Buenos Aires: Depalma, 1985. p. 3-23.

BLANCHARD, Margaret A. The American Urge To Censor: Freedom of Expression Versus the Desire to Sanitize Society-From Anthony Comstock to 2 Live Crew. 33 Wm. \& Mary L. Rev. v. 741, 1991.

BOHOSLAVSKY, Juan Pablo. ¿Usted también, doctor?: Complicidad de jueces, fiscales y abogados durante la dictadura. Buenos Aires: Siglo Veintiuno Editores, 2015.

BRASIL. Ato Institucional de 1964, de 9 de abril de 1964. Dispõe sobre a manutenção da Constituição Federal de 1946 e as Constituições Estaduais e respectivas Emendas, com as modificações introduzidas pelo Poder Constituinte originário da revolução Vitoriosa, 1964.

BRASIL. Comissão Nacional da Verdade: Relatório. Brasília: CNV, 2014.

BRASIL. Constituição de 1937, de 10 de novembro de 1937.

BRASIL. Pesquisa Brasil Nunca Mais. São Paulo: Arquidiocese de São Paulo, 1985.

BRASIL. Supremo Tribunal Federal. ADPF $n^{\circ} 153$, rel. min. Eros Grau, 2010.

BRASIL. Supremo Tribunal Federal. ADPF $n^{\circ} 320$, rel. min. Luiz Fux, 2013.

BRASIL. Supremo Tribunal Federal. Extradição n 1362, Rel. Min. Edson Fachin. Relator para o acórdão, min. Teori Zavascki, 2016.

BRASIL. Supremo Tribunal Federal: 150 anos. Brasília: STF, 1978.

BRENZEL, Jeff. Por que os super-heróis são bons? Os quadrinhos e o anel de Giges. Em: IRWIN, William
(Coord.). Super-Heróis e a Filosofia. Verdade, Justiça e o Caminho Socrático. São Paulo: Madras, 2009.

CALMON, Pedro. O Rei filósofo: vida de D. Pedro II. São Paulo: Companhia Editora Nacional, 1938.

CARROL, Lewis. Alice no País das Maravilhas. Trad. Clélia Regina Ramos. São Paulo: Universo dos Livros, 2014.

CARROL, Lewis. The Hunting of the Snark. Lightning Source, 2007.

CASTRO, Lola Aniyar de. Criminologia da Libertação. Rio de Janeiro: Revan, 2005.

CASTRO, Lola Aniyar de. La Criminologia Crítica em Siglo XXI como criminologia de los derechos humanos y contra-reforma humanística o las teorias criminológicas no son inocentes. Revista Interferencia - Derechos y seguridade humana, 2009.

CASTRO, Lola Aniyar de. O triunfo de Lewis Carroll. In: A NOVA criminologia latino-americana. Discursos sediciosos: crime, direito e sociedade. Rio de Janeiro: F. Bastos, 2000.

CASTRO, Lola Aniyar de. Pensamento Criminológico. Da Criminologia Clássica à Criminologia dos Direitos $\mathrm{Hu}-$ manos. Belo Horizonte: Mandamentos, 2004.

CASTRO, Lola Anyiar de. El Jardín de al lado. Revista Doctrina Penal, Buenos Aires, n. 8, 1985.

CASTRO, Lola Anyiar de. Un debate sin punto final. Revista Doctrina Penal, Buenos Aires, n. 11, 1988.

CAVALCANTI, Themístocles. O Supremo Tribunal Federal e a Constituição. In: MARINHO, Josaphat; ROSAS, Roberto (Coord). Sesquicentenário do Supremo Tribunal Federal. Brasília: UnB, 1982.

CODATO, Adriano Nervo. Uma história política da transição brasileira: da ditadura militar à democracia. Rev. Sociol. Polit. n. 25, 2005.

CORN-REVERE, Robert. Moral Panics, the First Amendment, and the Limits of Social Science. 28 Comm. Law, v. 4, 2011.

CORREA S, Jorge. Dealing with Past Human Rights Violations: The Chilean Case After Dictatorship. Notre Dame Law Review, v. 67, 1992.

DEL RÍO, Andrés. A Corte Suprema de Justiça Argentina e a Ordem Conservadora: Uma Análise de Trajetórias (1853-1930). Passagens: Revista Internacional de História Política e Cultura Jurídica, v. 1, p. 132-152, 2012. 
DEL RÍO, Andrés. El desarrollo Institucional de la Corte Suprema de Justicia Nacional y del Supremo Tribunal Federal: Trayectorias comparadas desde el estableciemiento a la democratización. Curitiba: CVR, 2014.

DEL RÍO, Andrés. La dictadura argentina en el banquillo: la trayectoria de la justicia y punición a los responsables por los crímenes de lesa humanidad. Política, globalidady ciudadania, v. 1, p. 1, 2015.

DREYFUSS, René Armand. 1964: A Conquista do Estado. Ação Política, Poder e Golpe de Classe. Trad. Laboratório de Tradução da Faculdade de Letras da UFMG. 5. ed. Petropolis. 1987.

DUSSICH, John P. J. Violence And The Media. Criminology 80, 1970; PET'TY, Ross D. The 'Amazing Adventures' of Super Hero. 100 Trademark Rep. 729, 2010.

FENNELL, Jack. The aesthetics of Supervillainy. 16 Law Text Culture, v. 1, 2012.

FERGUSON, Robert. Inferno: An Anatomy of American Punishment. New Haven: Harvard University Press, 2014.

FISS, Owen. The Death of a Public Intelectual. The Yale Law Journal, v. 104, 1995.

FRIEDMAN, Barry. The Will of the people: how public opinion has influenced the Supreme Court and shaped the Constitution. New York: FSG, 2009.

GALLOTTI, Luiz. [Discurso] Ao transmitir a presidência do Supremo Tribunal Federal. Diário da Justiça, 16 dez, Brasília: Diário Oficial da União, 1968. p. 53655366.

GALLOTTI, Luiz. [Discurso]. Sessão Solene do Plenário do Supremo Tribunal Federal, 1., 1969, Brasília, em 5 de fevereiro de 1969: homenagem aos Senhores Ministros Aposentados, Brasília: Diário da Justiça, 1969. p. 285-286.

GALVÃO, Flávio. Sebastião de Lacerda, juiz do Supremo Tribunal Federal. Revista do Tribunal de Contas do Município de São Paulo, n. 25, ano 8, abr. 1979.

GREENBERG, Marc H. Comics, Courts \& Controversy: A Case Study of the Comic Book Legal Defense Fund. 32 Loy. L.A. Ent. L. Rev. v. 121. 2011.

GUEMBE, Maria Jose. Reopening of Trials for Crimes Committed by the Argentine Military Dictatorship. SUR - Int'l J. on Hum Rts. v. 115, 2005.
HABERMAS, Jürgen. Facticidad y validez: sobre el derecho y el Estado democrático de derecho em términos de teoría del discurso. 4. ed. Madrid: Trotta, 2005.

HERRERA FLORES, Joaquín. La Reinvencion de los derechos humanos. Andalucía: Colecíon Ensayando, 2008.

HODAK, George. FDR Unveils Court-Packing Plan. ABA Journal, v. 93, Issue 2, Feb. 2007.

LACERDA, Mauricio. Historia de uma covardia. Rio de Janeiro: F. Bastos, 1927.

LARRAURI, E. La Herencia de la Criminología Crítica. 3. ed. Madri: Siglo Veintiuno de España Editores, 2000.

LEUCHTENBURG, William E. The Origins of Franklin D. Roosevelt's Court-Packing Plan. Supreme Court Review, v. 1966.

LUHMANN, N. La sociedad de la sociedad. Trad: Javier Torres Nafarrate. Cidade do México: Herder, 2007.

LUHMANN, Niklas. El derecho de la sociedad. Trad: Javier Torres Nafarrate. Cidade do México: Herder, 2005.

MACHADO, Bruno Amaral. Discursos criminológicos sobre o crime e o direito penal: comunicação e diferenciação funcional. Revista de Estudos Criminais, n. 45, p. 77-116, abr./jun. 2012.

MACHADO, Bruno Amaral: TAQUARY, Eneida Orbage. A tipificação do crime de desaparecimento forçado de pessoas: construção jus internacional e a memória como categoria criminológica crítica. Revista de Estudos Criminais, n. 63, p. 59-94, dez. 2016.

MACHADO, Bruno Amaral; ZACKSESKI, Cristina; PIZA, Evandro C. Cinema e Criminologia: narrativas sobre a violência. São Paulo: Marcial Pons, 2016.

MACHADO, Bruno Amaral; ZACKSESKI, Cristina; RAUPP, Rene Mallet. Tempos da investigação: o transcurso do inquérito policial no sistema de Justiça Federal. Revista Brasileira de Ciências Criminais, São Paulo, ano 24, v. 124, p. 143-181, out. 2016.

MALLIMACI, Fortunato. La Dictadura Argentina: Terrorismo de Estado e Imaginário de la Muerte. Buenos Aires, 2006.

MAYER, Rafael. Entrevista: História Oral do Supremo [1988-2013]. Rio de Janeiro: Escola de Direito da FGV, 2015.

MELLO, Thiago de. Entrevista: Autor de 'Faz Escuro Mas Eu Canto', Thiago de Mello comemora 90 anos 
em São Paulo. Estadão. Caderno Cultura, de 15 de março de 2016. Disponível em: <http://cultura.estadao.com. $\mathrm{br} /$ noticias/literatura,autor-de-faz-escuro-mas-eu-canto--thiago-de-mello-comemora-90-anos-em-sao-paulo,10000021236>. Acesso em: 21 nov. 2016

MELLO, Thiago de. Faz Escuro, mas eu canto. 21. ed. São Paulo: Bertrand Brasil, 2003.

MELOSSI, Dario. El estado del comtrol social. Un estudio sociológico de los cOnceptos de estado y de control social en la conformación de la democracia. México: Siglo XXI, 1992.

MEZAROBBA, Glenda. Between Reparations, Half Truths And Impunity: The Difficult Break With The Legacy Of The Dictatorship In Brazil. SUR - UR - Int'l J. on Hum Rts. v. 7, n. 13, Dec. 2010.

MIGNONET, Emilio Fermin; ESTLUNDTT, Cynthia L.; ISSACHAROFFTTT, Samuel. Dictatorship on Trial: Prosecution of Human Rights Violations in Argentina. 10 Yale J. Int'l L. v. 118, 1984.

MILLS, C. Wright. The Power Elite. Cambridge: Oxford University Press, 1999.

NINO, Carlos Santiago. Juicio al mal absoluto: ¿Hasta dónde debe llegar la justicia retroactiva en casos de violaciones masivas de los derechos humanos? Buenos Aires: Siglo Veintiuno, 2015

NINO, Carlos Santiago. La huida frente a las penas. No hay derecho, v. 2, n. 4, 1991.

NINO, Carlos Santiago. Los Limites de la Responsabilidad Penal: Una teoría liberal del delito. Buenos Aires: Editorial Astrea, 1980.

NINO, Carlos Santiago. Radical Evil on Trial. New Haven: Yale University Press, 1996.

NINO, Carlos Santiago. Se acabó el debate. No hay derecho. v. 3, n. 8, 1993.

NOVA MONREAL, Eduardo. Desorientación epistemológica en la criminología crítica? Revista Doctrina Penal, n. 8, Buenos Aires, 1985.

NOVA MONREAL, Eduardo. Lo que hay al lado no es un jardín: mi réplica a Lola Aniyar de Castro, Revista Doctrina Penal, n. 9, Buenos Aires, 1986.

OGDEN, C.K. Bentham' Theory of Fictions. New York: Kegan Paul, 1932.

OST, François. O tempo do Direito. Tradução: Elcio Fer- nandes. Bauru: Edusc, 2005.

PISARELLO, Gerardo. Un largo Termidor: historia y crítica del constitucionalismo antidemocrático. Quito: Corte Constitucional para el Período de Transición, 2012.

POSNER, Richard A. Remarks on Law and Literature. Loyola University Law Journal, v. 23, p. 181-195, 19911992.

REIBMAN, James E. Ralph Ellison, Fredric Wertham, M.D., And The Lafargue Clinic: Civil Rights And Psychiatric Services In Harlem. 26 Okla. City U. L. Rev. 1041, 2001.

REQUA, Marny. A Human Rights Triumph? Dictatorship-era Crimes and the Chilean Supreme Court. Human Rights Law Review, v. 12, n. 1, 2012.

REZEK, Francisco. Entrevista: História Oral do Supremo [1988-2013]. Rio de Janeiro: Escola de Direito da FGV, 2015.

RIVERA, Tânia. Arte e psicanálise. Rio de Janeiro: J. Zahar, 2002.

ROJAS, Gerardo Bernales. La Imprescriptibilidad de la Acción Penal en Procesos por Violaciones a los Derechos Humanos. Revista Ius et Praxis, v. 13, n. 1, p. 245 - 265, 2007.

SANTOS, Marcelo Paiva dos. A História Não Contada do Supremo Tribunal Federal. Porto Alegre: Safe, 2009.

SEÑA, Jorge F. Malem. Carlos Santiago Nino: A Biobibliographical Sketch. Interamerican Law Review, v. 27, n. $1,1995$.

SILVA, Evandro Lins e. O Salão dos passos perdidos: Depoimento ao CPDOC. Rio de Janeiro: Nova Fronteira; FGV, 1997.

SILVA, José Afonso da. O Constitucionalismo Brasileiro: Evolução Institucional. São Paulo: Malheiros, 2011.

SIMON, Paul; GARFUNKEL, Art. The Sounds of Silence. Sounds of Silence. Washington: Columbia, 1965.

SOITMAN, Daniel. Applauding Uruguay's Quest for Justice: Dictatorship, Amnesty, and Repeal of Uruguay Law no. 15.848. Washington University Global Studies Law Review, v. 12, 2013.

THORNTON. Pardon and Amnesty. Criminal Law Magazine, v. 6, n. 4, July, 1885.

TREANOR, William Michael. Lesson for Obama in Ford's selection of Stevens. Disponível em: <http://law.fordham. 
edu/17791.htm>. Acesso em: 22 nov. 2016.

TRINDADE, André Karam; GUBERT, Roberta Magalhães; COPETTI NETO, Alfredo. Direito \& Literatura: Discurso, Imaginário e Normatividade. Porto Alegre: Nuria Fabris, 2010

VALE, Osvaldo Trigueiro do. O Supremo Tribunal Federal e a instabilidade politico institucional. 1975. Dissertação (Mestrado). Escola de Administração Pública da FGV, Fundação Getúlio Vargas, Rio de Janeiro, 1975.

VAN SWAANINGEN, René. Critical Criminology: Visions from Europe. London: Sage, 1997,

VON JHERING, R En el cielo de los conceptos jurídicos. Una fantasia. In: R. VON JHERING, Bromas y $V_{e}$ ras en la jurisprudencia. Trad: Tomás A. Banzhaf. Buenos Aires: EJEA, 1974.

VON JHERING, R. In The Heaven for Legal Concepts: A Fantasy. Trad. Charlotte L. Levy. Temple Law Quarterly, v. 58, 1985.

WERTHAM, Fredric. Seduction of the Innocent. 2. ed. New York: Rinehart \& Co, Inc., 1954.
WILLIAMS, Sidney; MADAN, Falconer. Handbook of the Literature of the Rev. Penguin Books, 1974.

YOUNG, Gwen K. Amnesty and Accountability. 35 U.C. Davis L. Rev. v. 427, 2002

ZACKSESKI, Cristina; FREITAS, Felipe da Silva. O esquecimento como pena a partir da trajetória de Wilson Simonal. In: MACHADO, Bruno Amaral; ZACKSESKI, Cristina; DUARTE, Evandro Piza. Criminologia e Cinema: narrativas sobre a violência. São Paulo: Marcial Pons/Fundação Escola Superior do Ministério Público do Distrito Federal e Territórios, 2016.

ZAFFARONI, Eugenio Raúl. ¿Vale la pena? No bay derecho, v. 2, n. 5, 1992.

ZAFFARONI, Eugenio Raúl. A palavra dos mortos. São Paulo: Saraiva, 2012.

ZAFFARONI, Eugenio Raul. BATISTA, Nilo. SLOKAR, Alejandro. ALAGIA, Alejandro. Direito Penal Brasileiro: Teoria Geral do Direito Penal. Rio de Janeiro: Revan, 2003. 


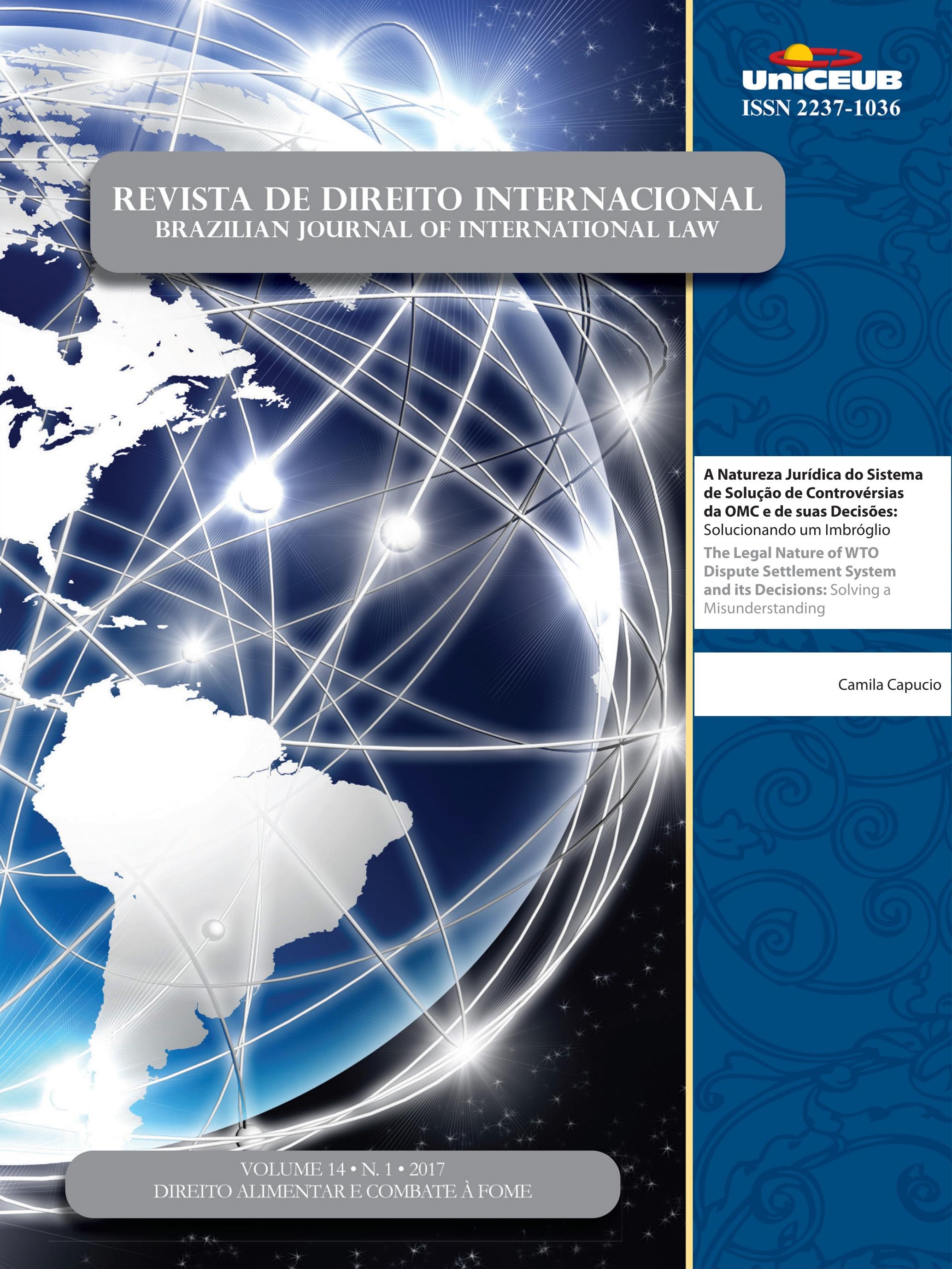




\section{A Natureza Jurídica do Sistema de Solução de Controvérsias da OMC e de suas Decisões: Solucionando um Imbróglio*}

\author{
The Legal Nature of WTO Dispute Settlement \\ System and its Decisions: Solving a \\ Misunderstanding
}

Camila Capucio**

\section{Resumo}

O trabalho tem o objetivo de localizar o Sistema de Solução de Controvérsias da OMC na sistemática mais ampla dos órgãos adjudicatórios internacionais, sem, contudo, ignorar suas especificidades. Assim, ao adentrarmos na evolução, componentes, características e procedimento do Sistema de Solução de Controvérsias da OMC, o estudo da natureza jurídica das decisões emanadas deste sistema pode ser realizado de maneira detalhada, sistêmica e coerente. Embora a temática do Sistema de Solução de Controvérsias da OMC não seja por si só inovadora, as análises desse Sistema comumente pressupõem sua natureza jurídica e de suas decisões, sem problematiza-las ou sem enfrentar a aparente contradição existente em seu processo decisório e composição. O valor científico do presente trabalho está, pois, na desconstrução de um equívoco comum acerca da natureza jurídica das decisões do Sistema de Solução de Controvérsias da OMC, constatando que, apesar da presença de um Órgão Político (Órgão de Solução de Controvérsias), as decisões emanadas deste sistema como um todo são jurídicas e obrigatórias.

Palavras-Chave: omc; sistema de solução de controvérsias; decisões adjudicatórias internacionais; adjudicação internacional

\section{Abstract}

The aim of this work is to locate the WTO Dispute Settlement System in the broader system of international adjudicatory bodies, without, however, ignoring its specificities. Thus, by studying the evolution of the WTO dispute settlement system, its components, its characteristics and its procedures, the study of the legal nature of the decisions emanating from this system can be carried out in a detailed, systemic and coherent way. Although not being the WTO Dispute Settlement System itself an innovative subject, the analysis of this topic usually presupposes its legal nature and the meaning of its decisions, without problematizing it or without dealing with the apparent contradiction. The main value of this paper, therefore, lies on the intente to deconstruct a misunderstanding about the legal nature of its decisions, noting, that despite the presence of a Political Body (Dispute Settlement 
Body), the decisions emanating from this system as a whole are legal and binding.

Keywords: wto; dispute settlement system; international adjudicative decisions; international adjudication

\section{Introdução: Contexto e Relevância da Análise Proposta}

Embora a solução de controvérsias no âmbito da Organização Mundial do Comércio [OMC] seja um tema presente em análises na doutrina estrangeira e nacional relativa ao Direito Internacional Econômico ${ }^{12}$ desde a sua criação, os estudos em geral pressupõem do leitor um conhecimento acerca de suas especificidades em face de outros arranjos de solução de controvérsias existentes no sistema jurídico internacional e inclusive de termos de seu vocábulo.

Adicionalmente, ao tratarem de maneira simplificada conceitos e elementos tecnicamente e essencialmente distintos - a exemplo do comum intercâmbio semântico entre "Mecanismo de Solução de Controvérsias da OMC" e "Órgão de Solução de Controvérsias da OMC" ou entre "decisões", "relatórios" e "recomendações" nesse contexto - a maior parte dos estudos existentes não se propõe a problematizar a natureza jurídica desse sistema e/ou de suas decisões, em face de categorias do Direito Internacional já existentes.

Não é incomum, portanto, que o estudioso aden-

1 uma visão sobre o desenvolvimento do Direito Internacional Econômico no Brasil como campo de estudos, remete-se ao interessante mapeamento empírico realizado por Michelle Ratton SanchezBadin, Fabio Costa Morosini e Inaê Siqueira de Oliveira. Partindo do universo da pesquisa dos autores, foi constado que a maior parcela das publicações na area do comércio envolve a OMC, dentre os quais é possível identificar a solução de controvérsias da OMC como um dos temas abarcados, embora sem destaque primário (em especial, p. 17-19). BADIN, Michelle Ratton Sanchez; MOROSINI, Fabio Costa; OLIVEIRA, Inaê Siqueira de. Direito Internacional Econômico no Brasil: quem somos e o que fazemos? Evidências empíricas de 1994 a 2014. Revista de Direito Internacional, Brasília, v. 13, n. 1, 2016 p. 5-25

2 Para uma visão de recentes discussões acerca da OMC e de suas diversas temáticas na doutrina nacional, remete-se à consulta da edição especial da Revista de Direito Internacional, v. 11, n. 2, 2014, entitulada "Os Vinte Anos da OMC" (https://www.rdi.uniceub.br/rdi/issue/view/197). De maneira correlata, a edição v. 13, n. 1, 2016, entitulada "Direito Internacional Econômico" publicou alguns artigos da III Conferência Bienal da Rede Latino-Americana de Direito Econômico Internacional (Red DEI) realizada no país (https://www.rdi.uniceub.br/rdi/issue/view/222) trando no campo do Direito Internacional Econômico interprete equivocadamente e/ou passe a replicar tais simplificações sem a consciência de que as mesmas tendem a levar a uma compreensão imperfeita da natureza jurídica do Sistema de Solução de Controvérsias da OMC e de suas decisões. ${ }^{3}$

Assim, o presente estudo se torna necessário em face da necessidade do estudo e do enfrentamento de aparentes contradições existentes no processo decisório e composição do Sistema de Solução de Controvérsias da OMC e a natureza jurídica de suas decisões. Isto é, a preocupação central do presente trabalho está, pois, na desconstrução de um equívoco comum acerca da natureza jurídica das decisões do Sistema de Solução de Controvérsias da OMC, constatando que, apesar da presença de um Órgão Político (Órgão de Solução de Controvérsias), as decisões emanadas deste sistema como um todo são jurídicas e obrigatórias.

Para tanto, propõe-se um estudo da evolução, dos componentes, das características e procedimentos do Sistema de Solução de Controvérsias da OMC neste tocante, com a finalidade de contextualizar suas especificidades mas abrange-las na teoria geral do Direito Internacional, de modo a permitir a classificação cientificamente embasada da natureza jurídica das decisões emanadas deste sistema, a prescindir de um replicamento de suas imprecisões.

\section{BREVE ANÁLISE DA EVOLUÇão HISTÓRICA do Sistema de Solução de Controvérsias da OMC}

\subsection{Do GATT à OMC}

Com o colapso da economia mundial no período que seguiu a grande depressão, restou evidente a necessidade de novas instituições que promovessem, simul-

3 A simplificação mais comum, que continua a ser propagada e, em nossa visão, impede a compreensão adequada do desenho institucional da solução de controvérsias na OMC é a identificação do Órgão de Solução de Controvérsias (OSC) como a esfera de análise e emissão da decisão do Mecanismo de Solução de Controvérsias (MSC) ou do Sistema de Solução de Controvérsias (SSC). Como se comenta adiante, o OSC é um dos órgãos do sistema, que não analisa juridica ou tecnicamente os casos, mas apenas chancela "quase automaticamente" a análise técnica dos órgãos judiciais 
taneamente, a liberalização e a regulamentação do comércio internacional. A Conferência de Bretton Woods foi responsável pela inauguração desta nova era, com a criação de instituições fundamentais para a recuperação da economia mundial: o Banco Internacional para Reconstrução e Desenvolvimento (BIRD), o Fundo Monetário Internacional (FMI) e o projeto de criação da Organização Internacional do Comércio (OIC).

Diante do fracasso da OIC, resultante da recusa de ratificação da Carta de Havana pelo Congresso norte-americano, o Acordo Geral de Tarifas e Comércio (GATT, sigla de General Agreement on Tariffs and Trade) - projetado em 1947 para funcionar como uma regulamentação temporária, no lapso até a entrada em vigor da Carta constitutiva da OIC - "teve que preencher o buraco nas relaçôes internacionais". ${ }^{4}$

Assim, não se pode olvidar que o GATT foi projetado como um acordo comercial, e não como uma verdadeira organização internacional, embora tenha sobrevivido surpreendentemente aos seus obstáculos, e se desenvolvido devido ao impulso contextual do fracasso da constituição da OIC. ${ }^{5}$ A despeito da falta de arcabouço institucional e de apoio financeiro, do seu caráter provisório e de sua abordagem contratualista, o GATT se tornou o principal instrumento de regulamentação do comércio internacional, por aproximadamente cinco décadas, até a criação da Organização Mundial do Comércio. ${ }^{6}$

Contudo, inobstante o inesperado êxito do GATT, a partir da década de 1980 houve percepção da necessidade e oportunidade de rearquitetura do sistema das regras do comércio internacional, tendo em conta sinais de seu esgotamento e o surgimento de crescentes complexidades nas relações comerciais internacionais. ${ }^{7} \mathrm{No}$

4 Tradução livre do original em língua inglesa: “[...] when the ITO failed to come into being, the GATT had to fill the gap in international relations". JACKSON, Jonh H. The Jurisprudence of GATT and the WTO. Cambridge: Cambridge University Press, 2000. p. 23.

5 No mesmo sentido: "As the central institution of the world trading régime GATT was structurally quite deficient. GATT was, in a sense, an accident." McRAE, Donald M. The contribution of international trade law to the development of international law. Recueil des cours, vol. 260, p. 99-238, 1996. p. 177.

6 Sobre as características do GATT, e suas deficiências, Cf: SACERDOTI, Giorgio. A Transformação do GATT na Organização Mundial do Comércio. In: CASELLA, Paulo Borba; MERCADANTE, Araminta de (coord.). Guerra comercial ou integração mundial pelo comércio?: a OMC e o Brasil. São Paulo: LTr, 1998, p. 50-69. p. 52-55.

7 MOTA, Pedro Infante. O Sistema GATT/OMC: Introdução intuito de satisfazer a novas necessidades e proclamas da sociedade internacional, iniciou-se em 1986 a Rodada do Uruguai, ciclo de negociações comerciais multilaterais que incluiu temas diversos como serviços, investimentos e propriedade intelectual, tendo como resultado a criação da Organização Mundial do Comércio. 8910

Em um relevante incremento de institucionalidade e juridicidade, a OMC surge, desse modo, como continuidade jurídica do GAT'T, incorporando uma notável herança de suas decisões, procedimentos e práticas costumeiras. ${ }^{11}$ A criação de uma complexa organização internacional engendrou, portanto, profundas mudanças em algumas esferas do sistema do comércio internacional, e uma das mais relevantes foi a reformulação de seu mecanismo de solução de controvérsias. ${ }^{12}$

Contudo, como fruto de seu contexto, o GATT guardava características de sua origem, que contrastavam com a realidade do comércio internacional então

Histórica e Princípios Fundamentais. Coimbra: Almedina, 2005. p. 27.

8 Segundo descreve Alcides Prates: "O processo de negociação que levou ao seu estabelecimento surpreendeu pela rapider. A Declaração de Punta del Este, que lançou a Rodada do Uruguai, em 1986, não continha referência à criação de uma organização. Apenas em 1990 começa-se a falar do assunto na Rodada. Há incertezas de quem foi o primeiro proponente deste novo avatar da Organização Internacional do Comércio, ou OIC, concebida formalmente na Conferência da Havana, encerrada em março de1948. [...] O Professor John Jackson, dos Estados Unidos, é citado como mentor acadêmico da proposta que, finalmente, ainda que com alterações profundas, veio a ser aprovada." PRATES, Alcides G. R. Comentários sobre o Acordo Constitutivo da OMC. In: CASELLA, Paulo Borba; MERCADANTE, Araminta de (coord.). Guerra comercial ou integração mundial pelo comércio?: a OMC e o Brasil. São Paulo: LTr, 1998, p. 94-124. p. 94.

9 THORSTENSEN, Vera. OMC - Organização Mundial do Comércio: As Regras do Comércio Internacional e a Nova Rodada de Negociações Multilaterais. $2^{a}$ ed. São Paulo: Aduaneiras, 2001. p. 27.

10 Para um histórico das rodadas de negociações do GATT, que resultaram na criação da OMC, Cf: SILVA, Roberto Luiz. Direito Econômico Internacional e Direito Comunitário. Belo Horizonte: Del Rey, 1995. Sobre seus resultados, p. 104-105.

11 Artigo XVI:I. Acordo Constitutivo da Organização Mundial do Comércio. Versão oficial em português segundo o decreto n. 1.355, de 30 dez. 1994, que promulga a Ata Final que Incorpora os Resultados da Rodada Uruguai de Negociações Comerciais Multilaterais do GAT'T.

12 Nas palavras de Celso Lafer: "O sistema de solução de controvérsias da OMC adensou a sua juridicidade, reduq̨indo a sua dimensão diplomáticacaracterizada pelo controle politico dos Estados-membros no encaminhamento das soluções - através da multiplicação das normas secundárias que regem a organização e o funcionamento do sistema. (...) " LAFER, Celso. O Sistema de Solução de Controvérsias da Organização Mundial do Comércio. In: CASELLA, Paulo Borba; MERCADANTE, Araminta de (coord.). Guerra comercial ou integração mundial pelo comércio?: a OMC e o Brasil. São Paulo: LTr, 1998, p. 729-755. p. 748. 
estabelecida, tornando evidentes as suas limitações na oferta de soluções às controvérsias comerciais, que crescentemente foram se acirrando. Exatamente em função do papel de regulamentação provisória que lhe incumbiria, a solução de controvérsias não era uma preocupação manifestada no texto do GATT. ${ }^{13}$

De fato, no tocante à solução de disputas, havia no GATT apenas dois dispositivos correlatos - o artigo XXII e o artigo XXIII - uma vez que a carta da OIC era o instrumento que previa com mais detalhes a solução de controvérsias que funcionaria no âmbito daquela organização. ${ }^{14}$

$\mathrm{O}$ artigo XXII ${ }^{15}$ previa as consultas entre as partes contratantes - fase que também naquele contexto foi erigida a pré-requisito para se invocar a solução de controvérsias. Em seu segundo parágrafo o dispositivo menciona, ainda, a possibilidade de entendimentos com as demais partes contratantes acerca da conduta questionada, sendo esse artigo a consubstanciação do estímulo à negociação para solucionar as controvérsias.

$\mathrm{O}$ artigo XXIII ${ }^{16}$, por sua vez, era a pedra angu-

13 Assim explicita Pierre Pescatore: "Whoever speaks of dispute settlement in GATT must start from nearly nothing. The General Agreement does not mention dispute settlement, nor does it institute any articulate machinery for such purpose. Everything in this field had to be created ex nibilo by necessity and by experience." PESCATORE, Pierre. The GATT Dispute Settlement Mechanism: Its Present Situation and its Prospects. Journal of International Arbitration, vol. 10, issue 1, p. 27-42, 1993. p. 27. 14 A solução de controvérsias prevista na Carta de Havana incluía procedimento ligado à consultas, à arbitragem, com papel ativo do Conselho Executivo e inclusive possibilidade de remeter pedido de opinião consultiva à CIJ. Cf, Capítulo VIII (Settlement of Differences) da Carta de Havana.

15 Artigo XXII. Acordo Constitutivo da Organização Mundial do Comércio. Versão oficial em português segundo o decreto n. 1.355, de 30 dez. 1994, que promulga a Ata Final que Incorpora os Resultados da Rodada Uruguai de Negociações Comerciais Multilaterais do GATT. "CONSULTAS 1. Cada Parte Contratante examinará com compreensão as representacõos que lhe sejam encaminhadas por qualquer outra Parte Contratante e deverá se prestar a consultas a respeito daquelas representações, desde que elas digam respeito a questões relativas à aplicação do presente Acordo. 2. As Partes Contratantes poderão, a pedido de uma das Partes Contratantes, entrar em entendimentos com uma ou várias Partes Contratantes sobre questões para as quais a solução satisfatória não poderia ser alcançada através das consultas previstas no parágrafo primeiro."

16 Artigo XXIII. Acordo Constitutivo da Organização Mundial do Comércio. Versão oficial em português segundo o decreto n. 1.355, de 30 dez. 1994, que promulga a Ata Final que Incorpora os Resultados da Rodada Uruguai de Negociações Comerciais Multilaterais do GATT. "PROTECÃO DE CONCESSÕES E VANTAGENS 1. No caso de uma Parte Contratante considerar que uma vantagem qualquer resultante para ela, direta ou indiretamente, do presente Acordo, está sendo anulada ou reduzida, ou que um dos objetivos do Acordo está sendo dificultado, em conseqüencia: (a) do não cumprimento por outra das Partes Contratantes lar da solução de controvérsias que se desenvolveu nas décadas seguintes. ${ }^{17}$ Sob o título de "proteção de concessões e vantagens", previa a possibilidade de investigação, pelas partes contratantes, de determinada conduta objeto de representação, podendo estas inclusive dirigir recomendações e autorizar a suspenção de certas obrigações resultantes do Acordo.

Ademais desses dispositivos, cuja linguagem deixava inicialmente a solução de controvérsias a cargo das próprias partes contratantes, as regras procedimentais foram sendo desenvolvidas pela prática ao longo dos anos, sendo posteriormente codificadas por meio de decisões e entendimentos de solução de controvérsias concluídos pelas então partes contratantes. ${ }^{18}$

dos compromissos pela mesma assumidos em virtude do presente Acordo; (b) da aplicação por outra das Partes Contratantes de uma medida, contrária ou não às disposições do presente Acordo; on (c) da existência de qualquer outra situação, dita Parte Contratante, a fim de obter solução satisfatória para a questão, poderá dirigir representações ou propostas por escrito à outra ou outras Partes Contratantes que the parecerem interessadas. Qualquer Parte Contratante, por essa forma interpelada, examinará, com boa vontade, as representações ou propostas que lhe tenham sido dirigidas. 2. Se as Partes Contratantes interessadas não chegarem a um Acordo satisfatório dentro de um prazo razoável, on se a dificuldade for uma das previstas no $\int 1$ (c) deste artigo, a questão poderá ser submetida às Partes Contratantes. As Partes Contratantes iniciarão, sem demora, uma investigação sobre qualquer assunto que lhes seja submetido e, se julgarem conveniente, dirigirão recomendações especiais e apropriadas às partes Contratantes que julguem interessadas, ou baixarão normas sobre a questão. As Partes Contratantes, quando acharem necessário, poderão efetuar consultas com as outras Partes Contratantes, com o Conselho Econômico e Social das Naçoes Unidas e com qualquer outra organização intergovernamental competente. Se elas consideram que as circunstâncias são suficientemente graves para justificar uma tal medida, poderão autorizar uma ou várias Partes Contratantes a suspender, com respeito a tal outra ou tais outras Partes Contratantes, a aplicação de qualquer concessão ou outra obrigação resultantes do Acordo geral cuja suspensão justificada elas examinarão, levando em conta as circunstâncias. Se uma tal concessão ou outra obrigação, for efetivamente suspensa com respeito a uma Parte Contratante, será permitido à referida Parte Contratante, no prazo de 60 dias, a contar da data da aplicação desta suspensão, notificar por escrito ao Secretário Executivo das Partes Contratantes, sua intenção de denunciar o Acordo geral; esta denúncia se efetuará ao término do prazo de 60 dias, contados a partir da data em que o Secretário executivo das Partes Contratantes tiver recebido a aludida notificação.".

17 Assim explicita Ronald McRae: "The GATT dispute settlement process was not created; it evolved. [...]" McRAE, Donald M. The contribution of international trade law to the development of international law. Recueil des cours, vol. 260, p. 99-238, 1996. p. 118.

18 Destaque para o documento "Understanding Regarding Notification, Consultation, Dispute Settlement and Surveillance," adotado pelas partes em nov. 1979, como resultado da Rodada de Tóquio. Jackson comenta que embora o status legal desse e de outros entendimentos resultantes dessa rodada não seja claro, o documento influenciaou largamente a solução de controvérsias desde então e até a constituição da OMC, podendo ser considerada uma interpretação definitiva do Acordo do GATT, consistindo em um arcabouço constitucional do manejo dos procedimentos após o GATT'. 
Inicialmente, diante da inexistência de previsão de normas e procedimentos prescritos, as partes tratavam das disputas em suas reuniões regulares. Logo em seguida, passaram a ser constituídos "grupos de trabalho" para tratar das controvérsias, e estes eram compostos por representantes das próprias partes contratantes. $\mathrm{Na}$ década de 50, contudo, operacionalizou-se uma pertinente transição, quando passou a ter lugar a prática de utilização de painéis para a análise dos litígios. ${ }^{19}$

Tendo em vista o contexto brevemente explicitado, são marcantes, ainda, na solução de controvérsias do GATT, a ausência de controle de interpretação normativa realizada pelos diferentes painéis, estabelecidos de maneira ad hoc, e a improbabilidade prática de adoção dos relatórios das disputas - tendo em vista que a exigência do consenso entre as Partes contratantes era obstaculizada pela parte demandada. ${ }^{20}$

Assim, a solução de controvérsias do GAT'T apresentava diversos problemas, principalmente devido à sua história e origem. São visíveis as seguintes falhas: (i) a linguagem vaga dos artigos, que levou a imprecisões sobre o procedimento e seus objetivos; (ii) o poder de supervisão do procedimento pelas partes era pouco definido, tendo a prática levado à adoção do consenso para diversos dos temas; (iii) o mecanismo de bloqueio da constituição de painéis e da adoção dos relatórios; (iv) e a existência de diversos procedimentos, que levavam a uma fragmentação da solução da controvérsia. ${ }^{21}$

Alguns desses problemas foram equacionados com a constituição da OMC, que desempenhou uma clara evolução da temática da solução de litígios, ao estabelecer um sistema de solução de litígios unificado, em relação aos Acordos que foram resultado da Rodada do

19 JACKSON, John H.; DAVEY, William J.; SYKES JR., Alan O. Legal Problems of International Economic Relations. Cases, Materials and Text. 4a ed. St. Paul: West Group, 2002. p. 257.

20 Acerca deste último traço marcante, JOHN JACKSON explicita o previsível mecanismo de bloqueio: "In effect, the procedure which relied on consensus meant that the nation which "lost" in the panel, and might otherwise be obligated to follow the panel obligations, could "block" the Council action by raising objections to the consensus. Thus, the losing party to the dispute could avoid the consequences of its defeat. This "blocking" was deemed to be the most significant defect in the GATT DS process." JACKSON, John. Sovereignty, the WTO and Changing Fundamentals of International Law. New York: Cambridge University Press, 2006. p. 141 21 JACKSON, John. Sovereignty, the WTO and Changing Fundamentals of International Law. New York: Cambridge University Press, 2006. p. 143-144.
Uruguai. ${ }^{22} 23$

Restou prejudicado o mecanismo de bloqueio, um dos mais graves entraves à solução de controvérsias do GATT', havendo, a partir de então, além do expresso direito dos membros de iniciar um procedimento de solução de litígios, o estabelecimento da regra do consenso reverso para adoção do relatório do painel, como se explicita a seguir.

\subsection{O"novo" sistema de solução de controvérsias alcançado na Rodada do Uruguai}

A criação do sistema de solução de controvérsias da OMC engendrou uma rearquitetura das engrenagens deste sistema, em consolidação à perspectiva legalista. O embate entre a perspectiva legalista ("rule-oriented") da solução de controvérsias no sistema multilateral de comércio e a perspectiva pragmática, de primazia do elemento político ("power-oriented") ${ }^{24}$, foi marcante durante a evolução do GATT'. ${ }^{25}$ Nesta contraposição a primeira

22 Na rodada de Tóquio houve a inclusão de mecanismos de solução de controvérsias nos Códigos então concluídos, suscitando inclusive um forum shopping. Neste sentido, foi de grande relevância a adoção de um sistema de solução de litígios unificado. MAROTTA RANGEL, Vicente. Marraqueche 94 e os Dois GATT: Breve Apresentação. In: CASELLA, Paulo Borba; MERCADANTE, Araminta de (coord.). Guerra comercial ou integração mundial pelo comércio?: a OMC e o Brasil. São Paulo: LTr, 1998, p. 126-136. p. 131. 23 No mesmo sentido: "[...] o Dispute Settlement Understanding, para faz̧er frente ao risco de fragmentação, traz̧ido pela dispersão dos diversos Códigos da Rodada Tóquio - cada um tendo o seu sistema próprio, o que ensejava o fórum-shopping- representou a criação de um sistema único da OMC" LAFER, Celso. O Sistema de Solução de Controvérsias da Organização Mundial do Comércio. In: CASELLA, Paulo Borba; MERCADANTE, Araminta de (coord.). Guerra comercial ou integração mundial pelo comércio?: a OMC e o Brasil. São Paulo: LTr, 1998, p. 729755. p. 745.

24 Jackson classifica esta dicotomia como o embate entre um sistema "rule-oriented" x "power oriented". Cf: "A power-oriented system might involve various power- oriented bargaining chips, and in even older days, military bargaining chips or military actions. Contrast this with today's notion (and certainly at least 50 percent of the notion of the original GATT DS system) of building jurisprudential predictability and leveling the playing field for parties of different wealth and power structures." p. 146 JACKSON, John. Sovereignty, the WTO and Changing Fundamentals of International Law. New York: Cambridge University Press, 2006. P. 144. 25 Hudec classifica a mesma dicotomia como um embate entre as perspectivas legalista x pragmática. Também ilustra a dicotomia como a tensão entre GATT x GABB. O autor esclarece que a utilização da expressão GABB (General Agreement on Better Bargaining) é uma ferramenta para caracterizar as críticas à visão legalista do sistema que tinha lugar quando da redação do trabalho. GABB é uma proposta ilusória de uma instituição alternativa, radicalmente pragmatica, que operaria sem regras substantivas. "The issue, of course, is not an all-or-nothing choice between GATT and GABB, for it is unlikely 
visão havia logrado êxito mais significativo nas últimas décadas do GATT, e se cristalizou com o redesenho da solução de litígios. ${ }^{26} 2728$

Assim, com o surgimento da OMC, a solução de controvérsias foi oportunamente sistematizada em um acordo específico, o Entendimento Relativo às Normas e Procedimentos sobre Solução de Controvérsias [ESC], que delineia um sistema de solução de controvérsias mais complexo, coeso e completo. Esta dimensão assume relevância vital para a organização, que tem na sua administração uma de suas funções erigidas pelo Acordo Constitutivo da OMC. ${ }^{29} 30$

Ademais, a submissão a seu sistema de solução de controvérsias, com competência exclusiva e universal no âmbito dos acordos multilaterais de comércio, tornou-se obrigatória a todos os mebros da OMC, através do denominado "single undertaking". ${ }^{31}$ Por meio desta nova

that either point of view would be carried to absolute extremes in practice. But the issue is of that general dimension. Unless governments decide, fairly soon, to make a major effort to save the old GATT code, the pressures of a changing world will leave no choice but to commit the major part of GATT's work to GABB-type procedures.” p. 1301. HUDEC, Robert E. GATT or GABB? - The Future Design of the General Agreement on Tariffs and Trade. Yale Law Journal Volume 80, n. 7, jun. 1971, pp. 1299-1387.

26 Retoma-se a ideia de "adensamento de juridicidade". LAFER, Celso. A OMC e a regulamentação do comércio internacional: uma visão brasileira. Porto Alegre: Livraria do Advogado, 1998. p. 123-125. LAFER, Celso. O Sistema de Solução de Controvérsias da Organização Mundial do Comércio. P. 748. In: CASELLA, Paulo Borba; MERCADANTE, Araminta de (coord.). Guerra comercial ou integração mundial pelo comércio?: a OMC e o Brasil. São Paulo: LTr, 1998. Pp. 729-755.

27 "The advent of the WTO dispute resolution system suggest that the process of settling trade disputes has become judicialised. (...) In fact, the move to a more "juridical" or "rule-oriented" approach preceded the emergence of the WTO, and has simply been extended." P. 249. CAMERON, James; GRAY, Kevin R. Principles of International Law in the WTO Dispute Settlement Body. International and Comparative Law Quarterly. Vol. 50, 2001. Pp. 249-298.

28 Para uma visão diferente desta evolução, argumentando que desde o início havia uma inidssociável interação entre direito e política, em oposição à visão geral de "legalização", Cf: PAUWELYN, Joost. The Transformation of World Trade. Michingan Law Review. Vol. 104, 2005-2006. p.1-66.

29 Artigo III: 1-5. Acordo Constitutivo da Organização Mundial do Comércio. Versão oficial em português dada pelo Decreto Legislativo n. 1.355, de 30 de Dezembro de 1994.

30 Para uma visão acerca do constitucionalismo e da relevância do Sistema de Solução de Controvérsias para essa interpretação/ teoria, Cf: CAPUCIO, Camilla. O constitucionalismo e a comunitarização no direito internacional: possibilidades para o comércio internacional? Revista de Direito Internacional, Brasília, v. 13, n. 1, 2016 p. 196-213.

31 'Por força deste dispositivo, materializou-se, no plano jurídico, o 'princípio da globalidade' (single undertaking), uma das linhas mestras das negociações da Rodada do Uruguai, ao menos na interpretação que faziam daquele princípio abordagem, o Acordo Constitutivo da OMC prevê, em seu artigo II:2, que o Entendimento Relativo às Normas e Procedimentos Sobre Solução de Controvérsias, tal qual os demais anexos, é parte integrante daquele presente acordo, sendo obrigatório a todos os Membros. ${ }^{32}$

A criação do Órgão de Apelação, como uma instância de revisão e controle de legalidade dos relatórios dos painéis, foi inovação diretamente ligada ao incremento de juridicidade do sistema de solução de controvérsias. Merecem destaque, ainda, a inclusão de prazos especificados para as diferentes etapas do processo de solução de controvérsias, e a instituição da regra do consenso reverso. ${ }^{33}$ Esta última, que será analisada detalhadamente, engendra a adoção quase automática dos relatórios, sendo a base para a caracterização deste sistema como adjudicatório e jurisdicional.

A relevância central deste sistema de solução de litígios é enunciada no Entendimento, ao reconhecê-lo como essencial para a previsibilidade e segurança do sistema multilateral de comércio. ${ }^{34} E$ E ainda destacado neste instrumento a primazia jurídica e exclusividade do sistema de solução de controvérsias em relação aos sistemas alternativos de solução de litígios fora da OMC..$^{35} 36$

os principais participantes desenvolvidos. (...) Assim, já não existem sistemas diferenciados, como passara a ocorrer no GATT (...). " p. 97. PRATES, Alcides G. R. Comentários sobre o Acordo Constitutivo da OMC. In: CASELLA, Paulo Borba; MERCADANTE, Araminta de (coord.). Guerra comercial ou integração mundial pelo comércio?: a OMC e o Brasil. São Paulo: LTr, 1998. Pp. 94-124.

32 Artigo II:2. Acordo Constitutivo da Organização Mundial do Comércio. Versão oficial em português dada pelo Decreto Legislativo n. 1.355, de 30 de Dezembro de 1994. "Artigo II Escopo da OMC 2.Os acordos e os instrumentos legais conexos incluídos nos anexos 1, 2 e 3 (denominados a seguir "Acordos Comerciais Multilaterais") formam parte integrante do presente acordo e obrigam a todos os Membros"

33 O autor cita ambos as inovações como concretização do "adensamento de juridicidade", com destaque para a constituição do Órgão de Apelação: “(...) essa segunda instância- quase única no Direito Internacional Público- reforça, pela sua função, o componente da juridicidade do sistema de solução de controvérsias da OMC." LAFER, Celso. O Sistema de Solução de Controvérsias da Organização Mundial do Comércio. p. 746. In: CASELLA, Paulo Borba; MERCADANTE, Araminta de (coord.). Guerra comercial ou integração mundial pelo comércio?: a OMC e o Brasil. São Paulo: LTr, 1998. Pp. 729-755.

34 Artigo IV.2 e nota de rodapé n. 1. Entendimento Relativo às Normas e Procedimentos sobre Solução de Controvérsias. Versão oficial em português dada pelo Decreto Legislativo n. 1.355, de 30 de Dezembro de 1994.

35 Artigo XXIII. Entendimento Relativo às Normas e Procedimentos sobre Solução de Controvérsias. Versão oficial em português dada pelo Decreto Legislativo n. 1.355, de 30 de Dezembro de 1994.

36 PETERSMANN, Ernst-Ulrich. The GATT/WTO Dispute Settlement System: International Law, International Organizations 
Em análise também dos objetivos implícitos do sistema de solução de controvérsias da OMC, Jackson reconhece diversos objetivos, dentre os quais destacamos os seguintes: (i) solucionar de maneira amigável as controvérsias, de modo a reduzir as tensões internacionais e os respectivos conflitos; (i) desfazer danos causados pelo membro demandado, corrigindo as lesões provocadas por sua conduta; (iii) solucionar as controvérsias de maneira eficiente ${ }^{37}$ (iv) completar as lacunas normativas e esclarecer as ambiguidades do texto dos acordos, (v) construir uma base de precedentes, no intuito de promover previsibilidade e segurança ${ }^{38}$; (vi) garantir o cumprimento das obrigações dos acordos, bem como das decisões do sistema de controvérsias, (vii) reequilibrar as vantagens percebidas pelos membros a partir dos Acordos; (viii) corrigir assimetrias de poder das relações econômicas interacionais; (ix) facultar aos membros o acesso a um procedimemto adjudicatório com garantias básicas; (x) garantir julgamentos fundamentados, que possam auxiliar na aceitabilidade pública do sistema multilateral de comércio. ${ }^{39}$

A a estas modificações trazidas pela construção normativa-institucional de um "novo" sistema se solução de controvérsias, são adicionados elementos inovadores, oriundos da própria evolução deste sistema por meio de sua atuação e da interpretação das normas do ESC. São exemplos desta atuação renovadora a possibilidade de participação de Organizações nãogovernamentais nos procedimentos, através de amicus

and Dispute Settlement. London: Kluwer Law International, 1997. p. 179.

37 Artigo III.3. "3.É essencial para o funcionamento eficaz da OMC e para a manutenção de equilibrio adequado entre os direitos e as obrigações dos Membros a pronta solução das situações em que um Membro considere que quaisquer beneficios resultantes, direta ou indiretamente, dos acordos abrangidos tenham sofrido restrições por medidas adotadas por outro Membro. "Entendimento Relativo às Normas e Procedimentos sobre Solução de Controvérsias. Versão oficial em português dada pelo Decreto Legislativo n. 1.355, de 30 de Dezembro de 1994.

38 Artigo III.2. "2.O sistema de solução de controvérsia da OMC é elemento essencial para trazer segurança e previsibilidade ao sistema multilateral de comércio. Os Membros reconbecem que esse sistema é útil para preservar direitos e obrigacõoes dos Membros dentro dos parâmetros dos acordos abrangidos e para esclarecer as disposiçoes vigentes dos referidos acordos em conformidade com as normas correntes de interpretação do direito internacional público. As recomendações e decisões do OSC não poderão promover o aumento ou a diminuição dos direitos e obrigações definidos nos acordos abrangidos." Entendimento Relativo às Normas e Procedimentos sobre Solução de Controvérsias. Versão oficial em português dada pelo Decreto Legislativo n. 1.355, de 30 de Dezembro de 1994.

39 JACKSON, John. Sovereignty, the WTO and Changing Fundamentals of International Law. New York: Cambridge University Press, 2006. P. 147-151. curiae, em interpretação dos artigos 13.1 e 13.2, e a aplicação da Convenção de Viena sobre o Direito dos Tratados como parâmetro de interpretação ${ }^{40}$, como abertura do sistema às normas do Direito Internacional Público. ${ }^{41}$

Embora resultado de considerável evolução, como evidenciado supra, o sistema de solução de controvérsias da OMC, ${ }^{42}$ assim como todas as instituições jurídicas concretizadas na dimensão fática da realidade, está sujeito a diversas críticas e à diferentes proposições para sua reforma. ${ }^{43}{ }^{44}$ As propostas de reforma, de modo geral, abarcam elementos como: (i) o incremento da transparência, (ii) a modificação da retaliação de modo a incluir um caráter reparatório, e não apenas prospectivo, e (iii) a inclusão de mecanismos de incentivo a participação de países menos desenvolvidos.

Esta última, que será analisada detalhadamente, engendra a adoção automática - ou quase automática - dos relatórios, sendo base para a caracterização deste sistema como adjudicatório e jurisdicional.

40 Segundo o autor, a aplicação das regras da Convenção de Viena sobre os Direitos dos Tratados na Interpretação das controvérsias da OMC é um dos elementos que o diferencia do GATT, cujos painéis mantinham uma "preferência pouco salutar pelas circunstâncias históricas do momento da confecção dos artigos do GATT como meio preferencial de interpretação. Isto é obviamente contrário aos Artigos 31 e 32 da Convenção de Viena sobre o Direito dos Tratados (...)” p. 16. KUYPER, Peter J. O Direito do GATT com um Campo Especial do Direito Internacional: Ignorância, Refinamentos Posteriores ou um Sistema Autocontinente de Direito Internacional? In: CASELLA, Paulo Borba; MERCADANTE, Araminta de (coord.). Guerra comercial ou integração mundial pelo comércio?: a OMC e o Brasil. São Paulo: LTr, 1998. p. 15-49. 41 "The WTO dispute settlement process has also been linked more directly to the general field of international law. The dispute settle- ment system is expressly designed to "preserve the rights and obli-gations of Members" and to clarify the provisions of the WTO agreements "in accordance with customary rules of interpretation of public international law." p. 184. McRAE, Donald M. The contribution of international trade law to the development of international law. Recueil des cours, Volume 260 (1996), pp. 99-238.

42 Para uma análise de desenvolvimentos recentes, e do Brasil em especial nesse context, Cf: BREVIGLIERI, Etiene M. Bosco; PEREIRA, Luciano Meneguetti. Os vinte anos da OMC, suas conquistas e desafios: uma análise do Brasil e o Sistema de Soluções de Controvérsias. Revista de Direito internacional, Brasília, v. 12, n. 2, 2014 p. 123-150.

43 VAN DER BORGHT, Kim. The Review of the WTO Understanding on Dispute Settlement: Some Reflections on the Current Debate. American University International Law Review. Vol. 14, 1998. Pp. 1223-1243.

44 BARRAL, Welber; PRAZERES, Tatiana. Solução de Controvérsias. p. 27-46. In: BARRAL, Welber (Org). O Brasil e a OMC. Curitiba: Juruá, 2006. 2a ed, 5a tir. 


\section{Os Componentes do sistema}

O Sistema de Solução de Controvérsias da OMC é composto por instâncias adjudicatórias - os painéis e o Órgão de Apelação - e por uma instância política, o Órgão de Solução de Controvérsias (OSC). O estudo destas instâncias, sob a perspectiva de suas competências e limites na engrenagem da solução de litígios, é essencial para a compreensão da natureza jurídica desse sistema e das decisões dele resultantes.

O Órgão de Solução de Controvérsias é considerado a instância política da engrenagem da solução de litígios na OMC, ${ }^{45}$ dada sua natureza diplomática. ${ }^{46}$ Assim é que a juridicidade do procedimento de solução de controvérsias na OMC "se insere em um contexto mais amplo, de natureza diplomática". 474849

45 Neste sentido explana Petros Mavroidis: "The Dispute Settlement Body (DSB) is not an adjudicating body since it can only adopt or reject (as presented) the findings of panels or the Appellate Body (AB). [...]" MAVROIDIS, Petros. Outsourcing of Law? WTO Law as Practiced By WTO Courts. American Journal of International Law, vol. 2, p. 421-474, 2008. p. 421

46 Assim explicita Celso Lafer: "O adensamento de juridicidade, que estou realçando, não exclui, muito pelo contrário, o papel do OSC como instância política diplomática de solução de controvérsias na OMC. [...]” LAFER, Celso. O Sistema de Solução de Controvérsias da Organização Mundial do Comércio. In: CASELLA, Paulo Borba; MERCADANTE, Araminta de (coord.). Guerra comercial ou integração mundial pelo comércio?: a OMC e o Brasil. São Paulo: LTr, 1998, p. 729755. p. 751

47 LAFER, Celso. O Sistema de Solução de Controvérsias da Organização Mundial do Comércio. In: CASELLA, Paulo Borba; MERCADANTE, Araminta de (coord.). Guerra comercial ou integração mundial pelo comércio?: a OMC e o Brasil. São Paulo: LTr, 1998, p. 729-755. p. 749.

48 Embora parte da doutrina lhe atribua natureza jurisdicional, ou quase-jurisdicional, aproximando-o de um tribunal administrativo, diversos são os obstáculos para tal reconhecimento. Com base nos elementos de sua composição, poderes e atuação, como explicitase em seguida, esta pesquisa confere ao OSC a natureza de órgão político (ou diplomático). Não se pode, pois, confundir a natureza do OSC, com a sua relação com os painéis e o Órgão de Apelação, ou com a sua função de vocalizador das decisões do Sistema de Solução de Controvérsias- este de natureza adjudicatória. Como exemplos de autores que conferem a natureza jurisdicional: "The DSB, especially the Appellate Body, has many characteristics of an administrative tribunal and other more established international tribunals, and some of a domestic court. [...]" CAMERON, James; GRAY, Kevin R. Principles of International Law in the WTO Dispute Settlement Body. International and Comparative Law Quarterly, vol. 50, p. 249-298, 2001. (Nota-se que pode ter havido um erro formal, de troca do DSB [Dispute Settlement Body] por DSS [Dispute Settlement System], pois os autores incluem o Órgão de Apelação como parte do Órgão de Solução de Controvérsias, o que não corresponde à arquitetura desenhada pelo Entendimento).

49 Entendimento semelhante, acerca da natureza quasi-jurisdi-
No que tange a seus componentes, o OSC é uma emanação, um "alter ego" do Conselho Geral da OMC, ${ }^{50}$ uma vez que sua composição é idêntica à do Conselho Geral, que se reúne como OSC para administrar os dispositivos do ESC. ${ }^{51}$

O marco normativo inicial do Órgão de Solução de Controvérsias é, pois, o ESC, que estabelece tal órgão como responsável pela aplicação e administração das normas de solução de controvérsias presentes no Entendimento. Criado para ser o "guardião" das normas procedimentais de solução de litígios na OMC, foi concedida ao OSC a competência para gerir e operacionalizar este sistema.

Para tal, o OSC possui competência para diversas ações, dentre as quais destacamos: (a) o estabelecimento dos painéis; (b) a adoção de relatórios dos painéis e do Órgão de Apelação; (c) a supervisão da aplicação das decisões e recomendações; (d) a autorização da suspensão de concessões e de outras obrigações previstas pelos acordos abrangidos, ${ }^{52}$ e (e) a informação aos pertinentes Conselhos e Comitês da OMC sobre o andamento de controvérsias. ${ }^{53}$

Para a maioria das decisões essenciais ao funcionamento prático do mecanismo, prevalece o que se denomina de consenso reverso, ou consenso negativo. $\mathrm{O}$ consenso reverso se consubstancia na inversão da regra do consenso enunciada no artigo 2.4, isto é, se considera que o OSC tomou uma decisão, salvo quando houver consen-

cional, mas aparentemente tratando o OSC como o SSC, encontrase espelhado no trabalho: FIGUEIREDO, Celso Henrique Cadete de. A promoção de accountability na Organização Mundial do Comércio: uma análise horizontal e vertical. Revista de Direito Internacional, Brasília, v. 12, n. 2, 2014 p. 279-309..

50 VAN DEN BOSSCHE, Peter; ZDOUC, Werner. The Law and Policy of the World Trade Organization. $3^{\mathrm{a}} \mathrm{ed}$. Cambridge: Cambridge University Press, 2013. p. 206.

51 Artigo 2.2. Acordo constitutivo da Organização Mundial do Comércio. Versão oficial em português segundo o decreto n. 1.355, de $30 \mathrm{dez}$. 1994, que promulga a Ata Final que Incorpora os Resultados da Rodada Uruguai de Negociações Comerciais Multilaterais do GATT.

52 Artigo 2.1. Entendimento Relativo às Normas e Procedimentos sobre Solução de Controvérsias. Versão oficial em português segundo o decreto n. 1.355, de 30 dez. 1994, que promulga a Ata Final que Incorpora os Resultados da Rodada Uruguai de Negociações Comerciais Multilaterais do GATT.

53 Artigo 2.2. Entendimento Relativo às Normas e Procedimentos sobre Solução de Controvérsias. Versão oficial em português segundo o decreto n. 1.355, de 30 dez. 1994, que promulga a Ata Final que Incorpora os Resultados da Rodada Uruguai de Negociações Comerciais Multilaterais do GATT. 
so no sentido de não tomar a referida decisão. ${ }^{54}$

A doutrina reconhece, assim, que a regra do consenso reverso, na prática, torna a adoção dos relatórios dos órgãos jurisdicionais - bem como o estabelecimento do painel e a autorização para retaliação - "quase automática" ${ }^{55}$ ou automática. ${ }^{56} 575859$

Isso se dá na medida em que, em situações normais, ao menos um membro do OSC - aquele cuja pretensão se beneficia com a posição explicitada no relatório - possuirá interesse substancial a ser resguardado, sendo improvável que se construa nesse órgão o consenso necessário para que não seja adotada a decisão. ${ }^{60}$

Como consequência, o papel do OSC e seu impacto na sistemática da solução de controvérsias da OMC é de fato limitado. Neste sentido é a reflexão de Peter Van

54 Sobre este assunto, John Croome comenta: "In effect, they [negotiators 7 retained the consensus rule, but turned it on its head. Whereas consensus had been required in order to move the dispute settlement process forward at each stage, they provided that, in future, consensus agreement would be required not to move. The effect would be to end the possibility of a country unilaterally blocking the dispute mechanism, and to build automaticity into the progress of a dispute through the system, unless all countries agreed that the process should be halted." CROOME, John. Reshaping the World Trading System: A history of the Uruguay Round. 2a ed. [S.l.]: [S.n.], 1998. Disponível em: <http://www.hse.ru/data/2011/12/05/1271919456/ Reshaping\%202_e.pdf> Acesso em: 1012 fevabr. 20174. p. 283.

55 PETERSMANN, Enst-Ulrich. The GAT'T/WTO Dispute Settlement System: International Law, International Organizations and Dispute Settlement. London: Kluwer Law International, 1997. p. 179.

56 VAN DEN BOSSCHE, Peter.; ZDOUC, Werner. The Law and Policy of the World Trade Organization. $3^{\mathrm{a}}$ ed. Cambridge: Cambridge University Press, 2013. p. 207.

57 O autor menciona a "automaticidade" como característica do Sistema de Solução de Controvérsias, em especial na adoção dos relatórios. LAFER, Celso. O Sistema de Solução de Controvérsias da Organização Mundial do Comércio. In: CASELLA, Paulo Borba; MERCADANTE, Araminta de (coord.). Guerra comercial ou integração mundial pelo comércio?: a OMC e o Brasil. São Paulo: LTr, 1998, p. 729-755. p. 745-747.

58 Neste sentido explana o autor: "[...] automaticity into the progress of a dispute through the system, unless all countries agreed that the process should be halted." CROOME, John. Reshaping the World Trading System: A history of the Uruguay Round. 2a ed. [S.l.]: [S.n.], 1998. Disponível em: <http://www.hse.ru/data/2011/12/05/1271919456/Reshaping\%202_e.pdf> Acesso em: 10 abr. 2017,.12 fev. 2014. p. 283. 59 Também compartilhado deste entendimento: "[...]This change is attributable to the negative consensus rule under the DSU where Panel and Appellate Body reports are automatically binding, subject to a negative vote by the parties in the Dispute Settlement Body. [...]”.CAMERON, James; GRAY, Kevin R. Principles of International Law in the WTO Dispute Settlement Body. International and Comparative Law Quarterly, vol. 50, p. 249-298, 2001. p. 249-250.

60 VAN DEN BOSSCHE, Peter.; ZDOUC, Werner. The Law and Policy of the World Trade Organization. $3^{\mathrm{a}}$ ed. Cambridge: Cambridge University Press, 2013. p. 207. den Bossche e Werner Zdouc:

Em virtude do fato de o OSC tomar as principais decisões de resolução de litígios acima referidas por consenso inverso, o impacto e a influência do OSC sobre as consultas ea adjudicação por grupos especiais e pelo Órgão de Apelação em litígios especificos é muito limitado. O envolvimento do OSC é, em grande parte, um legado do passado em que o litígio comercial era mais diplomático e político que de natureza judicial. No entanto, a participação do OSC em cada etapa importante de uma controvérsia cumpre três propósitos úteis: (1) mantém todos os Membros da OMC diretamente informados da solução de controvérsias da $\mathrm{OMC}$;2) assegura a supervisão multilateral das recomendacõos e decisões do OSC, pressionando assim a parte infractora a respeitar; $e$ (3) dá aos membros da OMC um fórum político designado no qual as questões decorrentes da utilização do sistema de solução de controvérsias possam ser debatidas. ${ }^{61}$

O OSC funciona, assim, como a instância vocalizadora da decisão, que, contudo, emana como resultado do procedimento tido no Sistema de Solução de Controvérsias da OMC, e por isso sua atuação não impede ou anula a juridicidade dos relatórios dos órgãos adjudicantes do sistema. Por outro lado, é a sua aprovação ao(s) relatório(s), ainda que sob a regra do consenso negativo, que confere formalmente a esses documentos efeitos jurídicos de uma decisão adjudicatória internacional. ${ }^{62}$

Em complementação a essa instância, são instâncias adjudicatórias os painéis e o Órgão de Apelação.

61 Tradução livre do original em língua inglesa: " $A$ s a result of the fact that the DSB takes the core dispute settlement decisions referred to above by reverse consensus, the DSB's impact and influence over consultations and adjudication by panels and the Appellate Body in specific disputes is very limited. The involvment of the DSB is, to a large extent, a legacy of the past in which trade dispute settlemet was more diplomatic and political that judicial in nature. Nevertheless, the involvement of the DSB in each major step of a dispute fulfils three useful purposes: (1) it keeps all WTO Members directly informed of the WTO dispute settlement; (2) it ensures multilateral surveillance of DSB recommendations and rulings, thereby exerting pressure on the offending party to comply; and (3) it gives WTO members a designated political forrum in which issues arising from the use of the dispute settlement system can be debated" VAN DEN BOSSCHE, Peter.; $\square$ ZDOUC, Werner. The Law and Policy of the World Trade Organization. $3^{\mathrm{a}}$ ed. Cambridge: Cambridge University Press, 2013. P. 208.

62 Assim sintetiza o autor: "Estilo e automaticidades, acima examinados e comentados, não convertem os reports dos panels e do Appellate Body em sentenças judiciais. Com efeito, os reports só adquirem plenitude de efeitos juridicos quando aprovados pelos Estados-membros, através de um órgão criado pela constituição da OMC - o "Dispute Settlement Body", o Órgão de Solução de Controvérsias - [...] Essa aprovação, ainda que tenba o potencial de automaticidade, é o que configura o exequatur, através de uma bomologação politica, por via de regra, do consenso negativo." LAFER, Celso. O Sistema de Solução de Controvérsias da Organização Mundial do Comércio. In: CASELLA, Paulo Borba; MERCADANTE, Araminta de (coord.). Guerra comercial ou integração mundial pelo comércio?: a OMC e o Brasil. São Paulo: LTr, 1998, p. 729-755. p. 747. 
Os painéis são grupos de especialistas formados com as funções principais de (a) avaliar objetivamente o litígio que lhe seja submetido, sob os aspectos dos fatos e de sua conformidade em relação aos dispositivos dos respectivos acordos; e (b) elaborar conclusões que auxiliem o OSC na formulação de recomendações e decisões. ${ }^{63}$

Embora a regra do consenso reverso esvazie a função do OSC na solução de controvérsias, empoderando as instâncias jurisdicionais, o texto do Entendimento busca conferir preponderância deste sob o painel, ao enunciar que a função do painel é auxiliar o "OSC a desempenhar as obrigacõoes que the são atribuidas". ${ }^{64}$

O painel é composto por indivíduos bem qualificados, especialistas em direito do comércio internacional ou política comercial internacional, escolhidos em sua capacidade individual, ainda que sejam funcionários governamentais. ${ }^{65}$ Embora os indivíduos possam ser selecionados dentre os nomes de uma lista indicada pelos membros, periodicamente atualizada, e na qual constam suas respectivas áreas ou setores de experiência ou competência técnica, a sua atuação deve se pautar pela independência na análise dos litígios. ${ }^{66}$

A segunda instância adjudicatória do Sistema de Solução de Controvérsias da OMC é o Órgão de Apelação,

63 Artigo 11. Entendimento Relativo às Normas e Procedimentos sobre Solução de Controvérsias. Versão oficial em português segundo o decreto n. 1.355, de 30 dez. 1994, que promulga a Ata Final que Incorpora os Resultados da Rodada Uruguai de Negociações Comerciais Multilaterais do GATTT.

64 Artigo 11. Entendimento Relativo às Normas e Procedimentos sobre Solução de Controvérsias. Versão oficial em português dada pelo Decreto Legislativo n. 1.355, de 30 de Dezembro de 1994.

65 O Artigo 8:1 explicita de modo amplo o espectro funcional dos membros do painel, permitindo não só a participação de agentes governamentais como de indivíduos que tenham representando alguma parte em um outro procedimento do mecanismo de solução de controvérsias: "1.Os grupos especiais serão compostos por pessoas qualificadas, funcionários governamentais ou não, incluindo aquelas que tenham integrado um grupo especial ou a ele apresentado uma argumentação, que tenham atuado como representantes de um Membro ou de uma parte contratante do GATT 1947 ou como representante no Conselho ou Comitê de qualquer acordo abrangido ou do respectivo acordo precedente, ou que tenha atuado no Secretariado, exercido atividade docente ou publicado trabalhos sobre direito on politica comercial internacional, ou que tenha sido alto funcionário na área de politica comercial de um dos Membros." Entendimento Relativo às Normas e Procedimentos sobre Solução de Controvérsias. Versão oficial em português dada pelo Decreto Legislativo n. 1.355, de 30 de Dezembro de 1994.

66 Artigo 8: 3 e 8:4. Entendimento Relativo às Normas e Procedimentos sobre Solução de Controvérsias. Versão oficial em português dada pelo Decreto Legislativo n. 1.355, de 30 de Dezembro de 1994. que foi instituído pelo OSC com a função de examinar apelações das decisões dos painéis, e é considerado pela doutrina como uma espécie de tribunal internacional permanente. ${ }^{67686970}$

O Órgão de Apelação é composto por sete membros, que atuam alternadamente em turmas de três integrantes $^{71}$, e são nomeados por períodos de quatro anos. ${ }^{72}$ Os indivíduos escolhidos para sua composição devem ser de notória competência, e possuidores de comprovada experiência em direito e em comércio internacional, bem como nas temáticas abarcadas pelos acordos. Diferentemente dos membros do painel, os membros apontados para o órgão de apelação não podem estar vinculados a nenhum governo. ${ }^{73}$

67 Este é o entendimento de Cesare Romano: "[...] disputes between WTO members are to be submitted to an ad hoc panel, composed of three experts chosen by the parties. These elements closely recall arbitral tribunals. The Appellate Body, conversely, has more pronounced judicial features. It is a standing organ that decides appeals against findings of ad hoc panels and is composed of seven persons, three of whom sit on any one case in rotation and can bear only appeals relating to points of law covered in the report and legal interpretations developed by the panel." ROMANO, Cesare. A Taxonomy of International Rule of Law Institutions. Journal of International Dispute Settlement, vol. 2, n. 1, p. 241-277, 2011. p. 262.

68 Assim explicitam os autores: "The DSU furthers the role of legal adjudication in international trade law by creating a permanent appellate tribunal. [...]". CAMERON, James; GRAY, Kevin R. Principles of International Law in the WTO Dispute Settlement Body. International and Comparative Law Quarterly, vol. 50, p. 249-298, 2001. p. 249. 69 O autor prefere caracterizá-lo como um órgão "jurídico": "Certain words are never used formally for the DSS [Dispute Settlement System], for instance, "court," "tribunal," or "judicial." These words seem too threatening to some notions of sovereignty. Yet some informal or academic comments bave explicitly used these or similar terms to describe the system. For some of these reasons, this book uses the slightly more ambiguous term of "juridical," to describe the WTO DSS." JACKSON, John. Sovereignty, the WTO and Changing Fundamentals of International Law. New York: Cambridge University Press, 2006. p. 136.

70 O autor destaca que o Órgão de Apelação não é chamado formalmente de tribunal internacional por seus instrumentos institutivos, o que se justifica por razões históricas que remontam ao GATT e à transição do GATT para a OMC: "[...] the Appellate Body is not formally called a tribunal. There are well known historical reasons for that, going back to the fact that the GATT (the predecessor of the WTO) was a transitional arrangement, pending the institution of the ITO. [...]" ABI-SAAB, GEORGES. The Normalization of International Adjudication: Convergence and Divergencies. New York University Journal of International Law \& Policy, vol. 43, p.1-43, 2010-2011. p. 12. 71 Artigo 17.1. Entendimento Relativo às Normas e Procedimentos sobre Solução de Controvérsias. Versão oficial em português dada pelo Decreto Legislativo n. 1.355, de 30 de Dezembro de 1994.

72 Artigo 17.2. Entendimento Relativo às Normas e Procedimentos sobre Solução de Controvérsias. Versão oficial em português dada pelo Decreto Legislativo n. 1.355, de 30 de Dezembro de 1994.

73 Artigo 17.3. Entendimento Relativo às Normas e Procedi- 
No que tange à competência deste órgão, cabe a ele (i) confirmar, (ii) modificar ou (iii) revogar as conclusões e decisões jurídicas do painel. ${ }^{74} \mathrm{~A}$ sua análise, contudo, deve se enquadrar nos limites da apelação pelos membros, que apenas podem contestar as questões de direito mencionadas no relatório do painel e as interpretações jurídicas adotadas. ${ }^{75}$

\section{Especificidades do Sistema de Solução de Controvérsias da OMC}

Destacam-seÉ possível destacar, como especificidades do Sistema de Solução de Controvérsias da OMC, em relação aos demais procedimentos adjudicatórios de solução de controvérsias no Direito Internacional: (i) a relação entre os órgãos adjudicatórios e o OSC na solução de litígios; (ii) a presença marcante do aspecto negocial em seu procedimento, seja na fase de consultas ou durante as demais etapas do procedimento; e (iii) o caráter "aberto" das decisões resultantes deste mecanismo, deixando um "espaço de manobra" para a colmatação pelo membro condenado.

A apurada relação entre os órgãos adjudicatórios - os painéis e o Órgão de Apelação - e o órgão político, é explicada por motivações históricas da negociação da passagem do GATT para a OMC. A regra do consenso reverso, contudo, trazendo automaticidade na adoção dos relatórios dos órgão adjudicantes, esvazia das funções concretas do OSC o controle prático de análises jurídicas. A existência deste controle - muito mais teórica que prática - não tem, portanto, o condão de impossibilitar o reconhecimento da natureza adjudicatória deste Sistema de Solução de Controvérsias, como se avalia em seguida.

Georges Abi-Sabi, que atuou como membro do Ór-

mentos sobre Solução de Controvérsias. Versão oficial em português dada pelo Decreto Legislativo n. 1.355, de 30 de Dezembro de 1994.

74 Artigo 17.13. Entendimento Relativo às Normas e Procedimentos sobre Solução de Controvérsias. Versão oficial em português segundo o decreto n. 1.355, de 30 dez. 1994, que promulga a Ata Final que Incorpora os Resultados da Rodada Uruguai de Negociações Comerciais Multilaterais do GATT.

75 Artigo 17.6. Entendimento Relativo às Normas e Procedimentos sobre Solução de Controvérsias. Versão oficial em português segundo o decreto n. 1.355, de 30 dez. 1994, que promulga a Ata Final que Incorpora os Resultados da Rodada Uruguai de Negociações Comerciais Multilaterais do GATT. gão de Apelação da OMC, explica tal especificidade do sistema de solução de controvérsias da OMC com base na busca pela conciliação e satisfação de expectativas políticas naquele sistema, individualizadas por meio de ambientes e mandatos particulares, requisitos tanto para o exercício de sua função judicial quanto de sua legitimação:

O Órgão de Apelação veio, assim, a existir como parte
de uma organização cuja sutil atmosfera, prologando-se da
era GATT, é encapsulada no mantra de que "esta é uma
organização dirigida pelos membros", e o sentimento geral de
que são os próprios membros que tomam todas as decisões
finais. Tinha por mandato interpretar e aplicar as disposições
muito detalhadas dos acordos, de elaboração pouco cuidadosa,
com a prescrição de que suas decisões "não podem aumentar
ou diminuir os direitos e obrigações previstos" nesses
tratados; e com os órgãos políticos e os Estados membros
acompanhando de perto (para não dizer que olhavam sobre
seus ombros) como ele interpreta e aplica tais disposições.
Mas, ao mesmo tempo, o Órgão de Apelação teve que agir
com o grau de independência como requisito necessário para o
exercício da função judiciária internacional

É, pois, no passado de cinquenta anos de GATT que essas peculiaridades do sistema de solução de controvérsia da OMC se justificam. Isto é, se por um lado as evoluções alcançadas no desenho do "novo" sistema de solução de litígios foram de pertinência substancial, por outro lado a manutenção de certos traços - potencializada por uma linguagem árida e tecnicista, que expressa de modo austero suas regras institucionais - foi elemento que garantiu o sucesso da negociação do então "novo" sistema.

Neste sentido, a manutenção de um controle político da função adjudicante dos painéis e do Órgão de Apelação, embora na prática inoperante, foi um dos elementos que entraram na equação das negociações para a criação da OMC. ${ }^{77}$ Foram criadas, ademais, limitações

76 Tradução livre do original em língua inglesa: "The Appellate body thus came into being as part of an Organization whose pervasive atmosphere, lingering from the GATT era, is encapsulated in the mantra that "this is a member-driven organization", and the general feeling that it is the members themselves that take all the final decisions. It had for mandate to interpret and apply very detailed treaty provisions, shoddily drafted, with the injunction that its rulings "cannot add to or diminish the rights and obligations provided in" these treaties; and with the political organs and the member states closely watching (not to say looking over its shoulder) how it interprets and applies them. But at the same time, the Appellate Body had to act with the necessary degree of independence requisite for the exercise of the international judicial function" ABI-SAAB, GEORGES. The Normalization of International Adjudication: Convergence and Divergencies. New York University Journal of International Law \& Policy p.1-43, Vol. 43, 2010-2011. P. 13-14.

77 Neste sentido é análise de Georges Abi-Saab: 'Indeed, one of the conditions by several states, and not the least, for accepting the vast extension of substantive regulation operated by the Marrakesh Agreements was the establish- 
à atuação das instâncias adjudicantes - como o cuidado com o equilíbrio entre os direitos e deveres expressamente previstos nos acordos às partes e os limites à revisão na apelação.

A segunda característica marcante do Sistema de Solução de Controvérsias da OMC é a inclusão da negociabilidade em diversas etapas e dimensões do procedimento. Isto pois o Sistema de Solução de Controvérsias da OMC apresenta uma combinação única de métodos de solução de conflitos, com especial espaço para a negociação em todas as fases do procedimento. ${ }^{78}$

Embora haja quem critique o caráter negocial do sistema, Joost Pauwelyn clama por maior papel da negociação no procedimento que, em sua opinião, poderia ser incrementado nas fases pré-litígio, durante o litígio e pós-litígio. Adicionalmente, defende a negociação ou arbitragem como uma alternativa ao litígio. ${ }^{79}$

Neste mesmo estudo, o autor rotula como "americanização" do sistema de solução de controvérsias da OMC o foco crescente na litigância, a prescindir da negociação. Esse fenômeno de "americanização" - que não seria inesperado haja vista a grande influência que os EUA exerceram na negociação da Rodada do Uruguaise manifestaria em três características do mecanismo de solução de controvérsias: (i) o direito ao estabelecimento de um painel automaticamente ${ }^{80}$, (ii) a juridicização trazida pela criação do Órgão de Apelação e sua linguagem legalista $^{81}$, e (iii) a natureza adversarial do mecanismo, derivada da natureza bilateral das obrigações da OMC.

Roberto de Azevêdo salienta a necessidade de explorar as muitas complexidades deste sistema, antes de

ment of a mechanism of judicial control." ABI-SAAB, GEORGES. The Normalization of International Adjudication: Convergence and Divergencies. New York University Journal of International Law \& Policy, vol. 43, p.1-43, 2010-2011. p. 13.

78 SPAIN, Anna. Integration Matters: Rethinking The Architecture Of International Dispute Resolution. University of Pennsylvania Journal of International Law, vol. 32, p. 1-56, 2010-2011. 79 PAUWELYN, Joost. The Limits of Litigation: "Americanization" and Negotiation in the Settlement of WTO Disputes. Ohio State Journal On Dispute Resolution. Vol. 19:1, 2003. p. 121-140, p. 137

80 PAUWELYN, Joost. The Limits of Litigation: "Americanization" and Negotiation in the Settlement of WTO Disputes. Ohio State Journal On Dispute Resolution. Vol. 19:1, 2003. p. 121-140. p. 122.

81 PAUWELYN, Joost. The Limits of Litigation: "Americanization" and Negotiation in the Settlement of WTO Disputes. Ohio State Journal On Dispute Resolution. Vol. 19:1, 2003. p. 121-140. p. 124. impingir qualquer análise. $\mathrm{O}$ seu processo é singular, e como já explicitado, embora seja eminente técnico - e portanto jurídico- traz uma dimensão política que deve ser interpretada caso a caso:

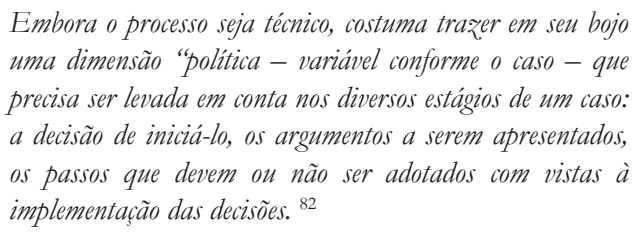
precisa ser levada em conta nos diversos estágios de um caso: a decisão de iniciá-lo, os argumentos a serem apresentados, os passos que devem ou não ser adotados com vistas à implementação das decisões. ${ }^{82}$

A terceira especificidade do sistema de solução de controvérsias da OMC diz respeito a aspectos formais e materiais da decisão adjudicatória resutante deste sistema. Cumpre destacar, desde logo, que a decisão é emanada pelo OSC, como vocalizador do resultado do procedimento, protagonizado pelos órgãos adjudicatórios. A aprovação pelo OSC, seja expressa ou pelo decorrer do prazo estabelecido no ESC, é condição formal para conferir aos relatórios o status de decisão do sistema de solução de controvérsias. ${ }^{83}$

No que se refere ao aspecto material destas decisões, o SSC da OMC se destaca pelo caráter aberto de sua formulação. Diferentemente da maioria das decisões adjudicatórias - ou sentenças internacionais-. neste sistema, em regra, apenas reconhece-se a desconformidade da conduta analisada, não havendo ad initio a cominação de consequências ou a determinação de condutas específicas. Deste modo, cabendo ao membro cuja conduta foi considerara desconforme adaptá-la às regras do sistema multilateral de comércio, lhe é concedido um espaço de discricionariedade na escolha dos meios pelos quais a conduta será trazida à conformidade.

Essas especificidades, que fazem do Sistema de Solução de Controvérsias da OMC um mecanismo único de solução de litígios, levaram à uma interpretação isolada ${ }^{84}$ e equivocada de seus dispositivos, e do significado

82 AZEVEDO, Roberto Carvalho de. Prefácio. In: BENJAMIN, Daniela Arruda. (Org). O sistema de solução de controvérsias da OMC : uma perspectiva brasileira. Brasília : FUNAG, 2013. P. 24. 83 “(...) entendo que os reports continuam tendo, no sistema da OMC, formalmente, a natureza jurídica de um parecer, de um tertius, acima das partes, dotado de vis directiva. A mudança - o desenvolvimento progressivo- reside no adensamento da juridicidade tanto do due process quanto da conversão do seu produto, os pareceres, em findings, dotados de eficácia jurídica." p. 748 LAFER, Celso. O Sistema de Solução de Controvérsias da Organização Mundial do Comércio. In: CASELLA, Paulo Borba; MERCADANTE, Araminta de (coord.). Guerra comercial ou integração mundial pelo comércio?: a OMC e o Brasil. São Paulo: LTr, 1998. Pp. $729-755$.

$84 \mathrm{O}$ autor avalia que esta interpretação isolada e tecnicista vem perdendo espaço para uma visão mais aberta, em face de críticas 
de suas decisões no contexto do sistema jurídico internacional como um todo. Contudo, certas facetas de seu procedimento, tal como a combinação não tradicional entre os meios para solução de litígios, podem inclusive ser vistas como bem sucedidas - o caminho para o qual a solução de controvérsias no Direito Internacional poderia evoluir. ${ }^{85} 86$

Se por um lado estas especificidades - sejam reais ou aparentes - levam alguns autores a captarem de modo enganoso a solução de controvérsias na OMC e o seu status em face do Direito Internacional, são também elas que conferem ao Sistema de Solução de Controvérsias da OMC singularidade e destaque em face dos demais mecanismos de solução de litígios existentes na atualidade. ${ }^{87}$

sobre o papel deste sistema: "These opposing considerations led the Appellate Body to stick closely to the specificities of the matter put before it, and to follow a judicial policy of "strict constructionism" in interpretation, with marked reluctance to indulge in interpretation on the basis of general principles or even the object and purpose of the agreements. But I have to say that this initial judicial policy has been slowly evolving towards more openness in the face of scathing criticisms of the WTO in general, and its Dispute Settlement System in particular, as a rutbless vebicle of economic globalization, oblivious (and to the detriment) of other major values or concerns of the international community." ABI-SAAB, GEORGES. The Normalization of International Adjudication: Convergence and Divergencies. New York University Journal of International Law \& Policy, vol. 43, p.143, 2010-2011. p. 13.

85 SPAIN, Anna. Integration Matters: Rethinking The Architecture of International Dispute Resolution. University of Pennsylvania Journal of International Law, vol. 32, p. 1-56, 2010-2011. 86 Destaca-se o ponto apresentado por Carlos Cozendey: "[... Numerosos casos foram resolvidos sem a necessidade de alcançar a fase de painel, demonstrando que, apesar da maior jurisdicionalidade, o sistema não perden a capacidade de criar espaços de negociação. É claro que o êxito de tais negociações se deve em boa parte à percepção de que o sistema funciona e de que, portanto, diante de posição frágil à luz das disciplinas multilaterais, melhor corrigir a situacão de forma controlada por meio da negociacão do que sujeitar-se a recomendacões cujo escopo e conteúdo podem ir além do esperado. [...]"COZENDEY, Carlos Márcio Bicalho. O Sistema de Solução de Controvérsias da OMC: para além dos contenciosos, a política externa. Disponível em: <http://www.itamaraty.gov.br/temas/temas-multilaterais/copy_of_desenvolvimento-comercio-e-financas/ organizacao-mundial-do-comercio/solucao-de-controversias/cgc/ artigo-cozendey> Acesso em: 15 dez. 201310 abr. 2017. p. 16.

87 Remete-se ao ensinamento de John Jackson: "This DSS is unique in international law and institutions, both at present and historically. It embraces mandatory exclusive jurisdiction and virtually automatic adoption of dispute settlement reports, extraordinary for an institution with such broad-ranging competence and responsibilities as the WTO - virtually every aspect of economic regulation and policy is touched upon at least potentially, if not actually, and it is already imposing obligations on 148 nations (out of 192 recognized), comprising 93 percent of world trade, and 87 percent of world population. The DSS has been described as the most important and most powerful of any international law tribunals, although some observers reserve that primary place to the World Court (International Court of Justice). Even some experienced World Court advocates, however, have been willing to concede that primacy under some cri-

\section{Natureza JURíDica}

Exatamente em função das especificidades deste sistema único, e do caráter híbrido de seu procedimento, para alguns autores predominaria a natureza política do sistema, o que os leva a interpretá-lo como um sistema "quase judicial". 8889

Acreditamos que a melhor análise, contudo, sejaé aquela que reconhece ao Sistema de Solução de Controvérsias da OMC uma natureza jurisdicional, como um sistema de função adjudicatória no Direito Internacional. Isto pois, embora a linguagem "árida" do Entendimento abstenha-se do uso de termos como "Tribunal", "Corte" ou "judicial" para se referir ao Sistema de Solução de Controvérsias, importa à sua caracterização a verificação dos requisitos da solução jurisdicional, como passamos a destacar. ${ }^{90}$

Isto pois as suas complexidades e especificidades não afastam sua classificação como solução jurisdicional de litígios, sob a perspectiva de que há uma terceira parte, que soluciona de modo obrigatório e definitivo a controvérsia, com base no Direito Internacional. ${ }^{91}$

Embora seja um meio mais intrusivo, pelo qual a solução é imposta às partes, ao escolherem a via jurisdicional, os Estados optam entre soluções de natureza arbi-

teria to the WTO DSS." JACKSON, John. Sovereignty, the WTO and Changing Fundamentals of International Law. New York: Cambridge University Press, 2006. p. 139.

88 Assim se posiciona Naigen Zhang: "The WTO dispute settlement has the character of a quasi-judicial procedure, i.e. a mixture of judiciary-oriented procedural rules and diplomatic negotiation to settle disputes, [... 'ZHANG, Naigen. Implementation of WTO Dispute Settlement. Manchester Journal of International Economic Law, vol. 5, issue 2, p.111125, 2008. p. 112

89 Para uma distinta visão, na qual o Sistema de Solução de Controvérsias da OMC se aproximaria de um sistema jurisdicional nacional de tradição civil, que permite o recurso à arbitragem, Cf: TANIGUCHI, Yasuhei. WTO Dispute Settlement as Seen by a Proceduralist. Cornell International Law Journal, vol. 42, p. 1-21, 2009.

90 O autor prefere utilizar o termo jurídico: "Certain words are never used formally for the DSS, for instance, "court," "tribunal," or "judicial." These words seem too threatening to some notions of sovereignty. Yet some informal or academic comments have explicitly used these or similar terms to describe the system. For some of these reasons, this book uses the slightly more ambiguous term of "juridical," to describe the WTO DSS." JACKSON, John. Sovereignty, the WTO and Changing Fundamentals of International Law. New York: Cambridge University Press, 2006. p. 136. 91 Este é o conceito apresentado por Lucius Caflisch: "Les modes juridictionnels de règlement consistent à charger une tierce partie de régler un litige de manière obligatoire et définitive sur la base du droit international." CAFLISCH, Lucius. Cent ans de règlement pacifique des différends interétatiques. Recueil des cours, vol. 288, p. 245-467, 2001. p. 285. 
tral (tribunal ad hoc) e de natureza judicial, pela submissão do litígio a um tribunal pré-constituído e permanente. ${ }^{92}$

Conforme destaca Lucius Caflish, a arbitragem e a solução judiciária formam a categoria dos meios adjudicatórios, e se distinguem do meios diplomáticos pelos seguintes elementos: (i) são compostos por procedimentos em contraditório, que correntemente se consubstanciam em uma fase escrita e uma fase oral, gerido por sujeitos independentes; (ii) os procedimentos objetivam alcançar uma solução de mérito definitiva para a controvérsia; (iii) a solução deve ser buscada no Direito Internacional, salvo acordo diverso entre as partes; (iv) a decisão é soberana e irrecorrível, e portanto vinculante às partes em litígio. ${ }^{93}$

Assim, se por um lado as decisões diplomáticas ou políticas são flexíveis e de adoção opcional, por outro as decisões jurisdicionais se caracterizam pela rigidez e vinculação ao resultado. Contudo, reside exatamente nestas características a sua vantagem, pois promotoras da substituição do poder pelo direito como meio de resolver os litígios:

Em outras palavras, enquanto os meios diplomáticos
são caracterizados pela sua flexibilidade e resultado
opcional, a solução jurisdicional se distingue pela
sua rigidez e da natureza definitiva e obrigatória
de seu resultado e, portanto, por sua natureza
altamente intrusiva. Por esta razão, os governos são
muitas vezes relutantes em aceitá-la. No entanto,
estas alegadas desvantagens são, ao mesmo
tempo, os principais pontos fortes do recurso
aos meios jurisdicionais; eles colocam um fim
à disputa com base no direito internacional,
e, assim, contribuem para a promoção do
papel do direito na condução das relações
internacionais. (grifo nosso)

Adentrando na análise estrutural das decisões jurisdicionais, referido autor explicita que essas decisões

92 CAFLISCH, Lucius. Cent ans de règlement pacifique des différends interétatiques. Recueil des cours, vol. 288, p. 245-467, 2001. p. 285.

93 CAFLISCH, Lucius. Cent ans de règlement pacifique des différends interétatiques. Recueil des cours, vol. 288, p. 245-467, 2001. p. 286.

94 Tradução livre do original em língua francesa: "Autrement dit, alors que les moyens diplomatiques se caractérisent par leur souplesse et leur issue facultative, le règlement juridictionnel se dis- tingue par sa rigidité et par le caractère contraignant et final de son résultat, donc par sa nature hautement intrusive. Pour cette raison, les Etats, souvent, hésitent à l'accepter. Toutefois, ces prétendus inconvénients sont, en même temps, les principaux atouts des moyens juridictionnels; ceux-ci mettent un point final au litige, sur la base du droit des gens, et contribuent ainsi à promouvoir le rôle du droit dans la conduite des relations internationales." CAFLISCH, Lucius. Cent ans de règlement pacifique des différends interétatiques. Recueil des cours, vol. 288, p. 245-467, 2001. p. 286. compreendem três partes: "[a] decisão, que inclui a qualificação (composição do órgão judicial, histórico do procedimento, fatos), os considerandos ou os motivos e o dispositivo (pontos decididos), é adotada pela maioria dos árbitros ou juizes." 95

Dessas análises podemos destacar que o que marca uma decisão como jurisdicional, portanto, é o caráter de obrigatoriedade ${ }^{96}$ e de definitividade, ${ }^{97}$ e não a sua maior ou menor definição no tocante aos meios para implementar aquele comando.

Dessas análises podemos destacar que o que marca uma decisão como jurisdicional, portanto, é o caráter de obrigatoriedade ${ }^{98}$ e de definitividade, e não a sua maior ou menor definição no tocante aos meios para implementar aquele comando.Cesare Romano, em seu minuscioso estudo, se inspira na técnica da taxonomia, inicialmente criada para a biologia, para classificar escalonadamente as instituições relacionadas ao International Rule of Law, e salienta que as especifidades são um desafio a toda forma de classificação. ${ }^{99}$

Contudo, apesar das especificidades, o autor classifica o Sistema de Solução de Controvérsias da OMC como instituição inserida (i) no "domínio" das Orga-

95 Tradução livre do original em límgua francesa: 'La décision, qui comprend les qualités (composition de l'organe juridictionnel, bistorique de la procédure, faits), les considérants on motifs et le dispositif (points décidés), est adopté à la majorité des arbitres ou juges" CAFLISCH, Lucius. Cent ans de règlement pacifique des différends interétatiques. Recueil des cours, vol. 288, p. 245-467, 2001. p. 411.

96 Relevante destacar que a obrigatoriedade da decisão se restringe às partes em conflito: 'L'article 59 du Statut de la CIJ dispose en effet que "[I] décision ... n'est obligatoire que pour les parties en litige et dans le cas qui a été décidé», cette dernière précision impliquant que la force obligatoire de la décision est limitée au dispositif de celle-ci." CAFLISCH, Lucius. Cent ans de règlement pacifique des différends interétatiques. Recueil des cours, vol. 288, p. 245-467, 2001. p. 413.

97 A definividade de uma decisão implica que esta se constitui como coisa julgada (res judicata): "Cela signifie en premier lieu que le contentieux est réglé et ne peut, en tant que tel, faire l'objet d'une nouvelle procédure arbitrale ou d'un recours, à moins que le contraire ne soit ou n'ait été convenu entre les Etats concernés". CAFLISCH, Lucius. Cent ans de règlement pacifique des différends interétatiques. Recueil des cours, vol. 288, p. 245-467, 2001. p. 413.

98 Relevante destacar que a obrigatoriedade da decisão se restringe às partes em conflito: "L'article 59 du Statut de la CIJ dispose en effet que "[I] décision ... n'est obligatoire que pour les parties en litige et dans le cas qui a été décidé», cette dernière précision impliquant que la force obligatoire de la décision est limitée au dispositif de celle-ci." CAFLISCH, Lucius. Cent ans de règlement pacifique des différends interétatiques. Recueil des cours, vol. 288, p. 245-467, 2001. p. 413.

99 ROMANO, Cesare. A Taxonomy of International Rule of Law Institutions. Journal of International Dispute Settlement, Vol. 2, n. 1 (2011), pp. 241-277. 
nizações Internacionais Governamentais ${ }^{100}$; (ii) no "reino" dos órgãos e procedimentos do International Rule of Law ${ }^{101}$; (iii) na "classe" dos meios adjudicatórios ${ }^{102}$.

Continuando a classificação, agora tomando em conta as características do Órgão de Apelação da OMC, este se insere (iv) na "ordem" das Cortes e Tribunais Internacionais ${ }^{103}$ - embora os painéis se insiram na "ordem" dos Tribunais Arbitrais ${ }^{104}$, e (v) na "família" dos Tribunais Internacionais responsáveis por litígios inter-estatais ${ }^{105}$.

Assim, ao reconhecê-lo como sistema adjudicatório,

100 "All international governmental organizations share three fundamental char-acteristics. They are: (i) Associations of states and/or other international governmental organizations; (ii) established by a treaty or other instruments governed by international law; and (iii) capable of generating through their organs an autonomous will distinct from the will of its members." p. 249. ROMANO, Cesare. A Taxonomy of International Rule of Law Institutions. Journal of International Dispute Settlement, Vol. 2, N. 1 (2011), pp. 241-277.

101 “...) what characterizes bodies within this Kingdom and separates them from other kingdoms are three further criteria: (iv) They apply international legal standards; (v) act on the basis of pre-determined rules of procedure; (vi) at least one of the parties to the cases they decide, or situation they consider, is a State or an international organization." p. 251. ROMANO, Cesare. A Taxonomy of International Rule of Law Institutions. Journal of International Dispute Settlement, Vol. 2, N. 1 (2011), pp. 241-277.

102 “(...) but what sets the Class of Adjudicative Means apart from the class of Non-Adjudicative Means are two features. (vii) They produce binding outcomes; (viii) They are composed of independent members." p. 253. ROMANO, Cesare. A Taxonomy of International Rule of Law Institutions. Journal of International Dispute Settlement, Vol. 2, N. 1 (2011), pp. 241-277.

103 "(...)International Courts and Tribunals: all bodies within the Order of International Courts and Tribunals share seven fundamental traits. They: (i) bave been established by an international legal instrument; (ii) rely on international law as applicable law; (iii) decide cases on the basis of pre-determined rules of procedure; (iv) are composed of independent members/judges; (v) only hear cases in which at least one party is a State or an international organization; (vi) issue legally binding judgments; and (vii) are permanent." p. 261-2. ROMANO, Cesare. A Taxonomy of International Rule of Law Institutions. Journal of International Dispute Settlement, Vol. 2, n. 1 (2011), pp. 241-277.

104 'Bodies can straddle different orders. For example, the World Trade Organization (WTO) and Mercosur (Mercado Comun del Sur) dispute settlement machineries have a two-level structure: an arbitral panel, as first instance of jurisdiction, and an appellate body. The first level of jurisdiction fits the order of Arbitral Tribunals, but the appellate level falls in the order of International Courts and Tribunals, and specifically the family of State-only Courts and the Genus of Courts with Specialized Jurisdiction.” p. 248. ROMANO, Cesare. A Taxonomy of International Rule of Law Institutions. Journal of International Dispute Settlement, Vol. 2, No. 1 (2011), pp. 241-277.

105 "(a) State-only Courts: International Courts and Tribunals of this family have jurisdiction mostly if not exclusively over cases between sovereign states." p. 264. ROMANO, Cesare. A Taxonomy of International Rule of Law Institutions. Journal of International Dispute Settlement, Vol. 2, No. 1 (2011), pp. 241-277. não se adentrando nas classificações posteriores, está-se a reafirmar que o sistema de solução de controvérsias da OMC foi constituído com a finalidade de resolver litígios com base nas normas, respeitando o procedimento fixado pelo ESC, por parte de membros independentes, e tendo como resultado uma decisão obrigatória aos membros em litígio. ${ }^{106}$

Embora o sistema não seja avesso à auto-composição dos conflitos, pelo contrário, diversas vantagens da solução de litígios por meios adjudicatórios em geral podem ser contextualizadas em relação ao Sistema de Solução de Controvérsias da OMC, ${ }^{107}$ na medida em que lhe conferimos natureza jurídica adjudicatória. Cumpre destacar, por fim, que a natureza adjudicatória deste sistema é correntemente reconhecida por diplomatas e advogados que atuam no dia-a-dia de seu procedimento. ${ }^{108}$

106 Independentemente do nome dado à decisão "First, the decisions of the organizations and bodies belonging to the Adjudicative Means class are binding, legally binding. It means that the outcome of the process, be it called decision, award, report or otherwise creates a new legal obligation on the parties, namely compliance with the outcome." p. 263. ROMANO, Cesare. A Taxonomy of International Rule of Law Institutions. Journal of International Dispute Settlement, Vol. 2, No. 1 (2011), pp. 241-277. 107 RICHARD BILDER, em análise sobre as vantagens e desvantagens às partes na escolha de dirimir seus litígios por meio de adjudicação internacional, aponta as seguintes vantagens que podem ser alcançadas pela adjudicação: (1) o caráter dispositivo da adjudicação, que com uma decisão jurídica põe fim à controvérsia; (2) a imparcialidade da adjudicação, pela qual uma terceira parte neutra e não envolvida pode decidir a disputa de modo mais justo; (3) o caráter principiológico da adjudicação, que consiste na aplicação do império do direito e dos princípios que o norteiam; (4) a autoridade da adjudicação, que pelo consentimento das partes presume legitimidade e respeito pela comunidade; (5) a impessoalidade da adjudicação, pela qual não há imputabilidade dos governos nacionais pelas decisões; (6) a seriedade da adjudicação, que por sua complexidade, custos e riscos para as partes, envolve um cálculo de confiança na legitimidade de seu pleito; (7) o caráter ordenado da adjudicação, a qual envolve um procedimento de fases e de cooperação em contraditório entre as partes; (8) o caráter de autoexecutoriedade da adjudicação, ligado à expectativa de cumprimento da decisão e ao fortalecimento do sistema internacional como um todo; (9) o caráter pacificador da adjudicação, que pode se traduzir em redução das tensões e negociação entre as partes; e (10) a criação de precedentes pela adjudicação, e seu auxílio no desenvolvimento do Direito Internacional, ao criar guias de conduta futura e esclarecer o conteúdo do Direito Internacional. BILDER, Richard B. Some Limitations of Adjudication as an International Dispute Settlement Technique. Virginia Journal of International Law, vol. 231, p. 146-151, 1982. 108 Os autores, diplomatas brasileiros, destacam esta visão: "W hile the discussion still rages about the correct nature of the dispute settlement mechanism of the WTO, the answer is quite clear to those that have found themselves in the middle of a panel or Appellate Body proceeding, especially in the hearings themselves: it looks like a court, it works much like a court, and one litigates as in a court. Although still evolving and still with some features atypical for 


\section{Detalhamento conceitual}

Em face das dificuldades de aplicação dos moldes tradicionais à singularidade do sistema de solução de controvérsias da OMC, faz-se necessário um detalhamento conceitual, que nos permita tratar dos elementos resultantes da análise jurídica deste sistema.

A tarefa não é simples, pois os conceitos foram apresentados no ESC de forma embaralhada e pouco clara $^{109}$, adicionando-se a isto confusões provocadas pela tradução oficial para o português. De todo modo, buscamos nos embasar inicialmente na literalidade dos artigos do Entendimento, não nos furtando da análise comparativa entre as versões em inglês e português. Assim, trataremos dos conceitos de (i) relatório, (ii) recomendações, e (iii) decisões, como abstraídos do Entendimento.

A palavra report, como substantivo, no singular ou plural, encontra-se expressa 73 vezes na versão original em inglês do ESC e seus apêndices. ${ }^{110} \mathrm{O}$ Relatório é o instrumento formal que apresenta o resultado dos trabalhos desenvolvidos pelo painel e pelo Órgão de Apelação. É, portanto, o documento pelo qual estas instâncias expressam a sua análise jurídica do objeto em exame.

Assim é que o artigo 12.7 explicita: "Nos casos em que as partes envolvidas na controvérsia não consigam encontrar uma solução mutuamente satisfatória, o grupo especial deverá apresentar suas conclusões em forma de relatório escrito ao OSC. (...)."

judicial bodies ("recommendations" and not "judgements" are passed, formal adoption of reports is required and performed by the DSB, a political body, and the panel "report" can be seen and commented on at its "interim" stage), the direction of this evolution is clear: a "thickening" of legality and of procedural standards/rules. Of course, considerable room remains for "diplomatic flexibility", particularly at the consultation phases (both formal and informal), in parallel to the quasi-judicial proceedings, and in the aftermath of the reports. During the panel and appeal stages, however, the nature of the game is quite clear." EVANS, David. PEREIRA, Celso de Tarso. DSU Review: A View From the Inside. In: YEARS, Rufus. WILSON, Bruce. (Ed.). Key Issues in WTO Dispute Settlement: The First Ten Years. Nova Iorque: Cambridge Univesity Press, 2005, p. 251-264. p. 262. 109 Citar obscuridade proposital

$110 \mathrm{Na}$ versão oficial em português do Entendimento Relativo às Normas e Procedimentos sobre Solução de Controvérsias, dada pelo Decreto Legislativo n. 1.355, de 30 de Dezembro de 1994, o vocábulo "relatório" encontra-se expresso 70 vezes. A pequena disparidade se deve à questões lingísticas, e não afeta materialmente o sentido. As menções adicionais do original em inglês, se comparado com a versão em português se referem a um subtítulo entre o artigo 17.13 e 17.14, que foi suprimido, e também à repetições do vocábulo nos artigos 20 e 26.2 .
Como um instrumento e um documento escrito, o relatório possui duas diferentes dimensões: a dimensão material, e a dimensão formal. Em seu aspecto material, ainda segundo o mesmo artigo, o relatório do painel deve conter (a) a verificação dos fatos; (b) a aplicabilidade dos dispositivos pertinentes e (c) a fundamentação por detrás de " [...] qualquer determinações e "recomendações" que ele fizer." ${ }^{111} \mathrm{Em}$ seu aspecto formal, o documento é composto, portanto, de uma parte expositiva - apresentação dos fatos e argumentação - ${ }^{112}$ e de uma parte de exame técnico-jurídico da controvérsia, seguida de conclusão. ${ }^{113}$

Assim, o resultado final do relatório se manifesta por meio de conclusões (findings). Tais conclusões podem se materializar por meio de determinações (rulings) e recomendações (recomendations). ${ }^{114}$

O conteúdo do relatório está limitado pelos "termos de referencia" do painel. Os termos de referencia adotados regularmente, caso as partes não acordem de modo diverso, estão expressos no artigo 7.1. ${ }^{115}$

Este documento, que na prática delimita a compe-

111 Do original em inglês: " [...] the report of a panel shall set out the findings of fact, the applicability of relevant provisions and the basic rationale bebind any findings and recommendations that it makes. [...]". Embora a versão oficial em português conste como " $[\ldots]$ o relatório do grupo especial deverá expor as verificações de fatos, a aplicabilidade de disposições pertinentes e o arrazoado em que se baseiam suas decisões e recomendações [...]", acredita-se que a melhor tradução do termo "rulings", tendo em vista este refinamento conceitual, seja "determinações".

112 Artigo 15.1: "Após consideração das réplicas e apresentações orais, o grupo especial distribuirá os capitulos expositivos (fatos e argumentações) de esboço de seu relatório para as partes em controvérsia [...]"

113 Artigo 15.2: "[...] o grupo especial distribuirá às partes um relatório provisório, nele incluindo tanto os capitulos descritivos quanto as determinações e conclusões do grupo especial. [...]"

114 É relevante destacar que a versão original em inglês se refere a "rullings" e "findings", juntamente com "recommendation". $\mathrm{Na}$ maior parte dos casos as duas primeiras expressões são traduzidas como "decisões". Apenas no artigo 15.2 se traduz findings como “determinações", e nos artigos 9.2., 11, 12.7, 15.3, 19.2 e 23.2. se traduz "findings" como "conclusões". No artigo 7.1. o que se traduz como "conclusões" está expresso como "rullings". O artigo 12.7. é um exemplo da não preocupação com o uso específico/técnico das palavras na traduçao em português, uma vez que a mesma expressão "findings" é traduzida ora como "conclusões" e ora como "decisões".

115 "Examinar, à luz das disposições pertinentes no (indicar o(s) acordo(s) abrangido(s) citado(s) pelas partes em controvérsia), a questão submetida ao OSC por (nome da parte) no documento ... estabelecer conclusões que auxiliem - OSC a fazer recomendações ou emitir decisões previstas naquele(s) acordo(s)". Artigo 23.2.a. Entendimento Relativo às Normas e Procedimentos sobre Solução de Controvérsias. Versão oficial em português dada pelo Decreto Legislativo n. 1.355, de 30 de Dezembro de 1994. 
tência e a função do painel, destaca que o papel do painel - a ser concretizado pelo Relatório - subjaz no (a) exame da controvérsia, e (b) enunciação de conclusões, que deversão auxiliar o OSC a "faz̧er recomendações e/ ou emitir decisões (...)"

Embora a linguagem adotada não seja cristalina, em especial no que tange à versão oficial em português traduzida do Inglês, é possível perceber que o foco de "decisão" e "recomendação" é conferido ao OSC, com base nas conclusões e determinações elaboradas da análise do painel e/ou do Órgão de Apelação, e contidas nos respectivos relatórios.

$\mathrm{O}$ artigo 11 do Entendimento reforça este quadro, ao expressar a função dos painéis:

um grupo especial deverá fazer uma avaliação objetiva do assunto que lhe seja submetido, incluindo uma avaliação objetiva dos fatos, da aplicabilidade e concordância com os acordos abrangidos pertinentes, e formular conclusões que auxiliem o OSC a fazer recomendações ou emitir decisões previstas nos acordos abrangidos. ${ }^{116}$

Embora possamos, em sentido latu, mencionar as "decisões" do painel ou do Órgão de Apelação, no intuito de fazer referência ao substrato material de sua análise fático-jurídica, e que em última instância "delibera" sobre o assunto, em um sentido técnico preferimos nos referir apenas a "decisões" uma vez que o respectivo relatório foi adotado, e portanto ganha validade formal como "decisão" adjudicatória, ao colocar fim de modo definitivo e obrigatório a uma controvérsia, com base no Direito Internacional. 117118

116 Artigo 11. Entendimento Relativo às Normas e Procedimentos sobre Solução de Controvérsias. Versão oficial em português dada pelo Decreto Legislativo n. 1.355, de 30 de Dezembro de 1994.

117 Segundo o autor transforma-se os pareceres dos painéis e do Órgão de Apelação em findings, dotados de eficácia jurídica. LAFER, Celso. O Sistema de Solução de Controvérsias da Organização Mundial do Comércio. P. 748. In: CASELLA, Paulo Borba; MERCADANTE, Araminta de (coord.). Guerra comercial ou integração mundial pelo comércio?: a OMC e o Brasil. São Paulo: LTr, 1998. Pp. 729-755.

118 "(...)Recommendations by a panel and/ or Appellate Body under Article 19 of the DSU (or Article 4.7 of the SCM Agreement) become effective only upon their adoption by the DSB. Once the DSB adopts a dispute settlement report, the findings and recommendations in that report become collective, operative DSB rulings and recommendations. The very notion of "measures taken to comply with the recommendations and rulings" in the text of Article 21.5 of the DSU is predicated upon DSB adoption of a panell Appellate Body report. No compliance obligation would arise unless and until panel and Appellate Body recommendations and rulings are adopted by the DSB to become DSB recommendations and rulings." Panel Report, US - FSC (Article 21.5 - EC II), para. 7.34-7.35.
É relevante destacar que, em sendo o OSC o "alter ego" da organização, as decisões do OSC passam a ser decisões do SSC da OMC como um todo, e é assim que preferimos tratá-las. Isto pois a natureza política do OSC, em uma análise apressada, pode obstaculizar a sua percepção como uma decisão adjudicatória. Mas ela o será, em face do papel formalmente existente, mas na prática virtualmente "automático" de adoção dos relatórios.

Assim, reforçamos o delicado desenho da deliberação: é a chancela (quase) automática de um órgão de natureza política que confere validade formal à análise jurídica realizada por um órgão de natureza adjudicatória, e que emana como uma decisão do Sistema de Solução de Controvérsias da OMC em sua visão totalizante.

Oportuno destacar que, de certo modo, o documento que resulta do trabalho de revisão do Órgão de Apelação é mais significativamente limitado em seu aspecto material, uma vez que este documento analisará “apenas" as questões pleiteadas no pedido de apelação ${ }^{119}$ Assim, no mesmo espírito já evidenciado por George Absabb, não incumbe ao órgão de apelação "analisar e decidir a controvérsia", mas lhe são conferidas três possibilidades: (a) confirmar, (b) modificar ou (c) revogar as determinações e conclusões jurídicas do painel.

Lembrando que o texto de um tratado internacional é um resultado delicado de embates de interesses e visões no momento de sua negociação, o artigo 19 do Entendimento enuncia o verdadeiro conteúdo material do relatório dos painéis e do Órgão de Apelação, o que nos leva a detalhar o conceito das "recomendaçôes" contidas nestes relatórios.

A palavra "recommendations", é expressa 37 vezes na versão original em inglês do ESC e seus apêndices, assim como o vocábulo recomendações na versão em português, e se refere tanto ao conteúdo material das deliberações das instâncias adjudicatórias, quanto à manifestações surgidas do OSC. .

No que tange as recomendações contidas nos Relatórios e no Órgão de Apelação, o artigo 19, cujo título é "Recomendações dos Grupos Especiais e do Órgão de Apelação", expressa:

119 Artigo 17.12. Entendimento Relativo às Normas e Procedimentos sobre Solução de Controvérsias. Versão oficial em português segundo o decreto n. 1.355, de 30 dez. 1994, que promulga a Ata Final que Incorpora os Resultados da Rodada Uruguai de Negociações Comerciais Multilaterais do GATT. 
19.1. Quando um grupo especial ou o órgão de Apelação concluir que uma medida é incompatível com um acordo abrangido, deverá recomendar que o Membro interessado torne a medida compatível com o acordo. Além de suas recomendações, o grupo especial ou o órgão de Apelação poderá sugerir a maneira pela qual o Membro interessado poderá implementar as recomendações.

$\mathrm{Na}$ primeira parte do artigo consta o resultado da deliberação que deve ser apresentado pelo painel e Órgão de Apelação. Na segunda parte deste artigo, contudo, consta uma observação de um elemento material “opcional", sugestões sobre o meio pelo qual o membro que deve trazer a medida à conformidade, que podem ser expressas no relatório.

Enquanto o relatório deve recomendar que o membro desconforme torne a medida compatível, em caso de conclusão da análise pelo descumprimento ${ }^{120}$, o relatório pode conter sugestões de meios pelos quais concretizar esta recomendação. Há, pois, uma clara distinção entre (a) recomendações e (b) sugestões. ${ }^{121}$

Relevante pontuar que, quanto às recomendações, o ESC não confere discricionariedade em relação a seu conteúdo substantivo, pois seu conteúdo material deve ser o de indicar que o autor da conduta ilegal deve torná-la conforme ("bring into compliance"). O resultado é que cabe ao membro destinatário da recomendação uma substancial margem de discricionariedade, quanto ao caminho a ser trilhado para dar concretude a esta recomendação. ${ }^{122}$

120 Esta recomendação, contudo, não será necessária em casos nos quais a medida em discussão não esteja em vigor. "(...) The rationale for this approach has to do with the (consistente by now) understanding of WTO adjudicating bodies that the purpode of dispute settlement is to belp resolve ongoing disputes. A recomendation to withdraw a measure is of no assistance to the resolution of the disputes. (...)" p. 146. MATSUSHITA, Mitsuo; MAVROIDIS, Petros C.; SCHOENBAUM, Thomas J. The World Trade Organization: Law, Practice, and Policy. 2a Ed. Oxford: Oxford University Press, 2006.

121 p. 146. MATSUSHITA, Mitsuo; MAVROIDIS, Petros C.; SCHOENBAUM, Thomas J. The World Trade Organization: Law, Practice, and Policy. 2a Ed. Oxford: Oxford University Press, 2006.

122 Como o painel explicitou no Relatório US- Section 301 Trade Act: "The obligation on Members to bring their laws into conformity with WTO obligations is a fundamental feature of the system and, despite the fact that it affects the internal legal system of a State, has to be applied rigorously. At the same time, enforcement of this obligation must be done in at the least intrusive way possible. The Member concerned must be allowed the maximum autonomy in ensuring such conformity and, if there is ore than one lawful way to achieve this, should have the freedom to choose that way which suits it best." (United States- Section 301-310 of the Trade Act of 1974 (WTO Doc WT/DS152/R, 22 dez 1999. Para 7.102)
Em relação à força jurídica destas recomendações, tendo em vista o consenso reverso, adotamos a perspectiva explicitada por Mitsuo MATSUSHITA, Petros MAVROIDIS, Petros e Thomas SCHOENBAUM:

Pelo fato de uma recomendação fazer parte de uma decisão do Órgão de Solução de Controvérsias dirigida ao Membro da OMC interessado (forma), e devido à redação inequívoca do art. 19 DSU (substância), tal recomendação vincula o seu destinatário ${ }^{123}$

As sugestões, por outro lado, se prestam a facilitar a implementação da recomendação, servindo como guias para se alcançar o seu cumprimento. Ainda que sejam requeridas, tais sugestões não são vinculantes às partes, quando outro caminho é possível. Contudo, a prática do SSC tem demonstrado que a explicitação de sugestões é mais comum em casos nos quais há apenas o meio sugerido como possibilidade de implementação. ${ }^{124}$

\section{Apontamentos Finais: Características daCompreendendo as decisões do Sistema de Solução de Controvérsias da OMC}

É relevante destacar que, embora possamos, em sentido latu, mencionar as "decisões" do painel ou do Órgão de Apelação, no intuito de fazer referência ao substrato material de sua análise fático-jurídica, e que em última instância "delibera" sobre o assunto, em um sentido técnico preferimos nos referir apenas a decisões uma vez que o respectivo relatório foi adotado, e portanto ganha validade formal como decisão adjudicatória, ao colocar fim de modo definitivo e obrigatório a uma controvérsia, com base no Direito Internacional. ${ }^{125}$

123 Tradução livre do original em língua inglesa: "By virtue of the fact that a recommendation will be part of a DSB decision addressed to the WTO Member concerned (form), and because of the unambiguous wording of Art. 19 DSU (substance), it is binding upon its adressee", p. 147. MATSUSHITA, Mitsuo; MAVROIDIS, Petros C.; SCHOENBAUM, Thomas J. The World Trade Organization: Law, Practice, and Policy. 2a Ed. Oxford: Oxford University Press, 2006.

124 p. 151. MATSUSHITA, Mitsuo; MAVROIDIS, Petros C.; SCHOENBAUM, Thomas J. The World Trade Organization: Law, Practice, and Policy. 2a Ed. Oxford: Oxford University Press, 2006.

125 Segundo Celso Lafer, os pareceres dos painéis e do Órgão de Apelação transformam-se em findings, dotados de eficácia jurídica. LAFER, Celso. O Sistema de Solução de Controvérsias da Organização Mundial do Comércio. In: CASELLA, Paulo Borba; MERCADANTE, Araminta de (coord.). Guerra comercial ou integração mundial pelo comércio?: a OMC e o Brasil. São Paulo: 
AssimComo exposto ao longo do trabalho, em sendo o OSC o "alter ego" da OMC, as decisões do OSC passam a ser decisões do Sistema de Solução de Controvérsias da OMC como um todo, e é assim que preferimos tratá-las. Isto pois a natureza política do OSC, em uma análise apressada, pode obstaculizar a sua percepção como uma decisão adjudicatória. Mas ela o será, em face do papel formalmente existente, mas na prática virtualmente "automático" de adoção dos relatórios.

Assim, reforçamos o delicado desenho da deliberação: é a chancela (praticamente) automática de um órgão de natureza política que confere validade formal à análise jurídica realizada por órgãos de natureza adjudicatória, e que emana como uma decisão do Sistema de Solução de Controvérsias da OMC em sua visão totalizante.

Isto posto, com base na arquitetura normativa-institucional explicitada, compreende-se que as decisões do Sistema de Solução de Controvérsias da OMC são decisões adjudicatórias internacionais. Ressalte-se, o OSC atua como vocalizador de tais decisões, que emanam como resultado de uma complexa inter-relação entre os órgãos do sistema. É a juridicidade do sistema que se manifesta em um contexto de diplomacia, reduzido ou quase anulado em sua dimensão prática.

Por fim, faz-se necessário brevemente explicitar as características dessas decisões, resultado do procedimento de solução de litígios submetidos ao Sistema de Solução de Controvérsias da OMC: (a) juridicidade; (b) obrigatoriedade e (c) (in)determinabilidade. Tais características consistem em uma síntese de discussões tidas ao longo deste trabalho, pois são consequências diretas das análises desenvolvidas.

O Sistema de Solução de Controvérsias da OMC, conquanto resultado de um delicado balanceamento histórico de interesses políticos e ainda com peculiaridades remanescentes desta origem, representa uma vitória do direito na resolução de litígios no Direito Internacional Econômico.

Em sua operacionalização, o Sistema de Solução de Controvérsias da OMC demonstra, ainda, um abandono do voluntarismo estatal na solução de litígios, sendo um avanço significativo nesta área. A obrigação de observância de regras pré-fixadas, bem como o caráter obrigatório de suas decisões, tornam o Sistema de Solução de Controvérsias da OMC um instrumento de apli-

LTr, 1998, p. 729-755. p. 748. cação do Direito Internacional. ${ }^{126}$

Assim, faz-se necessário brevemente explicitar as características dessas decisões, resultado do procedimento de solução de litígios submetidos ao Sistema de Solução de Controvérsias da OMC: (a) juridicidade; (b) obrigatoriedade e (c) (in)determinabilidade.Enquanto resultado de uma apreciação em procedimento adjudicatório, as decisões emanadas deste sistema são definitivas e obrigatórias, e embasadas no Direito Internacional, motivos pelos quais se caracterizam como jurídicas, em contraposição às decisões oriundas dos meios diplomáticos de solução de controvérsias.

No tocante à obrigatoriedade, as peculiaridades do Sistema de Solução de Controvérsias da OMC e a linguagem do ESC levaram a uma interpretação restritiva por parte de alguns autores, no sentido de que não haveria uma obrigatoriedade no cumprimento de suas decisões, ${ }^{127}$ supostamente havendo uma legítima e livre “opção" entre o realizar o cumprimento ou enfrentar as consequências do descumprimento. ${ }^{128}$

Compartilhamos, contudo, do entendimento de que, em uma leitura sistemática e teleológica, há diversos dispositivos que indicam esta obrigação de cumprir. ${ }^{129}$ Destacando-se apenas alguns desses dispositivos, o artigo 3.7 do ESC indica que "o primeiro objetivo do mecanismo de solução de controvérsias será geralmente o de conseguir a

126 "The decisions are binding, and bring about legal consequences; the mechanism, in sum, is an integral part of Public International Law, and orients itself by the due process of law, what is endowed with significance and relevance". TRINDADE, Antônio Augusto Cançado. International law for humankind: towards a new jus gentium (II). General course on public international law. Recueil des cours, vol. 317, p. 9-312, 2005. p. 205.

127 Nas palavras da autora: "TThe WTO rules are simply not "binding" in the traditional sense. When a panel established under the WTO Dispute Settlement Understanding issues a ruling adverse to a member, there is no prospect of incarceration, injunctive relief, damages for harm inflicted or police enforcement. The WTO has no jailhouse, no bail bondsmen, no blue belmets, no truncheons or tear gas. Rather, the WTO-essentially a confederation of sovereign national governments- relies upon voluntary compliance." BELLO, Judith Hippler. The WTO Dispute Settlement Understanding: Less Is More. Editorial Comment. American Journal of International Law, vol. 90, p. 416-418, 1996. p. 416.

128 Deste modo, conclui a sua interpretação: “[...] Compliance with the WTO, as interpreted through dispute settlement panels, remains elective. If its law or measure is successfully challenged, a members enjoys three choices. [...]" BELLO, Judith Hippler. The WTO Dispute Settlement Understanding: Less Is More. Editorial Comment. American Journal of International Law, vol. 90, p. 416-418, 1996. p. 417.

129 JACKSON, John. Sovereignty, the WTO and Changing Fundamentals of International Law. New York: Cambridge University Press, 2006. p. 168. 
supressão das medidas de que se trata [...]". ${ }^{130} \mathrm{O}$ artigo 21.1 expressa que "[o] pronto cumprimento das recomendações e decisões do OSC é fundamental para assegurar a efetiva solução das controvérsias, em benefício de todos os membros." 131

O artigo 21.6 do ESC estabelece o dever de vigilância do OSC na "aplicação das recomendações e decisões", sendo previsto que "a questão da implementação das recomendações e decisões [...] deverá permanecer na agenda do OSC até que seja resolvida". ${ }^{132} \mathrm{O}$ artigo 22.8 também é claro ao explicitar que "[a] suspensão de concessões ou outras obrigações deverá ser temporária [...]”, ${ }^{133}$ evidenciando, portanto, que o membro continua em falta com suas obrigações até promover a implementação, ou haver uma solução mutuamente acordada.

Há, ademais, a obrigação postulada no artigo XVI parágrafo 4 do Acordo que estabelece a OMC, segundo o qual "[t]odo membro deverá assegurar a conformidade de suas leis, regulamentos e procedimentos administrativos com as obrigacôes constantes dos Acordos anexos." 134

Os órgãos adjudicatórios do Sistema de Solução de Controvérsias da OMC já destacaram em diversas oportunidades a obrigatoriedade das decisões. ${ }^{135}$ A obriga-

130 Artigo 3.7. Entendimento Relativo às Normas e Procedimentos sobre Solução de Controvérsias. Versão oficial em português segundo o decreto n. 1.355, de 30 dez. 1994, que promulga a Ata Final que Incorpora os Resultados da Rodada Uruguai de Negociações Comerciais Multilaterais do GATT.

131 Artigo 21.1. Entendimento Relativo às Normas e Procedimentos sobre Solução de Controvérsias. Versão oficial em português segundo o decreto n. 1.355, de 30 dez. 1994, que promulga a Ata Final que Incorpora os Resultados da Rodada Uruguai de Negociações Comerciais Multilaterais do GATT'.

132 Artigo 21.6. Entendimento Relativo às Normas e Procedimentos sobre Solução de Controvérsias. Versão oficial em português segundo o decreto n. 1.355, de 30 dez. 1994, que promulga a Ata Final que Incorpora os Resultados da Rodada Uruguai de Negociações Comerciais Multilaterais do GATT.

133 Artigo 22.8. Entendimento Relativo às Normas e Procedimentos sobre Solução de Controvérsias. Versão oficial em português segundo o decreto n. 1.355, de 30 dez. 1994, que promulga a Ata Final que Incorpora os Resultados da Rodada Uruguai de Negociações Comerciais Multilaterais do GATT.

134 É aguçada a análise de Jackson a respeito deste parágrafo: "That sentence in particular can serve as an important basis for the notion that the result of the DS procedure is to establish an international law obligation to comply with the results of the interpretations and applications made in the DS process." JACKSON, John. International Law Status of WTO Dispute Settlement Reports: Obligation to Comply or Option to Buy Out? American Journal of International Law, vol. 98, p. 109-125, 2004. p. 112.

135 "It is axiomatic that alleged violations of the covered agreements must be redressed exclusively through the procedures set out in the DSU, providing for examination of such allegations by a panel and possibly the Appellate Body, and that, if violations are found and the relevant reports are adopted by toriedade apreendida de uma interpretação sistemática e teleológica dos dispositivos do OSC se confirma como uma das características das decisões emanadas de órgãos de natureza adjudicatória, uma vez que " [o]s resultados de processos contenciosos que envolvem disputas internacionais são decisões que são finais e vinculantes para as partes". ${ }^{136}$

Embora parte da doutrina discorde, ${ }^{137} 138$ prevalece a análise entabulada por Jackson de que, em uma perspectiva jurídica, as regras da OMC, como interpretadas pelo Sistema de Solução de Controvérsias, constituem obrigações jurídicas erigidas perante o Direito Internacional, cuja obrigatoriedade, ademais, resulta da Convenção de Viena do Direito dos Tratados. ${ }^{139} 140$

É necessário, ainda, relembrar que o descumprimen-

the DSB, the respondent Member is obliged to implement promptly the recommendations and rulings of the DSB. These recommendations and rulings are binding on implementing Members, and give rise to an obligation to bring their WTO-inconsistent measures into conformity with their obligations under the covered agreements" WTO. European Communities - Customs Classification of Frozen Boneless Chicken Cuts (Arbitration under Article 21.3(c) of the DSU). WT/DS269/13, 24 nov. 2005. para 55.

136 Tradução livre do original em língua inglesa: "[...][t] he outcomes of contentious proceedings involving international disputes are decisions which are final and binding on the parties." United Nations. Handbook on the Peaceful Settlement of Disputes between States. New York: United Nations, 1992. Office of Legal Affairs, Codification Division. OLA/COD/2394. p. 80.

137 Como exemplo desta posição, cita-se a posição dos autores: "[...] we simply note that the provisions of the DSU, taken as a whole, allow a violator to continue a violation in perpetuity, as long as it compensates or is willing to bear the costs of the retaliatory suspension of concessions. If WTO members really wanted to make compliance with dispute resolution findings mandatory, they would have imposed some greater penalty for noncompliance to induce it." SCHWARTZ, Warren.; SYKES, Alan 0. The Economic Structure of Renegotiation and Dispute Resolution in the World Trade Organization. Journal of Legal Studies, vol. 31, 179-204, 2002. p. 181.

138 Também sobre a possibilidade de "pagar" pelo descumprimento, segundo Joel Trachman a OMC "[...] does not normatively demand compliance at all costs. [...] the WTO's dispute settlement mechanism functions de facto, though not in a strictly legal sense, as a system of "breach and pay",. TRACHTMAN, Joel P. The WTO Cathedral. Standford Journal of International Law, vol. 43, p. 127-167, 2007. p. 130.

139 Este é o entendimento de Petros Mavroidis: "[...] the WTO member author of the illegal act continues the illegality and has not fulfilled its international obligations" MAVROIDIS, Petros. Remedies in the WTO Legal System: Between a Rock and a Hard Place. European Journal of International Law, vol. 11, 763-813, 2000. p. 800.

140 Como exemplo deste entendimento: "With respect to the "bindingness' of the DSB recommendations, it is widely acknowledged that the Member concerned whose measures have been found to be in violation of the WTO Agreements is 'bound' or bears a 'legal obligation' to implement the DSB recommendations. Nevertheless, persistent scepticism exists with regard to the 'bindingness' of the DSB recommendations." FUKUNAGA, Yuka. Securing Compliance Through the WTO Dispute Settlement System: Implementation of DSB Recommendations. Journal of International Economic Law, vol. 9, issue 2, p. 383-426, mai 2006. p. 396. 
to de um comando jurídico não o torna inoperante, ou retira sua obrigatoriedade. O caráter vinculante de uma decisão adjudicatória e os eventuais níveis concretos de descumprimento desvelam dimensões distintas do fenômeno jurídico. ${ }^{141}$ Basta lembrar que o descumprimento não é exclusividade do Direito Internacional, sendo aspecto rotineiro da ordem jurídica interna dos Estados, decorrente da diferença entre o mundo do ser (sein) e o mundo do dever-ser (sollen). ${ }^{142}$

O fato de um membro não cumprir as obrigações presentes em uma decisão do Sistema de Solução de Controvérsias da OMC, buscando promover a compensação ou submetendo-se à retaliação, não tem o condão de extinguir sua obrigação de cumprir referida decisão. Este membro continua em violação de suas obrigações contraídas por meio dos Acordos da OMC enquanto persistir o descumprimento. ${ }^{143} 144$

Por fim, uma característica marcante das decisões do Sistema de Solução de Controvérsias da OMC é o caráter aberto dos comandos dessa decisão. Isto é, trata-se de um sistema substancialmente diferente da prática mais comum dos Tribunais Internacionais, que, em geral, ao julgarem uma violação a uma norma jurídica internacional, determinam medidas precisas para a re-

141 É certo que afirmar o caráter vinculante de uma obrigação no Direito Internacional não significa necessariamente garantir-lhe efeitos concretos em sua aplicabilidade: "Of course, once the "binding" international law obligation to follow a panel or appellate report has been established, international law is not always efficient or effective in inducing compliance. [...]" United Nations. Handbook on the Peaceful Settlement of Disputes between States. New York: United Nations, 1992. Office of Legal Affairs, Codification Division. OLA/COD/2394. p. 117. 142 KELSEN, Hans. Teoria pura do direito. $7^{\text {a }}$ ed. São Paulo: Editora WMF Martins Fontes, 2006. CÂMARA FILHO, José Sette. Hans Kelsen e a teoria pura do Direito Internacional. Boletim da Sociedade Brasileira de Direito Internacional, n. 8, p. 70-91, jul./dez. 1948. p. 71-72.

143 Neste sentido é a posição do autor: "[...] However, in line with as long as a WTO Member is willing and able, either to compensate other Members affected by its treaty violation, or to endure trade retaliation-whose amount is determined by binding arbitration-the existing mechanism does indeed enable WTO Members to temporarily deviate from some of their obligations under WTO law. However, as noted above, this does not lead to the disappearance of the formal obligation to fully comply at some point in the future". ZIMMERMANN, Claus D. Toleration of Temporary Non-Compliance: The Systematic Safety Valve of WTO Dispute Settlement Revisited. Trade, Law \& Development, vol. 3, p. 382-406, 2011. p. 386.

144 Em modo correlato expressa Jackson: "[...] The D.S.U. makes compensation only a fall-back when performance does not occur, and keeps a matter under surveillance as long as performance has not occurred. [...]"JACKSON, John. The Great 1994 Sovereignty Debate: United States Acceptance and Implementation of the Uruguay Round Results. Columbia Journal of Transnational Law, vol. 36, p. 157-188, 1998. p. 180. paração desta ilegalidade.

Este caráter indeterminado, mas determinável, das obrigações meio para se alcançar a obrigação de resultado - o fim da desconformidade com a normativa multilateral - é decorrente da literalidade da primeira parte do artigo 19.1 do ESC. ${ }^{145}$

Em caso de violação das obrigações contidas nos Acordos da OMC, haverá, portanto, a recomendação de que o membro torne a medida compatível com referido Acordo violado. A princípio, o meio pelo qual o membro tornará a medida compatível insere-se em seu espaço de discricionariedade, podendo o painel sugerir meios pelos quais a implementação pode se concretizar - embora não esteja compelido a fazê-lo, nem mesmo quando tal sugestão é requerida pelas partes.

A escolha do meio pelo qual implementar a decisão permanece a critério do membro cuja conduta deve ser reformulada, ${ }^{146}$ embora as sugestões explicitadas possam ser de auxílio para guiar a implementação por parte do membro demandado, especialmente em casos de maior complexidade.

Referida discricionariedade na escolha do meio de implementação, contudo, não é um direito absoluto ou ilimitado, como expressou o árbitro no caso European Communities - Export Subsidies on Sugar. ${ }^{147}$ Entendimento

145 "Quando um grupo especial ou o órgão de Apelação concluir que uma medida é incompativel com um acordo abrangido, deverá recomendar que o Membro interessado torne a medida compativel com o acordo. Além de suas recomendações, o grupo especial ou o órgão de Apelação poderá sugerir a maneira pela qual o Membro interessado poderá implementar as recomendações" Artigo 19.1. Entendimento Relativo às Normas e Procedimentos sobre Solução de Controvérsias. Versão oficial em português segundo o decreto n. 1.355, de 30 dez. 1994, que promulga a Ata Final que Incorpora os Resultados da Rodada Uruguai de Negociações Comerciais Multilaterais do GATT.

146 Neste sentido explicitou o árbitro deste caso: "[...] Moreover, although the suggestion by the Panel, as part of a panel report adopted by the $D S B$, could serve as a useful contribution to the decision-making process in the implementing Member, I do not believe that the existence of such a suggestion ultimately affects the well-established principle that "choosing the means of implementation is, and should be, the prerogative of the implementing Member". WTO. Award of the Arbitrator, United States - Continued Dumping and Subsidy Offset Act of 2000 (Arbitration under Article 21.3(c) of the DSU). WT/DS217/14, WT/DS234/22, 13 jun. 2003. para. 52.

147 Tradução livre do original em língua inglesa: "[T] he choice of the method of implementation rests with the implementing Member. However, the implementing Member does not have an unfettered right to choose any method of implementation. Besides being consistent with the Member's WTO obligations, the chosen method must be such that it could be implemented within a reasonable period of time in accordance with guidelines contained in Article 21.3(c). Objectives that are extraneous to the recommendations and rulings of the DSB in the dispute concerned may not be included in the method if such inclusion 
semelhante foi expressado no laudo do árbitro do caso European Communities - Customs Classification of Frozen Boneless Cbicken Cuts. ${ }^{148}$

\section{Considerações finais}

O presente trabalho cumpriu o propósito de analisar, de maneira mais detida, o Sistema de Solução de Controvérsias da OMC e suas decisões, buscando desnaturalizar o intercâmbio semântico entre conceitos e elementos tecnicamente e essencialmente distintos, inserindo referido sistema em face de categorias do Direito Internacional já existentes.

Como restou demonstrado, as decisões do Sistema de Solução de Controvérsias da OMC, cujo conteúdo material expressa as recomendações de seus órgãos adjudicatórios, se apresentam como comandos de resultado, ao exigirem que a medida reconhecidamente desconforme seja tornada adequada às obrigações multilaterais.

A escolha do meio pelo qual será atingido o resultado é de determinação do Estado, em seu espaço de discricionariedade. Reitera-se que esta peculiaridade do resultado do procedimento perante o Sistema de Solução de Controvérsias da OMC, comumente interpretada como evidenciadora do suposta natureza política da decisão, não o descaracteriza como um sistema de natureza adjudicatória, não sendo a precisão do comando explicitado o requisito que diferencia as decisões adjudicatórias de decisões de outra natureza.

Assim, apesar da presença de um Órgão Político (Órgão de Solução de Controvérsias), as decisões emanadas deste sistema como um todo são jurídicas e obrigatórias. Embora a natureza política do OSC, em uma

were to prolong the implementation period. Above all, it is assumed that the implementing Member will act in "good faith" in the selection of the method that it deems most appropriate for implementation of the recommendations and rulings of the DSB." WTO. Award of the Arbitrator, European Communities - Export Subsidies on Sugar (Arbitration under Article 21.3(c) of the DSU). WT/DS265/33, WT/DS266/33, WT/DS283/14, 28 out. 2005. para. 69

148 "Although Members generally have discretion to determine their means of implementation, this discretion is not without bounds. Saying that selecting the means of implementing the recommendations and rulings of the DSB is the prerogative of the implementing member is not at all the same as saying that "anything goes". To declare otherwise would be to allow implementing Members the discretion also to pursue implementation measures that needlessly and unduly extend the reasonable period of time needed for implementation. And this would be contrary to the objective of Article 21.3 of the DSU." Award of the Arbitrator, European Communities - Customs Classification of Frozen Boneless Cbicken Cuts (Arbitration under Article 21.3 (c) of the DSU). WT/ DS269/13, WT/DS286/15, 20 fev. 2006. para. 56 análise apressada, possa obstaculizar a sua percepção da decisão do Sistema de Solução de Controvérsias como decisão adjudicatória, em face do papel formalmente existente, mas na prática virtualmente "automático" de adoção dos relatórios tal obstáculo se desconstitui.

Assim, reforçamos o delicado desenho da deliberação: é a chancela (praticamente) automática de um órgão de natureza política que confere validade formal à análise jurídica realizada por órgãos de natureza adjudicatória, e que emana como uma decisão do Sistema de Solução de Controvérsias da OMC em sua visão totalizante.

Isto posto, com base na arquitetura normativa-institucional explicitada, compreende-se que as decisões do Sistema de Solução de Controvérsias da OMC são decisões adjudicatórias internacionais. Ressalte-se, o OSC atua como vocalizador de tais decisões, que emanam como resultado de uma complexa inter-relação entre os órgãos do sistema. É a juridicidade do sistema que se manifesta em um contexto de diplomacia, reduzido ou quase anulado em sua dimensão prática.

Reitera-se que esta peculiaridade do resultado do procedimento perante o Sistema de Solução de Controvérsias da OMC não o descaracteriza como um sistema de natureza adjudicatória, não sendo a precisão do comando explicitado o requisito que diferencie as decisões adjudicatórias de decisões de outra natureza. ${ }^{149}$ Há quem compreenda, contudo, que tal especificidade se conecta à natureza prospectiva e não reparatória do Sistema de Solução de Controvérsias.

\section{ReferênCiAs}

ABI-SAAB, GEORGES. The Normalization of International Adjudication: Convergence and Divergencies. New York University Journal of International Law \& Policy, vol. 43, p.1-43, 2010-2011.

149 Até mesmo as decisões da CIJ não expressam sempre uma obrigação de fazer especificada: "In the majority of cases, the judgements are those requiring performance, but as has been done in some of the judgments of the International Court of Justice, a court may be requested to render declaratory judgements in which the court determines the guiding legal principles to be followed in dealing with a particular dispute, without giving a definitive decision on the dispute, or establishes that the violation of the principle of international law in question has no practical remedy." United Nations. Handbook on the Peaceful Settlement of Disputes between States. New York: United Nations, 1992. Office of Legal Affairs, Codification Division. OLA/COD/2394. p. 81. 
AZEVEDO, Roberto Carvalho de. Prefácio. In: BENJAMIN, Daniela Arruda. (Org). O sistema de solução de controvérsias da OMC : uma perspectiva brasileira. Brasilia : FUNAG, 2013.

BADIN, Michelle Ratton Sanchez; MOROSINI, Fabio Costa; OLIVEIRA, Inaê Siqueira de. Direito Internacional Econômico no Brasil: quem somos e o que fazemos? Evidências empíricas de 1994 a 2014. Revista de Direito Internacional, Brasília, v. 13, n. 1, 2016 p. 5-25.

BARRAL, Welber; PRAZERES, Tatiana. Solução de Controvérsias. Pp. 27-46. In: BARRAL, Welber (Org). O Brasil e a OMC. Curitiba: Juruá, 2006. 2a ed, 5a tir.

DER BORGHT, Kim. The Review of the WTO Understanding on Dispute Settlement: Some Reflections on the Current Debate. American University International Law Review. Vol. 14, 1998. Pp. 1223-1243.

BELLO, Judith Hippler. The WTO Dispute Settlement Understanding: Less Is More. Editorial Comment. American Journal of International Law, vol. 90, p. 416-418, 1996.

BILDER, Richard B. Some Limitations of Adjudication as an International Dispute Settlement Technique. Virginia Journal of International Law, vol. 231, p. 146-151, 1982.

BREVIGLIERI, Etiene M. Bosco; PEREIRA, Luciano Meneguetti. Os vinte anos da OMC, suas conquistas e desafios: uma análise do Brasil e o Sistema de Soluções de Controvérsias. Revista de Direito internacional, Brasília, v. 12, n. 2, 2014 p. 123-150.

CAFLISCH, Lucius. Cent ans de règlement pacifique des différends interétatiques. Recueil des cours, vol. 288, p. 245-467, 2001.

CÂMARA FILHO, José Sette. Hans Kelsen e a teoria pura do Direito Internacional. Boletim da Sociedade Brasileira de Direito Internacional, n. 8, p. 70-91, jul./dez. 1948.

CAMERON, James; GRAY, Kevin R. Principles of International Law in the WTO Dispute Settlement Body. International and Comparative Law Quarterly, vol. 50, p. 249-298, 2001.

CAPUCIO, Camilla. O constitucionalismo e a comunitarização no direito internacional: possibilidades para o comércio internacional? Revista de Direito Internacional, Brasília, v. 13, n. 1, 2016 p. 196-213.
COZENDEY, Carlos Márcio Bicalho. O Sistema de Solução de Controvérsias da OMC: para além dos contenciosos, a política externa. Disponível em: $<$ http://www.itamaraty.gov.br/temas/temas-multilaterais/copy_of_desenvolvimento-comercio-e-financas/ organizacao-mundial-do-comercio/solucao-de-controversias/cgc/artigo-cozendey> Acesso em: 10 abr. 201715 jul. 2016. p. 16.

CROOME, John. Reshaping the World Trading System: A history of the Uruguay Round. 2a ed. [S.1.]: [S.n.], 1998. Disponível em: <http://www.hse.ru/ data/2011/12/05/1271919456/Reshaping\%202_e. pdf> Acesso em: 12 set. 201610 abr. 2017.

EVANS, David. PEREIRA, Celso de Tarso. DSU Review: A View From the Inside. In: YEARS, Rufus. WILSON, Bruce. (Ed.). Key Issues in WTO Dispute Settlement: The First Ten Years. Nova Iorque: Cambridge Univesity Press, 2005, p. 251-264.

FIGUEIREDO, Celso Henrique Cadete de. A promoção de accountability na Organização Mundial do Comércio: uma análise horizontal e vertical. Revista de Direito Internacional, Brasília, v. 12, n. 2, 2014 p. 279-309.

FUKUNAGA, Yuka. Securing Compliance Through the WTO Dispute Settlement System: Implementation of DSB Recommendations. Journal of International Economic Law, vol. 9, issue 2, p. 383-426, mai 2006.

HUDEC, Robert E. GATT or GABB? - The Future Design of the General Agreement on Tariffs and Trade. Yale Law Journal Volume 80, Num. 7, Jun. 1971, pp. 1299-1387.

JACKSON, John. International Law Status of WTO Dispute Settlement Reports: Obligation to Comply or Option to Buy Out? American Journal of International Law, vol. 98, p. 109-125, 2004.

JACKSON, Jonh H. The Jurisprudence of GATT and the WTO. Cambridge: Cambridge University Press, 2000. p. 23.

JACKSON, John. The Great 1994 Sovereignty Debate: United States Acceptance and Implementation of the Uruguay Round Results. Columbia Journal of Transnational Law, vol. 36, p. 157-188, 1998.

JACKSON, John. Sovereignty, the WTO and Changing Fundamentals of International Law. New York: Cambridge University Press, 2006. 
JACKSON, John H.; DAVEY, William J.; SYKES JR., Alan O. Legal Problems of International Economic Relations. Cases, Materials and Text. 4a ed. St. Paul: West Group, 2002.

KUYPER, Peter J. O Direito do GAT'T com um Campo Especial do Direito Internacional: Ignorância, Refinamentos Posteriores ou um Sistema Autocontinente de Direito Internacional? In: CASELLA, Paulo Borba; MERCADANTE, Araminta de (coord.). Guerra comercial ou integração mundial pelo comércio?: a OMC e o Brasil. São Paulo: LTr, 1998.

KELSEN, Hans. Teoria pura do direito. 7 a ed. São Paulo: Editora WMF Martins Fontes, 2006.

LAFER, Celso. O Sistema de Solução de Controvérsias da Organização Mundial do Comércio. In: CASELLA, Paulo Borba; MERCADANTE, Araminta de (coord.). Guerra comercial ou integração mundial pelo comércio?: a OMC e o Brasil. São Paulo: LTr, 1998, p. $729-755$.

LAFER, Celso. A OMC e a regulamentação do comércio internacional: uma visão brasileira. Porto Alegre: Livraria do Advogado, 1998.

LAFER, Celso. O Sistema de Solução de Controvérsias da Organização Mundial do Comércio. In: CASELLA, Paulo Borba; MERCADANTE, Araminta de (coord.). Guerra comercial ou integração mundial pelo comércio?: a OMC e o Brasil. São Paulo: LTr, 1998, p. $729-755$.

MAROTTA RANGEL, Vicente. Marraqueche 94 e os Dois GATT: Breve Apresentação. In: CASELLA, Paulo Borba; MERCADANTE, Araminta de (coord.). Guerra comercial ou integração mundial pelo comércio?: a OMC e o Brasil. São Paulo: LTr, 1998, p. 126-136.

MATSUSHITA, Mitsuo; MAVROIDIS, Petros C.; SCHOENBAUM, Thomas J. The World Trade Organization: Law, Practice, and Policy. 2a Ed. Oxford: Oxford University Press, 2006.

MAVROIDIS, Petros. Outsourcing of Law? WTO Law as Practiced By WTO Courts. American Journal of International Law, vol. 2, p. 421-474, 2008.

MAVROIDIS, Petros. Remedies in the WTO Legal System: Between a Rock and a Hard Place. European Journal of International Law, vol. 11, 763-813, 2000.

McRAE, Donald M. The contribution of international trade law to the development of international law. Re- cueil des cours, vol. 260, p. 99-238, 1996.

MOTA, Pedro Infante. O Sistema GATT/OMC: Introdução Histórica e Princípios Fundamentais. Coimbra: Almedina, 2005.

PAUWELYN, Joost. The Limits of Litigation: "Americanization" and Negotiation in the Settlement of WTO Disputes. Ohio State Journal On Dispute Resolution. Vol. 19:1, 2003. p. 121-140.

PAUWELYN, Joost. The Transformation of World Trade. Michingan Law Review. Vol. 104, 2005-2006, p.1-66.

PESCATORE, Pierre. The GATT Dispute Settlement Mechanism: Its Present Situation and its Prospects. Journal of International Arbitration, vol. 10, issue 1, p. 27-42, 1993.

PETERSMANN, Ernst-Ulrich. The GATT/WTO Dispute Settlement System: International Law, International Organizations and Dispute Settlement. London: Kluwer Law International, 1997. p. 179.

PRATES, Alcides G. R. Comentários sobre o Acordo Constitutivo da OMC. In: CASELLA, Paulo Borba; MERCADANTE, Araminta de (coord.). Guerra comercial ou integração mundial pelo comércio?: a OMC e o Brasil. São Paulo: LTr, 1998, p. 94-124.

ROMANO, Cesare. A Taxonomy of International Rule of Law Institutions. Journal of International Dispute Settlement, vol. 2, n. 1, p. 241-277, 2011.

SACERDOTI, Giorgio. A Transformação do GATT na Organização Mundial do Comércio. In: CASELLA, Paulo Borba; MERCADANTE, Araminta de (coord.). Guerra comercial ou integração mundial pelo comércio?: a OMC e o Brasil. São Paulo: LTr, 1998, p. 50-69.

SCHWARTZ, Warren.; SYKES, Alan 0. The Economic Structure of Renegotiation and Dispute Resolution in the World Trade Organization. Journal of Legal Studies, vol. 31, 179-204, 2002.

SILVA, Roberto Luiz. Direito Econômico Internacional e Direito Comunitário. Belo Horizonte: Del Rey, 1995.

SPAIN, Anna. Integration Matters: Rethinking The Architecture Of International Dispute Resolution. University of Pennsylvania Journal of International Law, vol. 32, p. 1-56, 2010-2011. 
THORSTENSEN, Vera. OMC - Organização Mundial do Comércio: As Regras do Comércio Internacional e a Nova Rodada de Negociações Multilaterais. $2^{\mathrm{a}}$ ed. São Paulo: Aduaneiras, 2001.

TRACHTMAN, Joel P. The WTO Cathedral. Standford Journal of International Law, vol. 43, p. 127-167, 2007.

TRINDADE, Antônio Augusto Cançado. International law for humankind: towards a new jus gentium (II). General course on public international law. Recueil des cours, vol. 317, p. 9-312, 2005.

VAN DEN BOSSCHE, Peter.; ZDOUC, Werner. The Law and Policy of the World Trade Organization. $3^{a}$ ed. Cambridge: Cambridge University Press, 2013.
VARELLA, Marcelo Dias ; MONEBHURRUN, Nitish (eds). Os Vinte Anos da OMC, Revista de Direito Internacional, Brasília, v. 11, n. 2, 2014.

VARELLA, Marcelo Dias ; MONEBHURRUN, Nitish (eds). Direito Internacional Econômico, Brasília, Revista de Direito Internacional, v. 13, n. 1, 2016.

ZHANG, Naigen. Implementation of WTO Dispute Settlement. Manchester Journal of International Economic Law, vol. 5, issue 2, p.111-125, 2008.

ZIMMERMANN, Claus D. Toleration of Temporary Non-Compliance: The Systematic Safety Valve of WTO Dispute Settlement Revisited. Trade, Law \& Developmentm, vol. 3, p. 382-406, 2011. 


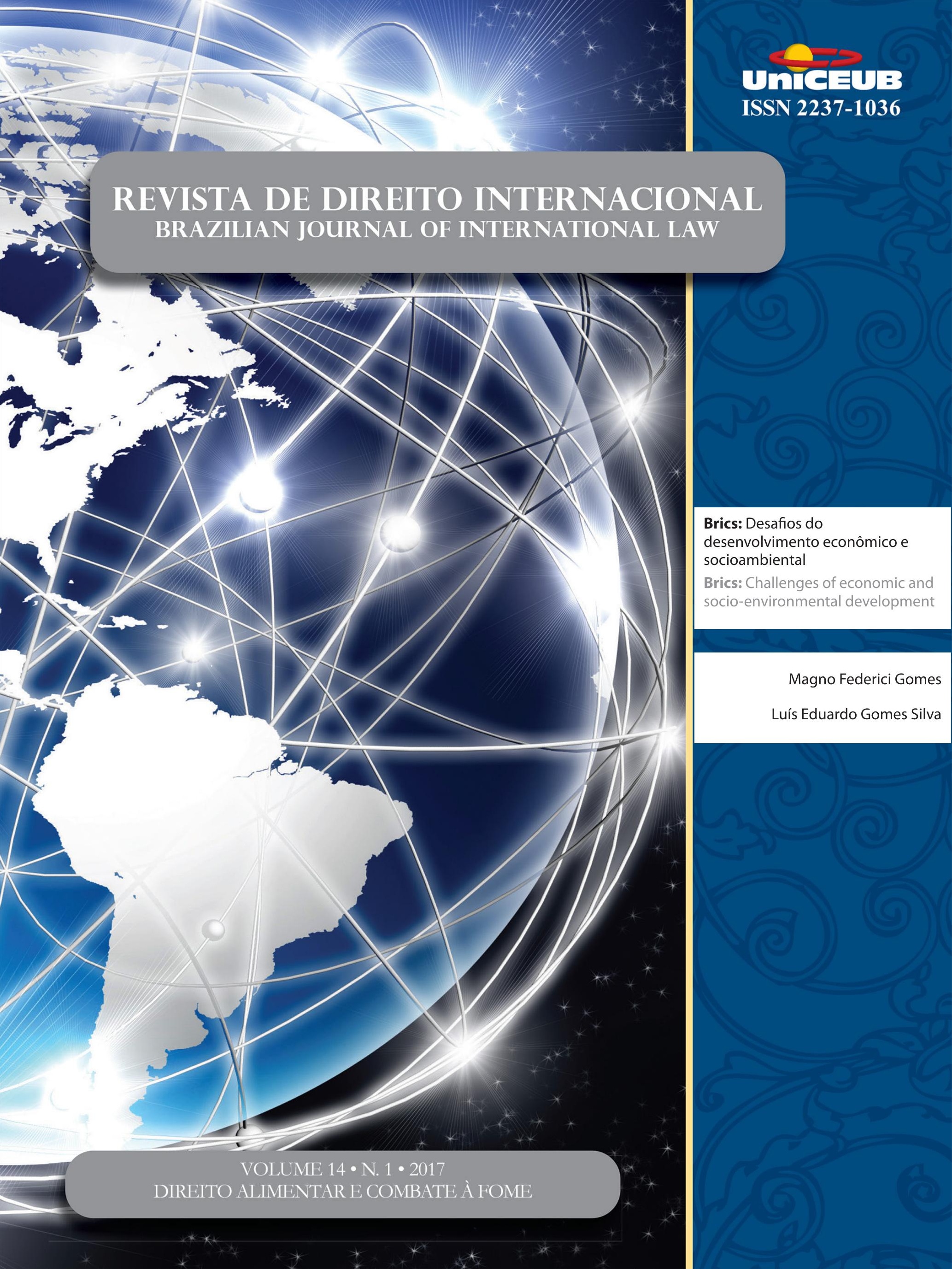




\section{Brics: Desafios do desenvolvimento econômico e socioambiental*}

\section{Brics: Challenges of economic and socio- environmental development}

* Recebido em 11/12/2016

Aprovado em 15/02/2017

Trabalho financiado pelo Edital $n^{\circ} 05 / 2016$ (Projeto n ${ }^{\circ}$ FIP 2016/11173-S2) do FIP/PUC Minas, resultante dos Grupos de Pesquisas (CNPQ): Regulação Ambiental da Atividade Econômica Sustentável (REGA) e CEDIS (FCT-PT).

** Pós-doutor em Direito Público e Educação pela Universidade Nova de Lisboa-Portugal. Pós-doutor em Direito Civil e Processual Civil, Doutor em Direito e Mestre em Direito Processual, pela Universidad de Deusto-Espanha. Mestre em Educação pela PUC Minas. Professor do Mestrado Acadêmico em Direito Ambiental e Sustentabilidade na Escola Superior Dom Helder Câmara. Professor Adjunto da PUC Minas e Professor Titular licenciado da Faculdade de Direito Arnaldo Janssen. Advogado Sócio do Escritório Raffaele \& Federici Advocacia Associada. Integrante dos grupos de pesquisa: Regulação Ambiental da Atividade Econômica Sustentável (REGA)/CNPQ-BRA e Centro de Investigação \& Desenvolvimento sobre Direito e Sociedade (CEDIS)/FCT-PT. ORCID: <http://orcid.org/0000-0002-47115310>. Currículo Lattes: <http://lattes.cnpq. br/1638327245727283>. Endereço eletrônico: federici@pucminas.br

*** Mestrando em Direito Ambiental e Desenvolvimento Sustentável pela Escola Superior Dom Helder Câmara. Especialista em Gestão Pública pela Universidade Federal de Juiz de Fora. Especialista em Direito do Consumidor e em Ciências Criminais pela Universidade Cândido Mendes. Graduado em Direito pela Faculdade de Direito Conselheiro Lafaiete. Oficial de Justiça Avaliador no Tribunal de Justiça do Estado de Minas Gerais. Currículo lattes: <http:// lattes.cnpq.br/1126147210941014>. Endereço eletrônico: luisdudugomes@gmail.com

\author{
Magno Federici Gomes** \\ Luís Eduardo Gomes Silva***
}

\section{Resumo}

Ao se ter como objetivo desvelar as interações entre o desenvolvimento econômico dos países emergentes e a demanda por um desenvolvimento sustentável, que possibilite o desenvolvimento de uma economia "verde" e que não seja agressiva ao meio ambiente, o presente artigo procura compreender, por meio da análise sistemática de argumentos e teorias, como se dá a introdução da proposta de desenvolvimento sustentável nos espaços de discussão e decisão dos países emergentes, em especial, Brasil, Rússia, Índia, China e África do Sul (BRICS), e como essa proposição se adequaria ao modelo de desenvolvimento adotado por esses países. Observa-se que o BRICS é responsável por importante fatia da produção econômica mundial, enquanto, por outro lado, não registra grande contribuição para a substituição de modelos de desenvolvimento ecologicamente "sujos" por outros que ameacem menos o meio ambiente, garantindo a efetivação do direito humano a um meio ambiente equilibrado. Com base nesses pontos, desenvolver-se-á, no presente trabalho, um estudo descritivo analítico por meio de pesquisa bibliográfica pura.

Palavras-chave: BRICS, Equilíbrio ambiental, Sustentabilidade, Economia.

\section{Abstract}

Aiming to reveal the interactions between the economic development of emerging countries and the demand for sustainable development, enabling the development of a "green" economy and is not aggressive to the environment, this article seeks to understand, through analysis systematic arguments and theories, how is the introduction of the proposed bio-sustainable development in discussion forums and decision of the emerging countries, in special, Brazil, Russia, India, China and South Africa (BRICS) and this proposal would fit the development model adopted by these countries. It is noted that the BRICS is responsible for major share of the world's economic output, while on the other side does not register great contribution to the replacement developing models Eco "dirty" by other threatening least the environment, ensuring the realization of the human right to a balanced environment. Based on these points, an analytical descriptive study will be developed in the present work through pure bibliographical research. 
Keywords: BRICS, Environmental balance, Sustainability, Economy.

\section{INTRODUÇÃO}

$\mathrm{Na}$ contemporaneidade, a exaustão do modelo de produção baseado na exploração sem fim de recursos naturais e a expansão da consciência em relação às consequências do processo de crescimento econômico, que vem se mostrando, em um curto período de tempo, potencialmente destrutivo para a vida na Terra, impõe novos desafios aos países.

Nesse sentido, os mecanismos de cooperação internacionais, como por exemplo, o BRICS ${ }^{1}$, que articulam meios de ampliação de seus mercados, tem sofrido forte pressão de setores da sociedade engajados na imposição da pauta do equilíbrio ecológico como ponto-chave para a definição de novas políticas que amenizem os efeitos da poluição global.

Desde o ano de 1972, data da Conferência de Estocolmo, em que, pela primeira vez, os países se reuniram para discutir os efeitos da industrialização acelerada e dos novos modelos de consumo, o conceito de desenvolvimento sustentável tem ganhado status em instâncias governamentais.

Surge, então, uma nova interpretação acerca da importância da valorização das populações locais para a administração do meio em que vivem e se desenvolvem, sendo direito do cidadão e dever do Estado contar com estratégias que harmonizem o desenvolvimento econômico com o que o ambiente realmente pode oferecer.

Para tanto, o termo desenvolvimento sustentável ganhou visibilidade internacional com a apresentação do Relatório de Brundtland, no ano de 1987, fruto da parceria entre diferentes órgãos das Nações Unidas, durante a Conferência das Nações Unidas para o Meio Ambiente e o Desenvolvimento, significando, em primeiras palavras, o uso equilibrado dos recursos naturais tendo em vista o bem-estar social e o futuro das gerações, garantindo a união entre os desenvolvimentos social, econômico e ecológico.

Observa-se que as vertentes econômicas que orien-

1 BRICS é um acrônimo que representa os cinco países emergentes que possuem alto potencial econômico e um crescimento mundial rápido: Brasil, Rússia, Índia, China e África do Sul. tavam os mercados, naquele período, já se mostravam extremamente prejudiciais para a gestão ambiental.

Nesse decurso, os Estados procuraram estabelecer políticas mais efetivas de combate à poluição de rios e solos, ao desmatamento, à precarização do trabalho, entre outras ações que se enquadram em uma gama de necessidades urgentes para a garantia da manutenção do equilíbrio entre a natureza e as inevitabilidades da vida humana, debruçando-se sobre essas questões os líderes políticos das grandes economias e, em especial, dos países que ganharam destaque nas últimas décadas por sua pujança econômica, isto é, os países emergentes, em especial, Brasil, Rússia, Índia, China e África do Sul (BRICS).

Compatibilizar a concepção de uma economia interligada, globalizada, com o equilíbrio ambiental, tão importante em um período de aquecimento global, requer, mais do que tudo, o empenho das instituições governamentais e da sociedade, propositando uma harmonia entre possibilidades e reais necessidades.

Ademais, o desenvolvimento sustentável agrupa em sua definição outros elementos que merecem igual atenção. São eles, em ordem respectiva: a superação da pobreza como obrigação inerente ao crescimento econômico inclusivo e ambientalmente seguro, e a dimensão positiva de se pensar em ações que ajudem a inibir um alto padrão de consumo.

Não há um consenso quanto à aplicabilidade dessas ações, mas o fato é que elas passaram a integrar o círculo de questões de Estado que influenciam, diretamente, na vida da sociedade.

A Eco-92, ocorrida no Rio de Janeiro, em 1992, firmou a conclusão de que os países desenvolvidos são os grandes responsáveis pela degradação do meio ambiente, e que os países em desenvolvimento, ou emergentes, necessitam de apoio técnico-financeiro para concretizarem medidas que visem uma caminhada coletiva para um futuro, ecologicamente, sustentável.

Diante desse panorama organizado, é possível elucidar a importância socioeconômica e política da introdução do desenvolvimento sustentável na vida prática e nos fundamentos da economia capitalista pós-industrial.

Assim, inicialmente, será realizada uma breve análise das implicações do desenvolvimento sustentável, para após se tratar dos países que integram o BRICS (e suas respectivas políticas públicas, dentre elas, aquelas volta- 
das para o desenvolvimento sustentável, finalizando a pesquisa com aspectos referentes a crise socioambiental na modernidade. Com base nesses pontos, desenvolver-se-á, no presente trabalho, um estudo descritivo analítico por meio de pesquisa bibliográfica pura, cujo marco teórico foi Carvalho e outros².

\section{Análise primeva do desenVolvimento SUSTENTÁVEL E SUAS IMPLICAÇÕES}

Hodiernamente, existem várias implicações acerca da possibilidade concreta de se instituir universalmente um modelo de desenvolvimento sustentável.

Entre essas implicações, vale destacar, por exemplo, a incompatibilidade entre o sistema de produção capitalista, que procura a reprodução ilimitada do capital, mesmo que isso acarrete graves danos ao meio ambiente e o modelo de desenvolvimento sustentável.

Carvalho e outros confirmam tal afirmação ao pontuarem que:

Mas modelo de desenvolvimento econômico baseado no capitalismo e que tem como característica a transformação das relações em mercadoria e como objetivo o lucro, é incompatível com o desenvolvimento sustentável uma vez que este alcança uma dimensão holística na relação entre os seres humanos e entre a humanidade e a natureza não contemplada pelo capitalismo. O DS busca suprir as demandas do presente, sem comprometer a capacidade das gerações futuras de responder às suas necessidades. É aquele que procura no presente preencher as lacunas econômicas, sociais, ambientais, políticas (no que tange à transparência e participação), além dos direitos humanos - inclusive o direito a um meio ambiente limpo e seguro - buscando-se conjuntamente a conservação destes para as gerações futuras ${ }^{3}$.

Veja-se que os representantes do sistema capitalista, empresários ou políticos, por exemplo, na definição exposta acima, são contraditórios quando afirmam acreditar em um desenvolvimento que respeite os direitos humanos e a natureza, tendo em vista que esse sistema, em sua essência, subsiste da exploração irresponsável dos recursos do planeta e do consumo ilimitado de bens e serviços.

2 CARVALHO, Natália Leal de, et al. Desenvolvimento sustentável x desenvolvimento econômico. Revista Monografias Ambientais, Santa Maria, v. 14, n³ , p. 109-117, set./dez. 2015.

3 CARVALHO, Natália Leal de, et al. Desenvolvimento sustentável x desenvolvimento econômico. Revista Monografias Ambientais, Santa Maria, v. 14, no 3, p. 109-117, set./dez. 2015, p. 112.
O crescimento constante da população mundial, em especial o crescimento populacional nos BRICS, gera preocupações que vão além da simples discussão teórica. Fatores como o esgotamento da água, a emissão de gases poluentes que atuam na irreversibilidade do efeito estufa e o consumo exagerado, são difíceis de resolver.

Assim, o crescimento indiscriminado das cidades, agindo em paralelo com o aumento da população residente, leva à ocupação de áreas destinadas originalmente à preservação, ocasionando enchentes e poluição de rios e lagos, por exemplo.

Nesse aspecto, é imperioso que se faça uma diferenciação de crescimento e desenvolvimento. Enquanto o crescimento é medida para a acumulação de capitais e bens na mão de alguns poucos, o desenvolvimento leva em conta outros aspectos, tais como a distribuição de renda, a melhora nos indicadores sociais e a inclusão de grupos historicamente marginalizados. Desse modo, o direito ao desenvolvimento segundo Nascimento, envolve "conflitos distributivos que precisam ser analisados sob a luz da conexão de distribuição e justiça, afastando-se a ideia das relações não somente no plano econômico, mas também nas possíveis reflexões normativas pertinentes ao direito contemporâneo"4.

No âmbito internacional, o direito ao desenvolvimento está presente em vários acordos e tratados, que procuram regulamentar as condições mínimas e vitais para a humanidade.

A primeira referência que se tem do direito ao desenvolvimento encontra-se inserida no parágrafo $3^{\circ}$ do art. $1^{\circ} \mathrm{da}$ Carta das Nações Unidas, de 26 de junho de 1946, que trata dos objetivos das Nações Unidas, ao estipular que seja realizada a cooperação internacional, com a resolução dos problemas internacionais de caráter econômico, social, cultural ou humanitário, promovendo e estimulando o respeito pelos direitos do homem e pelas liberdades fundamentais para todos, sem distinção de raça, sexo, língua ou religião, havendo a criação do Conselho Econômico e Social para o estudo de questões econômicas e sociais e a proteção dos direitos humanos objetivando garantir a cooperação internacional.

Igualmente, a Declaração Universal dos Direitos

4 NASCIMENTO, André Jansen do. Contratações públicas no âmbito da OMC: a política legislativa brasileira à luz do direito ao desenvolvimento. Revista de Direito Internacional, Brasília, v. 12, n 2, p. 191-209, 2014, p. 195. 
Humanos (DUDH), proclamada pela Assembleia Geral das Nações Unidas, em 10 de dezembro de 1948, procurou garantir o direito ao desenvolvimento garantindo-se aos seres humanos direitos econômicos, sociais e culturais indispensáveis à sua dignidade e ao livre desenvolvimento da sua personalidade. Para complementar as diretrizes contidas na DUDH, foi assinado o Pacto Internacional sobre Direitos Econômicos, Sociais e Culturais (PIDESC), adotado pela Assembleia Geral da ONU, em 1966, constituindo-se no principal instrumento internacional de proteção dos Direitos Econômicos, Sociais e Culturais.

Hodiernamente, as mais importantes declarações e resoluções pertinentes ao direito do desenvolvimento utilizados no direito internacional são: i) Resolução no 2.626 - estratégia Internacional do Desenvolvimento; ii) Resolução no 3.201 - Declaração da Nova Ordem Econômica Internacional; iii) Resolução no 3.202 - Declaração do Programa de Ação; e iv) Resolução no 3.291 - Carta dos Direitos e deveres Econômicos dos Estados.

Por sua vez, o direito ao desenvolvimento foi definitivamente consagrado após a Declaração sobre o Direito ao Desenvolvimento, da ONU, em 14 de dezembro de 1986, adotada pela resolução no 41/128 da Assembleia Geral das Nações Unidas.

Nesse ínterim, a Declaração dispõe acerca do desenvolvimento como um processo econômico, social, cultural e político abrangente, que visa à melhoria constante do bem-estar de toda a população e de todos os indivíduos com base na sua participação ativa, livre e significativa no processo de desenvolvimento e na justa distribuição dos benefícios dele derivados tratando-se de um direito difuso inalienável em que o Estado é o responsável em criar as condições favoráveis ao desenvolvimento supranacional e interno dos povos e dos indivíduos para plena realização de todos os direitos humanos e liberdades fundamentais.

Nas palavras de Nascimento:

O direito ao desenvolvimento, compreendido como direito de terceira geração e de caráter difuso, deve ocupar uma posição hierarquicamente superior aos demais tratados internacionais com verdadeiro status de norma jus cogens, para que se garanta o cumprimento de todas as normas garantidoras do desenvolvimento sem que se olvide dos critérios estruturantes de transformação social ${ }^{5}$.

5 NASCIMENTO, André Jansen do. Contratações públicas no
Essa interpretação, que hoje explica um pouco sobre o panorama do século XXI, amplia a discussão sobre a composição estrutural do desenvolvimento sustentável, em suas múltiplas diferenciações e concepções.

De acordo com Cavalcanti:

Para alcançarmos o Desenvolvimento Sustentável, a proteção do ambiente tem que ser entendida como parte integrante do processo de desenvolvimento e não pode ser considerada isoladamente; é aqui que entra uma questão sobre a qual talvez você nunca tenha pensado: qual a diferença entre crescimento e desenvolvimento? A diferença é que o crescimento não conduz automaticamente à igualdade nem à justiça sociais, pois não leva em consideração nenhum outro aspecto da qualidade de vida a não ser o acúmulo de riquezas, que se faz nas mãos apenas de alguns indivíduos da população. $\mathrm{O}$ desenvolvimento, por sua vez, preocupa-se com a geração de riquezas sim, mas tem o objetivo de distribuí-las, de melhorar a qualidade de vida de toda a população, levando em consideração, portanto, a qualidade ambiental do planeta ${ }^{6}$.

Com isso, dentre os inúmeros institutos consagrados nas últimas décadas em matéria de direito internacional do meio ambiente, as discussões acerca do desenvolvimento sustentável tem se destacado, sendo certo que é composto por três dimensões: econômica, social e ambiental. Esses elementos, quando atuando em conjunto, procuram obter o desenvolvimento econômico aliado ao respeito à natureza e a diversidade sociocultural dos povos, compatibilizando distribuição de renda e outras necessidades. Vê-se que, com a introdução do conceito de desenvolvimento sustentável ao longo do processo histórico, a "proteção do meio ambiente passou a ser considerada como um de seus elementos fundamentais, pois toda forma de crescimento não sustentável seria oposta ao conceito de desenvolvimento em si"'.

É importante frisar, nesse sentido, que o desenvolvimento sustentável exige a integração entre as políticas de desenvolvimento econômico, que se efetivam nos espaços de convivência humana e a conservação ambiental ${ }^{8}$. A importância dos incentivos econômicos

âmbito da OMC: a política legislativa brasileira à luz do direito ao desenvolvimento. Revista de Direito Internacional, Brasília, v. 12, nº 2, p. 191-209, 2014, p. 197.

6 CAVALCANTI, Clóvis. Desenvolvimento e natureza: estudos para uma sociedade sustentável. São Paulo: Cortez, 1995, p. 429.

7 MACIEL, Marcela Albuquerque; VARELLA, Marcelo Dias. O direito internacional ambiental como sistema complexo: características, metodologias e instrumentos de análise. Veredas do Direito. Belo Horizonte: v. 13, no 26, p. 235-261, maio/ago. 2016, p. 248.

8 Para analisar a ideia de desenvolvimento econômico em contra- 
para as legislações que versam sobre proteção ambiental são tema sempre presente nas discussões e fóruns internacionais sobre o assunto. Segundo Ferreira, "O padrão de produção e consumo que caracteriza o atual estilo de desenvolvimento tende a consolidar-se no espaço das cidades e estas se tornam cada vez mais o foco principal na definição de estratégias e políticas de desenvolvimento"'.

Assim, a igualdade social e ambiental está atrelada ao desenvolvimento econômico, e, desta forma, para a criação de alternativas sustentáveis, as instituições devem se ater ao comportamento humano, aos hábitos de consumo e modos de produção.

Nessa dinâmica, os BRICS, são órgãos vitais para a real implantação do desenvolvimento sustentável.

Um trabalho conjunto entre essas nações tende a contribuir imensamente para a mudança progressiva de práticas que não sejam mais ambientalmente válidas, considerando-se que sejam adotadas medidas rígidas em relação à extração de bens naturais e a produção poluidora.

\section{BRICS: CRISES E POLÍTICAS PÚBLICAS}

Nos anos 1990, crises ligadas à fuga de capitais financeiros ocorreram na Ásia, na Rússia, no Brasil e afetaram a maior parte dos países BRICS. $\mathrm{Na}$ década seguinte, o último termo aparece em artigo de Jim O’Neill, em que o mesmo advogava que Brasil, Rússia, Índia e China juntos ultrapassariam o PIB dos países do G-7. Como uma das maiores consequências da crise de 2008 entre os BRIC foi a criação do grupo BRIC, cuja primeira reunião se deu em 2009, em Ekaterimburgo.

Como na década não havia essa coalizão formada, investigar-se-á cada um dos países que o conformam. Entre os BRICS, talvez o mais comentado nos últimos vinte anos tenha sido a República Popular da China.

A potência reemergente sentiria os males da década

posição ao desenvolvimento sustentável e estudar um caso concreto, ver: BIZAWU, Kiwonghi; GOMES, Magno Federici. Oil exploitation at Virunga park as a threat to the environment and to endangered animal species. Veredas do Direito, Belo Horizonte, v. 13, $\mathrm{n}^{\circ} 27$, p. 11-29, set./dez. 2016, p. 18-21.

9 FERREIRA, Leila da Costa. A questão ambiental: sustentabilidade e políticas públicas no Brasil. São Paulo: Boitempo Editorial, 1998, p. 12. com a alta das commodities ${ }^{10}$, as tensões com muçulmanos uigures em Xinjiang, com o separatismo no Tibete e com a pressão por urbanização, com a pressão por abertura econômica e política vinda de Hong Kong. $\mathrm{O}$ governo de Pequim zela pela estabilidade social, o que demanda crescimento econômico alto para manter as demandas sociais baixas. Após a sucessão de Jiang Zemin (1992-2002), o líder político nacional foi Hu Jintao entre 2002 e 2012; nesse sentido, foi herdeiro das 4 modernizações da Era Deng Xioping; e teve especificidades no que se refere às políticas sociais.

O governo de $\mathrm{Hu}$ Jintao conduziu uma espécie de "New Deal" na China, com "reforma e/ou ampliação das políticas de educação, de saúde, de natalidade, agrária etc., em direção mais popular, guiado pelo ideário da coesão social, da sustentabilidade, e do combate aos desequilíbrios regionais" $"$.

Buscou-se, então, ampliar a cobertura da assistência social, das aposentadorias/pensões, mesmo que reformas anteriores tenham enfraquecido a proteção social do trabalhador. O sistema de saúde cobria na década em tela menos da metade da população urbana, e a população rural não tinha sistema equivalente.

Um dos desafios que o governo enfrentou foi regular a mobilidade urbana e controlar o crescimento desordenado das cidades. Portanto, é diferente da gestão anterior que focava mais no PIB e em negócios e da posterior (de Xi Jinping), que enfocou na melhoria da qualidade de vida e no combate à corrupção.

Assim, ao longo do período de crise, as políticas públicas, em geral, pareceram ter suscitado a perspectiva de maior regulação do governo, como forma de deter crises.

Ao longo dos anos, a percepção sobre o desenvolvimento na China mudou. Em vez do modelo de Bem-Estar Social, do modelo Socialista, e do modelo Neoliberal, a China optou pelo Estado Social de Mercado.

Primeiramente, desenvolvendo a economia como um todo, priorizou infraestrutura e as forças produ-

10 Essa palavra é usada para descrever produtos de baixo valor agregado. são artigos de comércio, bens que não sofrem processos de alteração (ou que são pouco diferenciados), como frutas, legumes, cereais e alguns metais.

11 HONGYI, Lai; WONG, John. The Hu-Wen. New Deal. In: HONGYI, L.; WONG, J. (eds.). China into the Hu-Wen era: policy initiatives and challenges. Cingapura: World Scientific, 2006. Cap. I, p. 3-33, p. 26. 
tivas; "a abertura econômica seguinte não enfocaria a proteção social, nem o fim da desigualdade, mas manteria o crescimento econômico entendido como parte dos direitos humanos no país, e caminho ao socialismo não mais doutrinário"12. Logo, a política econômica da China permaneceria quase inalterada em seus objetivos entre 1978, com Deng Xiaoping, e 2008, ainda com Hu Jintao.

As crises especulativas (Ásia, 1997; Rússia, 1998; Brasil, 1999), a crise de 2001 e a crise de 2008 não foram tão duras com o planejamento.

Curiosamente, a desigualdade social chinesa aumentou no período (com maior concentração de capital nas áreas urbanas), porém, houve a redução da pobreza com a ampliação de renda.

Um dos momentos-chaves dessa reconfiguração chinesa foi a condução da Olimpíada em Pequim em 2008. Ela mostrou a China de Hu Jintao com um perfil econômico, político e social, diferente da China de Jiang Zemin, Deng Xiaoping e de Mao Zedong. Estava lá a imagem da China que tinha aderido em 2001 aos padrões de comércio internacional estabelecidos pela Organização Mundial do Comércio (OMC). Estava lá uma China que abandonou o discurso aferrado terceiro-mundista e suavizou a retórica socialista.

Em matéria de política externa e de política de defesa, a China guia-se por princípios específicos. Enquanto internamente o princípio era de "sociedade harmoniosa", internacionalmente, a administração Hu Jintao foi marcada pelo conceito de "ascensão pacífica" no "mundo harmônico". Houve, claramente, uma retomada dos princípios do Confucionismo, que zelavam acima de tudo pela harmonia, mas também pela hierarquia, pela retidão, pela ação exemplar, prosperidade inclusiva etc. Mundo harmonioso "contém ideias de paz, cooperação, e desenvolvimento; em que interdependência e força nacional contariam mais que poder bélico, logo é visão de mundo pacifista"13.

Nessa orientação, segurança, meio-ambiente, e economia devem ser vistos de forma cooperativa. Não à

12 SHEYING, Chen. General public policy and development strategy. China Perspectives, Hong Jong: no 48, p. 1-11, jul./ago. 2003, p. 5 .

13 SU, Hao. Harmonious world: the conceived international order in framework of China's Foreign Affairs. In: IIDA, M. (ed.). China's shift. global strategy of the rising power. Tokyo: The National Institute for Defense Studies, 2009. Cap. 2, p. 29-55, p. 34. toa, a China participará, nessa década: Conselho de Segurança (desde 1971); G-20 financeiro (desde 1999); OMC (desde 2001); BASIC (desde 2009). Também é interessante ver que há outras modalidades de cooperação, não-globais, tendo preeminência chinesa: Organização de Cooperação de Xangai (OCX); BRICS; Conselho da Grande Região do Mekong. A China deixou de ser pária e passou a se tornar um país responsável, ainda que tenha de avançar em democracia e direitos humanos ${ }^{14}$.

A soberania ainda é uma questão crucial, o governo recrudesceu a segurança interna através de uma Lei Antissecessão, que prevê o uso da força; resposta aos casos de Tibete, Taiwan e Xinjiang. Logo, com Hu Jintao a "harmonia" deve ser perseguida como norte, interna e externamente; isso contrasta com a ênfase de Zemin na "prosperidade". As ideias que movem a política externa da China mudaram. Com a "Dinastia Qing era isolacionista, com Mao era revisionista, desde Deng tem sido integracionista, com aberturas e reformas associadas à ascensão internacional"15. Com a "crise internacional, em especial com a fraqueza dos EUA, a China adotou uma postura mais assertiva, principalmente com recursos naturais, com ascensão do nacionalismo internamente, e com velada disputa com estadunidenses"16. A forma de agir mudou, mas as ideias permaneceram.

Já a Federação Russa é um país que surgiu com a queda da URSS, em 1991. É possível entender as mudanças na Política Externa Russa se se entender as ideias que as regem. Primeiramente, é preciso distinguir 4 visões sobre o país: nacionalistas, que veem o país pela sua especificidade; os eurasanistas, que veem o país como meio-termo entre Ásia e Europa; os eslavófilos, que veem mais a sua parte asiática que europeia; e os ocidentalistas, que enxergam o país como eminentemente europeu.

O país é semipresidencial, mas é a presidência que tem prerrogativas em política externa. $\mathrm{O}$ governo de Gorbatchev, entre 1985 e 1991, foi o da Perestróika e

14 Conforme: FOOT, Rosemary. O poder chinês e a ideia de um país responsável. In: NEDAL, D.; SPEKTOR, M. (Orgs.). O que a China quer? Rio de Janeiro: FGV, 2010. Cap. 1.

15 Nesse sentido: LEGRO, Jeffrey. O que a China vai querer? As futuras intenções de uma potência em ascensão. In: NEDAL, D.; SPEKTOR, M. (orgs.). O que a China quer? Rio de Janeiro: FGV, 2010. Cap. 4.

16 LUKIN, Alexander. China's new foreign policy strategy and Russia's concerns. Rasprave I članci, 2011. Nova spoljnopolitickea strategija Kine $i$ zabrinutost Rusije, MP 4, p. 483-504, 2011, p. 483. 
da Glasnost, abertura político-econômica, aprofundada entre 1991 e 1999 com o governo Boris Yeltsin. Gorbatechev ainda sob o ideário soviético, Yeltsin, de ideário neoliberal. Nesse período, as 15 nações da URSS se tornam independentes, formando a Comunidade dos Estados Independentes.

Durante os anos 2000, pode-se ver a predominância do grupo político que viria a constituir-se no Partido Rússia Unida, de Vladimir Putin (1999-2008; 2012-) e de Dmitry Medvedev (2008-2012). De duas gestões "ocidentalistas" abertas, que antecederam a crise financeira russa de 1998, a Rússia entrou em um período de quase vinte anos de gestões "eurasianas"; com doses de patriotismo e Estado forte. Com Putin e Medvedev, houve um retorno da retórica nacionalista. No final dos 1990, o país "praticava o balanceamento, porém, após 2001, o país volta-se ao pragmatismo, ao crescimento econômico e à unidade estatal, aproxima-se dos EUA e classifica insere os separatismos no país no contexto do terrorismo global" ${ }^{17}$.

A Rússia associa seus problemas com separatismo, em especial na Chechênia, com o terrorismo. Um exemplo desses problemas é o sequestro da escola em Beslan, em 2004, Ossétia do Norte, feito por separatistas chechenos. Em 2000, foi formada a Comunidade Econômica Eurasiana. A ênfase de Putin, na razão de estado e na governabilidade, levou a uma "Concepção de Política Externa da Federação Russa”, como se pode ver em livro de Melville e Shakleina ${ }^{18}$. Nesse documento, as prioridades de relação são com CEI; UE; Grã-Bretanha; Alemanha; Itália; países bálticos.

Em defesa da integridade balcânica da Iugoslávia e demonstrando mistura de vontade de participar com crítica com relação à OTAN, demonstrou-se aberto a relações com os EUA; ASEAN; China; Índia; Japão; Irã.

No documento defendeu-se a multipolaridade e a centralidade do Estado, apesar da globalização e da interdependência.

Durante a década de 2000, prevaleceu o pensamento internacionalista russo realista; no início com ênfase em geopolítica (meados de 1990 a 2000), a Rússia via-se como "potência eurasiana; em seguida (2000-2004) ligado ao

17 TSYGANKOV, Andrei P. Russia's foreign policy: change and continuity in national identity. New York: Rowman \& Littlefield Publishers, 2016, p. 140.

18 Ver: MELVILLE, Andrei; SHAKLEINA, Tatiana. Russian foreign policy in transition: concepts and realities. Budapest, New York: Central European University Press, 2005. pragmatismo geoeconômico, via-se como superpotência responsável; desembocando, em seguida, em uma geoestratégia cultural de uma superpotência independente"19.

Após 2008, uma nova mudança surgiu, com o ministro Serguei Lavrov defendendo que não havia só valores e desenvolvimento ocidental, mas muitos outros; e o mundo tinha se tornado verdadeiramente global; é a defesa do mundo pós-ocidental ${ }^{20}$.

Também há relações nem sempre pacíficas com os vizinhos, algo recorrente na Ásia. Em 2008, em plena Olimpíada, há a guerra entre Rússia e Geórgia, em que a primeira ocupou o território da Ossétia do Sul, na Geórgia. Esse ano será marcante, pois, ao mesmo tempo, ocorrerá a Guerra Rússia-Geórgia e ocorrerá a crise econômica global; e torna a Rússia mais defensiva, moderada, recuada.

Entre 2001 e 2003, a Rússia cooperou com Europa e EUA; tendo atitude mais assertiva desde a Guerra do Iraque, "sendo conta alargar a OTAN, participando da OCX; há então as crises do Kosovo e Geórgia em 2008, e desde então, o país se afirma como potência que influi sobre a agenda internacional" 21 .

Em 1996 foi assinada a Declaração de Xangai, com: Cazaquistão; China; Quirguistão; Rússia; Tadjiquistão. A futura Organização de Cooperação de Xangai (OCX) (desde 2001) incluirá, além dos membros citados, o Uzbequistão. A julgar pela condição de observador da Índia e do Irã, o que se pode dizer é que, com a OCX está formada uma comunidade regional de defesa.

A crise de 2008 gerou um cenário interessante. Ao mesmo tempo em que afetou os investimentos e a bolsa russa, ela não quebrou o país; tampouco forçou mudanças em sua economia centrada na energia. O que se viu foi uma resiliência. A força da inércia se deu, principalmente, à força do setor de energia e mineração.

Os lucros vindos da exportação de hidrocarbonetos possibilitaram uma política social estatista mais forte, havendo quatro fundos russos extras orçamentários:

19 THORUN, Christian. Explaining change in Russian foreign policy: the role of ideas in post-soviet russia's conduct towards the west. Hampshire: Palgrave Macmillan, 2009, p. 32.

20 TSYGANKOV, Andrei P. Russia's foreign policy: change and continuity in national identity. New York: Rowman \& Littlefield Publishers, 2016, p. 165.

21 HAAS, Marcel De. Russia's foreign security policy in the $21^{\text {st }}$ century: Putin, Medvedev and beyond. London: Routledge, 2010. Cap. 6, p. 156-181, p. 169. 
para pensões; para aposentadoria; para seguro-desemprego; e para auxílio social.

O primeiro mandato de Putin enfatizou uma forte política social conduzida pela Federação e não pelos entes federados, e rigor fiscal, ao mesmo tempo. $\mathrm{O}$ discurso desde 2005 foi de justiça e inclusão social. Desde então, o país tem tentado criar um PIB per Capita em nível europeu, nas eleições de 2012 na Rússia Putin defendeu uma política social: a favor da fertilidade, de aumento de pensões acima da inflação, de aumento dos salários de professores universitários, de auxílio à moradia. A estratégia anunciada em 2005 não foi alterada com a crise de 2008; o que se viu foi uma manutenção das linhas gerais, novamente.

A ruptura da década de 1990 - pós-Guerra Fria - também causou influência sobre as opções econômicas da Índia. No princípio, a política econômica era nacionalista, intervencionista, desenvolvimentista, industrialista por substituição de importações; em seguida, de meados dos 1970 até os anos 1990 são feitas liberalizações; nos anos 1990 a Índia se voltou para exportação, para o investimento e para o setor de serviços, "e grandes grupos se consolidaram como Tata Group, Bharat Forge, entre outras"22.

Politicamente, a maior parte do tempo, esteve à frente o Partido do Congresso Indiano (PCI) de Mohandas Karamchandi "Mahatma" Gandhi e de Jawarhal Nehru. O principal opositor tem sido o BJP, partido nacionalista hindu. Um dos mentores das reformas econômicas dos anos 1990, Manmohan Singh (PCI), ocuparia a liderança do Executivo na maior parte da década, entre 2004 e 2014. No último ano, o BJP (Bharatiya Janata Party) voltou ao poder com Narendra Modi.

Em termos de políticas sociais, a Índia foi um dos primeiros países a trabalhar com as políticas de cotas, para incentivar a inclusão de castas mais discriminadas e povos indígenas. Com leis para cotas estabelecidas no período de Nehru, e nos anos 1990; uma lei de 2006 estabeleceu $27 \%$ de vagas universitárias para pessoas de casta menos favorecida.

As políticas de educação indianas não acabaram com o analfabetismo, mas, há poucos anos, a Índia tornou-se o país com maior número de doutores formados, sendo forte na alta tecnologia, apesar do problema da "fuga de cérebros". Por outro lado, 70\% dos trabalhos

22 GANGULY, Sumit; MUKHERJI, Rahul. A Índia desde 1980. Rio de Janeiro: Apicuri, 2014, p. 90. encontraram-se vinculados ao mundo rural. O que, de certa forma, "blindou" a sociedade indiana de crises relacionadas ao mercado imobiliário e ao mercado de ações. Uma sociedade eminentemente rural, com muitos analfabetos, de forte ação do Estado esteve menos sujeita à crise de 2007/2008.

A Índia possui um problema também encontrado na China. Conforme ocorre a urbanização, a infraestrutura e as políticas sociais (saúde, educação, segurança alimentar, combate à miséria, etc.) têm de melhorar. Caso não ocorra uma melhora nos serviços prestados aos cidadãos, é provável que ondas de protestos tornem a situação política no mínimo instável. Em termos de política externa, a Índia variou bastante.

Da posição não alinhada, presente no G-77 e no MNA, passou-se à aproximação com a URSS (sem aderir ao socialismo soviético). Nesse ínterim, guerras ocorreram com Paquistão, China; e a bomba nuclear indiana seria feita enquanto o país negava-se a assinar o Tratado de Não-Proliferação Nuclear. Em 1998, o país testa armas nucleares e rompe com a política de defesa de baixo perfil e com a política externa relativamente pacifista perseguida pelo paradigma de Nehru/ Gandhi. Eminentemente rural e com uma população enorme, logo preocupado com a segurança alimentar, o país defenderia posições comerciais defensivas com relação à produção de alimentos indiana. Presente no G-20 financeiro e no G-20 comercial, na OMC, o país tornou-se, paulatinamente, um ator relevante.

Após a crise de 2001, a afirmação como potência nuclear, aspiração à cadeira permanente no Conselho de Segurança da ONU (com Alemanha, Brasil e Japão; no G-4); a premência na sua região foi reforçada. Isso levaria à Índia a participar na coalizão contra os Talibãs no Afeganistão no contexto da Guerra ao Terror. Seguindo a lógica dos círculos concêntricos, na sua vizinhança buscando primazia, na Ásia buscando poder de veto, "no mundo buscando ser uma potência reconhecida e responsável; a Índia buscará alianças com grandes potências (China, EUA, Rússia) e afirmar-se-á como responsável, mais que autônoma"23. Narlikar chama a Índia de "ator com "poder de veto", normativa e estrategicamente, cujo consentimento seria necessário para mudanças no status quo, mas ainda não teria a capacidade

23 MOHAN, C. Raja. A Índia e o equilíbrio de poder. In: STUENKEL, O. (org.). A Índia na ordem global. Rio de Janeiro: FGV, 2013, p. 37. 
de moldar os resultados a seu favor" ${ }^{24}$.

Por fim, é interessante analisar o Brasil, que, entre os BRICS originais (a África do Sul só aderiu só em 2011), é o que tem menor poder econômico e militar.

A década de 1990 foi especialmente interessante para o país, com a alta do preço das commodities, o Brasil conseguiu colher lucros (principalmente com soja, carnes, e petróleo), ancorado na estabilização monetária alcançada na década anterior com o Plano Real. A política econômica na década foi ancorada no tripé da estabilidade macroeconômica: câmbio flutuante; metas de inflação; responsabilidade fiscal (incluindo superavit primário).

A década de 2000 deu maior ênfase ao crescimento, com o país menos afetado por surtos especulativos, como nos anos 1990; o que auxiliou o aprofundamento das políticas distributivas. No que se refere às políticas sociais, o principal norte foi a Constituição da República Federativa do Brasil (CRFB/1988), promulgada em outubro de 1988. Com a CRFB/1988, a seguridade social passou a ser vista como direito dos cidadãos englobando a assistência social, saúde e previdência; e "após o modelo bismarckiano, foi beveridgeano, marcado pela LOAS, pelos programas de redução da pobreza de FHC e Lula etc ${ }^{25}$. O modelo de política social não foi afetado pelas crises dos anos 2000 .

Presidencialismo de coalizão embasou as instituições políticas brasileiras contemporâneas: "com sistema de governo presidencialista, com sistema eleitoral proporcional, com troca entre Executivo e Legislativo representado pelos ministérios, votos e projetos; em que as coalizões são grandes e nem sempre coesas" ${ }^{\prime 26}$.

Na década de 2000, os países da América do Sul deram uma "guinada progressista", o Partido dos Trabalhadores (PT) liderou a coalizão presidencial no país, promovendo uma mudança na forma de se buscar autonomia do país no mundo. Ainda que muito se tenha destacado a diversificação de parcerias e a cooperação sul-sul na diplomacia brasileira do período, "ela se ancorou em princípios mais antigos, como o agir prudencial

24 NARLIKAR, Amrita. All that glitters is not gold: India's rise to power. Third World Quarterly. Cambridge: v. 28, n 5, p. 983-996, maio 2007, p. 983.

25 CUNHA, Eleonora Schettini Martins; SÁTYRO, Natália Guimarães Duarte. The path of Brazilian Social Assistance Policy post1988: the significance of institutions and ideas. Brazilian Political Science Review, São Paulo, v. 8, nº 1, p. 80-108, 2014, p. 86.

26 SANTOS, Fabiano Guilherme dos. O Poder Legislativo no presidencialismo de coalizão. Belo Horizonte: UFMG, 2003, p. 46. dos tempos de Paranhos Júnior, do pragmatismo, da solução pacífica de controvérsias, etc" ${ }^{27}$. Se por um lado há continuidade, por outro há inovações.

A relação do país com a área de defesa é interessante, pois espelha esse perfil. O país participou de $1 / 3$ das decisões do CSNU, como temporário, apoiando ações contra terrorismo; evocou o Tratado Interamericano de Assistência Recíproca (TIAR) em 2001; mobilizou diferentes órgãos para lidar com a questão; participou de "organismos internacionais para combater o terrorismo; e criou a Secretaria Extraordinária de Segurança para Grandes Eventos $(\mathrm{SESGE})^{28}$ para segurança em grandes eventos"29.

O país participou no regime contra o terrorismo, "mas enfatizando oposição a uma resposta militarizada; defendendo, ao invés, o multilateralismo, o direito internacional, e o desenvolvimento como soluções" ${ }^{30}$.

Alguns documentos orientaram a defesa brasileira na década de 2000. Em 1996 surgiu a primeira Política Nacional de Defesa (com reedições em 2005 e 2012); em 1999 foi criado o Ministério da Defesa, congregando as três Forças Armadas, em 2008 surgiu a Estratégia Nacional de Defesa; em 2012, o Livro Branco de Defesa. A END explicitou a aproximação entre sociedade e meio militar, enfatizando controle, mobilidade, presença.

Em 2012 surge a proposta do Livro Branco de Defesa Nacional. Pode-se dizer que para que essas ideias sejam mobilizadas integralmente, é preciso ter integração com outras políticas públicas, como por exemplo, a política externa.

\subsection{O BRICS e o Desenvolvimento ambiental}

A análise da emissão de CO2 na atmosfera, gás do efeito estufa, pelos países do BRICS e os países desen-

27 VELASCO JÚNIOR, Paulo Afonso. Autônoma, politizada, anticonformista, não subserviente: uma política externa fiel à sua tradição. Revista Insight Inteligência, Rio de Janeiro: ano XIV, nº 55, p. 118-124, out./nov./dez. 2011, p. 119.

28 A SESGE teve como principal escopo a coordenação da atuação dos órgãos envolvidos na segurança pública e defesa civil das esferas de governo, federal, estadual e municipal.

29 MORAES, Rodrigo Fracalossi de; SOUZA, André de Mello e. A relevância do terrorismo na política internacional contemporânea e suas implicações para o Brasil. In: SOUZA, A. de M. e; NASSER, R. M.; MORAES, R. F. de. (orgs.). Do 11 de setembro de 2001 à guerra ao terror: reflexões sobre o terrorismo no século XXI. Brasília: IPEA, 2014. Cap. 1, p. $13-45$, p. 36.

30 Nesse sentido: CUNHA, Ciro Leal M. da. Terrorismo internacional e a política externa brasileira após o 11 de setembro. Brasília: Fundação Alexandre de Gusmão, 2009, p. 133-135. 
volvidos representados pela OECD (Organização para a Cooperação e Desenvolvimento Econômico), em comparação com o restante do mundo, permite inferir que, em proporção, esse bloco econômico, emite mais gás carbônico que a maioria dos países.

Gráfico 1 - Emissões por grupo de países

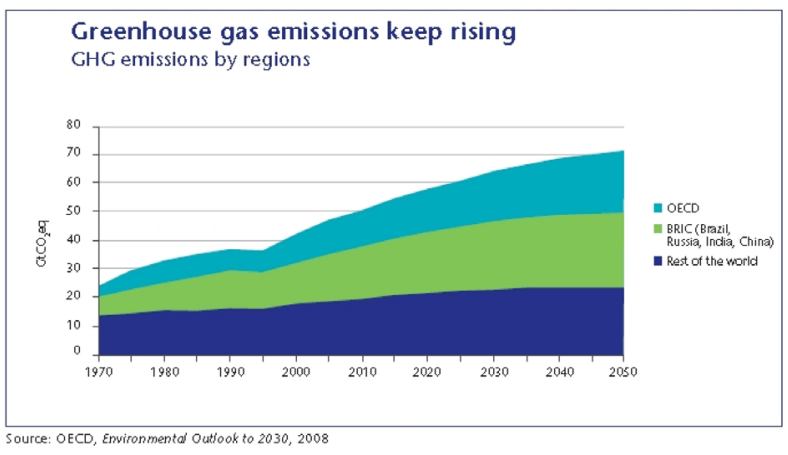

Fonte: World Business Council for Sustainable Development $\mathrm{t}^{31}$.

Com esses dados em mãos, é fácil argumentar que os BRICS, principal organização composta por países emergentes influentes, não têm feito grandes esforços para reduzir o impacto de suas atividades econômicas no mundo.

Em outra tabela, a taxa de crescimento econômico dos países que compõem o BRICS é maior do que a de países desenvolvidos. A emissão de CO2 está ligada, intimamente ,com o aumento da atividade econômica de um país, fato que revela que a política econômica dessas nações não foi um instrumento eficaz para a sustentação dos ecossistemas e dos recursos que o constituem. Veja-se:

Tabela 1 - Taxa de Crescimento Anual dos BRICS

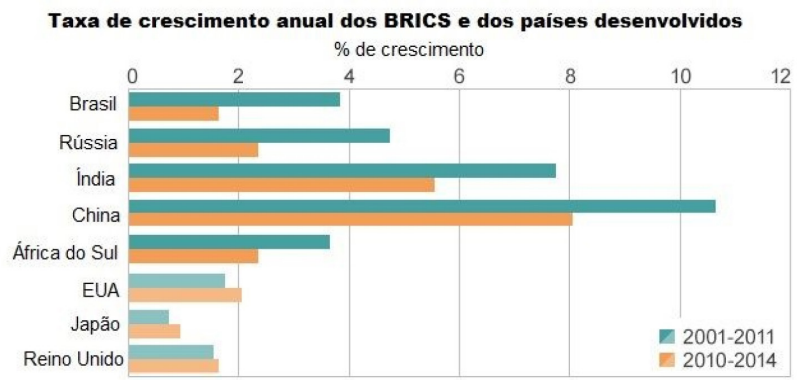

Fonte: International Monetary Fund. World Economic Outlook $^{32}$.

31 WORLD BUSINESS COUNCIL FOR SUSTAINABLE DEVELOPMENT. Greenhouse gas emissions keep rising. 2010, s/p.

32 INTERNATIONAL MONETARY FUND. World Economic Outlook. A survey by the staff of the International Monetary Fund. Washington, DC: International Monetary Fund, 2014, s/p.
O desafio que se coloca para os países do BRICS é, antes de tudo, uma questão de direitos humanos e garantia da plena cidadania de suas populações. O desenvolvimento sustentável, também, abarca outras questões de suma importância, como superação da pobreza e distribuição mais igualitária de renda. Segundo Lopes e outros,

Considerando esse indicador, observa-se que o BRICS representou um desenvolvimento social para os países que compõem o grupo. Entendese que avanços nesse aspecto sinalizam que o grupo econômico corresponde aos anseios de desenvolvimento sustentável. Evidentemente, os avanços apresentados pelos países que compõem o grupo não estão atrelados somente ao fato participação no mesmo. Várias são as ações tomadas pelos governantes desses países, como esforços para a otimização desses resultados. Contudo, entendese que a cooperação efetivada a partir da criação do grupo pode ter resultado no desenvolvimento observado, em consonância com Reis (2012), que destaca os avanços na saúde e redução da pobreza proporcionados por esse acordo de cooperação ${ }^{33}$.

Na próxima sessão o estudo direcionará seus argumentos para a questão dos direitos humanos como elemento que integra o desenvolvimento sustentável. Os avanços nos indicadores sociais devem ser a salvaguarda do desenvolvimento planejado.

\section{O desenVOLVIMENTO SUSTENTÁVEL E AS QUESTÕES SOCIAIS}

A sustentabilidade ambiental e as questões sociais andam de mãos dadas, e são o reflexo do anseio social por melhoria na qualidade de vida, na educação, na saúde e nas condições gerais de existência. O declínio do Estado de bem-estar social e a ascensão do neoliberalismo, na década de 1990, fizeram com que essas demandas fossem, temporariamente, suplantadas pela busca por crescimento econômico sempre alto, e pela expansão internacional das empresas.

$\mathrm{Na}$ atualidade, contudo, essas reivindicações ganham força, em razão da desaceleração das economias, e tendem a gerar uma crise social à medida em que as populações passam a enxergar o desenvolvimento como meio obrigatório da inclusão social e distribuição de

33 LOPES, Patrick Fernandes; et al. Desenvolvimento sustentável: uma análise contextual dos BRICS. Encontro Internacional sobre Gestão empresarial e ambiental (ENGEMA), São Paulo, 2013, p. 10. 
renda. Para Mendes,

Temos de fazer um paralelo entre crescimento e desenvolvimento. A diferença é que o crescimento não conduz automaticamente à igualdade nem à justiça sociais, pois não leva em consideração nenhum outro aspecto da qualidade de vida a não ser o acúmulo de riquezas, que se faz nas mãos apenas de alguns indivíduos da população. $\mathrm{O}$ desenvolvimento, por sua vez, preocupa-se com a geração de riquezas sim, mas tem o objetivo de distribuí-las, de melhorar a qualidade de vida de toda a população, levando em consideração, portanto, a qualidade ambiental do planeta ${ }^{34}$.

A nova concepção acerca do que é e o que representa o desenvolvimento para as pessoas gera discrepâncias em relação às bases do sistema capitalista, que não considera o desenvolvimento como meio sustentável de garantir seguro social. Essa dualização de pensamentos pode promover uma ruptura de paradigmas, que é necessária para que o desenvolvimento sustentável seja posto definitivamente em pauta, e aplicado como medida também para o crescimento econômico dos países.

Ao considerar o exposto acima é exequível afirmar que o desenvolvimento sustentável só poderá ser realizado com uma mudança estrutural no sistema capitalista. Afirmam Carvalho e outros:

\begin{abstract}
Acreditamos que isso tudo seja possível, e é exatamente o que propõem os estudiosos em DS, que pode ser definido como: equilíbrio entre tecnologia e ambiente, relevando-se os diversos grupos sociais de uma nação e também dos diferentes países na busca da equidade e justiça $\operatorname{social}^{35}$.
\end{abstract}

Os países que componham o BRICS, de certa forma, carregam duas responsabilidades: garantir a conciliação entre igualdade social e crescimento para a economia global.

Não é possível pensar em uma relação que não inclua o equilíbrio ambiental como sustentáculo básico da efetivação dos direitos do homem, como extensão dos direitos fundamentais. A sustentabilidade garante a proteção dos direitos humanos, isto é, é um ponto chave para o equilíbrio entre as relações sociais e o meio ambiente.

O desenvolvimento econômico, quando orientado para a geração de riquezas que contribuam para o bem-

34 MENDES, Marina Ceccato. Desenvolvimento sustentável. 2008, $\mathrm{s} / \mathrm{p}$.

35 CARVALHO, Natália Leal de, et al. Desenvolvimento sustentável x desenvolvimento econômico. Revista Monografias Ambientais, Santa Maria, v. 14, nº 3, p. 109-117, set./dez. 2015, p. 110.
- estar social, só pode ser chamado de desenvolvimento se não estiver apoiado no esgotamento de recursos naturais, e sim no manejo sustentável desses recursos para benefício de toda coletividade. Ações e pensamentos individuais não podem se sobrepor às necessidades fundamentais do homem. Conforme Araújo,

O problema é que a força do poder econômico, do egoísmo, dos fatores culturais e religiosos além da estupidez da discriminação proveniente de outros comportamentos humanos, como, v. g., o racismo - acaba levando alguns indivíduos a se acharem superiores aos outros. São pessoas que não conhecem o que é respeito, não entendem o que é paz social e nem se consideram participantes de uma coletividade ${ }^{36}$.

A concepção de coletividade, objeto orgânico fruto das interações entre indivíduos de diferentes células sociais, atravessa o conceito de desenvolvimento sustentável em duas frentes.

A primeira delas é a que indica que o sentido de coletividade e coesão é o instrumento para o estabelecimento da sustentabilidade como ferramenta dos direitos do homem, e da igualdade entre o homem.

O segundo deles versa acerca de que a coletividade, unida em um propósito de combate às práticas ambientalmente perigosas, pode contribuir para parte da mudança do modelo de extração exaustiva dos recursos da Terra, que são finitos. Segundo Araújo,

É sensato afirmar que a postura positiva em prol da defesa dos direitos fundamentais não pode prescindir de um eficaz e equânime tratamento às questões ambientais, ou seja, uma sociedade só consegue proteger seus direitos naturais partindo da proteção do ambiente em que vive. Parece inócuo, ou contraditório, defender direitos básicos e, ao mesmo tempo, aceitar o desrespeito ao habitat humano: não se efetivam direitos em um ambiente desequilibrado e hostil. Em termos axiológicos, pode-se dizer que o acesso a um ambiente saudável deve preceder à própria vida, uma vez que vida sem qualidade não passa muito de um estado vegetativo simplesmente, uma impropriedade sob o ponto de vista racional ${ }^{37}$.

A própria condição humana está acomodada à conjuntura do meio em que vive.

O homem, como sujeito histórico-cultural possui a

36 ARAÚJO, José Salvador Pereira. Direitos humanos, meio ambiente e sustentabilidade. Revista Direito Ambiental e Sociedade, Caxias do Sul, v. 3, nº 1, p. 289-317, jan./jun. 2013, p. 291.

37 ARAÚJO, José Salvador Pereira. Direitos humanos, meio ambiente e sustentabilidade. Revista Direito Ambiental e Sociedade, Caxias do Sul, v. 3, n 1, p. 289-317, jan./jun. 2013, p. 293. 
missão de questionar os modelos econômicos que não lhe garantem os direitos fundamentais, como o direito à saúde e ao meio ambiente ecologicamente equilibrado.

A importância que hoje se dá à preservação ambiental surgiu com base no medo de que divergências entre grandes potências pudessem dar fim à vida na Terra, pois a vida como é conhecida ganhou uma dimensão nova, dada a sua fragilidade.

Atualmente, é bastante aceita a ideia de que o
moderno pensamento preservacionista tenha
iniciado a partir da metade do século XX. Esse
perfil de indivíduo humano (preocupado com a
preservação do Planeta) surge basicamente no
período logo após o fim da Segundo Guerra
Mundial, quando o homem teve a exata noção do
seu alto poder destruidor. Segundo Ignacy Sachs,
as explosões atômicas trouxeram à humanidade
a certeza de que havia alcançado suficiente poder
técnico para destruir eventualmente toda a vida na
Terra. Para o autor, também foi no período pós-
guerra, com a chegada do homem à lua, que veio
a descoberta da finitude dos recursos naturais da
Terra, em sua visão, um paradoxo ${ }^{38}$.

A dimensão do pensamento preservacionista amplifica os ideais do ambientalismo contemporâneo, que pretende alertar as pessoas sobre o risco do consumo exagerado e do desperdício de recursos essenciais à vida, como a água.

Vê-se, portanto, que a participação da coletividade nesse processo é o ponto de partida para uma mudança progressiva de hábitos, que ajude a humanidade a alcançar um estilo de vida e consumo mais adequados à real capacidade da Terra.

\section{Crise socioambiental na modernidade}

A modernidade está baseada na ressignificação teórica dos conhecimentos técnico-científico para a resolução das problematizações que surgem com a interação social. A busca por uma equação ou símbolo matemático-científico que expresse a causa de todos os males é uma marca da contemporaneidade, período histórico em que a ciência, como razão estratégica para os Estados, ganha força como meio para a obtenção de soluções verdadeiras, que ofereçam uma resposta para os

38 ARAÚJO, José Salvador Pereira. Direitos humanos, meio ambiente e sustentabilidade. Revista Direito Ambiental e Sociedade, Caxias do Sul, v. 3, no 1, p. 289-317, jan./jun. 2013, p. 295. problemas humanos.

A modernidade representa a queda dos antigos paradigmas que impunham o sentido da vida, tendo em vista que a racionalidade instrumental ganha força. A razão como instrumento para o sistema de consumo perde força, à medida que se toma consciência de que uma crise ambiental está sendo gerada pela impossibilidade de se gerir o atual sistema de exploração da natureza.

\begin{abstract}
A racionalidade instrumental, típica da modernidade, que tem como fundamento a ética materialista do ter, apresenta sinais de exaustão à medida que as consequências desta mesma modernidade vislumbram um horizonte ambiental de crise, de insustentabilidade e colapso dos ecossistemas ${ }^{39}$.
\end{abstract}

A dificuldade de se imaginar como o futuro poderá ser administrado tendo em vista uma grave crise ambiental, agravada pela falta de alimentos e de água, indica que há um processo reverso em relação ao desenvolvimento tecnológico e à expansão dos saberes técnico-cientifico: a humanidade polui mais do que nunca. Segundo os autores,

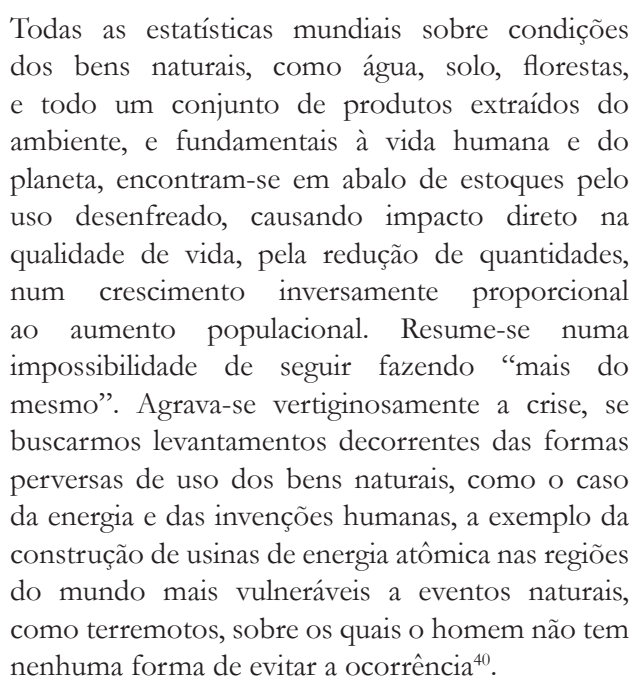

Assim, o uso irrestrito dos recursos do planeta, pensando-se em estudos que demonstram que os recursos naturais, como a água, diminuem, vertiginosamente, a cada ano, deve ser mudado para um modelo de desenvolvimento sustentável, que valorize o compartilhamento de bens e o consumo consciente.

39 CENCI, Daniel Rubens; BURMANN, Tatiana Kessler. Direitos humanos, sustentabilidade ambiental, consumo e cidadania. Revista Direitos Humanos e Democracia, Santa Rosa, v. 1, no 2, p. 131-157, jul./dez. 2013, p. 135.

40 CENCI, Daniel Rubens; BURMANN, Tatiana Kessler. Direitos humanos, sustentabilidade ambiental, consumo e cidadania. Revista Direitos Humanos e Democracia, Santa Rosa, v. 1, no 2, p. 131-157, jul./dez. 2013, p. 146. 


\section{Considerações finais}

O presente trabalho buscou repensar a produção material das sociedades como modelo potencialmente destrutivo para os ecossistemas e suas demais estruturas biológicas. Nesse sentido, a preservação do meio ambiente se impõe como necessidade para dar sentido real ao conceito de cidadania, incorporando os indivíduos como agentes de uma mudança que requer a modificação completa do sistema de produção capitalista.

O desenvolvimento sustentável é uma questão de direitos humanos, indubitavelmente. Não pode haver desenvolvimento social, isto é, distribuição equitativa de riquezas e a oferta de acesso aos direitos básicos sem que o meio ambiente, como elemento constituinte da cidadania, não esteja em equilíbrio com as aspirações humanas.

As grandes promessas da modernidade estão centradas na evolução dos conhecimentos científicos e tecnológicos em detrimento do melhoramento dos métodos de gestão dos recursos naturais. Essa questão é um ponto chave para que seja compreendida a importância da preservação ambiental.

Os surgimentos de novos movimentos globais que expressam preocupação com a perda de biodiversidade no planeta e a destruição dos ecossistemas são uma alternativa interessante para a economia mundial.

Os novos conhecimentos que se acumulam ao longo dos anos devem estar, também, à serviço do aperfeiçoamento de um modelo de vida sustentável, que permita a melhoria na qualidade de vida das populações.

Nesse contexto, os BRICS, "motores" da economia mundial, aparecem como possíveis líderes de uma revolução ambiental, que nasce com financiamento tecnológico e apoio dos países considerados desenvolvidos, sendo certo que a mudança de estrutura para servir não somente os objetivos econômicos, mas também ambientais e sociais surge como um desafio para os emergentes devendo ser pensada regionalmente para ser refletida globalmente.

Igualmente, a busca pela sustentabilidade tem que operacionalizar novas tecnologias para se adequar ao atual modelo ambiental que é referência no planeta, afastando da sociedade a adoção de um estilo de vida não sustentável, crescimento econômico desordenado e recursos poucos eficientes, tendo em vista que se persistirem as atuais tendências globais de degradação ambiental, a progressiva melhora nos índices socioambientais pelos BRICS poderá ser interrompida.

Para tanto, o estudo procurou fazer um detalhamento das perspectivas socioambientais que fazem parte das políticas públicas dos BRICS, tendo em mente a concepção de que a garantia de um meio ambiente limpo é parte dos direitos fundamentais do homem.

Procurar identidades de cada país envolvendo trajetória de negociações, reinvindicações e propostas estratégicas para o desenvolvimento das questões socioambientais aparecem como uma saída aos novos desafios, de modo que haja por exemplo, a redução de emissões de gases de efeito estufa, diminuição da poluição ambiental contribuindo com as questões das mudanças climáticas e a implantação de projetos de mecanismos de desenvolvimento limpo, através do uso de tecnologias que contemplam as energias renováveis, dando aos BRICS posições de destaque em seus discursos perante o mundo.

Com isso, os BRICS apresentarão possibilidades de desenvolvimento sustentável, todavia, maior cuidado e esforço deve ser empregado na promoção do desenvolvimento ambiental sustentável dos BRICS, além de medidas para promover a continuidade dos avanços no desenvolvimento econômico e social, havendo a necessidade de uma agenda sustentável comum dos BRICS com importantes políticas voltadas à mitigação dos impactos ambientais negativos impulsionando a proteção ambiental como fator essencial para o meio internacional.

Nesse passo, ainda constata-se que os BRICS ainda carecem de um desenvolvimento ligado à maioria dos problemas ligados à sustentabilidade. Por outro lado, já é possível observar inúmeros avanços como um Plano Nacional sobre Mudança do Clima no Brasil, que leva em conta a preservação da Amazônia e estabelece a meta de aumento da participação de fontes renováveis e de energias limpas na matriz energética do país, metas relacionadas à proteção ambiental e a eficiência energética na China e Rússia, bem como a realização de projetos de reflorestamento e a diversificação das fontes que compõem a matriz nacional na índia.

Todos esses avanços fazem parte de uma longa caminhada rumo à construção de uma futura agenda sustentável, que perpassa pela busca do desenvolvimento sustentável, incentivando o agrupamento BRICS; pela coordenação sistemática dos seus objetivos comuns, 
obtida com a maior institucionalização do Bloco; e, pela maior participação e comprometimento dos Estados BRICS e do agrupamento nos encontros internacionais de meio ambiente e temas afins.

\section{REFERÊNCIAS}

ARAÚJO, José Salvador Pereira. Direitos humanos, meio ambiente e sustentabilidade. Revista Direito Ambiental e Sociedade, Caxias do Sul, v. 3, n 1, p. 289-317, jan./jun. 2013. Disponível em: <http://www.ucs. $\mathrm{br} / \mathrm{etc} / \mathrm{revistas} /$ index.php/direitoambiental/article/ view/3627/2077>. Acesso em: 05 dez. 2016.

BIZAWU, Kiwonghi; GOMES, Magno Federici. Oil exploitation at Virunga park as a threat to the environment and to endangered animal species. Veredas do Direito, Belo Horizonte, v. 13, no 27, p. 11-29, set./dez. 2016. Disponível em: < http:/ /www.domhelder.edu.br/ revista/index.php/veredas/article/view/897>. Acesso em: 19 jan. 2017.

CARVALHO, Natália Leal de, et al. Desenvolvimento sustentável x desenvolvimento econômico. Revista Monografias Ambientais, Santa Maria, v. 14, n 3, p. 109-117, set./dez. 2015. Disponível em: <https://periodicos. ufsm.br/remoa/article/view/17768>. Acesso em: 12 nov. 2016.

CAVALCANTI, Clóvis. Desenvolvimento e natureza: estudos para uma sociedade sustentável. São Paulo: Cortez, 1995.

CENCI, Daniel Rubens; BURMANN, Tatiana Kessler. Direitos humanos, sustentabilidade ambiental, consumo e cidadania. Revista Direitos Humanos e Democracia, Santa Rosa, v. 1, no 2, p. 131-157, jul./dez. 2013. Disponível em: <https://www.revistas.unijui.edu.br/index.php/direitoshumanosedemocracia/article/viewFile/338/2460>. Acesso em: 07 nov. 2016.

CUNHA, Ciro Leal M. da. Terrorismo internacional e a política externa brasileira após o 11 de setembro. Brasília: Fundação Alexandre de Gusmão, 2009. Disponível em: <http://funag.gov.br/loja/download/617-Terrorismo_Internacional_E_PolItica_Externa_Brasileira_ Apos_O_11_De_Setembro.pdf>. Acesso em: 07 nov. 2016.

CUNHA, Eleonora Schettini Martins; SÁTYRO, Natália Guimarães Duarte. The path of Brazilian Social Assi- stance Policy post-1988: the significance of institutions and ideas. Brazilian Political Science Review, São Paulo, v. 8, no 1, p. 80-108, 2014. Disponível em: <http://www. bpsr.org.br/index.php/bpsr/article/view/190/176>. Acesso em: 07 nov. 2016.

FERREIRA, Leila da Costa. A questão ambiental: sustentabilidade e políticas públicas no Brasil. São Paulo: Boitempo Editorial, 1998.

FOOT, Rosemary. O poder chinês e a ideia de um país responsável. In: NEDAL, D.; SPEKTOR, M. (Orgs.). O que a China quer? Rio de Janeiro: FGV, 2010. Cap. 1.

GANGULY, Sumit; MUKHERJI, Rahul. A Índia desde 1980. Rio de Janeiro: Apicuri, 2014.

HAAS, Marcel De. Russia's foreign security policy in the $21^{\text {st }}$ century: Putin, Medvedev and beyond. London: Routledge, 2010. Cap. 6, p. 156-181.

HONGYI, Lai; WONG, John. The Hu-Wen. New Deal. In: HONGYI, L.; WONG, J. (eds.). China into the $H u$-Wen era: policy initiatives and challenges. Cingapura: World Scientific, 2006. Cap. I, p. 3-33.

INTERNATIONAL MONETARY FUND. World Economic Outlook. A survey by the staff of the International Monetary Fund. Washington, DC: International Monetary Fund, 2014. Disponível em: < https://www.imf. org/external/pubs/ft/weo/2014/02/pdf/text.pdf >. Acesso em: 05 dez. 2016.

LEGRO, Jeffrey. O que a China vai querer? As futuras intenções de uma potência em ascensão. In: NEDAL, D.; SPEKTOR, M. (orgs.). O que a China quer? Rio de Janeiro: FGV, 2010. Cap. 4.

LOPES, Patrick Fernandes; et al. Desenvolvimento sustentável: uma análise contextual dos BRICS. Encontro Internacional sobre Gestão empresarial e ambiental (ENGEMA), São Paulo, 2013. Disponível em: < http://engemausp.submissao.com.br/17/anais/arquivos/66.pdf > . Acesso em: 15 nov. 2016.

LUKIN, Alexander. China's new foreign policy strategy and Russia's concerns. Rasprave I članci, 2011. Nova spoljnopoliticka strategija Kine i rabrinutost Rusije, MP 4, p. 483-504, 2011. Disponível em: < http://www.doiserbia. nb.rs/img/doi/0025-8555/2011/0025-85551104483L. pdf>. Acesso em: 12 nov. 2016.

MACIEL, Marcela Albuquerque; VARELLA, Marcelo Dias. O direito internacional ambiental como sistema complexo: características, metodologias e instrumentos 
de análise. Veredas do Direito. Belo Horizonte: v. 13, $\mathrm{n}^{\circ} 26$, p. 235-261, maio/ago. 2016. Disponível em: <http:// www.domhelder.edu.br/revista/index.php/veredas/article/view/764/506>. Acesso em: 08 dez. 2016.

MELVILLE, Andrei; SHAKLEINA, Tatiana. Russian foreign policy in transition: concepts and realities. Budapest, New York: Central European University Press, 2005.

MENDES, Marina Ceccato. Desenvolvimento sustentável. 2008. Disponível em: <http://educar.sc.usp.br/biologia/textos/m_a_txt2.html >. Acesso em: 23 nov. 2016.

MIGON, Eduardo Xavier Ferreira. A inserção dos assuntos de defesa na agenda das políticas públicas. Tese (Doutorado) - Doutorado em Ciências Militares, Escola de Comando e Estado-Maior do Exército, Rio de Janeiro, 2011. Núcleo de Estudos Estratégicos, Porto Alegre, 2011. Disponível em: <http://www.nee.cms.eb.mil.br/ index.php/trabalhos-academicos/105-a-insercao-dosassuntos-de-defesa-na-agenda-das-politicas-publicas $>$. Acesso em: 07 nov. 2016.

, C. Raja. A Índia e o equilíbrio de poder. In: STUENKEL, O. (org.). A Índia na ordem global. Rio de Janeiro: FGV, 2013.

MORAES, Rodrigo Fracalossi de; SOUZA, André de Mello e. A relevância do terrorismo na política internacional contemporânea e suas implicações para o Brasil. In: SOUZA, A. de M. e; NASSER, R. M.; MORAES, R. F. de. (orgs.). Do 11 de setembro de 2001 à guerra ao terror: reflexões sobre o terrorismo no século XXI. Brasília: IPEA, 2014. Cap. 1, p. 13-45. Disponível em: < http:// www.ipea.gov.br/portal/images/stories/PDFs/livros/ livros/livro_11\%20de $\% 20$ setembro_web.pdf $>$. Acesso em: 05 dez. 2016.

NARLIKAR, Amrita. All that glitters is not gold: India's rise to power. Third World Quarterly. Cambridge: v. 28, $\mathrm{n}^{\circ}$ 5, p. 983-996, maio 2007.

NASCIMENTO, André Jansen do. Contratações públicas no âmbito da OMC: a política legislativa brasileira à luz do direito ao desenvolvimento. Revista de Direito
Internacional, Brasília, v. 12, no 2, p. 191-209, 2014. Disponível em: <https://www.publicacoesacademicas. uniceub.br/rdi/article/view/3087/pdf $>$. Acesso em: 01 fev. 2017.

SANTOS, Fabiano Guilherme dos. O Poder Legislativo no presidencialismo de coalizão. Belo Horizonte: UFMG, 2003.

SHEYING, Chen. General public policy and development strategy. China Perspectives, Hong Jong: $n^{\circ} 48$, p. 1-11, jul./ago. 2003. Disponível em: <http://chinaperspectives.revues.org/388 >. Acesso e: 12 nov. 2016.

SU, Hao. Harmonious world: the conceived international order in framework of China's Foreign Affairs. In: IIDA, M. (ed.). China's shift. global strategy of the rising power. Tokyo: The National Institute for Defense Studies, 2009. Cap. 2, p. 29-55. Disponível em: < http:// www.nids.mod.go.jp/english/publication/joint_research/series3/pdf/3-2.pdf>. Acesso e: 12 nov. 2016.

THORUN, Christian. Explaining change in Russian foreign policy: the role of ideas in post-soviet russia's conduct towards the west. Hampshire: Palgrave Macmillan, 2009.

TSOUKALIS, Loukas. The shattering of illusions - and what next? Journal of Common Market Studies, Malden: v. 49, no 1, p. 19-44, set. 2011.

TSYGANKOV, Andrei P. Russia's foreign policy: change and continuity in national identity. New York: Rowman \& Littlefield Publishers, 2016.

VELASCO JÚNIOR, Paulo Afonso. Autônoma, politizada, anticonformista, não subserviente: uma política externa fiel à sua tradição. Revista Insight Inteligência, Rio de Janeiro: ano XIV, no 55, p. 118-124, out./nov./dez. 2011. Disponível em: <http://insightinteligencia.com. br/pdfs/55.pdf>. Acesso em: 05 dez. 2016.

WORLD BUSINESS COUNCIL FOR SUSTAINABLE DEVELOPMENT. Greenhouse gas emissions keep rising. 2010. Disponível em: <https://noviental.files. wordpress.com/2011/01/emissoes-co2-grupopaiseswbcsd-2010.jpg >. Acesso em: 01 fev. 2017. 


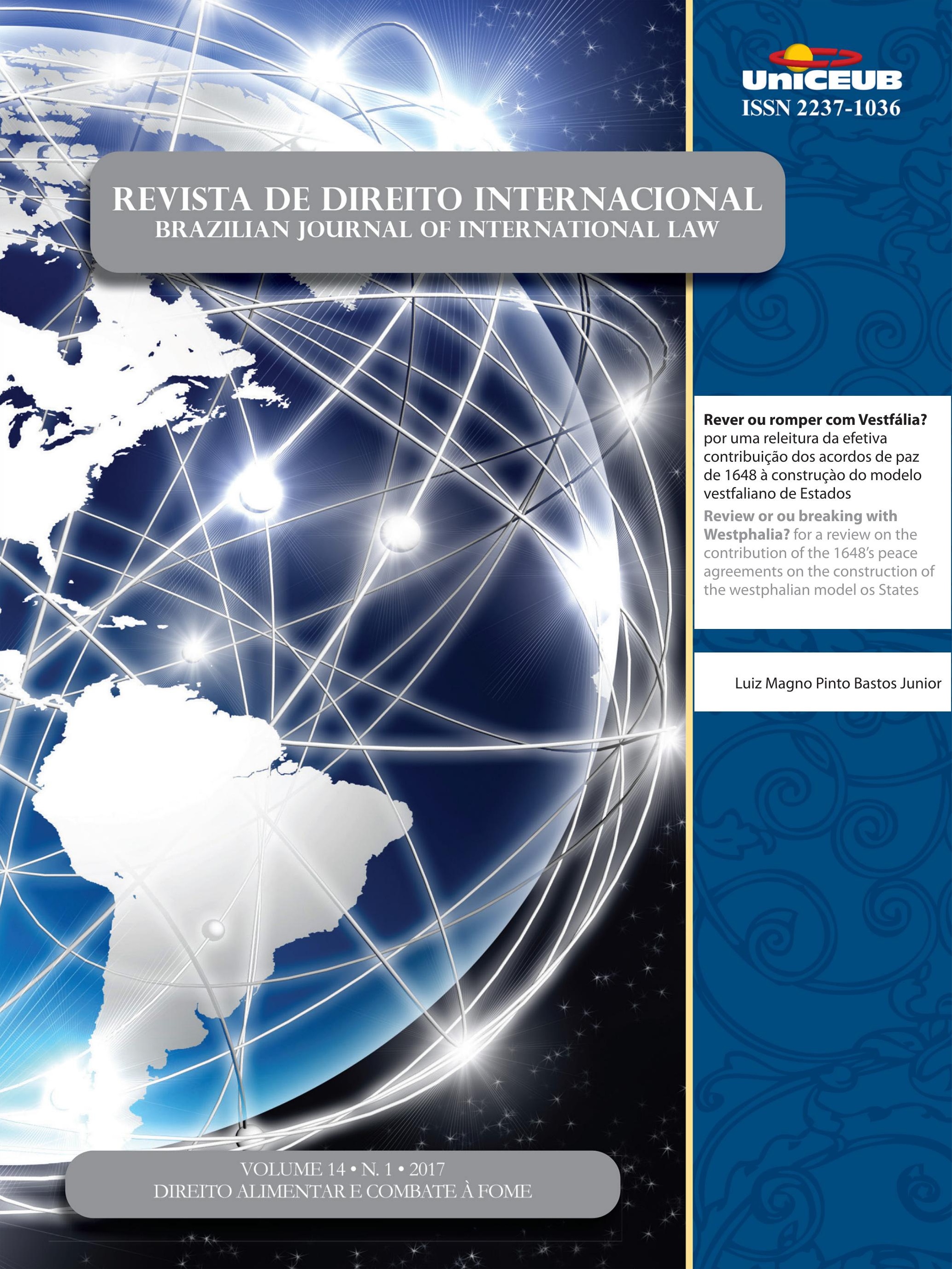




\section{Rever ou romper com Vestfália? por uma releitura da efetiva contribuição dos acordos de paz de 1648 à construçào do modelo vestfaliano de Estados*}

\author{
Review or ou breaking with Westphalia? \\ for a review on the contribution of the 1648's \\ peace agreements on the construction of the \\ westphalian model os States
}

Luiz Magno Pinto Bastos Junior**

\section{Resumo}

Este artigo tem por objetivo desconstruir as narrativas-padrão sobre o significado histórico dos tratados que puseram fim à Guerra dos Trinta Anos (os tratados de Vestfália) chamando à atenção para a dimensão simbólica que foi construída tanto no processo de consolidação da noção de soberania, quanto em face do entusiasmo com que a Carta da ONU de 1948 foi recebida por estudiosos da teoria das relações internacionais. Para tanto, empreendeu-se um duplo esforço de sistematização das referências bibliográficas levantadas, de um lado, de consolidar as narrativas que constituem o discurso padrão em torno do significado e do alcance dos tratados de Vestfália para a afirmação do sistema de estados; de outro, de reunir análises voltadas à desconstrução destas narrativas comuns, tendo por referência três dimensões específicas, o contexto histório, os aspectos supostamente inovadores das disposições convencionais e o papel desempenhado para a consolidação do sistema de Estados. Apesar de ser possível afirmar que os tratados de Paz de 1648 não são compatíveis com o que se conhece por "sistema vestfaliano", reconhece-se que a alusão aos mesmos se reveste de inegável força simbólica. O aspecto realmente diferenciado dos referidos acordos não decorre tanto de sua feitção internacional, mas sobretudo dos arranjos institucionais que a marcam a constituição do Império Sacro Romano. Isto posto, desconstruir Vestfáilia importa em empreender um convite que se revisite Vestfália, sobretudo em face do impacto que os Tratados tiveram para a consolidação de um sistema multinivelado de autoridades no interior do império e de suas conexões internacionais.

Palavras-chave: Guerra dos Trinta Anos. Tratados de Vestfália. Sistema de Estados. Desconstrução.

\section{Abstract}

This article aims to contribute to the desconstruction of the standard-narratives about the historical meaning of the treaties that ended the Thirty 
Years War (Peace Agreements of Westphalia) drawing attention to the symbolic dimension that had been built both during the consolidation process of the concept of sovereignty as because of the influence of those international relations scholars that celebrated the promulgation of the the UN Charter of 1948. Therefore, it has undertook a dual effort to systematize the references raised on the one hand, to consolidate the narratives that constitute the standard narratives about the meaning and scope of the Westphalia treaties for the affirmation of the international system of states; the other, to gather analysis focused on deconstructing these common narratives, with reference to three specific dimensions: the historiographical context, the supposedly innovative aspects of peace agreements and the role on the consolidation of system of states. Although it is possible to assert that the peace treaties of 1648 are not compatible with what is known as the "Westphalian system", it is recognized that the reference to them is of undeniable symbolic nature. What emerges as really differentiated from those agreements derives not so much from its international dimension, but especially the institutional arrangements that build the constitution of the Holy Roman Empire. That said, deconstructing Westphalia invites to revisit Westphalia, particularly in view of the impact that the treaties had on the consolidation of a multi-leveled system of authorities within the empire and its international connections.

Key-wors: Thirty Years War. Westphalia Treaties (1648). International system of states. Deconstruction.

\section{INTRODUÇÃo}

Os Tratados de Paz de Vestfália (1648) foram firmados com o escopo deliberado de porem termo à sangrenta Guerra dos Trinta Anos ${ }^{1}$. Este conflito figura na lista dos maiores conflitos mundiais, responsável pela morte de pelo menos 8 milhões de pessoas em uma época em que o continente europeu não contava

\footnotetext{
1 Nem todas as tensões beligerantes foram finalizadas em 1648. A guerra entre França e Espanha terminou, em 1659, com a Paz dos Pirineus. A guerra entre Suécia e Polônia, em 1660, com a Paz de Olivia. A guerra entre Suécia e Dinamarca, em 1660, com a Paz de Copenhagen BEAULAC, Stéphane. The Westphalian legal orthodoxy: mith or reality? The Journal of the History of International Law, v. 2, n. 2, 148-177, 2000. p. 161.
}

sequer com 100 milhões de habitantes ${ }^{2}$, sendo usualmente reconhecido como o primeiro conflito europeu de grandes proporções por ter envolvido a maioria das potências do continente europeu ${ }^{3}$. A tradição romântica alemã associa o potencial destrutivo da guerra e o intrincado arranjo institucional constituído a partir dos Tratados, como as razões justificadoras do "atraso" na consolidação do Estado alemão ${ }^{4}$.

Estes tratados são comumente considerados como marcos constitutivos do moderno sistema de Estados. Esta associação é tão estreita que é frequente a menção à existência de uma ordem vestfaliana pautada pela tríade Estado-soberania-território. O reforço da ideia de que o Sistema de Estados nasce em Vestfália, inclusive, se dá em face das narrativas frequentes à existência de modelos pós-vestfalianos que colocam em xeque a noção de soberania consolidada no século XIX. O imaginário político evocado por Vestfália exige, pois, que se explorem seus múltiplos significados e as noções de soberania e de fronteiras por este modelo veiculadas.

Este artigo tem por objetivo desconstruir as narrativas-padrão sobre o significado histórico dos tratados que puseram fim à Guerra dos Trinta Anos (os tratados de Vestfália) chamando à atenção para a dimensão simbólica que foi construída tanto no processo de consolidação da noção de soberania, quanto em face do entusiasmo com que a Carta da ONU de 1948 foi recebida por estudiosos da teoria das relações internacionais.

Para tanto, empreendeu-se um duplo esforço de sistematização das referências bibliográficas levantadas, de um lado, em consolidar as narrativas que constituem o discurso padrão em torno do significado e do alcance dos tratados de Vestfália para a afirmação do sistema de estados; de outro, de reunir análises voltadas à desconstrução destas narrativas comuns, tendo por referência três dimensões específicas, o contexto histório, os aspectos supostamente inovadores das disposições

2 WILSON, Peter. The causes of Thirty Years War. The English Historical Review, Oxford Journals, v. 123, n. 502, p. 554-586, 2008. p. 554.

3 Cf. GROSS, Leo. The Peace of Westphalia, 1648-1948. American Journal of International Law, American Society of International Law, v. 42, n. 1, p. 20-41, Jan. 1948.

4 Cf. LESAFFER, Randall. The Westphalia peace treaties and the development of the tradition of great European peace treaties prior to 1648. Grotiana: a journal under the auspices of the Foundation Grotiana, v. 18, p. 71-95, 1997; OSIANDER, Andreas. Sovereignty, international relations, and the Westphalian myth. International Organization, Cambridge Journals, v. 2, n. 55, p. 251-287, Spring 2001. 
convencionais e o papel desempenhado para a consolidação do sistema de Estados. Estas três perspectivas são abordadas em cada uma das seções que se sucedem.

\section{2. (Re)leituras SObre A NATUREZA E 0 SIGNIFICADO da GuerRa dos Trinta Anos}

Nesta seção, pretende-se reproduzir a crítica em torno da existência de uma narrativa-padrão acerca do significado da Guerra dos Trinta anos e do seu papel tradicionalmente associado à origem do sistema de Estados. Esta narrativa-padrão reforça a função simbólica atribuída aos tratados de Vestfália e, por conseguinte, a suposta ordem internacional de estados soberanos dele emergente.

De acordo com Peter Wilson, apesar de existirem múltiplas leituras sobre a sucessão de eventos associados à Guerra dos Trinta anos (seus antecedentes imediatos e seu desfecho com a celebração dos Tratados de Paz de 1648), elas não sucitam abordagens alternativas à visão compartilhada, integrando aquilo que ele denomina como interpretação-padrão ${ }^{5}$.

De acordo com o mainstream, a Guerra dos Trinta Anos é descrita como conflito que tem início na revolta dos protestantes Boêmios contra os católicos da Casa de Habsburgo, levada a efeito em 1618, através do incidente que se convencionou chamar de Defenestração de Praga ${ }^{6}$. Trata-se de um conflito de origem religiosa e, essencialmente interno à Alemanha, que teria se espalhado em círculos concêntricos por vasta região da Europa Central. Este processo de espraiamento do conflito, em um primeiro momento, teria sido resultado da existência de ligações entre as forças envolvidas na

5 Para o autor, esta interpretação-padrão funciona como um refúgio conveniente quando os historiadores iniciam o processo de seleção do material de pesquisa. WILSON, Peter. The causes of Thirty Years War. The English Historical Review, Oxford Journals, v. 123, n. 502 , p. $554-586,2008$. p. 555

6 Considerada por muitos o incidente que desencadeou a sequência de hostilidades que mais tarde passou a ser considerada como Guerra dos Trinta Anos. De acordo com Stephan Beaulac, o incidente pode ser descrito sinteticamente nos seguintes termos "On 23 May 1618, a group of Protestants in Prague invaded the Imperial palace and threw two Catholic members of the Bohemian Council out a window, some 70 feet above the ground. The rarely told aspect of the story, however, is that the officials fell into a pile of manure and suffered only minor injuries!" Cf. BEAULAC, Stéphane. The Westphalian legal orthodoxy: mith or reality? The Journal of the History of International Law, v. 2, n. 2, 148-177, 2000. p. 160 revolta e diferentes potências católicas e protestantes (príncipes alemães e reinos "estrangeiros") e, em um momento subsequente, teria sido provocado pela intervenção direta das potências europeias de então, preocupadas tanto em impedir que tais conflitos religiosos se propagassem em seus próprios domínios, quanto em ampliar e consolidar seus interesses econômicos e políticos sobre a região ${ }^{7}$.

A cronologia da Guerra é comumente descrita através de fases sucessivas, cada qual começando com a entrada na guerra de uma potência beligerante: na primeira fase, a Boêmia (1618-1620), o conflito se restringe ao conflito entre o Imperador e os revoltosos nas diversas províncias sob o domínio dos Habsburgos e seus respectivos aliados alemães; na segunda fase, a Palatina (1620-1624), não obstante o conflito ainda se restringir ao interior do Império, ganhou proporções geográficas maiores já que se espalhou para o oeste e para o sul e contou com a entrada das forças espanholas que, como representantes da Casa de Habsburgo, vieram em seu auxílio; as fases seguintes representam a intervenção direta de potências estrangeiras, amplificando o alcance do conflito e o seu potencial destrutivo, seriam as fases Dinamarquesa (1625-1629), a Sueca (1630-1634) e a Francesa (1635-1648).

Se por um lado, esta tentativa de periodização-padrão "facilitaria" uma espécie de ordenação sistemática dos fatos, por outro, deixaria de conferir acento à intricada correlação de forças, interesses e padrões de justificação em jogo, tanto no plano "interno" ao "império", quanto em relação às repercussões externas decorrentes das interconexões dinásticas. Portanto, na visão do autor, qualquer tentativa de reduzir o conflito e suas repercussões a explicações monocausais representa uma simplificação arbitrária, incapaz de lançar luzes acerca das principais questões políticas em jogo.

Apesar de existir um significativo desacordo sobre as origens desta Guerra e, por conseguinte, em torno de seu impacto e seus significados possíveis, Peter Wilson relata a existência de duas principais espécies de narrativas concorrentes sobre as origens e sua natureza: a primeira, que enfatiza as ações humanas mediante a identificação de evidências empíricas que retratam as motivações e as justificativas declaradas daqueles envolvidos

7 Cf. OSIANDER, Andreas. Sovereignty, international relations, and the Westphalian myth. International Organization, Cambridge Journals, v. 2, n. 55, p. 251-287, Spring 2001 
na guerra; a segunda, que se constrói a partir de explanações estruturais que assinalam um longo processo de mudanças latentes que culminaram na deflagração do conflito. Estas perspectivas serão sumarizadas a seguir.

Em relação ao primeiro conjunto, as narrativas comumente são constituídas a partir de evidências empíricas que privilegiam a identificação das rivalidades inter-estatais $^{8}$, das motivações dos atores envolvidos no conflito ${ }^{9}$ e, sobretudo, das motivações políticas de cunho ideológico e teológico ${ }^{10}$. Esta guerra, emblemática pelas suas dimensões, teria possibilitado a consolidação das condições institucionais que resultaram no despontamento, como situação política fática ${ }^{11}$, dos Estados como ordens políticas coletivas ${ }^{12}$.

8 É comum referir-se à guerra como um conflito entre "dinastias rivais" pelo domínio do continente europeu FRANCA FILHO, Marcílio Toscano. O paradigma vestefealiano e o estado contemporâneo: o que 1648 tem ainda a dizer em 2008? In: NOVELINO, M; ALMEIDA FILHO, A. (Org.). Leituras complementares de direito constitucional: teoria do Estado. Salvador: Juspodivm, 2009. p. 69-93., p. 75 , em especial contra uma pretensão supostamente expansionista da Casa de Habsburgo OSIANDER, Andreas. Sovereignty, international relations, and the Westphalian myth. International Organization, Cambridge Journals, v. 2, n. 55, p. 251-287, Spring 2001.

9 Stéphane Beaulac defende que as potências estrangeiras intervieram no conflito com a finalidade de tutelarem seus próprios interesses expansionistas BEAULAC, Stéphane. The Westphalian model in defining international law: challenging the myth. Australian Journal of Legal History, v. 8, n. 2, p. 181-213, 2004. Andreas Osiander defende que o papel "libertador" da intervenção sueca e francesa em favor dos príncipes alemães protestantes, se coaduna com o discurso de legitimação da propaganda francesa e foi enfatizado por conta daquilo que ele chama de uma "ideologia da soberania" OSIANDER, Andreas. Sovereignty, international relations, and the Westphalian myth. International Organization, Cambridge Journals, v. 2, n. 55, p. 251-287, Spring 2001.

10 Leo Gross ressalta a Guerra dos Trinta Anos e os Tratados de Vestfália como período decisivo em que se consolida o processo de desteologização (laicização) do fundamento de autoridade temporal. GROSS, Leo. The Peace of Westphalia, 1648-1948. American Journal of International Law, American Society of International Law, v. 42, n. 1, p. 20-41, Jan. 1948

11 Cf. MORGENTHAU, Hans J. The problem of sovereignty reconsidered. Columbia Law Review, New York, v. 48, p. 341-365, 1948. p. 341 .

12 Este padrão de agregação do poder social, segundo John Ruggie, tem nas guerras levadas a efeito no território europeu (do século XVII e XVIII), seus principais vetores de transformação. Para o autor, a Guerra dos Trinta Anos representa o apogeu das chamadas guerras constitutivas, no curso da qual foram forjados diferentes processos de organização do poder social. $\mathrm{O}$ autor sustenta que a agregação de poder social constitui-se através de três níveis: estrutura social doméstica, formação do território e formação de identidades coletivas territoriais. Ao referir-se às guerras ocorridas neste período, sustenta que elas evidenciam uma espécie de desenvolvimento e consolidação do princípio da legitimidade internacional. Cf. RUGGIE, John Gerard. Territoriality and beyond: problematizing
Neste sentido, são comuns as narrativas que se referem à Guerra como um conflito de feição nitidamente internacional entre potências europeias, tendo como leitmotiv a intolerância religiosa e a crise do fundamento universal da autoridade. Representariam o ponto culminante da tensão crescente entre o universalismo cristão e o localismo das diferentes formas de expressão política. Esta tensão forja grande parte das narrativas para justificar as dimensões da guerra, o que, de acordo com a leitura crítica de Andreas Osiander, parece reduzir o embate a uma oposição entre forças universalistas e particularistas:

[d]e um lado, estavam os atores universalistas: o Imperador e o Rei Espanhol, ambos membros da dinastia de Habsburgos. Fiéis à Igreja de Roma, eles reivindicavam seu direito, e o do Papa, de controlar a cristandade em sua totalidade. Seus oponentes eram os atores particularistas, especialmente a Dinamarca, os Países Baixos, a França e a Suécia, assim como os príncipes alemães. Estes atores rejeitavam a supremacia imperial e (em grande parte) a autoridade do Papa, defendendo ao invés, o direito de todos os estados à independência completa (soberania). ${ }^{13} 14$

Em relação ao segundo conjunto de narrativas, não raro são encontradas referências quanto à inevitabildade do conflito ${ }^{15}$. Tais narrativas envolvem diferentes análi-

modernity in international relations. International organization, Cambridge Journals, v. 47, n. 1, p. 139-174, Winter, 1993. p. 162-165.

13 Tradução livre do autor do seguinte trecho: "On one side were the 'univeralist' actors: the emperor and the Spanish king, both members of the Habsburg dynasty. Loyal to the Church of Rome, they asserted their right, and that of the Pope, to control Christendom in it is entirety. Their opponents were the "particularist" actors, specifically Denmark, the Dutch Republic, France, and Sweden, as well as the German princes. These actors rejected imperial overlordship and (for the most part) the authority of the Pope, upholding instead the right of all states to full independence ("sovereignty")". OSIANDER, Andreas. Sovereignty, international relations, and the Westphalian myth. International Organization, Cambridge Journals, v. 2, n. 55 , p. 251-287, Spring 2001. p. 252

14 Reproduzindo quase literalmente este discurso, pode-se transcrever a lição de Adam Watson que em obra considerada uma referência no estudo das relações internacionais refere-se a Vestfália como uma comunidade de estados anti-hegemônica, assinalando, textualmente: "The European society of states evolved out of the struggle between the forces tending towards a hegemonial order and those which succeeded in pushing the new Europe towards the independences end of our spectrum. The decisive feature of this process was the general settlement negotiated in Westphalia in the middle of the century after the exhausting Thirty Years War. The Westphalian settlement was the charter of a Europe permanently organized on an anti-hegemonial principle". WATSON, Adam. The evolution of international society. London: Routledge, 1992. p.182

15 Peter Wilson identifica inúmeras abordagens que defendem a inevitabilidade do conflito, tanto a partir de uma perspectiva da escola 
ses que fazem transparecer: uma tensão crescente entre forças políticas antagônicas sobre a autoridade (autoridades estas progressivamente estruturadas em bases territoriais); o fracionamento de "uma ordem política medieval" constituída sobre o pressuposto de existência de uma "comunidade normativa de cristãos" reproduzida mediante discursos de legitimação relativamente consistentes $^{16}$; e, em especial, o acirramento da intolerância religiosa e os conflitos internos suscitados em face da consagração, na Paz de Augsburgo (em 1555), do princípio cujus regio, eius religio. As tensões internas colocavam em xeque a ideia de que o medievo vivia sob os auspícios de uma comunidade cristã (Christian commonwealth), de um mundo harmoniosamente organizado e governado, no planos espiritual e temporal, pelo Papa e pelo Imperador ${ }^{17}$.

Ademais, o que parece ser a crítica mais contundente do autor, inúmeras das narrativas e perspectivas teóricas que constituem (e reforçam) as narrativas-padrão padecem de inconsistências, incompletudes e carência de evidências empíricas. Tais "explicações históricas" prestam-se mais a justificar (reproduzir) determinadas premissas pressupostas, do que a submeter o conhecimento produzido à prova (à falseabilidade).

O problema de adotar esta narrativa-padrão, sem questionar-lhe os fundamentos empíricos, como faz

do direito internacional (que veem na Guerra dos Trinta Anos uma continuidade das tensões anteriormente instauradas entre as potências europeias), quanto a partir da escola alemã que via o acirramento da intolerância religiosa no interior do Império, em especial, a partir da Paz de Augsburgo de 1555, como uma "panela de pressão" prestes a explodir. Todavia, o autor opõe-se a esta inevitabilidade, aduzindo que (i) as diferentes abordagens carecem de abordagem metodológica suficiente ao pressuporem que as tensões religiosas seriam suficientes para o estopim da guerra e para as suas proporções; (ii) trata-se de uma narrativa conveniente, pois enfeixa cada um problema a partir de um feixe de eventos causalmente articulados, reconstruindo os eventos como uma espécie de retrospectiva WILSON, Peter. The causes of Thirty Years War. The English Historical Review, Oxford Journals, v. 123, n. 502, p. 554-586, 2008. p. 556-561. 16 Em que pese a multiplicidade de formas de organizações políticas locais, era possível reconhecer a existência de uma unidade relativamente consistente (em torno das ideias de Respublica Christiana e cristandade) dos discursos de legitimação, veiculada (e reproduzida) através de instituições como o Papado e o Sacro Império Romano LAFER, Celso. Os dilemas da soberania. In: Paradoxos e possibilidades: estudos sobre a ordem mundial e sobre a política exterior do Brasil num Sistema Internacional em Transformação. Rio de Janeiro: Nova Fronteira, 1982.

17 Cf. GROSS, Leo. The Peace of Westphalia, 1648-1948. American Journal of International Law, American Society of International Law, v. 42, n. 1, p. 20-41, Jan. 1948. p. 28.
Franca Filho ${ }^{18}$, consiste na reprodução de um discurso sobre a história, forjado pelo romantismo alemão do século XIX, que deixa de lado uma série de contingências e circunstâncias úteis à compreensão das transformações porque passava a Alemanha e as relações de poder ao final do medievo.

Como resultado desta desconfiança metodológica, é possível colocar em xeque a visão triunfalista do Estado (na sua feição embrionariamente moderna) sobre o universalismo obscurantista do medievo e, mais ainda, o papel efetivamente desempenhado pelos Tratados de Vestfália, para a consolidação do direito internacional em sua feição moderna e para a própria construção da ordem "vestfaliana" de estados, como se verá nas próximas seções.

\section{QUAL O SIGNIFICADO DOS ACORDOS DE PAZ DE VestFália?}

A Paz de Vestfália foi composta por dois acordos distintos, ambos firmados em 24.10.1648, tendo como uma das partes signatárias o Sacro Império Romano: o primeiro deles, o Tratado de Osnabrück, concluído com o Reino (protestante) da Suécia, e o segundo deles, o Tratado de Münster, firmado com o Reino (católico) da França. Tais documentos foram redigidos após longo processo de negociação que contou com a presença de representantes de outros Reinos e de mais de trezentos principados e Stände (corpos políticos autônomos ou quase-autônomos) do próprio Império ${ }^{19}$.

O processo de negociação destes acordos reuniu os principais governantes e plenipotenciários europeus da época. O ponto de destaque deste processo residia na própria forma com que os delegados se apresentavam. Esses delegados referiam-se a si mesmos como o "Senado do mundo cristão" 20 , em clara referência à pre-

18 Cf. FRANCA FILHO, Marcílio Toscano. Westphalia: a paradigm? A dialogue between Law, art and philosophy os science. The German Law Journal, v. 8, n. 10, p. 955-976, 2007

19 De acordo com Stéphane Beaulac, a insistência por parte da França e da Suécia da presença nas negociações de paz dos príncipes alemães representava uma estratégia deliberada daquelas potências de enfraquecerem a posição do Imperador vis-à-vis os Príncipes. BEAULAC, Stéphane. The Westphalian model in defining international law: challenging the myth. Australian Journal of Legal History, v. 8, n. 2, p. 181-213, 2004. p. 199.

20 Cf. PHILPOTT, Daniel. Revolutions in sovereignty: how ideas shapped modern international relations. Princenton: Princenton 
sunção de uma "respublica christiana" (ou cristandade), capaz de integra-los a uma única comunidade. Contudo, ao longo do processo de negociação, os contendores não se posicionavam como membros dessa comunidade universal, senão como representantes de unidades políticas particulares ${ }^{21}$.

Indubitavelmente, tais acordos revestem-se de significativa importância histórica, tanto pela dimensão das potências e interesses envolvidos, quanto pelas suas consequências na organização institucional do Império e na relativa estabilidade territorial das fronteiras neles definidas. Isso não está em jogo.

O que se pretende trazer à tona neste artigo, no entanto, é a inconsistência dos discursos que vêm nestes tratados a consagração da ideia de soberaia e da natureza plenipotenciária dos signatários. Muito pelo contrário, estes tratados não apresentam cláusulas substancialmente novas em relação aos acordos bilaterais interdinásticos do período. Sua relevância decorre da natureza dúplice ${ }^{22}$ de que os mesmos se revestiram, a um só tempo, constituíam-se como típicos acordos de paz da época (bilaterais ${ }^{23}$, portanto) celebrados entre forças beligerantes ${ }^{24}$ e como leis internas ao Império

University Press, 2001. p. 82

21 Cf. ESTEVES, Paulo. Para uma genealogia do Estado territorial soberano. Revista de Sociologia e Política, Curitiba, n. 27, p. 15-32, nov. 2006. p 23

22 "Before and during the congress there had been a lot of discussion between the Emperor on one side and France and the imperial Stände on the other side. The emperor claimed that he alone could and should represent the whole of the Empire. The Stände, supported by France, claimed that their participation and approval was necessary. The result was a compromise. The preamble and the final clauses concerning signatures stated that the Stände participated alongside the emperor in the making of the agreement. This did not necessarily indicate that the emperor could not bind the Empire by himself, though naturally in the future he would have to reckon with art. 8, par 1 IPO. [...] The Emperor could thus claim that the participation in the negotiations and final approval of his subjects was solely due to the constitutional character of the agreement". LESAFFER, Randall. The Westphalia peace treaties and the development of the tradition of great European peace treaties prior to 1648. Grotiana: a journal under the auspices of the Foundation Grotiana, v. 18, p. 71-95, 1997. p. 77.

23 Portanto, não se pode falar em um prenúncio de tratados multilaterais como parece fazer crer algumas leituras que reforçam o caráter constitutivo destes tratados para a consolidação de um sistema de Estados, como tendo estabelecido as bases daquilo que se convenciona chamar de Constitutio Westphalica FRANCA FILHO, Marcílio Toscano. O paradigma vestefealiano e o estado contemporâneo: o que 1648 tem ainda a dizer em 2008? In: NOVELINO, M; ALMEIDA FILHO, A. (Org.). Leituras complementares de direito constitucional: teoria do Estado. Salvador: Juspodivm, 2009. p. 69-93 24 BEAULAC, Stéphane. The Westphalian model in defining international law: challenging the myth. Australian Journal of Legal His- que estabeleciam importantes garantias institucionais que pretendiam acomodar a tensão entre as unidades políticas com forte coloração de intolerância religiosa ${ }^{25}$.

Nesta seção, pretende-se reproduzir as críticas a leituras recorrentes que atribuem a determinadas cláusulas destes acordos características dos tratados internacionais contemporâneos e da afirmação da noção de soberania a partir de suas cláusulas ${ }^{26}$. Defende-se aqui que o aspecto mais relevante destes acordos de paz consiste no arranjo institucional que eles produzem no seio do Sacro Império e o pacto de compromisso que resultou na fixação de parâmetros para tolerância religiosa ${ }^{27}$.

\subsection{Reflexão crítica sobre o caráter juridicamente inovador dos acordos de paz para o direito internacional contemporâneo}

Os acordos de Paz de Vestfália revestem-se de alto grau de complexidade uma vez que encerram dispositivos sobre diversas questões e são recheados de fórmulas típicas dos acordos de paz da época que, lidas hodiernamente, dificultam a compreensão de sua dimensão e da natureza das obrigações por tais documentos veiculados ${ }^{28}$. Esta multiplicidade de elementos concorre para que Stephan Krasner reconheça ser mais fácil ver os acordos de Paz como uma nova constituição para o Sacro Império Romano, do que os ver como se fossem o ponto inaugural do que viria se chamar de sistema vestfaliano ${ }^{29}$.

tory, v. 8, n. 2, p. 181-213, 2004. p. 198.

25 STRAUMANN, Benjamin. The Peace of Westphalia as a secular constitution. Constelations, v. 15, n. 2, p. 173-188, 2008.

26 Stephan Krasner, com a deliberada pretensão de desconstrução desta visão tradicional sobre Vestfália, chega a pontuar que os aspectos centrais destes tratados de Paz podem ser resumidos em duas questões: a primeira, relativa à forma com que o Império, que tinha de facto perdido a Guerra, deveria atender à demanda francesa e sueca por conquistas territoriais; a segunda, como lidar com as desordens religiosas que estavam dilacerando a Europa e ameaçando minar a estabilidade dos regimes políticos que se instituíam ao longo de todo o continente. Cf. KRASNER, Stephan. Rethinking the sovereign state model. Review of International Studies, Cambridge Journals, v. 27 , n. 5 , p. 17-42, Dec. 2001.

27 Neste sentido, Randal Lesaffer é ainda mais enfático ao dizer que talvez seja este arranjo político constitucional, a única inovação jurídica dos referidos tratados. Cf. LESAFFER, Randall. The Westphalia peace treaties and the development of the tradition of great European peace treaties prior to 1648. Grotiana: a journal under the auspices of the Foundation Grotiana, v. 18, p. 71-95, 1997.

28 LESAFFER, Randall. The Westphalia peace treaties and the development of the tradition of great European peace treaties prior to 1648. Grotiana: a journal under the auspices of the Foundation Grotiana, v. 18, p. 71-95, 1997.

29 KRASNER, Stephan. Rethinking the sovereign state model. 
Os referidos tratados envolvem aspectos ligados a diversas reivindicações dinásticas, a demandas por compensação pelo esforço de guerra e por perdas territoriais, ao problema decorrente da intolerância religiosa e das correlatas disputas de poder, à organização do Império e a previsão de garantias institucionais às diferentes comunidades políticas constituídas no seu interior ${ }^{30}$.

Considerando os objetivos do trabalho, pretende-se, a partir do esquema fornecido por Stéphane Beaulac, enfrentar brevemente estes dispositivos a partir da sua reunião em grupos temáticos, para, em seguida, apresentar algumas peculiaridades observadas por Randall Lesaffer. Antes, porém, convém enfrentar uma primeira questão, qual seja, o significado jurídico da menção, no artigo $1^{\circ}$ de ambos os tratados.

Os artigos de portada dos acordos fazem referência tanto às potências estrangeiras aliadas (e aderentes) das partes contratantes, quanto aos eleitores, aos príncipes e aos Stände do Império. Diferentes autores superdimensionam a presença destas múltiplas autoridades e potências nominadas, referindo-se a elas como um prenúncio de uma autêntica carta pan-europeia ${ }^{31}$, ou como uma espécie de antecipação de noção contemporânea de tratados multilaterais ${ }^{32}$, ou ainda como reconhecimento implícito da ideia de igualdade jurídica entre os Estados ${ }^{33}$.

Como explicita Lesaffer, após estudo detido sobre inúmeros tratados de Paz do medievo celebrados anteriormente à Vestfália ${ }^{34}$, a referência às diferentes forças beligerantes (internas e externas) logo após o preâmbulo dos tratados representava uma prática reiterada da

Review of International Studies, Cambridge Journals, v. 27, n. 5, p. 1742, Dec. 2001. p. 35.

30 KRASNER, Stephan. Rethinking the sovereign state model. Review of International Studies, Cambridge Journals, v. 27, n. 5, p. 1742, Dec. 2001. p. 35.

31 GROSS, Leo. The Peace of Westphalia, 1648-1948. American Journal of International Law, American Society of International Law, v. 42, n. 1, p. 20-41, Jan. 1948. p. 20.

32 Cf. FRANCA FILHO, Marcílio Toscano. O paradigma vestefealiano e o estado contemporâneo: o que 1648 tem ainda a dizer em 2008? In: NOVELINO, M; ALMEIDA FILHO, A. (Org.). Leituras complementares de direito constitucional: teoria do Estado. Salvador: Juspodivm, 2009.

33 Cf. LAFER, Celso. Os dilemas da soberania...

34 Randal Lesaffer realiza uma análise detida dos quinze maiores tratados europeus de paz no período compreendido entre 1450 e 1648, a fim de avaliar o grau de inovação jurídica dos documentos em questão. LESAFFER, Randall. The Westphalia peace treaties and the development of the tradition of great European peace treaties prior to 1648. Grotiana: a journal under the auspices of the Foundation Grotiana, v. 18, p. $71-95,1997$. p. 75 . época ${ }^{35}$ e não está ligada à enunciação das autoridades que detinham o poder de celebrar os tratados ${ }^{36}$. A inclusão destes diferentes atores nos acordos de paz decorria do propósito assumido por intermédio dos tratados em restaurar a paz e a amizade entre as diferentes forças beligerantes (dentre as quais, os próprios Stände do Império, alguns dos quais que lutaram contra as forças do Imperador) ${ }^{37}$. Portanto, como dito anteriormente, tais acordos mantinham a sua natureza tipicamente bilateral.

De volta à análise das cláusulas dos tratados, na lição de Stéphane Beaulac, as mesmas podem ser categorizadas a partir dos seguintes eixos temáticos: (i) questões religiosas, (ii) questões territoriais, e (iii) questões relativas ao poder de firmar obrigações internacionais ${ }^{38}$.

Indubitavelmente, (i) as cláusulas de natureza religiosa dos tratados representam parte relevante de seu legado ${ }^{39}$. Tais cláusulas consagravam inúmeras garantias relativas à tolerância religiosa aptas a disciplinarem as práticas religiosas no interior do Império (em que pesem terem sido veiculadas em um documento internacional). A fixação destes parâmetros normativos representou um importante passo adiante se consideradas as regras definidas por ocasião da Paz de Augsburgo (de 1555), já que, como um autêntico prelúdio da salvaguar-

35 O autor relata que esta fórmula era familiar a muitos dos tratados de paz do século XVI e XVII. Ademais, associada à prática de referenciar no preâmbulo dos tratados somente os governantes supremos presente desde o séculos XV e XVI, reforça a tese de que a menção aos sujeitos nos artigos iniciais do acordo de Paz não tinha nenhuma relação direta com o poder de celebrar tratados LESAFFER, Randall. The Westphalia peace treaties and the development of the tradition of great European peace treaties prior to 1648. Grotiana: a journal under the auspices of the Foundation Grotiana, v. 18, p. 71-95, 1997. p. 78.

36 Essa questão, frequentemente, é saudada como uma das primícias da modernidade nos Tratados de Vestfália GROSS, Leo. The Peace of Westphalia, 1648-1948. American Journal of International Law, American Society of International Law, v. 42, n. 1, p. 20-41, Jan. 1948; FRANCA FILHO, Marcílio Toscano. Westphalia: a paradigm? A dialogue between Law, art and philosophy os science. The German Law Journal, v. 8, n. 10, p. 955-976, 2007.

37 Cf. LESAFFER, Randall. The Westphalia peace treaties and the development of the tradition of great European peace treaties prior to 1648. Grotiana: a journal under the auspices of the Foundation Grotiana, v. 18, p. 71-95, 1997. p. 77-78.

38 BEAULAC, Stéphane. The Westphalian model in defining international law: challenging the myth. Australian Journal of Legal History, v. 8, n. 2, p. 181-213, 2004.

39 Como ressalta Leo Gross, ao reforçar a importância da inclusão em Vestfália destas cláusulas de garantia e de busca de soluções pacíficas, nos desdobramentos futuros das relações internacionais. GROSS, Leo. The Peace of Westphalia, 1648-1948. American Journal of International Law, American Society of International Law, v. 42, n. 1, p. 20-41, Jan. 1948. p. 24-26. 
da das chamadas liberdade dos modernos ${ }^{40}$, foram definidos inúmeros limites à autoridade dos príncipes, antes absoluta (cujus regio, eius religio), sobre a esfera da religião.

Dentre esses limites, podem ser destacadas as seguintes regras: os príncipes não poderiam obrigar que seus súditos fossem coercitivamente convertidos; era reconhecida uma relativa margem de liberdade de consciência através da qual eram conferidos autênticos direitos aos súditos de prática de serviços religiosos e de educação religiosa; e, mais significativamente ainda, assegurava entre católicos e protestantes, cláusulas de representação paritária em assembleias e órgãos de deliberação do Império ${ }^{41}$. Portanto, em que pese sua relevância, não se pode associar diretamente tais cláusulas à consolidação da soberania moderna, pelo contrário, já que tais regramentos importaram em autêntica restrição ${ }^{42}$ (imposta através de um instrumento internacional) à forma de organização interna ao próprio Império.

O (ii) segundo grupo de cláusulas reunidas por Stéphane Beaulac diz respeito às disputas territoriais, dimensão igualmente importante dos Tratados e que, da mesma forma, é reconhecida como parte representativa de seu legado. Sem dúvida alguma, pôde-se perceber uma relativa acomodação das fronteiras advindas dos referidos acordos de $\mathrm{Paz}^{43}$ e, mais ainda, é possível ver na ênfase atribuída às questões territoriais nestes documentos, efetivamente, um indício da importância crescente atribuída à territorialidade como traço constitutivo do modelo de organização do poder político em consolidação na Europa ${ }^{44}$.

Todavia, a questão territorial colocada em evidência pelos tratados, diferentemente do que propaga a visão tradicional $l^{45}$, não implicou no reconhecimento da inde-

40 A expressão refere-se à clássica contraposição formulada por Benjamin Constant. CONSTANT, Benjamin. A Liberdade dos Antigos Comparada com a dos Modernos. Revista Filosofia Politica, Porto Alegre, n. 2, 1985. Disponível em: < http://caosmose.net/candido/ unisinos/textos/benjamin.pdf>.

41 Cf. BEAULAC, Stéphane. The Westphalian model in defining international law: challenging the myth. Australian Journal of Legal History, v. 8, n. 2, p. 181-213, 2004. p. 198-204.

42 Restrição esta reforçada pela ideia de garantia das potências estrangeiras em relação ao descumprimento.

43 Cf. WATSON, Adam. The evolution of international society. London: Routledge, 1992.

44 Cf. RUGGIE, John Gerard. Territoriality and beyond: problematizing modernity in international relations. International organization, Cambridge Journals, v. 47, n. 1, p. 139-174, Winter, 1993.

45 Representativa desta visão compartilhada sobre a natureza dos impactos da Paz de Vestfália, é o seguinte trecho extraído de Martin van pendência soberana das potências públicas envolvidas, tanto no conflito, quanto nas negociações de paz, mas teria se materializado, nos referidos acordos, através da acomodação de múltiplos interesses, tanto de potências estrangeiras, quanto das forças políticas internas ao Império.

É possível afirmar isto a partir das seguintes inferências: (i) à época da assinatura dos tratados, a condição de autonomia das potências envolvidas (segundo a tradição do medievo) não lhes era questionada (era o caso da França, da Suécia, da Dinamarca, da Espanha e do próprio Império); (ii) diferentemente do que é apregoado, não se pode afirmar que alguns Estados tiveram sua existência constituída pelos referidos Tratados, como muitas narrativas afirmam ter sido o caso dos Países Baixos ${ }^{46}$ e da Confederação Suíça; e, por fim, (iii) a satisfação dos interesses expansionistas da Suécia e da França se deu através de múltiplas soluções que não se resolviam, simplesmente, na outorga de poderes "soberanos" sobre territórios do Império àqueles Reinos.

O (iii) terceiro grupo diz respeito ao chamado poder de celebrar tratados, reconhecido textualmente aos

Creveld: "A Paz de Vestfália, que, em 1648, encerrou a guerra, marcou o triunfo do monarca sobre o Império e a Igreja. O território imperial foi repartido. O reino da Suécia ficou com grande parte do litoral báltico, ganho que, ao final, não seria permanente, pois foi perdido mais tarde para a Prússia; o rei da França recebeu uma parte considerável da Alsácia, que estava destinada a permanecer em suas mãos. Os suíços, que haviam se distanciado das leis imperiais em 1499, finalmente se libertaram e, assim, alcançaram a independência completa, que ainda conservam. [...]. O oeste e o centro da Europa foram divididos entre potentados soberanos seculares - embora seu número, engrossado pelos príncipes alemães que receberam 'domínio territorial' ou Landhboheit, tenha passado bastante de quinze. Os que estavam dentro do Império receberam praticamente todos os privilégios da soberania, inclusive o direito de manter suas próprias forças armadas e, o que pelo menos em teoria lhes havia sido negado até então, o direito de fazer alianças entre si e com potências estrangeiras 'contanto que não se voltassem contra o imperador'. Esse acordo complicado foi garantido por dois príncipes não-imperiais, os reis da França e da Suécia. Assim, chegara-se ao ponto em que o próprio Império, em vez de proteger a paz dos outros, precisava de proteção." VAN CREVELD, Martin. Ascensão e declínio do Estado. São Paulo: M. Fontes, 2004. p. 121-2

46 Primeiro, porque o reconhecimento formal das Províncias Unidas dos Países Baixos foi feito através do Tratado de Paz assinado em 30.1.1648, entre Espanha e Países Baixos, em Münster. Segundo, porque desde longa data já se reconhecia a perda do controle dos Países Baixos da autoridade da Espanha. OSIANDER, Andreas. Sovereignty, international relations, and the Westphalian myth. International Organization, Cambridge Journals, v. 2, n. 55, p. 251-287, Spring 2001; LESAFFER, Randall. The Westphalia peace treaties and the development of the tradition of great European peace treaties prior to 1648. Grotiana: a journal under the auspices of the Foundation Grotiana, v. 18, p. 71-95, 1997. 
príncipes alemães, nada mais significava do que uma prática já consolidada antes da Guerra e que, a rigor, reforçava a sua condição de relativa "subordinação" ao Império, quando limitava o exercício destas prerrogativas $^{47}$. Portanto, não lhes foi atribuído, por força dos Tratados, autoridade soberana, do contrário, tais documentos reforçaram os vínculos institucionais que os ligavam ao Império, o que permitiu a consolidação do chamado Landshoheit ${ }^{48}$, conceito este que se erige a partir de um complexo "sistema de relações recíprocas entre unidades políticas autônomas que justamente não se baseavam no conceito de soberania" ${ }^{\prime 4}$.

Mesmo reconhecendo que parte da importância atribuída a Vestfália decorre de uma europeinização post factum da ordem constitucional alemã e da propagação de suas cláusulas de tolerância religiosa no cenário político europeu, Randall Lesaffer ${ }^{50}$ menciona a existência de três espécies de cláusulas que podem ter contribuído para que, a partir do século XIX, fosse possível insinuar a existência de uma intenção de estabelecer uma ordem internacional mais permanente (algo como uma constituição europeia embrionária). Tratam-se das seguintes disposições (todas do Tratado de Onsbrück): a primeira, o compromisso de solução pacífica ${ }^{51}$ (art. 17.5); a

47 KRASNER, Stephan. Rethinking the sovereign state model. Review of International Studies, Cambridge Journals, v. 27, n. 5, p. 1742, Dec. 2001. p. 37-38.

48 Reproduzindo o publicista alemão Johann Jacob Moser (1745), Andreas Osiander defende ser possível definir o Landshobeit dos Estados do Império como: "um direito que lhes pertenciam e que lhes habilitava em suas terras e territórios a comandar, a proibir, a decretar, a exigir coercitivamente e a omitir qualquer coisa, da mesma forma que qualquer outro governante, na medida em que não se encontrassem constrangidos pelas leis e tradições do Império, pelos tratados com os demais Estados e súditos, as liberdades e tradições antigas e bem-estabelecidas, e assim por diante" (destaque acrescido). Tradução livre de: "a right pertaining to them and empowering them in their lands and territories to command, to forbid, to undertake, or to omit everything that... pertains to any ruler, inasmuch as their hands are not tied by the laws and traditions of the empire, the treaties with their local estates and subjects, the latter's ancient and well-established freedoms and traditions, and the like". OSIANDER, Andreas. Sovereignty, international relations, and the Westphalian myth. International Organization, Cambridge Journals, v. 2, n. 55, p. 251-287, Spring 2001. p. 272.

49 OSIANDER, Andreas. Sovereignty, international relations, and the Westphalian myth. International Organization, Cambridge Journals, v. 2, n. 55, p. 251-287, Spring 2001. p. 270.

50 LESAFFER, Randall. The Westphalia peace treaties and the development of the tradition of great European peace treaties prior to 1648. Grotiana: a journal under the auspices of the Foundation Grotiana, v. 18 , p. $71-95,1997$. p. $79-83$.

51 A primeira cláusula refere-se ao compromisso firmado no tratado de que se tentasse solucionar eventual tensão decorrente do segunda, a cláusula de intervenção das partes signatárias em caso de desrespeito ao pacto ${ }^{52}$ (art. 17.6); e, a terceira, as cláusulas de extensão a terceiros não-signatários ${ }^{53}$ (art. 17.8, esta última, textualmente reproduzida no $\$$ 127 do Tratado de Münster). Todavia, de acordo com o autor, tais cláusulas: não significaram nenhuma inovação jurídica significativa, já que haviam sido previstas em outros tratados de paz anteriormente celebrados; bem como, não têm o condão de conferir feição moderna às relações internacionais, já que estes Tratados, não distoam em nada dos "acordos de paz" típicos dos séculos XIV e XV.

Este esforço de desconstrução reforça a ideia de que aos tratados atribuíram-se funções que não decorrem especificamente da natureza jurídica de suas cláusulas, daí a natureza de mito etiológico preconizada por Stephan Beaulauc, como se verá na seção seguinte.

Convém registrar, porém, que Randall Lesasffer defende a existência de duas cláusulas que poderiam ser identificadas como primícias de modernidade no

descumprimento do Tratado, através de meios pacíficos por pelo menos três anos. Todavia, estas questões circunscreviam-se às garantias de índole religiosa fixadas no Tratado, portanto, em grande parte, permaneciam circunscritas às relações internas ao próprio Império. $\mathrm{O}$ autor ressalta, porém, que, em última instância, estas questões poderiam repercutir em problemas de índole territorial, ou ainda, potencialmente, poderia importar em algum incidente internacional, considerada a condição da titularidade dominial conferida à Suécia e as prerrogativas reconhecidas aos habitantes da região transferida ao domínio francês LESAFFER, Randall. The Westphalia peace treaties and the development of the tradition of great European peace treaties prior to 1648. Grotiana: a journal under the auspices of the Foundation Grotiana, v. 18, p. 71-95, 1997. p. 80.

52 A segunda cláusula representava uma autorização expressa de que as partes signatárias (no caso, a França e a Suécia), poderiam intervir em defesa de vítimas, no caso de desrespeito das garantias por parte do Império em relação aos Stände. A previsão deste tipo de cláusula (de cláusula de garantia de terceiras potências), de fato, ainda não existia até então, e, provavelmente, os tratados de Vestfália tiveram um impacto na prática dos países na segunda metade do século XVII. O que o autor ressalva, porém, é que em Vestfália esta questão circunscrevia-se aos arranjos institucionais do Império.

53 Através desta terceira cláusula, determinava-se que o compromisso de restaurar a paz e a amizade deveria ser estendido para além das partes contratantes, mas para seus aliados e aderentes. Tais cláusulas permitiram que fossem acrescentadas ao compromisso de restauração da paz, terceiras partes não signatárias. A restauração da paz, nestes tratados, significava que qualquer tipo de hostilidade entre eles deveria chegar a um fim, ou seja, de que as partes prometiam não prejudicar uns aos outros, tanto através de não participação em alianças e coalizões hostis, quanto através do uso direto de violência uns aos outros e em relação aos seus súditos LESAFFER, Randall. The Westphalia peace treaties and the development of the tradition of great European peace treaties prior to 1648. Grotiana: a journal under the auspices of the Foundation Grotiana, v. 18, p. 71-95, 1997. p. 83. 
direito internacional, a saber: as cláusulas de anistia geral pelas agressões e pelos abusos cometidos durante os conflitos $^{54} \mathrm{e}$ as cláusulas de restituição ao status quo anterior à guerra como forma de legitimação (baseada na legalidade) das decisões sobre a titularidade de bens e sobre a dominialidade dos territórios e bispados do Império ${ }^{55}$.

As primeiras disposições provocavam uma espécie de primeira ruptura com a ideia de moralidade ínsita ao conceito de guerra justa (própria do medievo ${ }^{50}$ ), já que as cláusulas de anistia veiculavam uma concepção não-discriminatória de guerra ${ }^{57}$. Por outro lado, as segundas permitem identificar traços de desteologização da autoridade e de introdução de uma espécie de dever de justificar as reivindicações territoriais em critérios de racionalidade legal ${ }^{58}$.

Ante todo o exposto, somente um elevado grau de entusiasmo consentâneo à recém promulgada Carta das Nações Unidas (1948) é que explicaria a alusão feita por Leo Gross (1948) aos tratados de Vestfália como uma autêntica Carta Pan-Europeia. Pelo contrário, os referidos documentos, como acordos internacionais, nada mais teriam veiculado que não a pretensão típica de firmar compromissos entre as potências dinásticas no final do medievo para por termo a um estado de beligerância.

Se por um lado, a contribuição dos mencionados documentos é muitíssimo reduzida para a posterior consolidação do modelo vestfaliano; por outro lado, o arranjo institucional do Landshoheit por eles veiculados tem sido contemporaneamente recuperado como uma experiência positiva ocorrida nos primórdios da modernidade ${ }^{59}$.

54 Artigo $2^{\circ}$ do Tratado de Onsbrück e $\$ 2^{\circ}$ do Tratado de Münster.

55 Artigo $3^{\circ}$, itens 1 e 2 , do Tratado de Onsbrück e $\int 5^{\circ}$ e $6^{\circ}$ do Tratado de Münster.

56 Paulo Emilio Borges de Macedo esclarece que o debate sobre o direito da guerra representa o marco constitutivo do direito internacional moderno e representa um passo decisivo de uma mudança no direito das gentes para o direito inter gentes. Cf. MACEDO, Paulo Emilio Vauthier Borges de. O nascimento do direito internacional. São Leopoldo: Unisinos, 2009.

57 Esta prática passou a se repetir com bastante frequência após Vestfália, acabando por reforçar a ideia da guerra como instrumento de política internacional dos Estados.

58 LESAFFER, Randall. The Westphalia peace treaties and the development of the tradition of great European peace treaties prior to 1648. Grotiana: a journal under the auspices of the Foundation Grotiana, v. 18 , p. $71-95,1997$. p. 95.

59 Não sem certa dose de exagero, em relação à dimensão multinivelada da autoridade no âmbito do Império, de um lado, Roderick Hills. HILLS, Roderick. Federalism as Westphalian Liberalism. Fordham Law Review, New York, v. 75, n. 2, p. 769-798, 2006, chama
Em que pese a relevância das questões suscitadas por este "retorno à Vestfália", a reflexão que mais se coaduna com os propósitos deste trabalho consiste na proposta de Andreas Osiander, preocupado exatamente com a crise da noção de soberania e com o desacoplamento entre território e autoridade. Para o autor, a constituição do Império (leia-se, os tratados de Vestfália, na sua dimensão interna) fornecia um arcabouço institucional que admitia uma espécie de compartilhamento de autoridade entre o Império e os Länder a partir de outros parâmetros que não a oposição entre soberania e autonomia dos corpos intermediários ${ }^{60}$.

\subsection{Reflexão crítica sobre a centralidade dos acordos de paz de vestfália para a afirmação da soberania dos estados}

Há uma visão de certa forma consolidada de que tais documentos constituiriam “a 'certidão de nascimento' do moderno Estado nacional soberano - base do Estado democrático de Direito atual e 'momento fundador' do sistema político internacional" ${ }^{\prime}$. Nos termos desta narrativa mais entusiasta, os tratados de Vestfália lançariam as bases da chamada Constitutio Westphalica, ou seja, representam o reconhecimento formal (por parte

a atenção pelo arranjo quase-federal a partir do qual se mantinham diferentes tipos de vínculos de cooperação entre o Império e os diferentes Länder, de outro lado, em sentido similar, Bejamin Straumann (Cf. The Peace of Westphalia as a secular constitution...) defende ser possível identificar alguns importantes mecanismos institucionais que permitiriam uma adequada proteção às liberdades religiosas ante a existência de desacordos profundos sobre religião. 60 De acordo com Andreas Osiander, o Império não tinha governo central (tanto antes, quanto depois de 1648), não era um Estado, mas um regime (segundo a terminologia das Relações Internacionais). A autonomia das entidades políticas era limitada de duas formas: externamente através das leis do Império, e, internamente, através dos arranjos constitucionais dentro de cada um dos territórios. Por sua vez, estas regras não poderiam ser alteradas sem que houvesse o consentimento dos corpos representativos existentes em seu interior. No século XVIII, o prestígio do Imperador e do Império como um arcabouço institucional residia em grande parte na proteção jurídica oferecida aos corpos deliberativos e aos cidadãos dentro de seus respectivos territórios. Ainda de acordo com o autor, o poder do imperador era grande o bastante, mas não o suficiente para valer-se deste poder para oprimir as autoridades locais. OSIANDER, Andreas. Sovereignty, international relations, and the Westphalian myth. International Organization, Cambridge Journals, v. 2, n. 55, p. 251-287, Spring 2001. p. 276-278

61 FRANCA FILHO, Marcílio Toscano. O paradigma vestefealiano e o estado contemporâneo: o que 1648 tem ainda a dizer em 2008? In: NOVELINO, M; ALMEIDA FILHO, A. (Org.). Leituras complementares de direito constitucional: teoria do Estado. Salvador: Juspodivm, 2009. p. 73. 
das potências europeias envolvidas) de um conjunto de normas mutuamente estabelecidas que, a um só tempo, permitiria a identificação das autoridades no cenário internacional europeu, fixaria as regras a serem seguidas para que tais autoridades fossem reconhecidas como tal; e, fixaria as prerrogativas ínsitas a estas autoridades.

Há um relativo consenso segundo o qual os Tratados de Paz de Vestfália representam o "fim de uma época" ${ }^{2}$. Afirmar isto implica postular um rompimento substancial com a concepção universalizante de unidade de valores cristãos largamente compartilhada durante a Cristandade $^{63}$. Este consenso abrangente sobre a origem vestfaliana do moderno sistema de Estados teria encontrado espaço nas diferentes tradições teóricas das relações internacionais e, em certa medida, ao ser associado à obra de Hugo Grócio, acabou por reforçar a narrativa em torno da paternidade do próprio direito internacional ${ }^{64}$.

Dois trabalhos considerados clássicos (The Peace of Westphalia, 1648-1948, de Leo Gross, e The Problem of Sovereignty Reconsidered, de Hans J. Morgenthau), ambos datados de 1948, acabaram por contribuir significativamente para a consolidação da ideia de que os Tratados de Paz de Vestfália representam uma "pedra angular" para a consolidação do moderno sistema de Estados. Tais trabalhos são representativos das principais correntes dos estudos das relações internacionais, o idealismo/institucionalismo e o realismo, e teriam contribuído para que tais premissas fossem assumidas por diferentes (e mesmo antagônicas) tradições científicas ${ }^{65}$.

62 Cf. GROSS, Leo. The Peace of Westphalia, 1648-1948. American Journal of International Law, American Society of International Law, v. 42, n. 1, p. 20-41, Jan. 1948. p. 28.

63 Sobre este momento de transição, interessante a lição de Adam Watson, para quem os estados independentes constituídos na Europa no século XVII, "[...] still felt themselves to be parts of the wider whole that had been Latin Christendom, and the interaction between them was now such that each state, and especially the more powerful ones, felt obliged to take account of the actions of the others. They recognized that, since the medieval restraints had disappeared or become irrelevant, new rules and procedures were needed to regulate their relations."

64 Cf. GROSS, Leo. The Peace of Westphalia, 1648-1948...; LESAFFER, Randall. The Westphalia peace treaties and the development of the tradition of great European peace treaties prior to 1648. Grotiana: a journal under the auspices of the Foundation Grotiana, v. 18, p. 71-95, 1997; MACEDO, Paulo Emilio Vauthier Borges de. O nascimento do direito internacional. São Leopoldo: Unisinos, 2009.

65 A literatura é pródiga em apontar a difusão das ideias de Leo Gross e de Hans Morgenthau no tocante ao caráter paradigmático dos Tratados de Paz de Vestfália, como se pode observar dos textos
O primeiro estudo vislumbra nos Tratados de Vestfália a pioneira dentre outras tantas iniciativas de se estabelecer algo que "se assemelhasse a uma unidade mundial constituída sobre a atuação de Estados no exercício de uma soberania irrestrita sobre determinados territórios e desprovidos de sujeição a qualquer autoridade terrena" ${ }^{\prime 6}$. O segundo estudo, por sua vez, reconhece que o exercício da soberania "como poder supremo" por ocasião da celebração daqueles Tratados, representava um "fato político inconteste", o que "significava a vitória dos príncipes territoriais sobre a autoridade universal do Imperador e do Papa, de um lado, e sobre as aspirações particularistas dos barões feudais, de outro lado" $"$.

Esta concepção de virada paradigmática encontra eco, igualmente, em importantes historiadores, como relata Kelly Gordon ${ }^{68}$, fazendo referência à releitura proposta por Josef Polisensky (historiador tcheco), o qual, através de sua The Thirty Years War, de 1971, analisa a relativa perenidade dos domínios territoriais após os Tratados. O autor defende, em síntese, duas questões centrais: que as mudanças territoriais ali estabelecidas possibilitaram um maior controle dos governantes sobre suas terras, contribuindo para a consolidação da doutrina da integridade territorial, e (não sem certa dose de exagero ou entusiasmo) que Vestfália inaugura-

de Andreas Osiander (OSIANDER, Andreas. Sovereignty, international relations, and the Westphalian myth. International Organization, Cambridge Journals, v. 2, n. 55, p. 251-287, Spring 2001), de Bruno Teschke (TESCHKE, Benno. Theorizing the Westphalian System of States: international relations from absolutism to capitalism. European Journal of International Relations, v. 8, n. 1, p. 5-48, 2002) e FALK, Richard. Revisiting Westphalia, discovering Westphalia. The Journal of Ethics: an international philosophical review, Springer Netherlands, v. 6, n. 4, p. 311-352, Dec. 2002.

66 Tradução livre de: "resembling world unity on the basis of states exercising untrammeled sovereignity over certain territories and subordinated to no earthly authority" GROSS, Leo. The Peace of Westphalia, 1648-1948. American Journal of International Law, American Society of International Law, v. 42, n. 1, p. 20-41, Jan. 1948. p. 20

67 Tradução livre de: 'By the end of the Thirty Years' War, sovereignty as supreme power over a certain territory was a political fact, signifying the victory of the territorial princes over the universal authority of emperor and pope, on the one hand, and over the particularistic aspirations of the feudal barons, on the other". MORGENTHAU, Hans J. The problem of sovereignty reconsidered. Columbia Law Review, New York, v. 48, p. 341-365, 1948. p. 341. 68 GORDON, Kelly. The origins of the Westphalian Sovereignty. Senior Seminar Thesis Papers, Western Oregon University, Spring 2008. Disponível em: <http://www.wou.edu/las/socsci/history/thesis $\% 2008 /$ KellyGordonWest phalianSovereignty.pdf $>$. Acesso em: 15 maio 2009. p. 6-8. 
ria uma era na qual a "história torna-se efetivamente um todo que envolve a totalidade do continente europeu e suas dependências ultramarinas" ${ }^{\prime 9}$.

Estes aspectos concorrem para o desenvolvimento da ideia de que a concretização material dos elementos constitutivos da soberania seria resultado direto da $\mathrm{Paz}$ de Vestfália ${ }^{70}$. Desta forma, a narrativa-padrão confere aos tratados de Paz um papel decisivo para o desaparecimento das instituições pré-modernas de autoridade política ${ }^{71}$, para a consolidação do estado territorial como princípio organizativo fundamental ${ }^{72}$ e para a laicização dos fundamentos de legitimidade do exercício do poder político ${ }^{73}$. Ademais, o correlato esforço teórico de afirmação do sentido de soberania, além de consolidar a territorialidade do Estado, teria o condão de combater, teórica e praticamente, no plano externo, a Igreja e o Império (dotados de pretensão universalizante de poder) e no plano interno a nobreza e as cidades (formas autóctones de organização fragmentada e

69 "[t]he Westphalia inaugurated an era where this history becomes effectively a unitary one involving the whole continent of Europe and the overseas dependencies of maritime powers" POLISENSKY, p. 225, apud GORDON, Kelly. The origins of the Westphalian Sovereignty. Senior Seminar Thesis Papers, Western Oregon University, Spring 2008. Disponível em: <http://www.wou. edu/las/socsci/history/thesis $\% 2008 /$ KellyGordonWest phalianSovereignty.pdf>. Acesso em: 15 maio 2009.

70 Cf. GORDON, Kelly. The origins of the Westphalian Sovereignty. Senior Seminar Thesis Papers, Western Oregon University, Spring 2008. Disponível em: <http://www.wou.edu/las/socsci/ history/thesis $\% 2008 /$ KellyGordonWest phalianSovereignty.pdf> . Acesso em: 15 maio 2009. p. 3-4.

71 "Estes [as autoridades políticas localmente limitadas], no entanto, sentiam-se vinculados, uma vez que tiveram vigência, naquela época, de um lado, à maneira de Dante Alighieri, a concepção de imperium mundi, inspirada na experiência de Roma; e, de outro lado, a de uma comunidade de valores religiosos - a Respublica Christiana. Daí, respectivamente, as instituições do Sacro Império e do Papado. Do ponto de vista jurídico, a comunidade internacional da Baixa Idade Média estava regida por duas ordens diferentes: (i) no interior do Sacro Império vigia o Direito Romano, e subsidiariamente o Direito Canônico e o Direito Feudal; e (ii) nas relações entre o Império e as comunidades situadas foras de seus limites, prevalecia uma certa consuetudo communis - um Direito Costumeiro extremamente rudimentar, pois o localismo do poder e da vida não fez prosperar os contactos entre comunidades distantes."

72 CAPORASO, James. Changes in the Westphalian order: territory, public authority, and sovereignity. In: (Org.). Continuity and change in the Westphalian order. Malden, USA; Oxford, UK: Blackwell Publishers, 2000. p. 1-28.

73 Cf. LAFER, Celso. Os dilemas da soberania. In: Paradoxos e possibilidades: estudos sobre a ordem mundial e sobre a política exterior do Brasil num Sistema Internacional em Transformação. Rio de Janeiro: Nova Fronteira, 1982. descentralizada $)^{74} /{ }^{75}$.

Com o escopo de sintetizar tais abordagens, James Caporaso identifica as seguintes ideias veiculadas por esta visão tradicional: (i) as ideias universais que conferiam coesão ao mundo medieval (não obstante se reconhecer a grande diversidade no interior da Respublica Christiana) deram lugar a estados e nações separadas, cada uma delas capazes de definir seus próprios propósitos e missões culturais ${ }^{76}$; (ii) a ideia de soberania enraizou-se, embora não imediatamente, e forneceu a justificação ideológica para o controle último dentro de um território específico, ao mesmo tempo em que conferia a base para o reconhecimento de outros Estados; (iii) soberanos faziam tratados com outros soberanos, aparelhavam-se para governar dentro do território, esforçavam-se em excluir outras autoridades de interferirem na política doméstica, desenvolveram controles rígidos sobre as fronteiras, e participavam ativamente na construção da noção de cidadania e de nacionalismo.

Esta leitura seria construída a partir de inúmeras inferências feitas tanto dos eventos históricos correlatos, quanto por uma (mal)compreensão de algumas das cláusulas dos referidos tratados. Segundo Randall Lesaffer, a propagação de tais ideias sustenta-se, em maior ou menor medida, das seguintes inferências: (i) da presença no conflito das maiores potências europeias da época; (ii) da existência de cláusulas de garantia convencional as quais conduziriam à construção de um balanço de poder permanente entre as potências fixado mediante cláusula convencional e salvaguardado por garantias jurídicas diretamente aplicáveis; (iii) da leitura de que tais documentos teriam representado um ato constitutivo de estados soberanos europeus, o que implicaria no reconhecimento entre si de uma sociedade de nações; (iv) da constituição da comunidade internacional em substituição à concepção medieval e hierárquica de Respublica christiana ${ }^{77}$.

74 Cf. VAN CREVELD, Martin. Ascensão e declínio do Estado. São Paulo: M. Fontes, 2004. p. 83-176.

75 Semelhante leitura é empreendida por Celso Lafer (Os dilemas da soberania...) para quem a luta era travada contra os collegia medievais existentes abaixo do nível do Estado e as autoridades universais existentes acima do Estado.

76 Desde o século XIV a presunção de um império universal capaz de prover sentido à dinâmica social, particularmente ao exercício do poder político, foi, progressivamente, perdendo sua capacidade de promover a ordem e a paz PHILPOT'T, Daniel. Revolutions in sovereignty: how ideas shapped modern international relations. Princenton: Princenton University Press, 2001. p. 75.

77 LESAFFER, Randall. The Westphalia peace treaties and the 
Contra esta visão tradicional, vêm crescendo inúmeras narrativas alternativas que pretendem reduzir a importância usualmente atribuída a estes tratados para a consolidação do conceito de soberania vestfaliana. Paradoxalmente, estas leituras revisionistas propõem visões aparentemente irreconciliáveis: de um lado, encontram-se aqueles que identificam a existência de traços significativos da soberania anteriormente aos referidos tratados de Paz; de outro lado, há aqueles que defendem que a ideia de soberania só teria se constituído como modelo normativo, muitos anos após Vestfália.

Em relação àqueles que defendem serem anteriores à Vestfália os traços constitutivos da soberania a si atribuídos podem ser listados James Caporaso ${ }^{78}$ e Bruno Bueno de Mesquita ${ }^{79}$. O primeiro defende que a concepção de soberania deve ser desconstruída, analiticamente, em três elementos constitutivos distintos (território, autoridade pública e "poder de decisão") $)^{80}$ e que, se fosse assumida como ponto de partida a concepção tradicional de soberania como prerrogativa exclusiva sobre determinado território, tal ideia já vinha sendo constituída a pelo menos cinco séculos. O segundo autor, de maneira ainda mais enfática, propõe que a noção de estado territorial seria tributária direta das tensões entre o Papado e os reis europeus (cujas bases remontam à Concordata de Worms ${ }^{81}$, de 1122) e que a solução

development of the tradition of great European peace treaties prior to 1648. Grotiana: a journal under the auspices of the Foundation Grotiana, v. 18, p. 71-95, 1997. p. 72-73.

78 Cf. CAPORASO, James. Changes in the Westphalian order: territory, public authority, and sovereignity. In: . (Org.). Continuity and change in the Westphalian order. Malden, USA; Oxford, UK: Blackwell Publishers, 2000.

79 Cf. MESQUITA, Bruce Bueno de. Popes, kings, and endogenous institutions: the Concordat of Worms and the origins of sovereignty. In: CAPORASO, J. (Org.). Continuity and change in the Westphalian order. Malden, USA; Oxford, UK: Blackwell Publishers, 2000. 80 Cf. BASTOS JUNIOR, Luiz Magno Pinto. Territorialidade, Soberania e Constituição: As Bases Institucionais do Modelo de Estado Territorial Soberano. Revista Novos Estudos Jurídicos, v. 19, n. 1, 2014. Disponível em: <http://siaiap32.univali.br/seer/index.php/ nej/article/view/5547/2953>.

81 Trata-se de um acordo firmado entre o Papa Calixto e o Rei Henrique IV do Sacro Império que puseram fim a um conjunto de tensões entre as autoridades eclesiais e seculares sobre o poder de nomear os bispos, os bispados representam fonte de autoridade tanto religiosa, quanto secular. Apesar de ser saudada como uma vitória do Papado que mantiveram o poder de selecionar e escolher os bispos, foi feito uma espécie de transação através da qual, ao Rei foi reconhecida a prerrogativa de investir os bispos com autoridade secular (simbolizada pela lança) nos territórios em que eles governavam, enquanto que a autoridade sagrada titularizada pelos bispos, lhes era investida através das autoridades eclesiais (simbolizada pelo anel e pelo báculo). Na prática, o resultado desta ambivalência é de compromisso que pôs termo à tensão entre estas autoridades permitiu a consolidação das bases territoriais dos bispados e, assim, permitiu o desenvolvimento de um conjunto de mecanismos institucionais de controle sobre o território que forneceriam as bases de sustentação para a consolidação do processo de centralização da administração, essencial à configuração da territorialidade do Estado moderno. Neste contexto, na visão destes autores, a Paz de Vestfália nada mais representaria do que um passo além no processo de consolidação das bases do estado soberano que lhe era anterior.

Em relação àqueles que defendem que este ideal de soberania só se materializaria muitos anos seguintes, encontram-se Kelly Gordon (2008), Andreas Osiander (2001) e Benno Teschke (2002). Entre tais autores, ademais, há leituras muito díspares sobre o papel desempenhado pelos Tratados de Vestfália para a consolidação da chamada soberania vestfaliana.

Para Kelly Gordon ${ }^{82}$, seria possível reconhecer nos tratados tão-somente fragmentos para a consolidação da ideia de integridade territorial, ocorrida dois séculos seguintes, já que os mesmos se limitavam a disciplinar questões de índole territorial e a fixar as bases para uma secularização das questões religiosas. Por sua vez, Andreas Osiander ${ }^{83}$ nega a existência de qualquer vínculo estrutural entre o moderno sistema de Estados e os referidos tratados de paz; para o autor, Vestfália resulta de uma construção novecentista, um mito fundacional sobre a origem do sistema de estados; doutrina esta forjada por aquilo que denomina de ideologia da soberania $^{84}$. Por fim, Benno Teschke ${ }^{85}$, além de negar

de que os bispos deviam fidelidade, tanto ao Papa, quanto ao rei. MESQUITA, Bruce Bueno de. Popes, kings, and endogenous institutions: the Concordat of Worms and the origins of sovereignty. In: CAPORASO, J. (Org.). Continuity and change in the Westphalian order. Malden, USA; Oxford, UK: Blackwell Publishers, 2000

82 Cf. GORDON, Kelly. The origins of the Westphalian Sovereignty. Senior Seminar Thesis Papers, Western Oregon University, Spring 2008. Disponível em: <http://www.wou.edu/las/socsci/ history/thesis\%2008/KellyGordonWest phalianSovereignty.pdf $>$. Acesso em: 15 maio 2009

83 Cf. OSIANDER, Andreas. Sovereignty, international relations, and the Westphalian myth. International Organization, Cambridge Journals, v. 2, n. 55, p. 251-287, Spring 2001.

84 Esta narrativa parece vir ao encontro da análise de Martin Koskenniemi, para quem o direito internacional do século XIX era embebido de uma consciência europeia movida pelo "sentido metafórico de Vestfália". KOSKENNIEMI, Martti. The gentle civilizer of nations: the rise and fall of international law 1870-1960. Cabridge: Cambridge University Press, 2001. p. 51

85 Cf. TESCHKE, Benno. Theorizing the Westphalian System of States: international relations from absolutism to capitalism. Euro- 
a presença de qualquer elemento em Vestfália que se assemelhe ao moderno sistema de Estados, vai além e defende que os tratados ali firmados coadunam-se com uma lógica inter-dinástica pré-moderna, ou seja, foram firmados entre dinastias e outras comunidades políticas estruturadas a partir de relações de propriedade social pré-capitalista; nestes termos, a Paz de Vestfália se constituiria não somente sem-Vestfália, mas contra-Vestfália ${ }^{86}$.

A breve exposição feita permite, ao final, sustentar que seria apressado ver os referidos Tratados de Paz como tendo sido, eles próprios, tanto expressão da consolidação da soberania, quanto constituintes do sistema moderno de Estados. Como visto, nos termos definidos por Stepahn Beaulac e Andreas Osiander, sua consolidação só veio a ocorrer ao longo do século XIX. Entrementes, para os propósitos deste trabalho, muito mais importante do que localizar no tempo o nascimento deste modelo de organização do político, afigura-se importante identificar as bases institucionais a partir das quais foi possível a sua construção.

O potencial transformativo dos tratados de Vestfália, como visto, teriam sido decorrentes de sua feição híbrida, já que a sua dimensão internacional permitiu que houvesse a posterior transferência das cláusulas de tolerância religiosa e dos arranjos institucionais de controle e contenção internas (entre o Imperador e os príncipes) para o cenário europeu. Somente simbolicamente é possível fazer retroagir a "lógica de Vestfália" aos acordos de Paz de Vestfália celebrados em Münster e Osnabrück, em 1648.

\section{Sistema (Lógica) de Vestfália e os traços CONSTITUTIVOS DO SISTEMA DE Estados.}

O sistema de Estados evocados pelo modelo vestfaliano pode ser, sinteticamente, resumido nos seguintes termos:

pean Journal of International Relations, v. 8, n. 1, p. 5-48, 2002.

86 Para o autor, somente é possível reconhecer a entrada na modernidade com o advento do primeiro Estado propriamente moderno (a Inglaterra), país que reestruturou as relações internacionais a partir de um longo processo de desenvolvimento socialmente desigual e geopoliticamente estruturado Cf. TESCHKE, Benno. Theorizing the Westphalian System of States: international relations from absolutism to capitalism. European Journal of International Relations, v. 8, n. 1, p. 5-48, 2002.
[...] sistema de estados organizados territorialmente em um desenvolvimento anárquico. Estes estados são constitucionalmente independentes (soberania) e detêm autoridade exclusiva de governo no interior de suas próprias fronteiras. Eles se relacionam com a população, no interior de suas fronteiras, como cidadãos e com os outros estados como juridicamente iguais. ${ }^{87}$

Como se viu, Vestfália é associada ao nascimento de um modelo de organização política baseado nas noções de soberania estatal, em face da qual ao Estado é atribuída a condição de ator principal das relações internacionais, relações estas mantidas por intermédio de corpos diplomáticos permanentes e supostamente reguladas pelo direito internacional ${ }^{88}$ (o qual, paulatinamente, converte-se de direito das gentes, para um direito inter-gentes).

A consolidação teórica e institucional dos elementos constitutivos deste paradigma de compreensão da ordem global (tanto na sua acepção política, quanto jurídica) deita raízes, como assinalado anteriormente, na tensão medieval entre o universalismo cristão e o localismo das diferentes formas de expressão política ${ }^{89}$. Esta concepção subjacente de matriz operacionalmente eurocêntrica ${ }^{90}$ fixou as bases para o desenvolvimento moderno da ideia de ordem mundial e, sobretudo, para a diferenciação a ser institucionalizada no período colonial entre o "nós" civilizados e o "eles" bárbaros".

87 Tradução livre de: "The basic idea is one of a system of territorially organized states operating in an anarchic environment. These states are constitutionally independent (sovereign) and have exclusive authority to rule within their own borders. They relate to the population within their borders as citizens (Staatsangehoeringe, those belonging to the State) and to other states as legal equals" (tradução livre). CAPORASO, James. Changes in the Westphalian order: territory, public authority, and sovereignity. In: __ (Org.). Continuity and change in the Westphalian order. Malden, USA; Oxford, UK: Blackwell Publishers, 2000. p. 2.

88 A síntese da força simbólica atribuída a Vestfália nestes termos é feita por Benno Teschke TESCHKE, Benno. Theorizing the Westphalian System of States: international relations from absolutism to capitalism. European Journal of International Relations, v. 8, n. 1, p. 5-48, 2002. p. 6.

89 A ideia reinante de "uma ordem política medieval" era dotada de uma substancial consistência veiculada através da ideia de Respublica christiana, a partir da qual se forjava uma concepção de "comunidade normativa entre cristãos" não obstante a existência de uma multiplicidade de formas de organizações políticas locais.

90 Cf. FALK, Richard. Revisiting Westphalia, discovering Westphalia. The Journal of Ethics: an international philosophical review, Springer Netherlands, v. 6, n. 4, p. 311-352, Dec. 2002.

91 A ideia de Vestfália é curiosamente recuperada pelos Estados no processo de descolonização, conceito importado da Europa e utilizado para reivindicar o status soberano frente à opressão das metrópoles Cf. SPRUYT, Hendrik. The End of Empire and the Ex- 
No entanto, defende-se nesta seção que esse modelo vestfaliano não guarda conexão com os acordos de Paz celebrados em 1648, mas são fruto da ideologia da soberania construída ao longo do século XIX. Trata-se de um modelo normativo construído a partir da ideia de que o nascimento do sistema de estados remonta à Vestfália.

O modelo vestfaliano veicula uma ideia-força que atua como um mecanismo orgânico (mito etiológico ${ }^{92}$ ) dotado de uma força social tremenda no seio da consciência compartilhada pela comunidade internacional ${ }^{93}$. Sua natureza mítica também é defendida por Andreas Osiander, para quem o modelo normativo por si veiculado representa o modelo contra o qual os esforços teóricos de explicação das mudanças em curso deverão ser confrontados (por isso esse retorno frequente a Vestfália) $)^{94}$.

O reconhecimento de que Vestfália reveste-se de natureza mítica decorre da constatação da existência do

tension of the Westphalian System: The Normative Basis of the Modern State Order. In: CAPORASO, J. (Org.). Continuity and change in the Westphalian order. Malden, USA; Oxford, UK: Blackwell Publishers, 2000. p. 65- 92.

92 De acordo com Stephan Beaulac, "Myths may be classified according to their topics, based on what they are about, although any such attempt is somewhat dubious as the categories are not mutually exclusive and the borders between them remain vague. Generally speaking, however, one can identify the following five types of myth: (i) aetiological myths, concerning the origin of things; (ii) eschatological myths, about the final end of things; (iii) soteriological myths, pertaining to momentous saving and salvation; (iv) ritual myths, combining rites with narratives; and, (v) heroic myths, relating to accounts of glorious deeds and accomplishments: see M S Day, The Many Meanings of Myth (1984) 21-27. Aetiology (spelt 'etiology' in American English) is interested in the beginning of things and the reason for things: see E Thomas Lawson, 'The Explanation of Myth and Myth as Explanation' (1978) 46 J American Academy Rel 507. Many authors have in fact restricted mythology to origin myths - also referred to as 'myths of beginnings' or 'creation-myths'. The aetiological category would include: (a) theogonic myths, pertaining to the origin of gods; (b) cosmogonic myths, concerning the origin of the world; and, (c) anthropogonic myths, relating to the origin of human kind." BEAULAC, Stéphane. The Westphalian model in defining international law: challenging the myth. Australian Journal of Legal History, v. 8, n. 2, p. 181-213, 2004. p. 186

93 A linguagem não tem o condão somente de representar a realidade, mas ela pode desempenhar um papel ativo na criação e transformação da própria realidade, inclusive, modelando a consciência compartilhada (shared consciousness) da sociedade BEAULAC, Stéphane. The Westphalian model in defining international law: challenging the myth. Australian Journal of Legal History, v. 8, n. 2, p. 181-213, 2004. p. 181-182.

94 Cf. OSIANDER, Andreas. Sovereignty, international relations, and the Westphalian myth. International Organization, Cambridge Journals, v. 2, n. 55, p. 251-287, Spring 2001 um consenso fartamente compartilhado sobre as explicações racionais relativas à origem deste sistema de Estados. Desta forma, por mais que se desconstruam as evidências empíricas sobre as quais se assentam suas premissas $^{95}$, mesmo que se demonstre que a Paz de Vestfália não se afigura compatível ao modelo de estados soberanos $^{96}$, ainda assim, a expressão não deixa perder sua função, já que se configura como um autêntico dogma, um sistema de crença sobre a origem das relações internacionais modernas. O conjunto de ideias por ela evocadas desempenha funções sociais que variam de acordo com o transcurso do tempo ${ }^{97}$, modelando a forma como são compreendidas as relações internacionais ${ }^{98}$ e fornecendo as bases para a construção da visão de mundo que estrutura cognitivamente (cognitive script ${ }^{9}$ ) a compreensão das relações no cenário internacional ${ }^{100}$.

A força constitutiva destas categorias é tamanha que Marcílio Franca Filho defende que toda a visão de mundo que estrutura os modos contemporâneos e mo-

95 Cf. OSIANDER, Andreas. Sovereignty, international relations, and the Westphalian myth. International Organization, Cambridge Journals, v. 2, n. 55, p. 251-287, Spring 2001.

96 Cf. KRASNER, Stephan. Rethinking the sovereign state model. Review of International Studies, Cambridge Journals, v. 27, n. 5, p. 17-42, Dec. 2001.

97 Cf. BEAULAC, Stéphane. The Westphalian model in defining international law: challenging the myth. Australian Journal of Legal History, v. 8, n. 2, p. 181-213, 2004. p. 177.

98 'They resort to the expression 'westphalian model', in most cases, as a 'convenient shortland' to explain the fundamental juristic basis of the world organization (or disorganization) founded on the principle of the sovereignty equality of states, in which is rooted the whole scheme of international relations, as well as the rules of international law. Legally-empowered image of our international system as an association of sovereign states." BEAULAC, Stéphane. The Westphalian model in defining international law: challenging the myth. Australian Journal of Legal History, v. 8, n. 2, p. 181-213, 2004. p. 212

99 KRASNER, Stephan. Rethinking the sovereign state model. Review of International Studies, Cambridge Journals, v. 27, n. 5, p. 17-42, Dec. 2001 defende que toda forma de organização política é constituída a partir de um conjunto de regras estruturantes que fornecem parâmetros para a compreensão e para a legitimação da atuação dos diferentes atores políticos envolvidos. Estas regras básicas (cognitive script), além de serem fartamente compreendidas, são sistematicamente violadas, constituindo aquilo que ele denomina de "hipocrisia organizada", quando há uma desconexão entre as normas e as ações políticas. Esta característica ("hipocrisia organizada"), na visão do autor, está presente em todos os modelos de organização (para além do modelo de soberania estatal) e uma adequada compreensão deste modelos pressupõe a sua articulação com as formas institucionalizadas de desrespeito às suas regras constitutivas.

100 KRASNER, Stephan. Rethinking the sovereign state model. Review of International Studies, Cambridge Journals, v. 27, n. 5, p. $17-$ 42, Dec. 2001. p. 17. 
dernos de compreender e aplicar o direito baseia-se no tripé: estatalidade-racionalidade-unidade ${ }^{101}$. De acordo com este tripé, o direito é identificado como as regras impostas somente pelo Estado, as quais configuram as únicas válidas, em uso e efetivas no seu território e concebidas em consonância com os princípios da coerência, sistematização, harmonia e lógica. A categoria jurídico-política "Estado", que emerge vinculada ao modelo de soberania estatal, é a base para o estudo e compreensão deste modelo de Direito que vem se formando desde a desintegração do mundo feudal ${ }^{102}$.

Neste mesmo sentido se encontra a lição de Celso Lafer, bastante difundida entre nós, para quem a força simbólica da Paz de Vestfália "representou a consolidação de uma ordem mundial constituída exclusivamente pelos governos dos Estados soberanos. Estes teriam liberdade absoluta para governar um espaço nacional - territórios - podendo entrar em acordos voluntários - tratados - para regular as relações externas e intraconexões de variados tipos"103. Este conjunto de ideias veicula uma lógica própria no âmbito das relações internacionais, denominada pelo autor de Lógica de Vestfália, segundo a qual: (i) os atores políticos são os Estados (soberanos e iguais por fiat jurídico, não em razão de uma ordem exterior); (ii) a lei teria como fundamento a vontade dos governos e a percepção recíproca dos interesses comuns; (iii) a harmonia entre os povos seria fruto de um equilíbrio mecânico do poder; (iv) a coexistência de uma multiplicidade de Estados soberanos, segurança baseada na capacidade de autodefesa e de alianças específicas com outros Estados.

Esta concepção jurídica da sociedade internacional como sendo estatalista (centrada na figura do Estado) guiou e condicionou os processos de adesão e participa-

101 FRANCA FILHO, Marcílio Toscano. Westphalia: a paradigm? A dialogue between Law, art and philosophy os science. The German Law Journal, v. 8, n. 10, p. 955-976, 2007. p. 957.

102 Estado e Direito mantêm entre si uma relação de interferência recíproca de forma tal que o Direito (a partir do direito constitucional) é tido como algo que dá forma, constitui e conforma um determinado sistema de organização política. Este, por sua vez, reveste-se da característica principal de monopolizar o poder político-jurídico sobre uma determinada comunidade circunscrita a um determinado território. FRANCA FILHO, Marcílio Toscano. Westphalia: a paradigm? A dialogue between Law, art and philosophy os science. The German Law Journal, v. 8, n. 10, p. 955-976, 2007. p. 957. 103 LAFER, Celso. Os dilemas da soberania. In: __. Paradoxos e possibilidades: estudos sobre a ordem mundial e sobre a política exterior do Brasil num Sistema Internacional em Transformação. Rio de Janeiro: Nova Fronteira, 1982. p. 69-70. ção em todas as instituições internacionais mais representativas. Somente os Estados plenamente soberanos são tratados como dotados das qualificações necessárias para sua completa associação e participação nestas organizações ${ }^{104}$. Este modelo (supostamente) vestfaliano, sem maiores dificuldades, possibilita a acomodação de realidades de desigualdade radical entre os Estados, quer seja em relação ao tamanho, à riqueza, ao poder ou ao papel internacional ${ }^{105}$.

Este sistema de estados que regia a política internacional, na definição de Mark Zacher, era regulado pelo "princípio legal de ordenação, a saber, a obrigação de respeito mútuo pela soberania" e caracterizado por uma "forma principal de conduta representada por um alto grau de autonomia do Estado nos assuntos internos e externos" ${ }^{106}$. Um conjunto de condições fundamentais, a que o autor denomina de "pilares de Vestfália"107, da-

104 Na visão de Claire Cutler, nisto reside os fatores da atual crise de legitimidade do modelo vestfaliano, ou seja, na sua incapacidade de descrever, adequadamente, uma série de fenômenos na prática internacional dos Estados. As noções de autoridade e de poder veiculadas por este modelo reconhecem somente os Estados e as instituições públicas como atores internacionais. A centralidade dos papéis desempenhados por estes atores é perceptível tanto no âmbito das organizações internacionais, quanto em relação ao reconhecimento como sujeito de direito. $\mathrm{Na}$ visão da autora, tais noções ignoram a participação de corporações transnacionais e de organizações sociais privadas (tais instituições operam como sujeitos invisíveis). Paradoxalmente, ao negar-lhe o status de sujeito de direito, tais noções concorrem para que se acelere a expansão do poder das corporações no mundo, através de movimentos de globalização, privatização e desregulamentação. A autora sustenta que a falta de adequação ou assimetria entre teoria e prática está se tornando mais aguçada, sinalizando a crise de legitimidade que subjaz latente ao modelo. Cf. CUTLER, A. Claire. Critical reflections on the Westphalian assumptios of international law and organization: a crisis of legitimacy. Review of International Studies, Cambridge Journals, v. 27, n. 2, p.133-150, 2001.

105 Cf. FALK, Richard. Revisiting Westphalia, discovering Westphalia. The Journal of Ethics: an international philosophical review, Springer Netherlands, v. 6, n. 4, p. 311-352, Dec. 2002.

106 Cf. ZACHER, Mark W. Os pilares em ruína do templo de Vestfália. In: ROSENAU, J.; CZEMPIEL, E-O. (Org.). Governança sem governo: ordem e transformação na política mundial. Brasília: UnB; Imprensa Oficial, 2000. p. 86-87.

107 O autor os lista da seguinte forma: "o desejo dos governantes de evitar incursões na área dos seus próprios poderes; a inexistência de uma ideologia transnacional que competisse seriamente com os Estados pela lealdade política dos povos; uma memória histórica (e/ ou a percepção da probabilidade) da existência de níveis sobrepostos de autoridade política e de lealdade conflitante, apontando para a desordem e a violência maciça; um conjunto comum de valores que engendram um elemento de respeito pelos outros Estados e por seus governantes; e a provisão aos cidadãos, pelos Estados, de valores importantes como a proteção da vida e o bem-estar econômico" ZACHER, Mark W. Os pilares em ruína do templo de Vestfália. 
vam sustentação ao princípio de respeito recíproco pela soberania dos Estados e afiguram-se, em certa medida, corroídos e erodidos ensejando a necessidade de sua suplantação.

A cadeia de coimplicação e de justificação recíproca em torno da unificação da autoridade, de um lado, e o desenvolvimento de mecanismos institucionais de dominação em bases territoriais, de outro, juntos, fornecem as bases materiais e funcionais para o desenvolvimento do princípio da territorialidade. A unidade territorial do Estado-nação passa a ser, então, a referência a partir do qual o problema da justa ordenação social é estruturado; afigura-se como a unidade metodológica por meio da qual a cartografia do poder distribui a autoridade em termos de unidades territoriais limitadas (bordered territorial unit $)^{108}$. Pertinente a imagem veiculada por Nancy Fraser, segundo a qual a ideia central de Vestfália representa "um imaginário político que mapeou o mundo como um sistema de Estados territoriais soberanos mutuamente reconhecidos" ${ }^{\prime 109}$.

\section{Considerações finais}

Apesar de todo o esforço de desconstrução até aqui empreendido e mesmo após a compilação de evidências empíricas a partir das quais seria possível afirmar que os tratados de Paz assinados nas cidades de Münster e Osnabrück em 1648 não são compatíveis com o que se conhece por "sistema vestfaliano", ainda assim, não se pode negar a força simbólica e o caráter mítico que se revestiu a expressão Vestfália. Ademais, a dimensão mítica sobre a origem do sistema de Estados e sobre a condição soberana de que se lhe reveste, é amplificada no âmbito do constitucionalismo, sendo incorporada à gramática do direito constitucional de tal forma que se passa a afirmar não haver direito, sem Estado; nem Estado, sem constituição; nem constituição, sem poder soberano.

In: ROSENAU, J.; CZEMPIEL, E-O. (Org.). Governança sem governo: ordem e transformação na política mundial. Brasília: UnB; Imprensa Oficial, 2000. p. 88.

108 SCHOLTE, Jan Aart. What is "global" about globalization? In: HELD, D.; McGREW, A.(Ed.). The global transformations reader: an introduction to the globalization debate. 2. ed. Cambridge; Malden: Polity Press, 2003. p. 84-91.

109 FRASER, Nacy. Reenquadrando a justiça em um mundo globalizado. Lua Nova: Revista de cultura e política, CEDEC, n. 77, p. 11-39, 2009. p. 13.
A expressão "ordem vestfaliana” e tudo o que ela representa se construiu muito depois de Vestfália e em (quase) nada se identifica com a natureza dos Acordos de Paz de 1648 e com o arranjo legal-institucional por eles forjados. Apesar disso, a expressão não perde sua função, já que se configura como um autêntico dogma, um sistema de crença sobre a origem das relações internacionais modernas.

O aspecto realmente diferenciado dos referidos acordos não decorre tanto de sua feitção internacional, mas sobretudo dos arranjos institucionais que a marcam a constituição do Império Sacro Romano. Isto posto, desconstruir Vestfáilia importa em empreender um convite que se revisite Vestfália. Não tanto para compreender a origem do Sistema de Estados, mas sobretudo o impacto que os Tratados tiveram para a consolidação de um sistema multinivelado de autoridades no interior do império e de suas conexões internacionais.

A identificação de Vestfália a uma narrativa-pardão sobre os eventos histórios e sobre os seus efeitos acaba por encobrir o fato de que tais narrativas se prestam a reproduzir determinadas premissas de um modelo que pretende fazer frente às necessidades europeias de justificação da expansão do século XIX. E, mais ainda, quando se pretende compreender os processos de reordenação nas relações internacionais (e de poder) nos cenários pós-vestfalianos.

Os acordos de Paz, apesar das dimensões continentais do conflito, não apresentaram nenhuma inovação significativa em face dos demais acordos de paz interdinásticos dos séculos XV e XVI. Não há mudanças significativas quanto ao "poder de celebrar tratados", quanto "ao reconhecimento internacional das autoridades envolvidas no conflito", nem exatamente, quanto ao "acoplamento da autoridade soberana ao território".

O potencial transformativo dos tratados de Vestfália, como visto, teriam sido decorrentes de sua feição híbrida, já que a sua dimensão internacional permitiu que houvesse a posterior transferência das cláusulas de tolerância religiosa e dos arranjos institucionais de controle e contenção internas (entre o Imperador e os príncipes) para o cenário europeu. Somente simbolicamente é possível fazer retroagir a lógica de Vestfália aos acordos de Paz de Vestfália celebrados em Münster e Osnabrück, em 1648.

Desta forma, olhar para além da narrativa tradicional atribuída aos tratados de Vestfália, muito mais do que 
um esforço de arqueologia conceitual, permite sejam produzidas visões alternativas/concorrentes que podem suscitar insights interessantes para o enfrentamento dos desafios contemporâneos de compartilhamento de autoridade em um mesmo espaço.

\section{REFERÊNCIAS}

BASTOS JUNIOR, Luiz Magno Pinto. Territorialidade, Soberania e Constituição: As Bases Institucionais do Modelo de Estado Territorial Soberano. Revista Novos Estudos Jurídicos, v. 19, n. 1, 2014. Disponível em: $<$ http://siaiap32.univali.br/seer/index.php/nej/article/view/5547/2953>.

BEAULAC, Stéphane. The Westphalian legal orthodoxy: mith or reality? The Journal of the History of International Law, v. 2, n. 2, 148-177, 2000.

BEAULAC, Stéphane. The Westphalian model in defining international law: challenging the myth. Australian Journal of Legal History, v. 8, n. 2, p. 181-213, 2004.

CAPORASO, James. Changes in the Westphalian order: territory, public authority, and sovereignity. In:

(Org.). Continuity and change in the Westphalian order. Malden, USA; Oxford, UK: Blackwell Publishers, 2000. p. $1-28$.

CONSTANT, Benjamin. A Liberdade dos Antigos Comparada com a dos Modernos. Revista Filosofia Politica, Porto Alegre, n. 2, 1985. Disponível em: < http:/ / caosmose.net/candido/unisinos/textos/benjamin.pdf $>$.

CUTLER, A. Claire. Critical reflections on the Westphalian assumptios of international law and organization: a crisis of legitimacy. Review of International Studies, Cambridge Journals, v. 27, n. 2, p.133-150, 2001.

ESTEVES, Paulo. Para uma genealogia do Estado territorial soberano. Revista de Sociologia e Política, Curitiba, n. 27, p. 15-32, nov. 2006.

FALK, Richard. Revisiting Westphalia, discovering Westphalia. The Journal of Ethics: an international philosophical review, Springer Netherlands, v. 6, n. 4, p. 311 352, Dec. 2002.

FRANCA FILHO, Marcílio Toscano. O paradigma vestefealiano e o estado contemporâneo: o que 1648 tem ainda a dizer em 2008? In: NOVELINO, M; ALMEIDA FILHO, A. (Org.). Leituras complementares de direito constitucional: teoria do Estado. Salvador: Juspodivm, 2009. p. 69-93.

FRANCA FILHO, Marcílio Toscano. Westphalia: a paradigm? A dialogue between Law, art and philosophy os science. The German Law Journal, v. 8, n. 10, p. 955-976, 2007.

FRASER, Nacy. Reenquadrando a justiça em um mundo globalizado. Lua Nova: Revista de cultura e política, CEDEC, n. 77, p. 11-39, 2009.

GORDON, Kelly. The origins of the Westphalian Sovereignty. Senior Seminar Thesis Papers, Western Oregon University, Spring 2008. Disponível em: < http://www. wou.edu/las/socsci/history/thesis $\% 2008 /$ KellyGordonWest phalianSovereignty.pdf $>$. Acesso em: 15 maio 2009.

GROSS, Leo. The Peace of Westphalia, 1648-1948. American Journal of International Law, American Society of International Law, v. 42, n. 1, p. 20-41, Jan. 1948.

HILLS, Roderick. Federalism as Westphalian Liberalism. Fordham Law Review, New York, v. 75, n. 2, p. 769798, 2006.

KOSKENNIEMI, Martti. The gentle civilizer of nations: the rise and fall of international law 1870-1960. Cabridge: Cambridge University Press, 2001.

KRASNER, Stephan. Rethinking the sovereign state model. Review of International Studies, Cambridge Journals, v. 27, n. 5, p. 17-42, Dec. 2001.

LAFER, Celso. Os dilemas da soberania. In:

Paradoxos e possibilidades: estudos sobre a ordem mundial e sobre a política exterior do Brasil num Sistema Internacional em Transformação. Rio de Janeiro: Nova Fronteira, 1982.

LESAFFER, Randall. The Westphalia peace treaties and the development of the tradition of great European peace treaties prior to 1648. Grotiana: a journal under the auspices of the Foundation Grotiana, v. 18, p. 71-95, 1997.

MACEDO, Paulo Emilio Vauthier Borges de. O nascimento do direito internacional. São Leopoldo: Unisinos, 2009.

MESQUITA, Bruce Bueno de. Popes, kings, and endogenous institutions: the Concordat of Worms and the origins of sovereignty. In: CAPORASO, J. (Org.). Continuity and change in the Westphalian order. Malden, USA; Oxford, UK: Blackwell Publishers, 2000. p. 93-118. 
MORGENTHAU, Hans J. The problem of sovereignty reconsidered. Columbia Law Review, New York, v. 48, p. 341-365, 1948.

OSIANDER, Andreas. Sovereignty, international relations, and the Westphalian myth. International Organization, Cambridge Journals, v. 2, n. 55, p. 251-287, Spring 2001.

PHILPOT'T, Daniel. Revolutions in sovereignty: how ideas shapped modern international relations. Princenton: Princenton University Press, 2001.

RUGGIE, John Gerard. Territoriality and beyond: problematizing modernity in international relations. International organization, Cambridge Journals, v. 47, n. 1, p. 139-174, Winter, 1993.

SCHOLTE, Jan Aart. What is "global" about globalization? In: HELD, D.; McGREW, A.(Ed.). The global transformations reader: an introduction to the globalization debate. 2. ed. Cambridge; Malden: Polity Press, 2003. p. 84-91.

SPRUYT, Hendrik. The End of Empire and the Extension of the Westphalian System: The Normative Basis of the Modern State Order. In: CAPORASO, J. (Org.).
Continuity and change in the Westphalian order. Malden, USA; Oxford, UK: Blackwell Publishers, 2000. p. 65- 92.

STRAUMANN, Benjamin. The Peace of Westphalia as a secular constitution. Constelations, v. 15, n. 2, p. 173188, 2008.

TESCHKE, Benno. Theorizing the Westphalian System of States: international relations from absolutism to capitalism. European Journal of International Relations, v. 8, n. 1, p. 5-48, 2002.

VAN CREVELD, Martin. Ascensão e declínio do Estado. São Paulo: M. Fontes, 2004.

WATSON, Adam. The evolution of international society. London: Routledge, 1992.

WILSON, Peter. The causes of Thirty Years War. The English Historical Review, Oxford Journals, v. 123, n. 502, p. 554-586, 2008.

ZACHER, Mark W. Os pilares em ruína do templo de Vestfália. In: ROSENAU, J.; CZEMPIEL, E-O. (Org.). Governança sem governo: ordem e transformação na política mundial. Brasília: UnB; Imprensa Oficial, 2000. p. $83-141$. 


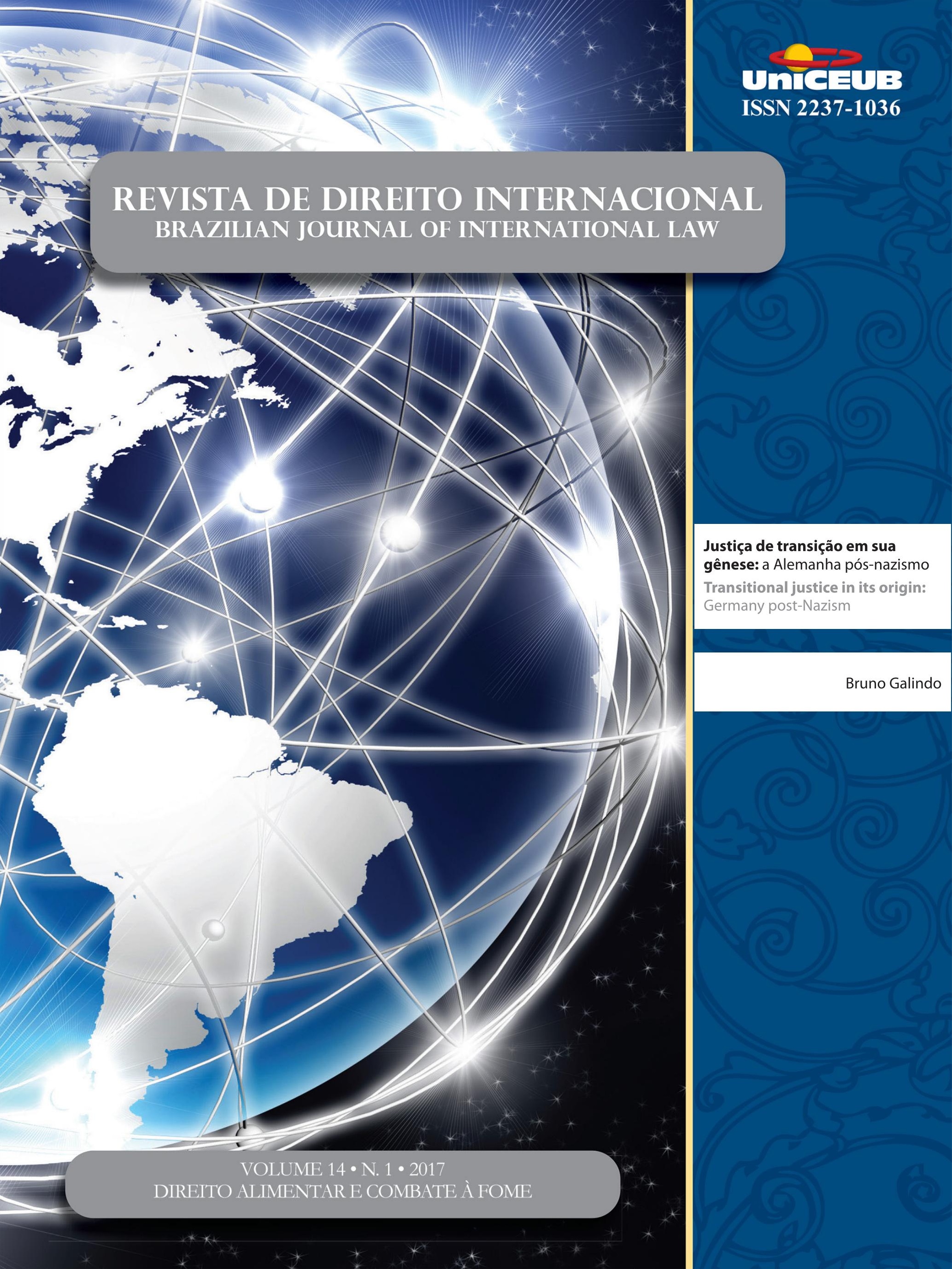




\section{Justiça de transição em sua gênese: a Alemanha pós-nazismo*}

\section{Transitional justice in its origin: Germany post-Nazism}

Bruno Galindo**

\section{Resumo}

Este artigo tem por objetivo tratar das questões referentes à justiça de transição em seu início, analisando a primeira experiência histórica do fenômeno, a Alemanha pós-nazismo e o enfrentamento dos problemas oriundos do período em que esse país esteve sob o jugo do regime nazista. $\mathrm{O}$ trabalho envolve a análise de algumas importantes questões do constitucionalismo alemão dos períodos envolvidos e da ascensão e queda do referido regime. Tem por base metodológica as premissas da denominada teoria intercultural da constituição, bem como a classificação das constituições quanto à conformação do processo político, do constitucionalista alemão Karl Loewenstein, e a Teoria dos Regimes Políticos Híbridos da Professora espanhola Inmaculada Szmolka Vida. No trabalho, essas perspectivas teóricas se relacionam com os conceitos fundamentais da Teoria da Justiça de Transição, o que provavelmente ainda não foi realizado em artigos temáticos a respeito. Ao fim, pretende-se traçar o alcance da justiça de transição na Alemanha em face da experiência do pós-nazismo, considerando as medidas e os objetivos propostos pela teoria da justiça de transição em seu atual estado da arte.

Palavras-chave: Justiça de transição. Pós-nazismo. Constitucionalismo. Alemanha.

\section{Abstract}

This paper discusses the questions about transitional justice in its origin, analysing the first historical experience of this phenomenon, Germany post-Nazism and how to deal with the problems of Nazi period in that country. The article has the analysis of some relevant questions of German constitutionalism of those times and the rise and fall of Nazi regime. It works with methodological basis of the premises of intercultural theory of constitution, the classification of the constitution as a form of political process, proposed by the German constitutionalist Karl Loewenstein, and the theory of hybrid political regimes, proposed by Spanish Professor Inmaculada Szmolka Vida. In the article, these theoretical perspectives are thought connected with the main concepts of transitional justice theory, something that probably none of scientific works in theme had done. Finally, it aims to expose the range of transitional justice in Germany beyond the post-Nazism experience, considering the measures and objectives proposed by transitional justice theory 
in its current "state of art".

Keywords: Transitional justice. Post-Nazism. Constitutionalism. Germany.

O judeuzinho de cabelos negros espreita, horas e horas, com um prazer satânico, a menina inocente que ele macula com o seu sangue, roubando-a ao seu povo. Não há meios que ele não empregue para estragar os fundamentos raciais do povo que ele se propõe vencer. Do mesmo modo que, segundo um plano traçado, vai corrompendo mulheres e mocinhas, também não recua diante do rompimento de barreiras impostas pelo sangue, empreendendo essa obra em grande escala, no país estranho. Foram e continuam a ser ainda judeus os que trouxeram os negros até o Reno, sempre com os mesmos intuitos secretos e fins evidentes, a saber: "bastardizar" à força a raça branca, por eles detestada, precipitá-la do alto da sua posição política e cultural e elevar-se ao ponto de dominá-la inteiramente.

Decorre daí que um povo de raça pura, consciente de seu sangue, nunca poderá ser subjugado pelo judeu.

(Adolf Hitler: Minha Luta)

\section{INTRODUÇÃO}

Talvez nenhum acontecimento tenha sido objeto de investigação tão frequente após a $2^{\mathrm{a}}$ Guerra Mundial quanto o nazismo alemão e seus desdobramentos. Das questões políticas às jurídicas, passando pelas visões da história dos povos e postulados morais, filosóficos, psicológicos e éticos, provavelmente nenhum fato tenha sido mais comentado, estudado, investigado, bem como abordado em revistas, livros e filmes, ficcionais ou abordando situações ocorridas de fato.

Por tal razão, não se pretende aqui aprofundar análises que outros fizeram mais e melhor do que o autor destas linhas. O objetivo desse ensaio é bem mais modesto, pois tão somente interessa colher dessa amarga experiência humana, o que é pertinente à abordagem das questões de justiça de transição. Essa análise envolve, principalmente, as questões pertinentes do constitucionalismo alemão dos períodos envolvidos e terá por base metodológica as premissas da denominada Teoria Intercultural da Constituição, bem como a classificação das constituições quanto à conformação do processo político, do constitucionalista alemão Karl Loewens- tein, e a Teoria dos Regimes Políticos Híbridos da Professora espanhola Inmaculada Szmolka Vida ${ }^{1}$

Em relação à justiça de transição, faz-se necessária uma definição para estabelecer os pontos de partida das análises deste ensaio. Para tal, o conceito de Louis Bickford traz uma definição bastante abrangente do que vem a ser a justiça de transição diante da variedade de experiências existentes. Para o autor, a justiça transicional consiste em um conjunto de medidas consideradas necessárias para a superação de períodos de graves violações a direitos humanos, ocorridas durante conflitos armados (ex:guerras civis) e/ ou regimes autoritários (ditaduras), implicando a adoção de providências com os seguintes objetivos:

\begin{abstract}
- esclarecimento da verdade histórica e judicial, dentre outras coisas com a abertura dos arquivos estatais do período de exceção;

- instituição de espaços de memória (ex.: memorial do Holocausto, na Alemanha), para que as gerações presentes e futuras possam conhecer e compreender a gravidade do que ocorreu no período de exceção;

- reformas institucionais em relação aos serviços de segurança, adequando-os à pauta axiológica do Estado democrático de direito, bem como sedimentando nas instituições públicas uma cultura democrática e humanista;

- reparação dos danos às vítimas (indenizações, reabilitações etc.);

- realização da justiça propriamente dita, com a responsabilização em variados graus dos violadores dos direitos humanos ${ }^{2}$.
\end{abstract}

1 GALINDO, Bruno. Teoria Intercultural da Constituição: a transformação paradigmática da Teoria da Constituição diante da integração interestatal na União Européia e no Mercosul. Porto Alegre: Livraria do Advogado, 2006; LOEWENSTEIN, Karl. Teoría de la Constitución. Barcelona: Ariel, 1964; SZMOLKA VIDA, Inmaculada. Los regímenes políticos híbridos: democracias y autoritarismos con adjetivos: su conceptualización, categorización y operacionalización dentro de la tipologia de regímenes políticos. Revista de Estudios Políticos, n. 147, Madrid, p. 103-135, 2010.

2 BICKFORD, Louis. Transitional justice. In: The encyclopedia of genocide and crimes against humanity. Michigan: Macmillan Reference USA, 2004. v. 3. p. 1045-1047.; GALINDO, Bruno. Constitucionalismo e justiça de transição: em busca de uma metodologia de análise a partir dos conceitos de autoritarismo e democracia. Revista da Faculdade de Direito da Universidade Federal de Minas Gerais, $n^{\circ}$ 67. Belo Horizonte: UFMG, pp. 100-102, 2015; GREIFF, Pablo de. La contribución de la justicia transicional a la construcción y consolidación de la democracia. In: BLEEKER, Mô; CIURLIZZA, Javier; BOLAÑOS-VARGAS, Andrea (Org.). Memorias: Conference Paper. Bogotá: ICTJ, 2007. p. 25-35. p. 26. Com ligeiras variações, cf. tb. PORTO, Humberto A. Sierra. La función de la corte constitucional en la protección de los derechos de las víctimas a la verdad, la justicia y la reparación en Colombia. Anuario de 
A partir desses objetivos, é possível traçar políticas concretas de justiça de transição, que envolvem todos ou alguns deles. Verdade histórica e judicial, preservação da memória, transformação da cultura autoritária em cultura democrática através de reformas das instituições, compensação possível pelas perdas das vítimas e de suas famíliase dentro da perspectiva do Estado democráticoe de direito e sem a generalizada "caça às bruxas" - estabelecimento da punibilidade dos agentes da repressão política que tenham perpetrado graves violações de direitos humanos

Diante disso, o estudo inicia por contextualizar o advento do nazismo no constitucionalismo do período dos anos 20/30 do século passado, procurando abordar as questões de maior relevância ao debate proposto. Em seguida, passa-se a analisar o surgimento e desenvolvimento da justiça de transição na Alemanha pós-nazismo, desde as medidas de caráter punitivo até as não judiciais, considerando-se o complexo contexto da divisão da Alemanha, das imposições dos Aliados e das opções político-constitucionais consentidas tomadas pelos próprios alemães. Ao fim, pretende-se traçar o alcance da justiça de transição na Alemanha em face da experiência do pós-nazismo, considerando as medidas e os objetivos propostos pela teoria da justiça de transição acima referida.

\section{Contextualizando o advento do nazismo}

Faz-se necessário contextualizar, introdutoriamente, a ascensão da ideologia nazista na Alemanha e como seu ideário levou ao cometimento dos crimes que horrorizaram a humanidade e resultaram em tão drásticas medidas político-jurídicas no período pós-nazismo.

A ideologia nazista pressupõe ao menos dois fundamentos: 1) nacionalismo germânico exacerbado, do qual decorrem posições políticas pangermanistas e ódio

Derecho Constitucional Latinoamericano, ano 15, Montevideo, p. 179-188, 2009.; UPRIMNY, Rodrigo; SAFFON, María Paula. Justicia transicional y justicia restaurativa: tensiones y complementaridades. 2010. Disponível em: <http://www.idrc.ca/en/ev-84576201-1-DO_TOPIC.html>. Acesso em: 26 nov. 2010; PIOVESAN, Flávia. Lei de anistia, sistema interamericano e o caso brasileiro. In: GOMES, Luiz Flávio; MAZZUOLI, Valério de Oliveira (Org.). Crimes da ditadura militar: uma análise à luz da jurisprudência atual da Corte Interamericana de Direitos Humanos. São Paulo: Revista dos Tribunais, 2011. p. 73-86. p. 78. ao que se coloca como influência estrangeira e internacional, dentre as quais a ideologia comunista internacionalista (daí o ferrenho anticomunismo dos nazistas, bem como o antiliberalismo) ${ }^{3}$ e 2) aceitação da desigualdade entre as raças, havendo por natureza raças superiores e inferiores e defendendo com este fundamento a supremacia da raça ariana, especialmente em relação aos judeus, e o igualmente ferrenho antissemitismo daí decorrente ${ }^{4}$. E interessados na "pureza" da raça ariana e da cultura germânica "superior", outros grupos sociais e raciais foram discriminados e violentamente perseguidos, a exemplo dos ciganos e homossexuais.

Em relação ao nacionalismo nazista, a sua postura abertamente anticomunista atraiu vários setores conservadores da direita alemã, temerosos que eram do advento de uma revolução nos moldes do bolchevismo russo. Embora antiliberal, a doutrina nacional-socialista assegurava aos empresários e proprietários (desde que arianos) proteção em relação às suas propriedades e empresas, mantendo os fundamentos capitalistas da economia. A pouca tradição liberal alemã, aliada aos efeitos devastadores da Crise de 1929, fez com que as elites da Alemanha paulatinamente apoiassem os nazistas, resultando na recuperação econômica do país. A implacável perseguição aos comunistas alemães completou a sedimentação de um modelo capitalista não liberal com a quase total destruição da oposição política na Alemanha dos anos 30 do século passado.

Por outro lado, se o nacionalismo germânico era, relativamente, recente em termos práticos, este não se pode afirmar do antissemitismo. Nem mesmo este pode ser atribuído apenas à sociedade alemã, pois o vasto

3 Hannah Arendt, ao contrário da maioria, vê o nacionalismo nazista a partir de outras variáveis, muito mais como uma estratégia de tomada e manutenção do poder político do que como algo genuíno, considerando os moldes do nacionalismo clássico na Europa. Para ela, "Os nazistas não eram meros nacionalistas. Sua propaganda nacionalista era dirigida aos simpatizantes e não aos membros convictos do partido. O "nacionalismo" nazista assemelhava-se à propaganda nacionalista da União Soviética, que também é usada apenas como repasto aos preconceitos das massas. Os nazistas sentiam genuíno desprezo, jamais abolido, pela estreiteza do nacionalismo e pelo provincianismo do Estado-nação. Repetiram muitas vezes que seu movimento, de âmbito internacional (como, aliás, é o movimento bolchevista), era mais importante para eles do que o Estado, o qual necessariamente estaria limitado a um território específico" ARENDT, Hannah. Origens do totalitarismo: anti-semitismo, imperialismo, totalitarismo. São Paulo: Companhia das Letras, 2000. p. 23-24.

4 MANN, Michael. Fascistas. Rio de Janeiro: Record, 2008. p. 192. 
apoio que os nazistas tiveram de nacionais de outros países, como França, Hungria, Polônia e demais que sofreram ocupação militar durante a $2^{\mathrm{a}}$ Guerra, foi em grande medida decorrente de uma simpatia de muitos cidadãos desses países pela postura antissemita do nazismo.

O antissemitismo pode ser, conceitualmente, dividido em tradicional e moderno. O primeiro remonta a tradições muito antigas, a começar pela aversão europeia medieval aos judeus. A Igreja Católica sustentou, durante séculos, violentos ataques aos judeus ao afirmar a superioridade do cristianismo. Daí se estabelecer com tamanha força mitos como o do deicídio (morte de Jesus de Nazaré atribuída aos judeus - "o seu sangue caia sobre nós e nossos filhos", Evangelho segundo Mateus $27,25)$ e da substituição do judaísmo pelo cristianismo. Isso se espalhou pela comunidade cristã, embora não se veja episódios de genocídios e congêneres associados ao antissemitismo tradicional ${ }^{5}$.

O antissemitismo moderno nasceu no século XIX, mais especificamente no seu último terço. Surgiu em termos práticos e, quase simultaneamente, na Alemanha, na Áustria e na França, associando-se aos escândalos financeiros e fraudes milionárias ocorridos nesses países com o envolvimento de grandes capitalistas e banqueiros judeus. Ao lado de fatos como esses e culminando com o tristemente célebre Caso Dreyfus na França (acusações forjadas contra um capitão judeu Alfred Dreyfus - condenado à prisão perpétua em 1894 e reabilitado em 1906), o antissemitismo moderno também contou com um aumento de sofisticação teórica, deixando de lado teses religiosas como a do deicídio e apelando à História e à natureza para justificar a desigualdade racial e explicar a supremacia da raça branca/ ariana, condenando os judeus a um plano de inferioridade racial. Destaquem-se os escritos do diplomata francês Joseph Arthur de Gobineau, enfatizando a impossibilidade de civilização verdadeira fora da raça branca, e do inglês (posteriormente naturalizado alemão) Houston Stewart Chamberlain, com a exaltação da "pureza do sangue teutônico" e da necessidade dos genuínos arianos tomarem posse da "herança da humanidade".

5 CARNEIRO, Maria Luiza Tucci. A Era nazi e o anti-semitismo. In: PINSKY, Jaime; PINSKY, Carla Bassanezi (Org.). Faces do fanatismo. São Paulo: Contexto, 2004. p. 102-133.

6 ARENDT, Hannah. Origens do totalitarismo: anti-semitismo, imperialismo, totalitarismo. São Paulo: Companhia das Letras, 2000. p. 129 - 201.; LACERDA, Gabriel. Nazismo, cinema e direito.
Esse arcabouço ideológico, embora influente, não teve consequências mais sérias do que o Caso Dreyfus até meados da década de 20 do século XX. Mesmo com a derrota alemã na $1^{a}$ Guerra Mundial, o regime político que adveio foi democrático com a promulgação da Constituição de 1919 (a "Carta de Weimar") e a pluralidade político-partidária. Os grupos extremistas de direita e de esquerda já eram ativos, mas não possuíam significativa inserção social nos primeiros anos daquela década. Foram nesses anos, todavia, que os nazistas deram seus primeiros passos: a fundação do Partido Nacional Socialista dos Trabalhadores Alemães (NSDAP Nationalsozialistische Deutsche Arbeiterpartei), rapidamente direcionado para a liderança quase absoluta de Adolf Hitler; a organização de um movimento de insurreição capitaneado por esse partido na Bavária para derrubar - sem sucesso - o governo estadual socialista daquele Estado alemão; a prisão e encarceramento de Hitler, ocasião em que este expõe, pela primeira vez, de forma escrita, suas ideias no famoso livro "Minha luta" (Mein Kampff); a estruturação partidária posterior em vários Estados alemães, concorrendo às suas eleições; a criação de forças paramilitares como as SA (Sturmabteilung - Esquadrão Tempestade) e as SS (Schutžstaffel - Escalão de Proteção).

Até a Crise de 1929, entretanto, o máximo que os nazistas conseguem em termos eleitorais são 12 cadeiras parlamentares, equivalendo à representação de 2,6\% do total do eleitorado ${ }^{7}$.

A recessão deflagrada pela referida Crise com a queda da Bolsa de Nova York, entretanto, terminou por ser um divisor de águas. A Alemanha é fortemente atingida, pressionada pelos financistas norte-americanos em relação à sua dívida externa, o desemprego atinge patamares elevados e a moeda se desvaloriza drasticamente. O cenário de grave crise a torna celeiro fértil a ideias extremistas.

Em tal contexto, os nazistas conseguem se tornar uma força política de grande relevância. Em 1932, Adolf Hitler concorre à Presidência da República, sen-

Rio de Janeiro: Elsevier; FGV, 2012. p. 20-21.

7 AMBOS, Kai; MEYER-ABICH, Nils. La superación jurídicopenal de las injusticias y actos antijurídicos nacionalsocialistas y realsocialistas en Alemania. Revista Penal, n. 24, Hannover/Göttingen: ZIS (Zeitschrift für Internationale Strafrechtsdogmatik), p. 3-22, 2009; MANN, Michael. Fascistas. Rio de Janeiro: Record, 2008. p. 250-251; LACERDA, Gabriel. Nazismo, cinema e direito. Rio de Janeiro: Elsevier; FGV, 2012. p. 9-10. 
do derrotado no $2^{\circ}$ turno pelo já octogenário Marechal Hindenburg, reeleito após mandato de sete anos como Presidente. Ainda assim, Hitler obteve 35\% dos votos. Com a dissolução do parlamento e a realização de novas eleições o partido nazista alcança $32 \%$ dos votos e elege 230 parlamentares, tornando-se partido majoritário da Alemanha. Em janeiro de 1933, diante de inúmeras pressões políticas, o Presidente Hindenburg nomeia Hitler Primeiro-Ministro ${ }^{8}$.

Após sua ascensão ao poder, curiosamente ocorrida com respeito às formas democráticas da Constituição de Weimar, os nazistas conseguiram, em menos de um ano, transformar a Alemanha de uma democracia política em uma ditadura totalitária. O famoso episódio do incêndio do edifício do Reichstag é utilizado por eles para justificar a edição de decreto de emergência suspendendo a esmagadora maioria das garantias constitucionais. A perseguição aos comunistas é generalizada e o Partido Comunista Alemão é esmagado. Outros partidos são dissolvidos ou pressionados a tal, de modo que em julho de 1933 o NSDAP já se torna o único partido alemão. A perseguição aos judeus começa a ganhar vulto.

Os acontecimentos posteriores são por demais conhecidos: a morte de Hindenburg em 1934 permite a Hitler acumular os dois cargos - Primeiro-Ministro e Presidente da República; as leis raciais de Nuremberg são aprovadas, facilitando a perseguição aos judeus, que aumenta gradativamente até chegar aos campos de concentração e à "solução final"; os nazistas promovem o nacionalismo expansionista, iniciando a $2^{a}$ Guerra Mundial que, nos seus primeiros anos, é significativamente vitoriosa para a Alemanha, tendência posteriormente invertida, com a entrada dos EUA no conflito e com a reação da então União Soviética, tornando-se esses países aliados (incluídos aqui o Reino Unido e o governo francês no exílio) contra os nazistas e seus apoiadores?.

Com a completa capitulação alemã, vieram à tona os graves crimes perpetrados pelos nazistas e sua dimensão tornou-se efetivamente conhecida. $\mathrm{O}$ antisse-

8 Segundo Michael Mann, os nazistas conseguiram tomar o poder porque sua liderança soube mobilizar 3 fontes essenciais do poder: o ativismo violento dos seus militantes, os votos de, pelo menos, um terço do eleitorado alemão e a ambivalência das elites nacionais em relação à democracia de Weimar. MANN, Michael. Fascistas. Rio de Janeiro: Record, 2008. p. 252-270.

9 LACERDA, Gabriel. Nazismo, cinema e direito. Rio de Janeiro: Elsevier; FGV, 2012. p. 11-16; FRIEDRICH, Otto. O fim do mundo. Rio de Janeiro: Record, 2000. p. 359s. mitismo moderno mostrou sua face mais intensamente desumana. Como se percebe, ao contrário do antissemitismo tradicional, o moderno trouxe consequências humanitárias muito mais devastadoras. Contou com justificativas teóricas mais sofisticadas e elaboradas, ainda que falsas, com meios tecnológicos mais avançados e, com as decisões políticas de levar o antissemitismo às últimas consequências, vieram, paulatinamente, a perseguição discriminatória, o esvaziamento de direitos de cidadania, a guetização e, por fim, os campos de concentração e a "solução final".

A partir de tais informações e a considerar os objetivos do presente trabalho, vejamos como se deu esse advento do ponto de vista constitucional.

\section{Constitucionalismo weimariano e SeU ESVAZIAMENTO MATERIAL}

A profunda ruptura política ocorrida na sociedade alemã com o advento do nazismo não foi acompanhada de uma ruptura igualmente profunda nas formas constitucionais. Aparentemente, os nazistas preservaram a essência das formas do texto constitucional da República de Weimar, nunca o revogando expressamente, tendo, contudo, esvaziado de sua materialidade o constitucionalismo da época, notadamente na questão dos direitos fundamentais e do exercício da cidadania.

Nesse contexto, é fundamental analisar o desenvolvimento do constitucionalismo weimariano como processo político-jurídico, de acordo com os conceitos expostos em outro trabalho, especialmente a classificação das constituições quanto à conformação do processo político, do constitucionalista alemão Karl Loewenstein, e da teoria analítica dos regimes híbridos, da Professora espanhola Inmaculada Szmolka Vida, verificando, a partir do seu texto constitucional, seu desenvolvimento doutrinário e jurisprudencial, sua inserção histórica e social e as mudanças e rupturas ocorridas sob sua vigência ${ }^{10}$.

10 GALINDO, Bruno. Constitucionalismo e justiça de transição: em busca de uma metodologia de análise a partir dos conceitos de autoritarismo e democracia. Revista da Faculdade de Direito da Universidade Federal de Minas Gerais, n. 67, Belo Horizonte, p. 75-104, 2015.; LOEWENSTEIN, Karl. Teoría de la Constitución. Barcelona: Ariel, 1964. p. 217-218; SZMOLKA VIDA, Inmaculada. Los regímenes políticos híbridos: democracias y autoritarismos con adjetivos: su conceptualización, categorización y operacionalización 
A Constituição alemã de 1919, conhecida como "Carta de Weimar" por ter sido elaborada e aprovada nesta cidade, é um caso singular em termos de legado histórico-constitucional. É quase sempre considerada como o marco inicial do constitucionalismo social do Estado de bem-estar e normalmente vista pelos estudiosos do direito constitucional como uma constituição essencialmente boa em seu texto e em seus objetivos ${ }^{11}$. É praticamente certo que, em qualquer manual ou curso elementar de direito constitucional, estará presente alguma alusão, ainda que superficial, à Constituição de Weimar, normalmente com comentários elogiosos.

Entretanto, foi uma constituição fracassada em termos políticos, não obstante seus grandiosos objetivos. Seu fracasso se deu precisamente pelo contexto no qual esteve inserida, situação histórica que não favoreceu o desdobramento dos propósitos textuais da referida Carta, antes os esvaziou. Foi um texto constitucional de qualidade elevada, mas elaborado em um contexto adverso.

Em 1919, a Alemanha era um país humilhado pela derrota na Primeira Guerra Mundial. Em pleno processo constituinte, é assinado o Tratado de Versailles que impõe pesados ônus aos alemães derrotados, incluindo significativas perdas territoriais. A nova Alemanha republicana nasceu dos destroços do antigo Reich imperial com uma Constituição promulgada e democrática, porém, sem gozar da confiança das forças políticas, desde os trabalhadores e as facções socialistas de esquerda à direita burguesa cética em relação ao novo Estado ${ }^{12}$.

A Constituição de 1919 abarca, em seu texto, uma tentativa de conciliar perspectivas ideológicas distintas. Consagra postulados ideológicos clássicos do liberalismo constitucional, como um sistema de freios e contrapesos (em que pese a existência de um poder presidencial moderador extremamente forte para um sistema parlamentarista) e direitos e garantias civis e políticos. Ao mesmo tempo, incorpora novidades constitucionais oriundas dos pleitos da classe trabalhadora e dos setores à esquerda no espectro político, como a ampliação

dentro de la tipologia de regímenes políticos. Revista de Estudios Políticos, n. 147, Madrid, p. 103-135, 2010.

11 GRIMM, Dieter. Constituição e política. Belo Horizonte: Del Rey, 2006. p. 266.

12 RÜRUP, Reinhard. Génesis y fundamentos de la Constitución de Weimar. Ayer, n. 5, p. 125-158, 1992. Disponível em: <http:// www.ahistcon.org/docs/ayer/ayer5_05.pdf>. Acesso em: 11 set. 2012. da educação obrigatória e gratuita, o condicionamento da liberdade econômica à realização de algum grau de justiça social - com limites ao direito de propriedade -, e ainda o reconhecimento da legitimidade dos movimentos trabalhistas e a criação de um sistema geral de seguridade social.

É uma Carta elaborada, essencialmente, por acadêmicos e professores - à frente Hugo Preuß - que tiveram uma grande preocupação com o fomento a uma cultura republicana e democrática na Alemanha, vislumbrando no texto constitucional um potencial que não encontrou terreno fértil na conjuntura política germânica da época ${ }^{13}$. Foi uma Constituição que passou por grandes provas de fogo contextuais, não fornecendo elementos para a solução das instabilidades dos anos 20/30 do século passado e não conseguindo ser o fator de integração política da sociedade alemã que autores como Rudolf Smend vislumbraram ${ }^{14}$.

Os primeiros anos da vigência da Constituição de 1919 não foram tranquilos, mas pode-se afirmar que ela pode inicialmente garantir as liberdades democráticas e o pluralismo político, admitindo até mesmo a organização de partidos e organizações sociais abertamente antidemocráticas (o que terminou por se revelar letal para o constitucionalismo weimariano). Os direitos sociais não são implementados da mesma maneira, mas a situação menos adversa da economia propicia uma conjuntura momentânea favorável à Carta alemã então vigente.

A Crise de 1929, todavia, mudou, completamente, esse cenário. A Alemanha é pesadamente atingida pela crise econômica mundial e a crise interna se agrava avassaladoramente no fim dos anos 20. A ineficiência da democracia republicana em relação à solução da crise fortalece, politicamente, os partidários de propostas extremistas. Os partidos nazista e comunista são os mais votados nas eleições parlamentares de 1932. As medidas

13 VEIGA, Gláucio. O direito econômico em Weimar: mito e espírito. Anuário dos Cursos de Pós-Graduação em Direito, n. 12. Recife: UFPE, 2002. p. 233-246.; RÜRUP, Reinhard. Génesis y fundamentos de la Constitución de Weimar. Ayer, n. 5, p. 125158, 1992. Disponível em: <http://www.ahistcon.org/docs/ayer/ ayer5_05.pdf $>$. Acesso em: 11 set. 2012.

14 SMEND, Rudolf. Constitución y derecho constitucional. Madrid: Centro de Estudios Constitucionales, 1985.; GALINDO, Bruno. Teoria Intercultural da Constituição: a transformação paradigmática da Teoria da Constituição diante da integração interestatal na União Européia e no Mercosul. Porto Alegre: Livraria do Advogado, 2006. p. 79-80; GRIMM, Dieter. Constituição e política. Belo Horizonte: Del Rey, 2006. p. 266-267. 
de caráter autoritário emergencial, previstas na Constituição para situações extremas, são utilizadas de forma generalizada pelo poder executivo para tentar resolver a crise, destacando-se nesse particular os denominados "decretos de emergência" (Notverordnungen) ${ }^{15}$.

$\mathrm{O}$ art. $48^{\circ}, \int 2^{\circ}$, da referida Carta previa esses decretos com o seguinte texto:

\section{$[\ldots]$}

$\int 2^{\circ}$. No caso de perturbação ou ameaça grave à segurança e ordem pública no Império compete ao Presidente decretar as medidas necessárias ao restabelecimento da ordem e da segurança, mesmo com o recurso à força armada. Para este fim, pode suspender, total ou parcialmente, os direitos fundamentais dos artigos $114^{\circ}, 115^{\circ}, 117^{\circ}, 118^{\circ}$, $123^{\circ}, 124^{\circ}$ e $153^{\circ}$.

Se inicialmente a ideia de que tal prerrogativa na competência do chefe de Estado, o Presidente do Reich é considerada de suma importância contra tentativas de subversão violenta da república, o conceito de "emergência" é ampliado irrestritamente, compreendendo ações políticas referentes a problemas econômicos (elevações e reduções de tributos, controle de capitais e do comércio de divisas), sendo quase todas as medidas impopulares do governo em relação às crises ocorridas por meio dos referidos decretos, numa relação de substituição da lei por eles ${ }^{16}$.

Os artigos referidos como passíveis de suspensão pelo dispositivo são, provavelmente, os mais importantes em termos substantivos, pois envolvem desde o direito à livre manifestação do pensamento até a propriedade e a liberdade de locomoção, o que possibilita ao Presidente por meio de um decreto unilateral e sem debate legislativo empreender o solapamento desses direitos e garantias.

A ascensão de Adolf Hitler ao cargo de Chanceler na esteira da vitória nazista nas eleições parlamentares de 1932 possibilita maior pressão contra os movimentos politicamente contrários, especialmente os comu-

15 MÜLLER, Friedrich. As medidas provisórias no brasil diante do pano de fundo das experiências alemãs. In: GRAU, Eros Roberto; GUERRA FILHO, Willis Santiago (Org.). Direito Constitucional: estudos em homenagem a Paulo Bonavides. São Paulo: Malheiros, 2001. p. 337-355. p. 339.

16 MÜLLER, Friedrich. As medidas provisórias no brasil diante do pano de fundo das experiências alemãs. In: GRAU, Eros Roberto; GUERRA FILHO, Willis Santiago (Org.). Direito Constitucional: estudos em homenagem a Paulo Bonavides. São Paulo: Malheiros, 2001. p. 337-355. p. 341-342. nistas. O temor de parte da elite tradicional alemã de uma revolução bolchevique ou algo do gênero leva os partidos conservadores a apoiarem o novo líder e suas propostas.

O famoso episódio do incêndio do Reichstag - até hoje não completamente esclarecido ${ }^{17}$ - leva os nazistas a aproveitarem a acusação aos comunistas para sustentarem a existência de uma conspiração destes para subverter a ordem pública e conseguem do então Presidente Hindenburg a assinatura, em 28 de fevereiro de 1933 (dia seguinte ao incêndio), de um decreto de emergência, o Reichstagbrandverordnung, que "para a proteção do povo e do Estado" permite na ocasião a suspensão de todos aqueles dispositivos constitucionais aludidos no art. $48^{\circ}, \int 2^{\circ}$, "até segunda ordem"18. Tal decreto permitiu ao governo do Reich empreender uma perseguição generalizada aos opositores políticos que, rapidamente, são presos e outros fogem ainda nos primeiros meses de 1933.

Em 24 de março do mesmo ano, é aprovada pelo Reichstag a Lei de Outorga de Poderes (Ermächtigungsgesets) que transfere ao governo o poder de fazer leis. A partir daí, os próprios instrumentos normativos de-

17 O incêndio do Reichstag foi utilizado como pretexto para uma vasta perseguição aos comunistas e tornou-se decisivo à afirmação concreta do poder nazista. Contudo, mesmo com todo o clima político de "caça às bruxas", o próprio processo de responsabilização penal dos réus foi profundamente inconclusivo: julgados em Leipzig, em 21 de setembro de 1933, dos cinco acusados, apenas Marinus van der Lubbe, holandês que já havia confessado o crime, foi condenado e sentenciado. Lubbe afirmara o tempo inteiro que agira só e pouco se interessou em efetivamente se defender. Já os demais acusados, o comunista alemão Ernst Torgler e outros três comunistas de nacionalidade búlgara, foram absolvidos diante da absoluta ausência de provas concretas contra os mesmos na acusação realizada, não obstante figuras de proa do regime nazista terem dado depoimentos em favor da condenação dos réus, a exemplo de Hermann Goering. O fato é que até hoje pesquisadores se debatem entre a versão da ação isolada de Lubbe, a possível colaboração dos comunistas com este ou mesmo a possibilidade de os próprios nazistas terem ateado fogo ao edifício para utilizarem o ocorrido como pretexto culpabilizador de seus inimigos, como terminaram por fazer, embora a versão de que incendiaram o prédio também não esteja provada. READER'S DIGEST. Os grandes mistérios do passado. Rio de Janeiro: Reader's Digest Brasil, 1996; THE GARDIAN. 75 years on, executed Reichstag arsonist finally wins pardon. Disponível em: < https://www.theguardian.com/world/2008/jan/12/secondworldwar.germany>. Acesso em: 27 dez. 2016.

18 "Ordem Presidencial para a proteção do povo e do Estado: Com base no art. 48 , parágrafo $2^{\circ}$, da Constituição do Reich Alemão, e em defesa contra atos de violência comunista que põem em perigo o estado, fica determinado o seguinte: $₫ 1^{\circ}$. Os arts. 114, 115, 117 , 118, 123, 124 e 153 da Constituição do Reich Alemão ficam suspensos até segunda ordem." 
nominados de leis serão, na verdade, decretos do governo, embora haja exceções relevantes, como as leis raciais de 15 de setembro de 1935 (conhecidas como "leis raciais de Nuremberg" - Nürnberger Rasse-Gesetz), aprovadas pelo Reichstag em sessão extraordinária realizada em Nuremberg ${ }^{19}$. Antes disso, em agosto de 1934, o Marechal Hindenburg, Presidente do Reich, morre, e ainda, de acordo com as formalidades constitucionais - especificamente o art. $51^{020}$-, Adolf Hitler acumula as funções de Chanceler e Presidente do Reich, embora torne permanente na prática o "transitório" previsto no dispositivo, tornando-se, politicamente, senhor absoluto do poder estatal alemão.

Ou seja, em pouco mais de dois anos, ainda que mantidas certas formas constitucionais, a Constituição de Weimar já está, materialmente, esvaziada. Como destacam Ambos e Meyer-Abich, os pilares do constitucionalismo democrático sucumbem completamente, sendo o decreto de emergência para a "proteção do povo e do Estado" a norma demolidora dos direitos fundamentais, ao passo que a Lei de Outorga de Poderes o ato normativo que destrói qualquer resquício de sistema de freios e contrapesos ou separação de poderes no direito alemão do período nazista ${ }^{21}$.

Além da constitucionalização formal dos atos normativos do governo de Hitler e da aceitação social das políticas oriundas de tais atos, aceitação esta ampliada pela aniquilação violenta das forças oposicionistas, os nazistas tiveram farta colaboração da doutrina e da jurisprudência.

Em relação à doutrina, a maior parte dos juristas de Weimar termina por aderir ao novo regime, embora poucos possam ser considerados efetivamente nazistas. José Esteve Pardo, em ensaio sobre a doutrina publicista alemã durante o nazismo, divide as posturas dos juristas germânicos (incluindo aí austríacos como Kelsen) em

19 RIGAUX, François. A lei dos juízes. São Paulo: Martins Fontes, 2000. p. 109.

20 "Em caso de impedimento transitório das funções presidenciais ou em caso de vagatura da presidência, enquanto não se realizar a nova eleição, fica o chanceler investido nas atribuições de Presidente do Império, conjuntamente com as do seu cargo. No entanto, se o impedimento deve prolongar-se, a forma de substituição é regulada por lei."

21 AMBOS, Kai; MEYER-ABICH, Nils. La superación jurídicopenal de las injusticias y actos antijurídicos nacionalsocialistas y realsocialistas en Alemania. Revista Penal, n. 24, Hannover/Göttingen: ZIS (Zeitschrift für Internationale Strafrechtsdogmatik), p. 3-22, 2009. relação ao regime nacional-socialista em quatro grupos:

a. Exilados externos - aqueles que corriam, direta e efetivamente, risco de vida (por sua origem judaica, militância política ou outra razão) com a ascensão dos nazistas ao poder e fugiram para garantir a própria vida. Cita entre eles o próprio Hans Kelsen, bem como Hans Nawiasky, Hermann Heller e Karl Loewenstein, que já em 1933 se evadiram do território alemão;

b. Exilados internos - aqueles que cortaram completamente ou reduziram ao mínimo sua vida pública e acadêmica, não obstante não terem fugido da Alemanha. Foram os casos de Gerhard Anschütz, Heinrich Triepel, Richard Thoma e Rudolf Smend;

c. Adesionistas (expressão minha) - aqueles que, embora não tivessem vínculos prévios com o nazismo, aderiram ao novo regime e colaboraram com o mesmo. $\mathrm{O}$ mais célebre deles foi Carl Schmitt, mas outros renomados juristas da Era Weimar também figuraram entre eles, a exemplo de Ernst Forsthoff, Otto Koellreuter, Theodor Maunz e Ulrich Scheuner. Esse grupo é considerado amplamente majoritário;

d. Nazistas - aqueles declaradamente partidários do nazismo, destacando-se Herbert Best, Reinhard Höhn e Walter Stuckart ${ }^{22}$.

Em relação à jurisprudência, a resistência ao regime nazista foi ainda mais tênue e isolada. Os nazistas foram eficientes em decretar normas que afastaram rapidamente do poder judiciário os juízes judeus e os considerados "politicamente indesejáveis", deixando na função judicante basicamente os magistrados subservientes aos novos poderosos. Nesse contexto, a posição dos magistrados é de cumprimento da ordem jurídica nazista, especialmente em instâncias superiores como o Reichsgericht, o tribunal mais relevante na estrutura constitucional weimariana do poder judiciário. As escassas decisões judiciais contrárias ao regime advinham da jurisdição de instâncias inferiores e normalmente eram reformadas pelo Tribunal do Reich ${ }^{23}$. Uma das poucas ocasiões em que esse último tribunal não atendeu aos interesses do III $^{\circ}$ Reich é quando condena apenas Marinus van der Lubbe pelo incêndio do prédio do Reichstag e absolve, por ausência de provas, os demais acusados, provocan-

22 PARDO, José Esteve. La doctrina alemana del derecho público durante el régimen nacionalsocialista: crónica de un debate tardío. Revista Española de Derecho Constitucional, n. 67, Madrid, p. 171-180, 2003.

23 RIGAUX, François. A lei dos juízes. São Paulo: Martins Fontes, 2000. p. 127-128. 
do reação imediata dos nazistas, instituindo em 1934 o Tribunal do Povo (Volksgerichtshof) com a competência para julgamento dos crimes políticos cometidos contra o regime. Em 1936, é criado o Tribunal de Guerra do Reich (Reichskeriegsgericht) ${ }^{24}$.

O que se percebe é que os nazistas, não obstante violarem continuamente a constitucionalidade material da Carta de Weimar, tiveram um curioso empenho em cobrir a brutalidade e o terror do regime que instauraram com uma espécie de véu de legalidade formal ${ }^{25}$. Praticamente, todos os atos normativos realizados pelos nazistas aparentam respeito às formas constitucionais da Constituição de 1919, não obstante violarem contínua e cotidianamente os mais elementares aspectos substantivos da referida Lei Maior.

Essa Carta corresponde como poucas a uma constituição semântica no conceito loewensteiniano, tendo sofrido, em termos de constitucionalismo, uma mutação no que diz respeito à conformação do poder político: com esse referencial, pode-se afirmar que a referida Constituição foi nominalista entre 1919 e 1933 e semântica a partir daí até $1945^{26}$.

Com a percepção do esvaziamento material pelo qual passou a Carta de Weimar, pode-se perceber melhor a natureza do regime autocrático nazista.

A partir dos conceitos de Franz Neumann, a autocracia nazista configura o tipo totalitário, com o domínio ditatorial dos meios tradicionais de coerção, a adesão popular à figura cesarista de Adolf Hitler e o desenvolvimento dos controles sociais totalitários através do partido único, da polícia política e da dominação absoluta da educação e dos meios de comunicação ${ }^{27}$.

24 AMBOS, Kai; MEYER-ABICH, Nils. La superación jurídicopenal de las injusticias y actos antijurídicos nacionalsocialistas y realsocialistas en Alemania. Revista Penal, n. 24, Hannover/Göttingen: ZIS (Zeitschrift für Internationale Strafrechtsdogmatik), p. 3-22, 2009; LACERDA, Gabriel. Nazismo, cinema e direito. Rio de Janeiro: Elsevier; FGV, 2012. p. 32.

25 RIGAUX, François. A lei dos juízes. São Paulo: Martins Fontes, 2000. p. 107; AMBOS, Kai; MEYER-ABICH, Nils. La superación jurídico-penal de las injusticias y actos antijurídicos nacionalsocialistas y realsocialistas en Alemania. Revista Penal, n. 24, Hannover/Göttingen: ZIS (Zeitschrift für Internationale Strafrechtsdogmatik), p. 3-22, 2009.

26 LOEWENSTEIN, Karl. Teoría de la Constitución. Barcelona: Ariel, 1964. p. 217-218.

27 NEUMANN, Franz. Estado democrático e Estado autoritário. Rio de Janeiro: Zahar, 1969; GALINDO, Bruno. Constitucionalismo e justiça de transição: em busca de uma metodologia de análise a partir dos conceitos de autoritarismo e democracia. Revis-
Estabelecendo uma precisão ainda maior do perfil da ditadura nazista, cabe a utilização dos critérios fornecidos por Szmolka Vida para análise dos regimes políticos, considerando a pontuação 1 como a do regime mais autoritário possível e a 4 o mais democrático possível, ficando os números 2 e 3 para situações normalmente intermediárias ${ }^{28}$ :

$1^{\text {a }}$ dimensão analítica: pluralismo e competição política na obtenção do poder e no desenvolvimento dos processos políticos

Variáveis e pontuações:

pluralismo político: 1

competição política: 1

periodicidade das eleições: 1

competição eleitoral: 1

transparência do processo eleitoral: 1

exercício do direito ao voto: 1

sistema eleitoral e distribuição de assentos parlamentares: 1

funções das eleições de representação e formação do governo: 2

$2^{\mathrm{a}}$ dimensão analítica: funcionamento do governo

$$
\text { Variáveis e pontuações: }
$$

autonomia das instituições representativas no exercício de suas funções: 1

governo sujeito à responsabilidade política (accountability): 1

agentes que decidem em nome do Estado não sujeitos à responsabilidade política: 1

domínios reservados: 2

fenômenos de corrupção e clientelismo: 1

$3^{\text {a }}$ dimensão analítica: direitos e liberdades públicas

Variáveis e pontuações:

direitos de associação e reunião: 1

liberdade de expressão: 1

liberdade de imprensa e pluralidade de meios de comunicação e acesso a fontes alternativas de

ta da Faculdade de Direito da Universidade Federal de Minas Gerais, n. 67, Belo Horizonte, p. 75-104, 2015. p. 92-95. p. 82-83.

28 SZMOLKA VIDA, Inmaculada. Los regímenes políticos híbridos: democracias y autoritarismos con adjetivos: su conceptualización, categorización y operacionalización dentro de la tipologia de regímenes políticos. Revista de Estudios Políticos, n. 147, Madrid, p. 103-135, 2010.; GALINDO, Bruno. Constitucionalismo e justiça de transição: em busca de uma metodologia de análise a partir dos conceitos de autoritarismo e democracia. Revista da Faculdade de Direito da Universidade Federal de Minas Gerais, n. 67, Belo Horizonte, p. 75-104, 2015. p. 92-95. 
informação: 1

autonomia do poder judiciário: 2

proteção legal e judicial contra os abusos cometidos pelo Estado ou por terceiros: 1

monopólio legítimo da violência pelo Estado: 1

respeito aos direitos humanos: 1

Qual o significado dessas pontuações? Avalio que, fundamentalmente, a descrição de um Estado totalitário em larga escala, repressor e desumano ao extremo, o que termina por gerar uma reação política e jurídica posterior sem precedentes, diante do grau de excepcionalidade da situação.

\section{DerRota militar E EXPOSIÇÃo dos CRIMES NAZISTAS}

A perspectiva nazista de poder é expansionista, o que faz o domínio sobre a Alemanha ser geopoliticamente insuficiente. Restaurar e ampliar sua força dominante, expandindo o poder político para além de suas fronteiras, torna-se algo politicamente fundamental. $\mathrm{O}$ Anschluss da Áustria natal de Hitler — sob o discurso do pangermanismo - , o Pacto de Munique - que praticamente entrega a então Tchecoslováquia à Alemanha, com a leniência de países como França e Reino Unido —, a invasão da Polônia e outros atos de beligerância perpetrados pelos comandados do Führer, demonstram que o país ressurge com força militar ainda maior do que na Primeira Guerra.

Os primeiros anos da Segunda Guerra Mundial são, claramente, favoráveis à máquina de guerra alemã. Ao leste e ao oeste, o domínio nazista se expande rapidamente, derrotando forças armadas bem equipadas e treinadas, fazendo sucumbir potências como a França e, em um primeiro momento, até mesmo a União Soviética, que sofreu pesadas derrotas nos primeiros atos da invasão germânica. As extraordinárias forças armadas alemãs, com a disciplina e a organização herdadas da Escola Militar Prussiana, conseguiram feitos bélicos admiráveis e assustadores, apenas não conseguindo invadir (dos lugares que almejou) o Reino Unido, não obstante a Luftwaffe (Força Aérea) ter bombardeado impiedosamente o território britânico e provocado pesadas perdas econômicas e militares àquele país. ${ }^{29}$

29 BARNETT, Correlli. Introdução. In: BARNETT, Correlli
A entrada dos EUA na guerra possibilita maior fôlego aos Aliados antinazistas. A necessidade de lutar em várias frentes dificulta a manutenção da situação inicialmente favorável pelas forças armadas alemãs. A reação dos Aliados ganha contornos de guinada decisiva especialmente em dois episódios daquele conflito. Um deles, o desembarque das forças armadas norte-americanas na Normandia em 1944 - conhecido como "Dia D" -, no qual a vitória foi decisiva para que os EUA/Reino Unido e insurgentes adentrassem a Europa ocidental até chegarem à Alemanha. $\mathrm{O}$ outro foi a emblemática Batalha de Stalingrado, na qual os soviéticos infligiram derrota avassaladora aos invasores nazistas e puderam adentrar leste europeu adentro até o território alemão, tomado de todos os lados no final da guerra pelos Aliados.

O desfecho é bem conhecido: completamente acuados, os membros do comando militar alemão decidem pela rendição incondicional exigida pelos Aliados, após as mortes de Hitler, Goebells e outros líderes nazistas. Em 7 de maio de 1945, o Almirante Karl Doenitz, sucessor do Führer, assina o ato de capitulação alemã. Berlin, assim como toda a Alemanha, ficam então sob o domínio quadripartite dos EUA, Reino Unido, França e URSS.

A partir do momento de seu domínio político, os Aliados, e, posteriormente, a comunidade internacional, têm acesso a pessoas, documentos, filmagens e provas as mais diversas de uma extensão de crimes cometidos pelos nazistas antes e durante a Guerra que provavelmente poucos imaginavam fossem em tal magnitude. Os horrores vistos em Auschwitz, Dachau, Sobibor, Treblinka e muitos outros deixam perplexas as potências vencedoras, já que não se trata apenas dos já conhecidos crimes de guerra previstos nas Convenções de Genebra e de Haia (não obstante também terem sido cometidos pelos nazistas), mas de condutas vistas como desumanas e cruéis em uma escala e sofisticação não antes vista em conflitos bélicos e regimes autoritários similares.

No afã de conquistarem o poder total, os nazistas cometeram, internamente, toda ordem de crimes contra seus opositores políticos. Todavia, as doutrinas da supremacia da raça ariana e da expansão do espaço vital alemão permitiram uma ampliação dos referidos atos contra uma série de pessoas que, na maioria das

(Org.). Os generais de Hitler, Rio de Janeiro: Jorge Zahar, 1990. p. 15-31. p. 22. 
vezes, pouco atuaram como inimigos dos nazistas. Simplesmente foram "escolhidas" por tais doutrinas como inimigas, sofrendo incomensuráveis indignidades em razão disso. A luta por uma comunidade ariana homogênea levou o regime nazista a promover uma "higiene racial" e uma supremacia dos "mais fortes pela natureza", privando judeus, ciganos, homossexuais e pessoas com deficiência de seus direitos, de sua liberdade, de sua dignidade e até de sua vida. ${ }^{30}$ São, tristemente, famosos os experimentos médico-científicos nos campos de concentração em que aquelas pessoas serviam de cobaias humanas (incluindo crianças e bebês) aos sadismos de pretensos cientistas médicos, a exemplo de Josef Mengele, em uma utilização da ciência para finalidades malévolas, nunca antes feita nessa dimensão, a ponto da filósofa Hannah Arendt ter se utilizado da polêmica expressão "banalidade do mal" para tentar descrever esse estado de coisas tão assustador ${ }^{31}$.

Estima-se que, na Europa, sob o domínio hitlerista sucumbiram entre cinco a seis milhões de judeus, assassinados por ou em consequência das políticas de "higiene racial" dos nazistas. Os não judeus, porém integrantes daquelas outras categorias de pessoas, sofreram tanto quanto, embora seja mais difícil a obtenção de estatísticas precisas a respeito.

Anteriormente, como o Tribunal do Povo ainda deu significativa contribuição aos números do horror: relativamente "parcimonioso" entre 1934 e 1939, período em que condenou à morte 85 pessoas por "crimes" contra o regime (leia-se crimes políticos), esse número alcança a cifra de 5.181 condenações à pena capital efetuadas entre 1940 e 1944, dentre elas as do Coronel Claus von Stauffenberg, um dos líderes da célebre Operação Valquíria, a mais significativa tentativa dos próprios alemães de removerem Hitler do poder. Em uma investigação governamental realizada em 1986, chegou-se ao número aproximado de 35 mil execuções por condenações à morte de criminosos políticos entre 1933 e 1945, período do $3^{\circ}$ Reich ${ }^{32}$. Por óbvio que

30 AMBOS, Kai; MEYER-ABICH, Nils. La superación jurídicopenal de las injusticias y actos antijurídicos nacionalsocialistas y realsocialistas en Alemania. Revista Penal, n. 24, Hannover/Göttingen: ZIS (Zeitschrift für Internationale Strafrechtsdogmatik), p. 3-22, 2009.

31 ARENDT, Hannah. Eichmann em Jerusalém: um relato sobre a banalidade do mal. São Paulo: Companhia das Letras, 2000.

32 AMBOS, Kai; MEYER-ABICH, Nils. La superación jurídicopenal de las injusticias y actos antijurídicos nacionalsocialistas y realsocialistas en Alemania. Revista Penal, n. 24, Hannover/Göt- aqui se trata apenas daquelas execuções de pessoas que sofreram condenação formal seguindo procedimentos jurídicos e com a realização de julgamentos pelo poder judiciário de então, embora inexistisse independência judicial ${ }^{33}$. Ou seja, não estão neste artigo relacionadas as milhares/milhões de execuções extrajudiciais realizadas nos campos de concentração ou fora deles, bem como as execuções "indiretas” por fome, desnutrição, "experiências científicas" e outras causadas e de responsabilidade dos nazistas.

\section{Parâmetros JuRídicos e humanitários da PRIMEIRA EXPERIÊNCIA DE JUSTIÇA DE TRANSIÇÃO DA HISTÓRIA}

Os Aliados venceram a $2^{\mathrm{a}}$ Guerra. A Alemanha nacional-socialista capitulou. Alguns dos principais líderes nazistas morreram, a exemplo de Goebells e do próprio Hitler. Um saldo de dezenas de milhões de mortos dentre militares e populações civis deixa um cenário devastador na Europa e várias partes fora dela. Crimes assustadores e graves violações de direitos humanos essenciais foram perpetrados em uma escala inédita.

Em um primeiro momento, pareceu ocorrer certo consenso em torno da ideia de que a humanidade precisava repensar suas práticas e teorias e engendrar esforços para que atos daquela natureza não mais se repetissem. E os Aliados possuíam um incomensurável papel moral nesses esforços.

A exposição dos crimes cometidos gerou perplexidade e espanto em um grau também inédito. É provável que até os mais obstinados antinazistas não imaginassem a dimensão e a forma que tais crimes adquiriram. Não que atos dessa natureza fossem exatamente uma novidade (recorde-se o massacre dos armênios pelo Império Turco Otomano ou os expurgos stalinistas na URSS da década de 30), mas o modo calculista, eficiente e racional de como esse mal foi praticado - especialmente nos

tingen: ZIS (Zeitschrift für Internationale Strafrechtsdogmatik), p. 3-22, 2009.

33 É interessante notar que boa parte desses processos eram essencialmente teatrais e espetaculizarizados, como aqueles conduzidos pelo Juiz Roland Freisler, seguramente um dos mais célebres magistrados que estiveram entusiasmadamente a serviço do $\mathrm{III}^{\circ}$ Reich. BATISTA, Nilo. Atualidade de Roland Freisler. Passagens: Revista Internacional de História Política e Cultura Jurídica, v. 7, n. 1, Rio de Janeiro, UFF, p. 5-14, 2015. 
campos de concentração - deixa atônito qualquer um que se debruça sobre o tema, por mais que pretenda estudá-lo de modo desapaixonado e científico ${ }^{34}$.

Diante desse quadro, os objetivos da justiça de transição - justiça, verdade, memória, reformas institucionais e reparações - precisavam ser levados adiante, muito embora os Aliados ainda não tivessem essa compreensão analiticamente articulada. Mas mesmo antes do fim do conflito e de diferentes modos, os Aliados começaram a debater quais medidas penais e extrapenais seriam necessárias para a responsabilização dos criminosos nazistas e de seus colaboradores, para a reparação e a reabilitação de suas vítimas e para a desnazificação da sociedade alemã, com o objetivo de reconstrui-la com perfil democrático e humanista ${ }^{35}$.

\subsection{Julgamentos dos criminosos nazistas: 0 Tribunal Militar Internacional de Nuremberg e seus desdobramentos judiciais}

De início, os debates sobre os aspectos de justiça material tomaram considerável vulto. No campo penal, era urgente empreender a responsabilização pelas gra-

34 HERF, Jeffrey. Divided Memory - The nazi past in the two Germanys. Cambridge/Massachussets: Harvard University Press, 1997, p. 357; FRIEDRICH, Otto. O fim do mundo. Rio de Janeiro: Record, 2000. p. 359s. Não desejo aqui afirmar que tais crimes somente foram cometidos pelos nazistas, o que seria, no mínimo, ingênuo. São bem conhecidos os bombardeios norte-americanos em Hiroshima e Nagasaki, onde utilizaram a recém-inventada bomba atômica para aniquilar centenas de milhares de seres humanos, a maior parte deles civis. Menos conhecido é o bombardeio aliado em Dresden, completamente desnecessário, como por vezes não se dá a devida atenção aos estupros e violências massivas contra populações civis alemãs, perpetrados principalmente por soldados soviéticos. Mas abordar tais questões fugiria aos modestos objetivos deste trabalho.

35 É necessário que se diga, no entanto, que a ideia de judicialização dos crimes dos nazistas nunca fora totalmente consensual. Antes, ao contrário, houve até explícitas defesas de execuções sumárias em massa, notadamente por soviéticos (o próprio Stalin) e norte-americanos (Henry Morgenthau Jr., Secretário do Tesouro, e, em alguma medida, o próprio Roosevelt), freadas, sobretudo, pela resistência do Primeiro-Ministro britânico Winston Churchill e, posteriormente, do Secretário de Guerra dos EUA, Henry L. Stimson. Curiosamente, o julgamento dos líderes nazistas por um tribunal internacional fora sugerida pela primeira vez publicamente pelo Ministro do Exterior da União Soviética, Vyacheslav Molotov, em carta aos governos dos países do Leste Europeu no exílio, datada de 14 de outubro de 1942 e foram também os soviéticos os primeiros a fazerem julgamentos em seu próprio território retomado das tropas alemãs de nazistas capturados e de seus próprios cidadãos quando acusados de colaboracionismo. GOLDENSOHN, Leon. As entrevistas de Nuremberg. São Paulo: Companhia das Letras, 2005. p. 8. víssimas violações de direitos humanos do período e a judicialização da questão foi ponderada como a forma mais adequada de lidar com a questão, não obstante a precariedade das condições para tal. Em sendo assim, os Aliados utilizaram diferentes meios de persecução penal dos crimes dos nazistas, que podem ser divididos em pelo menos 3:

1. Persecução penal cooperativa dos 4 Aliados, a exemplo do Tribunal Militar Internacional de Nuremberg;

2. Atuação das cortes militares nacionais de cada um dos Aliados em suas respectivas zonas de ocupação, sob a égide da Lei n ${ }^{\circ} 10$ do Conselho de Controle (Control Council Law n ${ }^{\circ} 10$ ) e das leis nacionais sobre crimes de guerra;

3. Atuação das cortes criminais alemãs, no início sob supervisão dos Aliados e, posteriormente, de forma independente ${ }^{36}$.

A divisão da Alemanha em quatro zonas de ocupação, administradas cada uma delas por um dos quatro países Aliados, fez com que as medidas de justiça de transição fossem diferenciadas em cada área. Contudo, os Aliados encontraram alguns denominadores comuns em torno de princípios norteadores de tais ações, sendo o principal deles a decisão política de criarem um tribunal composto por juízes dos quatro países em posição de paridade para efetuarem um julgamento em parâmetros judiciais das figuras de proa do regime nazista, realizando a aludida persecução penal cooperativa. A ideia seria romper com a clássica perspectiva de os vencedores simplesmente subjugarem os vencidos. Para tal, criaram estatutos e regras próprias ao funcionamento da Corte, delimitando o alcance das acusações e permitindo debates judiciais com algumas oportunidades de contraditório e de ampla defesa, não obstante o equilíbrio entre as partes não tenha sido efetivo.

Tendo nesse primeiro momento a justiça material como principal objetivo, os quatro países criaram, a partir das bases jurídicas do Acordo Londrino das Quatro Potências, de 6 de agosto de 1945, o Tribunal Militar Internacional, cujo Estatuto previa, além das regras processuais e procedimentais e de composição da corte, os crimes de sua competência em seu art. 6: crimes de guerra, crimes contra a paz e crimes contra a

36 COHEN, David. Transitional justice in divided Germany after 1945. In: ELSTER, Jon (Org.). Retribution and Reparation in the Transition to Democracy. New York: Cambridge University Press, 2006. p. 59-88. p. 59. 
humanidade. ${ }^{37}$ Sua sede foi estabelecida em Nürnberg/ Nuremberg, como uma resposta política simbólica ao ideário nazista: essa cidade foi palco dos maiores comícios e manifestações públicas daquela ideologia, bem como o local de aprovação das já referidas "Leis raciais de Nuremberg". E o objetivo principal desse Tribunal era julgar não somente indivíduos relevantes do regime, mas o próprio regime e suas instituições.

Em princípio, o TMI desconsiderou a Constituição semântica de Weimar e estabeleceu-se juridicamente com fundamento no direito internacional, inclusive em sua parte consuetudinária, ainda predominante nessa época. O Estatuto do TMI foi considerado a principal referência normativa levada em consideração pelo Tribunal, pois estabeleceu as competências deste, os procedimentos aos quais a Corte e os colaboradores (acusação, defesa, réus etc.) deviam obediência, e ainda a definição dos crimes objetos de julgamento. A própria irretroatividade da lei penal foi vista pelo TMI como princípio de justiça ajustável às necessidades de um mundo em mudança ${ }^{38}$.

Realizado entre os anos de 1945 e 1946, o processo do TMI de Nuremberg levou ao banco dos réus 22 acusados de grande importância do regime e 6 organizações oficiais do $\mathrm{III}^{\circ}$ Reich. No caso dessas últimas, foram consideradas, coletivamente, criminosas o Partido Nacional-Socialista dos Trabalhadores Alemães (NSDAP - Nationalsozialistische Deutsche Arbeiterpartei, mais especificamente sua cúpula dirigente), o Esquadrão de Proteção (a SS - Schutæstaffe), a Polícia Secreta do Estado (a Gestapo - Geheime Staatspolizer) e o Serviço de Segurança (o SD - Sicherheitsdienst). Ficaram de fora as Tropas de Assalto (as SA - Sturmabteilung) e o Corpo de Generais e Altos Mandatários das Forças Armadas $(\mathrm{OKW}-\text { Generalstab und Oberkommando der Webrmacht })^{39}$.

37 AMBOS, Kai; MEYER-ABICH, Nils. La superación jurídicopenal de las injusticias y actos antijurídicos nacionalsocialistas y realsocialistas en Alemania. Revista Penal, n. 24, Hannover/Göttingen: ZIS (Zeitschrift für Internationale Strafrechtsdogmatik), p. 3-22, 2009.

38 AMBOS, Kai; MEYER-ABICH, Nils. La superación jurídicopenal de las injusticias y actos antijurídicos nacionalsocialistas y realsocialistas en Alemania. Revista Penal, n. 24, Hannover/Göttingen: ZIS (Zeitschrift für Internationale Strafrechtsdogmatik), p. 3-22, 2009 .

39 AMBOS, Kai; MEYER-ABICH, Nils. La superación jurídicopenal de las injusticias y actos antijurídicos nacionalsocialistas y realsocialistas en Alemania. Revista Penal, n. 24, Hannover/Göttingen: ZIS (Zeitschrift für Internationale Strafrechtsdogmatik), p. 3-22, 2009. ; RIGAUX, François. A lei dos juízes. São Paulo: Mar-
No caso dos acusados, eles foram escolhidos não somente pelo papel que desempenharam na liderança de setores ligados ao regime extinto, mas também pela sua representatividade desses mesmos setores, permitindo forte simbolismo no que diz respeito à abrangência do julgamento, com a ideia de se responsabilizar não somente os militares, mas também diplomatas, industriais, economistas, comunicadores e todos aqueles que contribuíram de modo decisivo ao fortalecimento do poder nazista. Dos 22 réus, 19 foram condenados, sendo: 12 à morte por enforcamento (Hermann Goering, Alfred Jodl, Alfred Rosenberg, Artur Seyss-Inquart, Ernst Kaltenbrunner, Fritz Sauckel, Hans Frank, Joachim von Ribbentrop, Julius Streicher, Martin Borman, Wilhelm Frick e Wilhelm Keitel), 3 à prisão perpétua (Erich Raeder, Rudolf Hess e Walter Funk) e 4 a encarceramentos temporários (Albert Speer - 20 anos, Baldur von Schirach - 20 anos, Constantin von Neurath - 15 anos e Karl Doenitz - 10 anos). Foram absolvidos: Franz von Papen, Hans Fritzsche e Hjalmar Schacht ${ }^{40}$.

Diante dessas circunstâncias, o TMI terminou por concluir pela natureza criminosa do regime e, consequentemente, pela ilegitimidade do sistema normativo por ele imposto ${ }^{41}$.

Para além do direito internacional e nacional existentes na ocasião, a dimensão extraordinária do horror perpetrado fez com que o TMI assumisse medidas profundamente controversas de justiça material e processual, a se considerar as formas como tais responsabilizações são feitas nos parâmetros do Estado democrático de direito.

Do ponto de vista processual, há vários questionamentos até hoje debatidos quando da análise do TMI, sendo de se destacar as alegadas características de tribunal de exceção, o comprometimento da imparcialidade dos juízes e a ausência de recorribilidade judicial. Em termos de justiça material, é bastante controvertida a relativização do princípio da legalidade e da irretroatividade da lei penal, utilizada como artifício para se atingirem os criminosos nazistas e suas organizações ${ }^{42}$.

tins Fontes, 2000. p. 146.

40 GOLDENSOHN, Leon. As entrevistas de Nuremberg. São Paulo: Companhia das Letras, 2005. p. 18-19.

41 RIGAUX, François. A lei dos juízes. São Paulo: Martins Fontes, 2000. p. 145-146.

42 GONÇALVES, Joanisval Brito. Tribunal de Nuremberg 1945-1946: a gênese de uma nova ordem no direito internacional. Rio de Janeiro: Renovar, 2001. p. 147. 
De fato, o TMI foi instalado expost facto, o que, seguramente, lhe dá caracteres de tribunal de exceção, pois não havia até então qualquer previsão de cortes internacionais com competência delimitada para julgar tais crimes. Não houve critérios apriorísticos de seleção e escolha dos juízes e o tribunal foi extinto logo após proferir seu veredito ${ }^{43}$.

A imparcialidade dos julgadores é também questionável, pois somente juízes oriundos dos países vencedores da Guerra integraram o TMI. Tiveram a incumbência de julgar aqueles que até poucos meses antes eram inimigos de suas pátrias, o que, por mais dignos e probos que fossem, no mínimo, pode-se admitir a existência de um sério componente psicológico e subjetivo a levar a uma visão parcial e tendenciosa das questões. Brito Gonçalves destaca que um tribunal composto de juízes efetivamente neutros em relação à participação no conflito - suíços ou suecos, p. ex. - ou ao menos uma corte mista, seria potencialmente mais imparcial, sendo o caso de juízes neutros se manifestarem sobre acusações de uma promotoria formada pelos Aliados e uma defesa elaborada pelos próprios alemães ${ }^{44}$.

A definitividade da decisão, prevista no art. 26 do Estatuto, também terminou por não permitir correções de eventuais equívocos do TMI, o que talvez fosse mais recomendável, principalmente pelo fato de que o referido tribunal ainda atuara no calor dos acontecimentos e, possivelmente, sem o distanciamento necessário para decisões mais equânimes.

Do ponto de vista material, o aspecto mais controverso foi a parcial violação do princípio da legalidade, culminando com a retroatividade da lei em desfavor dos réus. O Estatuto do TMI, em seu art. 6, previu a existência de três tipos de crimes pelos quais os réus poderiam responder: crimes contra a paz, crimes de guerra e crimes contra a humanidade. Entretanto, apenas no caso dos crimes de guerra, havia expressa previsão normativa no direito internacional, mais precisamente como objeto das Convenções de Haia/1927 e de Genebra/1929. Os crimes contra a paz, essencialmente associados à preparação e premeditação de violações de tratados internacionais, e os crimes contra a humanidade, que

43 MELLO, Celso D. de Albuquerque. Direitos humanos e conflitos armados. Rio de Janeiro: Renovar, 1997. p. 441.

44 GONÇALVES, Joanisval Brito. Tribunal de Nuremberg 1945-1946: a gênese de uma nova ordem no direito internacional. Rio de Janeiro: Renovar, 2001. p. 153. se tornam, provavelmente, a grande inovação do TMI, alegando a necessidade de se punir efetivamente graves violações de direitos humanos (em especial o genocídio e o extermínio em massa) não estavam previstos em qualquer legislação internacional anterior aos fatos ${ }^{45}$.

São indubitavelmente plausíveis as críticas exaradas ao TMI, pois de fato este se estabelece violando uma série de clássicos e sedimentados entendimentos acerca dos princípios do Estado de direito presentes nos sistemas jurídicos dos Aliados vencedores (rule of law, Etat de droit), bem como o próprio Rechtstaat germânico anterior à ascensão nazista.

Todavia, permito-me aqui realizar certa defesa do TMI, procurando apontar os relevantes aspectos positivos de justiça material e processual na atuação da corte, principalmente se levarmos em conta o grau de excepcionalidade daquele momento imediatamente após a Guerra. Estabeleceram-se procedimentos e regramentos a serem observados, configurando uma razoável aplicação do devido processo legal. Muito embora a defesa não tenha sido tão ampla como no Estado de direito regular, houve debates judiciais e os réus e os defensores tiveram oportunidade de apresentar suas razões. Apesar de certa sanha persecutória por parte dos julgadores, estes tiveram algum discernimento para realizar dosimetrias das penas de modo que a culpabilidade foi avaliada caso a caso, não se configurando aí uma mera "caça às bruxas": as penas foram diversas entre os condenados e até mesmo absolvições ocorreram, o que, se contextualizadas as tensões políticas daquele período, o julgamento do TMI não deixa de ser um feito notável, apesar das imperfeições apontadas.

$\mathrm{Na}$ visão do Promotor norte-americano e principal acusador no julgamento, Robert Jackson, com a qual em linhas gerais eu concordo, “o julgamento representou um dos mais significativos tributos que o poder prestou à razão" ${ }^{\prime 4}$.

Com o encerramento das atividades do TMI, a persecução penal ficou a cargo de tribunais dos Aliados em suas respectivas zonas de ocupação, de acordo com a

45 GONÇALVES, Joanisval Brito. Tribunal de Nuremberg 1945-1946: a gênese de uma nova ordem no direito internacional. Rio de Janeiro: Renovar, 2001. p. 135-136.

46 "the trial represented one of the most significant tributes that Power has ever paid to reason", in: COHEN, David. Transitional justice in divided Germany after 1945. In: ELSTER, Jon (Org.). Retribution and Reparation in the Transition to Democracy. New York: Cambridge University Press, 2006. p. 59-88. p. 61. 
Lei n ${ }^{\circ} 10$ do Conselho de Controle, bem como de cortes alemãs, sob supervisão dos Aliados até 1952.

As questões de justiça material da justiça de transição pós-nazismo na Alemanha ocupada foram pensadas a partir das políticas gerais de desnazificação (Entnazifizierung), que envolviam os outros aspectos de natureza transicional, desde a educação até o funcionamento das instituições estatais.

Se, por um lado, a desnazificação da sociedade alemã era algo extremamente relevante, por outro, uma perseguição generalizada daqueles que possuíam vínculos com o nazismo tornaria inviável a construção de uma nova Alemanha, sedimentada em valores universalistas democráticos e humanistas. Em uma sociedade governada por um regime totalitário, a oposição política tende a ser aniquilada e os sobreviventes são, forçosamente ou não, assimilados ao regime. Não há neutralidade possível, os tentáculos totalitários se expandem por toda a sociedade, sendo a adesão e a colaboração com o regime uma condição mesma de sobrevivência das pessoas. E foi precisamente assim na Alemanha nazista.

Com a capitulação alemã, em maio de 1945 e a assunção do controle político do país pelos Aliados, estes constataram que, oficialmente, o Partido Nazista possuía 6.542.261 filiados, não incluídos aqui os colaboradores não oficiais e os simpatizantes. Diante da inviabilidade prática de se perseguir tanta gente, os tribunais aliados e alemães passaram a se utilizar dos critérios de categorização da culpabilidade, então já de uso corrente pelas comissões de desnazificação - as denominadas Câmaras de Sentença (Spruchkammern) -, para, valendo-se de certa parcimônia, empreender a persecução penal para os nazistas considerados, efetivamente, perigosos e responsáveis por crimes mais impactantes, deixando livres ou punindo brandamente os colaboradores e membros do NSDAP tidos como de menor importância ${ }^{47}$. Para tal, as categorias de culpabilidade, generalizadamente utilizadas, foram cinco, de acordo com a gradação criminosa:
1) culpado principal;
2) incriminado;
3) levemente incriminado;
4) simpatizante;

47 COHEN, David. Transitional justice in divided Germany after 1945. In: ELSTER, Jon (Org.). Retribution and Reparation in the Transition to Democracy. New York: Cambridge University Press, 2006. p. 59-88. p. 68.

$$
\text { 5) não incriminado }{ }^{48} \text {. }
$$

Em geral, apenas as duas primeiras categorias foram punidas de forma mais severa, com penas de perda de direitos civis, confisco de bens, prisão e até morte (neste caso, somente pelos tribunais aliados). Os levemente incriminados passaram por punições brandas (dificilmente sendo encarcerados, p. ex.), ao passo que os simpatizantes e os não incriminados em geral foram absolvidos e reabilitados ${ }^{49}$.

Todavia, tais categorias nem sempre eram interpretadas da mesma maneira pelos Aliados ocupantes e seus diferentes sistemas jurídicos, bem como pelos próprios alemães. Razões de natureza estritamente política, como o advento da chamada Guerra Fria, fizeram com que os Aliados buscassem a colaboração e a simpatia da população alemã em suas respectivas áreas de ocupação, tentando um alinhamento político com seus posicionamentos na nova conjuntura internacional, dando origem à formação de duas repúblicas alemãs distintas, a República Federal da Alemanha, oriunda da junção entre os setores britânico, francês e norte-americano, e a República Democrática Alemã, nascida do setor soviético.

Diante desse novo cenário, a transferência do processo de justiça de transição aos próprios alemães terminou por ser almejada em todas as áreas de ocupação. Mas entre 1945 e 1952, conviveram cortes aliadas e alemãs no processo de responsabilização dos nazistas, utilizando-se, cada uma a seu modo, das categorias aludidas de culpabilidade para realizarem seu trabalho.

Em Nuremberg, tribunais militares dos EUA efetuaram 12 julgamentos de membros das elites funcionais do $3^{\circ}$ Reich entre 1946 e 1949 . No restante do setor norte-americano de ocupação, outros processos ocorreram. As cortes norte-americanas levaram 1.941 pessoas aos bancos dos réus; em relação a estas, 324 foram condenadas à morte, 247 à prisão perpétua e 946 a penas de prisão temporária; 57 réus tiveram direito à suspensão de suas penas e 367 foram absolvidos ${ }^{50}$.

48 AMBOS, Kai; MEYER-ABICH, Nils. La superación jurídicopenal de las injusticias y actos antijurídicos nacionalsocialistas y realsocialistas en Alemania. Revista Penal, n. 24, Hannover/Göttingen: ZIS (Zeitschrift für Internationale Strafrechtsdogmatik), p. 3-22, 2009 .

49 COHEN, David. Transitional justice in divided Germany after 1945. In: ELSTER, Jon (Org.). Retribution and Reparation in the Transition to Democracy. New York: Cambridge University Press, 2006. p. 59-88. p. 74.

50 AMBOS, Kai; MEYER-ABICH, Nils. La superación jurídicopenal de las injusticias y actos antijurídicos nacionalsocialistas y 
$\mathrm{O}$ interesse norte-americano em ter a então Alemanha Ocidental como aliada no cenário da Guerra Fria fez com que o Alto Comissário John McCloy anunciasse em janeiro de 1951, após certa pressão política do Governo do Chanceler Konrad Adenauer e de parte da sociedade civil alemã ${ }^{51}$, que, dos 89 criminosos nazistas de alto escalão presos em decorrência dos julgamentos de Nuremberg, 78 tivessem suas penas reduzidas, sendo 31 deles, em razão da redução, imediatamente libertados, incluindo Alfried Krupp, altos oficiais da SS, generais, políticos e juízes ${ }^{52}$.

No setor britânico, as cortes militares do Reino Unido condenaram 1.085 réus, sendo 240 deles à morte. As ações de justiça transicional do Reino Unido em seu setor foram mais seletivas, tentando equilibrar a responsabilização criminal com os objetivos de reconstrução da Alemanha, não fazendo da primeira um objetivo central da ocupação daquele país ${ }^{53}$.

$\mathrm{Na}$ zona francesa de ocupação, os tribunais daquele país condenaram 2.107 réus, sendo 104 deles à pena capital. É considerado por diversos autores o país que menos priorizou as ações de justiça de transição, interessado que estava em garantir recursos alemães para a reconstrução da França, bem como em manter o vizinho enfraquecido e inofensivo ${ }^{54}$.

Nesses três setores - norte-americano, britânico e francês - mais da metade das penas de morte foram

realsocialistas en Alemania. Revista Penal, n. 24, Hannover/Göttingen: ZIS (Zeitschrift für Internationale Strafrechtsdogmatik), p. 3-22, 2009.

51 Pesquisas realizadas nos anos que se seguiram ao fim da $2^{a}$ Guerra, apontaram que o apoio dos alemães à desnazificação foi alto em seu início, diminuindo drasticamente ano a ano: $57 \%$ em 1946, $32 \%$ em 1948 e apenas 17\% em 1949. COHEN, David. Transitional justice in divided Germany after 1945. In: ELSTER, Jon (Org.). Retribution and Reparation in the Transition to Democracy. New York: Cambridge University Press, 2006. p. 59-88. p. 73.

52 COHEN, David. Transitional justice in divided Germany after 1945. In: ELSTER, Jon (Org.). Retribution and Reparation in the Transition to Democracy. New York: Cambridge University Press, 2006. p. 59-88. p. 86.; HERF, Jeffrey. Divided memory: the nazi past in the two Germanys. Cambridge; Massachussets: Harvard University Press, 1997. p. 294-295.

53 COHEN, David. Transitional justice in divided Germany after 1945. In: ELSTER, Jon (Org.). Retribution and Reparation in the Transition to Democracy. New York: Cambridge University Press, 2006. p. 59-88. p. 86.

54 COHEN, David. Transitional justice in divided Germany after 1945. In: ELSTER, Jon (Org.). Retribution and Reparation in the Transition to Democracy. New York: Cambridge University Press, 2006. p. 59-88. p. 79. comutadas em penas de prisão ${ }^{55}$.

No setor soviético, a justiça material levada adiante foi de caráter mais fortemente retributivo, muito embora os ocupantes também perceberam - a exemplo dos EUA — que uma persecução penal generalizada seria inviável. Utilizando-se de estratégia política, a URSS apelou à lealdade dos alemães daquele setor para reabilitá-los, caso demonstrassem clara e efetivamente seu rompimento com o nazismo. Também se utilizaram das categorias de culpabilidade para diferenciar os nazistas "reais" daqueles somente "nominais".

Ainda assim, a Administração Militar Soviética, trabalhando com a estreita colaboração do Grupo Ulbricht do Partido Comunista Alemão (o que ensejou uma participação dos alemães no processo de transição mais cedo do que nas demais áreas de ocupação), levou aos bancos dos réus de suas cortes 17.886 pessoas, com 8.055 condenações, sendo 436 à pena de morte ${ }^{56}$.

Finalmente, os casos de justiça material de transição processados por tribunais alemães. Kai Ambos e Niels Meyer-Abich dividem historicamente o tratamento jurídico dado a essas questões em 4 fases:

$\left.1^{a}\right)$ 1945-1949: "vontade de limpeza" desnazificação profunda;

$2^{a}$ ) 1950-1960: "política do passado" - alguns dos criminosos nazistas anistiados e protegidos contra futuros atos de persecução penal;

$3^{a}$ ) 1960-1980: "superação do passado" sistematização dos procedimentos de justiça transicional e maior frequência na utilização da prescrição penal com aquela finalidade;

$\left.4^{a}\right) 1980$ em diante: "preservação do passado" irrelevância da persecução penal e prioridade para a memória e a verdade acerca do período nazista ${ }^{57}$.

Ainda no ano de 1945, foram instaladas cortes compostas por juízes alemães, com competência para julga-

55 COHEN, David. Transitional justice in divided Germany after 1945. In: ELSTER, Jon (Org.). Retribution and Reparation in the Transition to Democracy. New York: Cambridge University Press, 2006. p. 59-88. p. 63.

56 AMBOS, Kai; MEYER-ABICH, Nils. La superación jurídicopenal de las injusticias y actos antijurídicos nacionalsocialistas y realsocialistas en Alemania. Revista Penal, n. 24, Hannover/Göttingen: ZIS (Zeitschrift für Internationale Strafrechtsdogmatik), p. 3-22, 2009.

57 AMBOS, Kai; MEYER-ABICH, Nils. La superación jurídicopenal de las injusticias y actos antijurídicos nacionalsocialistas y realsocialistas en Alemania. Revista Penal, n. 24, Hannover/Göttingen: ZIS (Zeitschrift für Internationale Strafrechtsdogmatik), p. 3-22, 2009. 
mento dos crimes nazistas cometidos por alemães contra seus próprios nacionais. Tais colegiados tribunalícios eram fiscalizados e supervisionados pelos Aliados, mas a ideia aqui já era a de delegar aos mesmos as competências dos tribunais dos ocupantes. E, mesmo diante de previsões normativas como a da Lei $\mathrm{n}^{\circ} 10$ do Conselho de Controle, art. III — que estabelecera a competência dos tribunais dos Aliados para julgarem o cometimento de crimes contra não alemães -, as cortes germânicas julgaram 260 criminosos nazistas nessa condição entre 1945 e 1950. Nesses anos, correspondentes à primeira fase da "vontade de limpeza", a persecução penal foi bastante intensa, ocasionando um total de 5.228 condenações por crimes nacional-socialistas nos tribunais criminais alemães das 3 zonas ocidentais de ocupação ${ }^{58}$.

Posteriormente, na então recém-formada República Federal da Alemanha e já sob a égide da Lei Fundamental de Bonn (a Constituição alemã de 1949), as persecuções penais e responsabilizações sofrem drástica diminuição. Leis de anistia e de desresponsabilização penal (genericamente denominadas de Straffreibeitsgesetze) são aprovadas no âmbito do novo Parlamento alemão ocidental, sendo de se destacar: a Lei de Concessão da Impunidade (Gesetz, über Gewährung von Straffreiheit), de 1949, que isenta de pena se a condenação for de até 6 meses de prisão; a Lei de Regulamentação das Relações Jurídicas das Pessoas Consideradas no art. 131 da Lei Fundamental (Gesetz, zur Regelung der Rechtsverbältnisse der unter Art. 131 des Grundgesetzes fallenden Personen), de 1951, restringindo as punições aos delitos de maior gravidade; a Lei sobre a Remissão das Penas e Multas Pecuniárias e do Arquivamento de Processos Penais e de Condenação Pecuniária (Gesetz über den Erlass von Strafen und Geldbußen und die Niederschlagung von Strafverfahren und Bußgeldverfahren), de 1954, que isenta de pena os crimes cometidos no final da Guerra cujas condenações não ultrapassem 3 anos de encarceramento ${ }^{59}$.

Embora com momentos de comoção popular e de mobilização social pró-criminalização, como em 1956 no julgamento de Bernhard Fischer-Schweder (ex-

58 COHEN, David. Transitional justice in divided Germany after 1945. In: ELSTER, Jon (Org.). Retribution and Reparation in the Transition to Democracy. New York: Cambridge University Press, 2006. p. 59-88. p. 82.

59 AMBOS, Kai; MEYER-ABICH, Nils. La superación jurídicopenal de las injusticias y actos antijurídicos nacionalsocialistas y realsocialistas en Alemania. Revista Penal, n. 24, Hannover/Göttingen: ZIS (Zeitschrift für Internationale Strafrechtsdogmatik), p. 3-22, 2009. -diretor da polícia nazista envolvido com massacres na Lituânia), a tendência das cortes alemãs ocidentais foi a de restringir cada vez mais a punição de criminosos do período. Em contraste com as mais de cinco mil condenações nos 5 primeiros anos da justiça material de transição realizada por aqueles tribunais, apenas 1.270 réus foram condenados entre 1950 e $2004^{60}$.

Em relação aos julgamentos das cortes alemãs da também recém-criada República Democrática Alemã, oriunda da zona soviética de ocupação, seguiram uma lógica diversa, apesar de terem sido igualmente intensificados nos primeiros anos do pós-Guerra e drasticamente diminuídos posteriormente.

O processo de justiça de transição na então Alemanha Oriental, aí incluídos os julgamentos criminais, fazia parte de um amplo programa político levado adiante pelos novos governantes e inspirado na ideologia dos ocupantes soviéticos. A persecução penal foi intensa até 1950, quando quase todos os 12.861 réus já haviam sido julgados. Entre 1951 e 1989, foram réus em processos dessa natureza apenas 734 alemães perante as cortes da RDA. A posição oficial desta na justificação da redução tão drástica foi dada ainda na década de 50 do século $\mathrm{XX}$, quando afirmou que o processo de desnazificação da sociedade e do Estado alemão oriental já havia se completado $^{61}$. Na nova sociedade socialista, o nazismo não mais teria vez nem voz, de acordo com os dirigentes da RDA.

\subsection{Aspectos transicionais não judiciais}

Como afirmei quando do esclarecimento das premissas metodológicas, a pretensão aqui é analisar as várias medidas de justiça de transição e não somente a judicialização das questões de justiça material, não obstante estas últimas merecerem uma maior atenção no contexto do trabalho.

60 COHEN, David. Transitional justice in divided Germany after 1945. In: ELSTER, Jon (Org.). Retribution and Reparation in the Transition to Democracy. New York: Cambridge University Press, 2006. p. 59-88. p. 82. ; AMBOS, Kai; MEYER-ABICH, Nils. La superación jurídico-penal de las injusticias y actos antijurídicos nacionalsocialistas y realsocialistas en Alemania. Revista Penal, n. 24, Hannover/Göttingen: ZIS (Zeitschrift für Internationale Strafrechtsdogmatik), p. 3-22, 2009.

61 COHEN, David. Transitional justice in divided Germany after 1945. In: ELSTER, Jon (Org.). Retribution and Reparation in the Transition to Democracy. New York: Cambridge University Press, 2006. p. 59-88. p. 85. 
Esse tópico, porém, serve à percepção do que foram as políticas de verdade, memória, reparação e reformas institucionais da(s) Alemanha(s) pós-nazismo.

Em relação à busca pela verdade, na experiência alemã do imediato Pós-Guerra - e diferentemente com o que ocorreu na maioria das experiências posteriores -, inicialmente não foram criados órgãos oficiais (que denomino aqui genericamente de comissões da verdade, ainda que não possuam tal nomenclatura formal) com a específica competência de esclarecerem os fatos referentes às graves violações de direitos humanos pelo regime de exceção. A priorização dos aspectos judiciais com a consequente judicialização ampla da apuração das graves violações de direitos humanos do período fez com que verdade e justiça estivessem indissociáveis, inseparabilidade esta que estava presente já no próprio discurso dos acusadores do primeiro julgamento de $\mathrm{Nu}-$ remberg $^{62}$.

É preciso que se diga que aqui tratamos da primeira experiência de justiça de transição da História, de modo que é um tanto precipitado falar na existência de um universalismo teórico justransicional na ocasião, sendo experiência mais analiticamente compreensível com base na abertura e no particularismo preconizados pela Teoria Intercultural da Constituição ${ }^{63}$.

O regime nazista registrou, com minuciosos detalhes, os próprios crimes cometidos. Recordando Hannah Arendt, o mal absoluto se tornou tão banal que não mais era visto como delito, mas, para uma grande parte dos agentes estatais alemães do período, tratava-se, essencialmente, de uma obrigação, um dever a ser cumprido, como ficou estigmatizado no célebre Caso Eichmann ${ }^{64}$. As acusações contra criminosos nazistas foram fundamentadas basicamente nos documentos e registros do próprio regime, sendo mais relevantes estes do que as provas testemunhais que, em linhas gerais,

62 COHEN, David. Transitional justice in divided Germany after 1945. In: ELSTER, Jon (Org.). Retribution and Reparation in the Transition to Democracy. New York: Cambridge University Press, 2006. p. 59-88. p. 62.

63 GALINDO, Bruno. Teoria Intercultural da Constituição: a transformação paradigmática da Teoria da Constituição diante da integração interestatal na União Européia e no Mercosul. Porto Alegre: Livraria do Advogado, 2006. p. 140.

64 ARENDT, Hannah. Eichmann em Jerusalém: um relato sobre a banalidade do mal. São Paulo: Companhia das Letras, 2000; COSTA, Alexandre. Sobre filósofos, sonâmbulos e mortos-vivos: os reflexos da incapacidade para pensar em Hannah Arendt. Revista da Faculdade de Direito de Caruaru, v. 35, n. 1, Caruaru, p. 2750, 2004.. p. 44. tendiam a corroborar com o que os registros do regime já explicitavam ${ }^{65}$.

$\mathrm{Na}$ verdade, talvez nenhum genocídio tenha sido tão fartamente documentado, seja em termos escritos, seja através de fotos e filmagens, que os massacres perpetrados pelos nazistas, antes e durante a $2^{\mathrm{a}}$ Guerra, o que torna no mínimo curiosas certas "teses" negacionistas/ revisionistas em relação ao fenômeno. $\mathrm{O}$ fato de terem se rendido de forma incondicional sem qualquer acordo sobre o que ocorreria no pós-Guerra permitiu aos Aliados amplo acesso à verdade documental sobre os crimes em questão, o que, pela priorização da justiça material, serviu inicialmente como fundamento dos julgamentos realizados pelas cortes aliadas e germânicas ${ }^{66}$.

Com a política geral de desnazificação levada adiante pelos Aliados, o conhecimento sobre a verdade dos fatos também serviu para impedir durante os primeiros anos do pós-Guerra a ocupação de cargos públicos e de funções socialmente relevantes por nazistas que, não obstante pudessem não terem sofrido condenações penais, seriam tidos por perigosos para a estabilização de uma democracia política na nova Alemanha. A título de exemplo, no setor norte-americano, os conselheiros do Gal. Eisenhower prepararam o "Manual do Governo Militar na Alemanha" (Handbook for the Military Government in Germany) que autorizava a imediata detenção de indivíduos que, por terem ocupado altos cargos na estrutura do NSDAP, poderiam representar esse perigo. Os ex-membros da Gestapo, SS, SD e SA também estavam automaticamente incluídos nessa leva de pessoas ${ }^{67}$.

Apesar da verdade sobre o período ter sido amplamente esclarecida, nem tudo era, totalmente. conhecido. Na República Federal da Alemanha, um famoso processo em Ulm com réus nazistas que haviam participado de um massacre de cerca de 120 mil judeus demonstrou que nem todos os crimes do nazismo estavam, devidamente, registrados e esclarecidos, o que gerou a criação, em 1958, do Serviço Central de Administração Judicial

65 COHEN, David. Transitional justice in divided Germany after 1945. In: ELSTER, Jon (Org.). Retribution and Reparation in the Transition to Democracy. New York: Cambridge University Press, 2006. p. 59-88. p. 62.

66 HERF, Jeffrey. Divided memory: the nazi past in the two Germanys. Cambridge; Massachussets: Harvard University Press, 1997. p. 71.

67 COHEN, David. Transitional justice in divided Germany after 1945. In: ELSTER, Jon (Org.). Retribution and Reparation in the Transition to Democracy. New York: Cambridge University Press, 2006. p. 59-88. p. 69. 
dos Estados para o Esclarecimento de Crimes do Nacional-socialismo (Zentrale Stelle der Landesjustizverwaltung zur Aufklarung nationalsozialistischer Verbrechen), com sede em Ludwigsburg. Ainda assim, esse Serviço Central serviu principalmente para proceder a investigações preliminares por conta própria antes de se judicializarem as questões sobre as graves violações de direitos humanos. Este órgão existe até hoje, porém, com a diminuição dos casos, seu funcionamento na atualidade volta-se, principalmente, para o registro de natureza histórica dos crimes nazistas ainda não completamente esclarecidos. Possui atualmente apenas 19 pessoas em seu corpo funcional e divide suas funções com os funcionários do Arquivo Federal (Bundesarchiv). Até 2013 realizou 7.555 investigações, com 7.522 encaminhamentos ao Ministério Público alemão para as devidas providências. Naquele ano estavam pendentes 33 investigações preliminares, como consta do seu último relatório disponível ${ }^{68}$.

A partir da drástica diminuição da desnazificação a partir do início da década de 50 do século passado nas então duas Alemanhas (Ocidental e Oriental), o conhecimento da verdade sobre o período passou a servir aos demais propósitos da justiça de transição pós-nazismo.

Em relação à memória, esta tem sido objeto de permanente reforço, seja pelos atos de Estado da própria Alemanha (antes e depois da reunificação), seja por outros países e também por organizações não governamentais diversas, notadamente as judaicas, tendo em vista terem sido os judeus as principais vítimas dos crimes do nazismo em termos estatísticos. Do lado estatal, a criação de monumentos como o Memorial do Holocausto e o Monumento aos Roma/Sinti (ciganos), em Berlin, o financiamento da preservação de campos de concentração (Buchenwald e Dachau, p. ex.) como museus do horror da era nazista, bem como inúmeros outros museus espalhados por toda a Alemanha e fora dela, mantém registrados para permanente recordação, os graves crimes de lesa humanidade praticados, com a ideia da não repetição como um horizonte das políticas de memória. ${ }^{69}$ Também as diversas organizações não estatais, com destaque para a indústria cinematográfica e

68 ZENTRALE STELLE DER LANDESJUSTIZVERWALTUNG ZUR AUFKLARUNG NATIONALSOZIALISTISCHER VERBRECHEN. Herzlich willkommen bei der zentralen stele. Disponível em: <www.zentrale-stelle.de>. Acesso em: 21 dez. 2016.

69 HERF, Jeffrey. Divided memory: the nazi past in the two Germanys. Cambridge; Massachussets: Harvard University Press, 1997. p. 353 as editoras, publicam livros e realizam filmes ficcionais e documentais que relembram permanentemente e também auxiliam na preservação da memória coletiva sobre a era nazista, fomentando a edificação de uma cultura democrática e humanista.

Em termos de reparação, a justiça de transição envolveu tanto indenizações pecuniárias como reabilitações. As primeiras ocorreram não somente dentro da Alemanha, mas em uma série de outros países prejudicados pela ação bélica alemã, bem como muitos dos seus respectivos cidadãos que sofreram com a perseguição empreendida. Em 1946, ainda sob estrito domínio dos Aliados, a Alemanha acordou indenizações com 19 países. No ano seguinte, foram promulgadas leis de reintegração em cada uma das zonas de ocupação. Mais medidas de reparação e de indenização surgiram em 1952, quando a RFA e o recém-constituído Estado de Israel celebraram tratado nesse sentido, bem como a primeira dispendeu cerca de 3,5 bilhões de marcos alemães em indenizações a organizações judaicas. Na mesma década, foram promulgadas várias leis de reparação e de recomposição que previram recursos em favor dos perseguidos pelo regime nacional-socialista por motivos raciais, religiosos ou políticos, bem como de famílias judias que haviam tido seus bens expropriados por atos do regime nazista. Merecem destaque a Lei Federal do Ressarcimento (Bundesentschadigungsgeseta), de 1956 (com efeitos retroativos a $1^{\circ}$ de outubro de 1953), a Lei Federal de Reintegração (Bundesruckerstattungsgesetv), de 1957, e a Lei para Criação da Fundação "Recordação, Responsabilidade e Futuro" (Gesetz, zur Errichtung einer Stiftung “Erinnerung, Verantwortung und Zukunft'), de 2000. Até o início de 1998, a RFA havia pago cerca de 102 bilhões de marcos alemães em indenizações em razão das violações de direitos perpetradas pelo nacional-socialismo.

A título de reabilitação, ainda nos anos 40, vários dos condenados por tribunais nacional-socialistas tiveram suas condenações revistas, sendo reabilitados também no âmbito dos Länder alemães nas décadas seguintes. Mais recentemente, em 1998, a Lei de Abolição de Sentenças Injustas Nacional-socialistas (Gesetz. zur Aufhebung nationalsozialistischer Unrechtsurteile) previa a completa anulação dos efeitos de decisões exaradas da época nazista ${ }^{70}$.

70 AMBOS, Kai; MEYER-ABICH, Nils. La superación jurídicopenal de las injusticias y actos antijurídicos nacionalsocialistas y realsocialistas en Alemania. Revista Penal, n. 24, Hannover/Göttingen: ZIS (Zeitschrift für Internationale Strafrechtsdogmatik), 
Por último, o objetivo das reformas institucionais. A Alemanha capitulou de modo incondicional, o que permitiu aos Aliados ocupantes e, posteriormente, aos sucessores alemães no poder político redimensionar por completo as instituições da era nazista. Tanto a Constituição de Weimar - já materialmente desconsiderada desde o primeiro ano da ascensão de Hitler ao poder -, como as leis nacional-socialistas mais importantes foram anuladas e/ou revogadas a partir de atos como a Lei Militar de Governo (Militärregierungsgesets) n $\mathrm{n}^{\mathrm{o}} 1 \mathrm{e}$ a Lei do Conselho de Controle (Kontrollratsgesetz) $n^{\circ} 1$, ambas de 1945. As organizações e instituições nazistas mais importantes, inclusive o Tribunal do Povo (Volksgerichtshof) e os vários tribunais especiais, foram extintas e temporariamente substituídas por instituições e tribunais dos Aliados e gradativamente, como visto, por novas instituições e tribunais alemães.

As novas instituições foram construídas com base em referenciais diferentes nas duas novas repúblicas alemãs.

$\mathrm{Na} \mathrm{RDA}$, Estado erigido na zona soviética de ocupação, a intensa desnazificação seguiu-se a construção de uma ordem jurídica e política aproximada ao modelo socialista, não obstante o texto constitucional de 1949 tivesse uma estruturação formal bastante semelhante à das constituições ocidentais, com a previsão de direitos fundamentais - inclusive os individuais -, e da forma federativa de Estado, com a presença das unidades federativas em uma $2^{a}$ câmara senatorial (a Länderkammer - arts. 71 e ss.), assim como previsões de independência entre os poderes legislativo, executivo e judiciário, estipulando uma divisão do poder estatal entre eles. Aparentemente assimilara significativamente em sua Constituição o universalismo teórico do constitucionalismo ocidental, particularizando-o no contexto da pretendida construção de uma sociedade socialista. Também extirpara por completo a herança nazista, com previsão expressa de expropriações de empresas pertencentes a nazistas (art. $\left.24,3^{71}\right)$ e repúdio às instituições daquela era em seu art.

p. 3-22, 2009; HERF, Jeffrey. Divided memory: the nazi past in the two Germanys. Cambridge; Massachussets: Harvard University Press, 1997. p. 3.

71 "As empresas pertencentes a criminosos de guerra e a nacional-socialistas ativos são expropriadas e transformadas em propriedade pública. O mesmo ocorre com os empreendimentos privados que estiveram a serviço da política de guerra" (tradução livre). No original: "Die Betriebe der Kriegsverbrecher und aktiven Nationalsozialisten sind enteignet und gehen in Volkseigentum über. Das gleiche gilt für private Unternehmungen, die sich in den Dienst einer
$144,2^{72}$, apesar de alguns dos antigos membros do status quo do NSDAP terem sido reabilitados com a adesão pública ao ideário socialista da $\mathrm{RDA}^{73}$.

No caso da RFA, ainda que condicionada pela ocupação dos Aliados e necessitando da permissão dos mesmos, ela consegue se erigir a partir da junção dos territórios e cidadãos das zonas britânica, francesa e norte-americana e também em 1949 realiza assembleia constituinte, promulgando a até hoje vigente Lei Fundamental (Grundgeset) de Bonn. Pensada, inicialmente, para ser uma espécie de "constituição provisória", até que a Alemanha recuperasse por completo sua soberania e pudesse atuar em uma assembleia constituinte, efetivamente livre e incondicionada (conforme previu seu art. $146^{74}$ ), a LF tornou-se permanente diante de seu sucesso como referencial normativo para as ações posteriores do Estado alemão e da conduta social e cívica no país ${ }^{75}$. Reconhecendo em princípio a validade das leis da desnazificação (art. 13976), a LF previu instituições solidamente democráticas, estipulando a existência de um parlamentarismo bastante funcional, bem como de um poder judiciário autônomo e independente, com destaque para a importância do Tribunal Constitucional Federal (Bundesverfassungsgericht) na estrutura institucio-

Kriegspolitik stellen.”

72 "As liberdades e direitos constitucionais não podem se constituir em óbices às disposições vigentes e a serem promulgadas com o objetivo de superarem o nacional-socialismo e o militarismo e repararem suas injustiças." (tradução livre). No original: "Die verfassungsmäßigen Freiheiten und Rechte können nicht den Bestimmungen entgegengehalten werden, die ergangen sind und noch ergehen werden, um den Nationalsozialismus und Militarismus zu überwinden und das von ihnen verschuldete Unrecht wiedergutzumachen." 73 Em verdade, essa configuração radicalmente diferente de suas instituições não permitiu ao Estado alemão oriental erigir-se como uma efetiva democracia constitucional, tendo se degenerado em outro tipo de regime autoritário, o que termina por gerar novas formas de graves violações de direitos humanos em lugar das antigas e, após a reunificação, uma nova experiência de justiça de transição. Contudo, isso foge aos objetivos do presente ensaio. Sobre isso, cf. Galindo: 2005, passim; Galindo: 2012a, pp. 109-111.

74 "Período de vigência da Lei Fundamental - Esta Lei Fundamental, que se aplicará a todo o povo alemão até a consumação da unidade e da liberdade da Alemanha, deixará de vigorar no dia em que entrar em vigor uma Constituição que tenha sido livremente adoptada por todo o povo alemão."

75 HESSE, Konrad. Elementos de direito constitucional da República Federal da Alemanha. 20. ed. Porto Alegre: Sergio Fabris, 1998. p. 76-77; GRIMM, Dieter. Constituição e política. Belo Horizonte: Del Rey, 2006. p. 265.

76 "Validade das prescrições legais sobre a "desnazificação" - As prescrições legais adoptadas para "a libertação do povo alemão do nacional-socialismo e do militarismo" não são afectadas pelas disposições desta Lei Fundamental." 
nal alemã, a Carta de 1949 foi bem sucedida em favorecer a edificação de uma cultura constitucional democrática e humanista nas novas instituições germânicas, praticamente dissociadas dos resquícios ideológicos nacional-socialistas, não obstante muitos dos antigos nazistas terem retornando às esferas de poder durante as primeiras décadas da RFA, em virtude da alteração das políticas de desnazificação a partir do início dos anos 50 do século XX. Forças Armadas, Judiciário, Legislativo, Executivo, administração pública em geral, organismos públicos em todas as esferas de poder da Federação foram pautados em sua concepção pelos valores do Estado democrático de direito presentes na LF de Bonn e contextualizados na nova experiência constitucional germânica.

Esse arcabouço constitucional consiste. Atualmente. no constitucionalismo de toda a Alemanha, reunificada em 1990 com a incorporação da antiga RDA à RFA, formando um único Estado soberano.

\section{A título Conclusivo: alCANCE DA JUSTIÇA de transição na Alemanha pós-nazismo}

Vislumbrar o alcance da justiça de transição na Alemanha pós-nazismo é tarefa das mais árduas, pois em verdade não se teve uma justiça de transição, mas várias: as dos Aliados (EUA, França, Reino Unido e URSS) em cada uma de suas zonas de ocupação, a da RFA e a da RDA durante sua existência enquanto Estado. Ainda assim, arrisco algumas possíveis respostas a perguntas formuladas em termos generalistas em outra ocasião $\mathrm{O}^{77}$.

Em relação às questões de justiça material, pode-se afirmar que, tanto Aliados como alemães na RFA e na RDA, foram bastante incisivos nos primeiros anos em buscar um acerto de contas com os perpetradores das graves violações de direitos humanos da era nazista, arrefecendo tais medidas a partir da década de 50 do século XX por razões primordialmente políticas, quando anistiar e perdoar foram ações consideradas mais eficazes para a construção de um Estado democrático do que a punição. Contudo, em princípio, nem o TMI de

77 GALINDO, Bruno. Justiça de transição na América do Sul: possíveis lições da Argentina e do Chile ao processo constitucional de transição no Brasil. In: FEITOSA, Enoque et. al. (Org.). O judiciário e o discurso dos direitos humanos. Recife: UFPE, 2012b. v. 2. p. 197-240. p. 199-200.
Nuremberg nem os demais tribunais e juízes aceitaram argumentos como o cumprimento do dever legal de obediência a ordens superiores ou a estrita tipificação legal dos crimes para absolver os criminosos. Houve uma tendência a punir com maior severidade aqueles que detinham funções mais relevantes de comando, especialmente no TMI. A prescrição como instrumento temporal de impunidade foi utilizada com maior parcimônia e com nuances diversas em relação ao seu tradicional uso no direito penal ${ }^{78}$.

Contudo, diferentemente do temor de alguns, as medidas de justiça material não abalaram a perspectiva de estabilidade democrática, antes, ao contrário, tenderam a solidificá-la, inaugurando uma nova fase de Recbtsstaat na Alemanha (especialmente na RFA), ao submeterem os réus a julgamentos pautados pelos valores desse mesmo Estado democrático de direito, como a ampla defesa e o devido processo legal (com todos os problemas que tiveram), diversamente dos sumários e arbitrários processos judiciais do $3^{\circ}$ Reich. Aqui parece que a abertura teórica à inovação em termos de justiça material permitiu um reforço axiológico ao novo Estado democrático de direito alemão.

No plano das políticas de verdade, os documentos do período foram amplamente divulgados, o que não foi suficiente para o esclarecimento completo, tendo em vista a formação posterior do Serviço Central de Administração Judicial dos Estados para o Esclarecimento de Crimes do Nacional-socialismo, na tentativa de suprir as lacunas acerca do conhecimento da verdade dos fatos de muitos episódios então ainda obscuros da ditadura nazista.

$\mathrm{Na}$ questão da memória, a opção pela completa exposição dos fatos, por mais dolorosos e chocantes que tenham sido, foi a seguida pelos alemães, especialmente na RFA. O apoio às organizações das minorias perseguidas durante o nazismo, especialmente às judaicas, nesse particular foi e continua sendo intenso. Os alemães também não tiveram grandes preocupações quanto à possibilidade de uma memória unilateral, em verdade,

78 AMBOS, Kai; MEYER-ABICH, Nils. La superación jurídicopenal de las injusticias y actos antijurídicos nacionalsocialistas y realsocialistas en Alemania. Revista Penal, n. 24, Hannover/Göttingen: ZIS (Zeitschrift für Internationale Strafrechtsdogmatik), p. 3-22, 2009; COHEN, David. Transitional Justice in Divided Germany after 1945. In: ELSTER, Jon (org.). Retribution and Reparation in the Transition to Democracy. New York: Cambridge University Press, passim, 2006. 
até limitando a própria liberdade de expressão no que diz respeito a manifestações de cunho nazista ou neonazista, proibindo-as com veemência e não desejando que a extrema liberalidade da Carta de Weimar a respeito se repetisse e permitisse uma nova escalada autoritária. Foi necessário contextualizar e particularizar a liberdade de manifestação do pensamento diante da necessidade de não se permitir que a democracia constitucional de Bonn não fosse autofágica como terminou por ser a democracia constitucional weimariana.

As reparações em termos de indenização e de reabilitação foram muitas, tendo o Estado alemão dispendido um grande montante financeiro para efetuá-las. Aparentemente, a maior parte delas foi garantida nos planos dos poderes legislativo e executivo, muito embora as informações constantes de processos judiciais tenham sido utilizadas como fontes para se determinar o grau de responsabilização estatal e a quem devam ser dirigidas as referidas medidas reparatórias, bem como o quantum adequado das mesmas, nos casos das indenizações.

No aspecto institucional e cultural, a justiça de transição pós-nazismo teve provavelmente seu desdobramento mais importante. Não obstante muitos dos antigos nazistas terem sido reabilitados a partir dos anos 50 - incluídos aí juízes, burocratas e militares -, tiveram que seguir um ideário axiológico completamente diverso daquele do período autoritário. A LF de Bonn permitiu que na RFA as forças armadas fossem estritamente controladas pelo poder civil democrático e modificou completamente sua anterior ideologia militarista. O próprio processo educacional, dos primeiros anos escolares à universidade, foi transformado na direção da construção de uma educação pautada em valores democráticos e humanistas. E com isso, a RFA pode tornar-se uma democracia sólida e bem-sucedida ao longo de mais de sete décadas que a separam da experiência nacional-socialista.

A RDA, por sua vez, teve maiores dificuldades em transformar as instituições, não obstante seu empenho discursivo em demonstrar a extirpação do ideário nazista do âmbito público. Apesar da forma, as constituições alemãs orientais não tiveram êxito em construir instituições efetivamente democráticas, pois a criação de estruturas totalitárias, ainda que de natureza diversa das nazistas, não permitiram uma superação de fato da herança autoritária, sendo em verdade uma nova forma de autoritarismo em lugar da antiga ${ }^{79}$.

Em que pese todas essas questões, o efeito pedagógico da justiça de transição pós-nazismo provavelmente foi o mais importante legado desta. Como afirmou David Cohen, se o processo de justiça transicional não logrou êxito em punir ampla e justamente os perpetradores de graves violações de direitos humanos (embora tenham ocorrido muitas condenações, remoções e exclusões de agentes nazistas avaliados como perigosos para a redemocratização alemã), foi, extremamente, eficaz em termos de estigmatização do regime nazista e de seus líderes, da educação do povo alemão acerca do que seus líderes fizeram em seu nome, e com isso, servindo à construção da verdade histórica e produzindo mecanismos de reabilitação e de integração dos perseguidos por aquele regime ${ }^{80}$.

\section{ReferênCias}

AMBOS, Kai; MEYER-ABICH, Nils. La superación jurídico-penal de las injusticias y actos antijurídicos nacionalsocialistas y realsocialistas en Alemania. Revista Penal, n. 24, Hannover/Göttingen: ZIS (Zeitschrift für Internationale Strafrechtsdogmatik), p. 3-22, 2009.

ARENDT, Hannah. Eichmann em Jerusalém: um relato sobre a banalidade do mal. São Paulo: Companhia das Letras, 2000.

ARENDT, Hannah. Origens do totalitarismo: antisemitismo, imperialismo, totalitarismo. São Paulo: Companhia das Letras, 2000.

BARNETT, Correlli. Introdução. In: BARNETT, Correlli (Org.). Os generais de Hitler, Rio de Janeiro: Jorge Zahar, 1990. p. 15-31.

79 GALINDO, Bruno. Entre os sonhos de Rosa Luxemburg e a realidade de Erich Honecker: para não esquecer as lições da antiga República Democrática Alemã. Revista da Faculdade de Direito de Caruaru, v. 36, n. 1. Caruaru, p. 81-108, 2005; GALINDO, Bruno. Democracia constitucional, justiça transicional e passado autoritário: entre a superação e o "esquecimento". In: MONTEIRO, Roberta Corrêa de Araújo; ROSA, André Vicente Pires (Org.). Direito Constitucional: os desafios contemporâneos (uma homenagem ao Professor Ivo Dantas). Curitiba: Juruá, 2012a. p. 101-126. p. 109111.

80 COHEN, David. Transitional justice in divided Germany after 1945. In: ELSTER, Jon (Org.). Retribution and Reparation in the Transition to Democracy. New York: Cambridge University Press, 2006. p. 59-88. p. 88. 
BATISTA, Nilo. Atualidade de Roland Freisler. Passagens: Revista Internacional de História Política e Cultura Jurídica, v. 7, n. 1, Rio de Janeiro, UFF, p. 5-14, 2015.

BBC. The rize of the Nazi Party and its consolidation of party. Disponível em: <http://www.bbc. co.uk/schools/gcsebitesize/history/tch_wjec/germa ny19291947/1 consolidatepower1.shtml>. Acesso: 27 dez. 2016.

BICKFORD, Louis. Transitional justice. In: The encyclopedia of genocide and crimes against humanity. Michigan: Macmillan Reference USA, 2004. v. 3. p. 1045-1047.

CARNEIRO, Maria Luiza Tucci. A Era nazi e o antisemitismo. In: PINSKY, Jaime; PINSKY, Carla Bassanezi (Org.). Faces do fanatismo. São Paulo: Contexto, 2004. p. 102-133.

COHEN, David. Transitional justice in divided Germany after 1945. In: ELSTER, Jon (Org.). Retribution and Reparation in the Transition to Democracy. New York: Cambridge University Press, 2006. p. 59-88.

COSTA, Alexandre. Sobre filósofos, sonâmbulos e mortos-vivos: os reflexos da incapacidade para pensar em Hannah Arendt. Revista da Faculdade de Direito de Caruaru, v. 35, n. 1, Caruaru, p. 27-50, 2004.

FRIEDRICH, Otto. O fim do mundo. Rio de Janeiro: Record, 2000.

GALINDO, Bruno. Constitucionalismo e justiça de transição: em busca de uma metodologia de análise a partir dos conceitos de autoritarismo e democracia. Revista da Faculdade de Direito da Universidade Federal de Minas Gerais, n. 67, Belo Horizonte, p. 75-104, 2015.

GALINDO, Bruno. Democracia constitucional, justiça transicional e passado autoritário: entre a superação e o "esquecimento". In: MONTEIRO, Roberta Corrêa de Araújo; ROSA, André Vicente Pires (Org.). Direito Constitucional: os desafios contemporâneos (uma homenagem ao Professor Ivo Dantas). Curitiba: Juruá, 2012a. p. 101-126.

GALINDO, Bruno. Entre os sonhos de Rosa Luxemburg e a realidade de Erich Honecker: para não esquecer as lições da antiga República Democrática Alemã. Revista da Faculdade de Direito de Caruaru, v. 36, n. 1. Caruaru, p. 81-108, 2005.
GALINDO, Bruno. Justiça de transição na América do Sul: possíveis lições da Argentina e do Chile ao processo constitucional de transição no Brasil. In: FEITOSA, Enoque et. al. (Org.). O judiciário e o discurso dos direitos humanos. Recife: UFPE, 2012b. v. 2. p. 197240 .

GALINDO, Bruno. Teoria Intercultural da Constituição: a transformação paradigmática da Teoria da Constituição diante da integração interestatal na União Européia e no Mercosul. Porto Alegre: Livraria do Advogado, 2006.

GOLDENSOHN, Leon. As entrevistas de Nuremberg. São Paulo: Companhia das Letras, 2005.

GONÇALVES, Joanisval Brito. Tribunal de Nuremberg 1945-1946: a gênese de uma nova ordem no direito internacional. Rio de Janeiro: Renovar, 2001.

GREIFF, Pablo de. La contribución de la justicia transicional a la construcción y consolidación de la democracia. In: BLEEKER, Mô; CIURLIZZA, Javier; BOLAÑOS-VARGAS, Andrea (Org.). Memorias: Conference Paper. Bogotá: ICTJ, 2007. p. 25-35.

GRIMM, Dieter. Constituição e política. Belo Horizonte: Del Rey, 2006.

HERF, Jeffrey. Divided memory: the nazi past in the two Germanys. Cambridge; Massachussets: Harvard University Press, 1997.

HESSE, Konrad. Elementos de direito constitucional da República Federal da Alemanha. 20. ed. Porto Alegre: Sergio Fabris, 1998.

LACERDA, Gabriel. Nazismo, cinema e direito. Rio de Janeiro: Elsevier; FGV, 2012.

LOEWENSTEIN, Karl. Teoría de la Constitución. Barcelona: Ariel, 1964.

MANN, Michael. Fascistas. Rio de Janeiro: Record, 2008.

MELLO, Celso D. de Albuquerque. Direitos humanos e conflitos armados. Rio de Janeiro: Renovar, 1997.

MÜLLER, Friedrich. As medidas provisórias no brasil diante do pano de fundo das experiências alemãs. In: GRAU, Eros Roberto; GUERRA FILHO, Willis Santiago (Org.). Direito Constitucional: estudos em homenagem a Paulo Bonavides. São Paulo: Malheiros, 2001. p. 337-355. 
NEUMANN, Franz. Estado democrático e Estado autoritário. Rio de Janeiro: Zahar, 1969.

PARDO, José Esteve. La doctrina alemana del derecho público durante el régimen nacionalsocialista: crónica de un debate tardío. Revista Española de Derecho Constitucional, n. 67, Madrid, p. 171-180, 2003.

PIOVESAN, Flávia. Lei de anistia, sistema interamericano e o caso brasileiro. In: GOMES, Luiz Flávio; MAZZUOLI, Valério de Oliveira (Org.). Crimes da ditadura militar: uma análise à luz da jurisprudência atual da Corte Interamericana de Direitos Humanos. São Paulo: Revista dos Tribunais, 2011. p. 73-86.

PORTO, Humberto A. Sierra. La función de la corte constitucional en la protección de los derechos de las víctimas a la verdad, la justicia y la reparación en Colombia. Anuario de Derecho Constitucional Latinoamericano, ano 15, Montevideo, p. 179-188, 2009.

READER'S DIGEST. Os grandes mistérios do passado. Rio de Janeiro: Reader's Digest Brasil, 1996.

RIGAUX, François. A lei dos juízes. São Paulo: Martins Fontes, 2000.

RÜRUP, Reinhard. Génesis y fundamentos de la Constitución de Weimar. Ayer, n. 5, p. 125-158, 1992. Disponível em: <http://www.ahistcon.org/docs/ayer/ ayer5_05.pdf $>$. Acesso em: 11 set. 2012.

SMEND, Rudolf. Constitución y derecho constitu- cional. Madrid: Centro de Estudios Constitucionales, 1985.

SZMOLKA VIDA, Inmaculada. Los regímenes políticos híbridos: democracias y autoritarismos con adjetivos: su conceptualización, categorización y operacionalización dentro de la tipologia de regímenes políticos. Revista de Estudios Políticos, n. 147, Madrid, p. 103$135,2010$.

THE GARDIAN. 75 years on, executed Reichstag arsonist finally wins pardon. Disponível em: <https://www.theguardian.com/world/2008/jan/12/ secondworldwar.germany>. Acesso em: 27 dez. 2016.

UPRIMNY, Rodrigo; SAFFON, María Paula. Justicia transicional y justicia restaurativa: tensiones y complementaridades. 2010. Disponível em: <http://www. idrc.ca/en/ev-84576-201-1-DO_TOPIC.html>. Acesso em: 26 nov. 2010.

VEIGA, Gláucio. O direito econômico em Weimar: mito e espírito. Anuário dos Cursos de Pós-Graduação em Direito, n. 12. Recife: UFPE, 2002. p. 233246.

ZENTRALE STELLE DER LANDESJUSTIZVERWALTUNG ZUR AUFKLARUNG NATIONALSOZIALISTISCHER VERBRECHEN. Herzlich willkommen bei der zentralen stele. Disponível em: <www.zentrale-stelle.de>. 


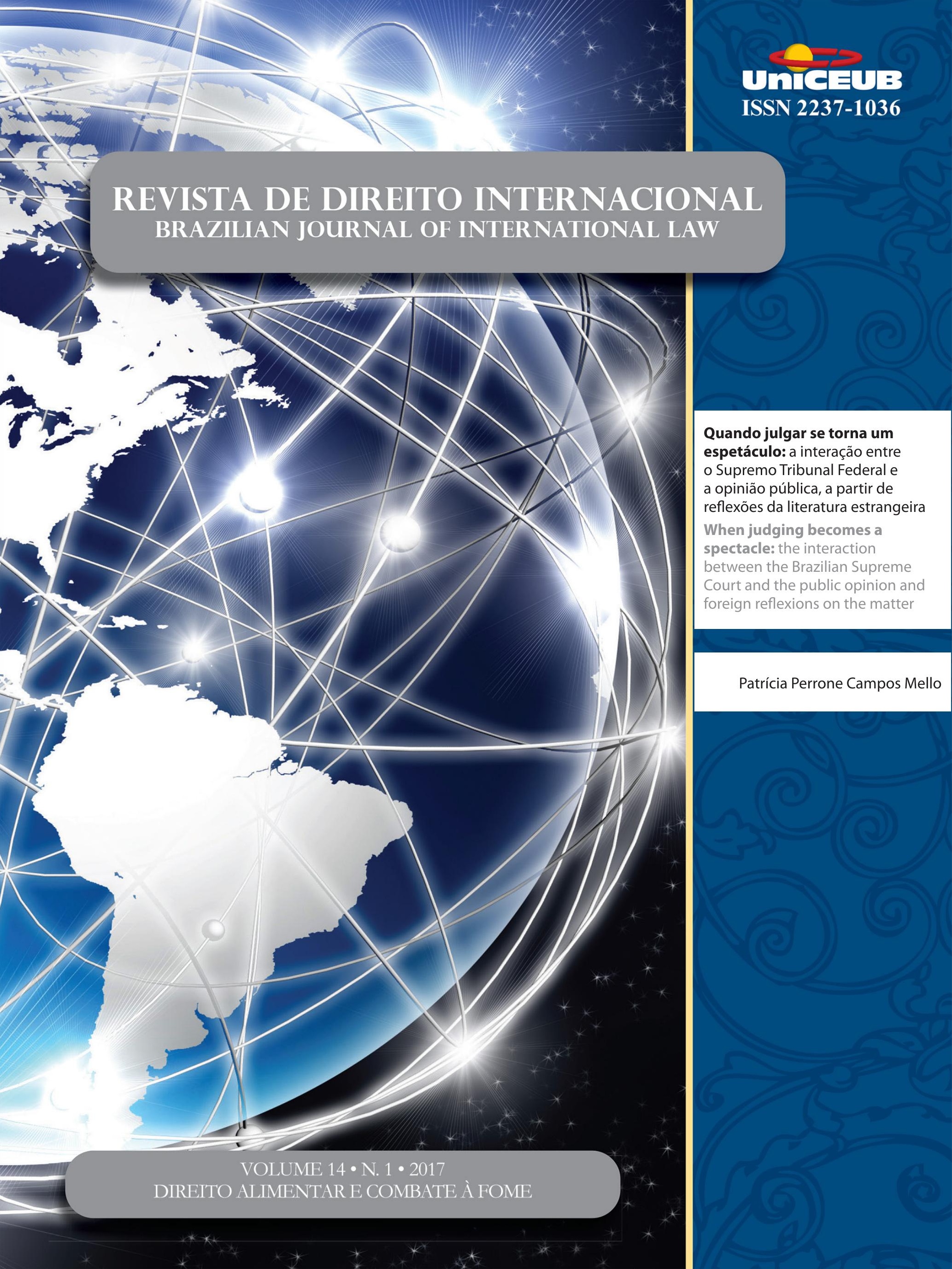




\title{
Quando julgar se torna um espetáculo: a interação entre o Supremo Tribunal Federal e a opinião pública, a partir de reflexões da literatura estrangeira *
}

\author{
When judging becomes a spectacle: the \\ interaction between the Brazilian Supreme \\ Court and the public opinion and foreign \\ reflexions on the matter
}

Patrícia Perrone Campos Mello **

\section{Resumo}

O ensaio procura demonstrar que o Legislativo e o Executivo podem não ser representativos da vontade popular; que o Supremo Tribunal Federal, não raro, julga de acordo com a vontade da maioria; e que esquemas tradicionais de separação de poderes precisam ser problematizados para que se compreenda a interação entre o STF e a opinião pública. Argumenta-se, ainda, que não apenas as decisões contramajoritárias, mas igualmente a decisões majoritárias do Supremo devem ser objeto de crítica. A tendência à espetacularização dos julgamentos da Corte e a forte exposição de seus membros à mídia torna-os vulneráveis ao contágio informacional, ao contágio reputacional e ao efeito manada. Com esse objetivo, o artigo recorre a estudos estrangeiros que explicam a interação entre cortes constitucionais e opinião pública; examina pesquisas de opinião sobre matérias decididas pelo Congresso Nacional e submetidas ao STF; analisa o julgamento de tais casos; e avalia as declarações dos ministros sobre a influência da opinião pública nos respectivos julgamentos.

Palavras-chave: Supremo Tribunal Federal. Jurisdição constitucional. Legitimidade democrática. Opinião pública. Mídia e imprensa. Espetáculo.

* Autora convidada

** Professora do Programa de Mestrado e Doutorado da Uniceub, Doutora e Mestre pela Universidade do Estado do Rio de Janeiro UERJ, Assessora de Ministro do Supremo Tribunal Federal, Procuradora do Estado. E-mail: patriciaperrone@uol.com.br

\section{Abstract}

The paper aims at demonstrating that Legislative and Executive powers can lack popular representation; that the Brazilian Supreme Court, not rarely, decides in accordance to the popular will; and that traditional division of powers schemes must be questioned in order to allow an accurate understanding of the interaction between the Court and Brazilian society. It also argues that not only countermajoritarian decisions of the Court may be monitored, but also the majoritarian ones. The media surveillance of the Brazilian Supreme Court and the over exposition of its justices to the press make them vulnerable to informational contagion, reputational contagion and cascades. With this goal, the paper presents foreign studies that explain 
the interaction between constitutional courts and public opinion; analyses public opinion polls on matters decided by the Brazilian Congress and submitted to its Supreme Court; studies the mentioned constitutional cases; and examines statements of Brazilian justices about the influence of public opinion over the Court's decisions.

Keywords: Brazilian Supreme Court. Constitutional jurisdiction. Democratic legitimacy. Public opinion. Media and press. Spectacle.

\section{INTRODUÇão}

Muito se tem debatido e escrito sobre os limites da atuação do Supremo Tribunal Federal. Discute-se até que ponto estaria o Tribunal legitimado a declarar a nulidade de atos produzidos pelos representantes eleitos pelo voto popular (integrantes do Legislativo e do Executivo), quando é composto por onze juízes que não foram eles próprios eleitos, mas meramente selecionados pelo Presidente da República e aprovados, após sabatina, pelo Senado federal.

Discute-se, ainda, se a superação do dogma do legislador negativo ${ }^{1}$ e a produção de decisões aditivas pela Corte $^{2}$ não implicariam uma clara violação ao processo democrático e ao princípio da separação dos poderes. A concepção de legitimidade que serve de base a tais questionamentos é clara: aqueles que a corroboram identificam a legitimidade da produção do Direito com o exercício de um mandato representativo. Segundo este critério, a voz do Executivo e a voz do Congresso expressam a vontade do povo e, por isso, devem prevalecer.

1 Segundo o dogma do legislador negativo, o Supremo Tribunal Federal deveria se limitar a proferir decisões que retirem do ordenamento normas incompatíveis com a Constituição. Não poderia, contudo, atuar como legislador positivo, acrescentando conteúdo ao ordenamento jurídico, quer com o propósito de compatibilizar o significado de normas infraconstitucionais com a Constituição, que com o objetivo de conferir efetividade a direitos previstos na Constituição e dependentes de regulamentação pelo legislador. Sobre a superação do referido dogma pela jurisprudência do STF, cf. BARROSO, Luís Roberto. O controle de constitucionalidade no direito brasileiro. São Paulo: Saraiva, 2004. p. 104-110 e 208-209.

2 As decisões de efeito aditivo ampliam o âmbito de incidência do texto da lei. As de efeitos substitutivos levam à substituição da disciplina prevista na norma por outra, compatível com o paradigma constitucional. Sobre o tema, v. MENDES, Gilmar Ferreira; COELHO, Inocêncio Mártires; BRANCO, Paulo Gustavo Gonet. Curso de direito constitucional. São Paulo: Saraiva, 2010. p. 1432-1435.
Pretende-se demonstrar, por meio deste ensaio, que a interação entre os diferentes poderes do Estado e a sociedade que pretendem normatizar é mais complexa do que o esquema tradicional de separação de poderes que habita o imaginário de tais críticos. A mera eleição pelo voto popular não assegura uma atuação efetivamente representativa e, portanto, legítima (segundo o critério acima), por parte das instâncias majoritárias. Por outro lado, o Supremo Tribunal Federal pode servir de espaço à expressão de pleitos majoritários, a despeito de não se compor de ministros eleitos. Como se verificará ao longo deste ensaio, é inadequado definir um critério estático e, sobretudo, formal — consistente na eleição pelo voto popular ou em uma concepção ortodoxa de separação dos poderes - para aferir a legitimidade de uma decisão. Todos os poderes falham, todos os poderes respondem perante a opinião pública ${ }^{3}$ e segui-la também envolve seus riscos.

Com tal objetivo, o artigo partirá de um exame das instâncias majoritárias, com o propósito de demonstrar que há, no direito constitucional brasileiro (e não só nele ${ }^{4}$ ), diversos mecanismos e incentivos para que tais instâncias não sejam perfeitamente representativas ${ }^{5}$. Demonstrar-se-á, em seguida, como e por que pleitos majoritários não acolhidos nas instâncias representativas podem encontrar caminho no Judiciário, especialmente no Supremo Tribunal Federal, o que tampouco significa que as decisões da Corte serão mais legítimas do que aquelas produzidas no Executivo e no Legislativo. Na sequência, o trabalho desenvolverá um estudo do processo de formação. Analisará o papel desempenhado pela imprensa, bem como a ação de mecanismos de contágio informacional e de contágio reputacional, que podem conduzir os tribunais - tanto quanto os demais poderes - à incompreensão de seus limites institucionais, ao populismo e ao erro.

3 Designa-se opinião pública o conjunto de ideias e de juízos partilhados pela maioria dos membros da sociedade sobre temas de interesse social. Esse é o conceito dominante na literatura consultada e empregado pelo dicionário Novo Aurélio NOVO Aurélio: o dicionário da língua portuguesa. Rio de Janeiro: Nova Fronteira, 1999. p. 1.449.

4 LAIN, Corinna Barrett. Upside-down judicial review. Social Science Research Network, [Rochester], 12 Jan. 2012. p. 11. Disponível em: $<$ http://ssrn.com/abstract=1984060>. Acesso em: 27 set. 2013.

5 Com a expressão "perfeitamente representativas" pretende-se aludir a uma efetiva correspondência entre o pensamento dominante na população e aquele resultante da deliberação das instâncias políticas majoritárias - Executivo e Legislativo. 


\section{As INSTÂNCIAS MAJORITÁRIAS PODEM NÃO SER REPRESENTATIVAS?}

Afirmar que as instâncias majoritárias podem não ser efetivamente representativas não constitui propriamente uma revelação no momento atual de nossa história constitucional. O ano de 2015 foi marcado por uma Presidente da República impedida pelo Congresso Nacional, por um Presidente da Câmara dos Deputados afastado e posteriormente cassado, por notícias de investigações criminais envolvendo o Presidente do Senado e pela descrença generalizada nas instituições majoritárias. Sem qualquer pretensão de exaurir as múltiplas causas responsáveis pelas disfunções do nosso sistema democrático, algumas dessas causas são de fácil identificação.

A primeira delas diz respeito ao mecanismo da representação. Não há dúvida de que a melhor forma de os cidadãos manifestarem sua vontade a respeito de determinada matéria é pela via direta, ou seja, por sua própria voz, por seu próprio voto. A entrega da manifestação de tal vontade a um representante naturalmente a sujeita a distorções. O Executivo ou o Legislativo precisará interpretar a vontade prevalecente na sociedade a respeito de determinada matéria. Tal interpretação sujeita-se ao erro e às limitações do próprio sujeito que interpreta. A vontade da maioria pode divergir das convicções dos seus representantes sobre determinando assunto. Pode conflitar, ainda, com os interesses dos partidos ou com os interesses pessoais dos parlamentares. Todos esses aspectos podem ensejar desvios representativos.

O sistema eleitoral também dispõe de particularidades que demandam atenção. Os membros da Câmara dos Deputados são eleitos pelo sistema proporcional de listas abertas. Nesse sistema, a maior parte dos candidatos não se elege com base na votação individual que recebe, mas sim com base na votação computada pelos partidos. Quanto maior é a votação recebida por um partido, maior será o número de assentos que conquistará na Câmara dos Deputados. Dentro de cada partido, os assentos conquistados serão preenchidos pelos candidatos mais votados ${ }^{6}$.

6 No sistema proporcional de listas abertas, os votos válidos são aqueles conferidos à legenda partidária e ao candidato. $\mathrm{O}$ quociente eleitoral diz respeito ao índice de votos a ser obtido para a distribuição das vagas. É calculado pela divisão dos votos válidos pelo número de lugares a serem preenchidos no Legislativo. O quociente partidário refere-se ao número de vagas alcançado pelos partidos na casa leg-
Os partidos políticos, como é de conhecimento geral, não possuem definições ideológicas claras e formam coligações partidárias de ocasião, com o propósito de aumentar suas chances de sucesso nas eleições. Valem-se, ainda, do expediente de lançar a candidaturas de personalidades populares, como artistas, jogadores de futebol e/ou políticos polêmicos e extremistas, como forma de captar a atenção, de majorar artificialmente a votação recebida pela agremiação e, por consequência, aumentar o número de cadeiras conquistadas no parlamento ${ }^{7}$.

Em razão disso, a votação recebida por cada partido pode não espelhar a efetiva concordância dos eleitores com suas inclinações ideológicas e com seus projetos - quando esses efetivamente existem. Ao votar em um candidato, o voto do eleitor é computado em favor do partido, podendo, por conseguinte, beneficiar diversos outros candidatos que integram a sua lista e com os quais não tem qualquer afinidade ideológica. Nessas condições, torna-se difícil avaliar a representatividade e a responsividade dos parlamentares ${ }^{8}$.

O impacto do poder econômico sobre as eleições e sua interferência sobre o sistema representativo também merece ser considerado. As eleições, no Brasil, têm mobilizado importâncias cada vez maiores, e as perspectivas de sucesso são diretamente proporcionais aos valores gastos nas campanhas. Como o financiamento privado por pessoas jurídicas era admitido de forma ilimitada, a capacidade dos candidatos de levantarem recursos privados tinha um papel relevante nas eleições. Por consequência, aqueles que desejassem concorrer em eleições futuras precisavam manter relações positivas com empresários e grupos econômicos capazes de contribuir para suas campanhas. Nessas condições,

islativa. É calculado pela divisão do número de votos conferidos ao partido ou aos seus candidatos pelo quociente eleitoral.

7 MS 26.602, MS 26.603 e MS 26.604, voto do Min. Gilmar Mendes, DJ, 03 out. 2008; PEREIRA, Rodolfo Viana; GELAPE, Lucas de Oliveira. O anacronismo do sistema proporcional de lista aberta no Brasil. Revista de Informação Legislativa, n. 205, p. 261-279, jan./mar. 2015.

8 As pesquisas disponíveis indicam que poucos eleitores se lembram dos candidatos a deputados em que votaram, o que sugere que não acompanham a sua atuação. Os parlamentares, por sua vez, atribuem o apoio recebido nas campanhas à conexão com a vida política local. De modo geral, consideram importante visitar habitualmente os municípios em que tiveram votação expressiva, obter recursos do orçamento para tais áreas e encaminhar pleitos de prefeitos e de lideranças locais. V. NICOLAU, Jairo. O sistema eleitoral de listas abertas no Brasil. Dados: Revista de Ciências Sociais. Rio de Janeiro, v. 49, n. 4, p. 689-720, 2006 a. 
contrariar determinados interesses empresariais poderia se tornar extremamente oneroso e implicar na inviabilidade de candidaturas futuras?.

Outro fator que interfere sobre a representatividade do Legislativo, em nosso sistema, é o número de cadeiras titularizado por cada estado em cada uma das casas do Congresso. No Senado, o número de representantes é fixo por determinação constitucional, correspondendo a três representantes por ente da federação ${ }^{10}$. Por consequência, os estados que detêm maioria nessa casa não necessariamente correspondem à maioria da população. Na Câmara, embora o número de membros deva guardar proporcionalidade com a população de cada estado, a Constituição prevê o limite mínimo de 8 (oito) e o limite máximo de 70 (setenta) deputados por ente. Disso resulta que os estados mais populosos possuem representação proporcionalmente menor do que os menos populosos, aspecto que também pode impactar sobre o caráter majoritário das deliberações do Congresso ${ }^{11}$.

Vale notar, ainda, que a Constituição de 1988 é extremamente analítica, tendo constitucionalizado um rol amplíssimo de matérias que vão desde o regime jurídico aplicável aos servidores públicos e às relações trabalhistas (regime este obstativo de reformas relevantes em momentos de crise) até normas eleitorais e regras sobre foro especial por prerrogativa de função (que favorecem a manutenção do status quo). A alteração de tais normas, por meio de emendas constitucionais, exige super maiorias correspondentes a 3/5 (três quintos) dos membros de cada casa do Congresso, o que significa, na prática,

9 ADI 4650, Rel. Min. Luiz Fux, Pleno, DJe, 24 fev. 2016.

10 Art. 46, \ $1^{\circ}$, CF: “Art. 46. O Senado Federal compõe-se de representantes dos Estados e do Distrito Federal, eleitos segundo o princípio majoritário. $\int 1^{\circ}$ - Cada Estado e o Distrito Federal elegerão três Senadores, com mandato de oito anos". BRASIL. Constituição (1988). Constituição da República Federativa do Brasil de 1988. Disponível em: < http://www.planalto.gov.br/ccivil_03/constituicao/constituicaocompilado.htm>. Acesso em: 24 mar. 2016.

11 Art. 45, $\iint 1^{\circ}$ e $2^{\circ}, \mathrm{CF}$, dispõe: "Art. 45. A Câmara dos Deputados compõe-se de representantes do povo, eleitos, pelo sistema proporcional, em cada Estado, em cada Território e no Distrito Federal. $\int 1^{\circ}-\mathrm{O}$ número total de Deputados, bem como a representação por Estado e pelo Distrito Federal, será estabelecido por lei complementar, proporcionalmente à população, procedendo-se aos ajustes necessários, no ano anterior às eleições, para que nenhuma daquelas unidades da Federação tenha menos de oito ou mais de setenta Deputados. \ $2^{\circ}$ - Cada Território elegerá quatro Deputados". BRASIL. Constituição (1988). Constituição da República Federativa do Brasil de 1988. Disponível em: <http://www.planalto.gov.br/ ccivil_03/constituicao/constituicaocompilado.htm>. Acesso em: 24 mar. 2016. a possibilidade de bloqueio das pertinentes deliberações por parlamentares que representem uma minoria ${ }^{12}$.

Também no que respeita ao processo legislativo, registram-se, ainda, como medidas aptas a empoderar a minoria no Congresso: a derrubada de vetos presidenciais a projetos aprovados pelo Legislativo, porque dependente de quorum qualificado equivalente à maioria absoluta de senadores e deputados ${ }^{13}$; bem como o procedimento especial, abreviado e célere, de aprovação de medidas provisórias, que exclui a submissão do projeto de lei às comissões temáticas, reduz o debate em torno da norma e enseja o trancamento da pauta do Congresso Nacional ${ }^{14}$. Até bem pouco tempo, admitia-se a inclusão de emendas parlamentares aos projetos de leis de conversão de medidas provisórias, sem que tais emendas guardassem qualquer relação com o tema objeto do projeto. Grupos de interesses passaram a se valer desse expediente para obter, junto ao Congresso, a aprovação inadvertida, açodada e desprovida de debate, de normas a respeito de temas de profunda relevância para o país ${ }^{15}$.

Basta lembrar que o regime diferenciado de contratação pública (RDC) ${ }^{16}$, que flexibilizou as normas so-

12 Art. 60: "A Constituição poderá ser emendada mediante proposta: I - de um terço, no mínimo, dos membros da Câmara dos Deputados ou do Senado Federal; II - do Presidente da República; III - de mais da metade das Assembleias Legislativas das unidades da Federação, manifestando-se, cada uma delas, pela maioria relativa de seus membros. [...]. $\ 2^{\circ}-$ A proposta será discutida e votada em cada Casa do Congresso Nacional, em dois turnos, considerandose aprovada se obtiver, em ambos, três quintos dos votos dos respectivos membros". BRASIL. Constituição (1988). Constituição da República Federativa do Brasil de 1988. Disponível em: <http:// www.planalto.gov.br/ccivil_03/constituicao/constituicaocompilado.htm>. Acesso em: 24 mar. 2016.

13 Art. 66, \ $4^{\circ}, \mathrm{CF}$ : “O veto será apreciado em sessão conjunta, dentro de trinta dias a contar de seu recebimento, só podendo ser rejeitado pelo voto da maioria absoluta dos Deputados e Senadores, em escrutínio secreto". BRASIL. Constituição (1988). Constituição da República Federativa do Brasil de 1988. Disponível em: <http:// www.planalto.gov.br/ccivil_03/constituicao/constituicaocompilado.htm>. Acesso em: 24 mar. 2016.

14 Art. 62, \$6 $6^{\circ}, \mathrm{CF}$ : "Se a medida provisória não for apreciada em até quarenta e cinco dias contados de sua publicação, entrará em regime de urgência, subseqüentemente, em cada uma das Casas do Congresso Nacional, ficando sobrestadas, até que se ultime a votação, todas as demais deliberações legislativas da Casa em que estiver tramitando". BRASIL. Constituição (1988). Constituição da República Federativa do Brasil de 1988. Disponível em: <http:// www.planalto.gov.br/ccivil_03/constituicao/constituicaocompilado.htm >. Acesso em: 24 mar. 2016.

15 ADI 5127, Rel. p/ o acórdão Min. Edson Fachin, Pleno, DJe, 11 maio 2016.

16 O Regime Diferenciado de Contratação Pública (RDC) foi 
bre licitações para contratações públicas ${ }^{17}$, com tantas potenciais repercussões sobre o bom uso dos recursos da coletividade, foi aprovado por meio de emenda parlamentar a projeto de lei de conversão de medida provisória, sem qualquer relação com o tema objeto da emenda ${ }^{18}$. Vale o registro, ainda, de que, posteriormente, o mesmo regime, originalmente justificado pela necessidade de viabilizar contratações mais céleres para cumprir prazos de estruturação para a Copa das Confederações de Futebol de 2013, para a Copa do Mundo de 2014 e para as Olimpíadas, teve seu objeto ampliado pelo mesmo mecanismo - emenda parlamentar sem pertinência temática - para hipóteses sem qualquer relação com os referidos eventos, tais como a contratação de obras do Programa de Aceleração da Economia e obras e serviços do Sistema Único de Saúde ${ }^{19}$.

As normas constantes dos regimentos internos do Senado e da Câmara dos Deputados possibilitam, por outro lado, que se estabeleçam múltiplas exigências durante a tramitação dos projetos de lei, de forma a postergar a sua apreciação. Exemplo desse tipo de artifício é a submissão de diplomas que contrariem interesses de minorias poderosas a diversas comissões temáticas, de forma a evitar a sua efetiva apreciação pela maioria da casa legislativa. Por esse mecanismo, o projeto pode acabar arquivado sem que sequer venha a ser efetiva-

criado pela Lei 12.462/2011, por meio de emenda sem pertinência temática com a Medida Provisória (MP) 527/2011. As considerações tecidas neste artigo ao seu respeito baseiam-se em pesquisa desenvolvida por Mateus Capatti, no âmbito do Núcleo de Produção de Monografias de Bacharelado da graduação em Direito da UniCEUB. 17 GUIMARÃES, José. Parecer apresentado em Plenário pelo Relator Designado para manifestar-se pela Comissão incumbida da apreciação da matéria: Medida Provisória no 527, de 2011. Disponível em: <http:// www.camara.gov.br/proposicoesWeb/prop_mostrarintegra?codte or $=890021 \&$ filename $=$ Tramitacao $-\mathrm{MPV}+527 / 2011>$. Acesso em: 23 mar. 2016.

18 A MP 527/2011 tinha por objeto a criação da Secretaria de Aviação Civil, a autorização da contratação de controladores de tráfego aéreo e a criação do Fundo Nacional de Aviação Civil. Não versava, portanto, sobre regime diferenciado de contratações públicas.

19 V. art. $1^{\circ}$, inc. IV, da Lei $12.462 / 2011$, com redação conferida pela Lei 12.688/2012, oriunda de emenda parlamentar que não aguardava pertinência temática com a MP 559/2012; e inc. V do mesmo dispositivo, com redação dada pela Lei 12.745/2012, produto de emenda parlamentar sem pertinência temática com a MP 580/2012. BRASIL. Lei $n^{\circ} 12.688$, de 18 de julbo de 2012. Disponível em: <http://www.planalto.gov.br/ccivil_03/_ato2011-2014/2012/ lei/112688.htm>. BRASIL. Lei no 12.745, de 19 de dezembro de 2012. Disponível em: <http://www.planalto.gov.br/ccivil_03/_ato20112014/2012/Lei/L12745.htm>. Acessos em: 24 mar. 2016. mente votado ${ }^{20}$.

Os eleitores, por sua vez, sabem muito pouco sobre o que efetivamente se passa no âmbito do poder público. É muito baixo o nível de informação de que se dispõe a tal respeito. Para se manterem adequadamente informados sobre os assuntos relevantes para o país, os cidadãos dependem de corpos intermediários dentre os quais destaca-se a imprensa. Entretanto, como se demonstrará mais adiante neste trabalho, a imprensa não é neutra, nem quanto à escolha dos assuntos a serem reportados, nem quanto à versão dos fatos que será disponibilizada.

Parte relevante dos fatos que ocorrem na seara pública não chega ao conhecimento dos cidadãos. A parte que chega a seu conhecimento não necessariamente compõe um enredo fiel aos eventos como efetivamente ocorridos. E, de todo modo, a interpretação e a avaliação crítica dos informes pressupõem disponibilidade de tempo, interesse e uma formação mínima por parte da população. Sem acesso a bons níveis de informação, de educação, e sem juízo crítico a seu respeito, é muito difícil que o eleitor efetivamente participe do debate público e exerça um controle sobre como agem os seus representantes. Também por isso, nem todas as atitudes e votos dos parlamentares se refletirão nas urnas, em futuras eleições.

20 De acordo com o Regimento Interno da Câmara dos Deputados: "Art. 140. Quando qualquer Comissão pretender que outra se manifeste sobre determinada matéria, apresentará requerimento escrito nesse sentido ao Presidente da Câmara, com a indicação precisa da questão sobre a qual deseja o pronunciamento [...].” Já o Regimento Interno do Senado prevê: "Art. 279. A discussão, salvo nos projetos em regime de urgência e o disposto no art. 349, poderá ser adiada, mediante deliberação do Plenário, a requerimento de qualquer Senador ou comissão, para os seguintes fins: I - audiência de comissão que sobre ela não se tenha manifestado; II - reexame por uma ou mais comissões por motivo justificado". Segundo definição da própria Câmara dos Deputados, as comissões permanentes que a integram: "São órgãos técnicos criados pelo Regimento Interno da Casa e constituídos de deputados(as), com a finalidade de discutir e votar as propostas de leis que são apresentadas à Câmara. Com relação a determinadas proposições ou projetos, essas comissões se manifestam emitindo opinião técnica sobre o assunto, por meio de pareceres, antes de o assunto ser levado ao Plenário; com relação a outras proposições elas decidem, aprovando-as ou rejeitando-as, sem a necessidade de submissão ao Plenário. A composição parlamentar desses órgãos técnicos é renovada a cada ano ou sessão legislativa". Disponível em: <http://www2.camara.leg.br/atividadelegislativa/comissoes>. Acesso em: 01 jun. 2013. 


\section{A INSTÂNCIA CONTRAMAJORITÁRIA PODE SER REPRESENTATIVA? CASOS EM QUE A JURISDIÇÃO CONSTITUCIONAL DEU VAZÃO À VONTADE POPULAR}

Segundo a doutrina constitucional, dois aspectos centrais justificam a invalidação de atos dos representantes eleitos pela jurisdição constitucional, sem que se possa falar em violação ao princípio democrático: i) a proteção dos direitos fundamentais e ii) a garantia do adequado funcionamento do próprio processo democrático ${ }^{21}$. De acordo com essa concepção, os direitos fundamentais teriam sido retirados pelo constituinte originário do alcance da deliberação majoritária porque representam aspectos inerentes à dignidade dos indivíduos, sem os quais não faria sentido viver em comunidade. A garantia de tais direitos seria, por isso, pressuposto de validade do próprio exercício do poder político.

A atuação das cortes constitucionais para assegurar o respeito ao adequado funcionamento do processo democrático, por sua vez, teria o propósito de assegurar a legitimidade das deliberações da maioria, evitando que essas sejam distorcidas. A título ilustrativo, medidas do Congresso que impliquem o cerceamento do exercício do direito de voto ou a limitação da circulação de informação sobre os candidatos violarão o princípio democrático mesmo que sejam produzidas com o alegado aval da maioria (porque podem mascará-la) e, por consequência, devem ter a inconstitucionalidade reconhecida $^{22}$. Essas são as razões tradicionalmente utilizadas

21 A discussão sobre a legitimidade democrática da jurisdição constitucional é abordada nos limites da necessidade desse trabalho e sem pretensão exaustiva. Sobre o tema, v., entre outros: DWORKIN, Ronald. Uma questão de princípio. Trad.: Luís Carlos Borges. São Paulo: M. Fontes, 2000; e DWORKIN, Ronald. Levando os direitos a sério. Trad.: Jefferson Luiz Camargo. São Paulo: M. Fontes, 2003; ELY, John Hart. Democracy and distrust. A theory of judicial review. Cambridge, London: Harvard University Press, 1980; ELSTER, John. Ulysses and the syrens. Cambridge: Cambridge University Press, 1979; e ELSTER, John. Ulysses unbound - Studies in rationality, precomitments and constraints. Cambridge: Cambridge University Press, 2000; ALEXY, Robert. Constitucionalismo Discursivo. Trad.: Luis Afonso Heck. Porto Alegre: Livraria do Advogado, 2007; ACKERMAN, Bruce. We the people - Transformations. Cambridge: Harvard University Press, 1998; BINENBOJM, Gustavo. A nova jurisdição constitucional brasileira: legitimidade democrática e instrumentos de realização. Rio de Janeiro: Renovar, 2001.

22 É válido destacar, ademais, que a ideia de democracia, ou de governo pelo povo, não se esgota na observância do princípio majoritário. É preciso que a igualdade de participação e de oportunidades seja minimamente assegurada, sem o que não há que se falar adequadamente em autogoverno. V. DWORKIN, Ronald. Freedom's Law: The moral reading of the American constitution. Cambridge: para justificar o poder judicial de invalidar atos do Executivo e do Legislativo, a despeito de serem integrados por membros eleitos pelo voto popular ${ }^{23}$.

Pode acontecer, ainda, de o Tribunal, ao efetuar o controle da constitucionalidade das normas, dar vazão justamente a pleitos da maioria que não foram acolhidos nas instâncias majoritárias. Não é correto associar o respeito à decisão produzida pelo Legislativo ou pelo Executivo à observância princípio democrático. Ao contrário, uma observação atenta permite constatar que decisões judiciais convergentes com o entendimento prevalecente na comunidade, proferidas em sede de controle de constitucionalidade, são mais comuns do que se imagina. Apresentam-se, a seguir, alguns casos que confirmam essa assertiva ${ }^{24}$.

i) Foro especial por prerrogativa de função

O primeiro desses casos diz respeito ao foro especial por prerrogativa de função. De acordo com o art. 102, I, (a) e (b), da Constituição, compete ao Supremo Tribunal Federal processar e julgar - originariamente - nas infrações penais comuns e nos crimes de responsabilidade as mais altas autoridades da República ${ }^{25}$. Segundo entendimento da jurisprudência centenária do $\mathrm{STF}^{26}$, con-

Harvard University Press, 1996. p. 16-17.

23 Tais razões justificam apenas parte da atuação do Supremo Tribunal Federal, que, em diversas situações, aprecia a constitucionalidade de atos em face de normas formalmente constitucionais, que não correspondem a direitos fundamentais ou se relacionam com o respeito ao processo democrático. A legitimação do STF para atuar com tamanha amplitude deriva, no caso brasileiro, de normas constitucionais expressas, que podem, todavia, ser problematizadas. DWORKIN, Ronald. Freedom's Law: The moral reading of the American constitution. Cambridge: Harvard University Press, 1996. p. 16-17.

Tais razões justificam apenas parte da atuação do Supremo Tribunal Federal. Em diversas situações, o Tribunal aprecia a constitucionalidade de atos em face de normas apenas formalmente constitucionais, que não interferem sobre direitos fundamentais ou se relacionam com o funcionamento do processo democrático. A legitimação do STF para atuar com tamanha amplitude deriva, no caso brasileiro, de normas constitucionais expressas.

24 BARROSO, Luís Roberto. Constituição, democracia e supremacia judicial: direito e política no Brasil contemporâneo. p. 33. Disponível em: <http://www.luisrobertobarroso.com.br/pt/noticias/constituicao_democracia_e_supremacia_judicial_11032010.pdf $>$. Acesso em: 2 jul. 2012; MELLO, Patrícia Perrone Campos. Nos bastidores do Supremo Tribunal Federal. Rio de Janeiro: Forense, 2015. p. 293 e ss.

25 Cf. art. 102, I, (a) e (b), CF. BRASIL. Constituição (1988). Constituição da República Federativa do Brasil de 1988. Disponível em: $<$ http://www.planalto.gov.br/ccivil_03/constituicao/constituicaocompilado.htm>. Acesso em: 24 mar. 2016.

26 A primeira decisão de que se tem notícia em tal sentido dataria de 25 de janeiro de 1842. Inquérito n. 687-4, STF, Pleno, Rel. Min. 
solidada em súmula simples e aplicada por pelo menos dez anos durante a vigência da Constituição de 1988, tal prerrogativa de foro se estenderia, ainda, aos ex-mandatários e aos ex-ocupantes de cargos públicos, a despeito de a Constituição não ter sido expressa no ponto, porque a independência da autoridade no exercício do cargo deveria ser preservada pela certeza de que, mesmo quando não estivesse mais no poder, ser-lhe-ia assegurado um julgamento justo e neutro, diretamente pela mais alta corte do país e não por qualquer outra instância ${ }^{27}$.

Ocorre que a prerrogativa de foro era compreendida pela população como sinônimo de impunidade porque, na prática, pouquíssimas são as ações penais efetivamente processadas pelo STF e mais raras ainda eram as condenações. De modo geral, a maior parte dos casos restava prescrita sem que uma resposta adequada fosse dada pelo Tribunal, situação que causava desgastes para sua credibilidade. Duas eram as explicações usualmente utilizadas para esse tipo de desfecho nos casos de foro especial. Afirmava-se que o julgamento de tais ações criminais demandavam do ministro relator uma atuação de juiz de primeiro grau, coletando e apreciando provas e ouvindo testemunhas, atuação para a qual o STF não estaria aparelhado, por se tratar de tribunal superior. E alegava-se que essa particularidade, somada à enorme sobrecarga de processos enfrentada pela Corte, acabava prejudicando o julgamento dos referidos casos.

Suprimir o foro especial das autoridades que se encontravam no curso do mandato ou na posse dos cargos de alto escalão demandaria a aprovação de uma emenda constitucional, já que a literalidade da Constituição não deixava dúvidas quanto à competência do STF para julgá-las, no que respeita à prática de crimes comuns e/ou de responsabilidade. Entretanto, a prerrogativa de foro de ex-mandatários e de ex-ocupantes de cargos públicos decorria de mera construção jurisprudencial. Poderia, portanto, ser revertida pela própria Corte.

Assim, em 1999, o STF decidiu superar sua antiga súmula para afirmar que a prerrogativa de foro se limitava àquelas autoridades que estivessem cumprindo o mandato ou que estivessem na posse do cargo. Uma vez findo o mandato ou exonerada do cargo, o STF declinaria da sua

Sydney Sanches, j. 25 ago. 1999, DJ 9 nov. 2001, voto do Ministro Sepúlveda Pertence.

27 Súmula 394, STF: "Cometido o crime durante o exercício funcional, prevalece a competência especial por prerrogativa de função, ainda que o inquérito ou a ação penal sejam iniciados após a cessação daquele exercício". competência e encaminharia o feito ao juiz natural para prosseguimento. Justificou-se a nova decisão com base no argumento literal de que a competência para julgar ex-ocupantes não estava expressa na letra da Constituição (diferentemente do que ocorria nas constituições anteriores). Alegou-se, ainda, que tal prerrogativa de foro voltava-se a proteger o exercício do mandato ou do cargo, não seu ex-titular, e que, por se tratar de exceção à regra geral, deveria receber interpretação restritiva.

A decisão não foi bem recebida pelos parlamentares, que se beneficiavam com a prerrogativa de foro. Por isso, em resposta a ela, o Congresso aprovou a Lei $n^{\circ}$ 10.628/02, que alterava o art. 82 do Código Penal para estabelecer que a competência especial por prerrogativa de função, relativa a atos administrativos do agente, prevaleceria ainda que o inquérito ou a ação judicial fossem iniciados após a cessação do exercício da função pública. Entretanto, a nova lei foi declarada inconstitucional em sede concentrada pelo STF, tendo-se reiterado, durante o julgamento, que a experiência mostrava que o STF não era um tribunal vocacionado para o exercício dessa competência ${ }^{28}$. Houve, igualmente, menção ao fato de que, de modo geral, os casos levados ao Tribunal restavam impunes ${ }^{29}$. Um ano mais tarde, alguns membros do Congresso voltariam a insistir na tentativa de reverter tal entendimento, desta vez, por meio de um projeto de emenda constitucional ${ }^{30}$.

O caso antes narrado é bem ilustrativo de como as instâncias majoritárias podem divergir do sentimento popular. De acordo com pesquisa contratada pela Associação dos Magistrados Brasileiros então, 79,8\% da população eram contra o foro especial ${ }^{31}{ }^{32}$. A despeito disso, o Congresso fez o que pode para mantê-lo na maior extensão possível. Curiosamente, coube ao Supremo Tribunal Federal, composto por juízes vitalícios e independentes, atender às expectativas da população. Em virtude disso, o foro especial por prerrogativa de

28 ADIs 2797 e 2860, Rel. Min. Sepúlveda Pertence, Pleno, DJ, 19 dez. 2006.

29 V. voto do Ministro Carlos Veloso nas ADINs n. 2797 e 2860. 30 ASSOCIAÇÃO DOS MAGISTRADOS BRASILEIROS. Juizes Contra a Corrupção. Disponível em: <http://www.amb.com.br/portal/ docs/noticias/estudo_corrupcao.pdf>. Acesso em: 18 jun. 2013.

31 OPINIÃO CONSULTORIA. A imagem das instituições públicas brasileiras. Brasília, set. 2007. p. 13. Disponível em: <http://www. amb.com.br/docs/pesquisa/imagem_instituicoes.pdf >. Acesso em: 18 jun. 2013.

32 Embora as pesquisas de opinião se sujeitem a alguma margem de erro, elas são um critério objetivo para aferir a opinião popular sobre determinado tema. 
função para ex-ocupantes de cargos e para ex-detentores de mandato deixou de existir.

Persiste, contudo, o foro para ocupantes e detentores atuais de mandatos (juntamente os mesmos problemas já narrados), já que a sua supressão nessa hipótese dependia da atuação dos parlamentares, por meio de emenda constitucional, o que, como era de se imaginar, até o momento, ainda não aconteceu. A matéria continua na ordem do dia. E a necessidade de alterar o foro especial vem sendo reiteradamente apontada por membros da Corte ${ }^{33}$.

\section{ii) Fidelidade partidária}

Um segundo caso em que o STF claramente deu vazão ao anseio popular foi aquele em que afirmou o dever de fidelidade partidária dos parlamentares eleitos pelo sistema proporcional de listas abertas. Como já mencionado acima, os candidatos, no referido sistema, geralmente se elegem com base na votação obtida pelo partido e não com base na votação individual do candidato. A despeito disso, durante muito tempo, o STF entendeu que o parlamentar eleito por intermédio de determinado partido não estava obrigado a permanecer na agremiação, podendo deixá-la a qualquer tempo e ainda assim manter o seu mandato. $\mathrm{O}$ entendimento tinha por base o fato de que o dispositivo constitucional que previa a perda do mandato por infidelidade partidária, na vigência da Constituição anterior, fora revogado pela Emenda Constitucional 25/1985 e não voltou a ser inserido na Constituição de 1988. Como a última trazia um rol das causas de perda de mandato e tendo em vista que tais causas constituem situações excepcionais, conferiu-se a elas interpretação restritiva ${ }^{34}$.

Em consequência, os deputados ficaram livres para se elegerem por um partido e, depois, mudarem de partido de acordo com interesses de ocasião. O troca-troca de agremiações tornou-se uma prática comum, que não desagradava aos partidos maiores. Com bancadas mais amplas e maior poder de barganha no Legislativo, esses partidos conseguiam atrair parlamentares infiéis de partidos menores e, assim, majorar seu poder no Congresso. Entretanto, tal prática constituía um grave problema para as agremiações menores. Embora o partido fosse

33 MEGALE, Bela. Ministro Luís Roberto Barroso quer o fim do foro privilegiado. Folha de São Paulo, 23 maio 2016. Disponível em: <http://www1.folha.uol.com.br/poder/2016/05/1774158ministro-do-stf-luis-roberto-barroso-quer-fim-do-foro-privilegiado. shtml >. Acesso em: 26 nov. 2016.

34 MS 20.927, Rel. Min. Moreira Alves, Pleno, DJ, 15 abr. 1994. determinante para a eleição de um deputado, corria o risco de perder todos os deputados que elegeu e, portanto, de não mais poder exercitar seu direito ao funcionamento parlamentar, a despeito de ter tido um razoável desempenho eleitoral. Tal expediente poderia, por sua vez, anular o direito de oposição e de representação das minorias e indiscutivelmente distorcia o processo democrático representativo.

Quase vinte anos haviam se passado, desde o julgamento do leading case em que o Supremo Tribunal Federal havia apreciado a matéria, quando este finalmente decidiu reexaminá-la. Nessa ocasião, observou que, na legislatura em curso, o percentual de deputados eleitos por votação individual era de aproximadamente $6 \%$ (seis por cento) apenas, de modo que ficava evidente que a conquista do mandato era resultante, ao menos, do somatório do desempenho eleitoral dos candidatos e dos partidos. Por essa razão e em respeito ao caráter representativo do mandato, uma vez eleito, o deputado não poderia simplesmente desligar-se da agremiação, como se fosse ela um mero instrumento de acesso ao poder. A troca de partido só poderia ocorrer caso demonstrasse estar sofrendo perseguição dentro da agremiação ou caso comprovasse ter havido alteração ideológica relevante. Excepcionadas tais circunstâncias, o desligamento do partido implicaria na quebra do dever de fidelidade partidária e, consequentemente, na perda do mandato parlamentar em favor do partido ${ }^{35}$.

A decisão seguramente não atendida aos interesses dos partidos que tinham maioria na Câmara dos Deputados e que poderiam ter corrigido tal distorção pela via legislativa. Não havia interesse em fazê-lo porque ela se prestava bem à preservação de seu poder na Câmara. Todavia, de acordo com pesquisa realizada pelo Instituto Brasileiro de Opinião Pública e Estatística - IBOPE, contratada pela Confederação Nacional das Indústrias CNI, $52 \%$ da população eram favoráveis à implementação do dever de fidelidade partidária contra $37 \%$, que se manifestaram contra a medida. Mais uma vez, portanto, coube ao STF dar voz aos anseios da maioria.

iii) Financiamento privado de campanha eleitoral

No terceiro caso selecionado, o Supremo Tribunal Federal apreciou a constitucionalidade do sistema privado de financiamento das campanhas eleitorais. $\mathrm{Na}$ ação, proposta

35 MS 26.602, Rel. Min. Eros Grau, Pleno, DJe, 17 out. 2008; MS 26.603, Rel. Min. Celso de Mello, Pleno, DJe, 19 dez. 2008; e MS 26.604, Rel. Min. Cármen Lúcia, Pleno, DJe, 3 out. 2008 
pelo Conselho Federal da Ordem dos Advogados, pleiteava-se: i) a declaração da inconstitucionalidade da doação por pessoas jurídicas a campanhas eleitorais ou a partidos políticos; ii) a limitação das doações de pessoas físicas e do uso de recursos próprios pelos candidatos para os mesmos fins, a fim de assegurar a igualdade nas eleições ${ }^{36}$.

De acordo com o relator do feito, Ministro Luiz Fux, em apenas dez anos, havia-se testemunhado um crescimento exponencial do custo das campanhas eleitorais: dos 798 milhões de reais, gastos em 2002, para mais de 4,5 bilhões de reais, em 2012, um aumento de 471\% em dez anos. Ainda segundo o relator, estima-se que $0,89 \%$ do produto interno bruto do Brasil era gasto no financiamento de campanhas eleitorais, quando, nos Estados Unidos da América, em que as campanhas são conhecidas por seus números expressivos, tal percentual alcançaria apenas 0,38\% do PIB. Este e outros argumentos levaram o ministro a reconhecer a "crescente influência do poder econômico sobre o processo político" 37 .

Constatou-se, ainda, que, quanto maior a capacidade de angariar recursos, maiores as chances de eleição dos políticos. Os candidatos eleitos não eram aqueles que apresentavam as melhores propostas, mas aqueles com financiamento mais robusto. Não representavam os cidadãos que os elegeram, mas os grupos econômicos que os financiaram. Tais grupos, por sua vez, se dispunham a verter tamanhas importâncias para campanhas eleitorais porque esperavam colher benefícios com a eleição dos candidatos apoiados. O quadro, tal como delineado, se mostrava incompatível com o princípio da igualdade de chances nas eleições e com o regime democrático.

Com base nesses argumentos, o STF julgou a ação parcialmente procedente para assentar a inconstitucionalidade do financiamento privado de campanhas por pessoas jurídicas tal como regulado na legislação em vigor, deixando aberta, contudo, a possibilidade de o po-

36 ADI 4650, Rel. Min. Luiz Fux, Pleno, DJe, 24 fev. 2016.

37 Confira-se trecho do acórdão: "Na mesma Audiência, o expositor e professor Geraldo Tadeu demonstrou que o gasto per capita nas campanhas eleitorais no Brasil é bastante superior aos da França, da Alemanha e do Reino Unido. No Brasil, essa cifra atinge o montante de $\$ 10,93$, enquanto que na França é de $\$ 0,45$, no Reino Unido, de $\$ 0,77$, e na Alemanha chega a 2,21. Quando comparado proporcionalmente ao PIB, o Brasil também se encontra no topo do ranking dos países que mais gastam com campanhas eleitorais: $0,89 \%$ de toda a riqueza gerada no país se presta a financiar candidaturas a cargos representativos. Aqui, ultrapassamos, inclusive, os Estados Unidos, em que apenas $0,38 \%$ do PIB vai para as campanhas eleitorais". Não fica claro, no trecho, o período a que os percentuais de $0,89 \%$ e $0,38 \%$ do PIB de cada país se referem. der Legislativo dispor sobre o tema em outras bases ${ }^{38}$.

Merece menção, contudo, o fato de que, quando o julgamento ainda estava em curso no STF, a Câmara dos Deputados levou à deliberação uma emenda constitucional que autorizava expressamente o financiamento privado de campanha por pessoa jurídica. A manobra tinha o propósito evidente de neutralizar o entendimento que seria proferido pelo Tribunal. Esse primeiro projeto de emenda foi rejeitado na Câmara, mas, um dia mais tarde, uma nova emenda sobre o tema foi aprovada, sob forte pressão de alguns grupos de parlamentares, permitindo a doação de pessoas jurídicas privadas a partidos ${ }^{39}$. Em seguida, o projeto foi encaminhado ao Senado para votação e pende de apreciação.

Ao que tudo indica, também nesse caso as instâncias majoritárias se afastaram da vontade popular e coube ao Supremo dar-lhe voz. De acordo com pesquisa divulgada pelo Datafolha, $74 \%$ da população eram contra o financiamento de campanha por empresas privadas e $79 \%$ estavam convictos de que esse tipo de financiamento estimulava a corrupção ${ }^{40}$.

38 Constou da ementa do julgado: "Ausência de modelo constitucional cerrado de financiamento de campanhas. Constituiçãomoldura. Normas fundamentais limitadoras da discricionariedade legislativa. Pronunciamento do Supremo Tribunal Federal que não encerra o debate constitucional em sentido amplo. Diálogos institucionais. Última palavra provisória. Mérito. Doação por pessoas jurídicas. Inconstitucionalidade dos limites previstos na legislação ( $2 \%$ do faturamento bruto no ano anterior à eleição). Violação aos princípios democráticos e da igualdade política. Captura do processo político pelo poder econômico".

39 Proposta de Emenda à Constituição no 182/2007: “Art. 17. [...]. \$5 5 ” É permitido aos partidos políticos receber doações de recursos financeiros ou de bens estimáveis em dinheiro de pessoas físicas ou jurídicas. $\$ 6^{\circ}$ É permitido aos candidatos receber doações de recursos financeiros ou de bens estimáveis em dinheiro de pessoas físicas. $\$ 7^{\circ}$ Os limites máximos de arrecadação e gastos de recursos para cada cargo eletivo serão definidos em lei”. A aprovação do projeto na Câmara dos Deputados levou alguns de seus membros a impetrar o MS 33.630, perante o STF, distribuído à relatoria da Ministra Rosa Weber, alegando violação ao art. $60, \$ 5^{\circ}$, CF. Entretanto, a liminar foi indeferida. O referido dispositivo constitucional estabelece: " $\int 5^{\circ}$ A matéria constante de proposta de emenda rejeitada ou havida por prejudicada não pode ser objeto de nova proposta na mesma sessão legislativa". PASSARINHO, Natália. Câmara aprova por na Constituição doação de empresas a partidos. G1. Política. 25 maio 2015. Disponível em: <http://g1.globo.com/politica/ noticia/2015/05/camara-aprova-incluir-na-constituicao-doacao-de-empresas-partidos-politicos.html>. Acesso em: 6 maio 2015.

40 SOUZA, André. Datafolha: Três em cada quatro brasileiros são contra o financiamento de campanha por empresas privadas. O Globo, Rio de Janeiro, 6 jul. 2015. Disponível em: <http:// oglobo.globo.com/brasil/datafolha-tres-em-cada-quatro-brasileiros-sao-contra-financiamento-de-campanha-por-empresas-privadas-16672767>. Acesso em: 5 ago. 2015. Por outro lado, de acordo com pesquisa realizada pelo Instituto Sensus, $75,2 \%$ da população é 
4. CASOS EM QUe a JURISDição CONSTITUCIONAL SE CURVOU À VONTADE POPULAR

Há casos, ainda, em que se constatam fortes indícios de que a decisão proferida pelo Supremo Tribunal Federal teria sido outra, não fosse a vigilância e a pressão exercida pelo público e pela imprensa. Os dois casos selecionados para ilustrar essa assertiva dizem respeito a um tema que encontrou considerável resistência no poder Judiciário: a criação do Conselho Nacional de Justiça (CNJ), órgão destinado a realizar o controle administrativo, financeiro e disciplinar do Judiciário e de seus magistrados ${ }^{41}$.

i) A criação do Conselho Nacional de Justiça

O Conselho Nacional de Justiça foi criado pela Emenda Constitucional 45/2004, de reforma do Judiciário. Como é intuitivo, a magistratura não recebeu bem a inovação e a Associação dos Magistrados Brasileiros (AMB) propôs uma ação direta de inconstitucionalidade contra a norma, alegando que um órgão com composição hibrida destinado ao controle do Judiciário atentava contra a separação dos poderes, a independência dos juízes e as demais garantias da magistratura. Observou, ainda, que a Súmula 646 do STF estabelecia ser "inconstitucional a criação, por Constituição Estadual, de órgão de controle administrativo do Poder Judiciário do qual participem representantes de outros poderes ou entidades", situação semelhante àquela do CNJ.

A ação era particularmente delicada para o STF. À época em que a emenda de reforma encontrava-se em discussão, a Corte havia deliberado, em sessão administrativa, por uma maioria de sete ministros, manifestar-se contrariamente à criação de um órgão de controle integrado por agentes externos à magistratura. No entanto, o órgão foi aprovado pelo Congresso e amplamente acolhido pela imprensa, pela comunidade jurídica e pelo público em geral.

O Supremo integrava o poder Judiciário. Mesmo que não se submetesse, ele próprio, ao $\mathrm{CNJ}$, uma even-

contra o financiamento público exclusivo das campanhas eleitorais. V. MILITÃO, Eduardo. Maioria é contra financiamento público de campanha. Uol, Congresso em foco, 26 jun. 2007. Disponível em: $<$ http://congressoemfoco.uol.com.br/noticias/maioria-e-contrafinanciamento-publico-de-campanha/>. Acesso em: 5 ago. 2015. 41 Cf. art. 103-B, J 4 ${ }^{\circ}$, CF. BRASIL. Constituição (1988). Constituição da República Federativa do Brasil de 1988. Disponível em: $<$ http://www.planalto.gov.br/ccivil_03/constituicao/constituicaocompilado.htm>. Acesso em: 24 mar. 2016. tual decisão pela inconstitucionalidade do Conselho, no contexto, seria interpretada como corporativista e contrária aos avanços amplamente apoiados pela população. O caso colocava a legitimidade da Corte em xeque, e os debates travados entre os ministros, durante o julgamento, evidenciavam a divergência entre eles e a preocupação com a imagem do tribunal.

O Ministro Carlos Velloso, por exemplo, lembrava a todos que a posição contrária a um Conselho de natureza híbrida já fora firmada pela Corte e parecia cobrar coerência de alguns ministros que se manifestaram administrativamente neste sentido. Questionado, o Ministro Peluso observou que, em âmbito administrativo, fizera um juízo de conveniência sobre a composição que considerava mais adequada para o CNJ. Não lhe agradava a composição híbrida. Disso não resultava, contudo, que ela fosse necessariamente inconstitucional. Em um debate duro, insinuou-se que alguns ministros que estariam votando favoravelmente ao Conselho no caso em exame teriam tido sua posição original "convertida". Confira-se:

O SENHOR MINISTRO CARLOS VELLOSO - [...]. Na sessão administrativa convocada pela presidência, os Srs. Ministros MAURÍCIO CORRÊA, eu próprio, MARCO AURÉLIO, ELLEN GRACIE, GILMAR MENDES E CEZAR PELUSO votamos contra a inclusão no Conselho dos não magistrados, dos representantes do Senado, da Câmara, dos advogados e dos membros do Ministério Público. Seis Ministros, portanto. A estes votos acresceu, em parte, o voto do Ministro SEPÚlVEDA PERTENCE, que inadmitia os representantes do Senado e da Câmara, mas admitia os advogados e membros do Ministério Público. Sete ministros, portanto, não admitiam os representantes da Câmara e do Senado.

O SENHOR MINISTRO CEZAR PELUSO (RELATOR) - Vossa Excelência me permite? [...]. Quando dei minha opinião e, de certo modo, reafirmei hoje o meu ponto de vista, de que do ponto de vista da conveniência não me agrada realmente a participação nem de membros da advocacia, do Ministério Público, [do] cidadão, na estrutura do Conselho, não significava que a questão, do ponto de vista constitucional, não fosse outra.

O SENHOR MINISTRO CARLOS VELLOSO Perfeito, Ministro Cezar Peluso. É o que o Ministro Marco Aurélio diz, o juiz costuma evoluir.

O SENHOR MINISTRO NELSON JOBIM (PRESIDENTE) - Ninguém evoluiu, permanece a mesma posição.

O SENHOR MINISTRO CEZAR PELUSO (RELATOR) - Não. Ninguém evoluiu. Eu não evoluí nada. Eu continuo com a minha convicção. 
O SENHOR MINISTRO CARLOS VELLOSO Ou pode involuir também. Ou pode ser convertido. Saulo foi convertido. Felizmente, não caminhei na estrada de Damasco. ${ }^{42}$

Mas por quem os ministros teriam sido convertidos?

É possível que uma pista esteja na fundamentação dos votos proferidos por cada qual. De fato, nota-se, por seu exame, que diversos ministros aludiram, ao votar, à sua preocupação com as expectativas da sociedade a respeito do desfecho do caso. Nessa linha, o ministro Celso de Mello, manifestou-se pela constitucionalidade do órgão, aludindo ao "contexto histórico" do país e à "realidade política", que impunham a viabilização de um processo de "fiscalização social" dos atos não-jurisdicionais do poder Judiciário. ${ }^{43} \mathrm{O}$ ministro Eros Grau defendeu a criação do CNJ, observando que não se podia desconsiderar "o imaginário social” e suas "expectativas", sob pena de se promover enorme desgaste para o Tribunal. O ministro Nelson Jobim ressaltou que o Poder Judiciário tornara-se "uma preocupação nacional", em virtude de seu isolamento da sociedade, do seu corporativismo e da necessidade de melhorar o serviço prestado à população. E defendeu não apenas a validade do CNJ, mas igualmente a imprescindibilidade da sua composição híbrida para que o necessário controle disciplinar dos magistrados fosse verdadeiramente efetuado. ${ }^{44}$

42 ADIN 3367, Rel. Min. Cezar Peluso, Pleno, DJ, 17 mar. 2006, p. $142-144$.

43 ADIn 3367, p. 345-348.

44 ADIn 3367, p. 369-373. Confiram-se as contundentes palavras do Ministro Jobim: "Assisti, durante todos esses anos, ao debate real que se travava naqueles fóruns, exatamente o debate do espaço de cada uma dessas corporações [dos juízes, dos membros do Ministério Público, da OAB, das associações de advogados públicos, de advogados trabalhistas e de outros especialistas] no controle do Poder Judiciário. Muito pouco se debatia sobre celeridade, sobre eficiência, mas debatiam-se os conflitos entre os espaços de cada um. [...]. Tudo isso levou sempre a um desenho e a um modelo autônomo-corporativo de isolamento, na linguagem de Cappelleti, que era exatamente a absolutização da independência, isolando o Poder Judiciário do resto da organização estatal e da sociedade. [...]. Quando chegamos ao ano 2000, o Poder Judiciário passou a ser uma preocupação nacional; não era mais mera preocupação das categorias ou de juristas e acadêmicos. Por quê? Qual a razão de se debater muito sobre a necessidade de um órgão que tem duas funções? Uma, a principal, sob o meu ponto de vista, é exatamente a função da formulação de uma política nacional do Poder Judiciário. Isso é decorrente do isolamento absoluto dos 96 tribunais que compõem a estrutura brasileira de hoje - reduzidos, agora, a 93, tendo em vista a extinção dos tribunais de alçada. [...]. Creio que o aparte feito pelo Ministro Carlos Britto, na leitura de uma manifestação do Desembargador Vladimir Passos Freitas, mostra exatamente porque a sociedade brasileira, por meio do Congresso Nacional, resolveu instituir um órgão não só funda-
O ministro Marco Aurélio, por sua vez, manifestou-se pela inconstitucionalidade do CNJ, afirmando que se dava "uma esperança vã à sociedade brasileira" com essa providência, porque, em lugar de avaliar os problemas enfrentados pelo Judiciário, tratava-se o assunto como se fosse uma questão disciplinar. ${ }^{45}$

A preocupação de diversos membros da Corte em dar uma resposta à sociedade, as diversas alusões ao momento histórico, às expectativas da população, ao imaginário social, à superação de um modelo de isolamento social indicam que a pressão exercida pela comunidade sobre o Tribunal influenciou no desfecho do caso. Veja-se que a percepção do sentimento popular, no caso, tinha peso tal que levava seus membros a decidir contrariamente a interesses da própria magistratura, a despeito do histórico corporativista antes mencionado.

\section{ii) $\mathrm{O}$ poder disciplinar concorrente do Conselho}

Entretanto, as polêmicas em torno do $\mathrm{CNJ}$ haviam apenas começado. Em meados de 2011, o Conselho editou a Resolução 135/2011, que dispôs sobre o procedimento disciplinar aplicável aos magistrados, e previu sua competência concorrente (com os demais tribunais) para processar e julgar os juízes por faltas disciplinares ${ }^{46}$. Em resposta, uma nova ação direta de inconstitucionalidade foi proposta pela AMB, desta vez, contra a resolução. A Associação defendia, dessa vez, que a competência do CNJ era meramente subsidiária, de modo que este só poderia agir, caso se verificasse que os tribunais não estavam exercendo adequadamente seu poder disciplinar. O entendimento da AMB tinha por base a redação do art. $103-\mathrm{B}, \mathbb{S} 4^{\circ}$, incisos III e $\mathrm{V}^{47}$, bem como a alegada

mental de formulação de políticas, mas, também, um órgão supletivo da questão disciplinar. Como disse o próprio Desembargador, tendo em vista a sua experiência como, hoje, Presidente do Tribunal Regional Federal da $4^{\mathrm{a}}$ Região, é difícil se ver a correição horizontal, é muito fácil se ver a correição vertical; mas nem sempre. Por isso creio que a presença de dois membros do Conselho, oriundos do Congresso Nacional, um do Senado e outro da Câmara, mostra que estamos revertendo ou virando a curva do isolamento, porque se o Conselho fosse integrado apenas por magistrados, advogados e promotores, teríamos ainda a manutenção de um sistema corporativo e de isolamento. A presença de dois membros externos ao sistema judicial possibilita, fundamentalmente, inclusive, o constrangimento em relação às decisões que possam ser tomadas".

45 ADIn 3367 , p. 308 e ss.

46 O dispositivo tinha a seguinte redação: "Art. 12. Para os processos administrativos disciplinares e para a aplicação de quaisquer penalidades previstas em lei, é competente o Tribunal a que pertença ou esteja subordinado o Magistrado, sem prejuízo da atuação do Conselho Nacional de Justiça".

47 Art. 103-B: "§ $4^{\circ}$ Compete ao Conselho o controle da atuação 
necessidade de harmonizar as competências em questão com a autonomia administrativa dos tribunais. ${ }^{48}$

Ocorre, todavia, que o exercício concorrente da competência disciplinar por parte do Conselho Nacional de Justiça era aprovado pela população, que via a resistência da magistratura como uma atitude corporativista que favorecia a impunidade. A nova ação da AMB gerou, então, uma polarização das posições. A imprensa, por sua vez, contribuía para tal polarização. Exercia uma vigilância intensa e persistente sobre o Supremo Tribunal Federal, publicava reiteradas matérias sobre o assunto e afirmava que a liminar pleiteada pela AMB (pedindo para que a resolução do $\mathrm{CNJ}$ tivesse seus efeitos suspensos) ainda não havia sido apreciada pela Corte apenas porque esta se sentia pressionada pela opinião pública a decidir contra os interesses corporativos da associação. De fato, chegou-se a publicar:

Diante da forte reação da opinião pública e das críticas ao corporativismo no Judiciário, o Supremo Tribunal Federal (STF) desistiu de julgar ontem a ação que tira do Conselho Nacional de Justiça (CNJ) poderes para investigar e punir magistrados. A maioria dos ministros do STF tendia a aceitar a ação, movida pela Associação dos Magistrados Brasileiros (AMB), mas o presidente da Corte, Cezar Peluso, adiou sua apreciação. "O momento não é adequado. Vamos deixar até que os fatos sejam mais esclarecidos”, resumiu Marco Aurélio Mello, relator da ação ${ }^{49}$.

administrativa e financeira do Poder Judiciário e do cumprimento dos deveres funcionais dos juízes, cabendo-lhe, além de outras atribuições que lhe forem conferidas pelo Estatuto da Magistratura: [...] III - receber e conhecer das reclamações contra membros ou órgãos do Poder Judiciário, inclusive contra seus serviços auxiliares, serventias e órgãos prestadores de serviços notariais e de registro que atuem por delegação do poder público ou oficializados, sem prejuízo da competência disciplinar e correicional dos tribunais, podendo avocar processos disciplinares em curso e determinar a remoção, a disponibilidade ou a aposentadoria com subsídios ou proventos proporcionais ao tempo de serviço e aplicar outras sanções administrativas, assegurada ampla defesa; [...]; V - rever, de ofício ou mediante provocação, os processos disciplinares de juízes e membros de tribunais julgados há menos de um ano".

48 Sobre a autonomia administrativa do Poder Judiciário, a Constituição de 1988 dispunha: "Art. 96. Compete privativamente: I aos tribunais: a) eleger seus órgãos diretivos e elaborar seus regimentos internos, com observância das normas de processo e das garantias processuais das partes, dispondo sobre a competência e o funcionamento dos respectivos órgãos jurisdicionais e administrativos"; e "Art. 99. Ao Poder Judiciário é assegurada autonomia administrativa e financeira".

49 BRÍGIDO, Carolina. No país da impunidade, STF em crise não consegue decidir sobre punição a juízes. Reação da opinião pública impede tribunal de retirar poderes do CNJ. O Globo, Rio de Janeiro, 29 set. 2011. p. 1.
De fato, o pedido de cautelar veiculado na ação foi pautado 13 (treze vezes), mas encerrou-se o ano judiciário sem que viesse a ser apreciado pelo $\mathrm{STF}^{50}$. Em virtude disso, o relator do feito, o Ministro Marco Aurélio, valeu-se de dispositivo regimental que o autorizava a apreciar monocraticamente a questão e deferiu a liminar, afirmando a competência meramente subsidiária do Conselho ${ }^{51}$. A decisão gerou, então, uma verdadeira comoção $^{52}$. A reação foi imediata: manifestações contrárias à decisão foram publicadas e atos de apoio ao CNJ foram organizados por entes da sociedade civil ${ }^{53}$. Veja-se como foi noticiada a reação da Ordem dos Advogados do Brasil $(\mathrm{OAB})$ à decisão:

Em seu discurso, Ophir [Presidente da OAB] afirmou ainda que não é só a questão da competência do CNJ que está em jogo. "É a visão conservadora de um lado, arraigada na ideia de tribunais soberanos, de juízes soberanos, inalcançáveis, incensuráveis, inquestionáveis e impermeáveis, refratários inclusive ao calor humano do mundo que os cercam", salientou. Ele observou que a Resolução 135 do CNJ, contestada na Adin da AMB, uniformizando as normas relativas ao procedimento administrativo disciplinar, "teve a grandeza de evitar a degeneração dos processos nas mãos dos próprios juízes, o que na prática vinha acontecendo, de tal forma isolando o Judiciário da sociedade, como demonstram os resultados das inspeções realizadas nos tribunais pela Corregedoria Nacional do CNJ. ${ }^{54}$

Quando o Supremo Tribunal Federal retomou seu funcionamento, no início do ano de 2012, a cautelar foi levada à apreciação do plenário e, por uma decisão apertadíssima, de 6 a 5, acabou não confirmada, preva-

50 O processo constou da pauta dos dias 14, 21 e 28 de setembro, $5,13,19$ e 26 de outubro, $3,16,23$ e 30 de novembro, 7 e 14 de dezembro.

51 RISTF, art. 21: "São atribuições do relator: “[...]; IV - submeter ao Plenário ou à Turma, nos processos da competência respectiva, medidas cautelares necessárias à proteção de direito suscetível de grave dano de incerta reparação, ou ainda destinadas a garantir a eficácia da ulterior decisão da causa; V - determinar, em caso de urgência, as medidas do inciso anterior, ad referendum do Plenário ou da Turma".

52 RECONDO, Felipe. Liminar do STF esvazia poder do CNJ para investigar juízes. O Estado de São Paulo, São Paulo, 20 dez. 2011. 53 CONSELHO FEDERAL DA OAB. Ophir defende competência do CNJ para preservar moralidade e evitar impunidade. 31 jan. 2012. Disponível em: <http://www.oab.org.br/noticia/23385/ophirdefende-competencia-do-cnj-para-preservar-moralidade-e-evitarimpunidade $>$. Acesso em: 16 jun. 2013.

54 CONSELHO FEDERAL DA OAB. Ophir defende competência do CNJ para preservar moralidade e evitar impunidade. 31 jan. 2012. Disponível em: <http://www.oab.org.br/noticia/23385/ophirdefende-competencia-do-cnj-para-preservar-moralidade-e-evitarimpunidade>. Acesso em: 16 jun. 2013. 
lecendo, por consequência, a competência concorrente do CNJ para processar e julgar disciplinarmente os magistrados.

Meses mais tarde, quando o Ministro Cezar Peluso se desligou da Presidência da Corte, em virtude de sua aposentadoria compulsória, o próprio reconheceria, em entrevista, que, no julgamento sobre a competência concorrente do CNJ, a Corte sofrera uma pressão fortíssima da opinião pública, que esta influenciara no desfecho da ação e que, em outras circunstâncias, é possivel que a questão tivesse sido decidida de modo divers $0^{55}$. Manifestou-se, ainda, preocupado com uma tendência que via no Tribunal de buscar se alinhar com a opinião popular, quando o papel de uma corte constitucional, do ponto de vista ortodoxo, seria decidir contra a maioria, se isso fosse necessário para preservar direitos constitucionais ${ }^{56}$. Vale a pena a leitura do trecho da entrevista transcrito abaixo:

\section{VALOR: O debate sobre os poderes do $\mathrm{CNJ}$ não foi uma crise no Judiciário?}

PELUSO: Eu acho que tivemos uma má coincidência. Decidir sobre aquela questão num momento de efervescência em relação à discussão sobre os limites das competências constitucionais do CNJ. Se isso tivesse sido decidido num outro clima o resultado poderia ter sido diverso. Houve certa pressão...

VALOR: Um clima de que ninguém investiga juízes no Brasil?

PELUSO: Isso. De intimidação contra os ministros do STF que estavam aparecendo na opinião pública como se fossem corporativistas, o que está longe de corresponder à verdade. Se essa decisão tivesse sido tomada num outro clima o resultado seria diferente. ${ }^{57}$

Os casos antes narrados demonstram que, por um lado, o Legislativo, muito embora composto por representantes eleitos pelo voto popular, nem sempre deci-

55 BASILE, Juliano. Peluso propõe esforço concentrado para julgar mensalão neste ano. Valor. São Paulo, p. A16, 19 abr. 2012, Política. Disponível em: <http://www2.senado.leg.br/bdsf/handle/id/470853>. Acesso em: 16 jun. 2013.

56 SOUZA, André de; BRÍGIDO, Carolina. Ministro Cezar Peluso ataca, alvos não revidam críticas. O Globo, Rio de Janeiro, 19 abr. 2012, p. 15. Disponível em: <http://oglobo.globo.com/brasil/ministro-cezar-peluso-ataca-mas-alvos-nao-revidam-criticas-4683776>. Acesso em: 16 jun. 2013. Segundo a reportagem, o ministro Peluso teria declarado textualmente: "Há uma tendência dentro da Corte em se alinhar com a opinião pública".

57 BASILE, Juliano. Peluso propõe esforço concentrado para julgar mensalão neste ano. Valor, São Paulo, 19 abr. 2012, p. A16. Política. Disponível em: <http://www2.senado.leg.br/bdsf/handle/id/470853>. Acesso em: 16 jun. 2013. de de forma convergente com o que pensa a maioria da população. Por outro lado, indicam também que o Supremo Tribunal Federal não é livre para decidir de forma contrária ao pensamento dominante na comunidade, a despeito de se compor por juízes vitalícios, cuja permanência no cargo independe da aquiescência de quaisquer dos poderes ou da opinião pública. Algumas das razões pelas quais o legislador pode se afastar da vontade popular já foram enfrentadas acima. É válido perquirir, igualmente, por que uma corte constitucional pode se sentir compelida a observá-la.

\section{RAZÕES DA CONVERGÊNCIA ENTRE AS CORTES CONSTITUCIONAIS E A OPINIÃO PÚBLICA: REFLEXÕES A PARTIR DA LITERATURA ESTRANGEIRA}

Uma consulta à literatura estrangeira permite a identificação de múltiplas causas explicativas da influência da opinião pública sobre as decisões das cortes constitucionais e/ou sobre os votos dos seus membros ${ }^{58}$. Afirma-se, primeiramente, que cortes que têm membros selecionados por um processo que épolítico são sensiveis à opinião pública porque o modo de escolha dos juízes favorece a nomeação de profissionais que trafegam na fronteira entre o jurídico e o político e que, por conseguinte, são influenciáveis pela política ${ }^{59}$.

Essa primeira explicação permitiria a formulação da seguinte hipótese: como os ministros do STF são indicados pelo Chefe do Executivo e aprovados pelo Senado, eles refletem, de alguma maneira, a ideologia de quem os selecionou, as tendências dominantes no meio político que os elegeu ou na comunidade de um modo geral, por serem profissionais permeáveis a ela ${ }^{60}$.

58 Obviamente, não se pretende importar conclusões extraídas de sistemas, tradições e culturas distintas. Os estudos estrangeiros são utilizados apenas com finalidade especulativa, tendo em vista que as obras nacionais sobre a matéria são ainda escassas.

59 No modelo norte-americano, que tem um processo de seleção dos justices da Suprema Corte semelhante ao brasileiro (indicação chefe do Executivo e aprovação pelo Senado), essa hipótese foi formulada por: DAHL, Robert A. Decision-making in a democracy: the Supreme Court as a national policy-maker. Journal of Public Law, v. 6, p. 570 e ss, 1957.

60 A tese é contestada com base em dois argumentos. Em primeiro lugar, observa-se que, mesmo que os presidentes procurem nomear juízes que se alinhem com as suas convicções fundamentais, nada garante que tal magistrado não os surpreenderá com decisões que conflitam com tais convicções. Há, ainda, na literatura, estudos que indicam que as cortes constitucionais são sensíveis a alterações ide- 
Se assim não fosse, não transitariam bem nos ambientes responsáveis por sua escolha. Entretanto, como já demonstrado, as tendências dominantes no meio político e na comunidade podem divergir ${ }^{61}$. Além disso, estudos empíricos já demonstraram que o fato de a maioria dos ministros do STF ter sido selecionada por presidentes de um mesmo partido não garante que decidirão de forma alinhada com os interesses deste último ${ }^{62}$.

Uma outra hipótese que poderia ser formulada: o processo seletivo que vigora no Brasil leva à escolha de operadores do Direito não apenas qualificados tecnicamente, mas que igualmente transitam bem entre as altas autoridades que poderiam apoiar uma "candidatura ao STF". Essas autoridades e os ambientes que frequentam são extremamente sensíveis à percepção popular, e aqueles que logram maior êxito neles tendem a refletir esse padrão ${ }^{63}$.

Uma segunda razão identificada na literatura para a convergência entre as decisões judiciais proferidas por cortes constitucionais e o pensamento da maioria da população diz respeito ao fato de que os ministros são cidadãos como quaisquer outros e, por isso, encontram-se expostos aos mesmos movimentos sociais e às mesmas influências ideologicas e políticas que interferem sobre o comportamento do resto da população. Disso decorreria uma inclinação a decidir de acordo com tais influências, sobretudo em temas que atraem a atenção popular, como é o caso do combate à impunidade dos poderosos, ao corporativismo e à perpetuação do status quo ${ }^{64}$.

ológicas na comunidade independentemente de haver mudança em sua composição. O fato de os juízes se alinharem a mudanças na opinião pública, mesmo quando já empossados em cargos vitalícios, alega-se, indicaria a existência de um vínculo direto entre o sentimento popular e as decisões da corte constitucional. V. GILES, Micheal W; BLACKSTONE, Bethany; VINING, Richard L. The Supreme Court in American democracy: unraveling the linkages between public opinion and judicial decision-making. Journal of Politics, v. 70, p. 293-306, 2008; MARSHALL, Thomas R. Public opinion and the Supreme Court. Nova York: State University of New York Press, 2008. p. 116-119.

61 Basta rever os três primeiros casos examinados acima.

62 MELLO, Patrícia Perrone Campos. Nos bastidores do Supremo Tribunal Federal. Rio de Janeiro: Forense, 2015. p. 77-87 e 322-369.

63 BARROSO, Luís Roberto. Constituição, democracia e supremacia judicial: direito e política no Brasil contemporâneo. p. 33. Disponível em:<http://www.luisrobertobarroso.com.br/pt/noticias/constituicao_democracia_e_supremacia_judicial_11032010.pdf>. Acesso em: 2 jul. 2012.

64 LAIN, Corinna Barrett. Upside-down judicial review. Social Science Research Network, [Rochester], 12 Jan. 2012. p. 492013 e ss. Disponível em: <http://ssrn.com/abstract=1984060>. Acesso em: 27 set. 2013; SUNSTEIN, Cass. A constitution of many minds. Nova Jersey: Princeton University Press, 2009. p. 142 e ss.; GILES, Micheal
Essa hipótese, poderia ser polemizada a partir dos casos do CNJ narrados acima. Havia neles um clamor popular por mudança, pela ampliação do controle do Judiciário e pela superação da impunidade de magistrados faltosos. Entretanto, havia outras influências concorrentes, como a apreensão da magistratura de que o Conselho representasse uma forma de limitar a independência do Judiciário e a pressão exercida pela AMB sobre a Corte. Parte dos ministros do STF eram juízes de carreira. É possível que tais ministros não fossem indiferentes à repercussão das suas decisões junto a seus colegas. O quórum de 6 a 5, pelo qual se decidiu manter a competência disciplinar concorrente do CNJ no julgamento cautelar, sugere que a comunidade e a magistratura representavam influências concorrentes e igualmente poderosas sobre a Corte.

Afirma-se, igualmente, que as cortes, ao decidirem, avaliam os impactos que determinado entendimento pode produzir sobre a sua legitimidade e credibilidade perante a comunidade $\mathrm{e}$ evitam se submeter a certos desgastes. Isso ocorreria porque o Judiciário, paradoxalmente, dependeria dos demais poderes e/ou do apoio da própria opinião pública para fazer valer suas decisões e sua independência no longo prazo. É que o Judiciário não é dotado de poder de coerção. Depende do Executivo para fazer cumprir seus julgados. Não dá a palavra final sobre o seu orçamento, sobre a remuneração dos juízes ou dos serventuários da justiça. Depende, neste ponto, do Legislativo. Executivo e Legislativo são poderes reativos à opinião pública. Portanto, há ônus institucionais importantes em contrariá-la também para o STF ${ }^{65}$.

W.; BLACKSTONE, Bethany; VINING, Richard L. The Supreme Court in American democracy: unraveling the linkages between public opinion and judicial decision-making. Journal of Politics, [West Nyack], v. 70, p. 293-306, 2008; BRENNER, Saul; WHITMEYER, Joseph M. Strategy on the United States Supreme Court. Nova York: Cambridge University Press, 2009. p. 134.

65 V. BICKEL, Alexander M. The least dangerous branch. 2. ed. New Haven: Yale University Press, 1986; FRIEDMAN, Barry. The will of the people: how public opinion has influenced the Supreme Court and shaped the meaning of the Constitution. Nova Iorque: Farrar, Strauss and Giroux, 2009. p. 375; PRITCHETT, C. Herman. Congress versus the Supreme Court: 1957-1960. Minneapolis: University of Minnesota, 1961; EGAN, Patrick J.; CITRIN, Jack. Opinion leadership, backlash, and delegitimation: Supreme Court rulings and public opinion. Social Science Research Network, Rochester, ago. 2009. Disponível em: < http:// ssrn.com/abstract=1443631>. Acesso em: 27 set. 2013; BARROSO, Luís Roberto. Constituição, democracia e supremacia judicial: direito e política no Brasil contemporâneo. p. 41-42. Disponível em: < http://www.luisrobertobarroso.com.br/pt/noticias/constituicao_democracia_e_supremacia_judicial_11032010.pdf>. Acesso em: 2 jul. 2012. 
Por consequência, quando uma corte constitucional cogita proferir uma decisão contramajoritária, seus juízes, afirma-se, fazem uma avaliação de custo-benefício sobre as consequências negativas de tal decisão. Ao longo de sua história, uma corte produz decisões majoritárias e contramajoritárias. Através das primeiras, constrói uma imagem positiva perante a população, adquire e acumula capital político. Por meio das últimas, consome este capital. Isso não significa que não deve ou que não pode tomar decisões contramajoritárias. Ao contrário, essa é uma das justificativas para atribuir o controle da constitucionalidade a juízes que não foram eleitos pelo voto popular: a necessidade de preservar alguns direitos contra decisões arbitrárias da maioria. Entretanto, como o capital político da corte é limitado e como seus integrantes sabem disso, tendem a usá-lo com parcimônia; nos casos que consideram verdadeiramente relevantes; e desde que acreditem que o resultado alcançado justifica o desgaste político que se sofrerá ${ }^{66}$.

Além disso, quando eventualmente uma corte constitucional opta por proferir uma decisão que entra em confronto com um pensamento muito consolidado na comunidade, é possível que um "diálogo social" estabelecido a partir da reação desta última a seu julgado faça com que recue e se realinhe ao sentimento popular. Isso ocorre porque nenhum poder, por mais independente que seja, é capaz de decidir sistematicamente em desacordo com a comunidade e, ainda assim, preservar a sua estabilidade institucional. Para não se fragilizar e, portanto, para não abrir mão do valor maior de poder influenciar nos rumos do Direito no longo prazo, até mesmo uma corte constitucional pode precisar ceder à uma vontade popular muito contundente ${ }^{67}$.

Talvez os casos que envolveram o Conselho Nacional de Justiça sejam ilustrativos dessa hipótese. É possível que a constitucionalidade de um órgão de controle do Judiciário composto por representantes de outros poderes e a atribuição de competência concorrente a este órgão para punir magistrados não fossem os entendimentos que a maioria dos membros do STF na ocasião preferia afirmar. Mas não é impensável que tenham concluído que manter uma decisão contra o $\mathrm{CNJ}$ nesses

66 EASTON, David. A re-assessment of the concept of popular support. British Journal of Politics Science, n. 5, p. 435 e ss, 1975,.

67 FRIEDMAN, Barry. The will of the people: how public opinion has influenced the Supreme Court and shaped the meaning of the Constitution. Nova York: Farrar, Strauss and Giroux, 2009. p. 379 e ss.; FRIEDMAN, Barry. The politics of judicial review. Texas Law Review, Austin, v. 84, p. 326, 2005; e FRIEDMAN, Barry. Mediated popular constitutionalism. Michigan Law Review, v. 101, p. 2615 e ss, 2003. casos ensejaria um ônus demasiadamente alto para o Supremo, comprometendo sua credibilidade para decidir outras matérias importantes no futuro.

Por fim, a própria relação que os ministros pessoalmente estabelecem com a opinião pública pode ampliar os efeitos desta sobre os julgamentos do Tribunal. Em um julgamento polarizado, em que metade dos membros tende a votar num sentido e a outra metade, no sentido inverso, se o magistrado que funcionar como o "fiel da balança" (swing justice) for muito sensível à vontade popular, esta acabará por prevalecer.

O juiz, por sua vez, pode ser sensível à opinião pública por múltiplas causas. Pode, pessoalmente, considerá-la um grupo de referência relevante para decidir; pode ter o reconhecimento por parte da população como objeto de desejo ou de vaidade; pode até mesmo nutrir silenciosamente a aspiração a ingressar na política majoritária $^{68}$. Não é incomum a mídia brasileira cogitar da candidatura de magistrados com maior projeção junto ao público para a presidência da República ${ }^{69}$ e aqueles rigorosos em matéria penal gozam de especial popularidade junto à mídia e aos cidadãos ${ }^{70}$.

\section{O STF E A JUSTIÇA ESPETÁCULO}

A última consideração traz, contudo, algumas inquietações. De fato, os cidadãos sabem muito pouco

68 POSNER, Richard. How judges think. Cambridge: Harvard University, 2008; POSNER, Richard. What do judges maximize? The same thing everybody else does. Supreme Court Economic Review, Nova Iorque, v. 3, p. 1, 1993; SCHAUER, Frederick. Incentives, reputation and the inglorious determinants of judicial behavior. Cincinnati Law Review, v. 68, p. 615-636, 2000; BAUM, Lawrence. Judges and their audiences: a perspective on judicial behavior. Nova Jersey: Princeton University, 2008. p. 28; ASHENFELTER, Orley; EISENBERG, Theodore; SCHWAB, Stewart. Politics and the judiciary: the influence of judicial background on case outcomes. Journal of Legal Studies, v. 24, p. 257, 1995; GOFFMAN, Irving. The presentation of self in everyday life. Nova Iorque: Double Day, 1959; WALSH, Katherine Cramer. Talking about politics: informal groups and social identity in American life. Chicago: The University of Chicago Press, 2004. p. 8-91.

69 SOFIA, Julianna. Cármen Lúcia aproxima STF da população e surge como nome para 2018. Folha de São Paulo, nov. 2016; BRUNO, Cássio; AMORIM, Silvia. Barbosa na pesquisa. Presidente do STF diz que está lisonjeado. O Globo, 2 jul. 2013, p. 6.

70 SCHREIBER, Simone. A publicidade opressiva de julgamentos criminais. Rio de Janeiro: Renovar, 2008; DINIZ, Laura; MARQUES, Hugo. O triunfo da justiça. Os ministros do Supremo Tribunal Federal condenam os mensaleiros, denunciam a corrupção e caem nas graças dos brasileiros, carentes de referências éticas. Veja, ano 45, n. 41, p. 71, 10 out. 2012. 
sobre o que efetivamente ocorre ou sobre o que se discute no âmbito de poder público. A maior parte dos fatos e dos debates chegará a seu conhecimento apenas se grupos intermediários entre as autoridades e a população os levarem a público. O principal desses grupos é a imprensa. É através dos jornais, do rádio, da televisão e das redes sociais que a maior parte das pessoas toma conhecimento sobre as principais questões que interessam ao país.

Para que um assunto chegue ao conhecimento da população, é preciso, primeiramente, que um jornalista, um repórter ou alguém com amplo acesso à rede tome conhecimento a seu respeito. Em seguida, é preciso que se considere o assunto ou o fato merecedor de notícia. Um ser humano fará sempre o primeiro filtro a respeito da informação. Aquelas que não considerar relevantes - a maior parte delas - não será sequer levada ao conhecimento geral. Uma vez interessado em determinada questão, o jornalista a reportará segundo as suas próprias percepções. Todo relato é, em alguma medida, uma versão produzida pela subjetividade de quem relata. Todas as pessoas são altamente influenciadas por suas visões de mundo, por suas experiências pretéritas, por seu background, pelos grupos com os quais se identificam, pela fé que professam, pelos valores pelos quais estão dispostas a lutar ${ }^{71}$.

Os jornalistas e os repórteres geralmente têm patrão. Trabalham para jornais, para revistas, para canais de televisão, para pessoas jurídicas com fins lucrativos e se pautam por uma determinada linha editorial.

Os meios de comunicação, por sua vez, vivem de seus anunciantes e daqueles que consomem a sua programação. Quanto mais amplo o conjunto dos seus consumidores, maior a capacidade de vender anúncios e, por consequência, maior a sua prosperidade. Para alcançar mais consumidores, é preciso diversificar os temas, simplificar a linguagem e eleger fatos com potencial de interessar a uma grande massa de pessoas ${ }^{72}$. Histórias que envolvam autoridades, escândalos relacionados a pessoas públicas, crimes, corrupção, aborto, falência da saúde pública, comportamento sexual compõem um cardápio de curiosidades que atraem o interesse do pú-

71 LIPPMANN, Walter. Opinião pública. Petrópolis: Vozes, 2008. p. 271-309.

72 KEHL, Maria Rita. Muito além do espetáculo. In: NOVAES, Adauto (Org.). Muito além do espetáculo. São Paulo: Senac, 2004. p. 234 e ss. blico. Aquele que libera em primeira mão a notícia, frui dos benefícios do "furo de reportagem". Leva os louros, vende os jornais, colhe os anunciantes, conquista os consumidores.

Nessas condições, não se pode perder muito tempo apurando fatos, verificando a credibilidade de fontes, confirmando responsabilidades. É preciso liberar rapidamente a matéria. Uma vez divulgada, os que não foram obtiveram o "furo" estão atrasados. Precisam replicá-lo e, assim, manter seus consumidores informados sobre o que há de mais recente em termos de informação. Não há tempo a perder. É preciso fazê-lo rápidamente porque é assim que a concorrência agirá. $\mathrm{O}$ mesmo cidadão, em poucas horas, provavelmente será exposto à reiteração da mesma notícia por múltiplas mídias. "Quem conta um conto, aumenta um ponto" "73. A replicação da informação gera novos relatos. A repetição dá sensação certeza. E, assim, matérias meramente especulativas tendem a se tornar a única verdade possível ${ }^{74}$.

Para manter leitores, ouvintes e telespectadores interessados, a mídia os trata não apenas como cidadãos em busca de informações neutras, a respeito das questões de Estado relevantes, sobre as quais devem opinar, ou sobre os assuntos importantes apreciados pelo STF. Trata-os como consumidores em busca de entretenimento. É preciso conquistá-los, prendê-los, vinculá-los aos produtos que têm a oferecer. Para fazê-lo, procura-se criar uma identificação entre o cidadão, as matérias trazidas a seu conhecimento e os personagens nelas envolvidos ${ }^{75}$.

Com esse objetivo, os fatos e seus sujeitos são relatados e construídos com o recurso a estereótipos, tal como nas novelas. As notícias bombásticas trazem heróis destemidos, anti-heróis torpes, políticos corruptos, cidadãos simples idôneos, minorias humildes e oprimidas. Como consequência, o público passa a se relacionar com os fatos como os espectadores interagem com as novelas. A depender do rótulo que recebe um determinado personagem, de como seu papel se encaixa no enredo, a grande massa o terá por culpado ou inocente,

\footnotetext{
73 Provérbio popular.

74 MORETZSOHN, Sylvia. Jornalismo em "tempo real". O fetiche da velocidade. Rio de Janeiro: Revan, 2002. p. 70 e ss.

75 LIPPMANN, Walter. Opinião pública. Petrópolis: Vozes, 2008. p. 249 ss; FISS, Owen M. A ironia da liberdade de expressão. Estado, regulação e diversidade na esfera pública. Rio de Janeiro: Renovar, 2005. p. $99-134$.
} 
torcerá por seu fracasso ou por seu sucesso ${ }^{76}$. E se a decisão final não corresponder à expectativa construída pressionará pela correção do roteiro ou se indignará com seu desfecho ${ }^{77}$.

O modo de funcionar dos meios de comunicação de massa gera dois mecanismos que podem interferir gravemente sobre a opinião da população a respeito de determinado tema: o contágio informacional e o contágio reputacional ${ }^{78}$. O contágio informacional é gerado pela intensa reiteração da notícia, tende a gerar uma confirmação da certeza dos fatos mesmo quando ela não é plena e uma amplificação da percepção ao seu respeito. O contágio reputacional é produto da forma como os cidadãos, os estereótipos e os relatos interagem. Quanto mais uma determinada opinião é professada e acolhida pelos meios de comunicação, maior é a tendência a tornar-se amplamente dominante, em especial se for reproduzida por "âncoras", por formadores de opinião ${ }^{79}$. Quando esse tipo de contágio se efetiva, há uma inclinação dos indivíduos a simplesmente reproduzirem a percepção alheia, quer porque têm as mesmas dificuldades de compreensão, porque sua própria capacidade crítica foi afetada, porque não estão dispostos a expor um entendimento que será ferozmente desqualificado ou, ainda, porque temem as sanções sociais dele decorrentes ${ }^{80}$. Uma espécie de efeito manada se produz na população e, nessas circunstâncias, qualquer grupo pode ser levado a posições extremas, equivocadas e reforçadoras de preconceitos $^{81}$.

76 MORETZSOHN, Sylvia. Jornalismo em "tempo real". O fetiche da velocidade. Rio de Janeiro: Revan, 2002. p. 75-77.

77 SCHREIBER, Simone. A publicidade opressiva de julgamentos criminais. Rio de Janeiro: Renovar, 2008. p. 408.

78 SUNSTEIN, Cass R. Deliberative trouble? Why groups go to extremes. Yale Law Journal, v. 110, p. 71-119, out. 2000. p. 101-102; BON, Gustave. Psicologia das multidões. São Paulo: M. Fontes, 2008. p. 116-120. Cf., ainda, sobre o tema: FREUD, Sigmund. Psicologia de grupo e a análise do ego. In: FREUD, Sigmund. Além do princípio de prazer, psicologia de grupo e outros trabalbos (1990-1922). Obras psicológicas completas de Sigmund Freud: Edição Standard Brasileira. Rio de Janeiro: Imago, 1996. p. 81-156.

79 SUNSTEIN, Cass R. Infotopia: how many minds produce knowledge. Nova York: Oxford University, 2006. p. 25-43; SUNSTEIN, Cass R. Deliberative trouble? Why groups go to extremes. Yale Law Journal, v. 110, p. 71-119, out. 2000. p. 71.

80 BIKHCHANDANI, Sushil; HIRSHLEIFER, David; WELCH, Ivo. Learning from the behavior of others: conformity, fads, and informational cascades. Journal of Economic Perspectives, v. 12, n. 3, p. 151, 1998.

81 SUNSTEIN, Cass R. A Constitution of many minds: why the founding document doesn't mean what it meant before. Nova Jersey: Princeton University, 2009. p. 169-170.
Os juízes, como qualquer cidadão, estão sujeitos a tais mecanismos. Como todas as pessoas, buscam o reconhecimento e temem o isolamento. É ínfimo o nível de informação direta de que se dispõe sobre o comportamento de um magistrado, sobre as decisões que profere ou sobre as suas opiniões. Os julgados que ganham visibilidade são levados a público sobretudo pela imprensa. A mídia é um poderoso intermediário entre os juízes de uma corte constitucional e todos os grupos com os quais se importam: os amigos, os colegas de profissão, a comunidade jurídica, os movimentos sociais e, sobretudo, a opinião pública ${ }^{82}$. A percepção geral a seu respeito não emerge necessariamente de forma espontânea. Sujeita-se a um processo de animação social que pode ser edificante ou devastador. Assim como a população em geral, os integrantes de uma corte são expostos e vulneráveis ao contágio informacional e ao contágio reputacional.

O Supremo Tribunal Federal tem julgado casos de grande relevo para o país, a exemplo do impeachment da presidente da República ${ }^{83}$, do afastamento do presidente da Câmara dos Deputados ${ }^{84}$ e da prisão preventiva de Senador da República ${ }^{85}$ acusado de obstar investigação federal sobre corrupção envolvendo a cúpula da política. As causas que examina tratam sobre questões determinantes para o futuro do país; atraem a atenção da mídia e o interesse de seus consumidores; suscitam preconceitos e provocam estereótipos.

Os julgamentos do pleno do STF são televisionados ao vivo. A corte comunica-se institucionalmente com o público pela Rádio Justiça, está presente nas redes sociais, recebe manifestações por meio da central do cidadão, convoca audiências públicas para debater temas de relevo sob a sua apreciação e admite a participação de entidades da sociedade civil nos feitos que aprecia, a fim de ampliar o debate neles travados. As palavras e os atos dos ministros são meticulosamente acompanhados pela mídia. Há enorme interesse a respeito das suas opiniões. Suas ações têm grande visibilidade. Suas declarações e votos geram ondas de comentários nas redes sociais. Seus entendimentos são avaliados pela imprensa e julgados pelo público; a mesma imprensa, os mesmos juízes

82 BAUM, Lawrence. Judges and their audiences. A perspective on judicial behavior. Nova Jersey: Princeton University, 2008. p. 140.

83 ADPF 378 MC, Rel. p/ o acórdão Min. Luís Roberto Barroso, DJe, 8 mar. 2016.

84 AC 4070 Ref., Rel. Min. Teori Zavascki, DJe, 12 maio 2016.

85 AC 4039 Ref., Rel. Min. Teori Zavascki, DJe, 27 nov. 2015. 
e o mesmo público que se sujeitam ao contágio informacional, ao contágio reputacional, ao efeito manada. De fato, o processo decisório e a vida dos ministros do Supremo têm sido tratados como um espetáculo. E a espetacularização da vida pode facilmente torná-la prisioneira da mídia, da opinião popular e do populismo judicial $^{86}$.

\section{Considerações finais}

Esse é o ponto de chegada desse ensaio. É importante, fundamental, em uma democracia, problematizar a legitimidade detida por juízes não eleitos pelo voto popular para proferir decisões que interferem fortemente sobre o processo político e que divergem da vontade da maioria. Essa é a discussão de que se tem ocupado tradicionalmente a academia, no que respeita à interação entre as cortes constitucionais e a opinião pública. Ocorre que talvez tais decisões contramajoritárias não sejam assim tão habituais. A literatura indica alguns fatores que podem ser fortemente indutores de uma convergência entre a opinião da maioria e os julgamentos das cortes constitucionais.

São eles: i) o critério político de seleção dos membros das cortes; ii) a sujeição dos ministros às mesmas influências, valores e tendências ideológicas a que se encontra sujeita a população de um modo geral; iii) a importância de preservar a credibilidade e a legitimidade do tribunal como instituição, tendo em vista que nenhum poder é capaz de se manter sistematicamente em desalinho com a opinião pública sem se colocar em risco; iv) a ocorrência de um diálogo social, por meio do qual decisões judiciais fortemente rejeitadas tendem a ser revistas; v) a preocupação dos ministros de uma suprema corte com a opinião pública como grupo de referência, seu desejo de reconhecimento, suas eventuais aspirações profissionais futuras.

86 MENDES, Conrado Hübner. Desempenho deliberativo de cortes constitucionais e o STF. In: MACEDO JUNIOR, Ronaldo Porto; BARBIERI, Catarina Cortada (Org.). Direito e interpretação. racionalidade e instituições. São Paulo: Saraiva, 2011. p. 353-361; PEREIRA, Jane Reis Gonçalves. O Judiciário e a opinião pública: riscos e dificuldades de decidir sob aplausos e vaias, 30 out. 2012. Disponível em: <http://www.osconstitucionalistas.com.br/o-judiciario-e-a-opiniao-publica-riscos-e-dificuldades-de-decidir-sob-aplausos-e-vaias>. Acesso em: 7 fev. 2014; SILVA, Virgílio Afonso da; MENDES, Conrado Hübner. Entre a transparência e o populismo judicial. Folha de São Paulo, São Paulo, maio, 2009. p. A3.
Ao menos nos casos de grande projeção, que movimentam estereótipos e preconcepções, que inflamam e mobilizam a população, o custo de proferir decisões divergentes da visão dominante na comunidade pode ser altíssimo para uma corte constitucional como instituição e para os seus ministros, profissional e pessoalmente. Há importantes desincentivos a elas que não devem ser desconsiderados.

Diante de tal quadro, é importante que, sem deixarmos de problematizar o aspecto contramajoritário das decisões do STF, passemos a problematizar igualmente suas decisões majoritárias. Não é porque uma decisão é momentaneamente majoritária que está certa. Não é porque é majoritária que é democrática; pode firmar-se em um quadro fático incompleto, pode ser produto de preconceito, pode decorrer do efeito contágio, do efeito manada e, em verdade, ferir os valores fundamentais que se deseja preservar. Convergir ou divergir da opinião pública não pode ser considerado um critério único ou estático de legitimação das decisões políticas ou judiciais.

A opinião pública erra. Os poderes de Estado erram. Seus membros erram. E como todas as instituições são falíveis, porque são construídas à imagem e semelhança de seus autores, não há segurança e nem justiça absolutas. A segurança e a justiça possíveis devem ser depositadas na fragmentação do poder político. $\mathrm{Na}$ divisão do poder entre instituições e entre agentes que funcionem com base em uma lógica distinta, sujeitos a limites e incentivos diversos. É fundamental evitar a preponderância de uma instituição, até mesmo quando ela aparentemente expressa o pensamento da maioria. É importante evitar a desqualificação das demais. É preciso refletir sobre a espetacularização dos julgamentos do Supremo Tribunal Federal.

\section{REFERÊNCIAS}

ASSOCIAÇÃO DOS MAGISTRADOS BRASILEIROS. Juizes Contra a Corrupção. Disponível em: <http:// www.amb.com.br/portal/docs/noticias/estudo_corrupcao.pdf $>$. Acesso em: 18 jun. 2013.

ASHENFELTER, Orley; EISENBERG, Theodore; SCHWAB, Stewart. Politics and the judiciary: the influence of judicial background on case outcomes. Journal of Legal Studies, v. 24, 1995. 
BARROSO, Luís Roberto. Constituição, democracia e supremacia judicial: direito e política no Brasil contemporâneo. p. 33. Disponível em: <http://www. luisrobertobarroso.com.br/pt/noticias/constituicao_ democracia_e_supremacia_judicial_11032010.pdf>. Acesso em: 2 jul. 2012.

BARROSO, Luís Roberto. O controle de constitucionalidade no direito brasileiro. São Paulo: Saraiva, 2004.

BASILE, Juliano. Peluso propõe esforço concentrado para julgar mensalão neste ano. Valor, São Paulo, 19 abr. 2012. Disponível em: <http://www2.senado.leg.br/ bdsf/handle/id/470853>. Acesso em: 16 jun. 2013.

BAUM, Lawrence. Judges and their audiences. A perspective on judicial behavior. Nova Jersey: Princeton University, 2008.

BICKEL, Alexander M. The least dangerous branch. 2. ed. New Haven: Yale University Press, 1986.

BIKHCHANDANI, Sushil; HIRSHLEIFER, David; WELCH, Ivo. Learning from the behavior of others: conformity, fads, and informational cascades. Journal of Economic Perspectives, v. 12, n. 3, 1998.

BON, Gustave. Psicologia das multidões. São Paulo: M. Fontes, 2008.

BRASIL. Câmara dos Deputados. MPV 489/2010. Brasília, 2010. Disponível em: <http://www.camara. gov.br/proposicoesWeb/fichadetramitacao?idProposic ao $=477274>$. Acesso em: 21 mar. 2016.

BRASIL. Constituição (1988). Constituição da República Federativa do Brasil de 1988. Disponível em: <http:// www.planalto.gov.br/ccivil_03/constituicao/constituicaocompilado.htm>. Acesso em: 24 mar. 2016.

BRASIL. Lei ñ 12.688, de 18 de julho de 2012. Disponível em: < http://www.planalto.gov.br/ccivil_03/_ato20112014/2012/lei/112688.htm>.

BRASIL. Lei no 12.745, de 19 de dezembro de 2012. Disponível em: <http://www.planalto.gov.br/ccivil_03/_ ato2011-2014/2012/Lei/L12745.htm>. Acessos em: 24 mar. 2016.

BRENNER, Saul; WHITMEYER, Joseph M. Strategy on the United States Supreme Court. Nova York: Cambridge University Press, 2009.

BRÍGIDO, Carolina. No país da impunidade, STF em crise não consegue decidir sobre punição a juízes. Reação da opinião pública impede tribunal de retirar poderes do CNJ. O Globo, Rio de Janeiro, 29 set. 2011.

BRUNO, Cássio; AMORIM, Silvia. Barbosa na pesquisa. Presidente do STF diz que está lisonjeado. O Globo, 2 jul. 2013.

CONSELHO FEDERAL DA OAB. Ophir defende competência do CNJ para preservar moralidade e evitar impunidade. 31 jan. 2012. Disponível em: <http://www.oab.org.br/ noticia/23385/ophir-defende-competencia-do-cnj-para-preservar-moralidade-e-evitar-impunidade $>$. Acesso em: 16 jun. 2013.

DAHL, Robert A. Decision-making in a democracy: the Supreme Court as a national policy-maker. Journal of $\mathrm{Pu}$ blic Law, v. 6, 1957.

DINIZ, Laura; MARQUES, Hugo. O triunfo da justiça. Os ministros do Supremo Tribunal Federal condenam os mensaleiros, denunciam a corrupção e caem nas graças dos brasileiros, carentes de referências éticas. Veja, ano 45, n. 41, 10 out. 2012.

DWORKIN, Ronald. Freedom's Law: The moral reading of the American constitution. Cambridge: Harvard University Press, 1996.

EASTON, David. A re-assessment of the concept of popular support. British Journal of Politics Science, n. 5, 1975.

EGAN, Patrick J.; CITRIN, Jack. Opinion leadership, backlash, and delegitimation: Supreme Court rulings and public opinion. Social Science Research Network, Rochester, ago. 2009. Disponível em: < http://ssrn.com/ abstract $=1443631>$. Acesso em: 27 set. 2013.

FISS, Owen M. A ironia da liberdade de expressão. Estado, regulação e diversidade na esfera pública. Rio de Janeiro: Renovar, 2005.

FREUD, Sigmund. Psicologia de grupo e a análise do ego. In: FREUD, Sigmund. Além do princípio de prazer, psicologia de grupo e outros trabalhos (1990-1922). Obras psicológicas completas de Sigmund Freud: Edição Standard Brasileira. Rio de Janeiro: Imago, 1996.

FRIEDMAN, Barry. Mediated popular constitutionalism. Michigan Law Review, v. 101, 2003.

FRIEDMAN, Barry. The politics of judicial review. Texas Law Review, Austin, v. 84, 2005.

FRIEDMAN, Barry. The will of the people: how public opinion has influenced the Supreme Court and shaped the meaning of the Constitution. Nova Iorque: Farrar, 
Strauss and Giroux, 2009.

GILES, Micheal W.; BLACKSTONE, Bethany; VINING, Richard L. The Supreme Court in American democracy: unraveling the linkages between public opinion and judicial decision-making. Journal of Politics, [West Nyack], v. 70, p. 293-306, 2008.

GOFFMAN, Irving. The presentation of self in everyday life. Nova Iorque: Double Day, 1959.

GUIMARÃES, José. Parecer apresentado em Plenário pelo Relator Designado para manifestar-se pela Comissão incumbida da apreciação da matéria: Medida Provisória no 527, de 2011. Disponível em: <http://www.camara.gov.br/ proposicoesWeb/prop_mostrarintegra?codteor $=8900$ $21 \&$ filename $=$ Tramitacao $-\mathrm{MPV}+527 / 2011>$. Acesso em: 23 mar. 2016.

KEHL, Maria Rita. Muito além do espetáculo. In: NOVAES, Adauto (Org.). Muito além do espetáculo. São Paulo: Senac, 2004.

LAIN, Corinna Barrett. Upside-down judicial review. Social Science Research Network, [Rochester], Jan. 2012. Disponível em: <http://ssrn.com/abstract $=1984060$. Acesso em: 27 set. 2013.

LIPPMANN, Walter. Opinião pública. Petrópolis: Vozes, 2008.

MARSHALL, Thomas R. Public opinion and the Supreme Court. Nova York: State University of New York Press, 2008.

MEGALE, Bela. Ministro Luís Roberto Barroso quer o fim do foro privilegiado. Folha de São Paulo, 23 maio 2016. Disponível em: <http://www1.folha.uol.com. br/poder/2016/05/1774158-ministro-do-stf-luis-roberto-barroso-quer-fim-do-foro-privilegiado.shtml $>$. Acesso em: 26 nov. 2016.

MELlO, Patrícia Perrone Campos. Nos bastidores do Supremo Tribunal Federal. Rio de Janeiro: Forense, 2015.

MENDES, Conrado Hübner. Desempenho deliberativo de cortes constitucionais e o STF. In: MACEDO JUNIOR, Ronaldo Porto; BARBIERI, Catarina Cortada (Org.). Direito e interpretação. racionalidade e instituições. São Paulo: Saraiva, 2011.

MENDES, Gilmar Ferreira; COELHO, Inocêncio Mártires; BRANCO, Paulo Gustavo Gonet. Curso de direito constitucional. São Paulo: Saraiva, 2010.

MILITÃO, Eduardo. Maioria é contra financiamen- to público de campanha. Uol, Congresso em foco, 26 jun. 2007. Disponível em: <http://congressoemfoco. uol.com.br/noticias/maioria-e-contra-financiamentopublico-de-campanha/>. Acesso em: 5 ago. 2015.

MORETZSOHN, Sylvia. Jornalismo em "tempo real". O fetiche da velocidade. Rio de Janeiro: Revan, 2002.

NICOLAU, Jairo. O sistema eleitoral de listas abertas no Brasil. Dados: Revista de Ciências Sociais, Rio de Janeiro, v. 49, n. 4, p. 689-720, 2006 a.

OPINIÃO CONSULTORIA. A imagem das instituições públicas brasileiras. Brasília, set. 2007. p. 13. Disponível em: <http://www.amb.com.br/docs/pesquisa/imagem_instituicoes.pdf $>$. Acesso em: 18 jun. 2013.

PASSARINHO, Natália. Câmara aprova por na Constituição doação de empresas a partidos. G1. Política. 25 maio 2015. Disponível em: <http://g1.globo.com/ politica/noticia/2015/05/camara-aprova-incluir-naconstituicao-doacao-de-empresas-partidos-politicos. html>. Acesso em: 6 maio 2015.

PEREIRA, Jane Reis Gonçalves. O Judiciário e a opinião pública: riscos e dificuldades de decidir sob aplausos e vaias. 30 out. 2012. Disponível em: <http://www. osconstitucionalistas.com.br/o-judiciario-e-a-opiniaopublica-riscos-e-dificuldades-de-decidir-sob-aplausose-vaias>. Acesso em: 7 fev. 2014.

PEREIRA, Rodolfo Viana; GELAPE, Lucas de Oliveira. $\mathrm{O}$ anacronismo do sistema proporcional de lista aberta no Brasil. Revista de Informação Legislativa, n. 205, p. 261-279, jan./mar. 2015.

POSNER, Richard. How judges think. Cambridge: Harvard University, 2008.

POSNER, Richard. What do judges maximize? The same thing everybody else does. Supreme Court Economic Review, Nova Iorque, v. 3, 1993.

PRITCHETT, C. Herman. Congress versus the Supreme Court: 1957-1960. Minneapolis: University of Minnesota, 1961.

RECONDO, Felipe. Liminar do STF esvazia poder do CNJ para investigar juízes. O Estado de São Paulo, São Paulo, 20 dez. 2011.

SCHAUER, Frederick. Incentives, reputation and the inglorious determinants of judicial behavior. Cincinnati Law Review, v. 68, p. 615-636, 2000.

SCHREIBER, Simone. A publicidade opressiva de julgamen- 
tos criminais. Rio de Janeiro: Renovar, 2008.

SILVA, Virgílio Afonso da; MENDES, Conrado Hübner. Entre a transparência e o populismo judicial. Folha de São Paulo, São Paulo, maio, 2009.

SOFIA, Julianna. Cármen Lúcia aproxima STF da população e surge como nome para 2018. Folha de São Paulo, nov. 2016.

SOUZA, André de; BRÍGIDO, Carolina. Ministro Cezar Peluso ataca, alvos não revidam críticas. O Globo, Rio de Janeiro, 19 abr. 2012, p. 15. Disponível em: $<$ http://oglobo.globo.com/brasil/ministro-cezar-peluso-ataca-mas-alvos-nao-revidam-criticas-4683776>. Acesso em: 16 jun. 2013.

SOUZA, André. Datafolha: Três em cada quatro brasileiros são contra o financiamento de campanha por empresas privadas. O Globo, Rio de Janeiro, 06 jul. 2015.
Disponível em: <http://oglobo.globo.com/brasil/ datafolha-tres-em-cada-quatro-brasileiros-sao-contrafinanciamento-de-campanha-por-empresas-privadas-16672767>. Acesso em 05 ago. 2015.

SUNSTEIN, Cass R. A Constitution of many minds: why the founding document doesn't mean what it meant before. Nova Jersey: Princeton University, 2009.

SUNSTEIN, Cass R. Deliberative trouble? Why groups go to extremes. Yale Law Journal, v. 110, p. 71-119, out. 2000.

SUNSTEIN, Cass R. Infotopia: how many minds produce knowledge. Nova York: Oxford University, 2006.

WALSH, Katherine Cramer. Talking about politics: informal groups and social identity in American life. Chicago: The University of Chicago Press, 2004. 


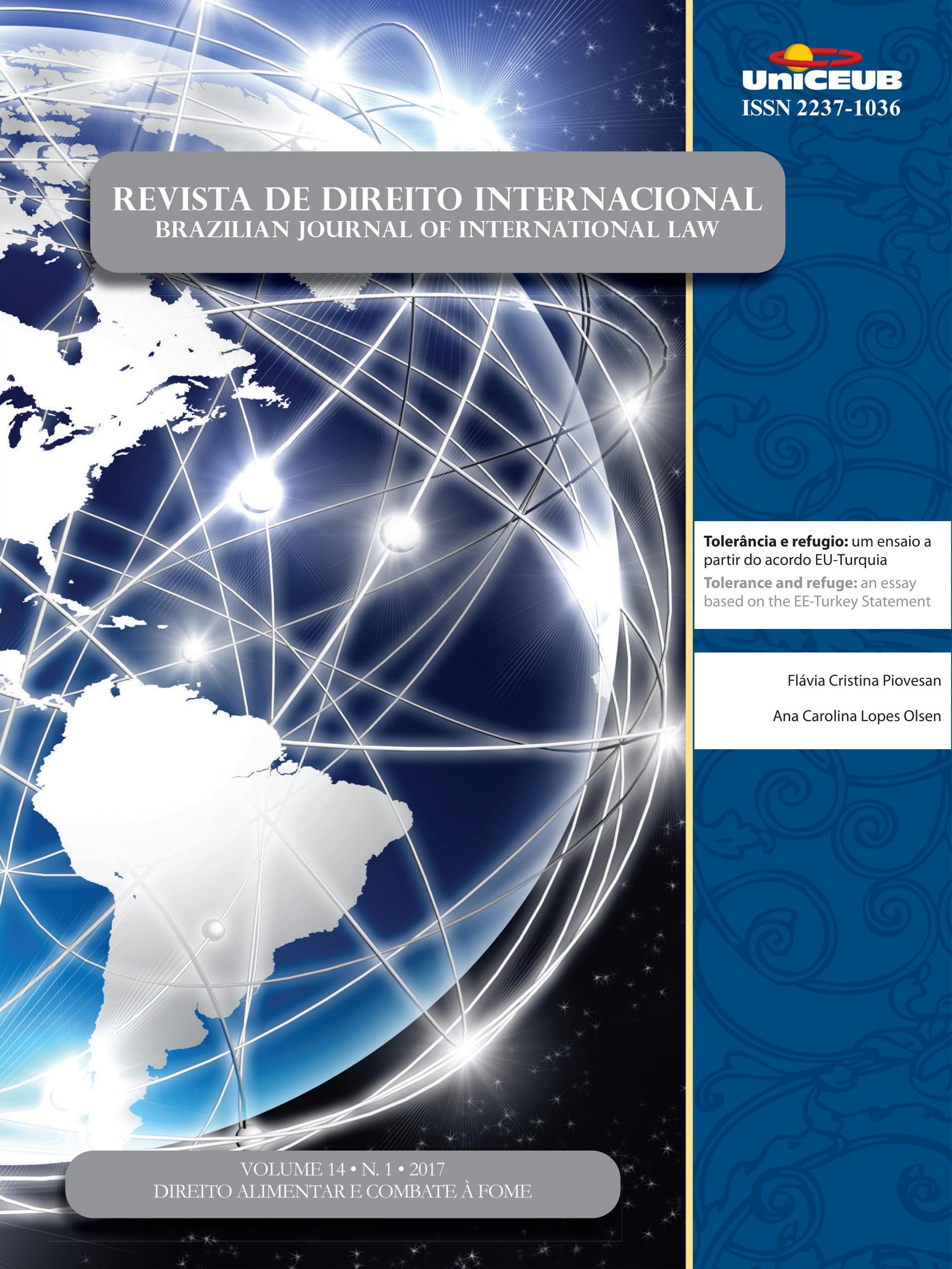




\title{
Tolerância e refugio: um ensaio a partir do acordo EU-Turquia*
}

\section{Tolerance and refuge: an essay based on the EE-Turkey Statement}

\author{
Flávia Cristina Piovesan** \\ Ana Carolina Lopes Olsen***
}

* Recebido em 17/01/2017

Aprovado em 07/05/2017

** Secretária de Direitos Humanos. Professora doutora em Direito Constitucional e Direitos Humanos da Pontifícia Universidade Católica de São Paulo, Professora de Direitos Humanos dos Programas de Pós Graduação da Pontifícia Universidade Católica de São Paulo, da Pontifícia Universidade Católica do Paraná e da Universidade Pablo de Olavide (Sevilha, Espanha); visiting fellow do Human Rights Program da Harvard Law School (1995 e 2000), visiting fellow do Centre for Brazilian Studies da University of Oxford (2005), visiting fellow do Max Planck Institute for Comparative Public Law and International Law (Heidelberg - 2007 e 2008); Humboldt Foundation Georg Forster Research Fellow no Max Planck Institute (Heidelberg, desde 2009); membro do Conselho Nacional de Defesa dos Direitos da Pessoa Humana. É membro da UN High Level Task Force on the implementation of the right to development $\mathrm{e}$ do OAS Working Group para o monitoramento do Protocolo de San Salvador em matéria de direitos econômicos, sociais e culturais. E-mail: flaviapiovesan@terra.com.br

*** Mestre em Direito do Estado pela Universidade Federal do Paraná; doutoranda em Direito pela Pontifícia Universidade Católica do Paraná; professora de Direitos Humanos na Faculdade Cenecista de Joinville. E-mail: anac. olsen@gmail.com

\section{Resumo}

O direito internacional dos refugiados, pós II Guerra Mundial, fundamentou-se na noção de "direito a ter direitos", de uma sociedade aberta para a diversidade e o pluralismo, com base na tolerância e na alteridade. Estas concepções estão em xeque com as recentes práticas adotadas pela União Europeia face aos refugiados, notadamente no Acordo União Europeia-Turquia (2016), que prevê a possibilidade de devolução de refugiados aos seus locais de origem, apesar do princípio do non-refoulement. A partir de pesquisa bibliográfica, e pelo método indutivo, o presente artigo busca compreender as implicações filosóficas e éticas da rejeição manifestada pela Europa ao grande contingente de refugiados de origem muçulmana, cuja cultura contrasta profundamente com os valores nutridos pelos povos europeus, a fim de sugerir uma nova compreensão da própria ideia de tolerância enquanto fundamento do Direito Internacional dos Refugiados, e mesmo dos direitos humanos. Conclui-se nesse ensaio que mecanismos burocráticos e jurídicos têm sido utilizados como máscara para a intolerância da Europa frente aos refugiados. Desse modo, a partir de contribuições teóricas de Rorty, Appiah, Heller e Ferénc, percebeu-se que somente a partir da superação da noção abstrata de tolerância, para uma compreensão cosmopolita que reconhece as pessoas em sua concretude histórica e social, bem como pelo alargamento da ideia de "nós" para enfrentar a dicotomia "nós-eles", que se pode fundamentar o direito de toda pessoa de ser acolhida, quando enfrenta o risco de sua própria aniquilação.

Palavras-chave: Refugiados; Direitos Humanos; Xenofobia; Tolerância; Europa.

\section{Abstract}

The Refugees International Law, created after the II World War, has been founded upon the idea of "a right to have rights", and a society open to diversity and pluralism, based on tolerance and alterity. The recent practices adopted by the European Union challenge these conceptions, notably the EU-Turkey Statement (2016), which prescribes the possibility of returning refugees to their origin or latest place of departure, despite of the "non-refoulement" principle. Using bibliographical research, by the inductive method, this 
article aims to understand the philosophical and ethical implications of the rejection of a great amount of muslin refugees by Europe, since their culture contrasts deeply with the values nourished by European peoples, in order to suggest a new comprehension of the ideal of tolerance as a bedrock to the Refugees International Law, and even to Human Rights Law. It concludes that legal and bureaucratic methods have been used as a mask to hide European intolerance towards refugees. Therefore, based on the contribution of Rorty, Appiah, Heller and Ferénc, it verified that tolerance can only be a keystone to the right to pledge refuge when understood in a cosmopolitan way, in which a person is seen in his historical concrete and social being, as well as the conception of "us" is enlarged, to face the dichotomy of "us-them".

Key-words: Refugees; Human Rights; Xenophobia; Tolerance; Europe.

\section{INTRODUÇão}

A preocupação jurídica com o deslocamento de pessoas forçadas a deixar seus países de origem ganhou corpo ao final da II Guerra Mundial. A Europa havia sido devastada pelos anos de conflito, e milhões de pessoas tinham deixado seus lares, sem poder regressar. Mas dessa vez, não apenas em função do conflito, como a história já havia testemunhado. Muitos europeus, e dentre eles um grande número de judeus, perderam sua nacionalidade, seu lar, em função de políticas estatais. Hitler e Stalin juntos promoveram o deslocamento de aproximadamente trinta milhões de pessoas entre 1939 e $1943 .{ }^{1}$

Havia poucos anos a Europa já havia sofrido com deslocamentos em outro grande conflito, a I Guerra, a qual deixara cem milhões de refugiados, dentre eles apátridas. Viviam à margem da sociedade, sem nenhum governo ou Estado que interviesse em seu favor. Estavam protegidos apenas pelo Tratado das Minorias ${ }^{2}$

\footnotetext{
1 "This was something new in the European experience. All wars dislocate the lives of noncombatants: by destroying their land and their homes, by disrupting communications, by enlisting and killing busbands, fathers, sons. But in World War Two it was state policies rather than armed conflit that did the worst damage". JUDT, Tony. Postwar: A Historty of Europe Since 1945. New York: Penguin Books, 2005, p. 22-23.

2 Segundo Hannah Arendt, "Os Tratados aglutinaram vários povos num só Estado, outorgaram a alguns o status de "povos estatais" e
}

que foi assinado por países europeus imediatamente após a I Guerra Mundial, sem nenhuma intenção real de obediência. Para essas pessoas, a expressão "direitos humanos" prevista no Tratado representava um ato de hipocrisia. ${ }^{3}$

Essa situação denunciou a falha ética de um sistema jurídico que admitia a existência de pessoas desapossadas do conceito de identidade nacional, privando-as de qualquer direito, bem como a total impotência da Liga das Nações em promover uma solução. Um sistema que gerava mais do que a violência, promovia o não reconhecimento do outro, sua estigmatização em uma categoria de indesejáveis. Como coloca Hannah Arendt, eram o "refugo da terra". ${ }^{4}$

Reconhecendo a insustentabilidade desse modelo, os Estados elaboraram um novo paradigma jurídico que deveria guiar os povos estabelecendo um mínimo ético irredutível: o ser humano como sujeito de direitos. Como observa Arendt, como não havia qualquer lugar "incivilizado" na terra, a humanidade precisaria aprender a conviver em um Mundo Único. Esses direitos perdidos, e a dignidade humana que eles outorgam, deveriam prevalecer independentemente de vinculação jurídica do sujeito a uma comunidade. ${ }^{5}$

lhes confiaram o governo, supuseram silenciosamente que os outros povos nacionalmente compactos [...] chegassem a ser parceiros no governo, o que naturalmente não aconteceu, e, com igual arbitrariedade, criaram com os povos que sobraram um terceiro grupo de nacionalidades chamadas minorias, acrescentando assim aos muitos encargos dos novos Estados o problema de observar regulamentos especiais, impostos de fora, para uma parte de sua população. Como resultado, os povos não agraciados com Estados, fossem "minorias nacionais" ou "nacionalidades", consideraram os Tratados um jogo arbitrário que dava poder a uns, colocando em servidão os outros. Os Estados recém-criados, por sua vez, que haviam recebido a independência com a promessa de plena soberania nacional, acatada em igualdade de condições com as nações ocidentais, olhavam os Tratados das Minorias como óbvia quebra de promessa e, como prova de discriminação, uma vez que somente os novos Estados, e nem mesmo a Alemanha derrotada [com exceção do território da Silésia oriental, dividida em 1920 com a Polônia em decorrência de plebiscito], ficavam subordinados a eles. ARENDT, Hannah. As origens do totalitarismo. Trad. Roberto Raposo. São Paulo: 2012, p. 302-303.

3 Afinal, os direitos criados pela revolução francesa haviam sido atrelados à condição da soberania nacional dos Estados, e o Tratado das Minorias instituído pela Liga das Nações não inspirava confiança porque era a própria Liga formada por Estados soberanos, não dispostos a abrir mão de sua soberania. ARENDT, H. As origens do totalitarismo. Trad. Roberto Raposo. São Paulo: 2012, p. $302-$ 303; 305.

4 ARENDT, H. As origens do totalitarismo. Trad. Roberto Raposo. São Paulo: 2012, p. 300.

5 ARENDT, H. As origens do totalitarismo. Trad. Roberto Raposo. São Paulo: 2012, p. 331. 
Diante dessa perspectiva, erigiu-se o Direito Internacional dos Refugiados, que procura reconhecer as necessidades prementes daqueles que se veem obrigados a deixar seu país com medo da morte, da tortura, da prisão. De matriz europeia, ele reconhece a todos que se encontram nessas condições o direito de solicitar asilo.

Todavia, em um mundo já pequeno em que todos precisam conviver, os grandes contingentes de refugiados sírios que batem à portas da Europa especialmente nos últimos anos, fugindo da Guerra Civil na qual mergulhou seu país desde 2011, colocou os próprios fundamentos básicos dos Direitos dos Refugiados em cheque, como a tolerância. No lugar de respeito e acolhimento, refugiados sírios passam a ser devolvidos à Turquia em função de um Acordo por ela firmado com a União Europeia em março de 2016.

Mediante pesquisa bibliográfica e pelo método indutivo, o presente artigo procura, numa primeira parte, investigar a tolerância como fundamento básico do Direito dos Refugiados, e dos direitos humanos, em sua matriz original universal. Num segundo ponto, analisa especificamente o Acordo UE-Turquia em suas principais determinações, e suas implicações para os refugiados sírios que chegam ao território europeu. Em uma terceira parte, procura-se demonstrar que o Acordo é uma evidência da intolerância com a qual a Europa tem tratado o problema dos refugiados, agindo com base no preconceito, no racismo e na xenofobia. Finalmente, na quarta e última parte, procura-se oferecer propostas de remodelação da própria noção de tolerância, a partir das lições do cosmopolitismo, e de visões teóricas que procuram enxergar, em cada ser humano, uma pessoa histórica e concreta.

\section{TOLERÂNCIA COMO FUNDAMENTO DO DIREITO INTERNACIONAL DOS REFUGIADOS}

Passados apenas três anos da criação da Organização das Nações Unidas, foi promulgada a Declaração Universal dos Direitos Humanos, instituindo uma nova era para o Direito Internacional. Com pretensão de aplicabilidade a toda a espécie humana, independentemente de vínculo jurídico qualquer que fosse, a Declaração Universal instituía que todos deveriam ser considerados iguais em dignidade e direitos, inaugurando a concepção contemporânea dos direitos humanos, cuja tônica é a recuperação do ser humano como valor fonte dos sistemas jurídicos, a ser valorizado em si a partir da concepção kantiana de que cada um é um fim em si mesmo, e a possibilidade de flexibilização da soberania dos Estados a fim de proteger os direitos da pessoa humana. ${ }^{6}$

Em seu artigo XIV, a Declaração Universal reconheceu o direito de pedir asilo a todos aqueles que fossem vítimas de perseguição. Essa foi a premissa jurídica para a elaboração, e promulgação em 1951, da Convenção de Genebra sobre o Estatuto dos Refugiados, seguida do Protocolo de 1967. A ideia central era de que qualquer pessoa que fosse vítima de perseguição em seu Estado teria direito de buscar asilo e dele usufruir em qualquer país. ${ }^{7}$

O conceito inaugural de refugiado, da Convenção de 1951, se aplicaria a todo aquele que abandonara seu país em virtude de perseguição por suas convicções políticas ou religiosas, ou por motivo de raça, cor ou nacionalidade, em razão dos acontecimentos anteriores a $1^{\circ}$ de janeiro de 1951, na Europa. A evidente preocupação com as consequências da II Guerra mostrou-se incompatível com os acontecimentos que lhe sucederam, gerando novas massas de refugiados carentes de proteção jurídica independentemente de uma limitação temporal ou geográfica. Assim, o conceito de refugiado foi alargado pelo Protocolo de 1967 a fim de abarcar todas as pessoas que se enquadrem na situação de perseguição em função de sua raça, credo, nacionalidade ou posição política, seja porque a perseguição é promovida pelo Estado da qual é nacional, seja porque este não consegue protege-la de quem a persegue. ${ }^{8}$ Este conceito abarca também pessoas que fogem de guerras, e de maciças violações de direitos humanos, e de catástrofes naturais que inviabilizaram a vida em seus países de origem. ${ }^{?}$

6 PIOVESAN, Flávia. Direitos Humanos e Justiça Internacional. 6 ed. São Paulo: Saraiva, 2015, p. 45-47.

7 PITA, Agni Castro. Direitos Humanos e Direito Internacional dos Refugiados. In GEDIEL, José Antônio Peres; GODOY, Gabriel Gualano de. (Org.) Refúgio e Hospitalidade. Curitiba: Kairós, 2016, p.7.

8 BARBOZA, Estefânia Maria de Queiroz; BACK, Alessandra. A proteção normativa dos refugiados políticos na América Latina e no Brasil. In GEDIEL, José Antônio Peres; GODOY, Gabriel Gualano de. (Org.) Refúgio e Hospitalidade. Curitiba: Kairós, 2016, p.92.

9 Trata-se do objeto da declaração do Secretário do Alto Comissariado das Nações Unidas para Refugiados, Aga Khan, em 1976. CAVARZERE, Thelma Thais. Direito Internacional da Pessoa Humana: A circulação internacional de pessoas. Rio de Janeiro: Renovar, 1995, p. 93. Nas Américas, a Declaração de Cartagena ampliou a noção de refugiado para também proteger as vítimas de conflitos na Nicarágua, Guatemala e El Salvador, de modo que refu- 
Esse Direito Internacional dos Refugiados, inaugurado com a Convenção de 1951, deve ser interpretado em consonância com o Direito Internacional dos Direitos Humanos, como ensina Cançado Trindade, pois ambos encontram fundamento nos mesmos pressupostos: toda pessoa é sujeito de direitos, em regime de igualdade para todo ser humano. Assim, um pretendente ao asilo é, antes de tudo, um titular de direitos humanos. $\mathrm{Na}$ medida em que o motivo que leva milhares de pessoas a abandonar seus países de origem é a violação dos direitos humanos, é preciso reconhecer que a proteção da pessoa humana se deve mesmo antes de consagrada a condição de refugiado. ${ }^{10} \mathrm{E}$ o reconhecimento dessa condição é verdadeiro direito dessa pessoa, e não mera discricionariedade do Estado. ${ }^{11}$

Uma questão que se pode colocar em busca de uma fundamentação ética para o direito ao refúgio ${ }^{12}$ poderia ser a seguinte: por que acolher? Se a resposta passa necessariamente pelo reconhecimento de que todas as

giados seriam "as pessoas que tenham fugido dos seus países porque a sua vida, segurança ou liberdade tenham sido ameaçadas pela violência generalizada, a agressão estrangeira, os conflitos internos, a violação maciça dos direitos humanos ou outras circunstâncias que tenham perturbado gravemente a ordem pública”. PAMPLONA, Danielle Anne. PIOVESAN, Flávia. O instituto do refúgio no Brasil: práticas recentes. In Revista de Direitos Fundamentais e Democracia, v. 17, n. 17, Curitiba: janeiro/junho de 2015, p. 46.

10 CANÇADO TRINDADE, Antônio Augusto. Tratado de Direito Internacional dos Direitos Humanos. Vol. I. Porto Alegre: Sérgio Antônio Fabris, 1997, p. 270-272.

11 Nesse sentido, o campo do dever ser determina a redução do domínio da discricionariedade do Estado, a fim de que direitos universalmente assegurados sejam efetivamente implementados. Vale dizer, ao direito de solicitar refúgio e dele gozar, enunciado em documentos internacionais como a Declaração Universal, há de corresponder o dever do Estado de conceder refúgio. PIOVESAN, Flávia. Refugiados sob a Perspectiva dos Direitos Humanos. In: Seminário Internacional "Fronteiras em Movimento: Deslocamentos e outras Dimensões do Vivido", Diversitas - Núcleo de Estudos das Diversidades, Intolerâncias e Conflitos, Universidade de São Paulo, São Paulo: 2013.

12 Liliana Jubilut formulou distinção que ora se adota de direito a refúgio e direito a asilo. $\mathrm{O}$ asilo corresponde ao "instituto pelo qual um Estado fornece imunidade a um indivíduo em face de perseguição sofrida por esse em outro”, garantindo ao Estado poder discricionário para decidir se concede proteção a determinado indivíduo. É precisamente o caráter de perseguição política (de crença, ideologia) que fundamenta essa decisão, ou seja, trata-se de "asilo político". O refúgio é um direito do indivíduo ou grupo, e um dever do Estado, assumido soberanamente ao ratificar a Convenção para o Estatuto dos Refugiados de 1951, e seu Protocolo de 1967, estando, portanto, fora do âmbito de discricionariedade que se reconhece ao Estado quando diante de pedido de asilo. JUBILUT, Liliana. O Direito internacional dos refugiados e sua aplicação no orçamento jurídico brasileiro. São Paulo: Método, 2007, p. 37-38; 42-44. pessoas são sujeito de direito, não podendo ser abandonadas quando buscam abrigo, sendo vítimas da injustiça e da perseguição, é porque se exige daqueles destinatários da obrigação de conceder o asilo ${ }^{13}$ uma tolerância ampla para com todas essas pessoas, mais ou menos diferentes deles próprios.

A tolerância como um fundamento ético para os direitos humanos dos refugiados, tal como concebidos na Convenção de 1951, e no Protocolo de 1967, tem inicialmente uma conotação universal pois dirigida a todas as pessoas, independentemente de sua origem, sua raça, sua cultura ${ }^{14}$. Como se pretende demonstrar, a tolerância de caráter universal e abstrato não tem dado conta do enfrentamento de culturas decorrente do grande afluxo de refugiados islâmicos para países ocidentais. Ela nasce com o propósito de ser cega em relação às diferenças, no lugar de procurar apontar caminhos para conviver com elas.

Para Norberto Bobbio, a tolerância diz respeito ao reconhecimento dirigido a todos que defendam ideias opostas do seu direito de existir, conviver, manifestar-se. Ela exige o método da persuasão para que os outros conheçam e eventualmente partilhem do que nós pensamos, o que jamais pode ser feito através da imposição. ${ }^{15}$ Significa dizer que dentro da lógica nacionais-estrangeiros ${ }^{16}$ personificando a dicotomia entre o 'nós'

13 Marcos Wachowicz defende que o direito ao asilo, em virtude de sua íntima conexão com os direitos humanos, não pode ser compreendido como uma mera faculdade do Estado concedente, mas como verdadeiro direito humano. Apoia-se, para tanto, na Declaração Hispano-Luso-Americana de 1951, que institui que "o Direito de Asilo é um direito inerente à pessoa humana, devendo conceder-lhe o Estado solicitado, em virtude da sociabilidade universal de todos os povos". WACHOWICZ, Marcos. O direito de asilo como expressão dos direitos humanos. In Revista da Faculdade de Direito da Universidade Federal do Paraná. Curitiba: UFPR, 2002. Disponível em: www.revistas.ufpr.br/direito/article/ download/1776/1473. Acesso em 07 ago. 2016, p. 153.

14 A concepção universal dos direitos humanos, nascida com a Declaração Universal dos Direitos Humanos, tem como fundamento a dignidade da pessoa, um valor intrínseco e inerente a todo ser humano. Para universalistas, existiria um "mínimo ético irredutível" abaixo do qual não se poderia defender nenhuma prática, pois ela representaria violação dos direitos humanos. Esse universalismo admite diversos graus, dependendo da abrangência do que se possa compreender por "mínimo ético irredutível". PIOVESAN, Flávia. Direitos Humanos e o Direito Constitucional Internacional. 13 ed. São Paulo: Saraiva, 2012, p. 215, 218.

15 BOBBIO, Norberto. Elogio da serenidade e outros escritos morais. Trad. Marco Aurélio Nogueira. São Paulo: UNESP, 2002, p. 153-154.

16 "Toda a lógica do Estado-nação moderno foi erigida a partir da construção da figura do estrangeiro, como o referencial negativo 
e os 'outros', a tolerância implicará que o nós respeite as ideias opostas dos outros, e todo e qualquer diálogo entre essas ideias deve fazer uso da ferramenta da persuasão, jamais da imposição. Dessa forma, ser tolerante, no contexto entre nacionais e estrangeiros refugiados, significa vencer o preconceito $^{17}$ que eventualmente se tenha, para ver nos outros, sujeitos de direitos assim como nós, bem como reconhecer como válido seu direito de pensar e agir diferente.

Essa noção ideal de tolerância sofre diferentes nuances a partir do espaço político em que se manifesta. Michael Walzer, em sua obra "Da Tolerância", verificou um comportamento diferente dos grupos sociais em relação a tolerância, como sociedades internacionais, Estados-nação ou sociedades de imigrantes ${ }^{18}$.

Nas sociedades internacionais, há um regime diferenciado de estruturação social, bastante fraco politicamente e extremamente tolerante, pois todas as práticas adotadas pelos Estados soberanos que as integram são formalmente toleradas. Os Estados negociam entre si através de seus agentes diplomáticos em virtude de interesses econômicos ou até políticos comuns, e convivem com a existência de práticas internas profundamente divergentes entre si, por vezes até internamente intolerantes e violentas. Só não serão tolerados atos ou práticas que "chocam a consciência da humanidade", já que a auto-determinação dos povos não poderia ser um escudo para a selvageria. De qualquer forma, os meca-

para a definição do nacional." Indo mais além, a dicotomia entre nós-eles, nacionais-estrangeiros, tem assumido uma feição ainda mais abissal: nós-resto. "No mesmo diapasão, Huntington elabora a categoria do "resto", como contraponto ao Ocidente. O "resto", diferente do "outro", não tem um conjunto de características independentes e consistentes de uma tribo, nação ou religião. Ele é um "aglomerado de distintas comunidades, nações e civilizações, com conjuntos diferenciados de características" (DAVUTOGLU, 2004, p. 110), mas que ficam rotuladas em sua despersonificação." OLSEN, Ana Carolina Lopes. Imigração e reconhecimento de direitos: o desafio do Brasil na era da (in)tolerância. Revista de Direito Econômico e Socioambiental, Curitiba, v. 6, n. 2, p. 122-155, jul./ dez. 2015. doi: http://www2.pucpr.br/reol/pb/index.php/direitoe conomico?dd1 $=15934 \& d d 99=$ view $\& d d 98=\mathrm{pb}$. Acesso em 22 jul. 2016, p. 125; 128.

17 Segundo Bobbio, o preconceito nada mais é que uma opinião ou doutrina que é aceita de forma irrefletida e acrítica, sendo transmitida pela tradição, pelo costume ou pela autoridade legitimamente reconhecida, de modo que não se erige contra ela nenhuma posição racional. BOBBIO, Norberto. Elogio da serenidade e outros escritos morais. Trad. Marco Aurélio Nogueira. São Paulo: UNESP, 2002, p. 103.

18 WALZER, Michael. Da Tolerância. Trad. Almiro Pisetta. São Paulo: Martins Fontes, 1999, p. 22-49. nismos de repressão são fracos, já que não há uma autoridade institucionalizada para determinar condutas. ${ }^{19}$

Já nas consociações, que correspondem a Estados bi ou tri-nacionais, as comunidades diferentes através de seus líderes, e elites cooperam entre si na construção de uma estrutura jurídica que proteja seus interesses divergentes. Esses grupos sociais essencialmente diversos se unem sob um mesmo arranjo constitucional em virtude de há tempos partilharem o mesmo território, e embora pensem diferentemente, pretendem se proteger contra inimigos comuns. Mas precisam, também, tolerar-se uns aos outros, de modo que aqui a tolerância surge como uma confiança partilhada entre os membros. ${ }^{20}$

Os Estados-nação, por sua vez, tem um regime bem mais restrito de tolerância: a partir da instituição de uma só nacionalidade, uma língua, um conjunto historicamente elaborado de valores, práticas divergentes só serão toleradas de forma individual - como se dirige uma tolerância liberal às idiossincrasias alheias. ${ }^{21}$ Pouco tolerantes com os grupos, os Estados-nação podem certamente exigir que os grupos sejam tolerantes com os indivíduos, já que todos são cidadãos com os mesmos direitos. Assim, as práticas dos grupos precisam ser aprovadas pelo escrutínio das maiorias. Consequentemente, os grupos passam a se tornar associações voluntárias, com baixo poder coercitivo em razão da proteção que o Estado-nação exerce sobre os indivíduos. ${ }^{22}$

Finalmente, as organizações políticas mais tolerantes são as sociedades de imigração, pois acolhem grupos diversos que abandonaram sua terra natal para chegar a um novo território, no qual se dispersaram. Para Walzer, o Estado adota uma posição neutra em relação às

19 WALZER, Michael. Da Tolerância. Trad. Almiro Pisetta. São Paulo: Martins Fontes, 1999, p. 28-30.

20 WALZER, Michael. Da Tolerância. Trad. Almiro Pisetta. São Paulo: Martins Fontes, 1999, p. 32.

21 Como defende Stuart Mill, em On Liberty, a tolerância é a disposição em aceitar e respeitar a inviolabilidade da vida privada das pessoas, de modo que o homem deve ter liberdade total para se definir individualmente, podendo contudo ser responsabilizado pelos seus atos na medida em que eles entrem na esfera pública. Cabe ao Estado garantir o espaço sócio-político para que todos desenvolvam suas personalidades e individualidades, promovendo um ambiente urbano diversificado em que cada um possa buscar sua felicidade. WOLFF, Robert Paul. Além da Tolerância. In WOLFF, Robert Paul; MOORE JR., Barrington; MARCUSE, Herbert. Crítica da Tolerância Pura. Trad. Ruy Jungmann. Rio de Janeiro: Zahar, 1970, p. 31-34.

22 WALZER, Michael. Da Tolerância. Trad. Almiro Pisetta. São Paulo: Martins Fontes, 1999, p. 37-38. 
práticas desses grupos, pois se preocupa basicamente com a titularidade da jurisdição única. As pessoas são absolutamente livres para escolher a que grupos pertencer, que práticas adotar, desde que estas práticas não afrontem direitos de outros cidadãos. Significa dizer que a tolerância para com a pluralidade de ideias, convicções políticas e religiosas, é incentivada como uma prática de Estado, como um dever de cada cidadão. ${ }^{23}$

Os grupos, por sua vez, têm muito limitado seu acesso ao poder do Estado. Só podem ascender através dos canais institucionais definidos juridicamente, os quais definem critérios, limites e condições para efetivamente ascender à esfera pública. Muitos grupos com ideias dissonantes ficam à margem do processo político, como observa Wolff. ${ }^{24}$ Não se sabe se sobreviverão dessa forma, ou se vão se diluir em um todo, mas o respeito que esses grupos encontram nas sociedades de imigrantes é o máximo regime de tolerância.

No panorama mundial atual, quando os países europeus se deparam com a chegada de milhões de refugiados como somalis, iraquianos, afegãos e especialmente sírios, seus níveis de tolerância são colocados à prova. Como será analisado adiante, fatos veiculados pela imprensa $^{25}$ dão indícios de que a tolerância e a solidarieda$\mathrm{de}^{26}$, essenciais para o direito de refúgio, tem dado lugar

23 Mas os grupos não podem se organizar de forma coercitiva, assumir o controle do espaço público e monopolizar recursos públicos. WALZER, Michael. Da Tolerância. Trad. Almiro Pisetta. São Paulo: Martins Fontes, 1999 p. 43.

24 Em análise da democracia pluralista norte-americana, que pode ser reconhecida como uma sociedade de imigração, verifica Wolff que somente os grupos sociais já estruturados conseguem, em competição pelo poder político, ter seus interesses satisfeitos. Dessa forma, certos grupos não conseguem ascender politicamente e suas vozes não são ouvidas, por mais razoáveis e certas que sejam. WOLFF, Robert Paul. Robert Paul. Além da Tolerância. In WOLFF, Robert Paul; MOORE JR., Barrington; MARCUSE, Herbert. Crítica da Tolerância Pura. Trad. Ruy Jungmann. Rio de Janeiro: Zahar, 1970, p. 47-48. No mesmo sentido, WALZER, Michael. Da Tolerância. Trad. Almiro Pisetta. São Paulo: Martins Fontes, 1999, p. 46-47.

25 "As cercas no leste da Europa, os muros entre os Estados Unidos e o México, as políticas de contenção nos países de origem, em sua maioria da África subsaariana (...), as devoluções da Grécia e, até mesmo, o fechamento temporário de várias fronteiras interiores na União Europeia não conseguiram frear os fluxos migratórios das 65,3 milhões de pessoas que se sentem perseguidas em seus países e cujas vidas correm perigo..." CEBRIÁN, Belén Domínguez. Guerra e perseguição tiram de suas casas 24 pessoas por minuto em todo o mundo. In: El País, Madri, 20 jun. 2016. Disponível em: http://brasil.elpais.com/brasil/2016/06/18/internacional/1466273687_619217.html . Acesso em 09 ago. 2016.

26 Segundo o secretário-geral da Nações Unidas, Ban Ki Moon: ao racismo e à discriminação.

\section{O tRATAMENTO DISPENSADO AOS REFugiados NO ACORDO UNIÃO EUROPÉIA-TURQUIA}

A fim de conter o significativo afluxo de refugiados que chegam às portas da Europa, a União Europeia celebrou com a Turquia um acordo em 18 de março de 2016. ${ }^{27}$ A Turquia foi alçada ao papel de parceira da União Europeia para o assunto de migrantes e refugiados em virtude de sua posição geográfica estratégica como porta de entrada de milhões de sírios que deixam seu país fugindo da Guerra Civil e das práticas radicais adotadas pelo Estado Islâmico, ou ISIS, bem como afegãos, iraquianos e somalis ${ }^{28}$.

Resumidamente, o acordo estabelece em sua primeira cláusula que todos os migrantes irregulares que deixarem a Turquia para adentrar a Grécia serão devolvidos ao solo turco, uma medida reconhecida como "extraordinária e temporária para pôr um fim ao sofrimento humano e restaurar a ordem pública"29. A cláusula prevê que aqueles que forem enquadrados pelas autoridades gregas como titulares do direito de asilo, terão processados individualmente seus pedidos. Os demais deverão ser retornados à Turquia.

A cláusula segunda trata especificamente dos sírios. Eles representam o maior contingente populacional de

"Não é uma crise de números, mas uma crise de solidariedade". CEBRIÁN, Belén Domínguez. Guerra e perseguição tiram de suas casas 24 pessoas por minuto em todo o mundo. El País, Madri, 20 jun. 2016. Disponível em: http://brasil.elpais.com/brasil/2016/06/18/ internacional/1466273687_619217.html . Acesso em 09 ago. 2016. 27 "In order to break the business model of the smugglers and to offer migrants an alternative to putting their lives at risk, the EU and Turkey today decided to end the irregular migration from Turkey to the EU."GENERAL SECRETARIAT OF THE COUNCIL. EU-Turkey statement, 18 March 2016. Brussels: Press Office, 18 mar 2016. Disponível em: http:// www.consilium.europa.eu/en/press/press-releases/2016/03/18eu-turkey-statement/ Acesso em 28 jul 2016.

28 FRONTEX. Eastern Mediterranean Route. Disponível em: http://frontex.europa.eu/trends-and-routes/eastern-mediterranean-route/ . Acesso em 15 jul. 2016. Trata-se da chamada "Rota dos Balcãs", a partir da qual sírios, afegãos, iraquianos e até somalis deixam seus países, passam pela Turquia, e a partir dela ingressam na União Europeia percorrendo Grécia, Macedônia, Sérvia e Hungria. 29 GENERAL SECRETARIAT OF THE COUNCIL, EUTurkey statement, 18 March 2016. Brussels: Press Office, 18 mar 2016. Disponível em: http://www.consilium.europa.eu/en/press/ press-releases/2016/03/18-eu-turkey-statement/. Acesso em: 28 jul. 2016. 
refugiados que chega à Europa, fugindo de uma guerra civil que dura mais de cinco anos. Segundo o Acordo, para cada sírio que seja retornado das ilhas gregas à Turquia, outro será reacomodado na União Europeia, a partir dos Critérios de Vulnerabilidade, desde que não tenha tentado entrar na União Europeia antes, irregularmente. Haveria uma disponibilidade para assentamento de 18.000 mil pessoas, sendo que a União Europeia estaria disposta a abrir vaga para mais 54.000 vulneráveis sírios. Interessante lembrar que somente em fevereiro de 2016, mais de 57.000 migrantes chegaram nas ilhas gregas, dos quais $52 \%$ eram sírios, e o restante iraquianos e afegãos. ${ }^{30}$ Com isso, a Turquia representaria o primeiro país a conceder asilo aos refugiados sírios, e de cada um que recebesse de volta e acolhesse, outro seria realocado pela própria União Europeia, para os países que estivessem em condições e disponibilidade para receber essas pessoas. ${ }^{31}$

Além disso, a fim de compensar essa devolução de sírios que buscam entrar irregularmente na Europa, a União Europeia se comprometeu em pagar uma cifra adicional de 3 bilhões de euros até 2018 (cláusula sexta), liberar o visto para turcos visitarem a Europa a partir de junho de 2016 (cláusula quinta) e facilitar os trâmites para que a Turquia venha a ser incluída na União Europeia (cláusula oitava).

O que se depreende do Acordo firmado é que, apesar do compromisso de reassentar refugiados que estejam regularmente acomodados na Turquia, todos aqueles que tentarem entrar na Europa irregularmente serão devolvidos - mesmo as vítimas da Guerra Civil Síria, e de perseguições dela decorrentes. A única porta de entrada seria pela via dos trâmites legais e burocráticos, os quais deverão ser providenciados inicialmente na Turquia. A mensagem deixada pelo Acordo é a do Presidente do Conselho Europeu: "não venham a Europa". ${ }^{32}$

Trata-se da materialização de uma tendência que já se verificava nos países industrializados especialmente a

30 COLLETT, Elizabeth. The Paradox of the EU-Turkey Refugee Deal. Migration Policy Institute, Washington, mar. 2016. Disponível em: http://www.migrationpolicy.org/news/paradox-eu-turkey-refugee-deal . Acesso em: 25 jun. 2016, p. 2-3.

31 ABELLÁN, Lucía; PÉREZ, Claudi. União Europeia e Turquia chegam a acordo para expulsar refugiados. El País. Bruxelas, 28 mar. 2016. Disponível em: http://brasil.elpais.com/brasil/2016/03/07/ internacional/1457352301_920991.html . Acesso em 20 jul. 2016, p. 2.

32 ABELLÁN, Lucía; PÉREZ, Claudi. União Europeia e Turquia chegam a acordo para expulsar refugiados, p. 4. partir da década de 90, em que barreiras físicas, legais e burocráticas foram erguidas para evitar que as pessoas que buscavam refúgio chegassem ao seu território. Verifica-se uma tendência retórica e prática de contenção dos fluxos de refugiados e migrantes, para que permaneçam em seus países, ainda que para enfrentar condições adversas em sentido econômico ou de perseguição política e jurídica. ${ }^{33}$ Especialmente porque sente que os refugiados ameaçam sua estabilidade política, social e econômica, a Europa decidiu adotar mecanismos refratores. $^{34}$

Para Collet, o Acordo EU-Turquia enfrenta um grave paradoxo. Se, de um lado, as autoridades europeias pretenderem torna-lo efetivo, precisarão atalhar mecanismos legais como proibição de detenções ou direito a recurso ${ }^{35}$ para poder devolver sírios ou outros estrangeiros que adentrarem ilegalmente suas fronteiras. Estarão comprometendo um discurso entoado há décadas com países vizinhos sobre os padrões de refúgio. Por outro lado, se decidirem cumprir fielmente todos os tratados e leis protegendo direitos humanos dessas pessoas, podem enfrentar a inviabilidade prática de promover a devolução daqueles que ingressarem irregularmente. Segundo Collet, os governos (da Europa e da Turquia) parecem estar confiando mais na mensagem do Acordo, do que na necessidade de sua efetiva implementação. ${ }^{36}$

Vale observar que um mês antes de o Acordo ser firmado, a Turquia tinha mais de duzentos mil pedidos de asilo não analisados. ${ }^{37}$ Este dado fornece uma noção

33 ACNUR. La situación de los refugiados em el mundo: en busca de soluciones. Madrid: Alianza, 1995, p. 59.

34 COLLETT, E. The Paradox of the EU-Turkey Refugee Deal. Migration Policy Institute, Washington, mar. 2016. Disponível em: http://www.migrationpolicy.org/news/paradox-eu-turkey-refugeedeal. Acesso em: 25 jun. 2016 p. 91.

35 Conforme Convenção sobre o Estatuto dos Refugiados de 1951, artigo 32 (2).

36 COLlETt, E. The Paradox of the EU-Turkey Refugee Deal. Migration Policy Institute, Washington, mar. 2016. Disponível em: http://www.migrationpolicy.org/news/paradox-eu-turkey-refugeedeal. Acesso em: 25 jun. 2016, p. 2. Conforme informa a imprensa, as devoluções já tiveram início, com levas de refugiados deixando a Grécia para a Turquia. Em abril de 2016, 600 refugiados foram devolvidos, causando manifestações contrárias e violência nos campos de refugiados. A eficácia do Acordo está sendo posta à prova na medida em que a Grécia mostra dificuldades de operacionalizar o deslocamento das pessoas em segurança, e o fluxo de chegadas de refugiados irregulares não diminuiu. COMEÇAM as novas expulsões de refugiados da União Europeia. In: El País. 4 abr. 2016. Disponível em: http://brasil.elpais.com/brasil/2016/04/03/internacional/1459712252_605155.html. Acesso: em 10 ago. 2016.

37 COMEÇAM as novas expulsões de refugiados da União Eu- 
mais próxima do que a União Europeia efetivamente pretende com o Acordo: (i) devolver todos os sírios que chegarem irregularmente as suas fronteiras para a Turquia, pois a porta de entrada só seria possível pelas vias legais; (ii) essa tramitação legal burocrática deverá ser realizada pela Turquia, apesar de ela já enfrentar dificuldades para se desincumbir do mister; (iii) somente aqueles que forem reconhecidos como refugiados sírios pela Turquia poderão ser encaminhados à Europa para assentamento em país a ser designado pela própria União Europeia ${ }^{38}$. Os números não desafiam a possibilidade de implementação da proposta, eles na verdade desmascaram a real intenção europeia: receber o menor número de refugiados possível. A Turquia que retenha, e contenha, os indesejáveis.

Um dos principais princípios postos em cheque pelo Acordo é o princípio do non-refoulement, ou da não devolução, pedra angular do Direito Internacional dos Refugiados. Segundo ele, as autoridades de um país estariam proibidas de devolver ao país de onde vieram pessoas em busca de asilo. Diferentemente da expulsão, na qual um país promove a retirada de pessoas já anteriormente admitidas, no refoulement, o Estado sequer permite que essa pessoa adentre seu território, sendo imediatamente devolvida ao seu local de origem. ${ }^{39} \mathrm{O}$ princípio do non-refoulement encontra abrigo no artigo 33, parágrafo primeiro da Convenção de 1951 sobre Direitos dos Refugiados, a qual prevê precisamente que um refugiado não pode ser retornado a um país em que sua vida ou liberdade sejam ameaçadas, precisamente em função de sua raça, religião, nacionalidade, grupo social ou opiniões políticas. ${ }^{40}$

Se as pessoas enfrentam as piores condições de jornada possíveis para buscar um lugar que as acolha

ropeia. In: El País. 4 abr. 2016. Disponível em: http://brasil.elpais. com/brasil/2016/04/03/internacional/1459712252_605155.html . Acesso: em 10 ago. 2016, p. 3.

38 Mesmo esse reconhecimento enfrenta barreiras graves como a dificuldade com a língua, ou seja, a dificuldade em articular uma narrativa, e demonstrar argumentativamente a existência das condições necessárias à configuração da qualidade de refugiado. GODOY, Gabriel Gualano de. Refúgio, Hospitalidade e os Sujeitos do Encontro. In GEDIEL, José Antônio Peres; GODOY, Gabriel Gualano de. (Org.) Refúgio e Hospitalidade. Curitiba: Kairós, 2016, p. 40-42.

39 CAVARZERE, Thelma Thais. Direito Internacional da Pessoa Humana: A circulação internacional de pessoas. Rio de Janeiro: Renovar, 1995, p. 97-98.

40 FRIEDRICH, Tatyana Scheila; BENEDETTI, Andréa Regina de Morais. A visibilidade dos Invisíveis e os Princípios de Proteção aos Refugiados: notas sobre os acontecimentos recentes. In GEDIEL, José Antônio Peres; GODOY, Gabriel Gualano de. (Org.) Refúgio e Hospitalidade. Curitiba: Kairós, 2016, p. 72. e proteja da perseguição, da fome, da privação de direitos, o princípio do non-refoulement, compreendido em consonância com os direitos humanos mais primários, justamente visa garantir que ela deve estar a salvo dessas privações. Ao lado da solidariedade, a tolerância surge como fundamento para esse princípio, no sentido de não se poder privar uma pessoa de direitos humanos em razão de sua raça, origem, convicções. Significa dizer que todas as identidades merecem respeito e acolhida quando buscam asilo, fugindo de perseguições e privações de direitos que certamente os levarão ao perecimento.

No caso do Acordo UE-Turquia, a União Europeia decide exatamente promover a devolução dos refugiados irregulares, apesar de a comunidade internacional questionar se a Turquia seria um país capaz de receber essas pessoas e evitar que sejam vítimas de perseguição e constantes violações de direitos humanos. ${ }^{41}$ Vale lembrar que ela passou por uma traumática tentativa de golpe de estado, mantém declarado estado de emergência e o atual vice-premiê anunciou a suspensão da Convenção Europeia de Direitos Humanos em seu território. ${ }^{42}$ A devolução de sírios para a Turquia significa encaminhá-los para um país que enfrenta, ele próprio, uma grave crise, com milhares de pessoas detidas e suspensão de direitos humanos.

Uma situação como essa é precisamente o que o princípio do non-refoulement visa prevenir, em se tratando de uma norma imperativa dos direitos humanos dos refugiados, a qual não poderia ser negociada ou derrogada por qualquer Acordo Internacional. ${ }^{43}$

41 Existem elementos para se responder a essa pergunta negativamente. Como salienta a Comissão Europeia para Ajuda Humanitária e Proteção Civil, a Turquia mantém cerca de 270.000 pessoas em 25 campos de refugiados, mas reconhece que $90 \%$ dos refugiados sírios que vivem fora desses campos não são considerados para dados estatísticos, e sobrevivem em condições desafiadoras, sem acesso a informação, serviços públicos como educação e saúde. EUROPEAN COMMISSION - Humanitarian Aid and Civil Protection. Turkey: Refugee Crisis. Bruxela, 2016. Disponível em: http:// ec.europa.eu/echo/files/aid/countries/factsheets/turkey_syrian_ crisis_en.pdf . Acesso em 25 jul. 2016.

42 Turquia suspende aplicação da Convenção Europeia dos Direitos Humanos. O Globo. 21 jul. 2016. Disponível em: http:/ /oglobo. globo.com/mundo/turquia-suspende-aplicacao-da-convencao-europeia-dos-direitos-humanos-19757361\#ixzz4H35ys1zT . Acesso em 11 ago. 2016.

43 FRIEDRICH, Tatyana Scheila; BENEDETTI, Andréa Regina de Morais. A visibilidade dos Invisíveis e os Princípios de Proteção aos Refugiados: notas sobre os acontecimentos recentes. In GEDIEL, José Antônio Peres; GODOY, Gabriel Gualano de. (Org.) Refúgio e Hospitalidade. Curitiba: Kairós, 2016, p. 73. 
Outro aspecto do Acordo que merece ser considerado é que ele aumenta o tempo de espera dos egressos sírios, afegãos e iraquianos pelo efetivo reconhecimento do direito ao refúgio ${ }^{44}$, nos campos de refugiados. Estes campos abrigam tanto os pretendentes a refugiados quanto os já assim identificados, materializando um processo de exclusão social. Ainda que os refugiados assim reconhecidos e designados sejam destinatários de proteção jurídica, organismos internacionais reconhecem que eles podem ser vítimas de intimidação ou agressão em campos de refugiados, seja por parte da comunidade anfitriã que os recebe, seja por seus próprios pares. ${ }^{45}$ Mulheres e crianças são um público ainda mais vulnerável, especialmente porque se encontram em um lugar que não necessariamente respeita seus valores culturais, e com autoridades mal aparelhadas para conter os abusos.

O fato de o Direito Internacional dos Refugiados mostrar-se impotente para conter violações de direitos humanos como estas parece denunciar mais que defeitos nos arranjos jurídico-administrativos internacionais, ou problemas econômicos enfrentados pelos países receptores. Nunca foi fácil receber populações de refugiados. Como observa José Manuel Oliveira Antunes ${ }^{46}$, o fim da II Guerra Mundial implicou graves fluxos de refugiados por toda a Europa. Naquele momento histórico, contudo, os Estados europeus enfrentavam grave destruição, de modo que os governos do pós-guerra

44 "O refugiado, pois, depende do reconhecimento de seu status (dos motivos fundados e subjetivos do temor que justificam a fuga) por parte de um outro Estado para readquirir, ainda que minimamente, qualquer possibilidade de acesso a direitos básicos. Embora supostamente protegido pelo guarda-chuva do direito humanitário e por agências governamentais internacionais [...], a retomada de seus direitos básicos depende, prioritariamente, de sua reintegração territorial e, por consequência, jurídica ao espaço da política governamental." MOLIN, Carolina. Os direitos humanos dos humanos sem direitos. Refugiados e a política do protesto. In Revista Brasileira de Ciências Sociais, v. 26, n. 76, São Paulo, junho, 2011, p. 145-155. Disponível em: http://www.redalyc.org/ articulo.oa?id=10719120008. Acesso em: 25 jul. 2016, p. 148.

45 "Como se demuestra por la reciente experiência de los refugiados ruandeses en Zaire y la anterior de los camboyanos en la frontera tailandesa, um campo de refugiados puede ser uno de los lugares más peligrosos del mundo, especialmente cuando está bajo el control de personas que han sido responsables de violaciones massivas de los derechos bumanos en su pátria". ACNUR, La situación de los refugiados en el mundo: en busca de soluciones. Madrid: Alianza, 1995, p. 59.

46 ANTUNES, José Manuel Oliveira. Refugiados: um pouco de história, para memórias curtas. In Público. Lisboa, 28 ago. 2015. Disponível em: https://www.publico.pt/mundo/noticia/refugiados-um-pouco-de-historia-para-memorias-curtas-1706138. Acesso em 10 ago. 2016. mostraram-se por isso receptivos ao acolhimento de mão-de-obra para recompor-se. Ainda assim, como salienta Oliveira Antunes, "procuravam sempre selecionar os mais convenientes", pois a política de integração com estrangeiros sempre foi vista com reservas.

$\mathrm{Na}$ medida em que sírios, afegãos e iraquianos batem às portas em grande volume, o discurso mostra-se drasticamente menos receptivo. O incômodo que os países europeus vêm na chegada dessas populações traz em seu âmago um preconceito profundo que os tem desviado da tolerância sempre propagandeada em tratados internacionais.

\section{INTOLERÂNCIA E DISCRIMINAÇÃO: AFLUXO DE REFUGIADOS DESAFIA A SINCERIDADE DOS VALORES EUROPEUS OCIDENTAIS}

Ao longo dos últimos anos, a Europa tem sido o palco de diversos atentados terroristas. Os mais recentes, contudo, têm tido sua autoria reivindicada pelo Estado Islâmico (ISIS), traduzindo a política de intolerância desse grupo radical com o modo de viver dos europeus, e com sua política restritiva de imigração. Se de um lado a Europa tinha uma tendência de tolerar práticas religiosas diversas, desde que não comprometessem sua organização política democrática, a realidade atual tem desencadeado sentimentos xenófobos, agravando um preconceito que talvez já estivesse plantado há muitos anos.

O Acordo UE-Turquia vem justamente proteger o território europeu, mediante alegações de que os refugiados sírios, afegãos ou iraquianos trazem entre si pessoas com propósitos terroristas. Ocorre que esses refugiados estão, eles próprios, fugindo de atentados terroristas em seu próprio país ${ }^{47}$.

Nesse caso, a União Europeia não tem se comportado como uma sociedade internacional, como ensina Walzer, que adota um padrão de tolerância extremamente forte, tendo em vista que carece de uma estrutura organizacional capaz de determinar obrigações e deveres, e cobrar o seu adimplemento. No caso europeu, a

47 FRIEDRICH, Tatyana Scheila; BENEDETTI, Andréa Regina de Morais. A visibilidade dos Invisíveis e os Princípios de Proteção aos Refugiados: notas sobre os acontecimentos recentes. In GEDIEL, José Antônio Peres; GODOY, Gabriel Gualano de. (Org.) Refúgio e Hospitalidade. Curitiba: Kairós, 2016, p. 69-70. 
tolerância condicionada parece ser própria do comportamento de Estados-nação ou sociedades de imigrantes. Grupos minoritários como os refugiados sírios só são admitidos se não oferecerem nenhum risco para o modo de vida europeu, pois ao fazê-lo, justificariam medidas de contenção e intervenção.

Os indivíduos são tolerados em suas características e práticas pessoais, mas os grupos a que pertencem não gozam da mesma proteção. A título de exemplo, nas questões de gênero se percebe um delicado embate entre o direito das comunidades de manter seus rituais (uso da burka, mutilação genital, sati $^{48}$ ) e o direito individual dos cidadãos de não se sujeitar a essas práticas. $\mathrm{Na}$ medida em que tanto Estados-nação quanto sociedades de imigrantes impõe uma lei única para homens e mulheres, estes costumes encontram forte resistência. ${ }^{49}$

O choque entre a cultura europeia, e a cultura islâmica, agravada pela chegada dos refugiados tem deixado aflorar entre europeus evidente preconceito, a ser traduzido como uma compreensão a respeito de algo ou alguém, recebida e reproduzida tradicionalmente de forma acrítica, pois dotada de tanta autoridade que não admite refutação racional. ${ }^{50}$ É nessa ordem que generalizações como "muçulmanos são terroristas" ganham a força retórica de um dogma, dificultando que se olhe para os refugiados como sujeitos de direitos.

Como consequência, no lugar de uma tolerância condicionada (e já não mais universal) surge o racismo como um preconceito em relação ao diferente, um

48 Imolação da viúva hindu sobre a pira funerária do marido. WALZER, Michael. Da Tolerância. Trad. Almiro Pisetta. São Paulo: Martins Fontes, 1999, p. 80.

49 Procurando estabelecer padrões mínimos para a tolerância, de forma mais radical, Zizek defende que a tolerância entre europeus e muçulmanos é impossível: "In short, things explode when members of a religious community consider the very way of life of another community as blasphemous or injurious, whether or not it constitutes a direct attack on their religion. To curb this propensity, one has to [...] First, formulate a minimum set of norms obligatory for everyone that includes religious freedom, protection of individual freedom against group pressure, the rights of women, etc. - without fear that such norms will appear "Eurocentric." Second, within these limits, unconditionally insist on the tolerance of different ways of life. And if norms and communication don't work, then the force of law should be applied in all its forms." ZIZEK, Slavoj. In the Wake of Paris Attacks the Left Must Embrace Its Radical Western Roots. In These Times. 16 nov. 2015. Disponível em: http://inthesetimes.com/article/print/18605/breaking-thetaboos-in-the-wake-of-paris-attacks-the-left-must-embrace. Acesso em 08 ago. 2016.

50 BOBBIO, Norberto. Elogio da serenidade e outros escritos morais. Trad. Marco Aurélio Nogueira. São Paulo: UNESP, 2002, p. 103. medo de que ele causará algum mal. Essa predisposição mental dirigida a grupos inteiros, determinando o receio de que as tradições culturais dos "outros" ofusquem, comprometam ou até mesmo violem as "nossas", o medo de perder espaço no mercado de trabalho, determinando o empobrecimento e o perecimento em virtude da chegada do outro, ainda pode levar além do racismo, à xenofobia. Enquanto os valores ocidentais passam a ser considerados universais, intrinsicamente bons e justos, outros são ridicularizados e menosprezados, senão até combatidos. ${ }^{51}$

No presente caso, o choque entre valores ocidentais (Europa) e orientais (Islã), acaba ganhando corpo quando associada a problemas de caráter econômico, como a crise do Estado de Bem-Estar na Europa e o medo de que a avalanche de pessoas miseráveis inviabilize por completo o sistema. Walzer já chamava a atenção para o fato de que a intolerância se mostra ainda mais grave quando aspectos religiosos, raciais, culturais são associados a grupos economicamente subordinados. Imigrantes, quando incorporados aos grupos nacionais europeus, costumam ser tolerados porque são invisíveis. ${ }^{52}$ Mas, no caso presente, a massa de refugiados sírios está longe da invisibilidade. Neste panorama o racismo ganha força, tomando a forma de um discurso ideológico entre o bem e o mal. ${ }^{53}$

Significa dizer que pode se materializar, como se suspeita no caso do Acordo UE-Turquia, verdadeira usurpação política e ideológica do racismo, a fim de implementar a possibilidade de grupos dominantes que se pretendem homogêneos de subjugar os diferentes a partir de concepções de raça, nação, povo. ${ }^{54}$

51 BOBBIO, N. Elogio da serenidade e outros escritos morais. Trad. Marco Aurélio Nogueira. São Paulo: UNESP, 2002, p. 124.

52 WALZER, M. Da Tolerância. Trad. Almiro Pisetta. São Paulo: Martins Fontes, 1999, p. 74-76.

53 Hannah Arendt, em estudo sobre o totalitarismo nazista, defendeu que seu sucesso estava intrinsicamente ligado à ideologia racista por ele implementada, a fim de afirmar a superioridade de uma raça pura ariana sobre as demais. Para ela, a raça foi a justificativa pronta e necessária para todas as atrocidades praticadas pelo nazismo, e a burocracia surgiu precisamente como o mecanismo que permitia a realização do assassinato em massa de forma desumanizada, de modo que nenhum homem poderia assumir sozinho a responsabilidade pelos atos praticados. Todos seriam membros de uma cadeia racional e jurídica que levava à aniquilação da raça considerada inferior. ARENDT, H. As origens do totalitarismo. Trad. Roberto Raposo. São Paulo: 2012, p. 238.

54 Não só na Europa o discurso racista foi apropriado pela direita, mas se trata de um movimento global, como se percebe das 
Com isso, o racismo europeu acaba por impulsionar práticas discriminatórias ${ }^{55}$. O Acordo UE-Turquia prevê que todos os refugiados que saíram da Turquia para a Grécia de forma irregular devem ser devolvidos. Quem são os refugiados que utilizam essa rota? Essencialmente sírios, afegãos e iraquianos, ou seja, povos islâmicos. Esse acordo não abrange, por exemplo, nigerianos que cheguem à Europa por mar a partir do Líbia ${ }^{56}$. Trata-se de uma discriminação jurídica que tem levado à marginalização social ${ }^{57}$, na medida em que esses refugiados são mantidos em campos no território turco, até que se vençam os trâmites burocráticos de legalização para assentamento em solo europeu.

Como bem enfatizou Walzer, ${ }^{58}$ são os membros de uma determinada estrutura (uma nação, um Estado) que escolhem quem vão admitir, a quem vão estender os laços de afiliação, e segundo quais critérios. A fim de proteger sua liberdade, seu bem-estar social e sua cultura, os Estados devem cuidar de suas fronteiras e impor restrições de acesso ao seu território. Quanto mais fechado for o Estado, mais abertas serão as pequenas comunidades que o formam, menos paroquiais. ${ }^{59}$ Significaria afirmar que precisamente para garantir a maior amplitude possível de mobilidade dentro dos Estados que a compõe (como no Acordo Schengen, que aboliu

declarações proferidas pelo então candidato, hoje Presidente eleito dos Estados Unidos, Donald Trump, em entrevista relatada na New York Review of Books, em que condena as decisões de um juiz de Indiana em razão de sua origem mexicana: "This judge is of Mexican heritage. I'm building a wall". TOMASKY, Michael. Can the Monster be Elected? In The New York Review of Books. V. LXIII, n. 12, New York: jul-ago 2016, p. 42.

55 Discriminação aqui compreendida como diferenciação injusta ou ilegítima, surgindo quando aqueles que deveriam ser tratados de maneira igual, são tratados de forma diferente, em seu prejuízo. BOBBIO, Elogio da serenidade e outros escritos morais. Trad. Marco Aurélio Nogueira. São Paulo: UNESP, 2002, p. 107.

56 Além de sírios e afegãos, também eritreus, somalis e nigerianos buscam a Europa fugindo da guerra e da privação de direitos humanos. AVELAR, Daniel; BALBINO, Leda. Saiba quais são os principais conflitos que alimentam a crise de refugiados na Europa. In Folha de S. Paulo. São Paulo, 03 set. 2015. Disponível em: http:/ / www1.folha.uol.com.br/asmais/2015/09/1676793-saiba-quaissao-os-conflitos-que-alimentam-a-crise-de-refugiados-na-europa. shtml Acesso em 10 ago. 2016.

57 BOBBIO, N. Elogio da serenidade e outros escritos morais. Trad. Marco Aurélio Nogueira. São Paulo: UNESP, 2002, p. 116.

58 WALZER, Michael. Esferas da Justiça: Uma defesa do pluralismo e da igualdade. Trad. Jussara Simões. São Paulo: Martins Fontes, 2003, p. 40-41.

59 WALZER, Michael. Esferas da Justiça: Uma defesa do pluralismo e da igualdade. Trad. Jussara Simões. São Paulo: Martins Fontes, 2003, p. 48-50. o controle nas fronteiras internas), a União Europeia precisa adotar políticas mais restritivas para os que pretendem nela ingressar.

Menos crédulo de uma identidade cultural europeia, Lehne observa que as migrações provenientes de países europeus mais pobres ocorridas no início dos anos 2000, com o alargamento das fronteiras da União Europeia, levaram a um certo desgaste do sentimento europeu. O Acordo Schengen, para ele, não pretendia necessariamente uma unidade cultural, mas facilitar o trânsito da mão de obra dentro das fronteiras, dinamizar e desonerar as trocas comerciais. Ainda que tenha tentado dar visibilidade à pretensão da Europa de se mostrar como um território integrado, cujos cidadãos gozam de uma "área de liberdade, segurança e justiça", ${ }^{60}$ esse intento não foi atingido. Para Lehne, a Europa não criou um espaço político comum, nem uma identidade europeia que pudessem ancorar a abertura interna. Não tendo logrado formar uma comunidade transnacional que possa gerar lideranças capazes de preservar o bem comum de forma efetiva, e enfrentar assimetrias internas, a Europa tem presenciado nas últimas décadas o refortalecimento dos Estados-nação, pois são as eleições internas que distribuem poder político, e o debate público ainda está entrincheirado nas linhas nacionais.

Num primeiro momento, a crise migratória teve efeito disjuntivo, pois diante de uma política receptiva adotada pela União Europeia como um todo, os governos se voltaram para medidas restritivas nacionais, passaram a questionar o futuro do Acordo Schengen e adotar a premissa "cada um por si", em franco prejuízo para a integração europeia. ${ }^{61} \mathrm{~A}$ união só surgiu quando a estrutura europeia se viu ameaçada pela grande massa de refugiados. Identidades fragmentadas se manifestaram para cobrar de seus estados políticas de admissão mais restritivas. Foi nesse sentido que a União Europeia conseguiu um consenso entre seus 28 países para adotar o Acordo com a Turquia, e parece defender a instauração de uma "Fortaleza Europa", com máximas restrições para a entrada de migrantes e refugiados. ${ }^{62}$

60 LEHNE, Stefan. The Tempting Trap of Fortress Europe. In Carnegie Europe. Bruxela, 21 abr. 2016. Disponível em: www.carnegieeurope.eu/2016/04/21/tempting-trap-of-fortress-europe/ixdx . Acesso em: 11 ago. 2016.

61 LEHNE, Stefan. The Tempting Trap of Fortress Europe. In Carnegie Europe. Bruxela, 21 abr. 2016. Disponível em: www.carnegieeurope.eu/2016/04/21/tempting-trap-of-fortress-europe/ixdx . Acesso em: 11 ago. 2016.

62 "By effectively keeping refugees out of Europe in the first place, a Fortress 
É preciso enfatizar que no caso de refugiados, segundo os padrões internacionais da Convenção de 1951, bem como dos direitos humanos, o acolhimento é quase uma imposição. Walzer demonstra essa preocupação ao lembrar que refugiados apresentam a reivindicação mais premente de todas: "Se você não me aceitar, dizem eles, serei assassinado, perseguido, brutalmente oprimido pelo governo do meu próprio país. O que podemos responder?" 63

Nesse caso, Walzer chega a sugerir que o tratamento a ser dispensado aos refugiados seja o mesmo que se teria com compatriotas, especialmente se aqueles que recebem os refugiados têm alguma responsabilidade com a condição deplorável em que se encontra seu país. Contudo, o aspecto cultural representa, para Walzer, um fator determinante. Afinidades ideológicas e étnicas atravessam fronteiras e exercem uma coerção moral que impulsiona os processos de admissão. Contrario sensu, quanto menor a identidade e a afinidade, mais difícil a receptividade dos refugiados. ${ }^{64}$

Assim, os refugiados encontram melhores políticas de admissão quando são culturalmente parecidos, de fácil integração $0^{65}$, além de estarem em números admi-

Europe policy would greatly reduce the burden to be shared and therefore obviate the necessity of such arrangements. And the conflicts between the first $E U$ countries in which migrants arrive, the transit states, and the countries of final destination — conflicts that have bedeviled the EU's work on this issue-would disappear." Para Lehne, essa pretensão tende a falhar por diversas razões, dentre as quais a imensa fronteira terrestre e marítima da Europa, incapaz de conter os afluxos populacionais, e a precariedade da estrutura público-administrativa-policial dos países vizinhos para conter e manter em seu território os refugiados. LEHNE, Stefan. The Tempting Trap of Fortress Europe. In Carnegie Europe. Bruxela, 21 abr. 2016. Disponível em: www.carnegieeurope.eu/2016/04/21/ tempting-trap-of-fortress-europe/ixdx . Acesso em: 11 ago. 2016.

63 WALZER, Michael. Esferas da Justiça: Uma defesa do pluralismo e da igualdade. Trad. Jussara Simões. São Paulo: Martins Fontes, 2003, p. 63.

64 Walzer cita como exemplo a acolhida de refugiados políticos pela Inglaterra no século XIX, dentre os quais existiam hereges e oposicionistas diversos, em luta contra as autocracias do Centro e Leste Europeus. Como partilhavam um inimigo comum, foram bem recebidos. Ainda, o exemplo de húngaros que deixaram seu país após a revolução fracassada em 1956, já que partilhavam os valores ocidentais. Em não havendo afinidade alguma, Walzer defende que os refugiados não podem ser aceitos em detrimento de outras pessoas igualmente necessitadas. Defende a existência de fronteiras definidas. WALZER, Michael. Esferas da Justiça: Uma defesa do pluralismo e da igualdade. Trad. Jussara Simões. São Paulo: Martins Fontes, 2003, p. 64.

65 Arendt lembra de duas soluções de naturalização diante da crise de refugiados pós I Guerra Mundial: a naturalização dos gregos expulsos da Turquia, naturalizados em bloco em 1922, e aquela que favoreceu os refugiados armênios da Turquia estabelecidos na Síria, nistráveis. Os Estados autores do Direito Internacional dos Refugiados, ironicamente, interpretam suas normas conforme seus próprios interesses, já que não há uma autoridade supranacional legitimada a determinar compulsoriamente o seu cumprimento. Ainda mais vulneráveis estão os refugiados pois o sistema internacional de proteção não previu mecanismos para receber petições ou denúncias individuais ou entre Estados. ${ }^{66}$

Walzer afirma que o direito internacional dos refugiados foi criado para indivíduos contados um a um, o que muda severamente agravada quando se trata de milhares, ou milhões de pessoas solicitando refúgio. ${ }^{67}$ Ainda que este pedido imponha, ética e juridicamente, a aceitação, dada a sua gravidade, a realidade mostra que a política adotada pelos Estados nem sempre tem olhos para a tolerância, e para a inclusão. Para Walzer, a acolhida de grandes números de refugiados, ainda que moralmente salutar, não pode suplantar o direito de uma comunidade de restringir aqueles a quem deseja conceder a afiliação. "O princípio do auxílio mútuo só pode modificar, e não transformar, as políticas de admissão arraigadas na interpretação que determinada comunidade faz de si mesma". ${ }^{68}$

A defesa de Walzer se justifica dentro de uma concepção comunitarista de sociedade. Todavia, se essa concepção implica a larga violação de direitos humanos essenciais à sobrevivência do homem, ela pode ser

Líbano e outros países ex-otomanos, a qual correspondia a uma população com a qual todo o Oriente Próximo compartilhava a cidadania turco-otomana ainda poucos anos antes. ARENDT, H. As origens do totalitarismo. Trad. Roberto Raposo. São Paulo: 2012, p. 318. Michael Sandel ainda lembra do resgate dos judeus etíopes pelo Estado de Israel, em virtude da guerra civil eclodida na Etiópia em 1991. SANDEL, Michael. Justiça: O que é fazer a coisa certa. 15 ed. Rio de Janeiro: Civilização Brasileira, 2014, p. 279-280.

66 MOREIRA, Julia Bertino. Direito Internacional dos Refugiados e a Legislação Brasileira. In RAMINA, Larissa; FRIEDRICH, Tatyana Scheila (Coord). Coleção Direito Internacional Multifacetado: Direitos Humanos, Guerra e Paz. V. III. Curitiba: Juruá, 2014, p.110-111.

67 Walzer lembra a situação em que milhões de russos foram capturados pelos aliados na II Guerra Mundial e depois devolvidos compulsoriamente para a União Soviética, mesmo sabendo-se que lá muitos deles seriam assassinados. Aqueles que cientes de seu destino pediram asilo, encontraram Estados-nacionais fechados, que por motivos políticos de conveniência (não de assimilação, nem nacionalidade) o negaram. WALZER, M. Esferas da justiça. Uma defesa do pluralismo e da igualdade. Trad. Jussara Simões. São Paulo: Martins Fontes, 2003, p. 66.

68 WALZER, M. Esferas da justiça. Uma defesa do pluralismo e da igualdade. Trad. Jussara Simões. São Paulo: Martins Fontes, 2003, p. 67. 
questionada. Enviar para o risco de morte grandes contingentes humanos não poderia ser justificado a partir de valores culturais comunitários.

$\mathrm{Na}$ verdade, bem andou Collet ao ressaltar o paradoxo em que o Acordo UE-Turquia colocou a comunidade ocidental europeia. ${ }^{69}$ Enquanto procura se fechar em uma fortaleza para preservar sua cultura, seus valores seculares, exclui de seu território os mais necessitados, determinando a devolução de refugiados. Ao fazê-lo, acaba por violar aqueles mesmos valores que pretendia proteger, como a tolerância para com o diferente, a inclusão, a isonomia. ${ }^{70}$ Se abrir completamente suas fronteiras, por outro lado, teme a União Europeia que, diante do grande afluxo de refugiados de culturas muito diversas, veja diluída e dissolvida mesma cultura.

A questão que fica é se seria possível pensar em recuperar e remodelar a tolerância como fundamento do direito dos refugiados, a fim de direcionar sua interpretação para uma prática de inclusão e respeito.

\section{Perspectivas para a Recuperação ou REMODELAÇÃO DA TOLERÂNCIA}

A defesa dos direitos humanos dos refugiados não admite a possibilidade de condicionamentos ${ }^{71}$. Essa

69 No mesmo sentido a crítica feita por Sam Kriss a Zizek: "What kind of Lacanian tells someone that they should effectively abandon their desire for something just because it's not attainable? Or are migrants not worthy of the luxury of an unconscious mind?) In Calais, migrants trying to reach the United Kingdom protested against their conditions with placards demanding "freedom of movement for all." Unlike racial or gender equality, the free movement of peoples across national borders is a supposedly universal European value that has actually been implemented - but, of course, only for Europeans. These protesters put the lie to any claim on the part of Europe to be upholding universal values". ZIZEK, Slavoj. In the Wake of Paris Attacks the Left Must Embrace Its Radical Western Roots. In These Times. 16 nov. 2015. Disponível em: http://inthesetimes.com/article/print/18605/breaking-thetaboos-in-the-wake-of-paris-attacks-the-left-must-embrace. Acesso em 08 ago. 2016.

70 Se os europeus ocidentais defendem que sua cultura enaltece a dignidade de cada pessoa humana, que todos são iguais e merecem os mesmos direitos, direito ao respeito a sua própria tradição, religião, raça, como justificar a barbarização do outro? AMADO, Juan Antonio García. ?Por qué no tienen los Inmigrantes dos Mismos Derechos que los Nacionales? In ARNAUD, André-Jean. Globalização e Direito I: Impactos nacionais, regionais e transnacionais. 2 ed. Rio de Janeiro: Lumen Iuris, 2005, p. 471-472.

71 PAMPLONA, Danielle Anne; PIOVESAN, Flávia. O instituto do refúgio no Brasil: práticas recentes. In Revista de Direitos Fundamentais e Democracia, v. 17, n. 17, Curitiba: janeiro/junho de 2015, p. 51. afirmação encontra-se amparada em uma concepção universal de direitos humanos que reconhece igualmente em cada pessoa um sujeito de direitos, que não pode ser deportado ou abandonado para perecer. Por fundamento, defende uma máxima tolerância para com a figura do outro, a fim de nele reconhecer um titular de direitos, de modo que sua qualificação como refugiado sírio não poderia ser suficiente para determinar sua devolução, ainda que chegue irregularmente.

A questão merece ser enfrentada à luz de uma alegação que partidários da Europa fazem como justificativa para fechar suas fronteiras, qual seja, a que dentre os refugiados sírios infiltram-se membros do Estado Islâmico que adentram território europeu com o objetivo de praticar atos terroristas. Diante dessa questão, seria necessário questionar se seria exigível ser tolerante também nesses casos.

É preciso esclarecer que não se trata de ser tolerante com terroristas, no sentido de admitir indiscriminadamente pessoas que se sabe ou se tem fundado receio de ser um criminoso. As redes de segurança europeia e internacional têm, de fato, que promover as devidas investigações a fim de localizar e levar a julgamento aqueles que praticam atos contrários aos direitos humanos, como o são os atos terroristas. A questão aqui é que não se pode presumir que as pessoas que deixam a Síria fugindo da intolerância de Bashar al-Assad, de um lado, e do Estado Islâmico, de outro, sejam todas convictos ou potenciais terroristas. Admitir essa presunção vai além de deitar por terra princípios caros ao Estado de Direito, implica a mais franca e desmedida xenofobia.

Refugiados sírios são devolvidos, barrados por muitos estados europeus sem qualquer rastro de tolerância ou solidariedade porque, segundo Walzer, os europeus não conseguem estabelecer com eles um laço de identidade - seja étnica, política, ideológica ou ainda cultural. Indo além, essas diferenças identitárias justificariam a proteção dos recursos econômicos em certa medida já escassos para os compatriotas. Todavia a Europa não logrou demonstrar a total impossibilidade de acolher os refugiados sírios. Talvez esse acolhimento - no grande volume como se apresenta - comprometesse o padrão de vida hoje mantido por muitos europeus, mas por certo não os levaria à fome e à miséria. Sandel, pensando sobre a possibilidade de se negar acesso ao Estado em função da preservação dos privilégios econômicos dos nacionais, rechaça essa possibilidade. Seria o mesmo que 
imaginar que somente as pessoas que tiveram a sorte de nascer naquele território tem direito de serem ricas. ${ }^{72}$

Ainda que o problema econômico possa ser questionado, a questão central parece ser mais simples: preconceito, racismo, xenofobia. Sentimentos que dificilmente serão afastados por um ideal universal de que todos partilham da mesma humanidade, pois são muito concretos e presentes. Como observa Silva, tornou-se hegemônico considerar como inferiores pessoas que não participam do mesmo grupo social, quando "não encontramos um pouco de nós mesmos nesse outro". 73 Essa dificuldade vem em razão de valores morais que diferem profundamente, como, no caso islâmico, o tratamento dispensado às mulheres, a laicidade do Estado, e o comprometimento religioso. Com esse nível de discordância, o recurso a um ser humano abstrato e universal não facilita o diálogo.

Richard Rorty observa que a solidariedade entre os grupos sociais surge precisamente em função de uma maior proximidade (étnica, política, religiosa) que possa haver entre eles. Para ele, maior será a solidariedade "quando aqueles com quem nos solidarizamos são vistos como 'um de nós', expressão em que 'nós' significa algo menor e mais local do que a raça humana". Se as semelhanças e diferenças entre os grupos são construídas de forma histórica e contingencial, uma solução universal abstrata seria de difícil sustentação. "É por isso que a frase 'porque essa pessoa é um ser humano' constitui uma explicação pouco convincente para um ato generoso." 74

Para Rorty, mesmo sem se recorrer a matrizes universalistas, é possível defender que grupos identificados como "nós" busquem alargar seu conceito para serem solidários com aqueles que inicialmente consideravam como "eles". Esse progresso moral caminharia no sentido de gerar uma maior solidariedade entre os homens, porém não em função de um “eu nuclear” que possa ser identificado em toda a humanidade, mas em função

72 SANDEL, Michael. Justiça: O que é fazer a coisa certa. 15 ed. Rio de Janeiro: Civilização Brasileira, 2014, p. 284. "Já que o acaso do local de nascimento não justifica o merecimento do direito [...] é difícil conceber como a restrição à imigração pode ser justificada em nome da preservação da riqueza". Se não se opõe a migrantes econômicos, em hipótese alguma se oporia a refugiados.

73 SILVA, Sérgio Gomes da. Direitos humanos: entre o princípio de igualdade e a tolerância. In Revista Praia Vermelha, v. 19, n. 1. Rio de Janeiro, jan-jul 2010, p. 80.

74 RORTY, Richard. Contingência, Ironia e Solidariedade. Trad. Vera Ribeiro. São Paulo: Martins Fontes, 2007, p. 313-315. de um maior desprezo sobre as diferenças tradicionais (origem, religião) e uma maior preocupação em torno de questões como dor e humilhação. ${ }^{75}$ Significaria ver no "outro" alguém que, tão historicamente e contingencialmente informado como "nós", tem os mesmos sentimentos.

A partir dessa proximidade, Rorty sugere acolher aqueles em que ordinariamente se pensa como "eles" para quem passem a ser "nós", no lugar de pensar em termos absolutos como se essa solidariedade existisse num momento pré-existente, como condição humana ${ }^{76}$. Esse "nós" não pode ser visto a partir de um mero etnocentrismo, mas de um etnocentrismo que coloca em dúvida a si mesmo, que questiona sobre sua capacidade de enxergar o outro.

Para Silva, não pode haver uma tolerância incondicional em relação ao outro, pois a tolerância sempre se dirige ao diferente a partir de certas condições que nós estabelecemos como válidas, pressupostos mínimos de aceitação. Para Silva, a tolerância incondicional seria caridade, e, portanto, uma espécie de dominação; ou seria então indiferença, mera aceitação do outro diante da inevitabilidade da vida em comum. Em nenhum desses casos, ela gera solidariedade. Em diálogo com as ideias de Rorty, defende que a tolerância deve propiciar alguma espécie de vínculo com o outro, de modo que ele possa ser visto como "nós", segundo uma categoria de "nós" contingencial e aberta. ${ }^{77}$

Nessa linha, uma situação seria perguntar ao outro se ele tem ou deseja ter as mesmas convicções que nós; outra, bem diferente, seria perguntar se ele está sofrendo. É na preocupação com a segunda resposta que a questão da solidariedade se apresenta de forma concreta e real. ${ }^{78}$

75 RORTY, Richard. Contingência, Ironia e Solidariedade. Trad. Vera Ribeiro. São Paulo: Martins Fontes, 2007. p. 316.

76 Este "nós" poderia ser compreendido como "nós, herdeiros das contingências históricas que criaram instituições políticas cada vez mais cosmopolitas e cada vez mais democráticas". RORTY, R.

Contingência, Ironia e Solidariedade. Trad. Vera Ribeiro. São Paulo: Martins Fontes, 2007, p. 322-323.

77 "A tolerância incondicional é algo desejável, porém, impossível. Nenhuma sociedade, nenhum grupo social ou comunidade, nenhum ser humano em lugar algum do mundo pode ser totalmente tolerante para com seu "irmão em humanidade". SILVA, Sérgio Gomes da. Sérgio Gomes da. Direitos humanos: entre o princípio de igualdade e a tolerância. In Revista Praia Vermelha, v. 19, n. 1. Rio de Janeiro, jan-jul 2010, p. 90-91.

78 RORTY, R. Contingência, Ironia e Solidariedade. Trad. Vera Ribeiro. São Paulo: Martins Fontes, 2007, p. 326. 
Seguindo esse mesmo caminho, e ciente de um mundo em que as diversidades culturais se chocam, Kwame Anthony Appiah propõe o cosmopolitismo como uma concepção de mundo fundada em duas noções: a de que as pessoas têm obrigações para com as outras, as quais transcendem os laços de família, ou cidadania; e a de que as vidas humanas em particular têm valor em si, o que traduz uma preocupação com práticas culturais identitárias. $^{79}$

Segundo Appiah, existem dois níveis de discordância sobre valores, o fraco, e o forte. No primeiro, encontram-se os padrões de certo, errado, belo, feio, sobre os quais praticamente todas as sociedades se posicionam, tendo práticas que se enquadram nestas categorias. No segundo, existem conceitos culturalmente profundos que não são partilhados, porque uma cultura simplesmente não tem o mesmo referente que a outra. Nesse caso, a discordância deve ser resolvida não com a aceitação do outro valor, ou sua incorporação, mas apenas com a sua compreensão. ${ }^{80} \mathrm{~A}$ tolerância - no sentido de reconhecimento - parte do diálogo com o outro, de modo a permitir que as duas culturas compreendam uma a outra, ainda que não concordem sobre determinados pontos. A "Regra de Ouro", segundo Appiah, é levar em consideração a ideia dos outros, sua concepção de mundo, seus interesses. É importante que as pessoas conheçam essa realidade alternativa, e experimentem, ainda que na imaginação, como seria vive-la. ${ }^{81}$

No caso em exame, o preconceito, o racismo e a xenofobia que transparecem a partir do Acordo UE-Turquia não pode ser vencido por uma ideia abstrata de tolerância para com o estrangeiro apenas porque são todos - europeus e sírios - da mesma espécie humana, nem por uma ideia que encerre possibilidade de diálogo

79 APPIAH, Kwame Anthony. Cosmopolitanism: Ethics in A World of Strangers. (e-book) New York: Penguin, 2007, p. 15.

80 APPIAH, Kwame Anthony. Cosmopolitanism: Ethics in A World of Strangers. (e-book) New York: Penguin, 2007, p. 102. Em outro trecho, o mesmo autor enfatiza que o relativismo cultural não leva ao diálogo: "Porque se o relativismo sobre ética e moralidade for verdadeiro, então, ao final de muitas discussões, cada um de nós acabaria dizendo: 'Do meu ponto de vista, estou certo. Do seu ponto de vista, você está certo'. E não haveria mais nada a dizer. [...] As pessoas sempre recomendam o relativismo porque entendem que ele levará à tolerância. Mas, se não pudermos aprender com o outro o que é certo pensar e sentir e fazer, então, a conversa entre nós será sem objeto. Relativismo deste tipo não é uma forma de se encorajar a conversa; é só uma razão para ficar em silêncio." (Tradução livre). P. 77.

81 APPIAH, Kwame Anthony. Cosmopolitanism: Ethics in A World of Strangers. (e-book) New York: Penguin, 2007, p. 130. em torno de diferenças culturais invencíveis. ${ }^{82}$ Entre os dois extremos, o cosmopolitismo propõe que um saiba calçar os sapatos do outro, e procurar entender suas necessidades, suas urgências. No caso dos refugiados sírios, o que também se aplica aos demais que buscam asilo na Europa, a luta pela própria sobrevivência é algo que transparece de sua própria existência pessoal, e precisa ser compreendida pelo povo europeu, precisa ser conhecida em concreto. Como bem assinala Appiah, “quando o estrangeiro não é mais imaginário, mas real e presente, compartilhando uma vida humana social, você pode gostar ou desgostar dele, pode concordar ou discordar; mas, se é o que vocês dois querem, vocês podem fazer sentido um do outro ao final". ${ }^{83}$

Dentro dessa proposta cosmopolita, Fachin propõe uma concepção de tolerância como fundamento inarredável para o diálogo entre as culturas, e superação do preconceito. No plano intrínseco a um sistema cultural, a tolerância permitiria reconhecer a validade das tradições culturais de um lado, e a autonomia individual de se submeter ou não a elas. ${ }^{84}$ No plano extrínseco, a tolerância representa o pressuposto para o diálogo intercultural a fim de evitar a imposição de um padrão cultural hegemônico. ${ }^{85}$

Heller e Feher também se ocuparam da necessidade de identificação de virtudes cívicas a serem desenvolvidas na vida em sociedade, precisamente a fim de permitir uma vida em comum diante das mais diversas culturas. Propõem o conceito de tolerância radical, partindo da premissa de que todas as pessoas devem ter iguais oportunidades de vida.

Assim, a partir do reconhecimento de que todas as necessidades humanas merecem indistintamente ser

82 FACHIN, Melina Girardi. Fundamentos dos Direitos Humanos: Teoria e práxis na cultura da tolerância. Rio de Janeiro: Renovar, 2009, p. 271

83 APPIAH, Kwame Anthony. Cosmopolitanism: Ethics in A World of Strangers. (e-book) New York: Penguin, 2007, p. 187.

84 Nesse sentido, recebem melhor acolhida no mundo ocidental pessoas que fogem dos sistemas islâmicos porque não desejam se submeter a eles, como no caso narrado por Khadija Kafir, que se insurgiu contra a tradição islâmica de sua família e logrou sobreviver com a ajuda de ocidentais, trocando de identidade. KAFIR, Khadija; JAMES, Sabatina. Por que minha mãe me quer morta. In Ex-muçulmanos. 1 set. 2015. Disponível em: < http://www.exmuculmanos. $\mathrm{com} /$ por-que-minha-mae-me-quer-morta/>. Acesso em 12 ago. 2016.

85 FACHIN, Melina Girardi. Fundamentos dos Direitos Humanos: Teoria e práxis na cultura da tolerância. Rio de Janeiro: Renovar, 2009, p. 280-281. 
atendidas (afastadas aquelas que usam outras pessoas como meios e podem impedir de se reconhecer necessidades para todos), também merecem reconhecimento diferentes formas de vida. ${ }^{86}$ Esse reconhecimento vai além da tolerância liberal (pela qual cada um pode perseguir individualmente seu ideal de felicidade, num sentido de não ingerência na liberdade alheia), pois tem uma conotação positiva, na medida em que determina uma relação ativa com o outro. A tolerância radical não aceita a força, a violência da dominação, autorizando o combate a todas as leis que negam o reconhecimento das formas de vida. Essa modalidade de tolerância vai além do "isso não é da minha conta" para implicar o "eu me importo". 87

É precisamente a ideia de se importar com o outro que motiva a solidariedade. Ela deve estar relacionada com a tolerância radical e a coragem cívica, sendo informada pelos valores universais da vida e liberdade, igualdade e racionalidade comunicativa. A solidariedade enquanto virtude deve ser traduzida em atos concretos de apoio aos grupos, movimentos sociais, comunidades, a fim de reduzir o nível de violência, dominação ou força nas instituições sociais e políticas. Não se trata de apoio irrestrito ao grupo, justamente exclui essa ideia na medida em que impõe condições: solidariedade a todos os grupos que reduzem a dominação, a força e a violência e ampliam o espaço de liberdade para todos. ${ }^{88} \mathrm{Nessa}$ linha, não se falaria em solidariedade para com o Estado Islâmico (ISIS), mas sim para com suas vítimas.

A fim de instrumentalizar a solidariedade, Appiah defende que as necessidades básicas de sobrevivência devem ser supridas, primeiramente, pela estrutura dos estados, de modo que os cidadãos têm responsabilidade de tomar providências para que esses estados atendam às necessidades de seus próprios nacionais. Indo além,

86 Nesse mesmo sentido, a solidariedade para com estrangeiros, como observado por Appiah, não exige que se nutra por eles o mesmo sentimento de simpatia que se tem pelos vizinhos, ou familiares e amigos. Partindo do princípio de que esse sentimento não está presente na maior parte das vezes, a solidariedade se dirige ao reconhecimento de que todas as pessoas têm necessidades básicas, como alimentação, abrigo, saúde, educação. APPIAH, Kwame Anthony. Cosmopolitanism: Ethics in A World of Strangers. (e-book) New York: Penguin, 2007, p. 279.

87 HELLER, Agnes; FEHÉR, Ferenc. A condição política pósmoderna. Trad. Marcos Santarrita. Rio de Janeiro: Civilização Brasileira, 1998, p. 122-124.

88 HELLER, Agnes; FEHÉR, Ferenc. A condição política pósmoderna. Trad. Marcos Santarrita. Rio de Janeiro: Civilização Brasileira, 1998, p. 126. na medida em que se aceita a estrutura política dos estados-nação, necessário reconhecer que as pessoas também têm um papel a cumprir na garantia de que outros estados garantam as necessidades de seu próprio povo, sem que isso signifique que cada um deva levar nas costas o peso da ineficiência, da corrupção ou mesmo da tirania alheia. ${ }^{89}$ A grande dificuldade está precisamente em determinar esse papel.

É certo que a solidariedade para com estrangeiros não pode inviabilizar a solidariedade/responsabilidade que cada um tem para com sua própria família, para com as pessoas que dele dependem ou procuram. Também não pode exigir que, em nome do cuidado para com o outro, alguém abandone os cuidados para consigo próprio. ${ }^{90}$

O cosmopolitismo exige que as pessoas se preocupem com os outros no sentido de procurar se informar sobre soluções razoáveis para os problemas. Não basta o engajamento, mas é preciso ter curiosidade, afinal é possível que certos cidadãos sejam coniventes com políticas que estão causando morte a outros, distantes de seus olhos. É preciso investigar por que grandes montantes financeiros são enviados para países pobres e não se vê melhora alguma na condição de vida de seus cidadãos. Como diz Appiah, "ele envolve não apenas ver uma pessoa sofrendo, mas uma vida humana desperdiçada". ${ }^{11}$

A solidariedade para com os estrangeiros não exige heroísmo, mas bom senso. Como fora salientado pela Conferencia de Direitos Humanos de 1993, trata-se de compartilhar responsabilidades, de modo que a comunidade internacional adote um planejamento abrangente a fim de coordenar atividades e promover uma maior cooperação com países envolvidos nas crises de refugia$\operatorname{dos}^{92}$. Para Appiah, trata-se de exigir dos representantes políticos que eles se lembrem dos estrangeiros, não porque estejamos chocados com seu sofrimento - até podemos estar - mas porque a sociedade responde à razão,

89 APPIAH, Kwame Anthony. Cosmopolitanism: Ethics in A World of Strangers. (e-book) New York: Penguin, 2007, p. 288-289.

90 APPIAH, Kwame Anthony. Cosmopolitanism: Ethics in A World of Strangers. (e-book) New York: Penguin, 2007, p. 292.

91 APPIAH, Kwame Anthony. Cosmopolitanism: Ethics in A World of Strangers. (e-book) New York: Penguin, 2007, p. 297.

92 PIOVESAN, Flávia. Refugiados sob a Perspectiva dos Direitos Humanos. In: Seminário Internacional "Fronteiras em Movimento: Deslocamentos e outras Dimensões do Vivido", Diversitas - Núcleo de Estudos das Diversidades, Intolerâncias e Conflitos, Universidade de São Paulo, São Paulo: 2013. 
a princípios, à consciência. Por mais distante, ou próximo, que os estrangeiros estejam, eles merecem viver. ${ }^{93}$

\section{Considerações finais}

Diante do exposto, é possível verificar, como já afirmara Zizek, que vivemos em tempos interessantes ${ }^{94}$. Tempos em que instrumentos normativos foram criados para vincular os Estados ao valor ético da pessoa humana, à sua dignidade. Como se depreende do Direito Internacional dos Refugiados, interpretado à luz dos direitos humanos, toda pessoa que se vê forçada a abandonar seu país em razão de perseguição, de medo da morte, da tortura, tem o direito de ser acolhida por comunidades estrangeiras, e protegida na qualidade de refugiada.

Todavia, a previsão abstrata de que todos partilhamos a mesma raça humana não foi motivo suficiente para que a Europa - conhecida mundialmente como berço dos direitos humanos - vencesse o preconceito em relação a grupos profundamente diferentes do seu ideal de bem viver. Quando as fronteiras europeias se viram assediadas por milhares de refugiados sírios, iraquianos, afegãos, o choque de civilizações falou mais alto, dando lugar ao preconceito, ao racismo e à xenofobia. O Acordo firmado pela União Europeia com a Turquia é talvez a expressão mais evidente dessa realidade, admitindo a devolução de refugiados que chegam às ilhas gregas para a Turquia. $\mathrm{O}$ princípio básico do Direito dos Refugiados, o non-refoulement parece ter sido esquecido. O Acordo prevê ajuda financeira dos países europeus para que a Turquia, ela própria enfrentando graves problemas políticos internos, inclusive de origem religiosa, acolha as massas de refugiados sírios. Ainda que preveja a possibilidade de reassentamento de refugiados legalmente instalados em solo turco nos países europeus, os números acabam por mostrar que a intenção da União Europeia de cumprimento de sua parte no acordo é, no mínimo, duvidosa.

Nesse sentido, a tolerância universal, idealizada, abs-

93 APPIAH, Kwame Anthony. Cosmopolitanism: Ethics in A World of Strangers. (e-book) New York: Penguin, 2007, p. 307-308.

94 ZIZEK, Slavoj. In the Wake of Paris Attacks the Left Must Embrace Its Radical Western Roots. In These Times. 16 nov. 2015. Disponível em: http://inthesetimes.com/article/print/18605/ breaking-the-taboos-in-the-wake-of-paris-attacks-the-left-must-embrace. Acesso em 08 ago. 2016: "We definitely live in interesting times." trata que deveria marcar as relações sociais entre povos diferentes mostrou-se um conceito de baixa operacionalidade. Os choques culturais entre refugiados sírios e o povo europeu são gritantes e concretos, além de terem sido agravados por atentados terroristas que apenas colocaram a Europa ainda mais "fortificada", para usar a expressão de Lehne. O Acordo UE-Turquia evidencia o fechamento de fronteiras em razão da intolerância, não apenas para com os terroristas em si, ou para com o Estado Islâmico (ISIS), mas também para com suas vítimas.

Diante desse quadro, sugere-se pensar a tolerância dirigida a sujeitos concretos, reconhecidos em sua historicidade, sua existência cultural e, nesta seara, sua dignidade. A partir das lições de Rorty, com seu conceito alargado de "nós" e Appiah, para quem os abismos culturais podem não se resolver pela aceitação, mas por um diálogo de compreensão. Urge pensar nos refugiados como pessoas concretas, com histórias que impõe a responsabilidade daquele a quem chegam, pela sua gravidade e premência.

Não se exige do europeu que ele abandone suas convicções para compreender as necessidades dos refugiados; sua estrutura ético-jurídica fornece um instrumental adequado para tanto na medida em que defende a liberdade religiosa, os direitos básicos essenciais à sobrevivência. Ele só precisa ser utilizado com sinceridade. A partir do respeito às normas de direitos humanos, conhecer o outro e nele reconhecer um sujeito de direitos. O preconceito, como bem colocado por Bobbio, nasce na cabeça dos homens, e só pode ser nela combatido, a partir da construção de uma consciência voltada para a tolerância. ${ }^{95}$

Tolerância radical, como defendem Heller e Fehér, que assume uma feição ativa para além do ideal liberal, defensor de uma liberdade plena para se nutrir convicções e com base nelas pautar uma existência. Uma feição ativa que se dirija ao outro e compreenda suas razões, suas necessidades, e em função desse encontro paute condutas de respeito e de acolhimento.

É certo que a realidade vivida hoje desafia a praticidade dessas noções. O contingente de refugiados é imenso, talvez sua acolhida implique sacrifícios para a Europa. O medo do terrorismo é igualmente avassala-

95 BOBBIO, Norberto. Elogio da serenidade e outros escritos morais. Trad. Marco Aurélio Nogueira. São Paulo: UNESP, 2002, p. 117. 
dor. Não há caminhos fáceis para solucionar o choque de intenções, pois os europeus dificilmente conseguirão se isolar diante do grande contingente de necessitados. $\mathrm{E}$ ao fazê-lo, estariam negando a si mesmos. Ciente dessas limitações, o próprio Direito Internacional dos Refugiados sugere que se combatam as causas do refúgio, mediante ações solidárias que possam impedir/punir perseguições dos nacionais em seus próprios estados, e permitir que eles sejam devolvidos aos seus lares. ${ }^{96}$ Medidas contra o terrorismo devem ser tomadas com investigações dedicadas, e punições seguras, não com exclusão de pessoas por presunções que só se sustentam enquanto manifestações racistas e xenofóbicas.

Se a dificuldade é grande, maior há de ser a superação. Como sugere o cosmopolitismo, não há necessidade de heróis, mas de efetivamente nos ocuparmos em enxergar os outros, cobrar dos Estados ações concretas e senão ética, juridicamente comprometidas com os direitos humanos. Em tempos de individualismo, talvez aí já haja uma boa dose de heroísmo. De fato, tempos interessantes.

\section{REFERÊNCIAS}

ABELLÁN, Lucía; PÉREZ, Claudi. União Europeia e Turquia chegam a acordo para expulsar refugiados. El País. Bruxelas, 28 mar. 2016. Disponível em: http:// brasil.elpais.com/brasil/2016/03/07/internacional/1457352301_920991.html. Acesso em 20 jul. 2016.

ACNUR. La situación de los refugiados en el mundo: en busca de soluciones. Madrid: Alianza, 1995.

AMADO, Juan Antonio García. ?Por qué no tienen los Inmigrantes dos Mismos Derechos que los Nacionales? In ARNAUD, André-Jean. Globalização e Direito I: Impactos nacionais, regionais e transnacionais. 2 ed. Rio de Janeiro: Lumen Iuris, 2005.

ANTUNES, José Manuel Oliveira. Refugiados: um pouco de história, para memórias curtas. In Público. Lisboa, 28 ago. 2015. Disponível em: https://www. publico.pt/mundo/noticia/refugiados-um-pouco-dehistoria-para-memorias-curtas-1706138. Acesso em 10 ago. 2016.

96 ACNUR. La situación de los refugiados en el mundo: en busca de soluciones. Madrid: Alianza, 1995, p. 62-63.
APPIAH, Kwame Anthony. Cosmopolitanism: Ethics in A World of Strangers (e-book). New York: Penguin, 2007.

ARENDT, Hannah. As origens do totalitarismo. Trad. Roberto Raposo. São Paulo: 2012.

AVELAR, Daniel; BALBINO, Leda. Saiba quais são os principais conflitos que alimentam a crise de refugiados na Europa. In Folha de S. Paulo. São Paulo, 03 set. 2015. Disponível em: http://www1.folha.uol.com. br/asmais/2015/09/1676793-saiba-quais-sao-os-conflitos-que-alimentam-a-crise-de-refugiados-na-europa. shtml. Acesso em 10 ago. 2016.

BARBOZA, Estefânia Maria de Queiroz; BACK, Alessandra. A proteção normativa dos refugiados políticos na América Latina e no Brasil. In GEDIEL, José Antônio Peres; GODOY, Gabriel Gualano de. (Org.) Refúgio e Hospitalidade. Curitiba: Kairós, 2016, p. 87-117.

COLLET'T, Elizabeth. The Paradox of the EU-Turkey Refugee Deal. Migration Policy Institute, Washington, mar. 2016. Disponível em: http:/ /www.migrationpolicy. org/news/paradox-eu-turkey-refugee-deal . Acesso em: 25 jun. 2016.

BOBBIO, Norberto. Elogio da serenidade e outros escritos morais. Trad. Marco Aurélio Nogueira. São Paulo: UNESP, 2002.

CAVARZERE, Thelma Thais. Direito Internacional da Pessoa Humana: A circulação internacional de pessoas. Rio de Janeiro: Renovar, 1995.

CEBRIÁN, Belén Domínguez. Guerra e perseguição tiram de suas casas 24 pessoas por minuto em todo o mundo. In E1 País, Madri, 20 jun. 2016. Disponível em: http://brasil.elpais.com/brasil/2016/06/18/internacional/1466273687_619217.html. Acesso em: 09 ago. 2016.

COMEÇAM as novas expulsões de refugiados da União Europeia. E1 País. 4 abr. 2016. Disponível em: http://brasil.elpais.com/brasil/2016/04/03/internacional/1459712252_605155.html Acesso em 10 ago. 2016.

EUROPEAN COMMISSION - Humanitarian Aid and Civil Protection. Turkey: Refugee Crisis. Bruxela, 2016. Disponível em: http://ec.europa.eu/echo/files/ aid/countries/factsheets/turkey_syrian_crisis_en.pdf . Acesso em 25 jul. 2016.

FACHIN, Melina Girardi. Fundamentos dos Direitos 
Humanos: Teoria e práxis na cultura da tolerância. Rio de Janeiro: Renovar, 2009.

FRIEDRICH, Tatyana Scheila; BENEDETTI, Andréa Regina de Morais. A visibilidade dos Invisíveis e os Princípios de Proteção aos Refugiados: notas sobre os acontecimentos recentes. In GEDIEL, José Antônio Peres; GODOY, Gabriel Gualano de. (Org.) Refúgio e Hospitalidade. Curitiba: Kairós, 2016, p. 67-85.

FRONTEX. Eastern Mediterranean Route. Disponível em: http://frontex.europa.eu/trends-and-routes/eastern-mediterranean-route/ . Acesso em 15 jul. 2016.

GENERAL SECRETARIAT OF THE COUNCIL. EU-Turkey statement, 18 March 2016. Brussels: Press Office, 18 mar 2016. Disponível em: http:/ /www.consilium.europa.eu/en/press/press-releases/2016/03/18eu-turkey-statement/ Acesso em: 28 jul 2016.

GODOY, Gabriel Gualano de. Refúgio, Hospitalidade e os Sujeitos do Encontro. In In GEDIEL, José Antônio Peres; GODOY, Gabriel Gualano de. (Org.) Refúgio e Hospitalidade. Curitiba: Kairós, 2016, p. 39-65.

HELLER, Agnes; FEHÉR, Ferenc. A condição política pós-moderna. Trad. Marcos Santarrita. Rio de Janeiro: Civilização Brasileira, 1998.

JUBILUT, Liliana. O Direito internacional dos refugiados e sua aplicação no orçamento jurídico brasileiro. São Paulo: Método, 2007.

JUDT, Tony. Postwar: A Historty of Europe Since 1945. New York: Penguin Books, 2005.

KAFIR, Khadija; JAMES, Sabatina. Por que minha mãe me quer morta. In Ex-muçulmanos. 1 set. 2015. Disponível em: http://www.exmuculmanos.com/porque-minha-mae-me-quer-morta/ . Acesso em: 12 ago. 2016.

LEHNE, Stefan. The Tempting Trap of Fortress Europe. In Carnegie Europe. Bruxela, 21 abr. 2016. Disponível em: www.carnegieeurope.eu/2016/04/21/temptingtrap-of-fortress-europe/ixdx . Acesso em: 11 ago. 2016.

MOLIN, Carolina. Os direitos humanos dos humanos sem direitos. Refugiados e a política do protesto. In Revista Brasileira de Ciências Sociais, v. 26, n. 76, São Paulo, junho, 2011, p. 145-155. Disponível em: http:// www.redalyc.org/articulo.oa?id=10719120008. Acesso em: 25 jul. 2016.

MOREIRA, Julia Bertino. Direito Internacional dos Re- fugiados e a Legislação Brasileira. In RAMINA, Larissa; FRIEDRICH, Tatyana Scheila (Coord). Coleção Direito Internacional Multifacetado: Direitos Humanos, Guerra e Paz. V. III. Curitiba: Juruá, 2014, p.110-111.

OLSEN, Ana Carolina Lopes. Imigração e reconhecimento de direitos: o desafio do Brasil na era da (in) tolerância. Revista de Direito Econômico e Socioambiental, Curitiba, v. 6, n. 2, p. 122-155, jul./dez. 2015. Disponível em: http://dx.doi.org/10.7213/rev. dir.econ.socioambienta.06.002.AO05 . Acesso em 22 jul. 2016.

PAMPLONA, Danielle Anne; PIOVESAN, Flávia. O instituto do refúgio no Brasil: práticas recentes. In Revista de Direitos Fundamentais e Democracia, v. 17, n. 17, Curitiba: janeiro/junho de 2015, p. 43-55.

PIOVESAN, Flávia. Direitos Humanos e Justiça Internacional. 6 ed. São Paulo: Saraiva, 2015.

Direitos Humanos e o Direito Constitucional Internacional. 13 ed. São Paulo: Saraiva, 2012.

Refugiados sob a Perspectiva dos Direitos Humanos. In: Seminário Internacional "Fronteiras em Movimento: Deslocamentos e outras Dimensões do Vivido", Diversitas - Núcleo de Estudos das Diversidades, Intolerâncias e Conflitos, Universidade de São Paulo, São Paulo: 2013.

PITA, Agni Castro. Direitos Humanos e Direito Internacional dos Refugiados. In GEDIEL, José Antônio Peres; GODOY, Gabriel Gualano de. (Org.) Refúgio e Hospitalidade. Curitiba: Kairós, 2016, p. 5-16.

RORTY, Richard. Contingência, Ironia e Solidariedade. Trad. Vera Ribeiro. São Paulo: Martins Fontes, 2007.

SANDEL, Michael. Justiça: O que é fazer a coisa certa. 15 ed. Rio de Janeiro: Civilização Brasileira, 2014.

SILVA, Sérgio Gomes da. Direitos humanos: entre o princípio de igualdade e a tolerância. In Revista Praia Vermelha, v. 19, n. 1. Rio de Janeiro, jan-jul 2010.

TOMASKY, Michael. Can the Monster be Elected? In The New York Review of Books. V. LXIII, n. 12, New York: jul-ago 2016.

Turquia suspende aplicação da Convenção Europeia dos Direitos Humanos. O Globo. 21 jul. 2016. Disponível em: http://oglobo.globo.com/mundo/turquia-suspen- 
de-aplicacao-da-convencao-europeia-dos-direitos-humanos-19757361\#ixzz4H35ys1zT . Acesso em: 11 ago. 2016.

WACHOWICZ, Marcos. O direito de asilo como expressão dos direitos humanos. In Revista da Faculdade de Direito da Universidade Federal do Paraná. Curitiba: UFPR, 2002. Disponível em: www.revistas. ufpr.br/direito/article/download/1776/1473 . Acesso em 07 ago. 2016, p. 143-156.

WALZER, Michael. Da Tolerância. Trad. Almiro Pisetta. São Paulo: Martins Fontes, 1999.

Esferas da Justiça: Uma defesa do plu- ralismo e da igualdade. Trad. Jussara Simões. São Paulo: Martins Fontes, 2003

WOLFF, Robert Paul. Além da Tolerância. In WOLFF, Robert Paul; MOORE JR., Barrington; MARCUSE, Herbert. Crítica da Tolerância Pura. Trad. Ruy Jungmann. Rio de Janeiro: Zahar, 1970

ZIZEK, Slavoj. In the Wake of Paris Attacks the Left Must Embrace Its Radical Western Roots. In These Times. 16 nov. 2015. Disponível em: http://inthesetimes.com/article/ print/18605/breaking-the-taboos-in-the-wake-of-paris-attacks-the-left-must-embrace . Acesso em 08 ago. 2016. 


\section{Normas Editoriais}

1. Serão aceitas colaborações inéditas e a publicação de um artigo está condicionada à sua adequação às normas editoriais, e seu simples recebimento desobriga a sua publicação. Revista de Direito Internacional classificará as colaborações de acordo com as seguintes seções:

1.1 Artigos: compreende textos que contenham relatos completos de estudos ou pesquisas concluídas, matérias de caráter opinativo, revisões da literatura e colaborações assemelhadas.

1.2 Resenhas: compreende análises críticas de livros, de periódicos recentemente publicados, dissertações e teses.

2. Excepcionalmente, a comissão editorial poderá aceitar a submissão de trabalhos que já tenham sido publicados e caso isso ocorra, serão submetidos ao mesmo processo de avaliação pelos pares que aqueles inéditos. $\mathrm{O}$ autor deverá apresentar autorização por escrito do editor da revista na qual seu trabalho tenha sido originalmente publicado, acompanhado de cópia do mesmo.

3. O processo de avaliação dos artigos e resenhas compreende duas fases: a primeira destinada à análise da adequação do trabalho à linha editorial da revista (Comissão Editorial) e a segunda referente à avaliação do conteúdo e qualidade dos trabalhos. Esta segunda fase é realizada mediante o processo de avaliação pelos pares, ou seja, os artigos serão submetidos à aprovação de no mínimo 2 pareceristas adhoc.

4. Os trabalhos serão enviados para a avaliação sem a identificação de autoria

5. Os trabalhos devem ser enviados no seguinte padrão:

$1^{a}$ Página: Começar com o título do título do trabalho, seguido do texto. Não inseriro nome dos autores ou outros elementos queidentifiquem a autoria. A autoria do artigo e a qualificação dos autores são inseridas nos campos específicos do formulário eletrônico. O objetivo aqui é garantir uma avaliação cega por pares. Os textos deverão ser digitados em Arial 12, espaço 1,5 margem de 2,5 $\mathrm{cm}$, numeração arábica das páginas no ângulo superior direito, em programa compatível com o World para Windows.

Título do trabalho: o título deve ser breve e suficientemente específico e descritivo para representar o conteúdo do texto e deverá ter a sua tradução para o inglês.

Resumo: em todos os artigos submetidos deve ser incluído um resumo informativo com o máximo de 250 palavras e espaço entre linhas simples. O resumo deve ser estruturado com as seguintes informações:

Objetivo do artigo (obrigatório);

Metodologia (obrigatório);

Conclusões (obrigatório);

Limitações da pesquisa e suas implicações (se aplicável);

Limitações práticas (se aplicável)

Originalidade ou valor (obrigatório); 
Destacar no mínimo três e no máximo seis palavraschave que representem o conteúdo do texto. O resumo e as palavras-chave deverão ter a sua tradução para o inglês.

Agradecimentos: agradecimentos a auxílios recebidos para a elaboração do trabalho deverão ser mencionados no final do artigo.

Notas: notas referentes ao corpo do artigo deverão vir no rodapé do texto.

Apêndices: apêndices podem ser empregados no caso de listagens extensivas, estatísticas e outros elementos de suporte.

Materiais gráficos: fotografias nítidas e gráficos (estritamente indispensáveis à clareza do texto) poderão ser aceitos e cada fotografia ou gráfico deverá vir no texto e além disso cada um deverá ser enviado em arquivo separado. Se as ilustrações enviadas já tiverem sido publicadas, mencionar a fonte e a permissão para reprodução.

Quadros: os quadros deverão ser acompanhados de cabeçalho que permita compreender o significado dos dados reunidos, sem necessidade de referência ao texto. Assinalar, no texto, pelo seu número de ordem, os locais onde os quadros devem ser intercalados.

Referências: as referências redigidas segundo a norma NBR 6023/2002 da Associação Brasileira de Normas Técnicas (ABNT), deverão ser apresentadas por ordem alfabética e constituir uma lista única no final do artigo. A exatidão e adequação das referências a trabalhos que tenham sido consultados e mencionados no texto do artigo são da responsabilidade do autor. Informações procedentes de comunicação pessoal, de trabalhos em andamento ou não publicados não devem ser incluídas na lista de referências, mas indicada em nota de rodapé.

Não utilizar o sistema Autor data para citações. O formato utilizado pela revista é o sistema numérico, onde a citação é indicada por número sobrescrito e a referência mencionada em nota de rodapé.

Recomendações: recomenda-se que se observem as normas da ABNT referentes à apresentação de artigos em publicações periódicas (NBR 6022/2002), apresen- tação de citações em documentos (NBR 10520/2002), apresentação de originais (NBR 12256), norma para datar (NBR 892), numeração progressiva das seções de um documento (NBR 6024/2003) e resumos (NBR $6028 / 2003)$.

A revista se reserva o direito de efetuar nos originais alterações de ordem normativa, ortográfica e gramatical, com vistas a manter o padrão culto da língua, respeitando, porém, o estilo dos autores.

A partir de 2009, consideramos útil formular algumas sugestões (não obrigatórias) aos autores, com base nos principais motivos por recusa de artigos nos anos anteriores.

7. Com a publicação do artigo o autor receberá cinco exemplares da revista. No caso de resenha o autor receberá dois exemplares.

8. Responsabilidades e conflitos de interesse: A responsabilidade pelas informações e opiniões indicadas nos artigos é exclusiva dos autores. Eventuais conflitos de interesse serão de responsabilidade dos próprios autores e não do periódico.

\section{Envio dos trabalhos:}

1. Os trabalhos deverão ser enviados para a equipe editorial da revista no endereço eletrônico www.rdi.uniceub.br

2. Cada autor deve enviar declaração de responsabilidade nos termos abaixo:

“Eu XXXX certifico que participei da concepção do trabalho tornar pública minha responsabilidade pelo seu conteúdo, que não omiti quaisquer ligações ou acordos de financiamento entre os autores e companhias que possam ter interesse na publicação deste artigo."

3. Para as colaborações inéditas, cada autor deve enviar a transferência de direitos autorais nos termos abaixo:

"Eu XXXX declaro que em caso de aceitação do artigo inédito, a Revista de Direito Internacional passa a ter os direitos autorais a ele referentes. 


\section{REVISTA DE DIREITO INTERNACIONAL \\ BRAZILIAN JOURNAL OF INTERNATIONAL LAW \\ V. 14, n.1}

\section{Edição especial}

Comemorativa do 5 anos do centro de excelência contra a fome do programa mundial de alimentos

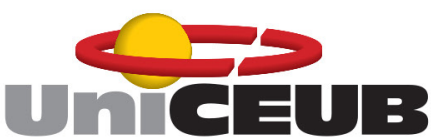

